Evaluatin

Earthquake Hazard in the Los Angele Rogion-

\author{
An Earth-Scionc \\ Perspectiv
}

U.S. GEOLOGICAL SURVI PROITISSTOUत PAPBR 13:1 


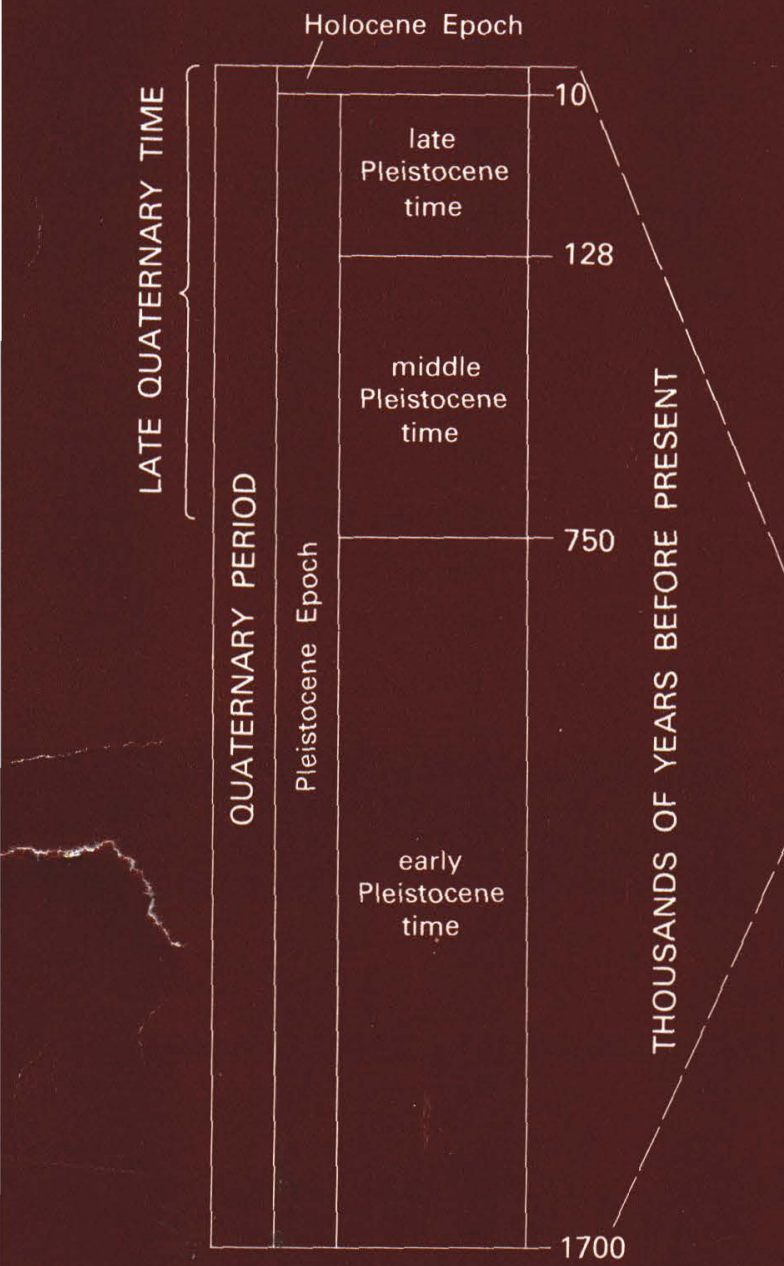

Chart showing late Quaternary time, as used in this volume, in relation to the commonly recognized geologic time scale. Ages of boundaries between geologic time units are approximate and are compiled as follows: boundaries and subdivisions of the Quaternary are from G. M. Richmond and D. S. Fullerton (U.S. Geological Survey) (written communication, 1984); Tertiary and earlier ages are from the U.S. Geological Survey (1984). Late Quaternary time is used to designate the time span since the BrunhesMatuyama magnetic polarity reversal, which also marks the boundary between early and middle Pleistocene time. This magnetic polarity reversal has not been dated directly by radiometric methods, but, in California, it must closely predate the age of the widespread Bishop ash bed $\{738,000 \mathrm{yr}$ B.P., according to Izett (1982)). The boundary between the middle and late Pleistocene is arbitrarily placed at the beginning of the last interglacial marine oxygen isotope stage $5 \mathrm{e}$, provisionally assigned an age of $128,000 \mathrm{yr}$ (Ruddiman and McIntyre, 1984). The base of the Holocene is arbitrarily placed at 10,000 yr B.P. (Hopkins, 1975). (References given by Ziony and Kockelman, this volume.)

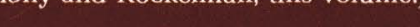




\section{Evaluating Earthquake Hazards in the Los Angeles Region- An Earth-Science Perspective}

\section{J. I. Ziony, Editor}

U.S. GEOLOGICAL SURVEY PROFESSIONAL PAPER 1360 An integrated set of studies describing methods for evaluating geologically controlled earthquake hazards as a basis for reducing future losses 


\section{DEPARTMENT OF THE INTERIOR \\ DONALD PAUL HODEL, Secretary}

\section{U.S. GEOLOGICAL SURVEY}

Dallas L. Peck, Director

\section{Library of Congress Cataloging-in-Publication Data}

Evaluating earthquake hazards in the Los Angeles region-An earth-science perspective.

(U.S. Geological Survey professional paper ; 1360)

Bibliography: p. 471

Supt. of Docs. no.: I 19.16:1360

1. Earthquakes-California-Los Angeles region. I. Ziony, Joseph I. II. U.S. Geological Survey professional paper ; 1360. QE535.2.U6E93 $1985 \quad 363.3^{\prime} 495^{\prime} 0979494 \quad 85-600239$

For sale by the Superintendent of Documents, U.S. Government Printing Office Washington, DC 20402 


\section{FOREWORD}

Devastating earthquakes have sporadically struck many populated centers of the United States (for example, Boston, Mass., in 1755; Charleston, S.C., in 1886; San Francisco, Calif., in 1906; Long Beach, Calif., in 1933; Tacoma and Seattle, Wash., in 1949 and 1965; Anchorage, Alaska, in 1964; and San Fernando, Calif., in 1971). Although a damaging earthquake at a given locality in the United States is a relatively rare event, the likelihood of truly catastrophic loss of life and property is increasing as development and construction accelerate in the 39 States that lie in regions of major or moderate potential for large earthquakes.

Beginning with Clarence E. Dutton's investigations of the 1886 Charleston earthquake, scientists of the U.S. Geological Survey have studied earthquakes and their effects. The great Alaska earthquake of 1964 and the 1971 San Fernando earthquake awakened officials to the threat facing many urban areas and stimulated geologists and seismologists to analyze the conditions that control the distribution of earthquake damage. The United States Congress, recognizing that the potential for large earthquakes is a national concern, enacted the Earthquake Hazards Reduction Act of 1977 (Public Law 95-124), which establishes objectives to (1) develop earthquake-resistant engineering-design methods; (2) predict earthquakes and characterize seismic hazards; (3) develop model codes for land use and construction; and (4) prepare plans for responding to major destructive earthquakes. Within these broad objectives, two major goals of the Geological Survey have been to improve methods of evaluating geologically controlled earthquake effects and to delineate earthquake hazards in major urban regions at high seismic risk.

Studies for Seismic Zonation of the San Francisco Bay Region (U.S. Geological Survey Professional Paper 941-A) was a solid advance in the assessment of earthquake hazards. That report presented methods for evaluating earthquake, surface-faulting, ground-shaking, and ground-failure potential and described a multidisciplinary approach to seismic zonation. Subsequent earth-science maps and evaluations of California's San Francisco Bay region prepared by the Geological Survey were the bases for derivative maps that are now being used in engineering design, land use planning, and emergencyresponse planning to reduce future earthquake losses.

Evaluating Earthquake Hazards in the Los Angeles Region-An Earth-Science Perspective, which builds on the foundations laid by the San Francisco Bay region studies, indicates how rapidly the science of earthquake hazard assessment is evolving. For example, innovative new concepts for predicting the extent and severity of strong shaking and of earthquake-triggered landsliding have resulted from research in the Los Angeles region. In presenting state-of-the-art methods, this volume describes the potential for damaging geologic and seismologic effects and demonstrates the application of evaluative techniques to selected areas of that region. We expect to publish more detailed maps of hazard potential for much of the region over the next several years. The hazard-evaluation methods described herein can also be used for evaluating and mapping earthquake hazards in other urban areas such as Salt Lake City, Utah, Seattle, Wash., and Anchorage, Alaska, all of which are vulnerable to earthquake damage.

The ultimate benefits of studies such as those reported in this volume are the reduced loss of life, injury, and property damage and the continued functioning of vital services and economic activities following a potentially destructive earthquake. To achieve these benefits, scientists, engineers, and planners must cooperate in the development of useful technical products. In turn, officials in both the private sector and in the government must determine which actions acceptable to the general public can best reduce future earthquake losses.

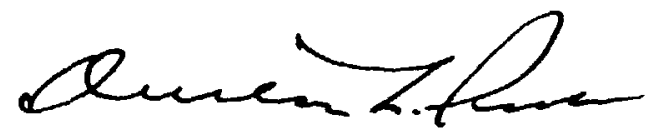

Dallas L. Peck

Director, U.S. Geological Survey

Foreword III 



\title{
CONTENTS
}

\author{
FOREWORD III \\ ABSTRACT IX \\ INTRODUCTION 1
}

J. I. Ziony and W. J. Kockelman

The earthquake threat, $\mathbf{1} \bullet$ Purpose and content of this volume, $\mathbf{4} \bullet$ Opportunities for reducing earthquake hazards, 8 - Users of information for reducing earthquake hazards, $11 \cdot$ Looking toward the future, 13

\section{GLOSSARY 15}

CONVERSION TABLE 23

\section{EARTHQUAKE AND SURFACE-FAULTING SOURCES}

GEOLOGIC AND SEISMOLOGIC SETTING $\mathbf{2 5}$

R.F. Yerkes

Plate-tectonic evolution of California, 25 • Present plate-tectonic setting, 25 - Effects of continuing deformation, 27 • Pattern of active faults, $32 \cdot$ Pattern of damaging earthquakes, $\mathbf{3 2} \bullet$ Pattern of modern seismicity, 33

EVALUATING EARTHQUAKE AND SURFACE-FAULTING POTENTIAL $\mathbf{4 3}$

J. I. Ziony and R. F. Yerkes

Potentially active faults of the region, 43 - Hazards from active faults, 60 - Examples of surface faulting and related effects from southern California earthquakes, 65 - Predicting the future behavior of faults, 69 - Implications for reduction of earthquake hazards, 89

\section{EARTHQUAKE GROUND MOTION}

PREDICTING EARTHQUAKE GROUND MOTION: AN INTRODUCTION 93

R. D. Borcherdt

Developing a data base for ground-motion estimation on a regional scale, 93 • Predicting earthquake intensities, 94 $\bullet$ Predicting quantitative characteristics of ground shaking, 95 • Estimating ground shaking for a postulated event, 97 • Common means for characterizing earthquake shaking, 97

MAPPING QUATERNARY SEDIMENTARY DEPOSITS FOR AREAL VARIATIONS IN SHAKING RESPONSE 101

J. C. Tinsley and T. E. Fumal

Mapping surficial geologic units, $101 \cdot$ Surficial geologic maps, $105 \cdot$ Description of map units, 105 - Using physical properties of surficial geologic units to estimate relative shaking response, 112 - Mapping shear-wave velocity groups, 114

\section{MAPPING SHEAR-WAVE VELOCITIES OF NEAR-SURFACE GEOLOGIC MATERIALS} 127

T. E. Fumal and J. C. Tinsley

Geologic factors affecting shear-wave velocity, 128 - Shear-wave velocity studies in the Los Angeles region, 129 - Shear-wave velocities in late Quaternary sedimentary deposits, $\mathbf{1 3 0}$ - Shear-wave velocities in pre-late Quaternary bedrock materials, $135 \bullet$ Preparing regional maps of shear-wave velocity, 135 
J. F. Evernden and J. M. Thomson

Why ground-motion parameters saturate at high magnitude, 152 • Method for predicting seismic intensities, $156 \cdot$ Correlating intensity with strong-motion parameters, $160 \cdot$ Applying the intensity prediction method, $170 \cdot$ Using seismic intensities to predict earthquake losses, $184 \cdot$ Mathematical details of model for predicting intensities, 201

PREDICTIVE MAPPING OF EARTHQUAKE GROUND MOTION 203

W. B. Joyner and T. E. Fumal

Predictive equations, 204 - Using local shear-wave velocity to improve predictions of site effects, $205 \cdot$ Characterizing earthquake sources, 208 Applying the method, 212 - Dependence of probabilistic ground-motion estimates on parameters of the magnitude-frequency relation, 216

PREDICTING RELATIVE GROUND RESPONSE 221

A. M. Rogers, J. C. Tinsley, and R. D. Borcherdt

Previous studies, 221 - Comparative ground response in the Los Angeles region, 224 - Geologic and geotechnical parameters affecting ground response, 226 - Comparing ground response with geologic factors, $233 \bullet$ Clustering sites to reflect ground-response variability, 236 • Predicting geographic variation in ground response, $241 \cdot$ Validity and limitations of technique, 246

\section{PREDICTING EARTHQUAKE GROUND-MOTION TIME-HISTORIES $\mathbf{2 4 9}$}

\section{P. A. Spudich and S. H. Hartzell}

The earthquake rupture process, 249 $\bullet$ How ground motions are simulated, 252 - Mathematical details, 254 - Green's functions and their approximation, $\mathbf{2 5 5} \bullet$ Detailed example of ground-motion simulation, $\mathbf{2 6 0}$

\section{EARTHQUAKE-TRIGGERED GROUND FAILURE}

EVALUATING LIQUEFACTION POTENTIAL $\mathbf{2 6 3}$

J. C. Tinsley, T. L. Youd, D. M. Perkins, and A. T. F. Chen

Liquefaction and resulting ground failure, 266 • Method for evaluating liquefaction potential, 267 Mapping liquefaction susceptibility, 268 $\bullet$ Liquefaction susceptibility in the Los Angeles region, 276 - Determining liquefaction opportunity, 297 - Liquefaction potential maps and their limitations, 314

PREDICTING AREAL LIMITS OF EARTHQUAKE-INDUCED LANDSLIDING $\mathbf{3 1 7}$

R. C. Wilson and D. K. Keefer

Landslides in historical earthquakes worldwide, 319 - Examples of landslides in California earthquakes, 323 - Numerical models for earthquake-induced landslides, 327 - Severity of shaking as a function of magnitude and distance, 332 • Predicting the limits of landsliding from an earthquake, 335 • A hypothetical site evaluation, 338

\section{EARTHQUAKE-RELATED PHENOMENA OFFSHORE}

IDENTIFYING POTENTIALLY ACTIVE FAULTS AND UNSTABLE SLOPES OFFSHORE 347

S. H. Clarke, Jr., H. G. Greene, and M. P. Kennedy

Acquiring and interpreting marine geophysical data, 350 • Potential geologic hazards in the offshore Los Angeles region, $\mathbf{3 5 7}$

\section{Contents}


EVALUATING TSUNAMI POTENTIAL 375

D. S. McCulloch

Tsunami generation and propagation, $376 \bullet$ California tsunami history, $387 \bullet$ Tsunami potential in coastal southern California, 392 • Tsunami hazard reduction, $402 \cdot$ California tsunamis from 1812 to 1975,409

\section{APPLICATIONS}

PREDICTED GEOLOGIC AND SEISMOLOGIC EFFECTS OF A POSTULATED MAGNITUDE 6.5 EARTHQUAKE ALONG THE NORTHERN PART OF THE NEWPORT-INGLEWOOD ZONE $\mathbf{4 1 5}$

J. I. Ziony, J. F. Evernden, T. E. Fumal, E. L. Harp, S. H. Hartzell, W. B. Joyner, D. K. Keefer, P. A. Spudich, J. C. Tinsley, R. F. Yerkes, and T. L. Youd

Geology of the demonstration area, 415 - The postulated earthquake, 417 • Surface faulting and deformation, $\mathbf{4 1 9} \cdot$ Seismic intensities, 420 . Horizontal acceleration, velocity, and response spectral values, $\mathbf{4 2 3} \bullet$ Timehistories of ground motion, $430 \bullet$ Liquefaction-related ground failure, 434 $\bullet$ Landsliding, $436 \bullet$ Other effects, 441

USING EARTH-SCIENCE INFORMATION FOR EARTHQUAKE HAZARD REDUCTION $\mathbf{4 4 3}$

W. J. Kockelman

Anticipating damage to critical facilities, $\mathbf{4 4 3}$ - Adopting seismic safety plans, 449 • Retrofitting highway bridges, 454 $\bullet$ Regulating development in potential surface fault rupture areas, 457 - Strengthening or removing unsafe masonry buildings, $461 \cdot$ Other examples, 465

\section{REFERENCES CITED 471}

\section{PHOTOGRAPH CREDITS}

p.42, aerial view northwestward along the San Andreas fault near San Bernardino (D. M. Morton, USGS); p. 100, aerial view above Pomona northeastward along eastern San Gabriel Mountains and part of upper Santa Ana River basin (D. M. Morton, USGS); p. 126, determining seismic velocities of near-surface geologic materials by using a truck-mounted recording system (L. J. Hwang, USGS); p. 150, computer-generated map showing Modified Mercalli intensities for 1952 Kern County earthquake (U.S. Geological Survey Professional Paper 1223); p. 248, San Onofre Nuclear Generating Station (J. I. Ziony, USGS); p. 316, landslide triggered by 1971 San Fernando earthquake on western side of Golden State Freeway (J. I. Ziony, USGS); p. 374, damage to railroad in Seward, Alaska, from tsunami waves generated by 1964 Alaska earthquake (U.S. Coast and Geodetic Survey, now the National Ocean Survey); p. 470, Olive View Hospital after 1971 San Fernando earthquake (Reuben Kachadoorian, USGS). 


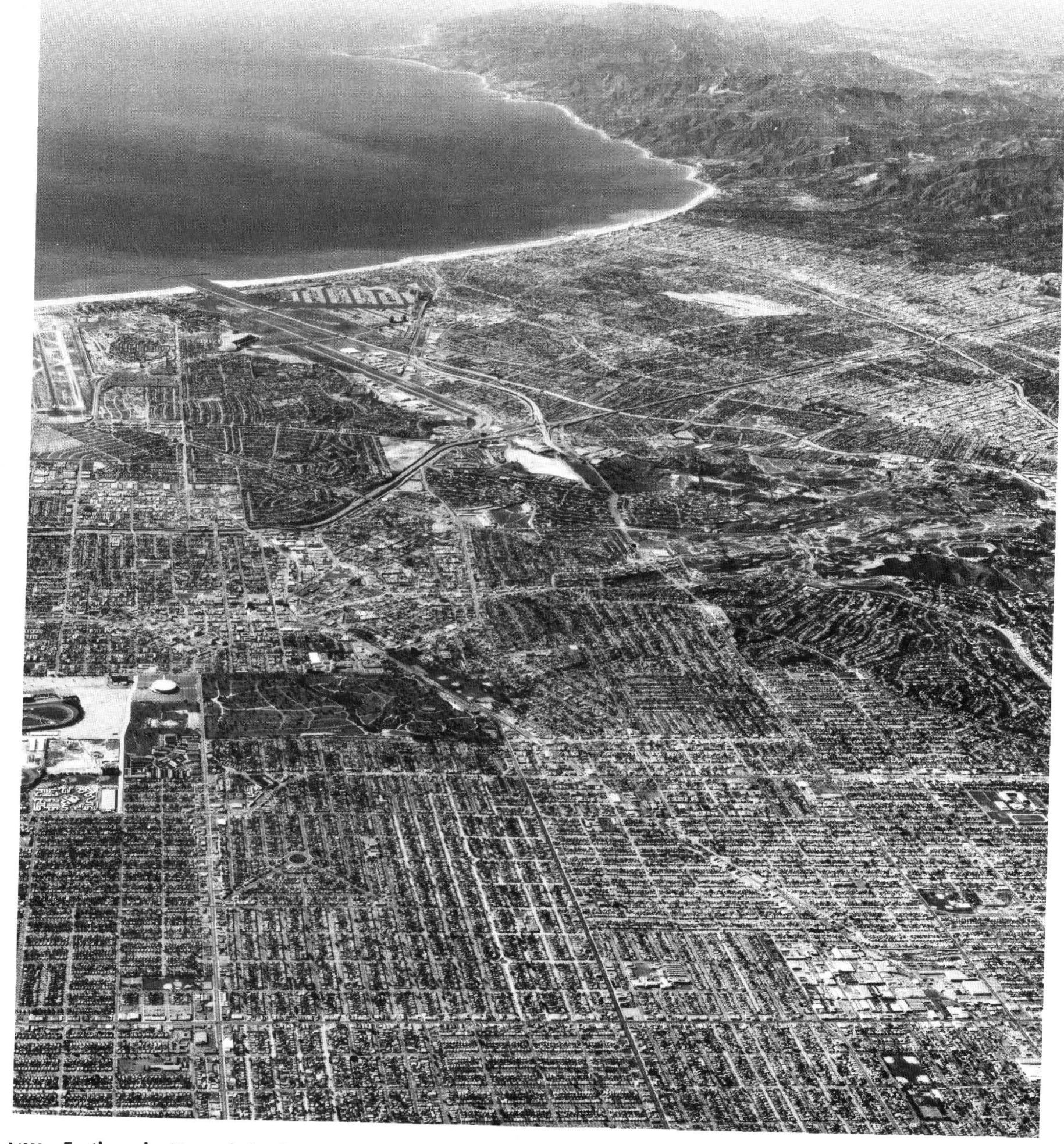

VIII Earthquake Hazards in the Los Angeles Region 


\title{
Evaluating Earthquake Hazards in the Los Angeles Region- An Earth-Science Perspective
}

\begin{abstract}
Potentially destructive earthquakes are inevitable in the Los Angeles region of California, but hazards prediction can provide a basis for reducing damage and loss. This volume identifies the principal geologically controlled earthquake hazards of the region (surface faulting, strong shaking, ground failure, and tsunamis), summarizes methods for characterizing their extent and severity, and suggests opportunities for their reduction.

Two systems of active faults generate earthquakes in the Los Angeles region: northwest-trending, chiefly horizontal-slip faults, such as the San Andreas, and west-trending, chiefly vertical-slip faults, such as those of the Transverse Ranges. Faults in these two systems have produced more than 40 damaging earthquakes since 1800. Ninety-five faults have slipped in late Quaternary time (approximately the past $750,000 \mathrm{yr}$ ) and are judged capable of generating future moderate to large earthquakes and displacing the ground surface. Average rates of late Quaternary slip or separation along these faults provide an index of their relative activity. The San Andreas and San Jacinto faults have slip rates measured in tens of millimeters per year, but most other faults have rates of about $1 \mathrm{~mm} / \mathrm{yr}$ or less. Intermediate rates of as much as $6 \mathrm{~mm} / \mathrm{yr}$ characterize a belt of Transverse Ranges faults that extends from near Santa Barbara to near San Bernardino. The dimensions of late Quaternary faults provide a basis for estimating the maximum sizes of likely future earthquakes in the Los Angeles region: moment magnitude $(M) 8$ for the San Andreas, $M 7$ for the other northwest-trending elements of that fault system, and $\boldsymbol{M} 7.5$ for the Transverse Ranges faults. Geologic and seismologic evidence along these faults, however, suggests that, for planning and designing noncritical facilities, appropriate sizes would be $M \mathbf{8}$ for the San Andreas, $M 7$ for the San Jacinto, M 6.5 for other northwest-trending faults, and $\mathbf{M} 6.5$ to 7 for the Transverse Ranges faults. The geologic and seismologic record indicates that parts of the San An-

dreas and San Jacinto faults have generated major earthquakes having recurrence intervals of several tens to a few hundred years. In contrast, the geologic evidence at points along other active faults suggests recurrence intervals measured in many hundreds to several thousands of years. The distribution and character of late Quaternary surface faulting permit estimation of the likely location, style, and amount of future surface displacements.

An extensive body of geologic and geotechnical information is used to evaluate areal differences in future levels of shaking. Bedrock and alluvial deposits are differentiated according to the physical properties that control shaking response; maps of these properties are prepared by analyzing existing geologic and soils maps, the geomorphology of surficial units, and geotechnical data obtained from boreholes. The shear-wave velocities of near-surface geologic units must be estimated for some methods of evaluating shaking potential. Regional-scale maps of highly generalized shearwave velocity groups, based on the age and texture of exposed geologic units and on a simple two-dimensional model of Quaternary sediment distribution, provide a first approximation of the areal variability in shaking response. More accurate depictions of near-surface shear-wave velocity useful for predicting ground-motion parameters take into account the thickness of the Quaternary deposits, vertical variations in sediment type, and the correlation of shear-wave velocity with standard penetration resistance of different sediments. A map of the upper Santa Ana River basin showing shear-wave velocities to depths equal to one-quarter wavelength of a 1-s shear wave demonstrates the threedimensional mapping procedure.

Four methods for predicting the distribution and strength of shaking from future earthquakes are presented. These techniques use different measures of strong-motion severity: seismic intensities, peak horizon-
\end{abstract}

Abstract IX 
tal acceleration and velocity (or response spectral values), amplification factors relative to ground motion on bedrock, and time-histories of ground motion.

Maps of predicted seismic intensities for the Los Angeles region are useful for emergency-preparedness planning and for estimating losses from future earthquakes. A computer-based technique for predicting earthquake intensities incorporates (1) a numerical model of the earthquake source, (2) a mathematical expression for the rate of attenuation in the crust of the region, (3) an empirical correlation of geologic ground conditions with differences of expected intensity, and (4) a digitized map of geologic ground conditions for the area studied. Comparison of observed intensities from the 1971 San Fernando earthquake with strong-motion records indicates that intensity correlates directly with expected levels of shaking from 0.5 to $3 \mathrm{~Hz}$ (periods of approximately 0.3-2 s), frequencies of concern to ordinary structures. Example applications of the predictive method to the Los Angeles region include predicting intensities for a postulated great earthquake on the San Andreas fault; calculating cumulative maximum intensities for a suite of 87 postulated earthquakes representative of the principal potentially active faults; deducing the likely fault sources for the earthquakes of 1812 from candidate predicted intensity maps; and mapping the estimated root-mean-square acceleration for a potential Los Angeles basin earthquake. The technique of pre dicting intensities can be extended to estimate losses from future earthquakes by incorporating empirical correlations between observed intensities and percentage of damage experienced by various types of structures. A comparison of predicted losses to wood-frame structures for possible earthquakes shows that a moderatesize earthquake in the Los Angeles basin would cause a much higher loss than a great earthquake on the San Andreas fault.

Predictive mapping of peak horizontal acceleration and velocity and of horizontal response spectral values provides an appraisal of areal shaking potential that is useful for engineering design and building codes. The technique relies on equations derived from regression analyses of an extensive set of strong-motion records. These equations link the ground-motion parameters to earthquake magnitude, source distance, and site conditions. The site effect can be expressed in terms of the shear-wave velocities of near-surface geologic materials. Thus, predictive maps of ground-motion values for a single postulated earthquake can be made by applying the predictive equations and taking into account the areal differences in shear-wave velocities. The uncertainty associated with the frequency of occurrence and the size of future earthquakes from multiple potential sources can be evaluated by means of a newly devel-

\section{$x$ Earthquake Hazards in the Los Angeles Region}

oped approach that uses fault-slip rates to compute the ground motion that will be exceeded at a specified annual probability. Predictive maps for the upper Santa Ana River basin made by using this method show the areal distribution of ground-motion values exceeded at a return period of $500 \mathrm{yr}$ for future large earthquakes on the San Andreas, San Jacinto, and Cucamonga faults.

Areal variations in shaking potential are also estimated by comparing measurements of ground motions from distant underground nuclear explosions recorded at 98 sites in the Los Angeles region. Because local ground response from these low-strain signals correctly predicts ground-motion amplification for higher strain levels caused by nearby large earthquakes, the data provide a way of assigning amplification factors relative to shaking on crystalline bedrock. At periods less than $0.5 \mathrm{~s}$, the most pronounced differences in observed site responses correlate with differences in sediment void ratios, thicknesses of surficial deposits, and depths to basement rocks; resonant effects having large amplifications over narrow frequency bands are observed for sites underlain by Holocene deposits 10 to $20 \mathrm{~m}$ thick. At periods greater than $0.5 \mathrm{~s}$, the most important geologic factors are depth to basement rocks and thickness of Quaternary sediments. When recorded motions are compared with what is known about geologic conditions at each site, the principal factors that affect amplification can be grouped, and distinctive types of sites can be identified through cluster analysis. These site types then become the basis for predictive mapping of relative shaking response. To demonstrate the mapping procedure, the areal distribution of expected amplification factors for part of the Los Angeles basin is shown for three period bands (3.3-10, 0.5-3.3, and $0.2-0.5 \mathrm{~s})$; locally, the spectral amplification is predicted to be as much as $6 \frac{1 / 2}{2}$ times greater than the shaking levels on crystalline bedrock.

Earthquake-resistant design of critical structures commonly requires elaborate estimates of the characteristics of ground motion at a particular site. Timehistories of ground motion from postulated earthquakes are predicted by estimating how each point on a slipping fault will be displaced, determining the ground motions caused by each point, and then summing the groundmotion contributions from all points to obtain the total motion at a given distant site. The method depends on assumptions concerning the detailed character of the expected rupture propagation and the velocity structure of the Earth's crust in the region analyzed. The timehistory of ground motion caused by slip of a single point on a fault is called a Green's function. Green's functions can be determined theoretically by solving the wave equation in a model of the crust, or they may be obtained empirically by using recordings of small earthquakes in 
the desired crustal structure. Economical methods of computing Green's functions by using simplifying assumptions are reviewed.

Secondary geologic effects such as liquefaction within the alluvial basins and landsliding within the upland areas can be expected as a result of strong shaking during future earthquakes. Liquefaction potential is evaluated by preparing two types of maps-one showing the susceptibility of sediment to liquefy with shaking and the other expressing the probabilities that critical levels of shaking needed for liquefaction will be attained. Areas of susceptible sediments are delineated by analyzing the physical properties of the late Quaternary alluvial deposits, grouping these deposits according to their probable content of cohesionless sand or silt, and determining whether they are saturated with ground water at depths of less than about $15 \mathrm{~m}$. Holocene sand and silt, especially if deposited during the past few hundred years, are the most susceptible to liquefactionrelated ground failure; these materials are mapped on the basis of soil-profile development, geomorphic expression, and geotechnical properties such as standard penetration resistance. Areas of the Los Angeles region deemed most vulnerable to liquefaction during future earthquakes include the flood plains of the Los Angeles, Santa Ana, and San Gabriel Rivers; parts of the San Fernando Valley and the Oxnard Plain; coastal and harbor areas of Long Beach and Marina Del Rey; and floodcontrol basins. The opportunity for liquefaction at a site containing susceptible sediments can be estimated by considering the earthquake potential and applying an empirically determined relation between earthquake magnitude and the limiting distances for liquefactionrelated ground failure. Regional liquefaction opportunity is mapped by summing, for points on a map, the expected annual rates of occurrence of earthquakes of $\boldsymbol{M} 5$ or greater from those fault sources that influence each point. Individual sites will experience ground shaking strong enough to cause liquefaction in susceptible sediment on an average of once every 30 to $50 \mathrm{yr}$.

The extent and severity of future earthquake-induced slope failure can be fully evaluated only when detailed information about the geologic and topographic controls on slope stability is available. Although such information is not yet complete for the Los Angeles region, a twofold approach has been developed to assess the areal limits of earthquake-triggered landslides for postulated earthquakes of specified size. The maximum distances from an earthquake source at which various classes of landslides can occur (given susceptible slopes) are estimated on the basis of worldwide data for historical earthquakes that have triggered landslides. The probability distribution of threshold levels of shaking capable of triggering slope failure can then be mapped by extending the Newmark method of slope-stability analysis; the procedure depends on newly established correlations between earthquake magnitude, critical displacement of a slope, and intensity of shaking for a given earthquake-source distance. The likelihood of slope failures from a postulated earthquake is evaluated for a sample site in the Santa Monica Mountains.

Faults and zones of potential slope instability on the sea floor off the Los Angeles region have been identified and evaluated by means of specialized remote-sensing methods. Acoustic reflection profiles reveal those faults that offset Quaternary sediments of the sea floor and also show potentially unstable slopes on which subaqueous sediment slides, mass flows, and gas-charged sediments occur. A regional analysis of these profiles indicates offshore counterparts to the onshore faults of the San Andreas system and the Transverse Ranges. Many of these offshore faults may generate moderate to large earthquakes and offset the sea floor. Scattered zones of sea-floor sliding as large as $60 \mathrm{~km}^{2}$ are mapped along the outer edge of the Santa Monica and San Pedro shelves and cover several hundred square kilometers in the central Santa Barbara Basin. Furthermore, potentially unstable gas-charged sediments apparently are widespread in the Santa Monica and San Pedro Basins. Some zones of sea-floor instability could fail during shaking caused by nearby large earthquakes.

Tsunamis are a threat to coastal areas, although the hazard in the Los Angeles region is much less than that in many other regions along the circum-Pacific border. A number of methods for predicting tsunami wave heights and frequency of occurrence from both distant and local sources are summarized. Predictive models for distantly generated tsunamis indicate that wave heights of $2 \mathrm{~m}$ are exceeded on the average of once every $500 \mathrm{yr}$, except locally along Santa Monica and San Pedro Bays and near Ventura, where wave heights of $3 \mathrm{~m}$ are exceeded on the average of once every $500 \mathrm{yr}$. A preliminary appraisal of the potential for locally generated tsunamis suggests that wave runup heights as great as 4 to $6 \mathrm{~m}$ could be caused by sea-floor faulting in the Santa Barbara Channel; wave runup heights no greater than 2 to $3 \mathrm{~m}$ are estimated for the dominantly strike-slip faults farther south. Earthquake-triggered sea-floor slides having the dimensions observed in the offshore region are unlikely to cause tsunamis.

To demonstrate the various hazard-evaluation methods discussed in this volume, the geologically controlled effects expected from a postulated $M$ 6.5 earthquake along the northern part of the Newport-Inglewood fault zone are evaluated. Predicted effects include:

1. Secondary faulting (normal-oblique slip) at the ground surface along one or more late Quater-

Abstract XI 
nary faults exposed in the Baldwin and Rosecrans Hills and possible subsurface slip along reverse faults at the northern end of the Dominguez Hills.

2. Shaking intensities of Modified Mercalli intensity VII distributed widely throughout the Los Angeles basin and the San Fernando Valley and scattered areas of intensity VIII as far as $18 \mathrm{~km}$ from the main fault.

3. Strong shaking lasting about 10 to $15 \mathrm{~s}$. Peak groundmotion values of about $0.4 \mathrm{~g}$ acceleration, 90 to $100 \mathrm{~cm} / \mathrm{s}$ velocity, $1.2 \mathrm{~g}$ pseudoacceleration response, and 160 to $180 \mathrm{~cm} / \mathrm{s}$ pseudovelocity response near the earthquake source zone. Peak ground-velocity values at the northwestern end of the fault zone will be higher than those at the southeastern end if the subsurface tectonic rupture propagates northwestward from the postulated epicenter.

4. Liquefaction in highly susceptible, water-saturated, cohesionless Holocene alluvial sediments as much as $18 \mathrm{~km}$ from the earthquake source zone.
5. Rock or soil falls and slides, the most common earthquake-triggered slope failures, occurring chiefly in upland areas within about $40 \mathrm{~km}$ of the earthquake source zone.

6. Minor harmonic waves (seiches) in enclosed small bodies of water.

Earth-science information can be used by planners, engineers, and decisionmakers to solve specific earthquake-related problems in southern California. Examples of the geologic and seismologic information used and the actions taken to reduce the hazard are discussed for the problems of anticipating damage to critical facilities, adopting seismic safety plans, strengthening highway bridges, regulating development in areas of potential surface faulting, and strengthening or removing unsafe masonry buildings. Effective measures for reducing future earthquake losses can result if adequate scientific data and interpretations are available and are thoughtfully applied by engineers, planners, and others responsible for public safety. 


\section{INTRODUCTION}

\section{By J. I. Ziony and W. J. Kockelman}

\section{THE EARTHQUAKE THREAT}

In July 1769, a Spanish expedition led by Captain Gaspar de Portola, civil and military governor of the province of Mexico, marched northward from San Diego and became the first documented group of Europeans to set foot on the plain near Los Angeles (Bancroft, 1884, p. 146):

... on the 28th, when the governor and his followers were on the Santa Ana River, four violent shocks of earthquake frightened the Indians into a kind of prayer to the four winds, and caused the stream to be named also Jesus de los Temblores. Many more shocks were felt during the following week; yet the foreigners were delighted with the region, noting the agricultural possibilities ....

This seismologic "greeting" introduced the newcomers to a distinctive feature of the Earth's crust in the Los Angeles region of California-the sporadic occurrence of strong earthquakes. Earthquakes at first were of little concern, but their occurrence became more significant as the Spanish proceeded to build missions and settle the region. The year 1812, recorded as "el año de los temblores" in mission archives, was marked by two major earthquakes that killed at least 40 people and severely damaged coastal missions from near Dana Point to near Point Arguello and others as far inland as the San Fernando and San Gabriel valleys. Many of the more than 40 additional strong earthquakes that have shaken parts of the region since 1812 have resulted in loss of life and property (table 1). We now know that similar earthquakes will occur as the inevitable result of the ongoing dynamic crustal processes characteristic of the region.

Today the Los Angeles region (fig. 1) is inhabited by more than 11 million people and is one of the key industrial, commercial, and cultural centers of the United States. As its population and development expand, so does its vulnerability to destructive earthquakes. The 1971 San Fernando earthquake, a moderate-sized event whose epicenter was on the margin of the Los Angeles metropolitan area, dramatically demonstrated how vulnerable a complex modern urban society is to the damaging effects of nearby earthquakes (fig. 2).

Even though the losses shown in table 1 are significant, they do not accurately reflect the actual risk to the Los Angeles region. Many of the damaging earthquakes listed in the table preceded major development in southern California, and none was as strong as the largest magnitude possible in the region. A recent assessment of the earthquake hazards in California (Federal Emergency Management Agency, 1980) concludes that catastrophic earthquakes are inevitable in the Los Angeles region. The probability that a large earthquake will occur sometime during the next $30 \mathrm{yr}$ along the San Andreas fault near Los Angeles is currently estimated to be 40 percent or greater (Lindh, 1983; Wesson and Wallace, 1985). Projected losses of billions of dollars and estimated casualties of tens of thousands (table 2) would surpass the results of any previous natural disaster in the United States. A catastrophic earthquake would severely strain the emergency-response and recovery capabilities of Federal, State, and local governments and profoundly impact the economies of the State and the Nation.

Earthquakes of sufficient size threaten lives and damage property by setting off a chain of effects that disrupts the natural and manmade environments. Widespread strong ground shaking is a geologic effect that can cause buildings to distort or fail. Vibratory earthquake motion, in turn, can induce secondary geologic effects such as liquefaction, landsliding, and related ground failure hazardous to structures or can generate sudden fluctuations of water levels in lakes, reservoirs, and wells. Some earthquakes are accompanied by permanent offset or distortion of the ground surface that can rupture or warp structures. Rare large surface displacements occurring within the marine environment can trigger seismic sea waves (tsunamis) that may damage coastal facilities thousands of miles from the earthquake source. Primary and secondary geologic ef fects that cause exceptionally severe damage to structures or lifelines may result in major nongeologic effects 


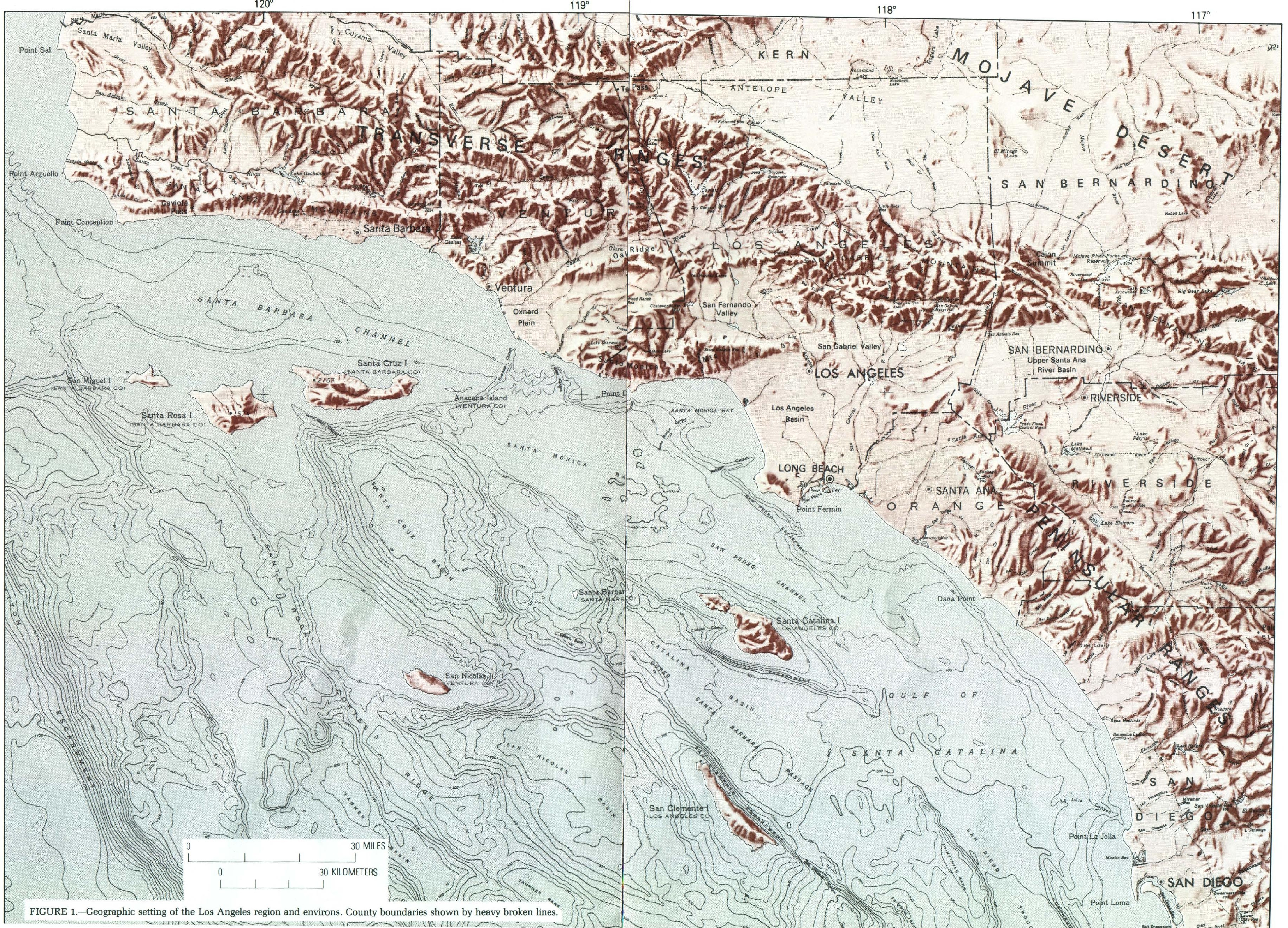


TABLE 1.-Losses from southern California earthquakes, 1812-1979, in which lives were lost or damage was known to have equaled or exceeded $\$ 100,000$

[Modified from U.S. Geological Survey (1981, table 1). NA, data not available]

\begin{tabular}{|c|c|c|}
\hline Location & Lives lost & $\begin{array}{l}\text { Dollar loss at } \\
\text { time of quake }\end{array}$ \\
\hline $1812-----$ San Juan Capistrano & 40 & NA \\
\hline $1899-----$ San Jacinto & 6 & NA \\
\hline 1915 ------ Imperial Valley & 6 & 900,000 \\
\hline $1918-----$ San Jacinto and Hemet & 0 & 200,000 \\
\hline 1925 ------ Santa Barbara & 13 & $8,000,000$ \\
\hline $1926------$ Santa Barbara & 1 & NA \\
\hline $1933-----$ Long Beach & 115 & $40,000,000$ \\
\hline $1940------$ Imperial Valley & 9 & $6,000,000$ \\
\hline 1941 ----- Santa Barbara & 0 & 100,000 \\
\hline 1941 ------ Torrance and Gardena & 0 & $1,100,000$ \\
\hline 1949 ------ Terminal Island & $\mathbf{0}$ & $9,000,000^{1}$ \\
\hline 1951 ------ Terminal Island & $\mathbf{0}$ & $3,000,000^{1}$ \\
\hline $1952-----$ Kern County & 14 & $60,000,000$ \\
\hline 1955 ------ Terminal Island & $\mathbf{0}$ & $3,000,000^{1}$ \\
\hline $1961-----$ Terminal Island & $\mathbf{0}$ & $4,500,000^{1}$ \\
\hline $1971------$ San Fernando & 65 & $504,950,000$ \\
\hline 1978 - - - Santa Barbara & 0 & $12,000,000$ \\
\hline 1979 ------ Imperial Valley & $\mathbf{0}$ & $30,000,000$ \\
\hline
\end{tabular}

'Subsurface damage to oil wells; no damage to surface structures reported. Earthquakes may have been triggered by oilfield operations.

(widespread fires, flooding of populated areas caused by failure of large dams, or release of toxic or radioactive materials) that could be more catastrophic than the initial effects of the earthquake. A more complete, nontechnical explanation of the various hazards posed by earthquakes has been presented by Blair and Spangle (1979).

Because the hazards to life and property resulting from the primary and secondary effects of earthquakes may vary substantially throughout a region, measures to reduce earthquake hazards must necessarily begin by delineating geographic areas having different potentials for fault offset or distortion of the land surface, strong ground shaking, ground failure, or other geologically controlled effects. This volume presents methods for characterizing these types of earthquake hazards on a regional scale and provides earth-science information vital to actions that could be taken in the Los Angeles region to reduce future earthquake losses.

\section{PURPOSE AND CONTENT OF THIS VOLUME}

The Los Angeles region became a major focus for seismic hazard research following the 1971 San Fernando earthquake, which stimulated national interest in earthquakes and expanded the resources available for earthquake studies. Earthquake prediction-the specifi-
TABLE 2.-Estimated losses in Los Angeles and Orange Counties from two postulated large earthquakes

[Losses from the failure of dams and transportation or communication systems and consequential losses such as unemployment and other economic impacts excluded. Summarized from Federal Emergency Management Agency (1980) and Steinbrugge and others (1981). Uncertainties associated with lossestimation procedures suggest that actual losses to buildings could vary upward or downward by a factor of as much as two to three]

\begin{tabular}{|c|c|c|}
\hline & \multicolumn{2}{|c|}{ Postulated earthquake } \\
\hline & $\begin{array}{l}\text { Magnitude } 8.3 \\
\text { on San Andreas } \\
\text { fault }\end{array}$ & $\begin{array}{c}\text { Magnitude } 7.5 \\
\text { on Newport-Inglewood } \\
\text { zone }\end{array}$ \\
\hline Deaths ---------------- & $-3,000-12,500^{1}$ & $4,400-21,000^{1}$ \\
\hline Hospitalized injured------- & $-12,000-50,000^{1}$ & $17,600-84,000^{1}$ \\
\hline Long-term homeless------ & $-------52,000$ & 192,000 \\
\hline $\begin{array}{l}\text { Damage to buildings and-- } \\
\text { contents (in billions of } \\
1980 \text { dollars). }\end{array}$ & -----------25 & 62 \\
\hline
\end{tabular}

\footnotetext{
${ }^{1}$ Depending on tirne of day.
}

cation of the time, place, and magnitude of an impending earthquake-is one goal of this research. Thus, some efforts have centered on monitoring the Earth's crust with a variety of instruments to detect possible fluctuations in geophysical signals that might foreshadow a major imminent southern California earthquake and permit its prediction within a time frame of a few days, weeks, or months. Progress toward short-term prediction has been slower than scientists had hoped, but there has been substantial progress in making long-term earthquake predictions (for example, determining the probability during the next several decades of a future large earthquake on the San Andreas fault) and in better understanding how earthquakes occur (Wesson and Wallace, 1985). Earthquake hazard assessment-the specification of the potential for destructive effects of future earthquakes-is another goal. Truly remarkable progress has been made on the earth-science aspects of this subject, as evidenced by the findings presented in this volume.

All strategies for reducing future losses from earthquakes rely on the ability to predict the geographic distribution and severity of the potentially damaging geologic and seismologic effects that commonly accompany major earthquakes-strong shaking, fault offset of the land surface, and disruption of the ground by liquefaction or landsliding. These hazards are the topics of the following chapters.

This professional paper provides an overview of the principal geologically controlled earthquake hazards in the Los Angeles region and summarizes the methods that earth scientists use to evaluate and characterize those hazards. Although the volume was initially planned to address the general public as well as earth- 
quake experts and researchers in related fields, this goal has been only partially achieved because of the complexity of the scientific problems associated with many of the hazards and the diversity of the potential audience. Most of the chapters emphasize the scientific bases for mapping and assessing geologically controlled earthquake hazards and thus will be of greatest interest to geologists and seismologists. Some chapters treating hazard-reduction issues have been written to be understood by planners, engineers, and decisionmakers who need to use earth-science information in specific situations to reduce those hazards. Our hope is that all readers, whatever their background or expertise, will gain a better understanding of the earthquake hazards facing the Los Angeles region and of the opportunities for reducing the risk to life and property.

A glossary (p. 15) containing the principal technical terms used in this volume will assist the nonspecialist. A table for converting from metric to English units of measure is on p. 23.

Most of the earth-science research summarized in this report has been conducted by scientists and engineers of the U.S. Geological Survey, the California Division of Mines and Geology, various universities, and private consulting firms, chiefly using funds provided by the Earthquake Hazards Reduction Program of the Geological Survey. Research activities have included detailed geologic and seismologic studies of faults, investigations of the factors that influence seismic shaking, and analysis of the geotechnical controls on liquefaction and landsliding. Many of the methods described in the following chapters have evolved from hazard-evaluation techniques first developed in a multidisciplinary study of seismic zonation in the San Francisco Bay region (Borcherdt, 1975), where the resulting earth-science products have been successfully used to reduce hazards. The studies in both the San Francisco Bay and the Los Angeles regions have significantly improved our ability to predict and map the geologic effects of future earthquakes. Because knowledge of the behavior of faults during late Quaternary time and of the distribution and character of sediments deposited during that time span is crucial to evaluating earthquake hazards, these topics have received special attention. Subdivisions of Quaternary time as used in this volume are shown on the accompanying geologic time chart (inside front cover).

This volume examines in sequence the causes of earthquakes in the Los Angeles region, the major geologic hazards likely to be associated with future earthquakes and the methods for evaluating and mapping those hazards, and examples of the impact of earthscience information on the decisionmaking processes that result in hazard reduction. The geologic factors that control the location and size of earthquakes and their rupture characteristics are evaluated in two chapters that describe:

- The plate-tectonic framework within which earthquakes occur in the Los Angeles region (Yerkes, p. 25).

- The identification of active faults, their potential for generating earthquakes and rupturing or distorting the land surface, and estimates of the likely size and frequency of major earthquakes along them (Ziony and Yerkes, p. 43).

Strong shaking, the chief threat posed by an earthquake because of the large area commonly affected, receives particular attention in seven chapters describing different aspects of that hazard:

- An introduction to available methods of predicting the extent and severity of strong shaking and the applicability of different predictive techniques to reducing earthquake hazards (Borcherdt, p. 93).

- How the late Quaternary sedimentary deposits of alluvial basins are differentiated and mapped to help characterize variations in the severity of future shaking (Tinsley and Fumal, p. 101).

- A technique for regrouping geologic units on the basis of their geotechnical properties and shearwave velocities for prediction of future shaking levels (Fumal and Tinsley, p. 127).

- Why it is useful to predict seismic intensities, how maps of predicted intensities are prepared for postulated earthquakes, and how these techniques can be applied to estimating future losses from earthquakes (Evernden and Thomson, p. 151).

- The quantitative prediction of ground-motion values by applying newly developed equations that link peak acceleration, peak velocity, and response spectra to earthquake magnitude, geologically determined fault slip rates, and site geology (Joyner and Fumal, p. 203).

- The use of ground motions from nuclear explosions in Nevada, recorded in the Los Angeles region, combined with geologic information obtained during the course of urban development, to map the relative shaking response expected for areas having different geologic characteristics (Rogers and others, p. 221).

- The methods for simulating numerically the timehistory of ground motion at a site from a postulated earthquake, information needed by structural engineers for the earthquake-resistant design of special facilities such as large dams and nuclear powerplants (Spudich and Hartzell, p. 249). 

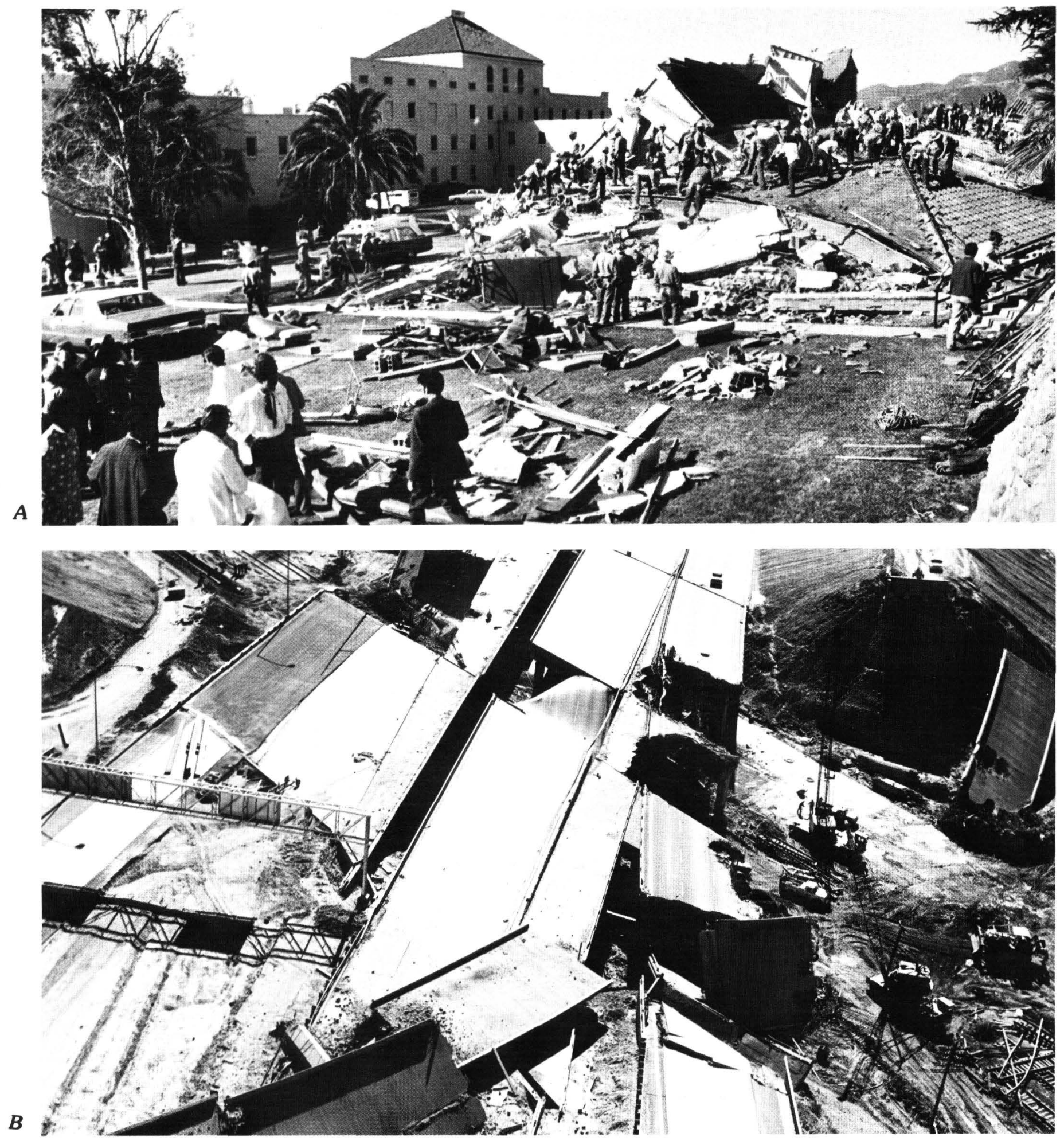

FIGURE 2.-The 1971 San Fernando earthquake demonstrated the vulnerability of a modern urban society to the damaging effects of a nearby earthquake. A, Damage at the Veterans Administration Hospital resulted in 47 deaths. Collapsed buildings were constructed in 1926, before earthquake-resistant design was required. The building at the left, constructed after 1933 and designed to resist strong shaking, did not sustain significant structural damage. (Photograph copyright 1971 by The Los Angeles Times.) B, Collapsed highway overpasses and bridges at the interchange of the Foothill and Golden State freeways. Because the earthquake occurred early in the morning, only three deaths resulted from this damage. However, the principal highway link between northern and southern California was temporarily cut, and traffic had to be rerouted for several months. (Photograph by R. E. Wallace, U.S. Geological Survey.) C, Overturned equipment at the Sylmar electrical converter station. Power distribution to more than 600,000 customers in southern California was disrupted because of widespread damage to electrical power facilities. (Photograph by T. L. Youd, U.S. Geological Survey.) D, The Lower Van Norman Dam, overlooking the heavily populated San Fernando Valley, was damaged nearly to catastrophic failure when part of the hydraulic-fill embankment and the concrete lining slid into the reservoir. About 80,000 people living downstream from the dam had to be evacuated as a precautionary measure. (Photograph by J. I. Ziony, U.S. Geological Survey.) 

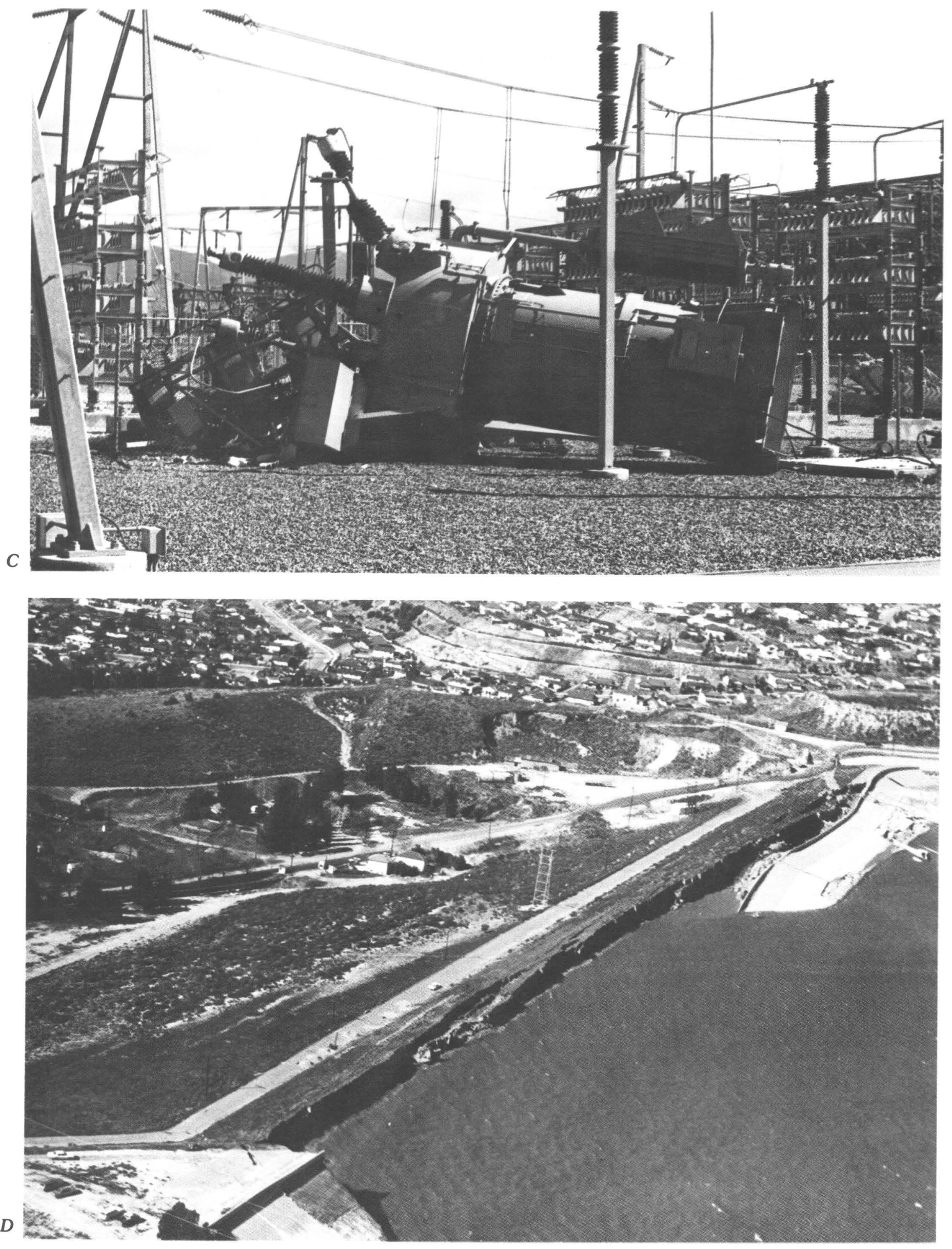
Strong shaking from major earthquakes commonly triggers secondary geologic processes that can result in localized but severe effects. These effects are the topics of chapters describing:

- A procedure for identifying the depositional and hydrologic environments in the Los Angeles region that have a potential for liquefaction, the temporary transformation of earth materials into a liquefied state that is the chief cause of ground failure in areas of low relief during prolonged strong shaking (Tinsley and others, p. 263).

- The empirical and theoretical methods for predicting the areal limits of earthquaketriggered slope failures in upland areas (Wilson and Keefer, p. 317).

The Continental Shelf offshore of the Los Angeles region poses distinctive hazards that are important to coastal development. These hazards are discussed in two chapters describing:

- The methods for identifying both faults that could offset the sea floor and potentially unstable sea-floor slopes that might fail and the general distribution of these potential hazards (Clarke and others, p. 347).

- The character of tsunamis (seismic sea waves), methods of predicting their occurrence and severity, and an evaluation of their threat to the southern California region (McCulloch, p. 375).

A summarizing chapter demonstrates how the preceding techniques can be used to predict the diverse and widespread geologic and seismologic effects of a potential earthquake along the northern part of the NewportInglewood zone (Ziony and others, p. 415). Specific predictions concern the location and severity of ground shaking, surface faulting, liquefaction, and landsliding associated with a moderate-sized earthquake.

The final chapter (Kockelman, p. 443) illustrates how earth-science information is used to reduce earthquake hazards. It gives examples of specific earthquakerelated problems faced by planners, engineers, and decisionmakers in southern California and discusses the geologic and seismologic information used, the actions taken, and the impact of each action or decision.

\section{OPPORTUNITIES FOR REDUCING EARTHQUAKE HAZARDS}

Although earthquake damage is inevitable in the Los Angeles region, it can be reduced by adopting strategies that avoid or accommodate the potential effects of earthquakes. Some earthquake hazards, such as fault offset of the land surface, have definite areal limits and can be avoided by careful land-use planning and development. Others, such as strong ground shaking, generally cannot be avoided, and attempts must be made to design and build structures that will accommodate distortion and minimize the possibility of lifethreatening failures. Whatever strategy is selected, various levels of government, private groups, corporations, and quasi-public organizations can play important roles in reducing earthquake hazard or damage.

An environment totally free of the risk of earthquake losses cannot be created in an earthquake-prone region. Choices must be made between known or perceived risks and the expected costs of reducing them. The actions chosen for hazard reduction depend on judgments of acceptable risk (that level of exposure to loss for which no action is considered appropriate). Risks acceptable to individuals may not be considered acceptable by society. In dealing with the earthquake threat to the Los Angeles region, individual citizens must decide where to purchase homes and what measures to take to protect themselves against earthquake effects. Private firms or corporations that site and operate facilities must also make choices, as must governmental bodies that set standards for the construction of facilities important to the continuing function and safety of a modern urban society. Whatever the decisions, they should be based on an understanding of the likely hazards and how they can be reduced.

A wide range of opportunities for reducing earthquake hazards is available to planners, engineers, and decisionmakers, both public and private (see list, p. 10). Techniques such as seismic-resistant design or the strengthening of unsafe structures are well known in the engineering profession. In the planning profession, an effective technique is public acquisition of hazardous areas; other planning techniques such as regulating development or posting warnings in potentially hazardous areas are obvious and practical but require consistent enforcement. Other techniques successfully used in reducing landslide, flood, windstorm, and soil hazards could be applied to earthquakes. These techniques and others listed on p. 10 may be used in a variety of combinations to help reduce earthquake hazards.

\section{Preparing Development Studies and Plans}

Wise planning and development involve selecting the best possible location, density, and arrangement of land

\section{Earthquake Hazards in the Los Angeles Region}


uses to minimize exposure to earthquake hazards and thus reduce earthquake damage. Such planning may include project reviews, environmental assessments, and appraisals of existing hazardous buildings, transportation networks, utility systems, and critical facilities and their relation to zones of potential surface faulting or ground failure. Land-use development based on sound information about earthquake hazards and implemented over an extended period of time can be among the most effective measures for saving lives and minimizing disruptions in case of an earthquake (U.S. Office of Science and Technology Policy, 1978, p. 54). Responsibility and authority for preparing and implementing land use or development plans are usually assigned to city and county governments, but State agencies and private corporations have key responsibilities.

\section{Designing and Building Safe Structures}

Modern experience with earthquakes in urban areas shows that properly designed and constructed facilities can withstand nearby large earthquakes. Thus, one of the most effective ways to reduce the loss of life and property from earthquakes is to ensure that appropriate engineering design and material standards are followed when structures are erected. More restrictive design standards generally result in a nominal increase in construction costs; in many instances, however, a better design of the building layout or configuration may be achieved at no additional cost and in some situations may actually save money (U.S. Office of Science and Technology Policy, 1978, p. 37).

Careful supervision of construction is very important, because the best earthquake-resistant design can be compromised by poor construction practices. Some complex forms of design and construction require special training or expertise for local building officials.

\section{Discouraging New or Removing Existing Hazardous Development}

Economical methods of reducing earthquake losses include discouraging development in potentially hazardous areas by means of public-information programs, posted warnings, public recording of the hazard, special assessments, tax credits, lenders' policies, publicfacility service-area policies, and disclosure to realestate buyers. Historically, financial institutions have funded projects in areas known to be hazardous, devel- opers have built on them, and people have occupied them. Sometimes, rebuilding in the same manner and in the same location will immediately follow a disaster, and government loans or other subsidies may even be used. Therefore, government funding incentives or disincentives can be important techniques for discouraging such development.

Removal of unsafe structures is sometimes the most effective safety measure. According to the Executive Office of the President (1978, p. 12), "Most deaths and injuries in earthquakes have been caused by collapsing buildings-generally older buildings and often those made of unreinforced masonry, although some modern buildings are also vulnerable. The public's vulnerability to earthquakes over the coming years will be dominated by these existing hazardous structures."

\section{Regulating Development}

It is costly and difficult to retrofit, strengthen, remove, or convert existing structures, and it is unrealistic to assume that all future development in exceptionally hazardous areas can be discouraged. Thus, regulating development in areas susceptible to earthquake damage may be a more efficient and economical way to avoid earthquake hazards and reduce damage.

Cities and counties have the authority to prepare and implement land use and development plans in their jurisdictions. The adoption and administration of city or county zoning, subdivision, building, health, and safety ordinances are authorized or, in some cases, required by the California Legislature. The Field and Garrison acts, for example, are statewide laws passed in 1933 and 1939, respectively, requiring earthquake-resistant design, construction, and examination of certain public school buildings. Numerous programs underway at the local level include plans for strengthening or removing existing unsafe buildings.

\section{Preparing for and Responding to Disasters}

Preparedness and response planning for anticipated emergencies enable an impacted area to better cope with any disaster and hence to reduce hazards and damage. Comprehensive plans for dealing with the effects of large earthquakes are particularly important because such events are different from other disasters 


\section{Some opportunities for using geologic and seismologic information to reduce earthquake hazards}

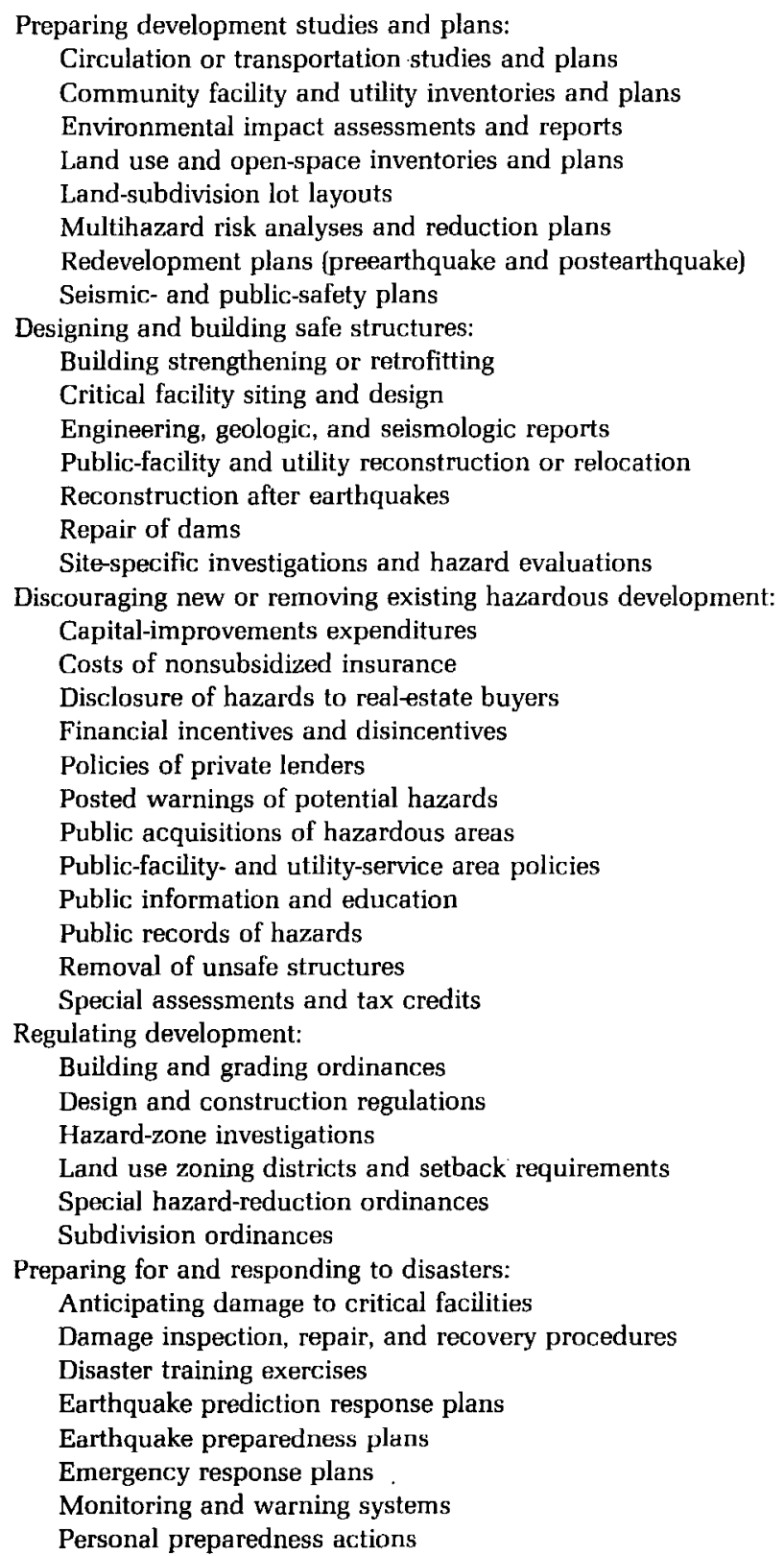

in that they are infrequent, usually unpredicted, and potentially catastrophic. Planning currently being done for the Los Angeles region under the Southern California Earthquake Preparedness Project is an excellent example of the complex efforts necessary to set up an earthquake preparedness and response system.

Personal preparedness applicable to the home, school, and place of work is a very important phase of what should be an unbroken chain of tasks extending from long-term mitigation before an earthquake through response during an earthquake to recovery and

\section{Earthquake Hazards in the Los Angeles Region}

reconstruction after an earthquake (Kockelman, 1984).

The last chapter in this volume discusses several techniques that may be used to reduce earthquake hazards. Many of the opportunities presented in the list on p. 10 have also been discussed by the U.S. Office of Science and Technology Policy (1978, p. 20-67), the California Legislature Joint Committee on Seismic Safety (1974, p. 45-180) and Blair and Spangle (1979, p. 67-78). Adequate geologic and seismologic information, similar to that discussed in the following chapters, is a prerequisite for the effective use of these opportunities. 


\section{USERS OF INFORMATION FOR REDUCING EARTHQUAKE HAZARDS}

Opportunities and responsibilities for reducing earthquake hazards reside in all segments of society. Actual and potential users of earthquake-hazard information such as that contained in this volume include many people at community, State, and national levels, both public and private. Some potential users are shown in the list on p. 12 under various general headings. Users also include scientists and engineers who use the information to resolve scientific or technical questions, planners and decisionmakers who must consider hazards in the context of other land use and development criteria, and interested citizens who must consider the likelihood of future earthquakes before making personal decisions.

Various levels of government, business, industry, and the services sector, voluntary organizations, professional societies, and special-interest groups play important roles in reducing earthquake hazards. Their contributions have been discussed in reports prepared by the U.S. Office of Science and Technology Policy (1978) and the California Legislature Joint Committee on Seismic Safety (1974). Blair and Spangle's (1979) report describing the governmental framework for reducing earthquake risk places special emphasis on California State agencies, programs, and mandates to local government.

\section{City, County, and Areawide Government Users}

City and county governments are empowered and obligated to provide for the public health, safety, and welfare of their citizens and are required by the California Legislature (1971) to prepare seismic-safety plans. The adoption and administration of city and county zoning, subdivision, building, grading, and safety ordinances are authorized or required by the California Legislature under various sections of the California Government and the Health and Safety codes. Because the principal governmental resource at the site of a disaster is usually the local government, local government agencies will of necessity be heavily involved in taking preventive actions as well as in coordinating onthe-scene response to and recovery from disasters. Local government will continue to be the primary agent for direct action in resolving seismic-safety problems (California Legislature Joint Committee on Seismic Safety, 1974, p. 31). Seismic safety can also be an integral part of the functions, programs, and plans of areawide agencies, such as the Southern California Association of Governments, and the various public-utility and school districts.

\section{Federal Government Users}

4 The Federal Government plays a crucial role in stimulating State and local governments to develop and improve their seismic-safety policies. Many direct Federal efforts to reduce risks have evolved from a national commitment to provide disaster relief to States and localities devastated by earthquakes. Federal agencies are also responsible for the seismic safety of their own facilities. In addition, the U.S. Government, through the Federal Emergency Management Agency (which leads the National Earthquake Hazards Reduction Program), formulates plans for national actions in response to catastrophic earthquakes (Schnell and Herd, 1984). These plans include large-scale preparedness for, response to, and recovery from major damage or loss of life and also may include search, rescue, and evacuation, provision for medical care, food, and shelter, police protection, and other emergency help.

\section{State Government Users}

The State of California has the ultimate non-Federal public responsibility for the health, safety, and welfare of its people. State agencies incorporate their own seismic-safety standards into their operations and also work with local governments to encourage community seismic-safety efforts. Officials in almost every California State government agency need to consider seismic safety in carrying out their duties. Blair and Spangle $(1979$, p. 24) note that the "location and construction of public facilities, management of State lands, provision of services, and delegation of powers and responsibilities to local governments should all reflect an awareness that damaging earthquakes are inevitable."

The California Legislature has led the way in defining and coordinating the State's role in reducing seismic risk. Passing the Field and Riley acts, creating the Seismic Safety Commission, requiring a seismic-safety plan for each city and county, and passing the AlquistPriolo Act requiring special studies in areas of potential surface fault rupture are some examples of the Legislature's seismic-safety actions.

\section{Other National Users}

Voluntary organizations (which provide aid to victims of disasters), national institutes, and scientific and

Introduction 11 
Some potential users of geologic and seismologic information for reducing earthquake hazards in the Los Angeles region

City, county, and areawide government users:

Building, engineering, planning, and safety departments

County boards of supervisors

Mayors and city council members

Multicity and multicounty planning, development, and preparedness agencies

Offices of emergency services o

Police, fire, and sheriff's departments

Public works departments

School districts

Southern California Association of Governments

Southern California Earthquake Preparedness Project

State government users:

Building Standards Commission

Coastal Commission

Department of General Services

Department of Housing and Community Development

Department of Insurance

Department of Real Estate

Department of Transportation

Department of Water Resources

Division of Mines and Geology

Earthquake Prediction Evaluation Council

Governor's earthquake safety councils and task forces

Legislature and legislative committees

Mining and Geology Board

National Guard

Office of Emergency Services

Office of Planning and Research

Office of the State Architect

Public Utilities Commission

Seismic Safety Commission

Federal Government users:

Army Corps of Engineers

Bureau of Land Management

Bureau of Reclamation

Congress and congressional staffs

Department of Housing and Urban Development

Department of Interior

Department of Transportation

Environmental Protection Agency

Farmers Home Administration

Federal Emergency Management Agency

Federal Housing Administration

Federal Insurance Administration

Federal Power Commission

Forest Service

General Services Administration

National Bureau of Standards

National Oceanic and Atmospheric Administration

Nuclear Regulatory Commission

Small Business Administration

Other national users:

Applied Technology Council

American Association of State Highway and Transportation Officials

American Public Works Association

American Red Cross

Association of Engineering Geologists

Association of State Geologists

Earthquake Engineering Research Institute

International Conference of Building Officials

National associations of cities, counties, and states

\section{Earthquake Hazards in the Los Angeles Region}




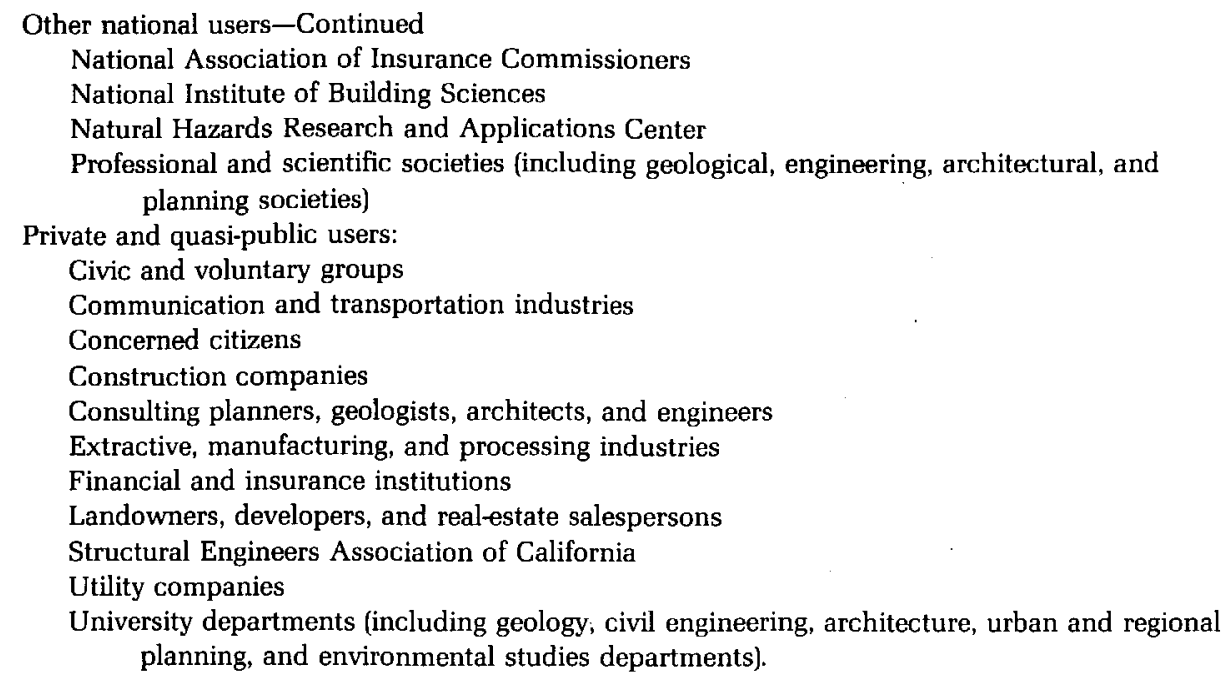

professional organizations make major and significant contributions to seismic safety. Research workers from many disciplines, including seismology, geology, earthquake engineering, and the social sciences, play a major role in reducing earthquake hazards by helping local, State, and Federal planners and decisionmakers formulate and evaluate their plans, programs, and procedures. Experts from the research community, for example, provide technical advice to special advisory groups that prepare model building codes. Scientific and professional organizations are major contributors to the worldwide exchange of information through publications and technical meetings.

\section{Private and Quasi-Public Users}

The private (including corporate) sector exercises perhaps the strongest influence on engineering design and land development in the United States. In choosing where to locate and how to construct facilities, industrial and commercial developers are sensitive to tax and other incentives offered by State and local governments, to favorable labor and retail markets, to transportation networks, and to terrain and water-resource conditions. Often, natural hazards are not weighted heavily in these development considerations unless they are likely to affect the facilities within their amortized lifetime or period of ownership. According to the Executive Office of the President (1978, p. 29):

Business, industry, and the services sector play the lead roles in constructing new buildings and in developing land. Seismic design provisions in local codes ... are minimum standards. Thoughtful businessmen interested in providing a safe environment for their consumers and employees, and in protecting their capital invest- ment will want to give careful consideration to earthquake hazards in planning, constructing and maintaining their facilities .... In some instances short-term profits may be reduced to increase the long-term benefits of saving lives, reducing property damage, and maintaining the functioning of the economy in the face of a major earthquake. Private financial institutions, including lending agencies and insurance companies, must continue their important role.

The effective use of geologic and seismologic information to avoid damage or to reduce loss requires a considerable effort on the part of both the producers and the users of the information. Unless scientific and engineering results are specifically tailored, the effective user community is limited to other geologists, seismologists, and engineers. If users do not become proficient in interpreting and applying technical information, the information is likely to be misused or even neglected in the decisionmaking process. Studies by Kockelman $(1975,1976,1979)$ on the use of earth-science information by city, county, and regional planners and decisionmakers in the San Francisco Bay region showed that the most effective use of hazard information was achieved when maps that clearly depicted the location, susceptibility, and severity of the hazards were provided. Furthermore, hazard reduction was more likely when agencies had geologists or engineers on their staffs. Their skills permitted a broader use of the technical materials, and agencies were able to make interpretations from the information for their own purposes.

\section{LOOKING TOWARD THE FUTURE}

The research results summarized in this volume demonstrate the progress that earth scientists have

Introduction 13 
made in predicting the location and severity of the potentially destructive geologic and seismologic effects of future earthquakes in the Los Angeles region. These results, however, do not represent the final word in characterizing such effects. Further improvements can be expected as a more detailed earth-science data base for the region is developed and as predictive methods are tested and refined.

A comprehensive geologic data base is the most crucial prerequisite for improving evaluations of earthquake hazard potential. Essential components of such a data base would include (1) detailed geologic maps that emphasize late Quaternary deposits, (2) measurements of the geotechnical and hydrologic properties of those deposits throughout the major alluvial basins, and (3) information on slope steepness and strength of geologic materials in upland areas. These data at present are variably incomplete for the Los Angeles region. The hazard potential maps used in this volume are chiefly at scales of 1:250,000 ( $1 \mathrm{in} . \approx 4 \mathrm{mi}$ ) or smaller. More detailed characterizations-for example, at 1:24,000 scale ( 1 in. $\approx 2,000 \mathrm{ft}$ ) - are desirable for many hazard reduction activities, but, for much of the Los Angeles region, the basic geologic data have not yet been acquired in the detail that permits mapping potentially hazardous conditions at large scales. Furthermore, improved estimates of fault slip rates, which are vital to assessing the earthquake potential, must await detailed analysis of geologic relations along the numerous potentially active faults of the region. Acquisition of geologic and geotechnical information such as that described here requires a sustained effort over a considerable time.

Differing scientific opinions about the prediction of earthquake ground motion also need to be resolved. The influence of geologic conditions on ground shaking, in particular, is incompletely understood (in this volume, for example, compare the views of Evernden and Thomson with those of Rogers and others concerning the effect of water-saturated alluvium on expected levels of shaking). A technical question deserving further investigation is what percentage-loss factors are appropriate in applying the intensity prediction method of Evernden and Thomson to estimating future earthquake losses. These topics are among the many scientific and technical issues that need additional study before estimates of the potential hazards and losses from future earthquakes in the Los Angeles region can be improved.

14 Earthquake Hazards in the Los Angeles Region
Even though many of the results reported here are preliminary and further research is still needed, the methods described can be applied to evaluating and mapping similar hazards in other earthquake-prone regions of the United States. The challenge now is to ensure that these techniques are used where they are needed, that the resulting scientific products are disseminated to planners and engineers, and that decisionmakers at all levels of government and in the private sector take this information into account in selecting ways to reduce earthquake hazards.

\section{Acknowledgments}

We gratefully acknowledge the many helpful comments of Robert D. Brown, Jr., and Robert L. Wesson, both of the U.S. Geological Survey, who reviewed an earlier manuscript of Professional Paper 1360. Their suggestions concerning the scope and content of the subject material significantly improved this volume.

A report of this size and complexity requires a major editorial and graphics preparation effort by the Office of Scientific Publications of the U.S. Geological Survey. Special thanks go to Kathie R. Fraser, the technical editor of this volume, for expertly coordinating the processing and production of the report at a continent's distance from the authors. She was especially adept in helping the scientists communicate their concepts to a broader audience. We also acknowledge the contributions of the graphics units in Reston, Va., and Menlo Park, Calif., for helping produce carefully crafted illustrations.

The following illustrations have been used to introduce the principal topical headings: Earthquake and Surface-Faulting Sources, a photograph by A. T. F. Chen (U.S.Geological Survey) of surface faulting from the 1971 San Fernando earthquake; Earthquake Ground Motion, an aerial photograph from Newsweek magazine of damage to the Veterans Hospital in 1971; EarthquakeTriggered Ground Failure, a 1971 aerial photograph of the damaged Van Norman Dam, by R. H. Gordon (Gordon Air Photo); Earthquake-Related Phenomena Offshore, a portion of an orthographic drawing by T. R. Alpha (U.S. Geological Survey); Applications, a portion of a map by the California Division of Mines and Geology. 


\section{GLOSSARY}

[Terms set in bold type are defined elsewhere in the glossary]

Acceleration. The time rate of change of velocity of a reference point during an earthquake. Commonly expressed in percentage of gravity (g, equal to $980 \mathrm{~cm} / \mathrm{s}^{2}$ ).

Accelerogram. The record from an accelerograph showing ground acceleration as a function of time.

Accelerograph. A compact, rugged, and relatively inexpensive instrument that records the signal from an accelerometer. Film is the most çommon recording medium.

Accelerometer. A sensor whose output is almost directly proportional to ground acceleration. The conventional strong motion accelerometer is a simple, nearly critically damped oscillator having a natural frequency near $20 \mathrm{~Hz}$.

Acoustic reflection profiling. Method using sound waves to map geologic features on and beneath the sea floor. A pulse of sound is transmitted downward through the water from a ship-mounted or towed acoustic source. The acoustic energy reflected from the sea floor and from the interfaces between distinctive underlying geologic units is recorded by the survey vessel. Continuous profiles show a cross section of acoustically distinct units plotted as a function of acoustic-wave traveltime beneath the ocean surface and of distance along the survey track.

Active fault. A fault that is considered likely to undergo renewed movement within a period of concern to humans.

Aftershocks. Secondary tremors that may follow the largest or main shock of an earthquake sequence. Such tremors can extend over a period of weeks, months, or years.

Alluvium. Loosely compacted gravel, sand, silt, or clay deposited by streams.

Amplification. An increase in seismic signal amplitude within some range of frequency as waves propagate through different Earth materials. The amplitude may be decreased in another frequency band.

Amplitude. Zero-to-peak value of any wavelike disturbance.

Angle of internal friction. A measure of the shear strength of rock or sediment related to the intrinsic frictional resistance on a potential shear fracture.

Anticline. A upwardly convex fold in originally planar sedimentary rocks. Commonly adjacent to a syncline, a fold that is downwardly convex.

Arias intensity. A ground-motion parameter derived from an accelerogram and proportional to the integral over time of the acceleration squared. Expressed in units of velocity (meters per second or centimeters per second).

Artesian. Refers to ground water confined under pressure greater than that produced by water table conditions.

Aquiclude. A body of relatively impermeable rock or sediment that impedes the flow of ground water.

Aquifer. A water-bearing body of porous and permeable rock or sediment.

Attenuation. A decrease in seismic signal amplitude as waves propagate from the seismic source. Attenuation is caused by geometrical spreading of seismic wave energy and by the absorption and scattering of seismic energy in different Earth materials.

B horizon. Soil horizon characterized by the accumulation of clay minerals, iron compounds, and (or) calcium carbonate. Commonly reddish colored.

Bandpass. Refers to a range (or band) of frequencies passed by a filtering operation that suppresses other frequencies.

Basement. Igneous and metamorphic rocks that underlie the main sedimentary rock sequences of a region and extend downward to the base of the crust.

Bedrock. Relatively hard, solid rock that commonly underlies softer rock, sediment, or soil. 
Body wave. Seismic wave propagated in the interior of the Earth. $\mathbf{P}$ and $\mathbf{S}$ waves are examples.

Bulk density. The weight of a material divided by its volume, including the volume of its pore spaces.

Clast. Fragment of rock produced by mechanical weathering of older materials.

Cluster analysis. A procedure for arranging data into homogeneous subgroups based on their mutual similarities and hierarchical relations.

Coherent slides. Landslides that consist of a few relatively intact blocks of rock or soil that move together. The basal failure surface of most such slides is several meters or tens of meters below the land surface.

Cohesionless. Refers to a sediment whose shear strength depends only on friction, because there is no bonding between the grains. Typical of clay-free sandy deposits.

Colluvium. Loose soil or rock fragments on or at the base of gentle slopes or hillsides. Deposited by or moving under the influence of rainwash or downhill creep.

Compressional wave. See $\mathbf{P}$ wave.

Convolution.A mathematical operation describing the interaction of two functions, such as a signal and a filter, that may result in a change of wave shape.

Corner frequency. That frequency at which the curve representing the Fourier amplitude spectrum of a recorded seismic signal abruptly changes slope.

Creep. Slow, more or less continuous movement that may occur either along faults owing to ongoing tectonic deformation or along slopes owing to gravitational forces.

Critical acceleration $\left(\boldsymbol{A}_{\boldsymbol{c}}\right)$. The minimum value of ground acceleration required to overcome the resistance of a particular slope to earthquake-induced sliding.

Critical displacement $\left(U_{c}\right)$. The minimum ground displacement required if a slope is to continue sliding after seismic shaking stops. In this volume, the assigned values are $10 \mathrm{~cm}$ for coherent slides and $2 \mathrm{~cm}$ for disrupted slides and falls.

Critical facilities. Structures whose ongoing performance during an emergency is required or whose failure could threaten many lives. May include (1) structures such as nuclear power reactors or large dams whose failure might be catastrophic; (2) major communication, utility, and transportation systems; (3) involuntary- or high-occupancy buildings such as prisons or schools; and (4) emergency facilities such as hospitals, police and fire stations, and disaster-response centers.

Crust. The outermost major layer of the Earth, ranging from 10 to $65 \mathrm{~km}$ in thickness worldwide and about $20 \mathrm{~km}$ thick in coastal California and characterized by $\mathbf{P}$ wave velocities less than about $8 \mathrm{~km} / \mathrm{s}$.

Damping. The reduction in amplitude of an oscillation owing to absorption of energy within a material. See also Geometrical attenuation.

Design earthquake. The postulated earthquake (commonly including a specification of the ground motion at a site) that is used for evaluating the earthquake resistance of a particular structure.

Dip. Inclination of a planar geologic surface (for example, a fault or a bed) from the horizontal.

Directivity. An effect of a propagating fault rupture whereby earthquake ground motion in the direction of propagation is more severe than that in other directions from the earthquake source.

Displacement. The difference between the initial position of a reference point and any later position. (1) In seismology, displacement is usually calculated by integrating an accelerogram twice with respect to time and is expressed in centimeters. (2) In geology, displacement is the permanent offset of a geologic or manmade reference point along a fault or a landslide.

Disrupted slides and falls. Landslides that are broken during movement into chaotic masses of small blocks, rock fragments, or individual grains. The basal failure surface of most such slides is within a few meters of the land surface.

Earthquake hazard. Any physical phenomenon associated with an earthquake that may produce adverse effects on human activities.

Effective stress. The average stress transmitted directly from particle to particle of a rock or sediment mass that controls how the mass deforms. Effective stress perpendicular to an arbitrary surface in a saturated porous material is the difference between the applied normal stress and the pore-water pressure.

\section{Earthquake Hazards in the Los Angeles Region}


Elastic dislocation theory. In seismology, a theoretical description of how an elastic Earth responds to fault slip, as represented by a distribution of displacement discontinuities.

Epicenter. The point on the Earth's surface vertically above the point (focus or hypocenter) in the crust where a seismic rupture initiates.

Fault. A fracture along which there has been significant displacement of the two sides relative to each other parallel to the fracture. Strike-slip faults are chiefly vertical fractures along which rock masses have shifted horizontally. Dip-slip faults are chiefly inclined fractures along which rock masses have shifted vertically. If the rock mass above an inclined fault is depressed, the fault is termed normal slip, whereas the term reverse slip (or thrust) indicates that the side above the fault is elevated. Oblique-slip faults have significant components of both strike and dip slip along them.

Fault-plane solution. An analysis to determine the attitude of the causative fault and its direction of slip from the radiation pattern of seismic waves for an earthquake recorded at numerous stations. The analysis most commonly uses the direction of first motion of $\mathbf{P}$ waves and yields two possible orientations for the fault rupture and the direction of seismogenic slip. From these data, inferences can be made concerning the principal axes of stress in the region of the earthquake.

Fault scarp. Steplike linear landform coincident with a fault trace. Caused by geologically recent offset of the land surface.

Fault trace. Intersection of a fault with the ground surface; also, the line commonly plotted on geologic maps to represent a fault.

Filter. In seismology, a physical system or a mathematical operation that changes the waveform or amplitude of a signal.

Filtering. Attenuation of certain frequency components of a seismic signal and the amplification of others. For a recorded signal, the process can be accomplished electronically or numerically in a digital computer. Filtering also can occur naturally as seismic energy passes through the Earth.

First motion. On a seismogram, the direction of ground motion as the $\mathbf{P}$ wave arrives at the seismometer. Upward ground motion indicates an expansion in the source region; downward motion indicates a contraction.

Focal-mechanism solution. See Fault-plane solution.

Focus. The point within the Earth where an earthquake rupture initiates. See also Hypocenter.

Fourier amplitude spectrum. The relative amplitude at different component frequencies as derived from a time series by Fourier analysis.

Fourier transform. The mathematical operation that resolves a time series (for example, a recording of ground motion) into functions showing the relative amplitude and phase components of the signal.

Free field. Refers to ground motion measurements that are not influenced by manmade structures.

Frequency. Number of cycles occurring in unit time. Hertz $(\mathrm{Hz})$, the unit of frequency, is equal to the number of cycles per second.

Fundamental period. The longest period for which a structure shows a maximum response. The reciprocal of natural frequency.

Geodetic. Refers to the determination of the size and shape of the Earth and the precise location of points on its surface.

Geometrical attenuation. That component of attenuation of seismic wave amplitudes owing to the radial spreading of seismic energy with distance from a given source.

Geomorphology. The study of the character and origin of landforms.

Geotechnical. Refers to the use of scientific methods and engineering principles to acquire, interpret, and apply knowledge of Earth materials for solving engineering problems.

Green's function. A mathematical entity that, in reference to earthquake shaking, is used to represent the ground motion caused by instantaneous slip on an individual part of a fault.

Ground motion. General term referring to the qualitative or quantitative aspects of shaking of the Earth's surface from earthquakes or explosions. 
Ground response. See Ground motion.

Halfspace. A mathematical model bounded by a planar surface but otherwise infinite. Properties within the model are commonly assumed to be homogeneous and isotropic, unlike the Earth itself, which is heterogeneous and anisotropic.

Hertz (Hz). A unit of frequency. Expressed in cycles per second.

Hydrostatic stress. The stress component in the Earth that is uniform in magnitude in all directions.

Hypocenter. The point within the Earth where an earthquake rupture initiates. See also Focus.

Intensity. A subjective numerical index describing the severity of an earthquake in terms of its effects on the Earth's surface and on humans and their structures. A condensed version of the Modified Mercalli intensity scale appears on the inside back cover of this volume.

Isoseismal. A line on a map bounding points of equal intensity for a particular earthquake.

Kinematic. Refers to the movement patterns that result in a particular deformation.

Lateral spreads and flows. Landslides that commonly form on gentle slopes and that display rapid fluidlike flow movement.

Least-squares fit. An approximation of a set of data having a curve such that the sum of the squares of the differences between the observed points and the curve is a minimum.

Liquefaction. Process by which water-saturated sediment temporarily loses strength, usually because of strong shaking, and behaves as a fluid.

Lithology. The description of rock composition and texture.

Lithosphere. The outer solid portion of the Earth, including the crust and uppermost mantle.

Love wave. A type of seismic surface wave having a horizontal motion that is transverse to the direction of propagation.

Magnetic polarity reversal. A change of the Earth's magnetic field to the opposite polarity. Polarity reversals in sequences of magnetized rocks are detected by analysis and, when compared with standard polarity time scales, are used to estimate geologic ages.

Magnitude. A number that characterizes the size of an earthquake, based on measurement of the maximum motions recorded by a seismograph for earthquake waves of a particular frequency. Scales most commonly used in the Western United States are (1) local magnitude $\left(\mathrm{M}_{\mathrm{L}}\right)$ (commonly referred to as "Richter magnitude"), (2) surface-wave magnitude $\left(\mathrm{M}_{\mathrm{S}}\right)$, and (3) body-wave magnitude $\left(\mathrm{m}_{\mathrm{b}}\right)$. None of these scales satisfactorily measures the largest possible earthquakes because each relates to only certain frequencies of seismic waves and because the spectrum of radiated seismic energy changes with earthquake size. The recently devised moment magnitude (M) scale, based on the concept of seismic moment, is uniformly applicable to all sizes of earthquakes.

Mantle. That part of the Earth's interior between the metallic core and the crust.

Microzonation. Geographic delineation on a regional or local scale of areas having different potentials for hazardous effects of earthquakes (including geologic effects such as surface faulting, strong ground shaking, and ground failure).

Newmark analysis. A numerical technique that models a potential landslide as a rigid friction block resting on a slope and uses a strong-motion record to calculate the expected displacement of the block under earthquake shaking.

Natural frequency(ies). The discrete frequency(ies) at which a particular elastic system vibrates when it is set in motion by a single impulse and not influenced by other external forces or by damping. The reciprocal of fundamental period.

Normal stress. That stress component perpendicular to a given plane.

Orthogonals. In oceanography, map lines constructed perpendicular to known or predicted wave fronts. Orthogonals are used to estimate the relative distribution of tsunami wave energy arriving at a coast line.

Oscillation. The alternating motion or vibration of a reference point.

Oscillator. A mass that undergoes alternating motion. In earthquake engineering, an idealized massspring system that is used as a model of the response of a structure to earthquake ground motion.

$P$ wave. A seismic body wave that involves particle motion (alternating compression and extension) in the direction of propagation.

\section{Earthquake Hazards in the Los Angeles Region}


Peak value. Largest value of acceleration, velocity, or displacement recorded for a particular earthquake time-history.

Pedogenic. Pertaining to processes that add, transfer, transform, or remove soil constituents.

Perched ground water. Ground water separated from the underlying main body of ground water by an unsaturated zone.

Period. The time interval required for one full cycle of a wave.

Period band. That range of periods being considered in an analysis of ground motion.

Permeability. A measure of the ability of fluid to pass through the pore spaces of a rock or sediment.

Phase. (1) A stage in periodic motion, such as oscillation, measured with respect to a given initial point and expressed in angular measure. (2) A pulse of seismic energy arriving at a definite time.

Physiographic. Refers to the character and distribution of landforms.

Plate tectonics. A well-proven theory that considers the Earth's crust and upper mantle to be composed of a number of large, thin, relatively rigid plates that move relative to one another. Interaction along their boundaries commonly results in earthquake and volcanic activity.

Poisson distribution. A probability distribution that characterizes discrete events occurring independently of one another in time.

Pore-water pressure. Stress transmitted by the water filling the voids of rock or sediment.

Pseudoacceleration response. The product of the relative displacement response and the square of the angular frequency of an oscillator.

Pseudovelocity response. The product of the relative displacement response and the angular frequency of an oscillator.

Quasi-harmonic decomposition. Technique whereby the filtering of a seismogram results in a sequence of narrow-band seismograms that are used to estimate the time pattern of individually arriving $\mathbf{P}$ wave pulses.

Radiometric. Pertaining to the measurement of geologic time by the analysis of certain radioisotopes in rocks and their known rates of decay.

Rayleigh wave. A seismic surface wave causing an elliptical motion of a particle at the free surface, with no transverse motion.

Recurrence interval. The average time span between events (such as large earthquakes, ground shaking exceeding a particular value, or liquefaction) at a particular site.

Reflection. The energy or wave from a seismic source that has been returned (reflected) from an interface between materials of different elastic properties within the Earth.

Reflector. An interface between materials of different elastic properties that reflects seismic waves.

Refraction. (1) The deflection of the ray path of a seismic wave caused by its passage from one material to another having different elastic properties. (2) Bending of a tsunami wave front owing to variations in the water depth along a coast line.

Refraction diagram. Map of the time-dependent positions of known or predicted tsunami wave fronts.

Regression analysis. A statistical technique applied to data to determine, for predictive purposes, the degree of correlation of a dependent variable with one or more independent variables.

Relaxation theory. Concept wherein radiated seismic waves of an earthquake result when stored strain within the Earth is released at the time of slip along a fault; adjacent fault blocks reach new states of equilibrium.

Rigidity. See Shear modulus.

Residual. The difference between the measured and the predicted values of some quantity.

Resonance. An increase in the amplitude of vibration in a body when the frequency(ies) of the shaking force is close to the natural frequency(ies) of a shaking body.

Response. The motion in a system resulting from shaking under specified conditions.

Response spectrum. A curve showing the response of a series of simple harmonic oscillators of different natural frequency(ies) subjected mathematically to a particular earthquake ground motion. Response spectra, commonly plotted on tripartite logarithmic graph paper, show the variation of spectral acceleration, displacement, and velocity of the oscillators as a function of vibration frequency and for various levels of damping. 
Return period. See Recurrence interval.

Root mean square. Square root of the mean square value of a random variable.

Rupture front. The instantaneous boundary between the slipping and unslipped parts of a fault during an earthquake.

Rupture velocity. The speed at which a rupture front propagates during an earthquake.

S wave. A seismic body wave that involves a shearing motion in a direction perpendicular to the direction of propagation. When it is resolved into two orthogonal components in the plane perpendicular to the direction of propagation, $\mathrm{SH}$ denotes the horizontal component and SV denotes the orthogonal component.

Sag pond. A small enclosed depression commonly filled with water; formed where recent faulting of the land surface has impounded drainage.

Sand boil. Sand and water ejected to the ground surface as the result of liquefaction at shallow depth; the conical sediment deposit that remains as evidence of liquefaction.

Saturation. (1) In seismology, the leveling off of ground-motion parameters with increasing earthquake magnitude. (2) In hydrogeology, the degree to which the pores of a sediment or rock are filled with water.

Seiche. Oscillation of the surface of an enclosed body of water owing to earthquake shaking.

Seismic hazard. See Earthquake hazard.

Seismic impedance. Seismic P wave velocity multiplied by the bulk density of a medium.

Seismic wave. An elastic wave generated by an impulse such as an earthquake or an explosion. Seismic waves may propagate either along or near the Earth's surface (for example, Rayleigh and Love waves) or through the Earth's interior ( $P$ and $S$ waves).

Seismicity. The geographic and historical distribution of earthquakes.

Seismic moment. A measure of the size of an earthquake based on the area of fault rupture, the average amount of slip, and the shear modulus of the rocks offset by faulting. Seismic moment can be calculated from the amplitude of long-period seismic waves.

Seismic risk. The probability of social or economic consequences of an earthquake.

Seismic zonation. Geographic delineation of areas having different potentials for hazardous effects from future earthquakes. Seismic zonation can be done at national, regional, and local scales. See also Microzonation.

Seismogenic. Capable of generating earthquakes.

Seismogram. A record of ground motion or of vibrations of a structure caused by an earthquake or an explosion.

Seismograph. An instrument system for amplifying and recording the signals from seismometers.

Seismometer. The sensor or instrument used to detect seismic wave energy and to transform it into an electrical voltage.

Separation. The distance between any two parts of a reference plane (for example, a sedimentary bed or a geomorphic surface) offset by a fault, measured in any plane. Separation is the apparent amount of fault displacement and is nearly always less than the actual slip.

Shear modulus. The ratio of shear stress to shear strain of a material during simple shear.

Shear stress. That stress component giving rise to tangential force across a given plane.

Shear wave. See $S$ wave.

Slip. The relative displacement of formerly adjacent points on opposite sides of a fault, measured in the fault surface.

Slip model. A kinematic model that describes the amount, distribution, and timing of slip associated with a real or postulated earthquake.

Slip rate. The average rate of displacement at a point along a fault as determined from geodetic measurements, from offset manmade structures, or from offset geologic features whose age can be estimated. It is measured parallel to the dominant slip direction or estimated from the vertical or horizontal separation of geologic markers.

20 Earthquake Hazards in the Los Angeles Region 
Soil. (1) In engineering, all unconsolidated material above bedrock. (2) In soil science, naturally occurring layers of mineral and (or) organic constituents that differ from the underlying parent material in their physical, chemical, mineralogic, and morphologic character because of pedogenic processes.

Soil profile. The vertical arrangement of soil horizons down to the parent material. Commonly subdivided into $\mathrm{A}, \mathrm{B}$, and $\mathrm{C}$ horizons.

Source. (1) The geologic structure that generates a particular earthquake. (2) The explosion used to generate acoustic or seismic waves.

Spectral amplification. A measure of the relative shaking response of different geologic materials. The ratio of the Fourier amplitude spectrum of a seismogram recorded on one material to that computed from a seismogram recorded on another material for the same earthquake or explosion.

Spectral ratio. See Spectral amplification.

Spectrum. The distribution or range of values of a characteristic of a physical system. In seismology, commonly a curve showing amplitude and phase as a function of frequency or period.

Standard deviation. The square root of the average of the squares of deviations about the mean of a set of data. Standard deviation is a statistical measure of spread or variability.

Standard penetration resistance. A measure of relative density expressed by the number of blows (blow count) needed to push a probe a standard distance into sediment. The "standard penetration test" determines the number of blows required to drive a standard sampling spoon $1 \mathrm{ft}$ into the sediment by repeatedly dropping a 140-lb weight from a height of $30 \mathrm{in}$.

Station. A ground position at which a geophysical instrument is located for an observation.

Strain. The percentage of change in the length, shape, or volume of a body subjected to deformation.

Stratigraphy. The study of the character, form, and sequence of layered rocks.

Stress. Force per unit area acting on a surface within a body. Six values are required to characterize completely the stress at a point: three normal components and three shear components.

Stress drop. The difference between the stress across a fault before and after an earthquake.

Strike. Trend or bearing, in relation to north, of the line defined by the intersection of a planar geologic surface (for example, a fault or a bed) and a horizontal surface.

Strong motion. Ground motion of sufficient amplitude and duration to be potentially damaging to engineered structures.

Subduction. In plate tectonics, the process whereby one plate of the lithosphere descends beneath another.

Subsidence. Downward settling of the Earth's surface with little or no horizontal motion. May be caused by natural geologic processes (such as sediment compaction or tectonic activity) or by human activity (such as mining or withdrawal of ground water or petroleum).

Surface faulting. Displacement that reaches the ground (or sea floor) surface during slip along a fault. Commonly accompanying moderate and large earthquakes having focal depths to $20 \mathrm{~km}$, surface faulting also may accompany aseismic tectonic creep or natural or man-induced subsidence.

Surface wave. Seismic wave that propagates along the Earth's surface. Love and Rayleigh waves are examples.

Tectonic. Refers to crustal rock-deforming processes that affect relatively large areas.

Thixotropic. Refers to the ability of certain colloidal materials, such as some clays, to weaken or change structure when shaken but to regain strength with time.

Time-history. The sequence of values of any quantity (such as a ground-motion parameter) during the time span of an event.

Time series. See Time-history.

Transform fault. A special variety of strike-slip fault along which the displacement changes form or stops. Commonly connects oceanic spreading ridges and subduction zones.

Traveltime curve. A graph of arrival times of $\mathbf{P}$ or $\mathbf{S}$ waves recorded at different points as a function of distance from the seismic source. Seismic velocities can be computed from the slopes of the resulting curve. 
Tsunami. An impulsively generated sea wave of local or distant origin that results from large-scale seafloor displacements associated with large earthquakes, major sea-floor slides, or exploding volcanic islands.

Tsunamigenic. Refers to those earthquake sources, usually along major subduction zone plate boundaries, such as those bordering the Pacific Ocean, that can generate tsunamis.

Tsunami magnitude $\left(\mathbf{M}_{\mathbf{t}}\right)$. A number used to compare sizes of tsunamis generated by different earthquakes and calculated from the logarithm of the maximum amplitude of the tsunami wave measured by a tide gauge distant from the tsunami source.

Velocity. The time rate of change of displacement of a reference point during an earthquake. Can be calculated by integrating an acceleration record once with respect to time. Expressed in centimeters per second.

Velocity structure. A generalized regional model of the Earth's crust that represents crustal structure by layers having different assumed seismic velocities.

Void ratio. The ratio of the volume of void space in a rock or sediment to the volume of solid material.

Water table. The upper surface of a body of unconfined ground water at which the water pressure is equal to the atmospheric pressure.

Wavelength. The distance between successive points of equal amplitude and phase on a wave (for example, crest to crest or trough to trough).

22 Earthquake Hazards in the Los Angeles Region 


\section{FACTORS FOR CONVERTING METRIC UNITS TO INCH-POUND UNITS}

Most quantitative information in this volume is given in the International System of Units (SI or metric), the measurement system commonly used by scientists. The inch-pound (English) units of measurement, however, may be more familiar to many readers. The following conversion table is for the convenience of those who prefer English units.

\begin{tabular}{lcl}
\hline Multiply SI unit & By & To obtain inch-pound unit \\
\hline Length & & \\
$\quad$ millimeter $(\mathrm{mm})$ & 0.0394 & inch (in) \\
$\quad$ centimeter $(\mathrm{cm})$ & .394 & inch (in) \\
$\quad$ meter $(\mathrm{m})$ & 3.28 & foot (ft) \\
$\quad$ kilometer $(\mathrm{km})$ & .62 & mile (mi) (land) \\
$\quad$ mile (mi) (nautical)
\end{tabular}




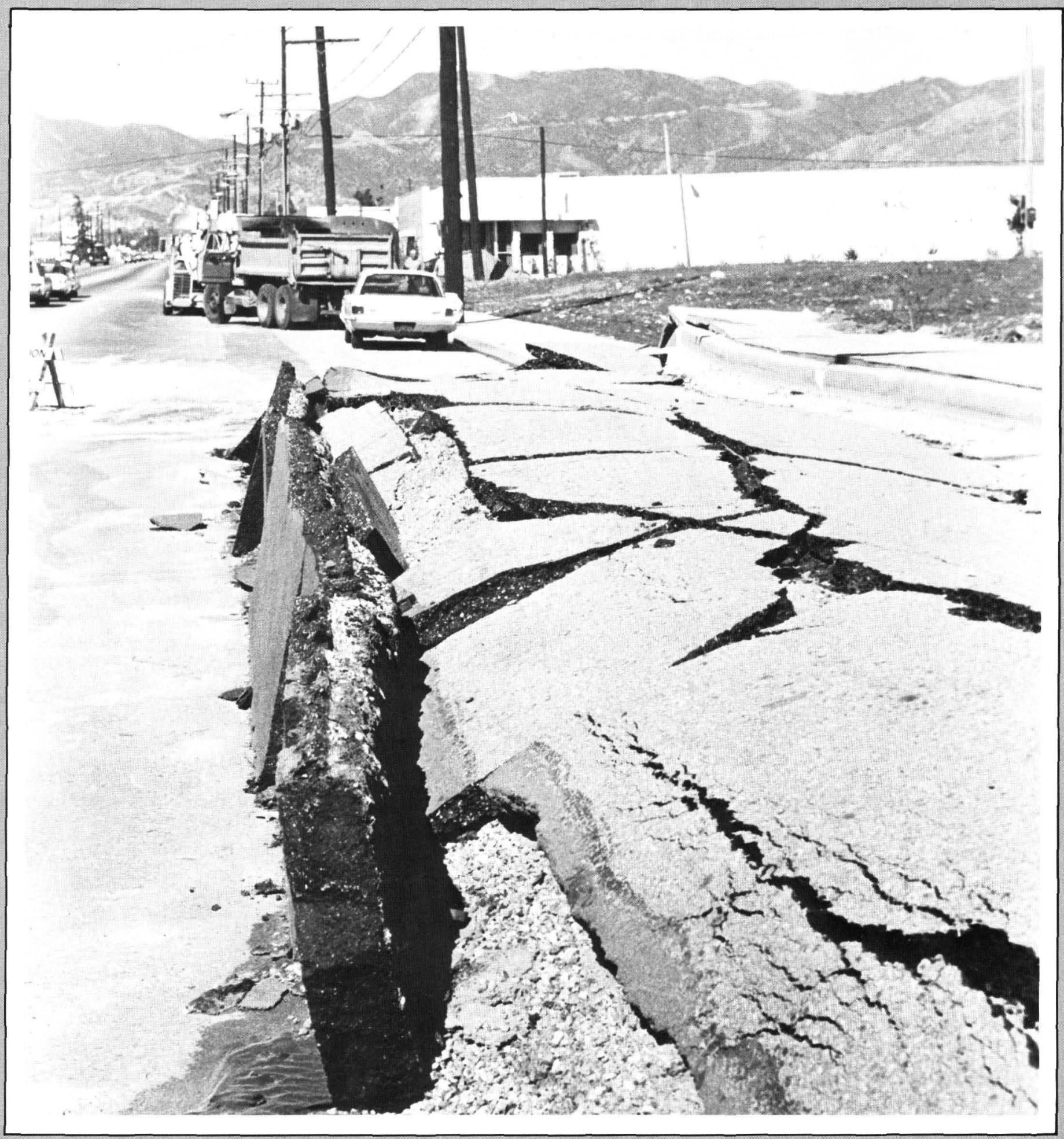

\section{Earthquake and Surface- Faulting Sources}




\title{
GEOLOGIC AND SEISMOLOGIC SETTING
}

\author{
By R. F. Yerkes
}

\section{INTRODUCTION}

This discussion of the geologic and seismologic setting of the Los Angeles region shows why and where earthquakes occur in that area. The basic framework for the discussion is the concept of plate tectonics, which relates many of the Earth's large-scale geologic processes to movement in marginal areas of relatively rigid crustal or lithospheric "plates" that are in slow, constant motion $(5-10 \mathrm{~cm} / \mathrm{yr})$ relative to one another. One of these margins, the San Andreas fault system, forms the broad boundary between the Pacific (oceanic) and the North American (continental) plates and passes obliquely through coastal California. Because this boundary transects or borders several of the State's major metropolitan centers, it is one of the most extensively urbanized tectonic plate boundaries on Earth.

We outline the evolution of coastal California in terms of plate tectonics and show how the Los Angeles region straddles the junction between two major active fault systems-the northwest-trending San Andreas and the east-trending Transverse Ranges-that are responding to present plate motions. We also describe the types of permanent deformation associated with movement along these faults and document the spatial and temporal distribution of historical damaging earthquakes associated with those movements.

\section{PLATE-TECTONIC EVOLUTION OF CALIFORNIA}

Plate tectonics, a global-scale process that has been going on for millions of years, involves relative movement of very large plates of the Earth's lithosphereblocks averaging about $100 \mathrm{~km}$ thick and thousands of kilometers across. Most seismic and volcanic activity is concentrated along boundaries between these plates. Three types of plate boundaries are recognized: spreading ridges, where oceanic plates are formed and spread laterally away from each other; transform faults, where plates slide horizontally past each other along strike-slip faults between spreading ridges; and subduction zones, where one plate (oceanic) dives beneath another. Tracing the history of the plates and their boundaries is a major component of modern geologic and seismologic studies (see, for example, Ernst (1981)).

Figure 3 is an interpretive map of the California region and its relation to both ancient and present tectonic plates. The following general history is envisioned. The inactive subduction zone off central California and Baja California, Mexico, presumably was the boundary between the once-continuous Farallon oceanic plate and the North American continental plate (Dickinson, 1981). About 29 m.y ago, a portion of the Farallon plate disappeared by subduction, and an ancestral segment of the East Pacific Rise (a spreading ridge now bounding the Farallon remnants) first contacted the subduction zone. The complex interactions set up by this encounter led to the development of the San Andreas system of transform faults and subsequent attachment of the displaced coastal terrane to the Pacific plate (see Dickinson and Snyder (1979) for details). Before 5 m.y. ago, transform slip occurred on equivalent faults west of the modern San Andreas, some of which are now offshore.

In plate-tectonic terms, all of California west of the San Andreas fault consists of several pieces of crust that have been transported in a relatively northwestward direction along the boundary as part of the Pacific plate. In the part of California considered here, the latest phase of this process ended before late Miocene time more than 5 m.y. ago (see geologic time-scale chart, inside front cover). Since then, continuing deformation has caused chiefly reorientation, folding, and faulting of the many separate unrelated pieces or "miniplates" that make up the region.

\section{PRESENT PLATE-TECTONIC SETTING}

The present San Andreas system is the locus of relative motion between the North American and Pacific 


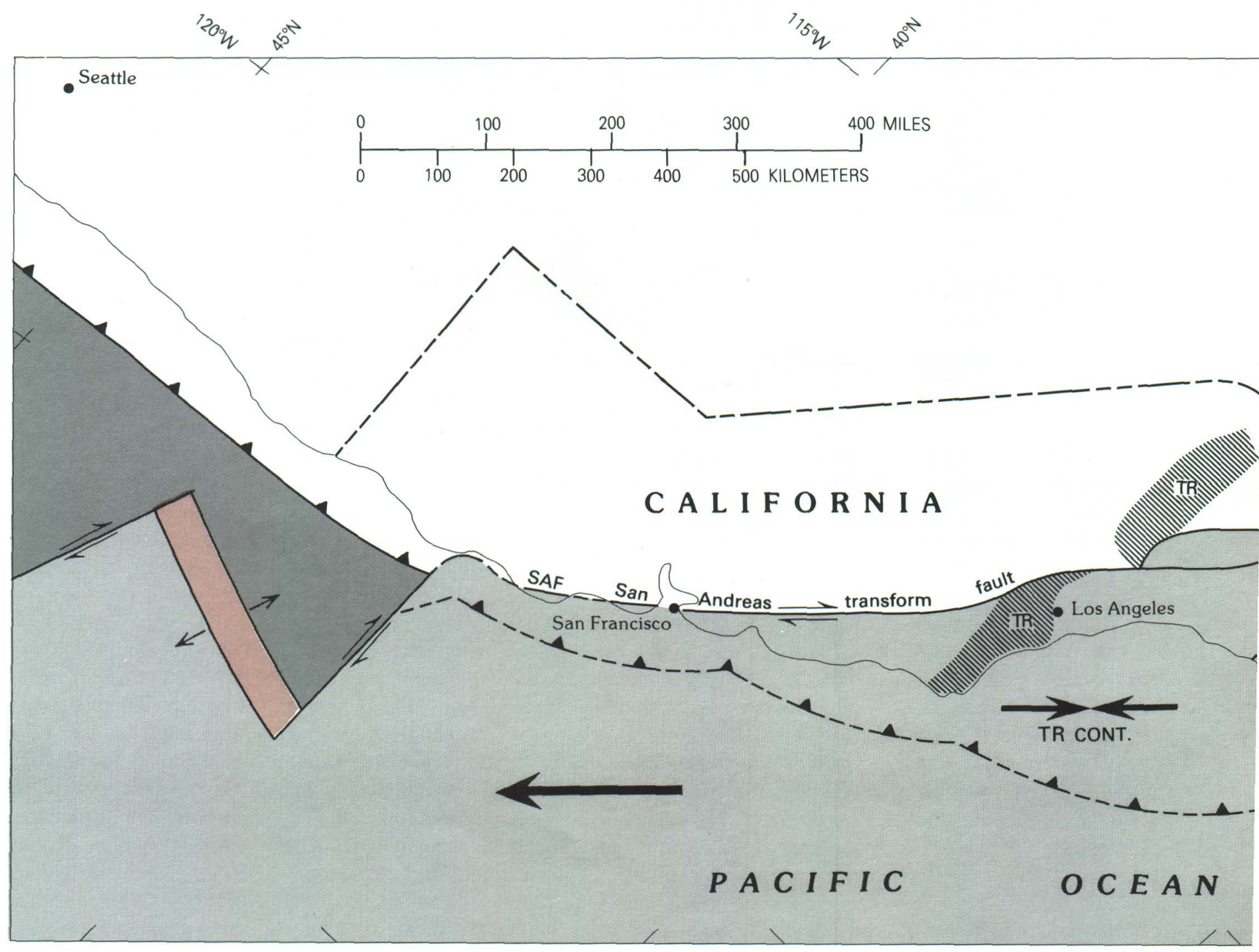

FIGURE 3.-Inferred relationships between San Andreas transform fault (SAF), Transverse Ranges (TR), and the Pacific and North American plates. Displacement on faults parallel to the long dimension of the map is parallel to the fault (strike slip); displacement on faults having other trends, such as reverse faults of the Transverse Ranges, is chiefly vertical (dip slip). The large arrow shows the motion of the Pacific plate relative to the North American plate (about $56 \mathrm{~mm} / \mathrm{yr}$ averaged over last $5 \mathrm{~m} . \mathrm{y}$.). Vectors labeled "TR cont." indicate the inferred maximum contraction across the Transverse Ranges since the Gulf of California began opening about 5 m.y. B.P. Adapted from Atwater (1970), Dickinson and Snyder (1979), and Moore (1981).

plates. The overall motion between these plates continues, perhaps at an accelerated rate; the average over the last $3 \mathrm{~m} . \mathrm{y}$. is at least $56 \mathrm{~mm} / \mathrm{yr}$ in a right-lateral sense (Moore, 1981). The most recent estimate for average relative motion along the San Andreas zone north of the Tranverse Ranges is at least $33 \mathrm{~mm} / \mathrm{yr}$ (Thatcher, 1979); the 23-mm/yr difference presumably reflects both relative movement along other faults of the San Andreas system and associated folding and faulting within and along the boundaries of the Transverse Ranges.

In southern California, the surface trace of the San Andreas itself may not represent the plate boundary at depth. One hypothesis is that the subsurface plate boundary is deflected more than $100 \mathrm{~km}$ northeast of the surface trace opposite the Transverse Ranges (Yeats, 1981). The deflection of the San Andreas-called the "big bend"-presumably is related to north-south contraction and east-west extension in the Transverse Ranges-Mojave Desert region.

The techniques for dating geologic materials and modeling geologic processes that have been developed and applied over the last few decades show very clearly that southern California west of the San Andreas fault is geologically very young (although it locally contains very old rocks derived from elsewhere) and is at the "leading edge" of continent-forming processes.

\section{Earthquake Hazards in the Los Angeles Region}




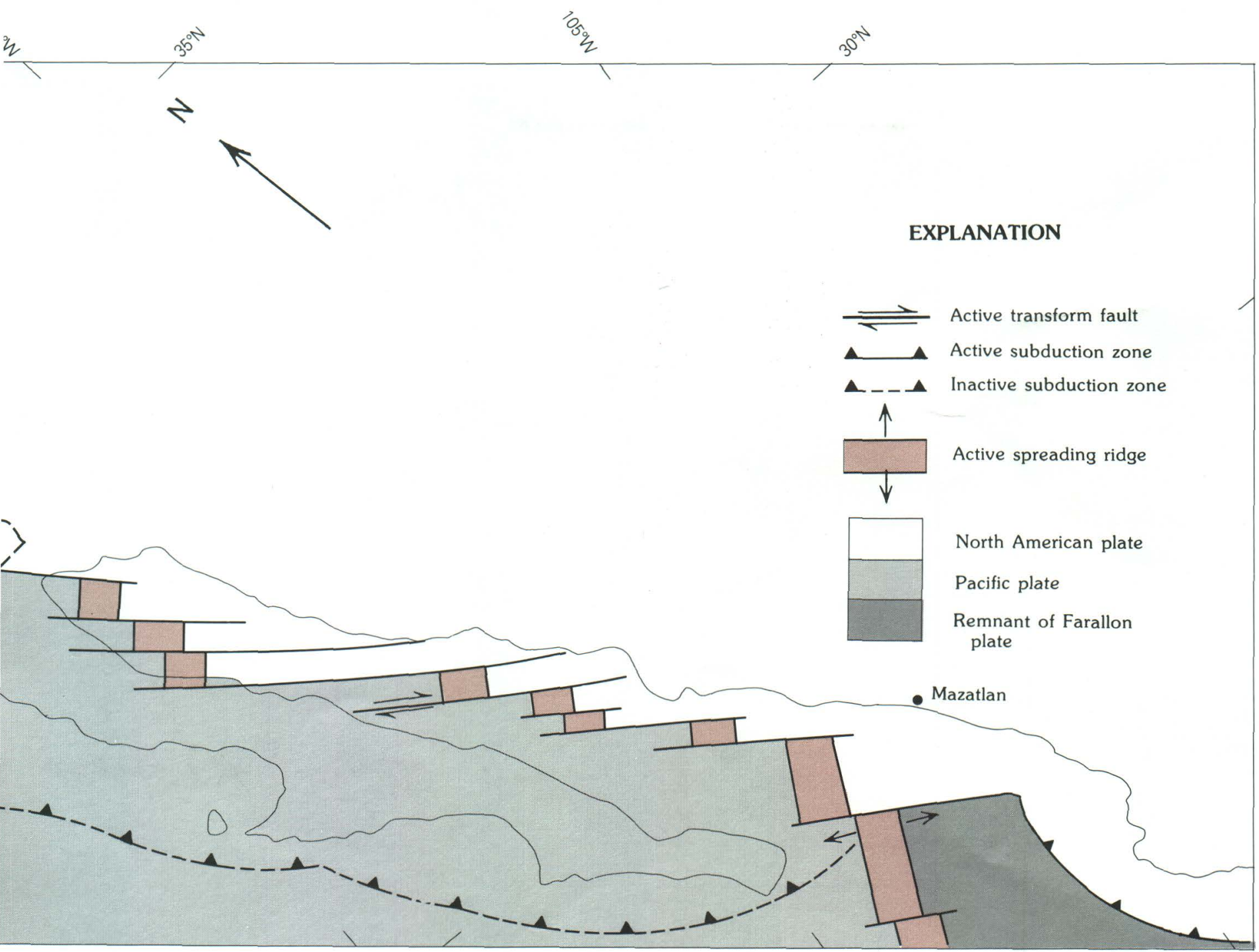

\section{EFFECTS OF CONTINUING DEFORMATION}

The deformational processes now operating in southern California are dominated by the intersection of the San Andreas and the Transverse Ranges fault systems (fig. 4); the effects of this intersection are evident in the local scenery, such as the spectacular southern face of the San Gabriel Mountains overlooking the Los Angeles-San Bernardino metropolitan area (fig. 5), or in the occurrence of transitory events such as earthquakes. Although these fault systems are part of a longterm continuing process now at least 5 m.y. old, they are currently responding to strain related to motion of the Pacific and North American plates either by horizontal (right-lateral) slip (faulting and earthquakes) on faults of the San Andreas system or by vertical (reverse) slip on Transverse Ranges faults. The effects of this deformation include (1) mountain building caused by sporadic displacement along reverse faults (for example, as much as $2 \mathrm{~m}$ of absolute uplift during faulting that accompanied the 1971 San Fernando earthquake); (2) basinal development exemplified by the extremely deep, long, narrow east-trending Santa Barbara Channel-Ventura basin, which is filled with young sediment and has flanks overturned by reverse faulting; (3) widespread deformation of late Quaternary marine and nonmarine terrace deposits, locally rising relative to sea level at long-term rates of 4 to $10 \mathrm{~mm} / \mathrm{yr}$ or 4 to $10 \mathrm{~km} / \mathrm{m}$.y. (Lajoie and others, 1979); (4) generation of earthquakes in the upper $15 \mathrm{~km}$ of the crust; and (5) widespread regional uplift (Castle, 1978) and strain accumulation (Savage and others, 1981) shown by analysis of horizontal and vertical survey data.

The distribution of most of these effects is shown in figure 6, which also shows epicenters of selected welllocated earthquakes for which fault-plane solutions (analyses of instrumentally well recorded earthquakes 


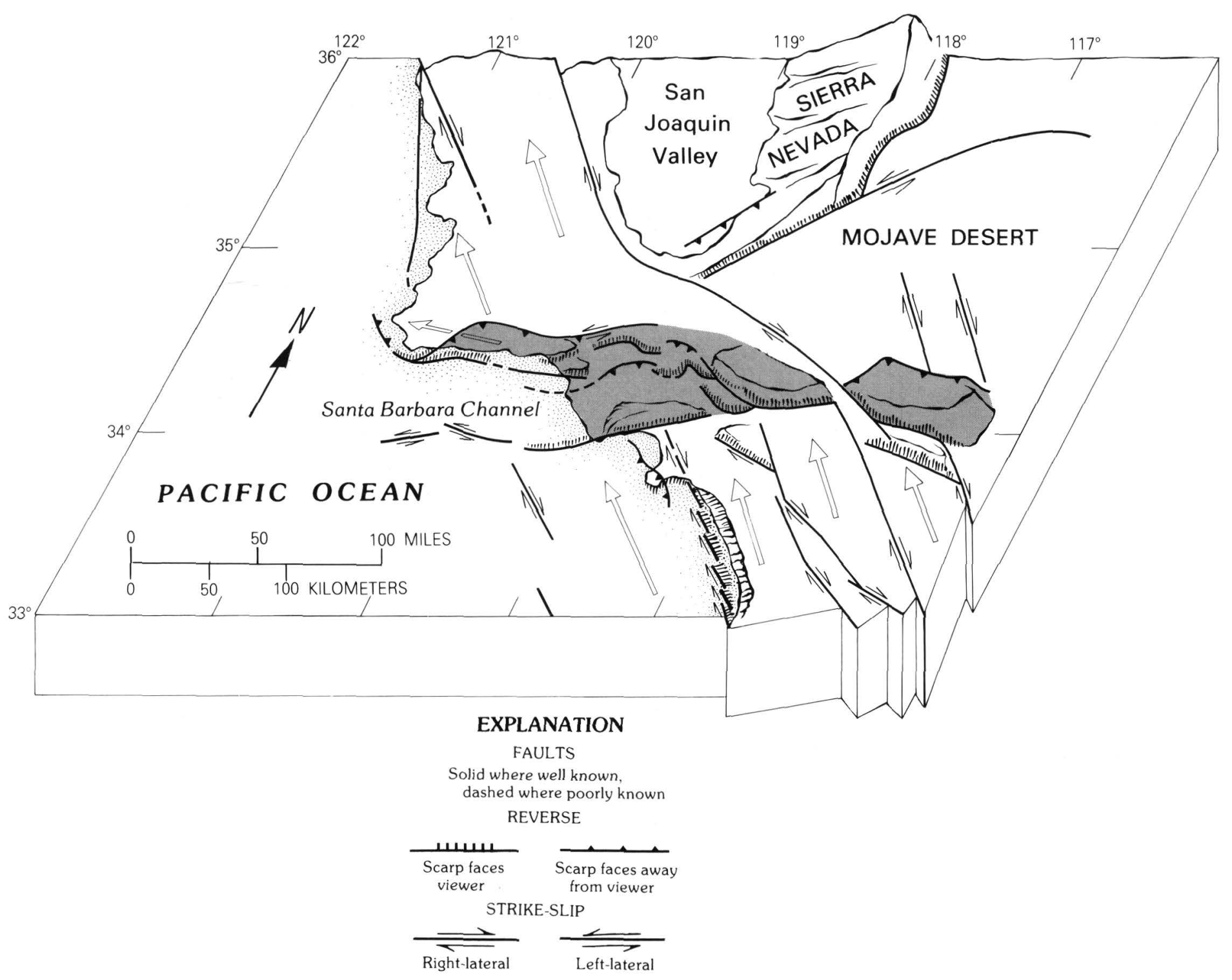

FIGURE 4.-Present relative motions of crustal blocks. Blocks in the foreground move northwest with the Pacific plate and represent the Peninsular Ranges; those representing the Transverse Ranges (shaded) generally are bounded by reverse faults and prominent scarps. Modified from Anderson (1971).

for which the sense and orientation of the generating fault displacement can be derived) are available. These epicenters are distributed throughout the region, and, although most represent earthquakes of local magnitude $\left(\mathrm{M}_{\mathrm{L}}\right)^{1} 5$ or less, they reflect the same strain field reflected by several larger earthquakes for which solutions are available-generally north-south compression. The maximum measured long-term rates of uplift occur

${ }^{1}$ Magnitude is a measure of the size or strength of an earthquake based on seismograph records and therefore dependent on wave path, site effects, and instrumental frequency response. Local magnitude $\left(M_{L}\right)$ was devised for southern California earthquakes (Richter 1935, 1958). A widely applicable measure independent of frequency and wave path, momen magnitude $(\mathbf{M})$ is numerically coincident with $M_{L}$ in the range 3 to 7 (Hanks and Kanamori, 1979). See Ziony and Yerkes (this volume) for more details. along the coast west of Ventura (Lajoie and others, 1979), in an area of intense seismicity and active folding and reverse faulting. Although measured rates are sparse for inland parts of the Transverse Ranges, those areas are also characterized by geologically recent reverse faulting, and estimated long-term rates of uplift for those areas are comparable. Figure 6 also shows the surface traces of major Quaternary faults, classified by age of latest movement at the surface. Those faults or fault segments that show geologic evidence of Holocene rupture also generally are seismically active. Not shown on the map are results of leveling surveys that indicate local areas of very rapid historic uplift-for example, 


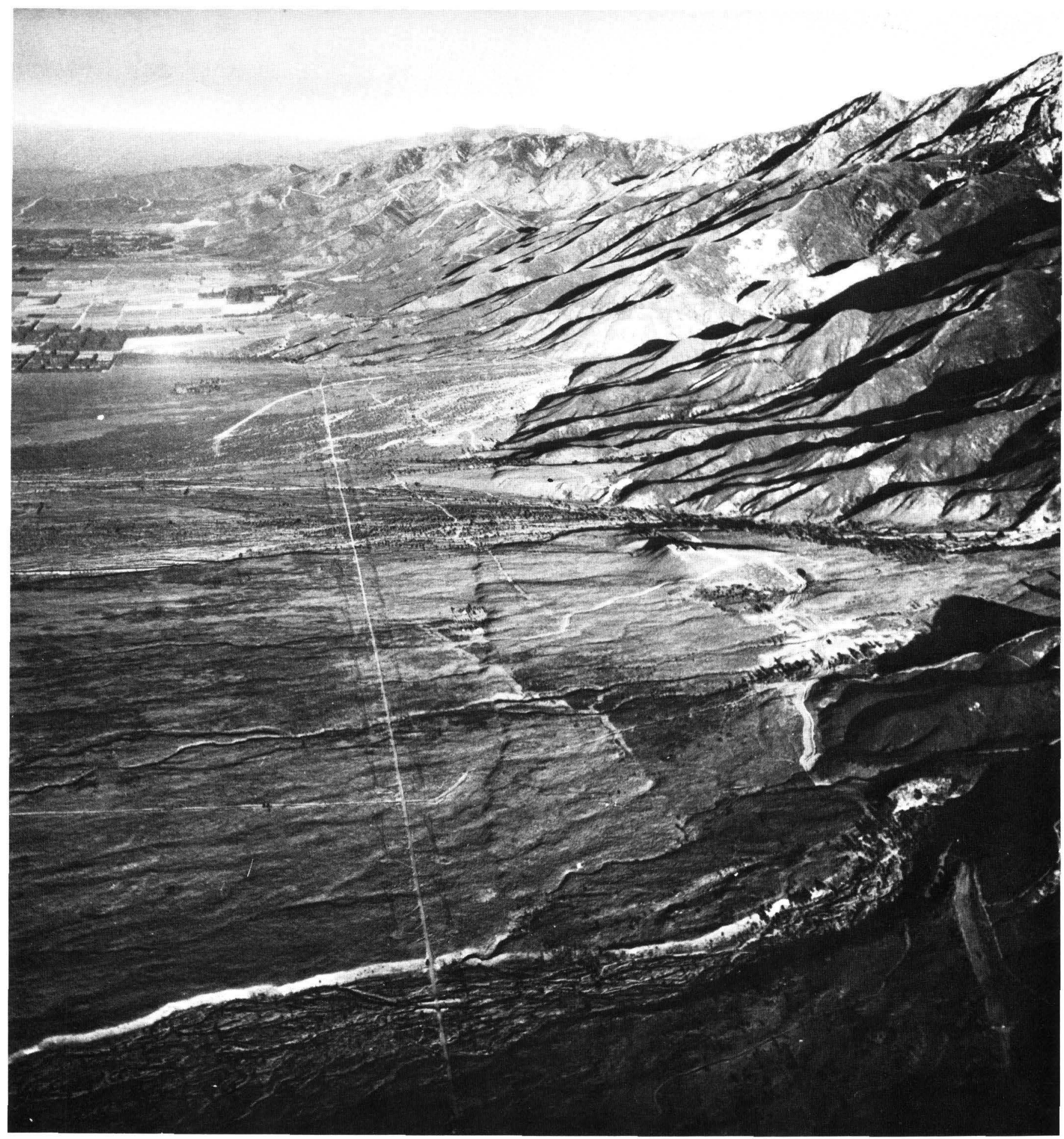

FIGURE 5.-Aerial view west along the southern front of the eastern San Gabriel Mountains. The south-facing scarp at right center (right of powerline) is the southernmost fault of the 1-km-wide Cucamonga segment of the Transverse Ranges frontal fault zone. The fault scarp is compound (the result of at least eight successive ruptures), slopes as steeply as $30^{\circ}$, is as much as $16 \mathrm{~m}$ high, and is about $5 \mathrm{~km}$ long; the last rupture occurred between 500 and 1,000 yr B.P. The scarp cuts late Pleistocene and Holocene fan deposits of Day Canyon but does not cut the most recent deposits in active streams (right foreground). Mesozoic and older rocks of the mountain block have been thrust hundreds of meters up and southward (left) over the fan deposits by recurrent movements on the north-dipping reverse faults at a long-term average rate of about $3 \mathrm{~mm} / \mathrm{yr}$ (Matti and others, 1982). The young alluvial lowland at the left extends almost continuously for $85 \mathrm{~km}$ from San Bernardino (20 km behind viewer) to Pasadena. (Photograph taken September 1960; copyrighted by J. S. Shelton. Used by permission.) 


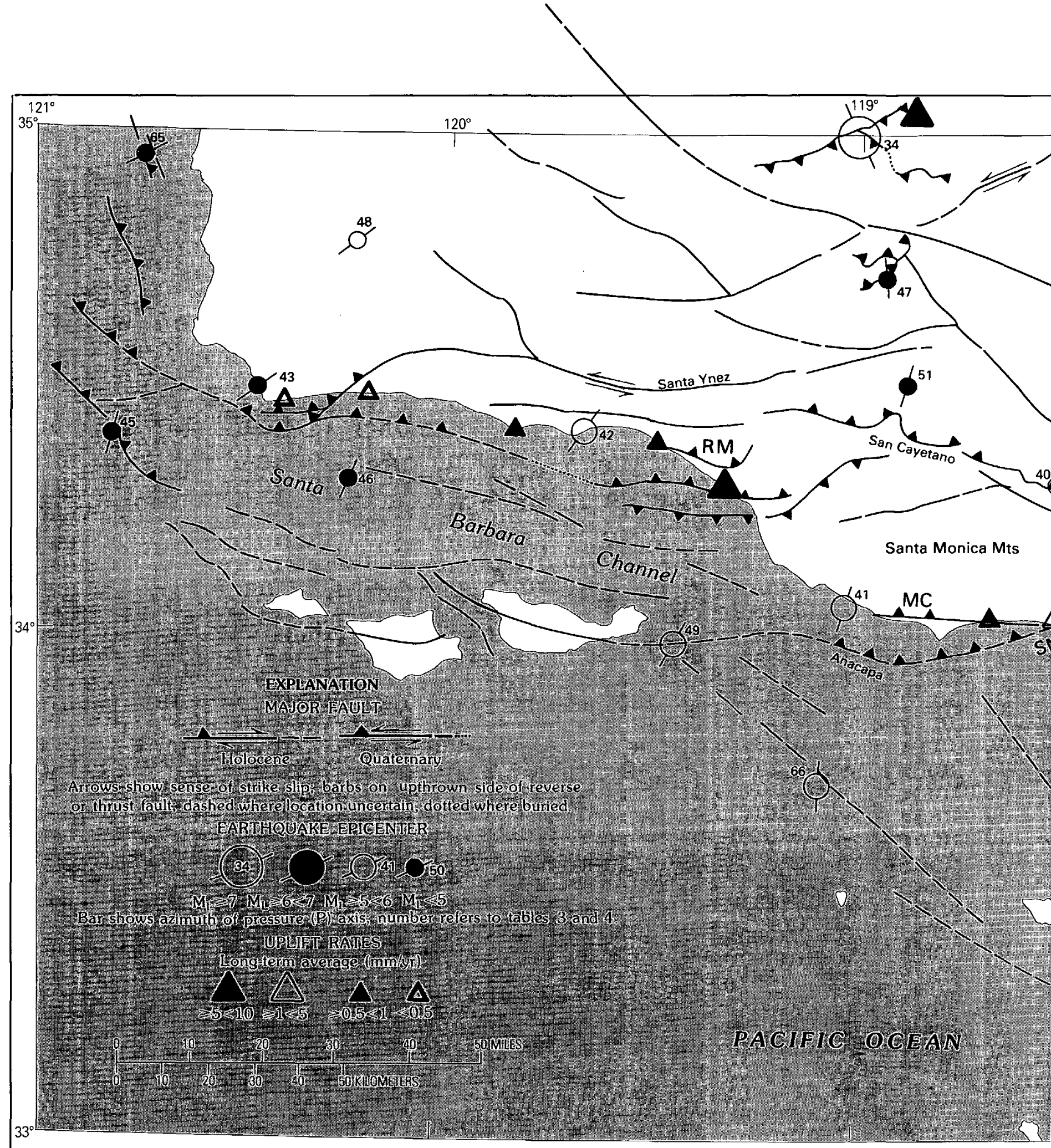

FIGURE 6.-Major Quaternary faults, directions of inferred maximum compressive stress (P axes) derived from fault-plane solutions, and localities of estimated long-term uplift rates (Lajoie and others, 1979). MC indicates Malibu Coast fault; Npt-Ingwd, Newport-Inglewood fault; PV, Palos Verdes Hills fault; Ry, Raymond fault; RM, Red Mountain fault; SF, San Fernando fault; SM, Santa Monica fault. Epicenters represent selected instrumentally located earthquakes from 1933 (event 26) to 1981 (event 66) for which well-constrained fault-plane solutions are available (event numbers from tables 3 and 4 ).

\section{Earthquake Hazards in the Los Angeles Region}




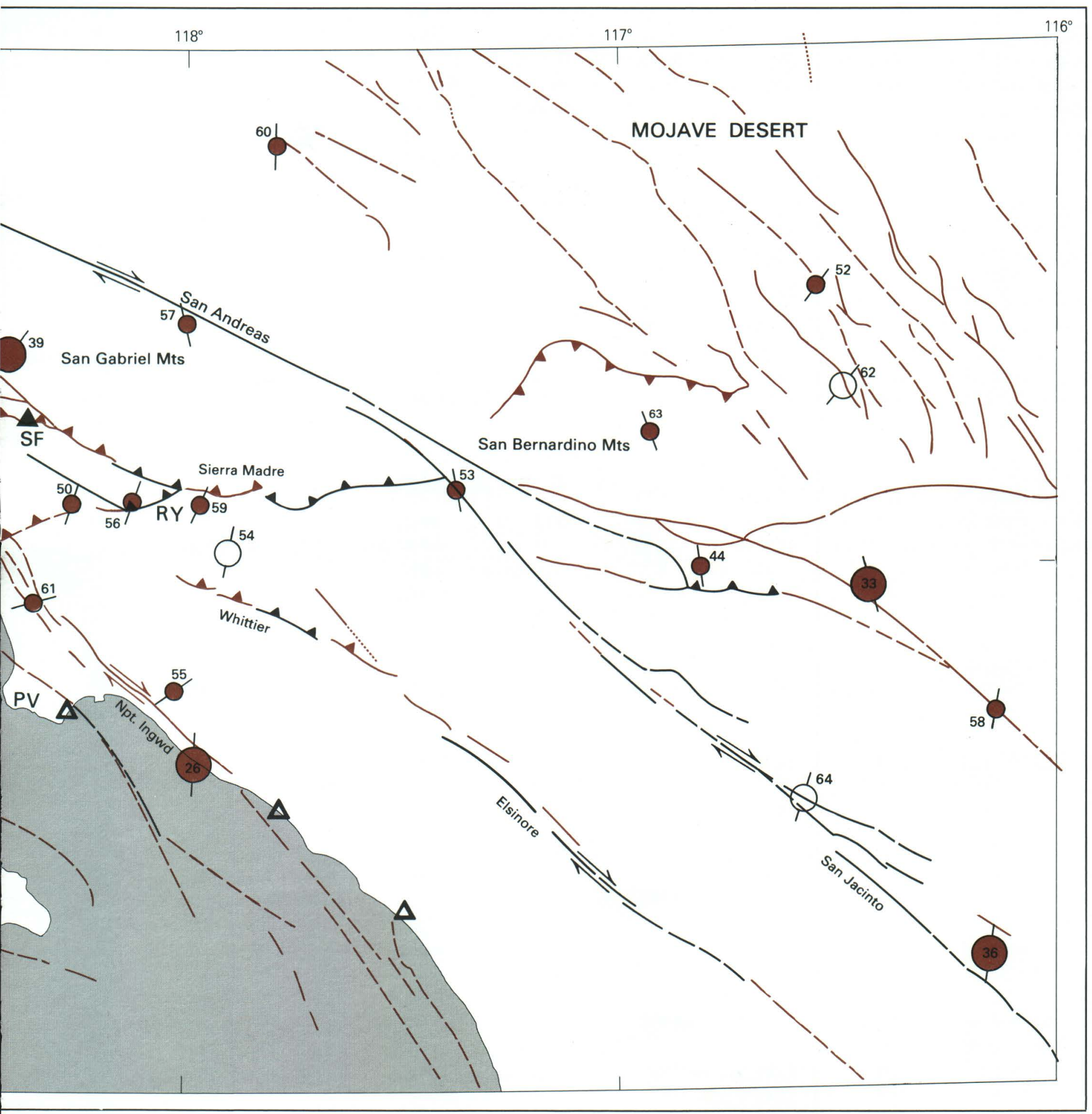


Point Conception during early years of this century (Yerkes and others, 1981) and the more extensive, transitory southern California uplift which is centered over the Mojave Desert but includes the Transverse Ranges (Castle, 1978).

Another means of describing the continuing regional deformation is to integrate all known slip rates of faults into a kinematic model. On this basis, long-term horizontal convergence rates across the Santa Barbara Channel-San Cayetano-Sierra Madre-Cucamonga zone may exceed $10 \mathrm{~mm} / \mathrm{yr}$ (Yeats, 1981), about 20 percent of the Pacific-North American plate motion. Such rates are consistent with other measured rates of deformation in the Transverse Ranges and are the highest modeled for any southern California fault west of the San Jacinto zone.

Thus, we see at several scales and through several independent lines of evidence the effects of north-south crustal shortening throughout the Transverse Ranges, effects generally associated with horizontal right-lateral movement along the plate boundary (the San Andreas and associated faults of coastal California). The compressive effects of deformation so characteristic of the Transverse Ranges have long been attributed to convergence between the "big bend" of the San Andreas fault and the Pacific plate, but this hypothesis does not account for similar effects east of the "big bend," nor is the origin of the "big bend" itself well understood. It is important to recognize that the Los Angeles region occupies the junction between two major intersecting zones of active faults, that the deformational processes probably are as active now as they have ever been (Atwater and Molnar, 1973), and that these processes are expected to continue at least at present rates.

\section{PATTERN OF ACTIVE FAULTS}

Figure 7 shows the pattern of major Quaternary faults in the Los Angeles region and epicenters of welllocated earthquakes of $M_{L} \geq 3$ for 1970 through 1981. The lowland area of the region is dominated by two seismically active fault systems-the northwest-trending right-lateral strike-slip San Andreas and its members (from east to west, the San Jacinto, the WhittierElsinore, and the Newport-Inglewood) and the westtrending reverse faults of the Transverse Ranges, the southernmost of which transects most members of the San Andreas system but not the San Andreas itself (see fig. 6). The lowland area also occupies the junction between two major physiographic provinces, the structural trends of which are controlled by the fault systems-the Peninsular Ranges province east and south of the Los Angeles basin, major elements of which parallel the San Andreas system, and the Transverse

\section{Earthquake Hazards in the Los Angeles Region}

Ranges province northwest, north, and northeast of the basin, elements of which trend generally east-west, transverse to the San Andreas system. The boundary between the two provinces is marked by a zone of westtrending reverse faults, which forms, for example, the steep southern slope of the San Gabriel Mountains (fig. 5). The damaging 1971 San Fernando earthquake occurred in this zone.

The northwest-trending Newport-Inglewood zone of faults and folds traverses the densely urbanized western Los Angeles basin and, at its northern end, is overridden by or merges with the east-trending Santa Monica zone of reverse faults. The onshore segment is about $60 \mathrm{~km}$ long from the Santa Monica zone at the northwest to the Santa Ana River at the southeast, beyond which the zone extends offshore toward San Diego. At least three damaging earthquakes have occurred along the onshore segment during historic time. The Newport-Inglewood zone has a relatively high rate of seismicity but a very low estimated long-term slip rate $(<1 \mathrm{~mm} / \mathrm{yr}$ ) (Woodward-Clyde Consultants, 1979).

\section{PATTERN OF DAMAGING EARTHQUAKES}

Because of the strong correlation (in California) between damaging earthquakes $(M \geq 5)$ (table 3) and geologically young faults mappable at the surface, the distribution of such earthquakes and faults in time and space is the best available index to the location of future damaging earthquakes. Figure 8 shows the epicenters and isoseismal patterns of 42 known damaging ( $M M \geq V I I)^{2}$ earthquakes, their relation to mapped Quaternary faults, and urbanized areas. Most damaging onshore earthquakes can be associated with known Quaternary faults, as Allen and others (1965) recognized. These faults also have been seismically active over the 11-yr period from 1970 to 1981. Even allowing for location errors for preinstrumental events, the map provides strong evidence that most Quaternary faults are seismically active. The lack of historical earthquakes on fault segments such as the San Cayetano, the Sierra Madre, and the Cucamonga in the Transverse Ranges cannot be interpreted as evidence of less hazard there; this lack is more likely to indicate earthquake recurrence intervals that exceed $180 \mathrm{yr}$, the time span since the beginning of written history in southern California.

\footnotetext{
${ }^{2} \mathrm{MM} \geq$ VII indicates a Modified Mercalli intensity equal to or greater than VII. Intensity is a measure of the effects of an earthquake at a given place based on observation. Intensity varies with magnitude but is highly dependent on the observer's experience, the site geology, and the distance from the earthquake source. MM VII is the lowest intensity at which damage to masonry of ordinary workmanship and mortar (not reinfonced or designed to resist lateral forces) appears. Several intensity scales are in use; the Modified Mercalli scale of 1931 or its successor (the 1956 version) is commonly used in the United States (Richter, 1958, p. 137). See inside back cover for a complete description of scale.
} 
An association between Holocene rupture and seismicity furnishes strong presumption of fault activity, but there have been prominent events in which one or both of these criteria have been missing or not recognized. For example, a major damaging earthquake (event 5) (fig. 6, table 3) and extensive surface rupture occurred in 1857 on a segment of the San Andreas fault that has been relatively quiet since; yet Allen (1981) has concluded that this segment still poses great seismic hazard. Furthermore, the occurrence of the 1971 San Fernando earthquake (event 39) (fig. 6, table 3) and surface rupture on a reverse fault having a well-developed young surface scarp but no recognized historical rupture or seismicity indicates that such faults also may generate damaging earthquakes.

The maps shown in figures 6,7 , and 8 identify six major sources of historical damaging earthquakes in southern California-the "big bend" segment of the San Andreas fault, the San Jacinto fault zone, the NewportInglewood zone, and the Santa Barbara Channel, San Fernando, and Raymond(?) faults of the Transverse Ranges. The San Andreas and White Wolf faults in the "big bend" area have produced the two largest southern California earthquakes of historic time (1857, M 7.9; 1952, M 7.5).

In terms of numbers of damaging earthquakes, the San Jacinto fault zone has been the most prolific in historical time. At least 10 events have taken place (1858-1980) over a fault length of about $200 \mathrm{~km}$ (table 3); about half of these events have caused damage in the San Bernardino-Riverside area.

The Newport-Inglewood zone and the Santa Barbara Channel faults each have generated several damaging earthquakes (table 3). As their reconstructed damage patterns indicate (Toppozada and others, 1981), the 1812 earthquakes were by far the largest associated with either zone.

In terms of exposure to damaging earthquakes, the $3,380 \mathrm{~km}^{2}$ of urbanized Los Angeles basin constitute about 5 percent of the onshore area mapped in figure 7 , but faults in the basin area have generated 10 ( 24 percent) of the 42 historical damaging earthquakes. All of the urbanized basin area has been shaken at $\mathrm{MM} \geq \mathrm{VII}$ at least once in the last $180 \mathrm{yr}$, about 91 percent has been shaken twice or more, about 57 percent has been shaken three times or more, about 27 percent has been shaken four times or more, and about 9 percent has been shaken five times or more.

\section{PATTERN OF MODERN SEISMICITY}

This section summarizes the distribution of instrumentally recorded seismicity and its relation to the regional and local tectonic framework. Abundant evidence shows that, in California, faults are the principal loci of stress release at and above seismic depths (Allen, 1975), generally within 10 to $15 \mathrm{~km}$ of the surface. Exposed fault traces represent roughly planar surfaces of shear that result from opposing movements of adjoining rock masses; along the plate boundary, this movement results from widespread, generally north-south compressive strain. The shearing is resisted by a frictionlike process that permits either intermittent impulsive slip (rupture), which causes earthquakes, or continuous slow movement (creep), which occurs sometimes without detectable earthquakes. Specific identification of earthquake-generating fault movements requires the ability to map earthquakes in three dimensions, especially where inclined fault surfaces are involved. Welllocated fault-plane solutions assist greatly in correlating surface and seismic evidence about the type and attitude of fault rupture (table 4), especially on inclined faults.

Figure 9 shows the relation of the Los Angeles region to the rest of California in terms of the 1980 and 1981 record of $\mathrm{M}_{\mathrm{L}} \geq 1.5$ earthquake epicenters mapped by seismograph networks that have been greatly augmented since about 1970. In central California, most earthquakes occur along mapped vertical faults of the northwest-trending San Andreas system that have Holocene right-lateral strike slip; dense alignments of small events are concentrated along segments that are known to be creeping (Allen, 1981). South of the Transverse Ranges in the Los Angeles region, similar alignments occur along the San Jacinto fault and, to a lesser degree, along portions of the Elsinore and Newport-Inglewood zones, which also are elements of the San Andreas system. The pattern of epicenters north and south of the Transverse Ranges thus reflects to a prominent degree the distribution of right-lateral strike slip on vertical faults that make up the active plate boundary. That this boundary zone is about twice as wide south of the Transverse Ranges as it is to the north perhaps reflects east-west extension south of the Transverse Ranges.

In and near the Transverse Ranges, however, the pattern of seismicity is much more diffuse (see also fig. 8). Instead of prominent northwest-trending alignments coincident with the traces of vertical faults, there are short arcuate patterns, such as those northeast of Santa Barbara Channel; tight clusters, such as those at San Fernando just to the east; or short east-west trends, such as those near the Anacapa fault. Fault-plane solutions show that the seismicity is along reverse or reverse-oblique north-dipping faults that can be mapped at the surface. East of the San Jacinto zone, some seismicity can be associated with reverse or reverseoblique displacement on the Banning and Mission Creek 


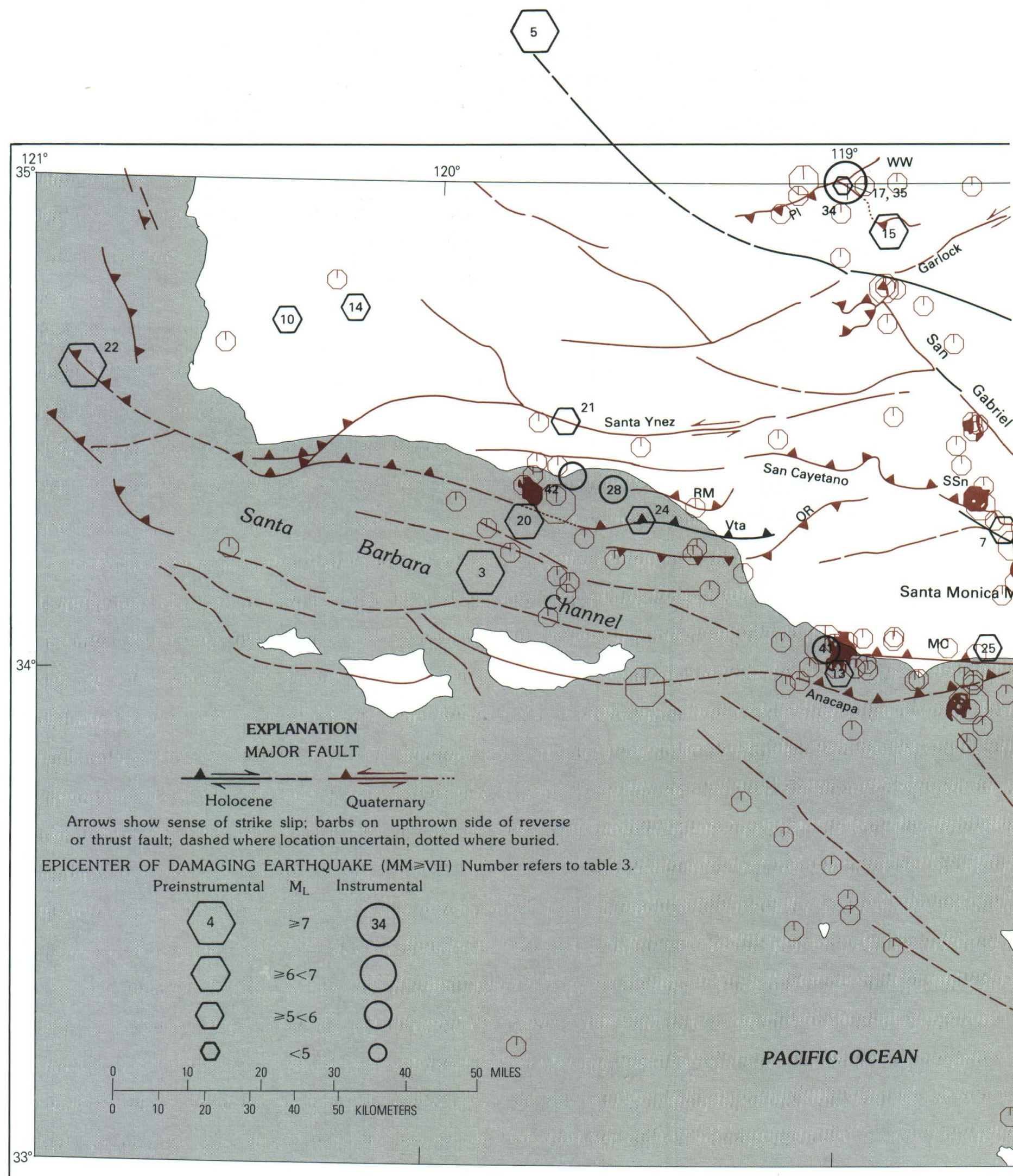

FIGURE 7.-Epicenters of 42 known damaging earthquakes (MM $\geq$ VII) from 1800 to 1978, major Quaternary faults, and 1970 to 1981 record of welllocated epicenters of $\mathrm{M}_{\mathrm{L}} \geq 3$ earthquakes (in brown). MC indicates Malibu Coast fault; M Ck, Mission Creek fault; Npt-Ingwd, NewportInglewood fault; OR, Oak Ridge fault; Pl, Pleito fault; PV, Palos Verdes Hills fault; Ry, Raymond fault; RM, Red Mountain fault; SF, San Fernando fault; SM, Santa Monica fault; S Sn, Santa Susana fault; Vta, Ventura fault; WW, White Wolf fault. 1970 to 1981 seismicity furnished by P. T. German, U.S. Geological Survey, Pasadena, Calif.; relative magnitude of event indicated by size of circle. 


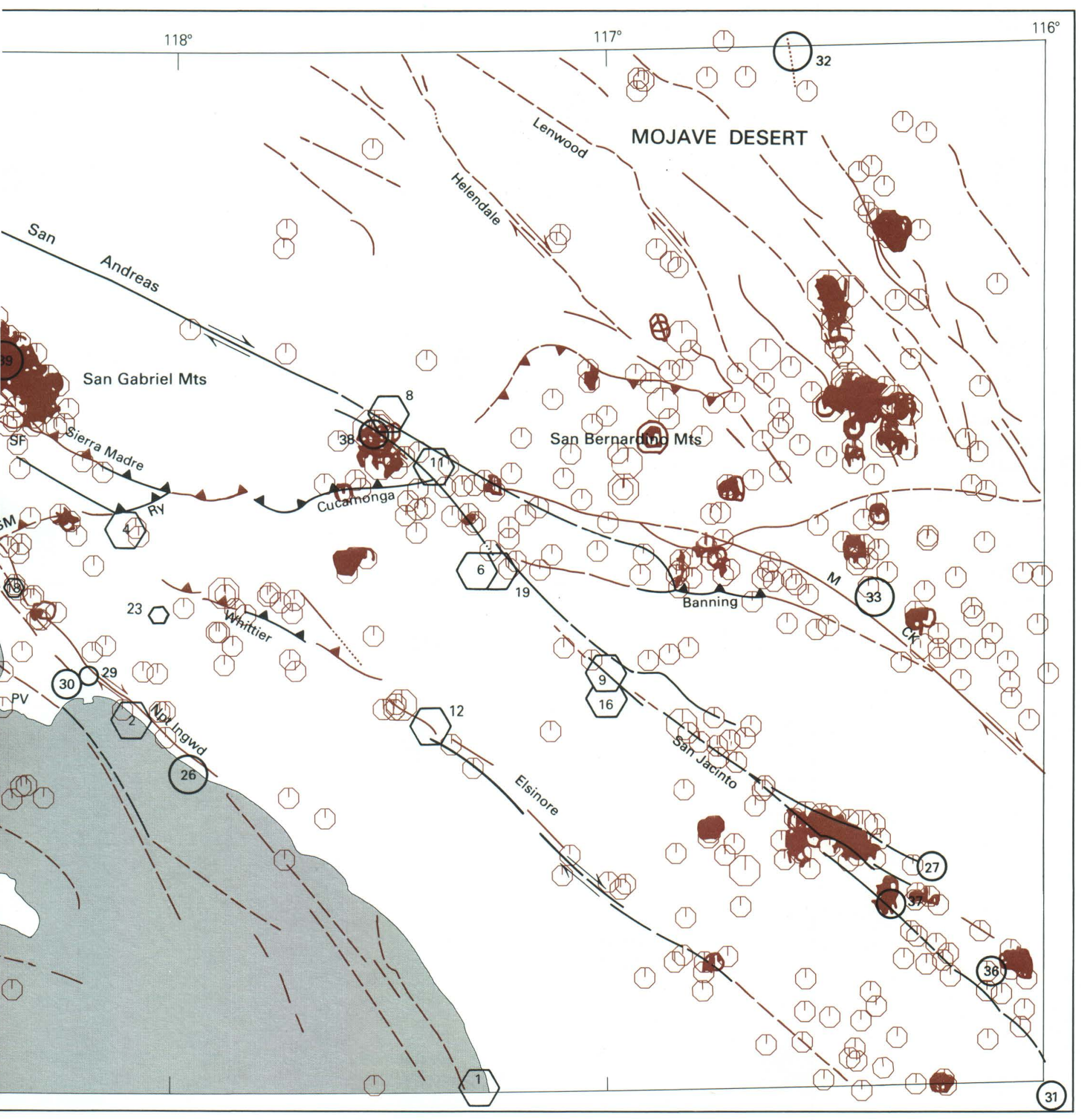


TABLE 3.-Historical (1800-1980) damaging (MM intensity $\geq \mathrm{VII}$ ) earthquakes

[Event numbers correspond to numbers used in fig. 6]

\begin{tabular}{|c|c|c|c|c|c|c|c|c|c|c|c|}
\hline $\begin{array}{l}\text { Event } \\
\text { no. }\end{array}$ & Year & Month & Day & Time $^{x}$ & $\begin{array}{l}\text { Latitude, } \\
{ }^{\circ} \mathrm{N} .\end{array}$ & $\begin{array}{l}\text { Longitude, } \\
{ }^{\circ} \mathrm{W} .\end{array}$ & $M$ & $\begin{array}{l}\text { Maximum } \\
\text { intensity } \\
\text { (MM) }\end{array}$ & $\begin{array}{l}\text { Area of } \\
\mathrm{MM} \geq 7 \\
\text { in } \mathrm{km}^{3}\end{array}$ & $\begin{array}{l}\text { Fault or } \\
\text { zone }\end{array}$ & $\begin{array}{l}\text { Remarks and } \\
\text { sources }\end{array}$ \\
\hline $1------$ & 1800 & Nov. & 22 & $21: 30$ & 33.0 & 117.3 & 6.5 & VII & $2,920^{3}$ & Rose Canyon(?) & 1 \\
\hline 2------ & 1812 & Dec. & 8 & $15: 00$ & 33.7 & $118.1^{2}$ & 6.9 & VII & 8,500 & Newport-Inglewood & 1 \\
\hline $3--\cdots$ & 1812 & Dec. & 21 & $19: 00$ & 34.2 & 119.9 & 7.1 & VIII & 13,000 & $\begin{array}{l}\text { Santa Barbara } \\
\text { Channel. }\end{array}$ & $\begin{array}{l}\text { One strong foreshock } \\
\text { and many strong } \\
\text { aftershocks; } 1 \text {. }\end{array}$ \\
\hline $4-----$ & 1855 & July & 11 & 04:15 & 34.1 & 118.1 & 6 & VIII & $775^{3}$ & Raymond(?) & 1 \\
\hline 5------ & 1857 & Jan. & 9 & 16:00 & 35.3 & 119.8 & 7.9 & $\mathrm{IX}+$ & 57,000 & San Andreas & $\begin{array}{c}\geq 360-\mathrm{km} \text { surface } \\
\text { rupture; } 1,2 \text {. }\end{array}$ \\
\hline 6-- - & 1858 & Dec. & 16 & $10: 00$ & 34.0 & $117.3^{2}$ & 6.5 & IX & $2,920^{3}$ & $\begin{array}{l}\text { San Andreas- } \\
\text { San Jacinto. }\end{array}$ & 1 \\
\hline 6a----- & 1892 & Feb. & 24 & $07: 20$ & 32.6 & 115.7 & 6.8 & $\mathrm{IX}+$ & 6,600 & $\begin{array}{l}\text { Laguna-Salada } \\
\text { (Elsinore). }\end{array}$ & 1,33 \\
\hline 7------ & 1893 & Apr. & 4 & $19: 40$ & 34.3 & $118.7^{2}$ & 5.5 & VIII & $205^{3}$ & $\begin{array}{l}\text { Santa Susana(?), } \\
\text { Simi(?). }\end{array}$ & 1 \\
\hline 8------ & 1899 & July & 22 & $20: 32$ & 34.3 & 117.5 & 6.7 & VIII & 4,300 & San Andreas(?) & 1 \\
\hline $9-----$ & 1899 & Dec. & 25 & $12: 25$ & 33.8 & 117.0 & 6.8 & IX & 4,700 & San Jacinto & 1,3 \\
\hline $10--\cdots$ & 1902 & July & 28 & $06: 57$ & $34.7^{2}$ & 120.4 & 5.4 & VIII & 202 & Los Alamos & $\begin{array}{l}\text { Two large } \\
\text { aftershocks in } 4 \\
\text { days }(4,5,6) .\end{array}$ \\
\hline $11-----$ & 1907 & Sep. & 20 & $01: 54$ & 34.2 & 117.4 & 6 & VII & $770^{3}$ & San Jacinto(?) & $3,4,6$ \\
\hline $12------$ & 1910 & May & 15 & $15: 47$ & 33.7 & 117.4 & 6 & VII & $775^{3}$ & Elsinore(?) & 4,6 \\
\hline $13--=--$ & 1912 & Dec. & 14 & & 34 & 119 & 5 & VII & $55^{3}$ & Offshore(?) & 4,6 \\
\hline $14------$ & 1915 & Jan. & 12 & $04: 31$ & 34.73 & 120.23 & 5.8 & VIII & 540 & Los Alamos & $4,5,6$ \\
\hline $15-----$ & 1916 & Oct. & 23 & $02: 44$ & 34.9 & 118.9 & 5.6 & VII & 260 & & $4,5 a, 6$ \\
\hline $16-----$ & 1918 & Apr. & 21 & $22: 32$ & 33.75 & 117.00 & 6.8 & IX & 7,000 & San Jacinto & $3,4,7$ \\
\hline $17------$ & 1919 & Feb. & 16 & $15: 57$ & 35 & 119 & 5 & VII & $55^{3}$ & White Wolf & 4,6 \\
\hline $18------$ & 1920 & June & 22 & $02: 48$ & 33.97 & 118.37 & 4.7 & VIII & 34 & Newport-Inglewood & $4,8,9$ \\
\hline $19------$ & 1923 & July & 23 & $07: 30$ & 34 & 117.25 & 6.0 & VII & $1,320^{3}$ & San Jacinto & $3,4,6$ \\
\hline $20-\ldots--$ & 1925 & June & 29 & $14: 42$ & 34.3 & 119.8 & 6.8 & IX & 3,800 & $\begin{array}{l}\text { Santa Barbara } \\
\text { Channel. }\end{array}$ & $\begin{array}{l}\text { Many strong } \\
\text { aftershocks; } 4,6 \text {, } \\
\text { 10, } 36,37 .\end{array}$ \\
\hline 21------ & 1926 & June & 29 & $23: 21$ & 34.5 & $119.7^{2}$ & 5.5 & VII & $200^{3}$ & Santa Ynez(?) & 4,6 \\
\hline $22------$ & 1927 & Nov. & 4 & $13: 50$ & 34.6 & 120.9 & 7.3 & IX & 2,200 & $\begin{array}{l}\text { Offshore Point } \\
\text { Arguello. }\end{array}$ & $4,6,11,12,36$ \\
\hline 23------ & 1929 & July & 8 & $16: 46$ & 33.9 & 118.04 & 4.7 & VIII & 40 & Norwalk & $4,6,13$ \\
\hline $24-----$ & 1930 & Aug. & 5 & $11: 25$ & 34.3 & 119.5 & 5 & VII & $55^{3}$ & $\begin{array}{l}\text { Santa Barbara } \\
\text { Channel. }\end{array}$ & 4,6 \\
\hline $25------$ & 1930 & Aug. & 31 & $00: 40$ & $33.95^{2}$ & $118.68^{2}$ & 5.2 & VII & 95 & Anacapa & $4,6,14$ \\
\hline $26-----$ & 1933 & Mar. & 11 & $01: 54$ & 33.62 & 117.97 & 6.2 & IX & 2,835 & Newport-Inglewood & $\begin{array}{l}\text { Twelve aftershocks } \\
\quad \geq M_{L} 5 \text { by Oct. } 2 \text {; } \\
6,15,16,17 \\
34,36 .\end{array}$ \\
\hline $27-\cdots--$ & 1937 & Mar. & 25 & $16: 49$ & 33.41 & 116.26 & 6 & VII & 775 & San Jacinto & $6,15,18$ \\
\hline $28-----$ & 1941 & July & 1 & $07: 50$ & 34.37 & 119.58 & 6.0 & VIII & $595^{9}$ & $\begin{array}{l}\text { Santa Barbara } \\
\text { Channel. }\end{array}$ & $\begin{array}{l}\text { Plus many strong } \\
\text { aftershocks; } 6,15 \text {. }\end{array}$ \\
\hline $29------$ & 1941 & Oct. & 22 & 06:57 & 33.8 & 118.2 & 4.9 & VII & 40 & $\begin{array}{l}\text { Newport- } \\
\text { Inglewood(?). }\end{array}$ & $6,15,19$ \\
\hline 30------ & 1941 & Nov. & 14 & $08: 41$ & 33.78 & 118.25 & 5.4 & $\mathrm{VII}+$ & $155^{3}$ & $\begin{array}{l}\text { Newport- } \\
\text { Inglewood(?]. }\end{array}$ & 6,15 \\
\hline $31------$ & 1942 & Oct. & 21 & $16: 22$ & 32.97 & 116.0 & 6.6 & VII & $2,920^{3}$ & San Jacinto & $3,6,15$ \\
\hline 32------ & 1947 & Apr. & 10 & $15: 58$ & 34.98 & 116.55 & 6.5 & VII & 4,700 & $\begin{array}{l}\text { Unknown, probably } \\
\text { not Manix. }\end{array}$ & $6,15,17,35$ \\
\hline 33------ & 1948 & Dec. & 4 & $23: 43$ & 33.93 & 116.38 & 6.0 & VII & 5,000 & Mission Creek & $6,15,20$ \\
\hline $34------$ & 1952 & July & 21 & $11: 52$ & 35.00 & 119.02 & 7.5 & $\mathrm{XI}$ & 30,000 & White Wolf & $\begin{array}{l}\text { Eleven aftershocks in } \\
4 \text { days: } 1 \mathrm{M}_{\mathrm{L}} \geq 6, \\
4 \mathrm{M}_{\mathrm{L}} \geq 5.5,6 \mathrm{M}_{\mathrm{L}} \geq 5 ; \\
\text { 53-km surface } \\
\text { rupture }[6,15,21) \text {. }\end{array}$ \\
\hline
\end{tabular}


TABLE 3. - Historical (1800-1980) damaging (MM intensity $\geq$ VII) earthquakes-Continued

\begin{tabular}{|c|c|c|c|c|c|c|c|c|c|c|c|}
\hline $\begin{array}{c}\text { Event } \\
\text { no. }\end{array}$ & Year & Month & Day & Time $^{1}$ & $\begin{array}{l}\text { Latitude, } \\
{ }^{\circ} \mathrm{N} .\end{array}$ & $\begin{array}{l}\text { Longitude, } \\
{ }^{\circ} \mathrm{W} .\end{array}$ & $M$ & $\begin{array}{l}\text { Maximum } \\
\text { intensity } \\
\text { (MM) }\end{array}$ & $\begin{array}{l}\text { Area of } \\
M M \geq 7 \\
\text { in } \mathrm{km}^{3}\end{array}$ & $\begin{array}{l}\text { Fault or } \\
\text { zone }\end{array}$ & $\begin{array}{l}\text { Remarks and } \\
\text { sources }\end{array}$ \\
\hline $35------$ & 1954 & Jan. & 12 & $23: 33$ & 35.0 & 119.02 & 5.9 & $\mathrm{VII}+$ & 540 & White Wolf & $6,15,22$ \\
\hline $36-----$ & 1968 & Apr. & 9 & 02:28 & 33.19 & 116.13 & 6.5 & VII & 1,330 & $\begin{array}{l}\text { Coyote Creek } \\
\text { (San Jacinto). }\end{array}$ & $6,15,23$ \\
\hline $37------$ & 1969 & Apr. & 28 & $23: 20$ & 33.34 & 116.35 & 5.8 & VII & 420 & San Jacinto & $6,15,24$ \\
\hline $38-\cdots--$ & 1970 & Sep. & 12 & $14: 30$ & 34.27 & 117.54 & 5.4 & VII & $175^{3}$ & North San Jacinto & $6,15,31$ \\
\hline $39-----$ & 1971 & Feb. & 9 & 14:00 & 34.41 & 118.40 & 6.6 & IX & 2,600 & San Fernando & $\begin{array}{l}\text { Four aftershocks in } \\
43 \min : 2 \mathrm{M}_{\mathrm{L}} \geq 5.5 \\
\text { 15-km surface rup- } \\
\text { ture; } 15,25,27 \text {. }\end{array}$ \\
\hline $40------$ & 1971 & Mar. & 31 & 14:52 & 34.29 & 118.52 & 5.1 & VII & 85 & San Fernando & 26,27 \\
\hline $41----$ & 1973 & Feb. & 21 & $14: 45$ & 34.07 & 119.04 & 5.3 & VII & 425 & Anacapa & 15,28 \\
\hline $42--$ & 1978 & Aug. & 13 & $22: 54$ & 34.40 & 119.68 & 5.6 & VII & 330 & $\begin{array}{l}\text { Santa Barbara } \\
\text { Channel. }\end{array}$ & $\begin{array}{l}\text { Plus many small } \\
\text { aftershocks; } 29 \text {, } \\
30,32 \text {. }\end{array}$ \\
\hline
\end{tabular}
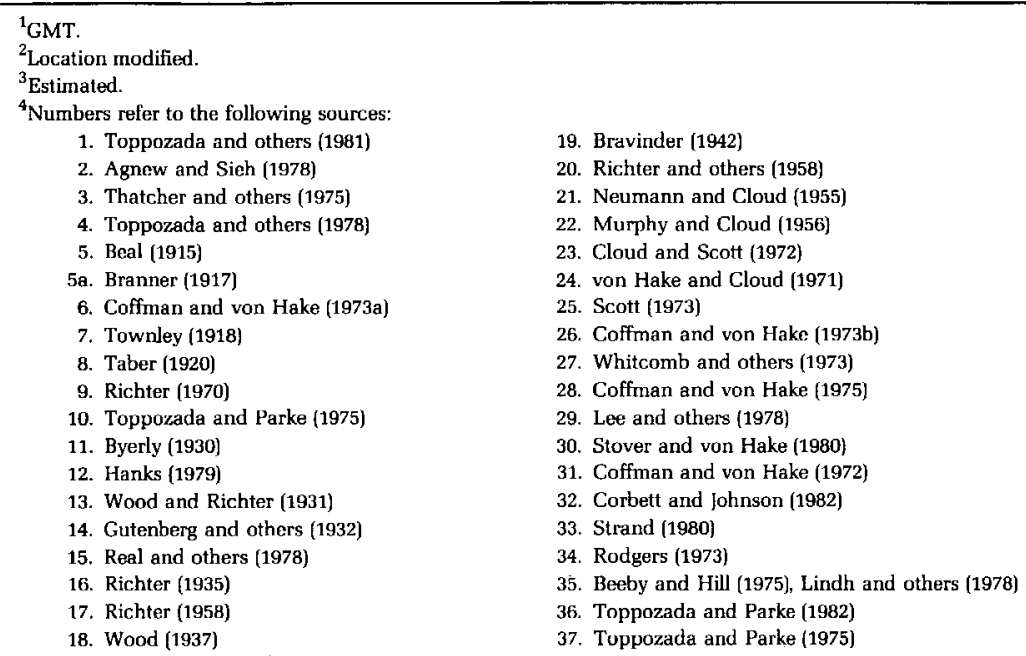

faults. Reverse faulting along this entire east-west belt generally marks the southern margin of such mountain ranges as the Santa Monica, the San Gabriel, and the San Bernardino Mountains.

The "cloud" of seismicity in the San Benardino Mountains is poorly understood. The few available fault-plane solutions are compatible with right-lateral strike slip on mapped vertical northwest-trending faults similar to those in the Mojave Desert to the north; none correlate with the south-dipping reverse faults that border the mountains on the north. The presence of this seismicity, as opposed to the relative lack in the adjoining San Gabriel Mountains, presumably is related to contrasting structure and shear resistance at depth.

The dense north-trending alignment of epicenters immediately east of the San Bernardino Mountains includes three events associated with historical surface rupture; the ruptures are aligned more nearly with the zone of epicenters than they are with the regional trend of faults in the Mojave Desert. The approximate coin- cidence of this alignment with the eastern boundary of seismicity, the eastward change in habit to normal faulting, and the sharp eastward rise in heat flow (Lachenbruch and others, 1978) suggest an association with ongoing adjustments of the plate boundary.

\section{SUMMARY}

Metropolitan southern California lies along the broad boundary between two of the Earth's moving crustal plates. Continuing deformation along the boundary, caused by generally north-south compression derived from relative motion of the plates, is expressed chiefly as right-lateral strike slip on vertical faults of the northwest-trending San Andreas system both north and south of the Transverse Ranges. In turn, this displacement is expressed as prominent alignments of earthquake epicenters that coincide with and directly reflect the fault traces and movement on them. In the Trans- 


\section{$\square$}

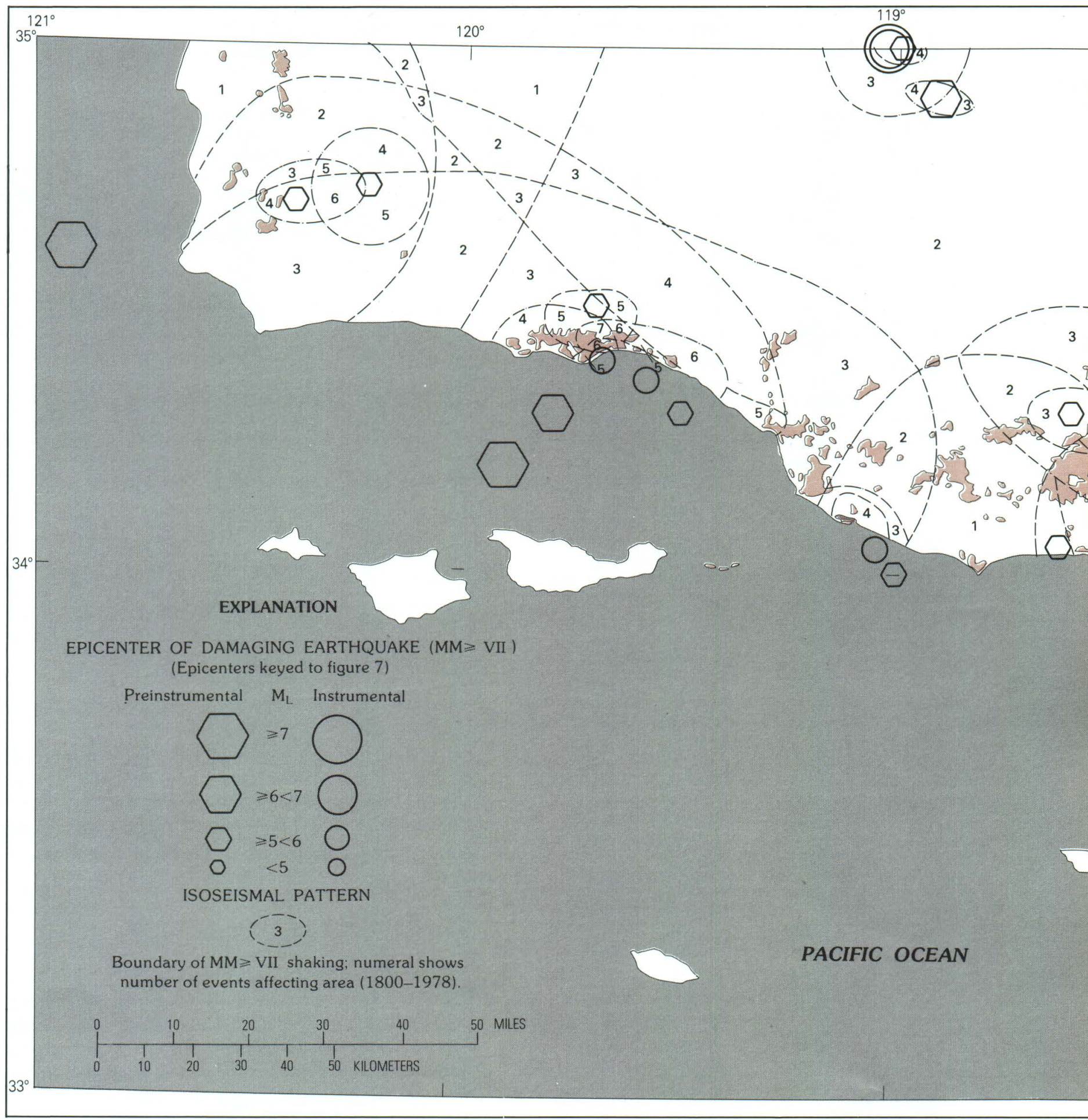

FIGURE 8.-Epicenters and isoseismal patterns of 42 known damaging ( $M M \geq V I I)$ earthquakes from 1800 to 1978 in relation to urbanized areas (in brown). Epicenters and patterns for preinstrumental events have been reconstructed, largely by Toppozada and others (1981), from contemporary records. 

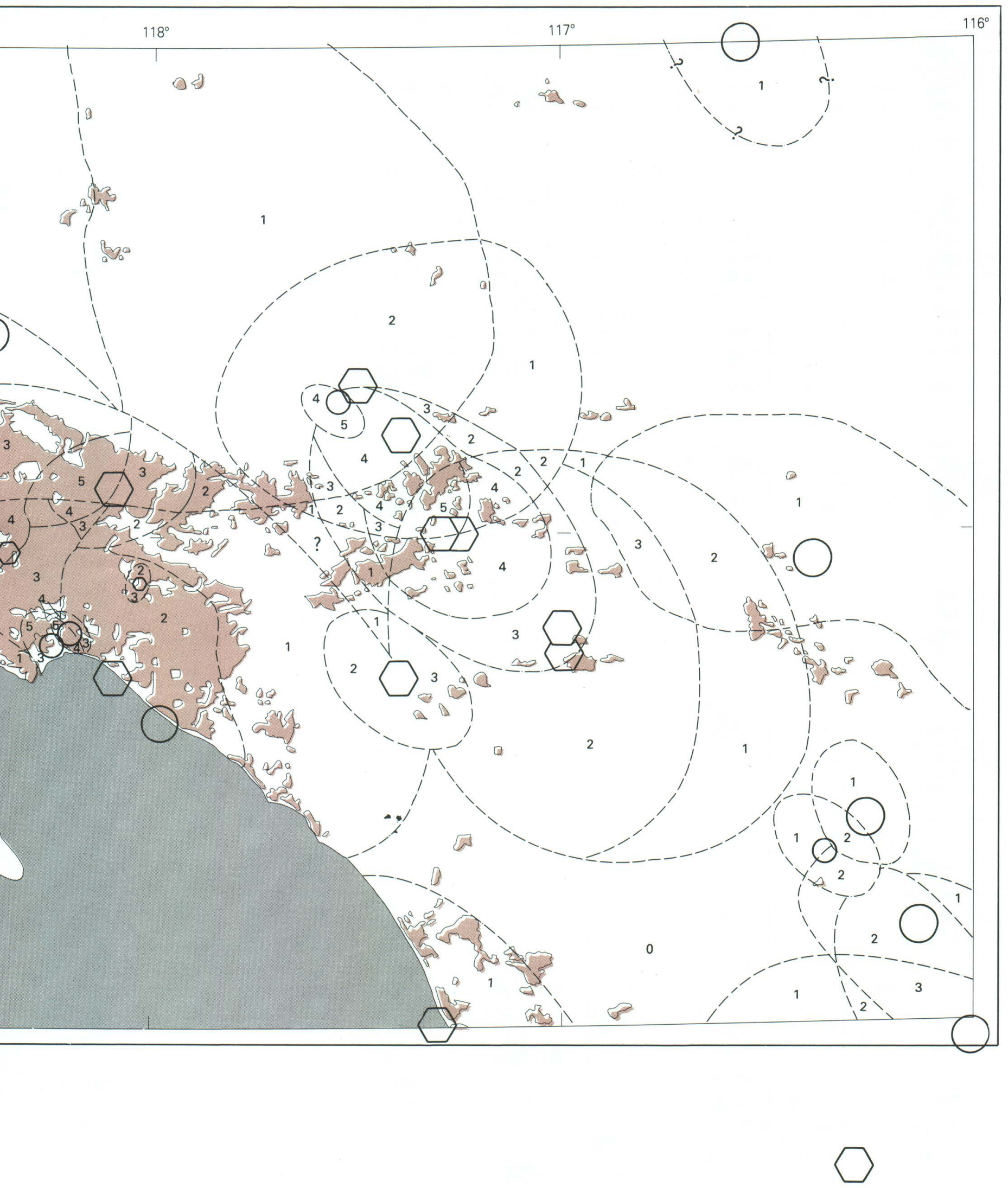
TABLE 4.-Selected earthquakes having known fault-plane solutions [Event numbers correspond to numbers used in fig. 6]

\begin{tabular}{|c|c|c|c|c|c|c|c|c|c|c|}
\hline $\begin{array}{c}\text { Event } \\
\text { no. }\end{array}$ & Year & Month & Day & Time $^{1}$ & $\begin{array}{l}\text { Latitude, } \\
{ }^{\circ} \mathrm{N} .\end{array}$ & $\begin{array}{l}\text { Longitude, } \\
{ }^{\circ} \mathrm{W} \text {. }\end{array}$ & $\mathrm{M}_{\mathrm{L}}$ & $\begin{array}{l}\text { Fault or } \\
\text { zone }\end{array}$ & Type & $\begin{array}{l}\text { Remarks and } \\
\text { sources }^{2}\end{array}$ \\
\hline $43------$ & 1959 & Oct. & 1 & 04:35 & 34.48 & 120.49 & 4.5 & $\begin{array}{l}\text { Point Conception } \\
\text { area. }\end{array}$ & Left-reverse oblique & 1 \\
\hline 44------ & 1965 & Oct. & 17 & $09: 45$ & 33.98 & 116.78 & 4.9 & Banning(?) & Reverse & 12 \\
\hline $45-----$ & 1969 & Oct. & 30 & $15: 36$ & 34.38 & 120.84 & 3.7 & $\begin{array}{l}\text { Off Point } \\
\text { Conception }\end{array}$ & Left-reverse oblique & 1 \\
\hline $46------$ & 1972 & Jan. & 17 & $05: 49$ & 34.30 & 120.26 & 2.7 & $\begin{array}{l}\text { Santa Barbara } \\
\text { Channel. }\end{array}$ & Reverse & 2 \\
\hline $47------$ & 1972 & July & 27 & 01:12 & 34.72 & 118.95 & 3.0 & Unknown & Thrust & 2 \\
\hline $48------$ & 1972 & Sep. & 23 & 03:23 & 34.78 & 120.25 & 3.0 & Alamos-Baseline & Left-reverse oblique & 1 \\
\hline $49------$ & 1973 & Aug. & 6 & $23: 29$ & 33.97 & 119.45 & 5.0 & Santa Cruz Island & Left-reverse oblique & 1 \\
\hline $50-----$ & 1974 & Dec. & 6 & $13: 45$ & 34.12 & 118.26 & 4.4 & Santa Monica(?) & Reverse & 7 \\
\hline $51-----$ & 1975 & Mar. & 24 & $10: 32$ & 34.50 & 118.89 & 2.7 & Unknown & Reverse & 2 \\
\hline $52-----$ & 1975 & May & 31 & 14:39 & 34.52 & 116.49 & 5.2 & Galway Lake & Right lateral & $\begin{array}{l}\text { 6.8-km surface } \\
\text { rupture; } 13 .\end{array}$ \\
\hline $53-----$ & 1975 & Nov. & 5 & & 34.13 & 117.34 & 3.0 & San Jacinto & Right lateral & 6 \\
\hline 54------ & 1976 & Jan. & 1 & $17: 20$ & 34.01 & 117.88 & 4.0 & Unknown & Right lateral & 5 \\
\hline $55-\cdots$ & 1976 & Oct. & 15 & $15: 56$ & 33.75 & 118.02 & 2.8 & $\begin{array}{l}\text { Newport- } \\
\text { Inglewood(?). }\end{array}$ & Reverse & 5 \\
\hline $56------$ & 1976 & Nov. & 30 & $16: 18$ & 34.08 & 118.12 & 2.5 & Raymond & Reverse & 6 \\
\hline $57 \ldots$ & 1977 & Mar. & 17 & & 34.46 & 117.98 & 3.0 & San Andreas & $\begin{array}{l}\text { Right-reverse } \\
\text { oblique. }\end{array}$ & 6 \\
\hline 58------ & 1978 & May & 14 & & 33.68 & . 116.04 & 2.2 & San Andreas & Right lateral & 12 \\
\hline 59------ & 1977 & June & 27 & $20: 59$ & 34.11 & 117.95 & 2.9 & Sierra Madre(?) & Reverse & 4 \\
\hline 60------ & 1978 & June & 19 & & 34.81 & 117.77 & 3.0 & Mirage Valley & Reverse & 6 \\
\hline $61-\cdots$ & 1978 & Dec. & 29 & $06: 30$ & 33.92 & 118.34 & 2.5 & Newport-Inglewood & Reverse & 5 \\
\hline 62----- & 1979 & Mar. & 15 & 21:07 & 34.32 & 116.44 & 5.2 & Homestead Valley & Right lateral & $\begin{array}{c}\text { 3-km surface } \\
\text { rupture; } 8 .\end{array}$ \\
\hline 63------ & 1979 & June & 30 & $00: 34$ & 34.23 & 116.89 & 4.9 & $\begin{array}{l}\text { San Bernardino } \\
\text { Mountains. }\end{array}$ & Strike slip & 9 \\
\hline 64------ & 1980 & Feb. & 25 & & 33.52 & 116.55 & 5.6 & San Jacinto & Right lateral & 10 \\
\hline 65------ & 1980 & May & 29 & & 34.94 & 120.78 & 4.8 & Hosgri & Reverse & 3 \\
\hline $66-----$ & 1981 & Sep. & 4 & $15: 50$ & 33.68 & 119.10 & 5.3 & $\begin{array}{l}\text { North of Santa } \\
\text { Barbara Island. }\end{array}$ & Right lateral & 11 \\
\hline
\end{tabular}

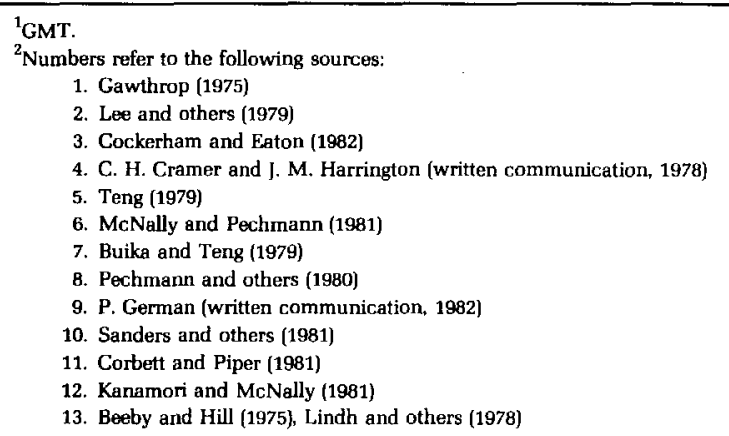

verse Ranges, however, the north-south compression is expressed by a large component of vertical deformation-folding and mountain building through reverse or reverse-oblique displacement on east-trending inclined faults. The resulting patterns of seismicity can be associated with specific faults only through correlation of surface geologic evidence with seismic evidence by means of well-located fault-plane solutions. Even so, nearly all historical damaging earthquakes in the Los
Angeles region ( 42 in $180 \mathrm{yr}$ ) and many smaller earthquakes can be associated with recognized Quaternary faults that are seismically active today. Essentially all urbanized areas of the region lie within range of one or more of these damaging earthquakes. We expect this deformational process to continue at least at present rates; present evidence indicates that future damaging earthquakes will occur on or near a recognized fault that shows evidence of geologically recent activity.

\section{Earthquake Hazards in the Los Angeles Region}




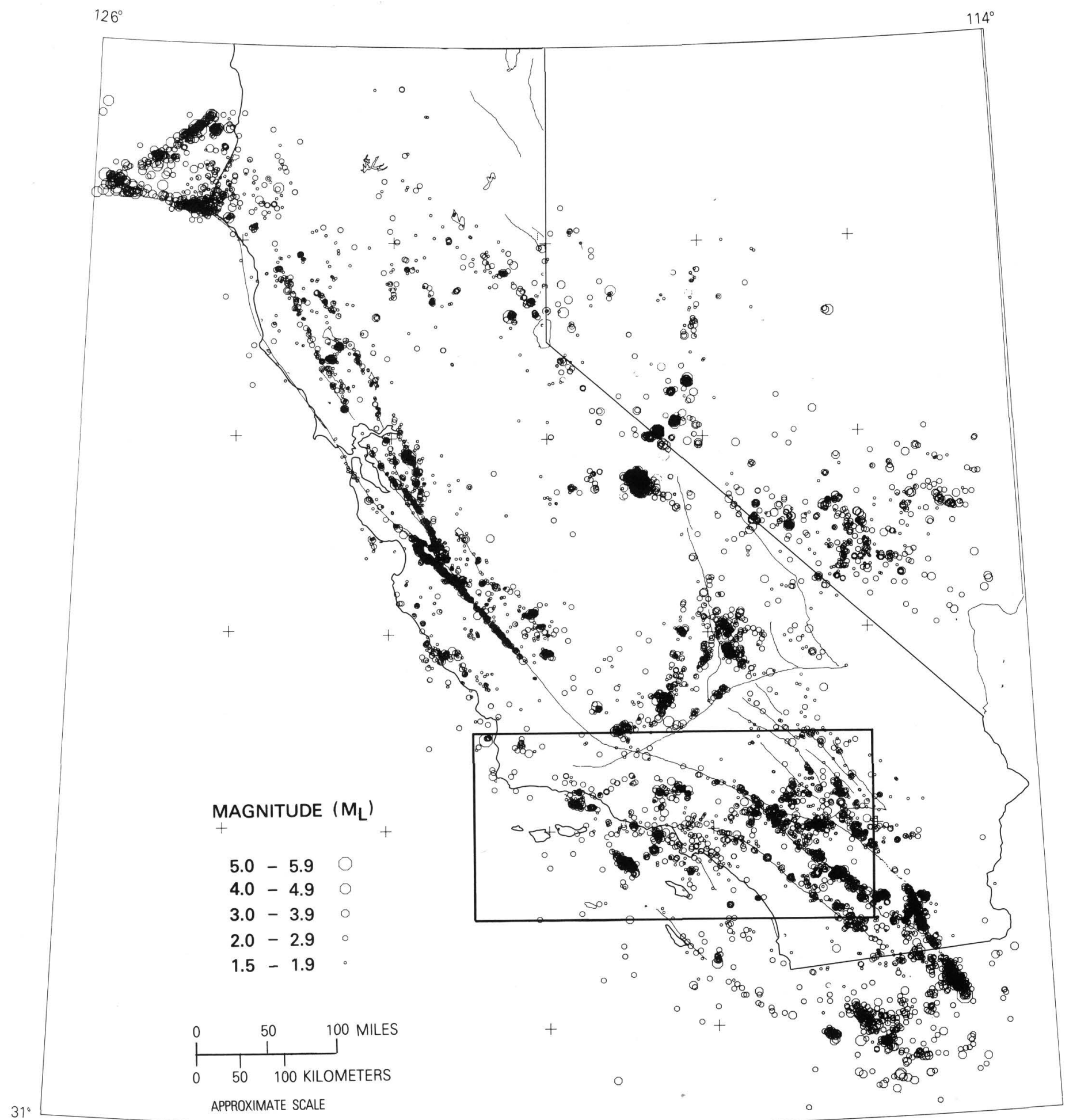

FIGURE 9.-Epicenter map of California. $M_{L} \geq 1.5$ epicenters for 1980 and 1981 and explanation of symbols. Box shows area of figures 6, 7, and 8. Map compiled and plotted by J. P. Eaton (U.S. Geological Survey, Menlo Park, Calif.) from unpublished data supplied by F. W. Lester (U.S. Geological Survey, Menlo Park, Calif.), C. E. Johnson (U.S. Geological Survey, Pasadena, Calif.), L. K. Hutton (California Institute of Technology, Pasadena, Calif.), A. S. Ryall (University of Nevada, Reno, Nev.), and A. M. Rogers (U.S. Geological Survey, Golden, Colo.). 


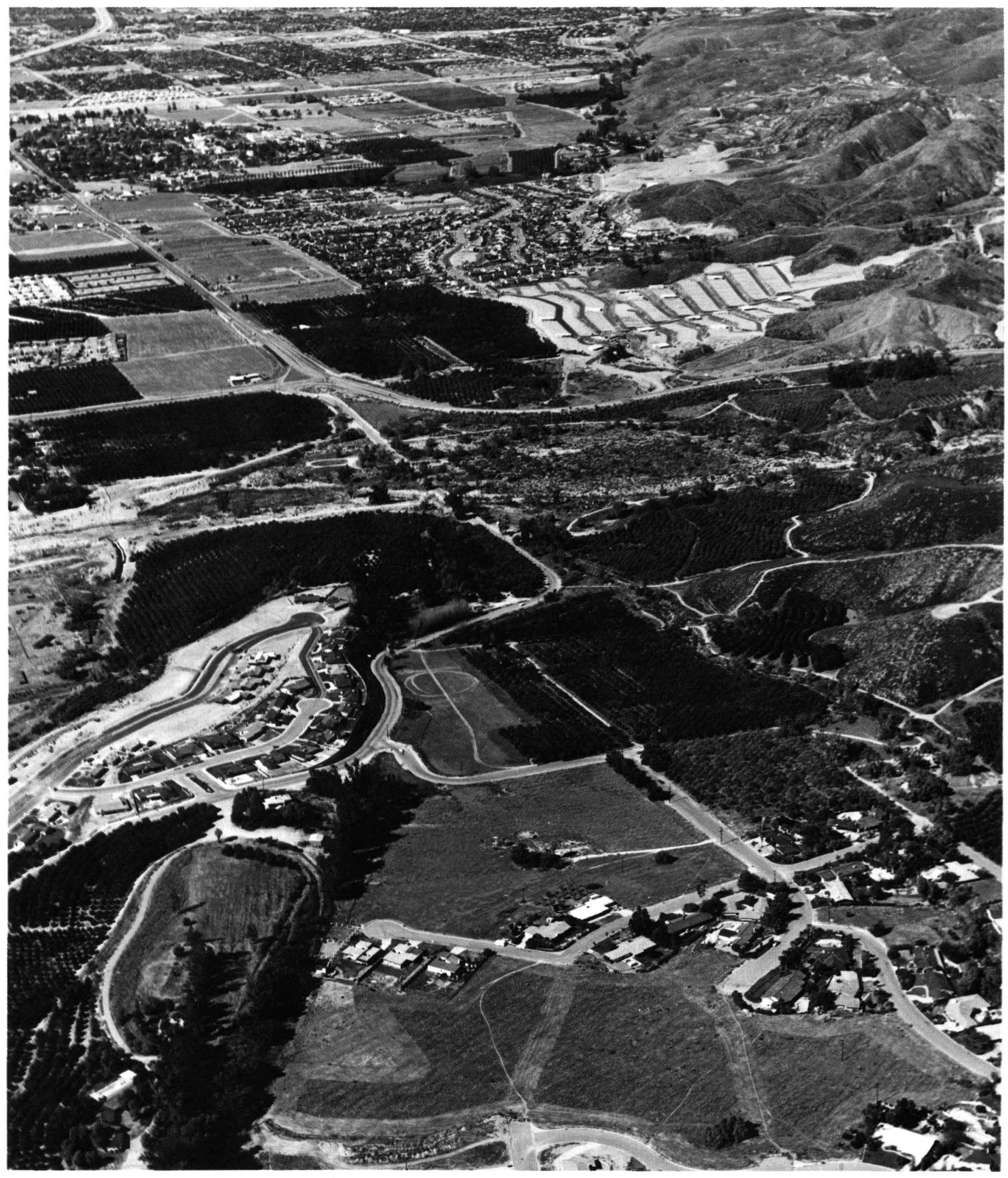

42 Earthquake Hazards in the Los Angeles Region 


\title{
EVALUATING EARTHQUAKE AND SURFACE-FAULTING POTENTIAL
}

\author{
By J. I. Ziony and R. F. Yerkes
}

\section{INTRODUCTION}

The Los Angeles region of California has been dissected by a complex pattern of faults produced over millions of years during markedly different episodes of crustal deformation. Although many of these faults apparently are no longer capable of movement, others are responding to ongoing strain accumulation associated with large-scale shifting of plates of the Earth's crust. As Yerkes (this volume) has discussed, current earthquake activity is associated with the northwest-trending strike-slip faults of the San Andreas system and the west-trending, dominantly reverse-slip faults of the Transverse Ranges. Several faults have undergone movement in historical time and generated damaging earthquakes; undoubtedly, they will slip again. Furthermore, the geologic or geophysical attributes of other faults suggest that they, too, may be capable of earthquake-generating movements within a time span of concern to residents of the region.

To avoid or to accommodate the destructive effects of earthquakes, planners and engineers need to know which faults are likely to slip suddenly again and what the likely results of such movement would be. The specific information needed includes the distribution of active faults, their relative activity, the likely size and frequency of large earthquakes along them, and their potential for rupture at the Earth's surface. This chapter describes the potentially damaging geologic effects directly associated with movement along faults, the techniques presently available for identifying and evaluating those effects, and current knowledge about the fault hazards of the Los Angeles region. Subsequent chapters will address other geologic effects such as the strong shaking and the resulting ground failure that are indirect products of sudden fault slip.

\section{POTENTIALLY ACTIVE FAULTS OF THE REGION \\ Faults and Their Character}

A fault is a fracture within the Earth's crust along which significant movement has occurred either sud- denly during earthquakes or slowly during a process called creep. Cumulative displacements of tens to hundreds of kilometers can result if the fault continues to slip over a long span of geologic time. Individual episodes of movement, however, are small-generally less than a few meters-and are commonly separated in time by tens, hundreds, or thousands of years.

A fault on a local scale is a more or less planar surface whose geometry can be characterized by strike (trend or bearing of the intersection of the fault with the Earth's surface in relation to north) and dip (inclination from the horizontal). Geologists classify faults according to the primary type of movement along them-that is, strike slip, dip slip, or oblique slip (fig. 10).

Strike-slip faults are chiefly vertical faults that have shifted rocks on one side of the fault horizontally in relation to the opposite side. Depending on whether the rock mass on the opposite side has shifted to the right or to the left, the designation of right lateral or left lateral is used. The San Andreas fault is the classic example of a right-lateral strike-slip fault. Dip-slip faults have changed the elevation of a rock mass on one side of the fault relative to the opposite mass. These faults are mostly inclined rather than vertical. If the side above the fault is depressed, the fault is termed normal slip; the term reverse slip is applied if the side above the fault is elevated. Oblique-slip faults have significant components of both strike and dip slip along them.

\section{Active Faults}

Active faults are those faults that are considered likely to undergo renewed movement within a period of concern to humans (Wallace, 1981). Faults that currently are slipping, that display earthquake activity, or that have had historical surface rupture clearly are active. Except in these limited cases, however, it is difficult to differentiate with certainty between faults capable of future movement and those that cannot move under the state of stress existing in the Earth's crust. Known active faults display a wide range of behavior, and the dynamic processes that result in fault movement are understood only partially.

Earthquake and Surface-Faulting Potential 

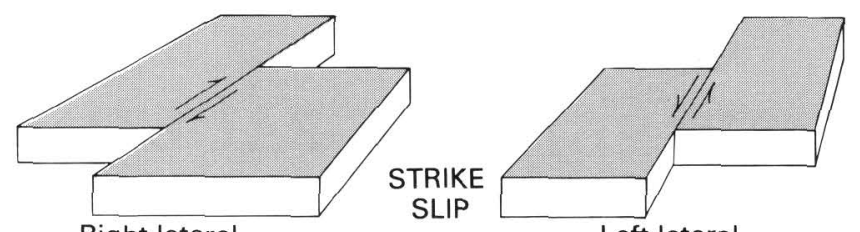

Right lateral

Left lateral
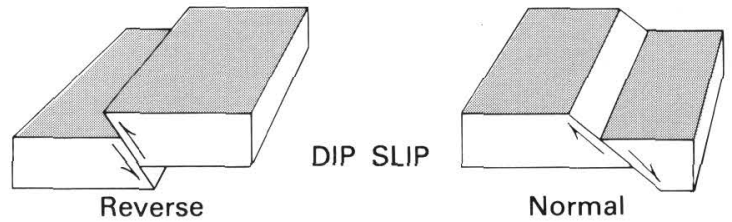

Normal

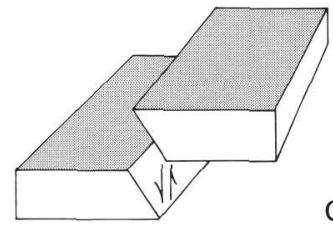

Reverse oblique
OBLIQUE SLIP

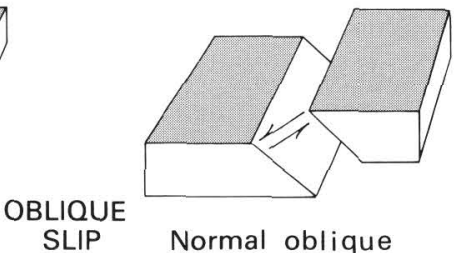

FIGURE 10.-Types of faulting common in the Los Angeles region, characterized by the sense of displacement of the blocks on opposite sides of the fault. Movement on oblique-slip faults has both strike- and dip-slip components.

An approach that has proved useful in identifying active faults is to determine the age of the most recent movement along a fault. Designation of a fault as active can be based on the assumption that the more recent the faulting, the more likely any future movement. Because different faults can lie dormant for different lengths of time before they slip again, however, there is no universally applicable time span for evaluating fault activity (see "Determining the Future Behavior of Faults"). Both historical and geologic evidence suggests that some faults may remain dormant for hundreds or thousands of years between major displacements.

This chapter considers those faults that show evidence of offset during late Quaternary time (approximately the past $750,000 \mathrm{yr}$ ) (see inside front cover) as candidates for future rupture in response to the present tectonic stress field. We have three reasons for selecting the late Quaternary as the appropriate time span within which to assess the potential activity of faults in the Los Angeles region.

1. Time spans of a few tens of thousands of years or less appear inadequate to judge fault activity, because large historical earthquakes and surface faulting have occurred worldwide along some faults that lacked evidence of historical or Holocene (the past $10,000 \mathrm{yr}$ ) activity.

2. The many late Quaternary deposits found in much of the Los Angeles region contain widespread datable markers for evaluating fault activity. Coastal sequences of marine terrace deposits are

44 Earthquake Hazards in the Los Angeles Region reliably dated back to 120,000 yr ago, according to various dating methods (Lajoie and others, 1979). In the Ventura basin, the ages of several volcanic ash layers interspersed with the Pleistocene sediments are accurately known (SarnaWojcicki and others, 1984). Inland, nonmarine alluvial deposits as old as about 750,000 yr locally (Bull and others, 1979; Meisling, 1984) are exposed extensively along the fault-bounded fronts of the major upland areas.

3. Geologic evidence in and near the Transverse Ranges suggests that major changes in the tectonic stress field of the region took place during early Pleistocene time, from about 1.7 m.y. to about $750,000 \mathrm{yr}$ ago. These changes were marked by the accelerated uplift and subsidence of major topographic elements of the Transverse Ranges, the initiation of slip along some faults, and the sharply accelerated rates of slip along other faults (Yeats, 1977, 1983; Stein and Thatcher, 1981; Meisling and Weldon, 1982b). Thus, many faults that were developed under earlier stress conditions may not be able to slip in the current stress field.

\section{Distribution of Late Quaternary Faults in the Los Angeles Region}

Faults in the Los Angeles region that show evidence of movement in late Quaternary time are shown in figure 11 and listed in table 5. Several of these faults have offset stratigraphic or physiographic features that suggest surface movements within Holocene time. A few have displaced the ground surface during historical time, which, for southern California, begins with the Spanish explorations in 1769.

As Yerkes (this volume) has pointed out, the present tectonic regime of the Los Angeles region is marked by interaction between two distinct systems of geologically young faults-the San Andreas fault and related northwest-trending faults, which have dominantly rightlateral strike-slip movement, and the west-trending faults of the Transverse Ranges, which have dominantly reverse-slip displacements. Ninety-five late Quaternary faults belonging to these systems have been identified in the region. The details of their geologic and seismologic character and sources of information about these faults are summarized in table 5. A discussion of the major faults, fault groups, or fault zones follows. Numbers in parentheses refer to the individual faults as listed in figure 11 and table 5 .

San Andreas fault zone.-The San Andreas fault zone is the dominant active fault in California. The main ele- 
ment of the boundary between the Pacific and the North American tectonic plates, it extends as a continuous surface feature from Cape Mendocino in northern California for more than $1,000 \mathrm{~km}$ to east of San Bernardino in southern California. Within the Los Angeles region, the San Andreas fault zone (1) trends southeastward along the margin of the Antelope Valley and extends through Cajon Canyon to form part of the southern boundary of the San Bernardino Mountains (fig. 12). Two great historical earthquakes marked by extensive surface faulting have occurred along this fault-the renowned 1906 San Francisco earthquake and the lesser known but possibly more severe 1857 Fort Tejon earthquake.

San Jacinto fault zone.-Echelon segments (including 2-8) of the San Jacinto fault zone extend from near San Bernardino southeastward more than $300 \mathrm{~km}$ through the Imperial Valley and into northern Baja California, Mexico. The zone at its northern end appears to merge with the San Andreas fault. For the past century, the San Jacinto fault zone has been the most active earthquake-generating feature in southern California; it has produced at least 10 earthquakes of about local magnitude $\left(\mathrm{M}_{\mathrm{L}}\right) 6.0$ or greater since 1890 .

Elsinore fault zone and related faults.-The northwest-trending Elsinore fault zone (including 13-20) extends nearly $200 \mathrm{~km}$ from the Mexican border to the northern edge of the Santa Ana Mountains. Beyond the city of Corona, the Chino fault (11) continues the trend of this zone almost to Pomona. The Whittier fault (12), which extends northwest from the Elsinore fault zone, forms part of the eastern margin of the densely populated Los Angeles basin.

Newport-Inglewood fault zone.-The NewportInglewood fault zone is a broad zone of discontinuous faults (25-31) and folds striking southeastward from near Santa Monica across the Los Angeles basin to Newport Beach. Faults having similar trends and projections occur offshore of San Clemente and in San Diego (the Rose Canyon and La Nacion faults). Altogether, these various faults constitute a system more than $240 \mathrm{~km}$ long that extends into Baja California, Mexico. A near-shore segment of the Newport-Inglewood fault zone was the source of the destructive 1933 Long Beach earthquake; this zone thus represents a major hazard to the densely populated Los Angeles basin.

Palos Verdes Hills fault.-The Palos Verdes Hills are separated from the rest of the Los Angeles basin by a major southwest-dipping fault that elevates rocks on the west. The Palos Verdes Hills fault (35) has an onshore extent of about $15 \mathrm{~km}$. It has, however, been mapped northwestward into Santa Monica Bay, where it apparently is truncated by or merges with west-trending faults of the Transverse Ranges. Segments of the fault also have been identified in San Pedro Bay nearly $30 \mathrm{~km}$ south of Long Beach.

San Pedro Basin fault zone.-The San Pedro Basin fault zone (38) is a poorly known offshore zone of echelon northwest-trending faults that extends from near Point Dume southeastward into the San Pedro Channel east of Catalina Island.

Faults of the Santa Cruz-Catalina sea-floor escarpment.-The faults of the Santa Cruz-Catalina sea-floor escarpment (39) include a number of faults that generally coincide with a prominent escarpment on the sea floor that extends southeastward from the eastern end of Santa Cruz Island. The character of these faults is less well known because of incomplete data. The escarpment bifurcates between Santa Barbara Island and Santa Catalina Island. The occurrence of the $M_{L} 5.21981$ Santa Barbara Island earthquake along this escarpment indicates that these faults pose an earthquake hazard.

Faults of the Mojave Desert.-The strike of a series of youthful faults occurring in the Mojave Desert is uniformly more northerly than that of the San Andreas fault. Within the region addressed in this report, these faults include the Mirage Valley (41), the Helendale (42), and the Lenwood (43) faults.

Faults along the margins of the San Bernardino Mountains.-The northern edge of the San Bernardino Mountains is delineated by an arcuate group of discontinuous faults (93) that have various trends and that generally dip southward into the mountain mass. The distribution and history of these faults are poorly understood and are currently being investigated.

South of the San Bernardino Mountains, the Banning fault zone (95), a complex band of north-dipping faults, extends eastward for about $50 \mathrm{~km}$. Although the Banning is shorter than many other faults, it is a key tectonic element, because it appears to link segments of the San Andreas fault to the northwest and the southeast.

Faults of the southern margin of the western Transverse Ranges.-The southern - boundary of the western Transverse Ranges is formed by an overlapping group of west- to east-northeast-trending late Quaternary faults. These faults, which dip steeply to moderately northward, comprise an essentially continuous narrow belt more than $300 \mathrm{~km}$ long that adjoins many of the major urban centers of the Los Angeles region.

Offshore, the faults include the Santa Rosa Island fault (76) and the Santa Cruz Island fault (77). The Anacapa (Dume) fault (78), probably an offshore extension of the Santa Cruz Island fault, appears to link with the Santa Monica fault (80). Onshore, the Santa Monica fault and the Hollywood fault (81) are subparallel elements along the northern margin of the Los Angeles basin. The Raymond fault (82) follows the same general trend and extends through Pasadena to intersect the 


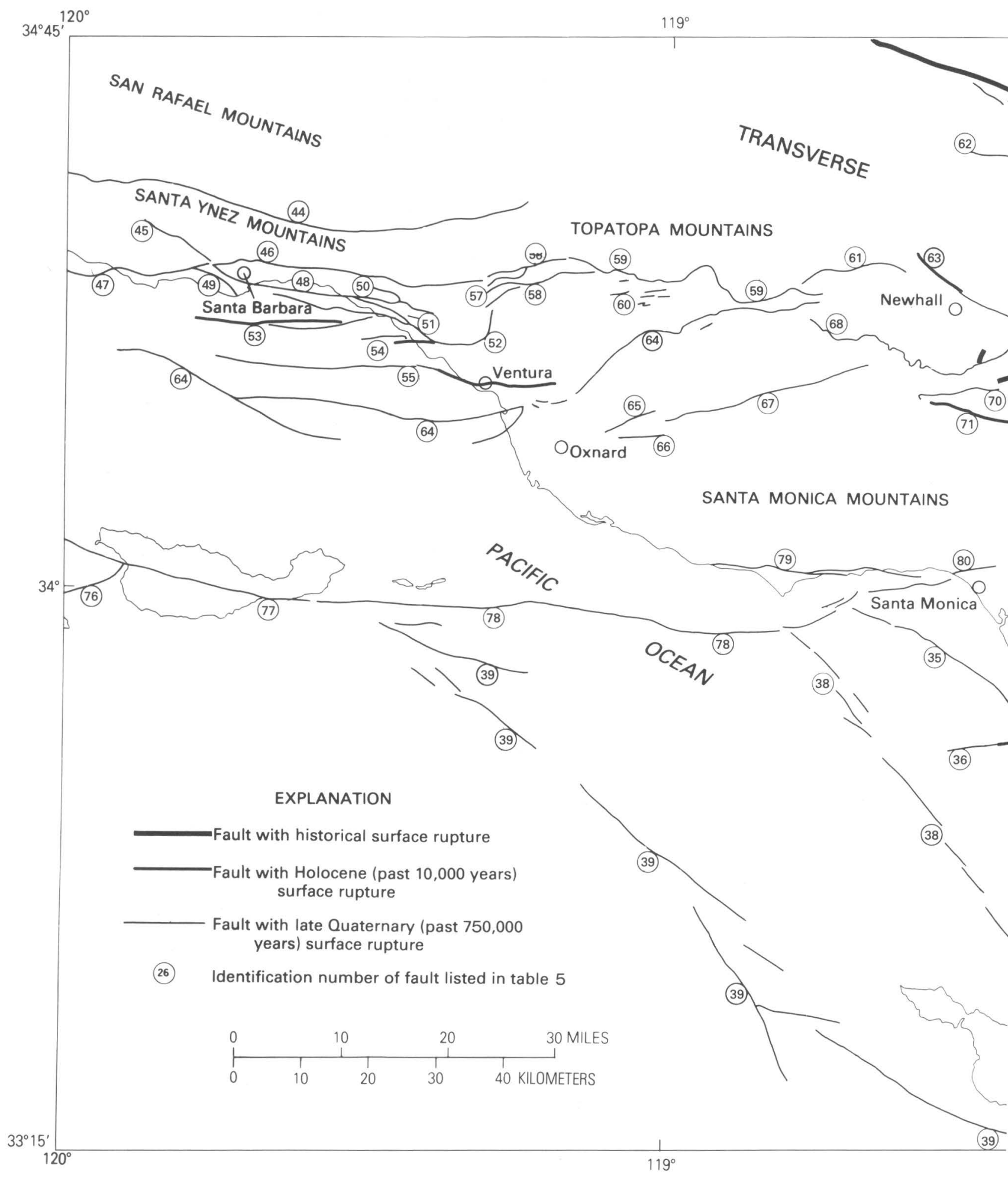

FIGURE 11.-Faults that may generate damaging earthquakes or surface rupture in the Los Angeles region. The latest surface displacements on these faults are known to have occurred either during historical time (since 1769 for southern California), during Holocene time, or during late Quaternary time. Identification numbers are keyed to table 5, which lists the faults and summarizes their geologic and seismologic character.

\section{Earthquake Hazards in the Los Angeles Region}


TABLE 5.-Geologic and seismologic characteristics of late Quaternary faults in the Los Angeles region

[For available geologic information on fault slip rates and recurrence intervals for major earthquakes, see tables 10 and 11, respectively. Evidence of faulting age: OS, offset stratigraphy; $P$, fault produced physiographic features; W, ground-water impediment within late Quaternary alluvial deposits. Type of faulting: R, reverse; N, normal; SR, right-lateral strike slip; SL, left-lateral strike slip; RRO, reverse right oblique; RLO, reverse left oblique; NRO, normal right oblique; NLO, normal left oblique]

\begin{tabular}{|c|c|c|c|c|c|}
\hline Map number and fault & Geometric aspects & $\begin{array}{l}\text { Age and evidence } \\
\text { of latest } \\
\text { surface faulting }\end{array}$ & $\begin{array}{c}\text { Type of } \\
\text { late } \\
\text { Quaternary } \\
\text { offset }\end{array}$ & Seismicity & Sources of information \\
\hline 1 San Andreas fault zone-- & $\begin{array}{l}\text { Numerous subparallel faults of } \\
\text { varied length in zone } \\
\text { generally } 0.3-1.5 \mathrm{~km} \text { wide (as } \\
\text { wide as } 4 \mathrm{~km} \text { near Palmdale } \\
\text { and Lake Hughes). Zone } \\
\text { strikes } \mathrm{N} .65^{\circ}-70^{\circ} \mathrm{W} \text {. but } \\
\text { near Banning strikes N. } 40^{\circ} \\
\mathrm{W} \text {. Most faults are approx- } \\
\text { imately vertical, although SE. } \\
\text { from Cajon Pass generally } \\
\text { dip } 55^{\circ}-60^{\circ} \mathrm{NE} \text {. The most } \\
\text { recently active element } \\
\text { within zone typically com- } \\
\text { posed of linear segments } 0.5 \\
\text { to } 11 \mathrm{~km} \text { long arranged in } \\
\text { echelon manner in belt as } \\
\text { wide as } 100 \text { m. Scattered } \\
\text { splay faults locally diverge } \\
\text { from trend of main zone. } \\
\text { Subsidiary south-dipping } \\
\text { faults common on southern } \\
\text { side of zone adjacent to } \\
\text { Antelope Valley. Fault zone } \\
\text { extends as continunus sur- } \\
\text { face feature from near Ban- } \\
\text { ning NW. more than } 1,000 \\
\text { km to Cape Mendocino. } \\
\text { Connected by Banning fault } \\
\text { (95) to Indio segment of San } \\
\text { Andreas fault NE. of Im- } \\
\text { perial Valley. }\end{array}$ & $\begin{array}{l}\text { Historical (1857) SE. to Wright- } \\
\text { wood. Holocene (OS, P) from } \\
\text { Wrightwood to near Ban- } \\
\text { ning. Splay and subsidiary } \\
\text { faults chiefly late Quaternary } \\
\text { (OS, P). }\end{array}$ & SR & $\begin{array}{l}\text { Source of } 1857 \text { Fort Tejon } \\
\text { earthquake (estimated } M \\
\text { 7.9), whose epicenter prob- } \\
\text { ably was in the } \\
\text { Parkfield-Cholame area of } \\
\text { central California. Possible } \\
\text { source of July 22, 1899, } \\
\text { earthquake (estimated } M_{L} \\
\text { 6.5) near San Bernardino. } \\
\text { Diffuse belt of scattered } \\
\text { small earthquakes } \\
\text { associated with fault zone. }\end{array}$ & $\begin{array}{l}\text { Mapping, Quail } \\
\text { Lake-Wrightwood: } \\
\text { Barrows and others (1985) } \\
\text { Mapping, Quail } \\
\text { Lake-Palmdale: } \\
\text { Beeby (1979) } \\
\text { Kahle (1979) } \\
\text { Kahle and others (1977) } \\
\text { Kahle and Barrows (1980) } \\
\text { Mapping, } \\
\text { Palmdale-Wrightwood: } \\
\text { Barrows and others (1976) } \\
\text { Barrows (1979, 1980) } \\
\text { Schubert and Crowell } \\
\text { (1980). } \\
\text { Mapping. } \\
\text { Wrightwood-Banning: } \\
\text { J. C. Matti (unpublished } \\
\text { data, 1983). } \\
\text { Miller (1979) } \\
\text { Morton and Miller (1975) } \\
\text { Ross (1969) } \\
\text { Slip/recurrence: } \\
\text { Davis and Duebendorfer } \\
\text { (1982). } \\
\text { Rasmussen (1982a) } \\
\text { Rust (1982) } \\
\text { Sieh (1978a, c, 1984) } \\
\text { Weldon and Sieh (1981) } \\
\text { Seismicity; } \\
\text { Green (1983) } \\
\text { Hileman and Hanks (1975) } \\
\text { C. E. Johnson (unpublished } \\
\text { data, 1982). }\end{array}$ \\
\hline \multirow[t]{2}{*}{$\begin{array}{l}\text { San Jacinto fault zone: } \\
2 \text { Glen Helen---- }\end{array}$} & $\begin{array}{l}\text { Single strand. Strikes } \\
\text { N. } 40^{\circ}-60^{\circ} \text { W. Presumed ver- } \\
\text { tical dip. Length at least } \\
8 \mathrm{~km} \text {. }\end{array}$ & Holocene $(P, W)$ & SR & $\begin{array}{l}\text { Closely associated small } \\
\text { earthquakes. Geometrically } \\
\text { compatible fault-plane } \\
\text { solutions. Possible source } \\
\text { for two damaging earth- } \\
\text { quakes of } M_{L} \geq 6 \text { (1899, } \\
\text { 1907). }\end{array}$ & $\begin{array}{l}\text { Cramer and Harrington } \\
\text { (1984, in press). } \\
\text { Pechmann (in press) } \\
\text { Sharp (1972) } \\
\text { Thatcher and others [1975) }\end{array}$ \\
\hline & $\begin{array}{l}\text { Several strands in zone as wide } \\
\text { as } 0.3 \mathrm{~km} \text {. Strikes N. } 40^{\circ}-60^{\circ} \\
\text { NW. Dips } 35^{\circ} \text { NE. to ver- } \\
\text { tical. Length approximately } \\
25 \mathrm{~km} \text {. }\end{array}$ & Late Quaternary (OS) & SR, RRO & $\begin{array}{l}\text { Numerous small earthquakes } \\
\text { near fault trace. } \\
\text { Geometrically compatible } \\
\text { fault-plane solutions. }\end{array}$ & $\begin{array}{l}\text { Cramer and Harrington } \\
\text { (1984, in press). } \\
\text { C. E. Johnson (unpublished } \\
\text { data, 1982). } \\
\text { Morton (1975, 1976) }\end{array}$ \\
\hline 4 Lytle Creek----------- & $\begin{array}{l}\text { Single strand. Strikes N. } 45^{\circ} \\
\text { W. Dips } 65^{\circ} \mathrm{SW} \text {. Length at } \\
\text { least } 12 \mathrm{~km} .\end{array}$ & Late Quaternary (OS, W) & RRO & $\begin{array}{l}\text { Numerous small earthquakes } \\
\text { near fault trace. } \\
\text { Geometrically compatible } \\
\text { fault-plane solutions. }\end{array}$ & $\begin{array}{l}\text { Cramer and Harrington } \\
\text { (1984, in press). } \\
\text { C. E. Johnson (unpublished } \\
\text { data, 1982). } \\
\text { Mezger and Weldon (1983) } \\
\text { Morton (1975, 1976) }\end{array}$ \\
\hline 5 Claremont--...-...... & $\begin{array}{l}\text { Single strand composed of } \\
\text { closely overlapping breaks. } \\
\text { Strikes N. } 40^{\circ}-55^{\circ} \mathrm{W} \text {. Dip } \\
\text { vertical or steeply NE. } \\
\text { Length approxinately } 65 \mathrm{~km} \text {. }\end{array}$ & $\begin{array}{l}\text { Holocene (OS, P, W); historical } \\
\text { creep near Hemet possibly } \\
\text { related to subsidence due to } \\
\text { ground-water withdrawal. }\end{array}$ & SR & $\begin{array}{l}\text { Scattered small earthquakes } \\
\text { near fault trace. Possible } \\
\text { source for four damaging } \\
\text { carthquakes of } M_{\mathrm{L}} \geq 6 \\
(1890,1899,1918,1923) \text {. }\end{array}$ & $\begin{array}{l}\text { Fett (1967) } \\
\text { Given (1981) } \\
\text { Green (1983) } \\
\text { C. E. Johnson (unpublished } \\
\text { data, 1982). } \\
\text { Morton (1978) } \\
\text { Sharp (1972) } \\
\text { Thatcher and others (1975) }\end{array}$ \\
\hline
\end{tabular}

\section{Earthquake Hazards in the Los Angeles Region}


TABLE 5.-Geologic and seismologic characteristics of late Quaternary faults in the Los Angeles region-Continued

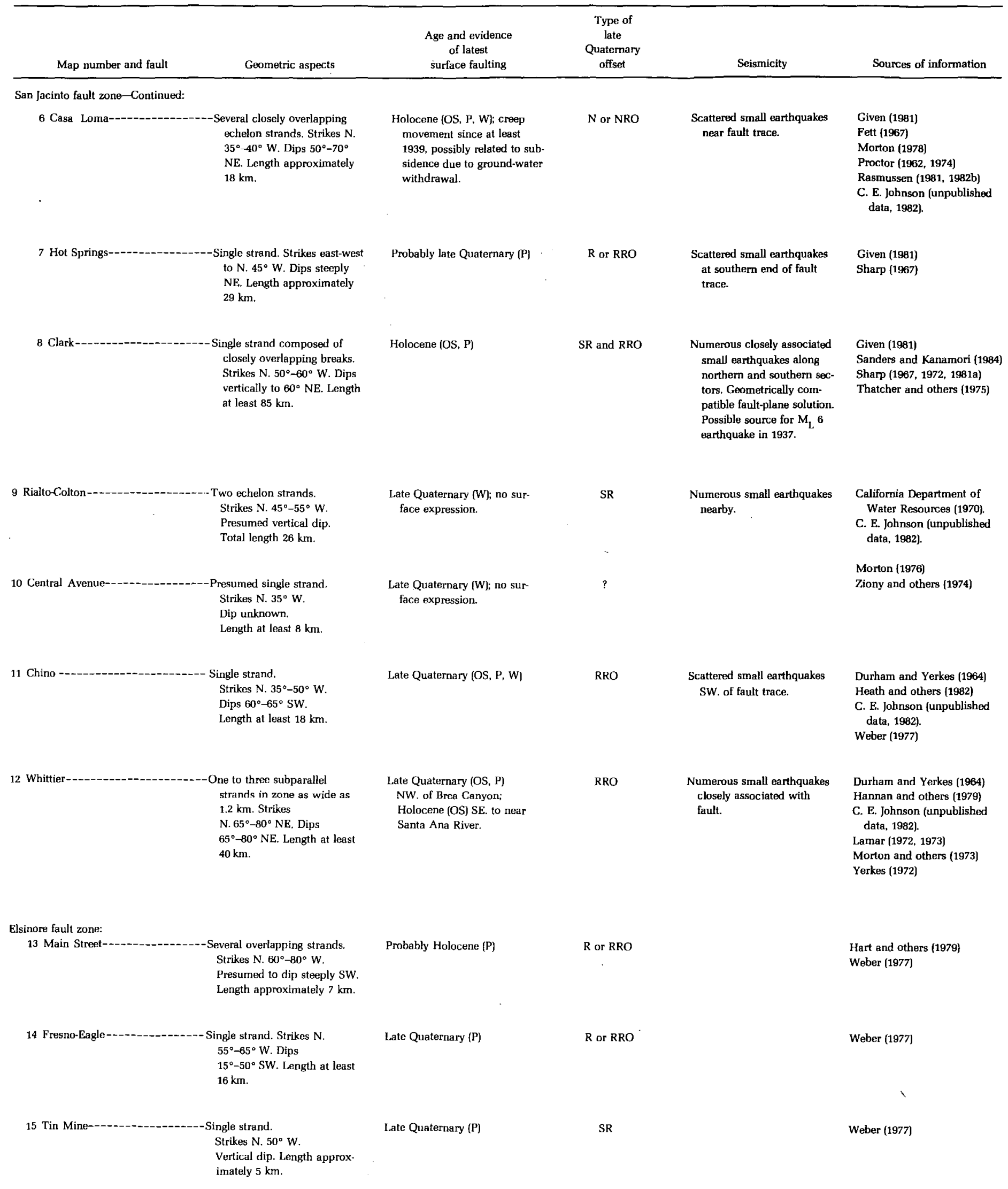


TABLE 5.-Geologic and seismologic characteristics of late Quaternary faults in the Los Angeles region-Continued

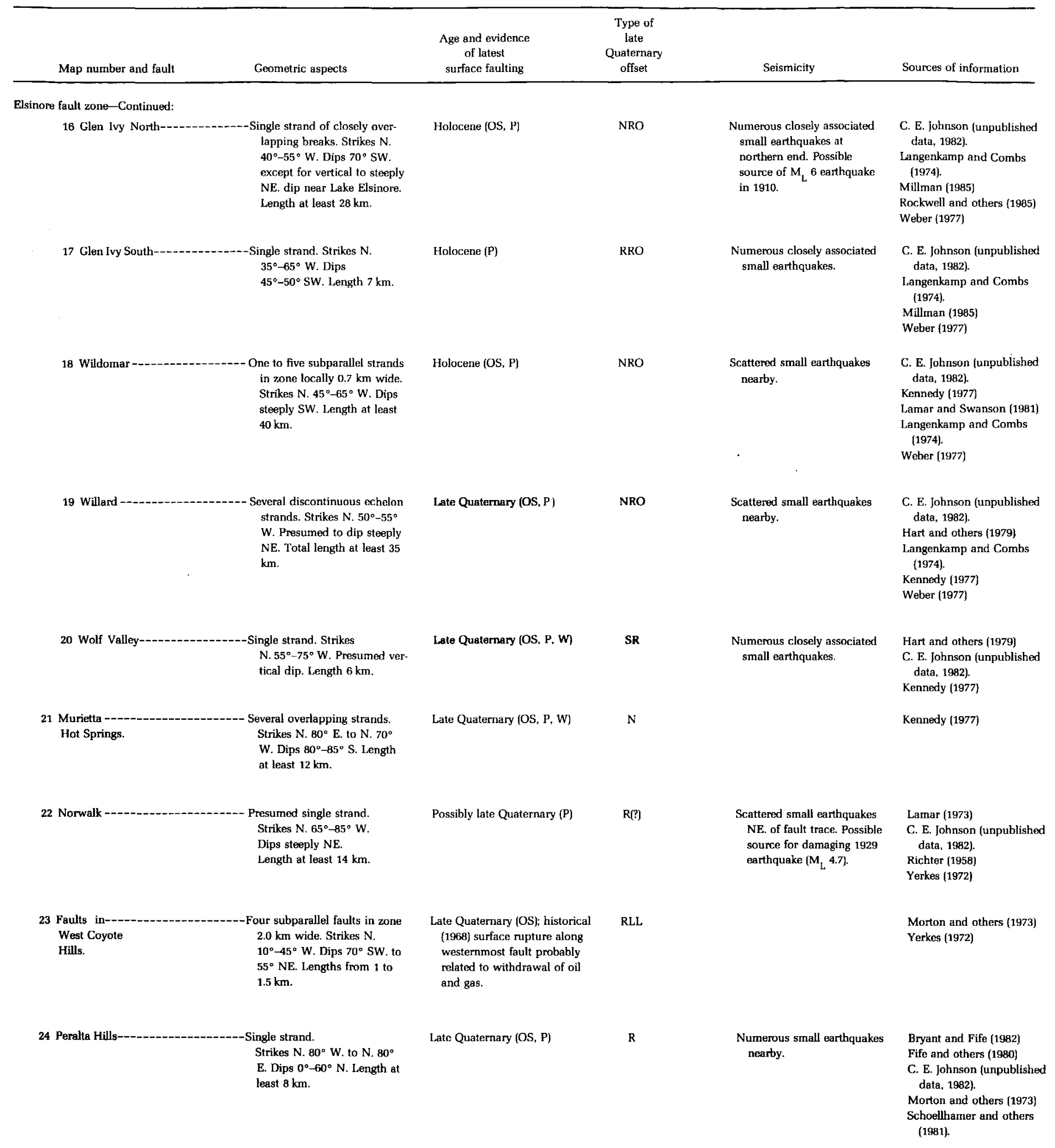

\section{Earthquake Hazards in the Los Angeles Region}


TABLE 5.-Geologic and seismologic characteristics of late Quaternary faults in the Los Angeles region-Continued

\begin{tabular}{|c|c|c|c|c|c|}
\hline Map number and fault & Geometric aspects & $\begin{array}{l}\text { Age and evidence } \\
\text { of latest } \\
\text { surface faulting }\end{array}$ & $\begin{array}{l}\text { Type of } \\
\text { late } \\
\text { Quaternary } \\
\text { offset }\end{array}$ & Seismicity & Sources of information \\
\hline \multicolumn{6}{|l|}{ Newport-Inglewood fault zone: } \\
\hline 25 Inglewood-- & $\begin{array}{l}\text {-Single strand locally offset by } \\
\text { short north- and } \\
\text { NE.-trending faults. Strikes } \\
\text { N. } 5^{\circ}-30^{\circ} \mathrm{W} \text {. Dips } 70^{\circ} \mathrm{W} \text {. } \\
\text { Length at least } 13 \mathrm{~km} \text {. }\end{array}$ & $\begin{array}{l}\text { Late Quaternary (OS, P); sur- } \\
\text { face faulting since 1957 } \\
\text { locally along north-trending } \\
\text { faults in response to } \\
\text { withdrawal of oil and gas. }\end{array}$ & $\mathrm{N}$ or NRO & $\begin{array}{l}\text { Numerous small earthquakes } \\
\text { nearby. Geometrically } \\
\text { compatible fault-plane } \\
\text { solution. Possible source } \\
\text { of } 1920 \text { earthquake }\left(\mathrm{M}_{\mathrm{L}}\right. \\
\text { 4.9). }\end{array}$ & $\begin{array}{l}\text { Barrows (1974) } \\
\text { Buika and Teng (1979) } \\
\text { Castle and Yerkes (1976) } \\
\text { Poland and others (1959) } \\
\text { J. C. Tinsley (unpublished } \\
\text { data, 1983). }\end{array}$ \\
\hline 26 Potrema-------------- & $\begin{array}{l}\text {-- Single strand. Strikes N. } 25^{\circ} \\
\text { W. Dips } 77^{\circ} \mathrm{W} \text {. at surface. } \\
82^{\circ} \mathrm{W} \text {. at depth. Length } \\
7 \mathrm{~km} \text {. }\end{array}$ & Late Quaternary $(\mathrm{P}, \mathrm{W})$ & $\mathrm{N}$ or NRO & $\begin{array}{l}\text { Numerous small earthquakes } \\
\text { nearby. }\end{array}$ & $\begin{array}{l}\text { Barrows (1974) } \\
\text { Buika and Teng (1979) } \\
\text { Poland and others (1959] }\end{array}$ \\
\hline 27 Avalon-Compton--- & $\begin{array}{l}\text { Single strand. } \\
\text { Strikes N. } 20^{\circ}-30^{\circ} \mathrm{W} \text {. } \\
\text { Presumed vertical. } \\
\text { Length at least } 4 \mathrm{~km} \text {. }\end{array}$ & $\begin{array}{l}\text { Late Quaternary }(P, W) \\
\text { historical }(1941,1944) \\
\text { faulting within } 1.5 \mathrm{~km} \text { of sur- } \\
\text { face along subsidiary south- } \\
\text { dipping reverse faults. }\end{array}$ & SR(?) & $\begin{array}{l}\text { Scattered small earthquakes } \\
\text { nearby. Epicenters of } 1941 \\
\left(M_{L} 4.9\right) \text { and } 1944\left(M_{L} 4.5\right) \\
\text { lie SW. of fault trace. }\end{array}$ & $\begin{array}{l}\text { Bravinder (1942) } \\
\text { Buika and Teng (1979) } \\
\text { Martner (1948) } \\
\text { Poland and others (1959) }\end{array}$ \\
\hline 28 Cherry-Hill --------- & $\begin{array}{l}\text {-- Single strand. } \\
\text { Strikes N. } 39^{\circ}-50^{\circ} \mathrm{W} \text {. } \\
\text { Dips } 80^{\circ} \mathrm{E} . \\
\text { Length at least } 9 \mathrm{~km} \text {. }\end{array}$ & Late Quaternary (OS, P, w) & R or RRO & $\begin{array}{l}\text { Numerous small earthquakes } \\
\text { lie east of trace. Fault } \\
\text { overlies aftershock zone of } \\
\text { 1933 Long Beach earth- } \\
\text { quake (M 6.2). 1941 Tor- } \\
\text { rance-Gardena earthquake } \\
\left(M_{L} 5.4\right) \text { located SW. of } \\
\text { fault trace. }\end{array}$ & $\begin{array}{l}\text { Hileman and others (1973) } \\
\text { C. E. Johnson (unpublished } \\
\text { data, 1982). } \\
\text { K. R. Lajoie (unpublished } \\
\text { data, 1983). } \\
\text { Poland and Piper (1956) } \\
\text { Yerkes and others (1965) }\end{array}$ \\
\hline $\begin{array}{l}29 \text { Reservoir Hill- - - } \\
\text { Seal Beach. }\end{array}$ & $\begin{array}{l}\text { Single strand. } \\
\text { Strikes } \mathrm{N} .59^{\circ} \mathrm{W} . \\
\text { Dips near vertical. } \\
\text { Length at least } 12 \mathrm{~km} \text {. }\end{array}$ & Late Quaternary (OS, P, W) & NRO or SR & $\begin{array}{l}\text { Numerous small earthquakes } \\
\text { near trace. Fault overlies } \\
\text { aftershock zone of } 1933 \\
\text { Long Beach earthquake (M } \\
\text { 6.2). }\end{array}$ & $\begin{array}{l}\text { Hileman and others (1973) } \\
\text { C. E. Johnson (unpublished } \\
\text { data, 1982). } \\
\text { Poland and Piper (1956) }\end{array}$ \\
\hline $\begin{array}{l}\text { 30 Newport-Inglewood----- } \\
\text { (North Branch). }\end{array}$ & $\begin{array}{l}\text {--One to three closely spaced } \\
\text { strands. Strikes N. } 40^{\circ}-60^{\circ} \\
\text { W. Dips steeply SW. Length } \\
\text { at least } 18 \mathrm{~km} \text {. }\end{array}$ & $\begin{array}{l}\text { Holocene (OS, W); possible } \\
\text { historical surface faulting } \\
\text { (1933) at Newport Mesa. }\end{array}$ & SR & $\begin{array}{l}\text { Scattered small earthquakes } \\
\text { near trace. Fault is adja- } \\
\text { cent to aftershock zone of } \\
1933 \text { Long Beach earth- } \\
\text { quake (M 6.2). }\end{array}$ & $\begin{array}{l}\text { Califomia Department of } \\
\text { Water Resources (1966, } \\
\text { 1968). } \\
\text { Guptill and Heath (1981) } \\
\text { Hileman and others (1973) } \\
\text { C. E. Johnson (unpublished } \\
\text { data, 1982). }\end{array}$ \\
\hline $\begin{array}{l}31 \text { Newport-Inglewood------ } \\
\text { (South Branch). }\end{array}$ & $\begin{array}{l}\text {-- Single strand. Strikes N. } 45^{\circ} \\
\text { W. Dips steeply SW. Length } \\
\text { at least } 10 \mathrm{~km} \text { and possibly } \\
\text { joins similarly oriented fault } \\
\text { offshore Dana Point. }\end{array}$ & Late Quaternary (P) & SR & $\begin{array}{l}\text { Scattered small earthquakes } \\
\text { near trace. Fault is adja- } \\
\text { cent to aftershock zone of } \\
1933 \text { Long Beach earth- } \\
\text { quake (M 6.2). }\end{array}$ & $\begin{array}{l}\text { California Department of } \\
\text { Water Resources (1968) } \\
\text { Hileman and others (1973( } \\
\text { C. E. Johnson (unpublished } \\
\text { data, 1982). } \\
\text { Poland and Piper (1956) }\end{array}$ \\
\hline $\begin{array}{l}32 \text { Faults offshore of-- } \\
\text { San Clemente. }\end{array}$ & $\begin{array}{l}\text {--Two echelon strands. Strikes } \\
\text { N. } 45^{\circ}-55^{\circ} \mathrm{W} \text {. Dip } \\
\text { unknown. Length of each } \\
\text { fault at least } 25 \mathrm{~km} \text {. }\end{array}$ & Late Quaternary (OS, P) & SR(?) & $\begin{array}{l}\text { Concentrations of small } \\
\text { earthquakes locally along } \\
\text { traces. }\end{array}$ & $\begin{array}{l}\text { Clarke and others (this } \\
\text { volume). } \\
\text { C. E. Johnson (unpublished } \\
\text { data, 1982). }\end{array}$ \\
\hline 33 Pelicạn Hill----------- & $\begin{array}{l}\text {--Several strands. } \\
\text { Strikes } \mathrm{N} .15^{\circ}-35^{\circ} \mathrm{W} \text {. } \\
\text { Dips } 75^{\circ} \mathrm{W} \text {. at surface but } \\
45^{\circ} \text { W. at depth. }\end{array}$ & $\begin{array}{l}\text { Late Quaternary (OS) along } \\
\text { subsidiary fault. }\end{array}$ & $\mathrm{N}$ or $\mathrm{NRO}$ & $\begin{array}{l}\text { Scattered small earthquakes } \\
\text { west of trace. }\end{array}$ & $\begin{array}{l}\text { Castle (1966) } \\
\text { Morton and others (1973) } \\
\text { J. E. Slosson (personal com- } \\
\text { munication, 1973). }\end{array}$ \\
\hline
\end{tabular}


TABLE 5.-Geologic and seismologic characteristics of late Quaternary faults in the Los Angeles region-Continued

\begin{tabular}{|c|c|c|c|c|c|}
\hline Map number and fault & Geometric aspects & $\begin{array}{l}\text { Age and evidence } \\
\text { of latest } \\
\text { surface faulting }\end{array}$ & $\begin{array}{l}\text { Type of } \\
\text { late } \\
\text { Quaternary } \\
\text { offset }\end{array}$ & Seismicity & Sources of information \\
\hline $\begin{array}{l}34 \text { Charnock and--------- } \\
\text { Overland Avenue. }\end{array}$ & $\begin{array}{l}\text { Two fault strands. } \\
\text { Strikes N. } 35^{\circ} \mathrm{W} \\
\text { Presumed vertical dip. } \\
\text { Length at least } 10 \mathrm{~km} \text {. }\end{array}$ & $\begin{array}{l}\text { Late Quaternary (OS); no sur- } \\
\text { face expression. }\end{array}$ & SR(?) & $\begin{array}{l}\text { Numerous small earthquakes } \\
\text { nearby. Geometrically } \\
\text { compatible fault-plane } \\
\text { solutions. }\end{array}$ & $\begin{array}{l}\text { Buika and Teng (1979) } \\
\text { Poland and others (1959) }\end{array}$ \\
\hline 35 Palos Verdes Hills & $\begin{array}{l}\text {-Several echelon strands locally } \\
\text { in a zone as wide as } 2 \mathrm{~km} \text {. } \\
\text { Strikes N. } 20^{\circ}-60^{\circ} \mathrm{W} \text {. On- } \\
\text { shore segment generally not } \\
\text { exposed. Dip } 70^{\circ} \mathrm{SW} \text {. in } \\
\text { subsurface of Palos Verdes } \\
\text { Hills, although exposed sub- } \\
\text { sidiary fault dips } 75^{\circ} \mathrm{NE} \text {. } \\
\text { Total length at least } 80 \mathrm{~km} \text {. }\end{array}$ & $\begin{array}{l}\text { Holocene (OS) in San Pedro } \\
\text { Bay. Late Quaternary (OS, P) } \\
\text { onshore and probably } \\
\text { overlain by Holocene } \\
\text { alluvium. Inferred late } \\
\text { Quaternary (OS) in Santa } \\
\text { Monica Bay. }\end{array}$ & $\mathrm{R}$ or RRO & $\begin{array}{l}\text { Numerous small earthquakes } \\
\text { near and west of fault } \\
\text { trace. Geometrically com- } \\
\text { patible fault-plane solution } \\
\text { in Santa Monica Bay. }\end{array}$ & $\begin{array}{l}\text { Buika and Teng (1979) } \\
\text { Clarke and others (this } \\
\text { volume). } \\
\text { Hileman and others (1973) } \\
\text { Junger and Wagner (1977) } \\
\text { Nardin and Henyey (1978) } \\
\text { Poland and others (1959) } \\
\text { Woodring and others (1946) } \\
\text { Yerkes and others (1965) }\end{array}$ \\
\hline 36 Redondo Canyon-- & $\begin{array}{l}\text {-Presumed single strand. Strikes } \\
\text { N. } 80^{\circ}-85^{\circ} \text { E. Dip unknown. } \\
\text { Length approximately } 13 \mathrm{~km} \text {. }\end{array}$ & Holocene (P) & $R(?)$ & $\begin{array}{l}\text { Scattered small earthquakes } \\
\text { near trace. }\end{array}$ & $\begin{array}{l}\text { Nardin and Henyey (1978) } \\
\text { Yerkes and others (1967) }\end{array}$ \\
\hline 37 Cabrillo--- & $\begin{array}{l}\text { - Several echelon strands. } \\
\text { Strikes } \mathrm{N} .20^{\circ}-50^{\circ} \mathrm{W} \text {. } \\
\text { Dips } 50^{\circ}-75^{\circ} \text { onshore. } \\
\text { Length approximately } 18 \mathrm{~km} \text {. }\end{array}$ & Holocene (OS) offshore & $\mathrm{N}$ or NRO & $\begin{array}{l}\text { Scattered small earthquakes } \\
\text { near fault trace. }\end{array}$ & $\begin{array}{l}\text { Clarke and others (this } \\
\text { volume). } \\
\text { Darrow and Fischer (1983) } \\
\text { Hileman and others (1973) } \\
\text { Lajoie and others (1979) } \\
\text { Woodring and others (1946) }\end{array}$ \\
\hline $\begin{array}{l}\text { 38 San Pedro Basin---- } \\
\text { fault zone. }\end{array}$ & $\begin{array}{l}\text {-Series of separate, left-stepping } \\
\text { echelon strands in zone } \\
\text { locally as wide as } 5 \mathrm{~km} \text {. } \\
\text { Strikes } N \text {. } 35^{\circ}-50^{\circ} \mathrm{W} \text {. } \\
\text { Presumed vertical dip. } \\
\text { Length of individual strands } \\
4-12 \mathrm{~km} \text {; length of entire } \\
\text { zone at least } 70 \mathrm{~km} \text {. }\end{array}$ & Late Quaternary (OS) & SR or RRO & $\begin{array}{l}\text { Numerous small earthquakes } \\
\text { near and east of fault } \\
\text { traces. Geometrically com- } \\
\text { patible fault-plane solu- } \\
\text { tions. }\end{array}$ & $\begin{array}{l}\text { Hileman and others (1973) } \\
\text { Junger and Wagner (1977) } \\
\text { Nardin (1981) } \\
\text { Yerkes and Lee (1979a, b) } \\
\text { C. E. Johnson (unpublished } \\
\text { data, 1982). }\end{array}$ \\
\hline $\begin{array}{l}39 \text { Faults of the---- } \\
\text { Santa Cruz- } \\
\text { Catalina sea-floor } \\
\text { escarpment. }\end{array}$ & $\begin{array}{l}\text { Echelon strands in zone locally } \\
4 \mathrm{~km} \text { wide. Strikes } \mathrm{N} \text {. } \\
50^{\circ}-60^{\circ} \mathrm{W} \text {. Length of in- } \\
\text { dividual strands } 5 \text { to } 40 \mathrm{~km} \text {; } \\
\text { length of entire zone at least } \\
120 \mathrm{~km} \text {. }\end{array}$ & Possibly late Quaternary (P) & SR & $\begin{array}{l}\text { Source of } 1981 \text { Santa Bar- } \\
\text { bara lsland earthquake } \\
\left(M_{L} 5.2\right) \text { and aftershotks. }\end{array}$ & $\begin{array}{l}\text { Corbett and Piper (1981) } \\
\text { C. E. Johnson (unpublished } \\
\text { data, 1982). } \\
\text { Junger and Wagner (1977) } \\
\text { Yerkes and Lee (1979a, b) }\end{array}$ \\
\hline $\begin{array}{l}\text { Faults of Mojave Desert region: } \\
40 \text { Llano-- }\end{array}$ & $\begin{array}{l}\text { Single strand. Strikes N. } 65^{\circ} \\
\text { W. Presumed dip to SW. } \\
\text { Length at least } 6 \mathrm{~km} \text {. }\end{array}$ & $\begin{array}{l}\text { Holocene (P) monoclinal } \\
\text { folding. }\end{array}$ & $\mathbf{R}$ & & $\begin{array}{l}\text { Guptill and others (1979) } \\
\text { Ponti and Burke (1980) }\end{array}$ \\
\hline 41 Mirage Valley-- & $\begin{array}{l}\text {-Several echelon strands, each } \\
1-7 \mathrm{~km} \text { long, locally in zone } \\
3 \mathrm{~km} \text { across. Strike N. } \\
40^{\circ}-50^{\circ} \text { W. Presumed ver- } \\
\text { tical dip. Total length of } \\
\text { zone approximately } 30 \mathrm{~km} \text {. }\end{array}$ & $\begin{array}{l}\text { Late Quaternary; overlain by } \\
\text { unfaulted Holocene alluvial } \\
\text { fan deposits. }\end{array}$ & SR(?) & & Ponti and Burke (1980) \\
\hline 42 Helendale -- & $\begin{array}{l}\text { Numerous echelon strands, } 1 \\
\text { to } 4 \mathrm{~km} \text { long, forming nar- } \\
\text { row linear zone as wide as } 1 \\
\mathrm{~km} \text {. Strands strike } \mathrm{N} \text {. } \\
45^{\circ}-50^{\circ} \mathrm{W} \text {. Presumed ver- } \\
\text { tical dips. Total length of } \\
\text { zone at least } 90 \mathrm{~km} \text {. }\end{array}$ & Holocene (P) & $\mathrm{SR}$ & $\begin{array}{l}\text { Closely associated small } \\
\text { earthquakes. }\end{array}$ & $\begin{array}{l}\text { G. S. Fuis (unpublished data, } \\
\text { 1983). } \\
\text { C. E. Johnson (unpublished } \\
\text { data, 1982). } \\
\text { Miller and Morton (1980) } \\
\text { Morton and others (1980) }\end{array}$ \\
\hline
\end{tabular}

\section{Earthquake Hazards in the Los Angeles Region}


TABLE 5.-Geologic and seismologic characteristics of late Quaternary faults in the Los Angeles region-Continued

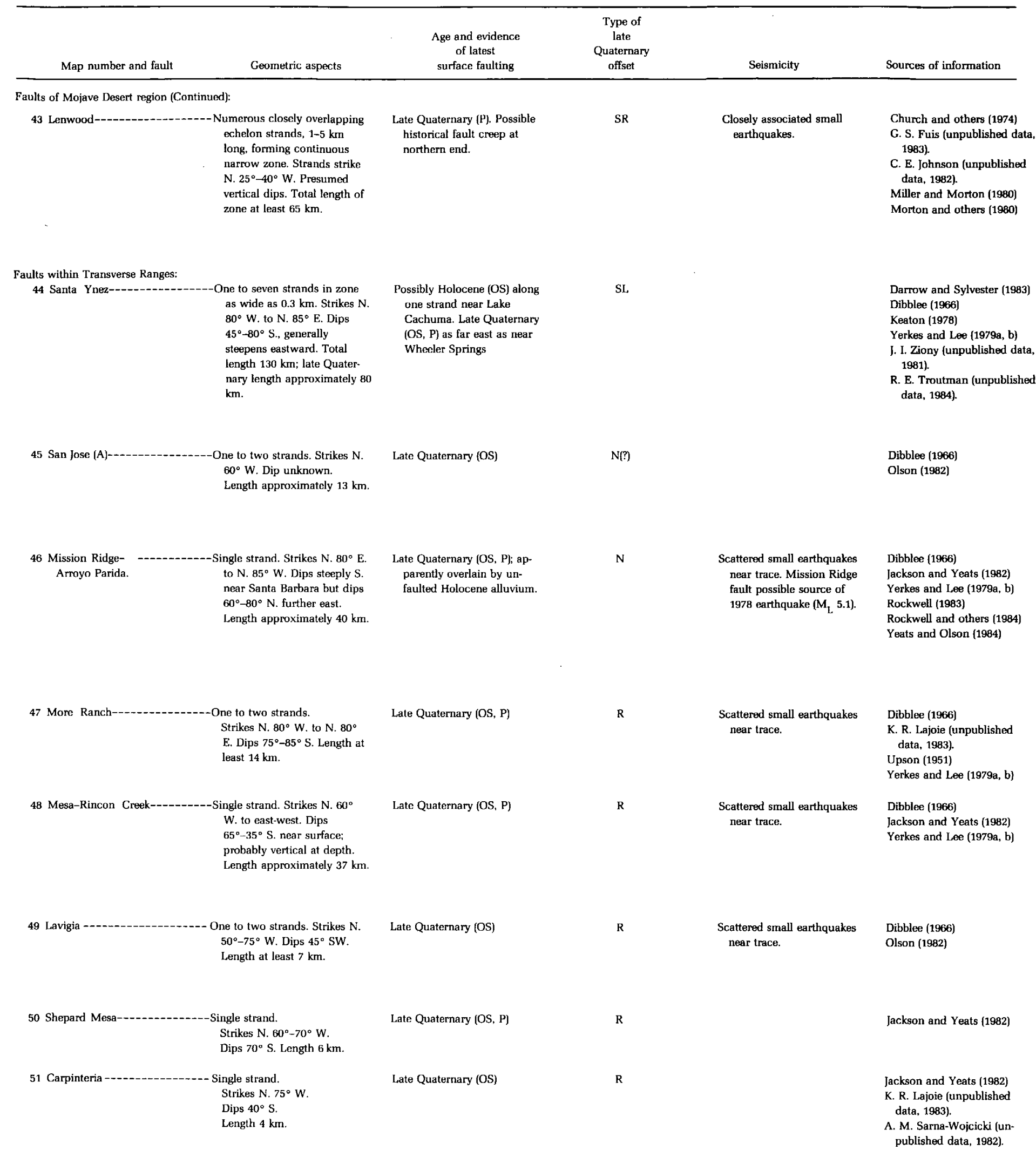


TABLE 5.-Geologic and seismologic characteristics of late Quaternary faults in the Los Angeles region-Continued

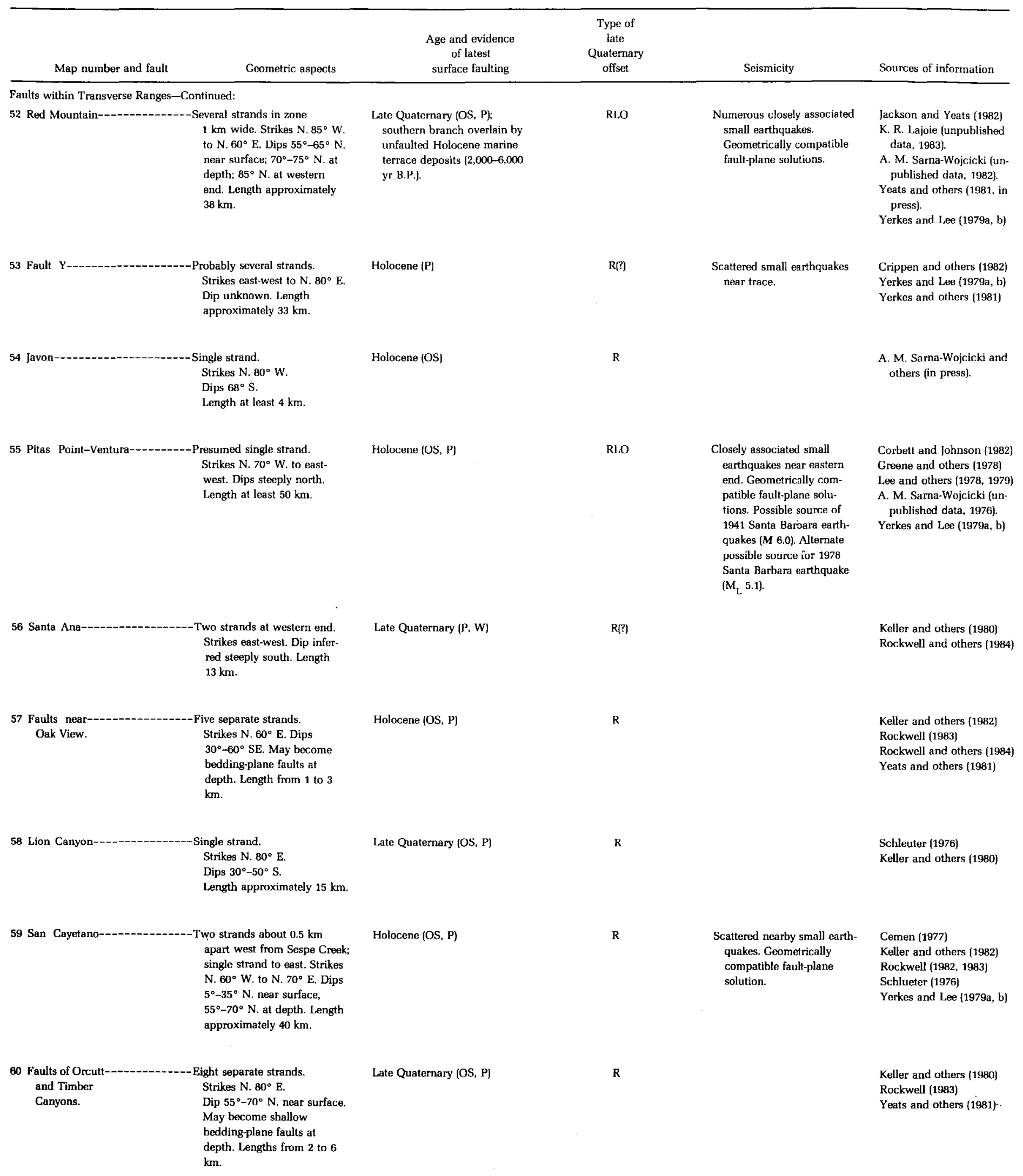

\section{Earthquake Hazards in the Los Angeles Region}


TABLE 5.-Geologic and seismologic characteristics of late Quaternary faults in the Los Angeles region-Continued

\begin{tabular}{|c|c|c|c|c|c|}
\hline Map number and fault & Geometric aspects & $\begin{array}{l}\text { Age and evidence } \\
\text { of latest } \\
\text { surface faulting }\end{array}$ & $\begin{array}{c}\text { Type of } \\
\text { late } \\
\text { Quaternary } \\
\text { offset }\end{array}$ & Seismicity & Sources of information \\
\hline \multicolumn{6}{|c|}{ Faults within Transverse Ranges-Continued: } \\
\hline 61 Holser-- & $\begin{array}{l}\text { Several closely spaced strands. } \\
\text { Strikes N. } 80^{\circ} \text { E. to N. } 70^{\circ} \\
\text { W. Dips } 60^{\circ}-70^{\circ} \mathrm{S} \text {. Length } \\
\text { approximately } 12 \mathrm{~km} \text {. }\end{array}$ & Late Quaternary (OS, P) & $\mathbf{R}$ & & $\begin{array}{l}\text { Cemen (1977) } \\
\text { Stitt (1983) } \\
\text { Weber }(1978,1982)\end{array}$ \\
\hline 62 Clearwater -- & $\begin{array}{l}\text { One to two strands. Strikes N. } \\
80^{\circ} \mathrm{W} \text {. to east-west. General- } \\
\text { ly dips } 70^{\circ}-80^{\circ} \mathrm{N} \text {. but local- } \\
\text { ly } 25^{\circ}-40^{\circ} \mathrm{N} \text {. Late Quater- } \\
\text { nary length approximately } 14 \\
\text { km. }\end{array}$ & $\begin{array}{l}\text { Late Quaternary (OS) near San } \\
\text { Francisquito Canyon but } \\
\text { overlain by unfaulted late } \\
\text { Quaternary river terrace } \\
\text { deposits elsewhere. }\end{array}$ & $R(?)$ & & $\begin{array}{l}\text { Los Angeles County } \\
\text { Engineer, unpublished } \\
\text { data, 1965). } \\
\text { Stanley (1966) }\end{array}$ \\
\hline $\begin{array}{l}63 \text { San Gabriel-- } \\
\text { (central portion). }\end{array}$ & $\begin{array}{l}\text { Several echelon strands in zone } \\
0.5 \mathrm{~km} \text { wide. Strikes } \mathrm{N} \text {. } \\
45^{\circ}-65^{\circ} \mathrm{W} \text {. Dips } 50^{\circ}-80^{\circ} \mathrm{N} \text {. } \\
\text { Late Quaternary length at } \\
\text { least } 32 \mathrm{~km} \text {. }\end{array}$ & $\begin{array}{l}\text { Holocene (OS, W) near Castaic. } \\
\text { Late Quaternary (OS, P) be- } \\
\text { tween Newhall and Big } \\
\text { Tujunga Canyon. }\end{array}$ & $\mathrm{N}$ or NRO & & $\begin{array}{l}\text { Cotton and others (1983) } \\
\text { Nelligan (1978) } \\
\text { Stitt (1983) } \\
\text { Weber (1978, 1982; un- } \\
\text { published data, 1984). }\end{array}$ \\
\hline 64 Oak Ridge-- & $\begin{array}{l}\text { One to three strands in zone as } \\
\text { much as } 0.5 \mathrm{~km} \text { wide. } \\
\text { Strikes N. } 60^{\circ} \mathrm{W} \text {. to N. } 50^{\circ} \\
\text { E. Generally dips } 65^{\circ}-80^{\circ} \mathrm{S} \text {. } \\
\text { but south of Fillmore dips } \\
5^{\circ}-30^{\circ} \mathrm{S} \text {. near surface. } \\
\text { Length approximately } 100 \\
\mathrm{~km} \text {. }\end{array}$ & $\begin{array}{l}\text { Late Quaternary }(\mathrm{W}, \mathrm{P}) \text {; } \\
\text { possibly Holocene south of } \\
\text { Fillmore (P) and offshore. } \\
\end{array}$ & R & $\begin{array}{l}\text { Numerous closely associated } \\
\text { small earthquakes near } \\
\text { western end. Geometrical- } \\
\text { ly compatible fault-plane } \\
\text { solution south of Santa } \\
\text { Paula. Western end possi- } \\
\text { ble source of } 1925 \text { Santa } \\
\text { Barbara earthquake (M } \\
\text { 6.8). }\end{array}$ & $\begin{array}{l}\text { Ricketts and Whaley (1975) } \\
\text { Rieser (1976) } \\
\text { Weber and Kiesling (1975) } \\
\text { Yeats and others (1981, 1982) } \\
\text { Yerkes and Lee (1979a, b) }\end{array}$ \\
\hline 65 Springville-.-.-- & $\begin{array}{l}\text { Two strands in zone about } 0.6 \\
\text { kn wide. Strikes N. } 65^{\circ}-75^{\circ} \\
\text { E. Dips } 55^{\circ}-80^{\circ} \text { N. Length } \\
\text { about } 9 \mathrm{~km} \text {. }\end{array}$ & Late Quaternary $(\mathrm{P}, \mathrm{W})$ & $R(?]$ & & Jakes (1978) \\
\hline 66 Camarillo -- & $\begin{array}{l}\text { Single strand. } \\
\text { Strikes east-west. } \\
\text { Presumed vertical dip. } \\
\text { Length at least } 6 \mathrm{~m} \text {. }\end{array}$ & Late Quaternary $(\mathrm{P}, \mathrm{W})$ & $\mathrm{R}[?]$ & & $\begin{array}{l}\text { Gardner (1982) } \\
\text { Jakes (1979) }\end{array}$ \\
\hline 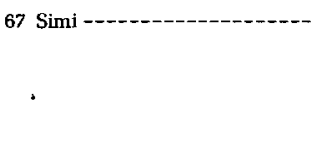 & $\begin{array}{l}\text { Single strand that bifurcates at } \\
\text { western end. Strikes } \mathrm{N} \text {. } \\
70^{\circ}-80^{\circ} \mathrm{E} \text {. Dips } 60^{\circ}-75^{\circ} \mathrm{N} \text {. } \\
\text { Length approximately } 31 \mathrm{~km} \text {. }\end{array}$ & $\begin{array}{l}\text { Late Quaternary (OS, P); } \\
\text { overlain by unfaulted } \\
\text { Holocene alluvium (about } \\
\text { 4,000 yr B.P.). }\end{array}$ & $\mathbf{R}$ & $\begin{array}{l}\text { Closely associated small } \\
\text { earthquakes, including } M_{L} \\
\text { 3.1 event in } 1969 .\end{array}$ & $\begin{array}{l}\text { Jakes (1979) } \\
\text { C. E. Johnson (unpublished } \\
\quad \text { data, 1982). } \\
\text { Hanson (1981) } \\
\text { Weber and Kiesling (1975) }\end{array}$ \\
\hline 68 Santa Susana-------------- & $\begin{array}{l}\text { Several strands in zone as } \\
\text { much as } 1 \mathrm{~km} \text { wide. Strikes } \\
\mathrm{N} .75^{\circ} \mathrm{W} \text {. to N. } 50^{\circ} \mathrm{E} \text {. Dips } \\
0^{\circ}-30^{\circ} \mathrm{N} \text {. near surface; } \\
55^{\circ}-60^{\circ} \mathrm{N} \text {. at depth. Length } \\
28 \mathrm{~km} \text {. }\end{array}$ & $\begin{array}{l}\text { Late Quaternary (OS); overlain } \\
\text { by unfaulted Holocene } \\
\text { stream terrace deposits (ap- } \\
\text { proximately } 10,000 \text { yr B.P.). } \\
\text { Locally at northeastern end, } \\
\text { historical surface faulting ac- } \\
\text { companied } 1971 \text { San Fernan- } \\
\text { do earthquake. }\end{array}$ & RLO & $\begin{array}{l}\text { Scattered associated small } \\
\text { earthquakes, including } M_{L} \\
\text { 4.6 event near Gillibrand } \\
\text { Canyon in } 1976 . \\
\text { Geometrically compatible } \\
\text { fault-plane solutions. }\end{array}$ & $\begin{array}{l}\text { Leighton and others (1977) } \\
\text { Lung and Weick (1978) } \\
\text { Simila and others (1982) } \\
\text { Weber (1975) } \\
\text { Yeats and others (1977) } \\
\text { Yerkes and Lee (1979a, b) }\end{array}$ \\
\hline 69 San Fernando---- & $\begin{array}{l}\text { Five major echelon strands. } \\
\text { Strikes N. } 75^{\circ} \text { E. to N. } 70^{\circ} \\
\text { W. Dips } 15^{\circ}-50^{\circ} \text { N. near } \\
\text { surface, } 35^{\circ} \text { N. at depth. } \\
\text { Total length at least } 15 \mathrm{~km} \text {. }\end{array}$ & $\begin{array}{l}\text { Surface faulting accompanied } \\
\text { 1971 San Fernando earth- } \\
\text { quake. }\end{array}$ & RLO & $\begin{array}{l}\text { Source of } 1971 \text { San Fernan- } \\
\text { do earthquake (M 6.6) and } \\
\text { aftershocks. Geometrically } \\
\text { compatible fault-plane } \\
\text { solutions. }\end{array}$ & $\begin{array}{l}\text { Allen and others (1975) } \\
\text { Barrows (1975) } \\
\text { Bonilla (1973) } \\
\text { Kahle (1975) } \\
\text { Sharp (1975) } \\
\text { U.S. Geological Survey Staff } \\
\text { (1971). } \\
\text { Weber (1975) }\end{array}$ \\
\hline
\end{tabular}

Earthquake and Surface-Faulting Potential 55 
TABLE 5.-Geologic and seismologic characteristics of late Quaternary faults in the Los Angeles region—Continued

\begin{tabular}{|c|c|c|c|c|c|}
\hline Map number and fault & Geometric aspects & $\begin{array}{l}\text { Age and evidence } \\
\text { of latest } \\
\text { surface faulting }\end{array}$ & $\begin{array}{l}\text { Type of } \\
\text { late } \\
\text { Quaternary } \\
\text { offset }\end{array}$ & Seismicity & Sources of information \\
\hline \multicolumn{6}{|c|}{ Faults within Transverse Ranges - Continued: } \\
\hline 70 Mission Hills------------- & $\begin{array}{l}\text {--Presumed single strand. } \\
\text { Strikes N. } 80^{\circ} \mathrm{E} \text {. to east-west. } \\
\text { Dips } 80^{\circ} \mathrm{N} \text {. near surface, } \\
45^{\circ} \mathrm{N} \text {. at depth. Length at } \\
\text { least } 10 \mathrm{~km} \text {. }\end{array}$ & $\begin{array}{l}\text { Late Quatemary or Holocene } \\
\text { (OS, P, W). }\end{array}$ & $\mathrm{R}(?)$ & & $\begin{array}{l}\text { Kowalewsky (1978) } \\
\text { Saul (1975) } \\
\text { Shields (1978) }\end{array}$ \\
\hline 71 Northridge --_- & $\begin{array}{l}\text { Several echelon strands in zone } \\
0.7 \mathrm{~km} \text { wide. Strikes } \mathrm{N} \text {. } \\
70^{\circ}-80^{\circ} \mathrm{W} \text {. Dips } 35^{\circ} \mathrm{N} \text {. near } \\
\text { surface, } 80^{\circ} \mathrm{N} \text {. at depth. } \\
\text { Length approximately } 15 \mathrm{~km} \text {. }\end{array}$ & $\begin{array}{l}\text { Late Quaternary or Holocene } \\
\text { (P, W). }\end{array}$ & $\mathbf{R}$ ? & $\begin{array}{l}\text { Several aftershocks of } 1971 \\
\text { San Fernando earthquake } \\
\text { are closely associated with } \\
\text { fault. }\end{array}$ & $\begin{array}{l}\text { Barnhart and Slosson (1973) } \\
\text { Shields (1978) } \\
\text { Weber (1980) }\end{array}$ \\
\hline 72 Verdugo ----- & $\begin{array}{l}\text { Presumed multiple strands in } \\
\text { zone } 0.5-1.0 \mathrm{~km} \text { wide. } \\
\text { Strikes N. } 50^{\circ}-70^{\circ} \mathrm{W} \text {. Infer- } \\
\text { red to dip } 45^{\circ}-60^{\circ} \mathrm{NE} \text {. } \\
\text { Length at least } 20 \mathrm{~km} \text {. }\end{array}$ & Holocene (OS, P, W) & $R(?)$ & $\begin{array}{l}\text { Scattered small earthquakes } \\
\text { near trace. }\end{array}$ & $\begin{array}{l}\text { C. E. Johnson (unpublished } \\
\text { data, 1982). } \\
\text { Weber (1980) }\end{array}$ \\
\hline 73 Eagle Rock------------ & $\begin{array}{l}\text {-Single strand. Strikes N. } 60^{\circ} \\
\text { W. to east-west. Dips } \\
15^{\circ}-30^{\circ} \mathrm{N} \text {. at western end. } \\
\text { Length at least } 5 \mathrm{~km} \text {. }\end{array}$ & $\begin{array}{l}\text { Possibly late Quaternary (OS, } \\
\text { P). }\end{array}$ & $\mathrm{R}(?)$ & & Weber $(1980)$ \\
\hline 74 San Rafael-o- & $\begin{array}{l}\text {--Echelon strands. } \\
\text { Strikes N. } 60^{\circ}-70^{\circ} \mathrm{W} \text {. } \\
\text { Presumed near-vertical dip. } \\
\text { Total length approximately } \\
6 \mathrm{~km} .\end{array}$ & Possibly late Quaternary (P) & $?$ & & Weber (1980) \\
\hline $\begin{array}{l}75 \text { Possible fault--- } \\
\text { in North } \\
\text { Hollywood. }\end{array}$ & $\begin{array}{l}\text {--Presumed single strand. } \\
\text { Strikes N. } 80^{\circ} \mathrm{E} \text {. } \\
\text { Presumed vertical dip. } \\
\text { Length approximately } 2 \mathrm{~km} \text {. }\end{array}$ & Possibly Holocene (P) & $?$ & & Weber (1980) \\
\hline \multicolumn{6}{|l|}{$\begin{array}{c}\text { Faults along southern margin of } \\
\text { Transverse Ranges: }\end{array}$} \\
\hline 76 Santa Rosa Island------- & $\begin{array}{l}\text {--Single strand. Regionally ar- } \\
\text { cuate, striking N. } 50^{\circ} \text { W. at } \\
\text { western end and N. } 60^{\circ} \text { E. at } \\
\text { eastern end. Dip unknown. } \\
\text { Length at least } 72 \mathrm{~km} \text {. }\end{array}$ & Late Quaternary [OS, P] & RLO & $\begin{array}{l}\text { Probable source of April } \mathrm{t} \\
\text { 1945, earthquake }\left(\mathrm{M}_{\mathrm{L}} 5.4\right)\end{array}$ & $\begin{array}{l}\text { Hileman and others (1973) } \\
\text { Junger }(1976,1979) \\
\text { Kew (1927) }\end{array}$ \\
\hline 77 Santa Cruz Island------- & $\begin{array}{l}\text { One to three echelon strands in } \\
\text { zone as wide as } 0.5 \mathrm{~km} \text {. } \\
\text { Strikes N. } 70^{\circ}-80^{\circ} \mathrm{W} \text {. Dips } \\
70^{\circ}-75^{\circ} \mathrm{N} \text {. Length at least } \\
68 \mathrm{~km} \text {. }\end{array}$ & Late Quaternary [OS, P] & RLO & $\begin{array}{l}\text { Generally lacks small earth- } \\
\text { quakes. Possible source of } \\
M_{L} 5.0 \text { earthquake near } \\
\text { Anacapa Island in } 1973 .\end{array}$ & $\begin{array}{l}\text { Junger }(1976,1979) \\
\text { Patterson }(1979) \\
\text { Yerkes and Lee }(1979 a, b]\end{array}$ \\
\hline 78 Anacapa (Dume)------- & $\begin{array}{l}\text {-Presumed single strand in } \\
\text { west; multiple strands in } \\
\text { east. Strikes } \mathrm{N} \text {. } 80^{\circ} \mathrm{W} \text {. to } \mathrm{N} \text {. } \\
60^{\circ} \mathrm{E} \text {. Inferred to dip } \\
\text { moderately north. Length at } \\
\text { least } 45 \mathrm{~km} \text {. }\end{array}$ & Probably late Quaternary $(\mathbf{P})$ & $\mathbf{R}$ & $\begin{array}{l}\text { Source of } 1973 \text { Point Mugu } \\
\text { earthquake (M 5.3) and } \\
\text { aftershocks. Geometrically } \\
\text { compatible fault-plane } \\
\text { solution. }\end{array}$ & $\begin{array}{l}\text { Junger and Wagner (1977) } \\
\text { Lee and others }(1979) \\
\text { Yerkes and Lee }(1979 a, b]\end{array}$ \\
\hline 79 Malibu Coast---- & $\begin{array}{l}\text {-Several subparallel strands in } \\
\text { zone as wide as } 0.5 \mathrm{~km} . \\
\text { Strikes east-west and dips } \\
45^{\circ}-80^{\circ} \mathrm{N} \text {. Length at least } \\
27 \mathrm{~km} .\end{array}$ & Late Quaternary (OS) & $\mathrm{R}$ & $\begin{array}{l}\text { Numerous small earthquakes } \\
\text { nearby. }\end{array}$ & $\begin{array}{l}\text { K. R. Lajoie (unpublished } \\
\text { data, 1983). } \\
\text { Yerkes and Wentworth } \\
\text { (1965). } \\
\text { C. E. Johnson (unpublished } \\
\text { data, 1982). }\end{array}$ \\
\hline
\end{tabular}

\section{Earthquake Hazards in the Los Angeles Region}


TABLE 5.-Geologic and seismologic characteristics of late Quaternary faults in the Los Angeles region-Continued

\begin{tabular}{|c|c|c|c|c|c|}
\hline Map number and fault & Geometric aspects & $\begin{array}{l}\text { Age and evidence } \\
\text { of latest } \\
\text { surface faulting }\end{array}$ & $\begin{array}{l}\text { Type of } \\
\text { late } \\
\text { Quaternary } \\
\text { offset }\end{array}$ & Seismicity & Sources of information \\
\hline \multicolumn{6}{|c|}{ Faults along southern margin of Transverse Ranges--Continued: } \\
\hline 80 Santa Monica----------- & $\begin{array}{l}\text { One or more strands. } \\
\text { Geometry poorly known. } \\
\text { Strikes N. } 60^{\circ}-80^{\circ} \text { E. } \\
\text { Presumed to dip } 45^{\circ}-65^{\circ} \\
\text { NW. at depth; some near- } \\
\text { surface traces are vertical. } \\
\text { Length at least } 40 \mathrm{~km} \text {. }\end{array}$ & Late Quaternary (OS, P, W) & RLO & $\begin{array}{l}\text { Small earthquakes closely } \\
\text { associated with eastern } \\
\text { end. Geometrically com- } \\
\text { patible(?) fault-plane solu- } \\
\text { tion. }\end{array}$ & $\begin{array}{l}\text { Buika and Teng (1979) } \\
\text { Crook and others (1983) } \\
\text { Hill (1979) } \\
\text { Hill and others (1979) } \\
\text { McGill (1981, 1982) } \\
\text { Real (in press) }\end{array}$ \\
\hline 81 Hollywood --- & $\begin{array}{l}\text { Presumed single strand. } \\
\text { Geometry poorly known. } \\
\text { Strikes N. } 80^{\circ} \mathrm{W} \text {. to N. } 60^{\circ} \\
\text { E. Inferred to dip about } 60^{\circ} \\
\text { N. Length approximately } 17 \\
\text { km. }\end{array}$ & Possibly Holocene $(\mathrm{P})$ & $\mathrm{R}$ or RLO & $\begin{array}{l}\text { Some small earthquakes } \\
\text { associated with eastern } \\
\text { end. }\end{array}$ & $\begin{array}{l}\text { Crook and others [1983) } \\
\text { Hill and others }\{1979] \\
\text { Weber (1980) }\end{array}$ \\
\hline 82 Raymond --------------- & $\begin{array}{l}\text { One to three strands locally in } \\
\text { zone } 0.4 \mathrm{~km} \text { wide. Strikes N. } \\
80^{\circ} \mathrm{W} \text {. to N. } 70^{\circ} \text { E. Dips } \\
50^{\circ}-55^{\circ} \mathrm{N} \text {. Length } 22 \mathrm{~km} \text {. }\end{array}$ & $\begin{array}{l}\text { Holocene (OS, P, W). Overlain } \\
\text { by unfaulted soil }[1,600 \mathrm{yr} \\
\text { B.P.). }\end{array}$ & $\mathrm{R}$ or RLO & $\begin{array}{l}\text { Scattered small earthquakes } \\
\text { lie north of fault trace. } \\
\text { Possible source of } 1855 \\
\text { Los Angeles earthquake } \\
\text { (Modified Mercalli intensi- } \\
\text { ty VIII). Geometrically } \\
\text { compatible fault-plane } \\
\text { solution. }\end{array}$ & $\begin{array}{l}\text { Bryant (1978) } \\
\text { Crook and others (in press) } \\
\text { Real (in press) } \\
\text { Weber (1980) } \\
\text { Yerkes (this volume) }\end{array}$ \\
\hline 83 Sierra Madre-------------- & $\begin{array}{l}\text { One to five anastomosing } \\
\text { strands in zone as wide as } 1 \\
\text { km. Four distinct salients. } \\
\text { Strikes N. } 55^{\circ} \text { W. to east- } \\
\text { west. Dips } 15^{\circ}-50^{\circ} \text { NE. and } \\
\text { north. Total length approx- } \\
\text { imately } 65 \mathrm{~km} \text {. }\end{array}$ & $\begin{array}{l}\text { Holocene (OS, P) between Big } \\
\text { Tujunga and Dunsmore } \\
\text { Canyons. Elsewhere, late } \\
\text { Quaternary (OS, P, W). Over- } \\
\text { lain by unfaulted Holocene } \\
\text { alluvium in several places. }\end{array}$ & $\mathbf{R}$ & $\begin{array}{l}\text { Few and scattered small } \\
\text { earthquakes. }\end{array}$ & $\begin{array}{l}\text { Crook and others (in press) } \\
\text { Pechmann (in press) }\end{array}$ \\
\hline 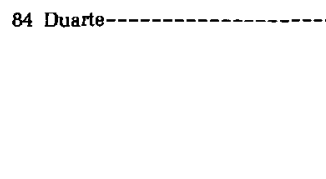 & $\begin{array}{l}\text { One to two subparallel strands } \\
\text { locally in zone } 1.5 \mathrm{~km} \text { wide. } \\
\text { Strikes N. } 60^{\circ} \mathrm{W} \text {. to N. } 70^{\circ} \\
\text { E. Presumed to dip steeply } \\
\text { NE. Length approximately } \\
14 \mathrm{~km} \text {. }\end{array}$ & $\begin{array}{l}\text { Late Quaternary (W); possibly } \\
\text { Holocene (P, W) along north- } \\
\text { ern strand near Azusa. }\end{array}$ & $\mathbf{R}$ & & Crook and others (in press) \\
\hline $\begin{array}{l}85 \text { Clamshell - - ------- } \\
\text { Sawpit Zone. }\end{array}$ & $\begin{array}{l}\text { Several subparallel strands in } \\
\text { zone as wide as } 1 \mathrm{~km} \text {. } \\
\text { Strikes N. } 60^{\circ} \text { E. Dips } \\
35^{\circ}-70^{\circ} \mathrm{NW} \text {. Length approx- } \\
\text { imately } 16 \mathrm{~km} \text {. }\end{array}$ & Late Quaternary (OS) & $\mathbf{R}$ & & $\begin{array}{l}\text { Morton (1973) } \\
\text { Crook and others (in press) }\end{array}$ \\
\hline 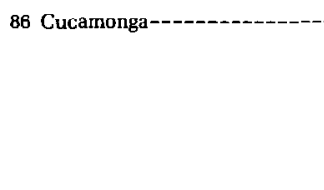 & $\begin{array}{l}\text { Two to three subparallel } \\
\text { strands in zone as wide as } 1 \\
\mathrm{~km} \text {. Strikes N. } 70^{\circ} \text { E. to east- } \\
\text { west. Dips moderately to } \\
\text { steeply north. Length at least } \\
25 \mathrm{~km} \text {. }\end{array}$ & $\begin{array}{l}\text { Holocene (OS, P) along } \\
\text { southern strands. Late } \\
\text { Quaternary (OS) along north- } \\
\text { em strand. }\end{array}$ & $\mathbf{R}$ & $\begin{array}{l}\text { Numerous small earth- } \\
\text { quakes. Geometrically } \\
\text { compatible fault-plane } \\
\text { solutions. }\end{array}$ & $\begin{array}{l}\text { Matti and others (1982, in } \\
\text { press) } \\
\text { Morton and Matti (in press) } \\
\text { Morton and others (1982) } \\
\text { Pechmann (in press) }\end{array}$ \\
\hline 87 Indian Hill---------- & $\begin{array}{l}\text { Presumed single strand. } \\
\text { Strikes east-west } \\
\text { Dip presumed steeply north. } \\
\text { Length approximately } 9 \mathrm{~km} \text {. }\end{array}$ & Late Quaternary $(\mathrm{P}, \mathrm{w})$ & $\mathrm{SL}(?)$ & $\begin{array}{l}\text { Scattered small earthquakes } \\
\text { nearby. }\end{array}$ & $\begin{array}{l}\text { California Department of } \\
\text { Water Resources (1970). } \\
\text { Cramer and Harrington } \\
\text { (1984, in press). } \\
\text { C. E. Johnson (unpublished } \\
\text { data, 1982). }\end{array}$ \\
\hline
\end{tabular}

Earthquake and Surface-Faulting Potential 57 
TABLE 5.-Geologic and seismologic characteristics of late Quaternary faults in the Los Angeles region-Continued

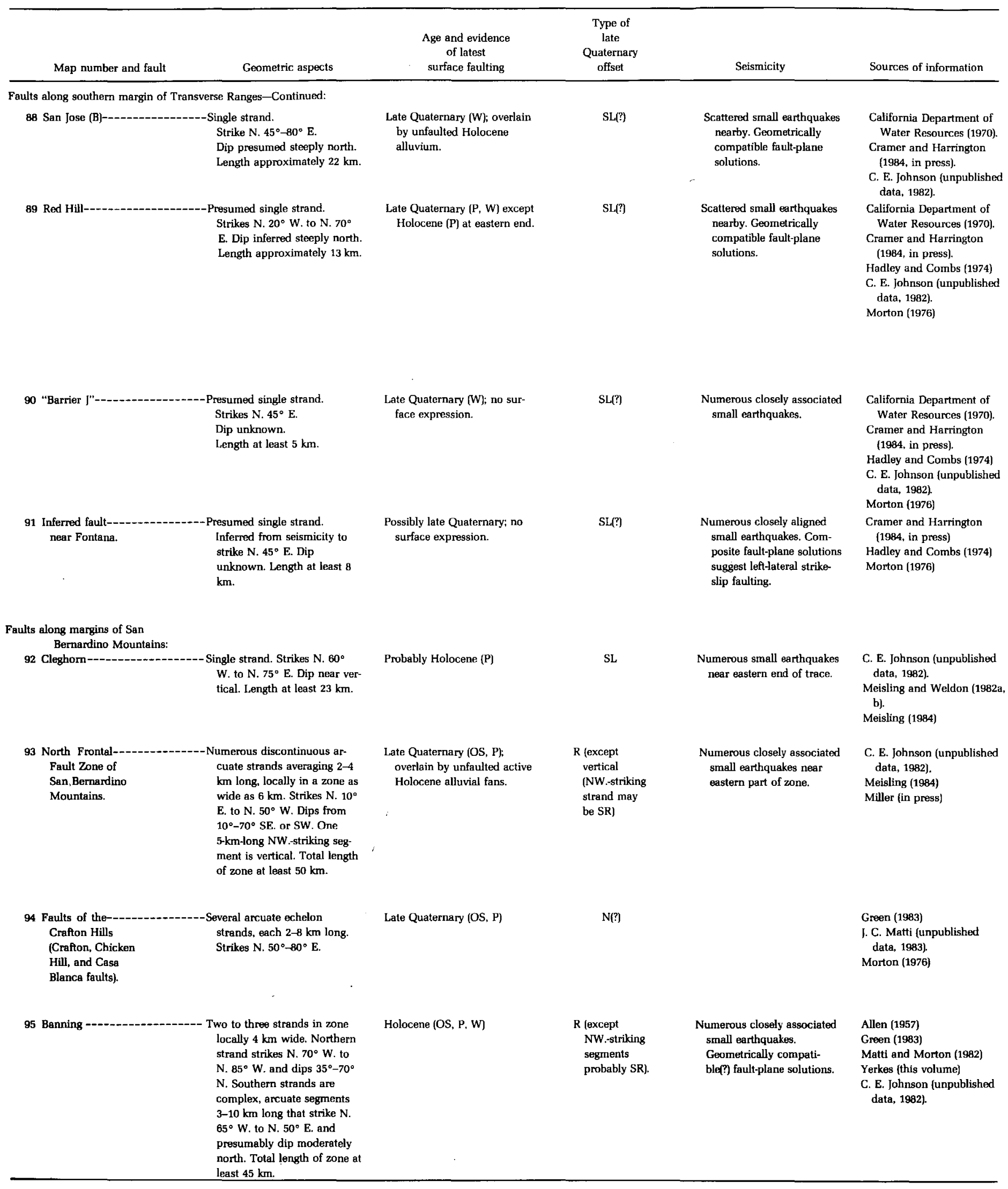

\section{Earthquake Hazards in the Los Angeles Region}




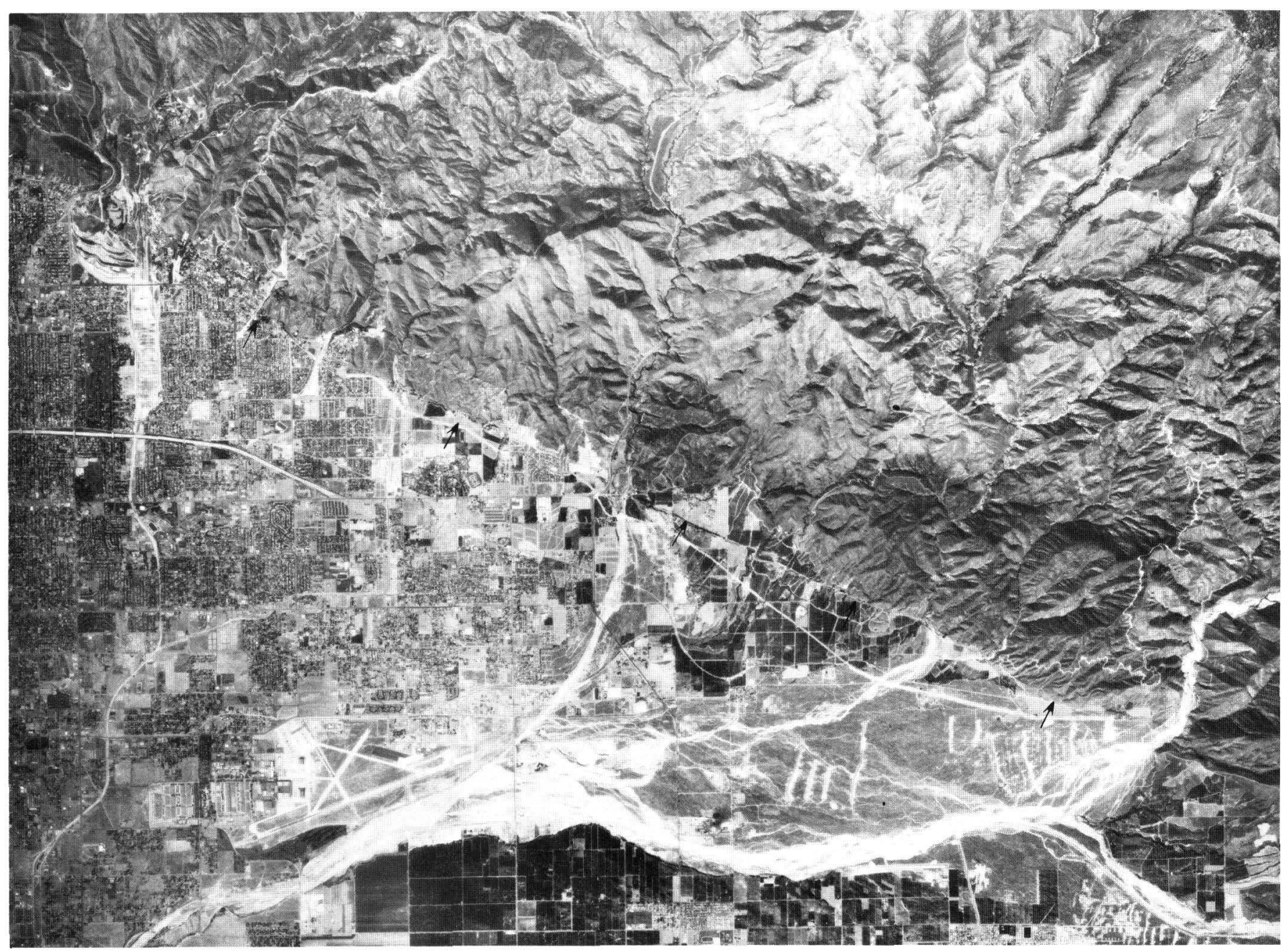

FIGURE 12.-Vertical aerial photograph of the northwestern San Bernardino Valley showing urbanization across the surface traces of the San Andreas fault zone, which here marks the southern boundary of the San Bernardino Mountains. Arrows point to the most recently active trace of the fault, the trace that offsets deposits and landforms of Holocene age. Future large earthquakes, accompanied by surface faulting and deformation, can be expected along this trace. (From U.S. Geological Survey photograph VDOB-2-48, scale approximately 1:80,000; taken in September 1975.)

Sierra Madre fault zone. The densely populated San Gabriel Valley is separated on the north from the San Gabriel Mountains by the geometrically complex zones of the Sierra Madre (83), Duarte (84), and Cucamonga (86) faults.

Several isolated late Quaternary faults that probably are Transverse Ranges structures lie south of the main mountain front. These faults include principally the San Jose B (88) and the Red Hill (89) faults, which extend through the Pomona area.

Faults within the western Transverse Ranges.-A broad band of late Quaternary faults traverses the interior of the western Transverse Ranges from beyond Santa Barbara eastward to Pasadena, where it merges with the southern boundary of the Transverse Ranges. The faults comprising the band are discrete arcuate elements that chiefly dip northward. Segments of this band were responsible for several historical damaging earthquakes near Santa Barbara and for the 1971 San Fernando earthquake.

The faults in the area around Santa Barbara, Ventura, and the Oxnard Plain have east to northeast trends. The major faults that have been active in late Quaternary time include the Santa Ynez (44), More Ranch (47), Mission Ridge-Arroyo Parida (46), Red Mountain (52), and Pitas Point-Ventura (55) faults. East of these faults are the San Cayetano (59), Oak Ridge (64), and Simi (67) faults.

The band of faults within and adjacent to the San Fernando Valley mostly strikes west-northwest. From west to east, these faults include the Santa Susana (68), San Fernando (69), and Sierra Madre (83) fault zones, which are closely linked segments of the same system. The central part of the San Fernando Valley is transected by the Northridge fault (71), which may merge eastward with the northwest-trending Verdugo fault (72) adjacent to 
Burbank. North of the valley, several segments of the San Gabriel fault (63) locally offset late Quaternary deposits, although other segments of this long fault apparently do not.

Although nearly 100 faults having late Quaternary offsets have been identified, others that may have ruptured as recently probably exist but are not now recognizable as geologically youthful. Unrecognized faults that have the potential to cause damaging earthquakes may underlie many of the areas covered by Quaternary alluvial deposits. Other such faults undoubtedly exist along the sea floor offshore of southern California, especially in the Santa Barbara Channel. Thus, we emphasize that figure 11 is not a final and complete accounting of the potentially active faults of the region. Indeed, it is expected that, as additional geologic and seismologic research is conducted, other active faults will be identified.

\section{HAZARDS FROM ACTIVE FAULTS}

Slip along a fault may result in one or more geologic effects that can damage or destroy structures and injure their inhabitants. Ground shaking and surface faulting are the effects of principal concern when rupture occurs along faults in the Los Angeles region. A related effect-the possible generation of tsunami waves by earthquakes beneath the sea-may be of concern to coastal parts of the region. For certain structures like pipelines, canals, and coastal facilities, the regionalscale uplift and subsidence that accompany some large earthquakes may pose a minor hazard.

\section{Earthquake Generation}

Sudden slip along all or part of a fault surface within the Earth's crust releases elastic strain energy that has accumulated within the nearby rocks and radiates that energy in the form of earthquake waves. Figure 13 is an idealized model of an earthquake source typical of the Transverse Ranges. Vibrational waves are propagated large distances in all directions away from the fault. As they pass through an area, they produce the shaking effects that are the predominant cause of earthquake damage. The severity of ground shaking at any point depends upon (1) the size of the earthquake, (2) the distance to the ruptured part of the fault plane, and (3) the local geologic conditions that either amplify or attenuate (reduce) the earthquake waves. Methods for predicting the severity of shaking and the effects of local geologic conditions on that shaking are discussed in subsequent chapters of this volume. Here we consider only the energy release associated with earthquakes.

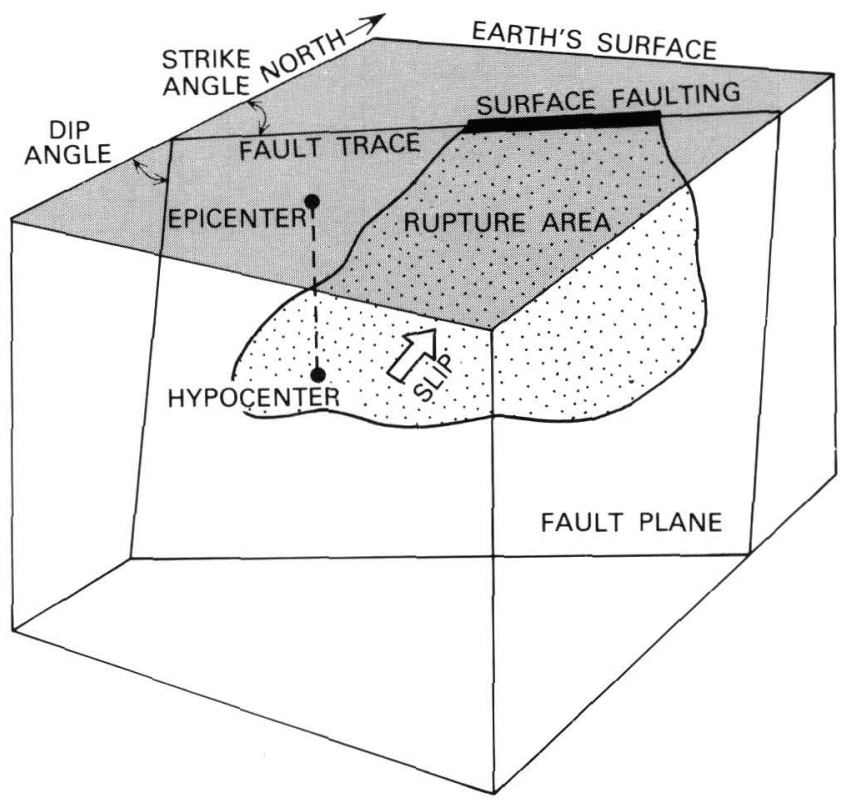

FIGURE 13.-Model of typical earthquake source (modified from Boore, 1977). Rupture first begins at a point within the Earth's crust, termed the focus or hypocenter, and spreads across part of the existing fault plane. Surface faulting occurs when the rupture propagates to the Earth's surface; the surface rupture does not necessarily coincide with the epicenter, the point on the Earth's surface directly above the hypocenter. The fault illustrated here is a reverse oblique-slip fault whose orientation is specified by its angles of strike and dip. The dimensions of an earthquake source at depth can usually be estimated from the distribution of carefully located aftershocks, the smaller earthquakes that commonly follow the main shock. In southern California, earthquake hypocenters generally are less than $15 \mathrm{~km}$ deep. The intersection of the fault with the ground surface, called the fault trace, is the line observed by geologists and plotted on maps (for example, fig. 11). If a significant component of vertical movement occurs along the fault, a low step, or scarp, may be formed along the fault trace. Fault scarps are the most obvious expression of active faults at the Earth's surface.

The most common expression of the size of an earthquake is magnitude, which is a number based on measurement of the maximum motions recorded by a seismograph for earthquake waves of a particular frequency. The concept of magnitude was introduced by Richter (1935), who defined it as the logarithm of the maximum recorded amplitude written by a seismograph of specified sensitivity $100 \mathrm{~km}$ from the earthquake (observations at distances other than $100 \mathrm{~km}$ are corrected to the standard distance by using empirical curves). The local magnitude scale, termed $\mathrm{M}_{\mathrm{L}}$, was originally devised for southern California earthquakes, which are generally less than $15 \mathrm{~km}$ deep. Later, other magnitude scales were developed for more distant and deeper earthquakes: $\mathrm{M}_{\mathrm{S}}$ estimates the strength of distant shallowfocus earthquakes from long-period seismic waves that propagate near the surface of the Earth, and $m_{b}$ 
TABLE 6.-Seismic moments, magnitudes, and likely fault sources for larger earthquakes in southern California since 1857

[Moments and magnitudes are chiefly from Hanks and others (1975), Hanks and Kanamori (1979), and Kanamori and Regan (1982)]

\begin{tabular}{|c|c|c|c|c|}
\hline \multirow[b]{2}{*}{ Date } & \multicolumn{3}{|c|}{ Magnitude } & \multirow[b]{2}{*}{ Probable fault source } \\
\hline & $\mathbf{M}_{\mathbf{L}}$ & $\mathrm{M}_{\mathrm{S}}$ & $\mathbf{M}$ & \\
\hline Jan. 9, $1857--------900$ & & & 7.9 & San Andreas \\
\hline Dec. $25,1899------15$ & & & 6.8 & Claremont (San Jacinto zone) \\
\hline Apr. $21,1918-----15$ & & 6.8 & 6.8 & Claremont (San Jacinto zone) \\
\hline July $23,1923 \ldots \ldots$ & & $6^{1 / 4}$ & 6.0 & Claremont (San Jacinto zone) \\
\hline June $29,1925-\ldots---20$ & & $6^{1 / 4}$ & 6.8 & In Santa Barbara Channel \\
\hline Nov. 4, $1927-------100$ & & 7.3 & 7.3 & Offshore Point Arguello \\
\hline Mar. 11, $1933------2$ & 6.3 & $61 / 4$ & 6.2 & Newport-Inglewood zone (offshore) \\
\hline May $19,1940------30$ & 6.4 & 6.7 & 7.0 & Imperial (San Jacinto zone) \\
\hline July $1,1941--\cdots--.9$ & 5.9 & 5.9 & 6.0 & In Santa Barbara Channel \\
\hline Oct. $21,1942-------9$ & 6.5 & $6^{1 / 2}$ & 6.6 & Coyote Creek (San Jacinto zone) \\
\hline Apr. 10, $1947------7$ & 6.2 & 6.4 & 6.5 & In Mojave Desert \\
\hline Dec. $4,1948------1$ & 6.5 & $6.5 \pm$ & 6.0 & Mission Creek \\
\hline July 21, $1952--------200$ & 7.2 & 7.7 & 7.5 & White Wolf \\
\hline Mar. 19, $1954------4$ & 6.2 & & 6.4 & Coyote Creek (San Jacinto zone) \\
\hline Apr, 9, $1968-------6$ & 6.4 & 6.7 & 6.5 & Coyote Creek (San Jacinto zone) \\
\hline Feb. 9, 1971 - & 6.4 & 6.6 & 6.6 & San Fernando \\
\hline Feb. 21, 1973------ .1 & 5.9 & 5.2 & 5.3 & Anacapa \\
\hline Oct. $15,1979-----7$ & 6.6 & & 6.5 & Imperial (San Jacinto zone) \\
\hline
\end{tabular}

estimates the strength of distant earthquakes of any focal depth from seismic waves that penetrate deep within the Earth. Each scale has limitations; none satisfactorily measures the very largest earthquakes because each relates to only certain frequencies of seismic waves and because the spectrum of radiated seismic energy changes with earthquake size. Other limitations on seismogram-derived magnitudes include uncertainties with regard to the attenuation characteristics of the Earth's interior through which the earthquake waves pass and the effect of geologic conditions near the instrument on recorded amplitudes. The different magnitude scales have been discussed in greater detail by Lee and Stewart (1981), Chung and Bernreuter (1981), and Nuttli and Hermann (1982).

A more fundamental measure of the size of an earthquake is seismic moment, which relates the strength of an earthquake directly to the physical attributes of the fault slip generating the event. Seismic moment is defined as the product of the area of the rupture, the average amount of slip, and the shear modulus (or strength) of the rocks involved. Seismic moment can be estimated from geologic information obtained after an earthquake (for example, the length of surface faulting or aftershock zone and the measured amounts of slip) or from analysis of seismograph recordings; it can also be estimated from the dimensions of shaking intensity patterns observed from an earthquake. Hanks and others (1975) have discussed seismic moment in greater detail.

A new magnitude scale based on the concept of seismic moment was recently devised (Hanks and Kanamori, 1979). Termed the moment magnitude (M) scale, it is uniformly applicable to all sizes of earthquakes. The $M$ scale is approximated by $M_{L}$ in the magnitude range 3 to 7 and by $M_{S}$ in the magnitude range 5 to $7 \frac{1}{2}$. Because the $M$ scale avoids many of the limitations of traditional instrumental magnitude scales and still relates well to other scales in the appropriate magnitude ranges, seismologists and geologists are using it more frequently to express earthquake size or strength. Other advantages are that the rate of occurrence of earthquakes having different $\boldsymbol{M}$ values can be related directly to the slip rate on faults (Molnar, 1979) and that the moment magnitude for both past and future earthquakes can be estimated directly from the assumed dimensions of fault rupture (Wallace, 1982).

Because $M$ is a newly developed quantity, it has been determined only for some of the most important past earthquakes. Table 6 compares the seismic moments and magnitudes of the larger earthquakes in southern California since 1857 . This chapter will use $\boldsymbol{M}$ values, where they have been computed, to express the size of earthquakes being discussed.

Like other magnitude scales, $\boldsymbol{M}$ uses small numbers to express vast differences in earthquake size. In absolute terms of radiation of seismic energy, energy release increases about 32 times with each increase in magnitude unit (table 7). Because the amount of energy radiation reflected in the various magnitude scales increases geometrically, small differences in magnitude are much more significant at the higher ends of the scales than they are at the lower ends. The difference in radiated energy between earthquakes of $\boldsymbol{M} 7.9$ and $\boldsymbol{M}$ 8.0, for 
TABLE 7.-Comparison of differences in magnitude and radiated energy for any two earthquakes

[Modified from a table by K. R. Lajoie (Blair and Spangle, 1979)]

\begin{tabular}{|c|c|}
\hline $\begin{array}{l}\text { Difference in } \\
\text { magnitude }\end{array}$ & $\begin{array}{l}\text { Difference in } \\
\text { radiated energy }\end{array}$ \\
\hline \multicolumn{2}{|c|}{ 5--------- } \\
\hline \multicolumn{2}{|c|}{$4------1-1,000,000$} \\
\hline \multicolumn{2}{|c|}{ 3--------- } \\
\hline \multicolumn{2}{|c|}{ 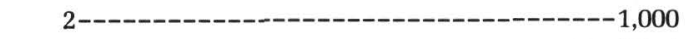 } \\
\hline \multicolumn{2}{|c|}{ 1----------- } \\
\hline \multicolumn{2}{|c|}{ 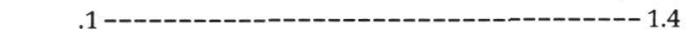 } \\
\hline
\end{tabular}

example, is about one million times larger than the difference between earthquakes of $\boldsymbol{M} 3.9$ and $\boldsymbol{M} 4.0$. Although wider areas may be damaged by larger earthquakes, however, damage is not proportional to the radiated energy.

Regardless of the method used to express the strength of an earthquake, a fundamental relation that holds for all magnitude scales has been observed-the amount of earthquake energy released is related to the size of the fault area that has slipped and to the amount of the displacement. Figure 14 shows that larger areas of fault rupture generally result in larger earthquakes.

\section{Surface Faulting and Related Permanent Ground Deformation}

When slip along a fault plane extends to the Earth's surface, the effects can have profound significance for buildings, dams, pipelines, and other structures that straddle or cross the fault trace. These effects include rupture and offset of the land surface, local warping and tilting of the ground near the fault trace, and, less commonly, uplift or subsidence of adjoining areas. These permanent ground deformations, although they affect smaller areas than the shaking effects of an earthquake affect, can damage or even destroy structures. Examples of structural damage caused by surface faulting and distortion that accompanied a modern earthquake in an urban area are shown in figure 15.

Whether slip along a fault during an earthquake reaches the ground surface depends on the size, depth, and orientation of the earthquake rupture surface. Large shallow earthquakes in California commonly are accompanied by surface faulting or deformation. Generally, surface faulting is associated with earthquakes having hypocenters shallower than $15 \mathrm{~km}$ and magnitudes of $\boldsymbol{M} 5.5$ or greater. Under special circumstances, surface rupture has occurred in association with earthquakes as small as $M 2.5$ (Yerkes and others, 1983); offsets for such shocks, however, are typically small.

\section{Earthquake Hazards in the Los Angeles Region}

Comparison of worldwide data on historical surface faulting indicates that larger magnitude earthquakes are associated with longer surface faults and greater displacements (Bonilla and Buchanan, 1970; Slemmons, 1977; Mark and Bonilla, 1977; Scholz, 1982). About 444 $\mathrm{km}$ of the surface trace of the San Andreas fault in northern California, for example, ruptured during the 1906 San Francisco earthquake (M 7.7). In California, surface rupture has accompanied many of the moderate to large historical earthquakes. Maximum values of historical surface rupture length and surface displacement are presented in table 8 for the major types of faulting that have occurred in California.

Surface faulting is rarely confined to a simple narrow line. More commonly, a complex fault pattern results where the main fault zone is complicated by branching and secondary faults. Occasionally, secondary faults may be as far as $70 \mathrm{~km}$ from the main fault zone. The pattern of surface rupture commonly reflects the mode of faulting, the pattern of the dip-slip surface faults being more complex than that of the strike-slip surface faults.

The amount of surface displacement along historical ruptures has varied greatly in short distances. Commonly, the displacement is not symmetrical along the fault

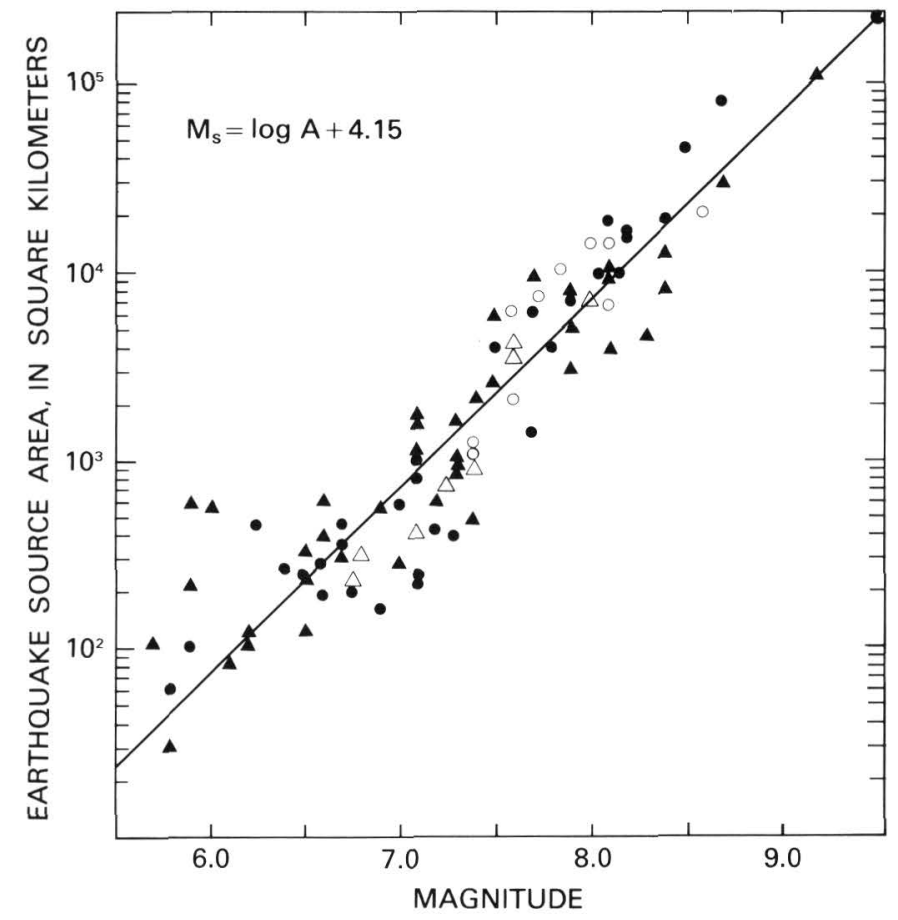

FIGURE 14.-Comparison of area of earthquake rupture surface with surface-wave magnitude (modified from Wyss, 1979, fig. 2). Solid circles, open circles, and solid and open triangles indicate data from various investigators for historical earthquakes worldwide. Progressively larger areas of fault rupture generally result in larger earthquakes. 


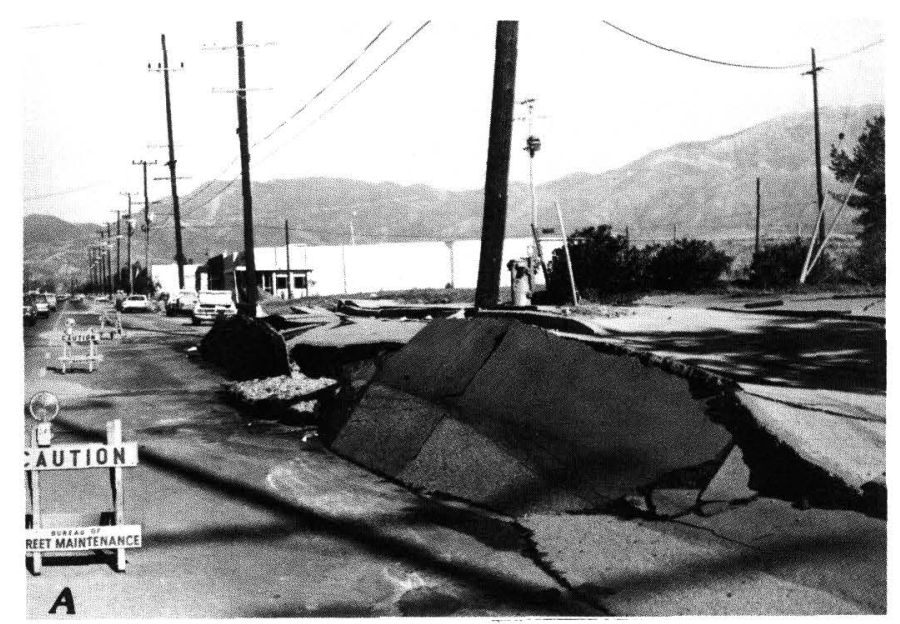

FIGURE 15.-Examples of surface displacement that accompanied the 1971 San Fernando earthquake. A, Damage to sidewalk and pavement along Foothill Boulevard about $1 \mathrm{~km}$ east of the San Fernando airport. The scarp, which is about $1 \mathrm{~m}$ high, resulted from reverse left-oblique fault slip. View looks northwest along Foothill Boulevard. (Photograph by J. I. Ziony, U.S. Geological Survey.) B, Damage to house, sidewalk, and pavement near Pacoima Wash. View looks westward. The concrete floor slab was offset and tilted, and the house had to be razed (Youd and others, 1978, fig. 4A). C, Simplified cross section illustrating faulting and damage (Youd and others, 1978, fig. 4B).

trace but may reach a maximum near one end of the fault and may show several high points in offset along the fault trace (fig. 16).

Surface faulting commonly is accompanied by permanent horizontal or vertical distortion within a few meters to several hundred meters of the main fault. Usually, the distortion, which can tilt the ground surface, is minor in comparison with the amount of fault offset. Sometimes, however, the distortion is a substantial proportion of or even exceeds the fault offset. The ratio of vertical distortion to vertical fault offset, for example, was two to one along the part of the Coyote Creek fault that was activated by the 1968 Borrego Mountain earthquake in Imperial Valley (Clark and others, 1972).

Not all surface displacements along faults occur suddenly in direct association with earthquakes. Fault creep is slow, differential movement caused chiefly by aseismic tectonic processes. It also can be artificially induced by human activity, such as the withdrawal of fluids from shallow parts of the Earth's crust.

Tectonic creep has been recognized along faults in several parts of California, particularly in central California (Herd, 1979; Wesson and others, 1975) and in the Salton Trough region. The most notable example occurs along the San Andreas fault south of the San Francisco Bay region, where creep accounts for as much as $32 \mathrm{~mm} / \mathrm{yr}$ of contemporary right-lateral slip (Burford and Harsh, 1980). Monitoring studies there have shown
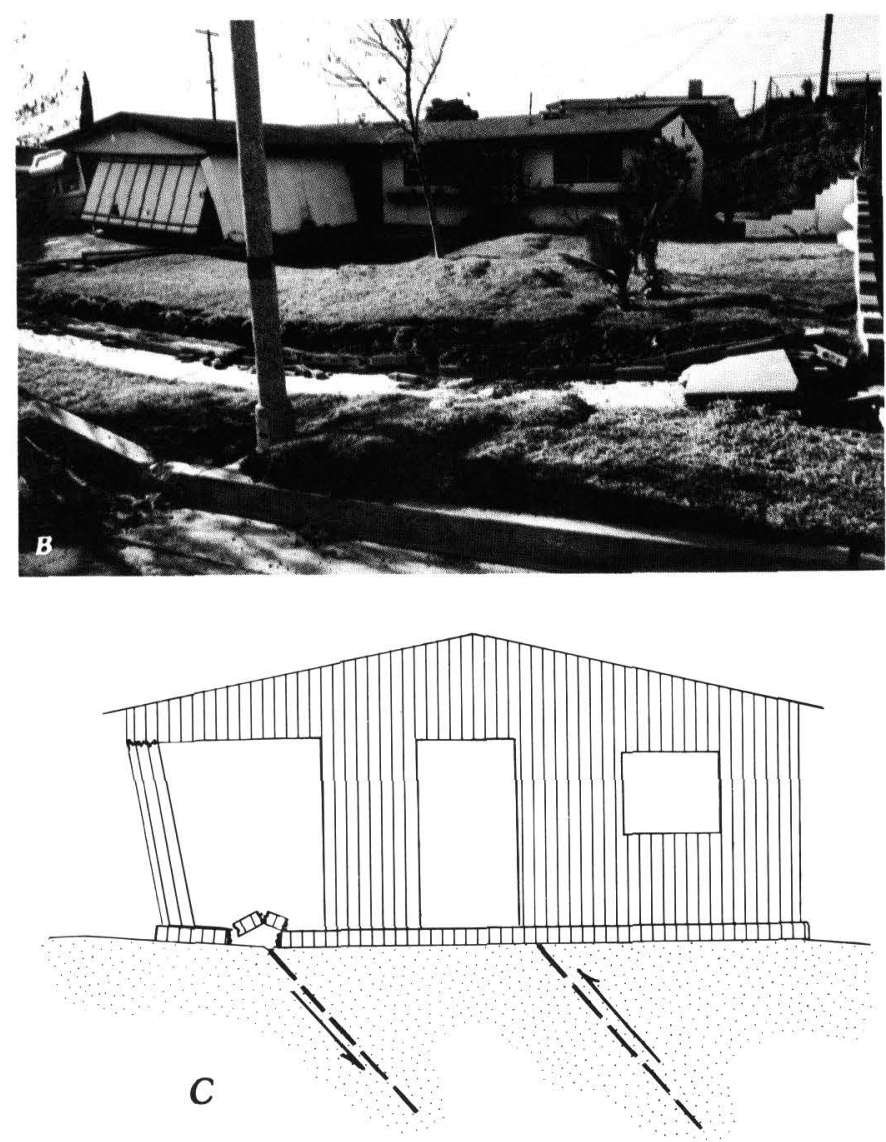

that tectonic creep occurs either as discrete small increments of slip within intervals of hours or days or as nearly uniform motion. Commonly, the creep rate along a fault shows variations both with position along the fault and with time.

Short-term tectonic creep, termed afterslip, occasionally is associated with surface faulting. The amount of such slip may approach the amount of sudden slip

TABLE 8.-Maximum values of length of surface rupture and amount of surface displacement from historical earthquakes in California

[Derived from Bonilla and others (1984, table 3) and Slemmons (1977, table 16). Moment magnitude estimates from Hanks and Kanamori (1979). Rupture length and displacement maximums for a given fault type are not necessarily from the same earthquake]

\begin{tabular}{|c|c|}
\hline $\begin{array}{c}\text { Length of } \\
\text { surface rupture, in } \mathrm{km}\end{array}$ & $\begin{array}{l}\text { Maximum surface } \\
\text { displacement, in } \mathrm{m}\end{array}$ \\
\hline Normal slip-------------91 & $0.6^{1}$ \\
\hline Normal oblique slip------ $110^{2}$ & $6.4^{2}$ \\
\hline Reverse oblique slip------ $52^{3}$ & $2.1^{5}$ \\
\hline Strike slip-- & $9.4^{6}$ \\
\hline
\end{tabular}

$1_{1950}$ Fort Sage Mountain earthquake $\left(M_{L} 5.6\right)$.

${ }^{2} 1872$ Owens Valley earthquake (M 7.8).

${ }^{3} 1952$ Kern County earthquake (M 7.5).

${ }^{4} 1906$ San Francisco earthquake (M 7.7).

$5_{1971}$ San Fernando earthquake (M 6.6).

${ }^{6}{ }_{1857}$ Fort Tejon earthquake (M 7.9). 


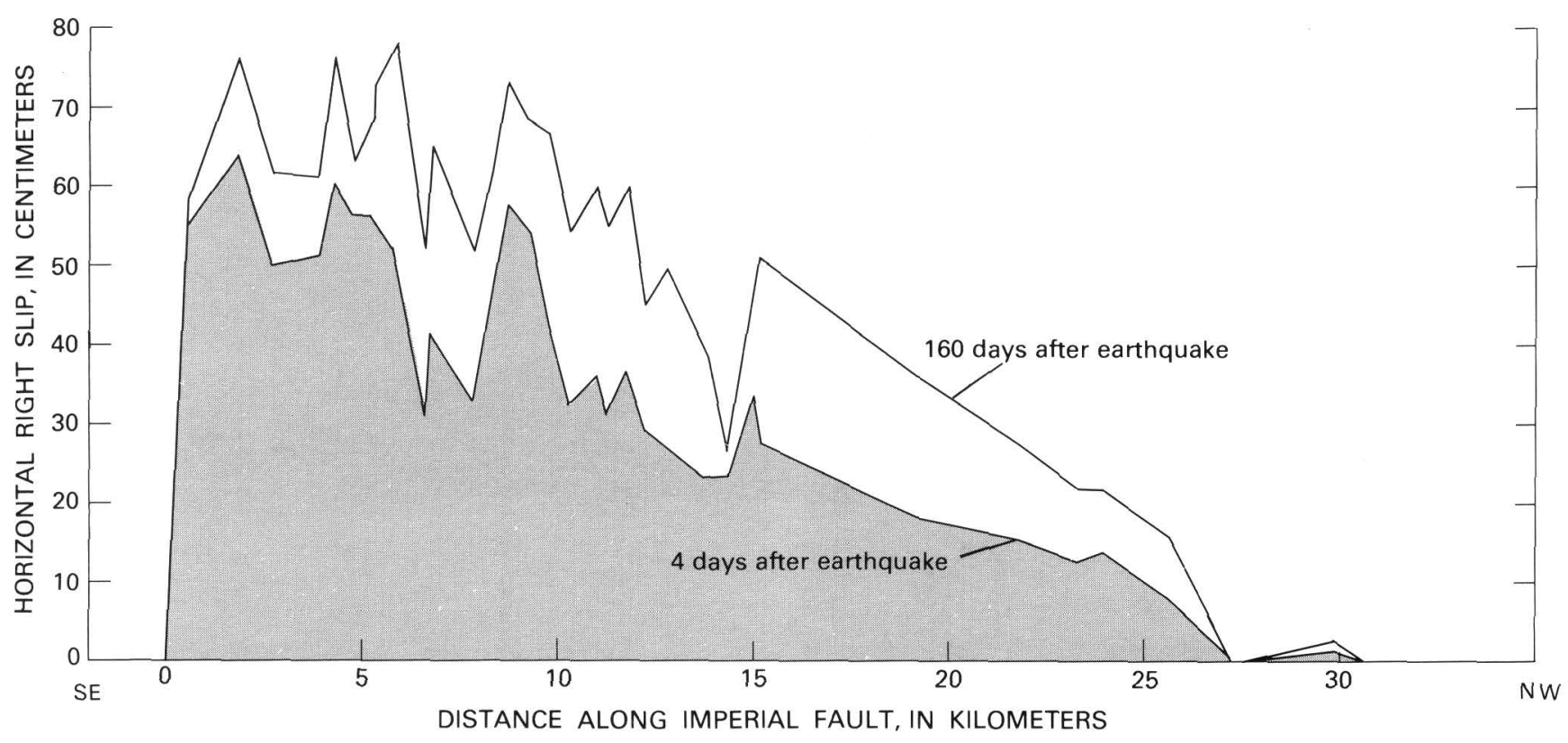

FIGURE 16.-Horizontal component of surface offset measured along the rupture trace of the Imperial fault following the October 15, 1979, Imperial Valley earthquake (modified from Sharp and others, 1982, fig. 101). The 1979 surface rupture was about $30 \mathrm{~km}$ long and overlapped the northern half of the surface rupture associated with the 1940 Imperial Valley earthquake. The amount of displacement is distributed asymmetrically along the rupture and is greatest near its southeastern end. Significant creep occurred after the main shock. One hundred and sixty days following the earthquake, the location of maximum right slip was shifted slightly northwestward, and postearthquake creep accounted for a significant proportion of the total surface displacement.

directly associated with the main ground rupture event. For example, average horizontal displacement along the Imperial fault increased from about 27 to $31 \mathrm{~cm}$ just after the October 15, 1979, Imperial Valley earthquake to 41 to $45 \mathrm{~cm} 6$ months later (Sharp and others, 1982).

Tectonic creep has not yet been observed in the Los Angeles region, although creep from other causes has been recognized along several faults. Surficial displacements of as much as $18 \mathrm{~cm}$ have occurred during the past three decades in the Baldwin Hills, near the northern end of the Newport-Inglewood fault zone, along a series of north- to northeast-trending short normal faults. Although these faults probably originated as tectonic features, their contemporary displacements are attributed to differential subsidence caused by withdrawal of petroleum and gas from an underlying oilfield (Castle and Yerkes, 1976).

Creep also has been observed along the Casa Loma and Claremont strands of the San Jacinto fault zone north of Hemet (Fett and others, 1967; Proctor, 1962). The dominantly dip-slip movement probably results chiefly from compaction of sediments caused by withdrawal of ground water from a narrow alluvial basin bounded by the faults; maximum subsidence of this basin has averaged 3.5 to $4.0 \mathrm{~cm} / \mathrm{yr}$ since 1939 (Morton, 1978). Evidence that subsidence has occurred at rates of about 2 to $6 \mathrm{~mm} / \mathrm{yr}$ for the past 15,000 to $42,000 \mathrm{yr}$ (Lofgren, 1976), however, suggests that tectonic processes may contribute to the contemporary fault slip.

64 Earthquake Hazards in the Los Angeles Region

\section{Tsunami Generation}

Large earthquakes that originate beneath or near the sea sometimes are accompanied by tsunamis. A tsunami-an ocean wave generated by rapid displacement of a large volume of sea water-results either from vertical faulting or warping of the sea floor or from large-scale submarine landsliding. Waves of destructive size and force may strike nearby coasts or may travel thousands of miles across the open ocean to hit distant shorelines. As a tsunami enters shallow waters, its velocity diminishes, but the wave heights increase (occasionally to several tens of meters), the result being potentially destructive effects.

Within the Pacific basin, damaging tsunamis are most common along the margins of coastal Alaska, the Japanese islands, and the islands of the mid-Pacific Ocean. Coastal California also has experienced destructive tsunamis. The harbor in Crescent City in northern California, for example, was badly damaged and 11 people were drowned when the distant 1964 Alaska earthquake generated a train of sea waves.

As McCulloch (this volume) discusses in greater detail, small tsunamis of local origin have struck coastal southern California sporadically. The Santa Barbara Channel earthquake of December 21, 1812, reportedly caused waves that inundated the lower reaches of the coast between Santa Barbara and Goleta. Other small tsunamis have occurred near the Los Angeles region, 
perhaps the best documented being a 2-m-high wave generated by the 1927 Point Arguello earthquake.

\section{Regional Tectonic Deformation}

Uplift and subsidence on a regional scale accompany some large earthquakes, especially those associated with large components of dip-slip displacement. Although the amounts of uplift or subsidence rarely exceed a few meters, vertical deformation can have adverse effects on facilities along coast lines and on pipelines and canals inland.

The area of uplift or subsidence is determined by fault dimensions and displacement and can extend over tens of square kilometers to hundreds of thousands of square kilometers. The great Alaska earthquake of 1964, for example, which resulted from reverse-slip motion along a low-angle fault of regional extent, was accompanied by vertical uplift and subsidence of an area of more than $285,000 \mathrm{~km}^{2}$; local changes in elevation exceeded $11 \mathrm{~m}$. In the Los Angeles region, tectonic deformation on a much smaller scale has been documented for the 1971 San Fernando earthquake (Savage and others, 1975) and suggested as likely for the 1933 Long Beach earthquake (Gilluly and Grant, 1949).

\section{EXAMPLES OF SURFACE FAULTING AND RELATED EFFECTS FROM SOUTHERN CALIFORNIA EARTHQUAKES}

The range of surface faulting effects likely to be associated with future major earthquakes in the Los Angeles region can best be illustrated by considering three historical southern California earthquakes that ruptured the land surface. The 1857 Fort Tejon earthquake is representative of the largest event likely to occur along the San Andreas fault; the 1968 Borrego Mountain earthquake was a moderate-sized event within the Peninsular Ranges along the dominantly strike-slip San Jacinto fault zone; the 1971 San Fernando earthquake is an example of a destructive earthquake along one of the dominantly dip-slip faults within the Transverse Ranges.

\section{Fort Tejon Earthquake}

The 1857 Fort Tejon earthquake is the largest event known to have affected the Los Angeles region since exploration of the area by the Spanish in 1769. Although this earthquake occurred before the advent of seismograph recordings, a comparison of the amount of fault slip that it generated with that generated by the instrumentally measured 1906 San Francisco earthquake $\left(M_{S}\right.$
$8^{1 / 4}$, equivalent to $M 7.7$ ) indicates that the Fort Tejon event was clearly larger (Sieh, 1978a); Hanks and Kanamori (1979) assign it $\boldsymbol{M}$ 7.9.

Although the 1857 event was named for Fort Tejon, which is located south of Bakersfield, historical accounts of foreshock activity strongly suggest that the epicenter was actually located along the central part of the San Andreas fault near Cholame, northeast of San Luis Obispo, and that the earthquake rupture surface propagated several hundred kilometers southeastward into the Los Angeles region (Sieh, 1978b).

No systematic observations of the earthquake effects were made immediately after the event. Contemporary accounts, however, indicate that surface faulting accompanied by strike-slip offsets of several meters extended along the San Andreas fault from Cholame at least to Lake Elizabeth near Palmdale, a distance of about $230 \mathrm{~km}$. A modern geomorphic analysis of offset stream channels crossing the fault has documented that surface ruptures apparently extended southeastward to near Wrightwood (Sieh, 1978a). The total length of surface faulting thus probably exceeded $360 \mathrm{~km}$ (fig. 17).

Detailed character of the rupture trace can only be inferred, because no fault mapping was done at the time of the earthquake. The 1857 break is believed to be restricted to the geomorphically most prominent trace in the San Andreas fault zone, although it is likely that subsidiary faulting occurred along some parallel strands within a kilometer or so of the main trace. Geomorphic expression of several subsidiary faults adjacent to the San Andreas near Palmdale, for example, is fresh enough to suggest that these fault elements also slipped in 1857 (Barrows and others, 1976).

Estimates of the style and amount of slip have been made by analysis of displaced small drainage features that cross the main fault trace (Sieh, 1978a). Stream channels are offset systematically in a right-lateral sense; there is little or no vertical component. Slip along the fault apparently reached a maximum of about $9.5 \mathrm{~m}$ in the Carrizo Plain west of Bakersfield and diminished rapidly toward the southeast. Along the margin of the Antelope Valley, slip is estimated to have been between 3 and $4.5 \mathrm{~m}$.

Locally, dip-slip components of displacement probably accompanied the earthquake. Fresh-looking meter-high scarps across alluvial fans, for example, may record subsidiary faulting along the southwest-dipping Elkhorn thrust, which lies about $3 \mathrm{~km}$ northeast of the San Andreas fault in the southern Carrizo Plain.

\section{Borrego Mountain Earthquake}

The M 6.5 Borrego Mountain earthquake of April 9, 1968, was generated by sudden slip on the northwest-

Earthquake and Surface-Faulting Potential 65 


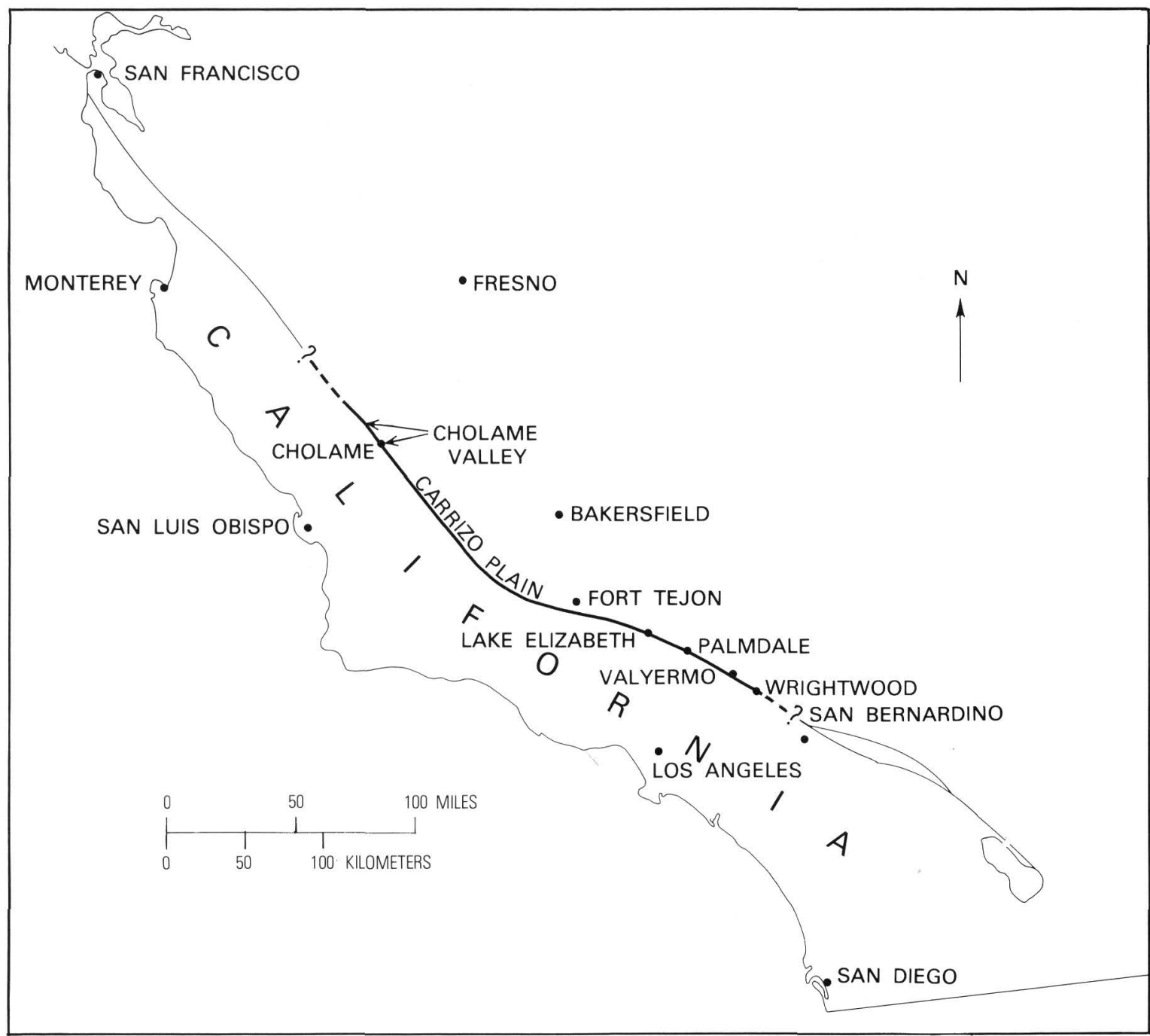

FIGURE 17.-Extent of surface fault rupture (heavy line) along the San Andreas fault associated with the 1857 Fort Tejon earthquake (modified from Sieh, 1978a, fig. 2). Right-lateral surface offset reached a maximum of about $9.5 \mathrm{~m}$ in the Carrizo Plain and was about 2 to $4 \mathrm{~m}$ between Lake Elizabeth and Wrightwood.

striking Coyote Creek fault, an element of the San Jacinto fault zone about $100 \mathrm{~km}$ southeast of Hemet outside the Los Angeles region. The main shock was approximately midway along a broad, complex zone of aftershocks about $60 \mathrm{~km}$ long. Surface-faulting and deformation effects of this earthquake were intensively studied (Allen and others, 1972; Burford, 1972; Clark, 1972; Clark and others, 1972; Sharp and Clark, 1972) and are summarized below.

Surface faulting occurred along $31 \mathrm{~km}$ of the Coyote Creek fault in three distinct bands of echelon fractures trending approximately N. $30^{\circ}-50^{\circ}$ W. (fig. 18A). Most of the ground displacement took place within $20 \mathrm{~m}$ of the trace, although some occurred as much as $500 \mathrm{~m}$ away. Isolated evidence of faulting was observed as much as $3 \mathrm{~km}$ from the main trace.

\section{Earthquake Hazards in the Los Angeles Region}

Offsets along the main trace were chiefly right lateral, and the maximum measured strike slip was $38 \mathrm{~cm}$. In contrast, outlying surface ruptures that diverged from the trend of the main fault had large vertical components of offset, locally as great as $23 \mathrm{~cm}$. Compression and distortion, which produced locally complex patterns of surface deformation, characterized the areas at the ends of the echelon fault segments (fig. 18B). Studies of the patterns of the 1968 faulting and earlier movements recorded by offset of preexisting physiographic features showed that the 1968 displacements in every case matched the sense of earlier slip events along the Coyote Creek fault.

Aseismic creep continued for several years after the earthquake and was concentrated mainly along the central and southern sectors of the fault, which had ex- 


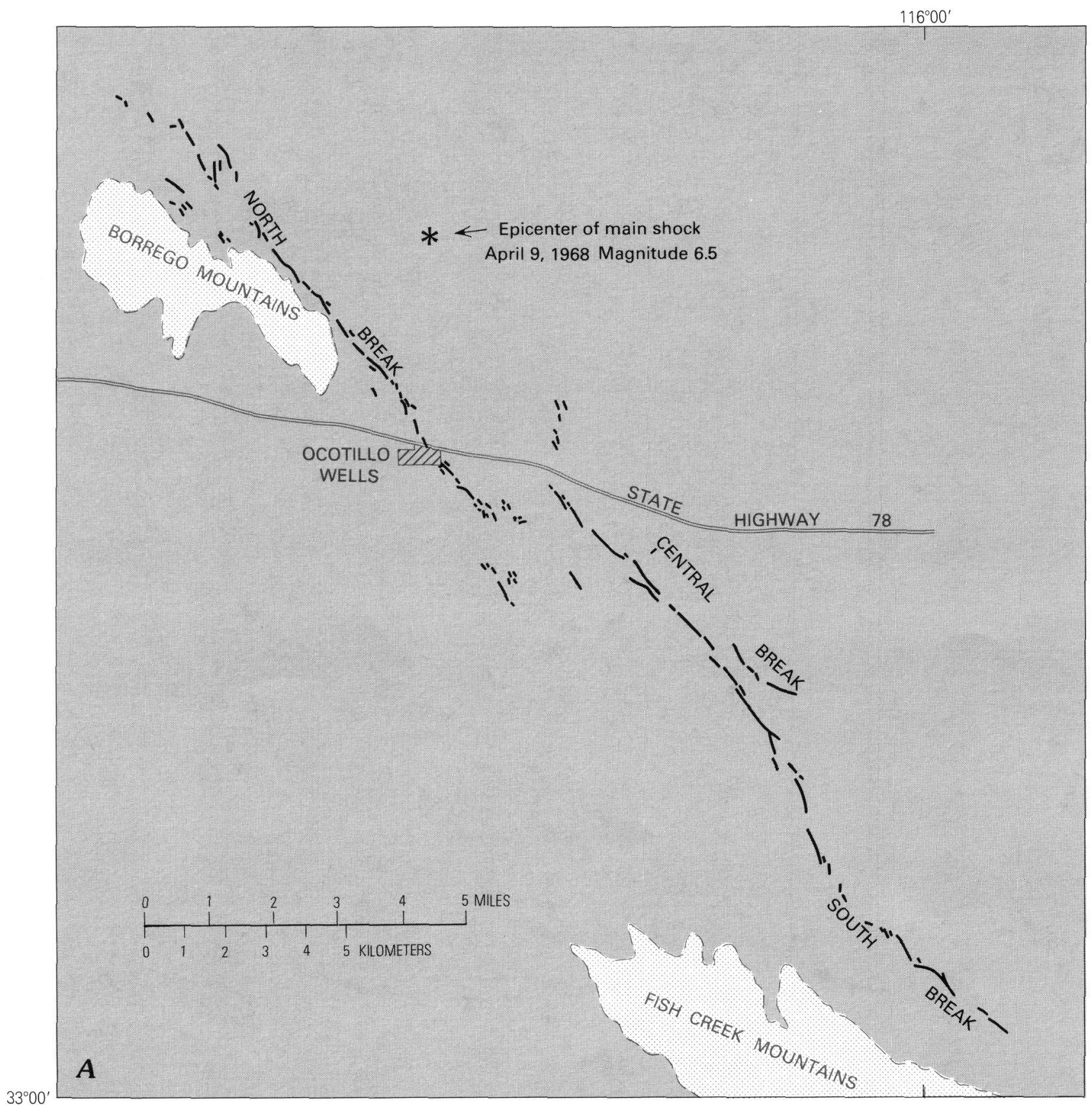

FIGURE $18 A$

FIGURE 18.-Surface faulting associated with the Borrego Mountain earthquake of April 9, 1968. A, Major surface ruptures along the Coyote Creek fault (generalized from Clark, 1972, pl. 1). B, Surface faulting along the northern segment of the 1968 rupture (portion from Clark, 1972, pl. 1). Note the left-stepping echelon pattern of many of the breaks. C, Relation of the Coyote Creek fault, which was the source of the 1968 earthquake, to the three distant faults-the San Andreas, the Superstition Hills, and the Imperial-along which minor surface offsets were triggered at distances as great as $70 \mathrm{~km}$ from the epicenter (modified from Allen and others, 1972, fig. 52).

perienced the least amount of coseismic slip. Locally, postearthquake creep was as much as $18 \mathrm{~cm}$.

Interestingly, the Borrego Mountain earthquake triggered small $(1-2.5 \mathrm{~cm})$ right-lateral surface displacements along three subparallel faults at distances of as much as $70 \mathrm{~km}$ from the main shock (fig. 18C). The faults that ruptured sympathetically were the Imperial fault (for $22 \mathrm{~km}$ ), the Superstition Hills fault (for $23 \mathrm{~km}$ ), and the southern San Andreas fault north of the Salton Sea (for $30 \mathrm{~km}$ ). 


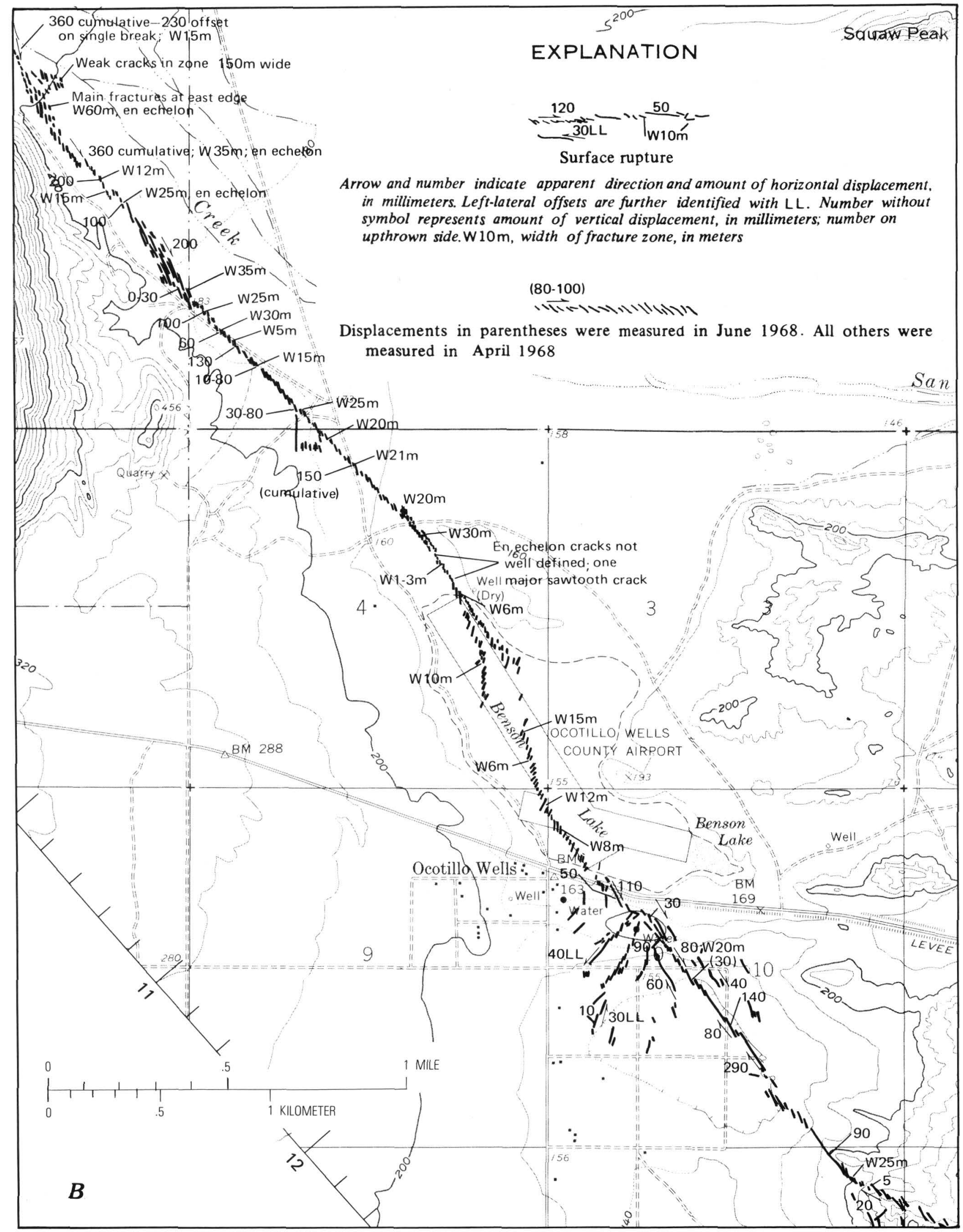

FIGURE $18 B$

68 Earthquake Hazards in the Los Angeles Region 


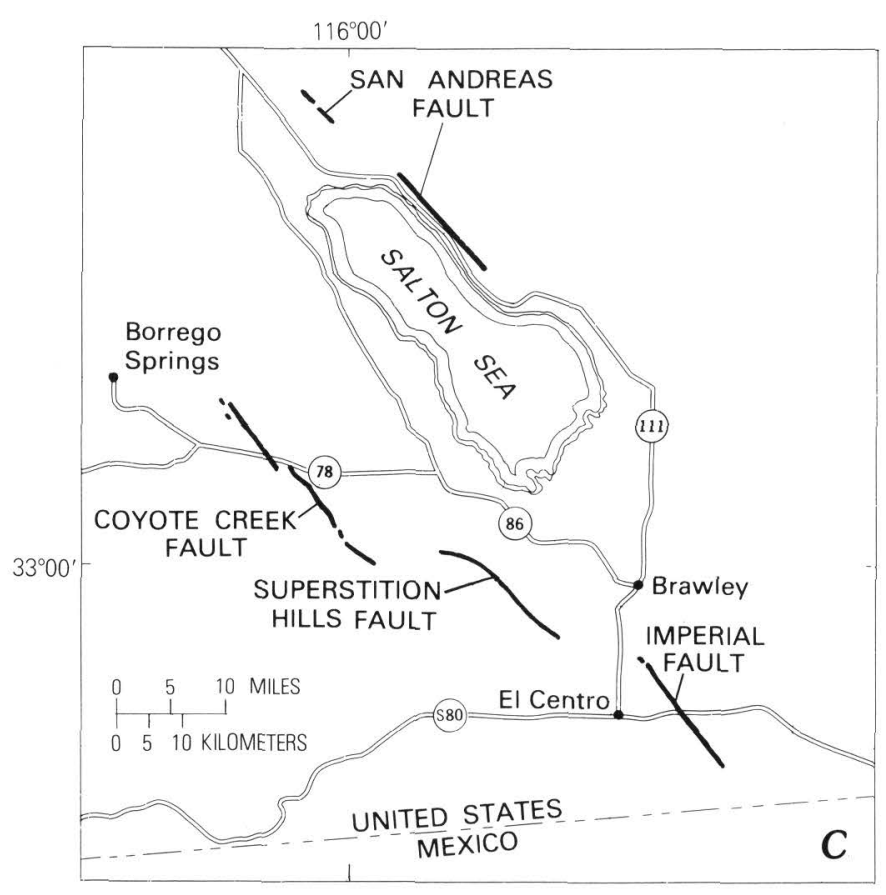

FIGURE $18 C$

\section{San Fernando Earthquake}

Tectonic surface rupturing that caused extensive damage to parts of the heavily populated San Fernando Valley accompanied the M 6.6 1971 San Fernando earthquake. The surface-faulting effects have been documented in detail (U.S. Geological Survey Staff, 1971; Kamb and others, 1971; Barrows, 1975; Kahle, 1975; Weber, 1975; Sharp, 1975, 1981a; Youd and others, 1978).

The zone of surface ruptures was about $15 \mathrm{~km}$ long, extending from the western side of San Fernando to Big Tujunga Canyon. Displacements were the result of reverse left-oblique slip of as much as $2.1 \mathrm{~m}$ along the San Fernando fault zone, which dips north about $55^{\circ}$. Detailed mapping showed that five separate segments of this fault zone were activated at the surface during the earthquake. Nearly all of the tectonic surface offsets were restricted mostly to the upper block, or hanging wall, of the fault zone. The zone of surface faulting coincided with a buried ground-water barrier formed by pre-1971 faulting in the Holocene alluvial deposits of the valley and was aligned with fault-produced geomorphic features of late Quaternary age.

The character of ground deformation varied along each segment. The distal parts of the fault zone were marked by relatively simple rupture zones less than about $5 \mathrm{~m}$ wide. In contrast, fractures comprising the west-central segment that traverses the alluviated San Fernando Valley were much more complex (fig. 19). This segment consisted of a main belt of thrusting about 75 to $200 \mathrm{~m}$ wide and bordered on the north by a broad (1-1.5 $\mathrm{km}$ wide) zone of discontinuous, mostly normal-slip faults having small offsets (several millimeters).

Subsidiary faulting along short faults in the foothills occurred at distances of as much as $2 \mathrm{~km}$ from the main trace. Some of these offsets indicated as much as $1 \mathrm{~m}$ of reverse left-oblique slip.

Secondary faulting accompanied by small amounts of left-lateral and reverse slip was observed along about $450 \mathrm{~m}$ of the Santa Susana fault northwest of the primary faulting (Weber, 1975). Similar rupturing may have occurred along a short segment of the Buck Canyon-Watt fault near its junction with the San Gabriel fault $8 \mathrm{~km}$ northeast of San Fernando.

The earthquake was also accompanied by permanent ground distortion, including uplift (fig. 20) and horizontal displacements. Comparison of precise leveling surveys made before (1968-70) and after the earthquake shows that changes in elevation formed an east-west arch that affected much of the northern San Fernando Valley (Savage and others, 1975; Yerkes and others, 1974). The greatest changes were in the foothills east of the valley, where maximum uplift was about $2 \mathrm{~m}$. Because maximums in the patterns of uplift coincide with topographic highs, such deformation probably was the most recent result of ongoing (but sporadic) geologic processes. Horizontal displacements, locally of more than $2 \mathrm{~m}$ and occurring over a broad area, showed an abrupt discontinuity along the zone of surface faulting in the pattern and amount of horizontal distortion (Yerkes and others, 1974).

The preceding three examples illustrate some of the kinds of surface faulting and deformation that might accompany future major earthquakes in the Los Angeles region. The faults that produced these effects could slip again in the near future and perhaps duplicate their historical surface offsets. Other faults within the region have attributes similar to those discussed, and major earthquakes along these faults could produce comparable patterns of surface rupture and distortion. The next section addresses ways of identifying which faults might be the source of future seismic events and estimating the likely character of future earthquakes and tectonic surface deformation along those faults.

\section{PREDICTING THE FUTURE BEHAVIOR OF FAULTS}

\section{Identifying Active Faults}

Geologists and seismologists use various criteria based on current manifestations or the history of a fault to infer its potential for future rupture. These criteria include historical surface faulting or creep, historical and 


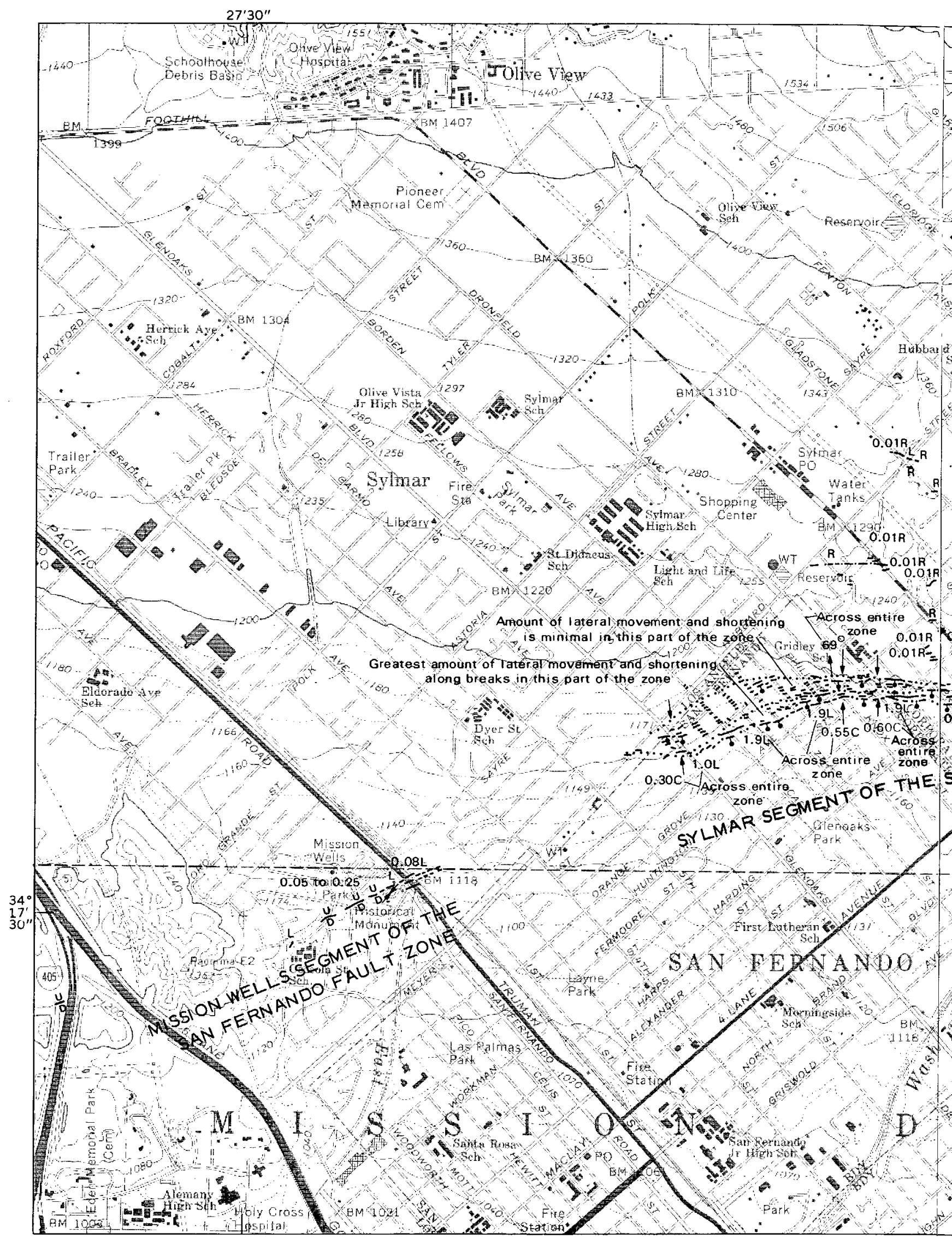

FIGURE 19.-Western segments of tectonic surface ruptures produced by dominantly reverse left-oblique faulting associated with the 1971 San Fernando earthquake (U.S. Geological Survey Staff, 1971, fig. 2). Note the complexity of the Sylmar segment, which traverses the alluvium of the San Fernando Valley, in comparison with the relatively simple traces of the Tujunga segment that separates bedrock foothills from alluvium. 


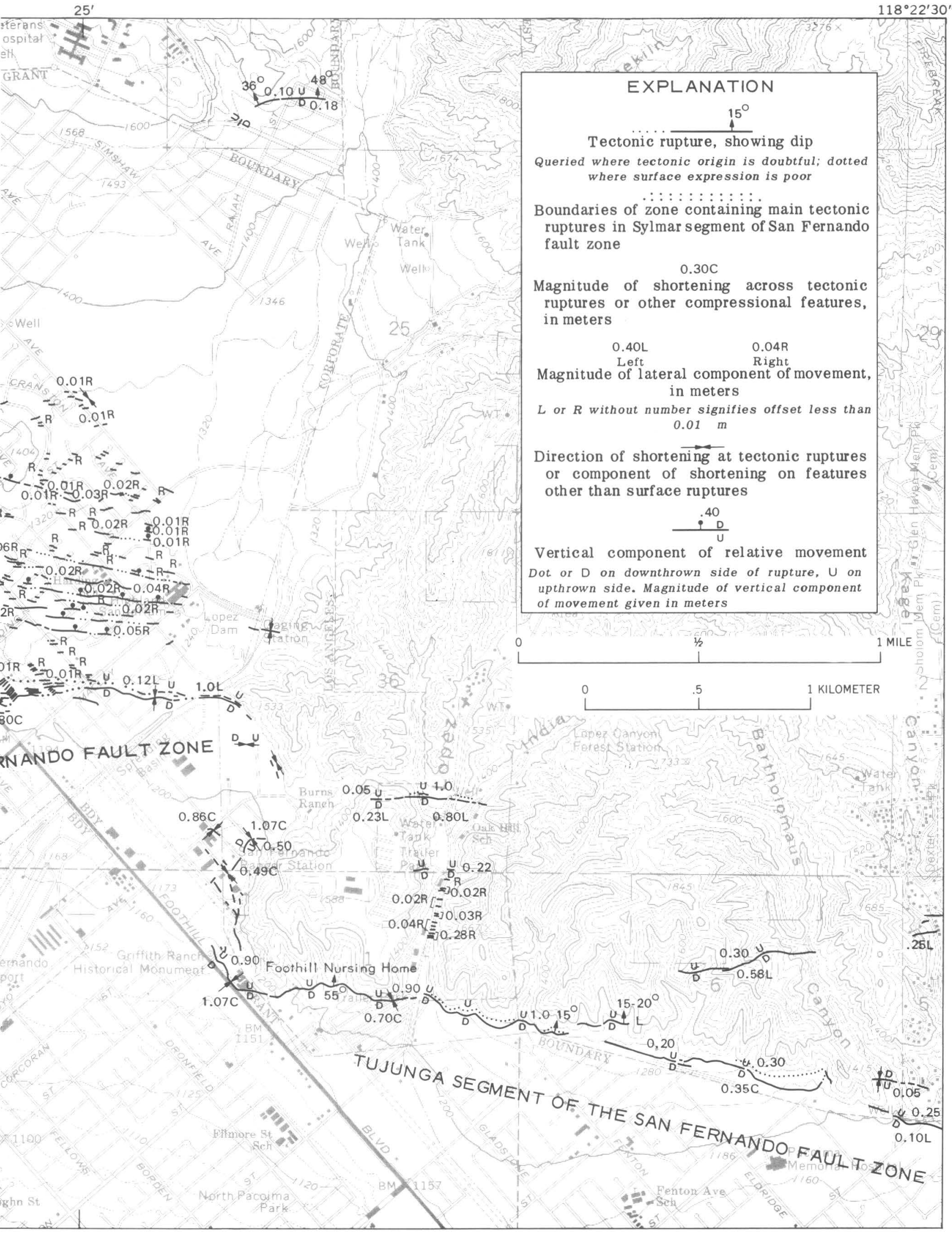

Earthquake and Surface-Faulting Potential 71 


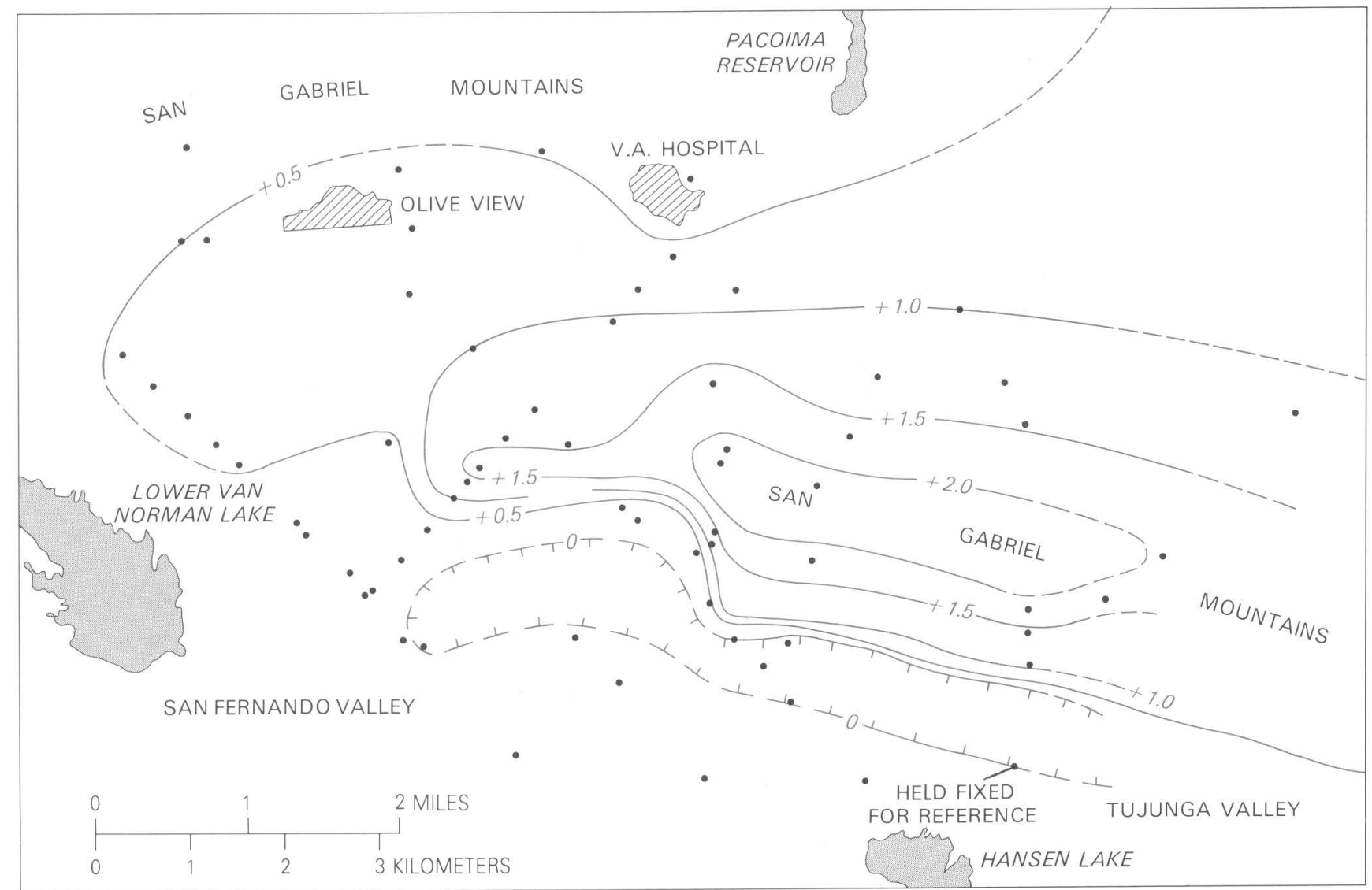

FIGURE 20.-Relative elevation changes (in meters) in the northern San Fernando Valley determined from surveys before and after the 1971 earthquake (from Savage and others, 1975, fig. 2). The steepest gradient (where changes of elevation contours are spaced most closely) generally coincides with the zone of surface faulting. Contours of elevation changes are dashed where inferred and hachured where subsidence occurred. Solid circles are surveyed points.

contemporary seismicity, contemporary accumulation of strain as revealed by repeated geodetic surveying across faults, episodes of slip in the recent geologic past as deduced from displaced rock or soil units of known age, and physiographic features that record geologically young movements at the ground surface.

Although our understanding of the behavior of faults is incomplete, enough is known to show that the manner and frequency of movements along these faults can vary greatly. Some faults can be dormant for thousands of years and then slip suddenly tens of meters, whereas other faults release strain through frequent small earthquakes or by more or less continuous creep. Because the range in fault behavior is great, earth scientists do not currently agree as to what criteria differentiate with certainty between an active fault and one that will remain inactive.

An approach commonly used to designate active faults is to consider how recently displacements have occurred along them (Ziony and others, 1973). Geologic evidence along a fault is evaluated to determine the age of the youngest faulted material or the age of the youngest landforms produced by faulting. A fault then can be assigned to the age class (for example, historical, Holocene, or late Quaternary) that most closely brackets the time span containing its youngest slip event. Systematic regional evaluations of faults have been made by Wentworth and others (1970) for the Los Angeles basin, by Ziony and others (1974) for coastal southern California, by Buchanan-Banks and others (1978) for coastal central California, and by Pampeyan (1979) for the San Francisco Bay region.

Which time span is chosen to designate a fault as active depends on the likely consequences of renewed faulting. In evaluating the locations of structures intended for human occupancy, for example, the State of California uses evidence of offset during Holocene time (approximately the past $10,000 \mathrm{yr}$ ) to designate a fault as active (Hart, 1980). Longer spans of geologic time are used for types of construction whose possible failure would pose high risks to the public. Thus, for the siting of large dams, the U.S. Bureau of Reclamation considers a fault active if it has experienced slip during the past 100,000 yr. The U.S. Nuclear Regulatory Commission,

\section{Earthquake Hazards in the Los Angeles Region}


which is responsible for approving the siting and design of nuclear power facilities, considers faults that have slipped several times during the last $500,000 \mathrm{yr}$ as active.

A complication in identifying potentially active faults is that, although most such faults in California displace young alluvial deposits or topographic features, active faults in certain tectonic settings do not reach the Earth's surface. The $M_{L} 6.71983$ Coalinga earthquake in central California demonstrated that damaging seismogenic slip can occur on a concealed fault that is manifested at the surface only by recurrently active young folds (Stein and King, 1984). The earthquake was generated by thrusting in basement rocks along a lowangle active fault that does not completely penetrate the overlying Cretaceous and late Cenozoic sedimentary rocks (Yerkes and others, 1984).

Faults in the Los Angeles region that show evidence of movement at or near the Earth's surface within the past approximately 750,000 yr are indicated in figure 11 . Although additional studies along other faults in the region may subsequently reveal evidence for geologically recent activity, we are reasonably confident that the suite of historical, Holocene, and late Quaternary faults identified in this chapter contains those faults that are most likely to cause damaging earthquakes. Table 5 summarizes what is known about the physical characteristics of each fault, our current appraisal of the age of the most recent displacement, the type of geologically recent slip, and the evidence for associated earthquakes.

\section{Evaluating Relative Activity}

Simply designating a fault as active does not adequately predict its future behavior. Significant differences between the degrees of activity of active faults may exist and must be considered. Two faults that have both been active in Holocene time, for example, may have vastly different intervals and amounts of recurrent movement. Geologists and seismologists now recognize that the slip rate, the size and recurrence intervals of earthquakes, and the amount of slip per movement event provide a more precise and useful characterization of fault activity than the age of the latest offset alone provides.

Analysis of the slip rates of faults provides one means for assessing degrees of activity. Rates can be obtained directly from observed or geodetically measured historical offsets along faults that are currently creeping. For most active faults, however, slip rates must be deduced from the displacement of geologically young markers. The average rate of slip for a length of geologic time is calculated by dividing the cumulative net displacement of a stratigraphic or physiographic marker by the amount of time elapsed since the marker was first displaced by the fault. Most commonly, this time span is assumed to be the age of the displaced marker as measured by radiometric dating techniques, as estimated from stratigraphic relations, or as inferred from physiographic expression.

Geologically determined slip rates provide a measure of only the long-term average displacement rate along the fault. Faults, however, do not necessarily move at constant rates of slip. Although the inferred average slip rate along part of the San Jacinto fault zone, for example, during the past 730,000 yr B.P. is about 8 to more than $12 \mathrm{~mm} / \mathrm{yr}$, comparison of measured offsets from different segments of that time-span indicates that the slip rate fluctuated, dropping as low as 1 to $2 \mathrm{~mm} / \mathrm{yr}$ for parts of that period (Sharp, 1981b). Fluctuating rates of slip during the past 2 m.y. also have been documented for the Oak Ridge fault (Yeats, 1977). Most commonly, however, the average slip rate is the only estimate that can be obtained, because data are insufficient to show changes in the slip rate of an individual fault.

Comparison of the average rates of slip for different active faults in a region can provide a quantitative measure of their relative activity. Provisional classifications of faults according to rates of long-term average slip have been proposed by Matsuda (1975, 1977), Slemmons (1977), Cluff (1978), and Knuepfer and others (1981). Table 9 is an example of such a classification. An assessment of the degree of activity, based on this classification, has been completed for the faults of Japan (Research Group for Active Faults of Japan, 1980).

Geologic slip rates have been estimated for many of the major faults in the Los Angeles region (Lamar and others, 1973; Anderson, 1979). The estimates for different faults, however, have been computed by using measured offsets representing widely different spans of geologic time; in some cases, offset geologic features as old as 6 to $17 \mathrm{~m} . y$. provide the basis for estimating the

TABLE 9.-Degree of fault activity from long-term slip rates during late Quaternary time

[From Matsuda (1977) and Slemmons (1977)]

\begin{tabular}{|c|c|c|c|}
\hline Class & Degree of activity & $\begin{array}{l}\text { Average slip rate, } \\
\text { in } \mathrm{mm} / \mathrm{yr}\end{array}$ & Comments \\
\hline AA---- & Very high & $10-100$ & $\begin{array}{l}\text { Restricted to major } \\
\text { plateboundaries. }\end{array}$ \\
\hline A----- & High & $1.0-10$ & $\begin{array}{l}\text { Generally well- } \\
\text { developed } \\
\text { physiographic } \\
\text { evidence } \\
\text { of recent faulting. }\end{array}$ \\
\hline B -- - - & Moderately high & $.1-1.0$ & \\
\hline C ----- & Moderate & $.01-0.1$ & \\
\hline
\end{tabular}

Earthquake and Surface-Faulting Potential 73 
TABLE 10.-Late Quaternary slip rates estimated for some faults of the Los Angeles region

\begin{tabular}{|c|c|c|c|c|}
\hline \multirow[b]{2}{*}{ Fault (map number) } & \multicolumn{3}{|c|}{ Slip rate, in $\mathrm{mm} / \mathrm{yr}$} & \multirow[b]{2}{*}{ Component $^{1}$} \\
\hline & Minimum & Maximum & Preferred & \\
\hline San Andreas (1)----------- & 20.0 & 30.0 & 25.0 & $\mathrm{H}$ \\
\hline San Jacinto zone, Clark (8)--------- & 8.0 & $>12.0$ & -- & $\mathrm{H}$ \\
\hline Chino (11)----------------- & .02 & .06 & -- & $\mathrm{V}$ \\
\hline \multicolumn{5}{|l|}{ Newport-Inglewood zone: } \\
\hline Inglewood (25)-------------- & .12 & .6 & -- & $\mathrm{V}$ \\
\hline North Branch (30)---------- & .1 & 1.2 & -- & $\mathrm{V}$ \\
\hline Palos Verdes Hills (35)------------ & .02 & .3 & -- & $\mathrm{V}$ \\
\hline 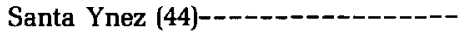 & .15 & 10.1 & 1.0 & $\mathrm{~T}$ \\
\hline Arroyo Parida (46)----- & .35 & .4 & -- & $\mathrm{V}$ \\
\hline More Ranch (47)-- & .2 & $>.3$ & $>.3$ & $\mathrm{~V}$ \\
\hline Red Mountain (52)-- & .4 & 1.5 & -- & D \\
\hline Javon Canyon (54)---- & .7 & 2.5 & -- & $\mathrm{T}$ \\
\hline Ventura (55)---_- & .8 & 2.4 & -- & $\mathrm{D}$ \\
\hline Faults near Oak View (57)----- & .27 & 1.34 & -- & $\mathrm{T}$ \\
\hline San Cayetano (59)-- & .88 & 2.9 & -- & $\mathrm{T}$ \\
\hline $\begin{array}{l}\text { Faults of Orcutt and -- } \\
\text { Timber Canyons (60). }\end{array}$ & .05 & 2.36 & -- & $\mathrm{T}$ \\
\hline Santa Cruz Island (77)----------- & .2 & $>.56$ & -- & $\mathrm{v}$ \\
\hline Santa Cruz Island (77)---------- & .86 & -- & -- & $\mathrm{H}$ \\
\hline Malibu Coast (79)---1 & .04 & .09 & -- & $\mathrm{T}$ \\
\hline Santa Monica (80)-- & .27 & .39 & -- & $\mathrm{V}$ \\
\hline Raymond (82)------------------- & .1 & .22 & .13 & $\mathrm{~V}$ \\
\hline Sierra Madre (83)----- & .36 & 4.0 &.- & $\mathrm{V}$ \\
\hline Cucamonga (86)---_- & 2.9 & 6.4 & -- & $\mathrm{T}$ \\
\hline Cleghorn (92)--- & 2.0 & 16.0 & 3.3 & $\mathbf{H}$ \\
\hline Ord Mountain (93)- & .04 & .7 & 0.1 & $\mathrm{~V}$ \\
\hline
\end{tabular}

${ }^{1} \mathrm{~T}$, true slip rate; $\mathrm{H}$, horizontal component of slip rate; $\mathrm{V}$, vertical component of slip rate; $\mathrm{D}$, dip component of slip rate.

long-term slip rate. It is highly doubtful whether rates averaged over more than a few million years are representative of slip rates associated with the current tectonic stress field.

Comparison of rates of offset for only late Quaternary time provides a more reliable basis for characterizing the present relative activity of faults in the Los Angeles region. Marine and nonmarine deposits of late Quaternary age, which are widespread in the region, serve as markers for fault displacements and can be dated locally with reasonable precision by using various absolute and relative dating techniques. Measured offsets of late Quaternary deposits or of physiographic features that can be related to these deposits are known for about half of the faults listed in table 5. Most of the measurements, however, are of a component of the displacement (for example, the vertical separation or throw) rather than of true slip; therefore, the computed rates in many cases are less than the actual slip rates. Furthermore, the ages of offset deposits or geomorphic features can be reliably estimated for less than half of the localities where offsets (either separation or slip) have been

\section{Earthquake Hazards in the Los Angeles Region}

measured. Thus, rates of displacement can be estimated for less than 25 percent of the potentially active faults of the region.

Known late Quaternary slip rates are summarized for the Los Angeles region in table 10. These values may change as new information about the ages of the offset features or the amounts of offset comes to light. Although true slip rates can be calculated for a few faults, most data are for either the horizontal component, the vertical component, or the dip component (and thus give less than the true rate). The most common parameter available for comparing the relative activities of different faults is the vertical component of the slip rate. Although component rates are less than true slip rates, they can be useful if the ratio of vertical slip to horizontal slip along a fault is known. Thus, horizontal component rates computed for the dominantly strike-slip San Andreas, San Jacinto, and Cleghorn faults closely approximate their true rates, because these faults have large ratios of horizontal to vertical slip. Similarly, rates of vertical separation can be used to estimate true rates for faults known to be dominantly dip slip. Even where 


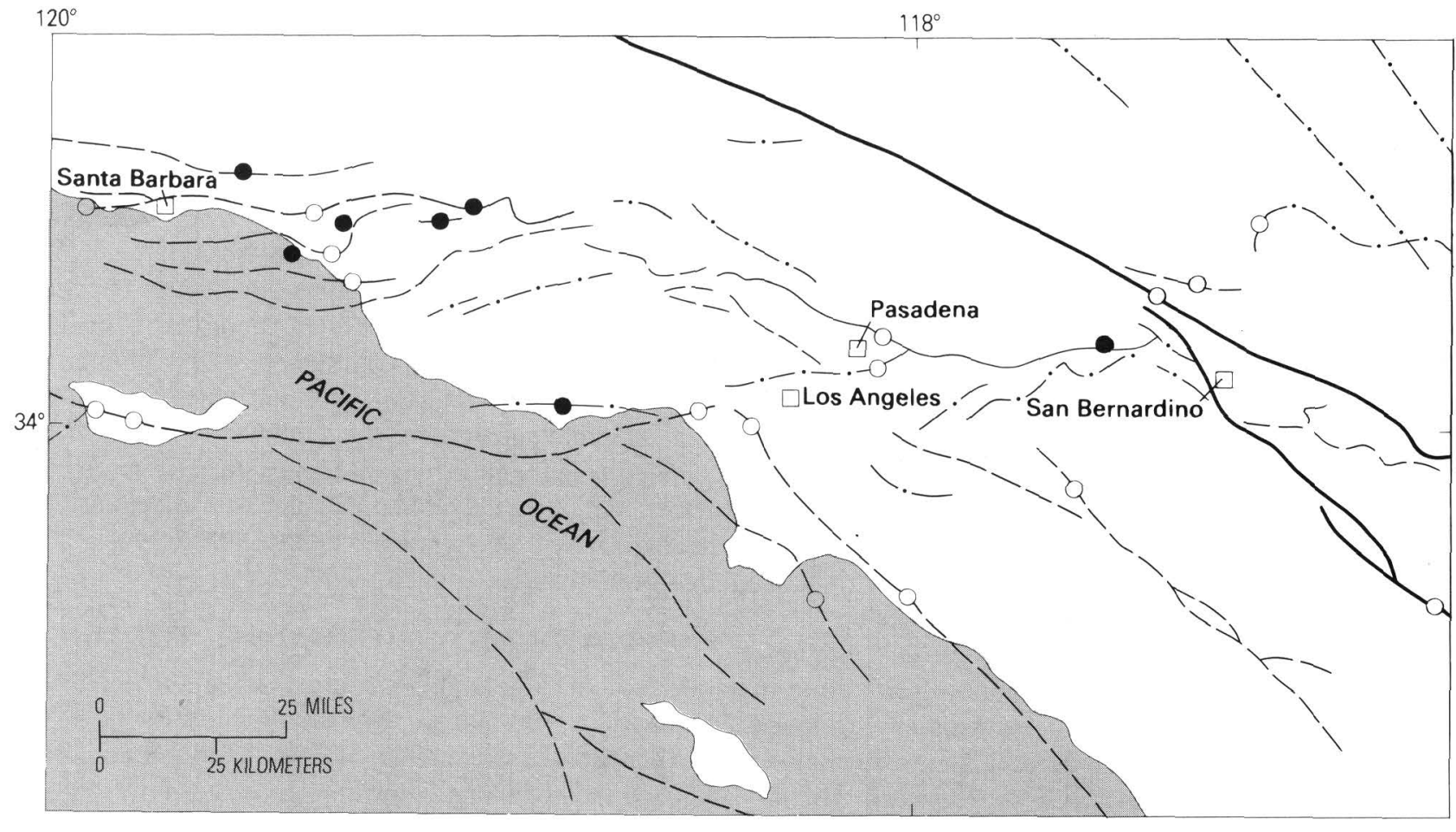

EXPLANATION

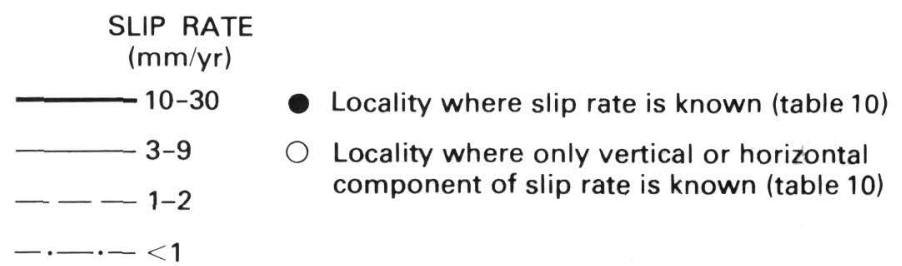

FIGURE 21.-Late Quaternary faults of the Los Angeles region classified according to known or inferred rates of slip within the past several hundred thousand years. Rates from faults having no constraining geologic offsets are provisionally assigned on the basis of connection with faults of known rate, tectonic setting, and geomorphic expression.

slip ratios are uncertain, comparing component rates for individual faults having similar trends provides a gross estimate of their relative activity.

Vertical component rates for the chiefly reverse-slip faults of the Transverse Ranges, for example, approximate their true slip rates, if it is assumed that vertical separations measured across these faults are equivalent to the vertical components of slip. That this assumption is not strictly correct is shown by oblique-slip historical surface offset along the San Fernando fault and by a dominant slip vector for the province that plunges $55^{\circ}$ NE., determined from earthquake faultplane solutions (Yerkes and Lee, 1979b, fig. 3). This assumption is, however, a reasonable working hypothesis that can be tested against variations in assumed fault dip and slip-vector orientation. Geometric analysis, for example, shows that the vertical component rate for a pure reverse-slip fault dipping $70^{\circ}$ will be about 94 percent of the true slip rate, whereas the vertical component rate for an oblique-slip fault of similar dip would be about 67 percent of the true slip rate. For shallower faults, of course, vertical separation is a much less accurate measure of slip. Nevertheless, vertical component rates can estimate true slip rates within a factor of two for the faults of the Transverse Ranges.

Integrating the sparse and mostly incomplete data from table 10 into a provisional slip-rate map for the region (fig. 21), we have assigned faults to one of four categories representing estimated ranges in true slip rate by taking into account available slip-rate data, probable styles of fault displacement, and possible connections with other faults of known rate. We have also compared known vertical component rates and relative geomorphic expressions of faults having similar tectonic settings. Systematic areal differences in estimated slip rates are shown on the provisional map-the San An-

Earthquake and Surface-Faulting Potential 75 
dreas and San Jacinto faults have slip rates measured in tens of millimeters per year, from 2 to 30 times greater than those of other active faults in the region. The next most active system is the belt of faults that extends diagonally across the Transverse Ranges from near Santa Barbara to San Bernardino. Individual faults in this system have rates that range from 1 to $6 \mathrm{~mm} / \mathrm{yr}$, the higher rates occurring where the belt is narrow and composed of only a few faults (for example, along the southern boundary of the Transverse Ranges eastward from Pasadena). In contrast, rates for the southern boundary faults of the Transverse Ranges west from Pasadena appear to be less than $1 \mathrm{~mm} / \mathrm{yr}$. Although few data are available for the northwest-trending fault systems that lie west of the San Jacinto fault, estimates of about $1 \mathrm{~mm} / \mathrm{yr}$ for each appear consistent with what is known.

Reliable geologic data with which to closely estimate a late Quaternary slip rate for the Elsinore fault zone in the Los Angeles region are not yet available. Proposed slip rates range widely-from about $0.8 \mathrm{~mm} / \mathrm{yr}$ (Lamar and Swanson, 1981) to about $7 \mathrm{~mm} / \mathrm{yr}$ (Kennedy, 1977)and are based on apparent horizontal separations of sedimentary facies boundaries rather than on unambiguous measurements of slip. We provisionally assign a rate of about $1 \mathrm{~mm} / \mathrm{yr}$ to the fault zone. Studies in progress southeast of Corona (Millman, 1985), however, suggest that a higher rate could be appropriate on the basis of apparent lateral offets of presumed middle to late Pleistocene alluvial fan deposits. Pinault and Rockwell (1984) have proposed a Holocene slip rate of about $4 \mathrm{~mm} / \mathrm{yr}$ for the southern Elsinore fault zone about $20 \mathrm{~km}$ north of the California border with Mexico.

Closely constrained late Quaternary slip rates have not yet been determined for the Newport-Inglewood and the Palos Verdes Hills fault zones, which pose a major earthquake threat to the densely populated Los Angeles basin. For the Newport-Inglewood zone, WoodwardClyde Consultants (1979) estimate an average slip rate of $0.5 \mathrm{~mm} / \mathrm{yr}$ since late Miocene time on the basis of inferred right-lateral displacements of geologic markers 3 to $5 \mathrm{~m}$.y. old; this value may not be representative of the offset rate during the past several hundred thousand years, however. Late Quaternary rates of vertical separation of 0.6 and $0.3 \mathrm{~mm} / \mathrm{yr}$ have been calculated locally for the Newport-Inglewood and Palos Verdes Hills fault zones, respectively. Because the geometry of the zones suggests dominantly right-lateral displacement, the vertical components of the offset rate probably are a fraction of the actual slip rate. Displaced late Pleistocene marine-terrace shoreline angles-near San Diego (Kern, 1977) suggest a slip rate of 1.2 to $1.4 \mathrm{~mm} / \mathrm{yr}$ for the Rose Canyon fault, a probable southern extension of the Newport-Inglewood zone. Thus, we can reasonably

76 Earthquake Hazards in the Los Angeles Region assign provisional slip rates of about $1 \mathrm{~mm} / \mathrm{yr}$ to each of these fault zones.

New methods of seismic risk analysis that use geologically determined slip rates to estimate the average rate of seismic moment release on a fault have been proposed recently (for example, Anderson, 1979; Wesnousky and others, 1982; Joyner and Fumal, this volume). The spatial and size distributions of future earthquakes in Japan, for instance, have been predicted from Quaternary slip-rate data (Wesnousky and others, 1984). Although these promising methods can be used to estimate seismic hazard for the Los Angeles region on the basis of existing slip-rate information, more reliable estimates will require considerable improvement in the knowledge of slip rates for the entire suite of late Quaternary faults.

\section{Determining Earthquake Potential}

A fault can generate earthquakes when it is suitably oriented to slip within the tectonic stress field of the Earth's crust and when it lies within rocks strong enough to store large amounts of strain energy for sudden release. How can we decide which active faults will generate future damaging earthquakes, and what will be the likely size and frequency of occurrence of these earthquakes?

Instrumentally recorded seismicity, although it indicates only the short-term patterns of release of earthquake energy, is a key tool for assessing the ability of a fault to produce earthquakes. The seismogenic nature of a fault is established where there is a close spatial relation between fault geometry and earthquakes. Comparison of fault-trace maps (fig. 11) with earthquake epicenter maps for the region is a first step in identifying seismogenic faults; this approach is severely limited, however, where faults are inclined rather than vertical, as they are in the Transverse Ranges, or where they are closely spaced. The earthquake-generating ability of a fault is established with greater certainty where geologic and seismologic information is detailed enough to accurately map earthquake hypocenters and to associate them with a specific fault at depth (for example, the Red Mountain fault) (fig. 22). The strongest evidence that a fault is seismogenic is found in cases where earthquakes are aligned along a fault in three dimensions and where focal mechanism solutions agree with the orientation and sense of movement from geologic data.

Absence of seismicity along a fault alone, however, does not imply a lack of potential for future damaging events. For the Los Angeles area, there are only about $50 \mathrm{yr}$ of reasonably good instrumental recordings of seismicity and only about $200 \mathrm{yr}$ of written history with which to compare earthquake occurrences and the distribution of geologically youthful faults. Experience both 


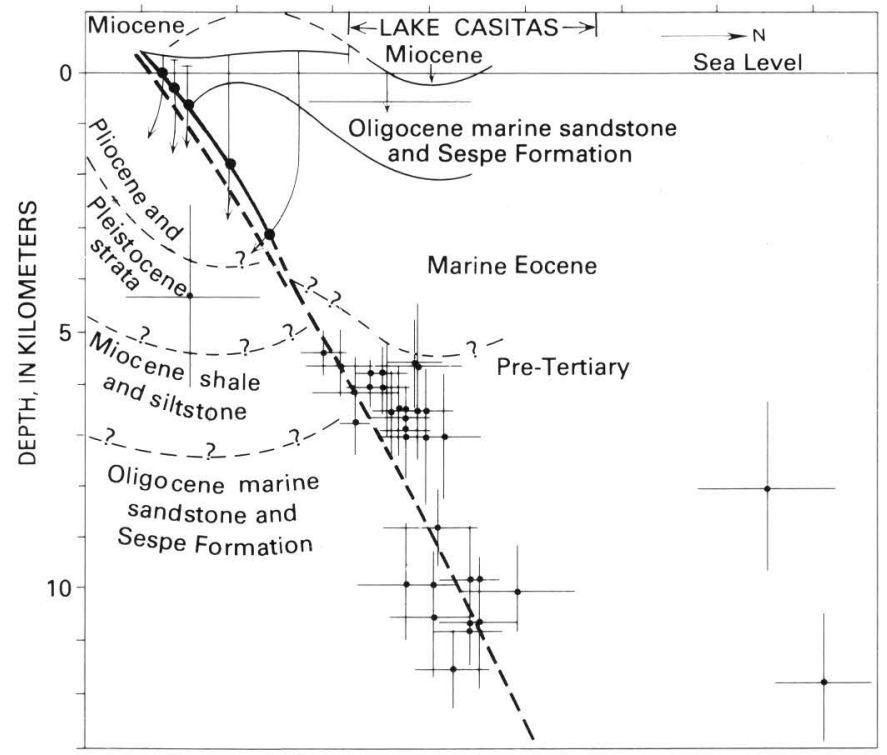

FIGURE 22.-North-south cross section through the Red Mountain fault northwest of Ventura showing closely associated small earthquakes from 1970 to 1975 (modified from Yeats and others, 1981, fig. 8). Hypocenters (small solid circles) are projected from nearby points onto the plane of the cross section; vertical and horizontal bars around hypocenters give error limits in the original locations of the earthquakes. The position of the Red Mountain fault to depths of about $4 \mathrm{~km}$ (solid line) is accurately defined by numerous oil wells (approximately vertical lines) that intersect it at points shown by large solid circles. Several fault-plane solutions are in agreement with the geologic evidence that the fault movement is predominantly reverse and has a minor left-slip component (Yerkes and Lee, 1979b). Contacts between geologic units are dashed where approximately located.

locally and worldwide has shown that these spans of time are much too short for appraising the long-term seismic behavior of faults. Large earthquakes often occur along faults that have little or no previous record of seismicity. Furthermore, the reconstruction of earthquake history for those parts of the world having the longest historical records (for example, Turkey, China, and Japan) indicates that there are large long-term temporal and spatial variations in earthquake activity (Allen, 1975). Because of these inherent difficulties in using instrumental or historical seismicity, scientists have increasingly relied on the late Quaternary geologic history of faulting as a guide to estimating the seismogenic nature of faults.

A complication in assessing earthquake potential is that not all active faults are capable of causing damaging earthquakes. The dimensions of some faults may be too small in terms of potential rupture surface to produce significant earthquakes. Furthermore, a few faults release all their elastic energy by aseismic creep. Others may be shallow features that are not deep enough to penetrate high-shear-strength rocks that can store large amounts of elastic strain energy. In the Ventura area, for example, several active faults that offset late Quaternary deposits are postulated to result from flexural-slip folding that involves only shallow strata (Yeats and others, 1981; Yeats, 1982). Consequently, these particular faults may pose no earthquake hazard, although movements along them may rupture the ground surface.

Estimating the maximum earthquake for a fault.Modern engineering practice for the design of important structures such as dams, large buildings, and nuclear power reactors includes the calculation of expectable ground-motion values based chiefly on estimates of the maximum sizes of earthquakes that could be generated by nearby or distant faults. Methods used to estimate the size of future earthquakes include (1) analysis of the regional earthquake history to determine the largest event associated with a particular fault, (2) comparison of the earthquake history of a particular fault with the histories of other faults in analogous structural or tectonic settings (for example, fig. 23), and (3) use of empirically determined magnitude-fault length relations. Each approach has limitations and problems that introduce large uncertainties into the estimation of maximum magnitude.

Seismologists and geologists have recognized for several decades that the size of an earthquake generally increases as the dimensions of the activated fault surface increase. Empirical relations between dimensions of faulting and earthquake magnitude have been derived from studies of historical large earthquakes worldwide. Correlations have been made between magnitude and fault length and between magnitude and maximum displacement (Bonilla and Buchanan, 1970; Mark and Bonilla, 1977; Slemmons, 1977; Bonilla and others, 1984). Figure 24, for example, shows one correlation between earthquake magnitude and length of surface rupture.

These kinds of correlations are widely used by engineers for estimating the maximum earthquake likely for a particular fault and a particular length of future rupture. A common approach is to base estimates on the assumption that half the total fault length can rupture in any single earthquake (for example, Wesson and others, 1975). There is much uncertainty, however, about what proportion of a fault will rupture in a single event. Historical data indicate that major earthquakes have resulted from rupture of anywhere from a small fraction to nearly 100 percent of a preexisting fault surface. Furthermore, because faults commonly have discontinuous and complex patterns and are locally concealed by young deposits or by bodies of water, there are inherent difficulties in accurately determining the length of a fault. 

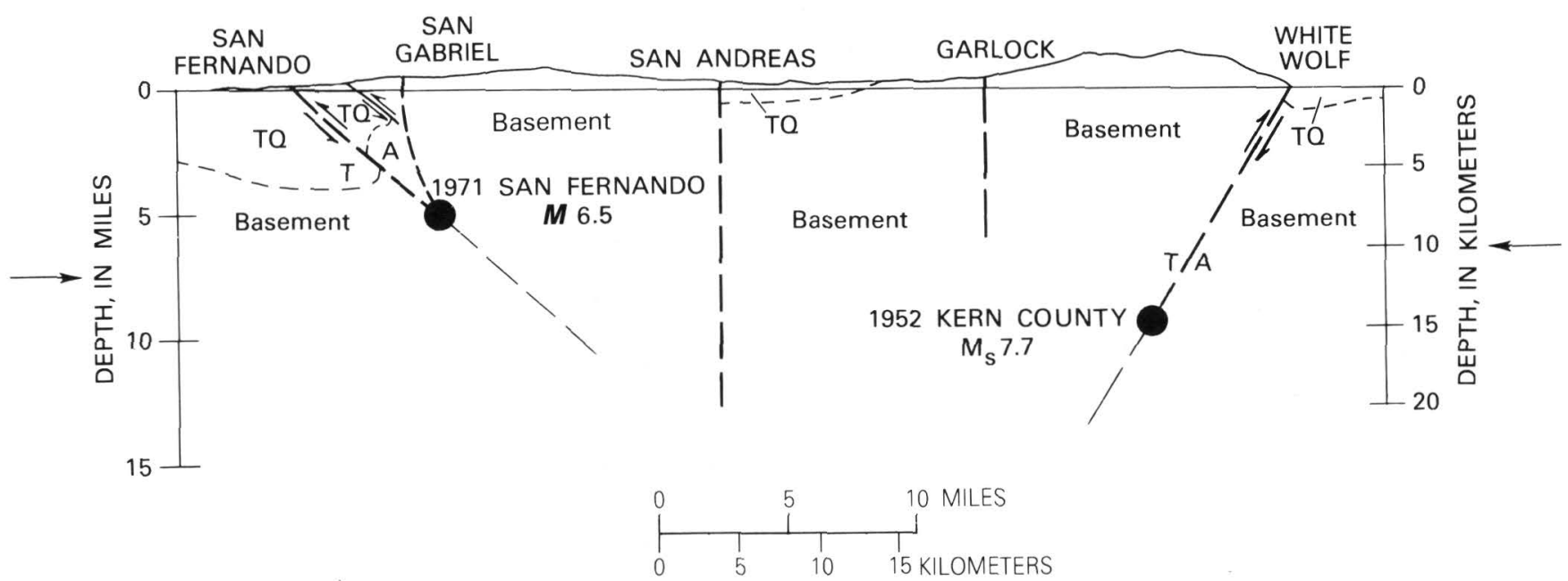

FIGURE 23.-Vertical section, offset $80 \mathrm{~km}$ along the San Andreas fault, through the hypocenters of the $1952 \mathrm{Kern}$ County and the 1971 San Fernando earthquakes (Wesson and others, 1974, fig. 1). Both the White Wolf and the San Fernando faults, which generated these earthquakes, are reverse left-oblique slip faults that dip toward the San Andreas fault. Similarities in the tectonic settings of the two faults were used as one of the bases for inferring that a future earthquake as large as M 7.5 is possible for the Sierra Madre-San Fernando-Santa Susana system of faults. TQ indicates Tertiary and Quaternary sedimentary rocks; T, relative movement toward reader; A, relative movement away from reader. Arrows indicate the general direction of lateral compression to which the earthquakes are attributed.

Because of these uncertainties and difficulties, any estimate of future earthquake size based on these empirical correlations must be viewed with great caution. Even though estimates of the maximum earthquake commonly are expressed as numbers (sometimes to tenths of an integer), such estimates are crude approximations only.

Although studies of fault hazards in other regions (for example, Wesson and others, 1975) have estimated maximum magnitudes for individual faults on the basis of empirical relations between fault length and magnitude, we do not consider the application of this procedure appropriate for the faults of the Los Angeles region. First, many of the Los Angeles faults are overlapping echelon segments of longer zones, and knowledge of their configuration and possible linkage at depth is insufficient to define with reasonable certainty their effective lengths for possible earthquake generation. Second, the basic data for magnitude-fault length relations are sparse, especially for reverse faults, and show a wide scatter, which implies considerable uncertainty in those relations.

General constraints on the size of future earthquakes likely to occur in the Los Angeles region are, however, provided by considering the historical record of large earthquakes, the 15- to $20-\mathrm{km}$ limiting depth for instrumentally recorded seismicity in the region, and the range in dimensions of the late Quaternary faults.

\section{Earthquake Hazards in the Los Angeles Region}

Table 6 lists the magnitudes and seismic moments for the larger earthquakes in southern California since 1857. By far the largest event was the 1857 earthquake (M 7.9, corresponding to an estimated moment of $9 \times 10^{27}$ dyne-cm), which was more than 4 times greater in moment than the next largest event and 10 to 100 times greater than the other listed events.

The 1857 event, which was associated with more than $360 \mathrm{~km}$ of surface rupture along the south-central San Andreas fault as far south as Wrightwood, probably approaches being the largest earthquake that might occur on that fault. A somewhat greater event might occur if a future San Andreas earthquake caused rupture along the entire south-central trace, including the San Bernardino area. Raleigh and others (1982) have suggested that the entire San Andreas fault in southern California, including that segment east of Indio, could rupture in a single great earthquake event; such throughgoing rupture, however, may not be mechanically feasible in light of the apparent truncation of the Holocene surface trace of the south-central San Andreas by the west-trending Banning fault.

As table 6 shows, the most prolific source in terms of numbers of major earthquakes is the San Jacinto fault zone, which has generated 8 of the 18 listed events. These earthquakes have been as large as $\mathbf{M} 7$ (moment of $3 \times 10^{26}$ dyne-cm). Although the fault zone extends for more than $300 \mathrm{~km}$, individual fault segments are about 


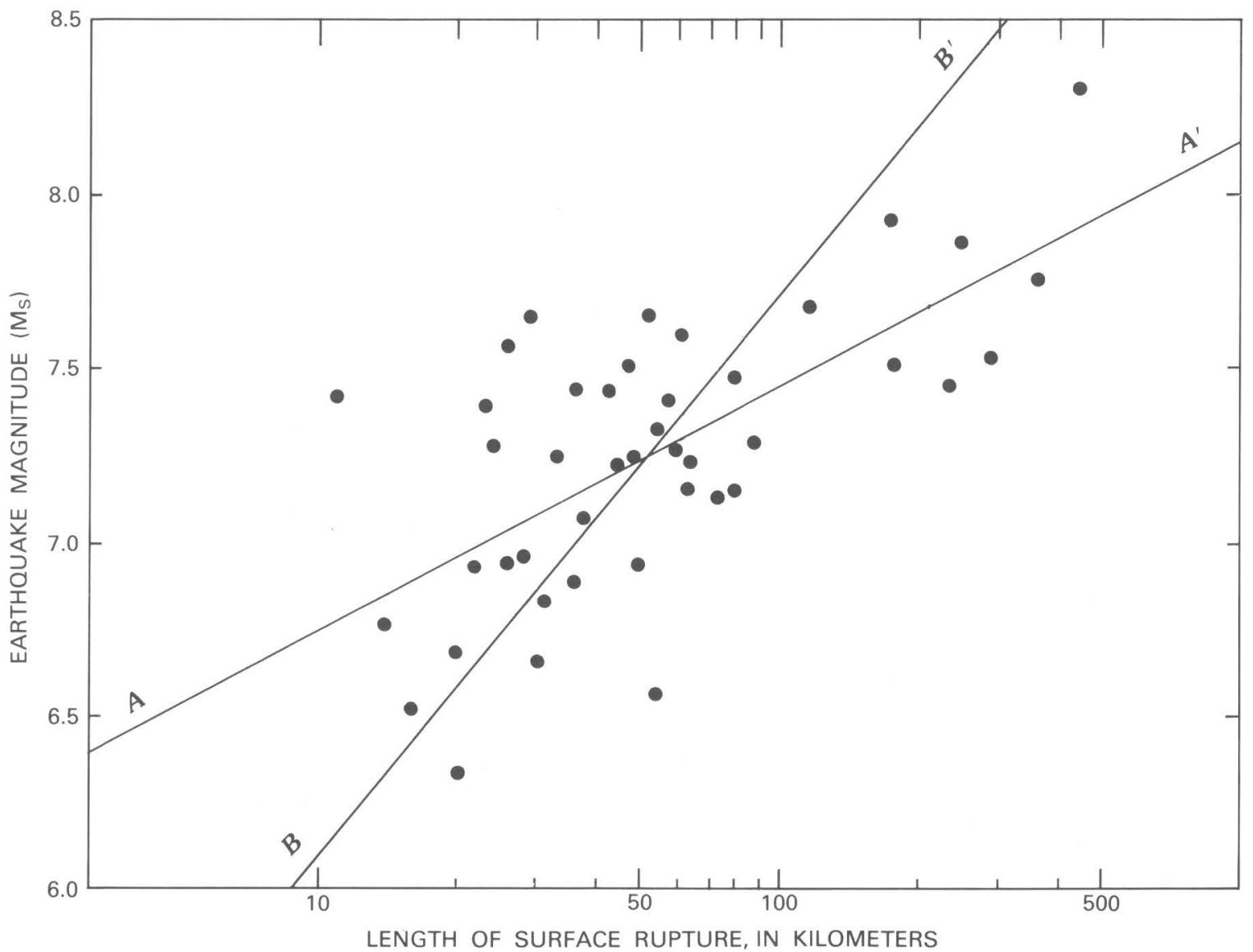

FIGURE 24.-Length of surface-fault rupture of historical earthquakes worldwide in relation to magnitude for all types of faults (modified from Bonilla and others, 1984, fig. 1A). Because of the statistics involved in estimating maximum values, line $A-A^{\prime}$ is used to estimate the most likely earthquake magnitude associated with a given length of surface rupture, whereas line $\mathrm{B}^{-\mathrm{B}^{\prime}}$ is used to estimate the most likely rupture length associated with a given earthquake magnitude.

$85 \mathrm{~km}$ or less in length and, in contrast to the San Andreas fault zone, are discrete echelon segments whose end points are 5 to $10 \mathrm{~km}$ apart. These spatial characteristics, together with the fact that each historical event has involved only one fault segment of the zone, suggest that $\mathbf{M} 7$ is probably the maximum earthquake size for the San Jacinto fault zone. This value probably is a reasonable upper bound for the other major northwest-trending zones in the region-the Newport-Inglewood and Elsinore fault zones-which are similar in overall length but have generally shorter fault segments.

Estimating the maximum earthquake for faults of the Transverse Ranges is especially difficult. Individual late Quaternary faults are as long as $\mathbf{8 0} \mathrm{km}$, and many of them appear to link, the suggestion being that two or more adjoining faults might rupture simultaneously to generate much larger earthquakes. The occurrences of the 1927 Point Arguello earthquake (M 7.3) offshore from the western Transverse Ranges and of the 1952 Kern County earthquake (M 7.5) along a reverse fault just north of the Transverse Ranges suggest that events of comparable magnitude may be possible within the province. Wesson and others (1974) have concluded that a $M_{L} 7^{1 / 2}$ to $73 / 4$ (equivalent to $M$ 7.5) event is a reasonable maximum magnitude to expect along the Sierra MadreSan Fernando-Santa Susana fault system on the basis of the regional seismic history, the analogous tectonic settings of the 1952 Kern County and 1971 San Fernando earthquakes (fig. 23), and the combined lengths of those faults. Similar arguments can be applied to the Santa Cruz Island-Anacapa-Santa Monica-HollywoodRaymond fault system and to comparable belts of late Quaternary faults in the Ventura-Santa Barbara Channel area.

In summary, an upper limit of about $\mathbf{M} 8$ (seismic moment of about $10^{28}$ dyne-cm) for earthquakes in the Los Angeles region is compatible with the historical data and with what is known about the geometry of the faults; future earthquakes approaching this size probably will be restricted to the San Andreas fault zone. The largest earthquake likely along the other northwest-trending 
zones of the San Andreas system is estimated to be $M$ (seismic moment of $3 \times 10^{28} \mathrm{dyne-cm}$ ). An upper bound of about $M 7.5$ appears appropriate for the major reverseslip fault systems within the Transverse Ranges.

Estimating likely earthquake size for ordinary planning and design purposes.-Although maximummagnitude events are important to the seismic design of critical structures, such earthquakes imply rupture along most of the area of a fault plane and thus generally can be expected to recur only rarely. More significant for ordinary planning and design purposes, therefore, is the likely size of an earthquake that has a reasonable probability of occurring during the lifetime of most structures (about 50 to $100 \mathrm{yr}$ ).

The concept that individual active faults repeatedly generate major earthquakes of the same size (termed characteristic earthquakes) was recently proposed by Schwartz and Coppersmith (1984). They suggest that long fault zones do not break along their entire length during surface-faulting earthquakes but, instead, rupture along the same discrete segments. The distribution of slip associated with major earthquakes along each segment would be expected to be repeated during successive large events. If this assumption is correct, the characteristic earthquake model implies that the most likely earthquake size for particular faults could be determined from the geologic attributes that influence segmentation of a fault zone.

A growing body of geologic evidence suggests that the south-central segment of the San Andreas fault, which includes that portion in the Los Angeles region, is ruptured repeatedly by a characteristic large event such as the 1857 earthquake (Sieh, 1981; Schwartz and Coppersmith, 1984). The evidence for this conclusion is (1) marked differences in long-term slip rates $(33-64 \mathrm{~mm} / \mathrm{yr}$ at Wallace Creek, west of Bakersfield, in comparison with 20-30 mm/yr at Cajon Canyon near San Bernardino) that are consistent with a model of repeated 1857-type events having maximum displacement in the sector west of Bakersfield and (2) geologic data on recurrence at scattered sites along the south-central segment suggesting that large events of about the same size occur repeatedly along this segment of the San Andreas fault (see "Estimating the Likely Frequency of Damaging Earthquakes"). Since the 1857 earthquake, this part of the fault appears to be locked and displays a low rate of seismicity. On the basis of what is known about the Holocene displacement history of the San Andreas fault, the probability of occurrence of 1857-type earthquakes along the fault is currently estimated to be about 1 percent/yr but about 40 percent within the next $30 \mathrm{yr}$ (Lindh, 1983). Thus, an earthquake of about $\boldsymbol{M} 8$ appears credible for ordinary planning and design purposes.

\section{Earthquake Hazards in the Los Angeles Region}

Possible guides to selecting design earthquakes for noncritical structures for the other strike-slip faults of the region are their historical seismicity and their inferred lengths of Holocene surface rupture. The Claremont and Clark faults (highly seismic elements of the San Jacinto fault zone), for example, have Holocene lengths of about 65 and $85 \mathrm{~km}$, respectively; the former is the probable source for three major historical earthquakes, two of which were M 6.8. A M 7 event thus seems reasonable for either of these two faults. In contrast, current levels of seismicity along the Palos Verdes Hills, Newport-Inglewood, Whittier, Elsinore, and similar northwest-trending fault zones are much lower, and their Holocene traces are mostly less than $20 \mathrm{~km}$ long (the implication being that, within the past few thousand years, these faults probably did not generate earthquakes whose associated rupture surfaces exceeded a few tens of kilometers in length). Thus, $M 6.5$ design earthquakes are reasonable for these faults.

Considerable uncertainty exists about the design earthquakes for noncritical structures to be applied to the dominantly reverse-slip faults of the Transverse Ranges. Many of these faults appear to link into systems $100 \mathrm{~km}$ or more long (fig. 11). The segments having demonstrated Holocene offset, however, are discontinuous and range from a few kilometers to a few tens of kilometers in length, the suggestion being that the associated earthquakes have not been greater than about $M$ 7. Segmentation into separate fault elements of 20 to $30 \mathrm{~km}$ is especially evident for the systems of faults that form the southern boundary of the Transverse Ranges, possibly because of mechanical interaction with the northwest-trending strike-slip faults that characterize the region farther south.

Data on surface faulting from the 1971 San Fernando earthquake (Sharp, 1975, 1981) and from ancient seismic events deciphered from the geologic record along several faults (Bonilla, 1973; Matti and others, 1982; Crook and others, in press; Sarna-Wojcicki and others, in press) indicate that Transverse Ranges reverse faults typically produce about 0.5 to $2 \mathrm{~m}$ of vertical separation during a major earthquake event. On the basis of all the foregoing evidence, we conclude that $\mathbf{M} 6.5$ to 7 events are appropriate design earthquakes for such faults when noncritical structures are considered.

In summary, our current judgment, based largely on the segmented character of faulting during Holocene time, is that credible earthquakes for ordinary planning and design purposes are San Andreas fault, $M$ 8; San Jacinto fault zone, $\boldsymbol{M} 7$; other northwest-trending late Quaternary faults, $\boldsymbol{M}$ 6.5; and late Quaternary reverse faults of the Transverse Ranges, $M$ 6.5 to 7. These estimates will be highly speculative until considerably 
more information becomes available on the recurrence of major faulting events along individual faults.

\section{Estimating the Likely Frequency of Damaging Earthquakes}

An approximate measure of the historical frequency of damaging earthquakes in the Los Angeles region is provided by the record since 1800 (Yerkes, this volume, table 3), which indicates that some part of the area has been shaken by a moderate or large event on the average of about once every $4 \mathrm{yr}$. How often, however, can a specific fault be expected to generate a damaging earthquake? This question, of particular significance to planning and engineering design decisions, can be answered satisfactorily at present for only a few faults in the region.

With the exception of the San Jacinto fault zone, which has generated at least 10 major earthquakes since 1890, the historical seismic record of southern California is inadequate to reliably estimate the frequency of potentially damaging events for a particular fault or fault zone. Evidence of ancient earthquakes locally preserved in the geologic record along some of the late Quaternary faults can, however, be used to demonstrate the ability of such faults to produce significant earthquakes and to estimate the time intervals between such events.

The study of prehistoric earthquakes has emerged as a powerful technique in evaluating the recurrence intervals of major earthquakes along faults (Clark and others, 1972; Sieh, 1981; Wallace, 1981; Sieh and Jahns, 1984). Because moderate and large seismic events commonly are accompanied by surface faulting and related deformation or by secondary effects of shaking such as liquefaction-produced sand boils (see Tinsley and others, this volume), careful analysis of deposits or physiographic features along a fault may reveal discrete episodes of past earthquake-induced deformation. The historical seismic record for many faults worldwide that generate large earthquakes suggests that events of approximately the same size are repeated through time along individual faults. The concept of an average recurrence interval for a specific fault may be applicable to many faults (Sieh, 1981). Although the time intervals between events may range from tens to hundreds of years, they are commonly more or less regularly spaced over periods of several hundred to a thousand or so years.

To reconstruct the prehistoric earthquake history of a fault, geologists search within Holocene or late Pleistocene deposits near the fault for evidence of repeatedly offset stratigraphic or physiographic features (see Sieh and Jahns (1984) for a well-documented study at a site along the San Andreas fault in central California), for sediments whose character suggests derivation from local fault scarps (fig. 25), or for sedimentary features indicative of past liquefaction events. These studies generally require three-dimensional exposures of geologic relations, so that subtle features can be observed and documented in great detail; usually, excavation by trenching has been required to expose critical stratigraphic relations and datable materials that can provide time constraints on the inferred events.

The number of discrete seismic events identified at a site along a fault depends both on preservation of the geologic evidence for each event and on the geologist's ability to discern the relevant evidence. Because some major earthquakes that have produced small surfacefaulting displacements may go unrecognized, geologic estimates of earthquake recurrence will always represent the maximum time intervals between major earthquakes and the minimum number of events.

If discrete episodes of past earthquakes cannot be clearly discerned from the geologic record preserved along a fault, an average recurrence interval for major events can be estimated approximately by dividing the amount of slip for a particular time period by the displacement or slip for a single event inferred to be characteristic of that fault. Matti and others (1982, in press), for example, have observed that fault scarps developed in alluvial deposits formed during the past $13,000 \mathrm{yr}$ along strands of the Cucamonga fault west of San Bernardino show systematic increments in height of about $2 \mathrm{~m}$; applying $2 \mathrm{~m}$ as an average value for fault slip accompanying a surface-faulting earthquake event, they have inferred 18 episodes of ground displacement and estimated a recurrence interval of about 700 yr for the Cucamonga fault. The slip-rate method presumes, however, that the slip events are essentially equal in size and that all slip is seismic. If the assumed value of the single-event displacement is not representative of the long-term behavior of that particular fault or if a substantial part of the total slip is due to creep movement, estimates of average recurrence interval using this method can be grossly inaccurate.

Recurrence intervals of major earthquakes have been estimated so far for only a handful of faults in the Los Angeles region (table 11). The sparse data that have been obtained suggest that the San Jacinto and San Andreas faults have generated potentially damaging earthquakes in intervals of several tens to a few hundred years (for any particular fault segment). In contrast, the other potentially active faults in the region have estimated recurrence intervals of many hundreds to several thousands of years.

Earthquake and Surface-Faulting Potential 

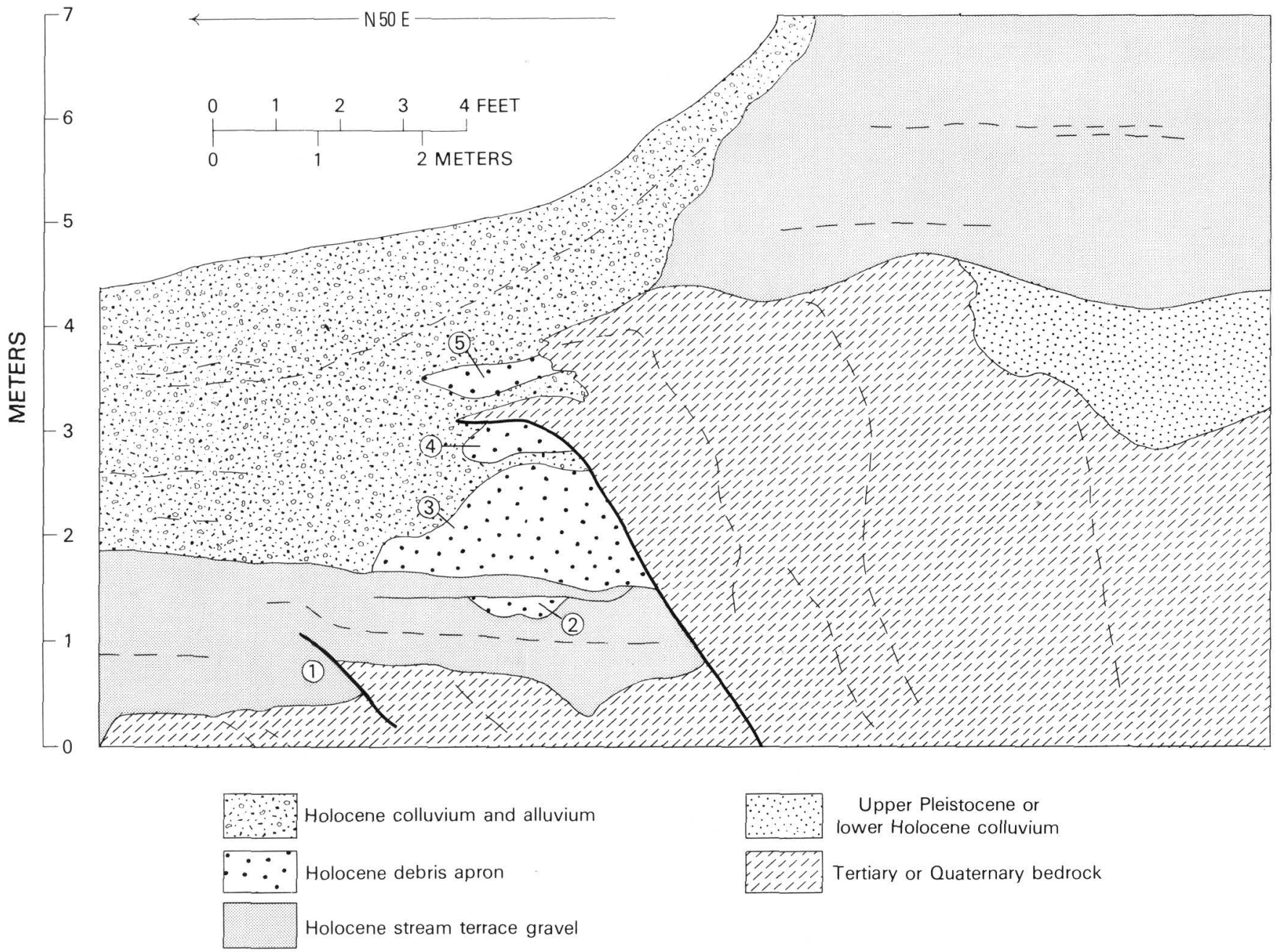

Upper Pleistocene or

lower Holocene colluvium

Tertiary or Quaternary bedrock

FIGURE 25.-Geologic relations on canyon wall exposing the Javon Canyon fault near Pitas Point about $10 \mathrm{~km}$ northwest of Ventura (modified from Sarna-Wojcicki and others, in press). The reverse-slip fault offsets by approximately $4 \mathrm{~m}$ a stream-terrace platform estimated to be about $3,500 \mathrm{yr}$ old and thus implies a long-term average slip rate of about $1.1 \mathrm{~mm} / \mathrm{yr}$. The small fault (1) and the superposed aprons of angular rock fragments $(2,3,4,5)$ immediately adjacent to the Javon fault are interpreted to represent discrete slip events on the fault and to record separate vertical displacements ranging from 0.5 to $1.3 \mathrm{~m}$. These geologic relations have been used to infer that four or five moderate-sized prehistoric earthquakes occurred about 350 to $1,000 \mathrm{yr}$ apart, the average recurrence interval being approximately $700 \mathrm{yr}$.

The best geologic information on earthquake recurrence in the Los Angeles region is for the San Andreas fault (fig. 26). At Pallett Creek, about $30 \mathrm{~km}$ southeast of Palmdale, the most complete record of prehistoric earthquakes known for a single fault anywhere in the world has been deciphered by detailed stratigraphic analysis of deposits of a late Holocene marsh exposed by trenching (Sieh, 1978c, 1984). The depositional environment of the ancient marsh was ideal for rapid burial and preservation of earthquake-induced deformation that occurred during its 2,000-yr history. Reasonably precise time constraints on individual earthquake episodes are possible, because the sedimentary sequence contains abundant carbonaceous layers that have been dated by the ${ }^{14} \mathrm{C}$ method. Evidence for distinct earthquake episodes in- cludes sand-boil deposits and other features induced by liquefaction; buried fault scarps and fissures; and lateral offsets of some horizons. The initial study of the Pallett Creek site (Sieh, 1978c) identified nine large earthquakes (including the 1857 event) since about 500 A.D., for a suggested average recurrence interval of about 160 yr; more recent investigations (Sieh, 1984) have extended the record back to about 0 A.D. and have postulated the occurrence of 12 significant earthquakes since about 260 A.D., for an average recurrence interval of about $145 \mathrm{yr}$.

Prehistoric events also have been reconstructed from trenched Holocene deposits along the San Andreas fault near Three Points, about $45 \mathrm{~km}$ northwest of Palmdale, and at San Emigdio Creek, about $25 \mathrm{~km}$ west of Gorman

\section{Earthquake Hazards in the Los Angeles Region}


TABLE 11.-Geologically determined estimates of the recurrence intervals of major earthquakes for a given point along some late Quaternary faults of the Los Angeles region

\begin{tabular}{|c|c|c|c|}
\hline Fault (map no.) & $\begin{array}{l}\text { Recurrence interval, } \\
\text { in yr }\end{array}$ & Remarks & References \\
\hline San Andreas (1)--- & $65-270$ & Twelve events within past $1,700 \mathrm{yr}$ & Sieh (1984) \\
\hline $\begin{array}{l}\text { San Jacinto-- } \\
\text { fault zone } \\
(2-8) \text {. }\end{array}$ & 30-150 ARI (SM) & $\begin{array}{l}\text { Assumes range of slip rate }(8-12 \mathrm{~mm} / \mathrm{yr}) \text { and } \\
\text { range of estimated event displacements } \\
(0.4-1.2 \mathrm{~m}) \text { during past } 730,000 \mathrm{yr} \text {. }\end{array}$ & Sharp (1981b) \\
\hline San Fernando (69)- & $100-300$ & Two events since about $100-300$ yr ago. & Bonilla (1973) \\
\hline Cucamonga (86)--- & 700 ARI (SM) & $\begin{array}{l}\text { Assumes } 18 \text { displacements averaging } 2 \mathrm{~m} \\
\text { within past } 13,000 \mathrm{yr} \text {. }\end{array}$ & Matti and others (1982, in press) \\
\hline Javon Canyon (54)-- & $350-1,000$ & Four or five events within past $3,500 \mathrm{yr}$. & Sarna-Wojcicki and others (in press) \\
\hline $\begin{array}{l}\text { Elsinore fault ----- } \\
\text { zone (13-20): }\end{array}$ & 300-2,000 ARI (SM) & $\begin{array}{l}\text { Assumes slip rate of } 0.8 \mathrm{~mm} / \mathrm{yr} \text { during past } \\
5 \mathrm{~m} . \mathrm{y} \text {. and range of estimated event } \\
\text { displacements }(0.3-1.2 \mathrm{~m}) .\end{array}$ & Lamar and Swanson (1981) \\
\hline $\begin{array}{l}\text { Glen Ivy North -- } \\
\text { (16). }\end{array}$ & $200-300$ & $\begin{array}{l}\text { Three or more events since about } \\
750 \text { уг ago. }\end{array}$ & Rockwell and others (1985] \\
\hline Wildomar (18)--- & $2,000-3,000$ & $\begin{array}{l}\text { One or two events since about } \\
4,000 \text { yr ago. }\end{array}$ & Lamar and Swanson (1981) \\
\hline Raymond (82)----- & $3,000-4,500 \mathrm{ARI}$ & $\begin{array}{l}\text { Eight events in past } 36,000 \mathrm{yr} \text {, three events } \\
\text { in the past } 10,000 \mathrm{yr} .\end{array}$ & Crook and others (in press) \\
\hline $\begin{array}{l}\text { Red Mountain (52)- } \\
\text { (south branch). }\end{array}$ & More than 4,500 & $\begin{array}{l}\text { Overlain by unfaulted deposits about } 4,500 \text { yr } \\
\text { old. }\end{array}$ & Yeats and others (in press) \\
\hline Sierra Madre (83)-- & $\begin{array}{l}\text { More than } 1,000 \\
\text { to } 10,000 .\end{array}$ & $\begin{array}{l}\text { Overlain by unfaulted deposits between about } \\
1,000 \text { and } 10,000 \text { yr old. }\end{array}$ & Crook and others (in press) \\
\hline Santa Susana (68)-- & More than 10,000 & $\begin{array}{l}\text { Overlain by unfaulted deposits about } \\
10,000 \text { yr old. }\end{array}$ & $\begin{array}{l}\text { Leighton and others (1977), Lung and Weick } \\
\text { (1978). }\end{array}$ \\
\hline
\end{tabular}

${ }^{1}$ Range of recurrence interval given, except where average recurrence interval (ARI) indicated. SM, recurrence interval derived from slip-rate method.

just north of the area shown in figure 11. Although the Holocene record at these localities is much less complete than that at Pallett Creek, at least two pre-1857 earthquakes have been inferred at each of these sites (Rust, 1982; Davis and Duebendorfer, 1982); the dates of both events correlate reasonably well with the dates of inferred events at Pallett Creek. This correlation suggests that the San Andreas fault along the southern margin of the Antelope Valley probably is repeatedly ruptured by large surface-faulting earthquakes of approximately the same size.

\section{Predicting the Character of Surface Deformation Associated with Future Movement along Faults}

Surface faulting and permanent ground distortion induce shearing, compressional, tensional, and rotational strains that can damage or destroy even well-built structures. Predicting the likely distribution and severity of such processes is vital to developing hazard-mitigation strategies that would avoid or accommodate these effects; therefore, earth-science researchers have paid particular attention to the characteristics of faulting at the ground surface. Methods for predicting the patterns of rupture and distortion and for estimating the amounts of future surface offset have been developed and are now being widely applied (Bonilla, 1970, 1982; Wesson and others, 1975; Slemmons, 1977; Wallace, 1977).

Data for evaluating surface-rupture hazards in the Los Angeles region are still incomplete. The likely location and type of future surface offset can be predicted with relative confidence from studies of offset late Quaternary deposits. It is possible to obtain rough estimates of the amount of surface displacement for individual events by using empirical relations based on worldwide historical observations. It is, however, very difficult to assess the actual likelihood of surface rupture along specific late Quaternary faults in the region. Only a few of the larger earthquakes in the region have been accompanied by tectonic surface rupture. For example, although the 1971 San Fernando earthquake generated surface faulting, three earthquakes of comparable size or larger along the Claremont fault of the San Jacinto fault zone apparently were not accompanied by surface-fault rupture.

Location and pattern of surface faulting.-Worldwide evidence from historical surface-faulting events shows that nearly all ground ruptures have closely followed preexisting fault traces. Displacements have occurred 


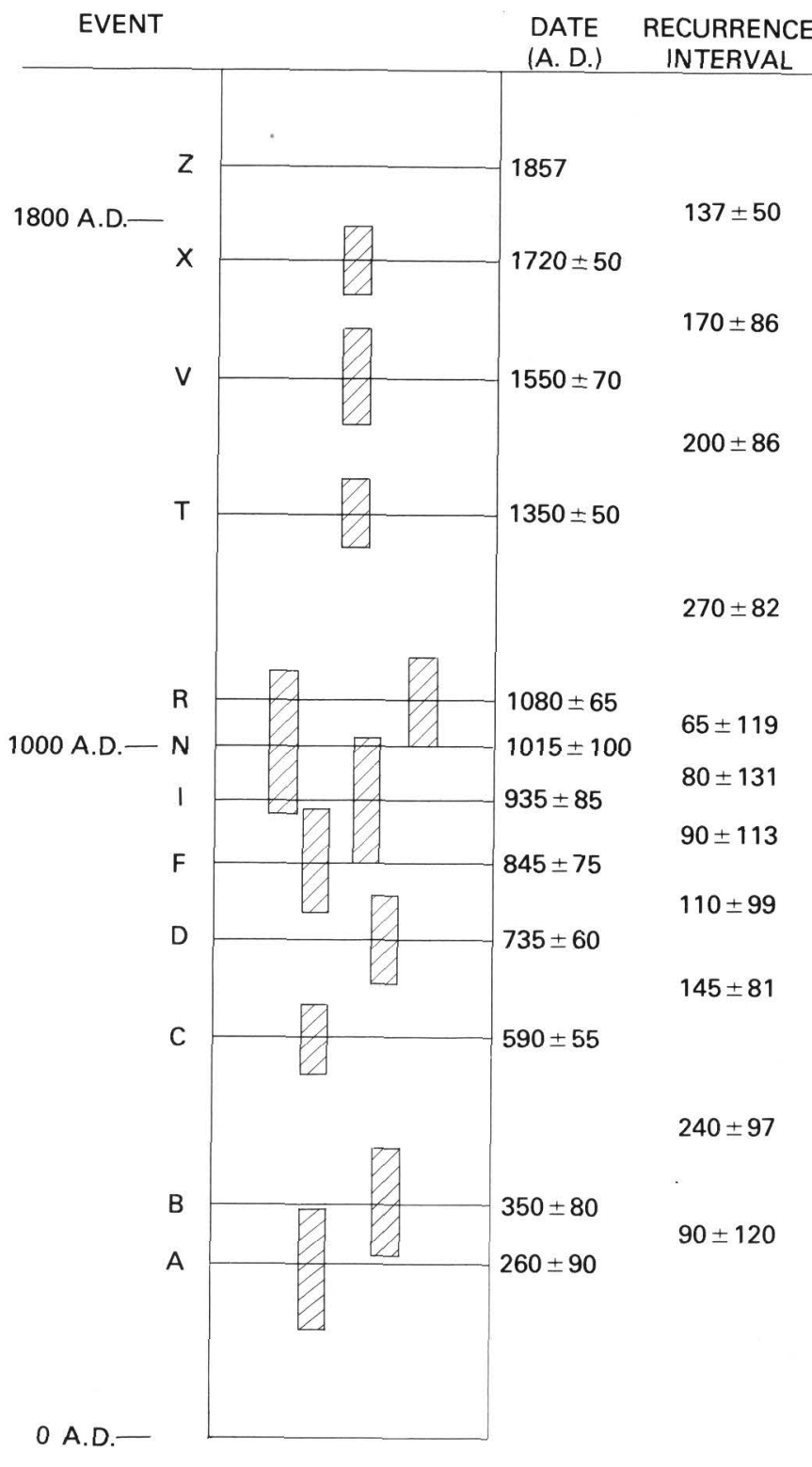

FIGURE 26.-Dates of 12 large earthquakes, along with their recurrence intervals, inferred from geologic relations in Holocene marsh deposits along the San Andreas fault at Pallett Creek about $30 \mathrm{~km}$ southeast of Palmdale (from Sieh, 1984, tables 2-4). The events are assigned letter designations in reverse alphabetical order starting with the youngest (1857). The uncertainty in each date is shown by a vertical bar and plus or minus values. Recurrence intervals for the events shown average $145 \mathrm{yr}$ but vary from about 65 to about 270 yr. Events X, V, T, R, and F each were accompanied by about 1 to $2 \mathrm{~m}$ of strike-slip displacement of the ground surface and apparently were similar in size to the $\mathbf{M} 7.91857$ earthquake. Events $N$ and I produced lateral offsets of only a few centimeters at Pallett Creek and presumably were smaller earthquakes. Reliable estimates of the sizes of events $A, B, C$, and D have not been established.

repeatedly along or near the same fault plane and nearly always with the same sense of offset (strike, dip, or oblique slip) as that which can be inferred for the recent geologic past. The location and pattern of future surface faulting thus can be predicted, within reasonably close limits, from geologic relations commonly discernible at the Earth's surface.

Surface faulting normally produces a complex pattern of ruptures that includes (1) a main fault trace and (2) subsidiary faults of lesser displacement that may occur many meters or even several tens of kilometers from the main break (Bonilla, 1970). Statistical data on all types of faulting suggest that 90 percent of the total surface faulting in any one event will be within $5 \mathrm{~km}$ of the main break and that most of the secondary faulting will be within $15 \mathrm{~km}$ of the main trace; displacements along subsidiary faults generally are less than 30 percent of the maximum displacement on the main fault (Bonilla, 1982). The main trace at the ground surface can be a single rupture or can consist of parallel, branching, or interlacing fractures. Studies of historical examples show that the width of the zone of faulting adjacent to the main trace has varied from a few centimeters to hundreds of meters, depending on the type of faulting, the magnitude of the associated earthquake, and the near-surface geologic materials along the fault trace. Although the maximum distance to the most distant secondary fault is about the same for all types of faulting, the main traces of strike-slip faults generally are narrow and simple in comparison with the traces of normal-, reverse-, or oblique-slip faults (Slemmons, 1977; Bonilla, 1982).

Physiographic features produced by surface faulting (fig. 27) are particularly useful to delineate fault traces likely to rupture the ground surface again. Scarps, linear valleys and ridges, sag ponds, and offset drainage channels in distinctive aligned patterns result from repeated rupture at the Earth's surface. By observing and accurately mapping these features, geologists can delineate patterns of likely future surface faulting.

Geologic maps of the late Quaternary faults shown in figure 11 provide a general guide to the location and pattern of future surface displacement in the Los Angeles region. The existing maps of many of these faults, however, were prepared for purposes other than evaluation of surface-rupture potential and at scales that are too small for complete and accurate mapping of all significant fault traces. Special-purpose geologic mapping and analysis that document the evidence for the youthfulness of individual fault traces and of faultproduced topographic features are available for some of the major faults. Parts of the San Andreas, San Jacinto, and Elsinore fault zones and the Ventura, San Fernando, Sierra Madre, Cucamonga, Raymond, Hollywood, and Verdugo faults have been mapped in sufficient detail (1:24,000 to $1: 6,000$ scale) to accurately depict the loca-

\section{Earthquake Hazards in the Los Angeles Region}




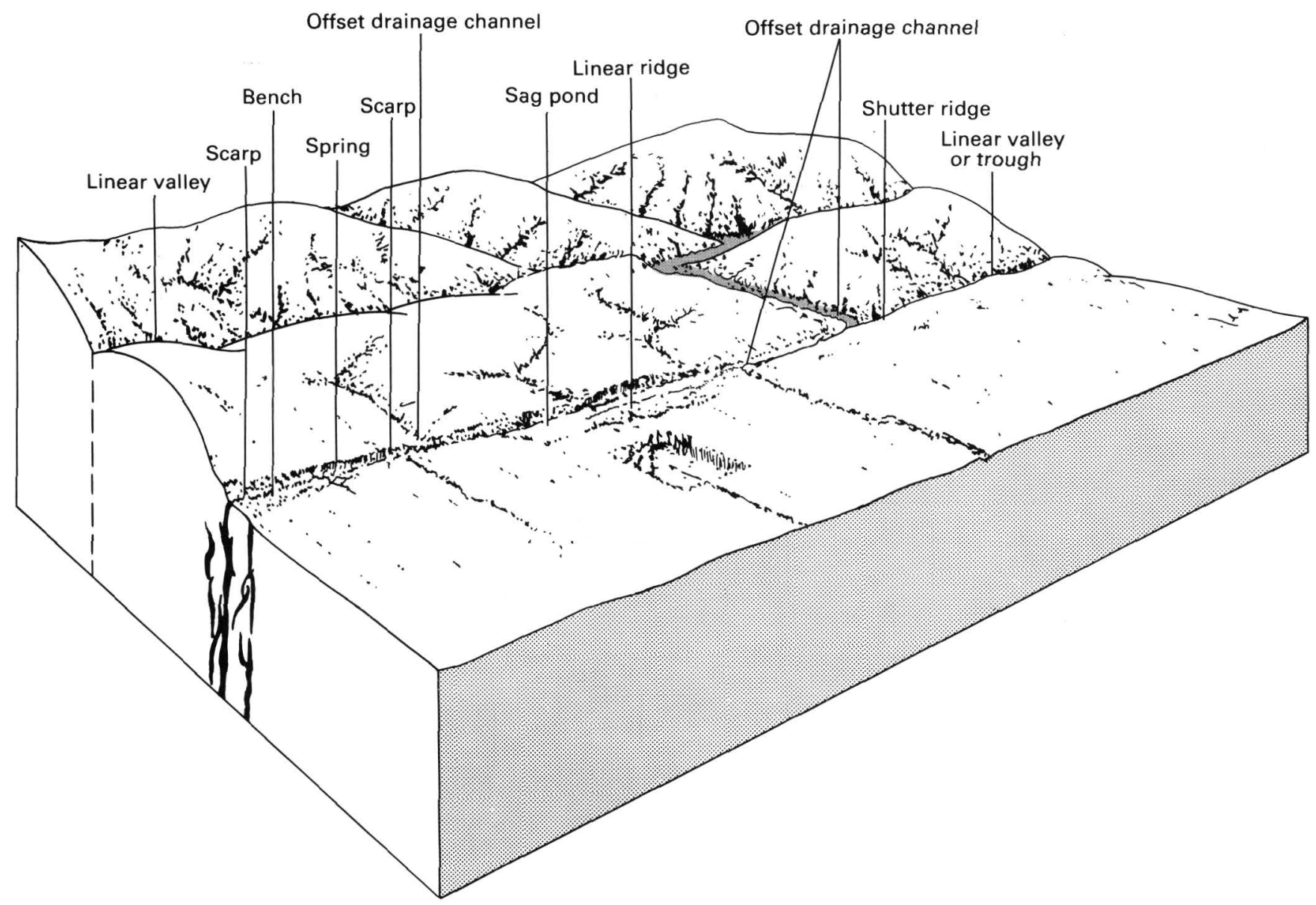

FIGURE 27.-Landforms typically developed along active strike-slip faults (from Wesson and others, 1975, fig. 11). Landforms developed along active reverse-, normal-, and oblique-slip faults commonly are more complex and discontinuous in pattern.

tion of fault traces that are candidates for future surface displacement.

Maps of Special Studies Zones for fault-rupture hazard as designated by the California Division of Mines and Geology (Hart, 1980) are available for many of the Holocene faults in the Los Angeles region (fig. 28); the geologic evidence for Holocene surface displacements has been tabulated by Hart and others (1977, 1978, 1979). Faults designated for special studies to date include the San Andreas fault; the San Jacinto zone; the Ventura, San Fernando, Raymond, and Cucamonga faults; the Newport-Inglewood zone; and Holocene segments of the Sierra Madre, Whittier, and Elsinore fault zones. These 1:24,000-scale maps delineate recently active fault traces inferred from stratigraphic offsets, physiographic evidence, or geophysical techniques and are detailed enough to depict the major fault traces. More detailed geologic studies, including trenching, are, however, necessary to accurately locate and describe all evidence bearing on the rupture hazard for specific sites. Lamar and Scrivner (1983) have summarized the geologic evidence obtained from trenching investiga- tions that bears on the recency of faulting within many of the Special Studies Zones in the Los Angeles region.

Type and amount of displacements.-The type of future movement likely to occur on a fault can be estimated from the prevalent style of its geologically recent movements (strike slip, dip slip, or oblique slip). Although a fault that has been in existence for millions of years may have slipped in different ways in the geologic past, the type of slip that has characterized it for the last several hundred thousand years probably is the most reliable indicator of future slip. For currently active faults, seismologic (fault-plane solutions) or geodetic evidence of slip direction also can be used to infer the likely type of displacement. The slip characteristics of the late Quaternary faults in the Los Angeles region are given in table 5 .

The amount of future displacements likely to occur along specific faults can also be estimated from offsets in historical earthquakes or inferred from analysis of geologic relations along a fault. Amounts of prehistoric offset can be inferred from the morphology of fault scarps (Wallace, 1977, 1981), from systematically offset

Earthquake and Surface-Faulting Potential 85 


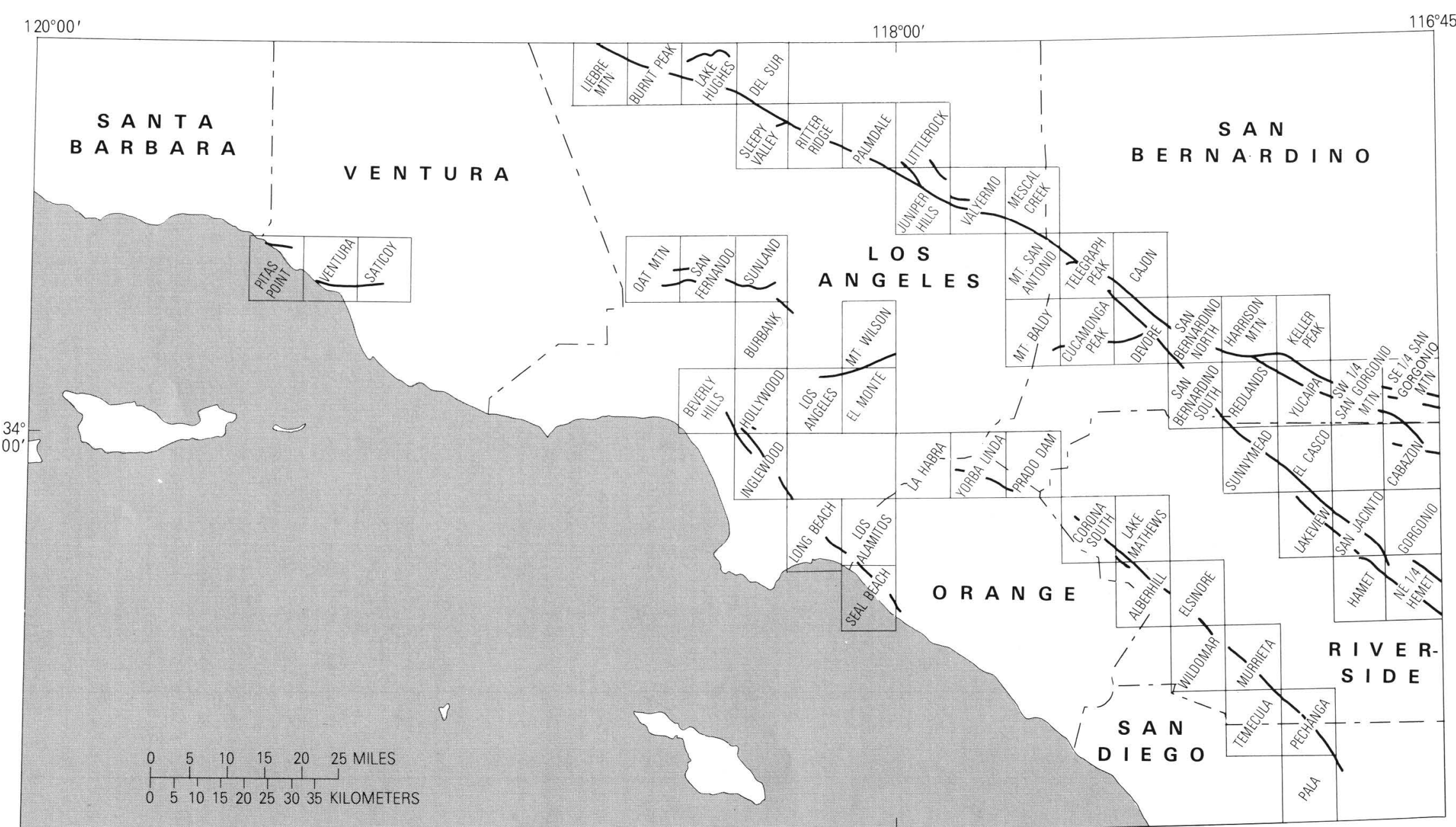

FIGURE 28.-Index to maps of Special Studies Zones for fault-rupture hazard in the Los Angeles region (from Hart, 1980). These maps, compiled and issued by the California Division of Mines and Geology, show (at a scale of 1:24,000) (1 in. =2,000 ft) the traces of Quaternary faults within selected major Holocene fault zones as a guide for delineating the legal boundaries of areas within which site-specific investigations for active faults (as defined by the Alquist-Priolo Act of the State of California) are required when structures are planned for human occupancy. As new information on the location and recency of faulting becomes available, these maps are revised. 

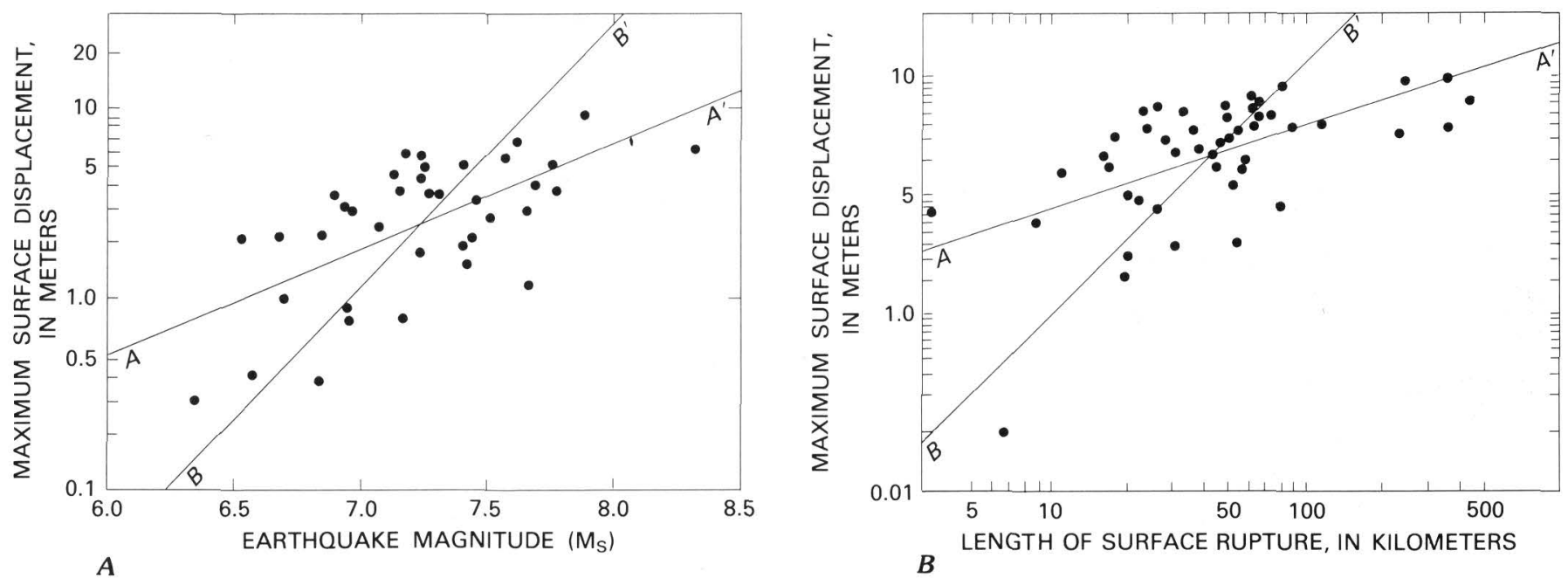

FIGURE 29.-Empirical relations useful for estimating the maximum surface displacements likely for future earthquakes (modified from Bonilla and others, 1984, figs. 2A, 3A). Based on worldwide data on historical surface faulting. A, Relation between maximum surface displacement and earthquake magnitude, $M_{S}$. B, Relation between maximum surface displacement and length of surface rupture. Lines show least-squares fit to data for all types of faults. Because of the statistics involved in estimating maximum values, lines labeled A- $\mathrm{A}^{\prime}$ are used to estimate the most likely maximum surface displacement associated with a given magnitude earthquake $(A)$ or length of surface rupture $(B)$. Lines labeled $B-B^{\prime}$ are used to estimate the most likely earthquake magnitude $(A)$ or length of surface rupture $(B)$ associated with a given maximum surface displacement.

stream channels crossing fault traces (Wallace, 1981; Sieh and Jahns, 1984), or from geologic relations exposed in trenches cut across faults (Bonilla, 1973; Sieh, 1978c). In the Los Angeles region, for example, geomorphic analysis of fault scarps along strands of the Cucamonga fault suggests that the strands have ruptured repeatedly during the past $13,000 \mathrm{yr}$ in events that averaged about $2 \mathrm{~m}$ of vertical offset (Matti and others, 1982, in press).

Another technique for estimating the amount of likely displacement uses the empirical relations that link displacement with various parameters determined from analysis of historical earthquake observations worldwide (Bonilla, 1970, 1982; Bonilla and others, 1984). These relations can provide approximate limits on the amount of surface-fault displacement to be expected for different types of faults. Thus, maximum surface displacement can be estimated for an earthquake of a particular magnitude along a specific type of fault (fig. 29A); although data are too sparse to draw conclusions for specific types of faults, larger values of displacement within the same range of magnitudes are generally associated with reverse-slip faults. Alternatively, if geologic mapping provides a basis for limiting the likely total length of future surface rupture, empirical relations can be used to estimate the maximum displacement (fig. 29B).

Although historical surface-faulting events in the Los Angeles region are too few to use as a guide to the likely maximum amounts of future displacements, the data base of historical surface offsets in all of California (table 8) provides a general frame of reference for what might be expected for different types of faulting. Approximate upper limits on the amount of future displacements associated with earthquakes on specific types of faults also can be estimated from the relation between maximum fault offset and length of surface rupture (fig. 29B) by assuming that future surface-faulting events will not exceed the mapped lengths of late Quaternary fault traces in the Los Angeles region. For the San Andreas fault, which is hundreds of kilometers long, the implied upper bound would be about $10 \mathrm{~m}$. Similarly, the San Jacinto and other northwest-trending strike-slip fault zones have single strands that are as long as $85 \mathrm{~km}$, the implication being that horizontal surface displacements of as much as $4 \mathrm{~m}$ are possible. Most other late Quaternary faults in the region are less than $40 \mathrm{~km}$ long, and displacements on these faults are unlikely to exceed 2 to $3 \mathrm{~m}$ per event.

Regional tectonic deformation.-The geologic and historical records provide rough clues to the patterns of regional tectonic deformation that could be associated with future earthquakes. Late Quaternary marine and nonmarine terraces, which are excellent markers for reconstruction of past crustal movements, indicate that regional uplift and subsidence are continuing; although these processes are sporadic, they reflect ongoing deformation that has elevated or depressed the same areas repeatedly during the recent geologic past.

The land surface of the Los Angeles basin and adjacent uplands exemplifies this pattern of ongoing vertical deformation (fig. 30). Continued uplift of the hills and mountains and subsidence of the lowland areas are reflected in the folded and faulted near-surface rocks. 


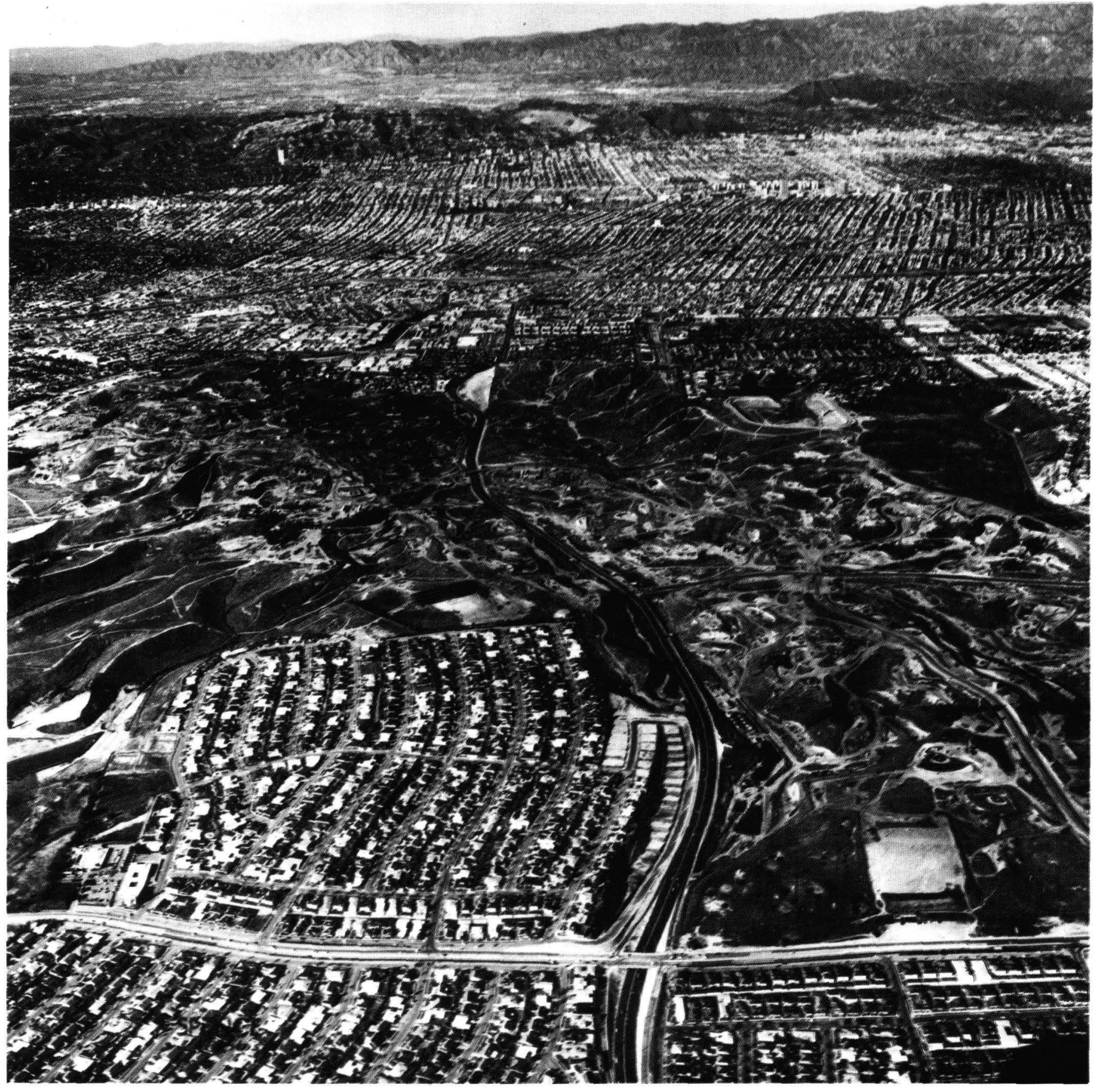

FIGURE 30.-Oblique aerial photograph looking north along the Inglewood fault in the Baldwin Hills at the northern end of the Los Angeles basin. The Santa Monica and Hollywood faults form the southern margin of the Santa Monica Mountains, which extend approximately northeastward across the top of the photograph. The Baldwin Hills and Santa Monica Mountains are the result of repeated episodes of tectonic uplift and folding during late Quaternary time. Future moderate to large earthquakes along these potentially active faults may be accompanied by uplift, warping, or tilting of these upland areas. (Photograph by Spence Air Photos, February 1967. Reproduced by permission of the Department of Geography, University of California, Los Angeles.)

Thus, the series of hills along the Newport-Inglewood zone express the trend and vertical uplift of subsurface faulted anticlines. Although some aseismic deformation cannot be precluded, much of the folding probably ac- companied moderate or large earthquakes along the Newport-Inglewood fault zone.

Regional tectonic warping associated with two historical earthquakes in the region shows what future

\section{Earthquake Hazards in the Los Angeles Region}


effects are possible. The 1933 Long Beach earthquake (M 6.2) apparently caused uplift and subsidence over an area of at least $260 \mathrm{~km}^{2}$ east of the Newport-Inglewood fault zone; the deformed area comprised a northwesttrending upwarp having a maximum uplift of $18 \mathrm{~cm}$ centered on the Alamitos Plain and extended southeast from near Compton (Gilluly and Grant, 1949). The 1971 San Fernando earthquake (M 6.6), as noted earlier, was associated with a broad uplift of perhaps $600 \mathrm{~km}^{2}$ on the upthrown (northern) side of the north-dipping reverse fault. Tectonic uplift locally exceeded $2 \mathrm{~m}$ (Savage and others, 1975) and was accompanied by small amounts of horizontal expansion and contraction distributed in a complex pattern across the uplift (Yerkes and others, 1974, fig. 8).

The future patterns of uplift and subsidence caused by earthquakes can be estimated by numerical modeling from elastic dislocation theory. The distribution of vertical surface deformation from idealized strike-slip and dip-slip faults has been calculated on the basis of this theory (for example, Chinnery, 1965; Barnett and Freund, 1975; Freund and Barnett, 1976). The theory also has been applied successfully to deduce the character of slip at depth from the observed surface deformations of several major dip-slip earthquakes in southern California (Jungels and Frazier, 1973; Savage and others, 1975; Stein and Thatcher, 1981). An inverse application of these latter modeling techniques can be used to define the approximate limits and amounts of vertical deformation likely to be associated with a postulated future earthquake. That is, one could calculate the expected pattern of uplift and subsidence by assuming the geometry of the causative fault and the direction, amount, and distribution of slip.

We conclude that large-scale uplift and subsidence resulting from future earthquakes in the Los Angeles region will reflect the established patterns of vertical deformation indicated by the physiography of the region. Tectonic elevation changes will be related to the geometry of the earthquake-generating fault and may extend over hundreds of square kilometers. The largest changes in elevation will be associated chiefly with the dip-slip faults of the Transverse Ranges. Regional uplift and subsidence may, however, accompany components of vertical faulting along some strike-slip faults. Although the maximum changes in elevation probably will be no more than a few meters, such movements occurring along the coast could pose a significant functional hazard to coastal facilities. The overall impact of such tectonic distortion accompanying future earthquakes in the Los Angeles region will be small in comparison with damage caused by shaking, landslides, and surface-fault rupture.

\section{IMPLICATIONS FOR REDUCTION OF EARTHQUAKE HAZARDS}

Potentially damaging future earthquakes are the inevitable result of the tectonic environment of the Los Angeles region. Although the events themselves cannot be prevented, many of their destructive effects can be avoided or accommodated-and property damage, injuries, and loss of life significantly limited-by using information on the expected location and character of fault hazards. Reduction of earthquake hazards begins with the recognition that the faults described in this chapter are the likely sources of future moderate- to largemagnitude earthquakes and that any associated surface faulting or distortion will be localized along their traces. This information can be applied to (1) develop and implement governmental land use policies and building codes, (2) provide technical data for use in decisions about the siting and design of structures, and (3) stimulate emergency preparedness actions by governmental agencies, the corporate community, and the general public.

Because the dominant strategy in earthquake-hazard reduction is to design structures that will accommodate earthquake shaking (design for surface rupture is generally impractical), the size of future earthquakes that might occur along the different faults is a key issue for which geologic and seismologic data can provide important constraints. Although building codes, which apply to ordinary structures such as dwellings and other low-rise construction, specify lateral force (shaking) requirements based indirectly on regional estimates of seismic hazard, modern engineering practice for larger or more critical structures develops seismic design parameters through a series of analytical steps that includes the specification of a design earthquake (both location and size), the largest event that it is appropriate to design a particular structure or class of structures to withstand (Hays, 1980).

Specification of a design earthquake represents a qualitative judgment that incorporates understanding of the tectonic and seismologic environment, the physical characteristics of nearby faults, and an assessment of the acceptable level of risk for a particular type of structure. For critical facilities such as nuclear power reactors or large dams that necessitate extremely large factors of safety, the design earthquake usually is the maximum event that can be expected from a nearby seismic source, even though such an event might occur only once in several thousand years. The earthquake size chosen for the design of most other types of structures, however, is usually that which might reasonably occur within the lifetime of the structure-50 to $100 \mathrm{yr}$.

Earthquake and Surface-Faulting Potential 89 
In special design situations (for example, LNG Seismic Review Panel, 1981), different levels of shaking parameters are based on the largest sizes of earthquakes that might be expected to occur over different spans of time-for example, a recurrence of a few hundred years, a few thousand years, or a few tens of thousands of years.

Potential surface faulting is the earthquake hazard most amenable to loss-reduction strategies, because it is a localized hazard that is easily studied and delineated by direct geologic observations. The potentially destructive effects of surface faulting and associated ground distortion are commonly reduced by siting structures to avoid future displacements; in special cases, structures such as pipelines are designed to accommodate those displacements without destruction or loss of function.

Selective siting to avoid zones of potential rupture is the most effective way to reduce risks from this hazard. This strategy, which relies on the ability of geologists to identify and map fault traces that may be the loci of future movement at the ground surface, is being implemented in California through the Alquist-Priolo Special Studies Zones Act of 1972. This act specifies that no structures for human occupancy are permitted on or within $50 \mathrm{ft}$ of an active fault (defined as a fault that has had surface displacement during Holocene time). Geologic maps compiled by the California Division of Mines and Geology identify fault zones showing evidence of Holocene surface displacement along one or more segments and form the legal basis for delineating zones within which city and county governments must regulate development (Hart, 1980). Usually, these local agencies require further detailed geologic investigations, including trenching, to assess the presence or absence of fault-rupture hazards for specific sites.

Avoiding fault traces may be impossible for structures of extended dimensions, such as pipelines or canals, or for large special structures whose siting is controlled by other factors. For those structures that cannot be selectively sited, special engineering design is necessary to accommodate likely differential surface movements. In these cases, estimates not only of the expected location of future faulting but also of the style and amount of fault slip are needed to guide engineering judgments.

Because earthquake-associated regional uplift or subsidence is not localized, avoidance is not usually a practical strategy. In the Los Angeles region, the potential for future vertical deformation from earthquakes is reflected in the series of broadly warped late Quaternary marine terrace deposits along the coast, whose uplift-at long-term rates as high as $10 \mathrm{~mm} / \mathrm{yr}$ (Lajoie and others, 1979)-probably reflects numerous episodes of regional warping associated with past large earthquakes. The adverse consequences of uplift or subsidence for facilities being built along the coast are best reduced by designing to accommodate such effects.

\section{SUMMARY}

Fault hazards in the Los Angeles region can be anticipated by evaluating the currently available geologic and seismologic information. Although the data base is incomplete and some methods of hazard assessment are still evolving, enough is known to identify most of the hazardous faults and predict the areal distribution and type of future surface displacements along them (and, less confidently, the likely amounts of surface rupture). The sizes and frequency of significant earthquakes likely to occur along these faults can be estimated, although with much less certainty.

We can now identify, in the Los Angeles region, nearly 100 fault strands having surface offsets in late Quaternary time. Many of these faults, especially those showing displacements in Holocene time, are the sources of large historical earthquakes or have produced recent small earthquakes or both. These late Quaternary faults are likely to generate future destructive earthquakes and associated surface rupture and tectonic deformation.

These faults differ greatly in degree of activity and severity of hazard. Studies now in progress seek to determine geologically recent rates of offset along these faults as an index of their relative activity. The most reliable estimates of slip rates, averaged over the past several hundred thousand years, are for the San Andreas fault (20-30 mm/yr) and the San Jacinto fault zone ( 8 to more than $12 \mathrm{~mm} / \mathrm{yr}$ ). Estimated offset rates for most other faults are less than $1 \mathrm{~mm} / \mathrm{yr}$, except for a belt of Transverse Ranges faults that extends from near Santa Barbara to San Bernardino and has rates of slip or vertical separation as high as $6 \mathrm{~mm} / \mathrm{yr}$. Slip rates of about $1 \mathrm{~mm} / \mathrm{yr}$ are reasonable assumptions for the Palos Verdes Hills and Newport-Inglewood fault zones.

Preliminary findings on earthquake recurrence suggest that parts of the San Andreas and San Jacinto fault zones have generated major earthquakes at intervals of several tens of years to a few hundred years. The time intervals between major earthquakes on other faults appear to be many hundred to several thousand years. Additional study of late Quaternary faults is needed to adequately assess the recurrence intervals for moderate to large earthquakes on many faults.

The type of future surface displacement likely to occur on many faults is known. The San Andreas fault

90 Earthquake Hazards in the Los Angeles Region 
and most other northwest-trending faults will have dominantly right-lateral strike-slip motion, but significant vertical components of slip (chiefly reverse) locally can be anticipated along parts of the San Jacinto, Elsinore, Whittier, Newport-Inglewood, and Palos Verdes Hills fault zones. Chiefly reverse slip is likely along the faults of the Transverse Ranges, although significant left-lateral strike-slip components can be expected along the Santa Ynez, Santa Cruz Island, and San Fernando faults.

Earthquakes as large as $\boldsymbol{M} 8$, accompanied by as much as $10 \mathrm{~m}$ of chiefly horizontal surface offset, can be expected along the San Andreas fault. The largest earthquake likely to occur along the other major fault zones in the Los Angeles region is estimated to be $\boldsymbol{M} 7.5$; such earthquakes can generate as much as $3 \mathrm{~m}$ of surface offset. Except on the San Andreas fault, maximummagnitude events probably are very rare. Thus, we judge that earthquakes of $\boldsymbol{M} 6.5$ to 7 , accompanied by as much as $2 \mathrm{~m}$ of surface displacement, are appropriate design earthquakes for ordinary planning purposes for most other faults of the region.

Large surface-faulting displacements along the reverse-slip faults in the Santa Barbara Channel may generate local tsunamis that could be hazardous to coastal facilities. In addition, tectonic upwarp and subsidence of broad areas may accompany some future large earthquakes in the Los Angeles region, although historical events suggest that the changes in elevation probably will not exceed a few meters at any point. Surface uplift and subsidence are more likely to be associated with major earthquakes along the westtrending faults of the Transverse Ranges, because vertical displacements are characteristic of those faults.

Planning and engineering decisions can reduce many of the potentially hazardous effects of faulting through the twin strategies of avoidance and accommodation. Of all the earthquake hazards, surface fault rupture is the most easily addressed because its potential effects are areally restricted and can be reliably predicted. Thus, for example, detailed geologic maps now available for many of the potentially active faults of the Los Angeles area provide a guide for selective siting of construction under the State of California's Alquist-Priolo Special Studies Zones Act.

On the other hand, the seismic shaking that results from sudden rupture along a fault is widespread and generally must be accommodated through engineering design. Reduction of this hazard depends not only on an estimate of the likely size of a future earthquake but also on a knowledge of how seismic energy is modified as it passes through the complex geologic structure of the Earth. The problem of predicting the location and severity of the shaking effects-the major challenge of earthquake hazard reduction-is discussed in the following chapters. 


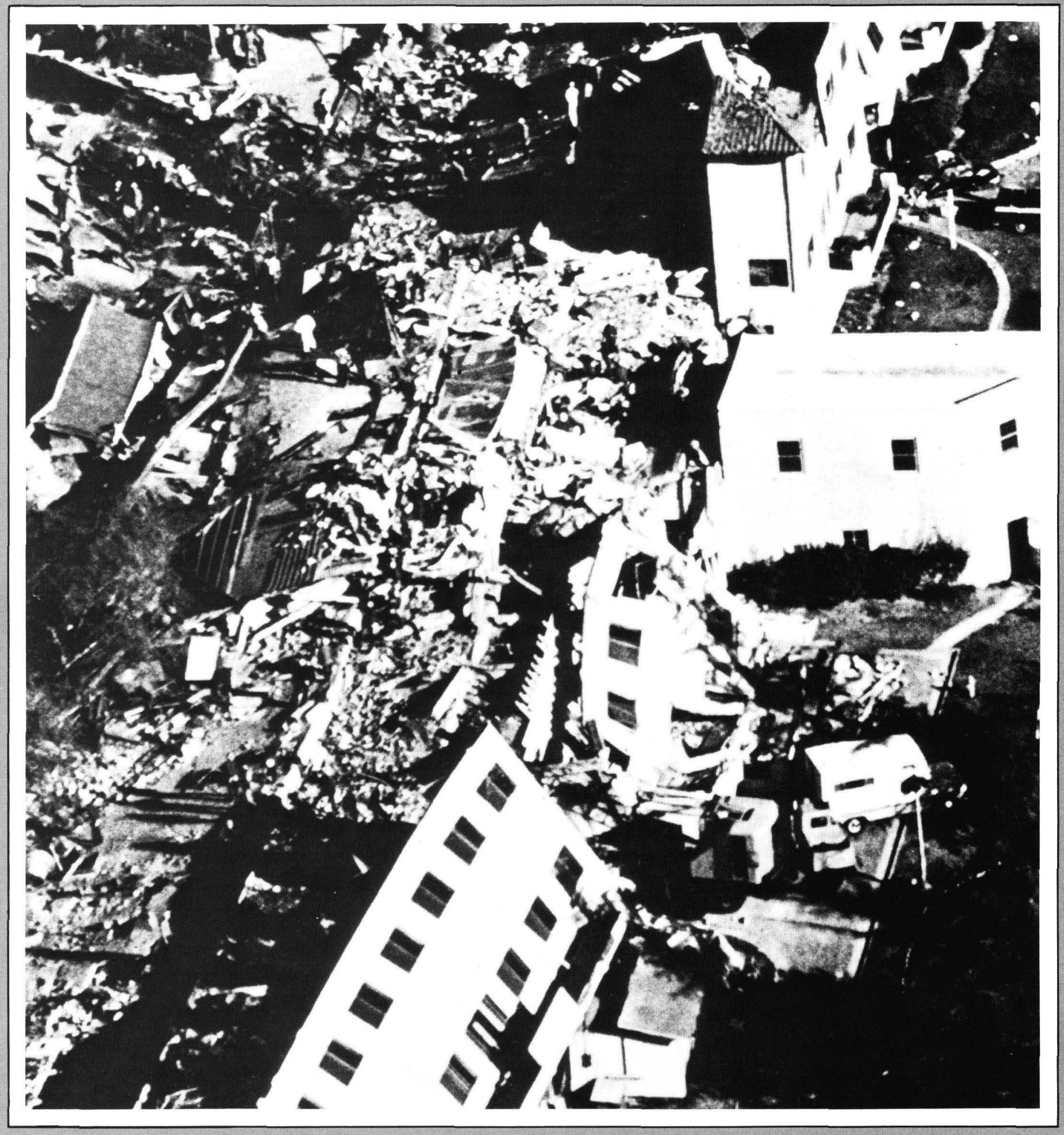

Earthquake Ground

Motion 


\section{PREDICTING EARTHQUAKE GROUND MOTION: AN INTRODUCTION}

\section{By R. D. Borcherdt}

\section{INTRODUCTION}

The damaging effects of earthquakes, with the exception of those associated with tectonic surface displacements, are caused by strong ground shaking. Ground shaking generally causes the most widespread effects not only because it propagates to considerable distance from the earthquake source but also because it may trigger secondary effects associated with ground failure and water inundation. Consequently, accounting for the effects of strong ground motion generated by future large earthquakes is a major factor in safeguarding life and property.

Reducing loss of life and property from strong ground shaking requires conscientious application of earthquake-resistant design and construction practices, development of adequate land use policies, and implementation of appropriate measures to strengthen vulnerable structures. For the design of critical structures at specific sites (such as nuclear powerplants, dams, and high-rise structures), it is feasible to collect detailed geologic and seismologic data sets on which to develop elaborate estimates. For routine construction and development of land use policy, collection of such data sets is not feasible, and more generalized predictions on a regional scale are necessary. This chapter provides the framework for subsequent chapters concerned with ground-motion estimation on both a regional and a site-specific basis. In brief, these chapters are concerned with development of geologic and geotechnical data bases useful for making ground-motion estimates on a regional scale (Tinsley and Fumal; Fumal and Tinsley), regional estimates of earthquake intensities (Evernden and Thomson), estimates of quantitative measures of ground motion on a regional scale Joyner and Fumal), regional delineations of potential variations in local ground response (Rogers and others), and sitespecific estimates of potential ground-shaking timehistories (Spudich and Hartzell). These chapters, which are addressed to a broad audience, summarize current- ly available data sets and methodologies pertinent to predicting ground motion for seismic zonation, land use policy development, and site-specific design of critical structures.

Earlier work on developing ground-motion estimates in the San Francisco Bay region for seismic zonation purposes (Borcherdt, 1975) found broad public interest and application in most city and county seismic safety plans (Kockelman, 1975; Kockelman and Brabb, 1979). The work emphasized the importance of local geologic conditions in determining the character of strong ground shaking and showed the existence of resonancetype wave propagation phenomena capable of increasing the amplitude of certain frequencies of ground shaking significantly at sites underlain by different types of alluvial deposits (Borcherdt, 1970; Borcherdt and Gibbs, 1976). This work resulted in regional predictions of maximum expected earthquake intensity, attenuation relations for strong shaking with distance (Page and others, 1975), geographic delineation of potential variations in shaking owing to local geologic conditions, and model estimates of strong shaking at specific sites for an earthquake of given size and location. These studies have contributed to a rapidly evolving research effort in strong-motion seismology, which, together with significant improvements in the strong-motion data base, has resulted in a number of advances pertinent to understanding the nature of ground motions generated by large earthquakes. Many of these advances are applied in subsequent chapters to the problem of estimating future strong ground motions and resultant earthquake intensities for the Los Angeles region.

\section{DEVELOPING A DATA BASE FOR GROUND-MOTION ESTIMATION ON A REGIONAL SCALE}

Local geologic conditions are known to strongly influence the character of earthquake-generated ground 
shaking (Wood, 1908; Kanai, 1952; Borcherdt, 1970, 1975; Rogers and others, 1980). Consequently, quantitative estimates of strong ground shaking and its effects on a regional scale must account for these influences and be based on earth-science data available throughout the region of interest. The data most readily available on a regional scale are geologic data presented in the form of geologic maps. Most standard geologic maps, however, are compiled for inferring geologic history and are not easily adapted to many special-purpose interpretive products. For example, most geologic maps differentiate bedrock units in considerable detail but only crudely differentiate young, unconsolidated sedimentary deposits of interest for estimating the severity of future shaking or the potential for liquefaction-induced ground failure. Lajoie and Helley (1975) used inferences regarding age and depositional environment based on physical characteristics of map units to differentiate sedimentary deposits in the San Francisco Bay region. Tinsley and Fumal (this volume) have extended this methodology to the Los Angeles region. They discuss the compilation of an extensive physical-property data base, the geologic data base available for portions of the region, and the methodology for delineating Quaternary sedimentary deposits in the Los Angeles region. Such compilations provide the regional basis for deriving special-purpose interpretative maps.

To extend the available geologic and physicalproperty data bases for preparing regional estimates of future ground shaking, an extensive program was undertaken to collect seismic velocity and geologic logs in all major sedimentary units in the San Francisco Bay region (Gibbs and others, 1975, 1976, 1977, 1980) and the Los Angeles region (Fumal and others, 1981, 1982, 1984). Results of this program show that the seismic velocities of different units correlate with variations in measured ground motions and observed earthquake intensities (Borcherdt and others, 1979). In addition, detailed comparative studies conducted by Fumal (1978) have defined surficial units in terms of geotechnical and geologic parameters that have distinguishable seismic velocities and, in turn, distinct response characteristics (Borcherdt and others, 1979). The availability of geologic and geotechnical parameters on a regional scale allows near-surface seismic velocities to be mapped on a regional scale for delineating variations in future ground response.

Fumal and Tinsley (this volume) summarize the seismic-velocity data base collected for the Los Angeles region. They define seismic-velocity units on the basis of a detailed comparative study of geologic and geotechnical parameters. These definitions are used in conjunction with thickness information to map average shear-wave velocity over a thickness of one-quarter wavelength at a reference period of $1 \mathrm{~s}$. Shear-wave velocity maps provide a basis for estimating future ground motion on a regional scale. Methodologies for preparing predictive ground-motion maps are discussed in subsequent chapters.

\section{PREDICTING EARTHQUAKE INTENSITIES}

Predicted earthquake intensities are especially useful for reducing earthquake hazards on a regional scale. Because earthquake intensities are based on a direct assessment of the effects of ground shaking on manmade structures and natural features, estimated earthquake intensities provide a regional assessment of potential earthquake losses from future damaging earthquakes. Predicted intensity maps developed for the San Francisco Bay region (Borcherdt and others, 1975a) and the Los Angeles region (Evernden and others, 1981) have been used extensively by Federal, State, county, and city planning agencies as well as by the public for both land use planning (Kockelman, 1979, 1980) and predisaster response planning (Davis and others, 1982a, b). Maps showing predicted intensities provide estimates on a regional scale of the severity of expected earthquake effects and as such are especially useful for seismic-risk and seismic-hazard evaluations. A discussion of seismic intensity and commonly used intensity scales is provided for additional reference in appendix 1 ; an abridged version of these scales appears on the inside back cover.

General factors influencing earthquake intensities are characteristics of the earthquake source (such as size, fault depth and extent, and rupture type), seismic energy transmission characteristics of the regional crustal structure, and local site conditions. A subsequent chapter (Evernden and Thomson, this volume) discusses a general predictive model for earthquake intensities that accounts for each of these factors and applies the model to predict maximum expected earthquake intensities on a regional scale for the Los Angeles region. On the basis of intensity predictions for a suite of possible California earthquakes, Evernden and Thomson extend the procedures of Blume and others (1980) to provide estimates of dollar loss expected for wood-frame construction. Because such estimates are dependent on the location and extent of urbanization relative to the earthquake source, they indicate the relative seismic risk associated with the major seismogenic faults in California.

The amount of damage that a particular structure experiences during an earthquake depends on the structure's design and construction characteristics. Consequently, the severity of damage to an individual struc-

\section{Earthquake Hazards in the Los Angeles Region}


ture is not always a reliable indicator of ground shaking. To investigate the reliability of earthquake intensity as an indication of ground shaking, Evernden and Thomson compare observed intensities from the 1971 San Fernando earthquake with instrumental recordings of strong shaking in different frequency bands. Their results indicate that predicted earthquake intensities correlate directly with expected levels of shaking in the frequency band 0.5 to $3 \mathrm{~Hz}$. This correlation suggests that predicted intensities might be used in conjunction with present building codes for the earthquake-resistant design of particular types of structures in the Western United States. In the past, earthquake intensities have been used for design purposes primarily in regions such as the Eastern United States, where few instrumental recordings of strong motion have been obtained.

Although predicted earthquake intensities may not provide a quantitative estimate of the amplitude and frequency characteristics of strong ground shaking and do not predict whether a particular structure will fail, they do delineate potential regional variations in the severity of expected effects of earthquake-generated strong ground shaking. As such, they are especially useful for regional hazard assessments as well as for the development of future land use policies and disaster response plans.

\section{PREDICTING QUANTITATIVE CHARACTERISTICS OF GROUND SHAKING}

Earthquake-resistant design codes are based on quantitative estimates of ground shaking in the form of either time-history parameters or spectral parameters. Thus, estimating these parameters on both a site-specific and a regional basis is a fundamental component of efforts to reduce losses from future earthquakes. Methodologies for making quantitative estimates in the Los Angeles region are presented in subsequent chapters. A detailed description of parameters used to quantitatively describe strong ground shaking for engineering design is presented in appendix 1.

The basic data set required for making quantitative estimates of ground shaking consists of instrumental recordings of damaging earthquakes obtained near the sources of those earthquakes. Unfortunately, recordings of ground motions for many types of potential earthquakes at distances of engineering interest have not yet been obtained; significant improvements have been made in the strong-motion data set within the last decade, however, the most notable addition being the recordings from the Imperial Valley earthquake of 1979. These recent data have been incorporated in groundmotion estimates derived in subsequent chapters.

\section{Estimating Peak Acceleration, Velocity, and Response Spectral Parameters}

Joyner and Fumal (this volume) have used a regional map of near-surface shear-wave velocities (Fumal and Tinsley, this volume) in conjunction with parameters derived from instrumental recordings of strong-motion data to estimate ground-motion parameters for future earthquakes of specific magnitude and location and to estimate the exceedance level of certain ground-motion parameters at a specified annual probability. The predictive method presented by Joyner and Fumal (this volume) is based on attenuation relations specifying the statistical regression of parameters such as peak horizontal acceleration, velocity, and response spectral values on earthquake magnitude, source distance, and local site conditions. Characterization of the local site conditions is based on the premise that ground-motion body-wave amplitudes can be expected, in many situations, to be approximately inversely proportional to the corresponding seismic-wave velocity as mapped by Fumal and Tinsley (this volume), which in turn is based in part on the delineation of Quaternary deposits provided by Tinsley and Fumal (this volume). The technique presented by Joyner and Fumal (this volume) can be used to provide ground-motion estimates at specific sites as well as on a regional scale. To account for the uncertain times and sizes of future events, data on fault-slip rate (Ziony and Yerkes, this volume) are incorporated to estimate regional and site-specific ground-motion parameters that will be exceeded at a specified annual probability.

These regional and site-specific quantitative estimates of ground-motion parameters are expected to be useful in the earthquake-resistant design of both noncritical and critical structures. The set of strong-motion data used by Joyner and Fumal (this volume) permits estimates of expected ground-motion amplitude level averaged over relatively broad frequency bandwidths. Some local geologic deposits, however, are known to amplify ground shaking considerably over relatively narrow frequency bandwidths owing to resonant effects (Borcherdt, 1970; Borcherdt and others, 1975c). Rogers and others (this volume) have used recordings of a variety of seismic events to develop an empirical data base for predicting the frequency-dependent nature of ground response in detail.

\section{Estimating Regional Variations in Local Ground Response}

Rogers and others (this volume) have used strongmotion recordings of the 1971 San Fernando earth-

Predicting Earthquake Ground Motion 95 
quake, recordings of distant nuclear explosions, and the extensive geologic and seismic data bases compiled by Tinsley and Fumal (this volume) to prepare a quantitative estimate of potential variations in ground response over the frequency bandwidth of engineering design interest. On the basis of comparative groundresponse measurements at 37 locations, Rogers and others (1984) have found that local ground response determined from low-strain signals from distant nuclear events can be used to predict ground response to signals of higher strain levels like those generated by the San Fernando earthquake. This conclusion suggests that comparative measurements of ground shaking recorded at 98 sites in the Los Angeles region from distant nuclear explosions can be used to provide quantitative estimates of ground response for future damaging earthquakes. In general, these comparative measurements show that levels of ground shaking at periods of less than $0.5 \mathrm{~s}$ at sites underlain by Holocene and Pleistocene sedimentary deposits are commonly three to four times greater than those at sites underlain by crystalline rock. Resonant effects having larger amplifications over narrow frequency bands are observed for sites underlain by Holocene deposits 10 to $20 \mathrm{~m}$ thick. For periods of shaking greater than $0.5 \mathrm{~s}$, levels of ground shaking generally increase as the thickness of Quaternary deposits increases.

By using cluster analysis techniques, Rogers and others (this volume) demonstrate how these data on measured ground response can be matched with the geologic and geotechnical information to predict relative ground response over bands of different periods for a set of map units. The resulting predictive groundresponse maps for the Burbank-Los Angeles-Compton urban corridor provide a quantitative estimate of the frequency-dependent amplitude variation expected in ground motions owing to local site conditions. Such maps would be useful for regional planning and for general earthquake-resistant design.

\section{Site-Specific Prediction of Ground-Shaking Time-Histories}

Design of critical structures at specific sites (such as nuclear powerplants, high-rise buildings, and dams) often requires an elaborate and accurate description of the characteristics of the ground motions likely to be experienced during the life of the structure. In rare instances, the ground motions likely to be generated may have been previously recorded at the site, but, in most cases, no such recording exists, and design must be based on theoretical model estimates derived from data recorded elsewhere. The recent growth of the strongmotion data set has contributed to a rapidly evolving research effort in strong-motion seismology; this research is directed toward the development of theoretical models to describe the nature of the earthquake rupture process and the resulting generation and propagation of seismic shaking. Spudich and Hartzell (this volume) have discussed these recent developments and their application to the problem of predicting groundmotion time-histories at specific sites.

Spudich and Hartzell (this volume) describe the nature of the earthquake rupture process, including deceleration and acceleration of rupture fronts caused by stress and strength heterogeneities on the fault surface, and its role in generating high-frequency ground motions significant to earthquake-resistant design. They review models describing the nature of the rupture process and its generation of seismic waves as inferred from strong-motion data recorded from the $1979 \mathrm{Im}$ perial Valley earthquake. They also examine published techniques for calculating Green's functions, which permit computation of ground shaking at any point on the Earth's surface, given a linear model of the Earth's structure and a mathematically tractable representation of a physical model of the earthquake source. Their review discusses several methods for describing wave propagation, including the equivalent Green's function representation for several linear Earth models having layered and continuous velocity gradients.

Spudich and Hartzell (this volume) discuss sitespecific simulations made by Apsel and others (1981) for postulated earthquakes on the Mojave segment of the San Andreas fault and on the Newport-Inglewood fault zone. Such deterministic simulations are reasonably successful in reproducing frequencies of recorded strong-motion time-histories of less than 1 to $2 \mathrm{~Hz}$. Limitations are imposed on higher frequencies by a lack of knowledge regarding details of the rupture timehistory and the intervening crustal structure. Stochastic simulations of the source rupture characteristics and detailed crustal structure determinations help remove these limitations. The success of the simulation procedures in reproducing recorded ground motions suggests that, in those cases for which elaborate estimates are feasible, reasonably confident predictions of ground-shaking time-histories can be developed for earthquake-resistant design.

\section{Earthquake Hazards in the Los Angeles Region}




\section{ESTIMATING GROUND SHAKING FOR A POSTULATED EVENT}

Measures designed to safeguard life and property from the destructive effects of strong ground shaking may use any or all of the various methodologies for estimating strong ground shaking discussed herein, including regional estimates of earthquake intensity, generalized estimates on a regional scale of parameters used in earthquake design codes, regional delineations of potential variations in local ground response, and elaborate predictions of ground-motion time-histories. These various techniques are applied to a postulated earthquake (M 6.5) on the northern part of the NewportInglewood fault zone in a later chapter (Ziony and others, this volume). This composite analysis illustrates the application of the various methodologies for assessment of seismic hazards owing to potential strong ground motion in the Los Angeles region.

\section{APPENDIX 1.-COMMON MEANS FOR CHARACTERIZING EARTHQUAKE SHAKING}

The severity of ground motion from an earthquake can be characterized either qualitatively-from the observed or expected effects of strong shaking on man and his structures-or quantitatively-from parameters that can be instrumentally recorded. Detailed descriptions of parameters commonly used to characterize ground motion are given by Richter (1958), Page and others (1975), and Hays (1980). A summary of these parameters follows.

A qualitative measure of shaking.-Seismic intensity is a numerical index based on subjective analysis of the observed effects upon humans, manmade structures, and the Earth's surface. Several different intensity scales have been defined. The Modified Mercalli intensity scale (inside back cover), which was adopted in 1931 by the U.S. Coast and Geodetic Survey (now the National Ocean Survey), is in most common usage. Although this scale is currently used for most earthquake investigations in the United States, some researchers prefer the older Rossi-Forel intensity scale, because its units appear to scale better with physical measurements of ground motion (Evernden and others, 1973, 1981). At the higher intensities (X, XI, and XII), the Modified Mercalli scale describes effects that relate chiefly to ground failure and do not necessarily indicate increased levels of shaking.

Isoseismal maps depict the geographic distribution of different grades of intensity observed for particular earthquakes. Because the patterns on these types of maps commonly are influenced by local geologic conditions, methods for predicting intensities of future large earthquakes have received particular attention in hazard-analysis research (for example, Borcherdt and others, 1975c; Evernden and others, 1973, 1981).

Quantitative measures of shaking.-The severity of ground motion can be expressed in quantities that may be scaled or computed from on-scale recordings of strong shaking instrumentally recorded from damaging earthquakes. The most common strong-motion recordings are accelerograms that depict ground shaking as a function of time (fig. 31) in a format proportional to acceleration for band frequencies considered to be of engineering significance. Maximum, or peak, amplitude parameters obtained from accelerometers are commonly used in engineering design. These parameters include peak acceleration, peak velocity, and peak displacement. Typically, peak acceleration occurs at frequencies in the range 2 to $10 \mathrm{~Hz}$, whereas the dominant frequencies of velocity and displacement are in the ranges 0.5 to $2 \mathrm{~Hz}$ and 0.06 to $0.5 \mathrm{~Hz}$, respectively (Page and others, 1975).

The response of structures to strong ground shaking is dependent not only on the amplitude of shaking.but also on the frequencies and duration of shaking. Response spectra provide a useful means of characterizing the relative frequency content of shaking. Response spectra, defined as the maximum response of a suite of linear, damped, single-degree-of-freedom oscillators subjected to a specified time-history of motion (fig. 32), provide estimates useful for calculating actual structural response. Response spectra typically are plotted on tripartite logarithmic paper and show the variations of peak spectral velocity, acceleration, and displacement as a function of vibration period. Each different representation of response spectra has a particular physical significance for building design (see Hays, 1980, p. 35). Joyner and Fumal (this volume) present a method for estimating pseudoacceleration and pseudovelocity response spectral values on a regional scale. 

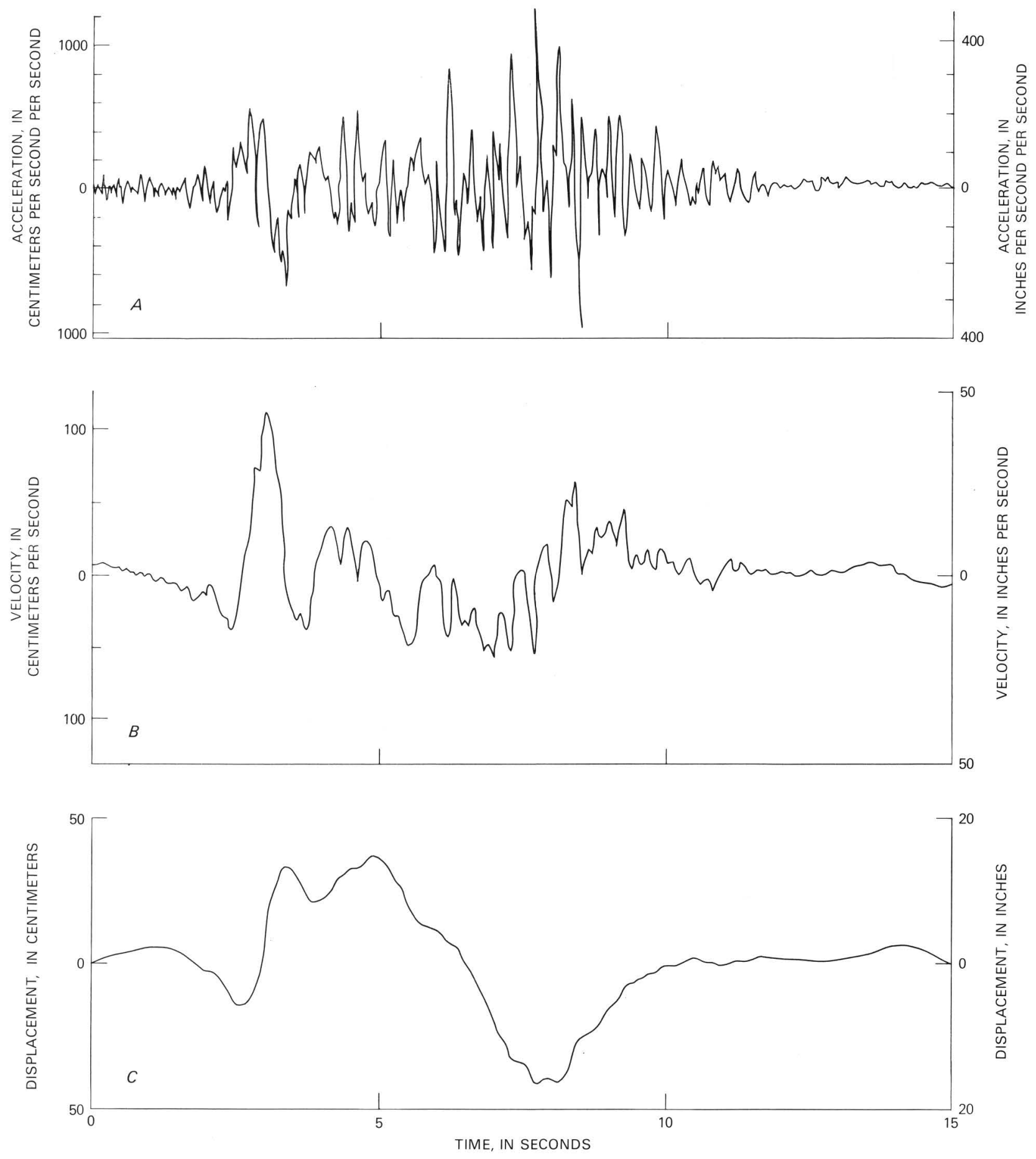

FIGURE 31.-Recordings of N. 14 E. component of horizontal ground motion at Pacoima damsite for 1971 San Fernando earthquake (from Page and others, 1975). Velocity $(B)$ and displacement $(C)$ records are obtained by integrating accelerogram $(A)$ once and twice, respectively.

98 Earthquake Hazards in the Los Angeles Region 


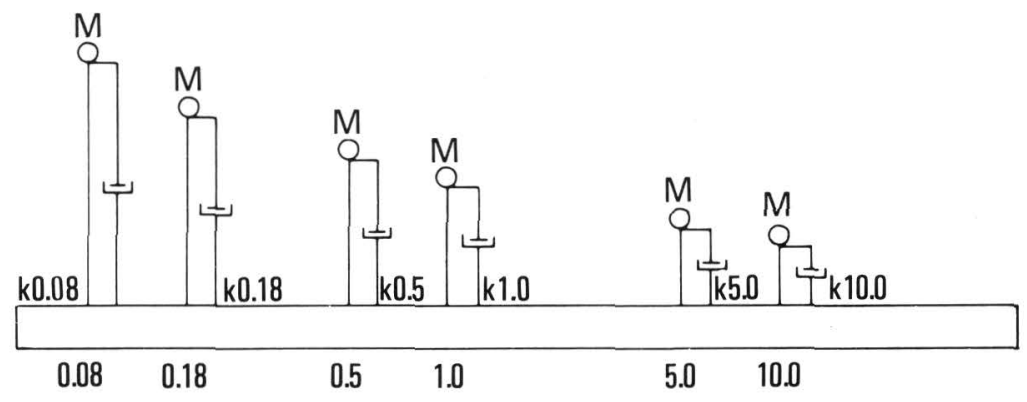

FREQUENCY, IN HERTZ

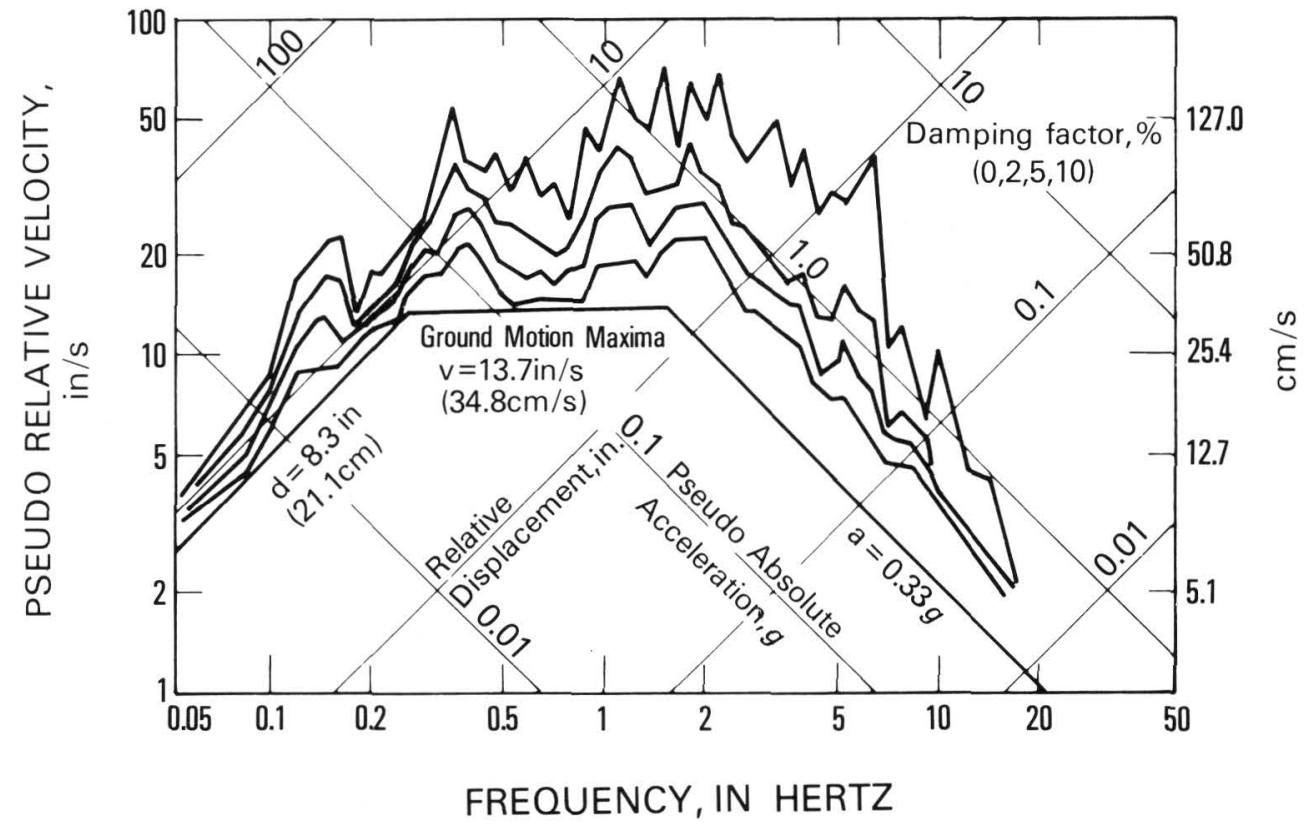

\begin{tabular}{|l|l|l|}
\hline$>7$ Story & $3-7$ Story & $1-2$ Story \\
\hline
\end{tabular}

FIGURE 32.-Response spectra portray the variations of ground-motion parameters as a function of vibration period (modified from Hays, 1980, fig. 32). Top, Schematic ensemble of single-degree-of-freedom oscillators. $M$ and $k$ represent the mass and spring constants of the equivalent mechanical system. Middle, Response spectra derived from the 1940 Imperial Valley earthquake accelerogram. Heavy lines show response calculated assuming damping factors of $0,2,5$, and 10 percent, respectively. Bottom, Bar graph showing ranges of natural frequencies for buildings of different heights in relation to schematic ensemble and response spectra. 


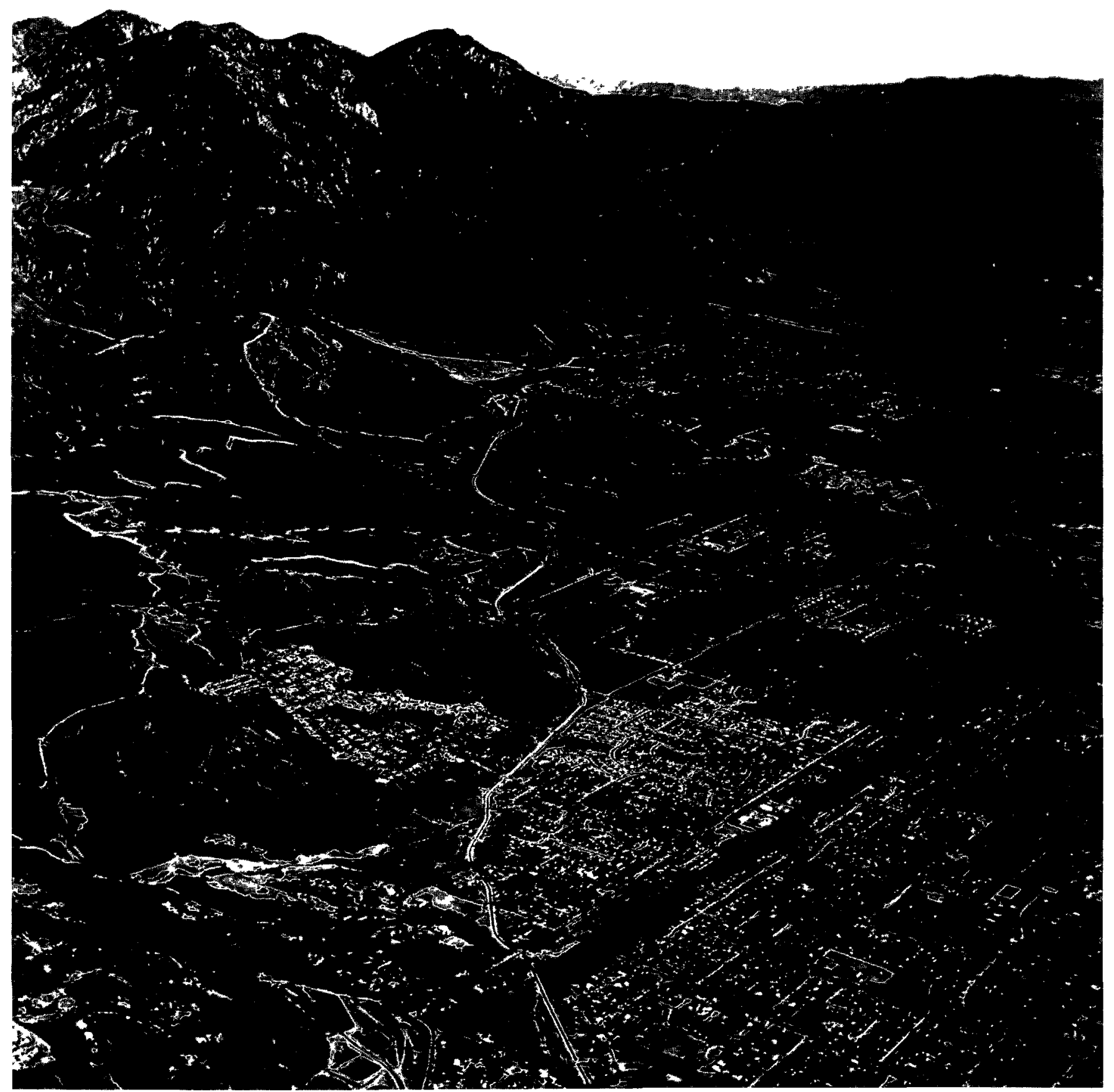

100 Earthquake Hazards in the Los Angeles Region 


\section{MAPPING QUATERNARY SEDIMENTARY DEPOSITS FOR AREAL VARIATIONS IN SHAKING RESPONSE}

\author{
By J. C. Tinsley and T. E. Fumal
}

\section{INTRODUCTION}

Areal differences in damage caused by shaking from earthquakes commonly can be related to variations in near-surface geologic materials (Milne, 1908; Lawson and others, 1908; Kanai, 1952; Gutenberg, 1957; Medvedev, 1962; Borcherdt, 1970; Borcherdt and others, 1975; Rogers and others, 1979; Fumal, 1978; Fumal and Tinsley, this volume; Rogers and others, this volume; Evernden and Thomson, this volume). In particular, ground shaking often is greatest on young, loose sedimentary deposits. The 1933 Long Beach earthquake, for example, caused greater damage in Compton than it did in Long Beach (Wood, 1933, p. 49, 52). Wood has ascribed this difference mainly to variations in Quaternary geology. Campbell (1976) has also studied the 1933 Long Beach earthquake and has shown that, for a given distance from the Newport-Inglewood fault zone, the damage at sites underlain by "unconsolidated soils" was greater than that at sites underlain by "consolidated soils." Long Beach is sited chiefly on relatively well consolidated late Pleistocene sedimentary deposits, whereas Compton is located on poorly consolidated, water-saturated Holocene alluvial deposits of the Los Angeles River and its tributaries (Thomas and others, 1961; Yerkes and others, 1965). These observations, and similar ones made elsewhere in the world, demonstrate the importance of determining the distribution and characteristics of the Quaternary sedimentary deposits upon which most of the world's urban centers are sited.

For the Los Angeles region, we present a technique for differentiating Quaternary sedimentary deposits that we hope will be transferrable to other areas. First, we describe a reconnaissance technique for dividing such deposits according to age and grain-size distinctions. This technique is used to prepare small-scale surficial geologic maps of parts of the major alluvial basins of the region (fig. 33). These maps are fundamental data sets for identifying areal variations in the physical properties of the alluvial sediment and of the adjacent uplands. Then, sediment age and grain size are related to secondary parameters such as shear-wave velocity, which are useful for predicting shaking response during earthquakes. The approach that we follow is derived from studies done in the San Francisco Bay region by Lajoie and Helley (1975) but incorporates studies of the shear-wave velocities of near-surface alluvial materials in the Los Angeles region (Fumal and Tinsley, this volume). Comparing selected physical properties of the rock and sediment units with measurements of shearwave velocity permits identification of areal groupings having distinct ranges in shear-wave velocity. On the basis of a two-dimensional model of sedimentation pattern, we present a series of regional maps grouping the surficial deposits according to distinctive ranges in shear-wave velocity; these maps provide an approximate characterization of relative shaking response.

\section{MAPPING SURFICIAL GEOLOGIC UNITS}

Techniques of traditional geologic mapping evolved chiefly in response to the needs of the mineral industries; consequently, standard geologic maps commonly emphasize the detailed distribution and character of bedrock units, including lithology, age, and rock structure (bedding, foliation, lineation, fractures, folds, and faults). In contrast, areas underlain by relatively uncemented or loose alluvium or other sediment without apparent structural or stratigraphic mineral potential commonly are depicted as a single map unit. Variations in the physical properties of Quaternary alluvial deposits that pertain to the delineation of geologic hazards such as ground shaking or ground failure are not usually distinguished on standard geologic maps. Because urban areas at risk from earthquakes commonly are located on Quaternary alluvial deposits, conventional geologic maps usually are not adequate for evaluating earthquake hazards. For this reason, during 


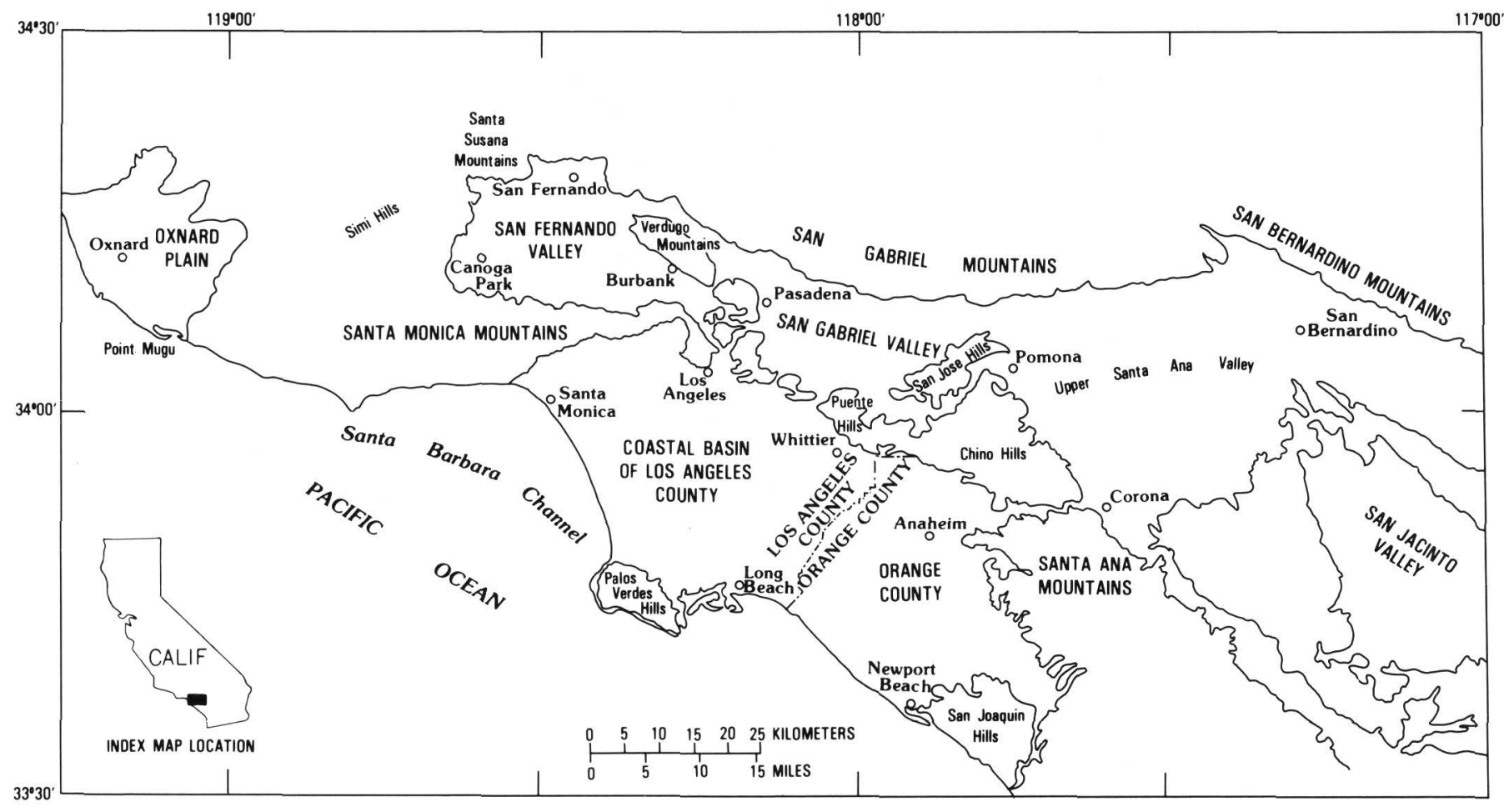

FIGURE 33.-Index map of the Los Angeles region showing areas mapped and evaluated for this study.

the past two decades, specialized mapping techniques directed specifically at identifying and evaluating earthquake hazards in alluvial deposits have evolved (Borcherdt, 1970; Borcherdt and others, 1975; Lajoie and Helley, 1975).

We have adapted the approach of Lajoie and Helley (1975) and have mapped surficial deposits in the Los Angeles region. Principal sources of information include topographic maps, aerial photographs, soil maps, descriptive accounts of excavations (including logs of water wells, oil wells, and other boreholes), trenches and foundations, and exposures in cliffs, streambanks, quarries, and roadcuts. Geologic units are defined and mapped on the basis of geologic and genetic criteria such as geomorphic expression, inferred depositional environment, soil-profile development, and grain size. For the most part, work was done chiefly in the office, but, locally, we have incorporated our own field observations.

\section{Topographic Maps}

Topographic maps represent the landscape by using topographic contour lines, bathymetric contour lines, culture symbols, stream courses, and many additional symbols. Older topographic maps showing the pre-urban landscape are especially valuable for making inferences about the character and distribution of Quaternary sediments, especially if their contour intervals are small. The principal basin areas of Los Angeles County, for example, were mapped by the U.S. Geological Survey at a scale of 1:24,000, at a contour interval of $5 \mathrm{ft}$, during the 1920's and early 1930's. These early maps clearly outline many principal physiographic elements of the pre-urban landscape, including mountains, foothills, canyons, and other features underlain by consolidated rocks; areas likely to be underlain by streamtransported sediment such as alluvial channels, alluvial fans, river flood plains and marshes; and areas likely to be underlain by other sedimentary deposits, including beach deposits, windblown dune deposits, and coastal estuarine muds. In contrast to modern topographic maps (which have contour intervals of 20 to $40 \mathrm{ft}$ ), the closely spaced contour lines of the early vintage maps reveal many landforms having only subtle topographic expression and now obliterated.

\section{Aerial Photographs}

Black-and-white vertical aerial photographs first became available for extensive areas of the Los Angeles region in the late 1920's; when these photographs are viewed in overlapping stereographic pairs, they afford a three-dimensional view of the landscape, including

\section{Earthquake Hazards in the Los Angeles Region}


alluvial deposits, drainages, and many other geomorphic features or landforms. The margins of landscape features noted on topographic maps (such as subtle channels, swamps, flood plains, dunes, and other landforms) often can be delineated more precisely by using aerial photographs than by using maps alone. The deposits associated with these landforms may have distinctive physical properties; thus, a geologic map emphasizing surficial deposits reflects the distribution of the physical properties that may be significant in evaluating geographic variations in shaking response.

\section{Soil Maps and Soil Stratigraphy}

Before extensive urban development in the Los Angeles region, the U.S. Department of Agriculture mapped soils in the area to encourage use of the best farming practices and cultivation of the most appropriate crops (Holmes and others, 1915; Nelson and others, $1915,1916)$. We use these soil maps as guides to the areal distribution of physical and chemical characteristics of agricultural soils; thus, these maps may reflect basic differences in the grain sizes and in other physical and chemical age-dependent attributes of the deposits in which the soil forms. For example, a soil on an alluvial fan mapped by the U.S. Department of Agriculture as a stony soil phase typically contains boulders and may be difficult or impossible to plow and hence of limited agricultural value. However, we use grain-size information (presence of boulders) to infer that the alluvial unit is very coarse grained.

The characteristics of a soil profile can indicate the age of the land surface if certain conditions are met. A soil profile may be moderately developed or well developed, as indicated by the presence of a clayenriched zone (B horizon) in which clay, iron oxides, and other products of weathering have been concentrated over a long period of time. Or, the profile may be poorly developed, as is the case chiefly on flood plains, natural levees, and channels of modern rivers and on young alluvial fans. Jenny $(1941,1961)$ has shown that, as a soil develops, the profile's characteristics are functions of the type of parent material, the climate, the vegetation, the topographic position in the landscape, and the age. In areas where all these "state factors" (soil-forming parameters) (with the exception of age) are similar, the chemical and physical characteristics in soil profiles may reflect the duration and intensity of weathering, and differences among profiles may reflect the time required to form the soil. The soil profile can serve as a rapid means of distinguishing rather young alluvial deposits from rather old ones-a sort of clock that begins to run when deposition or erosion of sediment proceeds at a rate that is slower than the rate of soilprofile development.

In the Los Angeles region, McFadden (1982) has recognized seven stages of soil formation and has shown that Jenny's (1941) soil-formation factors vary within a narrow enough range for us to conclude that alluvial deposits characterized by well-developed soil profiles have been subjected to weathering conditions to greater profile depths for a significantly longer period of time and hence are older than alluvial deposits characterized by relatively thin, poorly developed soil profiles. Well-developed soil profiles occur on alluvial fans or river flood plains or on shallow marine sedimentary deposits that have been tectonically uplifted or folded and no longer receive sediment from the present drainage network. Poorly developed soil profiles occur along the channels, levees, and flood basins of current streams graded to modern sea level and include areas where sediment transport and deposition ensued before construction of the largely successful civilengineering efforts to control floods and debris flows in the Los Angeles region.

Differences in soil-profile development can be correlated with the age distinctions of the underlying deposits. Radiocarbon dates from the Los Angeles region (Hastorf and Tinsley, 1981) indicate that moderately developed and well-developed soil profiles characterized by diagnostic subsurface horizons containing noteworthy clay accumulations, reddening owing to oxidation of ferrous iron compounds to hematite, and increased bulk density are associated with weathering and soil formation in alluvial deposits dated as late Pleistocene and older. Conversely, poorly developed soil profiles lack much pedogenic accumulation of clay, ferric oxides, and increased bulk density and are usually less than about $10,000 \mathrm{yr}$ old. Holocene deposits generally lack the conspicuous chemical and physical alterations of the sediment, including clast weathering, a reduction of pore volume, and an increase in soil strength, that commonly distinguish pre-Holocene deposits from Holocene deposits. This trend is shown by penetrometer studies and shear-wave velocity studies, which will be discussed in a later section of this chapter.

Rates and processes of soil genesis in the Los Angeles region (McFadden, 1982) and elsewhere (Birkeland, 1984) are reasonably well documented and clearly help to distinguish between Holocene and Pleistocene deposits, especially where the surface soil profile can be examined. Analyses of soil profiles using the techniques of soil stratigraphy (Birkeland, 1984) have been used in part by many workers, including Eckis (1934), Thomas and others (1961), McCoy and Sarna-Wojcicki (1978), Poland (1959), Lamar (1970), and Cox and Morton (1978)

Shaking Response of Quaternary Sediments 
TABLE 12.-Approximate age and geologic and geomorphic setting of selected soil series mapped in the Los Angeles region by the U.S. Bureau of Soils, 1915-1920

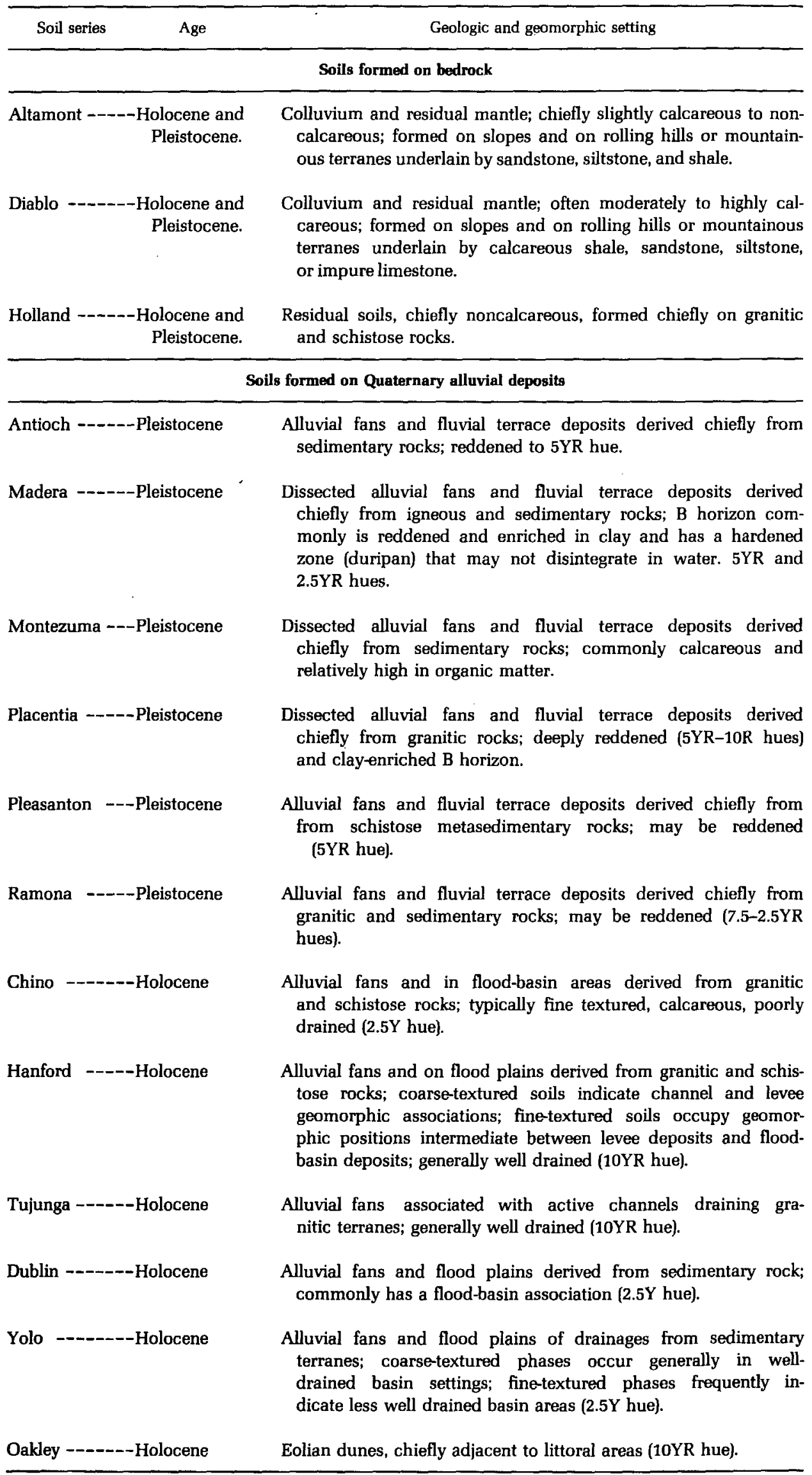




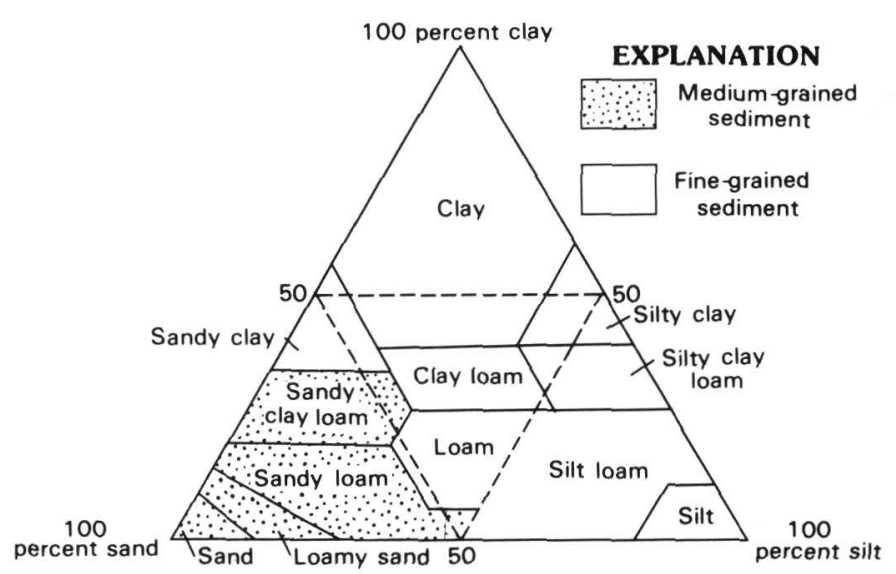

FIGURE 34.-Soil textural classes and grain-size designations of alluvial sediments (after Soil Survey Staff, 1975, p. 471).

to help distinguish Holocene deposits from late Pleistocene deposits in the Los Angeles region. Our study substantiates and incorporates many of the inferences of these earlier workers.

\section{SURFICIAL GEOLOGIC MAPS}

Geologic maps delineating areas underlain by Quaternary sedimentary deposits, Tertiary and pre-Tertiary sedimentary rock, and pre-Tertiary plutonic and metamorphic rock have been prepared for five alluvial basins in the Los Angeles region: (1) the San Fernando Valley, (2) the San Gabriel Valley, (3) the Los Angeles basin, (4) the Oxnard Plain, and (5) the upper Santa Ana River basin (fig. 33). We have divided the alluvial deposits into four grain-size categories and two inferred-age categories (Pleistocene and Holocene) by using the techniques described above; the mapping was done by J. C. Tinsley at 1:24,000 scale. The mapped grain-size designations are very coarse, coarse, medium, and fine. The geologic age is based chiefly on the profile characteristics of soils mapped by the U.S. Department of Agriculture's Bureau of Soils, consistent with modern established principles of soil stratigraphy (Birkeland, 1984) and with field studies of soils and soil genesis in the Los Angeles region (McFadden and others, 1980; McFadden and Tinsley, 1982, p. 15). Representative soil series identified from the early soil surveys and the geologic age designations used in this chapter are shown in table 12 . The relations among the soil textures and the grain-size designations of the alluvial sediments are presented in figure 34 . The generalized areas of bedrock were compiled from the geologic map of California (scale 1:250,000) (Rogers, 1965, 1969; Jennings, 1962; Jennings and Strand, 1969). The map units shown in figures $35,36,37,38$, and 39 are described briefly from youngest to oldest.

\section{DESCRIPTION OF MAP UNITS}

\section{Holocene Deposits (Less than 10,000 Yr Old)}

Qyf (fine-grained Holocene alluvium).-Chiefly poorly sorted, plastic, locally carbonaceous sandy silt, silt, silty clay, and clay in poorly drained flood basins adjacent to coastal marshlands, on distal parts of alluvial fans, in localized tectonic depressions along recently active faults, and in parts of alluvial plains adjacent to uplands composed of fine-grained sedimentary rock. Occasional lenses and small channels of well-sorted sand and fine gravel; occasional marine and estuarine pelecypod and gastropod shells and foraminifer tests in and near coastal marshes. Contains fossils of living vertebrate species and may contain freshwater pelecypod and gastropod shells. Interfingers with and grades both laterally and upstream into medium-grained alluvium; overlies late Pleistocene alluvium and bedrock; 0 to $50 \mathrm{~m}$ thick in coastal basins and generally less than $10 \mathrm{~m}$ thick in inland basins on alluvial plains and on lower parts of alluvial fans.

Qym (medium-grained Holocene alluvium).-Loose, moderately well drained, moderately sorted to wellsorted sand and silty sand forming alluvial plains and natural levees along streams. Locally contains thin beds of well-sorted clay, silt, gravel, and occasional cobbles and boulders. Contains freshwater pelecypod and gastropod shells. Intermediate in character and lateral extent between fine- and coarse-grained alluvium with which it interfingers; generally overlies late Pleistocene alluvium; generally less than $50 \mathrm{~m}$ thick in coastal basins and less than $10 \mathrm{~m}$ thick in inland basins.

Qyc (coarse-grained Holocene alluvium).-Loose, welldrained, moderately sorted, highly permeable sand and gravel deposited by modern streams and forming natural levees and flood plains and higher parts of alluvial fans; gravel predominates near stream channels and toward fan heads. Locally contains beds and lenses of well-sorted silt, sand, and gravel; contains freshwater pelecypod and gastropod shells. Interfingers with medium-grained alluvium and very coarse grained alluvium. Generally overlies late Pleistocene deposits and bedrock. Thickness ranges from $50 \mathrm{~m}$ in large canyons and near fan heads to $5 \mathrm{~m}$ or less on alluvial plains, stream channels, and alluvial fans.

Qyvc (very coarse grained Holocene alluvium).Loose, very well drained, very highly permeable cobbly and bouldery gravel and interstitial sand forming channel deposits and alluvial fan deposits on fan heads and in channels of principal canyons draining steep mountainous terranes. Pebbles and sand become dominant downfan and laterally away from stream channels issuing from major canyons. Locally contains beds of wellsorted silt, sand, and gravel; contains fossils of living 

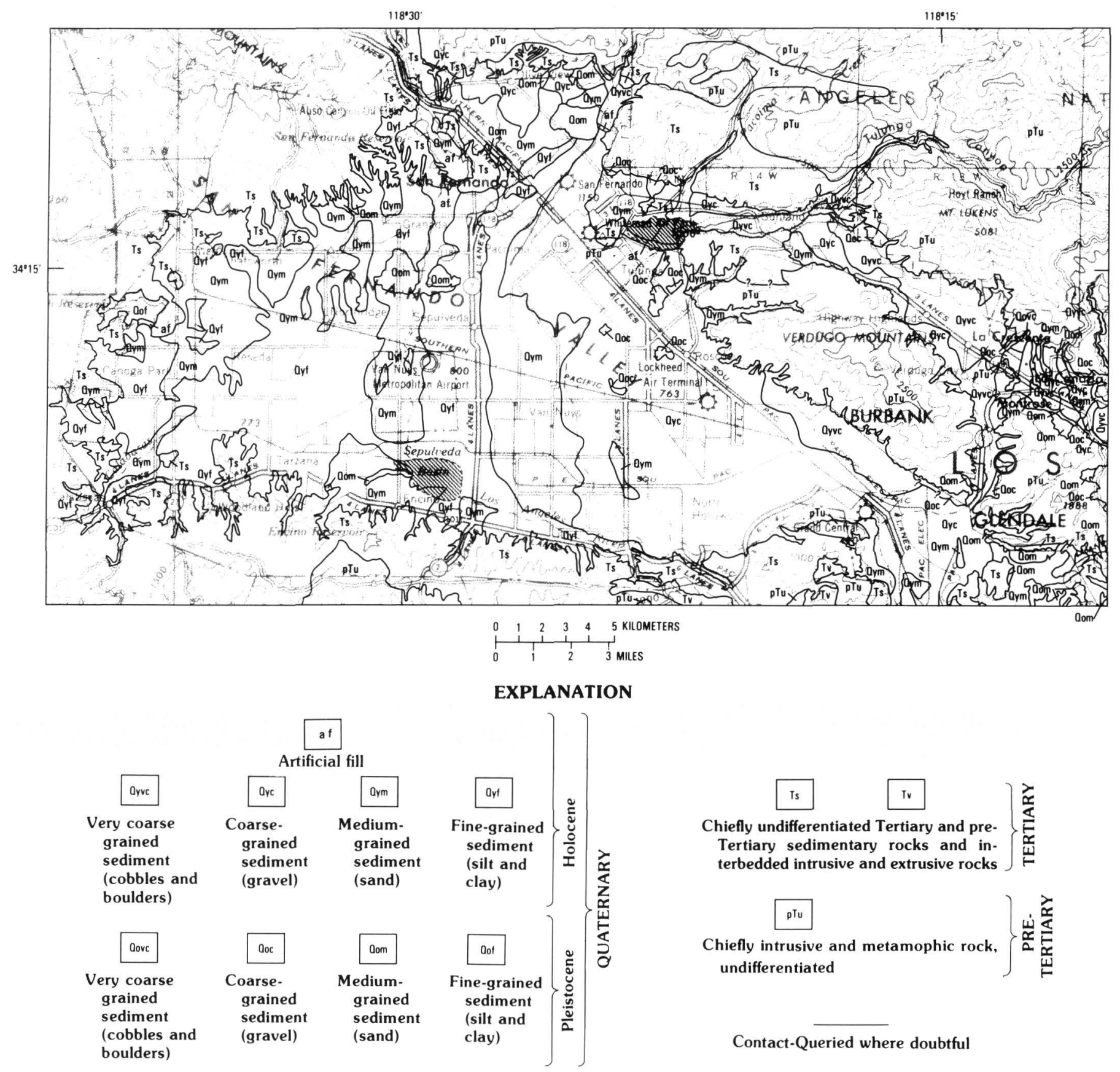

FIGURE 35.-Age and textural character of surficial geologic materials in the San Fernando Valley.

vertebrate species and freshwater pelecypod and gastropod shells. Thickness ranges from $50 \mathrm{~m}$ in fan heads and canyons to $5 \mathrm{~m}$ or less on upper parts of alluvial fans where deposits interfinger with coarse-and medium-grained alluvium. Overlies late Pleistocene alluvium and bedrock.

\section{Earthquake Hazards in the Los Angeles Region}

Pleistocene Deposits $(10,000$ to $1,700,000$ Yr Old)

Qof (fine-grained Pleistocene alluvium).-Weathered, slightly indurated and consolidated to moderately in- 


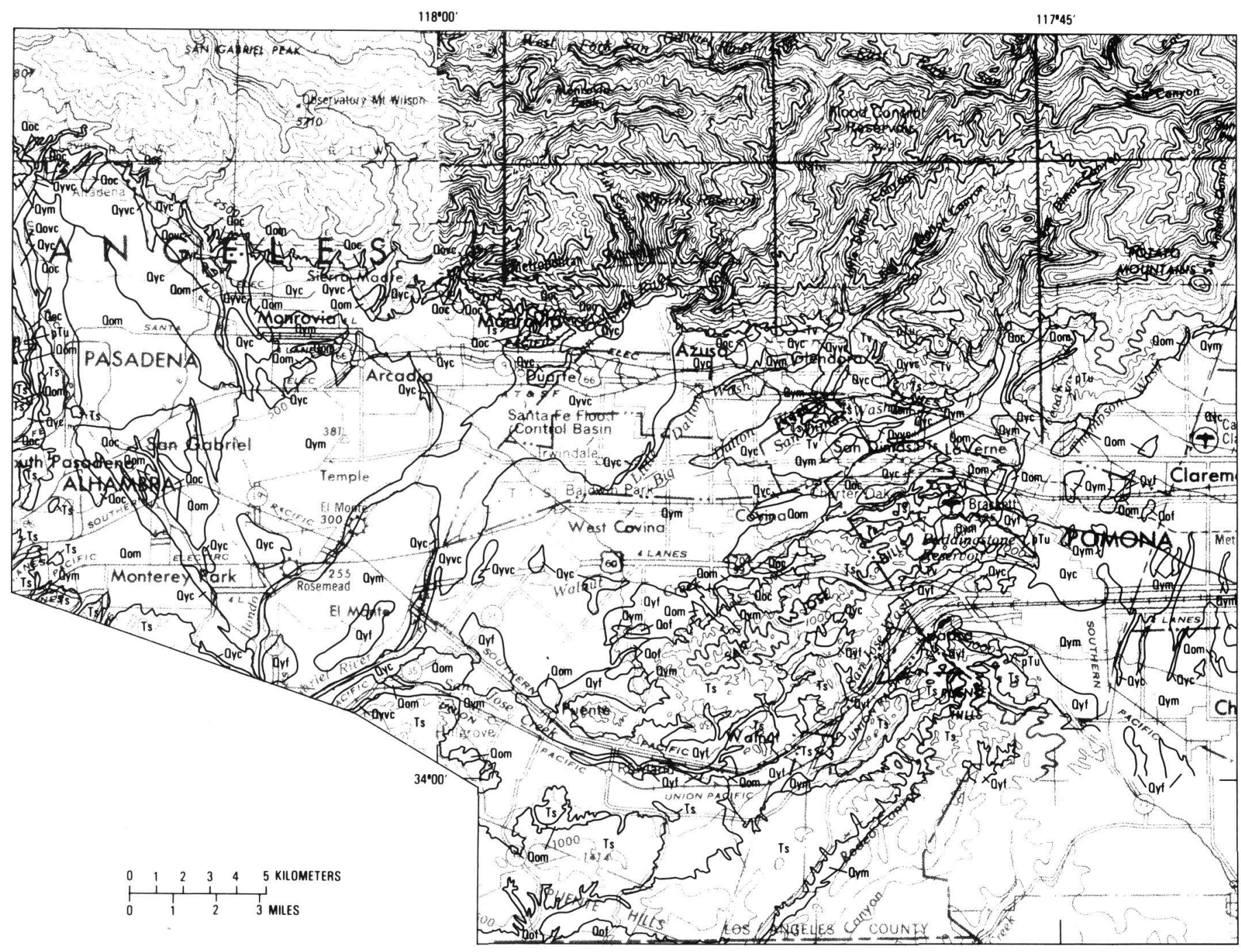

EXPLANATION

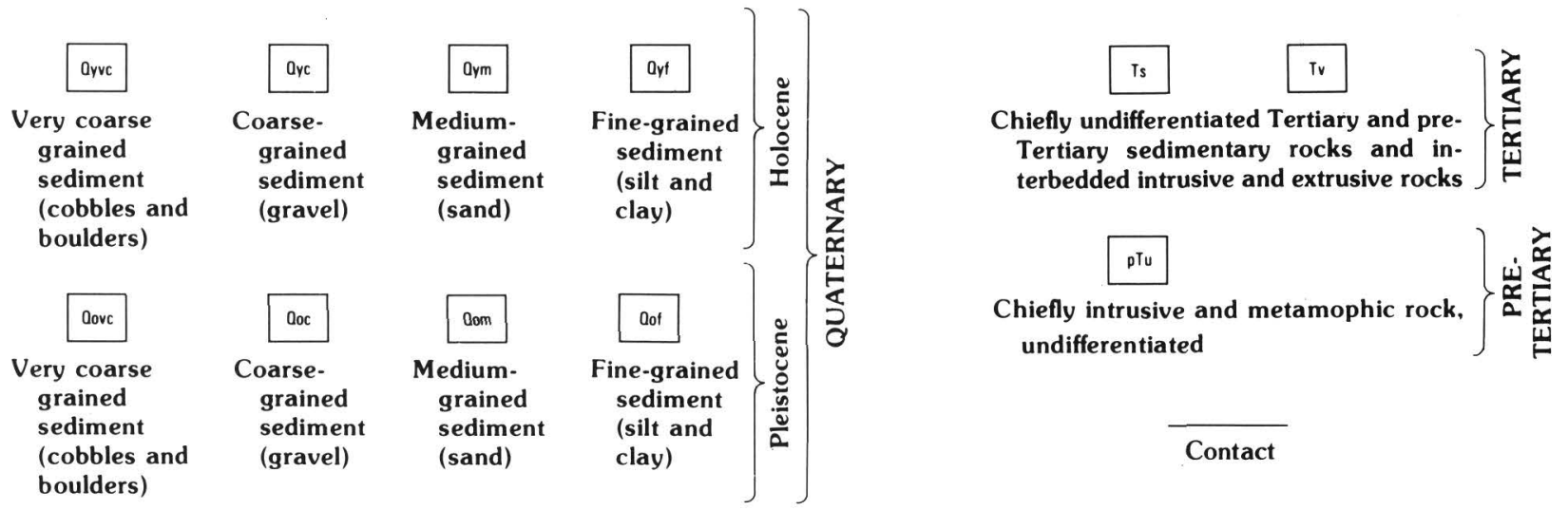

FIGURE 36.-Age and textural character of surficial geologic materials in the San Gabriel Valley. 

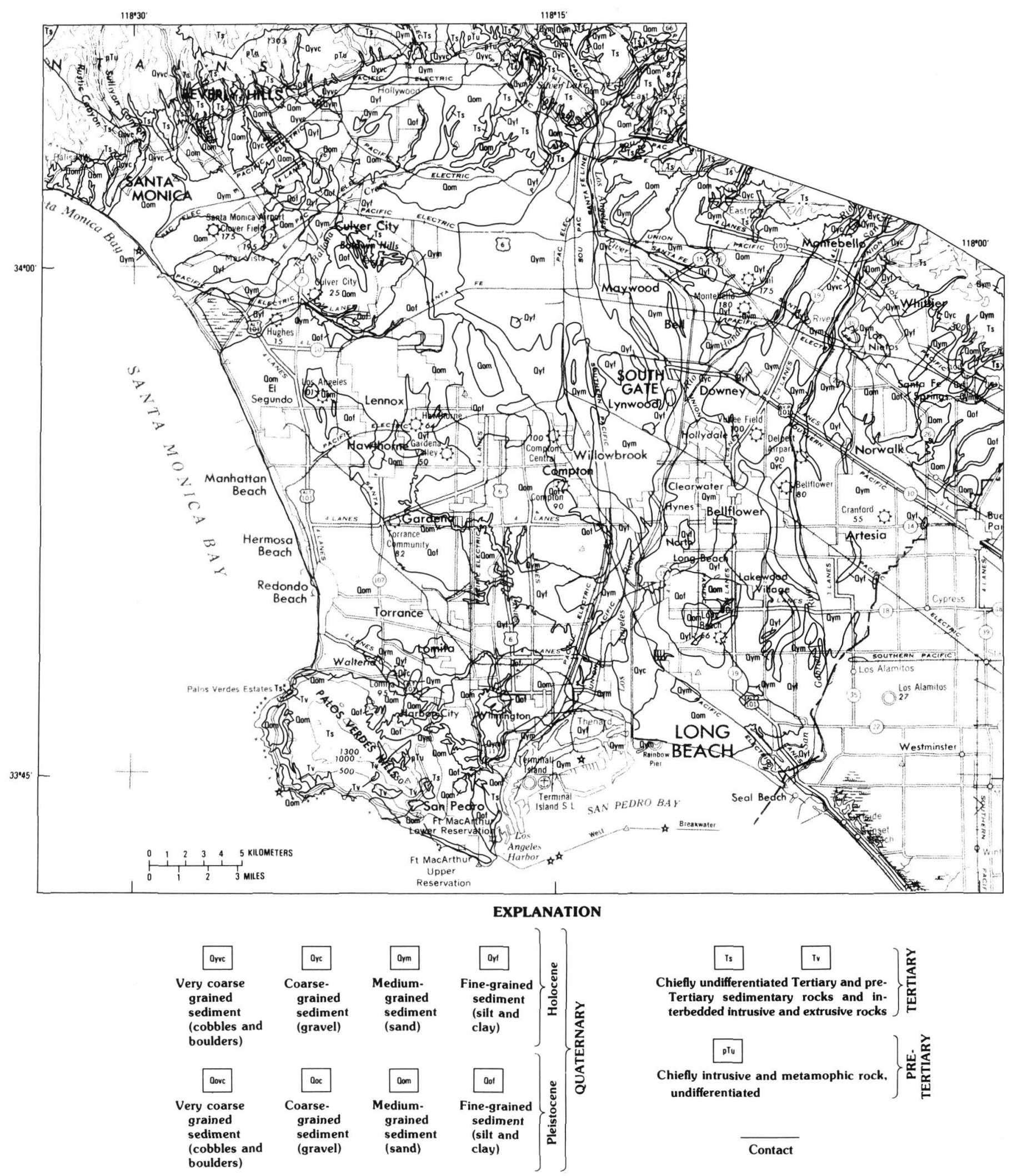

FIGURE 37.-Age and textural character of surficial geologic materials in part of the Los Angeles basin. 


\section{EXPLANATION}

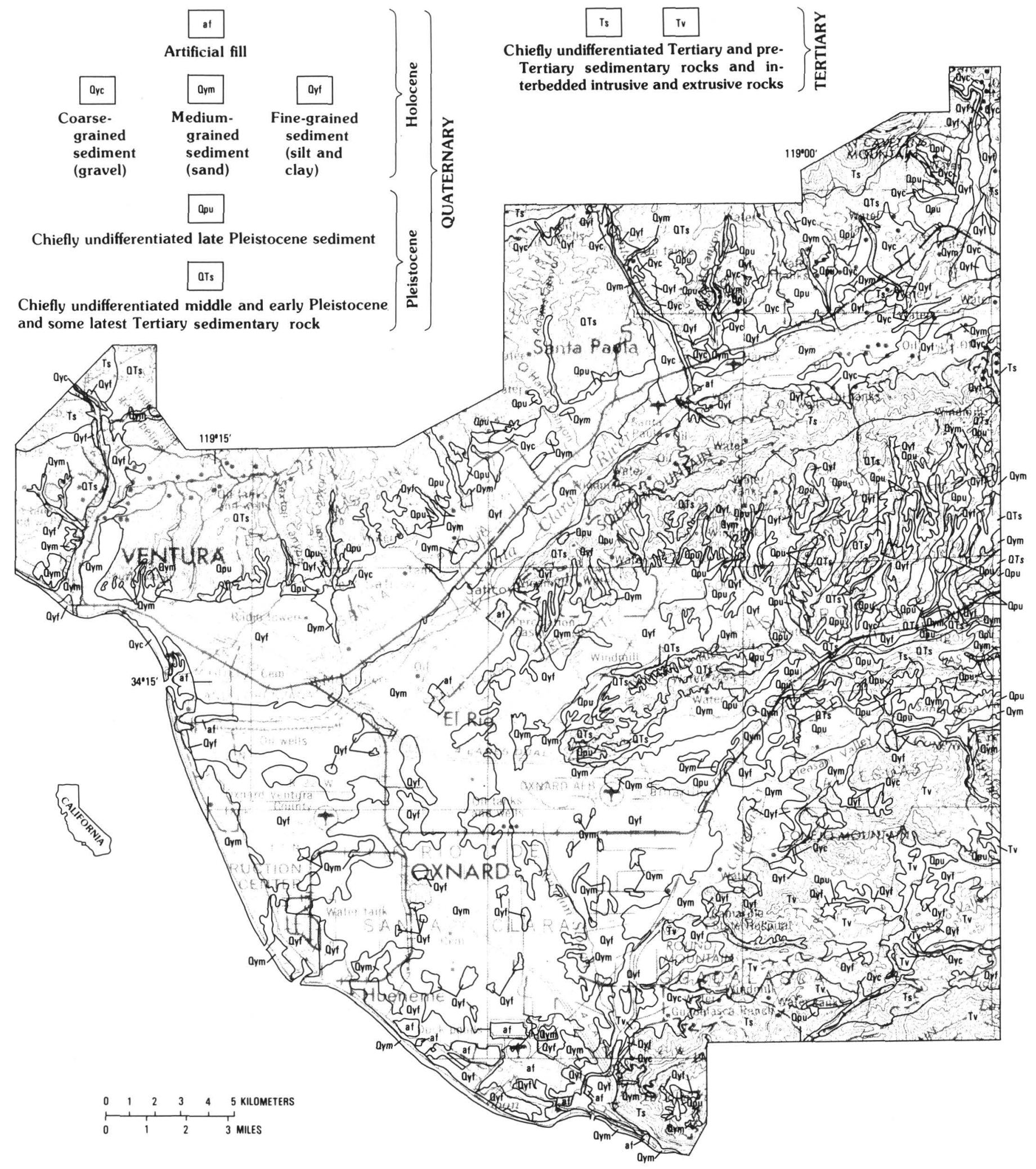

FIGURE 38.-Age and textural character of surficial geologic materials in the Oxnard Plain area. 


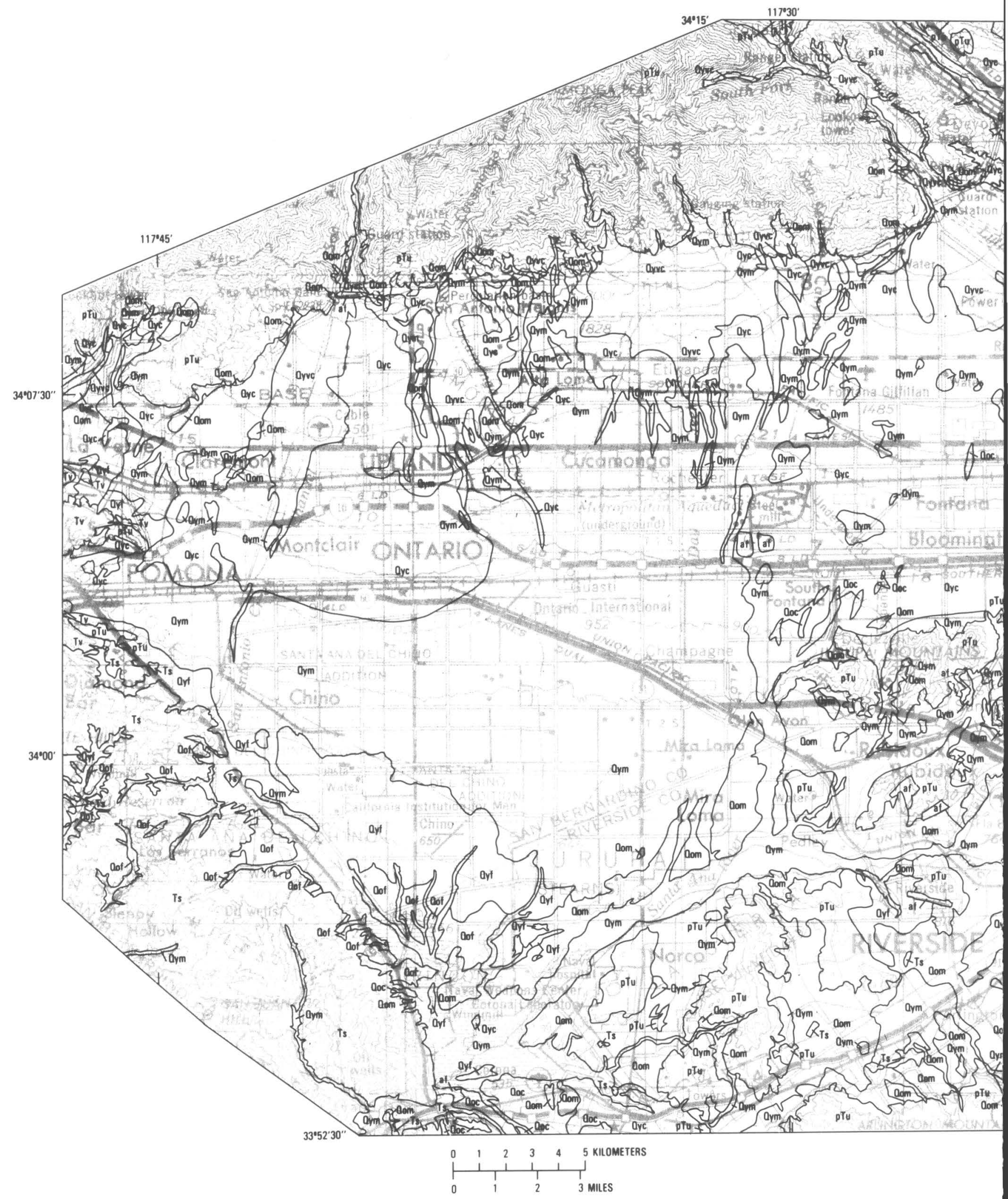

FIGURE 39.-Age and textural character of surficial geologic materials in the upper Santa Ana River basin.

110 Earthquake Hazards in the Los Angeles Region 


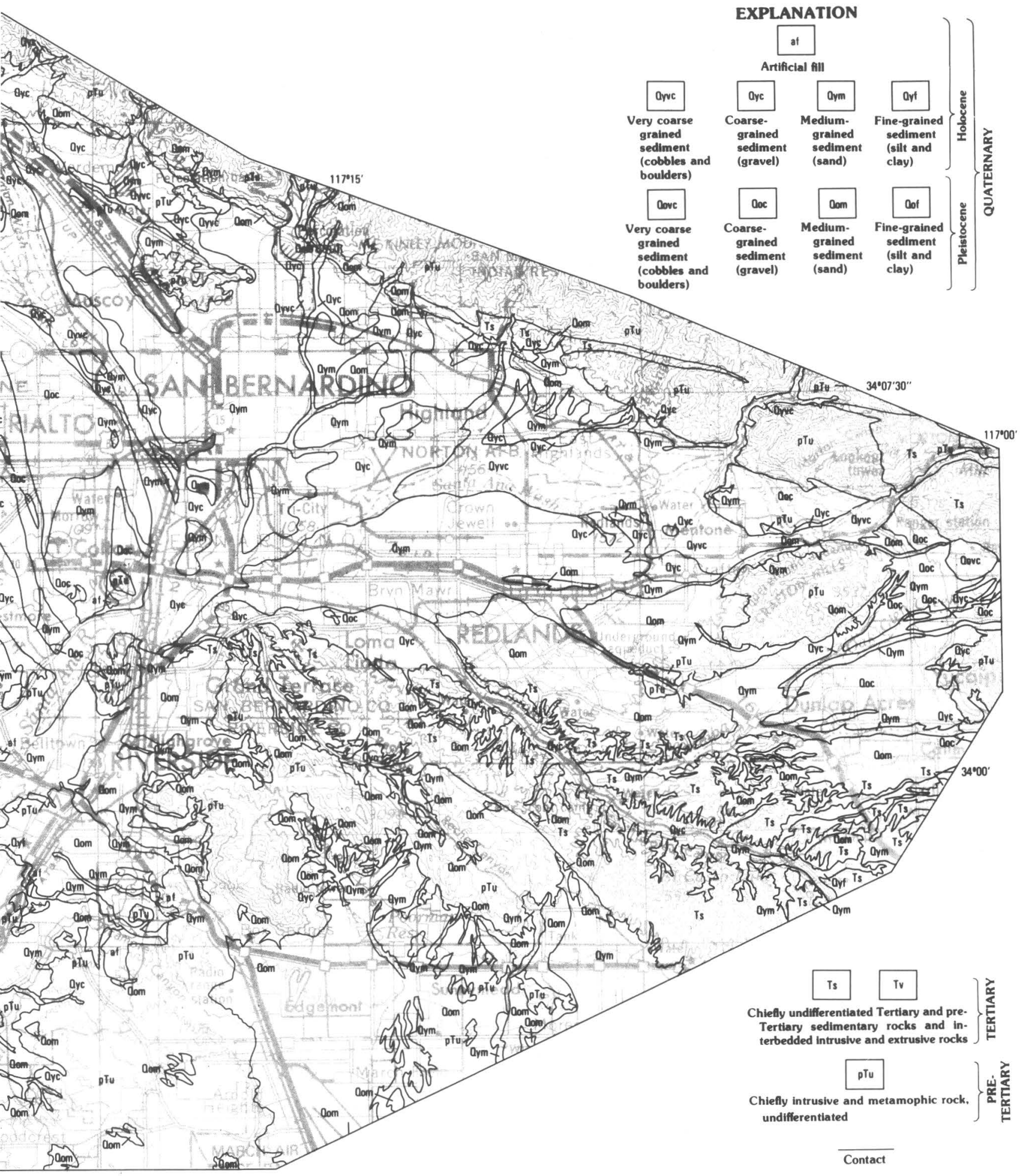

Shaking Response of Quaternary Sediments 
durated and well-consolidated, poorly drained deposits on lower parts of older dissected alluvial fans and flood basins. Consists chiefly of silt and clay and contains occasional lenses of gravel and sand. Commonly subsurface but is exposed along flanks of anticlinal uplifts and along uplifted fault blocks. Relict soils commonly reddened to 5YR and redder hues (Munsell notation) (Munsell Soil Color Charts, 1975). Less permeable than Holocene alluvium. Locally contains freshwater gastropod and pelecypod shells and extinct vertebrate fossils. Overlain by Holocene deposits along lower parts of alluvial plains and along some margins of anticlinal folds; in coastal basins is incised by channels that are partially to completely filled with Holocene alluvium. Maximum thickness unknown but is at least $300 \mathrm{~m}$ in coastal basins. Nonmarine in inland areas, marine and estuarine in parts of coastal basins.

Qom (medium-grained Pleistocene alluvium).Compact to very dense, moderately drained, moderately sorted, moderately permeable sand containing lenses of small gravel, silt, and clay. Exposed on inactive alluvial fans and alluvial plains in intermediate positions between channels and flood-basin deposits in surface and subsurface localities. Locally contains freshwater pelecypod and gastropod shells and extinct vertebrate fossils. Maximum thickness unknown. Overlies bedrock and underlies Holocene alluvium.

QOC (coarse-grained Pleistocene alluvium).Weathered, slightly consolidated to well-consolidated and indurated alluvial fan and flood-plain deposits consisting primarily of gravel, sand, and some silt. Relict soils commonly reddened to 5YR and redder hues (Munsell notation). Permeable but less so than Holocene equivalent. Interfingers with and overlies marine deposits in parts of coastal basins; overlain by Holocene deposits on upper parts of alluvial fans and alluvial plains; incised by channels that are partially filled with Holocene alluvium. Maximum thickness unknown but is at least $300 \mathrm{~m}$ in coastal basins where marine beds provide control on the base of the Quaternary section.

Qovc (very coarse grained Pleistocene alluvium).Weathered, slightly consolidated to well-consolidated and indurated alluvial fan and flood-plain deposits consisting primarily of bouldery and cobbly gravel and sand and locally containing some beds of silt. Relict soils commonly reddened to 5YR and redder hues (Munsell color notation). Permeable but less so than the texturally equivalent Holocene unit. Interfingers with and overlies marine deposits in coastal basins; interfingers with coarse- and medium-grained Pleistocene alluvium in inland valleys on alluvial fan heads and in stream channels. Incised by channels that are partially filled with Holocene alluvium. Maximum thickness unknown but is at least $300 \mathrm{~m}$ along mountain fronts.

\section{Earthquake Hazards in the Los Angeles Region}

\section{Tertiary and Mesozoic Deposits}

Ts (Tertiary and pre-Tertiary sedimentary rock, undifferentiated).-Weathered to slightly weathered shale, siltstone, sandstone, and conglomerate. Poorly to well sorted. Moderately soft to well-cemented and wellindurated strata. Chiefly marine origin; some nonmarine units. Underlies alluvial deposits and overlies basement rocks. Maximum aggregate thickness exceeds $10 \mathrm{~km}$ in deepest parts of major coastal basins, but thickness varies markedly across the Los Angeles region.

$\mathrm{Mz}$ (Mesozoic and pre-Mesozoic crystalline and metasedimentary rocks, undifferentiated).-Comprises the basement complexes exposed in principal mountain ranges and encountered in exploratory borings near basin margins. Includes basement terrane rocks of the Santa Monica Mountains, the San Bernardino Mountains, the San Jacinto Mountains, the northern Perris block, and the northern Santa Ana Mountains.

\section{USING PHYSICAL PROPERTIES OF SURFICIAL GEOLOGIC UNITS TO ESTIMATE RELATIVE SHAKING RESPONSE}

This section describes a method for using several physical properties of sediments as a guide to approximating their likely relative response to seismic shaking. Grain size and sorting are sediment properties that depend chiefly on the depositional environment. Other physical properties of sediments that significantly influence its strength and hence correlate broadly with its shear-wave velocity include consistency (for cohesive soils) and relative density (for cohesionless soils) as measured with a penetrometer (Fumal and Tinsley, this volume). These properties also are related to and tend to increase with the geologic age of the deposit and also with its thickness (Lajoie and Helley, 1975, p. 49; Fumal and Tinsley, this volume; Rogers and others, this volume).

We use shear-wave velocity $\left(V_{S}\right)$ as an index of the strength, relative density, and induration of the sediment and thus as a means of approximating the response of a deposit to seismic shaking. Medvedev (1962) has shown that seismic impedance (defined as the product of the shear-wave velocity and the bulk density, $V_{S} \cdot \rho$ ) is useful for estimating relative shaking response. Amplification of seismic waves in layered media is proportional to the contrast (difference) in the impedances of superposed deposits (Medvedev, 1962). Lajoie and Helley (1975) and Borcherdt and Gibbs (1975) have shown that, for layers of a given thickness, relative 
TABLE 13.-Comparison of relative bulk density, penetration resistance, shear-wave velocity, and calculated impedance values of surficial geologic units

[--, no data available $]$

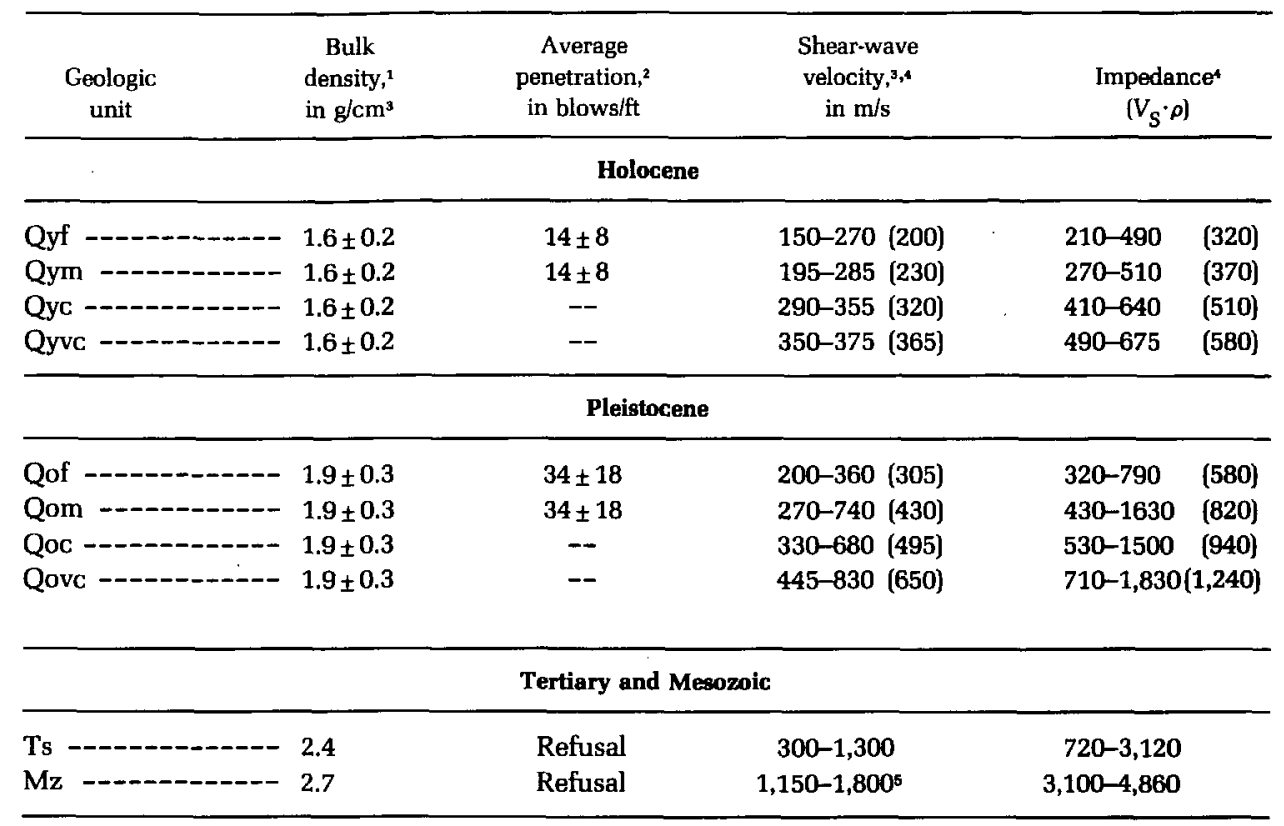

${ }^{1}$ Bulk densities $(\rho)$ for Quaternary deposits from McFadden (1982) and Los Angeles County Flood Control District (unpublished data, 1950-1980).

${ }^{2}$ From CALTRANS freeway borings; 5 to $10 \mathrm{ft}$ subsurface, 140-lb hammer, 30-in. drop. Penetrometer tests not reliable in gravelly and bouldery deposits. Refusal indicates failure to advance the penetrometer through the Earth materials.

${ }^{3}$ Holocene and Pleistocene values from Fumal and Tinsley (this volume, table 18). Mean value in parentheses.

${ }^{4}$ Mean value in parentheses.

${ }^{5}$ Value may be lower for weathered crystalline rock.

shaking response should be greatest where the surface geologic units have the lowest impedance values (finegrained Holocene) and where the impedance contrast between the surface layer and a subjacent layer is the greatest. The impedance contrast and the relative shak ing response for a given thickness of fine-grained Holocene deposits overlying Tertiary sedimentary rock, for example, should be higher than those of the same thickness of fine-grained Holocene deposits overlying Pleistocene fine-grained sediments.

Selected physical properties are shown in table 13 for the surficial geologic units that we mapped in the Los Angeles area: (1) penetration resistance (blows per foot), taken from penetrometer studies made by the California Department of Transportation (CALTRANS), (2) range and mean values of shear-wave velocity $\left(V_{S}\right)$ within each geologic unit measured to depths of $30 \mathrm{~m}$ by using downhole techniques, and (3) relative impedance values calculated by using bulk density values for near-surface sites (McFadden, 1982) and bulk density measurements of sediment sampled below the principal zone of soil formation during soilengineering studies of storm-drain facilities in the Los Angeles region (Los Angeles County Flood Control District, unpublished data, 1950-1980).
Shear-wave velocities have been measured at 84 sites in the Los Angeles region, chiefly in Holocene and Pleistocene alluvial deposits. The alluvium is grouped according to geologic age and physical properties (grain size, consistency, and relative density). Correlations are then recognized with respect to shear-wave velocities. Relative density and consistency of sediment, as measured by the standard penetrometer test, are correlated with geologic age (Fumal and Tinsley, this volume). Thus, geologic maps showing age and grain size are sufficient for regional studies of areal variations in relative shaking response. Fumal and Tinsley (this volume) show that standard penetrometer tests, where they are available, afford a basis for further subdividing certain classes of sediment (primarily sand and clay) to reduce the variance with respect to measured shear-wave velocities. In this chapter, however, standard penetrometer data are not incorporated into the definitions of the geologic map units or of the shear-wave velocity groups. Therefore, although the geologic map units are more broadly applicable to the Los Angeles region, the precision of the results obtained from using the twodimensional model of sediment distribution for estimating relative ground shaking is correspondingly reduced.

Shaking Response of Quaternary Sediments 
TABLE 14.-Comparison of mean shear-wave velocities and shear-wave velocity groups for surficial geologic units in the Los Angeles region

\begin{tabular}{|c|c|c|c|c|}
\hline \multirow[b]{2}{*}{ Age and texture } & \multicolumn{3}{|c|}{ Mean shear-wave velocity } & \multirow[b]{2}{*}{$\begin{array}{l}\text { Shear-wave } \\
\text { velocity group }\end{array}$} \\
\hline & $\begin{array}{l}\text { Mean } \pm 1 \text { s.d., } \\
\quad \text { in } \mathrm{m} / \mathrm{s}\end{array}$ & $\begin{array}{l}\text { Number of } \\
\text { sites studied }\end{array}$ & $\begin{array}{l}\text { Range, } \\
\text { in } \mathrm{m} / \mathrm{s}\end{array}$ & \\
\hline \multicolumn{5}{|l|}{ Holocene sediment: } \\
\hline $\begin{array}{l}\text { Fine grained } \\
\text { (silt and clay). }\end{array}$ & $200 \pm 20$ & 23 & $150-270]$ & I \\
\hline $\begin{array}{l}\text { Medium grained } \\
\qquad \text { (<15 percent gravel). }\end{array}$ & $230 \pm 30$ & 38 & 195-285 J & \\
\hline $\begin{array}{l}\text { Coarse grained and } \\
\text { very coarse grained } \\
(>15 \text { percent gravel; } \\
\text { cobbles and } \\
\text { boulders). }\end{array}$ & $330 \pm 30$ & 12 & $290-375$ & \\
\hline Pleistocene sediment: & & & & II \\
\hline $\begin{array}{l}\text { Fine grained }- \\
\text { (silt and clay). }\end{array}$ & $305 \pm 50$ & 18 & $200-360$ & \\
\hline $\begin{array}{l}\text { Medium grained } \\
\qquad(<15 \text { percent gravel). }\end{array}$ & $430 \pm 115$ & 57 & $270-740$ & \\
\hline $\begin{array}{l}\text { Coarse grained and }--- \\
\text { very coarse grained } \\
\text { ( }>15 \text { percent gravel; } \\
\text { cobbles and } \\
\text { boulders). }\end{array}$ & $535 \pm 125$ & 23 & $330-830$ & III \\
\hline Sedimentary rock --- & $530 \pm 250$ & 27 & $300-1300^{1}$ & IV \\
\hline Crystalline rock -- - & $1,130_{ \pm} 440$ & 12 & $670-1,900^{1}$ & V \\
\hline
\end{tabular}

${ }^{1}$ Range includes $V_{S}$ values for moderately weathered crystalline rocks.

\section{MAPPING SHEAR-WAVE VELOCITY GROUPS}

For regional evaluation, we classify the eight Pleistocene and Holocene surficial geologic units into three shear-wave velocity groups (table 14): group I, which includes Holocene fine and medium-grained deposits $\left(V_{S}<285 \mathrm{~m} / \mathrm{s}\right)$; group II, which includes very coarse grained and coarse-grained Holocene deposits and fine and medium-grained Pleistocene deposits $\left(290 \mathrm{~m} / \mathrm{s}<V_{S}<740\right.$ $\mathrm{m} / \mathrm{s}$ ); and group III, which includes coarse-grained Pleistocene sedimentary deposits $\left(330 \mathrm{~m} / \mathrm{s}<V_{S}<830 \mathrm{~m} / \mathrm{s}\right)$. Areas underlain directly by sedimentary or crystalline rock are divided into two units solely on the basis of lithology. Group IV consists of areas underlain by sedimentary rock and by sedimentary rock interbedded with intrusive or extrusive igneous rocks; group V consists of areas underlain by crystalline (chiefly granitic and metamorphic) rock.

Table 14 shows that the average shear-wave velocity decreases within each age category as the sediment becomes finer in texture, a trend suggesting that shaking effects on fine-grained deposits may be more severe than those on coarse-grained deposits for a given thickness and layered sequence of materials at a given distance from an earthquake source. Thus, future levels of shaking are expected to be most severe in areas delineated as group I; the expected level of shaking would decrease relatively from group I through group V. In fact, the character of ground shaking at a point on the Earth's surface during an earthquake depends on additional factors not specifically addressed by this general approach. These factors include the distance from the causative fault, the orientation of the fault, the sense in which the earthquake energy is released or focused, the size of the earthquake, the basin geometry, and the presence of subsurface configurations of layers suitable for trapping or amplifying seismic energy in narrow periods of interest for engineering purposes.

\section{Rationale for Projection of Surficial Physical Properties Data to Depth}

Information on the subsurface character of Quaternary sedimentary deposits in the Los Angeles region is severely limited for many of the alluvial basins. This

\section{Earthquake Hazards in the Los Angeles Region}




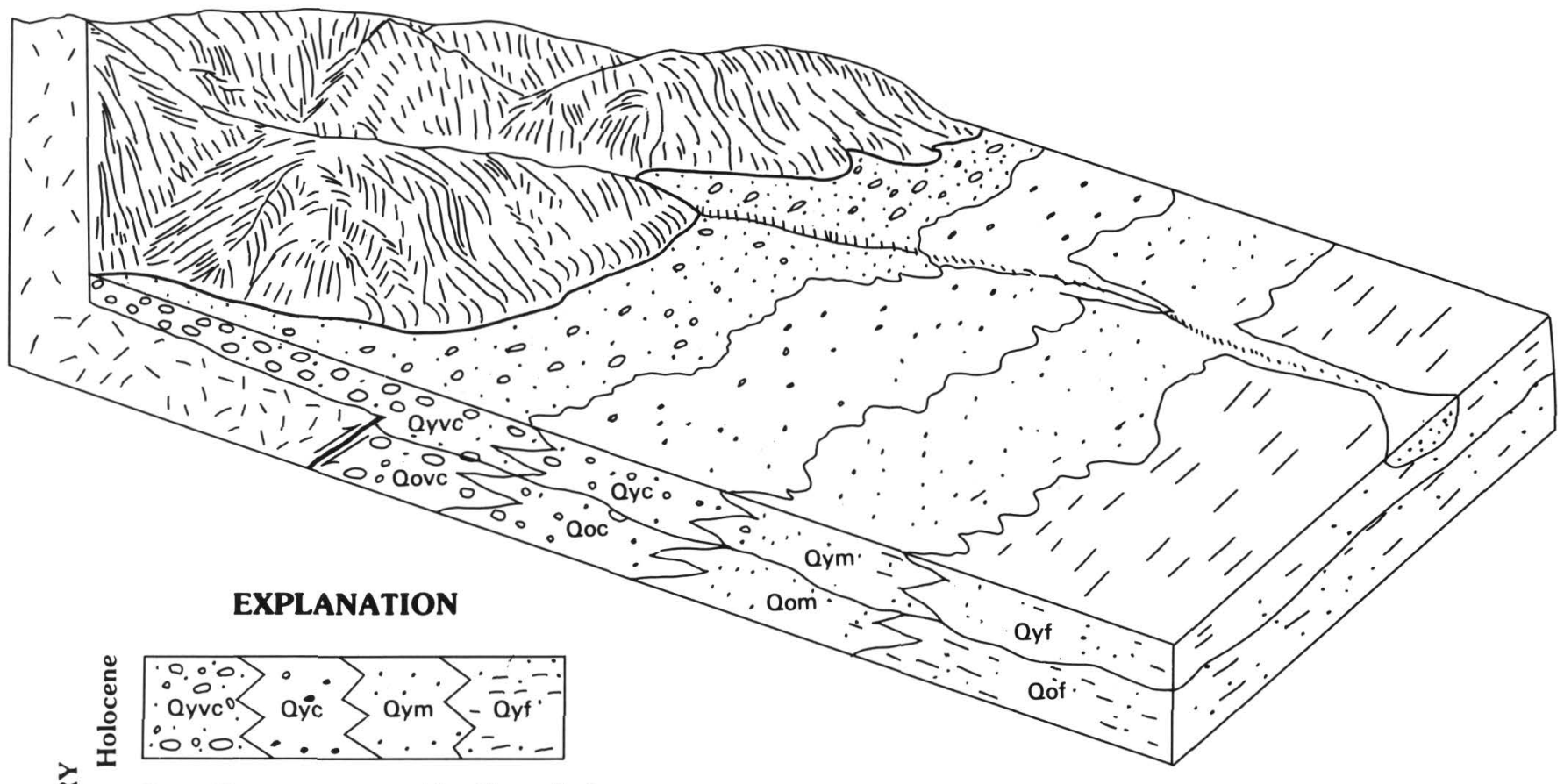

Qyvc: Very coarse-grained bouldery alluvium

Qyc: Coarse grained gravelly alluvium

Qym: Medium grained sandy alluvium

Qyf: Fine-grained silty, clayey alluvium

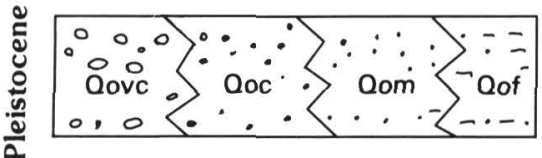

Qovc: Very coarse grained bouldery alluvium Qoc: Coarse grained gravelly alluvium Qom: Medium-grained sandy alluvium Qof: Fine-grained silty or clayey alluvium

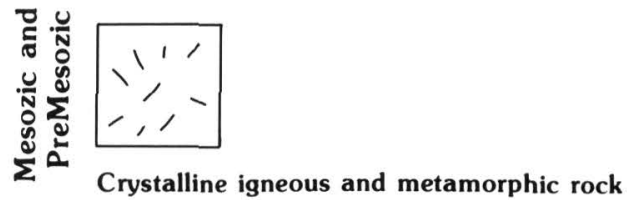

Fault: arrows indicate relative sense of displacement

FIGURE 40.-Generalized depositional model of Quaternary sedimentary deposits in the Los Angeles region. This simplistic model implies that, for sediment of a given grain-size distribution, the locus of deposition has been relatively constant during Quaternary time. To the extent that these conditions are met, the texture of sediment at the surface of the ground may indicate the texture of the geologic units at depth.

limitation has forced us to adopt a two-dimensional model of sediment deposition (fig. 40) to evaluate what is actually a three-dimensional problem, even though the model has inherent shortcomings and uncertainties. The grain-size designations mapped at the surface are assumed to represent the grain size of the sediment to depths that would influence shaking response. The depositional model reflects the distance from the source, the nature and types of the rock in the source terranes, and the facies that a given deposit may represent within the depositing alluvial system. Coarse materials at the surface near the San Gabriel Mountains, for example, are assumed to overlie areas underlain by coarsegrained materials to depths sufficient to influence shear-wave propagation and seismic response. Joyner and Fumal (this volume) suggest that a thickness equal to one-quarter wavelength of a 1-s shear wave is useful in determining a minimum depth of significance for evaluating strong ground motion. Regional geologic relations within the Quaternary sediments support this assumption; evidence confirming both the broad applicability and the shortcomings of this approach is indicated by studies of alluvial deposits and ground-water basins and logs of borings within the Los Angeles region (Eckis, 1928; California Water Rights Board, 1962; Thomas and others, 1961) and in other basins elsewhere (Schumm, 1977). That is, the coarsest Quaternary deposits occur adjacent to upland areas as alluvial fans and channel deposits of high-gradient streams that drain intensely jointed and fractured, chiefly crystalline igneous and metamorphic terranes. In contrast, finegrained deposits occur chiefly either (1) in flood plains 
as the uppermost deposits of fluvial fining-upward sequences or (2) in distal parts of all Quaternary sedimentary basins of the region and generally throughout those Quaternary alluvial basins having source areas of siltstone- and shale-rich rocks. This general trend grain size as a function of depositional environment and distance from source) is demonstrated by a transect along the Los Angeles River from the Los Angeles Civic Center to the Los Angeles harbor area using shallow boreholes (table 15) and deeper water wells (table 16). Locations of borings are shown in figures $41 \mathrm{~A}$ and $41 \mathrm{~B}$. Relative proportions of coarse alluvium intersected by borings decrease downstream as the proportions of finegrained alluvium increase downstream.

\section{Generalized Maps of Shear-Wave Velocity Groups}

Using tables 13 and 14 , we can assign ranges of $V_{S}$ to the geologic units in figures $35,36,37,38$, and 39 . When these geologic units are grouped into units having distinct ranges of shear-wave velocity, maps of nearsurface $V_{S}$ can be prepared (figs. 42, 43, 44, 45, 46). These maps provide a first approximation of likely shaking response in terms of the model presented above.

In the absence of information concerning additional geologic factors that commonly influence shaking response (depth to basement rocks, Holocene thickness, vertical variations in sediment type, and so on) (Rogers and others, this volume), these maps could provide a reasonable first approximation of relative shaking response. Although representing highly generalized areal differences in shear-wave velocity, these maps could be used for earthquake microzonation and for general planning to reduce hazards from future strong shaking. The next chapter will show how more precise estimates, which are useful in seismic design, can be derived by accounting for sediment thickness and vertical variations in lithology to depths equal to onequarter wavelength of a 1-s shear wave.

TABLE 15.-Percentage of sediment designated as "aquiclude" (nonwater-bearing) as opposed to chiefly medium- and coarse-grained sediment designated as "aquifer" (water-bearing) horizons in the subsurface of the coastal plain area of Los Angeles County, after Thomas and others (1961)

[Wells listed in sequence from proximal (near) to distal (far) positions with respect to source of sediments. Proportion of fines in a section increases generally in a downstream direction, but trend reflects local sources of sediment. Locations of arrays ane shown in fig. 41A]

\begin{tabular}{|c|c|c|c|c|}
\hline $\begin{array}{c}\text { State well } \\
\text { no. }\end{array}$ & $\begin{array}{l}\text { Section } \\
\text { thickness, } \\
\text { in } \mathrm{ft}\end{array}$ & $\begin{array}{l}\text { Aquiclude } \\
\text { thickness, } \\
\text { in } \mathrm{ft}\end{array}$ & $\begin{array}{l}\text { Proportion of } \\
\text { fine sediment, } \\
\text { in percent }\end{array}$ & $\begin{array}{l}\text { Proportion of } \\
\text { medium and coarse } \\
\text { sediment, in percent }\end{array}$ \\
\hline \multicolumn{5}{|c|}{ Section K-K'-K", Los Angeles Civic Center, Dominguez Gap to Terminal Island } \\
\hline 2S/13W-10P6 -------- & 700 & 275 & 39 & 61 \\
\hline $2 S / 13 W-15 M 3------$ & 700 & 345 & 49 & 51 \\
\hline 2S/13W-15P8 -------- & 690 & 350 & 51 & 49 \\
\hline $2 S / 13 W-22 P 2-\cdots---$ & 660 & 365 & 55 & 45 \\
\hline $2 S / 13 W-34 A 2$ & 640 & 415 & 65 & 35 \\
\hline $2 S / 13 W-03 R 1-------$ & 600 & 285 & 48 & 52 \\
\hline 3S/13W-11E1 -------- & 600 & 210 & 35 & 65 \\
\hline 3S/13W-15H1 - - - - & 575 & 200 & 35 & 65 \\
\hline $3 \mathrm{~S} / 13 \mathrm{~W}-22 \mathrm{H} 7$ & 560 & 314 & 56 & 44 \\
\hline $3 S / 13 W-26 L 2------$ & 560 & 357 & 64 & 36 \\
\hline 3S/13W-26N1 --- & 550 & 286 & 52 & 48 \\
\hline 3S/13W-35P1 -- - - & 550 & 314 & 57 & 43 \\
\hline 4S/13W-03R1 ------- & 540 & 236 & 44 & 56 \\
\hline 4S/13W-15A2 ------ & 530 & 314 & 59 & 41 \\
\hline 4S/13W-23M1 ------ & 520 & 143 & 27 & 73 \\
\hline $4 \mathrm{~S} / 13 \mathrm{~W}-27 \mathrm{H} 1$ & 520 & 136 & 26 & 74 \\
\hline 4S/13W-35M3 --- & 510 & 428 & 84 & 16 \\
\hline 5S/13W-03K1 ------ & 500 & 286 & 57 & 43 \\
\hline
\end{tabular}

116 Earthquake Hazards in the Los Angeles Region 
TABLE 15.-Percentage of sediment designated as "aquiclude" (nonwater-bearing) as opposed to chiefly medium- and coarse-grained sediment designated as "aquifer" (water-bearing) horizons in the subsurface of the coastal plain area of Los Angeles County, after Thomas and others (1961)-Continued

\begin{tabular}{|c|c|c|c|c|}
\hline $\begin{array}{c}\text { State well } \\
\text { no. }\end{array}$ & $\begin{array}{l}\text { Section } \\
\text { thickness, } \\
\text { in } \mathrm{ft}\end{array}$ & $\begin{array}{l}\text { Aquiclude } \\
\text { thirkness, } \\
\text { in } \mathrm{ft}\end{array}$ & $\begin{array}{l}\text { Proportion of } \\
\text { fine sediment. } \\
\text { in percent }\end{array}$ & $\begin{array}{l}\text { Proportion of } \\
\text { medium and coarse } \\
\text { sediment, in percent }\end{array}$ \\
\hline \multicolumn{5}{|c|}{ Sextion Q-Q', along the Orange-Los Angeles County line from the Puente Hills to Seal Beach } \\
\hline $3 \mathrm{~S} / 11 \mathrm{~W}-12 \mathrm{~J} 1$ & 693 & 329 & 47 & 53 \\
\hline $3 \mathrm{~S} / 11 \mathrm{~W}-12 \mathrm{P} 2-\cdots$ & 700 & 200 & 29 & 71 \\
\hline $3 S / 11 W-26 B 1-\cdots$ & 507 & 357 & 70 & 30 \\
\hline $3 \mathrm{~S} / 11 \mathrm{~W}-26 \mathrm{E} 1 \mathrm{-}-$ & 464 & 300 & 66 & 34 \\
\hline $3 \mathrm{~S} / 11 \mathrm{~W}-27 \mathrm{~N} 1$ & 457 & 271 & 59 & 41 \\
\hline 3S/11W-34E1 - & 450 & 243 & 54 & 46 \\
\hline 4S/11W-05A1 ----- & 436 & 293 & 67 & 33 \\
\hline 4S/11W-05P4 ----- & 428 & 200 & 47 & 53 \\
\hline 4S/11W-08E2 ------ & 428 & 236 & 55 & 45 \\
\hline $4 \mathrm{~S} / 11 \mathrm{~W}-18 \mathrm{~J} 1$ & 427 & 293 & 69 & 31 \\
\hline 4S/11W-30M1 - & 414 & 286 & 69 & 31 \\
\hline $4 \mathrm{~S} / 12 \mathrm{~W}-25 \mathrm{H} 1$ & 408 & 229 & 56 & 44 \\
\hline $5 \mathrm{~S} / 12 \mathrm{~W}-02 \mathrm{~B} 4-\cdots-$ & 406 & 129 & 32 & 58 \\
\hline $5 \mathrm{~S} / 12 \mathrm{~W}-02 \mathrm{R} 1 \ldots$ & 402 & 236 & 59 & 41 \\
\hline $5 \mathrm{~S} / 12 \mathrm{~W}-11 \mathrm{G} 1 \mathrm{--}$ & 402 & 193 & 48 & 52 \\
\hline $5 \mathrm{~S} / 12 \mathrm{~W}-10 \mathrm{~A} 1$ & 400 & 229 & 57 & 43 \\
\hline
\end{tabular}

Section M-M'-M", from Whittier Narrows Dam south to the Pacific Ocean west of Seal Beach

\begin{tabular}{|c|c|c|c|c|}
\hline $2 \mathrm{~S} / 11 \mathrm{~W}-06 \mathrm{~J} 1 \mathrm{-}$ & 800 & 15 & 2 & 98 \\
\hline $2 \mathrm{~S} / 11 \mathrm{~W}-12 \mathrm{~A} 6$ & 800 & 180 & 22 & 78 \\
\hline $2 \mathrm{~S} / 12 \mathrm{~W}-13 \mathrm{D} 7 \mathrm{--------}$ & 780 & 175 & 22 & 78 \\
\hline $2 \mathrm{~S} / 12 \mathrm{~W}-23 \mathrm{~B} 4-------$ & 750 & 150 & 20 & 80 \\
\hline $2 \mathrm{~S} / 12 \mathrm{~W}-27 \mathrm{G} 5-------$ & 750 & 180 & 24 & 76 \\
\hline $2 \mathrm{~S} / 12 \mathrm{~W}-28 \mathrm{~J} 6 \quad------$ & 690 & 150 & 22 & 78 \\
\hline 3S/12W-04D2 -------- & 725 & 230 & 32 & 68 \\
\hline 3S/12W-04Q2 - - ---- & 665 & 220 & 33 & 67 \\
\hline 3S/12W-09L1 -------- & 700 & 350 & 50 & 50 \\
\hline $3 S / 12 W-16 L 1 \quad------$ & 690 & 415 & 60 & 40 \\
\hline $3 \mathrm{~S} / 12 \mathrm{~W}-28 \mathrm{H} 3 \quad-------$ & 675 & 435 & 64 & 36 \\
\hline 3S/12W-33F1 -------- & 650 & 400 & 62 & 38 \\
\hline $4 S / 12 W-09 B 3--------$ & 640 & 490 & 76 & 24 \\
\hline $4 \mathrm{~S} / 12 \mathrm{~W}-16 \mathrm{H} 1$ & 630 & 360 & 57 & 43 \\
\hline 4S/12W-21M4 ------ & 630 & 215 & 34 & 66 \\
\hline $4 \mathrm{~S} / 12 \mathrm{~W}-28 \mathrm{H} 10-------$ & 625 & 230 & 37 & 63 \\
\hline
\end{tabular}

\section{SUMMARY}

Geologic conditions in Quaternary sediments vary across a region and commonly influence shaking response during earthquakes. Delineating surficial geologic units in order to evaluate areal differences in shaking response from future earthquakes requires knowledge of the surface and subsurface distribution of Quaternary sedimentary deposits according to their wave-propagation characteristics. In the absence of detailed subsurface information for all the alluvial basins in the Los Angeles region, a two-dimensional model of the areal distribution of Quaternary sediments according to age and grain size is used to characterize likely relative ground response by means of readily available data. Derivative maps that broadly characterize the near-surface shear-wave velocities across a wide geographic region provide a first approximation of the likely areal variability in relative shaking response from future earthquakes. 
TABLE 16.-Relative proportions of gravel, sand, and silt and (or) clay expressed as a percentage of total alluvial stratigraphic thickness as logged in CALTRANS exploratory boreholes

[Boreholes mainly along State highways 11 and 7 (Harbor and Long Beach freeways) from near the Los Angeles Civic Center to the Long Beach and Los Angeles areas (north to south) across the Los Angeles river flood plain. Locations of boreholes shown schematically in fig. 41B. tr, trace]

\begin{tabular}{|c|c|c|c|c|c|c|}
\hline $\begin{array}{c}\text { Freeway } \\
\text { no. }\end{array}$ & $\begin{array}{c}\text { Borehole } \\
\text { no.' }\end{array}$ & $\begin{array}{c}\text { Borehole } \\
\text { depth, in } \mathrm{ft}\end{array}$ & $\begin{array}{c}\text { Gravel, }^{2} \\
\text { in percent }\end{array}$ & $\begin{array}{c}\text { Sand, } \\
\text { in percent }\end{array}$ & $\begin{array}{l}\text { Silt and } \\
\text { clay, } \\
\text { in percent }\end{array}$ & Comments \\
\hline $101---$ & $53-722-\mathrm{B} 3$ & 48 & 0 & 13 & 87 & $\begin{array}{l}\text { Siltstone is local } \\
\text { sediment source. }\end{array}$ \\
\hline 5 & 53-1183-B3 & $35 / 33^{5}$ & 36 & 64 & 0 & \\
\hline $5-----$ & $53-1360-\mathrm{B} 2$ & 23 & 75 & 25 & 0 & \\
\hline 5 & $53-601-\mathrm{B} 3$ & 35 & 67 & 33 & tr & \\
\hline $7-----$ & 53-2505-B12 & $56 / 22^{5}$ & 18 & 27 & 55 & $\begin{array}{l}\text { Siltstone is local } \\
\text { sediment source. }\end{array}$ \\
\hline $7----$ & 53-1152-B2 & 40 & 38 & 42 & 20 & \\
\hline $7---$ & $53-840-B 6$ & 75 & 5 & 90 & 5 & \\
\hline 7 ----- & $53-833-B 4$ & 55 & 0 & 47 & 58 & \\
\hline 7 - & 53-828-B5 & 90 & 7 & 82 & 11 & \\
\hline $7-----$ & 53-824-B5 & 68 & 0 & 76 & 24 & \\
\hline $7---$ & 53-2143-B17 & 90 & $\operatorname{tr}$ & 68 & 32 & \\
\hline $7---$ & $53-1210-B 4$ & 70 & 6 & 77 & 17 & \\
\hline $7-----$ & $53-725-B 3$ & 33 & 0 & $94^{6}$ & 6 & \\
\hline $11---$ & $53-538-\mathrm{B} 1$ & 27 & 59 & 41 & 0 & \\
\hline $11---$ & 53-793-B1 & 45 & 78 & 0 & 22 & \\
\hline $11----$ & $53-856-\mathrm{B} 2$ & 26 & 46 & 54 & 0 & \\
\hline $11 \ldots$ & 53-906-B3 & 40 & 20 & 80 & 0 & \\
\hline $11---$ & 53-926-B6 & 60 & 0 & 77 & 23 & \\
\hline $11 \ldots$ & 53-981-B3 & 40 & $\mathbf{0}$ & $82^{8}$ & 18 & \\
\hline $11----$ & 53-955-B3 & 50 & 0 & $88^{8}$ & 12 & \\
\hline $11----$ & $53-960-B 1$ & 48 & 0 & $85^{8}$ & 15 & \\
\hline $11----$ & 53-964-B3 & 56 & 0 & 80 & 20 & \\
\hline $11---$ & $53-976-B 2$ & 35 & 0 & 100 & 0 & \\
\hline
\end{tabular}

${ }^{1}$ CALTRANS borehole code. For example, in 53-7583-B3, 53 denotes Los Angeles County, 7583 is bridge or structure number, and B1 is boring number.

${ }^{2}$ Includes intervals containing gravelly sand, sandy gravel, clayey gravel, pebbly sand, and very coarse detritus such as cobbles and boulders.

${ }^{3}$ Includes intervals containing silty sand or clayey sand.

${ }^{4}$ Includes intervals containing sandy or silty clay and sandy or clayey silt.

$5_{35 / 33}$ denotes $35-\mathrm{ft}$ boring that penetrated $33 \mathrm{ft}$ of alluvium before entering bedrock. Percentages computed relative to thickness of alluvium.

${ }^{6}$ All sand logged as fine sand.

\section{Earthquake Hazards in the Los Angeles Region}




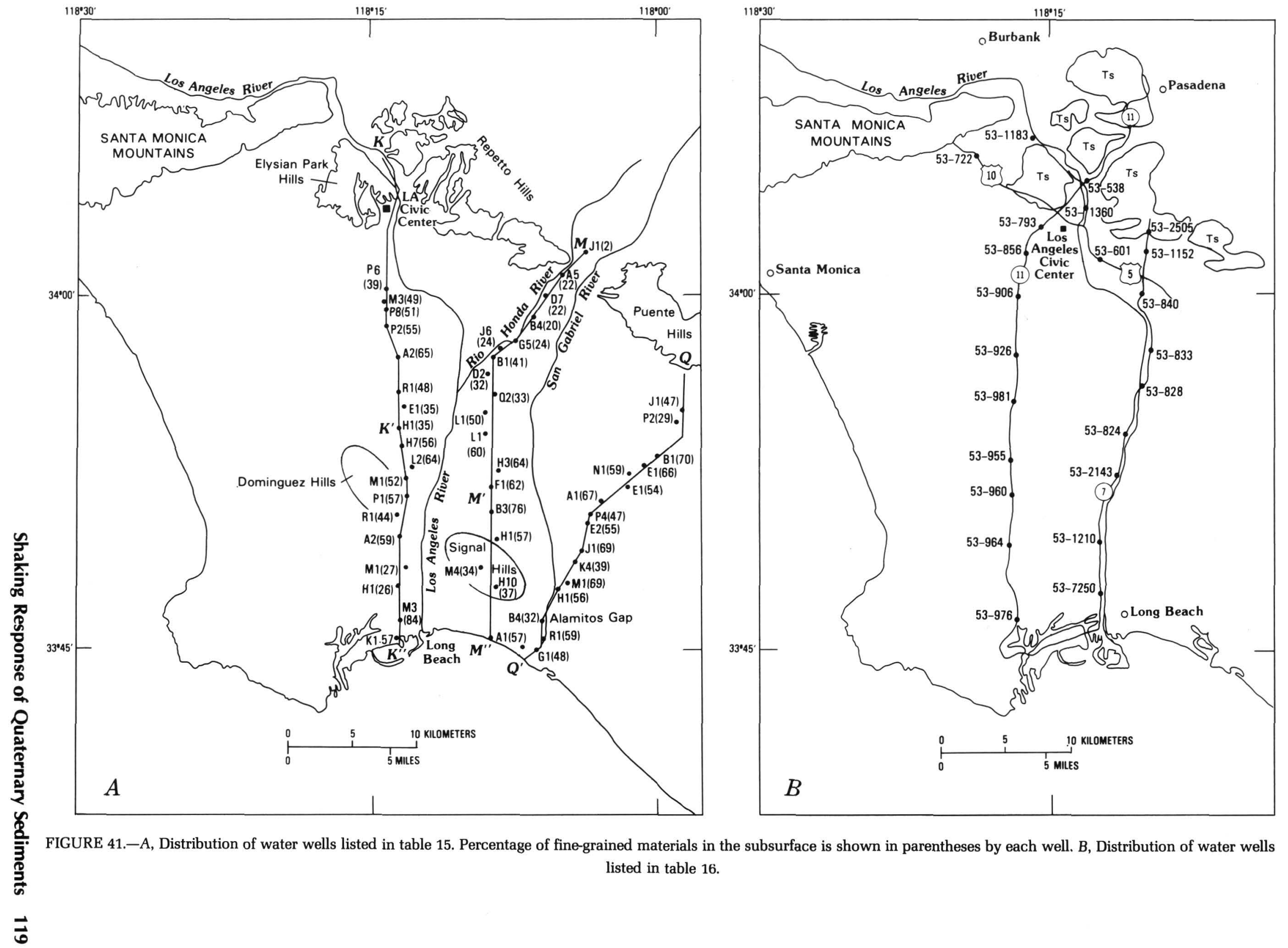




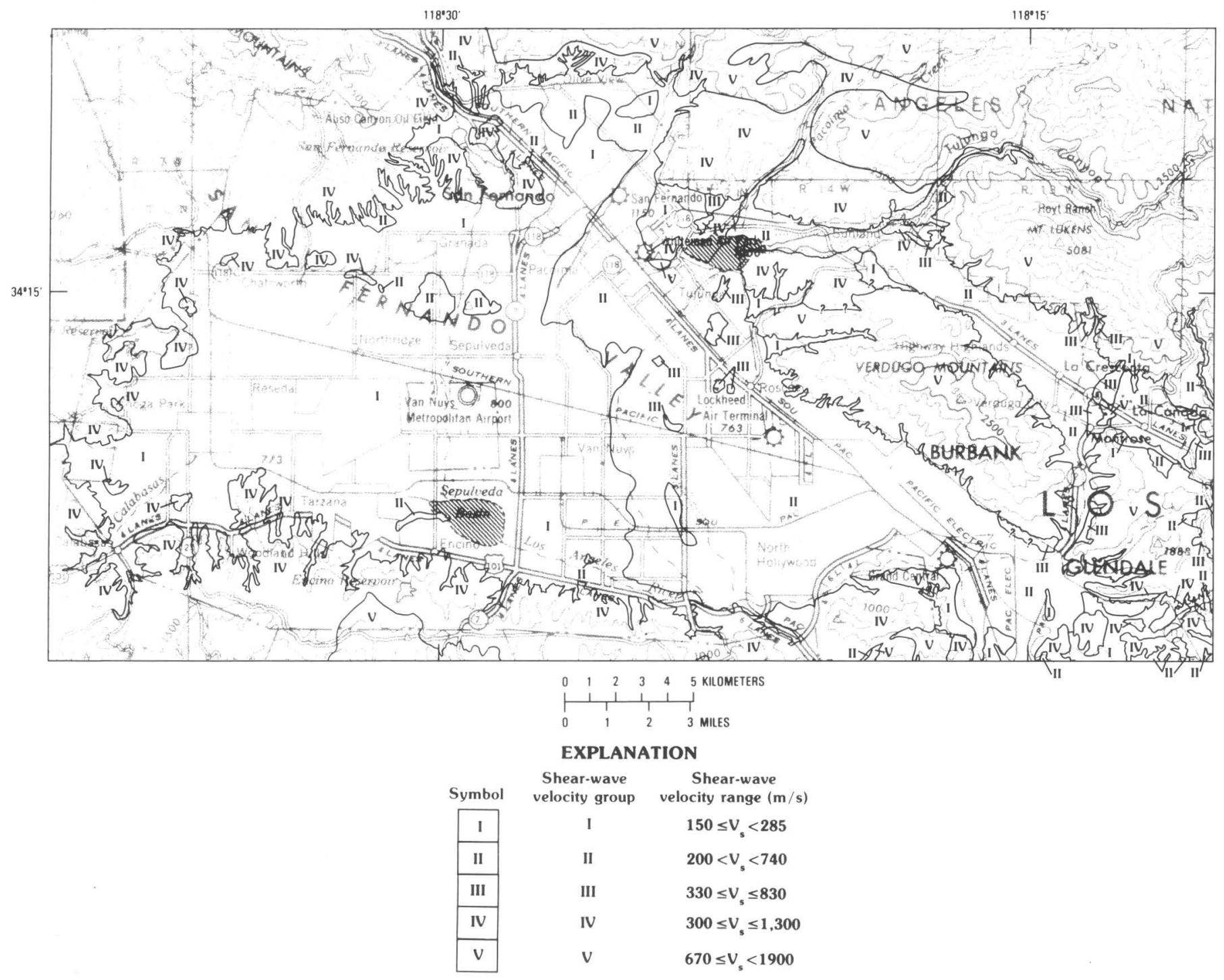

FIGURE 42.-Generalized shear-wave velocity groups in the San Fernando Valley. Surficial textural characteristics are assumed to extend to depths of significance to shaking response. 


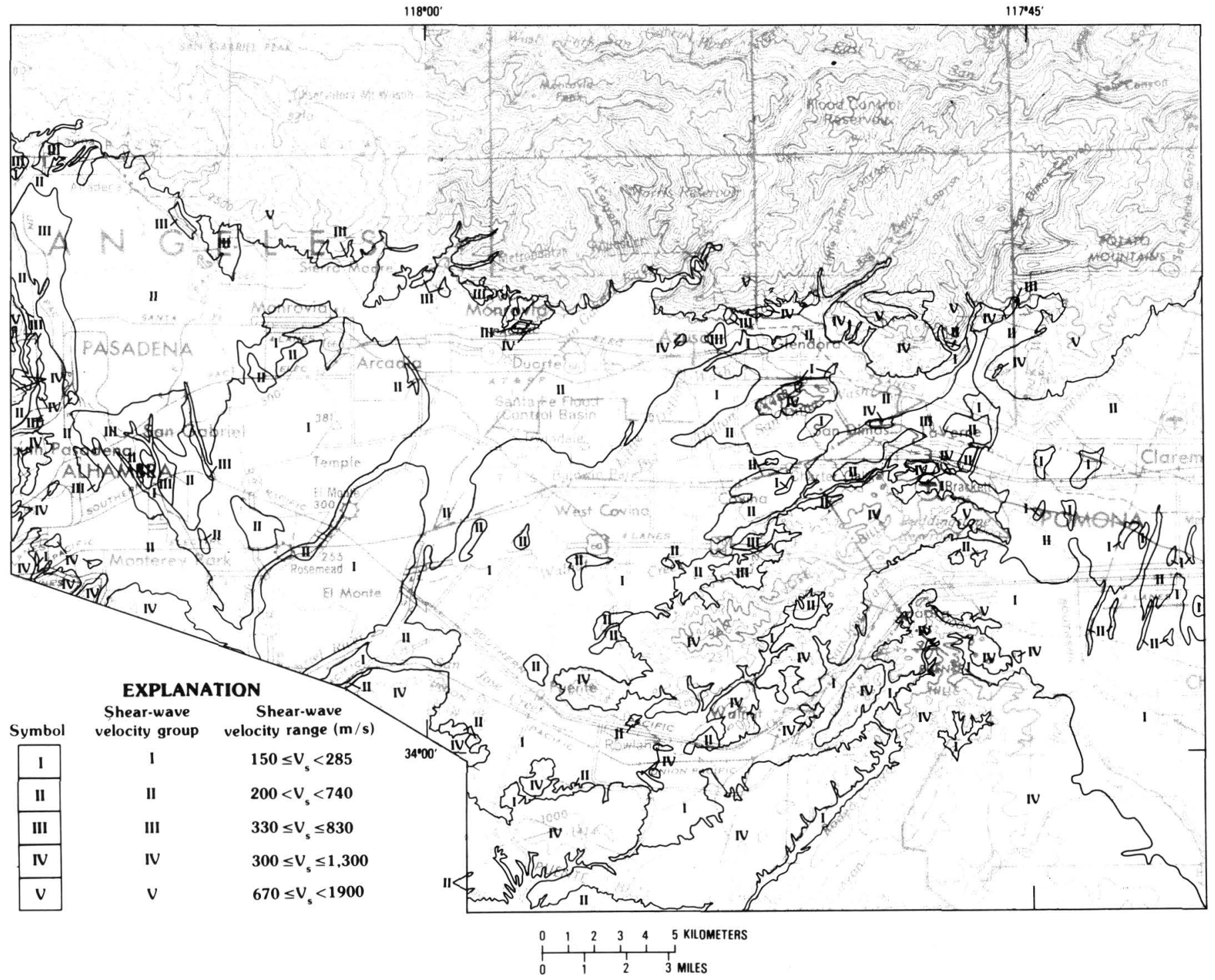

FIGURE 43.-Generalized shear-wave velocity groups in the San Gabriel Valley. Surficial textural characteristics are assumed to extend to depths of significance to shaking response. 


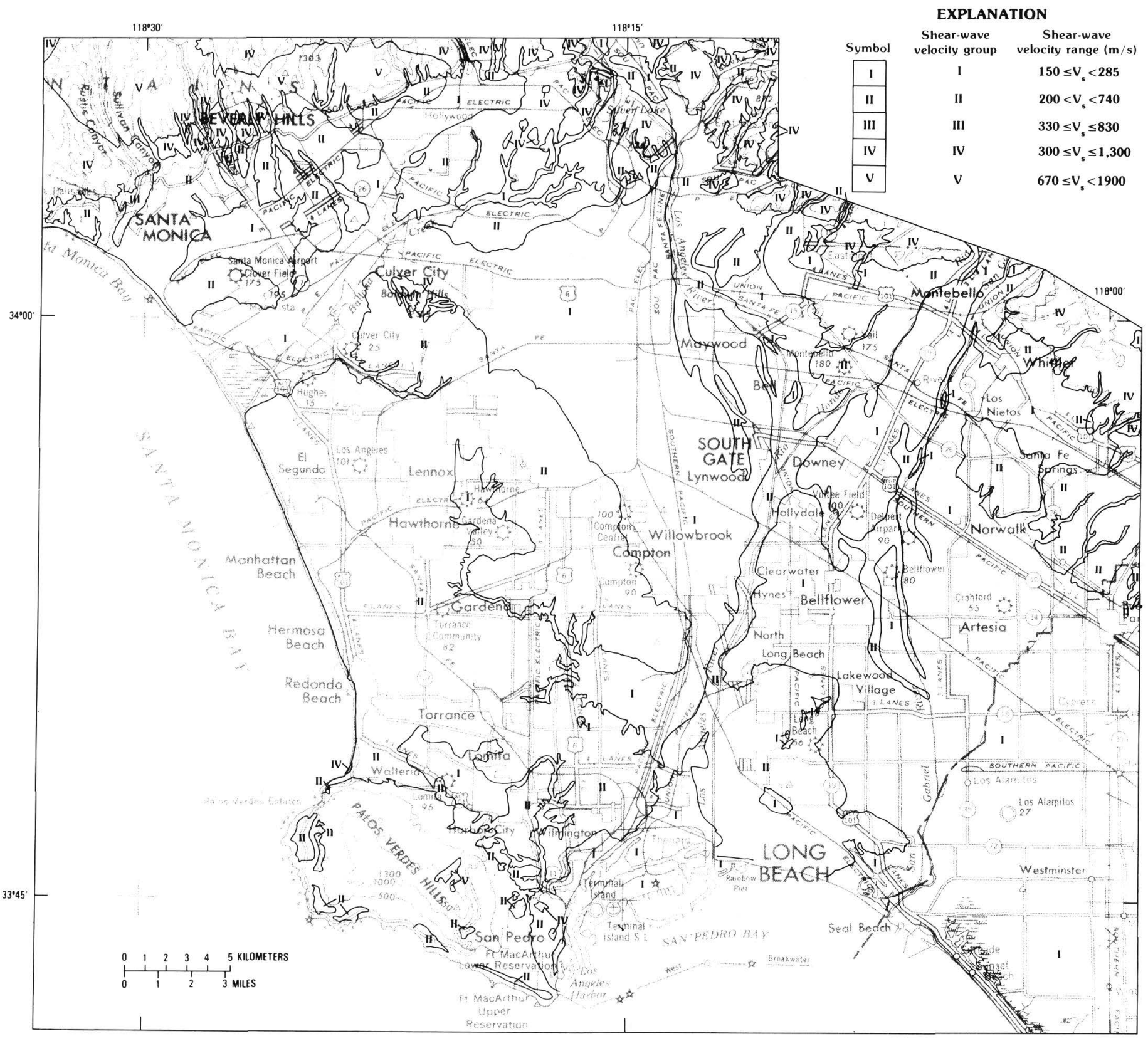

FIGURE 44.-Generalized shear-wave velocity groups in part of the Los Angeles basin. Surficial textural characteristics are assumed to extend to depths of significance to shaking response. 


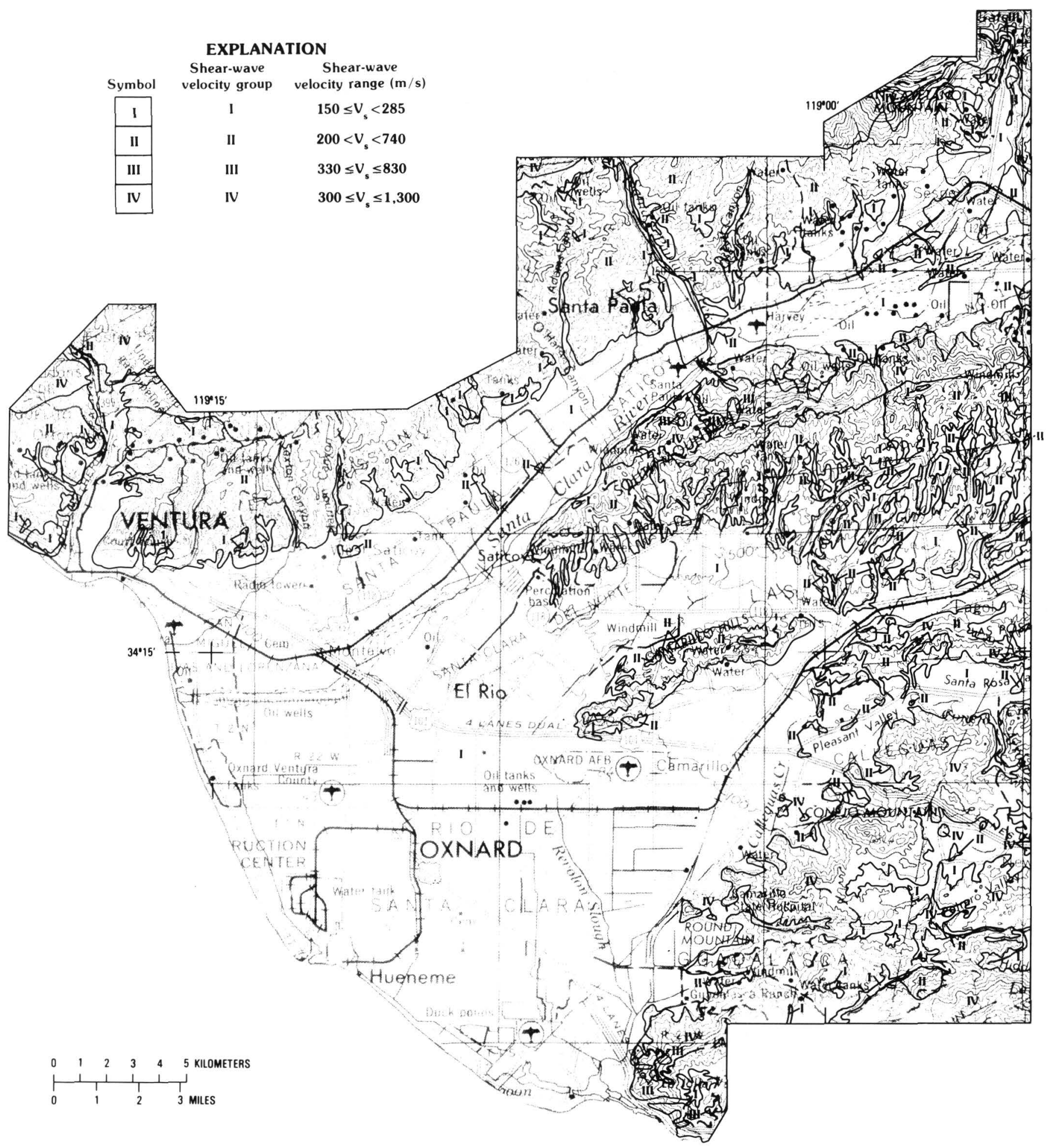

FIGURE 45.-Generalized shear-wave velocity groups in the Oxnard Plain area. Surficial textural characteristics are assumed to extend to depths of significance to shaking response. 


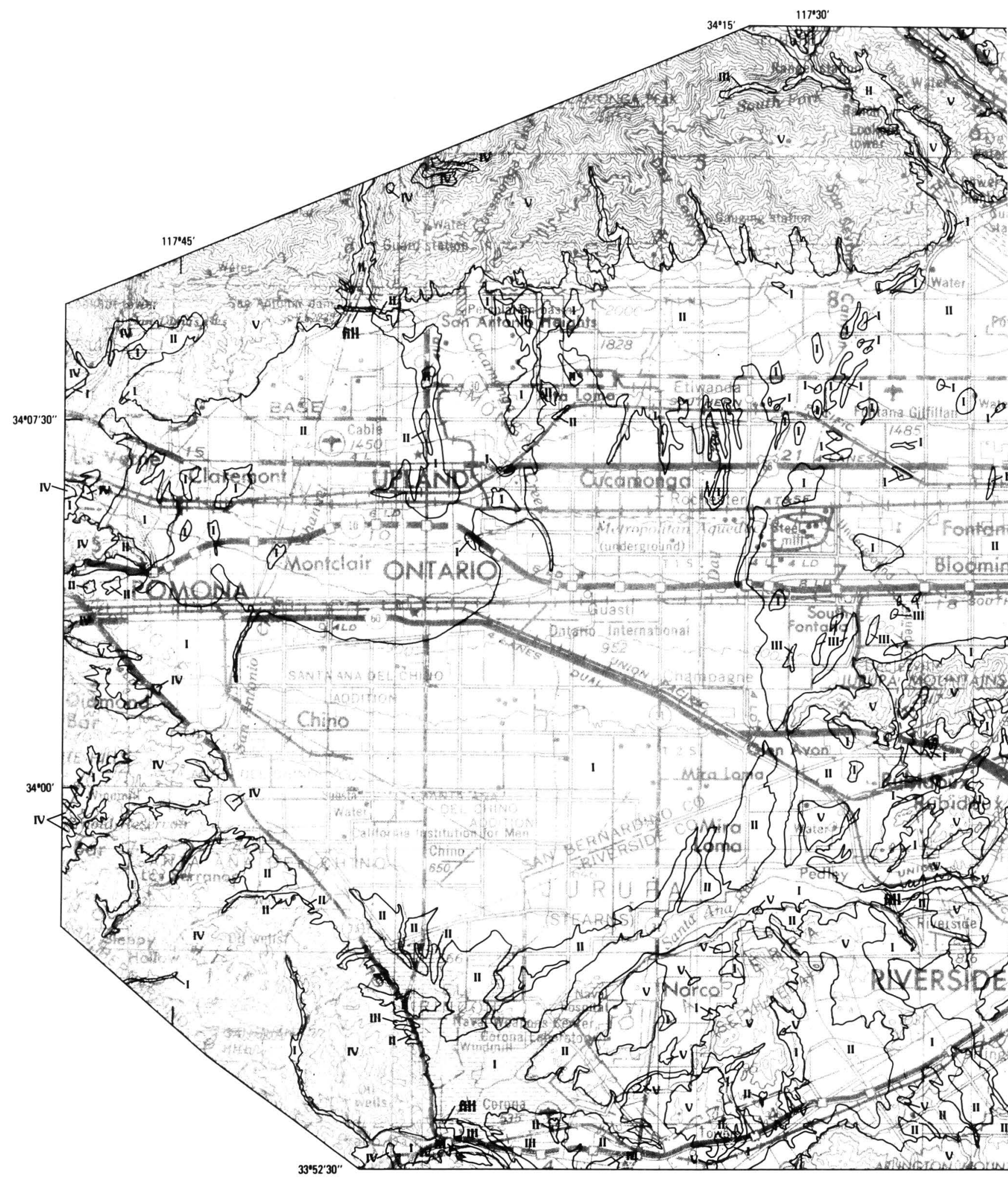

FIGURE 46.-Generalized shear-wave velocity groups in the upper Santa Ana River basin. Surficial textural characteristics are assumed to extend to depths of significance to shaking response.

\section{Earthquake Hazards in the Los Angeles Region}




\section{EXPLANATION}

\begin{tabular}{|c|c|c|}
\hline Symbol & $\begin{array}{l}\text { Shear-wave } \\
\text { velocity group }\end{array}$ & $\begin{array}{c}\text { Shear-wave } \\
\text { velocity range }(\mathrm{m} / \mathrm{s})\end{array}$ \\
\hline I & I & $150 \leq V_{s}<285$ \\
\hline II & II & $200<V_{s}<740$ \\
\hline III & III & $330 \leq V_{8} \leq 830$ \\
\hline IV & IV & $300 \leq V_{s} \leq 1,300$ \\
\hline$v$ & v & $670 \leq V_{s}<1900$ \\
\hline
\end{tabular}

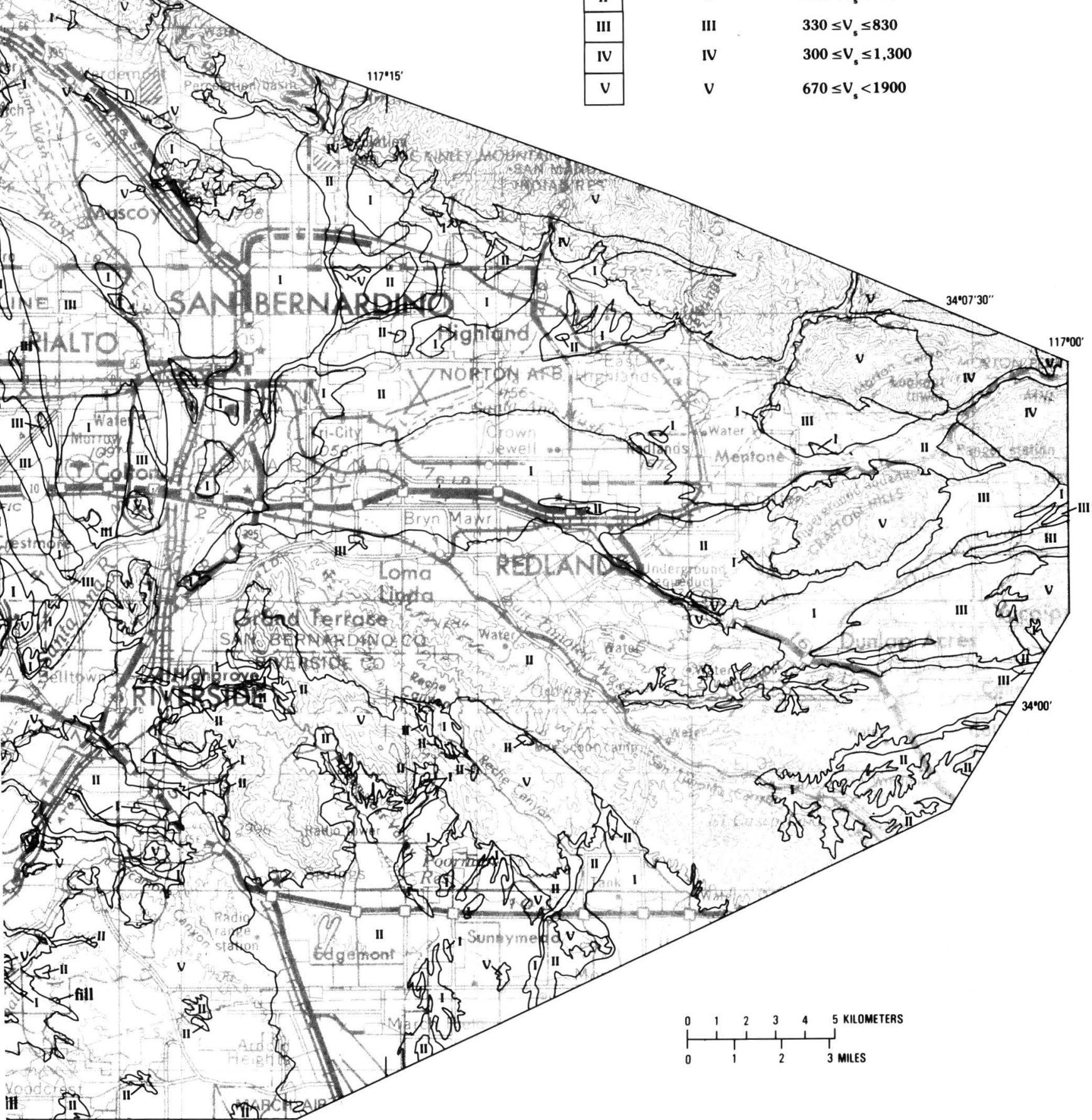




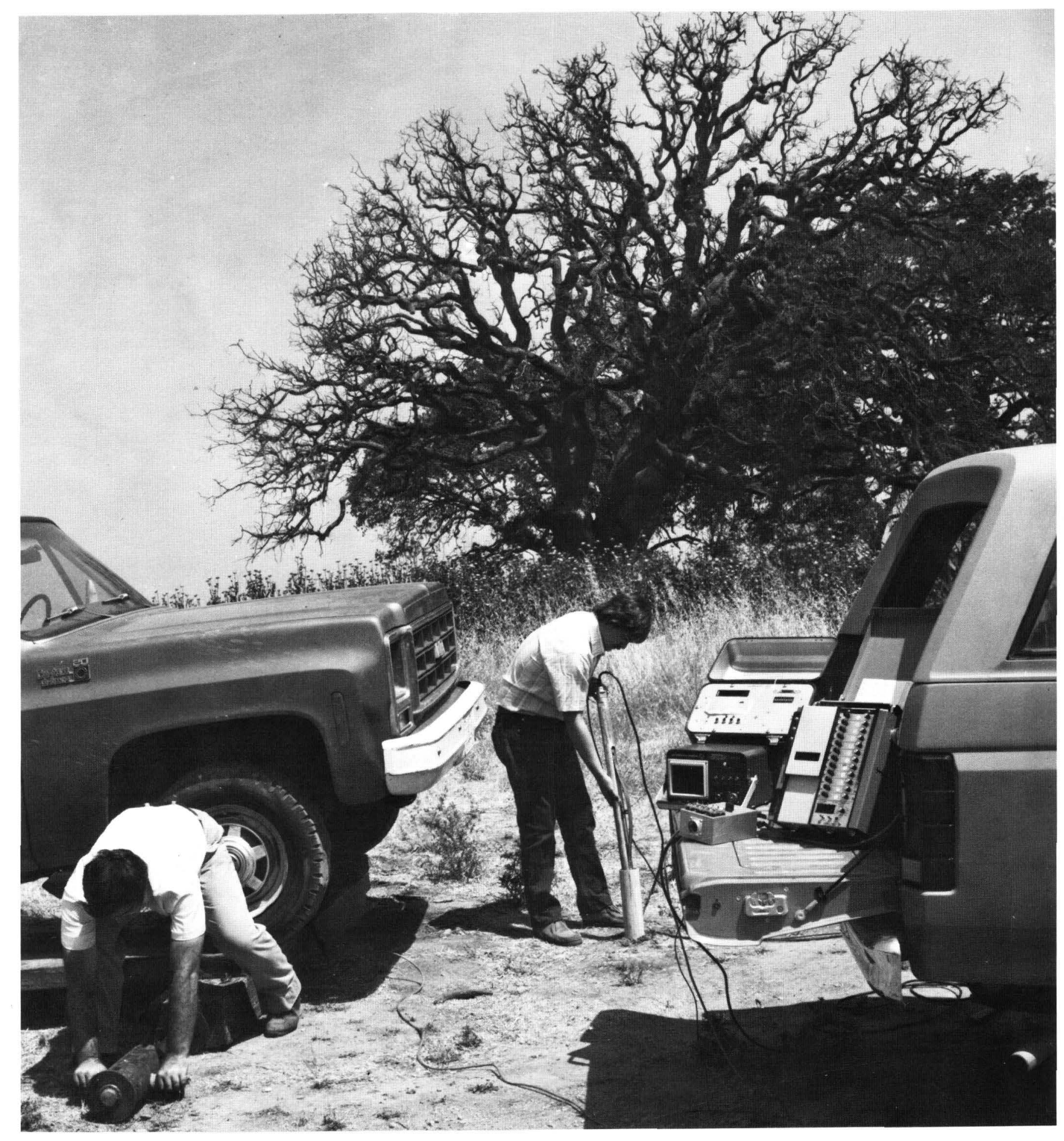

126 Earthquake Hazards in the Los Angeles Region 


\section{MAPPING SHEAR-WAVE VELOCITIES OF NEAR-SURFACE GEOLOGIC MATERIALS}

By T. E. Fumal and J. C. Tinsley

\section{INTRODUCTION}

The distribution of damage caused by earthquake ground shaking commonly reflects areal differences in local geologic conditions. Damage on thick deposits of unconsolidated sediments, for example, is frequently observed to be much greater than that on bedrock at nearby locations. To map geographic variations in shaking response, parameters are needed that can be used to predict these variations in ground motion due to differences in site geology. Recent studies indicate that shear-wave velocity is a critical factor in determining the amplitude of ground motion Uoyner and Fumal, this volume) and thus might be a useful parameter in preparing predictive maps of strong ground motion.

Measurements of near-surface shear-wave velocities are now available for many sites in the San Francisco Bay and Los Angeles regions of California (Gibbs and others, 1975, 1976, 1977, 1980; Fumal and others, 1981, 1982, 1983). Comparisons between the shear-wave velocity data and several measures of ground motion demonstrate the potential usefulness of shear-wave velocity for predicting site effects on ground motion. For the San Francisco Bay region, Borcherdt and others (1978) have found that average shear-wave velocity to a depth of $30 \mathrm{~m}$ correlated inversely with intensities from the 1906 San Francisco earthquake. The intensities experienced at sites having mean shear-wave velocities of $300 \mathrm{~m} / \mathrm{s}$, for example, were about two units higher than those experienced at sites at the same distance from the ruptured fault but having velocities near $800 \mathrm{~m} / \mathrm{s}$. A similar inverse correlation was found between average shear-wave velocity and amplifications of low-strain ground motion generated by nuclear explosions. Joyner and Fumal (this volume) present a relation between site shear-wave velocity and peak horizontal ground velocity measured at strong-motion stations in central and southern California.
If maps of mean shear-wave velocity were available, these important relations could be used to prepare maps showing predicted levels of various ground-motion parameters. Unfortunately, it is expensive and time consuming to measure seismic velocities at the large number of sites necessary to adequately characterize a geologically complex region. As an alternative, we have identified relations between shear-wave velocity and several other physical properties of geologic materials that can be mapped more readily on a regional scale.

We have developed a method for assigning shearwave velocities to the mapped geologic units in the San Francisco Bay region (Fumal, 1978). According to this method, the geotechnical measures that show useful correlations with shear-wave velocity are texture (relative grain-size distribution) and standard penetration resistance for unconsolidated sedimentary deposits and fracture spacing, hardness, and lithology for bedrock materials.

In this chapter, we extend our analysis to include the Los Angeles region. We first briefly review the factors that affect shear-wave velocity and discuss correlations between seismic velocity and other physical properties of the geologic units. We next examine the shear-wave velocities of the various geologic units in the Los Angeles region and determine which units or groups of units have distinct velocity characteristics. Finally, we demonstrate how these velocity units, together with information on the three-dimensional distributions of sedimentary deposits and bedrock materials, can be used to construct a map of mean shear-wave velocity for the urbanized upper Santa Ana River basin. In a subsequent chapter (Joyner and Fumal, this volume), this map is used to prepare predictive maps of selected groundmotion parameters. Our technique of mapping mean shear-wave velocities of near-surface geologic materials differs from the more simplified approach described by Tinsley and Fumal (this volume) in that it accounts for

Shear-Wave Velocities of Near-Surface Materials

127 
areal variations in the thickness of sedimentary deposits and vertical variations in lithology.

\section{GEOLOGIC FACTORS AFFECTING SHEAR-WAVE VELOCITY}

Shear-wave velocity is dependent on the rigidity of the structure of a soil or rock mass and is controlled by the porosity of the structure and the forces holding the structure together, including cohesion, friction, cementation, and effective stress. The primary physical properties that control the velocities of shear waves in sediments are different from those in rock and so will be discussed separately.

\section{Soil}

Hardin and Drenevich (1972) have conducted laboratory studies investigating the effects of numerous factors on the shear modulus in soils. The shear modulus is equal to the product of the soil density and the square of the shear-wave velocity. For the soils that we studied, density variations are small $\left(1.7-2.15 \mathrm{~g} / \mathrm{cm}^{3}\right)$ and correlate with the shear-wave velocity, so that the shear modulus is proportional to the square of the shear-wave velocity. We would therefore expect that the soilcondition factors found by Hardin and Drenevich to have the most important effect on shear modulus-void ratio and effective mean principal stress (or degree of saturation in partially saturated cohesive soils)-are also important for shear-wave velocity.

Hardin and Drenevich found that void ratio (the ratio of the volume of voids to the volume of solids) is one of the most important parameters affecting the shear modulus in both clean sands and cohesive soils. Void ratio is dependent on the grain-size characteristics of the soil (primarily mean particle size and sorting (Meade, 1968)) and the packing density of the soil particles. We have used soil texture (relative grain-size distribution) as a partial measure of void ratio. Texture is particularly useful, as it can be readily determined in the field by techniques developed by the U.S. Soil Conservation Service (Soil Survey Staff, 1951). The sedimentary deposits in the San Francisco Bay region were divided into four textural categories based on grain-size distribution: (1) clay and silty clay, (2) silt loam and sandy clay, (3) sand, and (4) gravel. In these sediments, shear-wave velocity generally increases as mean grain size increases.

Void ratio is also dependent on the packing density of the soil particles. The relative density of sands is frequently estimated directly by using the results of the
Standard Penetration Test (SPT) and the classification given by Terzaghi and Peck (1967). For cohesive soils, Terzaghi and Peck have suggested using the SPT to estimate the unconfined compressive strength (twice the undrained shear strength), which increases as void ratio decreases. Furthermore, because the SPT sampler penetration primarily involves dynamic soil shear behavior, Schmertman (1978) has suggested that it is reasonable to expect a correlation between $N$ values (resiśtance, measured in blows per foot) and shear-wave velocities. We found that, for the San Francisco data, shear-wave velocity increases as penetration resistance increases for both cohesionless and cohesive soils, and we used these relations to subdivide the clay and silty clay and sand categories.

In addition to void ratio, mean principal effective stress is a very important factor controlling shear modulus in laboratory samples at a given strain amplitude (Hardin and Drenevich, 1972). It is reasonable, then, to expect an increase in shear-wave velocity with depth in sedimentary deposits even if there is little textural variation. This relation was confirmed at several sites in the San Francisco Bay area on thick sections of loose to medium-dense sands. Most often, however, changes in velocity correlated with changes in texture, soil stiffness, or age. Many sites having layers of stiff clay and silt or dense sand 15 to $25 \mathrm{~m}$ thick showed no significant increase in velocity with depth, an indication that factors other than effective stress controlled velocity in these deposits.

Time-dependent processes, including thixotropic hardening of clays and cementation, can increase the rigidity of the sediment structure beyond values solely attributable to void ratio and effective stress. Laboratory studies (Hardin and Black, 1968; Stokoe and Richart, 1973) show that these effects can increase shear velocity by 1 to 2 percent for silty sand and by 10 to 15 percent for kaolinite clay per log cycle of time. For natural sediments, our field measurements indicate that these time-dependent velocity increases are much more important than they appear to be from laboratory studies and may become the dominant factor controlling shear velocity (Fumal, 1978) (see fig. 50).

\section{Rock}

Studies by Walsh and Brace (1966) have suggested that the elastic behavior of rock depends very strongly on the total porosity of the rock mass in the form of both cracks and intergranular pores. They found that the effect of narrow elliptical cracks on the elastic moduli is nearly the same as that of an equal concentration of roughly spherical pores, in spite of the fact that the

\section{Earthquake Hazards in the Los Angeles Region}


porosity in the case of the pores is much greater than that in the case of the cracks. Thus, formation of cracks in a rock could significantly lower the elastic modulus (and hence the seismic velocity) without changing the total porosity appreciably. Furthermore, Walsh and Brace have found that the longest cracks, such as joints and bedding-plane partings, have the greatest effect. An estimate of fracture spacing therefore should correlate with shear-wave velocity.

The hardness (relative resistance to penetration) (see fig. 55) of the intact rock also affects the shear-wave velocity. Hardness, a measure of the strength and toughness of rock, is related to the lithology and the characteristic fabric of each rock type. Igneous rocks have crystalline fabrics consisting of interlocking crystals and are generally hard. Sandstones, on the other hand, have a cemented fabric in which the space between grains is partially or completely filled with cement. Sandstones display a wide variation in hardness depending on the degree of induration.

The fracture spacing and hardness of bedrock materials are strongly affected by weathering processes. Weathering causes the progressive disintegration of rock through both mechanical and chemical processes. Mechanical weathering primarily involves the opening of existing fractures as well as the formation of new ones. Chemical weathering generally decreases the hardness of the intact rock through dissolution of cement and decomposition of mineral grains. Both weathering processes act to decrease shear-wave velocity.

Data from the San Francisco Bay region show that shear-wave velocity increases as the hardness of the intact rock and the fracture spacing increase (the fracture spacing has the dominant effect). These two properties, plus lithology, were used to define seven categories of bedrock materials having distinct velocity characteristics (Borcherdt and others, 1978).

The physical properties of the bedrock materials at each site vary with depth depending on the degree of weathering. The depth to which the bedrock has been significantly altered by weathering processes varies considerably from site to site because of differences in lithology and permeability. Rock types such as chert, porcelaneous shale, and serpentine are little affected by weathering even at shallow depths, whereas granitic rock may be significantly weakened to depths greater than $30 \mathrm{~m}$. Velocities were obtained for moderately weathered and fresh rock at most sites. The difference between these values increases as the strength of the fresh rock increases- 80 to $250 \mathrm{~m} / \mathrm{s}$ for low- to mediumstrength sedimentary rocks to 750 to $1,050 \mathrm{~m} / \mathrm{s}$ for highstrength igneous rocks.

\section{SHEAR-WAVE VELOCITY STUDIES IN THE LOS ANGELES REGION}

Shear-wave velocities were measured by using the downhole technique at 84 sites in the Los Angeles basin and vicinity (fig. 47). Most sites were chosen to provide geologic and seismic data to compare with groundmotion measurements made at nuclear-explosion recording stations (48 sites) and strong-motion stations (23 sites). A few sites were selected to provide additional data from particular sedimentary deposits.

At each site selected, rotary-wash equipment was used to drill a borehole to a depth of about $30 \mathrm{~m}$; a few holes in very hard rock were as shallow as $21 \mathrm{~m}$. Representative samples of each dominant type of material encountered were recovered during drilling. Generally, three to five Pitcher sampler, split-spoon, or diamond-core samples were taken at each site. Geologic logs, including soil texture and color and estimates of hardness and fracture spacing in rocks, were compiled for each hole from descriptions of the samples and a field $\log$ based on continuous monitoring of drill cuttings and roughness and rate of drilling, on-site inspection of samples, and inspection of nearby outcrops (fig. 48A). The geologic logs were examined, and estimates of the age (usually Holocene or late or middle Pleistocene) were made for the sedimentary deposits encountered in each hole by geologists experienced in mapping in the Los Angeles region (J. C. Tinsley and D. Ponti, personal communication, 1982).

Shear waves were generated at the ground surface by a horizontal traction source similar to the one developed by Kobayashi (1959) and discussed by Warrick (1974). Recordings of seismic signals were made in the boreholes by using a three-component geophone package usually at intervals of $2.5 \mathrm{~m}$. Velocities were calculated for depth intervals determined from changes in the slopes of traveltime curves (fig. 48B). To minimize the effects of picking errors, these depth intervals are a minimum of $5 \mathrm{~m}$ (three traveltime measurements) for materials having velocities less than $350 \mathrm{~m} / \mathrm{s}$ and $7.5 \mathrm{~m}$ (four traveltime measurements) for stiffer materials.

Because physical properties were determined by field methods, they are generally only relative evaluations of the average properties of the sediment or rock mass. Measurements of standard penetration resistance, density, and seismic-wave velocity were the only quantitative determinations made. Although this procedure may lack refinement, it is potentially widely applicable to other seismically active areas having similar geologic units.

Comparison of the interval shear-wave velocities with the physical properties indicated on the geologic logs shows correlations for the Los Angeles area that are

Shear-Wave Velocities of Near-Surface Materials 


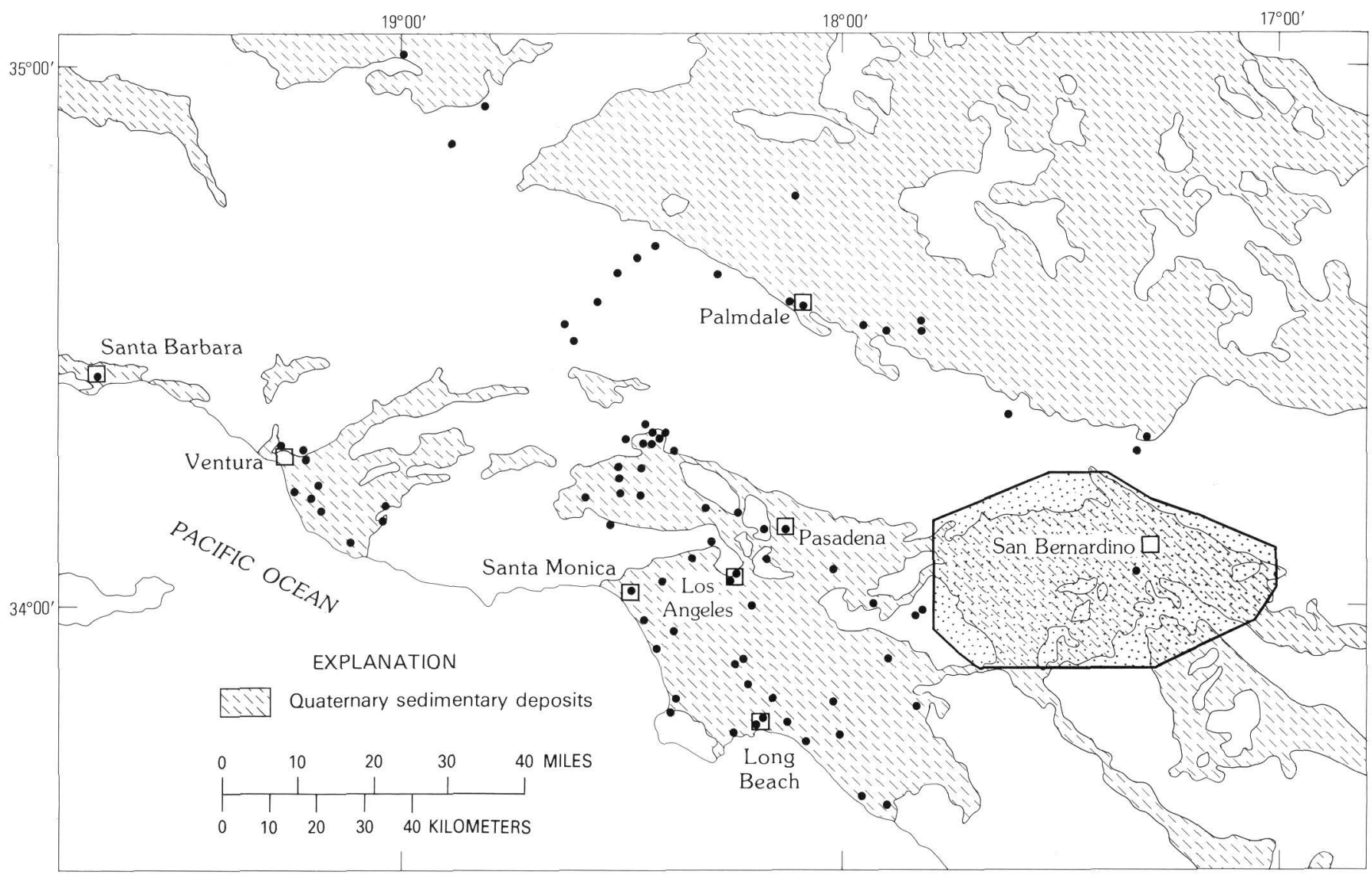

FIGURE 47.-Locations of sites in the Los Angeles region at which seismic velocity and geologic data have been obtained from drill holes to depths of $30 \mathrm{~m}$. Stippled area is the demonstration area in the upper Santa Ana River basin.

very similar to those for the San Francisco Bay region. For ease of discussion, we have divided the geologic materials of the Los Angeles region into two broad categories based on degree of induration: (1) unconsolidated to moderately consolidated sedimentary deposits and (2) bedrock. The first group is comprised of all deposits ranging in age from Holocene through middle Pleistocene less than about 250,000 yr old. The second group includes all older materials. The velocity characteristics of each category will be discussed separately.

\section{SHEAR-WAVE VELOCITIES IN LATE QUATERNARY SEDIMENTARY DEPOSITS}

\section{Correlation with Physical Properties}

Unconsolidated to moderately consolidated sedimentary deposits are greater than $30 \mathrm{~m}$ thick at 58 sites and

\section{Earthquake Hazards in the Los Angeles Region}

5 to $21 \mathrm{~m}$ thick at 15 others. Because of the large number of velocity measurements for these materials, it was convenient to analyze separately the data from three subareas: (1) the Los Angeles basin, (2) the San Fernando and Antelope Valleys, and (3) the Ventura-Oxnard area. Only the Los Angeles basin results, which are generally similar to those for the other subregions, will be illustrated. The following discussion, however, applies to all three areas. The means, ranges, and standard deviations of the complete data set are listed in accompanying tables, along with separate listings for groups that show significant geographic variation.

The results of measurements in the Los Angeles basin subarea are summarized in figure 49 , which shows average velocity over the depth intervals obtained from traveltime curves. Because these sediments are for the most part thickly bedded, the velocity intervals generally correspond to materials having relatively homogeneous physical properties. From two to five such velocity intervals were determined for each site. Figure $48 \mathrm{C}$ shows, for an individual site, how the velocities calculated by using the traveltime curves are plotted as interval velocities in figure 49. 


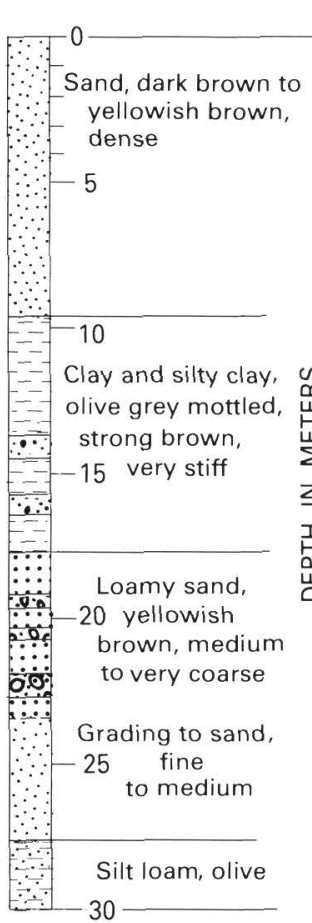

A

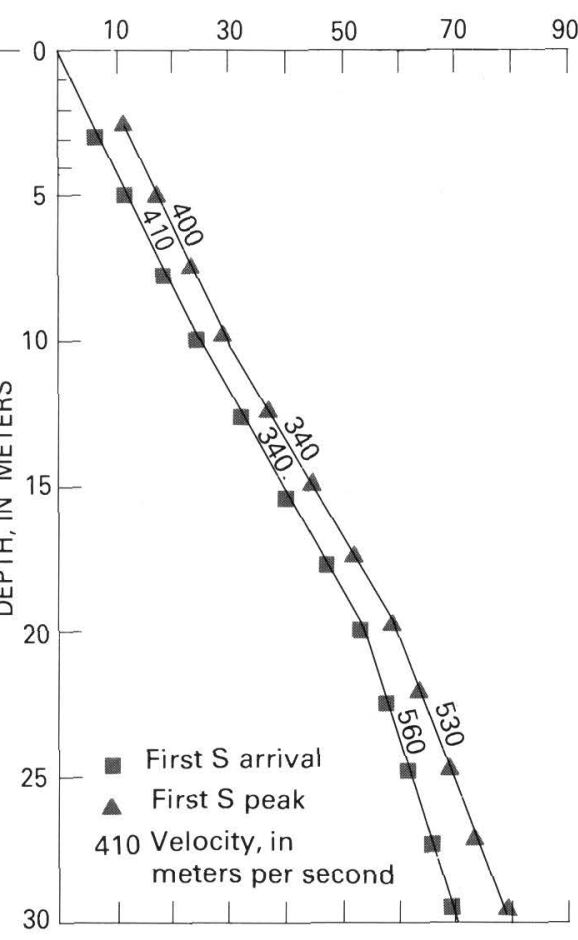

B

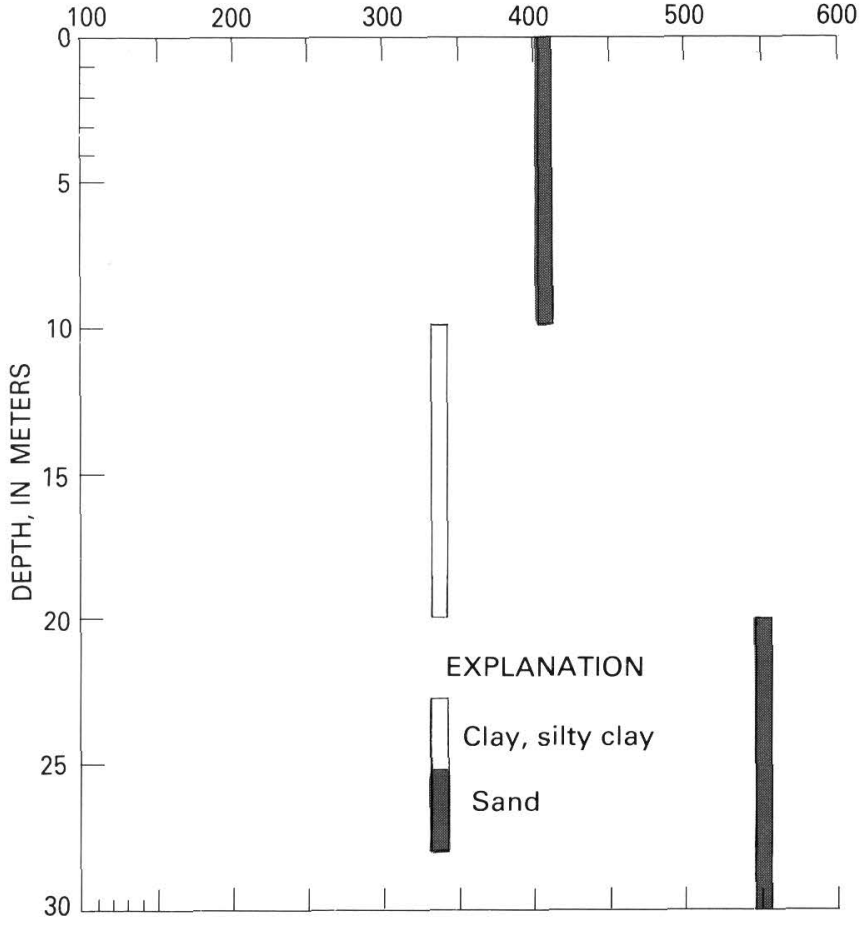

C

FIGURE 48.-A, Geologic log for a site in the Los Angeles basin. B, Traveltime curve for the same site. C, Method for combining and plotting these data on the interval velocity graph shown in figure 49.

Figure 49 groups the sediments according to texture and standard penetration resistance. Although some of the resulting groups have wide ranges in velocity and there is overlap between groups, these parameters have the advantage of being widely available for urban regions because the requisite tests ordinarily are conducted during routine engineering studies. The means, ranges, and standard deviations of the velocities of each group are shown for the complete data set in table 17 .

The sediments of the Los Angeles region are divided into five categories according to grain-size distribution: (1) clay and silty clay, (2) silt loam and sandy clay, (3) sand, (4) gravelly sand and gravel ( $>20$ percent gravel), and (5) cobble to boulder gravel. The data in figure 49 show that shear-wave velocity increases as mean grain size increases. Because of the greater proportion of sand having high void ratios sampled in the Los Angeles area, this trend is not as pronounced here as it is in the San Francisco region.

SPT results for three of the textural groups in the Los Angeles region are shown in figure 50 . The $N$ value (resistance, measured in blows per foot) for a given sample is plotted versus the mean shear-wave velocity for the depth interval containing that sample. Values for several age designations are given. We have applied corrections to the standard penetration values for very fine or silty sand below the water table (after Terzaghi and Peck, 1967) and for effective overburden pressure in sands (after Bazarra, 1967) (equivalent to $C_{N}$ (Seed and others, 1983) for $96 \mathrm{kPa} \leq \sigma_{0} \leq 48 \mathrm{kPa}$ ). Presumably, overburden pressure also affects $N$ values in cohesive soils, but no correction was found in our literature search.

The wide scatter shown in figure $\mathbf{5 0}$ is similar to that found in the San Francisco Bay region. In addition to variations in equipment and measurement technique, differences in sampling scale may account for a significant part of this scatter. Penetration resistance is recorded cumulatively over a $0.3-\mathrm{m}$ interval and is very sensitive to small inhomogenieties. The shear-wave velocity, on the other hand, is an average value over 5 to $25 \mathrm{~m}$.

Consequently, the good correlation for clay (correlation coefficient 0.97 ) is remarkable, and the $N$ value can be used to predict shear-wave velocity with some confidence for these sediments. Although the scatter for sand is much greater (correlation coefficient 0.81) than that for clay, the relations between penetration

Shear-Wave Velocities of Near-Surface Materials 131 


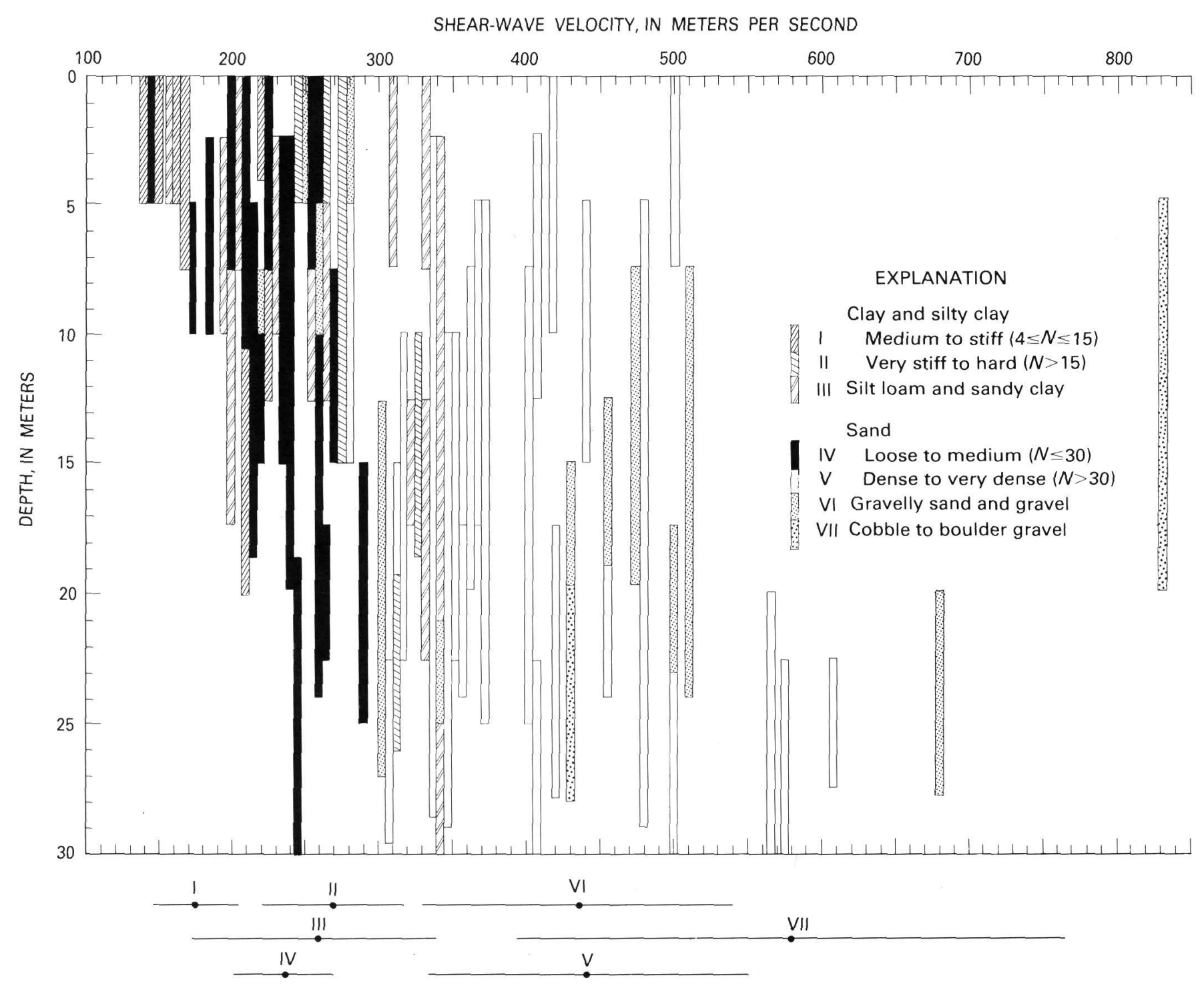

FIGURE 49.-Shear-wave velocities for depth intervals determined from traveltime curves in unconsolidated to moderately consolidated sedimentary deposits in the Los Angeles basin subarea. The deposits are divided into groups according to texture and standard penetration resistance $N$ (number of blows per foot). Means (solid circles) and standard deviations (bars) of velocity for each unit in the Los Angeles region are shown along the lower abscissa.

resistance and shear-wave velocity are very similar for both groups. We have subdivided these two categories by using relations between penetration resistance and other index properties of the soils given by Terzaghi and Peck (1967). For cohesive soils, penetration resistance serves as an index of consistency (relative firmness). We have subdivided the clays and silty clays into two groups: medium to very stiff $(4 \leq N \leq 15)$ and very stiff to hard $(N>15)$. No significant thicknesses of soft to very soft $(N<4)$ clays were found at our sites in the Los Angeles area. For sands, penetration resistance has been related to relative density and is most useful for $N<50$.
We have subdivided the sands into two groups: loose to medium dense $(N \leq 30)$ and dense to very dense $(N>30)$. Because of the corrections applied to the data for sands, this boundary is lower than that $(N=40)$ used in the San Francisco Bay region.

The relation between penetration resistance and shear-wave velocity is poor for the silt loam and sandy clay group (correlation coefficient 0.62 ). It was not used to subdivide that group, although the distribution of velocity in these sediments is bimodal (two distinct subsets). The distribution of velocity is also bimodal for the gravelly sand and gravel and the cobble to boulder 
TABLE 17.-Shear-wave velocities in late Quaternary sedimentary deposits of the Los Angeles region $[\mathrm{N}$, number of blow per foot from standard penetration resistance tests]

\begin{tabular}{|c|c|c|c|c|}
\hline \multirow[b]{2}{*}{ Physical property unit } & \multirow[b]{2}{*}{$\begin{array}{l}\text { No. of } \\
\text { elocity intervals }\end{array}$} & \multicolumn{3}{|c|}{ Shear-wave velocity } \\
\hline & & $\begin{array}{l}\text { Mean, } \\
\text { in } \mathrm{m} / \mathrm{s}\end{array}$ & $\begin{array}{l}\text { Standard } \\
\text { deviation }\end{array}$ & $\begin{array}{l}\text { Range, } \\
\text { in } m / s\end{array}$ \\
\hline \multicolumn{5}{|l|}{ Clay and silty clay: } \\
\hline Medium to very stiff $(4 \leq N \leq 15)-$ & -- & 175 & 30 & $140-225$ \\
\hline Very stiff to hard $(N>15)$ & -- & 270 & 50 & $200-340$ \\
\hline Silt loam and sandy clay - & $-\quad 29$ & 260 & 80 & $160-360$ \\
\hline \multicolumn{5}{|l|}{ Sand: } \\
\hline Loose to medium dense $(\mathrm{N} \leq 30)-$ & --40 & 235 & 35 & $140-285$ \\
\hline \multicolumn{5}{|l|}{ Dense to very dense $(N>30)$} \\
\hline Los Angeles-Ventura -- & $--\quad 29$ & 400 & 100 & $270-610$ \\
\hline San Fernando-Antelope Valleys -- & $--\quad 26$ & 485 & 70 & $310-740$ \\
\hline 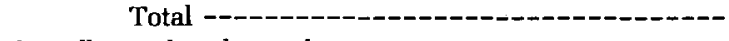 & --55 & 440 & 110 & $270-740$ \\
\hline \multicolumn{5}{|l|}{ Gravelly sand and gravel: } \\
\hline Los Angeles ---- & 7 & 485 & 110 & $305-680$ \\
\hline Ventura ---- & -- & 445 & 150 & $300-620$ \\
\hline San Fernando-Antelope Valleys ------------- & --16 & 410 & 90 & $290-540$ \\
\hline Total --_-_-_-_- & -28 & 435 & 105 & $290-680$ \\
\hline Cobble to boulder gravel -_- & -- & 580 & 185 & $350-830$ \\
\hline
\end{tabular}

gravel groups. Penetration resistance is not very useful in these coarse-textured sediments, nor are most other geotechnical tests, because of the difficulty of sampling.

To investigate the importance of time effects in the Los Angeles region, the in situ shear-wave velocities were compared with expected values calculated by using equations derived from laboratory investigations. Void ratios of samples collected were calculated from measured bulk densities (assuming 100 percent saturation) and plotted versus interval shear-wave velocity in figure 51. Expected shear-wave velocity was calculated for each sample by using equations suggested by Hardin and Richart (1963):

$$
\begin{aligned}
& \left.V_{s}=(111-50.9 e) \sigma_{0}^{0.25} \text { (for } \sigma_{0}>96 \mathrm{kPa}\right) \\
& V_{s}=(90.2-42.4 e) \sigma_{0}^{0.30} \text { (for } \sigma_{0} \leq 96 \mathrm{kPa} \text { ) }
\end{aligned}
$$

where $V_{S}$ is in meters per second, $e$ is the void ratio, and $\sigma_{0}$ is the mean principle effective stress. As a simplifying assumption, $\sigma_{0}$ was taken to be equal to the overburden pressure. The actual effective stress is probably lower because of pore pressures; thus, the calculated shearwave velocity is a maximum value.

We determined that whether the sample was taken with a Pitcher barrel or a split spoon and whether it was taken above or below the water table have little effect on the relation between void ratio and shear-wave velocity. Texture is somewhat important, since void ratios of fine-grained sediments are higher than those of sands and gravelly sands for a given shear-wave velocity. The age of the deposit, however, strongly affects the relation between void ratio and in situ shear-wave velocity (fig. 51). The velocities of late and middle Pleistocene sediments are significantly higher than those of Holocene sediments for the entire range of measured void ratios. Furthermore, it was found that in situ velocities for the Holocene deposits are generally within 10 percent of the values expected from equations 1 and 2, whereas velocities of late and middle Pleistocene deposits are 15 to 80 percent higher than the ċalculated velocities.

Although shear-wave velocity is inversely related to void ratio, there is considerable scatter in the data. For Holocene sediments, penetration resistance appears to be a better predictor of velocity than void ratio is, especially for clays. For late and middle Pleistocene sediments, shear-wave velocity is nearly independent of void ratio for values less than 0.5 , whereas, for values between 0.9 and 0.5 , void ratio seems to predict velocity somewhat better than $N$ value does. As there is with penetration resistance, there is significant variation of void ratio within mappable geologic units (see, for example, Rogers and others, this volume, fig. 114). Thus, although the addition of void-ratio data would probably not be an improvement over a classification based on texture and standard penetration alone, such data could serve as an alternative where they are available.

\section{Correlation with Sedimentary Units}

The previous section has shown that the shear-wave velocities of near-surface sedimentary deposits can be 

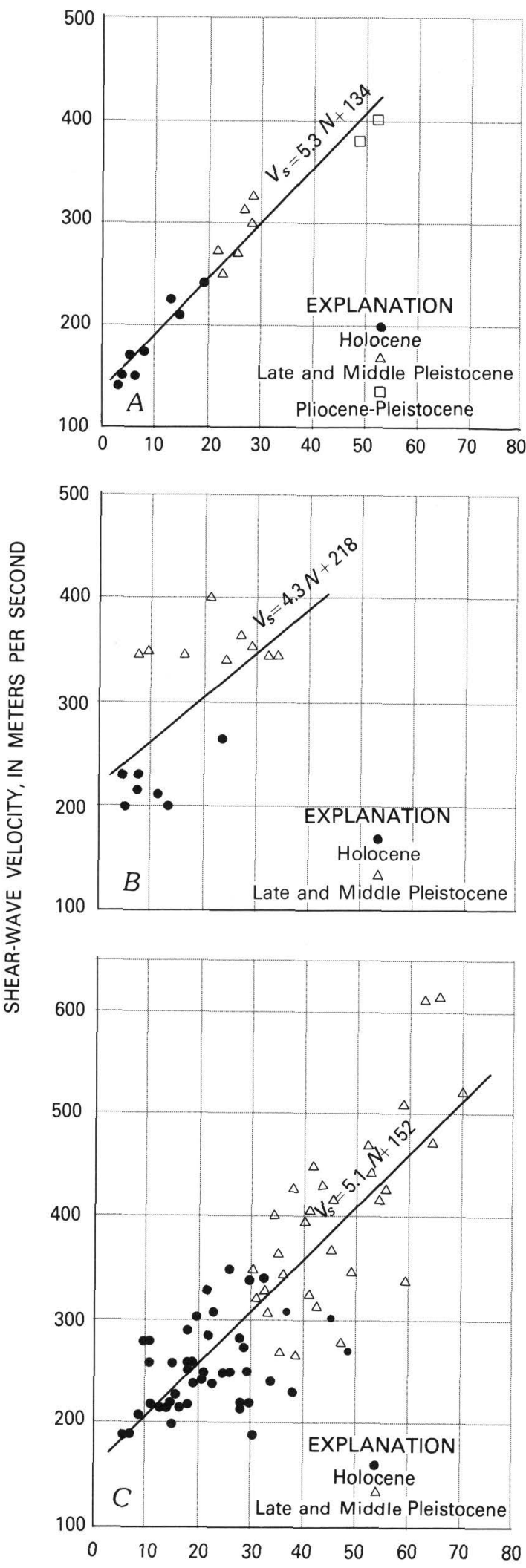

PENETRATION RESISTANCE, IN BLOWS PER FOOT

134 Earthquake Hazards in the Los Angeles Region
FIGURE 50.-Variation of shear-wave velocity with standard penetration resistance for three textural groups of sedimentary deposits in the Los Angeles region. A, Clay and silty clay; B, silt loam and sandy clay; $C$, sand and gravelly sand. Lines are least-squares fits to the data that give the equations shown. The correlation coefficients for these equations are 0.97 (clay), 0.62 (silt), and 0.81 (sand). Penetration tests were performed in conjunction with rotary-wash drilling; the cathead and rope technique was used to drop a 42.5-kg hammer a distance of $76 \mathrm{~cm}$.

related to several readily determined physical properties. Knowing the areal distribution of these properties would aid in estimating ground response from future earthquakes. Unfortunately, such information can be obtained only indirectly, if at all, from most geologic maps. Although areas underlain by unconsolidated sedimentary deposits are most susceptible to ground shaking hazards, these areas generally are not subdivided on ordinary regional-scale geologic maps.

Recent mapping in the Los Angeles region has provided geologic maps of sedimentary deposits that are more useful for evaluating earthquake hazards. Tinsley and Fumal (this volume) describe techniques based on Lajoie and Helley's (1975) methods of classifying and mapping alluvial deposits according to age and texture. Each age category (Holocene and late and middle Pleistocene) is divided into fine-, medium-, and coarsegrained and very coarse grained units, which correspond to chiefly silt and clay, sand, gravelly deposits (>15 percent gravel), and bouldery and cobbly deposits, respectively.

Shear-wave velocities measured in these mappable units in the Los Angeles basin are shown in figure 52. Means, ranges, and standard deviations of the velocities for each unit in the entire region are presented in table 18. For the late and middle Pleistocene medium- and coarse-grained units, significant variation was found between the Los Angeles basin and the San Fernando Valley-Antelope Valley areas, and separate values are shown. Each mappable unit in the Los Angeles region has distinct shear-wave velocity characteristics, reflecting the important influence of age and texture on the physical properties that control velocity.

The relations between the velocity units based on physical properties (fig. 49) and the mapped geologic units (fig. 52) are shown schematically in figure 53. Each textural group has two distinct ranges of velocity, which correspond to the Holocene and late and middle Pleistocene age groups. For the clays and sands, the age divisions nearly coincide with the divisions based on standard penetration resistance (Holocene clays, however, can have $N$ values as high as 20 , a few sands having $\mathrm{N} \leq 30$ are late Pleistocene, and some Holocene sands have $N>30$ ). The distinct velocities in silt loams and sandy clays of different ages are not, however, reflected in 
the penetration test results. Although the clay and silty clay and the silt loam and sandy clay categories have distinct velocity characteristics, they generally cannot be mapped separately. Each of the fine-grained Holocene and fine-grained late and middle Pleistocene groups thus include portions of both the clay and silt units.

Because the late and middle Pleistocene medium- and coarse-grained deposits have rather wide ranges in shear-wave velocity, a means of subdividing them would be desirable. Studies of shear-wave velocity in late Quaternary stratigraphic units mapped in the Antelope Valley (Ponti and Burke, 1980; Ponti and others, 1981) show that shear-wave velocity systematically increases as the age of the deposit increases (fig. 54). These units can be differentiated in the field by the degree of soilprofile development. In particular, deposits older than about 100,000 yr can be distinguished from younger deposits by a pronounced reddening of the soil. Additional studies are in progress to determine whether this trend in shear-wave velocity exists in other basins; if it does, reddening of the soil may provide an easily recognizable means of subdividing the late and middle Pleistocene medium- and coarse-grained sediments for purposes of mapping shear-wave velocity.

\section{SHEAR-WAVE VELOCITIES IN PRE-LATE QUATERNARY BEDROCK MATERIALS}

Shear-wave velocities were measured in bedrock materials at 42 sites in the Los Angeles region. Rocks at most of these sites comprise two categories: (1) middle Miocene to early Pleistocene sedimentary rocks and (2) granitic rocks of the San Gabriel, San Bernardino, and Santa Monica Mountains. Because a much wider range of materials was sampled in the San Francisco Bay region, data from that region were relied on to a large extent in developing criteria for estimating shear-wave velocities of bedrock map units in the Los Angeles region.

In the San Francisco Bay region, shear-wave velocity increases as both the hardness of the intact rock and the fracture spacing increase; the effect of the fracture spacing is dominant (Fumal, 1978). These two properties, together with lithology, were used to define seven categories of bedrock materials having distinct velocity characteristics. Figure 55 shows interval velocities obtained in moderately weathered to fresh bedrock in the Los Angeles region grouped into these categories. Ranges of velocity for these units in the San Francisco Bay region are shown for comparision. Results from the two regions compare very favorably. Means, ranges,

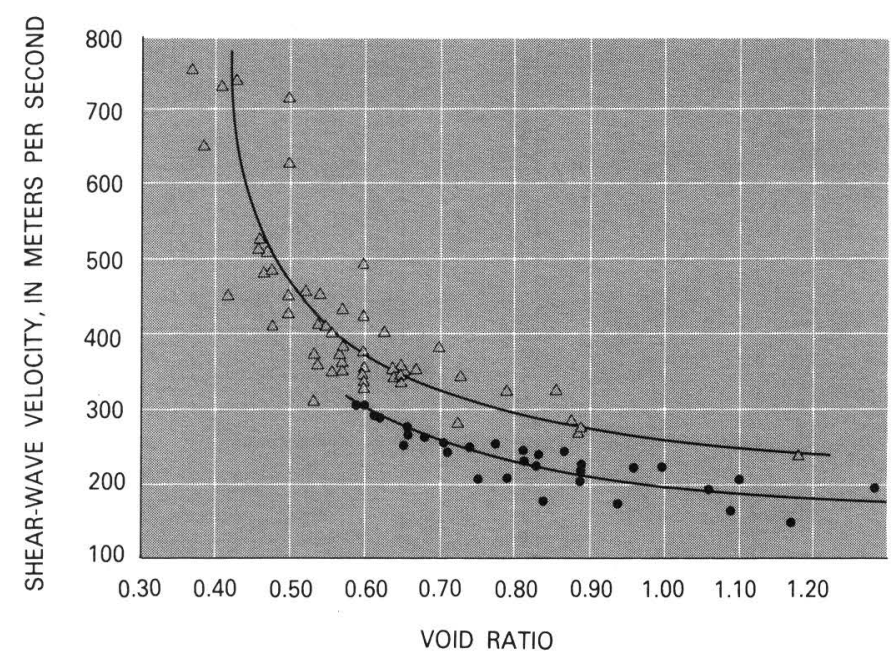

FIGURE 51.-Variation of measured shear-wave velocity with void ratio for Holocene (solid circles) and late and middle Pleistocene (open triangles) sediments in the Los Angeles region. Data are primarily for sand and fine-grained sediments, along with some gravelly sand. Solid lines are visually determined approximate fits to the data.

and standard deviations of the velocities for the combined data set are presented in table 19.

Standard geologic maps ordinarily contain very little information about the relative hardness and fracture spacing of bedrock units and are thus unsatisfactory for estimating shear-wave velocity. In the San Francisco Bay region, Wentworth and others (1985), recognizing the need for engineering data for bedrock materials, have prepared detailed descriptions of hardness, fracture spacing, and other geotechnical properties of the geologic units in San Mateo County. These descriptions can be used in conjunction with the velocity data to assign velocity categories to each map unit or groups of similar units.

For the Los Angeles basin, Wentworth and others (1970) have grouped the numerous mapped bedrock units into eight engineering-geologic units based on lithology, induration or rock hardness, and the degree of parting developed along bedding planes. Although this compilation is generalized and restricted areally, it provides a useful grouping of the units for estimating shearwave velocities in the Los Angeles basin and in other areas where comparable geologic units are present. These engineering-geologic units are presented in table 20 , along with the velocity units from table 19 assigned to them and equivalent geologic units.

\section{PREPARING REGIONAL MAPS OF SHEAR-WAVE VELOCITY}

The correlations between shear-wave velocity, physical properties, and geologic units can be used to

Shear-Wave Velocities of Near-Surface Materials 
TABLE 18.-Shear-wave velocities in mappable late Quaternary sedimentary units in the Los Angeles region

\begin{tabular}{|c|c|c|c|c|}
\hline \multirow[b]{2}{*}{ Geologic unit } & \multirow[b]{2}{*}{$\begin{array}{c}\text { No. of } \\
\text { velocity intervals }\end{array}$} & \multicolumn{3}{|c|}{ Shear-wave velocity } \\
\hline & & $\begin{array}{l}\text { Mean, } \\
\text { in } \mathrm{m} / \mathrm{s}\end{array}$ & $\begin{array}{l}\text { Standard } \\
\text { deviation }\end{array}$ & $\begin{array}{l}\text { Range, } \\
\text { in } \mathrm{m} / \mathrm{s}\end{array}$ \\
\hline \multicolumn{5}{|c|}{ Holocene } \\
\hline Fine - -1 & $----\quad 23$ & 200 & 20 & $150-270$ \\
\hline 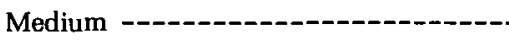 & ----38 & 230 & 30 & 195-285 \\
\hline Coarse ------1-- & $----\quad 10$ & 320 & 25 & $290-355$ \\
\hline Very coarse - - & --- & 365 & 20 & $350-375$ \\
\hline \multicolumn{5}{|c|}{ Late and middle Pleistocene } \\
\hline 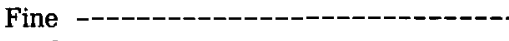 & ---18 & 305 & 50 & $200-360$ \\
\hline \multicolumn{5}{|l|}{ Medium: } \\
\hline Los Angeles-Ventura ----------- & ---31 & 395 & 100 & $270-620$ \\
\hline San Fernando-Antelope Valleys --- & $\cdots 26$ & 470 & 115 & $310-740$ \\
\hline 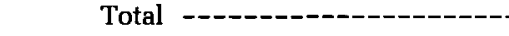 & ---57 & 430 & 115 & $270-740$ \\
\hline \multicolumn{5}{|l|}{ Coarse: } \\
\hline Los Angeles-Ventura - & --- & 550 & 85 & $450-680$ \\
\hline San Fernando-Antelope Valleys --- & ---10 & 460 & 70 & $450-680$ \\
\hline Total & ---17 & 495 & 85 & $330-680$ \\
\hline 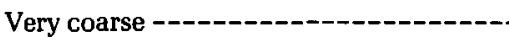 & ---6 & 650 & 155 & 445-830 \\
\hline
\end{tabular}

construct maps of estimated mean velocity for use in predicting ground response. To illustrate the method, we have prepared maps for the upper Santa Ana River basin. As Joyner and others (1981) proposed, we calculated mean shear-wave velocities over depths equal to onequarter wavelength of a 1-s shear wave. For the upper Santa Ana River basin, the corresponding depths range from $100 \mathrm{~m}$ for alluvium to $400 \mathrm{~m}$ for hard granitic rock. This method requires extrapolating the nearsurface data to these greater depths. Unfortunately, reliable shear-wave velocity measurements from deep boreholes are scarce. Seismic measurements obtained from two holes in central California (Warrick, 1974; Joyner and others, 1981) give values of $380 \mathrm{~m} / \mathrm{s}$ for largely fine-grained Pleistocene alluvium and $630 \mathrm{~m} / \mathrm{s}$ for interbedded medium- and coarse-grained Pleistocene alluvium over the depth interval of about 40 to $180 \mathrm{~m}$. These values are comparable to those that we have obtained at $30 \mathrm{~m}$ and suggest that extrapolating the shallow data for alluvium to greater depths gives reasonable approximations. Increases in velocity with depth in fresh bedrock are largely controlled by the closing of cracks (Walsh and Brace, 1966). Actual shearwave velocities in these materials therefore may be somewhat greater than the assigned values if fractures close appreciably in the upper $400 \mathrm{~m}$.

The method that we use for mapping near-surface seismic velocity variations is shown schematically in figure 56, along with sample calculations that will be discussed in more detail later. Two types of geologic information are required: (1) a map showing the areal

136 Earthquake Hazards in the Los Angeles Region extent of exposed geologic materials and (2) the distribution and thicknesses of concealed geologic materials as depicted on geologic cross sections and on maps showing the thickness of alluvial deposits (isopach maps). Mean shear-wave velocities are assigned to exposed geologic map units by comparing them with similar materials in the Los Angeles and San Francisco Bay regions (tables 18 and 19). The geologic map and subsurface data are used to compile a set of the distinct types of geologic profiles in the basin. Mean velocities are then calculated for each profile over a depth equal to one-quarter wavelength of a 1-s shear wave. Those profiles or groups of profiles that have significantly different mean velocities are then used to prepare a map of mean shear-wave velocity to a depth of one-quarter wavelength of a 1-s wave for the demonstration area.

Descriptions of the exposed geologic materials in the upper Santa Ana River basin and a map of their areal distribution (scale 1:125,000) have been compiled by Cox and Morton (1978). Mean shear-wave velocities assigned to the mapped geologic units are presented in table 21, and a map of the units themselves is shown in figure 51. The Holocene units mapped in this basin are equivalent to those in the Los Angeles area, so their velocities are used directly. Very little information concerning the thickness or subsurface texture of mapped late and middle Pleistocene units is available at this time; therefore, the mean shear-wave velocity obtained for all late and middle Pleistocene sediments in the Los Angeles area $(435 \mathrm{~m} / \mathrm{s})$ is assumed for these deposits. An estimate of mean shear-wave velocity in the bedrock 


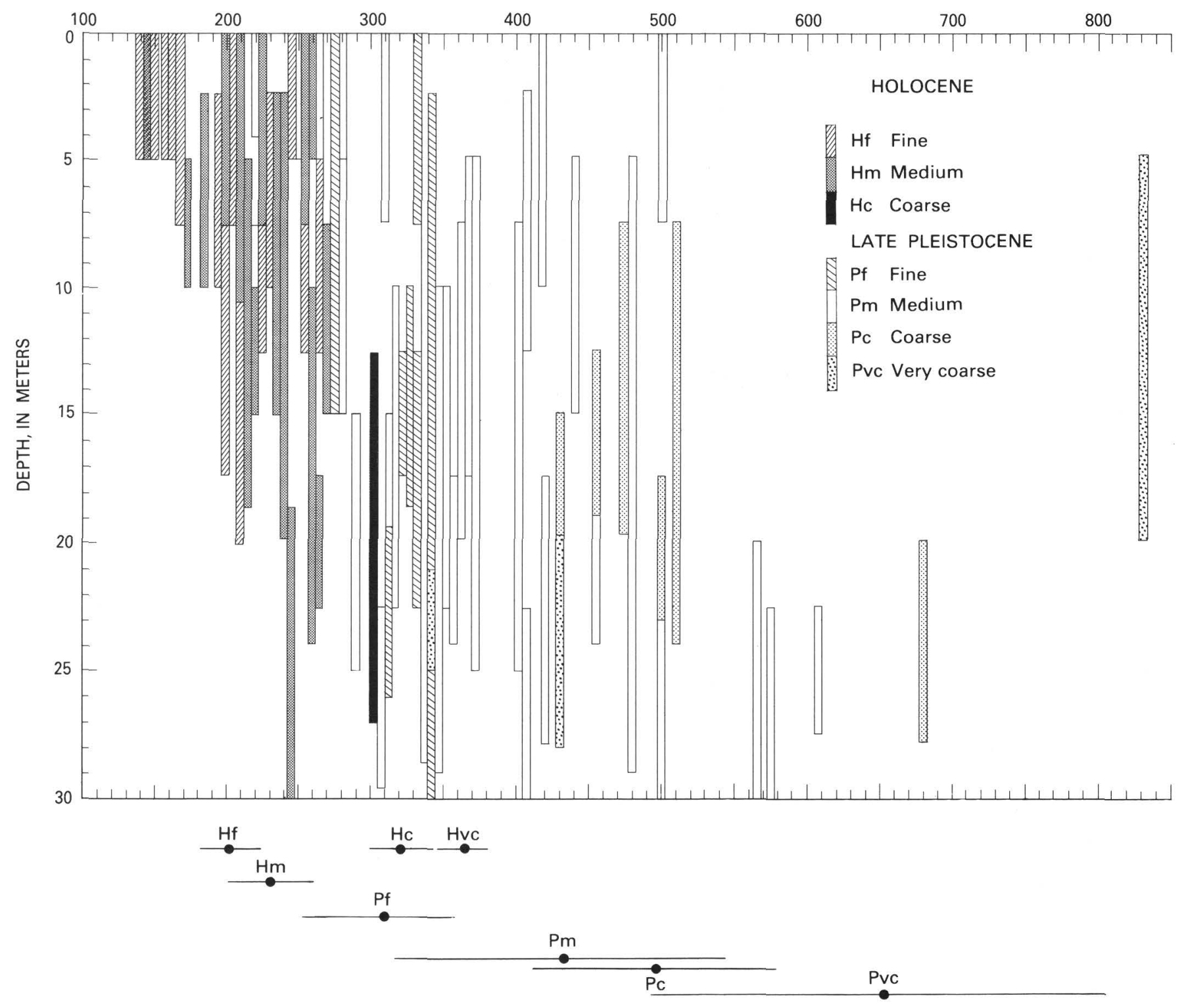

FIGURE 52.-Shear-wave velocities for depth intervals determined from traveltime curves for Holocene and late and middle Pleistocene sedimentary units in the Los Angeles basin subarea defined according to age and texture. Means (solid circles) and standard deviations (bars) for each unit in the Los Angeles region are shown along the lower abscissa. Note that the very coarse grained Holocene unit was not sampled in the Los Angeles basin subarea.

materials was made by determining from map descriptions which of the physical property units listed in table 19 comprise each map unit.

Thicknesses of Holocene sediments compiled from California Department of Transportation borehole logs and water-well drillers' logs show that these sediments are probably less than $15 \mathrm{~m}$ thick across most of this basin (S. Carson and J. C. Matti, written communication, 1983). We used an average value of $7 \mathrm{~m}$ in calculating shear-wave velocities. Maps showing total thicknesses of late Quaternary alluvium at a scale of 1:125,000 and a contour interval of $100 \mathrm{ft}$ are available for nearly all of the study area except a narrow strip north of the Cucamonga fault (California Department of Water Resources, 1970; California Division of Mines and Geology, 1976).

A set of distinct types of geologic profiles was compiled by using Cox and Morton's (1978) geologic map and subsurface data on thickness and distribution of concealed geologic materials. For areas where the 


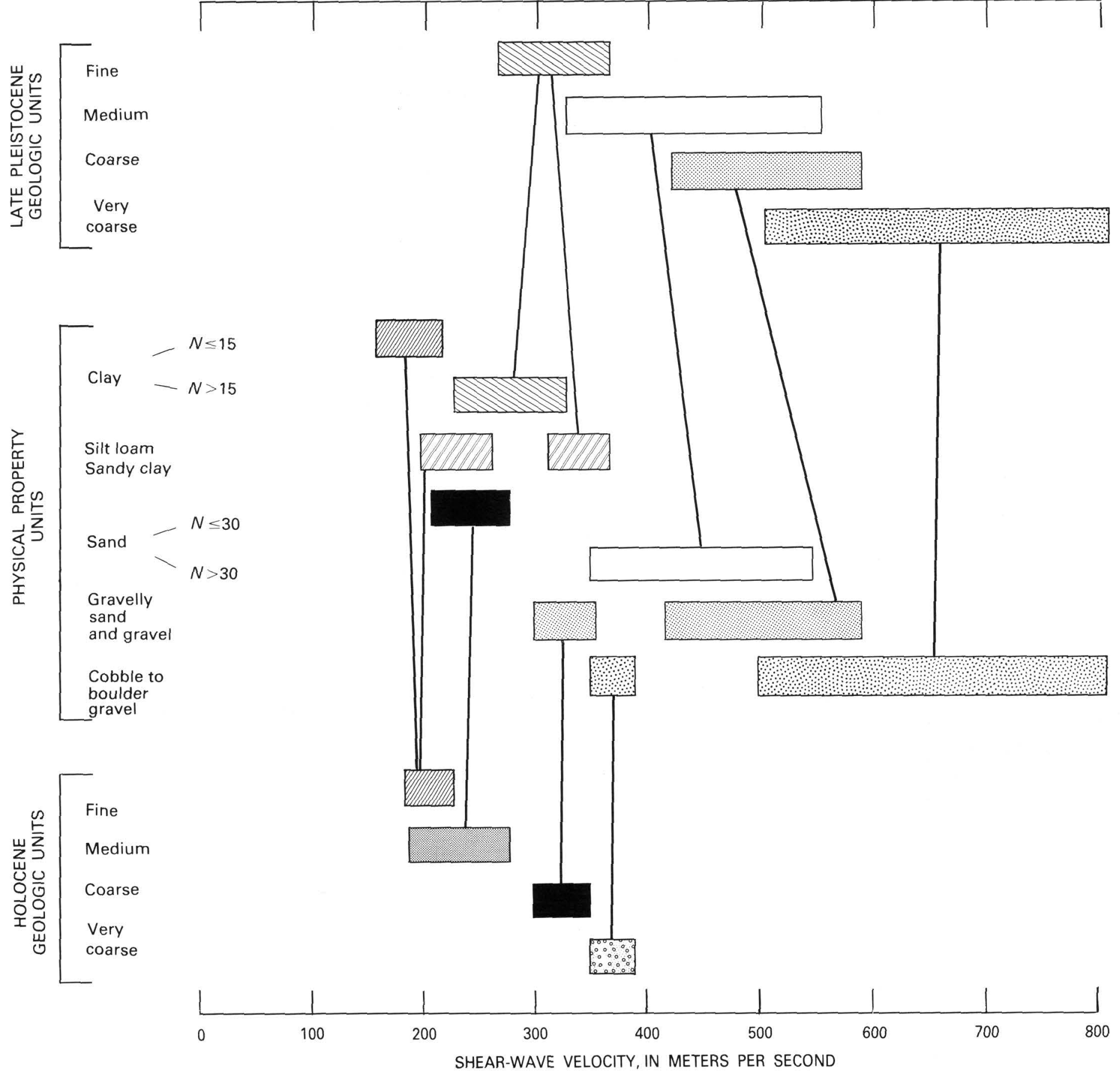

FIGURE 53.-Relation between units defined on the basis of physical properties and Holocene and late and middle Pleistocene geologic units. Patterns are the same as those in figures 49 and $52 . \mathrm{N}$ is standard penetration resistance measured in blows per foot. The length of the box for each unit is equal to two standard deviations of the shear-wave velocity data for that unit.

thickness of alluvium was greater than about $101 \mathrm{~m}$, four profiles were constructed, each consisting of $7 \mathrm{~m}$ of one of the Holocene units overlying $94 \mathrm{~m}$ of late and middle Pleistocene deposits, plus one profile consisting entirely of late and middle Pleistocene sediments. For the other areas having alluvium at the surface, three or four profiles were constructed, one at each of the $100-\mathrm{ft}$ thickness contours, and so consisted of $7 \mathrm{~m}$ of one of the
Holocene units present in that portion of the study area overlying $84.5,54$, or $23.5 \mathrm{~m}$ of late and middle Pleistocene alluvium overlying the appropriate bedrock. Forty-seven distinct types of geologic profiles were identified in the upper Santa Ana River basin.

Mean shear-wave velocities were calculated over a depth equal to one-quarter wavelength of a 1-s wave for each of these profiles (see fig. 56 for sample calculation).

\section{Earthquake Hazards in the Los Angeles Region}




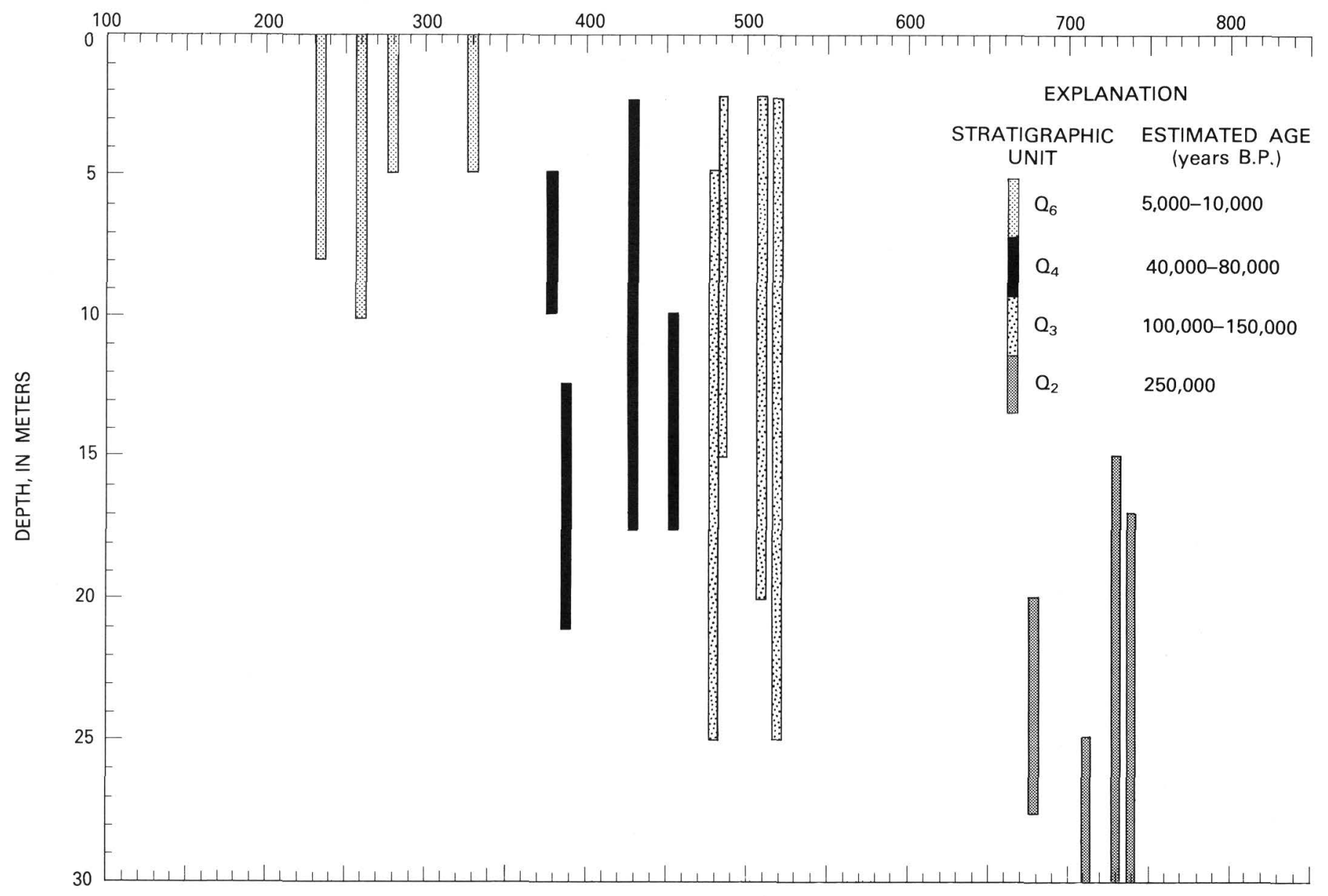

FIGURE 54.-Shear-wave velocities for depth intervals determined from traveltime curves for late Quaternary stratigraphic units in the Antelope Valley as mapped by Ponti and Burke (1980) and Ponti and others (1981). Approximate ages are assigned through correlation with a similar dated sequence in the San Joaquin Valley (D. Ponti, personal communication, 1982).

For each profile, the thickness of each geologic unit was divided by the mean shear-wave velocity assigned to that unit to give a traveltime through that layer. These layer traveltimes were summed downward through the profile until a total traveltime of $0.25 \mathrm{~s}$ was reached. The total thickness transited was divided by $0.25 \mathrm{~s}$ to give the mean shear-wave velocity for that profile. Those profiles that had shear-wave velocities differing from each other by more than 7 percent were judged to be significantly different. We divided the 47 geologic profiles into 15 groups, each having a distinct mean shear-wave velocity. These groups of profiles were used to prepare the map of mean shear-wave velocity to a depth of one-quarter wavelength of a 1-s wave for the upper Santa Ana River basin shown in figure 58.

For areas where the thickness of alluvium is less than about $100 \mathrm{~m}$, the calculated mean shear-wave velocity changes rapidly depending on depth to bedrock. Velocity also changes laterally, to a lesser degree, along sedi- ment thickness contours, being lower where the surface layer is composed of fine- or medium-grained Holocene alluvium. These rapid areal changes of velocity are difficult to present clearly on a small-scale map such as figure 57. For this reason, mean shear-wave velocity in these areas of thin alluvium is depicted on the map as contours of equal velocity by using values obtained from geologic profiles composed of late and middle Pleistocene sediment overlying bedrock. Where the surface layer is composed of fine- or medium-grained Holocene alluvium, the total profile thicknesses were adjusted (8-9 $\mathrm{m}$ thinner), so that the calculated mean shear-wave velocities equaled those obtained for the late and middle Pleistocene sediment over bedrock profiles. For this reason, the contours depicted in figure 58 make slight incursions toward the bedrock areas where fine- or medium-grained alluvium is exposed at the surface.

The general features of the method for mapping shear-wave velocity presented here are widely ap-

Shear-Wave Velocities of Near-Surface Materials 139 


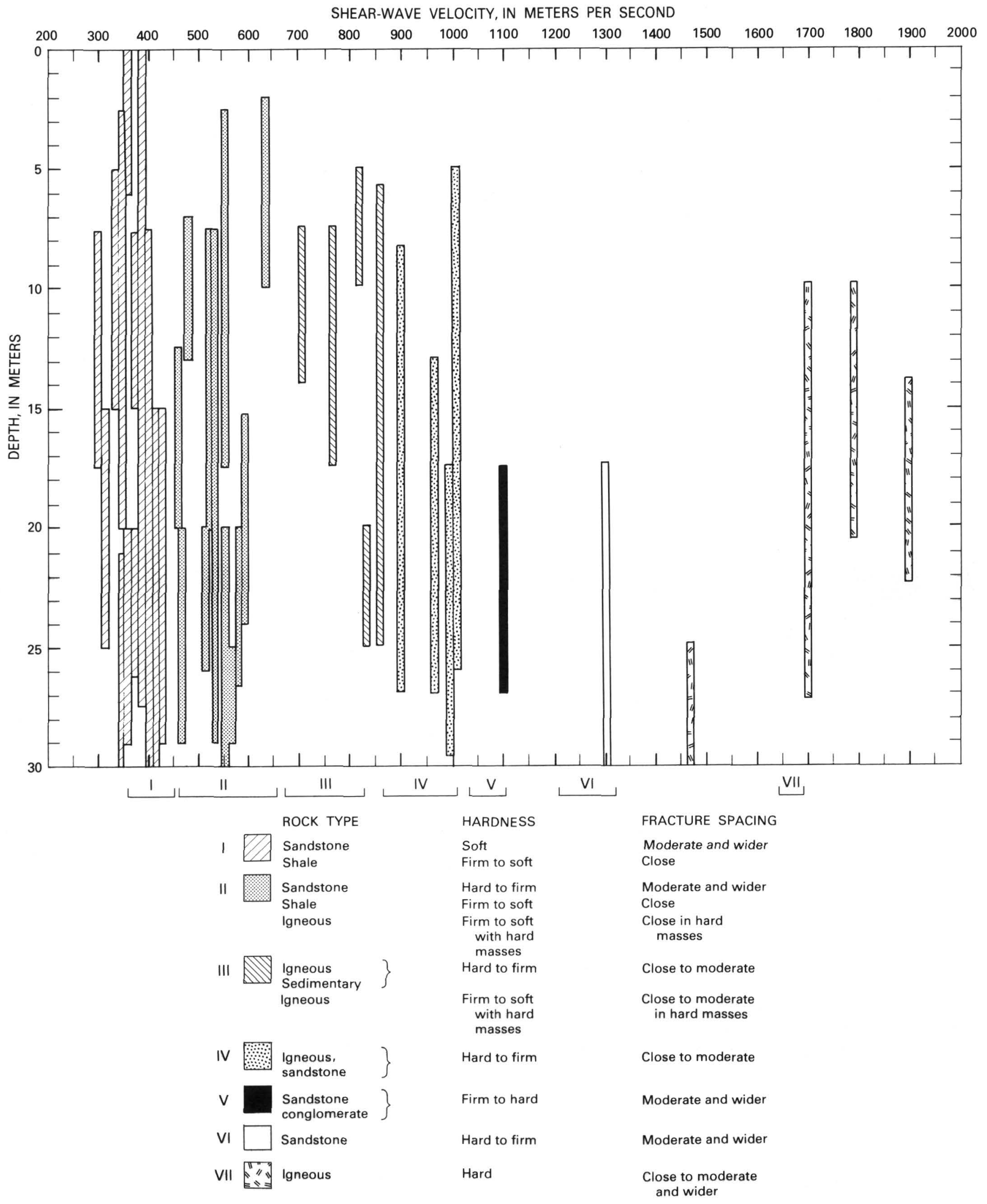

140 Earthquake Hazards in the Los Angeles Region 
TABLE 19.--Shear-wave velocities in pre-late Quaternary bedrock materials for the Los Angeles basin and San Francisco Bay region

[Physical property units defined by using lithology, hardness, and fracture spacing as shown in fig. 55]

\begin{tabular}{|c|c|c|c|c|}
\hline \multirow[b]{2}{*}{ Physical property unit } & \multirow[b]{2}{*}{ No. of samples } & \multicolumn{3}{|c|}{ Shear-wave velocity } \\
\hline & & $\begin{array}{l}\text { Mean, } \\
\text { in } \mathrm{m} / \mathrm{s}\end{array}$ & $\begin{array}{l}\text { Standard } \\
\text { deviation }\end{array}$ & $\begin{array}{l}\text { Range, } \\
\text { in } \mathrm{m} / \mathrm{s}\end{array}$ \\
\hline I --------- & --19 & 385 & 45 & $300-455$ \\
\hline II -------- & ---19 & 550 & 55 & $455-655$ \\
\hline III -------- & ---21 & 770 & 70 & $670-900$ \\
\hline IV -------- & ---8 & 945 & 50 & $870-1,000$ \\
\hline V ------- & ----4 & 1,080 & 35 & $1,030-1,100$ \\
\hline VI -------- & ---5 & 1,265 & 45 & $1,210-1,310$ \\
\hline VII ------- & ---6 & 1,690 & 130 & $1,500-1,900$ \\
\hline
\end{tabular}

plicable. The details of the procedure used for a particular area, however, are dependent on the quality of the available geologic data, especially subsurface data. In most areas, such as the upper Santa Ana River basin, the character of subsurface alluvium is poorly known. The geologic materials in these areas can be represented by a small number of representative geologic profiles. In the Los Angeles basin, the distribution and thicknesses of the subsurface sedimentary layers are better known. In this area, we calculated mean shearwave velocity at several hundred points along cross sections through the basin. A map of mean shear-wave velocity was constructed (Ziony and others, this volume) by contouring the values at these points.

The map prepared for the upper Santa Ana River basin (fig. 58) shows striking contrasts between the velocities of the two predominant types of geologic materials exposed there (unconsolidated sedimentary deposits and hard granitic rocks). Because the sedimentary deposits are generally more than $100 \mathrm{~m}$ thick, the map shows that the lowest estimated velocities are relatively uniformly distributed over the valley floor, including most of the heavily urbanized areas. In sharp contrast, in those areas where the sedimentary deposits are less than $100 \mathrm{~m}$ thick, the shear-wave velocity increases very rapidly approaching the high velocities estimated for the hard granitic rocks.

FIGURE 55.-Shear-wave velocities for depth intervals determined from traveltime curves in bedrock materials in the Los Angeles region. These materials are divided into groups according to fracture spacing, hardness, and lithology. Terms for fracture spacing and hardness are those proposed by Ellen and others (1972). For fracture spacing, very close is 0 to $1 \mathrm{~cm}$, close is 1 to $5 \mathrm{~cm}$, moderate is 5 to $30 \mathrm{~cm}$, wide is 30 to $100 \mathrm{~cm}$, and very wide is more than $100 \mathrm{~cm}$. Hardness is the response of the material to a geologic hammer. Hard indicates that the hammer bounces off with a solid sound; firm, the hammer dents with a thud, and the pick point dents or penetrates slightly; and soft, the pick point penetrates. Ranges of velocities for these units in the San Francisco Bay region are shown along the lower abscissa.

\section{SUMMARY}

Recently developed relations between mean shearwave velocity and strong-ground-motion parameters indicate that seismic velocity can be used to characterize local geologic conditions for predicting ground response from future earthquakes. In order to prepare maps of mean shear-wave velocity for this purpose, we established correlations between seismic velocity and other more readily obtainable physical properties of the geologic materials. These correlations can be applied to a particular area by using data concerning the areal distribution, physical properties, and thickness of the geologic units present to estimate and map shear-wave velocity.

We analyzed seismic and geologic data from 84 sites in the Los Angeles region. These data suggest several useful correlations between shear-wave velocity and soil texture, standard penetration resistance, rock hardness, fracture spacing, and lithology. The late Quaternary sedimentary deposits are grouped into five categories on the basis of mean grain size: (1) clay and silty clay, (2) silt loam and sandy clay, (3) sand, (4) gravelly sand and gravel, and (5) cobble to boulder gravel. Shearwave velocity generally increases as mean grain size increases in these deposits. Standard penetration resistance, an indicator of consistency (clays) or relative density (sands), can be used to subdivide (1) clay and silty clay into medium to stiff $(4 \leq N \leq 15)$ and very stiff to hard ( $N>15$ ) categories and (2) sand into loose to medium $(N \leq 30)$ and dense to very dense $(N>30)$ categories. For bedrock materials, shear-wave velocity increases as the hardness of the intact rock and the fracture spacing in the rock mass increase, the latter having the dominant effect. Lithology is important primarily for differentiating between hard sedimentary rocks and hard igneous rocks. These three physical properties were used to define seven categories of bedrock materials in the Los

Shear-Wave Velocities of Near-Surface Materials 
TABLE 20.-Shear-wave velocity units assigned to the engineering-geologic units for bedrock materials in the Los Angeles basin

\begin{tabular}{|c|c|}
\hline Engineering-geologic unit ${ }^{1}$ & $\begin{array}{l}\text { Equivalent geologic } \\
\text { units }\end{array}$ \\
\hline Chiefly soft sedimentary rocks ----1-- & $\begin{array}{l}\text { San Pedro Formation } \\
\text { Niguel Formation } \\
\text { Fernando Formation } \\
\text { Capistrano Formation } \\
\text { Sycamore Canyon Member of Puente Formation } \\
\text { Vaqueros, Sespe, and Santiago Formations in } \\
\text { Santa Ana Mountains and San Joaquin Hills. } \\
\text { Trabuco Formation in Santa Monica Mountains }\end{array}$ \\
\hline 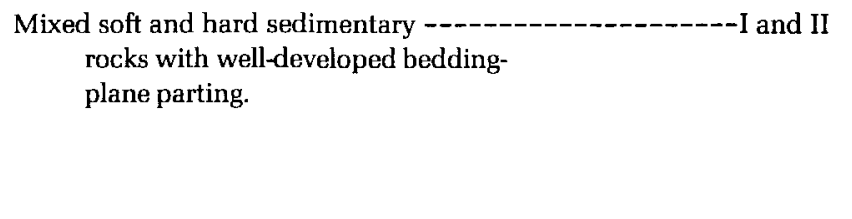 & $\begin{array}{l}\text { Modelo Formation } \\
\text { Puente Formation, exclusive of Sycamore Canyon } \\
\text { Member. } \\
\text { Monterey Shale } \\
\text { Upper Topanga Formation of Durrell (1954) } \\
\text { Hollycrest Formation of Neuerburg (1953) }\end{array}$ \\
\hline $\begin{array}{l}\text { Mixed soft and hard sedimentary --------------II-V } \\
\text { rocks lacking well-developed bedding-plane parting. }\end{array}$ & $\begin{array}{l}\text { San Onofre Breccia. } \\
\text { Griffith and Cahuenga Beds of Neuerburg (1953) } \\
\text { Sespe Formation in Santa Monica Mountains } \\
\text { Silverado Formation } \\
\text { Williams Formation } \\
\text { Ladd Formation } \\
\text { Trabuco Formaton in Santa Ana Mountains } \\
\text { Topanga Formation in San Jose Hills and area } \\
\text { southwest of Pasadena. }\end{array}$ \\
\hline $\begin{array}{l}\text { Mixed soft to hard serpentinite --- } \\
\text { and related rocks. }\end{array}$ & $\begin{array}{l}\text { Unnamed serpentinite and gneissic rock on Santa } \\
\text { Catalina Island. }\end{array}$ \\
\hline $\begin{array}{l}\text { Mixed soft to hard volcanic and } \\
\text { shallow intrusive rocks: } \\
\text { Fragmental rocks --- } \\
\text { Flow rocks: } \\
\quad \text { Moderately weathered - } \\
\text { Fresh - }-1 \text { - }\end{array}$ & $\left\{\begin{array}{l}\text { El Modeno Volcanics } \\
\text { Glendora Volcanics } \\
\text { Conejo Volcanics of Blackerby (1965) } \\
\text { Middle Topanga Formation of Durrell (1954). } \\
\text { Unnamed extrusive and intrusive rocks of Palos } \\
\text { Verdes Hills, Santa Catalina Island, and San } \\
\text { Joaquin Hills. }\end{array}\right.$ \\
\hline $\begin{array}{l}\text { Chiefly hard sedimentary rocks --------------------IV and V } \\
\text { with well-developed bedding-plane parting. }\end{array}$ & $\begin{array}{l}\text { Lower Topanga Formation of Durrell (1954) } \\
\text { Topanga Formation in Santa Ana Mountains and } \\
\text { San Joaquin Hills. } \\
\text { Vaqueros Formation in western Santa Monica } \\
\text { Mountains. }\end{array}$ \\
\hline $\begin{array}{l}\text { Chiefly hard sedimentary rocks ---------------------------VI } \\
\text { without well-developed bedding-plane parting. }\end{array}$ & $\begin{array}{l}\text { Martinez Formation } \\
\text { So-called Chico Formation of Santa Monica } \\
\text { Mountains. }\end{array}$ \\
\hline $\begin{array}{l}\text { Hard, closely fractured } \\
\text { metamorphic and granitic rocks: } \\
\text { Moderately weathered - } \\
\text { Fresh }\end{array}$ & $\left\{\begin{array}{l}\text { Granitic rocks in Santa Monica and San Gabriel } \\
\text { Mountains and in mountains northwest of } \\
\text { Pasadena. } \\
\text { Santa Monica Slate } \\
\text { Bedford Canyon Formation } \\
\text { Catalina Schist } \\
\text { Schist (Franciscan?) in Palos Verdes Hills } \\
\text { Metamorphic complex in San Gabriel Mountains } \\
\text { and mountains northwest of Pasadena. }\end{array}\right.$ \\
\hline
\end{tabular}

\footnotetext{
${ }^{1}$ From Wentworth and others $(1970$, table 1).

${ }^{2}$ From table 19.
}

\section{Earthquake Hazards in the Los Angeles Region}




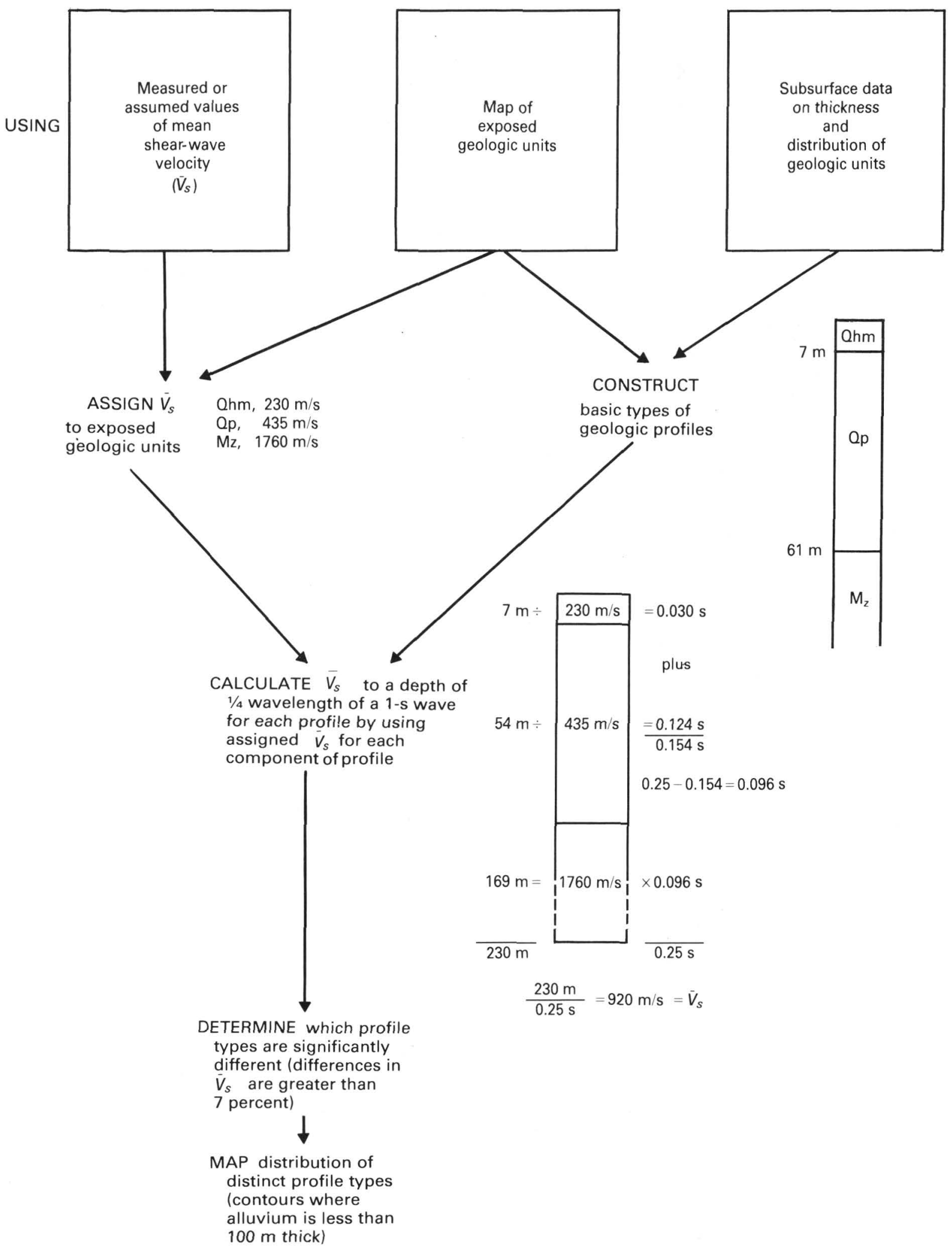

FIGURE 56.-Method used to construct a map of average shear-wave velocity to a depth of one-quarter wavelength of a 1-s wave. Calculations for a sample geologic profile are also shown. 

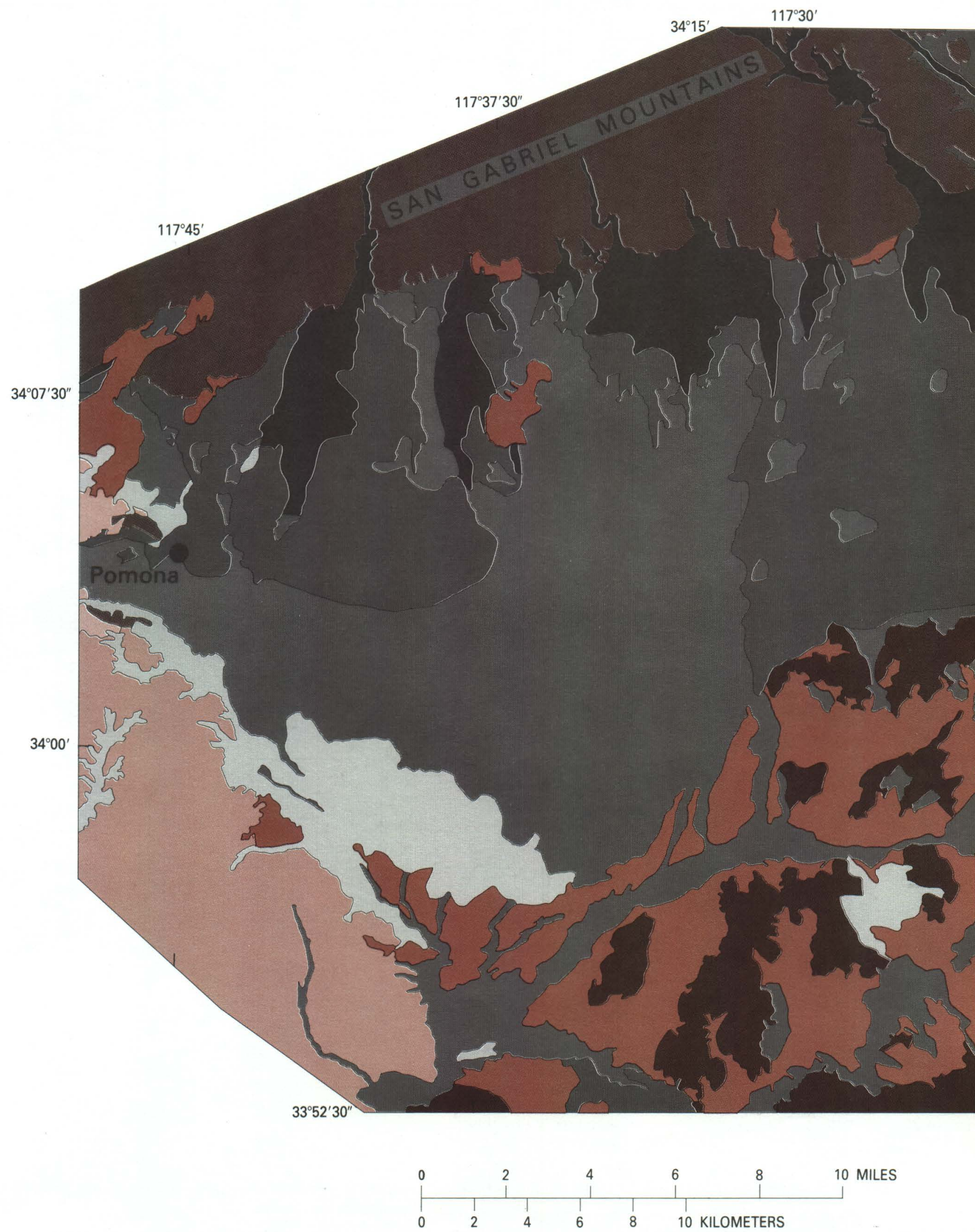

FIGURE 57.-Assigned mean shear-wave velocities for geologic map units in the upper Santa Ana River basin. Values shown are based on correlation with similar materials in the Los Angeles basin. Geologic data were compiled by Cox and Morton (1978). 


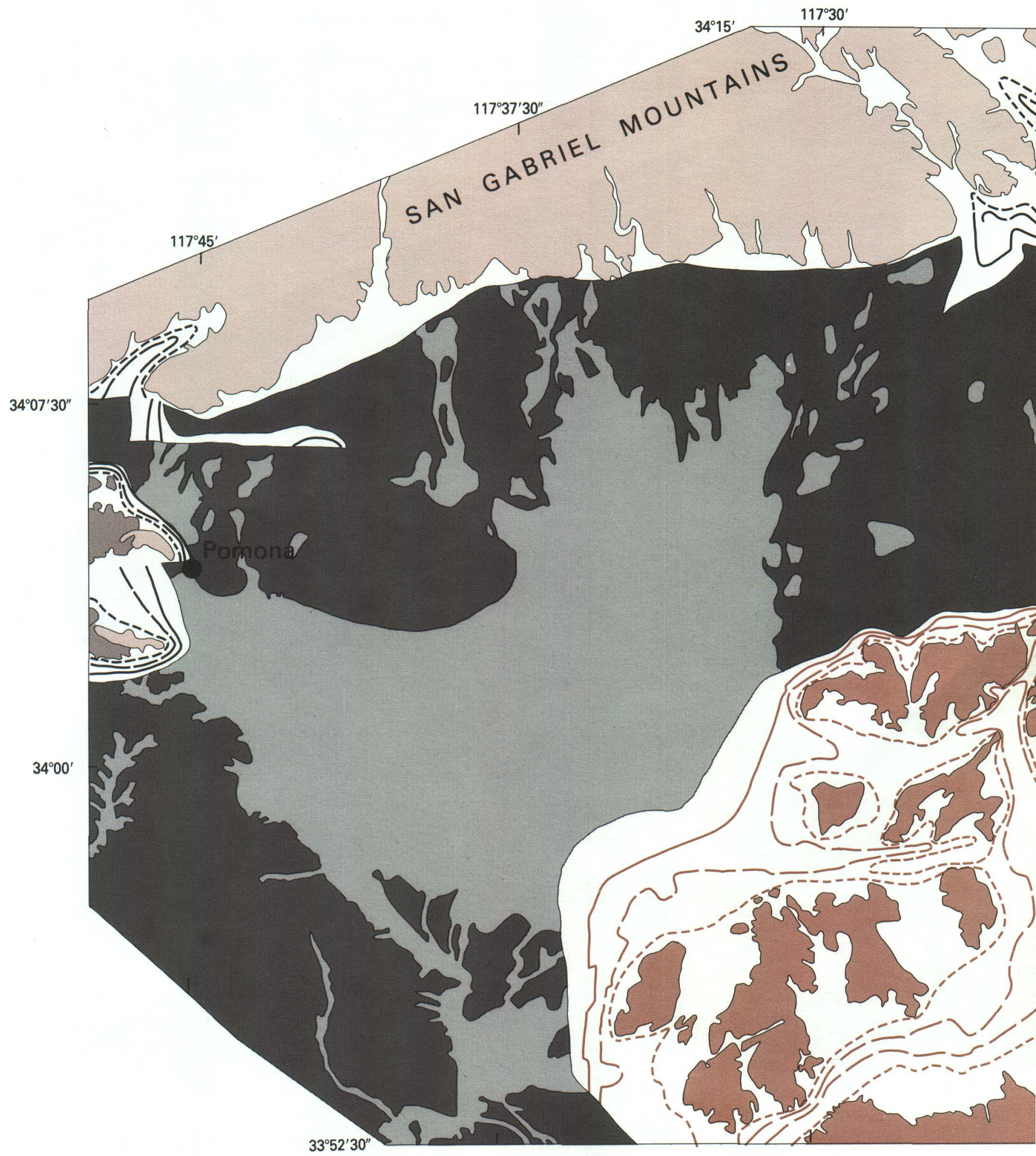

FIGURE 58.-Mean shear-wave velocity calculated over a depth of one-quarter wavelength of a 1-s shear wave for the upper Santa Ana Rir basin.

146 Earthquake Hazards in the Los Angeles Region 
COMPUTED MEAN SHEAR-WAVE VELOCITY, $\mathrm{m} / \mathrm{sec}$

AREAS OF BEDROCK

OR ALLUVIUM

$>100 \mathrm{~m}$ THICK

$117^{\circ} 22^{\prime} 30$

(3)
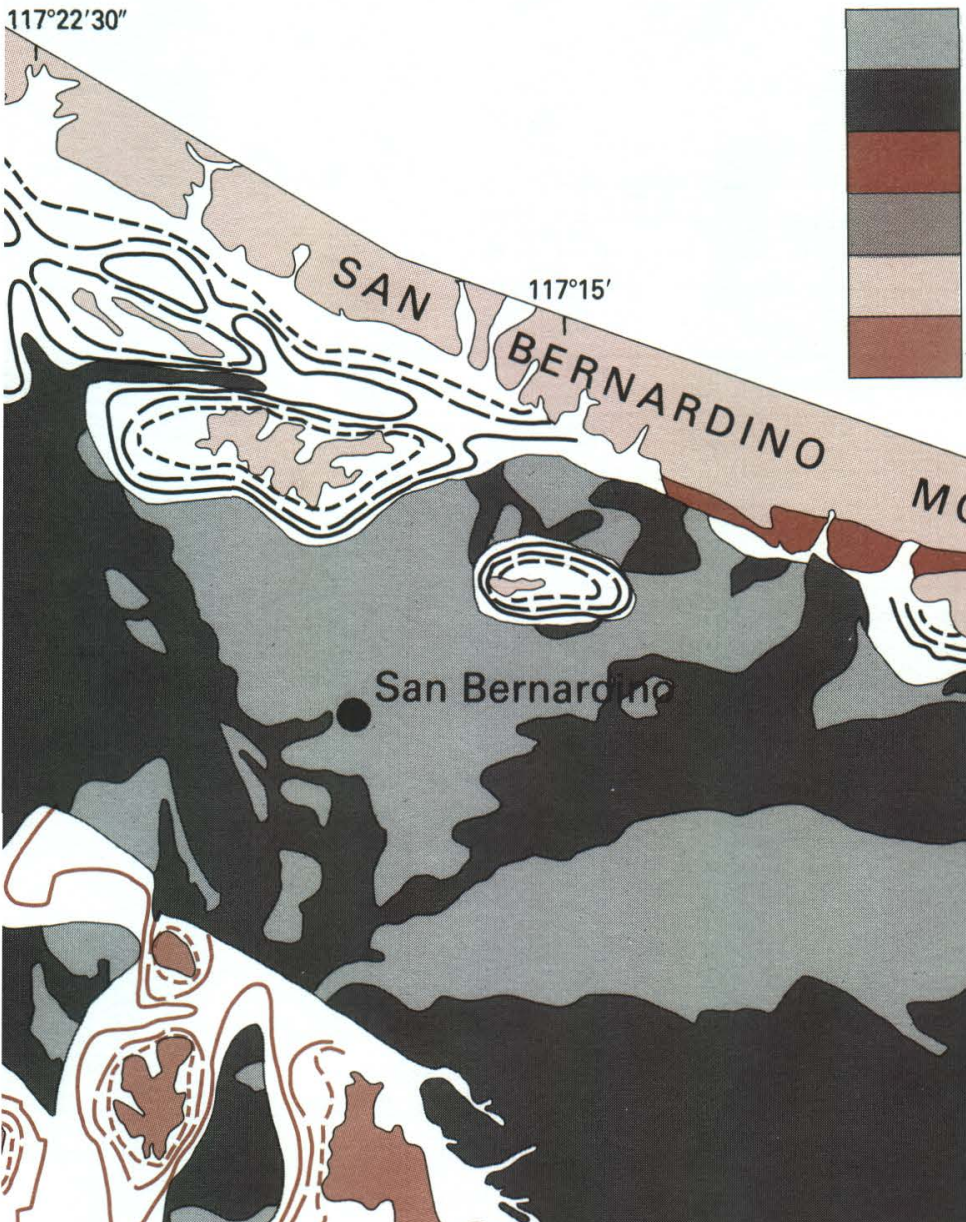

410
435
550
770
1150
1760

760
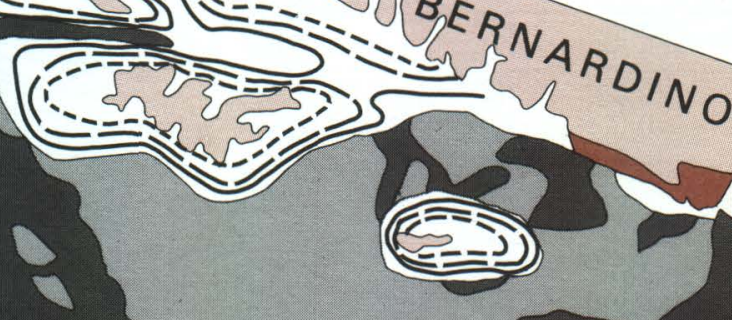

San Bernardíc
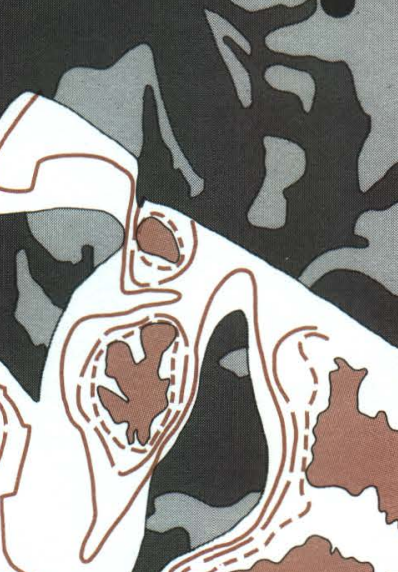

AREAS OF ALLUVIUM $<100 \mathrm{~m}$ THICK

Peninsular

San Gabriel -

Ranges

San Bernardino Mountains
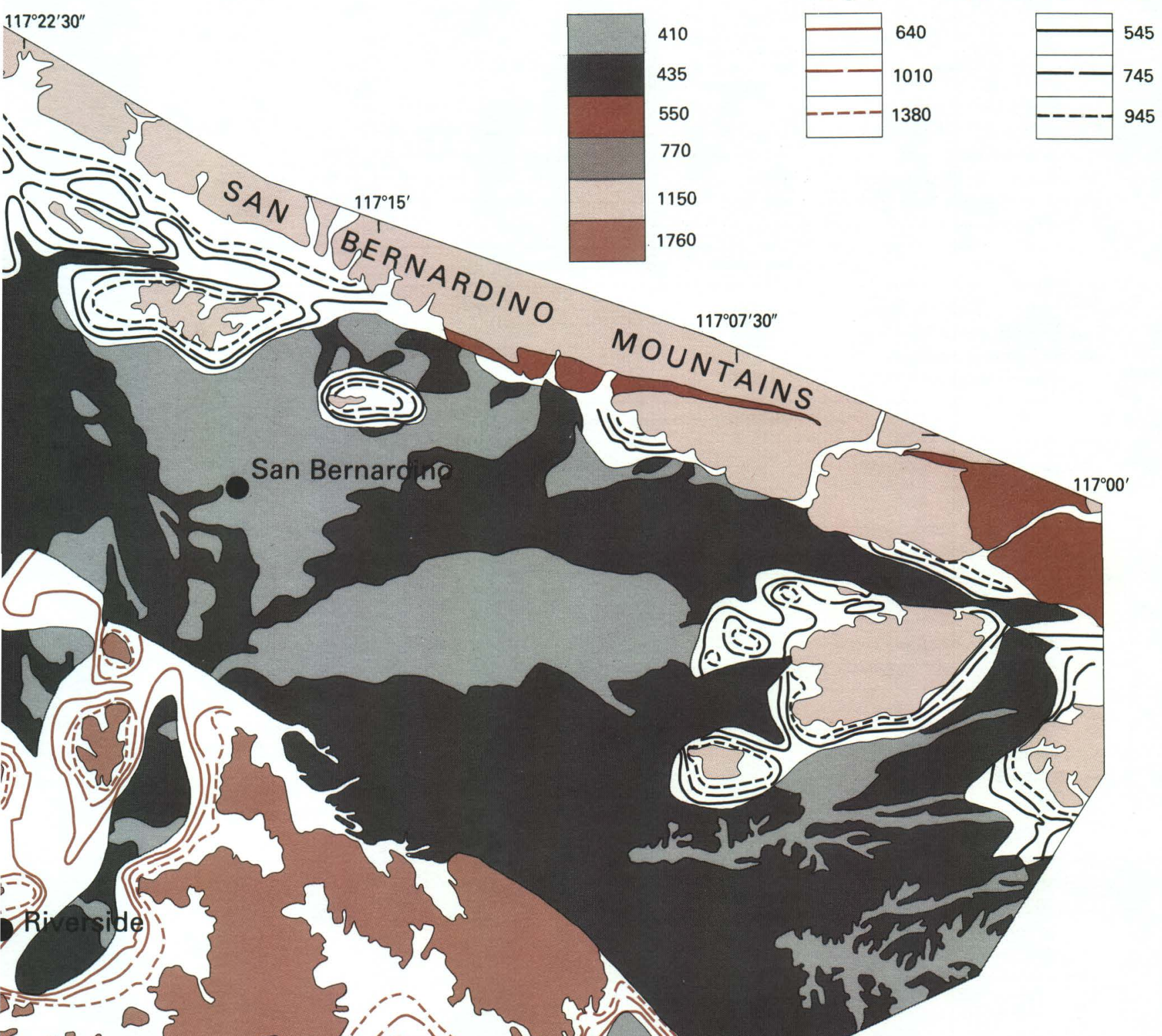

$=$

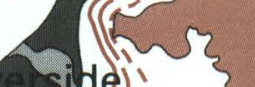

sidde!

3)

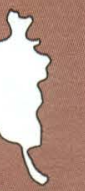

0

$\sqrt{2}$

PENINSULAR

RANGES
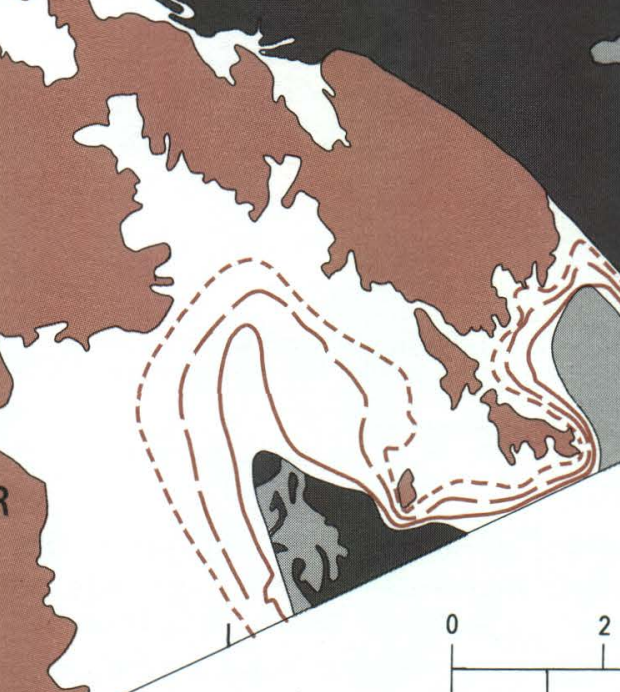
TABLE 21.-Assigned shear-wave velocities of exposed geologic units in the upper Santa Ana River basin

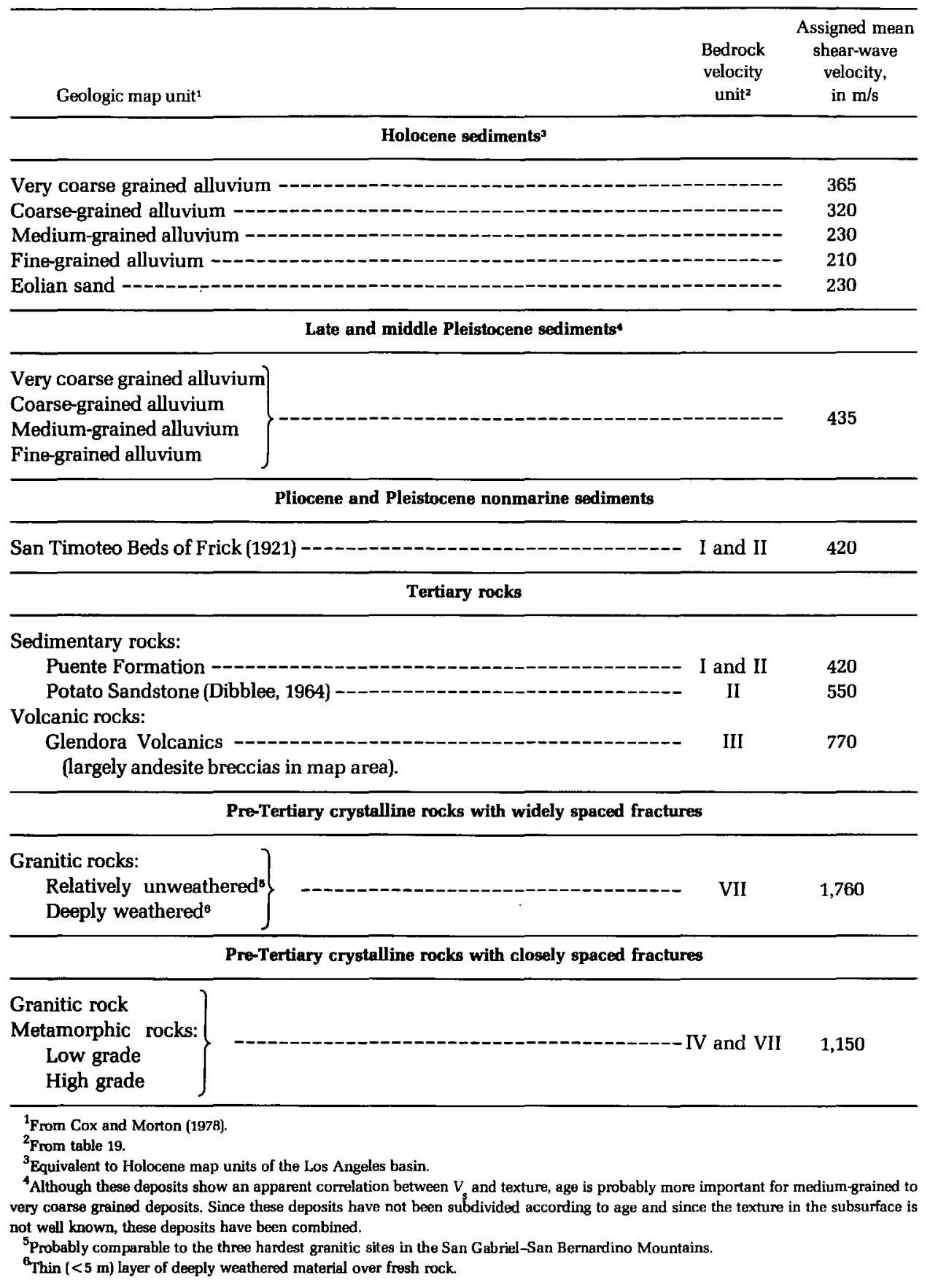

Angeles and San Francisco Bay regions having distinct shear-wave velocities.

Geologic maps incorporating data on physical properties are becoming available for the Los Angeles region. Tinsley and Fumal (this volume) describe a mapping scheme that divides Holocene and late and middle Pleistocene alluvium into four textural categories, each having distinct shear-wave velocity characteristics.
Detailed studies in the Antelope Valley suggest that velocity increases with age in the late and middle Pleistocene alluvium. The distinct reddening of soils developed on deposits older than about 100,000 yr may be a useful criterion for estimating shear-wave velocity. Wentworth and others (1985) have provided detailed descriptions of hardness and fracture spacing for all mappable bedrock units in San Mateo. County (near San

\section{Earthquake Hazards in the Los Angeles Region}


Francisco). A similar, although much more general, map compilation prepared for the Los Angeles basin by Wentworth and others (1970) is useful for determining which physical property group or groups comprise each mappable bedrock unit and thereby provides a basis for estimating shear-wave velocity for bedrock materials.

Regional maps of mean shear-wave velocity can be constructed by using these correlations between shearwave velocity, physical properties, and geologic map units. Two types of geologic information are required: (1) a map showing the areal extent of exposed geologic materials and (2) subsurface data on the distribution and thicknesses of concealed geologic materials. Subsurface data are the more difficult to obtain; the quality of data available determines the procedure for estimating mean shear-wave velocity. In most areas, such as the upper Santa Ana River basin, the character of subsurface alluvium is poorly known. Estimated mean shear-wave velocity in these areas is largely dependent on the texture and age of the surficial deposits and the depth to bedrock. In the upper Santa Ana River basin, we have compiled a set of a small number (15) of representative geologic profiles having distinct mean shear-wave velocities. We have used these profiles to construct a map of shear-wave velocity to a depth of one-quarter wavelength of a 1-s wave. In the Los Angeles basin, more detailed geologic data are available. The subsurface sedimentary deposits there occur in alternating fine and coarse-grained layers that are continuous over large areas of the basin. The distribution and thicknesses of these layers are relatively well known. In this area, we calculated mean shear-wave velocity at several hundred points along cross sections through the basin rather than for a few representative profiles. These points were contoured to provide a map of mean shear-wave velocity. Subsequent chapters of this volume Uoyner and Fumal, Ziony and others) illustrate how these maps of mean shear-wave velocity can be used to construct predictive maps of earthquake ground-motion parameters. 


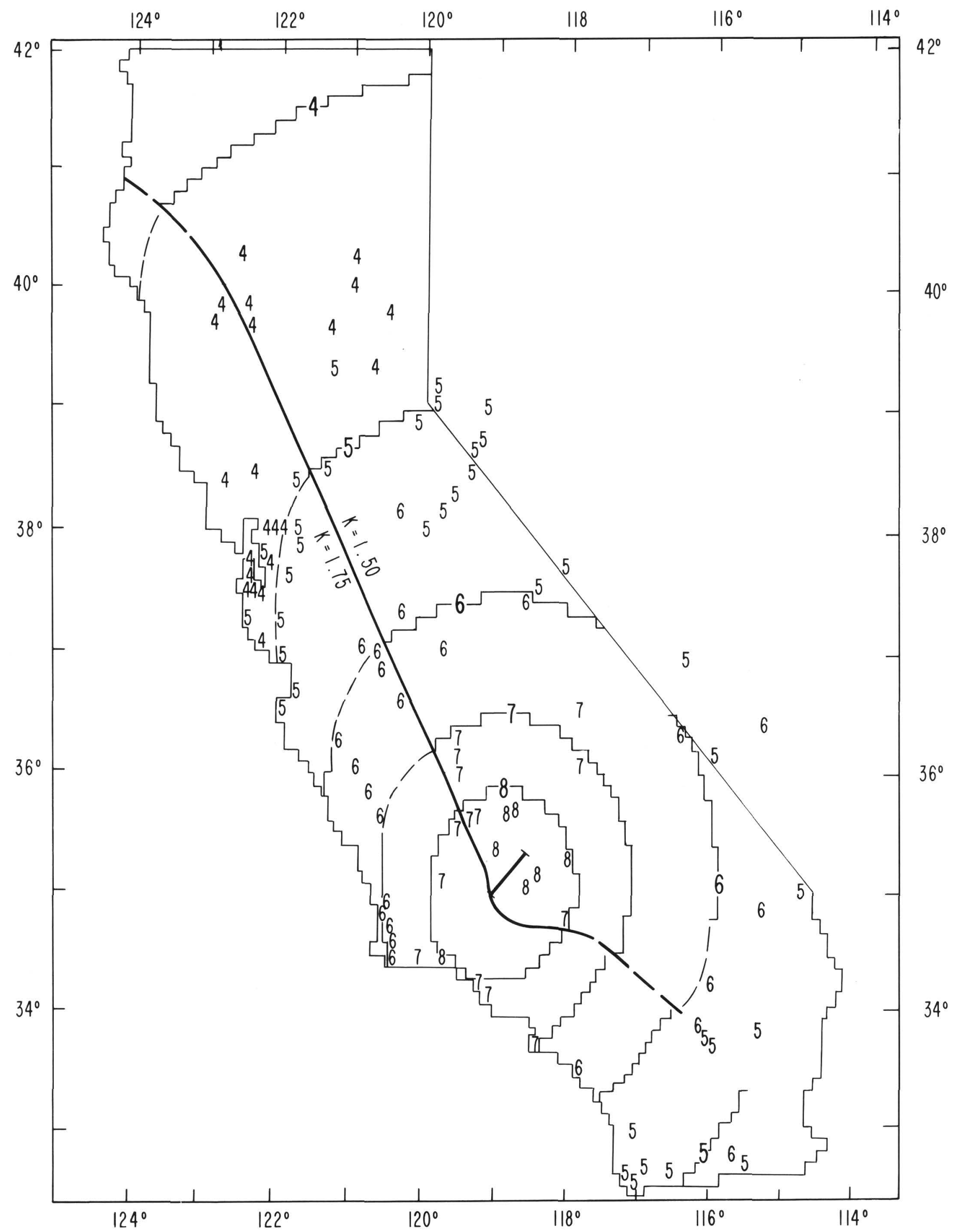

150 Earthquake Hazards in the Los Angeles Region 


\title{
PREDICTING SEISMIC INTENSITIES
}

\author{
By J. F. Evernden and J. M. Thomson
}

\section{INTRODUCTION}

The main purposes of this chapter are to describe the technique used to calculate seismic intensities for any postulated earthquake within any region of the conterminous United States, to show the strong correlation of certain parameters of strong-motion records with seismic intensities, and to demonstrate how the method of predicting intensities can be applied to answer important questions about the potential for strong ground shaking in the Los Angeles region. We also will apply known relations between intensity and percent loss for different structures to estimate future loss or replacement costs due to shaking from various postulated California earthquakes.

Intensity is the only one of the several commonly used measures of ground shaking from earthquakes that correlates directly with damage to ordinary structures and can be accurately predicted for a postulated earthquake. Although many investigators in engineering seismology currently emphasize prediction of groundmotion quantities that can be instrumentally recorded (such as peak acceleration and peak velocity), we believe that seismic intensity is a more useful measure of shaking potential. For example, it is well known that peak acceleration shows a poor correlation with damage and risk. Blume $(1981$, p. 16) has stated:

All too often, peak acceleration is misguidedly used as a direct measure of earthquake damage potential. It is convenient to discuss an earthquake that has just occurred in terms of its location, magnitude, and peak acceleration. But, as time goes on, magnitude and acceleration may no longer be so relevant. There is a vast gap between peak instrumental acceleration and the base shear coefficients used to design buildings.... They can be reconciled only if all the many factors related to the earthquake are considered....it follows that the spikes observed on records have little or no structural design significance....We need to continue to record acceleration and to treat it as a valuable tool but to recognize that it is not a reliable index of damage potential.

Possible reasons for this poor correlation are (1) weak correlation at best between peak acceleration and magnitude for large earthquakes because of saturation of recorded ground motion, (2) peak accelerations that often occur at frequencies outside the band of relevance to structural damage and intensities, and (3) inadequate correlation between peak acceleration and spectral energy distribution (see Hanks and McGuire (1981) for statements to the same effect). Available data suggest that, on the average, there is a correlation of timedomain peak acceleration versus frequency with intensity (Medvedev, 1962; Trifunac and Brady, 1975). Trifunac and Brady (1975) reported that scatter in the data of peak acceleration versus intensity is so great as to render the mean correlation useless for interpretive purposes. Finally, peak acceleration is devoid of any measure of signal persistence; thus, it would be surprising if such a parameter showed a satisfactory correlation with damage and thus with intensity.

What is required for purposes of estimating future levels of earthquake shaking is a quantity that is both (1) clearly correlatable with damage and risk and (2) predictable. The earliest leaders in the field of earthquake microzonation recognized that the only truly useful and available quantity is intensity (Medvedev, 1962, 1976; Richter, 1958, 1972; Friedman, 1969, 1975). They recognized and exploited the fact that the very definition of intensity units guarantees a correlation of shaking parameter (that is, intensity value) with damage or risk to structures of the type used in specifying the intensity units and thus establishes for this parameter the first of the two previously noted characteristics of a truly useful microzonation parameter. A recent quote (Smolka and Berz, 1981, p. 23) on the same theme is:

Although intensity is subjective by nature and is by definition linked to the loss extent, it is the only measure available which takes into account such important damage factors as the spectral characteristics and the duration of earthquake ground motion in addition to its

Predicting Seismic Intensities 
severity. Therefore, Mercalli intensity is still superior to all known objective quantities such as, e.g., instrumental intensity (Housner intensity, Arias intensity) or spectral acceleration, which have failed up to now in reflecting the whole of important damage factors.

A point not specifically addressed here but also of great importance is stated by Smolka and Berz (1981, p. 23): "The use of intensity permits the inclusion of historical earthquakes in the seismic risk analyses. ...The seismic risk study for Switzerland shows in an exemplary fashion how historical data can be incorporated into a risk analysis." Lomnitz (1981, p. 34) has stated, "If peak horizontal acceleration is not necessarily an appropriate predictor of earthquake damage, is there a better parameter which answers to the requirements for this purpose? As we have suggested, such a parameter has existed for many years: it is the seismic intensity as measured on the Mercalli scale."

None of these workers chose to place in the record the fact that intensities are predictable in a useful context; that is, it is possible, from the seismologically and geologically established parameters of an earthquake and region length of break and depth of focus of the earthquake, regional attenuation factor, groundcondition scaling), to predict observed patterns of intensities in different regions. We have attempted to fill this gap in documentation by publishing a series of papers (Evernden and others, 1973, 1981; Evernden, 1975b).

Before discussing the predictive method and its applications, however, it is important that a somewhat confusing phenomenon be addressed and explained. All measures of ground motion relative to seismic intensity as usually defined saturate for high-magnitude earthquakes in California, saturation meaning that all of these parameters cease increasing as length of break exceeds $20 \mathrm{~km}$ or so. The chapter begins with an explanation of this phenomenon, and the several topics mentioned above then follow in order.

Those who may wish to compare the predicted intensities of this volume or of a forthcoming series of USGS maps with those of other authors (Blume and others, 1980; Davis and others, 1982a, b) should realize that the latter have based their analyses on maps of predicted intensity provided by the USGS. The differences between succeeding maps for the same postulated earthquake in the same region are an expression of improved estimates of seismic ground conditions, not of different modes of calculation.

\section{Earthquake Hazards in the Los Angeles Region}

\section{WHY GROUND-MOTION PARAMETERS SATURATE AT HIGH MAGNITUDE}

The observational fact that maximum shaking intensities, local magnitude, and peak acceleration saturate (that is, cease increasing) at magnitudes above $M 6^{6.5^{3}}$ has been well known for some years. Although efforts to correlate maximum intensity with magnitude have been made, they have all foundered on the observation that maximum shaking intensity for $M 6.5$ earthquakes in California is as large as it is for $M 8.3$ earthquakes. Inspection of any catalogue of intensity maps will illustrate this point.

Hanks and Johnson (1976) pointed this out by study of seismograms, and Blume (1981, p. 15) stated it in an engineering context:

If one studies the many structures that have been exposed over the years to nearby largemagnitude earthquakes, it becomes fairly clear that the amplitude of ground shaking during very large magnitude events does not increase much, if at all, over that during events of, say, $M 6^{1 / 2}$ or $M 7$. The shaking will last longer and, of course, will extend over much greater areas during the great events, but there seems to be some sort of limit, or saturation level, for local magnitude.

It may be useful to stress that the frequency range of relevance in this saturation is frequencies of $0.3 \mathrm{~Hz}$ or so and higher (that is, all frequencies of relevance to intensities as usually defined). Hanks and McGuire (1981) limited the range of applicability of their statistical relation between peak acceleration and magnitude to magnitudes of $M 6.5$ or less because of the saturation effects at higher magnitudes. The work of Joyner and Boore (1981) agrees as to the absence of any useful correlation of peak acceleration and magnitude at higher magnitudes. Joyner and Boore did report a best-fit leastsquares correlation of magnitude and peak horizontal acceleration, but this correlation is such that the eightyfourth percentile of the $M 6.5$ distribution is equal to the fiftieth percentile of the $M 7.5$ distribution. Factors other than magnitude must more significantly influence observed near-field values of acceleration. The later

sSee appendix 2 for definition of $M$ as used in this chapter. 


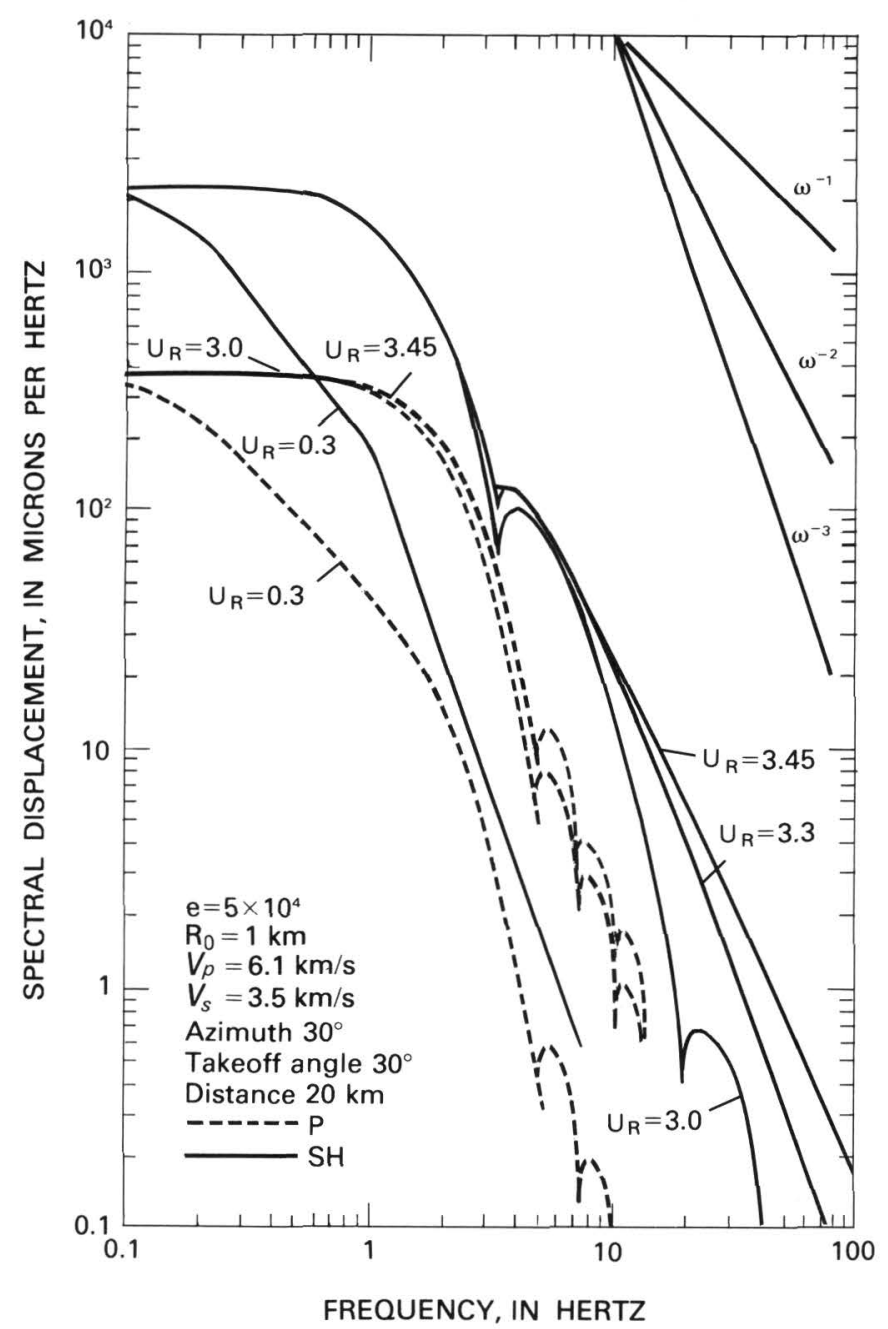

FIGURE 59.-Theoretically predicted spectra of compressional (P) and shear $(\mathrm{SH})$ waves versus rupture velocity for a $2-\mathrm{km}$ fault rupture (distance of $20 \mathrm{~km}$ ) (Minster, 1973). Rupture velocity (in kilometers per second) indicated by $U_{R}$.

discussion of the record obtained at Pacoima Dam for the 1971 San Fernando earthquake is an example of this relation.

The failure of local magnitude to significantly increase as the length of break of California earthquakes exceeds $20 \mathrm{~km}$ or so is just another expression of the phenomenon of saturation of ground-motion parameters for high-magnitude earthquakes in California.

Understanding the reasons for this saturation is vital for interpreting observed seismograms and predicting expected levels of ground motion. Therefore, a somewhat elaborate explanation of the phenomenon will be included. Although the explanation could be presented in a variety of ways, the route chosen is the physical model of the earthquake source expressed in relaxation theory, because it is capable of predicting all spectral values and because it makes all the necessary assumptions within a physical description of the earthquake process. Although rupture velocity is an assumed parameter in each prediction, the correctness of the value chosen when studying any specific seismogram can be checked by spectral examination of the seismogram.

Saturation of compressional wave spectra of earthquakes has been recognized for some time (Evernden, 1975a) and is a phenomenon explained by models of an earthquake based upon a relaxation source (Evernden and Archambeau, in press, in preparation). However, the waves causing major damage and those generally analyzed by strong-motion seismograms are horizontal shear waves rather than compressional waves. For such waves, relaxation theory (Archambeau, 1968; Archambeau and Minster, 1978; Minster, 1973; Evernden and Archambeau, in press, in preparation) predicts a flat long-period displacement source spectrum and two corner frequencies that scale with the ratio of rupture velocity to length of break. The amplitudes of frequencies between the two corner frequencies are inversely proportional to the square of the frequency $\left(\mathrm{f}^{-2}\right)$ if the rupture velocity approaches the shear-wave velocity, and the amplitudes of frequencies higher than the second corner frequency scale inversely as the cube of the frequency $\left(\mathrm{f}^{-3}\right)$. Source spectral relationships versus rupture velocity as predicted by relaxation theory are shown in figure 59 (Minster, 1973). Note the dependence of spectral shape on rupture velocity. Figure 60 indicates how these spectra are predicted to scale with size of an earthquake, for an assumed rupture velocity of $0.95 V_{s}$. For ease of drawing, all roundings of corners predicted on figure 59 are ignored on figure 60. Since figure 60 is intended to be illustrative of general relations, amplitudes are expressed in terms of logarithms of seismic moment $M_{0}$, so that readers can see the implied relations of spectral corner frequencies and spectral falloff as a function of event size for California earthquakes. The relation developed by Evernden and others (1981) $\left(\log M_{0}=23.04+1.91\right.$ log (length of break)) can be used to relate moment $M_{0}$ to rupture length and thus to magnitude for southern California earthquakes. The loci of both corner frequencies in figure 60 left and right) are lines having slopes of $\mathrm{f}^{-3}$, their exact locations depending on stress drop and rupture velocity. All amplitudes scale linearly with stress drop, figure 60 being intended to model stress drops of about 75 bars. It is important to note that the locus of points for the righthand corner frequency is the asymptote for all high- 


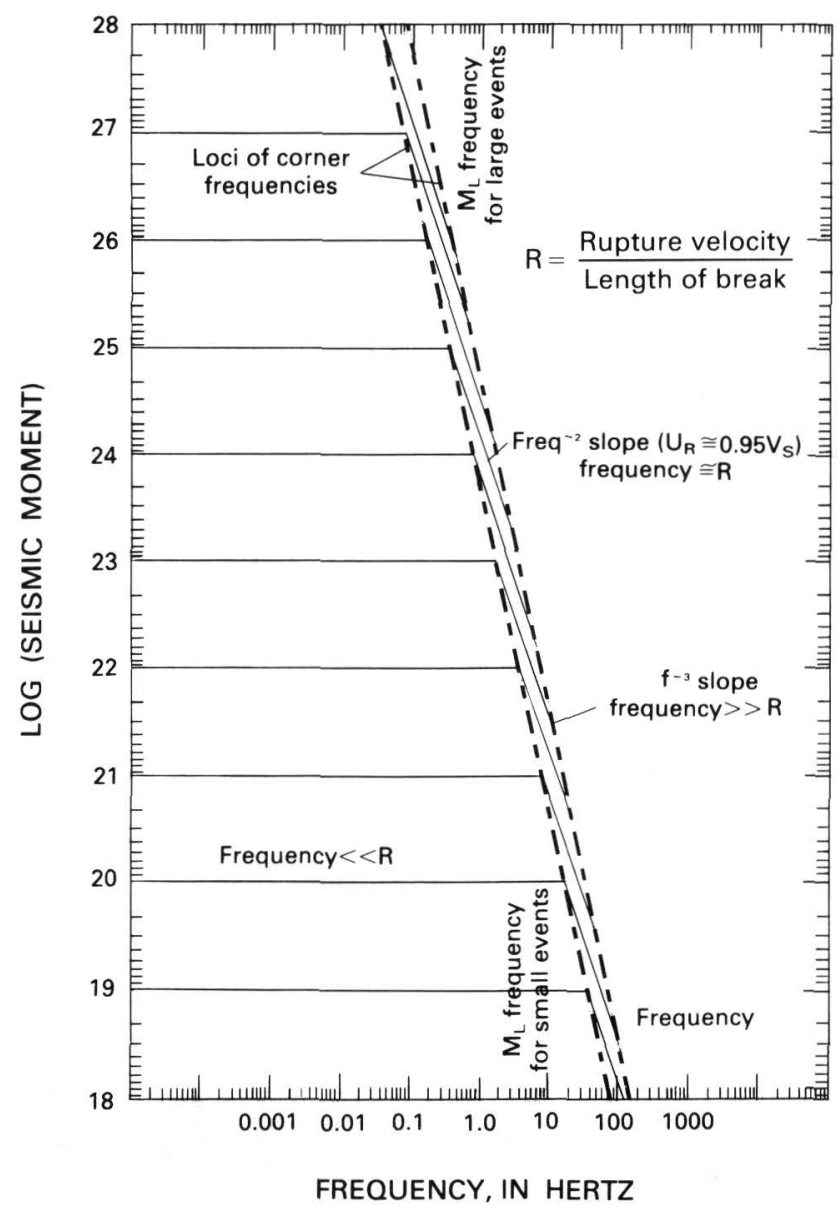

FIGURE 60.-Theoretically predicted horizontal shear-wave source spectra for earthquakes (relaxation model, rupture velocity $U_{R}=0.95 V_{s}$ ).

frequency amplitudes; that is, the source spectral curve beyond the right-hand corner frequency is common for all earthquakes.

To understand the physical bases for the predicted relations in figures 59 and 60 , it is helpful to consider the correlative values of frequency, $R$ (the ratio of rupture velocity and length of break), and spectral behavior. For frequencies distinctly less than $R$ (see fig. 60 ) or, equivalently, for wavelengths long relative to length of break, the earthquake is effectively modeled as a point source, all movement at the fault taking place in a small fraction of all relevant periods. The result is a flat amplitude versus frequency relation. At frequencies distinctly greater than $R$ or, equivalently, for wavelengths small relative to length of break, the potential radiation at each point of the fault at such frequencies is complete. One can think in terms of the fault's appearing infinitely long at such short wavelengths (that is, long enough that energy radiation at a point is no longer influenced by length of the fault). The result is that amplitudes at such frequencies will be the same for all earthquakes having lengths of break sufficiently large (that is, saturation of amplitudes), and a plot of amplitude versus frequency for a given earthquake will follow a $\mathrm{f}^{-3}$ relationship. At frequencies between the above two extremes, the amplitude versus frequency relationship steepens in some manner from being flat to having a $\mathrm{f}^{-3}$ slope. For shear waves and for a rupture velocity about 0.95 times the shear-wave velocity in the rocks surrounding the fault, the slope of the amplitude versus frequency is predicted to follow a $\mathrm{f}^{-2}$ relation for about an order of magnitude increase in frequency as shown in figure 60 . If the rupture velocity were actually to reach the shear-wave velocity $\left(V_{s}\right)$, the $f^{-2}$ slope would be maintained to infinite frequencies. Note that, on the $\mathrm{f}^{-2}$ leg of the spectral curve, amplitudes increase by only a factor of three for a tenfold increase in amplitude at low frequencies. As noted above, the sharp corners of the spectral curves in figure 60 are artificial (see fig. 59 ), as the three conditions discussed above are gradational in their applicability. As regards observations at some distance from the source, a variety of factors associated with propagation and interference effects will lead to further rounding of the predicted corners and to irregularity in details of the observed spectra.

Do these theoretical predictions agree with observations? Tucker and Brune (1973) have published shearwave displacement spectra for many of the small aftershocks of the 1971 San Fernando earthquake. They found that long-period spectra were indeed flat and that the rate of high-frequency falloff to the right of the lefthand corner frequency of figure 60 did indeed tend to follow an $\mathrm{f}^{-2}$ relationship, establishing that the rupture velocity of most of these small earthquakes did approach the shear-wave velocity of the rocks around the failure zone. Tucker and Brune paired observational data of level of long-period shear-wave spectrum (which scales with seismic moment for a fixed stress drop) and corner frequency. Their data for two different ranges of stress drop are shown in figure 61. The predictions of relaxation theory agree with their observations.

For large earthquakes in California, effectively total release of all 1- to 2-s energy at the center of the break after fault lengths exceed $20 \mathrm{~km}$ or so means that peak value of acceleration at frequencies relevant to intensities, as well as local magnitude and intensity, will not increase as the length of break increases further. Total energy radiated in the bandpass will increase with increasing length of break, but energy density at these frequencies will not increase. Therefore, near-field values of ground motion should not increase as length of break exceeds $20 \mathrm{~km}$ or so, except for the fortuitous location of a recording instrument near a shallow asperity or strong point on the fault or fortuitous aspects of instrument siting. For large earthquakes in California, factors such as ground condition, heterogeneity of source and 
propagation path, and so on can influence near-field amplitudes much more than "magnitude" of the event can.

If the spectra in figure 60 are replotted in the format in common use in earthquake engineering, figure 62 is obtained. If the roundings of figure 59 were included, a zone of nearly uniform velocity versus frequency would exist. The important fact illustrated by this figure is that spectral curves versus magnitude (as indicated by seismic moment) do not scale vertically on such a plot. Highfrequency accelerations saturate. Figure 62 shows clearly that peak accelerations at damage-relevant frequencies do not continue to increase for large earthquakes.

To further clarify the character of strong-motion seismograms and resultant implications for correlation with intensity, one horizontal component of the strongmotion records of the 1971 San Fernando earthquake as recorded at Pacoima Dam is analyzed in two different ways: bandpassed seismograms and quasi-harmonic decomposition of the seismogram into a set of undispersed (that is, body'wave) arrivals. Figure 63 presents an example of the first technique as applied to the S. $16^{\circ} \mathrm{E}$. horizontal-motion strong-motion record obtained at Pacoima Dam for the 1971 San Fernando earthquake. A set of such filtered traces provides a very clear picture of the frequency versus time structure of the seismogram. For simplicity, figure 63 presents the original seismogram and filtered seismograms for the three bandwidths from 0.1 to 1,1 to 10 , and 10 to $20 \mathrm{~Hz}$ only. Peak acceleration values for each trace are indicated in the figure. Peak accelerations at frequencies less than 1 $\mathrm{Hz}$ are associated with the beginning of the seismogram and thus probably with the initial deep rupturing of the San Fernando fault. The high frequencies associated with this deep rupturing apparently have been lost already owing to scattering or attenuation (or else they never existed, perhaps implying low initial rupture velocity). The peak accelerations occurred approximately $8 \mathrm{~s}$ after initial motion, too late to be an aspect of the main rupturing.

The second technique (quasi-harmonic decomposition) allows an even better look at the pattern of energy release for this earthquake. Figure 64 illustrates the decomposition of the same seismogram used in the analysis above. The technique consists of analyzing the seismogram in terms of coherent, undispersed, reasonably broad band arrivals, the shape of the arrivals within the time domain being dictated by the results of decomposition and comparison of the resultant suite of narrow-band seismograms, not by an ad hoc assumption of arrival shape. The program does require specification of the minimum number of narrow-band filtered seismograms on which an arrival at a common time ap-

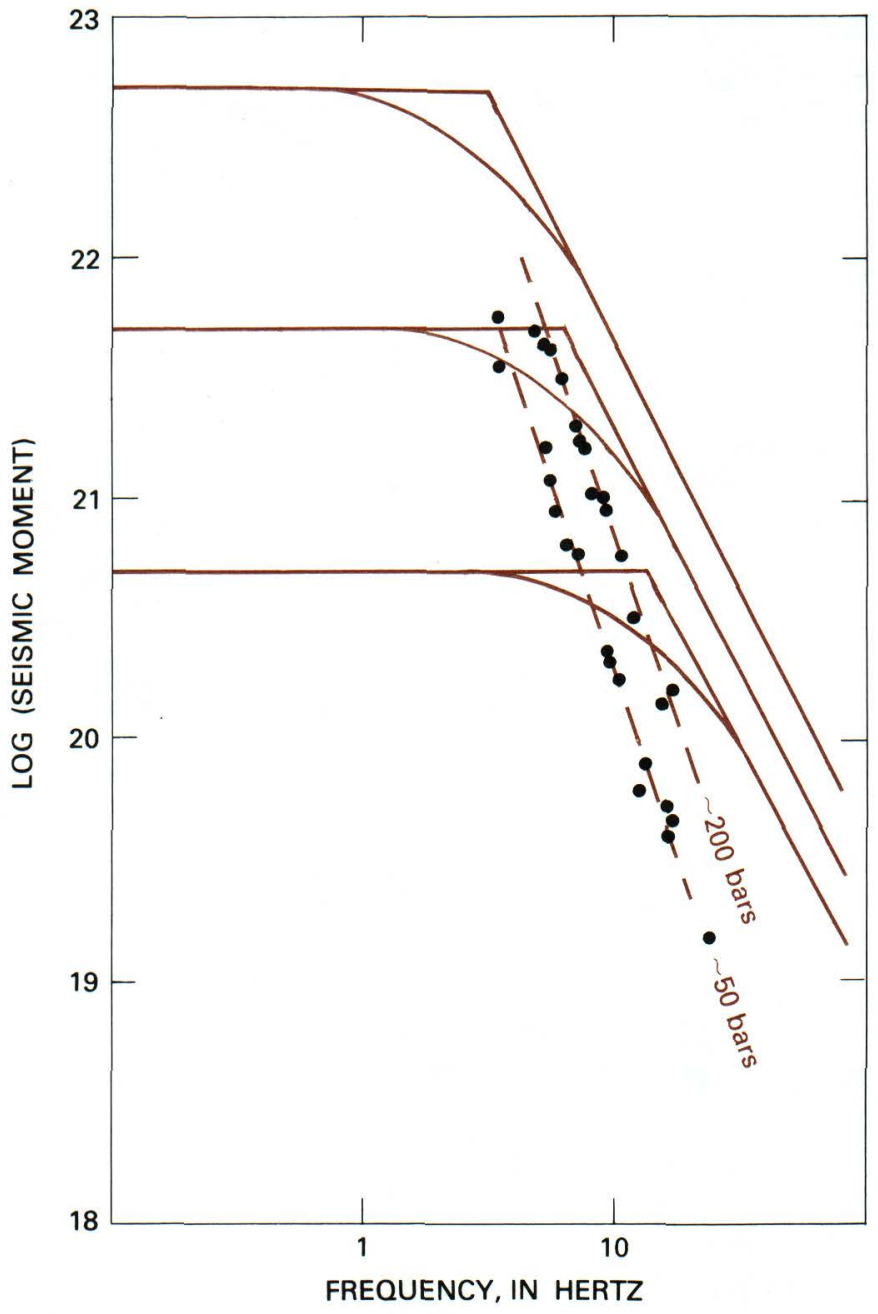

FIGURE 61.-Theoretically predicted horizontal shear-wave spectra (solid lines) for earthquakes (relaxation model) and observed spectral data (solid circles) for aftershocks of the 1971 San Fernando earthquake (Tucker and Brune, 1973.) Spectra are shown both idealized (with sharp corner frequencies) and actual (with smooth curves connecting straight-line segments). Dashed lines indicate different values of stress drop.

pears. If this minimum number is reached, the data for this time interval are processed for definition of an arrival. Complete description of the technique will not be attempted here, since such an elaboration is in the process of being published by C. B. Archambeau. The first trace on figure 64 is the original seismogram, the third through thirty-third traces are the individual arrivals defined by decomposition, and the second trace is the reconstituted seismogram based on summing of the 31 traces below. The complete failure to reproduce the longer periods at the beginning of the seismogram results from the narrow-band character of that part of the record. All of the later high-frequency portion of the seismogram appears to be a series of individual pulses 


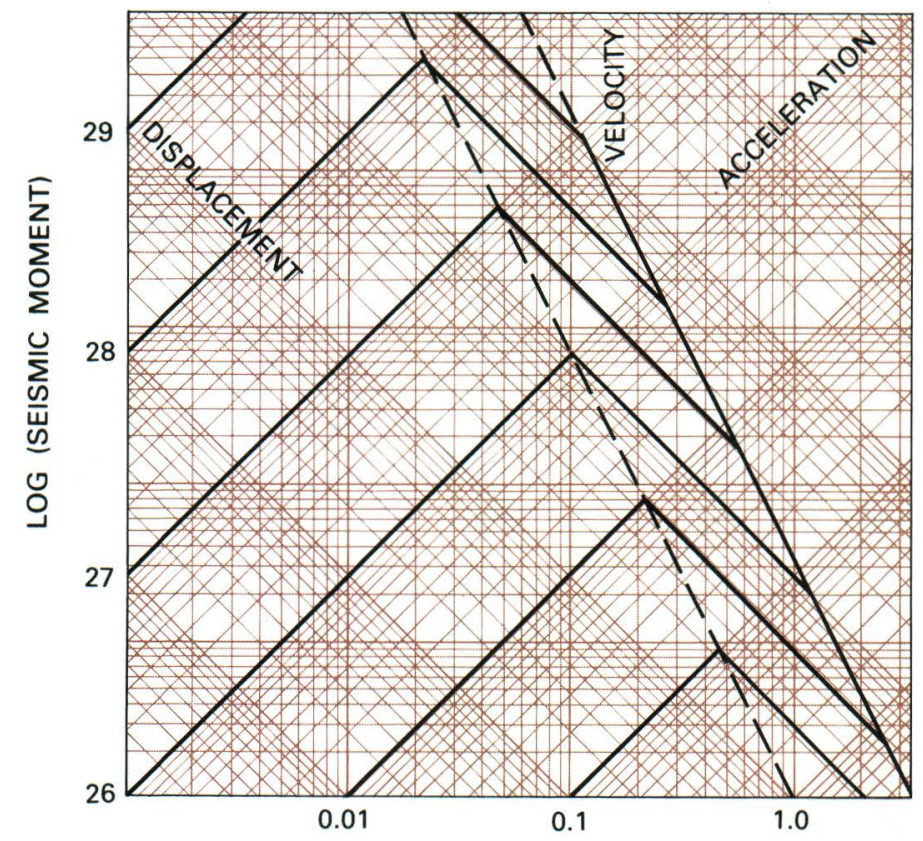

FREQUENCY, IN HERTZ

FIGURE 62.-Theoretical spectra of figure 60 replotted in the format generally used in earthquake engineering.

or spikes of very similar shape, not a coherent continuous signal. The marked grouping in time of the stronger pulses suggests a limited source volume, while their character of high-frequency spikes suggests an origin near the seismometer. This analysis suggests that the value of peak acceleration on a near-source strongmotion record is largely a matter of pure chance. This value is critically controlled by the fortuitous disposition of seismometers and strong spots at shallow depth on the fault surface. It may have very little to do with the magnitude of the earthquake, whereas the ground motion at lower frequencies is more closely linked to the magnitude of the earthquake. Attempts to synthesize the high-frequency part of the spectrum after the event must be somewhat arbitrary, as there will never be enough seismometers to yield a unique interpretation of structure of the fault surface.

If one desires or is compelled by seismic design regulations to continue using quantities such as peak acceleration, it might be advisable to consider maximum acceleration in a set of narrow-band spectral windows rather than peak acceleration from the entire seismogram, assuming that such a suite of values can be shown to have some useful correlation with damage or risk for particular types of structures. This point will be investigated later.

\section{METHOD FOR PREDICTING SEISMIC INTENSITIES}

A computer-based procedure for calculating intensity patterns for specified earthquakes has been developed (Evernden and others, 1973, 1981; Evernden, 1975b). The procedure has been tested by extensively comparing predicted and observed patterns of intensity for numerous historical earthquakes throughout the conterminous United States and eastern Asia. As noted earlier, this computer program has been used by both State and Federal agencies to estimate, for emergency preparedness planning, the likely levels of shaking intensity for various potential earthquakes. For example, intensities have been predicted for possible earthquakes affecting major California population centers (U.S. Geological Survey, 1981).

A brief summary and flow diagram (fig. 65) of the procedures of calculation are presented here (see app. 2 for mathematical details). The ingredients of the intensity modeling technique are (1) a law expressing the rate of attenuation of intensity-related seismic waves in the region to be investigated; (2) a correlation of geologic ground condition and expected relative intensity (saturated alluvium is used as a reference ground condition); (3) a map giving the distribution of the several defined seismic ground conditions throughout the region to be investigated; and (4) a mathematical model of the earthquake source (including location, length of break, and depth of focus), plus a scheme of calculation that conceptually radiates energy from each segment of the fault, attenuates each such increment according to element 1, calculates a quantity intended to simulate the root-mean-square (RMS) acceleration over a time window of 10 to $20 \mathrm{~s}$ (matter of choice) centered on the strongest arrival (that is, from nearest point on fault), converts this RMS acceleration into a predicted intensity on saturated alluvium, and then, by using the data from elements 2 and 3, calculates the predicted intensity for the site ground condition. The present computer program can provide either Rossi-Forel or Modified Mercalli intensities. A description of the Modified Mercalli scale, with Rossi-Forel equivalents, is presented on the inside back cover of this volume.

An attenuation map of the region under consideration is an essential first step toward predicting intensities successfully. Figure 66, a first attempt at such a map for the conterminous United States, is based on study of the intensity patterns of earthquakes throughout the country. The second step is to correlate length of break, 

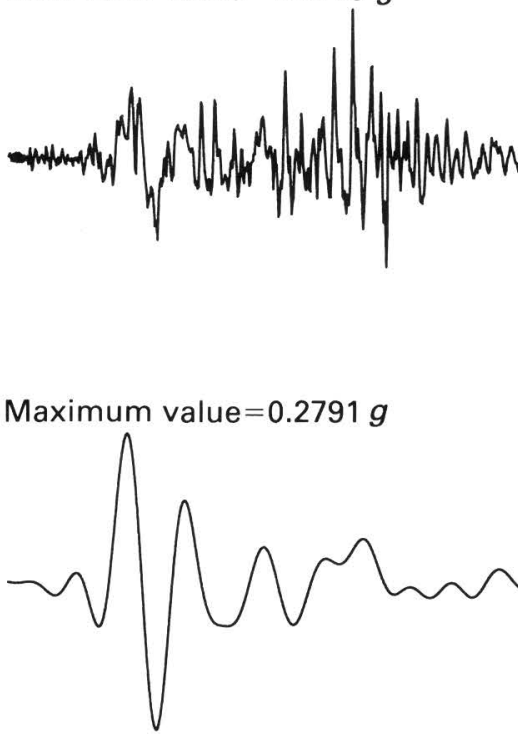

Maximum value $=0.9231 \mathrm{~g}$

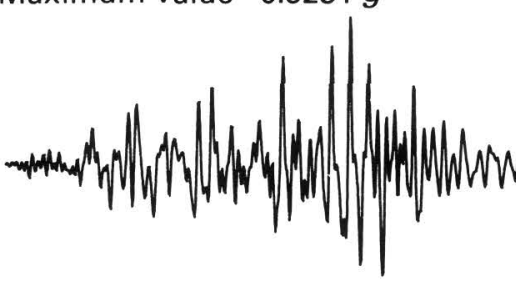

Maximum value $=0.2003 \mathrm{~g}$

$10-20 \mathrm{~Hz}$

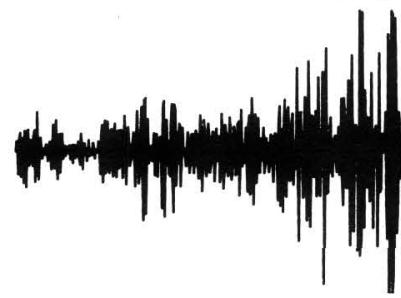

TIME, IN SECONDS

FIGURE 63.-Strong-motion seismogram recorded at Pacoima Dam for the San Fernando earthquake of February 9, 1971. S. $16^{\circ}$ E. component. The upper curve is the original accelerogram. Lower curves are filtered versions of the upper accelerogram, the band of frequencies used for each curve being indicated on the figure. 


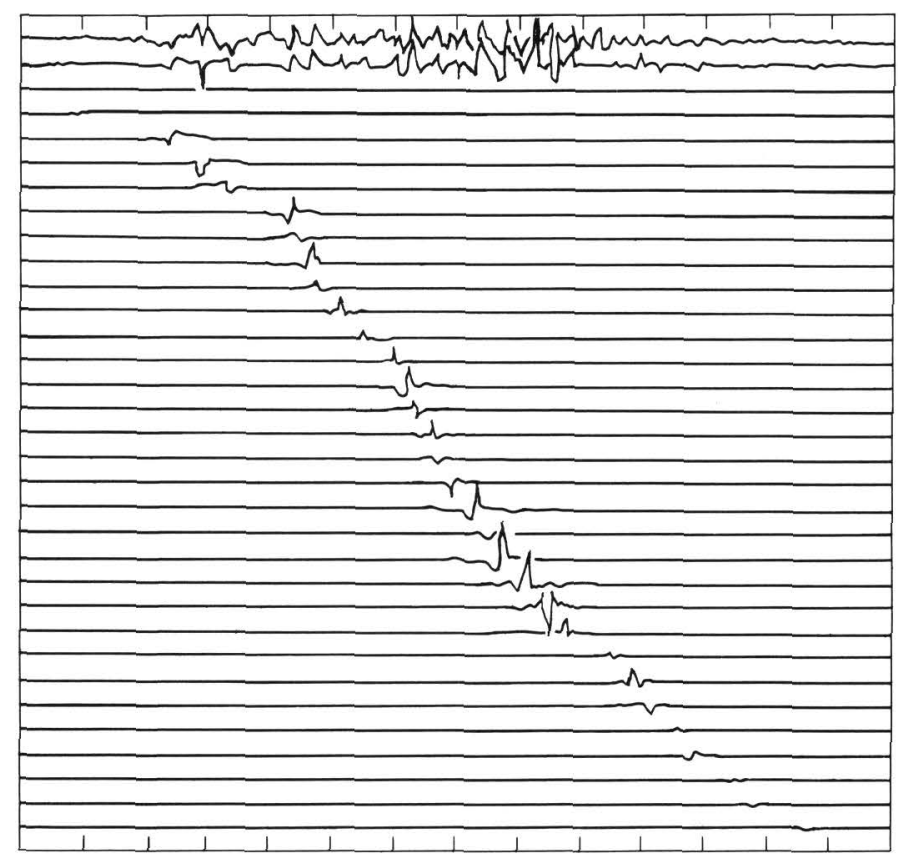

TIME, IN SECONDS

FIGURE 64.-Quasi-harmonic decomposition of the S. $16^{\circ}$ E. component of the Pacoima Dam record from the 1971 San Fernando earthquake (see fig. 63).

depth of focus, and intensity pattern on saturated alluvium in each of the different regions defined by the attenuation parameter. All the details of the procedures and data required to construct figure 66 and to achieve the above correlation have been presented by Evernden (1975b) and Evernden and others (1981) and are not repeated here. Note that we do not say "correlate magnitude and intensity pattern." Ongoing seismologic research ultimately may establish such a correlation on a regional basis. However, many current users of "magnitude" have an erroneous concept in mind. Properly used, magnitude is a scale of the relative sizes of earthquakes by certain very specific measurements recorded on a very specific instrument within a region of uniform attenuation characteristics. By using careful calibration procedures and definitions, events of "equivalent" magnitude can be defined in different regions but only after such careful calibration and after somewhat arbitrary assertion of the definition of "equivalence." For $M_{S}$ and $m_{b}$, two routinely used magnitude measurements based on long-range observations, such calibration and definition are possible by largely accepted procedures. Consistent interregional definition of "local" magnitudes, however, has not been achieved, so little detailed meaning can be attached to many such values today for areas where attenuation is different from that in southern and western California, particularly when the formula developed by Richter for ap- plication to earthquakes in southern California (a region of very high attenuation) is used indiscriminately in regions having different attenuation characteristics. The extent of interpretive error and confusion that can so result has been suggested by Evernden and others (1981). Correct procedures using conventional seismologic data are available for solving this problem, but they are laborious and time consuming and have not been applied throughout the United States. A procedure applicable in all regions for defining local magnitude by means of intensity data has been described by Evernden and others (1981) and used by Evernden (1983).

The third step required is correlation of geologic ground condition with seismic ground condition (expected intensity relative to saturated alluvium). Two procedures are used. We followed Borcherdt (1970) in achieving intercalibration by means of the relative amplitudes of seismic waves recorded at sites on various rock and sediment types in the San Francisco Bay region. Because Borcherdt's data were not correlated with depth to water table, we followed Medvedev (1962) in decreasing the predicted intensity by one unit if the water table was at a depth of $10 \mathrm{~m}$ or more in Quaternary alluvium. No adjustment is made for depth to water table in any other materials.

This empirically developed scale for geologic units in the San Francisco Bay area was extended to all units on the 1:250,000-scale map sheets of the Geologic Atlas of California (California Division of Mines and Geology [1958-1969]) on the basis of similarity of relevant rock properties, the resultant correlations being given in table 22. Expected relative intensities of the seismic ground-condition units in table 22 are given in table 23. The fact that these modes of calibration of relative intensities achieved an excellent correlation with observations confirmed the much earlier demonstration by Medvedev (1962) that differences in intensity on ground of various types are directly linked to measurable, quantitative aspects of the several rock or sediment types. Because intensities on all rock or sediment types (even the highest shaking intensities) can be explained by linear scaling from relative amplitudes of low-amplitude waves (Evernden and others, 1973), it is established that high shaking intensities are primarily an aspect of elastic response, not of inelasticity or other aspects of ground failure. Of course, if amplitudes become too high in water-saturated cohesionless sand or silt (Tinsley and others, this volume), the ground may liquefy and fail, and nonshaking aspects of damage may result. Shaking damage, however, is predictable by a model based on scaling by means of low-amplitude elastic behavior of all rock and sediment types.

Given the above correlations, the final requirement is a theoretical model of the earthquake source. A detailed

\section{Earthquake Hazards in the Los Angeles Region}




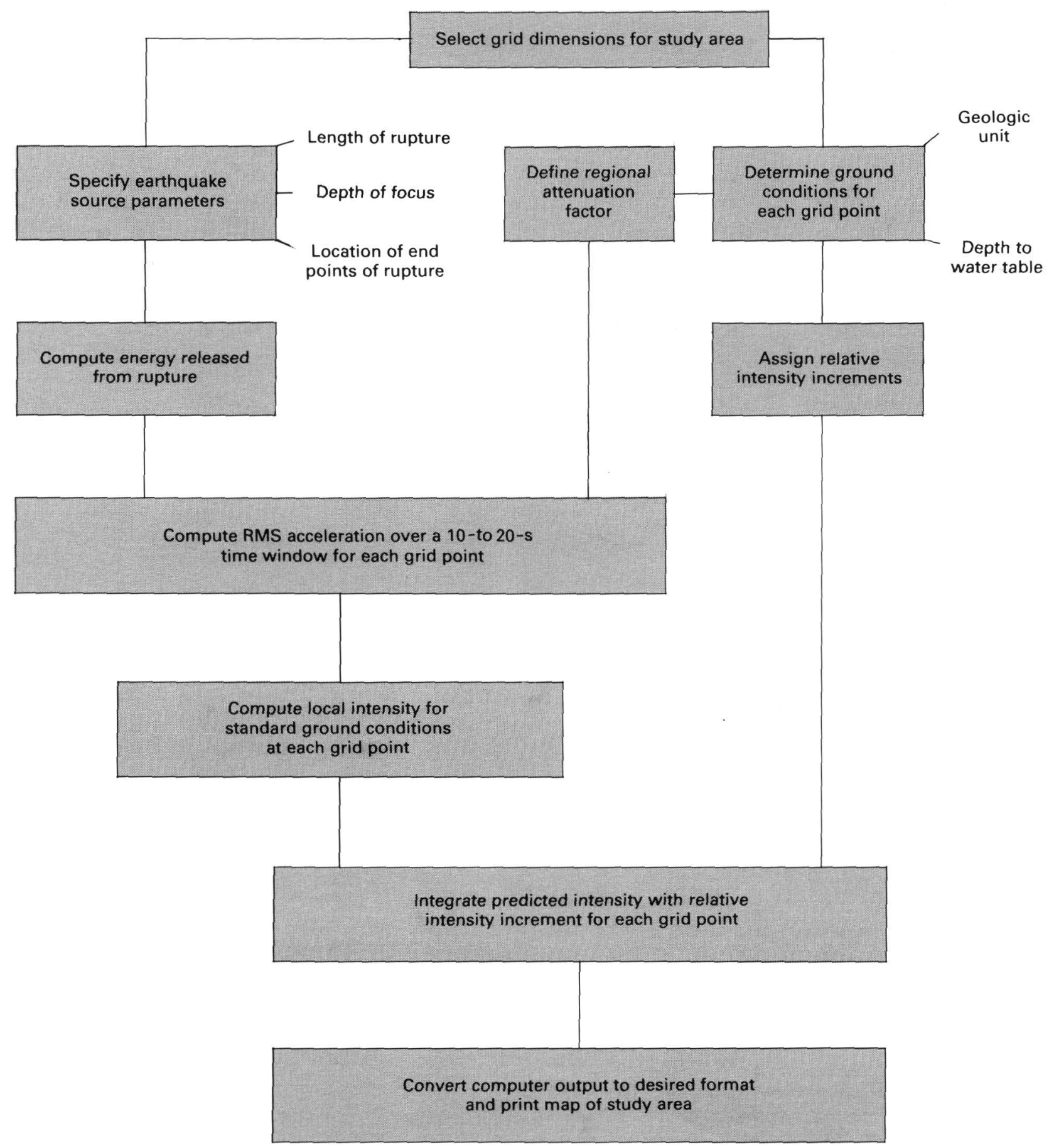

FIGURE 65.-Flow chart for predicting seismic intensity values for a specified earthquake in a given region.

description of the model used has been given by Evernden and others (1981) and is repeated in a condensed version in appendix 2 . Only one point need be stressed here. The model as now implemented calculates essentially RMS acceleration over a time interval of potentially $20 \mathrm{~s}$, including arrivals as much as $10 \mathrm{~s}$ before the arrival from the nearest point of the fault break to arrivals as much as $10 \mathrm{~s}$ after that arrival. The intent of this pro- cedure is to build signal persistence into the calculation of intensity. The original calculation is for saturated alluvium. The last step in the program is to make the correction for the actual seismic ground condition at the site by using data described above.

Given all of these parameterized and modeled factors, accurate predictions are possible. Evernden and others (1981) and Evernden (1982) have presented samples of 


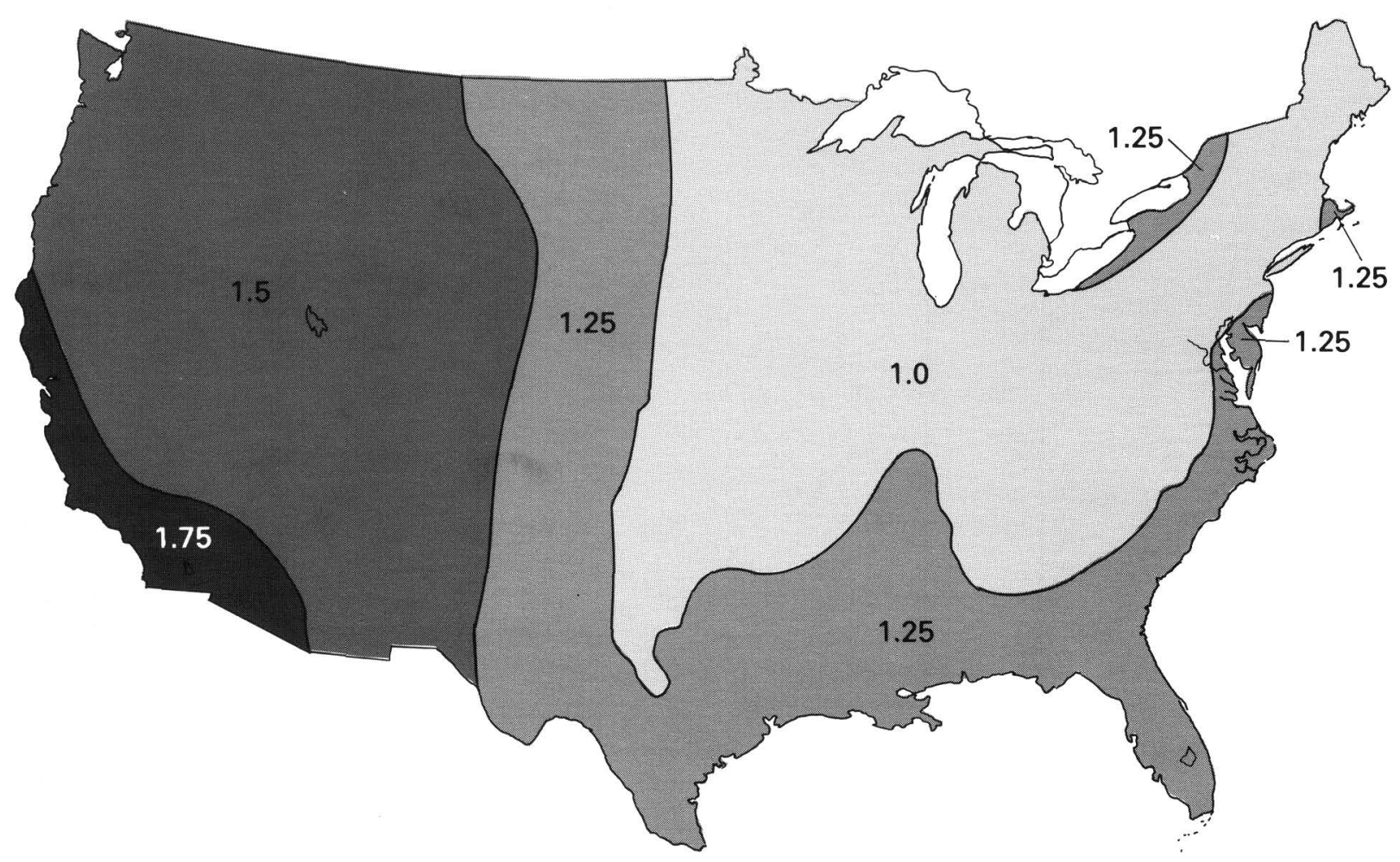

FIGURE 66.-Generalized attenuation map for the conterminous United States expressed in values of $k$ ( $k$ is defined in app. 2.)

observed and predicted intensities for numerous earthquakes, so none will be given here. The discussions in those papers indicate that intensity fulfills the second required characteristic of a useful microzonation parameter; that is, it is predictable in a detailed and useful manner.

A major difficulty in using predicted intensity maps in the future is the current tendency of those who make and use intensity maps to ignore one of the critical facets of the definitions of intensity units-the fact that these definitions are related to very particular types of structures. Today, changes in construction practice commonly are ignored in assigning intensities. When definitions based on pre-1940 construction are applied to post-1940 construction, confusion in understanding and interpretation results (see later discussion of San Fernando, Coyote Lake, and Imperial Valley earthquakes). Unless this practice ceases, it is certain that interpretation of future published intensity maps and their prediction will become impossible. If intensity prediction is to remain useful, it will be essential to apply old definitions rigorously and to generate all auxiliary and corollary definitions required to achieve uniform estimates of intensity in spite of variations in building types and modes of construction. As an effective example of such calibration, the current definitions of
Modified Mercalli intensities used in the People's Republic of China are in terms of Chinese structures, these definitions having been established only after careful analysis and comparison. It was only because of this effort by the Chinese that the analysis reported by Evernden (1983) was successful.

\section{CORRELATING INTENSITY WITH STRONG-MOTION PARAMETERS}

\section{Previous Studies}

Several investigations of correlations between intensities and acceleration data derived from strong-motion seismograms have been published, one of the first having been Medvedev's (1962) (see fig. 67). His technique was to measure frequency versus acceleration directly from analog records of U.S. strong-motion seismograms and to plot maximum acceleration at various periods versus intensity as interpreted from "U.S. Earthquakes," an annual publication of the U.S. Coast and Geodetic Survey (USCGS), now the National Ocean Survey. These procedures were the best available at the time, and the plotted data in figure 67 indicate the cor- 
TABLE 22.-Correlation of geologic units on 1:250,000-scale geologic map of California with groundcondition units for California

\begin{tabular}{|c|c|}
\hline $\begin{array}{l}\text { Geologic map } \\
\text { units }^{1}\end{array}$ & $\begin{array}{l}\text { Ground-condition } \\
\text { unit }\end{array}$ \\
\hline \multicolumn{2}{|l|}{$\begin{array}{l}\text { Granitic and metamorphic rocks } \\
\text { (Kjfv, gr, bi, ub, JT }{ }_{R v}, m, m V, P p V, P m V \\
\text { Cv, Dv, pS, pSv, pCc, PCgr, pC, epC, TI) }\end{array}$} \\
\hline $\begin{array}{l}\text { Paleozoic sedimentary rocks } \\
\text { (Ms, PP, Pm, C, CP, CM, D, S, pSs, O, E) }\end{array}$ & $--B$ \\
\hline $\begin{array}{l}\text { Early Mesozoic sedimentary rocks } \\
\qquad(\mathrm{Jk}, \mathrm{Ju}, \mathrm{JmE}, \mathrm{Tr}, \mathrm{Kj} f)\end{array}$ & $-\cdots-C$ \\
\hline $\begin{array}{l}\text { Cretaceous thirough Eocene sedimentary rocks -- } \\
\quad(E c, E, E p c, E p, K, K u, K E)\end{array}$ & $-\cdots-D$ \\
\hline $\begin{array}{l}\text { Undivided Tertiary sedimentary rocks } \\
\text { (QTc, Tc, TE, Tm) }\end{array}$ & 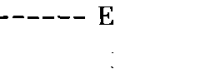 \\
\hline $\begin{array}{l}\text { Oligocene through middle Pliocene sedimentary } \\
(\mathrm{PmEc}, \mathrm{PmE}, \mathrm{Mc}, \mathrm{Muc}, \mathrm{Mu}, \mathrm{Mmc}, \mathrm{Mm}, \mathrm{ME}, \mathrm{d}\end{array}$ & $----F_{i}$ \\
\hline $\begin{array}{l}\text { "PliocenePleistocene" sedimentary rocks } \\
\text { (Qc, OP, Pc, Puc, Pu) }\end{array}$ & $-----G$ \\
\hline $\begin{array}{l}\text { Tertiary volcanic rocks } \\
\text { (Pv, Mv, Olv, Ev, QTv, Tv) }\end{array}$ & $-----H$ \\
\hline $\begin{array}{l}\text { Quaternary volcanic rocks } \\
\text { (Qrv, Qpv) }\end{array}$ & ----1 \\
\hline $\begin{array}{l}\text { Quaternary sedimentary deposits } \\
\text { (Qs, QaE, Qsc, Qf, Qb, Qst, QE, Qq, Qt, Qm) }\end{array}$ & $\cdots---J$ \\
\hline
\end{tabular}

TABLE 23.-Relative expected intensity for ground-condition units

\begin{tabular}{|c|c|}
\hline $\begin{array}{l}\text { Ground-condition } \\
\text { unit }\end{array}$ & $\begin{array}{l}\text { Relative intensity } \\
\text { compared to } \\
\text { saturated alluvium }\end{array}$ \\
\hline \multicolumn{2}{|c|}{ Derived from geologic map of California ${ }^{1}$ : } \\
\hline 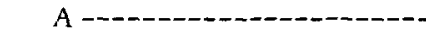 & -------3.00 \\
\hline B $-\cdots--1--1-1$ & $-------\quad-2.60$ \\
\hline $\mathrm{C}-\mathrm{C}=--\mathrm{C}-\mathrm{C}$ & $------\quad-2.20$ \\
\hline 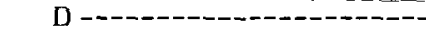 & $-1.80^{-}$ \\
\hline E - - - - - - - - - - - - - & -----1.70 \\
\hline 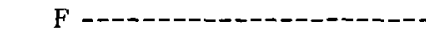 & -----1.50 \\
\hline 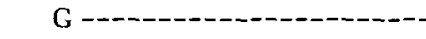 & $-\cdots-1.00$ \\
\hline H & -----2.70 \\
\hline 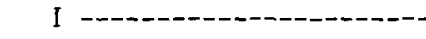 & $------\quad-2.70$ \\
\hline J (saturated alluvium) & - \\
\hline \multicolumn{2}{|l|}{$\begin{array}{l}\text { Alluvial units based on depth } \\
\text { in feet to water table: }\end{array}$} \\
\hline $\mathrm{J}^{2}-----------\cdots-----\cdots$ & ------ \\
\hline $\mathrm{L}^{3}-\cdots-----------\cdots$ & $-\infty---1.00$ \\
\hline 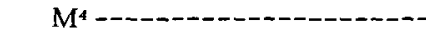 & ----1.50 \\
\hline \multicolumn{2}{|c|}{$\begin{array}{l}{ }^{1} \text { From California Division of Mines and Geology }[1958-1969] . \\
{ }^{2} 0 \mathrm{ft}<\text { water table }<30 \mathrm{ft} . \\
3_{30 \mathrm{ft}<\text { water table }<100 \mathrm{ft} .} \\
{ }_{100 \mathrm{ft}<\text { water table. }}^{4}\end{array}$} \\
\hline
\end{tabular}

relation achieved. Trifunac and Brady (1975), using peak acceleration data without regard to frequency from the strong-motion records of the 1971 San Fernando earthquake and other earthquakes and intensities read from the published intensity maps of the earthquakes, found a quite poor correlation. A few comments on their procedures, as regards both use of peak acceleration and use of intensities directly read from the published map of Scott (1973) for the 1971 San Fernando earthquake, seem necessary in order to make clear why we used somewhat different procedures in the analysis that follows. Peak accelerations are often at frequencies that-are- outside-the-band-relevant- to-intensity-determinations. Peak accelerations (or peak velocities) from records filtered to include only the range of frequencies relevant to intensities should show better correlation with intensities. Because a major factor in observed intensities is almost certainly the length of time over which amplitudes of relevant frequencies persisted at significant amplitude, an even better correlation might be achieved by comparing intensity and a parameter related to signal amplitude over a relevant period of time. Such parameters will be defined and investigated below. A few comments on the appropriate intensity values to use are required. Trifunac and Brady (1975) simply read values according to latitude and longitude from Scott's (1973) map for the 1971 San Fernando earthquake. However, as discussed elsewhere (Evernden, 1975b), maps such as Scott's have the major flaw of nearly all intensity maps. They accentuate the highest intensities in a region but totally ignore the lower intensities. Thus, the hard rock terranes in the general vicinity of the 197.1 San Fernando earthquake are simply not 


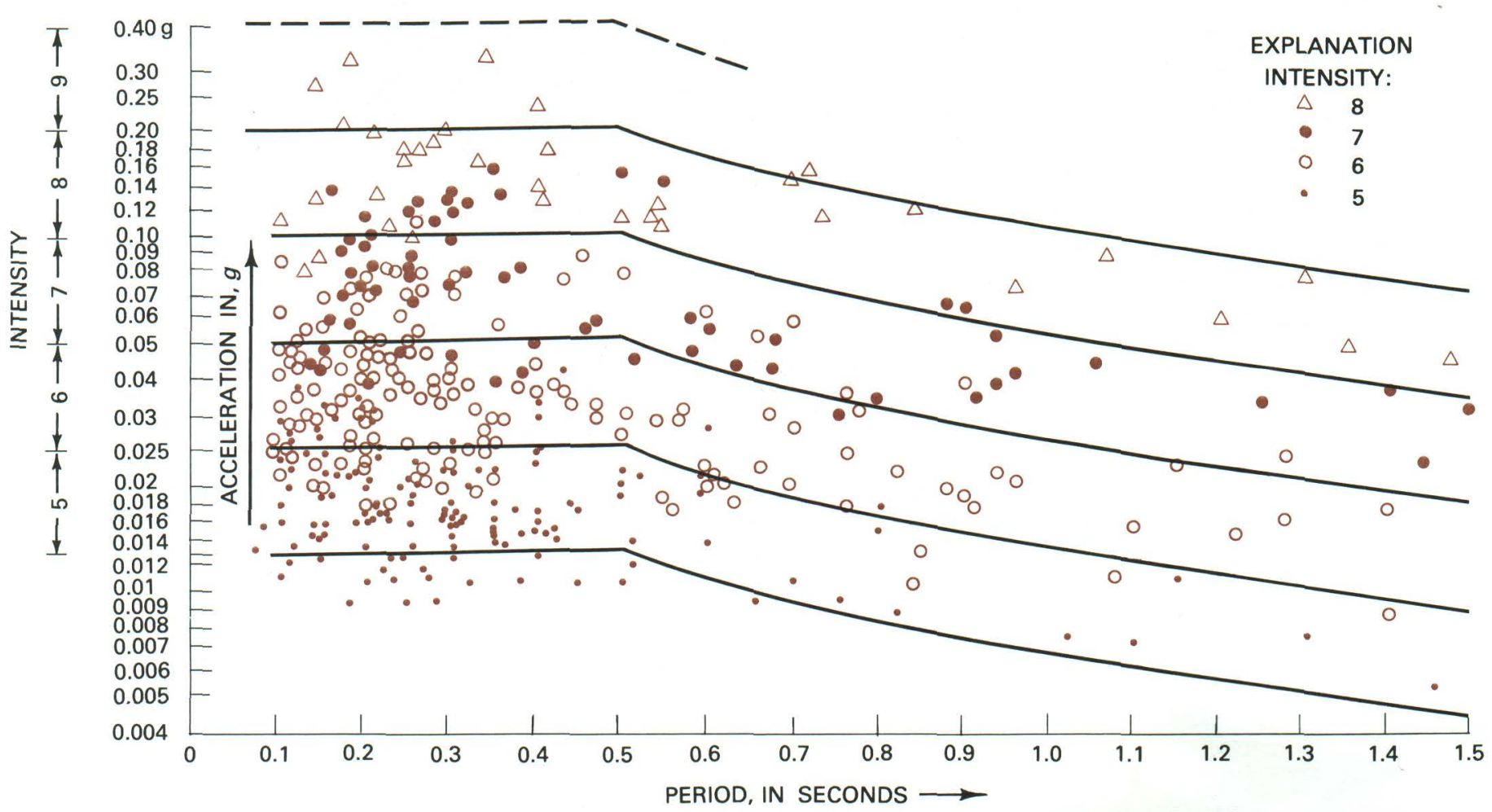

FIGURE 67.-Acceleration data at different periods in comparison with Modified Mercalli intensity (from Medvedev, 1962, fig. 4.12). Heavy lines divide diagram into several fields where points representing a particular intensity predominate.

observable from Scott's map-not because high intensities were observed at such sites but rather because the lack of damage reports led to blank areas that were later encompassed in the surrounding alluvial areas.

\section{Analysis of Data from the 1971 San Fernando Earthquake}

Table 24 presents the "observed" and predicted intensities determined by us for strong-motion sites on alluvium for the 1971 San Fernando earthquake; sites on "thin alluvium" are not included, as we were unsure about the meaning of such statements as regards the appropriate corrections from saturated alluvium. The definition and source of the "observed" intensities should be understood clearly. The values used are derived as follows:

1. Assume that Scott's (1973) isoseismal map for the San Fernando earthquake effectively contours intensity on saturated alluvium (see earlier comment on general prevalence of this practice), as regions of shallow ground water are scattered throughout the area.

2. Interpret Scott's intensity boundaries as being at half-magnitude points; that is, the boundary between VI and V is interpreted as 5.5.
3. Read intensities from Scott's map to one-tenth intensity unit.

4. Decrease values from Scott's map for depth to water table (WT), using data of Maley and Cloud (1973) or data supplied by J. C. Tinsley $(0.0$ adjustment if $\mathrm{WT}<20 \mathrm{ft},-0.5$ if $20 \leq \mathrm{WT}<30 \mathrm{ft},-1.0$ if $\mathrm{WT} \geq 30$ $\mathrm{ft}$.

These intensity values will be markedly different from those used by Trifunac and Brady (1975). As the predicted values are also corrected for depth to water table, the agreement of observed and predicted values in table 24 is an indication of the agreement of predicted and observed intensities on saturated alluvium; that is, values and rate of dieoff are as predicted in our model. The incorporation of depth of water table was not essential for table 24 other than to point up the occasional site that needs further investigation. However, such adjustment is vital in comparing intensity and strong-motion parameters (figs. 68A-70E).

We used predicted intensities at all sites, whether alluvial or otherwise, to compare with strong-motion parameters under the assumption that, because predicted agree with observed where we are sure of ground condition, the predicted values are preferred over

\section{Earthquake Hazards in the Los Angeles Region}


TABLE 24.- "Observed" and predicted intensities for the 1971 San Fernando earthquake for sites on alluvium

[Based on values reported by Scott (1973) but adjusted for depth to water table as discussed in text. Some "observed" Modified Mercalli intensity values may differ by as much as one intensity unit from those read from Scott's map. All localities are in Los Angeles unless otherwise indicated. Measurements were taken as close to ground level as possible]

\begin{tabular}{|c|c|c|c|c|}
\hline \multirow[b]{2}{*}{ Location } & \multirow{2}{*}{$\begin{array}{l}\text { Latitude, } \\
{ }^{\circ} \mathrm{N} .\end{array}$} & \multirow{2}{*}{$\begin{array}{l}\text { Longitude, } \\
{ }^{\circ} \mathrm{W} \text {. }\end{array}$} & \multicolumn{2}{|c|}{ Modified Mercalli intensity ${ }^{1}$} \\
\hline & & & "Observed" & Predicted \\
\hline 9841 Airport Blvd. -- & 33.946 & 118.386 & 5.6 & 5.7 \\
\hline Anza, Anza Post Office - & 33.556 & 116.674 & 4.8 & 4.0 \\
\hline San Bernardino, Hall of Records - & 34.106 & 117.284 & 4.6 & 5.0 \\
\hline Long Beach, 205 W. Broadway -------- & 33.769 & 118.194 & 5.8 & 5.0 \\
\hline Glendale Municipal Service Building ------ & 34.133 & 118.247 & 6.3 & 6.5 \\
\hline Pasadena, CIT, Athenaeum -- & 34.139 & 118.121 & 6.0 & 6.3 \\
\hline Costa Mesa, W. 19th St. -- & 33.644 & 117.926 & 3.6 & 4.4 \\
\hline 5260 Century Blvd. -- & 33.945 & 118.372 & 5.6 & 5.7 \\
\hline Orange, $4000 \mathrm{~W}$. Chapman Ave. ------- & 33.781 & 117.893 & 5.3 & 4.7 \\
\hline $\begin{array}{l}\text { Santa Ana, Orange County Engineering ---- } \\
\text { Building. }\end{array}$ & 33.750 & 117.867 & 5.7 & 4.6 \\
\hline Colton, Edison Building -- & 34.059 & 117.313 & 5.4 & 5.0 \\
\hline 234 Figueroa St. -- & 34.056 & 118.257 & 6.2 & 6.1 \\
\hline Alhambra, 900 S. Fremont Ave. -- & 34.085 & 118.149 & 6.2 & 6.1 \\
\hline 250 E. First St. -- & 34.050 & 118.241 & 6.5 & 6.6 \\
\hline 222 Figueroa St. - & 34.057 & 118.251 & 6.0 & 6.6 \\
\hline 7080 Hollywood Blvd. - & 34.101 & 118.344 & 6.3 & 6.4 \\
\hline 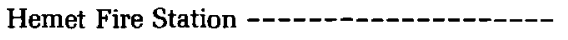 & 33.730 & 116.979 & 3.8 & 3.6 \\
\hline San Juan Capistrano -- & 33.489 & 117.671 & 5.0 & 4.8 \\
\hline Long Beach State College ----------- & 33.776 & 118.113 & 5.8 & 5.9 \\
\hline 8639 Lincoln Ave. - - & 33.960 & 118.419 & 5.6 & 5.7 \\
\hline Pasadena, CIT, Millikan Library --------- & 34.137 & 118.125 & 6.2 & 6.3 \\
\hline 1640 S. Marengo St. - & 34.060 & 118.213 & 5.7 & 6.1 \\
\hline Fullerton, 2600 Nutwood Ave. -- & 33.878 & 117.881 & 4.7 & 4.9 \\
\hline Hollywood, 1760 N. Orchid Ave. - - & 34.103 & 118.339 & 6.6 & 6.4 \\
\hline 646 S. Olive Ave. - & 34.047 & 118.254 & 6.3 & 7.1 \\
\hline 435 N. Oakhurst Ave. -- & 34.078 & 118.391 & 6.5 & 6.3 \\
\hline 808 S. Olive Ave. - & 34.035 & 118.251 & 6.3 & 6.0 \\
\hline 8244 Orion Blvd. -----1 & 34.221 & 118.471 & 7.0 & 7.0 \\
\hline Gorman, Oso Pumping Plant --_----- & 34.801 & 118.718 & 5.0 & 5.2 \\
\hline Pearblossom, Pumping Plant ----------- & 34.508 & 117.922 & 5.6 & 5.7 \\
\hline Port Hueneme -- & 34.150 & 119.200 & 5.5 & 5.6 \\
\hline Palmdale Fire Station -- & 34.578 & 118.113 & 5.1 & 6.0 \\
\hline 120 N. Robertson Blvd. - & 34.076 & 118.383 & 6.5 & 6.8 \\
\hline Beverly Hills, 450 N. Roxbury Dr. - - & 34.069 & 118.406 & 6.5 & 6.7 \\
\hline 6430 Sunset Blvd. - & 34.097 & 118.329 & 5.9 & 6.4 \\
\hline 6464 Sunset Blvd. -- & 34.097 & 118.331 & 5.9 & 6.4 \\
\hline 3407 Sixth St. --- & 34.063 & 118.295 & 6.4 & 6.2 \\
\hline Terminal Island --- & 33.765 & 118.225 & 6.0 & 5.9 \\
\hline 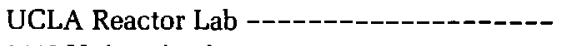 & 34.067 & 118.450 & 6.3 & 6.2 \\
\hline 3440 University Ave. - & 34.023 & 118.283 & 5.6 & 6.0 \\
\hline 14724 Ventura Blvd. -- & 34.152 & 118.455 & 6.7 & 7.1 \\
\hline 15250 Ventura Blvd. -- & 34.154 & 118.464 & 6.2 & 6.6 \\
\hline 15107 Vanowen - & 34.195 & 118.128 & 5.6 & 6.5 \\
\hline Vernon CDM Building ------- & 34.000 & 118.200 & 5.6 & 5.9 \\
\hline 15910 Ventura Blvd. - & 34.160 & 118.480 & 6.1 & 6.6 \\
\hline 3470 Wilshire Blvd. - - & 34.061 & 118.299 & 6.5 & 6.2 \\
\hline 4680 Wilshire Blvd. -- & 34.061 & 118.331 & 6.4 & 6.2 \\
\hline Whittier Narrows Dam --------------- & 34.020 & 118.053 & 5.5 & 5.7 \\
\hline Wheeler Ridge ------------------- & 35.018 & 118.985 & 4.7 & 4.4 \\
\hline 3710 Wilshire Blvd. -- & 34.062 & 118.307 & 6.4 & 6.2 \\
\hline 9100 Wilshire Blvd. - & 34.067 & 118.389 & 5.9 & 6.2 \\
\hline
\end{tabular}


ROSSI-FOREL INTENSITIES

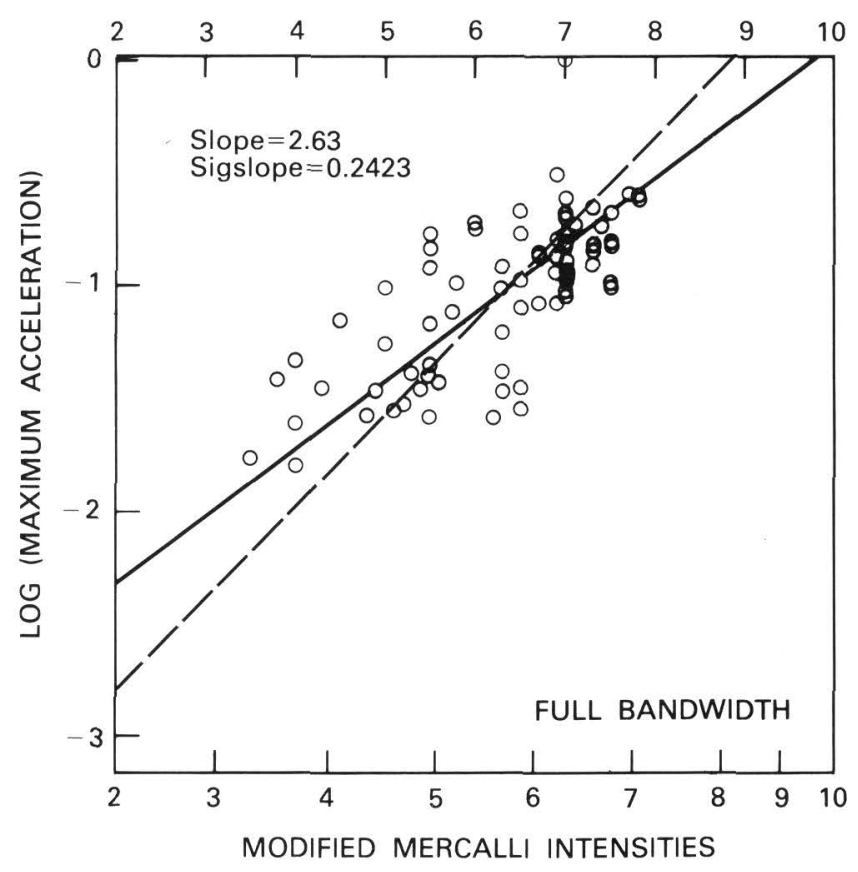

A

ROSSI-FOREL INTENSITIES

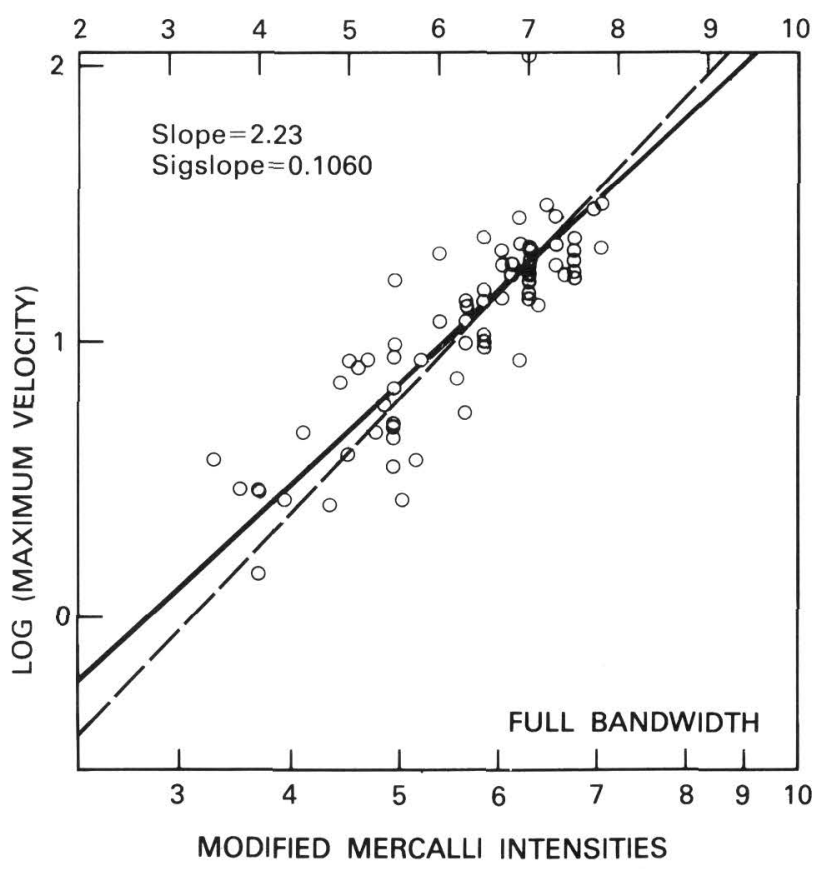

C

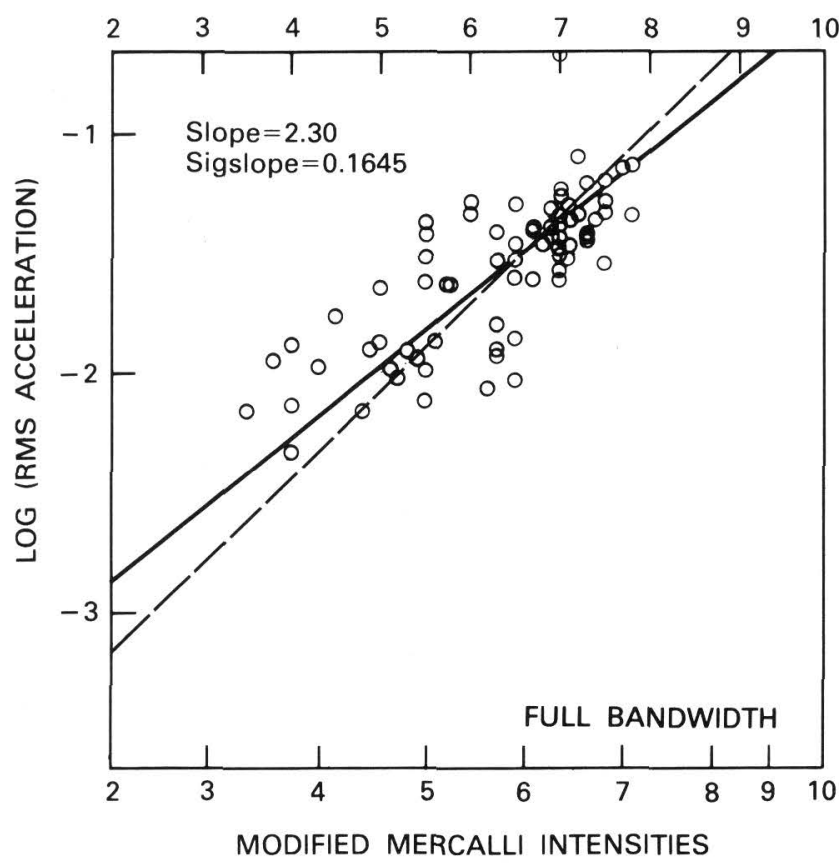

$B$

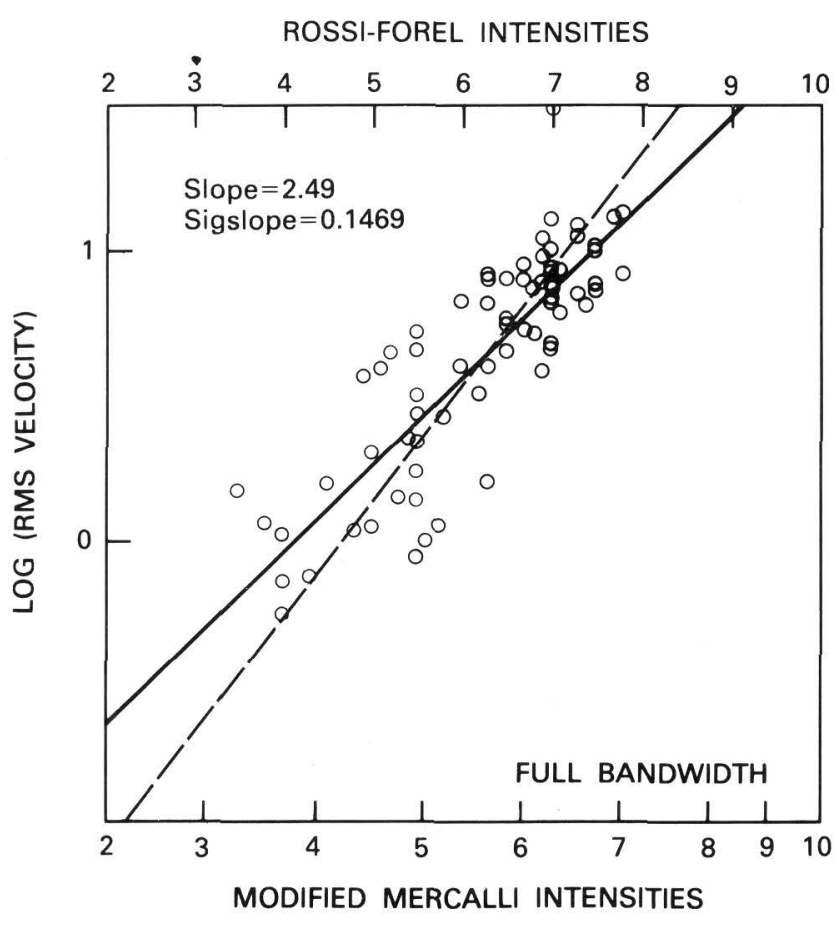

$D$

FIGURE 68.-Comparisons of intensities and parameters of full bandwidth (0.1-25 Hz) strong-motion seismograms from the 1971 San Fernando earthquake. $A$, Intensity versus peak acceleration. B, Intensity versus RMS acceleration in a 10-s time window centered on the peak value. $C$, Intensity versus peak velocity. $D$, Intensity versus RMS velocity in a 10-s time window centered on the peak value of the velocity. Slope is the slope of the least-squares linear fit of log (strong-motion parameter) to Rossi-Forel intensities under the assumption that only predicted intensity values may be in error. Sigslope is the standard deviation of the Slope value. 


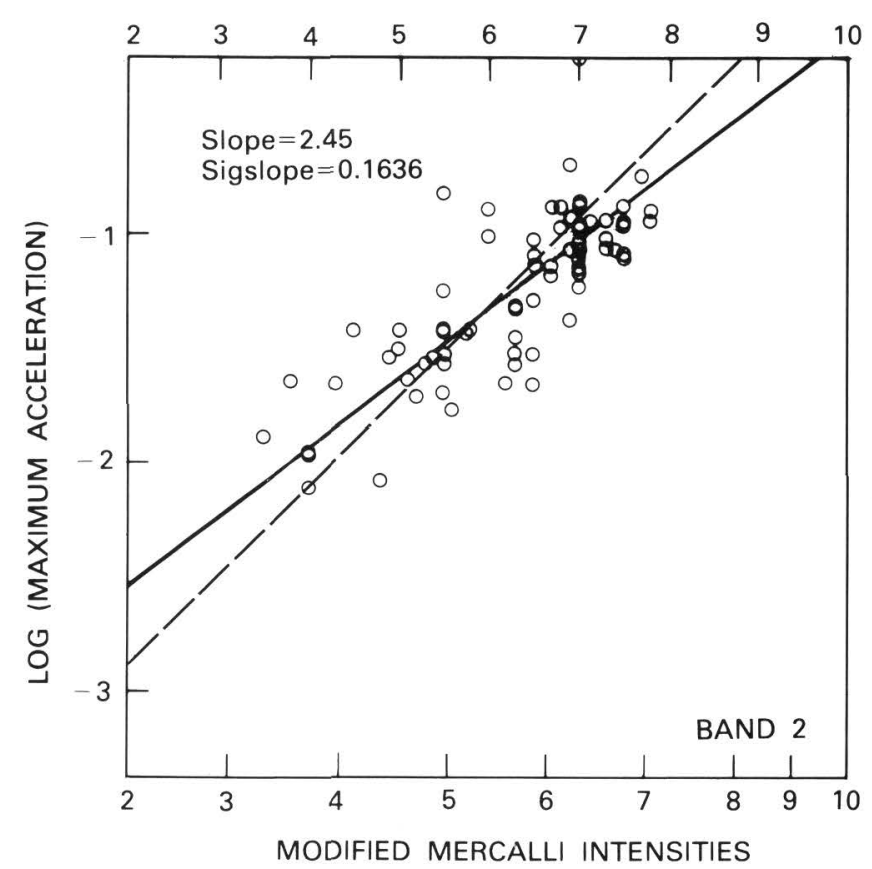

A

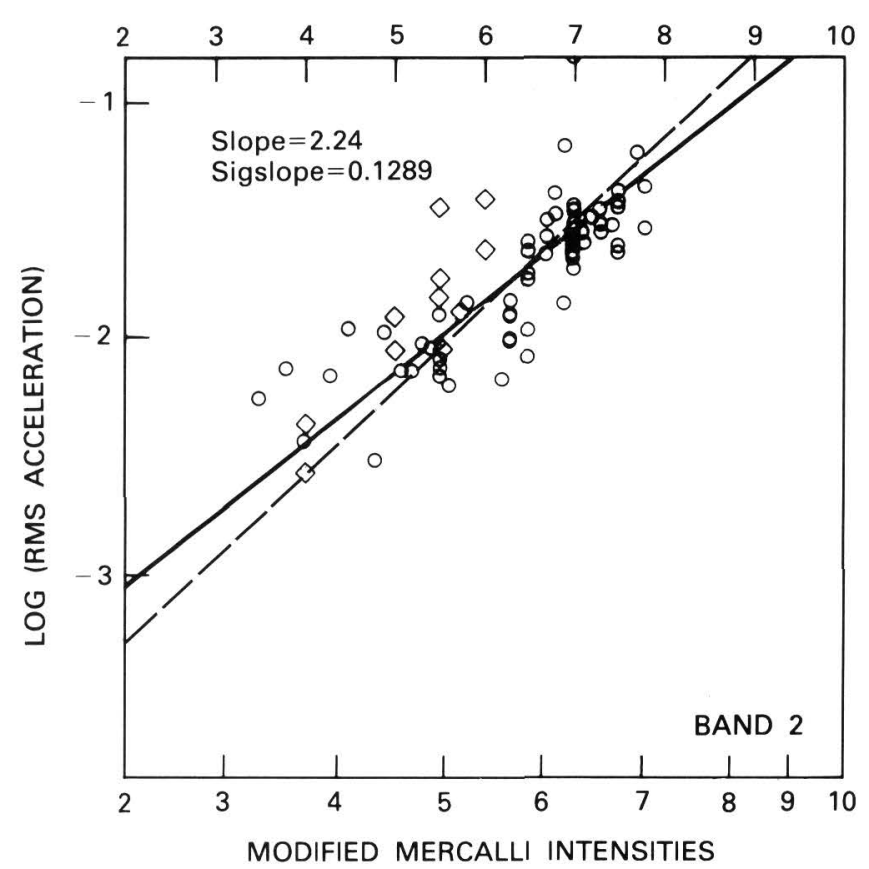

$B$

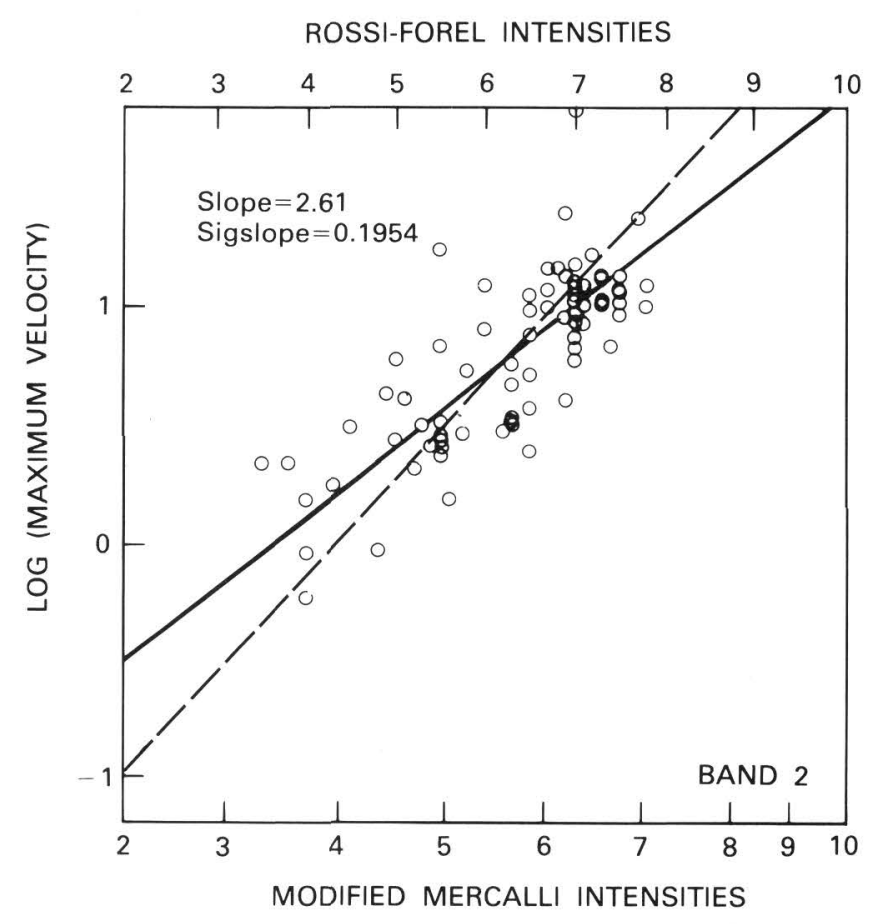

C

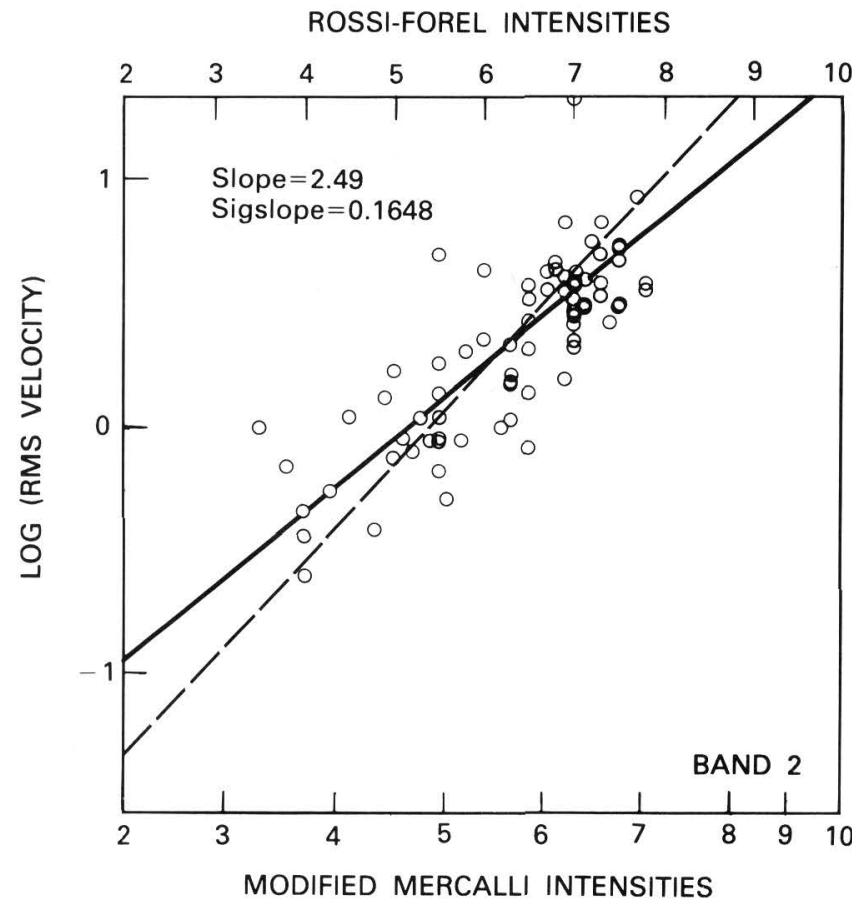

$D$

FIGURE 69.-Comparisons of intensities and parameters of strong-motion accelerograms from the 1971 San Fernando earthquake. A, Intensity versus peak acceleration on accelerograms filtered to include only frequencies between 0.5 and $3 \mathrm{~Hz}$ (band 2). B, Intensity versus RMS acceleration in a 10-s time window centered on the peak value for accelerograms filtered to include only frequencies between 0.5 and $3 \mathrm{~Hz}$ (band 2). Squares indicate values on hard rock. $C$, Intensity versus peak velocity on velocity seismograms filtered to include only frequencies between 0.5 and $3 \mathrm{~Hz}$ (band 2). $D$, Intensity versus RMS velocity in a 10-s time window centered on the peak value of velocity seismograms filtered to include only frequencies between 0.5 and $3 \mathrm{~Hz}$ (band 2). Slope is the slope of the least-squares linear fit of log (strong-motion parameter) to RossiForel intensities under the assumption that only predicted intensity values may be in error. Sigslope is the standard deviation of the Slope value. 


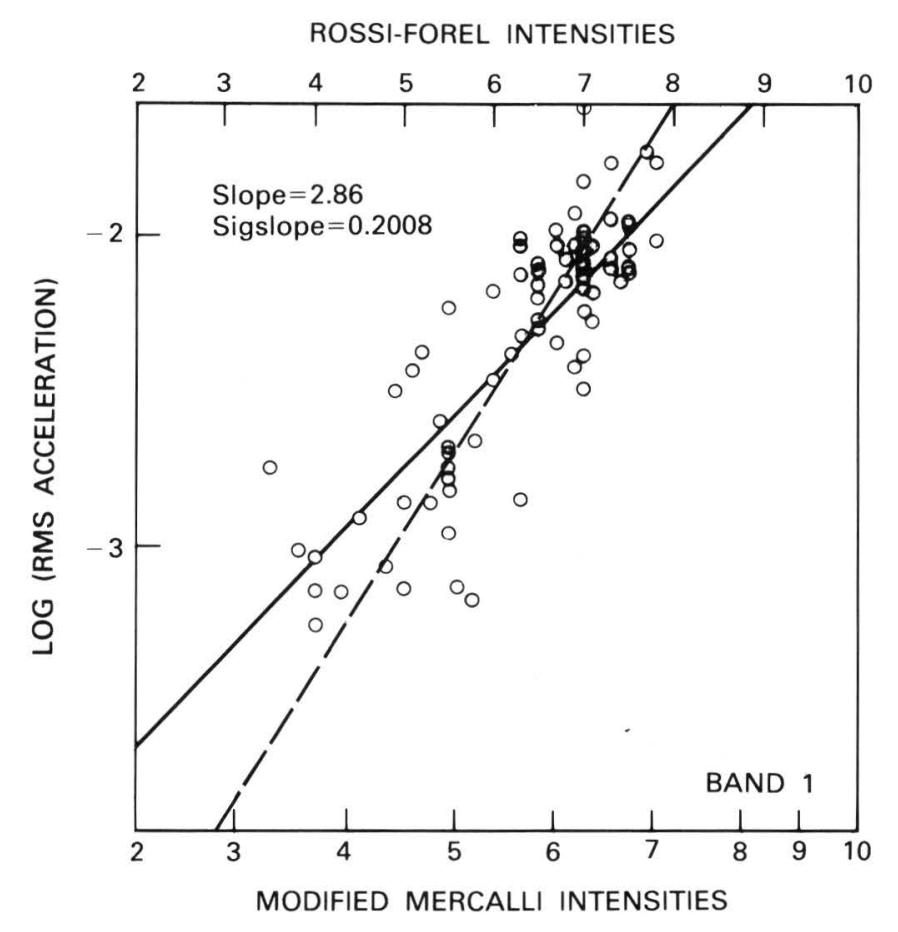

A

ROSSI-FOREL INTENSITIES

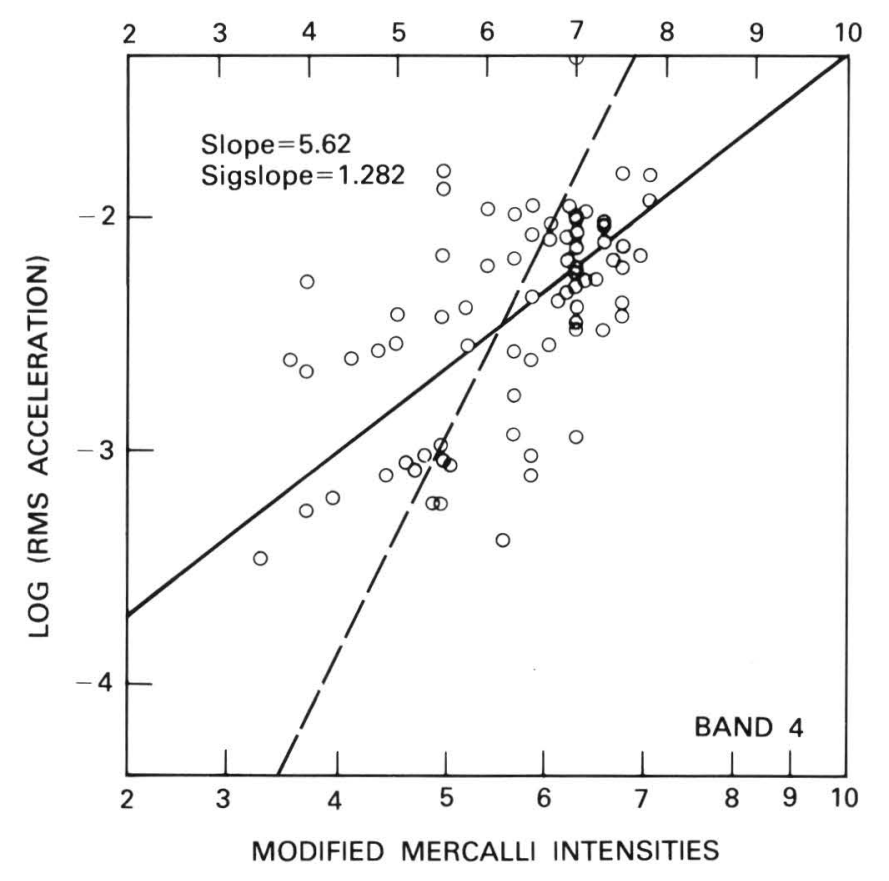

C

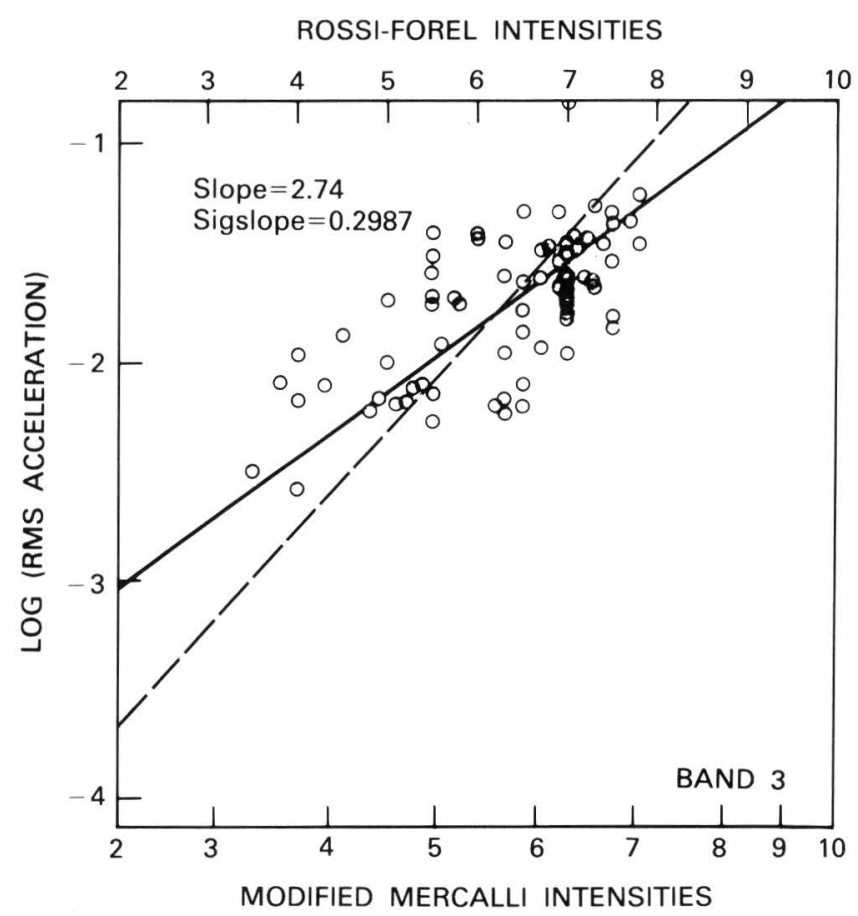

B

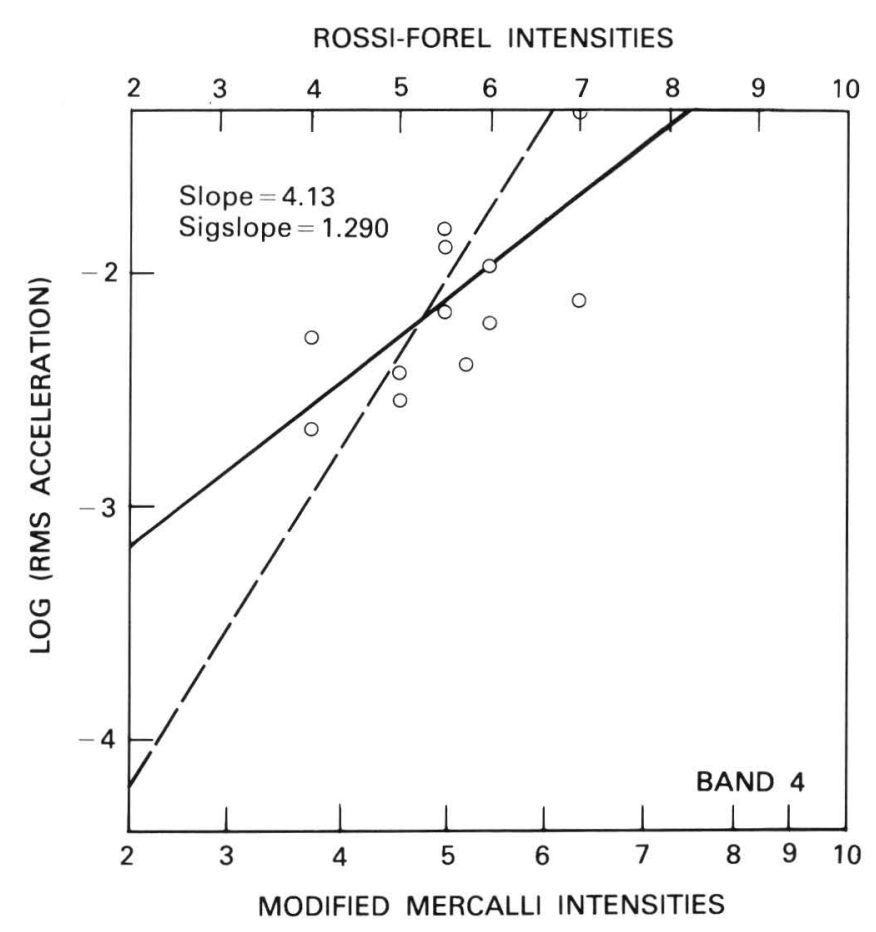

D

166 Earthquake Hazards in the Los Angeles Region 


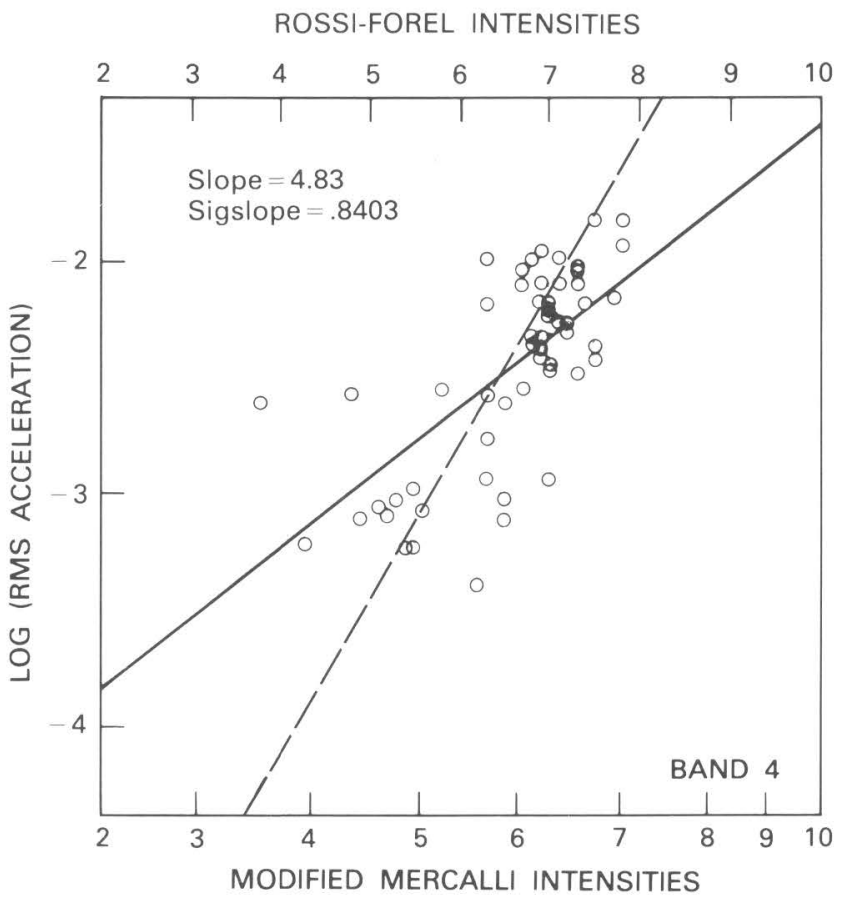

E

FIGURE 70.-Comparisons of intensities and parameters of strongmotion accelerograms of the 1971 San Fernando earthquake. A, Intensity versus RMS acceleration in a 20-s time window centered on the peak value for accelerograms filtered to include only frequencies less than $0.5 \mathrm{~Hz}$ (band 1). B, Intensity versus RMS acceleration in a 10-s time window centered on the peak value for accelerograms filtered to include only frequencies between 3 and $10 \mathrm{~Hz}$ (band 3). C, Intensity versus RMS acceleration in a 10-s time window centered on the peak value for accelerograms filtered to include only frequencies between 10 and $25 \mathrm{~Hz}$ (band 4). D, Same type of data as $C$ but only for sites on hard rock. E, Same type of data as $C$ but only for sites on alluvium. Slope is the slope of the least-squares linear fit of log (strong-motion parameter) to RossiForel intensities under the assumption that only predicted intensity values may be in error. Sigslope is the standard deviation of the Slope value.

extrapolated values in areas where the local ground condition is not alluvium.

The correlation of numerous strong-motion parameters with intensity currently is being investigated. The analysis reported here will be concerned solely with data of the 1971 San Fernando earthquake and with only a few of the strong-motion parameters. No data acquired above the first floor in any building have been used. The parameters to be discussed are:

1. Peak acceleration and RMS acceleration in a 10-s time window centered on the peak value of the unfiltered accelerograms of the 1971 San Fernando earthquake as prepared by the California Institute of Technology (CIT) (figs. 68A, 68B).
2. Peak velocity and RMS velocity in a 10-s time window centered on the peak value of the digitized calculated velocity seismogram as prepared by CIT (figs. 68C, 68D).

3. Peak acceleration and RMS acceleration in a 10-s time window centered on the peak value of the CIT accelerogram filtered to include only frequencies between 0.5 and $3 \mathrm{~Hz}$ (band 2) (figs. 69A, 69B).

4. Peak velocity and RMS velocity in a 10-s time window centered on the peak value of the CIT velocity seismograms filtered to include only frequencies between 0.5 and $3 \mathrm{~Hz}$ (figs. 69C, 69D).

5. RMS acceleration in a 20-s time window centered on the peak value of the CIT accelerograms filtered to include only frequencies lower than $0.5 \mathrm{~Hz}$ (band 1) (fig. 70A).

6. RMS acceleration in a 10-s time window centered on the peak value of the CIT accelerograms filtered to include only frequencies between 3 and $10 \mathrm{~Hz}$ (band 3) (fig. 70B).

7. RMS acceleration in a 10-s time window centered on the peak value of the CIT accelerograms filtered to include only frequencies between 10 and $25 \mathrm{~Hz}$ (band 4). Figure 70C includes all sites; figure 70D includes only sites on hard rock; figure $70 \mathrm{E}$ includes only sites quite certainly on alluvium.

It is a feature of the model for calculating intensities that acceleration is assumed to increase by a factor of two for each one-unit increase in Rossi-Forel intensity, analysis having shown that Rossi-Forel intensities so scale, whereas Modified Mercalli intensities do not. Therefore, the solid line on all figures is a theoretical line along which the parameter plotted versus intensity increases by a factor of two for each one-unit increase in Rossi-Forel intensity. The line is positioned to pass through the centroid of the data. The dashed line is a linear least-squares fit to the data under the assumption that there is only error in the predicted intensity. The Slope parameter in the upper left-hand corner of each figure is the slope of the dashed line; the Sigslope value is the standard deviation of the slope. The value of the strong-motion parameter used for each station is the greater of the two values obtained from the pair of orthogonal horizontal instruments. Slightly greater values might be obtained by search through all azimuths, but marked changes, particularly for the RMS values, seem unlikely. There is distinct uncertainty about some of the predicted intensities on the basis of available data.

The strong-motion records obtained near Pacoima Dam either are anomalous relative to all other data or 
require special explanation. They can be made concordant by assigning a shaking intensity of IX or so to the small ridge on which the instruments were located. Such assignment is certainly incorrect for nearby areas. Scott $(1973$, p. 28) noted that the caretaker's house at the dam, a one-story wood-frame house $2 \mathrm{ft}$ off the ground on a concrete perimeter foundation, suffered only minor damage, and its brick chimney was undamaged. Other wooden structures in the immediate area were undamaged, and another unsupported brick chimney did not fall. The assignment of very high intensity to this general area apparently was based largely on massive rock slides. Although rock slides are a described aspect of high intensity, they are certainly a poor criterion, as so many factors other than shaking are critical to generation of such slides. Also, the model cannot predict such high intensity at a rock site for a source at the known depth of the San Fernando earthquake. A suggested explanation for the high accelerations recorded near Pacoima Dam is a focusing of energy in the small ridge on which the instrument is placed. We have not used the Pacoima Dam data in the least-squares analysis but have plotted the datum point for that locality at RFI VII in figures 68,69 , and 70 .

Inspection of figures $68 \mathrm{~A}$ and $68 \mathrm{~B}$ indicates that RMS acceleration on the unfiltered accelerograms over a 10-s time window centered on the peak value achieves markedly better agreement with the predicted intensities than does peak acceleration on the same accelerograms, an expected result in light of an analysis published by Hanks (1979). Therefore, at the very least, it would seem appropriate to use RMS acceleration rather than peak acceleration from such accelerograms for damage prediction. It is interesting that peak velocity versus predicted intensity (fig. 68C) achieves the lowest values of Slope and Sigslope of any parameter, although not significantly better than RMS acceleration in figures 68B (seismogram) and 69B (band 2). One point to be noted throughout these figures is that the parameters having the lowest Sigslope values have the lowest Slope values, the suggestion being that the theoretical Slope of 2.0 is probably indistinguishable from observations. It would seem probable that the value of Slope in figure $68 \mathrm{C}$ is smaller than that in figure $68 \mathrm{D}$ simply because of statistical scatter.

Inspection of figures $69 \mathrm{~A}$ and $69 \mathrm{~B}$ (acceleration data for band 2) again shows that RMS acceleration achieves better agreement with intensity data than does peak acceleration. However, the fact that the least-squares data for figure 69B are not significantly better than those for figure $68 \mathrm{~B}$ suggests, in conjunction with figures $70 \mathrm{~A}$ through $70 C$, that the RMS values of acceleration of the total seismogram are largely controlled by the data of band 2. Note that all Slope and Sigslope values of figures
$70 \mathrm{~A}$ through $70 \mathrm{C}$ (bands 1,3 , and 4) are greater than those for figure 68B, particularly for bands 1 and 4 . These results indicate that RMS values of acceleration in bands 1,3 , and 4 decrease more rapidly with decreasing intensity than do those of band 2 . Since intensity and epicentral distance are strongly correlated for sites on a given rock type, the behavior in bands 3 and 4 for sites on alluvium is probably the result of greater attenuation with increasing frequency. The apparently similar behavior in band 1 would require a markedly different explanation.

\section{Relations Between Intensity and Root-Mean-Square Acceleration}

A set of interesting relations can be found by analysis of the RMS acceleration data considering Slope and intercept data for all frequency bands for all stations, for stations on alluvium, and for stations on hard rock. Several strong-motion instruments at sites of uncertain ground condition are excluded from the following analysis, as are instruments on Miocene and Eocene sediments.

For band $2(0.5-3 \mathrm{~Hz})$, the fields of RMS acceleration for sites on hard rock and alluvium largely overlap (fig. $69 \mathrm{~B}$ ), this overlap implying that the 3.0 adjustment of predicted intensity for sites on hard rock leads to consistent estimates of RMS acceleration in band 2 for the same predicted intensity, an expected result. Also, it was noted above that the least-squares fit of RMS acceleration and predicted intensity in band 2 yielded a Slope value in close agreement with that used in the intensity prediction model $(2.2 \pm 0.1$ versus 2.0 , where scaling intensity is predicted Rossi-Forel intensity), supporting the case for validity of the model parameterization. These clear statistical correlations of observed acceleration data and predicted intensities seem sufficient to justify using the observed relations of intensity and RMS acceleration in band 2 to convert the predicted intensity map to a predicted band 2 RMS acceleration map. Such a map will be presented later (fig. 78).

The data of band $4(10-25 \mathrm{~Hz})$ are markedly different from those of band 2 (figs. $70 C, 70 D, 70 E$ ). The Slope value is high on all of these figures, being somewhere around 4.5 to 5 rather than 2.2 , as for band 2 , the result being that RMS acceleration in band 4 decreases as the square of the rate appropriate to band 2. Amplitudes decrease at essentially the same rate on both hard rock and alluvium, thus confirming another assumption of the model that decay rate is related to the shaking response of the bedrock, not to the behavior of surficial materials, which influences the level of ground motion and the spectral composition of ground motion for a given basement input. At the same intensity (band 2 RMS accelera- 
ROSSI-FOREL INTENSITIES

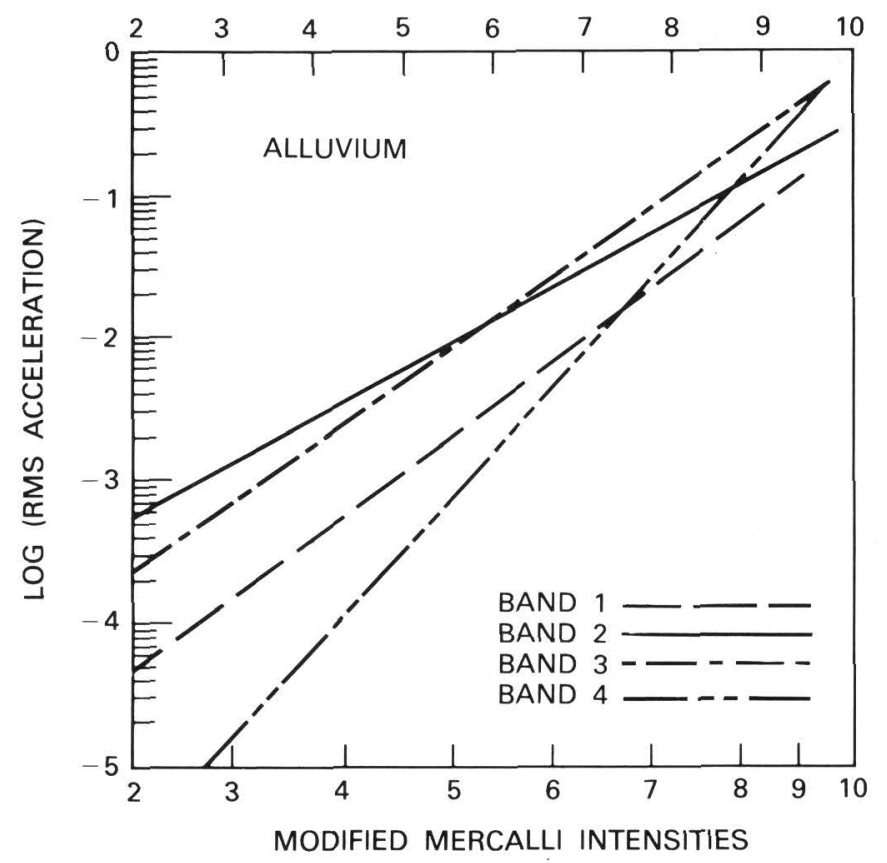

A

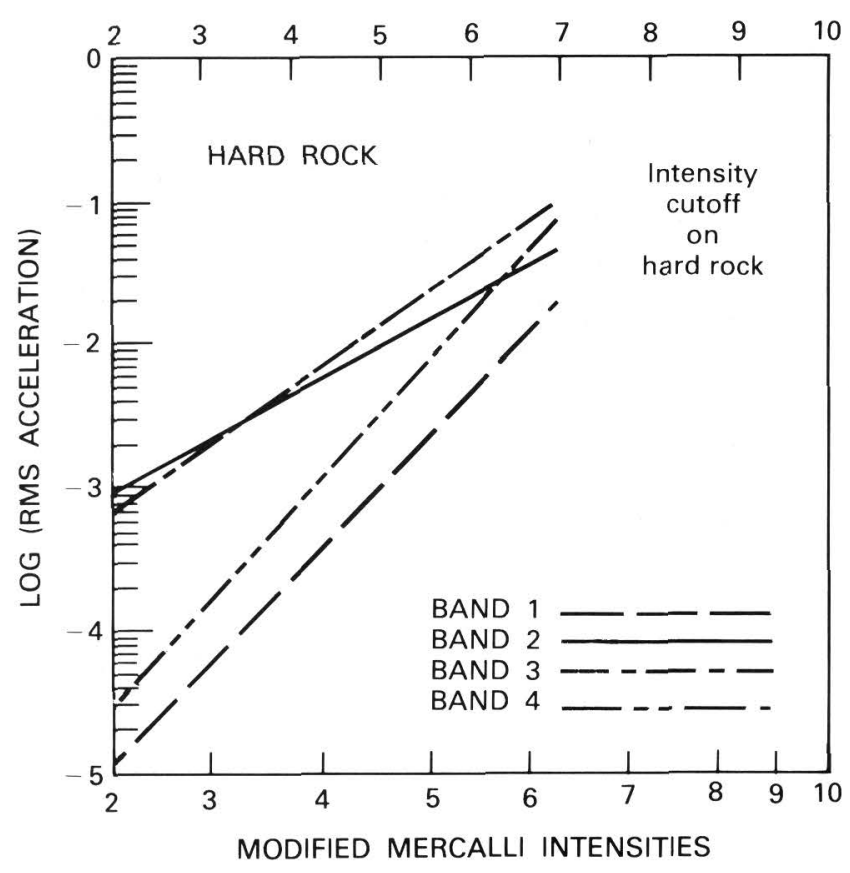

B

FIGURE 71.-Comparisons of intensities and RMS accelerations of the 1971 San Fernando earthquake in all frequency bands. A, Alluvium sites. B, Hard rock sites.

tion), RMS acceleration on hard rock in band 4 is about 10 times that on alluvium. However, this tenfold increase is simply the result of the same intensity's being at much shorter range on hard rock than it is on alluvium, the much higher Slope value for data of band 4 leading to much more rapid decrease with distance of band 4 RMS values than of band 2 values. In fact, RMS acceleration values in band 4 are higher on alluvium than they are on granite at the same distance. In terms of RMS values versus frequency, the signals on alluvium and hard rock at the same range are very similarly shaped, the values for all bands being several times greater on alluvium than they are on hard rock. It should be remembered that we are speaking here of RMS acceleration values over time windows of about $10 \mathrm{~s}$, not peak acceleration values, which have been generally used in the past. For peak acceleration, values are higher on hard rock than they are on alluvium at the same range, this peak value generally occurring in band 4 . If one considers RMS acceleration as being a more useful predictor of expected shaking damage than peak acceleration, there is no basis in the data of the 1971 San Fernando earthquake for considering hard rock sites as being at the same risk as alluvium sites at any frequency.

These relations as well as others are displayed in figures $71 \mathrm{~A}$ (alluvium sites) and $71 \mathrm{~B}$ (hard rock sites). Curves for all four bands are included. An interesting point is that all bands have similar RMS values at short range (that is, at the maximum possible shaking intensity on each rock type). Such a relation is predicted by seismic source theory (that is, a flat source spectrum in acceleration for all frequencies above the left-hand corner frequency, this corner frequency for the shear waves of the 1971 San Fernando earthquake being at a frequency of 0.2 to 0.1 ). The comparison of spectral composition and level at equal intensity on both alluvium and hard rock is obvious. The comparison at equal range can be approximated by comparing values at intensity $I$ on hard rock with intensity $I+2.5$ to 3 on alluvium. The statements made earlier derive from such a comparison. It can also be seen in the figures that the spectral behavior with intensity is very similar in bands 2 and 3 , band 3 having the slightly greater Slope value.

The fact that Slope values are steeper for band 1 than they are for band 2 was noted earlier. Note that the Slope value for hard rock sites is greater than 4 and that the Sigslope value is apparently small. The critical point here may be that intensity IV on hard rock is at a range of only $50 \mathrm{~km}$, so that nearly all observations for band 1 on hard rock are in the near field for waves having periods of several seconds or longer. Thus, the explanation of the high rate of falloff at long periods may be that it is an expression of the presence in these data of the theoretically predicted near-field terms of elastic theory, terms displaying higher rates of falloff than the usually observed far-field terms. 
It is concluded that RMS values of acceleration do indeed show better agreement with intensity than do peak acceleration values, even if peak values are band limited. It also is concluded that data bandpassed to include only energy in the intensity-relevant band (band 2) achieve better fit to observed intensities than do data from any other band. It does appear that, at least for the data of the 1971 San Fernando earthquake, RMS acceleration in a 10-s time window from the unfiltered seismogram achieves as good a fit to intensity data as does RMS acceleration in the $0.5-$ to $3-\mathrm{Hz}$ bandpass. Finally, it appears that the assumption that Rossi-Forel intensities increase by one unit for a doubling of the ground-motion parameter is supported by these data, in conformance with earlier analyses.

The scatter of data in band 2 relative to predicted intensities is influenced by uncertainty in detailed ground condition, uncertainty in optimum bandpass and optimum parameter, and by the fact that virtually none of the strong-motion records can be considered as recordings of free-field ground motion. Although only records from first floors or basements were used, the fact that most of the sites were in tall buildings means that the recordings obtained will be influenced to some degree by building response. From a seismologist's point of view, there should be many more true free-field measurements of strong ground motion.

Obviously, we favor a quantitative use of intensities during all phases of damage and risk analysis. As generally defined or used, intensity is a narrow-band parameter, although definitions do frequently intermix phenomena of markedly different effective periods. We recommend attempting to define spectrally determined intensities following the spirit of Medvedev. Such an effort might well bring into focus the long-period spectral contrasts of larger earthquakes.

\section{APPLYING THE INTENSITY PREDICTION METHOD}

In this section, we present examples of how the computer program for predicting intensities can be used to address different questions of concern regarding the earthquake shaking potential in the Los Angeles region.

\section{Importance of Ground-Condition Assumptions}

A point stressed previously but requiring recurrent statement is that predicted intensities are linked directly and importantly to the assumed ground conditions. One simply must not inspect a map of predicted intensities without also consulting the map of assumed ground conditions for the particular study area. Figure
72 gives the presently assumed ground conditions throughout the Los Angeles region. In the region, all areas shown on the 1:250,000-scale map sheets of the Geologic Atlas of California (California Division of Mines and Geology [1958-1969]) as alluvium of any type are treated as having similar physical characteristics; variations in ground response are regarded solely as a function of depth to water table (less than or greater than $30 \mathrm{ft}$ ). The detailed analysis of Quaternary sedimentary deposits recently completed by Tinsley and Fumal (this volume) was not available in time to be used in the present study. In addition, ground-water levels (a major control over shaking intensity) can undergo radical seasonal and long-term changes. Proper future use of predicted intensity maps made today is possible only if changes or differences from the ground conditions assumed today are incorporated into the analysis. Also, the minimum cell size used for the studies in this chapter is $1 / 2 \min \times 1 / 2 \min$ (that is, about $3,000 \times 2,500 \mathrm{ft}$ ). Details of geology below that scale are lost on the maps. Proper use of the maps requires that one note the ground condition used for the prediction at the point of interest and modify the prediction based on the relative ground response of the actual site under consideration and the assumed ground response for the appropriate grid element. The requisite scale for converting from geologic units to ground response or seismic units is presented in table 23.

The depth to water table is an important ground parameter for sites on valley alluvium. Shaking intensity drops about one intensity unit for an increase of depth to water table from 0 to $30 \mathrm{ft}$ relative to ground level. It may drop another half unit for an increase of depth to water table from 30 to $100 \mathrm{ft}$ or more. That is, intensities can change from, say, IX $1 / 2$ to VIII (from extremely severe shaking to only strong shaking) by simply changing the depth to water table. The most important single step that a community located on thick alluvium can take to protect itself from extreme earthquake-induced shaking is to lower the water table to about $50 \mathrm{ft}$; the worst possible thing that it can do is to raise the water table to the surface.

\section{Predicting Intensities for a Specific Earthquake}

Maps showing the distribution of predicted intensities from individual postulated earthquakes are useful in estimating future damage patterns and in preparing emergency response plans. For example, Davis and others $(1982 a, b)$ have used our predictive method to evaluate the effects of hypothetical great earthquakes along the San Andreas fault on lifeline systems

170 Earthquake Hazards in the Los Angeles Region 
(transportation, water, and communication networks) in the Los Angeles and San Francisco metropolitan areas.

As examples of calculating intensities for specific earthquakes, we model in this volume both a $30-\mathrm{km}-\mathrm{long}$ rupture on the northern part of the Newport-Inglewood zone (see fig. 74; table 25, event $9 \mathrm{~A}$, for location and parameters of this earthquake), and a repeat of the 1857 Fort Tejon rupture on the San Andreas fault.

The predicted intensities for the Newport-Inglewood earthquake are presented- by Ziony and others (this volume, figs. 213,214 ) for comparison with results from other methods of predicting earthquake ground motion. Two major reasons for modeling this earthquake are the anticipated level of damage and our interpretation of the earthquake of December 8, 1812 (see later section). The entire course of the postulated fault break is within areas that have been nearly completely urbanized or industrialized in the past $50 \mathrm{yr}$ since the Long Beach earthquake of 1933, an earthquake that occurred on the same fault system immediately south of the postulated earthquake. The 1933 earthquake was a significantly larger earthquake than generally considered (Evernden and others, 1981); it has been assigned too small a stature in the hierarchy of historical California earthquakes because of an accident of history. The 1933 Long Beach earthquake was the first significant earthquake to occur after the USCGS changed from Rossi-Forel intensities to Modified Mercalli intensities (MMI), and the large differences in meaning of some of the highest shaking intensities, although fully documented by the USCGS at the time of change, apparently were ignored by most investigators. By using Modified Mercalli intensities, the occurrence of intensity IX was nearly eliminated, an obvious aspect of the published intensity maps of both the 1933 Long Beach and 1952 Kern County earthquakes. If the intensity map of the Long Beach earthquake had been described in Rossi-Forel units, there would have been a large area of intensity IX and a consequent realization of the larger size of the earthquake. In 1952, after the Kern County earthquake, amazement at the limited area of intensity MMI IX for an earthquake associated with such violent ground displacement was expressed in print.

Other features that may have contributed in some measure to assigning too small a size to the 1933 Long Beach earthquake were that most of the rupture was offshore and that much of the area surrounding the onshore portion of the rupture was undeveloped. The entire area is now heavily developed, and the hypothetical earthquake that we model is immediately north of the portion of the Newport-Inglewood fault that ruptured in 1933. The entire line of modeled rupture is on land.

We include in this section predicted values of Modified Mercalli intensities for a postulated repeat of the 1857 Fort Tejon earthquake on the San Andreas fault. Given that average repeat times for major earthquakes on the Mojave Desert section of the San Andreas fault are about $150 \mathrm{yr}$ and that it is over $125 \mathrm{yr}$ since the last great earthquake along this segment of the San Andreas fault, the probability of a repeat within the next few decades must be considered high. Therefore, it is important to determine just what shaking levels are to be expected. The State of California (Davis and others, 1982a) has published such a study, basing its predictions of damage to lifelines on intensity estimates provided by us. Since giving the State those estimated intensities, we have extensively refined the data relative to depth to ground water from information provided by J. C. Tinsley of the USGS. This refinement is the basis for any differences in predicted intensities between the maps published by Davis and others (1982a) and those published here as figure 73.

Figure 73 indicates that very little of the vast residential area in the Los Angeles basin will experience markedly damaging intensities as a result of this great earthquake. Note that at no place in the Los Angeles basin are damaging intensities predicted to be as high as they were in the 1971 San Fernando earthquake. Most of the basin will experience no greater intensity that MMI VII. Comparison of predicted intensities for the modeled earthquake on the northern part of the Newport-Inglewood zone (Ziony and others, this volume, figs. 213, 214) with those for the 1857 Fort Tejon repeat (fig. 73) show clearly that the Newport-Inglewood earthquake will produce higher intensities within the Los Angeles basin.

A comment on the character of the predicted intensity maps presented in this volume may be useful. Because no damage occurs to modern structures at intensities of less than VI, such low intensities are not shown on the maps; all areas of predicted intensity $\mathrm{V}$ or less are shown without symbol. The small-scale maps published in this volume are intended only to illustrate the mode of presentation to be followed on larger scale versions of these maps to be published elsewhere by the USGS at a scale of $1: 250,000$.

Intensities on these maps are shown as either singlestroke or block numbers. Single-stroke numbers are relevant to the lower half of an intensity unit (for example, single-stroke 6 covers intensities from 5.50 to 6.0 ), and block numbers are relevant to the upper half (for example, solid 6 covers intensities from 6.0 to 6.5 ).

\section{Predicting Maximum Potential Intensities Across the Region}

We have extended our computing program to generate maps showing the composite maximum predicted in- 


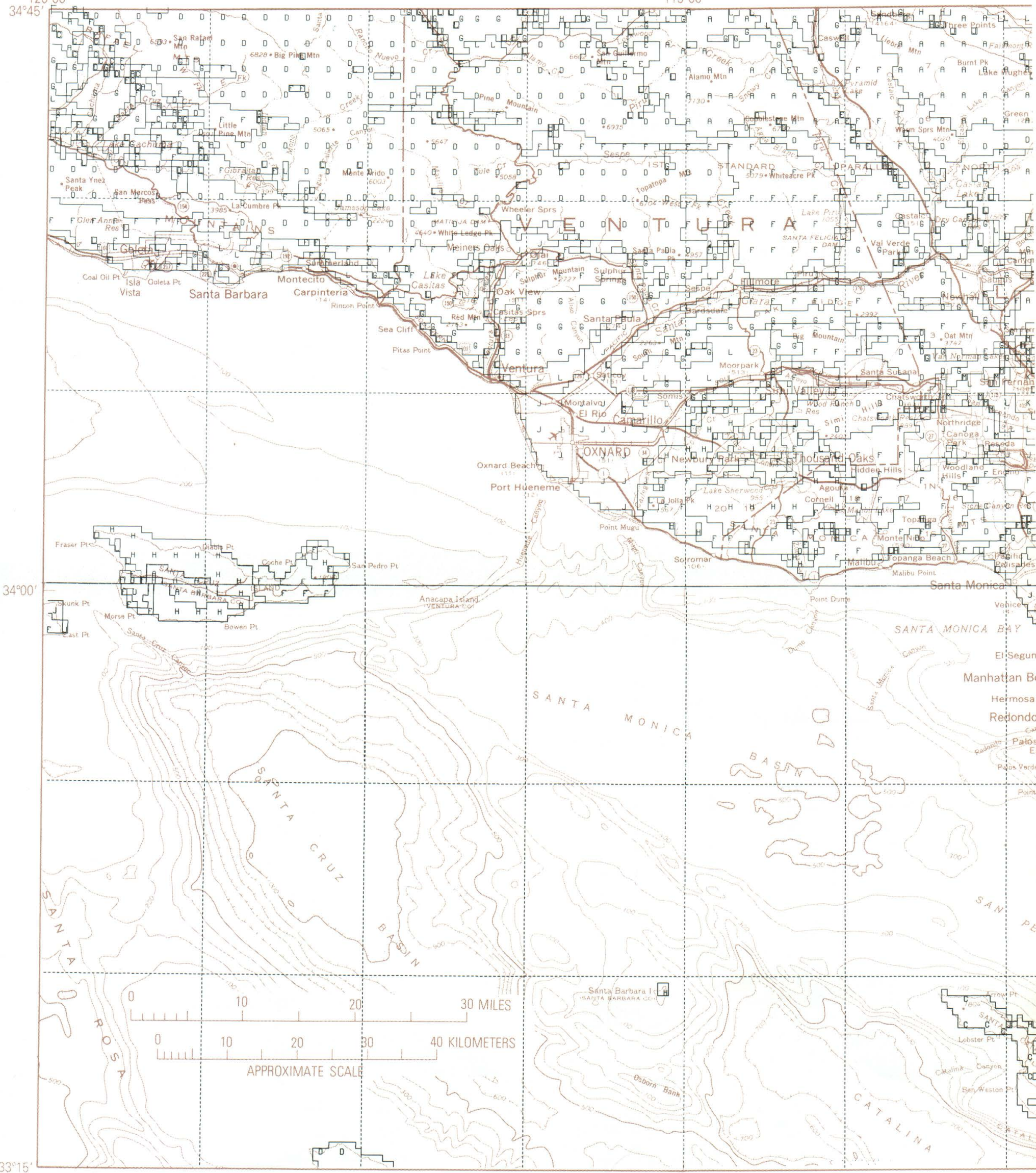

FIGURE 72.-Assumed ground conditions for the onshore Los Angeles region. Map units are explained in table 22. Base from parts of the Los Angeles, Long Beach, San Bernardino, and Santa Ana $1^{\circ} \times 2^{\circ}$ sheets. 


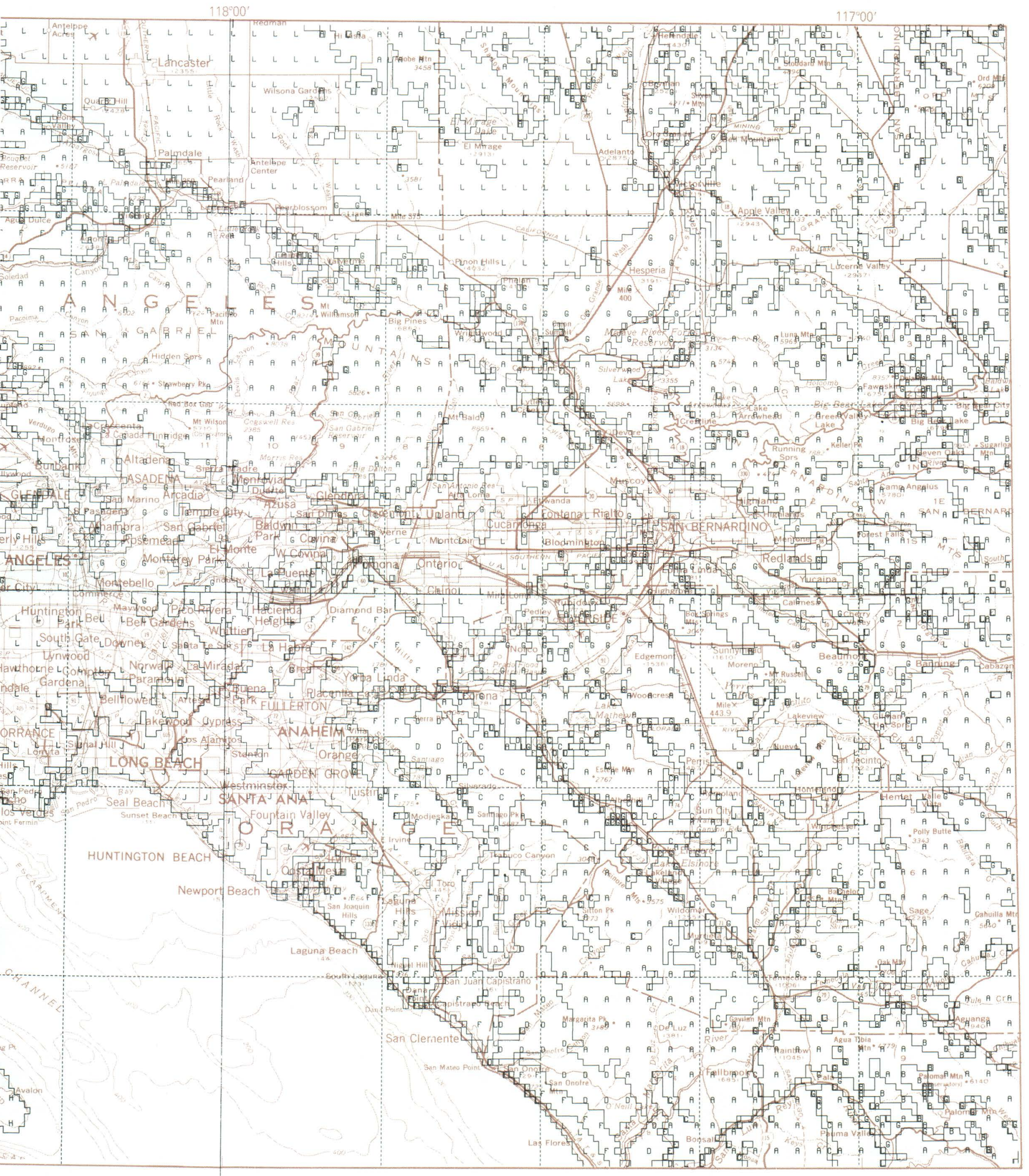


TABLE 25. -87 postulated earthquakes used to calculate composite maximum intensities for the Los Angeles region

[Events marked with asterisks are modeled as reverse-faulting earthquakes. Rupture lengths are shown in fig. 74]

\begin{tabular}{|c|c|c|}
\hline Fault zone & $\begin{array}{l}\text { Length of break, } \\
\text { in km }\end{array}$ & $\begin{array}{l}\text { Magnitude } \\
\text { (M) }\end{array}$ \\
\hline 1A - - - San Andreas & 320 & 8.1 \\
\hline $18--\sim-$ San Andreas & 68 & 7.2 \\
\hline 2A - - - San Jacinto & 27 & 6.6 \\
\hline 2B - - - San Jacinto & 20 & 6.4 \\
\hline 2C - - - San Jacinto & 50 & 7.0 \\
\hline $2 \mathrm{D}-\cdots--$ San Jacinto & 18 & 6.4 \\
\hline $2 E-\cdots--$ San Jacinto & 45 & 6.9 \\
\hline 3 - - Central Avenue & 7 & 5.8 \\
\hline $4---\cdots--$ Chino & 18 & 6.4 \\
\hline $5^{*}-2----$ Whittier & 30 & 6.7 \\
\hline 6A ------- Elsinore & 18 & 6.4 \\
\hline 6B ------ Elsinore & 29 & 6.7 \\
\hline 6C ------- Elsinore & 22 & 6.5 \\
\hline 6D ------- Elsinore & 27 & 6.6 \\
\hline 7 - - - Murrieta & 15 & 6.2 \\
\hline $8^{*}$ - - - Norwalk & 12 & 6.1 \\
\hline $9 A-\cdots$ & 30 & 6.7 \\
\hline 9B -- - Newport-Inglewood & 22 & 6.5 \\
\hline 9C - . N Newport-Inglewood & 22 & 6.5 \\
\hline 9D - - - Newport-Inglewood & 27 & 6.6 \\
\hline 9E -- --- Newport-Inglewood & 30 & 6.7 \\
\hline 10A - - Palos Verdes Hills & 27 & 6.6 \\
\hline $10 \mathrm{~B}-\sim--$ Palos Verdes Hills & 29 & 6.6 \\
\hline 10C - - Palos Verdes Hills & 21 & 6.4 \\
\hline $10 \mathrm{D}----$ Palos Verdes Hills & 24 & 6.5 \\
\hline $11 \mathrm{~A}-----$ San Pedro Basin & 18 & 6.3 \\
\hline 11B ----- San Pedro Basin & 25 & 6.6 \\
\hline 11C - - San Pedro Basin & 28 & 6.6 \\
\hline 12A - - - Santa Cruz-Catalina escarpment & 23 & 6.5 \\
\hline 12B - - - Santa Cruz-Catalina escarpment & 19 & 6.4 \\
\hline 12C - - - Santa Cruz-Catalina escarpment & 30 & 6.7 \\
\hline 12D - - - Santa Cruz-Catalina escarpment & 27 & 6.6 \\
\hline 12E ---- Santa Cruz-Catalina escarpment & 30 & 6.7 \\
\hline 12F - - - - Santa Cruz-Catalina escarpment & 30 & 6.7 \\
\hline $13^{*}$-n- Llano & 6 & 5.7 \\
\hline $14-----$ Mirage Valley & 30 & 6.7 \\
\hline 15A -- -- Helendale & 30 & 6.7 \\
\hline 15B - - - Helendale & 30 & 6.7 \\
\hline 16A -- --- Lenwood & 25 & 6.5 \\
\hline 16B ------ Lenwood & 27 & 6.6 \\
\hline 17 --- - Camp Rock & 30 & 6.7 \\
\hline $18------$ Cleghorn & 23 & 6.5 \\
\hline $19 A^{*}-----$ North Front-San Bernardino Mountains & 15 & 6.2 \\
\hline 19B - --- North Front-San Bernardino Mountains & 11 & 6.0 \\
\hline 19C - - North Front-San Bernardino Mountains & 13 & 6.2 \\
\hline $19 \mathrm{D}-\cdots--$ North Front-San Bernardino Mountains & 14 & 6.2 \\
\hline 20 -.-.- Crafton & 20 & 6.4 \\
\hline 21* - - - Banning & 30 & 6.7 \\
\hline 22A - - - Santa Ynez & 31 & 6.7 \\
\hline 22B - - - Santa Ynez & 29 & 6.6 \\
\hline 22C ----- Santa Ynez & 29 & 6.6 \\
\hline $23^{*}$-n-- More Ranch & 25 & 6.6 \\
\hline $24--\cdots--$ Mission Ridge & 27 & 6.6 \\
\hline 25 - - - Arroyo Parida & 23 & 6.5 \\
\hline $26^{*}-----$ San Cayetano & 32 & 6.7 \\
\hline 27 ------ Mesa-Rincon Creek & 24 & 6.5 \\
\hline $28^{*}$----- Red Mountain & 27 & 6.6 \\
\hline
\end{tabular}

174 Earthquake Hazards in the Los Angeles Region 
TABLE 25. - 87. postulated earthquakes used to calculate composite maximum intensities for the Los Angeles region-Continued

\begin{tabular}{|c|c|c|}
\hline Fault zone & $\begin{array}{l}\text { Length of break, } \\
\text { in km }\end{array}$ & $\begin{array}{l}\text { Magnitude } \\
\text { (M) }\end{array}$ \\
\hline $29 A^{*}-----$ Pitas Point-Ventura & 25 & 6.6 \\
\hline 29B* ----- Pitas Point-Ventura & 24 & 6.5 \\
\hline $30 A^{*}-----$ Oak Ridge & 19 & 6.4 \\
\hline $30 \mathrm{~B}^{*}----$ Oak Ridge & 25 & 6.6 \\
\hline $30 C^{*}----$ Oak Ridge & 24 & 6.5 \\
\hline 30D* ----- Oak Ridge & 32 & 6.7 \\
\hline $31^{*}------$ Simi & 27 & 6.6 \\
\hline $32^{*}$------ Holser & 10 & 6.0 \\
\hline 33 ------- San Gabriel & 30 & 6.7 \\
\hline $34^{*}-----$ Santa Susana & 26 & 6.6 \\
\hline $35^{*}$------ Northridge & 14 & 6.2 \\
\hline $36 *$-- --- San Fernando & 19 & 6.4 \\
\hline $37^{*}-----$ Verdugo & 20 & 6.4 \\
\hline $38 A^{*}$----- Sierra Madre & 28 & 6.6 \\
\hline 38B* ----- Sierra Madre & 24 & 6.5 \\
\hline 39* ------ Cucamonga & 25 & 6.5 \\
\hline 40 ------ Santa Rosa Island & 25 & 6.5 \\
\hline $41 A^{*}-----$ Santa Cruz Island & 30 & 6.7 \\
\hline 41B* ----- Santa Cruz Island & 28 & 6.6 \\
\hline $42 A^{*}-----$ Anacapa & 32 & 6.7 \\
\hline $42 \mathrm{~B}^{*}-----$ Anacapa & 20 & 6.4 \\
\hline 43A* ----- Santa Monica & 26 & 6.6 \\
\hline 43B* ----- Santa Monica & 23 & 6.5 \\
\hline $44^{*}$----- Malibu Coast & 29 & 6.6 \\
\hline $45^{*}$ - - - - Hollywood & 24 & 6.5 \\
\hline $46^{*}$------ Raymond & 14 & 6.2 \\
\hline 47 ------ Indian Hill & 10 & 6.0 \\
\hline 48 - - - San Jose & 20 & 6.4 \\
\hline 49 ------- Red Hill & 12 & 6.1 \\
\hline 50 ------ Fontana & 8 & 5.9 \\
\hline
\end{tabular}

tensities from multiple postulated events in the same region. If enough earthquake sources in a region are considered, the resulting map can delineate those areas having the greatest long-term exposure to shaking hazards. As a first approximation of the areal shaking potential in the Los Angeles region, we recently evaluated a suite of six potential earthquakes and mapped the maximum expected values of Modified Mercalli intensity (Evernden, 1982, fig. 9; U.S. Geological Survey Staff, 1982, fig. 1).

To demonstrate predicted intensity maps that might be used for microzonation or in regional planning, we have generated the cumulative maximum predicted intensities at points within the Los Angeles region resulting from a suite of expectable earthquakes along the principal active faults. The 87 events used were specified by J. I. Ziony and represent his current appraisal of the earthquake potential of the principal late Quaternary faults of the region. Distinctive fault segments were identified from their surficial geologic character and were the basis for postulating rupture lengths. Larger earthquakes might be possible if actual ruptures were to spread to two or more adjacent fault segments during a single earthquake. However, such spreading would have little effect on predicted nearfield maximum potential intensities, because such intensities saturate in the neighborhood of $M$ 6.2. The 87 potential earthquakes used are shown in figure 74 and listed in table 25. The calculated maximum intensities at each site resulting from these 87 earthquakes are plotted in figure 75 .

These calculated intensities can serve two purposes: (1) to delineate areas of potentially hazardous shaking and (2) to delineate areas having little chance of experiencing high, damaging intensities. These maps can be considered as a conservative prediction of future shaking levels across the Los Angeles region. Although we know the potentially active faults, we do not know when any will slip, and so we calculate intensities from all of them. As Ziony and Yerkes (this volume) point out, the repeat times for major earthquakes along segments of the San Andreas and San Jacinto fault zones range from several tens of years to a few hundred years; in contrast, repeat times along other active faults prob- 


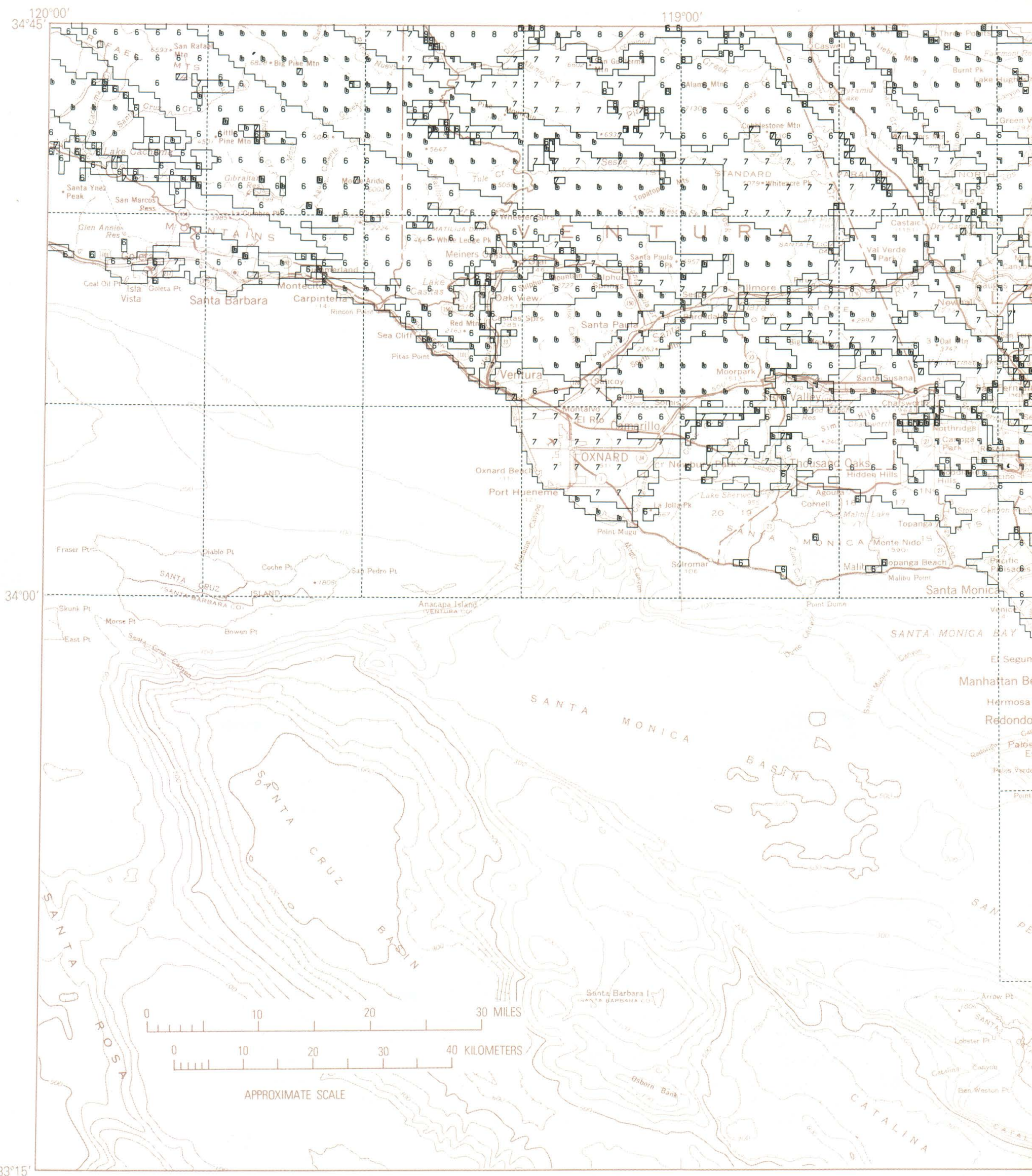

FIGURE 73.-Predicted Modified Mercalli intensities in the onshore Los Angeles region from a repeat of the 1857 Fort Tejon earthquake on the San Andreas fault. Heavy line indicates trace of postulated seismic rupture. Base from parts of the Los Angeles, Long Beach, San Bernardino, and Santa Ana $1^{\circ} \times 2^{\circ}$ sheets. Arabic numerals are used instead of the standard Roman numerals, so that gradations in Modified Mercalli intensities can be shown. Single-stroke characters indicate intensities in the lower half of an intensity band; hollow characters indicate intensities 


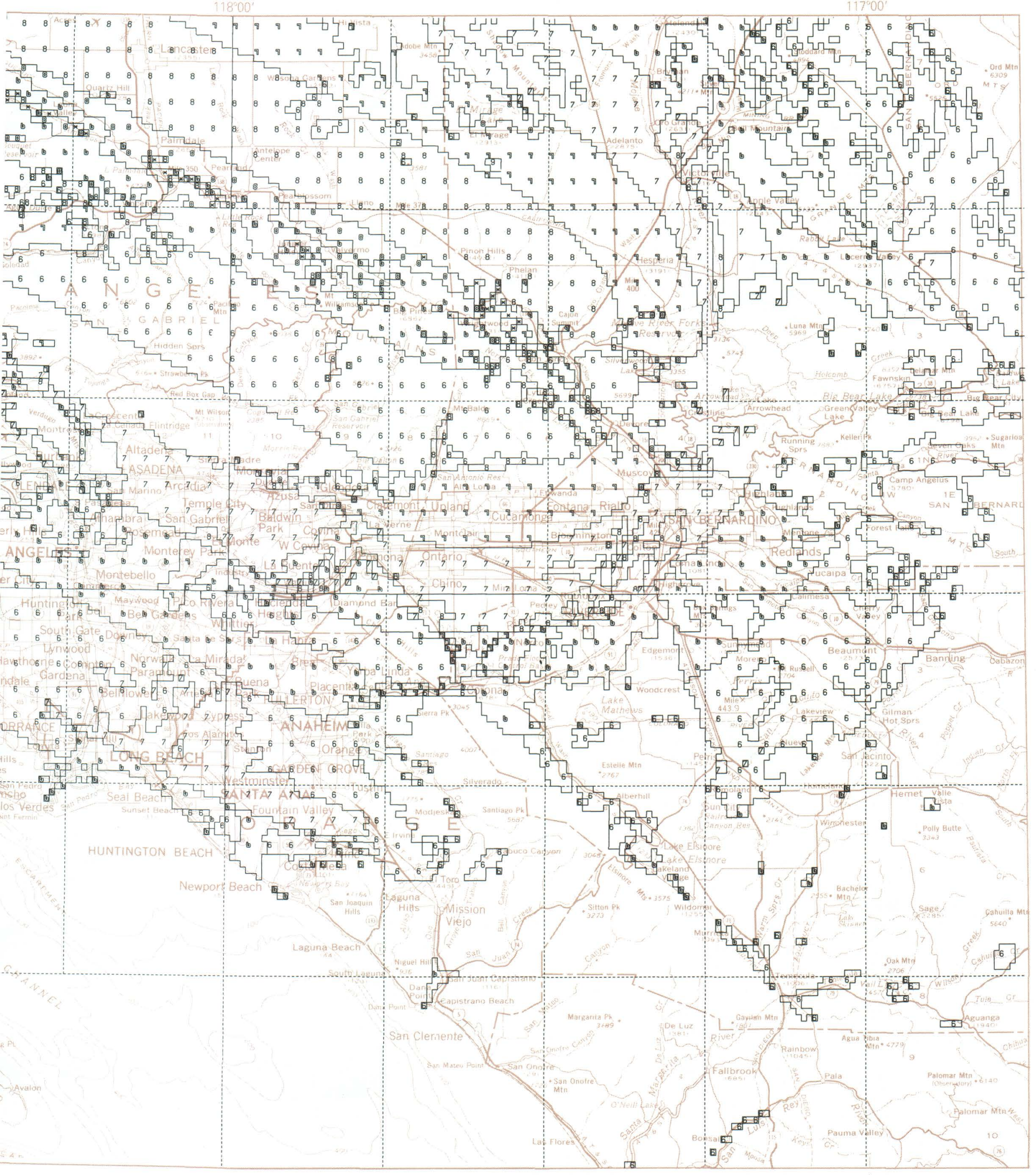

in the upper half. For example, intensities 5.50 to 5.99 are indicated by the single-stroke character 6; intensities 6.00 to 6.50 are indicated by a hollow 6 . Intensity 10 is indicated by an asterisk. All areas of intensity V or less are shown without symbols, because little damage to modern
structures occurs at those intensities. 


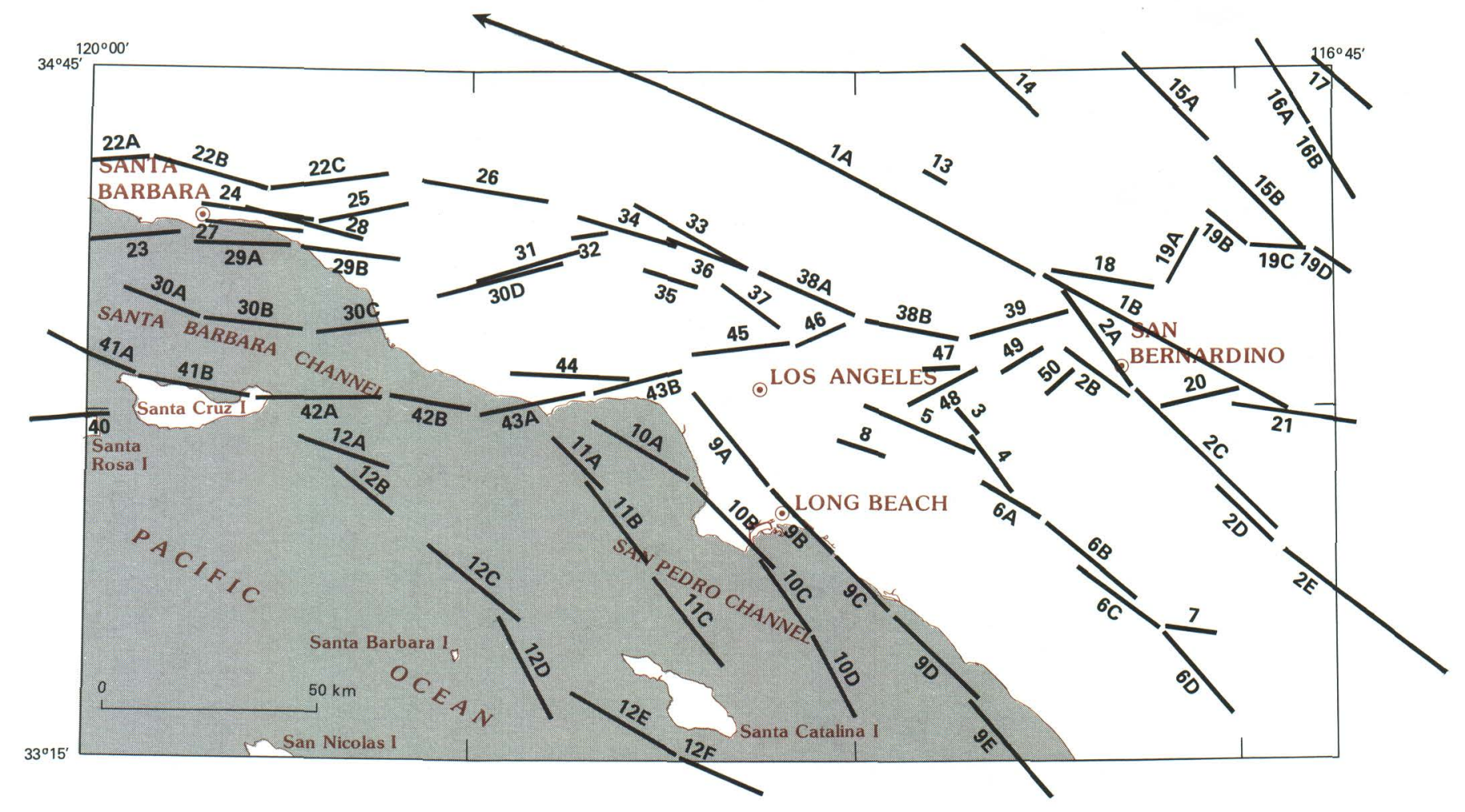

FIGURE 74.-Map of Los Angeles region showing rupture lengths for 87 postulated earthquakes (table 25). These events were selected by J. I. Ziony to be typical earthquakes that might occur along particular fault segments considered potentially seismogenic. The northern end of event $1 \mathrm{~A}$, a repeat of the 1857 Fort Tejon earthquake, lies about $150 \mathrm{~km}$ north of the map area. Coordinates of end points for the reverse-slip earthquakes (see table 25) were displaced horizontally $6 \mathrm{~km}$ in the downdip direction from the surface traces of the respective faults.

ably range from many hundreds of years to several thousand years. We cannot say whether figure 75 does or does not represent the short-term hazard for any specific point. Given this basic uncertainty, these maps have relevance within the context of defining areas that must be avoided for structures that should have a nearvanishing probability of sustaining significant damage due to any potential earthquake.

A second, inverse way of using these maps may be of more interest. As we can see by comparing figure 75 with figure 72 , figure 75 is distinctly more than a restatement of the ground-condition maps. In other words, great areas of alluvium have both a water table at least $30 \mathrm{ft}$ below the surface and locations sufficiently removed from potentially active faults that predicted maximum intensities do not exceed MMI VII, a shaking level that has minimal effect on well-designed buildings. The very limited areas predicted to potentially experience intensities of MMI IX and X are very near active faults and presently have the water table at or very near the ground surface (for example, the Oxnard Plain in fig. 75). The maps in figure 75 are particularly useful for delineating favorable areas for siting facilities whose immunity from shaking damage at the time of an earthquake is vital. Of course, if hard rock sites are available, one need not be concerned with defining alluvium sites of low expected intensity. However, some communities or organizations may find it necessary or desirable to exploit such alluvium sites.

\section{Locating Pre-instrumental Historical Earthquakes}

A third application based on the intensity prediction model is to use the model in conjunction with available observations of intensities, ground conditions, and mapped faults to estimate locations and magnitudes (lengths of rupture) of past earthquakes, including those for which instrumental recordings are not available. The locations and sizes of these earthquakes may have great significance in evaluating the earthquake hazards of a region.

Evernden and others (1981) analyzed the intensity data of two past southern California earthquakes whose fault sources are not definitely known. With the quantity of data available, it was feasible to enfold the intensity prediction program within a statistical framework and to base predictions of location and size on minimization of a statistical parameter. The details of that statistical model have been given by Evernden and others (1981) and will not be repeated here. The earthquakes studied were the 1927 Point Arguello and 1933 Long Beach

\section{Earthquake Hazards in the Los Angeles Region}


earthquakes. The 1927 earthquake was shown at very high statistical confidence to have been associated with rupture of the Hosgri fault offshore. A location even $10 \mathrm{~km}$ farther at sea than the Hosgri fault is strongly rejected by available intensity data and the intensity model. A location on the Santa Lucia Bank fault zone is rejected at far greater than 0.99 confidence. Such a location is grossly inconsistent with the intensity data.

The solution for the 1933 Long Beach earthquake was constrained to lie on the Newport-Inglewood fault zone because the seismologic data were unequivocal. The position and length were determined by the statistical model. The location found by the intensity data was consistent with conventional seismologic data but was more definitive in establishing a length of break of about $30 \mathrm{~km}$, the northern end of the break being onshore. The break shown as $9 \mathrm{~B}$ on figure 74 is nearly that found for the 1933 Long Beach earthquake.

In this chapter, we attempt to determine the locations of the two large earthquakes that occurred on December 8 and 21, 1812, the largest historical earthquakes to occur in southern California before the 1857 Fort Tejon earthquake. The available shaking data for these earthquakes can be derived from descriptions given by Ban- croft (1885) from records of the Franciscan missions then present in the area. It is clear that the records of low intensities (below those causing damage) are very incomplete; it is quite unreasonable, for example, to think that San Gabriel mission could have suffered considerable damage at the time of the December 8 earthquake while the earthquake was not felt at San Fernando mission. The scribes at one mission may have noted shaking equivalent to intensity IV, while others chose not to mention effects equivalent to intensities $\mathrm{V}$ and VI. The general paucity of earthquake records from such a seismically active area suggests that familiarity had bred lack of noteworthiness. Our analysis will assume that shaking inadequate to cause damage may or may not have been noted. Together with the constraints imposed by our model, the available data, and the reporting assumed above, all solutions are tightly constrained. For example, the use of an intensity no higher than IV ("felt but no damage") at Purisima tor the December 8 earthquake is controlled by no report of damage at San Fernando.

The damage reports gleaned from Bancroft (1885) and our interpretations of the shaking intensities for the two earthquakes are as follows:

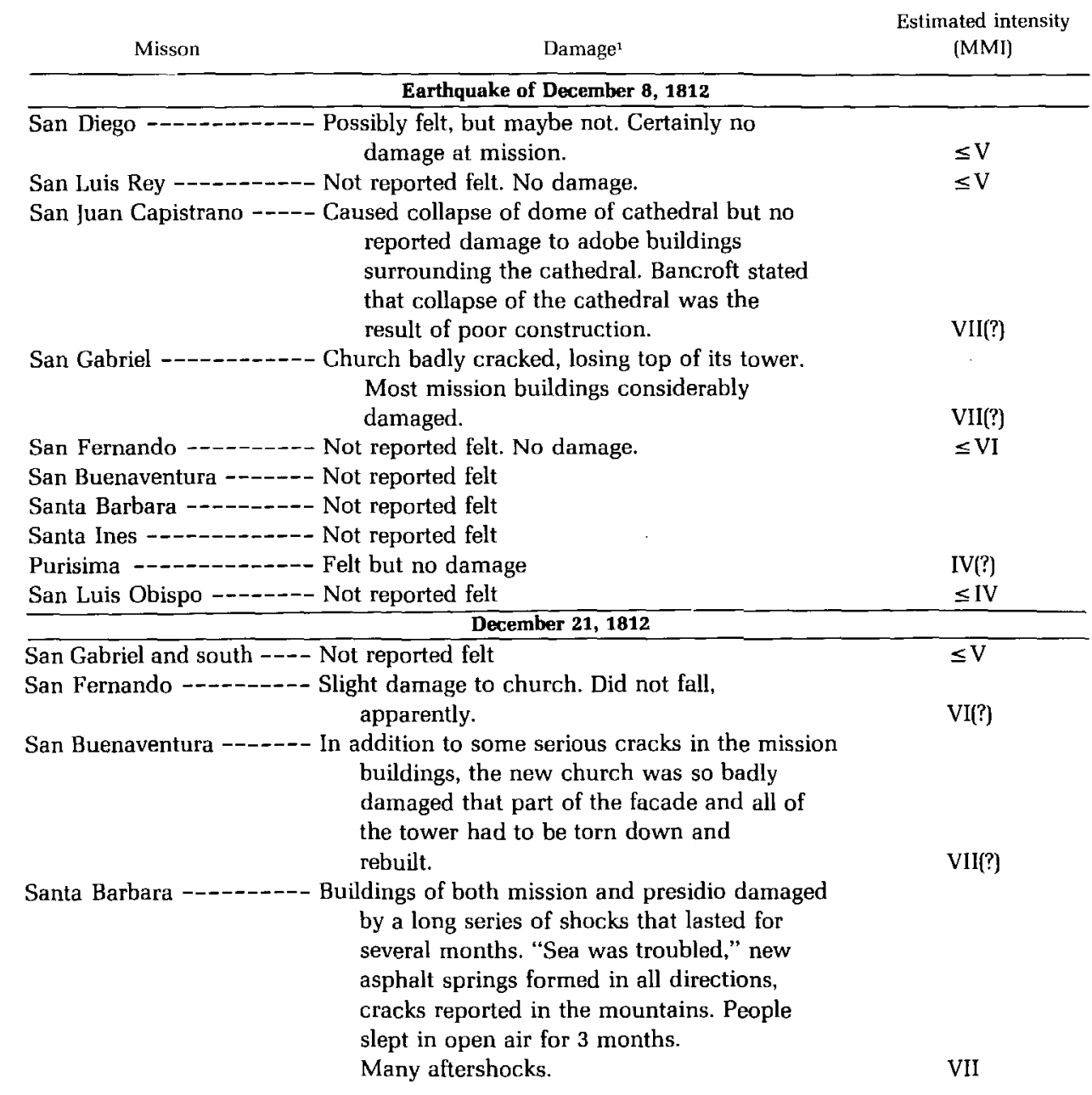




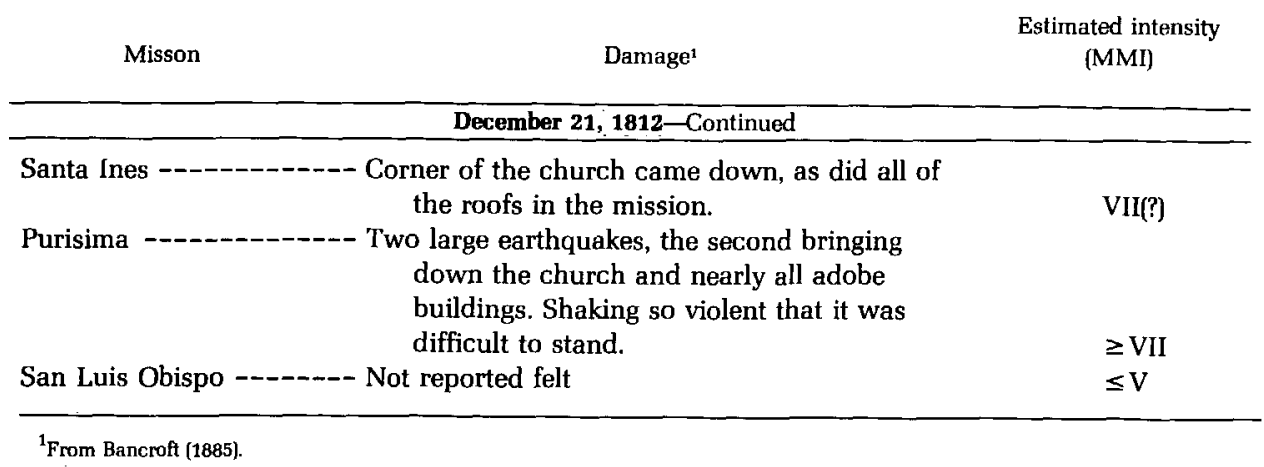

These data become much more understandable when the ground conditions at the several missions are considered:

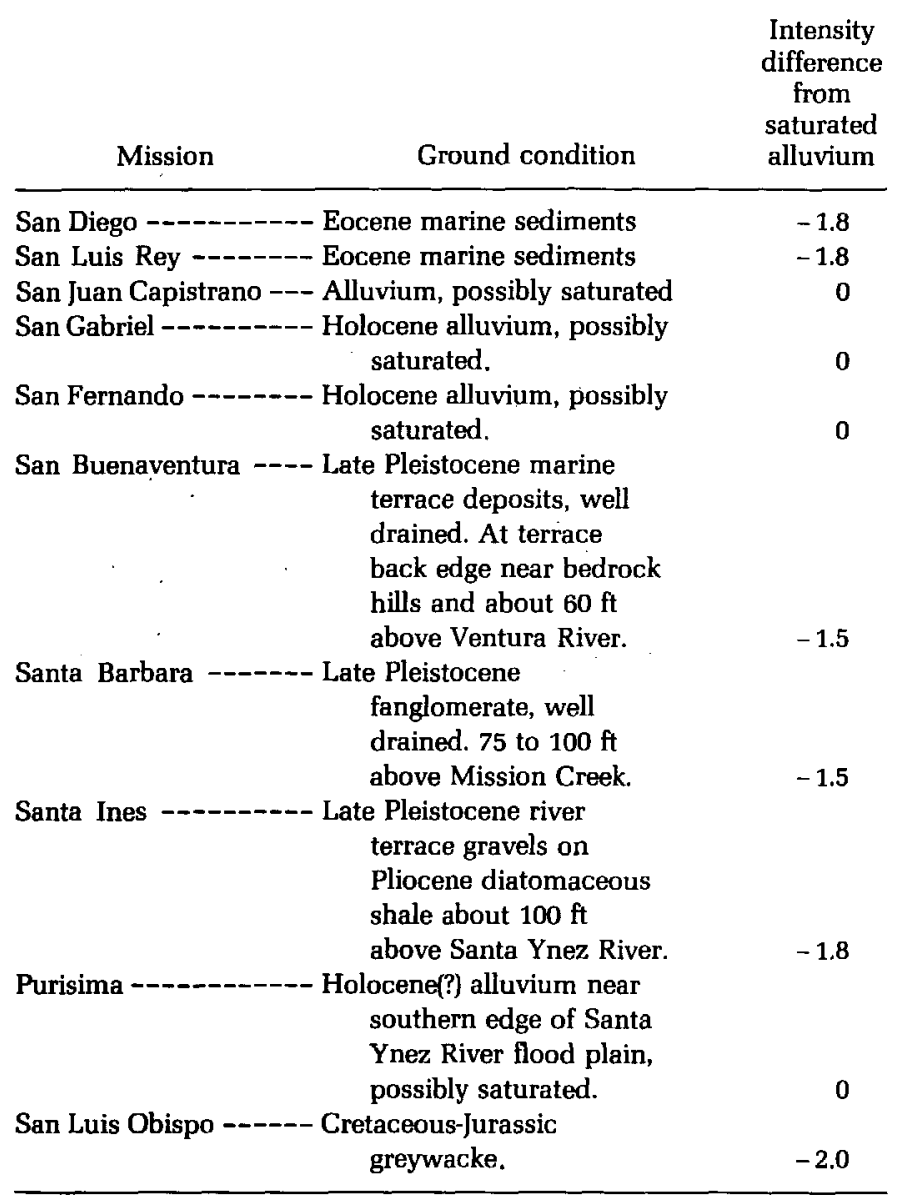

It may seem that the intensities that we are assigning to the sites damaged are too low. We think not. The buildings damaged were of such construction as to invite destruction even under moderate shaking. Bancroft noted that travelers in California in the 1820's commented upon the decrepit state of nearly all of the missions, their condition apparently resulting from simple disintegration and failure to repair, not from earthquake damage. Most of these missions were very weak structures.

Figure $76 \mathrm{~A}$ models a rupture along the southern half of the Newport-Inglewood fault ( $9 \mathrm{C}$ and $9 \mathrm{D}$ of fig. 74) (41 km long, $M$ 6.9) as a possible source of the December 8 earthquake. San Juan Capistrano has the highest predicted intensity (MMI VIII). San Gabriel is next (MMI VII). San Fernando is predicted as borderline (MMI V-VI), and San Diego (just off the map) and San Luis Rey are predicted to have experienced MMI IV. San Buenaventura, Santa Barbara, and Santa Ines are predicted to have experienced MMI III or less, while Purisima, placed as it was on the flood plain of the Santa Ynez River, is predicted to have experienced MMI IV. Thus, a 41-km break on the southern Newport-Inglewood fault zone explains all observations. Other models that might be considered are ruptures on the Elsinore fault zone (6A, 6B, and $6 \mathrm{D}$ of fig. 74) (73 km long, $M$ 7.2) and on the southern half of the Palos Verdes Hills fault (10C and $10 \mathrm{D}$ of fig. 74) (41 km long, $M$ 6.9). The first model requires such great length to cause MMI IV at Purisima but consequently predicts MMI VI at San Luis Rey (fig. $76 B$ ), which seems most unlikely. In addition, field evidence suggests that the modeled break is unlikely because fresh fault scarps have not been recognized along that part of the Elsinore fault zone. A break along the southern half of the Palos Verdes Hills fault lowers the predicted intensity at San Juan Capistrano (MMI VII) but not enough to invalidate the model (fig. 76C). The Palos Verdes Hills fault displays Holocene surface faulting on the San Pedro shelf (Ziony and Yerkes, this volume), whereas the Newport-Inglewood fault zone broke immediately north of the modeled portion in 1933. Our knowledge of the progressive occurrence of earthquakes along fault zones in many areas leads us to infer that the December 8, 1812, earthquake was on the southern half of the Newport-Inglewood fault zone. The apparent progression northward of historical earthquakes on this fault zone suggests that the detailed

\section{Earthquake Hazards in the Los Angeles Region}


study of the geologic and seismologic effects of a postulated break on the northern quarter of the Newport-Inglewood fault zone (Ziony and others, this volume) may be a pertinent scenario.

The earthquake of December 21,1812, was clearly at a far different location. The reports that many people left both Santa Barbara and San Buenaventura missions for as long as 3 months and that many aftershocks were felt at Santa Barbara (probably also at San Buenaventura but not noted in records by Bancroft) strongly suggest an east-west locus of rupture reasonably near both sites. For completeness, we demonstrate (fig. $77 \mathrm{~A}$ ) that a large break (90 km long) along the San Andreas fault, positioned to give maximum predicted intensities at Santa Barbara, is inadequate to generate the required intensities at Santa Barbara, San Buenaventura, and Purisima. Because the greatest historical earthquake in southern California occurred along this very fault only $45 \mathrm{yr}$ later, a major earthquake along the same segment in 1812 seems unreasonable.

More likely candidates for the locus of this earthquake are the Santa Ynez fault and the Pitas PointVentura fault (and its probable western extension). The major requirement of the model is that MMI VI be reached at San Fernando and at least MMI VII be reached at Purisima. As will be seen, a rupture length of $80 \mathrm{~km}$ or more is required. Assuming that several segments of the Santa Ynez fault can break as a unit, we model such a break in figure $77 B$ (events $22 \mathrm{~A}, 22 \mathrm{~B}$, and $22 \mathrm{C}$ of fig. 74 ) ( $87 \mathrm{~km}$ long, $M$ 7.3). MMI VII is predicted at Purisima, MMI IV at San Luis Obispo, MMI VII at Santa Barbara and Santa Ines, MMI VI to VII at San Buenaventura, MMI VI at San Fernando, and lower values to the southeast. We must assume that MMI VI at San Fernando from the December 8 earthquake weakened the church structure but caused no detectable damage, whereas the same intensity 13 days later led to detectable damage requiring repairs. If only two of the three segments of the fault are used in the model, the intensities at either Purisima or San Fernando are predicted as too low. The problems with the model in figure $77 \mathrm{~B}$ are that it gives no basis for the tsunami (McCulloch, this volume) apparently generated by the earthquake and that evidence of historical surface faulting along the fault has not been demonstrated.

Figure $77 \mathrm{C}$ models $\mathrm{a}^{\circ}$ rupture along the Pitas PointVentura fault and its probable western extension events (29A, 29B, and 23 of fig. 74) (90 km long, $M$ 7.3). This earthquake is modeled as a thrust, so that a pseudodepth value of 20 is used rather than 25 , and thus the locus of the energy release is moved $6 \mathrm{~km}$ to the north of the trace of the fault zone, such perturbations of the usual model for strike-slip earthquakes having been required to explain the high near-field intensities of the 1971 San Fernando thrust earthquake (Evernden and others, 1981). The predicted MMI value at Purisima is low VII, an only marginally adequate value. Predicted intensity at Santa Ines is VI to VII, at Santa Barbara and San Buenaventura VIII, at San Fernando VI, and at San Gabriel V. Shortening of the fault rupture on the east would lower predicted intensities at San Fernando to V, an unacceptable result. On the other hand, a further extension on the west to increase predicted intensity at Purisima seems desirable. Thus, figure $77 D$ adds $10 \mathrm{~km}$ to the line shown on figure $74(100 \mathrm{~km}$ long, $M$ 7.4), the result being that the predicted MMI value at Purisima is slightly higher. There is no reason why the rupture could not be extended even farther west.

Other potential earthquake sources offshore of Santa Barbara (fig. 74) have been modeled up to the maximum length consistent with present interpretations, and all fail to predict adequately high MMI values at Purisima, Santa Ines, and San Fernando. A location along the Pitas Point-Ventura trend, however, is consistent with many aftershocks being felt at Santa Barbara and San Buenaventura, with generation of a tsunami by this offshore thrust fault, and with numerous small fractures in the hanging wall block (the landward side of the fault) during subsequent aftershocks. We conclude that available intensity data, when interpreted within the confines of our model, indicate the earthquake(s) of 21 December, 1812 , to have been associated with rupture of about 100 $\mathrm{km}$ along the offshore trend of the Pitas Point-Ventura fault. In light of the reports from Purisima of two earthquakes about one-half hour apart, the second earthquake being much more violent, it may be that the eastern half of the fault ruptured first, this initial rupture being followed by an earthquake of essentially equivalent magnitude $(M \approx 7.0)$ along the western half of the fault. No other known fault zone appears adequate to explain all observations.

\section{Predicting Root-Mean-Square Acceleration}

As we pointed out earlier and as figures $71 \mathrm{~A}$ and $71 B$ illustrate, RMS acceleration shows strong correlation with predicted intensity and rock type. In band 2, RMS acceleration is nearly independent of rock type, being only a function of intensity. Therefore, a direct conversion of predicted intensity to predicted RMS acceleration in band 2 is possible. Figure 78 gives the predicted RMS acceleration in band 2 for part of the Long Beach 


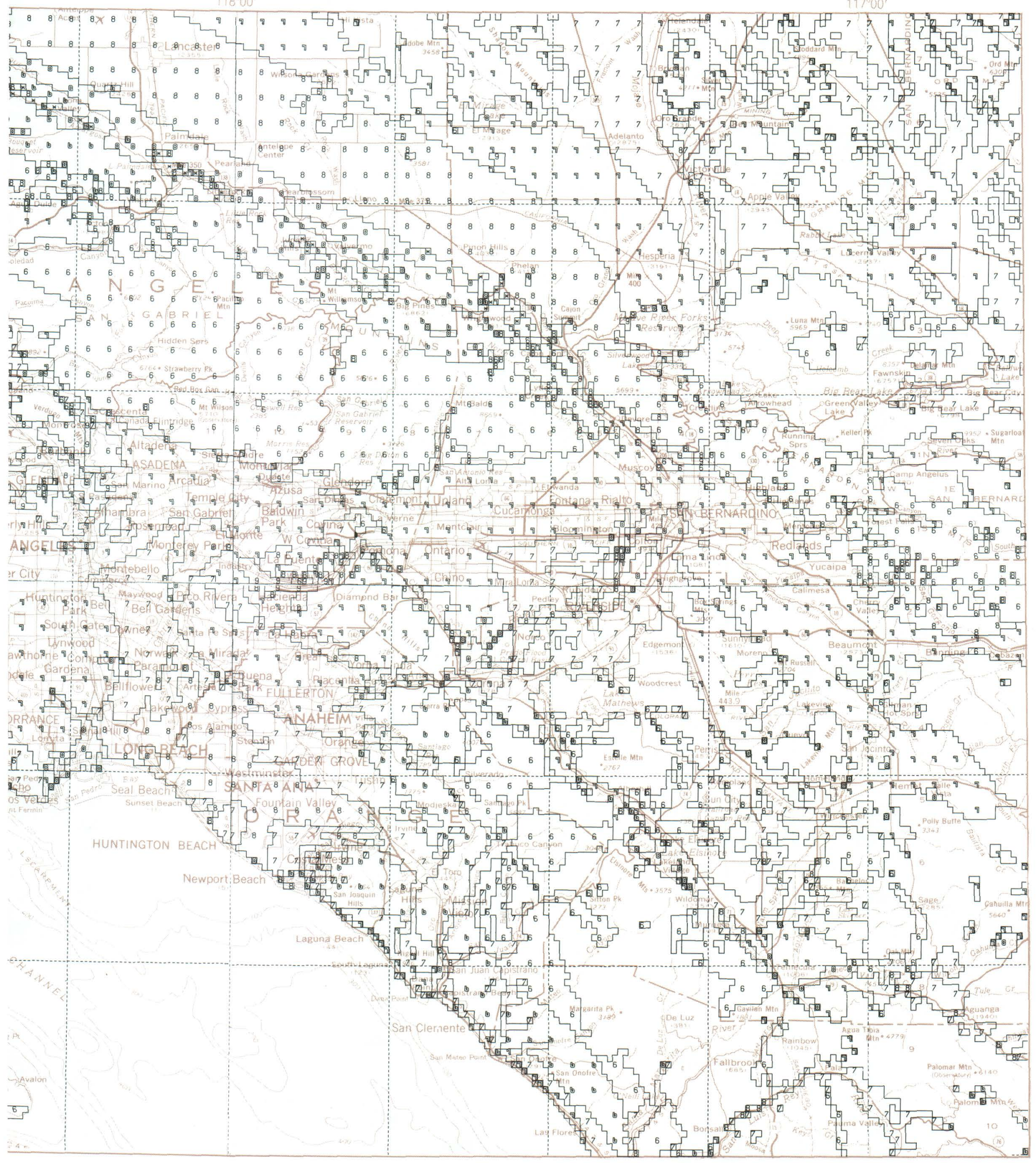

tensities 5.50 to 5.99 are indicated by the single-stroke character 6 ; intensities 6.00 to 6.50 are indicated by a hollow 6 . Intensity 10 is indicated by an asterisk. All areas of composite maximum intensity of $\mathrm{V}$ or less are shown without symbol, because little damage to modern structures 


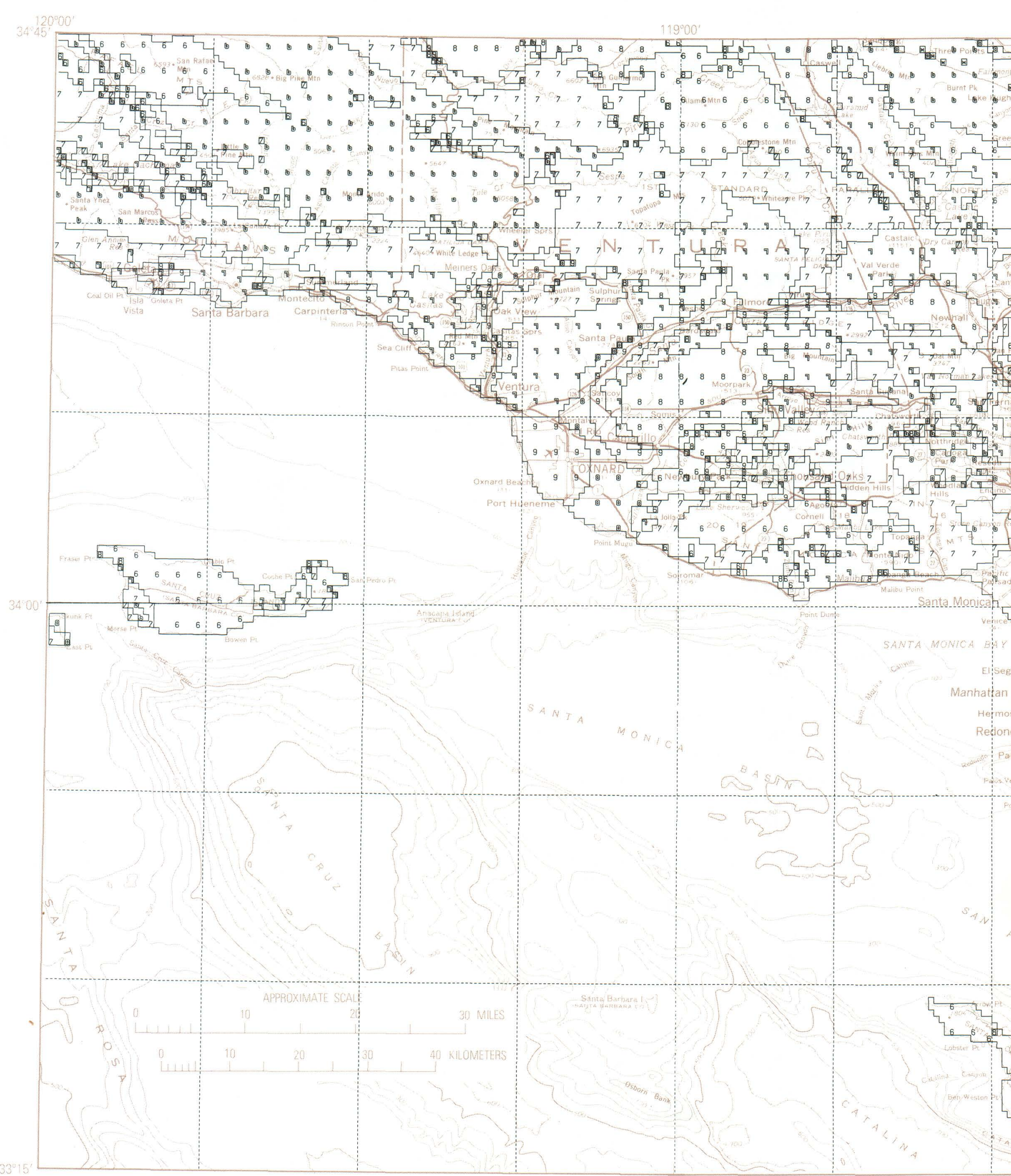

FIGURE 75.-Predicted composite maximum Modified Mercalli intensities in the onshore Los Angeles region for 87 postulated earthquakes (listed in table 25 and located in fig. 74). Base from parts of the Los Angeles, Long Beach, San Bernardino, and Santa Ana $1^{\circ} \times 2^{\circ}$ sheets. Arabic numerals are used instead of the standard Roman numerals, so that gradations in Modified Mercalli intensities can be shown. Single-stroke characters indicate intensities in the lower half of an intensity band; hollow characters indicate intensities in the upper half. For example, in- 


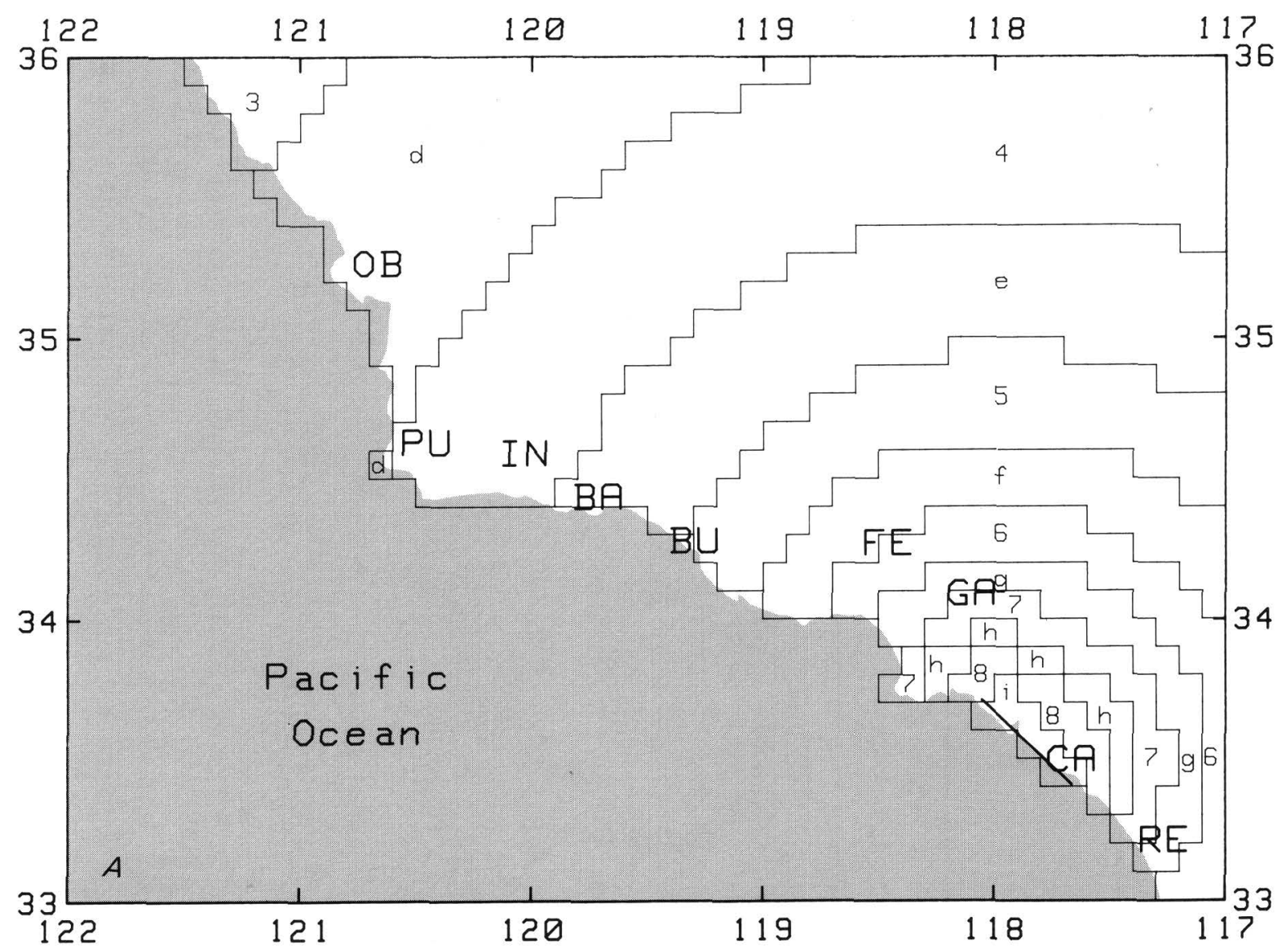

FIGURE 76.-Predicted intensities for candidate fault ruptures to explain reported effects of the earthquake of December 8 , 1812. A, Southern half of the Newport-Inglewood fault zone ( $9 \mathrm{C}$ and $9 \mathrm{D}$ of fig. 74). B, Elsinore fault zone (6A, $6 \mathrm{~B}$, and $6 \mathrm{D}$ of fig. 74). C, Palos Verdes Hills fault zone (10C and 10D of fig. 74). Digitization scale is $0.1^{\circ} \times 0.1^{\circ}$. Calculation point is the center of the grid element. Numbers refer to the lower half of an intensity unit (" 8 " to intensities between 7.5 and 8.0 ); the associated letters refer to the upper half (" $\mathrm{i}$ " to intensities between 8.0 and 8.5). An asterisk refers to intensities between 9.5 and 10.0. Two-letter symbols indicate locations of Franciscan missions (center of symbol). Intensities shown are for ground conditions of saturated alluvium.

$1^{\circ} \times 2^{\circ}$ sheet from the postulated earthquake along the northernmost $30 \mathrm{~km}$ of the Newport-Inglewood zone.

\section{USING SEISMIC INTENSITIES TO PREDICT EARTHQUAKE LOSSES}

\section{Correlating Intensity with Percent Loss}

A particularly important derivative application of predicted intensity maps is based on the fact that, because damage-causing intensities are defined in terms of type of building and extent of damage, it is possible to construct empirical graphs correlating building type, intensity, and level of damage (usually ex- pressed as percent of value); such graphs are possible for structures that suffer damage owing to frequencies within the intensity-related bandpass (band 2, corresponding to $0.5-3.0 \mathrm{~Hz}$ ). This principle certainly applies to wood-frame structures and has been shown to apply to unreinforced concrete buildings also. Thus, figure 79 presents empirically derived curves of percent damage versus intensity for pre-1940 California woodframe construction, post-1940 California wood-frame construction, and both residential and commercial unreinforced concrete construction. The first curve is from Evernden and others (1981), and the last three are derived from Gulliver (in press). These graphs allow direct conversion of predicted intensity to predicted average percent loss from shaking (assuming that buildings of the relevant type are at the sites of predicted loss), leading to the suite of maps presented in figures 80 through 83 for the modeled Newport-

\section{Earthquake Hazards in the Los Angeles Region}




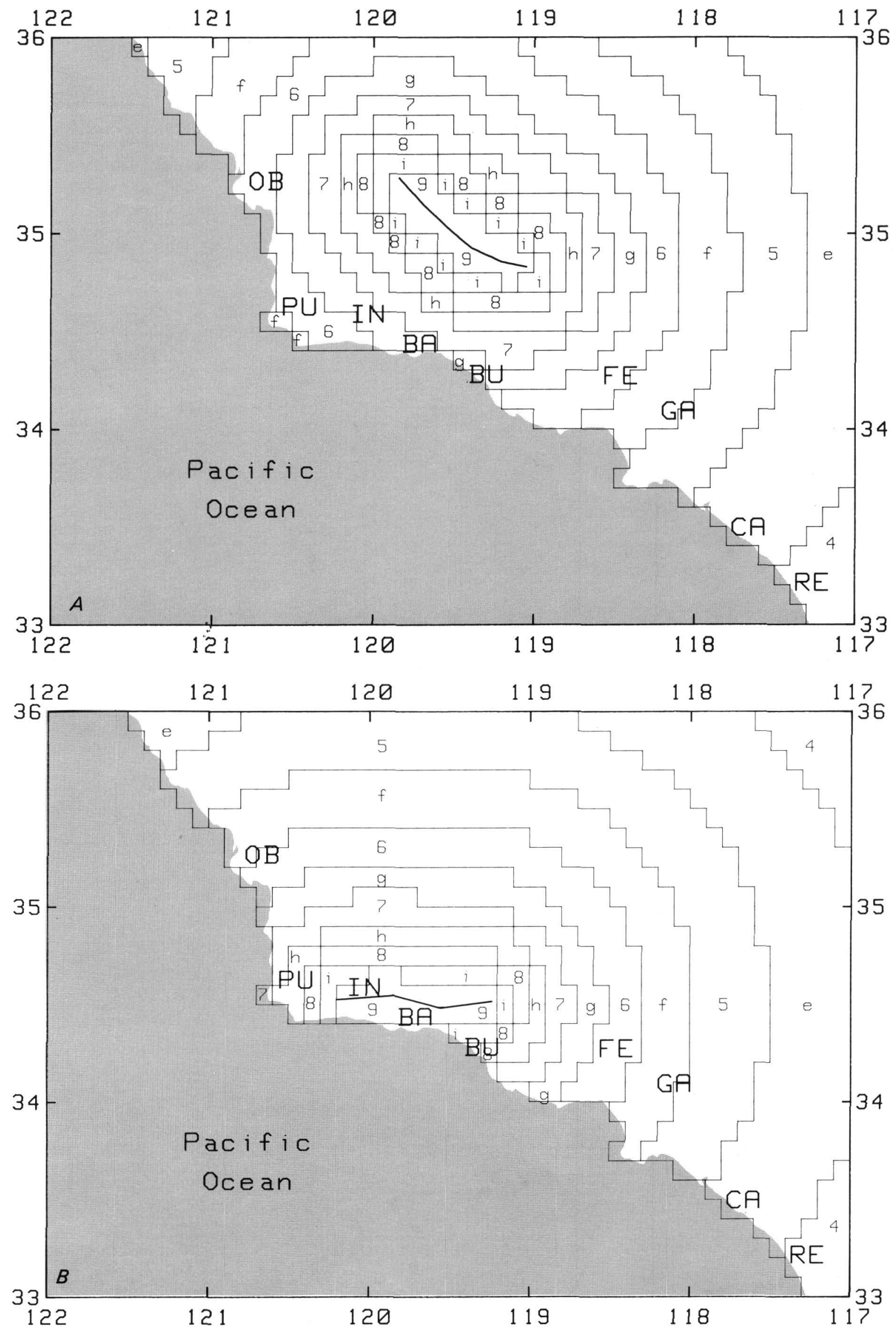

FIGURE 77.-Predicted intensities for candidate fault ruptures to explain reported effects of the earthquake of December 21, 1812. A, 90-km rupture on the San Andreas fault (portion of $1 \mathrm{~A}$ of fig. 74). B, Santa Ynez fault (22A, 22B, and 22C of fig. 74). C, Pitas Point-Ventura fault (29 and 23 of fig. 74). $D$, Same as $C$ plus $10 \mathrm{~km}$ added on the western end. Digitization scale is $0.1^{\circ} \times 0.1^{\circ}$. Calculation point is the center of the grid ele- 

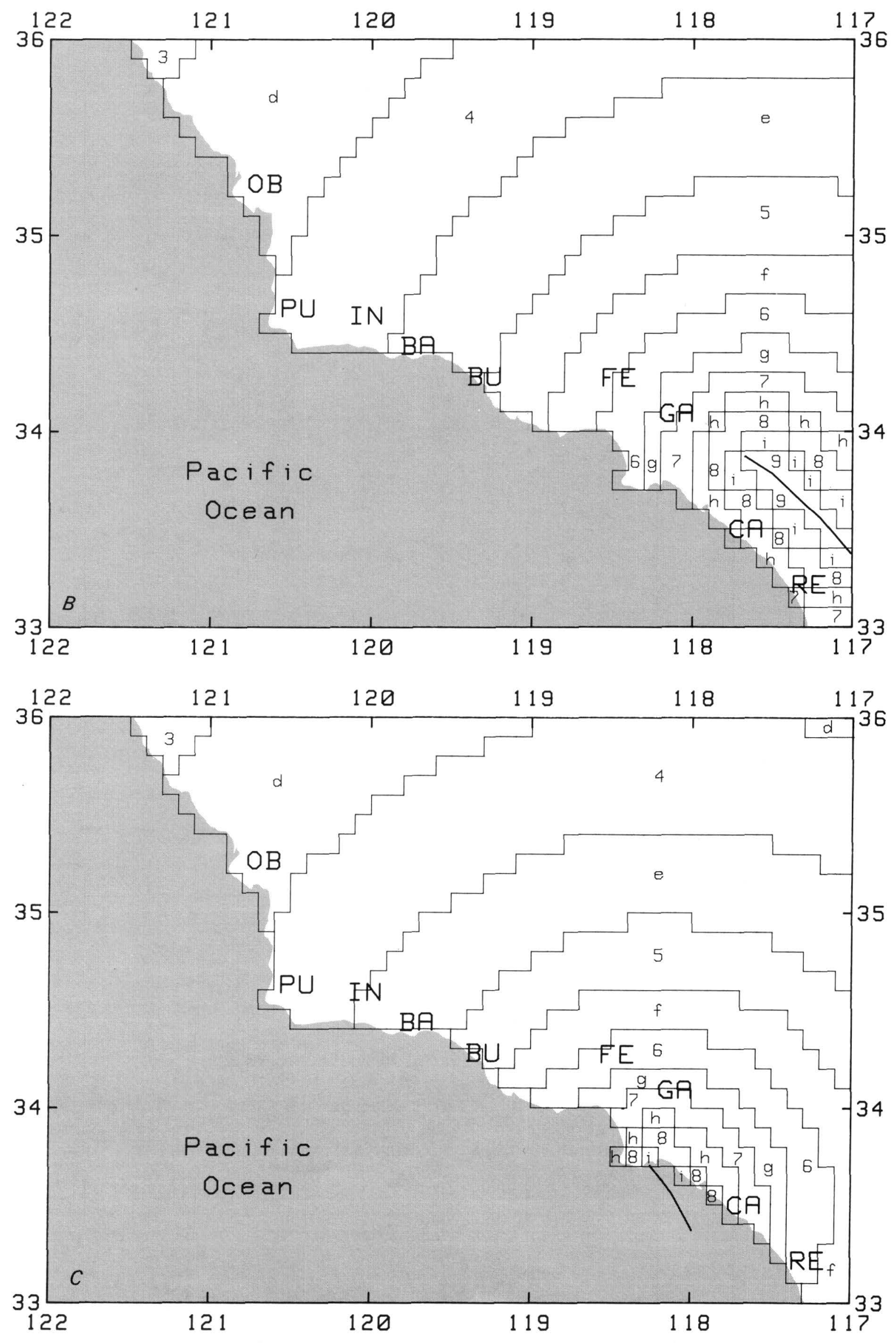


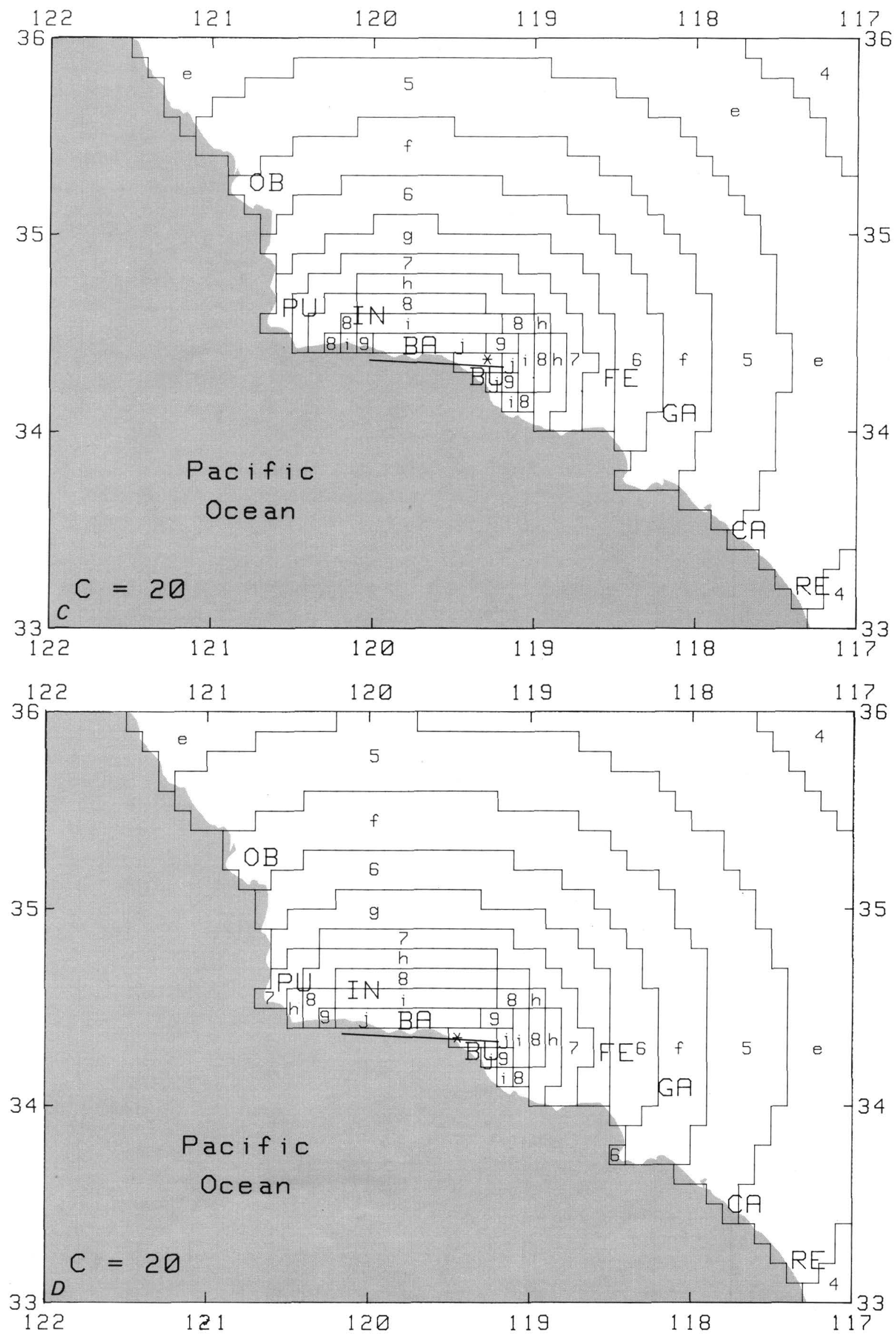

ment. Numbers refer to the lower half of an intensity unit (" 8 " to intensities between 7.5 and 8.0); the associated letters refer to the upper half (" $\mathrm{i}$ " to intensities between 8.0 and 8.5). An asterisk refers to intensities between 9.5 and 10.0. Two-letter symbols indicate locations of Franciscan missions (center of symbol). Intensities shown are for ground conditions of saturated alluvium. 


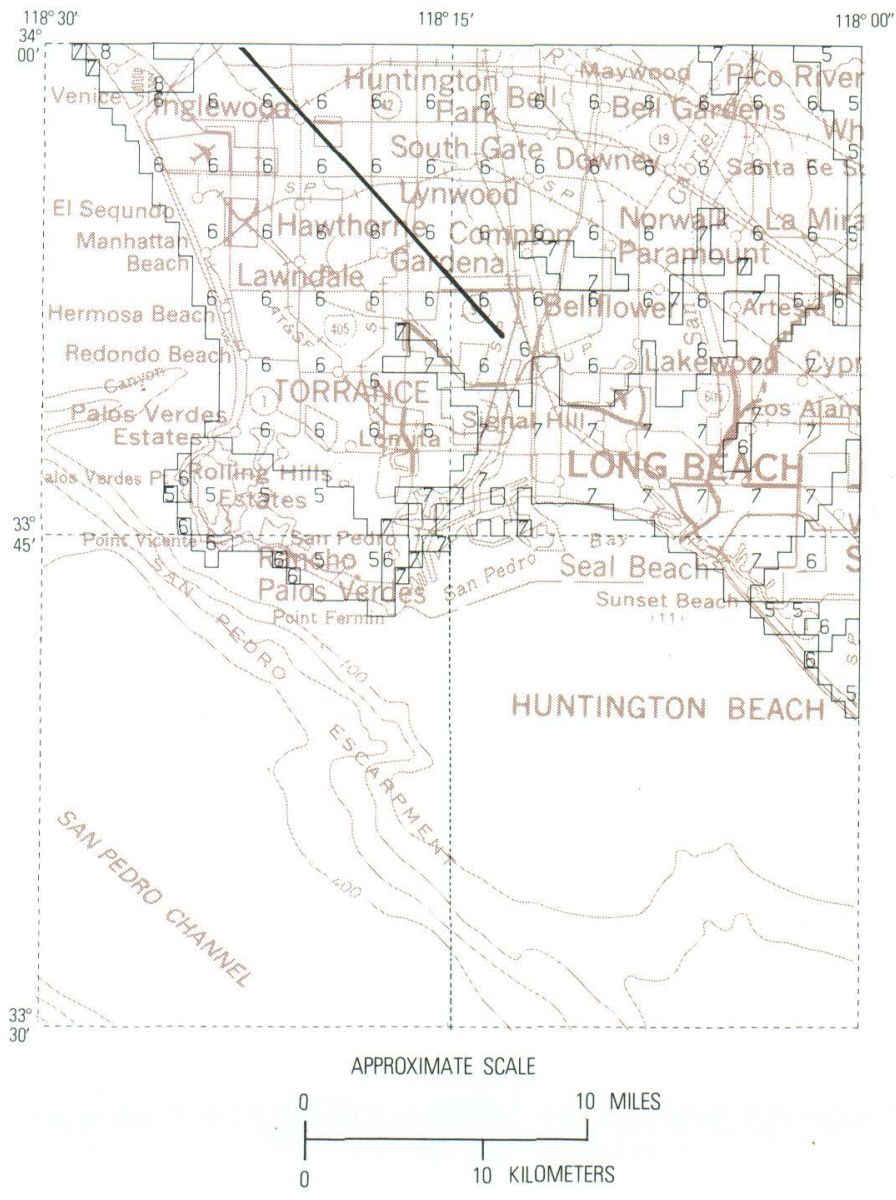

FIGURE 78.-Predicted root-mean-square (RMS) acceleration over a 10 -s window in band 2 (frequencies of $0.5-3.0 \mathrm{~Hz}$ ) in part of the Long Beach $1^{\circ} \times 2^{\circ}$ sheet from a postulated earthquake along the northernmost $30 \mathrm{~km}$ of the Newport-Inglewood zone. Numbers designate the following ranges in RMS acceleration: $5,>0.016$ to $0.032 \mathrm{~g} ; 6,>0.032$ to $0.064 \mathrm{~g} ; 7,>0.064$ to $0.128 \mathrm{~g} ; 8,>0.128$ to 0.256 g. Heavy line is the trace of the postulated seismic rupture, which extends northwestward about another $10 \mathrm{~km}$ into the Los Angeles basin.

Inglewood earthquake. Figure 79 and a comparison of figures 80 through 83 with figure 213 of Ziony and others (this volume) illustrate the well-known truth that poorly designed structures can collapse at comparatively low intensities. Death and destruction resulting from earthquakes are more a matter of poor construction and poor planning than of high intensity.

A direct parameter of damage such as predicted percent loss may be more immediately useful in interpretation and analysis than the more abstruse intensity. However, the limitations of maps such as figures 80 through 83 is that they give the average percent structural damage to be expected only if relevant buildings exist within the area. A much more useful map would be one correlating actual building distribution and predicted level of damage. Such a map would require availability of a digitized census of relevant building types. As no such data base presently exists for the Los Angeles region, we cannot present a map based on such correlation, although it would be one of the more useful derivative products of predicted intensity maps. A version of this type of map could express predicted percentage and (or) number of homeless on a grid or areal basis and thus immediately and clearly flag the areas requiring major post-earthquake relief efforts. Gulliver (in press) has assembled much of the data required to implement such a map for the Los Angeles region.

Maps indicating predicted dollar loss, both by building type and by total structural loss, could be developed. At present, such sophisticated maps are beyond the capabilities of available building inventories or data bases. The programming required to generate such maps after the data bases become available is a matter of a few hours, given presently available programs, but man-years may be required to assemble the relevant data. For the time being, predictions of dollar loss to wood-frame structures from shaking and total loss to all structures must depend on generalized loss estimation schemes such as the one developed by Blume and others (1980) and slightly modified by Evernden and others (1981). Because the results of that analysis may be of interest and are as sophisticated as we can now do, they are presented here, along with the description of the mathematical procedures as well as some additional comments.

It must be stressed that all damage estimates given below are for structural and architectural damage due to shaking alone. Potential losses resulting from damage to contents of buildings, dam failure and consequent inundation, rupturing of dikes, extensive fires, and other hazards are not included, nor are indirect costs resulting from disruption of a variety of services and industries.

\section{Predicting Dollar Loss for Wood- Frame Construction}

For use as a guide to relative risks associated with different faults and potential earthquakes on these faults, we have written a simple computer program that estimates replacement value for wood-frame construction damaged by the modeled earthquakes (Evernden and others, 1981). The procedures, which closely follow those of Blume and others (1980), have been implemented for California and could be implemented in any region at any desired scale of population unit. As presently designed, the data sets required are:

1. List of all California cities (or segments of cities) and unincorporated areas, including county, popula- 
tion, latitude, longitude, and typical geologic ground condition.

2. Estimated dollar value of wood-frame construction in a city of 75,000 in California. Value used is $\$ 1.06$ billion (Blume and others, 1980) and is appropriate to 1977. Application of this analysis in subsequent years will require determination of the proper scaling relationship in order to get values appropriate to the year of concern.

3. Table of percentage of damage $(\mathrm{P})$ to wood-frame construction versus Rossi-Forel intensity (RFI) or Modified Mercalli intensity. The following table, for example, is based on values given by Freeman (1932) and Blume and others (1980) and is equivalent to the curve for pre-1940 construction in figure 79:

(i) if $\leq$ RFI $<5.9 \quad \mathrm{P}=0$

(ii) $5.9 \leq \mathrm{RFI}<6.0 \quad \mathrm{P}=(\mathrm{RFI}-5.90)$

(iii) $\quad 6.00 \leq \mathrm{RFI}<6.80 \quad \mathrm{P}=(\mathrm{RFI}-6.00) \times 0.25+0.1$

(iv) $\quad 6.80 \leq \mathrm{RFI}<7.40 \quad \mathrm{P}=(\mathrm{RFI}-6.80) \times 0.5+0.3$

(v) $7.40 \leq$ RFI $<7.85 \quad \mathrm{P}=$ (RFI -7.40$) \times 1.11+0.6$

(vi) $\quad 7.85 \leq \mathrm{RFI}<8.25 \quad \mathrm{P}=(\mathrm{RFI}-7.85) \times 2.25+1.1$

(vii) $8.25 \leq \mathrm{RFI}<8.70 \quad \mathrm{P}=(\mathrm{RFI}-8.25) \times 333+2.0$

(viii) $\quad 8.70 \leq \mathrm{RFI}<9.05 \quad \mathrm{P}=(\mathrm{RFI}-8.70) \times 7.14+3.5$

(ix) $9.05 \leq$ RFI $<9.50 \quad \mathrm{P}=(\mathrm{RFI}-9.05) \times 6.67+6.0$

(x) $\quad 9.50 \leq$ RFI $<10.0 \quad \mathrm{P}=(\mathrm{RFI}-9.50) \times 6.00+9.0$

(xi) $10.00 \leq \mathrm{RFI} \quad \mathrm{P}=12$

The procedure of calculation is straightforward:

A. For each community:

1. Calculate expected RFI (or MMI) by standard formula and using appropriate ground condition.

2. Calculate estimated percent damage (P) to woodframe or other construction (table above or figure 79).

3. Calculate estimated replacement value by using parameters given above or modified for changed value of structures since 1977. Answer in billions of dollars.

\section{B. For each county:}

Sum estimated replacement values for all communities in county.

C. For State:

Sum estimated replacement values for all counties.

D. Sort loss amounts by percent loss and print table of distribution of losses by percent loss.

\section{Estimates of Dollar Loss for Potential California Earthquakes}

A condensed set of estimated future losses to woodframe construction is given in tables 26 through 28 for the modeled Newport-Inglewood earthquake and possi-

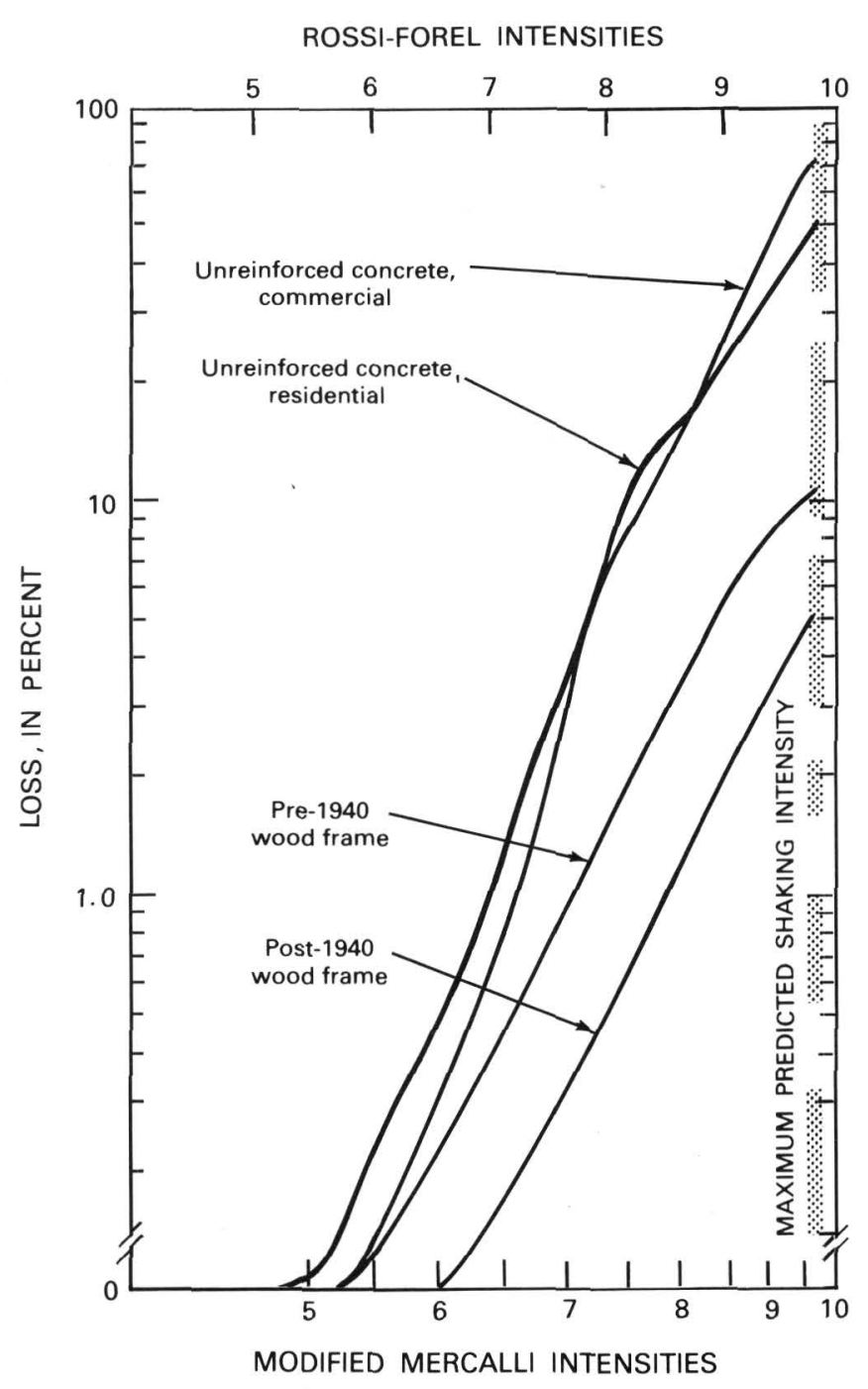

FIGURE 79.-Percent loss from shaking versus intensity versus various types of structures (data from Evernden and others, 1981; Gulliver, in press).

ble repeats of the Fort Tejon (1857) and San Francisco (1906) earthquakes. The first part of each table gives totals by counties and Statewide for two ground conditions (saturated alluvium and one intensity unit lower than expected on saturated alluvium), using intensity versus damage scales for pre-1940 wood-frame construction (Evernden and others, 1981) and post-1940 wood-frame construction (Gulliver, in press). The second part of each table tabulates losses against percent damage, this table well illustrating that predicted damages in southern California, particularly for the Fort Tejon repeat, are based on summing low levels of damage over the great number of structures at risk. Compare the second parts of all three tables to see how concentration of structures near the pertinent fault leads to much higher damage. 


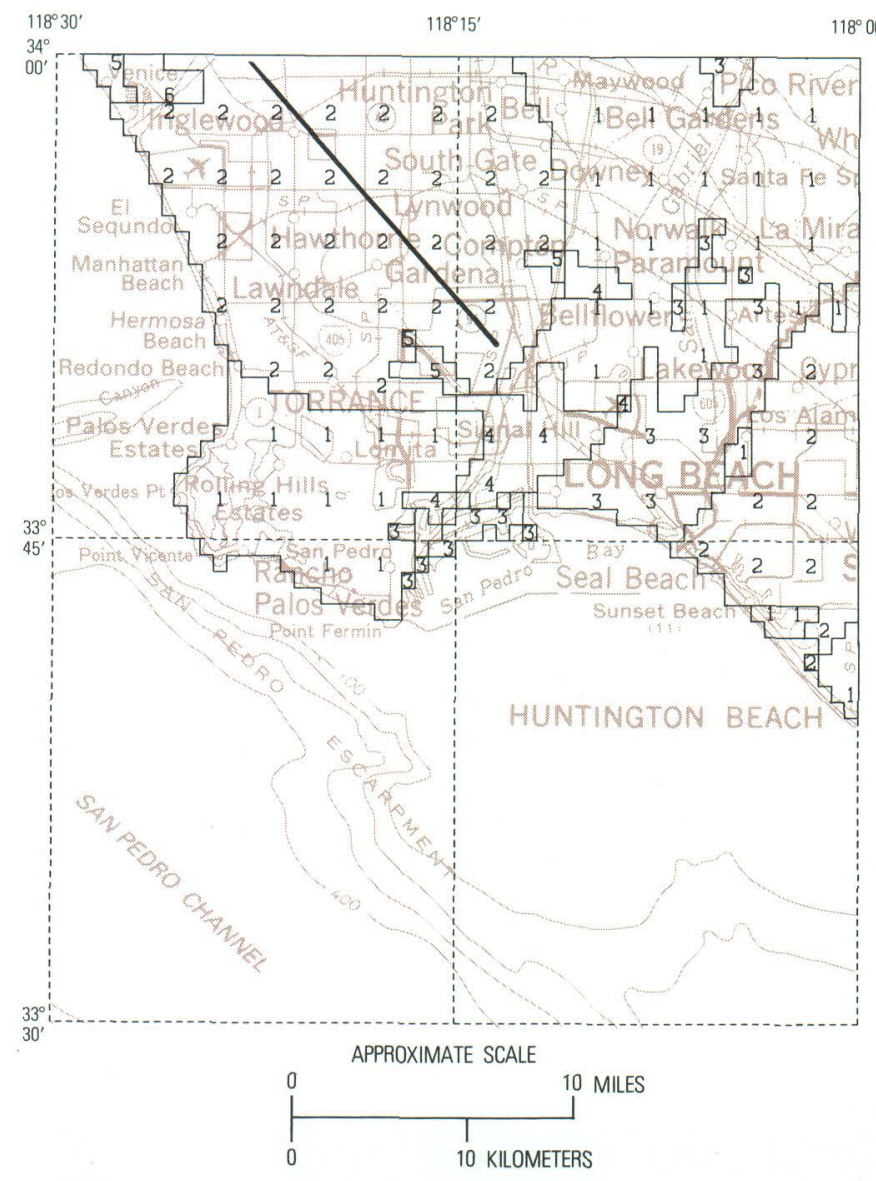

FIGURE 80.-Predicted percent damage to pre-1940 wood-frame construction in part of the Long Beach $1^{\circ} \times 2^{\circ}$ sheet as a result of shaking from a postulated earthquake along the northernmost $30 \mathrm{~km}$ of the Newport-Inglewood zone. Numbers designate the percent loss if this type of construction is present. Heavy line is the trace of the postulated seismic rupture, which extends northwestward about another $10 \mathrm{~km}$ into the Los Angeles basin.

\section{Effects of Improved Construction Practices}

Further discussion of these tables is essential if they are to be of use to readers. In the first place, the "J (saturated alluvium)" columns are certainly not based on the appropriate ground condition for nearly any of the communities in either northern or southern California. The reason for inclusion of those columns will be apparent in a later discussion. The "Pre-1940 J-1" column is that used by Evernden and others (1981) and assumes relevance of the curves of intensity versus damage for pre-1940 structures. We must admit that the estimates of damage under "Post-1940 J-1" are much lower than one's intuition might suggest. Are figures such as those given in the far right-hand columns to be believed? Three recent California earthquakes suggest that they have merit.

\section{Earthquake Hazards in the Los Angeles Region}

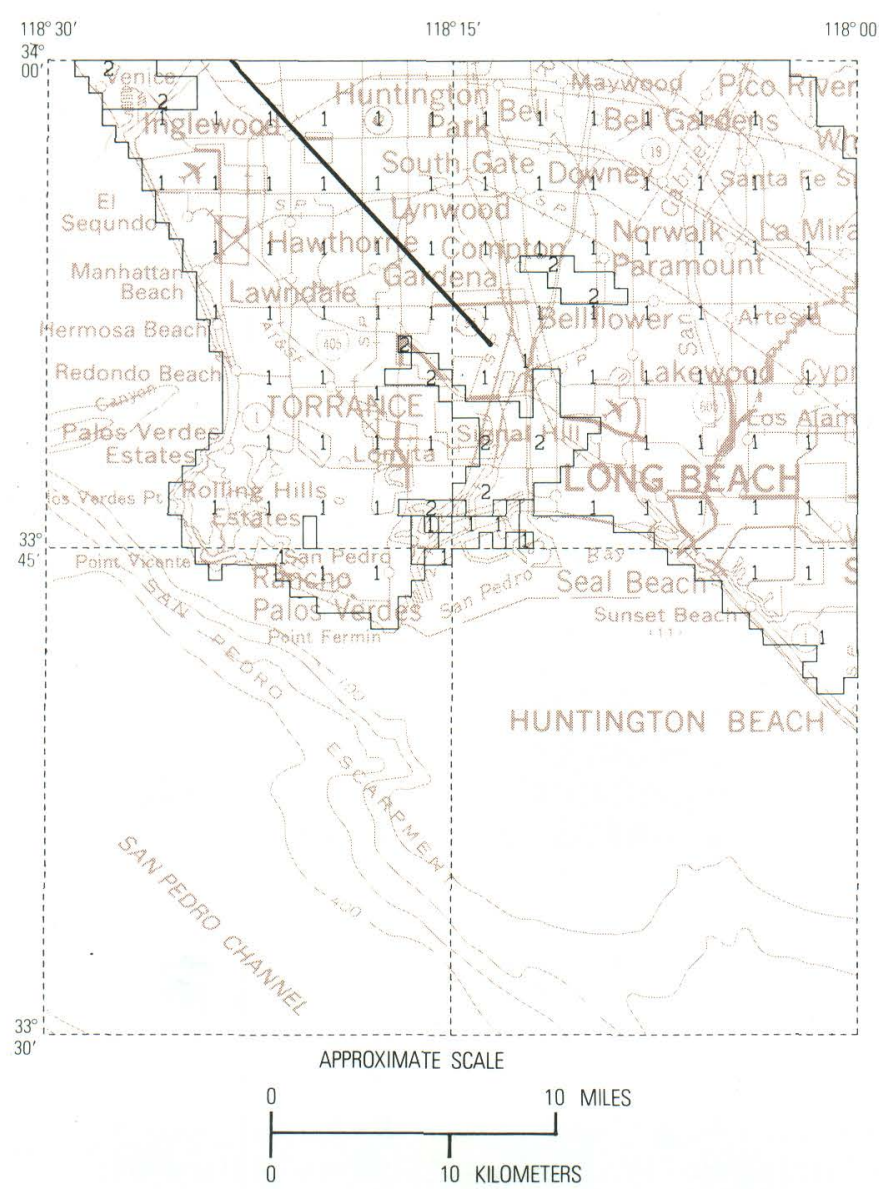

FIGURE 81.-Predicted percent damage to post-1940 wood-frame construction in part of the Long Beach $1^{\circ} \times 2^{\circ}$ sheet as a result of shaking from a postulated earthquake along the northernmost $30 \mathrm{~km}$ of the Newport-Inglewood zone. Numbers designate the percent loss if this type of construction is present. Heavy line is the trace of the postulated seismic rupture, which extends northwestward about another $10 \mathrm{~km}$ into the Los Angeles basin.

First, consider the 1971 San Fernando earthquake. Assuming a deep water table at all sites and using the damage curve appropriate to pre-1940 construction predict a replacement value of $\$ 258$ million for woodframe construction, whereas use of the damage curve appropriate to post-1940 construction predicts a total replacement value of $\$ 85$ million. Detailed corrections for the actual ground-water levels would increase this figure. Steinbrugge and Schader (1973) reported a minimum loss figure of $\$ 114$ million. That figure agrees much more closely with the predicted value based on the pattern of pre- and post-1940 construction in the San Fernando area than with that predicted from the pre-1940 curve.

Second, consider the 1979 Coyote Lake earthquake, which occurred in the southern San Francisco Bay region. Figure 84 illustrates that the available data $\left(\mathrm{M}_{\mathrm{L}}\right.$, 


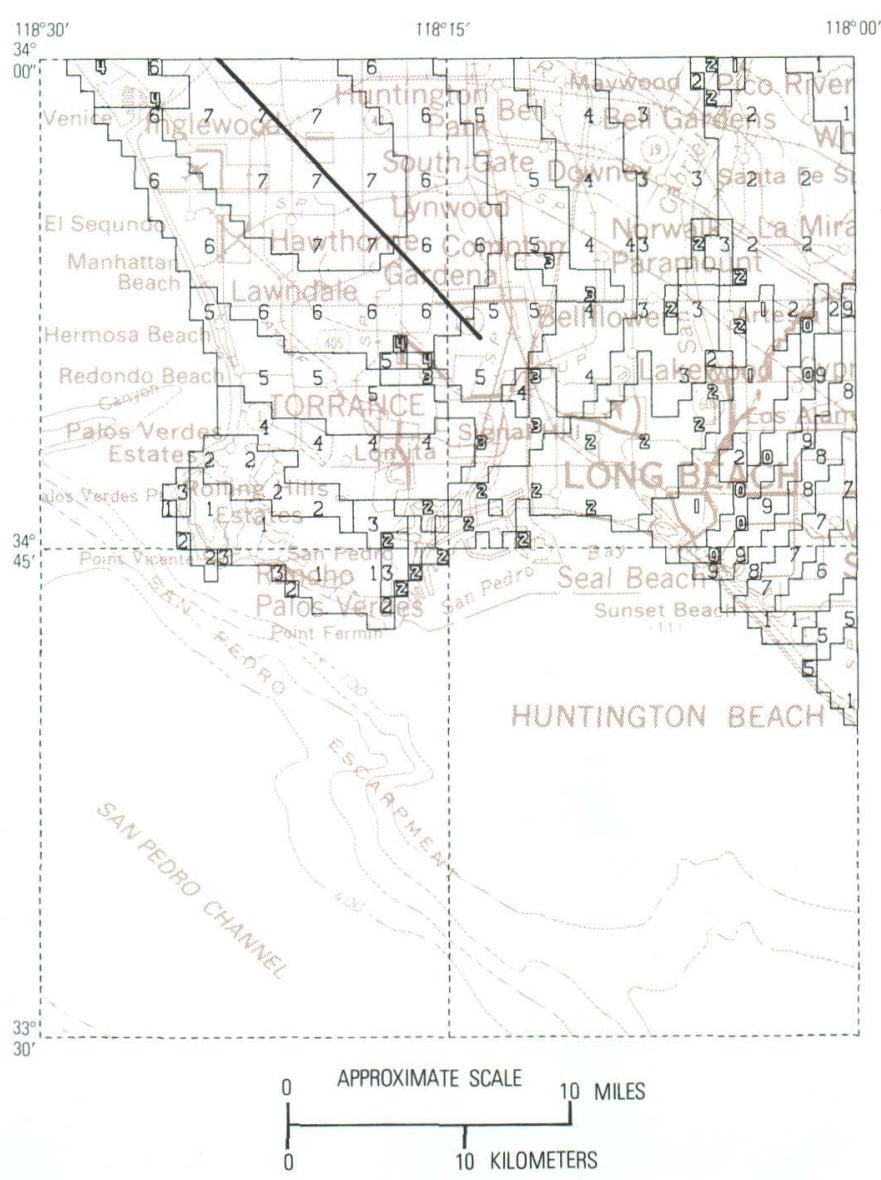

FIGURE 82.-Predicted percent damage to unreinforced concrete residential structures in part of the Long Beach $1^{\circ} \times 2^{\circ}$ sheet as a result of shaking from a postulated earthquake along the northernmost $30 \mathrm{~km}$ of the Newport-Inglewood zone. Values indicate percent loss if this type of construction is present. Solid numbers (1-9) indicate corresponding percent loss. Hollow numbers designate the following ranges in percent loss: $0,>9$ to 10 percent; $1,>10$ to 12 percent; $2,>12$ to 16 percent; $3,>16$ to 20 percent; $4,>20$ to 25 percent. Heavy line is the trace of the postulated seismic rupture, which extends northwestward about another $10 \mathrm{~km}$ into the Los Angeles basin.

intensity pattern, and length of break) all agree when interpreted in terms of expected correlations for an earthquake in western California. Evernden (1983) has presented a description of figures of this type and a demonstration of the sensitivity of such plots to event parameters and $\mathrm{k}$ value. The test imposed by a figure such as figure 84 is that agreement exists between the model and the observations only if the observations lie along a vertical line on the figure. The intensities for this earthquake were largely determined by nonstructural data. Given the agreements shown in figure 84, table 29 was calculated for a variety of relations between intensity and damage. In addition, the level of damage incurred in Gilroy, Calif., and reported by Kustu (1981) is included. Intensities were calculated for saturated

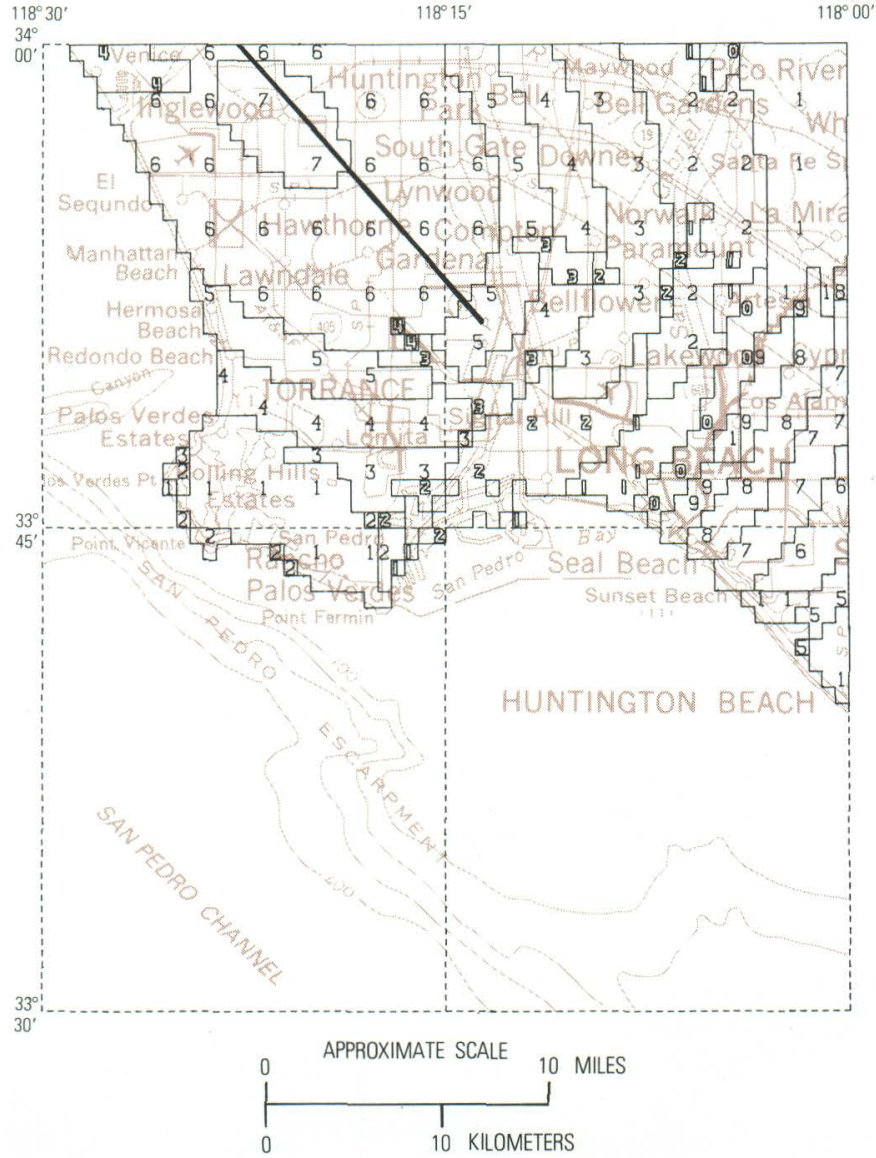

FIGURE 83.-Predicted percent damage to unreinforced concrete commercial structures in part of the Long Beach $1^{\circ} \times 2^{\circ}$ sheet as a result of shaking from a postulated earthquake along the northernmost $30 \mathrm{~km}$ of the Newport-Inglewood zone. Values indicate percent loss if this type of construction is present. Solid numbers (1-9) indicate corresponding percent loss. Hollow numbers designate the following ranges in percent loss: $0,>9$ to 10 percent; $1,>10$ to 12 percent; $2,>12$ to 16 percent; $3,>16$ to 20 percent; $4,>20$ to 25 percent. Heavy line is the trace of the postulated seismic rupture, which extends northwestward about another $10 \mathrm{~km}$ into the Los Angeles basin.

alluvium $(0)$ and for water table at $30 \mathrm{ft}$ or greater $(J-1)$. The value of intensity used for calculating damage was the one of this pair that was closer to the reported intensity. Under "Losses, predicted," the column headed 0 uses this intensity and the pre-1940 damage curve. The sequence of columns to the right is for losses calculated when relevant intensity is decreased in half-intensity increments, it being presumed that the protection achieved by post-1940 construction can be expressed as an increment of intensity protection. About 88 percent of all houses in Gilroy and Hollister have been built since 1940. Therefore, losses observed should give some idea of the protection achieved by the change in building codes. Direct interpretation of table 29 would suggest that a protection of greater than one full intensity unit is 
TABLE 26.-Calculated replacement costs for wood-frame construction (pre- and post-1940) damaged by postulated earthquake along northernmost $30 \mathrm{~km}$ of the Newport-Inglewood zone using different assumptions of ground conditions

[Losses are for shaking only and exclude damage to building contents]

\begin{tabular}{|c|c|c|c|c|}
\hline \multirow[b]{3}{*}{ County } & \multicolumn{4}{|c|}{ Loss, in billions of 1977 dollars } \\
\hline & \multicolumn{2}{|c|}{ Pre-1940 } & \multicolumn{2}{|c|}{ Post-1940² } \\
\hline & $\begin{array}{l}\mathrm{J} \text { (saturated } \\
\text { alluvium) }\end{array}$ & $J-1$ & $\begin{array}{l}\mathrm{J} \text { (saturated } \\
\text { alluvium) }\end{array}$ & $J-1$ \\
\hline Los Angeles ---- & --2.764 & 0.697 & 0.927 & 0.260 \\
\hline Orange - - - & --.156 & .045 & .058 & .007 \\
\hline Riverside -....- & ---.005 & .000 & .000 & .000 \\
\hline San Bernardino - & -0.07 & .000 & .001 & .000 \\
\hline Santa Barbara -- & 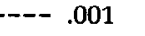 & .000 & .000 & .001 \\
\hline Ventura ------- & ---.015 & .003 & .004 & .000 \\
\hline \multicolumn{2}{|c|}{ All of State ----------2.948 } & .746 & .991 & .268 \\
\hline & \multicolumn{4}{|c|}{ Ratio of percent loss to cumulative loss } \\
\hline & \multicolumn{2}{|c|}{ Pre-1940' } & \multicolumn{2}{|c|}{ Post-1940² } \\
\hline Loss percent & $\begin{array}{l}\mathrm{J} \text { (saturated } \\
\text { alluvium) }\end{array}$ & $\mathrm{J}-1$ & $\begin{array}{l}\text { J (saturated } \\
\text { (alluvium) }\end{array}$ & $J-1$ \\
\hline$\leq 1--$ & --0.159 & 0.404 & 0.427 & 0.268 \\
\hline$\leq 2 \quad--$ & ---.418 & .746 & .991 & .268 \\
\hline$\leq 3--$ & ---1.281 & .746 & .991 & .268 \\
\hline$\leq 4--$ & ---1.570 & .746 & .991 & .268 \\
\hline$\leq 5---$ & ---2.199 & .746 & .991 & .268 \\
\hline$\leq 6 \quad--$ & ---2.948 & .746 & .991 & .268 \\
\hline$\leq 7--$ & ---2.948 & .746 & .991 & .268 \\
\hline
\end{tabular}

${ }^{1}$ From Evernden and others (1981).

${ }^{2}$ From Gulliver (in press).

achieved by post-1940 building requirements. It is interesting to note that, in addition to a change in building code since 1940, there is now a generally enforced home-loan requirement that a termite inspection precede the sale of a dwelling. This factor, whose enforcement has nothing to do with earthquake design, may be as or more important in preventing damage at the time of an earthquake than most of the provisions in the building code.

Third, consider the 1940 and 1979 Imperial Valley earthquakes. For brevity, we will only note a fact that anyone can confirm by inspecting the intensity maps for those earthquakes. That fact is that the reported patterns for the lower intensities for those two earthquakes in southern California were essentially identical. Modeling of those earthquakes would have predicted this identity on the basis of their observed surface breaks, the length of break into Mexico for the 1940 earthquake having little effect on the intensities in southern California. Also, strong-motion records obtained at the same site for the 1940 and 1979 earthquakes were very similar. Actually, the peak velocity on the 1979 record was nearly twice that on the 1940 record, peak accelerations on both being similar (fig. 85). Although the 1940 record persisted longer than the 1979 record did, the period of high amplitudes was essentially the same for both records, the average peak values on the 1979 record being distinctly higher. Given the fact that intensity values scale by powers of two of the strong-motion parameter (see earlier discussion), the low-amplitude persistence of the 1940 record seems highly unlikely to have influenced intensities in any significant way. The minor differences between the $0.5-$ to $3-\mathrm{Hz}$ filtered accelerograms for the two earthquakes can be seen in figure 85. It is pertinent in this regard to note that the Imperial County Services Building failed at the moment of the peak velocity shown on figure 85 (Rojahn and Mork, 1982), the one markedly different parameter between the 1940 and 1979 records. This incident would suggest that failure in 1940 was probably more closely linked to the time of high amplitudes than to the time of persistent low amplitudes. On this basis of evaluation, the record of the 1979 earthquake implies the higher level of destructive ground motion.

Therefore, it seems probable that ground shaking was at least as strong along the fault in $\mathbf{1 9 7 9}$ as it was in 1940. However, reported intensities in the hardest hit areas were at least an intensity unit lower for the 1979 earthquake than they were for the 1940 earthquake. The seemingly logical conclusion to draw from these relations is that the reported lower near-range inten-

\section{Earthquake Hazards in the Los Angeles Region}


TABLE 27.-Calculated replacement costs for wood-frame construction (pre- and post-1940) damaged by postulated repeat of $\mathbf{1 8 5 7}$ Fort Tejon earthquake, using different assumptions of ground conditions [Losses are for shaking only and exclude damage to building contents]

\begin{tabular}{|c|c|c|c|c|}
\hline \multirow[b]{3}{*}{ County } & \multicolumn{4}{|c|}{ Loss, in billions of 1977 dollars } \\
\hline & \multicolumn{2}{|c|}{ Pre-19401 } & \multicolumn{2}{|c|}{ Post-1940² } \\
\hline & $\begin{array}{l}\text { J (saturated } \\
\text { alluvium) }\end{array}$ & $J-1$ & $\begin{array}{l}\text { J (saturated } \\
\text { alluvium) }\end{array}$ & $J-1$ \\
\hline \multicolumn{2}{|c|}{ Fresno -------------- 0.007} & 0.000 & 0.001 & 0.000 \\
\hline \multicolumn{2}{|c|}{ 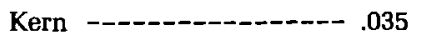 } & .010 & .013 & .003 \\
\hline \multicolumn{2}{|c|}{ Kings -------------- .003 } & .001 & .001 & .000 \\
\hline \multicolumn{2}{|c|}{ Los Angeles - } & .363 & .466 & .108 \\
\hline \multicolumn{2}{|c|}{ Orange -- } & .040 & .051 & .003 \\
\hline \multicolumn{2}{|c|}{ Riverside -- } & .017 & .021 & .006 \\
\hline \multicolumn{2}{|c|}{ San Bernardino -- 199} & .051 & .067 & .019 \\
\hline \multicolumn{2}{|c|}{ San Diego ---------- .002 } & .000 & $: 000$ & .000 \\
\hline \multicolumn{2}{|c|}{ San Luis Obispo ------ .015} & .004 & .005 & .001 \\
\hline \multicolumn{2}{|c|}{ Santa Barbara -------- .020 } & .006 & .007 & .000 \\
\hline \multicolumn{2}{|c|}{ Tulare ------------- .003 } & .000 & .000 & .000 \\
\hline \multicolumn{2}{|c|}{ Ventura -------------- .047 } & .013 & .017 & .002 \\
\hline \multicolumn{2}{|c|}{ All of State -- -- } & .505 & .650 & .144 \\
\hline \multirow[b]{3}{*}{ Loss percent } & \multicolumn{4}{|c|}{ Ratio of percent loss to cumulative loss } \\
\hline & \multicolumn{2}{|c|}{ Pre-19401 } & \multicolumn{2}{|c|}{ Post-1940² } \\
\hline & $\begin{array}{l}\text { J (saturated } \\
\text { alluvium) }\end{array}$ & $J-1$ & $\begin{array}{l}\text { J (saturated } \\
\text { (alluvium) }\end{array}$ & $\mathrm{J}-1$ \\
\hline$\leq 1$ & ---0.449 & 0.439 & 0.498 & 0.137 \\
\hline$\leq 2$ & ---.975 & .483 & 620 & .144 \\
\hline$\leq 3--$ & ----1.427 & .485 & .623 & .144 \\
\hline$\leq 4--$ & ----1.617 & .500 & .623 & .144 \\
\hline$\leq 5--$ & ---1.743 & .505 & .643 & .144 \\
\hline$\leq 6$ & ---1.790 & .505 & .650 & .144 \\
\hline$\leq 7--$ & ---1.792 & .505 & .650 & .144 \\
\hline$\leq 8$ & ---1.793 & .505 & .650 & .144 \\
\hline$\leq 12$ & ---1.858 & .505 & .650 & .144 \\
\hline
\end{tabular}

sities for the 1979 earthquake resulted not from lower levels of ground shaking but from improved structural design.

We conclude that the damage data of these four earthquakes support the case for assuming that post-1940 wood-frame construction does indeed reduce predicted losses to wood-frame construction by a factor of about three. One can make the case that the righthand column in all of these tables is that appropriate for estimating average damage to most California woodframe homes in future earthquakes.

\section{Other Estimates of Dollar Loss}

However, before blithely accepting all of these conclusions, one must at least pay some attention to an assessment by the Federal Emergency Management Administration (FEMA) (1980) that predicts a $\$ 25$ billion total loss to all building types as the result of a repeat of the 1906 San Francisco earthquake. Although not published in the cited document, this total includes a $\$ 10.6$ billion loss to wood-frame construction; the mode of calculation used to achieve the latter figure has been described by the analyst, K. V. Steinbrugge (oral presentation and written notes, 1980). When the curve for pre-1940 construction was used, nearly every parameter value used in our calculations was within a few percent of that used by Steinbrugge. One factor-percent loss to wood-frame structures-was not. Steinbrugge made no correlation of site, distance from fault, geology, or expected intensity with resultant percent structural damage. He assumed that there would be an average of 12-percent loss to all wood-frame structures in the San Francisco Bay region (all six counties of table 30). As can be seen in figure 79, this assumption presumes that all communities in the region will experience intensity $\mathrm{X}$ and are of pre-1940 construction. As a matter of fact, no communities (not even downtown San Francisco) ex- 
TABLE 28.-Calculated replacement costs for wood-frame construction (pre-and post-1940) damaged by postulated repeat of 1906 San Francisco earthquake, using different assumptions of ground conditions

[Losses are for shaking only and exclude damage to building contents]

\begin{tabular}{|c|c|c|c|c|}
\hline \multirow[b]{3}{*}{ County } & \multicolumn{4}{|c|}{ Loss, in billions of 1977 dollars } \\
\hline & \multicolumn{2}{|c|}{ Pre-1940 } & \multicolumn{2}{|c|}{ Post-1940² } \\
\hline & $\begin{array}{l}\text { J (saturated } \\
\text { alluvium) }\end{array}$ & $J-1$ & $\begin{array}{l}\text { I (saturated } \\
\text { alluvium) }\end{array}$ & $J-1$ \\
\hline Alameda ----- & -0.907 & 0.240 & 0.315 & 0.079 \\
\hline Contra Costa - & --.231 & .060 & .079 & 021 \\
\hline Humboldt ----- & --.010 & .003 & .004 & .001 \\
\hline 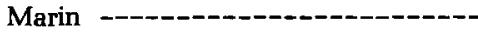 & --.231 & .079 & .105 & .026 \\
\hline 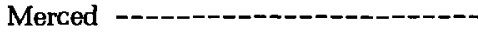 & -.003 & .000 & .001 & .000 \\
\hline Monterey ----c- & $-\quad .099$ & .026 & .033 & .009 \\
\hline Napa $--1-1-1$ & $-\quad .012$ & .003 & .004 & .001 \\
\hline 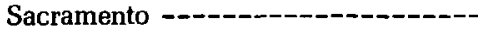 & --.009 & .000 & .000 & .000 \\
\hline San Benito ---- & $-\quad .012$ & .003 & .005 & .001 \\
\hline San Francisco - & -1.034 & .357 & .502 & .124 \\
\hline San Mateo - & --819 & .347 & .449 & .117 \\
\hline Santa Clara -- & -1.236 & .416 & .543 & .139 \\
\hline Santa Cruz - - &.- & .040 & .053 & .013 \\
\hline 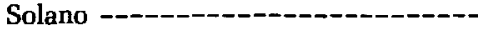 & --.037 & .010 & .013 & .003 \\
\hline Sonoma --1 & $-\quad .079$ & .021 & .028 & .007 \\
\hline Stanislaus - - & $-\quad .005$ & .000 & .001 & .000 \\
\hline 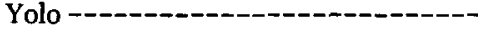 & -.002 & .000 & .000 & .000 \\
\hline \multicolumn{2}{|c|}{ All of State -- } & 1.608 & 2.142 & .543 \\
\hline & \multicolumn{4}{|c|}{ Ratio of percent loss to cumulative loss } \\
\hline & \multicolumn{2}{|c|}{ Pre-19401 } & \multicolumn{2}{|c|}{ Post-1940 } \\
\hline Loss percent & $\begin{array}{l}\text { J (saturated } \\
\text { alluvium) }\end{array}$ & $\mathrm{J}-1$ & $\begin{array}{l}\text { J (saturated } \\
\text { (alluvium) }\end{array}$ & $\mathrm{J}-1$ \\
\hline 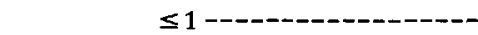 & -0.047 & 0.058 & 0.064 & 0.186 \\
\hline 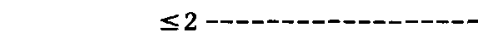 & -.095 & .357 & .204 & .544 \\
\hline$\leq 3-----1--1$ & -.208 & .599 & .498 & .544 \\
\hline$\leq 4-----------$ & -.249 & 1.144 & .779 & .544 \\
\hline 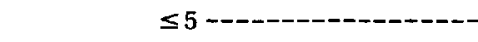 & -.268 & 1.537 & 1.429 & .544 \\
\hline 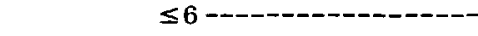 & $-\quad .625$ & 1.608 & 1.696 & .544 \\
\hline 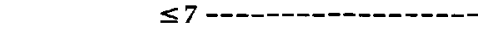 & $-\quad .921$ & 1.608 & 2.142 & .544 \\
\hline 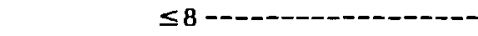 & 1.457 & 1.608 & 2.142 & .544 \\
\hline 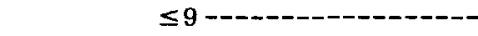 & -2.049 & 1.608 & 2.142 & .544 \\
\hline$\leq 10$ - & -2.302 & 1.608 & 2.142 & .544 \\
\hline$\leq 11-11-0-1$ & -3.975 & 1.608 & 2.142 & .544 \\
\hline$\leq 12-0-12-1-0-1$ & -4.855 & 1.608 & 2.142 & .544 \\
\hline
\end{tabular}

perienced such intensity in 1906 , and most wood-frame structures in the region have been built since 1940. As Freeman (1932) noted long ago, average percent loss in the areas hardest hit by earthquakes in the first part of this century seldom if ever exceeded 5 percent of value. The San Francisco earthquake of 1906 was no exception. In a document published in 1979 (Algermissen and Steinbrugge, 1979), an estimate of loss to all one- to fourfamily dwellings (nearly all of the wood-frame structures) in the greater San Francisco Bay area as a result of a repeat of the 1906 San Francisco earthquake was given as $\$ 1.51$ billion (1970 dollars). This figure is similar to the one calculated by Evernden and others (1981) and in this chapter by using the pre-1940 curve. Therefore, the logic behind assuming the 12-percent loss is unclear.

To demonstrate fully the level of uncertainty of present estimates of damage, consider the calculated values in table 30 . In this table, the value of all wood-frame residences in the six San Francisco Bay region counties is assumed to be $\$ 88$ billion. Five models are used for calculating replacement values:

\section{Earthquake Hazards in the Los Angeles Region}


1. As used by Steinbrugge for the FEMA report (that is, 12-percent damage throughout the six counties).

2. Geology as given by Helley and others (1979) and intensity scaling of the geologic units following R. D. Borcherdt (personal communication, 1983); a few modifications dictated by historical intensity data have increased predicted intensities in all cases $(\mathrm{H} / \mathrm{B})$.

3. Ground conditions as above with one intensity unit protection (RFI) achieved through 1940 building code (H/B-1).

4. Water table assumed to be at a depth of at least $30 \mathrm{ft}$ throughout all regions shown as Quaternary alluvium on the geologic map of California; all such sites assumed to have the properties of recent alluvium $(J-1)$.

5. Ground conditions as above with one intensity unit

(RFI) protection achieved by the 1940 building code $(0-1)-1)$.

Note that the values given in columns 3 and 5 of table 30 are predictable as the most credible in the table on the basis of the analysis given above of the 1971 San Fernando, 1979 Coyote Lake, and 1940 and 1979 Imperial Valley earthquakes, considering that only a small fraction of bay area residences are on saturated alluvium. There is no evidence of a quantitative analysis that rejects the general notion that post-1940 structures in the San Francisco Bay region will suffer damage as predicted in columns 3 and 5 . These results contrast significantly with the $\$ 10.6$ billion obtained by following the procedures used for the FEMA study. The FEMA report (Federal Emergency Management Agency, 1980, p. 21), however, noted the uncertainties in loss estimation: “...Methodologies for estimates of this type are approximate at best. Consequently, the figure shown...may vary upward or downward by as much as a factor of two or three." The results that we present in this chapter are at the lower limit of or beneath the uncertainty range of the FEMA results. One concludes that the range of results from various loss estimation techniques currently in practice is at least as great as the uncertainties given by FEMA.

In this era of rapidly fluctuating building prices, current-dollar damage assessments are poor estimators for planning disaster relief and subsidization. A far more useful parameter is an average percent structural damage, as there are empirical data that allow correlation of the average percent damage with an estimation of the percent of homeless anticipated (Gulliver, in press). Therefore, this parameter of percent damage is included in table 30 in the column labeled "Percent damage."

Table 31 and figure 86 indicate potential California earthquakes that have been modeled for estimates of

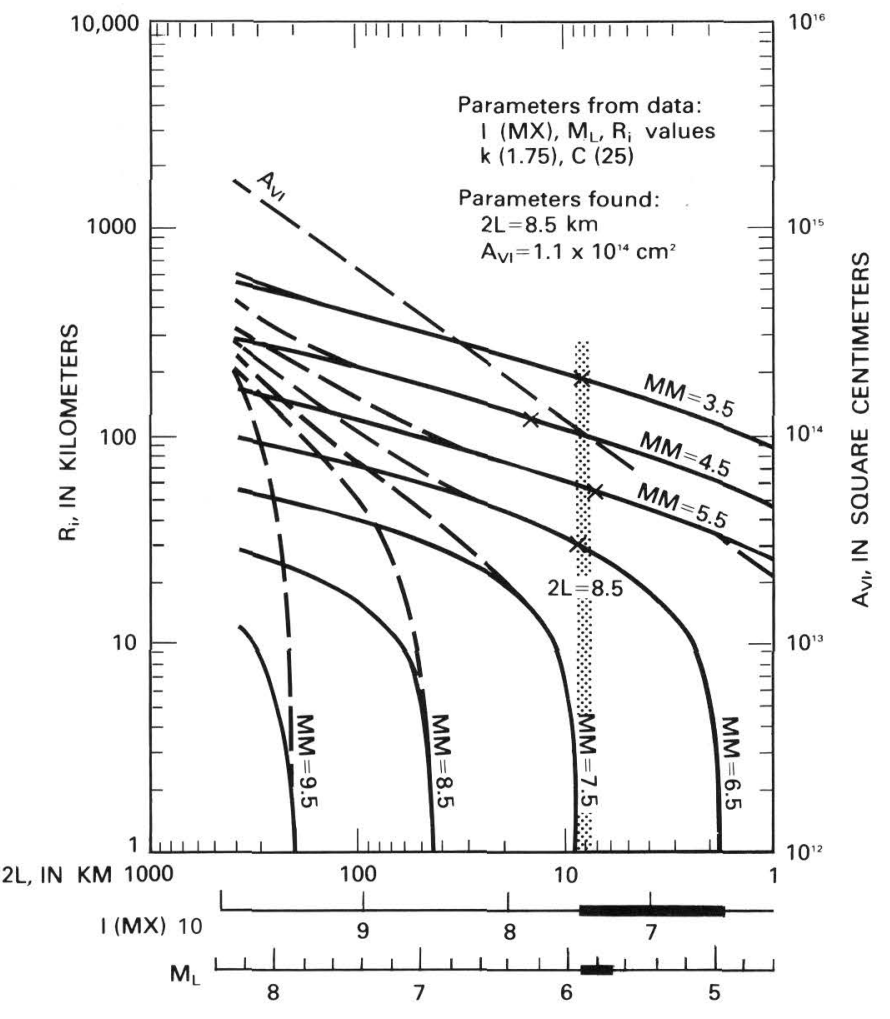

FIGURE 84.-Data for 1979 Coyote Lake earthquake. Parameters from data: $k=1.75$ (attenuation function); $C=25$ (artificial number reflecting assigned depth of postulated earthquake (approximately 15 greater than depth)); $I(M X)$, maximum intensity; $M_{L}$, local magnitude; $R_{i}$, radius of area within intensity contour. Parameters found: $2 L=8.5 \mathrm{~km}$ (length of fault break); $A_{\mathrm{VI}}=1.1 \times 10^{14} \mathrm{~km}^{2}$ (area with intensity VI contour). Values of Modified Mercalli intensity are given in arabic numerals rather than roman numerals, so that gradations in intensity can be indicated.

losses to wood-frame construction. All values in this table are based on the curve for pre-1940 construction. Approximate conversion to wood-frame losses predicted for post-1940 construction is achieved by dividing the loss values in table 31 by a factor of three (see tables 26-28). A vital point to note in table 31 is the comparatively low loss expected from a repeat of the 1857 Fort Tejon earthquake. Virtually any large earthquake in the San Francisco Bay region would cause a comparable level of damage, and maximum-size potential earthquakes on the San Andreas and Hayward faults would cause much greater damage than a repeat of the 1857 earthquake. In addition, several comparatively small earthquakes in southern California would cause as much or more damage than an 1857 repeat. Most particularly, a M 6.7 earthquake modeled for a rupture along the Santa Monica fault would cause more than twice the damage expected from an 1857 repeat. Of course, the reasons for this relation between earthquake size and caused damage are locations of the pertinent faults relative to manmade structures and the high 
TABLE 29.-Predicted and actual losses to wood-frame construction in the southern San Francisco Bay region due to 1979 Coyote Lake earthquake [n/r, not reported]

\begin{tabular}{|c|c|c|c|c|c|c|c|c|c|}
\hline \multirow[b]{3}{*}{ City } & \multicolumn{3}{|c|}{$\begin{array}{l}\text { Modified Mercalli } \\
\text { intensity }\end{array}$} & \multirow{3}{*}{$\begin{array}{l}\text { Apparent } \\
\text { ground } \\
\text { condition }\end{array}$} & \multicolumn{5}{|c|}{ Losses, in millions of dollars } \\
\hline & \multirow[b]{2}{*}{ Observed } & \multicolumn{2}{|c|}{ Predicted $^{1}$} & & \multicolumn{4}{|c|}{ Predicted } & \multirow[b]{2}{*}{ Actual } \\
\hline & & $\mathrm{J}=0^{2}$ & $J=1^{3}$ & & $0^{4}$ & $0.5^{5}$ & $1.0^{5}$ & $1.5^{5}$ & \\
\hline 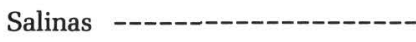 & VI & 5.9 & 5.1 & 0 & 1.46 & 0.65 & 0 & 0 & $\mathrm{n} / \mathrm{r}^{9}$ \\
\hline San Juan Bautista ----------- & VI & 6.5 & 5.7 & -1 & .23 & 0 & 0 & 0 & $\mathrm{n} / \mathrm{r}$ \\
\hline Gilroy ------------------- & VII & 7.2 & 6.3 & 0 & 2.18 & .91 & 0.53 & $0.27^{6}$ & $0.05^{7}$ \\
\hline Milpitas -----_------_------- & VI & 5.9 & 5.3 & 0 & .75 & .33 & 0 & $\mathbf{0}$ & $\mathrm{n} / \mathrm{r}$ \\
\hline Morgan Hill -- & VI & 7.2 & 6.3 & -1 & .34 & .17 & 0 & 0 & $\mathrm{n} / \mathrm{r}$ \\
\hline San Martin --------------- & VI & 7.3 & 6.4 & -1 & .08 & .04 & .02 & 0 & $\mathrm{n} / \mathrm{r}$ \\
\hline 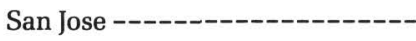 & $\mathrm{V}$ & 6.2 & 5.4 & -1 & 0 & 0 & 0 & 0 & $\mathrm{n} / \mathrm{r}$ \\
\hline Sunnyvale ------------- & VI & 5.8 & 5.1 & 0 & 2.02 & 0 & 0 & 0 & $\mathrm{n} / \mathrm{r}$ \\
\hline Santa Cruz ------------- & VI & 5.9 & 5.3 & 0 & .96 & .43 & 0 & 0 & $\mathrm{n} / \mathrm{r}$ \\
\hline Hollister ----------------- & VII & 6.5 & 5.6 & 0 & .63 & .32 & .19 & 0 & $.02^{8}$ \\
\hline 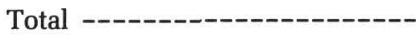 & & & & 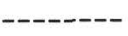 & 8.65 & 2.85 & .74 & .27 & .07 \\
\hline
\end{tabular}

\footnotetext{
${ }^{1}$ Arabic numerals are used here instead of the standard roman numerals, so that gradations in Modified Mercalli intensities can be shown.

${ }^{2} \mathrm{~J}=0$ is predicted intensity under assumption of water table at surface in alluvial areas.

${ }^{3}=1$ is predicted intensity under assumption of water table at a depth of $30 \mathrm{ft}$ in alluvial areas.

${ }^{4}$ Predicted loss for predicted intensity under $\mathrm{J}=0$ or $\mathrm{J}=1$ that most closely agrees with the observed intensity.

${ }^{5}$ Predicted loss for intensities $0.5,1.0$, or 1.5 less than used under the column headed 0 . Since an observed intensity VII encompasses predicted intensities of 6.5 to 7.5 , modeling such as that used here can estimate only approximately the appropriate correction for post-1940 construction.

${ }^{6}$ If observed intensity were 6.8 rather than 7.2 (water table down $10 \mathrm{ft}$ within model), dollar loss $(1.5)=0$.

${ }^{7}$ From Kustu (1981).

${ }^{8}$ (Ratio of populations in Hollister and Gilroy) $\times$ (ratio of damage ratios in these two cities) $\times$ (damage in Gilroy)
}

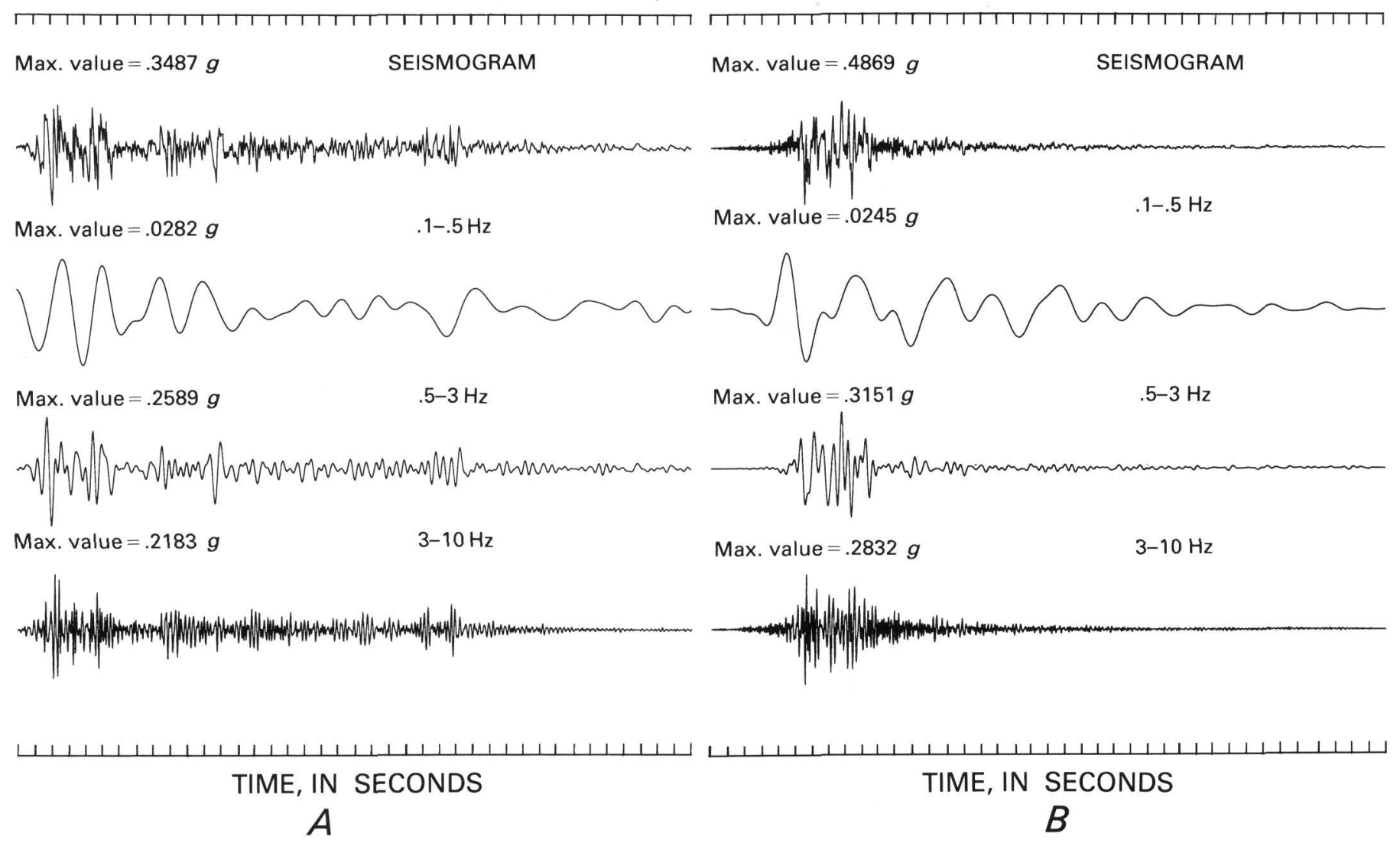

FIGURE 85.-Selected acceleration and velocity records for the Imperial Valley earthquakes of May 18, 1940, and October 15, 1979. All records are from the same site at El Centro, Calif. $\left(32.80^{\circ} \mathrm{N}\right.$., $115.54^{\circ} \mathrm{W}$.). Figures present full bandwidth seismograms and seismograms filtered for bands 1, 2, and 3. Maximum values are given for each record. A, Ground acceleration for earthquake of May 18,1940 (180 component). B, 


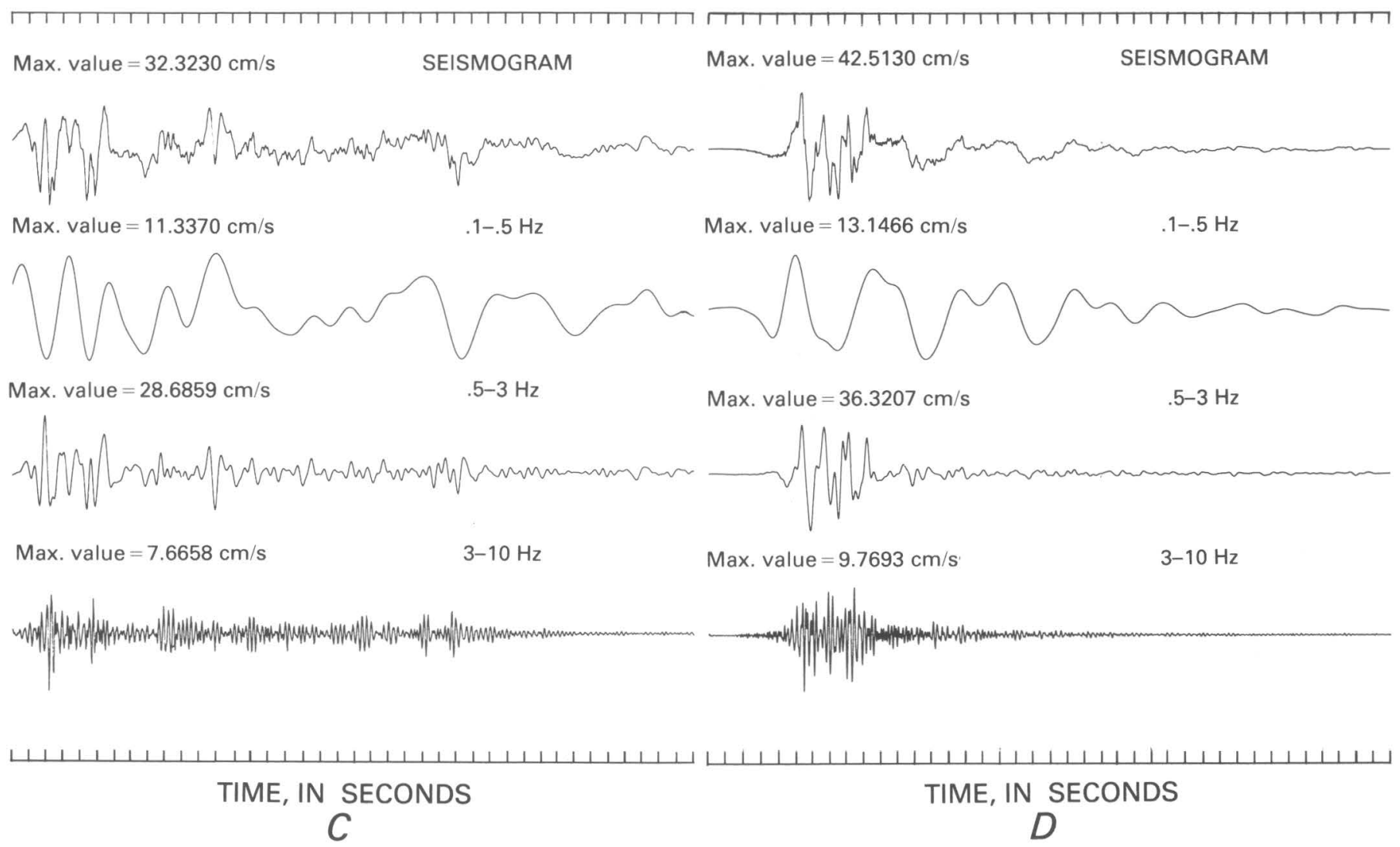

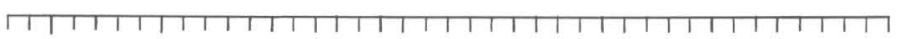

Max. value $=36.4730 \mathrm{~cm} / \mathrm{s}$

SEISMOGRAM

Max. value $=67.7660 \mathrm{~cm} / \mathrm{s}$

SEISMOGRAM

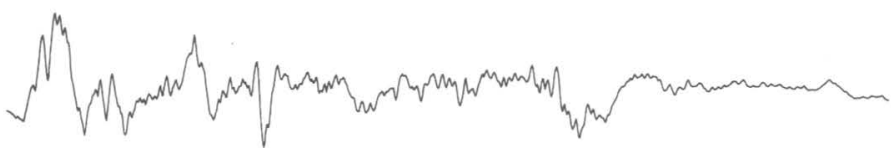

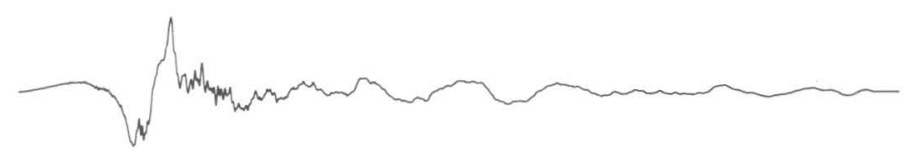

Max. value $=27.9296 \mathrm{~cm} / \mathrm{s}$

$.1-.5 \mathrm{~Hz}$

Max. value $=40.7498 \mathrm{~cm} / \mathrm{s}$

$.1-.5 \mathrm{~Hz}$

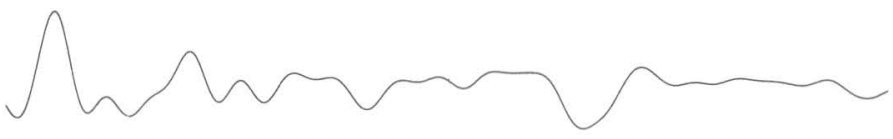

Max. value $=20.4745 \mathrm{~cm} / \mathrm{s}$

$.5-3 \mathrm{~Hz}$

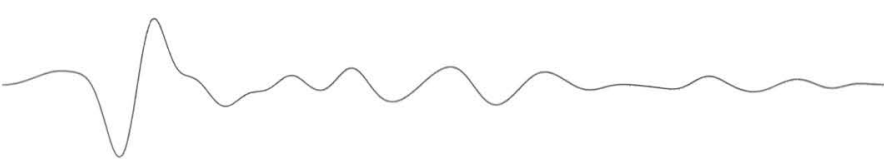

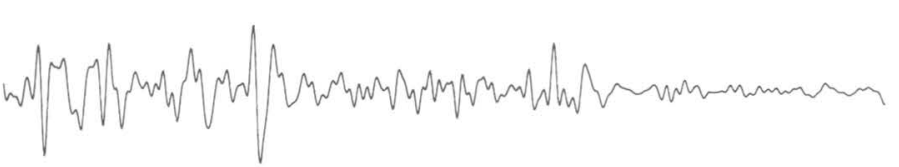

Max. value $=27.4606 \mathrm{~cm} / \mathrm{s}$

$.5-3 \mathrm{~Hz}$

Max. value $=3.5238 \mathrm{~cm} / \mathrm{s}$

3-10 Hz

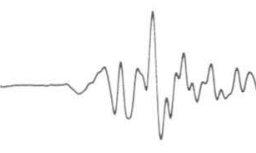

Max. value $=10.0339 \mathrm{~cm} / \mathrm{s}$

$3-10 \mathrm{~Hz}$
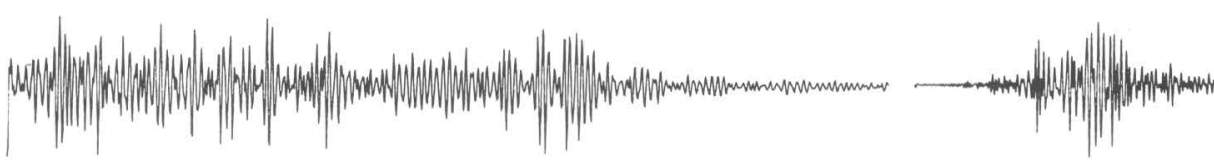

TIME, IN SECONDS

E
TIME, IN SECONDS

$F$

Ground acceleration for earthquake of October $15,1979\left(180^{\circ}\right.$ component). C, Ground velocity for earthquake of May 18,1940 (180 ${ }^{\circ}$ component). D, Ground velocity for earthquake of October 15,1979 ( $360^{\circ}$ component). E, Ground velocity for earthquake of May 18,1940 (270 ${ }^{\circ}$ component). F, Ground velocity for earthquake of October 15,1979 (270 ${ }^{\circ}$ component). 
TABLE 30.-Calculated replacement costs (in billions of 1977 dollars) for wood-frame construction damaged by shaking from postulated repeat of 1906 San Francisco earthquake

[Based on various assumptions about percent loss and geologic ground conditions. Replacement values are totals; percent damages are averages]

\begin{tabular}{|c|c|c|c|c|c|c|c|c|c|c|}
\hline \multirow[b]{2}{*}{ County } & \multicolumn{2}{|c|}{ FEMA $^{1}$} & \multicolumn{2}{|c|}{$\mathrm{H} / \mathrm{B}^{2}$} & \multicolumn{2}{|c|}{$\mathrm{H} / \mathrm{B}-\mathrm{1}^{3}$} & \multicolumn{2}{|c|}{$\mathrm{J}-1^{4}$} & \multicolumn{2}{|c|}{$(J-1)-1^{5}$} \\
\hline & $\begin{array}{l}\text { acement } \\
\text { alue }\end{array}$ & $\begin{array}{l}\text { Percent } \\
\text { damage }\end{array}$ & $\begin{array}{l}\text { Replacement } \\
\text { value }\end{array}$ & $\begin{array}{l}\text { Percent } \\
\text { damage }\end{array}$ & $\begin{array}{l}\text { Replacement } \\
\text { value }\end{array}$ & $\begin{array}{l}\text { Percent } \\
\text { damage }\end{array}$ & $\begin{array}{c}\text { Replacement } \\
\text { value }\end{array}$ & $\begin{array}{l}\text { Percent } \\
\text { damage }\end{array}$ & $\begin{array}{l}\text { Replacement } \\
\text { value }\end{array}$ & $\begin{array}{l}\text { Percent } \\
\text { damage }\end{array}$ \\
\hline Alameda - - & 2.8 & 12 & 0.223 & 0.9 & 0.055 & 0.2 & 0.363 & 1.5 & 0.099 & 0.4 \\
\hline Contra Costa - & 1.3 & 12 & .051 & .5 & .011 & .1 & .092 & .8 & .025 & .2 \\
\hline Marin - - - & .5 & 12 & .073 & 1.9 & .023 & .6 & .119 & 3.1 & .031 & .8 \\
\hline San Francisco -- - & 2.0 & 12 & .189 & 1.2 & .054 & .3 & .546 & 3.3 & .145 & .9 \\
\hline San Mateo - & 1.4 & 12 & .400 & 3.4 & .137 & 1.2 & .530 & 4.5 & .130 & 1.1 \\
\hline Santa Clara - & 2.6 & 12 & .508 & 2.4 & .133 & .6 & .636 & 3.0 & .159 & .7 \\
\hline Total/average --- - & 10.6 & 12 & 1.44 & 1.6 & .413 & .5 & 2.29 & 2.6 & .589 & .7 \\
\hline
\end{tabular}

${ }^{1}$ Values used in calculating total building losses for Federal Emergency Management Agency (1980), according to K. V. Steinbrugge (oral and written communications, 1980).

${ }^{2}$ Various ground conditions as given by Helley and others (1979) and relation of ground condition and intensity from R. D. Borcherdt (personal communication, 1982). Pre-1940 construction.

${ }^{3}$ Same as H/B but for post-1940 construction (assumed to give one Rossi-Forel intensity unit protection).

${ }^{4}$ Treated all Quaternary deposits on geologic map of California as being of same character and having water table at $30 \mathrm{ft}$.

${ }^{5}$ Same as J- 1 but for post-1940 construction (assumed to give one Rossi-Forel intensity unit protection).

TABLE 31.-Predicted replacement value of wood-frame constructon damaged by shaking from potential earthquakes in western California

[Based on earthquake intensity loss curve for pre-1940 construction. Typical ground conditions assumed to be alluvium with water table $30 \mathrm{ft}$ or more below ground surface. Excludes damage to building contents. Modified from Evernden and others (1981, table 25)]

\begin{tabular}{|c|c|c|c|c|c|c|}
\hline \multirow[b]{2}{*}{ Fault } & \multirow[b]{2}{*}{$\begin{array}{l}\text { Symbol } \\
\text { (fig. 86) }\end{array}$} & \multicolumn{2}{|c|}{ Ends of break } & \multirow[b]{2}{*}{$\begin{array}{l}\text { Length, } \\
\text { in } \mathrm{km}\end{array}$} & \multirow[b]{2}{*}{ Magnitude } & \multirow{2}{*}{$\begin{array}{l}\text { Predicted replacement } \\
\text { value for } \\
\text { wood-frame } \\
\text { construction, } \\
\text { in billions of } \\
1977 \text { dollars }\end{array}$} \\
\hline & & $\begin{array}{c}\text { Latitude, } \\
{ }^{\circ} \mathrm{N} .\end{array}$ & $\begin{array}{l}\text { Longitude, } \\
{ }^{\circ} \mathrm{W} .\end{array}$ & & & \\
\hline San Andreas (1906 repeat) -- & 1 & $\begin{array}{l}3651.00 \\
4015.90\end{array}$ & $\begin{array}{l}12133.10 \\
12427.20\end{array}$ & 400 & 8.3 & 1.72 \\
\hline Hayward - - & $2 \mathrm{~A}$ & $\begin{array}{ll}38 & 00.61 \\
37 & 11.76\end{array}$ & $\begin{array}{l}122 \quad 22.92 \\
121 \quad 44.62\end{array}$ & 100 & 7.4 & 1.14 \\
\hline Hayward --_-_-_-_- & $2 B$ & $\begin{array}{l}3748.89 \\
3724.46\end{array}$ & $\begin{array}{l}12213.73 \\
12154.58\end{array}$ & 50 & 7.0 & .54 \\
\hline Hayward --_-_-_- & $2 \mathrm{C}$ & $\begin{array}{l}3727.53 \\
3711.76\end{array}$ & $\begin{array}{l}12152.28 \\
12144.62\end{array}$ & 20 & 6.4 & .11 \\
\hline Calaveras (1911 repeat) --- & 3 & $\begin{array}{l}3709.10 \\
3714.20\end{array}$ & $\begin{array}{l}12134.90 \\
12139.90\end{array}$ & 11 & 6.1 & .02 \\
\hline San Gregorio -- & 4 & $\begin{array}{l}3705.68 \\
3650.47\end{array}$ & $\begin{array}{ll}122 & 18.31 \\
122 & 10.47\end{array}$ & 30 & 6.7 & .04 \\
\hline Zayante --n-- & 5 & $\begin{array}{l}3702.43 \\
3656.55\end{array}$ & $\begin{array}{l}12153.64 \\
12147.03\end{array}$ & 15 & 6.3 & .02 \\
\hline Hosgri --_- & 6 & $\begin{array}{l}3729.90 \\
3412.20\end{array}$ & $\begin{array}{l}12954.50 \\
12105.90\end{array}$ & 80 & 7.3 & .01 \\
\hline Hosgri (1927 repeat) ----------- & 7 & $\begin{array}{l}3436.00 \\
3511.90\end{array}$ & $\begin{array}{l}12038.80 \\
12054.50\end{array}$ & 70 & 7.2 & .02 \\
\hline Nacimiento (1952) -- & 8 & $\begin{array}{l}3544.20 \\
3552.10\end{array}$ & $\begin{array}{l}12107.70 \\
12116.90\end{array}$ & 20 & 6.4 & $\leq .001$ \\
\hline Santa Barbara -- & $9 A$ & $\begin{array}{l}3428.20 \\
3425.70\end{array}$ & $\begin{array}{l}12004.80 \\
11939.10\end{array}$ & 40 & 6.9 & .023 \\
\hline $\begin{array}{l}\text { Near Santa Barbara: } \\
1925 \text { repeat }\end{array}$ & 9B & $\begin{array}{l}3427.70 \\
3425.90\end{array}$ & $\begin{array}{l}12000.10 \\
11941.40\end{array}$ & 29 & 6.7 & .015 \\
\hline 1978 repeat ---1-- & 10 & $\begin{array}{l}3422.20 \\
3423.34\end{array}$ & $\begin{array}{l}11943.00 \\
11945.44\end{array}$ & 4 & 5.4 & .003 \\
\hline San Andreas (1857 repeat) --_-- & 11 & $\begin{array}{l}3418.30 \\
3545.10\end{array}$ & 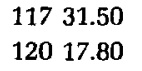 & 300 & 8.1 & .51 \\
\hline Offshore San Clemente -- & 12 & $\begin{array}{l}33 \quad 34.05 \\
3318.65\end{array}$ & $\begin{array}{l}11756.10 \\
11736.92\end{array}$ & 40 & 6.9 & .16 \\
\hline
\end{tabular}

198 Earthquake Hazards in the Los Angeles Region 
TABLE 31.-Predicted replacement value of wood-frame constructon damaged by shaking from potential earthquakes in western California-Continued

\begin{tabular}{|c|c|c|c|c|c|c|c|}
\hline \multirow[b]{2}{*}{ Fault } & \multirow[b]{2}{*}{$\begin{array}{l}\text { Symbol } \\
\text { (fig. 86) }\end{array}$} & \multicolumn{2}{|c|}{ Ends of break } & \multirow[b]{2}{*}{$\begin{array}{l}\text { Length, } \\
\text { in } \mathrm{km}\end{array}$} & \multirow{2}{*}{\multicolumn{2}{|c|}{ Magnitude }} & \multirow{2}{*}{$\begin{array}{l}\text { Predicted replacement } \\
\text { value for } \\
\text { wood-frame } \\
\text { construction, } \\
\text { in billions of } \\
1977 \text { dollars }\end{array}$} \\
\hline & & $\begin{array}{l}\text { Latitude, } \\
{ }^{\circ} \mathrm{N} \text {. }\end{array}$ & $\begin{array}{l}\text { Longitude, } \\
{ }^{\circ} \mathrm{W} .\end{array}$ & & & & \\
\hline \multirow[t]{2}{*}{ Newport-Inglewood --------- } & $13 \mathrm{~A}$ & 3354.50 & 11817.40 & 45 & & 6.9 & .90 \\
\hline & & 3336.30 & 11758.80 & & & & \\
\hline \multirow[t]{2}{*}{ Newport-Inglewood --------- } & 13B & 3354.50 & 11817.40 & 22 & & 6.5 & .53 \\
\hline & & 3345.50 & 11808.10 & & & & \\
\hline \multirow{2}{*}{$\begin{array}{l}\text { Newport-Inglewood -- } \\
\text { (1933 repeat). }\end{array}$} & $13 \mathrm{C}$ & 3345.40 & 11808.10 & 22 & & 6.5 & .33 \\
\hline & & 3336.30 & 11758.80 & & & & \\
\hline \multirow[t]{2}{*}{ Newport-Inglewood ---------- } & $13 \mathrm{D}$ & 3402.69 & 11825.77 & 42 & & 6.9 & 1.05 \\
\hline & & 3345.50 & 11808.10 & & & & \\
\hline \multirow{2}{*}{ 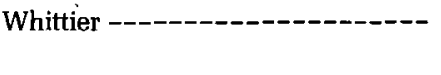 } & 14 & 3358.99 & 11800,00 & 20 & & 6.4 & .35 \\
\hline & & 3355.14 & 11747.80 & & & & \\
\hline \multirow{2}{*}{ Raymond --- } & 15 & 3412.18 & 11801.95 & 10 & $(C=20)^{1}$ & 6.0 & .26 \\
\hline & & 3410.35 & 11807.80 & & $(C=25)^{1}$ & & \\
\hline \multicolumn{8}{|l|}{ Elsinore: } \\
\hline \multirow[t]{2}{*}{ 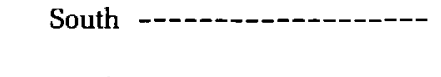 } & $16 \mathrm{~A}$ & 3325.80 & 11700.00 & 70 & & 7.2 & .04 \\
\hline & & 3300.00 & 11627.00 & & & & \\
\hline \multirow[t]{2}{*}{ North } & $16 \mathrm{~B}$ & 3340.54 & 11722.93 & 30 & & 6.7 & .03 \\
\hline & & 3329.19 & 11709.27 & & & & \\
\hline \multirow[t]{2}{*}{ San Fernando (1971 repeat) ------ } & 17 & 3422.78 & 11830.31 & 19 & $(C=20)^{1}$ & 6.4 & .26 \\
\hline & & 3418.62 & 11816.55 & & & & \\
\hline \multirow[t]{2}{*}{ San Jacinto ------------ } & $18 \mathrm{~A}$ & 3403.04 & 11711.80 & 30 & & 6.7 & .06 \\
\hline & & 3351.89 & 11702.44 & & & & \\
\hline \multirow[t]{2}{*}{ San Jacinto --- } & $18 \mathrm{~B}$ & 3408.96 & 11716.76 & 38 & & 6.8 & 09 \\
\hline & & 3351.89 & 11702.44 & & & & \\
\hline \multirow[t]{2}{*}{ Malibu Coast ------------ } & 19 & 3406.10 & 11856.44 & 31 & $(C=20)^{1}$ & 6.7 & .38 \\
\hline & & 3405.10 & 11833.17 & & & & \\
\hline \multirow[t]{2}{*}{ Santa Monica -------------- } & 20 & 3406.10 & 11833.17 & 32 & $(C=20)^{1}$ & 6.7 & 1.14 \\
\hline & $21 A$ & 3410.01 & 11809.27 & & & 70 & \\
\hline Rose Canyon - - & $21 \mathrm{~A}$ & 3253.11 & 11718.05 & 51 & & 1.0 & .28 \\
\hline \multirow{2}{*}{ Rose Canyon --- } & 21B & 3230.41 & 11658.79 & 32 & & 6.7 & $\begin{array}{l}.07^{2} \\
.23\end{array}$ \\
\hline & & 3234.67 & 11702.40 & & & & $.06^{2}$ \\
\hline
\end{tabular}

${ }^{1}$ For thrust earthquakes, a $C$ value of 20 is used (rather than 25 , as used for strike-slip earthquakes).

${ }^{2}$ Assumes that typical ground condition in San Diego results in shaking two intensity units less than that for saturated alluvium.

rates of attenuation of intensity-relevant energy in western and southern California.

Although the San Jacinto fault is the most seismically active fault in southern California today, its location and the apparently limited maximum size of earthquakes that occur on it render it a limited regional threat, although: it certainly is of great significance to San Bernardino and environs. Because the earthquakes hypothesized for the San Jacinto fault are assumed to be located on the northern 30 or $39 \mathrm{~km}$ of that fault, even a doubling of the rupture length by extension southward would not significantly increase predicted structural damage. The losses calculated for San Diego as the result of hypothesized earthquakes on the Rose Canyon fault are based on intensities assuming ground-motion characteristics equivalent to one and two intensity units less than predicted for saturated alluvium. Since most of the city is built on bedrock or raised marine terraces, figures based on saturated alluvium seem inappropriate as estimators of predicted damage, although they certainly are appropriate at particular sites.

Although other fault breaks could have been modeled, the examples given illustrate the numerous possibilities that exist for extensive damage in southern California and demonstrate that the San Andreas fault is not the primary threat to the Los Angeles region. A fact of great importance is that the calculations given in table 31 indicate that damage to wood-frame structures amounting to more than five times that incurred at the time of the 1971 San Fernando earthquake is not to be expected.

Given the limited data bases presently available, the only route to estimating total loss for all structures is by 


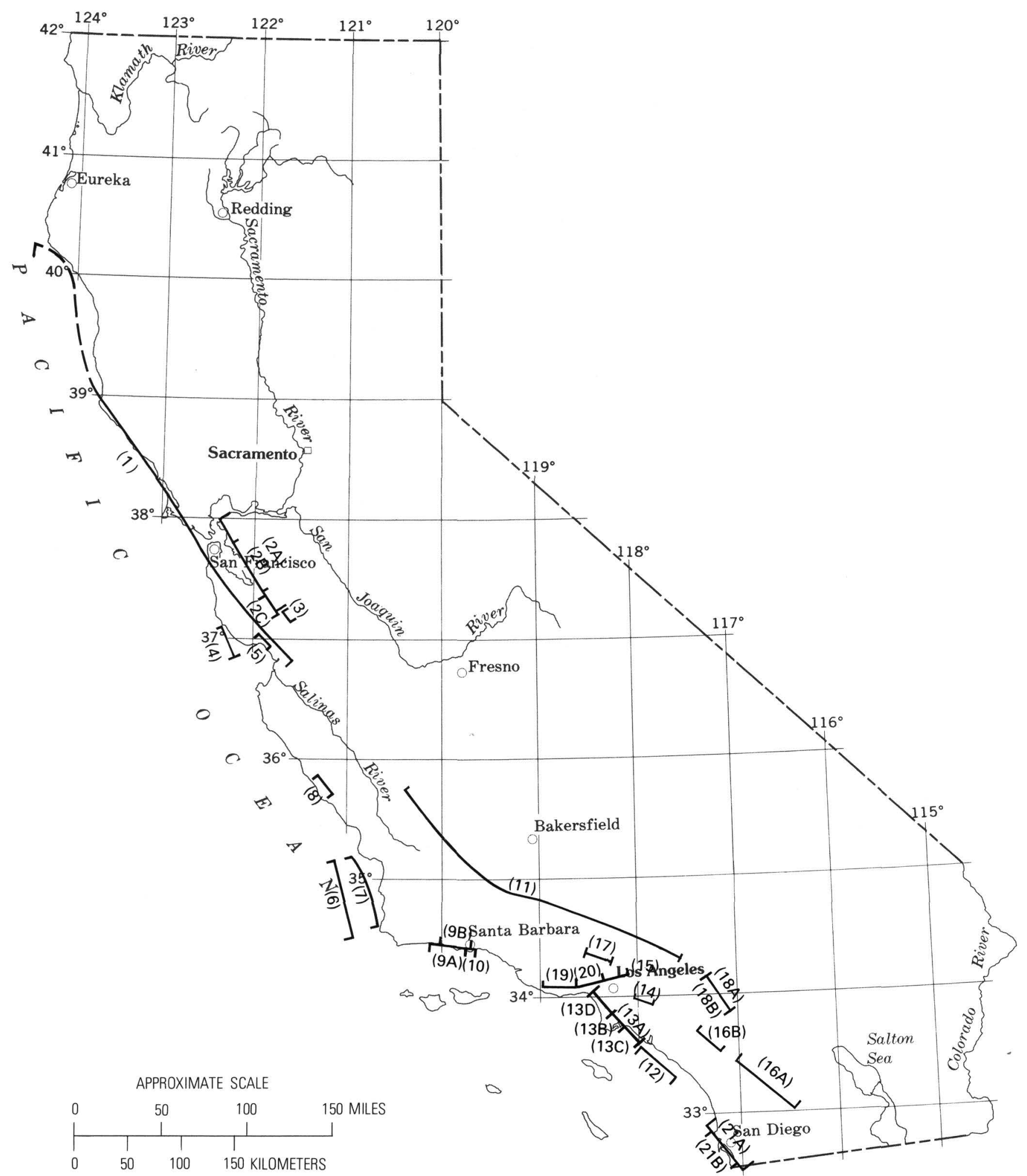

FIGURE 86.-Postulated earthquakes in western California that were modeled for estimating losses to wood-frame construction listed in table 31. From Evernden and others (1981, fig. 25). 
empiricism based on very limited data sets. Blume and others (1980) multiplied wood-frame losses by a factor of 2.0 to get total losses when using the curve appropriate to pre-1940 wood-frame structures for estimating woodframe losses. Steinbrugge apparently used a factor of 2.39 in the FEMA study discussed above. If one estimates wood-frame losses by the post-1940 curve, one should use a multiplication factor of four or five to empirically estimate losses to all structures.

\section{SUMMARY}

Of the several commonly used measurements of ground shaking associated with earthquakes, only seismic intensity has the properties of correlating directly with expected damage to structures of a specific bandpass (aproximately $3-0.5 \mathrm{~Hz}$ ) and of being predictable with high accuracy. Given these unique properties, it is the logical parameter to incorporate into computer-based schemes for estimating local and regional seismic risk and damage. Maps showing predictions of intensity for any potential earthquake in the Los Angeles region can be easily prepared. These maps can be used to estimate losses to wood-frame construction caused by shaking resulting from such potential earthquakes and illustrate the relative risks associated with different faults in California.

\section{APPENDIX 2.-MATHEMATICAL DETAILS OF MODEL FOR PREDICTING INTENSITIES}

A long curved fault (only possible in regions where $k=13 / 4$ ] is assumed to be a series of uniform point sources as closely spaced as desired. The formula used is

$$
a=A\left(\frac{10^{11.8+1.5 M}}{n}\right) 1 / \gamma\left(\sum_{i=1}^{n}\left(R_{i}+C\right)^{-k \gamma}\right)^{1 / \gamma}
$$

(effectively equation 7 of Evernden and others (1973), where $\gamma=4$ and the coefficient of $M$ is 0.864 rather than 0.80 ) and

$$
I=3(0.5+\log a)
$$

(Richter, 1958), where $a=$ "acceleration."
$I=$ Rossi-Forel intensity

$M=M_{S}=M_{L}$ (local magnitude) up to $M_{S}=6.5$.

$\mathrm{n}=$ number of equally spaced subevents used in the model to achieve nearly uniform release of energy along the fault break.

$e=10^{11.8+1.5 \mathrm{M}}=$ energy (ergs) released by an earthquake of magnitude $M$ (Richter, 1958, p.366).

$R_{i}=$ distance, in kilometers, from point $i$ of $n$ points on a fault to the point of observation.

$C=$ pseudodepth term chosen to give proper nearrange dieoff of intensities. Intensity values beyond 50 to $100 \mathrm{~km}$ are nearly insensitive to variation in expected values of $C$ for earthquakes in the United States.

$k=$ term controlling rate of dieoff of $a\left(a \propto \Delta^{-k}\right)$ and thus effectively of $I$.

$\gamma=\log$ (energy arriving at a point) $/(a)$ or $a=$ (energy arriving at a point) ${ }^{1 / \gamma}$.

$A=0.779=$ arbitrary leading coefficient selected to give correct intensity values at a uniform ground condition for a particular earthquake. Once set for the normalizing earthquake, it cannot be changed. The value used was set to give identical shortrange $I$ values as given by Evernden and others (1973), where $\gamma=4$.

The points of the "fault" are distributed over a length (2L) appropriate to the $M$ value (or an $M$ value is used appropriate to the length of break 2L) (see discussion below).

When shorter or straight faults are considered, equation 3 can be slightly altered to simplify analysis and manipulation and to escape the multipoint aspect of energy release. Details of this formulation of equation 3 have been given by Evernden and others (1981).

A brief discussion of the role of the several defined factors in controlling predicted intensities follows.

$L$ and $M$.-When this discussion is limited to conditions appropriate to southern California, empirical data of this area indicate a general correlation between $L$ and $M$. Associating a $2 L$ of $10 \mathrm{~km}$ with an $M$ of 6.0 and a $2 L$ of $400 \mathrm{~km}$ with an $M$ of 8.25 leads to $M=(3.2667+\log$ (length of break)/0.711. Table 32 gives a tabular presentation of this formula.

Leading coefficient.-The coefficient used is arbitrary and was chosen as appropriate for predicting I values on saturated alluvium, the control data used being intensity values for the San Francisco earthquake of 1906.

Mode of calculating RMS acceleration.-For long fault breaks such as the 1906 San Francisco and the 1857 Fort Tejon, it is appropriate to consider energy from only a small portion of the fault, because energy 
TABLE 32.-Magnitude (M) relative to length of break $(2 L)$ and energy density $\left(\log e_{D}\right)$

[Applicable only to regions of $k=1.75$.]

\begin{tabular}{ccc}
\hline$M$ & $2 L$ & $\log e_{D}$ \\
\hline $4----$ & 0.4 & 18.2 \\
$5----$ & 2 & 19.0 \\
$5.5----$ & 4.5 & 19.4 \\
$6----$ & 10 & 19.8 \\
$6.5----$ & 23 & 20.2 \\
$7-----$ & 50 & 20.6 \\
$71 / 2---$ & 116 & 21.0 \\
$8-----$ & 265 & 21.4 \\
$8.25---$ & 400 & 21.6 \\
$8.5----$ & 600 & 21.8 \\
$9----$ & 1,350 & 22.2 \\
\hline
\end{tabular}

from distant parts arrives so late that it is of no importance for influencing intensity. For such earthquakes, the program calculates $a$ as the square root of the sum of the squares of the a values arriving at the station from those points on the fault having traveltimes such that they arrive in a time window of $20 \mathrm{~s}$ centered around the arrival from the closest point on the fault. Use of this time-window procedure led to changing $k$ from 2.0, as Evernden and others (1973) had used, to 1.75 , as they used in all subsequent papers. Evidence for the validity of this change is that it then became possible to accurately predict intensities for all magnitudes from about 5.5 to 8.25 , a very powerful check on the accuracy of the scaling parameters. Further details have been given by Evernden and others (1981). 


\title{
PREDICTIVE MAPPING OF EARTHQUAKE GROUND MOTION
}

\author{
By W. B. Joyner and T. E. Fumal
}

\section{INTRODUCTION}

This chapter describes methods for the predictive mapping of quantities used in the engineering design of earthquake-resistant structures. The most useful such quantities are horizontal response spectral values, but we also discuss peak horizontal acceleration and velocity. The response spectrum is the basis, either directly or indirectly, of most earthquake-resistant design. It is used directly as input in the dynamic analysis of structures and indirectly in building codes as the basis for the relation between the lateral design force coefficient and the period (Applied Technology Council, 1978). The response spectrum is useful because it represents the response to a given ground motion of a simple set of mathematical models of structures. It can be defined as the response of a set of single-degree-of-freedom oscillators (for example, mass-spring systems) having different natural periods and damping. An example is given in figure 87, which shows the response spectrum computed for one of the horizontal components of ground motion recorded in the 1979 Imperial Valley earthquake at station number 7 of the El Centro array. Among the different kinds of response spectra, we make use in this chapter of pseudovelocity response spectra and pseudoacceleration response spectra. The pseudovelocity response is defined as the product of the relative displacement response and the angular frequency of the oscillator; the pseudoacceleration response is defined as the product of the relative displacement response and the square of the angular frequency of the oscillator.

Although response spectral values are the most useful parameters for earthquake-resistant design, we include discussions of peak horizontal acceleration and velocity because they have commonly been used to characterize earthquake ground motion. In fact, the conventional method for estimating response spectral values uses peak horizontal acceleration to scale some normalized spectral shape such as the Nuclear Regulatory Commis- sion's Regulatory Guide 1.60 spectrum (U.S. Atomic Energy Commission, 1973). Such a procedure would be generally valid only if the shape of the response spectrum were independent of earthquake magnitude, source distance, and recording site conditions. In fact, a number of independent studies (McGuire, 1974; Trifunac and Anderson, 1978; Joyner and Boore, 1982a, b) have shown that the shape of the response spectrum is strongly dependent on magnitude and site conditions. This problem is largely avoided by Newmark and Hall's (1969) scaling method, which scales the short-period portion of the spectrum by peak acceleration, the intermediate portion (about 0.3 to $2.0 \mathrm{~s}$ ) by peak velocity, and the long-period portion by peak displacement. The ideal approach, however, is to predict response values directly, as McGuire (1974), Trifunac and Anderson (1978), and, incorporating data from the 1979 Coyote Lake and Imperial Valley earthquakes, Joyner and Boore (1982a, b) have done.

The two basic elements in any method of making predictive ground-motion maps are (1) predictive equations giving the dependence of the ground-motion parameters on variables such as magnitude, distance and nearsurface geologic conditions and (2) a means of specifying the location and magnitude of future earthquakes. The predictive equations used here are derived from regression analysis of strong-motion accelerograph data from shallow earthquakes in western North America. Previously published equations are modified to incorporate an improved method of predicting site effects using local shear-wave velocity. Shear-wave velocity is estimated by the methods of Fumal and Tinsley (this volume). As for the magnitude and location of the earthquakes, predicted ground motion can be mapped for a postulated earthquake of specified magnitude and location, or the ground-motion value that will be exceeded at a specified annual probability can be mapped, taking into account potential earthquakes on a number of faults. In the latter case, fault slip rates are used to characterize the earthquake potential of different faults. 


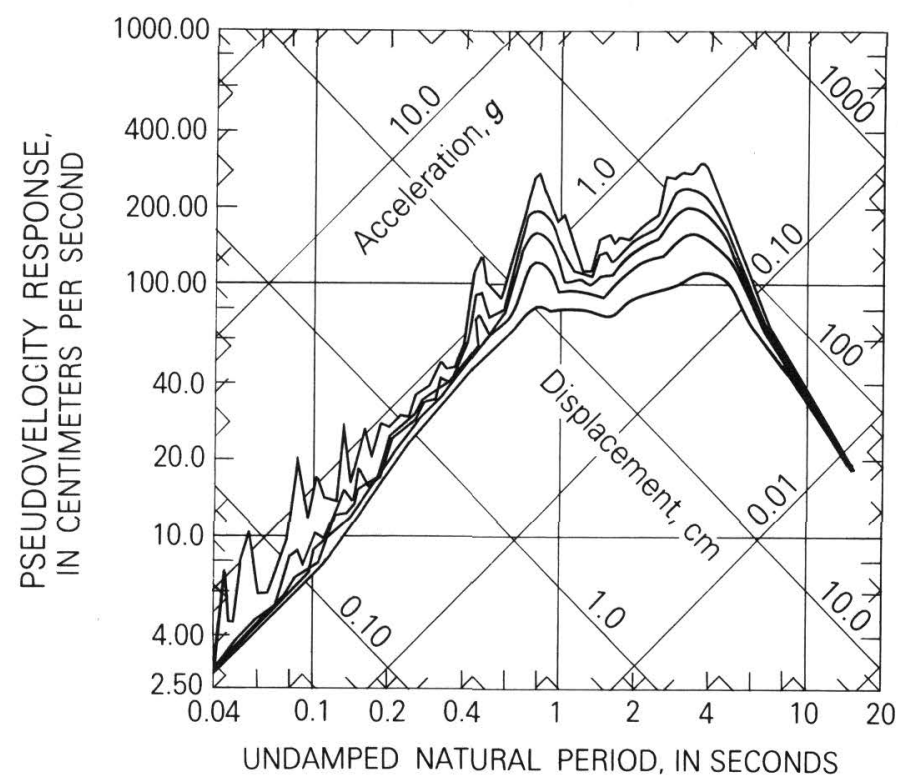

FIGURE 87.-Pseudovelocity response spectra for the 1979 Imperial Valley earthquake. El Centro array, station $7,230^{\circ}$ component (Brady and others, 1980). Spectra are shown for 0, 2, 5, 10, and 20 percent of critical damping.

\section{PREDICTIVE EQUATIONS}

To calculate the effect of earthquake magnitude and distance on ground-motion values, we use the predictive equations developed by Joyner and Boore $(1981,1982 a$, b) from analysis of strong-motion recordings:

$$
\begin{aligned}
\log y=c_{0}+c_{1}(\mathbf{M}-6)+c_{2}(\mathbf{M}-6)^{2}+c_{3} \log r+c_{4} r+S \\
5.0 \leq \mathbf{M} \leq 7.7 \\
r=\left(d^{2}+h^{2}\right)^{1 / 2} \\
S=0 \text { (rock sites) } \\
S=c_{5} \text { (soil sites) }
\end{aligned}
$$

where $\mathrm{y}$ is the ground-motion parameter to be predicted, $\boldsymbol{M}$ is moment magnitude (Hanks and Kanamori, 1979), and $d$ is the shortest distance from the site where ground motion is being predicted to the vertical projection of the earthquake fault rupture on the surface of the Earth. The parameters $c_{0}$ through $c_{5}$ and $h$ have been determined from the strong-motion data by a two-stage regression procedure described by Joyner and Boore (1981, 1982a, b). The predictive equations for peak horizontal acceleration are illustrated in figure 88, those for peak horizontal velocity in figure 89 , and those for horizontal response spectra in figures 90, 91, and 92.

The parameter $h$ is a fictitious depth introduced to allow for the fact that the source of the peak motion (or the maximum response in the case of response spectral values) may not be the closest point on the rupture surface. The value obtained for $h$ incorporates all the fac- tors that tend to limit (or enhance) motion near the source. Using a value of $h$ that is independent of magnitude is equivalent to assuming that the curve showing the attenuation of the predicted parameter with distance has the same shape independent of magnitude; in other words, the change in the predicted parameter for a given change in magnitude is the same at every distance. Boore and Joyner's (1982; Joyner and Boore, 1981, 1982a, b) examination of the data for peak horizontal acceleration, velocity, and response spectra does not support a magnitude-dependent shape. Campbell (1981) has arrived at a different conclusion with respect to peak horizontal acceleration, but, in spite of this difference and other differences in assumptions and method, his predictions for peak horizontal acceleration and those of Joyner and Boore (1981) differ by only small amounts in comparison with statistical uncertainty.

The measure of distance used is the shortest distance to the vertical projection of the fault rupture on the surface of the Earth rather than the shortest distance to the rupture, because the introduction of the parameter $h$ makes allowance for, among other things, the fact that the source of the peak motion (or maximum response) may lie at some depth below the surface. Using the shortest distance to the rupture surface for $d$ in equation 5 would be, in effect, compensating twice for the effect of depth. In making predictive ground-motion maps, we must, of course, use the same definition of distance $d$ that was used in developing the predictive equations from the strong-motion data. The actual distribution of ground motion close to a specific earthquake, particularly directly over a dipping fault, will undoubtedly be more complex than these simple equations predict, but we believe that these relations are a sound basis for making useful ground-motion estimates even close to the earthquake.

Moment magnitude (Hanks and Kanamori, 1979) is defined as

$$
\mathbf{M}=\frac{2}{3} \log M_{0}-10.7
$$

where $M_{0}$ is the seismic moment in dyne-centimeters. Determination of the seismic moment of potential earthquakes, therefore, permits the use of equation 5 to estimate ground motion.

Table 33 gives the parameters of the predictive equations for the larger of two horizontal components of pseudovelocity response (5-percent damping), peak acceleration, and peak velocity. Table 34 gives the corresponding parameters for the random horizontal component. The estimated standard deviation of an individual prediction, $\sigma_{y}$, is also given in tables 33 and 34 . The quantities $C_{6}$ and $V_{0}$ in tables 33 and 34 have to do with improved estimates of site effects obtained by using site 


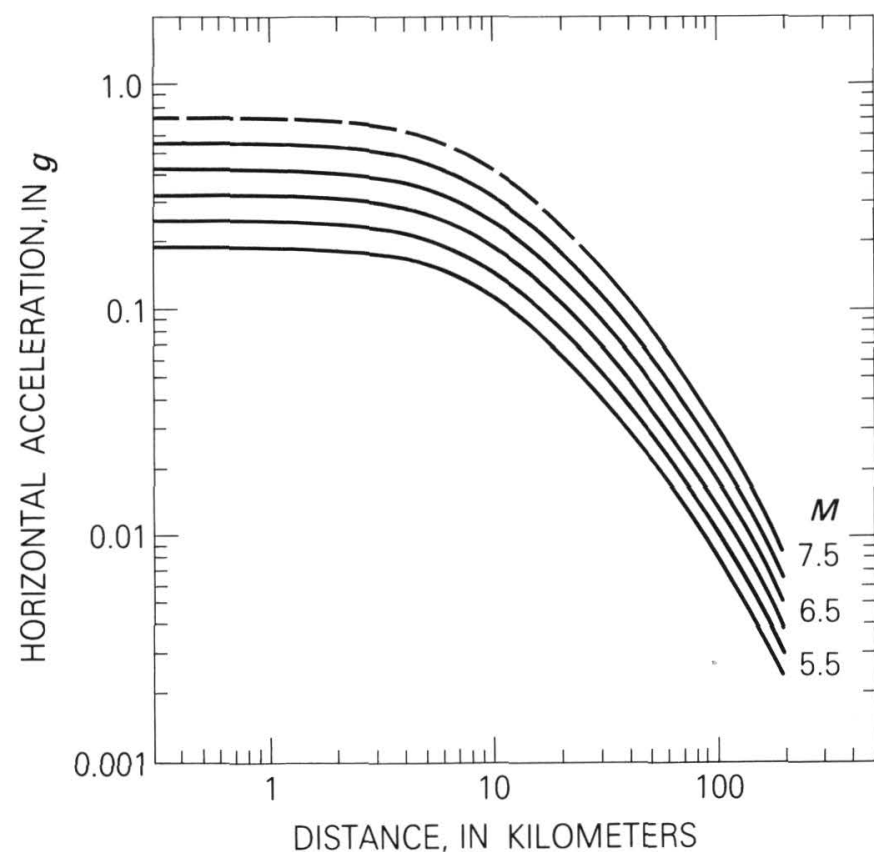

FIGURE 88.-Predicted value of peak acceleration for the randomly oriented horizontal component as a function of distance and moment magnitude. Curves are dashed where not constrained by data.

shear-wave velocity as discussed in the following section. The parameters given in table 34 for the predictive equations for the random component of peak horizontal acceleration and velocity were obtained from the values given by Joyner and Boore (1982b) for the larger of two horizontal components by changing the constant term $c_{0}$ by an amount determined by averaging the difference between the logarithm of the larger peak and the average logarithm of the two peaks over a selected subset of the data set used by Joyner and Boore (1982b).

The coefficient $c_{2}$ of the quadratic term in magnitude is not significantly different from zero at the 90-percent confidence level for peak acceleration and peak velocity (Joyner and Boore, 1981) and so is given on tables 33 and 34 as zero. Also for the response spectral values at most periods, $c_{2}$ is not significantly different from zero at the 90-percent confidence level, but the values obtained at different periods are consistent enough to convince Joyner and Boore (1982b) that inclusion of the quadratic term is warranted. The maximum resulting difference in predicted values, with and without the quadratic term, is only about 20 percent. The $c_{2}$ coefficient warrants special interest because, for the response spectral values, it is of such sign and size that it causes the curve of response versus magnitude for constant distance to level off with increasing magnitude, an effect commonly referred to as saturation.

The data set from which the predictive equations were determined contained no events having magni-

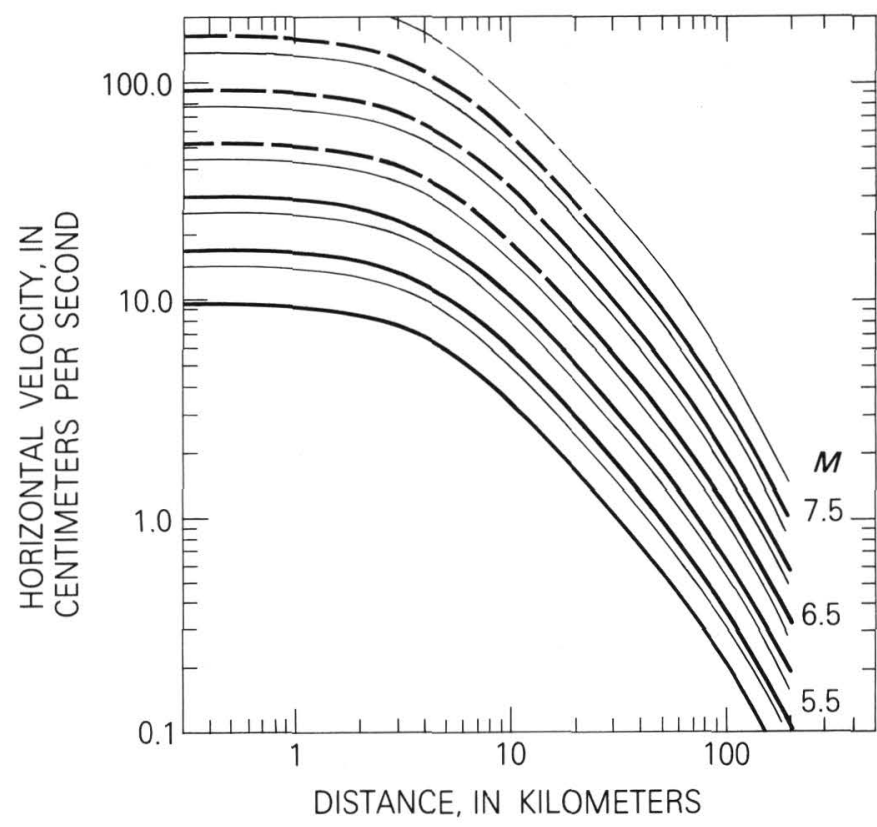

FIGURE 89.-Predicted value of peak velocity for the randomly oriented horizontal component as a function of distance and moment magnitude at rock sites (heavy line) and soil sites (thin line). Curves are dashed where not constrained by data.

tudes outside the range 5.0 to 7.7 ; the equations thus should not be used outside that range. For magnitudes greater than 7.7, we use the values computed from the predictive equations for a magnitude of 7.7. The predictive equations are constrained by data at soil sites for the entire distance range of interest for magnitudes less than 6.5. For values of $d$ less than $15 \mathrm{~km}$ and magnitudes greater than 6.0 at rock sites and for values of $d$ less than $25 \mathrm{~km}$ and magnitudes greater than 7.0 at all sites, the predictive equations are not constrained by data, and the predicted values should be treated with caution. Examples presented in this chapter show such values by dashed contour lines.

\section{USING LOCAL SHEAR-WAVE VELOCITY TO IMPROVE PREDICTIONS OF SITE EFFECTS}

The use of a simple rock-versus-soil classification to account for site effects in the predictive equations described in the previous section is necessitated by limited knowledge of the geology at the strong-motion sites. We have, however, measured shear-wave velocity, in drill holes to depths generally equal to or greater than $30 \mathrm{~m}$, at 33 of the strong-motion sites where data used in deriving the predictive equations were recorded. Included in these 33 locations are most of the sites in the 
data set (Joyner and Boore, 1981) for the 1971 San Fernando earthquake. We use these shear-wave velocity data to derive a modification of the predictive equations intended to improve the prediction of site effects. The method is described briefly here; a fuller discussion is planned for submission to the Bulletin of the Seismological Society of America. The development of predictive equations in terms of site shear-wave velocity permits us to make predictive ground-motion maps using the methods described by Fumal and Tinsley (this volume) for mapping shear-wave velocity.

There is a basis in traditional seismologic theory (Bullen, 1965; Aki and Richards, 1980) for using local shear-wave velocity to estimate the site effect on ground-motion amplitude. If we neglect losses caused by reflection, scattering, and anelastic attenuation, the energy along a tube of rays is constant, and the amplitude is inversely proportional to the square root of the product of the density and the propagation velocity. If we include a correction for the change in the crosssectional area of the ray tube caused by refraction in a medium where velocity is a function of depth, the amplitude of ground motion is proportional to

$$
(\cos i)^{-1 / 2}(\rho V)^{-1 / 2}
$$

where $\rho$ is the density, $V$ is the propagation velocity, and $i$ is the angle of incidence measured from the vertical. The variations in density are relatively small and tend to correlate with the shear-wave velocity. Because propagation velocity tends to increase with depth, incidence angles are small near the surface, and the factor in cos $i$ can be neglected. Thus, amplitude is approximately proportional to the reciprocal of the square root of the propagation velocity. As Joyner and others (1981) proposed in analyzing data from the 1979 Coyote Lake earthquake, we use shear-wave velocity, measured over a depth of one-quarter wavelength of the period of concern, for predicting the site effect on ground motion. This method of predicting site effects does not account for resonance effects, which involve reinforcing multiple reflections. Narrow-band measures of ground motion such as Fourier spectra or undamped response spectra are certainly affected significantly at some sites by resonance. Broader band measures such as we propose to predict, however, will in general be less affected. Resonance effects appear in undamped response spectra as sharp peaks at the resonant frequency. Such peaks are substantially reduced in the 5-percent damped spectral values that we propose to predict.

To develop the modified predictive equations, we consider sites in the strong-motion data set for which shearwave velocity data are available and take the residuals of $\log y$ with respect to the values predicted by equation

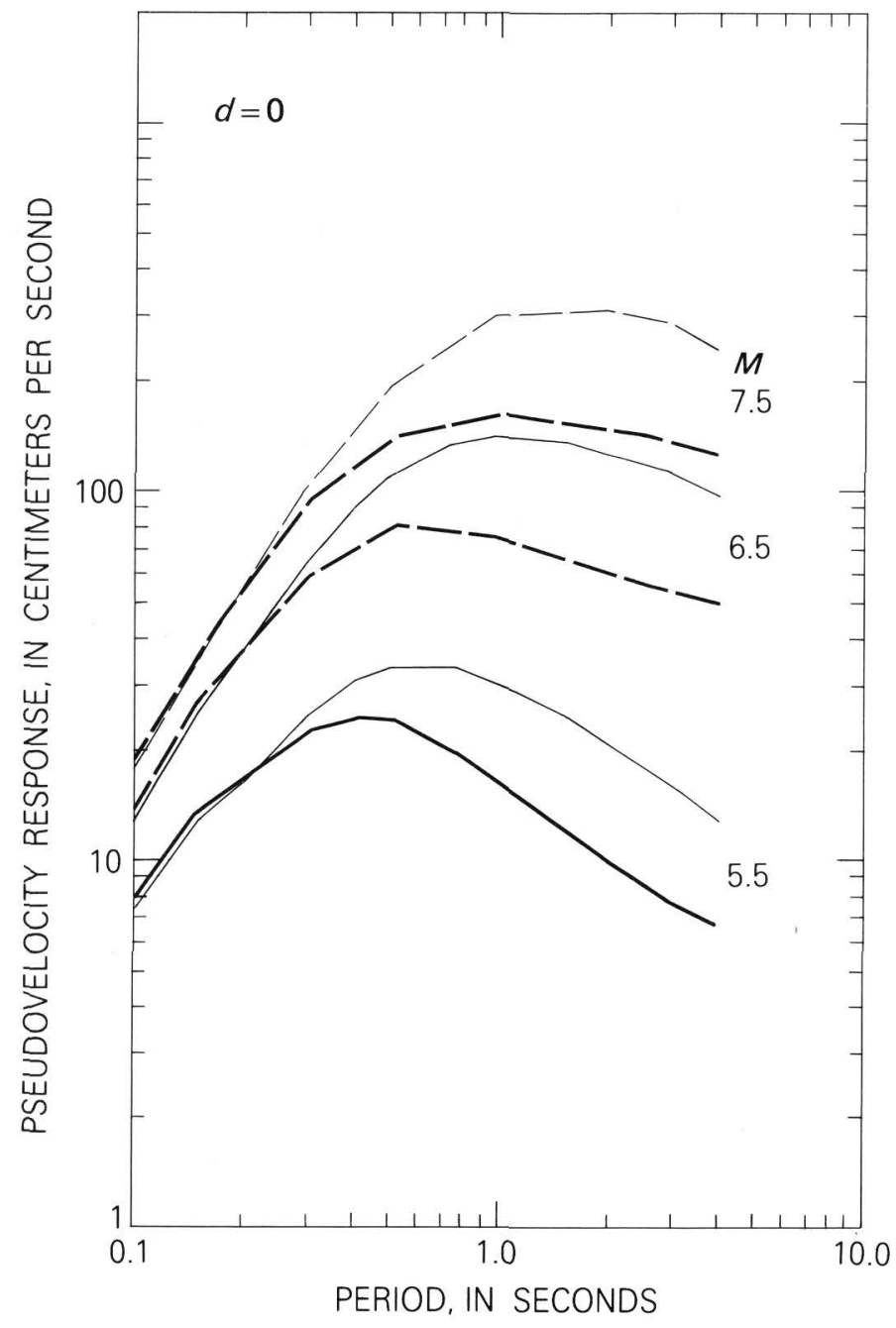

FIGURE 90.-Predicted pseudovelocity response spectra for 5-percent damping at rock sites (heavy line) and soil sites (thin line) for $d=0$ and $M=5.5,6.5$, and 7.5. Spectra correspond to the randomly oriented horizontal component. Curves are dashed where not constrained by data.

5 for rock sites. A linear regression is done between those residuals and the logarithm of the average shearwave velocity to a depth of one-quarter wavelength of the period of interest. This analysis requires extending the downhole shear-wave velocity profile in many cases to depths substantially greater than the deepest measurement, with the help of whatever geologic data are available. Ground-motion data show some variation between earthquakes in addition to variations caused by differences in magnitude. To avoid confusing variation caused by site conditions with variation between earthquakes, the regression is done using the equation

$$
\log R_{\mathrm{ij}}=p_{i}+c_{6} V_{j}
$$

where $R_{i j}$ is the residual for earthquake $i$ at site $j, V_{j}$ is the average shear-wave velocity to the appropriate 


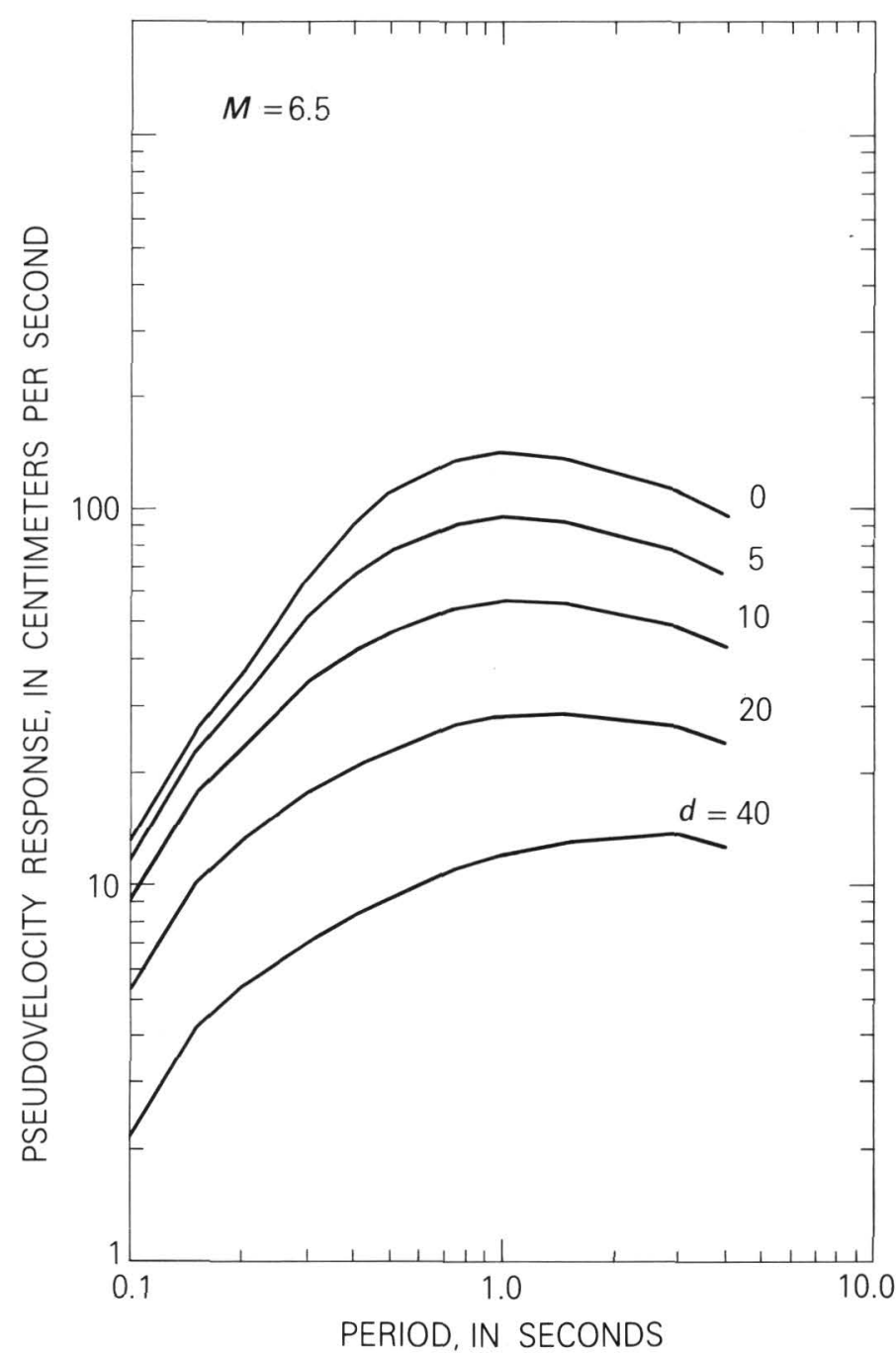

FIGURE 91.-Predicted pseudovelocity response spectra for 5-percent damping at soil sites for $\boldsymbol{M}=6.5$ and $d=0,5,10,20$, and $40 \mathrm{~km}$. Spectra correspond to the randomly oriented horizontal component.

depth at site $j$, and $p_{i}$ and $c_{6}$ are parameters determined by the regression. Figure 93 shows a log-log plot of the residuals against shear-wave velocity for peak horizontal ground velocity. The regression using equation 7 gives the slope of the straight line relating the logarithm of ground motion residual to the logarithm of site shearwave velocity, but it does not give a unique intercept. We obtain the intercept by requiring that the average site effect term calculated by using the shear-wave velocity be the same as the average calculated for the same group of stations by using the simple rock-versussoil classification. The resulting site effect term can be cast in the form

$$
S=C_{6} \log \left(\frac{V}{V_{0}}\right)
$$

where $V$ is the local shear-wave velocity and $V_{0}$ is a

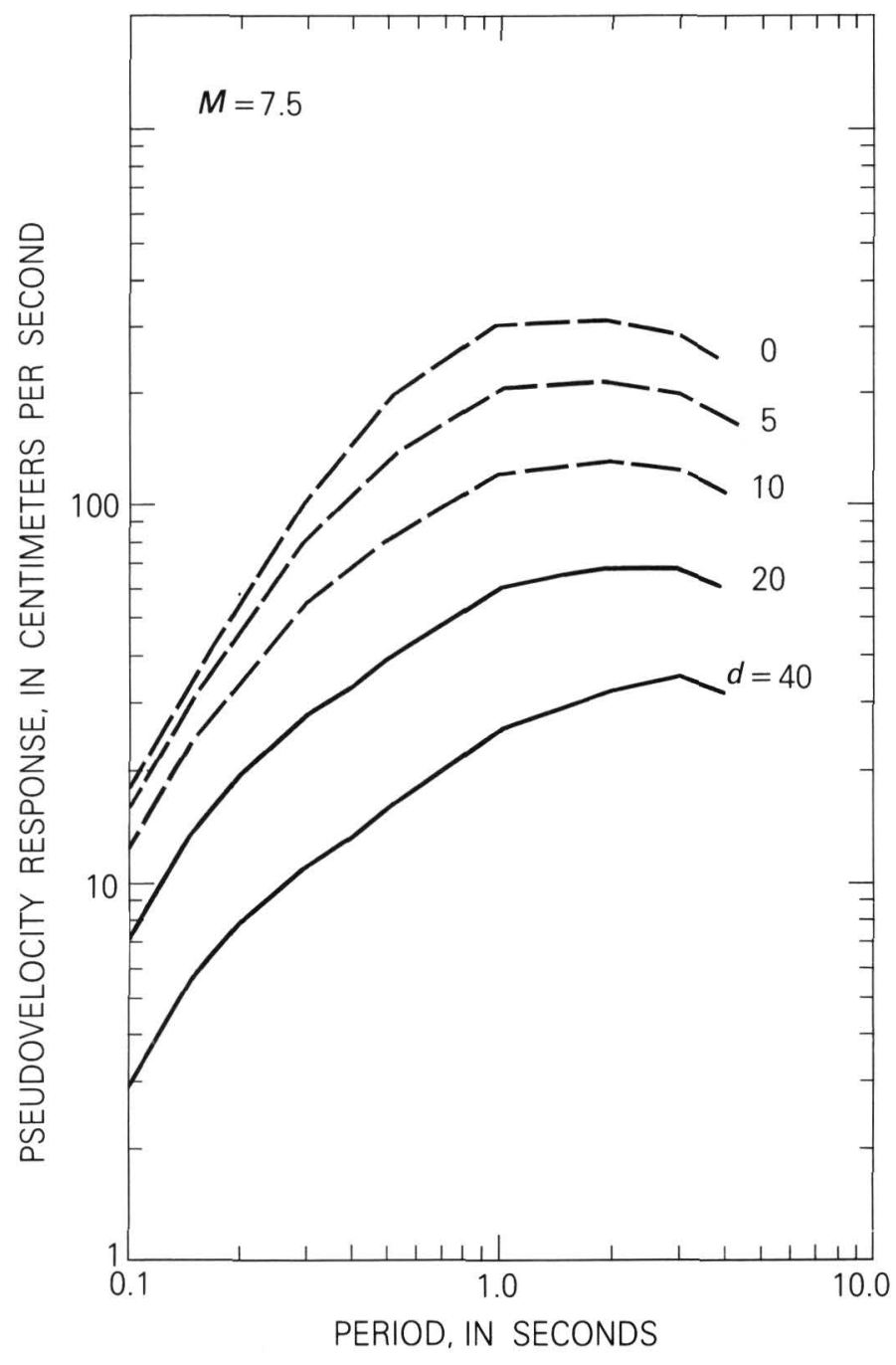

FIGURE 92.-Predicted pseudovelocity response spectra for 5-percent damping at soil sites for $M=7.5$ and $d=0,5,10,20$, and $40 \mathrm{~km}$. Spectra correspond to the randomly oriented horizontal component. Curves are dashed where not constrained by data.

reference velocity. Values of $C_{6}$ and $V_{0}$ are given in tables 33 and 34 for the various ground-motion quantities to be predicted, except for peak acceleration and a few of the short-period response values for which the correlation between the logarithm of ground-motion residual and the logarithm of shear-wave velocity is not statistically significant at the 90-percent level.

To avoid problems resulting from the ground-motion variation between earthquakes, data from a single earthquake (the 1971 San Fernando earthquake) are used to compare the effectiveness of the two methods of accounting for site effects. Analysis of the peak horizontal velocity data from the San Fernando earthquake shows a significant reduction in residual variance when shear-wave velocity rather than the twofold site classification is used to predict the site effect. For response spectral values at $1.0 \mathrm{~s}$, the reduction is not 
TABLE 33.-Parameters in the predictive equations for the larger of two horizontal components of pseudovelocity response (cm/s) at 5-percent damping and of peak acceleration $(\mathrm{g})$ and velocity $(\mathrm{cm} / \mathrm{s})$

[ $c_{0}$ through $c_{3}$ and $h$ are used in equation 5 and were determined from strong-motion data by a two-stage regression procedure (Joyner and Boure, 1981, 1982a, b]. $\sigma_{y}$ is the standard error of an individual prediction by equation $5 . c_{8}$ and $V_{0}$ are used in equation 8 and were determined by a regression procedure described in the text]

\begin{tabular}{|c|c|c|c|c|c|c|c|c|c|c|}
\hline $\begin{array}{c}\text { Period, } \\
\text { in } s\end{array}$ & $c_{0}$ & $c_{1}$ & $c_{2}$ & $\begin{array}{c}h, \\
\text { in } \mathrm{km}\end{array}$ & $c_{3}$ & $\begin{array}{c}\mathcal{c}_{4} \\
\text { in } \mathrm{km}^{-1}\end{array}$ & $c_{5}$ & $\begin{array}{c}V_{0} \\
\text { in } \mathrm{m} / \mathrm{s}\end{array}$ & $c_{\theta}$ & $\sigma_{y}$ \\
\hline \multicolumn{11}{|c|}{ Pseudovelocity response } \\
\hline $0.1--\infty-\infty---$ & 2.24 & 0.30 & -0.09 & 10.6 & -1.0 & -0.0067 & -0.06 & & & 0.27 \\
\hline $.15-------1--\infty \cdots+---$ & 2.46 & .34 & -.10 & 10.3 & -1.0 & -.0063 & -.05 & & & 0.27 \\
\hline .2 -------- - - - - - - - & 2.54 & .37 & -.11 & 9.3 & -1.0 & -.0061 & -.03 & & & 0.27 \\
\hline . 3 - - - - - - - - - - - - & 2.56 & .43 & -.12 & 7.0 & -1.0 & -.0057 & .04 & 650 & -0.20 & 0.27 \\
\hline $.4-----------------$ & 2.54 & .49 & -.13 & 5.7 & -1.0 & -.0055 & .09 & 870 & -.26 & 0.30 \\
\hline 5 --1--ー-ー- & 2.53 & .53 & -.14 & 5.2 & -1.0 & -.0053 & .12 & 1050 & -.30 & 0.32 \\
\hline .75 --1-- - - - - - & 2.46 & .61 & -.15 & 4.7 & -1.0 & -.0049 & .19 & 1410 & -.39 & 0.35 \\
\hline 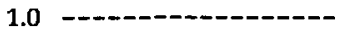 & 2.41 & .66 & -.16 & 4.6 & -1.0 & -.0044 & .24 & 1580 & -.45 & 0.35 \\
\hline 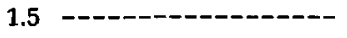 & 2.32 & .71 & -.17 & 4.6 & -1.0 & -.0034 & .30 & 1780 & -.53 & 0.35 \\
\hline $2.0----------\infty-----$ & 2.26 & .75 & -.18 & 4.6 & -1.0 & -.0025 & .32 & 1820 & -.59 & 0.35 \\
\hline 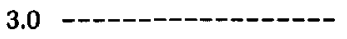 & 2.17 & .78 & -.19 & 4.6 & -1.0 & .0 & .29 & 1620 & -.67 & 0.35 \\
\hline 4.0 ----ー--- & 2.10 & .80 & -.20 & 4.6 & -.98 & .0 & .24 & 1320 & -.73 & 0.35 \\
\hline \multicolumn{11}{|c|}{ Peak acceleration } \\
\hline & 0.49 & 0.23 & 0.0 & 8.0 & -1.0 & -0.0027 & 0.0 & & & 0.28 \\
\hline \multicolumn{11}{|c|}{ Peak velocity } \\
\hline & 2.17 & 0.49 & 0.0 & 4.0 & -1.0 & -0.0026 & 0.17 & 1190 & -0.45 & 0.33 \\
\hline
\end{tabular}

significant. In both cases, the reduction in variance is not large in comparison with the total variance, and it is not well determined because of the limited number of sites for which we have shear-wave velocity data. For these reasons, a separate value of $\sigma_{y}$ for the case when the site effect is predicted from shear-wave velocity is not given. The fact that the reduction in variance is relatively small should not be taken to mean that it does not matter much which method of predicting the site effect is used. At a typical site, it may make little difference which method is used, but, at some sites, the difference is large, and we believe that the use of shear-wave velocity will give better estimates.

\section{CHARACTERIZING EARTHQUAKE SOURCES}

If the magnitude and location of an earthquake are specified, as they are for the postulated earthquake described by Ziony and others (this volume), the predictive equations described in the preceding two sections are all that is needed to make predictive ground-motion maps. On the other hand, we may wish to determine the level of ground motion that has a specified annual probability of being exceeded, given one or more seismogenic faults. Methods of solving this classic problem in engineering seismology are discussed by Cornell (1968),
Der Kiureghian and Ang (1977), Algermissen and Perkins (1976), and McGuire (1978). When these computations are made, the statistical variation in groundmotion values about the expected value given by the attenuation relation is commonly neglected but need not be (McGuire, 1978). Historical seismicity data are commonly used to define the activity of the sources, but geologic data on fault slip rates may also be used (McGuire and Shedlock, 1981). In California, particularly, the use of slip-rate data is appealing because the historical record is relatively short and geologically determined slip-rate data of relatively high quality are becoming available (Allen, 1975).

One very important advantage of using slip rate to characterize the seismicity is that, by doing so, one can make ground-motion estimates that are to a good approximation independent of assumptions concerning the details of the magnitude-frequency relation. We illustrate the proposition here with a simple example; a demonstration that the proposition holds true in general is given in appendix 3 . For the example (fig. 94), we take a site $10 \mathrm{~km}$ from a strike-slip fault having a slip rate of $0.4 \mathrm{~cm} / \mathrm{yr}$, and we estimate the value of peak horizontal acceleration that is exceeded at an average return period of $500 \mathrm{yr}$. The first case that we consider is a sequence of earthquakes all of the same size and occurring at an average rate of once every $250 \mathrm{yr}$ (fig. 94A). To satisfy the specified slip rate, each of these events

\section{Earthquake Hazards in the Los Angeles Region}


TABLE 34.-Parameters in the predictive equations for the randomly oriented horizontal component of pseudovelocity response (cm/s) at 5-percent damping and of peak acceleration $(\mathrm{g})$ and velocity $(\mathrm{cm} / \mathrm{s})$

[ $c_{0}$ through $c_{s}$ and $h$ are used in equation 5 and were determined from strong-motion data by a two-stage regression procedure (joyner and Boore, 1981, 1982a, b]. $\sigma_{y}$ is the standard error of an individual prediction by equation $5 . c_{t}$ and $V_{0}$ are used in equation 8 and were determined by a regression procedure described in the text]

\begin{tabular}{|c|c|c|c|c|c|c|c|c|c|c|c|}
\hline & $\begin{array}{l}\text { Period, } \\
\text { in } s\end{array}$ & $c_{0}$ & $c_{1}$ & $c_{2}$ & $\begin{array}{c}h, \\
\text { in } k m\end{array}$ & $c_{3}$ & in $\mathrm{km}^{-1}$ & $c_{5}$ & $\begin{array}{c}V_{0}, \\
\text { in } \mathrm{m} / \mathrm{s}\end{array}$ & $c_{n}$ & $\sigma_{y}$ \\
\hline \multicolumn{12}{|c|}{ Pseudovelocity response } \\
\hline 0.1 & - - - - - - - - - - - - & 2.16 & 0.25 & -0.06 & 11.3 & -1.0 & -0.0073 & -0.02 & & & 0.28 \\
\hline .15 & 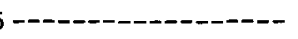 & 2.40 & .30 & -.08 & 10.8 & -1.0 & -.0067 & -.02 & & & .28 \\
\hline .2 & - - - - - - - - - - - - & 2.46 & .35 & -.09 & 9.6 & -1.0 & -.0063 & -.01 & & & .28 \\
\hline .3 & 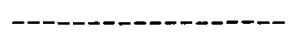 & 2.47 & .42 & -.11 & 6.9 & -1.0 & -.0058 & .04 & 590 & -0.28 & .28 \\
\hline .4 & 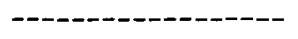 & 2.44 & .47 & -.13 & 5.7 & -1.0 & -.0054 & .10 & 830 & -.33 & .31 \\
\hline .5 & ------------------ & 2.41 & .52 & -.14 & 5.1 & -1.0 & -.0051 & .14 & 1020 & -.38 & .33 \\
\hline .75 & ; - - - - - - - & 2.34 & .60 & -.16 & 4.8 & -1.0 & -.0045 & .23 & 1410 & -.46 & .33 \\
\hline 1.0 & - - - - - - - - - - - - - & 2.28 & .67 & -.17 & 4.7 & -1.0 & -.0039 & .27 & 1580 & -.51 & .33 \\
\hline 1.5 & ---------------- & 2.19 & .74 & -.19 & 4.7 & -1.0 & -.0026 & .31 & 1620 & -.59 & .33 \\
\hline 2.0 & 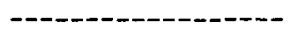 & 2.12 & .79 & -.20 & 4.7 & -1.0 & -.0015 & .32 & 1620 & -.64 & .33 \\
\hline 3.0 & 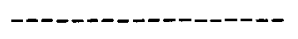 & 2.02 & .85 & -.22 & 4.7 & -.98 & .0 & .32 & 1550 & -.72 & .33 \\
\hline 4.0 & 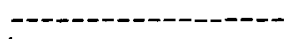 & 1.96 & .88 & -.24 & 4.7 & -.95 & .0 & .29 & 1450 & -.78 & .33 \\
\hline \multicolumn{12}{|c|}{ Peak acceleration } \\
\hline & & 0.43 & 0.23 & 0.0 & 8.0 & -1.0 & -0.0027 & 0.0 & & & 0.28 \\
\hline \multicolumn{12}{|c|}{ Peak velocity } \\
\hline & & 2.09 & 0.49 & 0.0 & 4.0 & -1.0 & -0.0026 & 0.17 & 1190 & -0.45 & 0.33 \\
\hline
\end{tabular}

must have a slip of $100 \mathrm{~cm}$. By definition, the median peak horizontal acceleration for earthquakes of this magnitude will be exceeded for half of the events, or once every $500 \mathrm{yr}$. So, the quantity that we seek to estimate is the median peak horizontal acceleration for the magnitude corresponding to a slip of $100 \mathrm{~cm}$. To determine the magnitude, we first calculate the seismic moment. The definition of seismic moment is

$$
\mathrm{M}_{\mathbf{0}}=\mu U L W
$$

where $\mu$ is the rigidity, $U$ is the slip, $L$ is the length of the rupture, and $W$ is the width measured in the plane of the rupture. Slip is proportional to length (Bonilla, 1967; Slemmons, 1977; Sykes and Quittmeyer, 1981; Scholz, 1982; Bonilla and others, 1984); that is,

$$
U=\alpha L
$$

where $\alpha$ is the constant of proportionality. Combining equations 9 and 10 gives the equation used for calculating moment:

$$
M_{0}=\mu U^{2} W / \alpha
$$

Given the moment, the moment magnitude is obtained from equation 6 . We obtain a magnitude of 7.0 for the earthquake having $100 \mathrm{~cm}$ of slip and occurring once every $250 \mathrm{yr}$. In the calculations, a value of $3.4 \times$ $10^{11} \mathrm{dyn} / \mathrm{cm}^{2}$ is assumed for the rigidity, a value of $10 \mathrm{~km}$ is assumed for the width, and a value of $1.1 \times 10^{-5}$ is assumed for $\alpha$ (see table 35). Equation 5 gives $0.33 \mathrm{~g}$ for the median peak horizontal acceleration $10 \mathrm{~km}$ from a magnitude 7.0 event. So, $0.33 \mathrm{~g}$ is the estimate corresponding to an average return period of $500 \mathrm{yr}$. To show the insensitivity of the estimate to the magnitudefrequency relationship, we compare the result obtained for the sequence of earthquakes having $100 \mathrm{~cm}$ of slip once every $250 \mathrm{yr}$ with that obtained for a sequence having $20 \mathrm{~cm}$ of slip once every $50 \mathrm{yr}$ (fig. 94B). Proceeding as before, we obtain a magnitude of 6.0 for the $20-\mathrm{cm}$ events. Since there are 10 of these events in $500 \mathrm{yr}$, the value of peak horizontal acceleration that is exceeded at an average return period of $500 \mathrm{yr}$ is the value corresponding to the ninetieth percentile of the probability distribution curve. If it is assumed that the logarithm of peak horizontal acceleration is normally distributed and that the standard deviation $\sigma_{y}$ is as given in table 34 , that value is $0.44 \mathrm{~g}$ (equation 5). The difference between 0.33 and $0.44 \mathrm{~g}$ is small in comparison with the variation indicated by the given value of $\sigma_{y}$. This relative insensitivity to the magnitude-frequency relation results from the compensating action of two opposing effects. Smaller magnitude events give smaller median ground-motion estimates, but, the smaller the magnitude, the larger the number of events and the higher the percentile cor- 


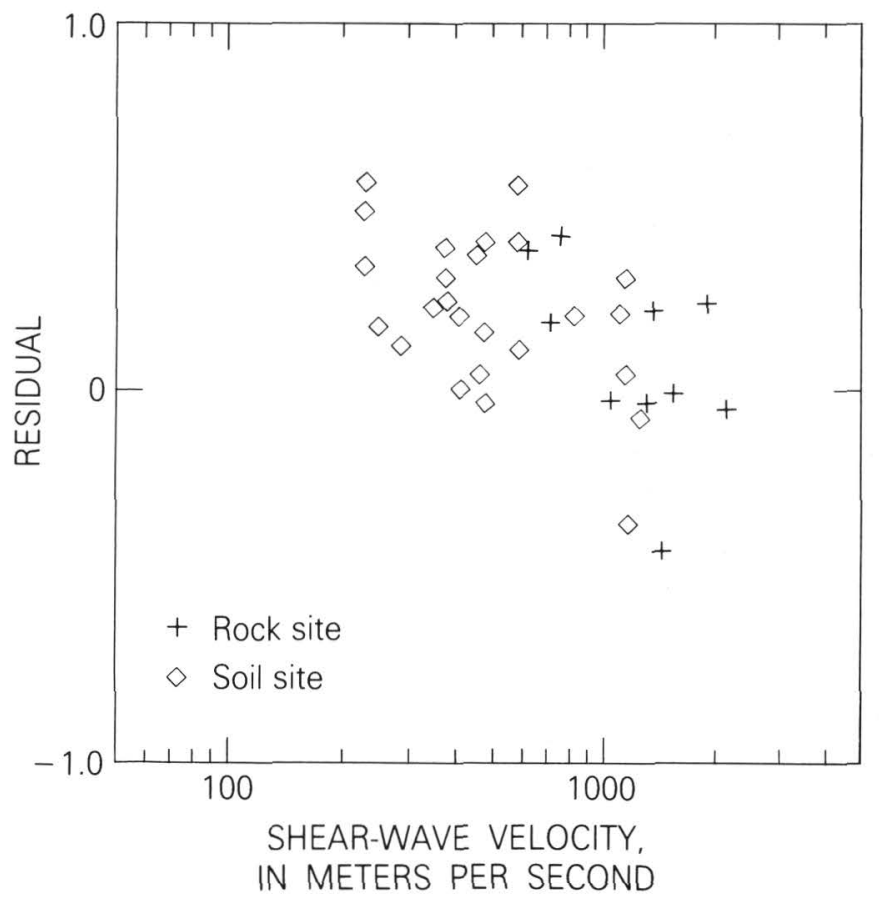

FIGURE 93.-Residuals of the logarithm of peak horizontal ground velocity with respect to the values predicted for rock sites by equation 5, plotted against average shear-wave velocity to a depth of one-quarter wavelength of a 1-s wave. The plot shows that there is a good correlation between site effects and site shear-wave velocity.

responding to the estimate for a 500-yr return period. This compensation obviously depends on the constraint that the magnitude-frequency relation satisfy the given slip rate.

The example above suggests a very simple method for making predictive maps showing ground-motion values that are exceeded at an average return period $T_{r}$. Whatever the real earthquake sequence along a fault, it is replaced for purposes of calculation by a simple sequence of earthquakes all of the same magnitude and occurring at an average rate of twice per time period $\mathrm{T}_{\mathrm{r}}$. Since the median ground-motion value for that magnitude will be exceeded for half of the events, it will be exceeded at a return period equal to $T_{r}$. The median value is calculated by using the predictive equations of the preceding sections and is used in making the map, provided that the calculated magnitude does not exceed the largest magnitude possible on the fault. The largest possible magnitude can be calculated by using the total length of the fault with equations 6,9 , and 10 . If the largest possible magnitude is less than the magnitude calculated for earthquakes occurring at an average rate of twice per time period $T_{r}$, the real earthquake sequence is replaced by a sequence of earthquakes, all of which are of the largest possible magnitude and which occur at an average rate chosen to satisfy the slip rate.
The predictive equations are then used to calculate a ground-motion value for the probability level determined by the average number of events per time period $T_{r}$, as in the second part of the simple example.

To understand the method, it is important to remember that the return period $T_{r}$ is not chosen on any basis having to do with the rate of occurrence of earthquakes but rather corresponds to a probability level that is of interest to the user of the map and is determined by considerations of acceptable risk.

A further simplification used in making the predictive maps is considering each fault separately. At each point, the maps portray the value of ground motion that will be exceeded at a specified probability as a consequence of earthquakes on only one fault-the fault for which the computed value is largest. This approximation will be relatively good at points close to the faults, and such points are the most important from the standpoint of the shaking hazard. To get an idea of the significance of the error made by using this approximation, consider a mapped area containing only two faults. In general, the locus of points for which the groundmotion level corresponding to the specified probability level is identical for both faults will fall along a curved line. If both faults are taken into account, the true probability level along that locus is twice that given by the approximate method. Everywhere else, the difference between the true level and the approximation is smaller. As appendix 3 shows, the difference in ground-motion level corresponding to a factor of two in probability is relatively small.

Describing the simple method more precisely, we seek to map the ground-motion value that is exceeded at a certain annual rate $N_{r}$, which is the reciprocal of the average return period $T_{r}$. (It is more convenient to work with the annual rates at which the mapped value is exceeded rather than with the annual probability that it is exceeded. The two quantities are approximately the same, and one can be computed exactly from the other if necessary.) For the given value of $N_{r}$ and a given fault slip rate $\dot{U}$, we define the moment $\left(M_{0}\right)_{\text {ref }}$ of what we will call the reference earthquake as follows. We divide $\dot{U}$ by $2 N_{r}$ to obtain the mean slip $U_{\text {ref }}$ for the reference earthquake:

$$
U_{\text {ref }}=\dot{U} /\left(2 N_{r}\right)
$$

Combining equations 11 and 12, we obtain an expression for the moment of the reference earthquake:

$$
\left(\mathrm{M}_{0}\right)_{\text {ref }}=\frac{\mu}{\alpha}\left(\frac{\dot{U}}{2 N_{\mathrm{r}}}\right)^{2} W_{\text {tot }}
$$

where $W_{\text {tot }}$ is the maximum width of that portion of the

\section{Earthquake Hazards in the Los Angeles Region}




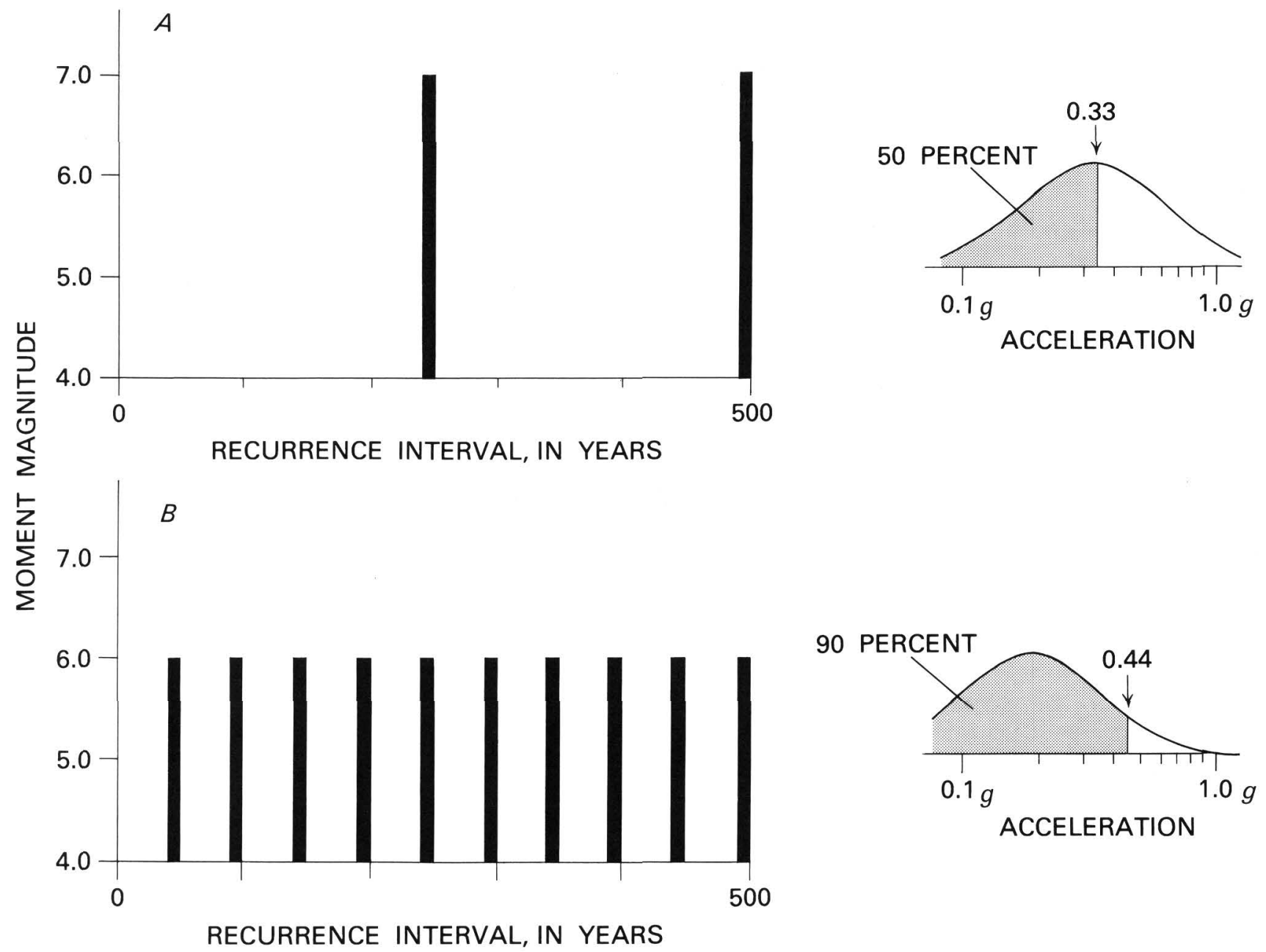

FIGURE 94.-Schematic diagram of a simple example illustrating that probabilistic ground-motion estimates are insensitive to the details of the magnitude-frequency relation, provided that the slip rate is constrained. A, Earthquakes occurring once every 250 yr. B, Earthquakes occurring every $50 \mathrm{yr}$.

fault capable of generating earthquakes. We are assuming here that the reference earthquake will be large enough to rupture the maximum width. (For typical California faults, this assumption implies an earthquake of moment magnitude larger than about 6.0 to 6.5.) We also define a moment $\left(M_{0}\right)_{\text {lim }}$, which represents the largest earthquake that the fault is capable of generating. Combining equations 9 and 10, we obtain

$$
\left(M_{0}\right)_{\text {lim }}=\mu \alpha L_{\text {tot }}^{2} W_{\text {tot }}
$$

where $L_{\text {tot }}$ is the total length of the fault.

If the calculated value of $\left(M_{0}\right)_{\text {ref }}$ is less than $\left(M_{0}\right)_{\text {lim }}$, we take the median ground-motion value for a moment of $\left(M_{0}\right)_{\text {ref }}$ as the value that will be exceeded at the annual rate of $N_{r}$. We are representing the earthquake sequence by an equivalent simple sequence of earthquakes of equal moment $\left(M_{0}\right)_{\text {ref }}$ occurring at an annual rate $2 N_{r}$. The median ground-motion value for moment $\left(M_{0}\right)_{\text {ref }}$ will be exceeded, by definition, for half the events, for a corresponding annual rate of $N_{r}$. If $\left(M_{0}\right)_{1 \text { im }}$ is less than the calculated value of $\left(M_{0}\right)_{\text {ref }}$, then an earthquake of moment $\left(M_{0}\right)_{\text {ref }}$ is not possible, and we represent the earthquake sequence by an equivalent sequence of earthquakes of equal moment $\left(\mathrm{M}_{0}\right)_{\text {lim }}$ occurring at an annual rate $\dot{\mathrm{M}}_{0} /\left(\mathrm{M}_{0}\right)_{\text {lim }}$, where $\dot{\mathrm{M}}_{0}$ is the long-term rate of moment release on the fault obtainable from the slip rate and the definition of moment (equation 9). We calculate the ground-motion value $\mathrm{z}$ that is exceeded at an annual rate $N_{\mathrm{r}}$ by solving the equation

$$
N_{\mathrm{r}}=\frac{\dot{M}_{0}}{\left(M_{0}\right)_{\text {lim }}} P\left[y \geq z \mid\left(M_{0}\right)_{l i m}\right]
$$

where $P\left[y \geq z \mid\left(M_{0}\right)_{1 \text { im }}\right]$ denotes the probability that the ground motion $y$ will exceed value $z$ given the occurrence of an earthquake of moment $\left(M_{0}\right)_{\text {lim }}$. The equation can be rewritten 
TABLE 35.-Values of $\alpha$ for strike- and reverse-slip earthquakes in California

\begin{tabular}{|c|c|c|c|c|}
\hline $\begin{array}{c}M_{0} \\
\text { in dyn-cm }\end{array}$ & $\begin{array}{c}\mathrm{L}, \\
\text { in } \mathrm{km}\end{array}$ & $\begin{array}{c}W \\
\text { in } \mathbf{k m}\end{array}$ & $\alpha^{1}$ & References \\
\hline \multicolumn{5}{|c|}{ Strike-slip earthquakes } \\
\hline San Francisco (1906) -- & 450 & 10 & $0.58 \times 10^{-5}$ & Thatcher (1975) \\
\hline Parkfield (1966) - - & 25 & 7 & $.94 \times 10^{-5}$ & $\begin{array}{l}\text { Tsai and Aki (1969) } \\
\text { Eaton and others (1970) } \\
\text { Lindh and Boore (1981) }\end{array}$ \\
\hline Borrego Mountain (1968) ------- $1.0 \times 10^{28}$ & 45 & 11 & $1.32 \times 10^{-5}$ & $\begin{array}{l}\text { Hamilton (1972) } \\
\text { Hanks and Wyss (1972) } \\
\text { Hanks and others (1975) } \\
\text { Swanger and Boore (1978) }\end{array}$ \\
\hline Imperial Valley (1979) ---------- $6.0 \times 10^{25}$ & 35 & 10 & $1.44 \times 10^{-5}$ & $\begin{array}{l}\text { H. Kanamori (oral communication, 1981) } \\
\text { Chavez and others (1982) } \\
\text { Sharp and others (1982) } \\
\text { T. H. Heaton (oral communication, 1982) }\end{array}$ \\
\hline \multicolumn{3}{|c|}{ Average for strike-slip earthquakes - } & \multicolumn{2}{|l|}{$1.1 \times 10^{-5}$} \\
\hline \multicolumn{5}{|c|}{ Reverse-slip earthquakes } \\
\hline Kern County (1952) -------- $1.5 \times 10^{27}$ & 70 & 23 & $3.91 \times 10^{-5}$ & $\begin{array}{l}\text { Dunbar and others }(1980) \\
\text { D. M. Boore and H. Kanamori (unpublished data, 1979) }\end{array}$ \\
\hline San Fernando (1971) ------- $1.0 \times 10^{28}$ & 20 & 16 & $4.60 \times 10^{-5}$ & $\begin{array}{l}\text { Allen and others (1973) } \\
\text { Hanks and others (1975) }\end{array}$ \\
\hline Average for reverse-slip earthquakes -......- & --- & --- & $4.3 \times 10^{-5}$ & \\
\hline
\end{tabular}

$$
\begin{gathered}
{ }_{\alpha=\frac{M_{0}}{\mu L^{2} W}} \text {, where } \mu=3.4 \times 10^{11} \mathrm{dyn} / \mathrm{cm}^{2} . \\
N_{r}=\frac{\dot{M}_{0}}{\left(M_{0}\right)_{\text {lim }}}[1-F(\mathrm{x})]
\end{gathered}
$$

where $\mathrm{x}=\left[\log \mathrm{z}-\log Z_{\mathrm{lim}}\right] / \sigma, F$ is the cumulative normal probability distribution function, $\log Z_{\text {lim }}$ is the mean of the logarithm of the ground-motion value given by the predictive equations for the moment $\left(M_{0}\right)_{1 \mathrm{~m}}$, and $\sigma$ is the standard deviation of the logarithm of an individual observation. Strictly speaking, the value used for $\sigma$ should not be the value representing ground motion in general obtained from the analysis of the strong-motion data set but rather should be the value representing individual observations of ground motion at the same site from earthquakes at generally different locations on the same fault. We do not have a reliable estimate for the latter value, however, and therefore use the former in the belief that the resulting error will be acceptably small.

\section{APPLYING THE METHOD}

To map predicted ground motion from an earthquake of specified magnitude and location, we compile data on

\section{Earthquake Hazards in the Los Angeles Region}

shear-wave velocity to a depth of one-quarter wavelength of the period of interest, as Fumal and Tinsley (this volume) describe. These data, together with equations 5 and 8 , define a predicted value of ground motion at every point and are all that is necessary to make the map. Maps of this kind for peak acceleration, velocity, and response at 0.2 and $1.0 \mathrm{~s}$ for 5-percent damping for the randomly oriented horizontal component are given in the chapter on the postulated earthquake in the Newport-Inglewood zone (Ziony and others, this volume). If data adequate for estimating shear-wave velocities are not available, equation 5 can be used with the twofold rock-versus-soil classification of sites, or a map can be made for some reference site condition with the understanding that allowance for local site effects will be made separately.

If we wish to map an estimate of the ground motion that will be exceeded at an annual rate $N$, we need to know the location, the dimensions, and the long-term slip rates of the relevant fault zones. For each fault, we calculate moments $\left(M_{0}\right)_{\text {ref }}$ and $\left(M_{0}\right)_{1 \text { im }}$ by using equations 13 and 14. (We use a value of $3.4 \times 10^{11} \mathrm{dyn} / \mathrm{cm}^{2}$ for $\mu$ in equations 13 and 14. For $\alpha$, we use values derived in 
table 35 for strike-slip and reverse-slip faults in California.) If $\left(M_{0}\right)_{\text {ref }}$ is less than $\left(M_{0}\right)_{\text {lim }}$, we take as our estimate the mean value given by equations 5,6 , and 8 for the moment $\left(M_{0}\right)_{\text {ref }}$. If $\left(M_{0}\right)_{\text {lim }}$ is less than $\left(M_{0}\right)_{\text {ref }}$, we take as our estimate the solution of equations 5 and 15, using for $\sigma$ in equation 15 the value of $\sigma_{y}$ given in tables 33 or 34 . If the moment magnitude is greater than 7.7 , the value used in equation 5 is 7.7. The ground-motion value mapped at each site is the largest estimate obtained after all the seismogenic faults in the region have been considered. Contour lines are dashed-an indication that the predictive equations are not constrained by data-at rock sites for distances less than $15 \mathrm{~km}$ and magnitudes greater than 6.0 and at all sites for distances less than $25 \mathrm{~km}$ and magnitudes greater than 7.0.

To illustrate the application described in the preceding paragraphs, maps of the upper Santa Ana River basin have been compiled showing, for the randomly oriented horizontal component, the values of peak acceleration (fig. 95), peak velocity (fig. 96), pseudoacceleration response at $0.2 \mathrm{~s}$ for 5-percent damping (fig. 97), and pseudovelocity response at $1.0 \mathrm{~s}$ for 5-percent damping (fig. 98) that are exceeded at an annual rate $N_{r}$ of 0.002 . This rate, which represents a return period of $500 \mathrm{yr}$, was chosen simply to illustrate the method. It is essentially the same rate as that implicit in the zoning maps of the United States contained in the Applied Technology Council's (1978) study, "Tentative Provisions for the Development of Seismic Regulations for Buildings." Figures 95 and 96 are included because they show peak horizontal acceleration and velocity, which are more familiar measures of earthquake ground motion, but we believe that maps of response values such as those shown in figures 97 and 98 will prove more useful for earthquake-resistant design and seismic zonation.

The map of shear-wave velocity data used in making figures 96 and 98 is figure 58 of Fumal and Tinsley (this volume). Three major seismogenic faults need to be considered in the upper Santa Ana River basin study area: the San Andreas, the San Jacinto, and the Cucamonga. The essential data on these faults are taken from Ziony and Yerkes (this volume) and are shown in table 36, along with the derived quantities used in making the maps in figures 95 through 98. The fault zones are assumed to extend from the surface to a depth of $10 \mathrm{~km}$, and the widths are therefore

$$
W=\frac{10}{\sin \theta}
$$

in kilometers, where $\theta$ is the dip angle. The dip is also taken into account in determining the vertical projection of the rupture zones on the surface of the Earth. As we noted previously, the distance $d$ in equation 5 is measured from that projection of the rupture surface.
Contours in figure 96 show predicted peak horizontal velocities of 200 and $400 \mathrm{~cm} / \mathrm{s}$, values greatly in excess of the largest ever measured. We know of no reason to believe that such values could not occur, but data are not available to support them, as the dashed contours indicate. The map of predicted pseudovelocity response at $1.0 \mathrm{~s}$ (fig. 98) also shows values in excess of the largest ever measured but not by nearly as large a factor as those in figure 96. It is gratifying that the factor is not so large in figure 98 in view of the greater engineering utility of predicted response maps.

Whether the maps show ground motion from a specified earthquake or ground motion that is exceeded at a specified rate from multiple sources, the exact technique by which the maps are made is of secondary importance. The predicted values could be calculated over a dense grid of points and the contours interpolated between grid points. Various short cuts are possible. It is obviously not necessary to calculate a value for every grid point. The technique that we used for the sample maps in this chapter and for the maps in the chapter on the postulated earthquake (Ziony and others, this volume) was to prepare, for each source zone and each ground-motion contour value, a table of distances corresponding to a selected set of near-surface shear-wave velocity values. The distance of each contour from a rupture zone was scaled off on the map, taking into account the areal distribution of shear velocities.

\section{SUMMARY}

Predictive maps of peak horizontal acceleration, velocity, and response spectral values can be prepared by new methods based on predictive equations that give ground-motion values in terms of magnitude, distance, and site conditions. The equations are modified to improve the prediction of site effects by using the local shear-wave velocity of near-surface geologic materials. Predictive ground-motion maps can be made for ground motion from an earthquake of specified magnitude and location; samples of such maps are included in a later chapter (Ziony and others, this volume). Predictive maps can also be made showing the ground-motion value that will be exceeded at a specified annual probability taking into account future earthquakes on a number of faults. We have demonstrated that probabilistic estimates of near-fault ground motion from earthquakes on a single fault are, to a good approximation, independent of the parameters of the magnitude-frequency relation, provided that the relation is constrained by the fault slip rate. On the basis of this proposition, a simple method is developed for making predictive maps showing probabilistic estimates of ground motion from earthquakes on

Predictive Ground-Motion Mapping 


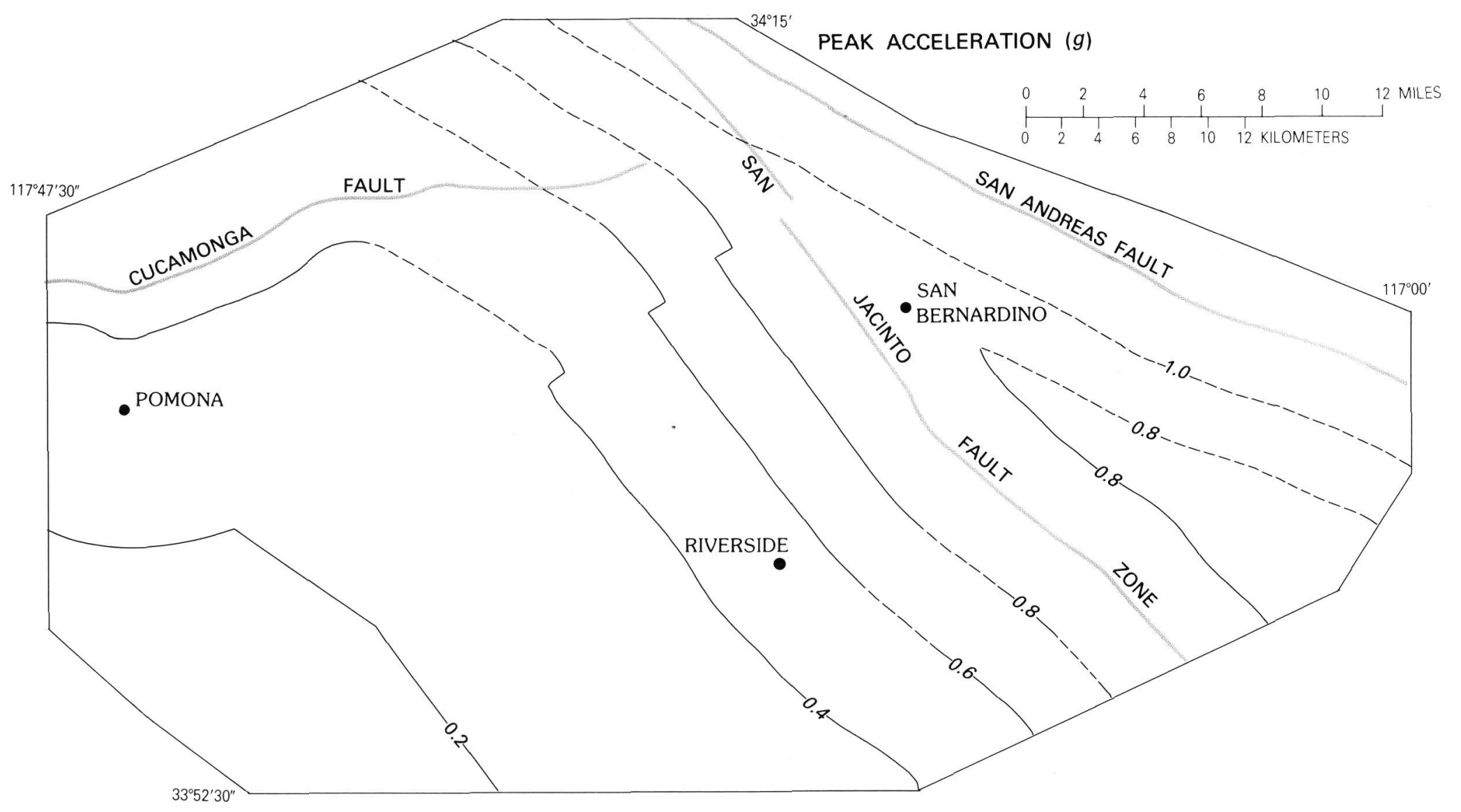

FIGURE 95.-Map of the upper Santa Ana River basin showing, for the randomly oriented horizontal component, the value of peak acceleration that is exceeded at an annual rate of 0.002 (return period of $500 \mathrm{yr}$ ). Dashed contours correspond to combinations of magnitude and distance for which the predictive equations are not constrained by data.

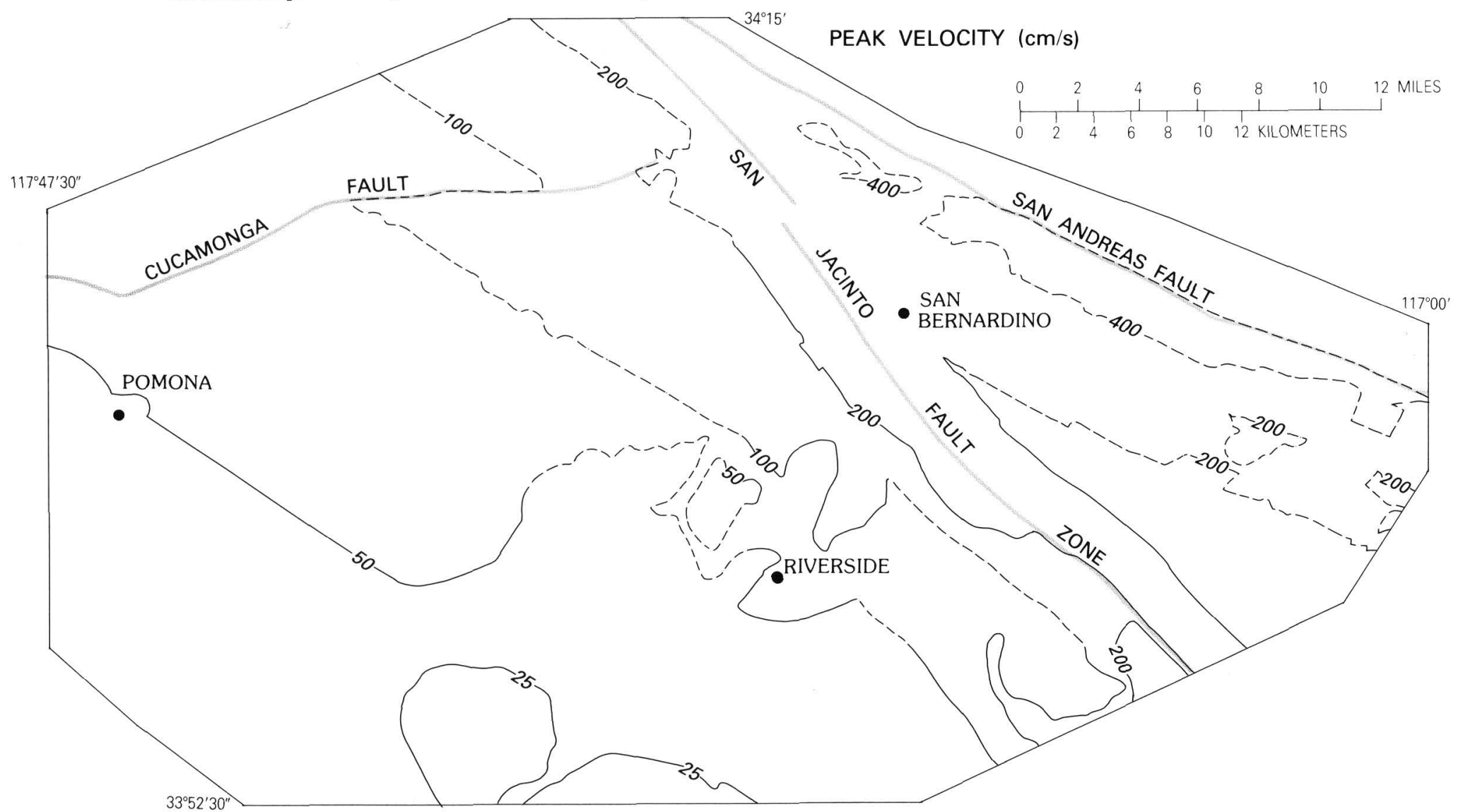

FIGURE 96.-Map of the upper Santa Ana River basin showing, for the randomly oriented horizontal component, the value of peak velocity that is exceeded at an annual rate of 0.002 (return period of $500 \mathrm{yr}$ ). Dashed contours correspond to combinations of magnitude, distance, and site conditions for which the predictive equations are not constrained by data. Note the geometric contour interval. 


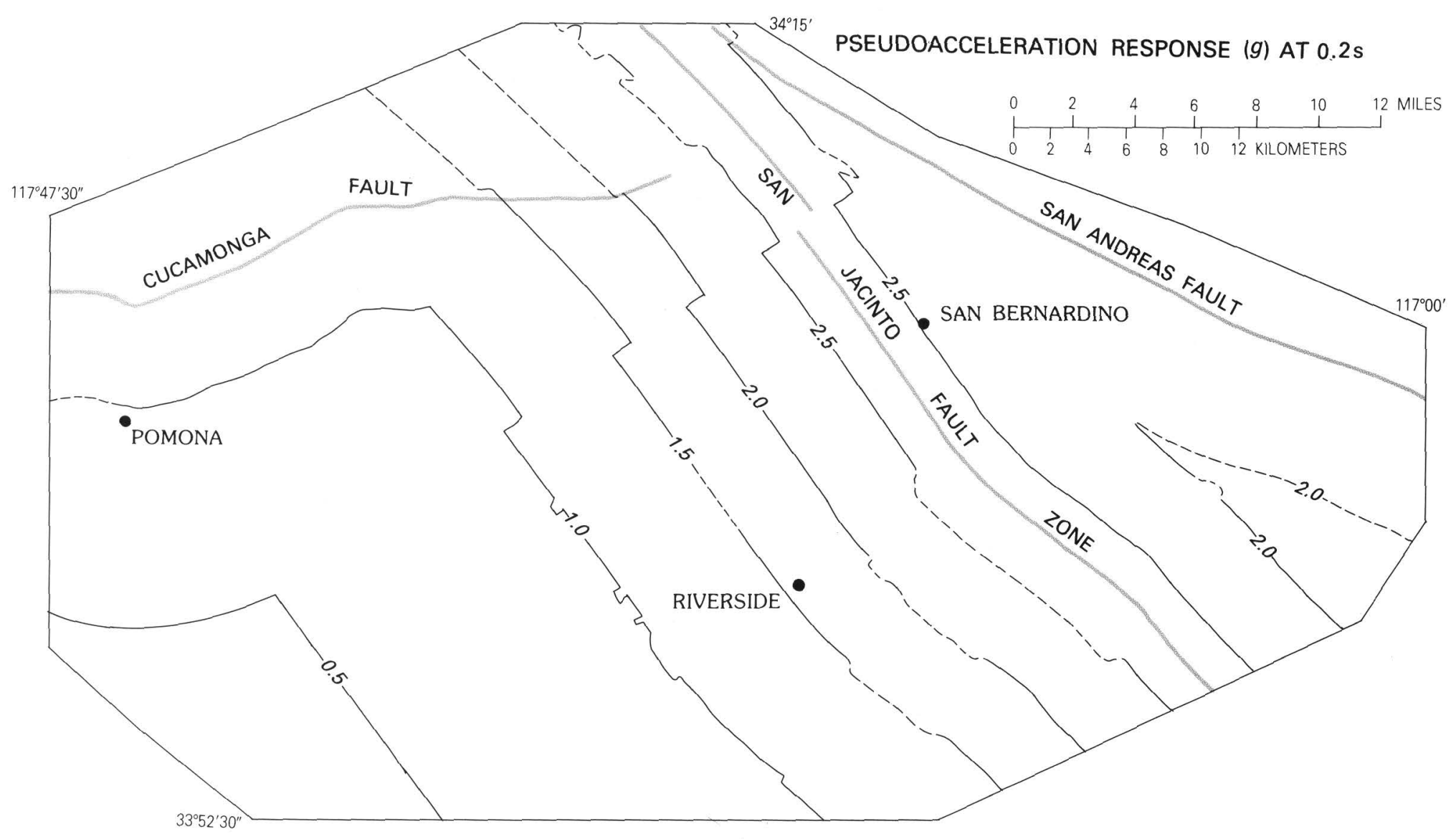

FIGURE 97.-Map of the upper Santa Ana River basin showing, for the randomly oriented horizontal component, the value of pseudoacceleration response at $0.2 \mathrm{~s}$ and 5-percent damping that is exceeded at an annual rate of 0.002 (return period of $500 \mathrm{yr}$ ). Dashed contours correspond to combinations of magnitude and distance for which the predictive equations are not constrained by data.

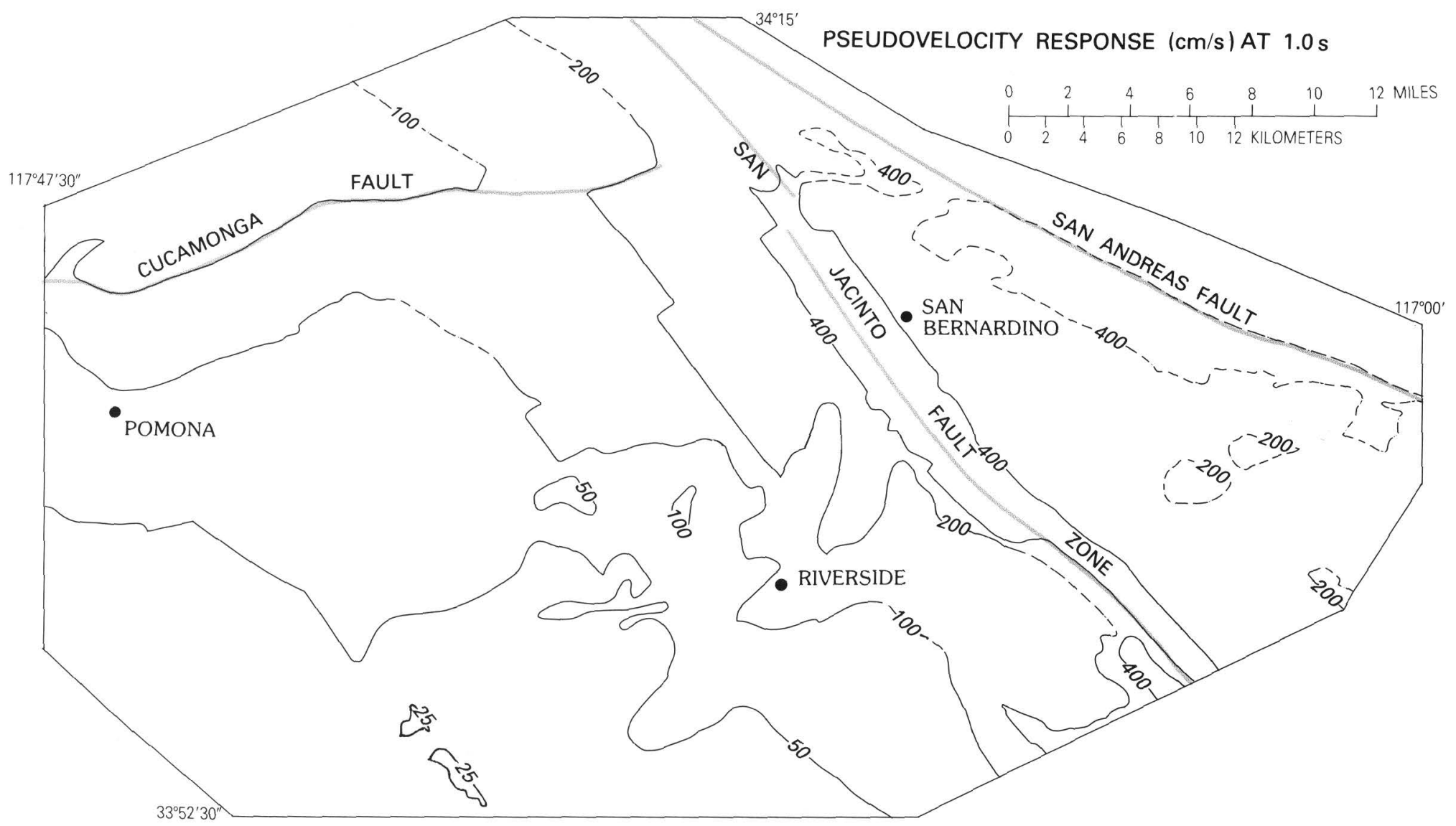

FIGURE 98.-Map of the upper Santa Ana River basin showing, for the randomly oriented horizontal component, the value of pseudovelocity response at $1.0 \mathrm{~s}$ and 5-percent damping that is exceeded at an annual rate of 0.002 (return period of 500 yr). Dashed contours correspond to combinations of magnitude, distance, and site conditions for which the predictive equations are not constrained by data. Note the geometric contour interval. 
TABLE 36.-Assumed parameters for principal earthquake sources in the upper Santa Ana River basin area [Data on fault type, dip, and slip rate from Ziony and Yerkes (this volume)]

\begin{tabular}{|c|c|c|c|c|c|c|c|}
\hline Fault & $\begin{array}{c}\dot{U}, 1 \\
\text { in } \mathrm{cm} / \mathrm{yr}\end{array}$ & Dip & $\begin{array}{l}\mathrm{L}_{\mathrm{tot}}^{2} \\
\text { in } \mathrm{km}\end{array}$ & $\begin{array}{l}W_{\text {tot }} \\
\text { in } \mathrm{km}\end{array}$ & $\mathbf{M}_{\text {ref }}$ & $\boldsymbol{M}_{\text {lim }}$ & $\left(\mathbf{M}_{\mathbf{0}}\right)_{\mathrm{him}}$ \\
\hline San Andreas (Mojave segment) --------- Strike slip & 3.0 & Vertical ${ }^{3}$ & 400 & 10 & 8.1 & 7.8 & 0.0068 \\
\hline $\begin{array}{l}\text { San Jacinto zone ------------- Strike slip } \\
\text { (Glen Helen and Claremont faults). }\end{array}$ & 1.0 & Vertical & 75 & 10 & 7.5 & 6.8 & .012 \\
\hline Cucamonga - - & 3 & $45^{\circ} \mathrm{N}$ & 25 & 14 & 6.5 & 6.7 & \\
\hline
\end{tabular}

${ }^{1}$ Estimated average late Quatemary slip rate. In making the maps, a preliminary value of $0.3 \mathrm{~cm} / \mathrm{yr}$ was used for the slip rate on the Cucamonga. That value falls at the lower end of the range 0.29 to $0.64 \mathrm{~cm} / \mathrm{yr}$ given by Ziony and Yerkes (this volume).

${ }^{2}$ Maximum Holocene length.

${ }^{3}$ Dips $60^{\circ}$ NE. southeastward from San Bernardino.

any number of faults for which slip rates are known or can be reliably estimated. A suite of maps for the upper Santa Ana River basin illustrates the latter method.

\section{APPENDIX 3.-DEPENDENCE OF PROBABILISTIC GROUND-MOTION ESTIMATES ON PARAMETERS OF THE MAGNITUDE-FREQUENCY RELATION}

In this chapter, we have described a simple system for estimating the ground-motion values that will be exceeded at a specified annual rate. In this appendix, we attempt to show that the resulting values are good approximations of the values that would be obtained if more conventional magnitude-frequency relations were used. The usual form for describing the rate of occurrence of earthquakes of different magnitudes is that given by Gutenberg and Richter (1954; Ishimoto and Iida, 1939):

$$
\log N=a-b M
$$

where $N$ is the annual number of events having magnitudes greater than or equal to $M$ and $a$ and $b$ are constants. The Gutenberg-Richter relation must be truncated at a maximum magnitude $M_{\max }$ to avoid an infinite rate of moment release. There are two options. The cumulative distribution given above can be truncated, or the corresponding density distribution can be truncated. Both options are considered here. If the cumulative distribution is truncated, the resulting relation includes as a special case, for $b=0$, the characteristic earthquake model in which all of the earthquakes are the same size. The simple model described in the text is a characteristic earthquake model.

216 Earthquake Hazards in the Los Angeles Region
We show in this appendix that probabilistic groundmotion estimates are insensitive to the parameters of the magnitude-frequency relation as long as the slip rate is satisfied. This matter is of some importance because, in the general case, there may not be a good basis for choosing values for the parameters. Values near one are commonly used for $b$, but a growing body of opinion in recent years holds that, for individual faults, much lower values may be appropriate (Singh and others, 1981; Schwartz and others, 1981; Lahr and Stephens, 1982; Wesnousky and others, 1983). $M_{\max }$ is commonly taken as the magnitude corresponding to rupture of the entire length of the fault zone, but in general there is no basis for assuming that earthquakes so large actually occur.

We first consider the case of a Gutenberg-Richter cumulative distribution truncated at a maximum magnitude $M_{\text {max }}$. Following Brune (1968) and Molnar (1979), we apply the definition of moment magnitude given in equation 6 , introduce a maximum moment $\left(M_{0}\right)_{\max }$, and require that the long-term rate of moment release in the earthquake sequence equal a known value $\dot{M}_{0}$. The resulting equation is

$$
N\left(M_{0}\right)=(1-\beta) \frac{\dot{M}_{0} M_{0}^{-\beta}}{\left(M_{0}\right)_{\max }^{1-\beta}}\left\{1-\mathrm{H}\left[M_{0}-\left(M_{0}\right)_{\max }\right]\right\}
$$

where $N\left(M_{0}\right)$ is the annual number of earthquakes having moments greater than or equal to $M_{0}, H$ represents the Heaviside function, and $\beta$ is a constant equal to $2 / 3$ b. As we noted before, $\dot{M}_{0}$ for a fault can be obtained from the slip rate (corrected if necessary for aseismic slip) and the definition of moment (equation 5). We distinguish between $\left(M_{0}\right)_{1 \mathrm{~m}}$, the largest moment permitted by the size of the entire fault, and $\left(M_{0}\right)_{\max }$, the largest moment that is implied by our adopted magnitudefrequency relation. $\left(M_{0}\right)_{\max }$ should never be larger than 
$\left(M_{0}\right)_{l i m}$, but, in general, nothing prevents us from postulating a smaller value.

For general values of $\beta$, we calculate the groundmotion value $\mathrm{z}$ that will be exceeded at an annual rate $N_{r}$ as the solution of the equation

$$
N_{r}=\int_{0}^{\infty} \frac{L\left(M_{0}\right)}{L_{t o t}} n\left(M_{0}\right) P\left(y \geq z \mid M_{0}\right) d M_{0}
$$

where

$$
n\left(M_{0}\right)=-\frac{d N\left(M_{0}\right)}{d M_{0}}
$$

$L\left(M_{0}\right)$ is the rupture length corresponding to moment $M_{0}$, and $P\left(y \geq z \mid M_{0}\right)$ is the probability that the ground motion $y$ will exceed value $z$ given the occurrence of an earthquake of a moment $M_{0}$. The quantity $n\left(M_{0}\right) d M_{0}$ is the annual number of earthquakes in the moment range $d M_{0}$ for the entire fault. Multiplication by the ratio $L\left(M_{0}\right) / L_{\text {tot }}$ gives the annual number of earthquakes that rupture that portion of the fault adjacent to a specific site, the assumption being that earthquakes along other parts of the fault can be neglected. That assumption is good for sites where the distance to the fault is small in comparison to the rupture length.

$$
P\left(y \geq z \mid M_{0}\right)=1-F(x)
$$

where $F$ is the cumulative normal probability distribution function,

$$
x=(\log z-\log Z) / \sigma
$$

$\log Z$ is the mean of the logarithm of the ground-motion value for the moment $M_{0}$, and $\sigma$ is the standard deviation.

We consider in turn the three factors of the integrand in equation 17 . Obviously,

$$
\frac{L\left(M_{0}\right)}{L_{\text {tot }}}=\frac{L_{\max }}{L_{\text {tot }}} \frac{L\left(M_{0}\right)}{L_{\max }}
$$

where $L_{\max }$ is the rupture length corresponding to moment $\left(M_{0}\right)_{\max }$. Assuming that earthquakes of moment $M_{0}$ are large enough to rupture the maximum width of the fault zone, we can obtain, with the aid of equations 9 and 10,

$$
\frac{L\left(M_{0}\right)}{L_{\text {tot }}}=\frac{L_{\max }}{L_{\text {tot }}} \frac{M_{0}^{1 / 2}}{\left(M_{0}\right)_{\max }^{1 / 2}}
$$

(For earthquakes smaller than the moment corresponding to rupture of the maximum width, the exponents should be $1 / 3$ where they are $1 / 2$ in equation 20 . Repeating the analysis with exponents of $1 / 3$ instead of $1 / 2$ gives results not greatly different from the results presented here.) By differentiating equation 16 (Molnar, 1979; Anderson and Luco, 1983), we can obtain

$$
\begin{aligned}
n\left(M_{0}\right) d M_{0}= & (1-\beta) \frac{\dot{M}_{0}}{\left(M_{0}\right)_{\max }}\left\{d M_{0} \delta\left[M_{0}-\left(M_{0}\right)_{\max }\right]\right. \\
& \left.-d\left(\left[\frac{\left(M_{0}\right)}{\left(M_{0}\right)_{\max }}\right]-\beta\right)\left(1-H\left[M_{0}-\left(M_{0}\right)_{\max }\right]\right)\right\}
\end{aligned}
$$

where $\delta$ is the Dirac delta function.

If we define

$$
q=\left(\log z-\log Z_{\max }\right) / \sigma
$$

where $\log Z_{\max }$ is the mean of the logarithm of the ground-motion value for the moment $\left(M_{0}\right)_{\max }$, then substitution in equation 19 gives

$$
x=q+\left(\log Z_{\max }-\log Z\right) / \sigma
$$

If we can express $\log z$ in the form

$$
\log \mathrm{z}=c_{0}+c_{1} \mathbf{M}
$$

where $\boldsymbol{M}$ is the magnitude corresponding to moment $\mathbf{M}_{0}$, then we obtain

$$
\mathrm{x}=q+\frac{c_{1}}{\sigma}\left(M_{\max }-M\right)
$$

Substituting from equations 18, 20, and 21 into equation 17 gives

$$
N_{\mathrm{r}}=(1-\beta) \frac{\dot{M}_{0}}{\left(M_{0}\right)_{\max }} \frac{L_{\max }}{L_{\text {tot }}} I
$$

where

$$
\begin{aligned}
& I=\int_{M_{0}=0}^{\left(M_{0}\right)_{\max }}\left[\frac{M_{0}}{\left(M_{0}\right)_{\max }}\right]^{1 / 2}\left\{\mathrm{dM}_{0} \delta\left[M_{0}-\left(M_{0}\right)_{\max }\right]\right. \\
& \left.-d\left(\left[\frac{\left(M_{0}\right)}{\left(M_{0}\right)_{\max }}\right]^{-\beta}\right)\right\}[1-\mathrm{F}(\mathrm{x})]
\end{aligned}
$$

and $\mathrm{x}$ is given by equation 24 . To simplify equation 25 , we assume that an earthquake of moment $\left(M_{0}\right)_{\text {ref }}$ is large 


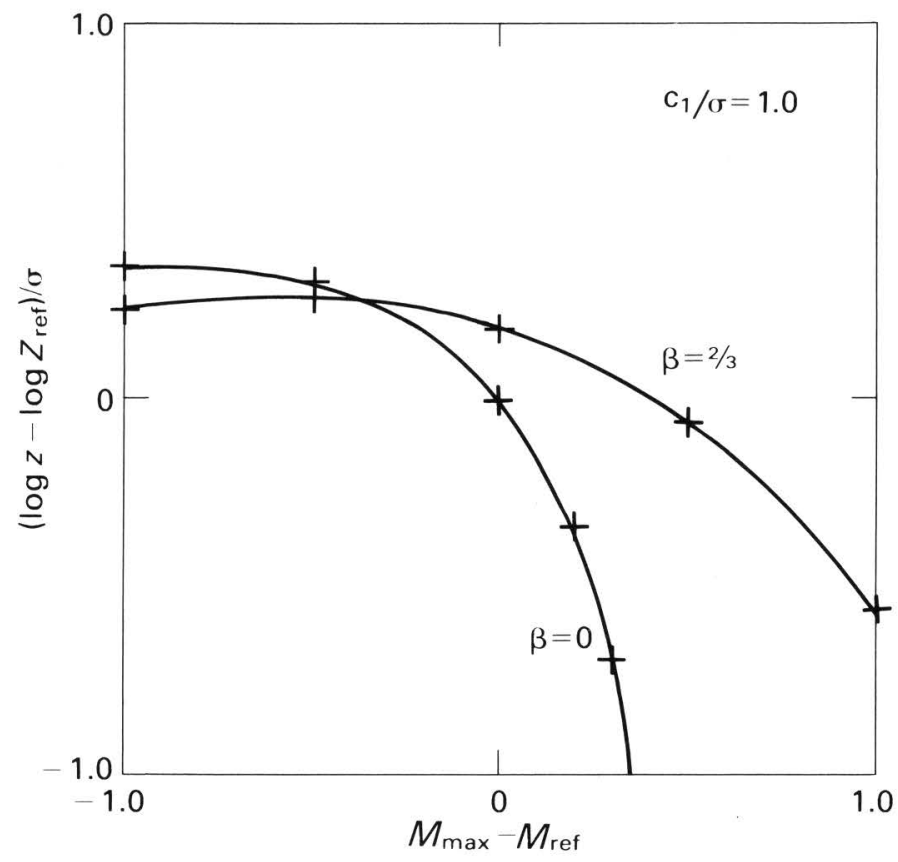

FIGURE 99.-Difference between the ground-motion value predicted by the simple model and the value predicted by using a magnitudefrequency relation of the Gutenberg-Richter type whose cumulative distribution curve is truncated at a maximum magnitude $\mathbf{M}_{\mathrm{max}}$. Other symbols are explained in the text. A value of one for the $c_{1} / \sigma$ ratio is appropriate for peak horizontal acceleration and for shortperiod horizontal response spectra. Note that the difference is normalized by $\sigma$, the standard deviation of an individual prediction from the predictive equation.

enough to rupture the maximum width of the fault zone, and we use the definition of moment given in equation 9 to obtain

$$
\left(M_{0}\right)_{\text {ref }}=\mu U_{\text {ref }} L_{\text {ref }} W_{\text {tot }}
$$

Substituting from equation 12 gives

$$
\left(M_{0}\right)_{\text {ref }}=\mu \frac{\dot{U}}{2 N_{r}} L_{\text {ref }} W_{\text {tot }}
$$

By differentiating the definition of moment, we obtain

$$
\dot{\mathrm{M}}_{0}=\mu \dot{U} \mathrm{~L}_{\text {tot }} W_{\text {tot }}
$$

Solving equations 27 and 28 for $\dot{M}_{0}$ in terms of $\left(M_{0}\right)_{\text {ref }}$ gives

$$
\dot{M}_{0}=2 N_{r}\left(M_{0}\right)_{\text {ref }} \frac{L_{\text {tot }}}{L_{\text {ref }}}
$$

Substituting from equation 29 into equation 25 and rearranging give

$$
I=\frac{1}{2(1-\beta)} \frac{\left(M_{0}\right)_{\max }}{\left(M_{0}\right)_{\text {ref }}} \frac{L_{\text {ref }}}{L_{\text {max }}}
$$

\section{Earthquake Hazards in the Los Angeles Region}

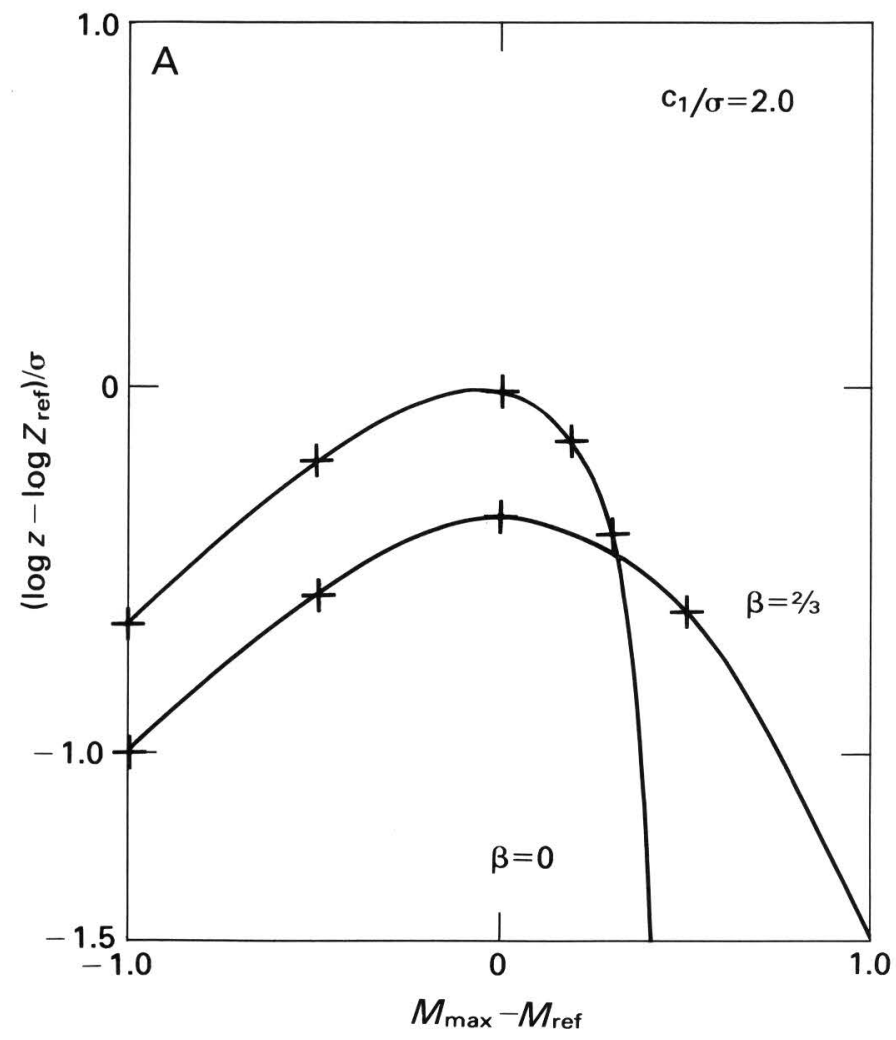

FIGURE 100.-Difference between the ground-motion value predicted by the simple model and the value predicted by using a magnitudefrequency relation of the Gutenberg-Richter type whose cumulative distribution curve is truncated at a maximum magnitude $\mathbf{M}_{\max }$. Other symbols are explained in the text. A value of two for the $c_{1} / \sigma$ ratio is appropriate for peak horizontal velocity and for intermediate-period horizontal response spectra. Note that the difference is normalized by $\sigma$, the standard deviation of an individual prediction from the predictive equation.

As we did previously, we assume that earthquakes of moment $\left(M_{0}\right)_{\text {ref }}$ are large enough to rupture the maximum width of the fault zone, and we use equations 9 and 10 to obtain further simplification:

$$
I=\frac{1}{2(1-\beta)}\left[\frac{\left(M_{0}\right)_{\max }}{\left(M_{0}\right)_{\text {ref }}}\right]^{1 / 2}
$$

Equations 26 and 30 can be rewritten in terms of moment magnitude, a step that we do not bother to show here. Equations 24, 26, and 30 constitute a system that we solve by successive approximation using numerical integration to obtain values of $q$ for given values of $\left(M_{0}\right)_{\max } /\left(M_{0}\right)_{\text {ref }}$. Once we find $q$, we can use equation 22 to obtain

$$
\left(\log z-\log Z_{\text {ref }}\right) / \sigma=q+\left(\log Z_{\text {max }}-\log Z_{\text {ref }}\right) / \sigma
$$

or, equivalently,

$$
\left(\log \mathrm{z}-\log \mathrm{Z}_{\mathrm{ref}}\right) / \sigma=q+\frac{\mathbf{C}_{1}}{\sigma}\left(\mathbf{M}_{\max }-\mathbf{M}_{\mathrm{ref}}\right)
$$

The left-hand side of equation 31 is the difference be- 


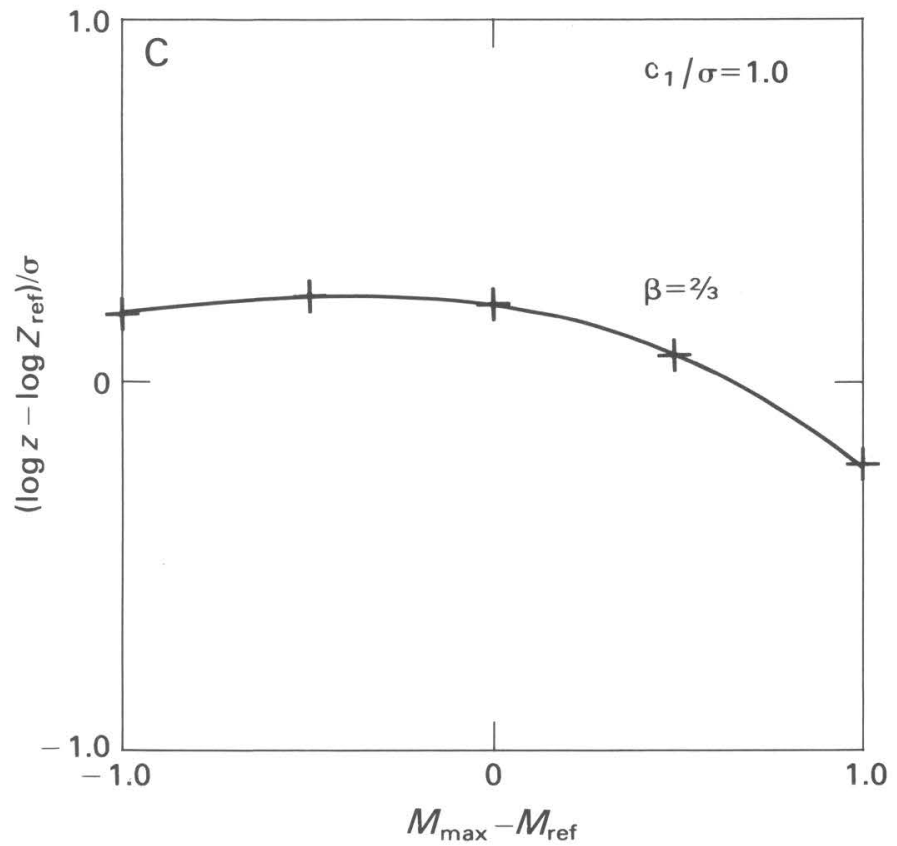

FIGURE 101.-Difference between the ground-motion value predicted by the simple model and the value predicted by using a magnitudefrequency relation of the Gutenberg-Richter type whose density distribution curve is truncated at a maximum magnitude $\mathbf{M}_{\max }$. Other symbols are explained in the text. A value of one for the $c_{1} / \sigma$ ratio is appropriate for peak horizontal acceleration and for shortperiod horizontal response spectra. Note that the difference is normalized by $\sigma$, the standard deviation of an individual prediction from the predictive equation.

tween the ground motion predicted by equation 17 and that predicted by the simple model, normalized by $\sigma$. The difference is shown in figures 99 and 100 by curves for $\beta=0$ and $\beta=2 / 3$, plotted against $\left(\boldsymbol{M}_{\max }-\boldsymbol{M}_{\mathrm{ref}}\right)$, where $\boldsymbol{M}_{\max }$ and $\boldsymbol{M}_{\text {ref }}$ are the moment magnitudes corresponding to moments $\left(M_{0}\right)_{\max }$ and $\left(M_{0}\right)_{\text {ref }}$. The curves in figure 99 are for the ratio $C_{1} / \sigma=1$, which approximates the value appropriate for peak acceleration and short-period response; the curves in figure 100 are for the ratio $c_{1} / \sigma=2$, which approximates the value appropriate for peak velocity and intermediate-period response (Joyner and Boore, 1981, 1982a, b). Except for large values of $\left(\boldsymbol{M}_{\max }-\boldsymbol{M}_{\text {ref }}\right)$, the differences are relatively small in comparison with $\sigma$. This circumstance is fortunate in that it frees us from the necessity of establishing accurate values of $\beta$ and $\boldsymbol{M}_{\max }$. Although figures 99 and 100 show large differences between the predictions of the simple model and those of equation 17 for small values of $\beta$ and large values of $\left(\boldsymbol{M}_{\max }-\boldsymbol{M}_{\text {ref }}\right)$, we contend that the simple model is generally the more appropriate basis for ground-motion predictions. The falloff of the curves for $\beta=0$ at large $\left(\boldsymbol{M}_{\max }-\boldsymbol{M}_{\mathrm{ref}}\right)$ on figures 99 and 100 represents assumed earthquake sequences consisting of very large magnitude events occurring at a very low annual rate. If we could really be confident that such sequences were representative of the real seismicity, we could use them as a basis for predicting ground motion.

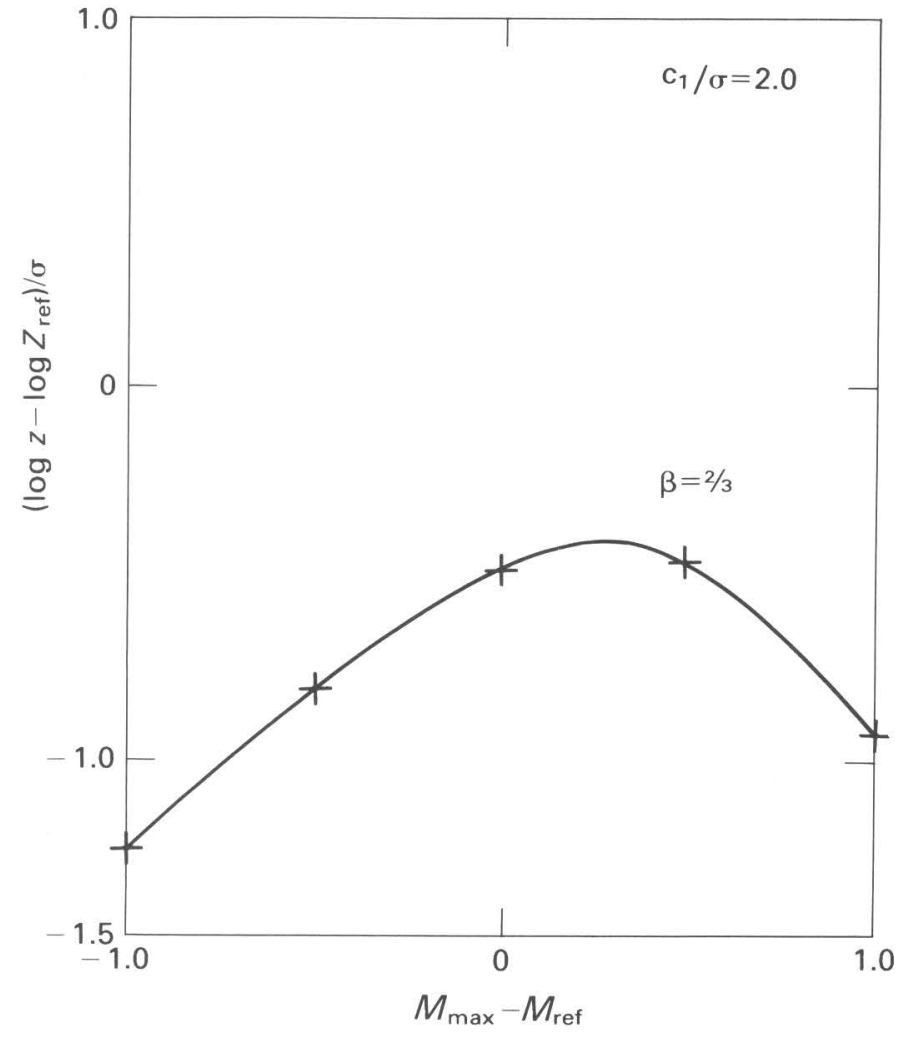

FIGURE 102.-Difference between the ground-motion value predicted by the simple model and the value predicted by using a magnitudefrequency relation of the Gutenberg-Richter type whose density distribution curve is truncated at a maximum magnitude $\boldsymbol{M}_{\max }$. Other symbols are explained in the text. A value of two for the $c_{1} / \sigma$ ratio is appropriate for peak horizontal velocity and for intermediate-period horizontal response spectra. Note that the difference is normalized by $\sigma$, the standard deviation of an individual prediction from the predictive equations.

In general, however, there is no basis for confidence, and those sequences represent an imprudent basis for prediction.

Figures 99 and 100 are based on equation 16, which represents a cumulative distribution curve of the Gutenberg-Richter type truncated at a maximum moment $\left(M_{0}\right)_{\max }$ as described by Molnar (1979). An alternative, perhaps more appealing on physical grounds, is to truncate the density distribution rather than the cumulative distribution. To compare this alternative with the simple model, the analysis described above was repeated, except that equation 21 was replaced by the following equation:

$$
n\left(M_{0}\right)=\frac{(1-\beta) \dot{M}_{0}}{\left(M_{0}\right)_{\max }^{1-\beta}} M_{0}^{-\beta-1}
$$

The results, shown in figures 101 and 102, are quite similar to those obtained by using equation 21 , shown in figures 99 and 100.

The same simple model that we propose as a basis for making ground-motion predictions can be used to estimate the effect on those predictions of using different values of the annual rate $N_{r}$ at which it is assumed 
that the predicted value will be exceeded. According to equation 13 , the reference moment $\left(M_{0}\right)_{\text {ref }}$ for the simple model scales as $N_{r}{ }^{-2}$. From the $c_{1}$ coefficient of tables 33 and 34 and the definition of moment magnitude given in equation 6, we see that peak horizontal acceleration and short-period response scale approximately as $\left(M_{0}\right)_{\mathrm{ref}}^{1 / 6}$, which is equivalent to $N_{r}^{-1 / 3}$, and that horizontal velocity and intermediate-period response scale approximately as $\left(M_{0}\right)_{\mathrm{ref}}^{1 / 3}$, which is equivalent to $N_{r}^{-2 / 3}$. In other words, a change by a factor of two in $N_{r}$, or equivalently in probability, corresponds to a change by a factor of 0.79 in peak acceleration and by a factor of 0.63 in peak velocity. The result for peak horizontal acceleration is approximately the same as that obtained by a completely different method by Algermissen and Perkins (1976], who gave as a rule of thumb that peak horizontal acceleration scales as $N_{r}^{-0.43}$. 


\section{PREDICTING RELATIVE GROUND RESPONSE}

\section{By A. M. Rogers, J. C. Tinsley, and R. D. Borcherdt}

\section{INTRODUCTION}

The character of ground shaking at a point on the Earth's surface generated by an earthquake is influenced by distance from the causative fault, characteristics of the earthquake source, and geologic conditions within the Earth's mantle and crust. Geologic conditions at or near a site are known to exert an especially significant influence on the nature of ground shaking (Milne, 1898; Lawson and others, 1908; Kanai, 1952; Gutenberg, 1957; Medvedev, 1962; Borcherdt, 1970; Murphy and others, 1970; Rogers and others, 1979). In the Los Angeles region, Wood (1933) noted that the 1933 Long Beach earthquake caused more damage in Compton than it did in Long Beach and ascribed this difference to local geologic effects. For the same earthquake, Campbell (1976) showed that, for a given distance from the Newport-Inglewood zone, damage at sites underlain by unconsolidated soils was greater than that at sites underlain by consolidated soils. Certain frequencies of strong shaking may be amplified considerably by thin low-velocity surface layers, and the overall spectral level of ground motion may increase as the seismic velocity of near-surface materials decreases and (or) as the thickness of sediments increases (Murphy and Hewlett, 1975; Borcherdt and Gibbs, 1976; Rogers and others, 1979). Although the importance of local geologic conditions has long been recognized, the quantitative prediction of the influence of these conditions on ground shaking by either empirical or theoretical models is still in the developmental stage.

\section{PREVIOUS STUDIES}

Problems central to the theoretical or empirical prediction of site response are related to differences in wave types, angles of incidence, azimuth of approach, and Earth heterogeneity (Hudson and Douglas, 1975; Murphy and Hewlett, 1975; Esteva, 1977) and to the question of nonlinear soil behavior (Seed and Idriss, 1970; Hardin and Drnevich, 1972). Relative changes in the proportions of body- and surface-wave energy as a function of epicentral distance, for instance, might alter the ground response in a manner not predicted by either theory or empiricism. Nevertheless, site-specific velocity models have been used with linear or nonlinear models of shear-wave propagation in a layered geologic column to obtain theoretical estimates of local siteresponse effects (Kanai, 1952; Kanai and Yoshizawa, 1958; Murphy and others, 1971; Lastrico, 1970; Joyner and Chen, 1975). Comparisons of theory and observed data indicate that theoretical models can often be used to predict site response (Borcherdt and Gibbs, 1976; McEvilly and Johnson, 1980; Joyner and others, 1981). Simple one-dimensional models frequently are used because they provide first-order approximations of site response. These models also apply to either radial or transverse components of motion because the angle of incidence through near-surface low-velocity sediments is nearly vertical (Murphy and others, 1970). The disadvantage of these models is that essential subsurface data are not available everywhere; furthermore, the models are not applicable in all situations.

Empirical methods are not limited in the same manner that most theoretical solutions are. Because measurements of site response incorporate the effects of waves arriving from many directions (backscattering) and the effects of both body and surface waves, they provide a smoothed estimate to the solution of the more complex problem, reflecting the effects of true Earth geometry. Underground nuclear explosions were first used as distant seismic sources in empirical studies of site effects by Borcherdt (1970) and Murphy and others (1971). Lowstrain measurements of small earthquakes or distant nuclear explosions obtained over a region on a variety of local site conditions can directly provide a map of potential geographic variations in site response (Murphy and Hewlett, 1975; Hays and Algermissen, 1982; Hays and King, 1982). Correlation of site response and known geologic data is also a useful technique for extrapolating relative shaking effects over a broad region or for making estimates at specific sites. Borcherdt and Gibbs (1976), for example, have established a relation between the age of surficial deposits and the mean spec- 
tral amplification in the San Francisco Bay region that has enabled them to produce a regional map showing expected geographic variations in shaking intensity. These studies and those of Mueller and others (1982), King (1982), and Rogers and others (1984) suggest that, for many situations, effects of local site conditions may predominate over other effects such as changing source azimuth, wave type, and angle of incidence. These studies have shown that changes in mean spectral amplification from low-level ground motions are correlated with geologic structure, measured in-situ shearwave velocities, and changing earthquake intensities and spectral levels; these correlations suggest that, in many cases, site effects can be predicted empirically as well as theoretically.

Using nuclear explosions to study or predict site amplification assumes that site effects produced by lowlevel ground motions from distant nuclear explosions are similar to those that would be observed during strong shaking. A significant question of engineering interest is, "To what extent can ground-response measurements determined from low levels of shaking (small strains less than $10^{-5}$ ), such as those recorded from distant nuclear explosions, be extrapolated to predict ground response at higher levels of shaking induced by nearby damaging earthquakes?" Laboratory-based studies suggest that soils behave in a nonlinear fashion when strain levels exceed about $10^{-5}$ (Seed and Idriss, 1970) or $10^{-4}$ (Turner and Stokoe, 1982). That is, at strains of this level or greater, soils begin to lose strength (as reflected by a decrease in shear modulus, which causes increased wave amplitudes) and to increase wave attenuation or damping (as reflected by an increase in the damping coefficient, which causes decreased wave amplitudes). Theoretical modeling of soils suggests that, at certain frequencies, the ratio of surface to base-input motion for soils undergoing nonlinear high-strain behavior will be lower than the ratio for the same soils responding in a linear manner to lower base-input motions. This behavior is due to the fact that the effects of increased damping dominate the effects of reduction in shear modulus (Borcherdt and others, 1975; Joyner and Chen, 1975). The changes in soil properties produced by nonlinearity increase the fundamental resonant period of site shaking and lower the resonant peak level. For the most part, however, these effects of nonlinear soil behavior have not been observed in strong-ground-motion records.

On the contrary, field data suggest that highamplitude soil response is similar to low-amplitude soil response, perhaps for strains up to $10^{-3}$. Using recordings of nuclear events at two Nevada Test Site locations (Murphy and others, 1971), Rogers and Hays (1978) have shown that site response measured at strains of $10^{-3}$ and $10^{-4}$ are essentially equal. Joyner and others (1981) have demonstrated that linear theoretical models predict the site response at a recording site in the area of the Coyote Lake, Calif., earthquake for strains as large as $10^{-4}$. Rogers and others (1984) have compared site response measured by using distant nuclear explosions (strains near $10^{-5}$ ) with site response at the same locations measured by using data from the 1971 San Fernando earthquake (strains near $10^{-3}$ ) and have found that the two data sets are equivalent within the expected variability of the statistics (fig. 103). Field observations of earthquake damage also suggest that high-amplitude soil response and low-amplitude soil response are similar.

A high correlation between mean spectral amplification was determined for sites near San Francisco from Nevada Test Site nuclear explosions and from observed 1906 earthquake intensities, up to San Francisco intensity level 4 (Borcherdt and others, 1975). Espinosa and Algermissen (1972) found a correlation between the thickness of alluvial sediments, mean spectral amplification derived from low-level ground motions generated by small earthquakes, and damage to highrise buildings in the 1967 Caracas, Venezuela, earthquake. These studies provide evidence supporting the assumption that soil responds to very high levels of damaging shaking without significant nonlinear behavior. These studies also support the argument that differences between wave types and other factors caused by ground motions resulting from distant low-level sources and those caused by nearby strong earthquakes have only secondorder significance in comparison with the site-response phenomena. These results suggest that, for in situ soils, the changes produced in the shear modulus and in the damping factors by strong shaking are smaller than the changes suggested by the results of laboratory testing of samples.

Soils have been observed to sustain large damaging ground motions that include soil amplification effects. In addition to the examples cited in the introduction, table 37 shows that ground motions as large as $0.7 \mathrm{~g}$ and $108.8 \mathrm{~cm} / \mathrm{s}$ have been recorded on soils. In the Italian earthquakes cited in table 37, accelerations (at some sites as large as $0.5 \mathrm{~g}$ ) recorded on thin soils (less than $20 \mathrm{~m}$ ) were higher by factors of as much as four in comparison with those recorded on thick soils or rock. These cases may or may not have exhibited nonlinear behavior but, nonetheless, demonstrate large damaging ground motions at sites underlain by soil. Even though nonlinear behavior can limit the magnitude of ground motions on soils, the upper limits of shaking on soils still appear to be high in some cases.

The effect of nonlinear soil response may also be restricted to a small area surrounding the causative

\section{Earthquake Hazards in the Los Angeles Region}


A

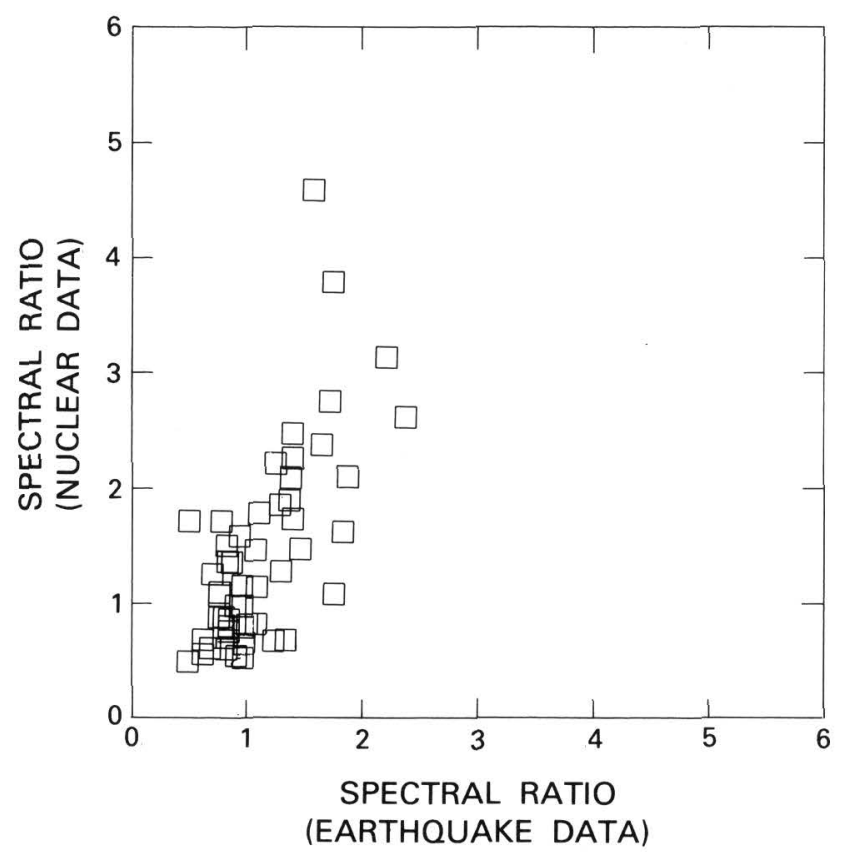

$C$

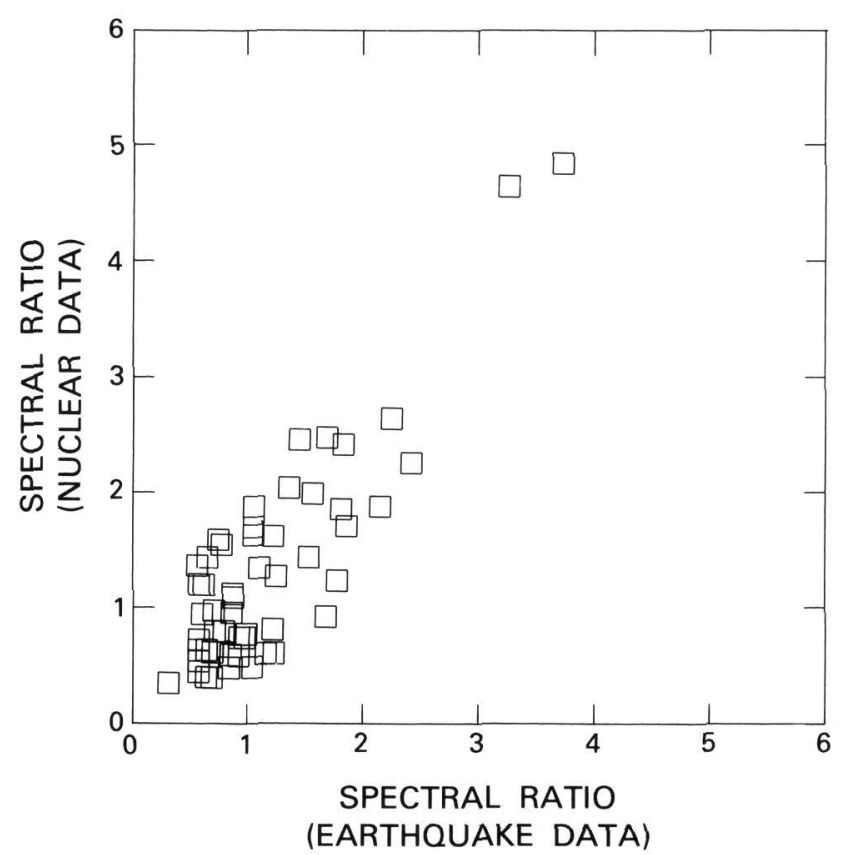

B

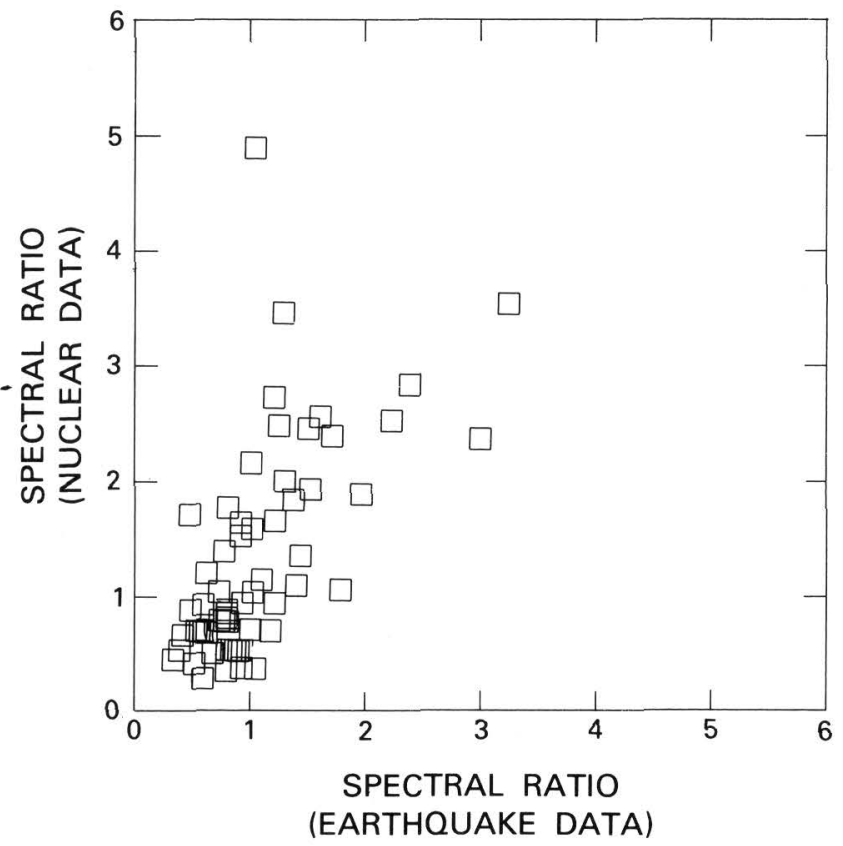

$D$

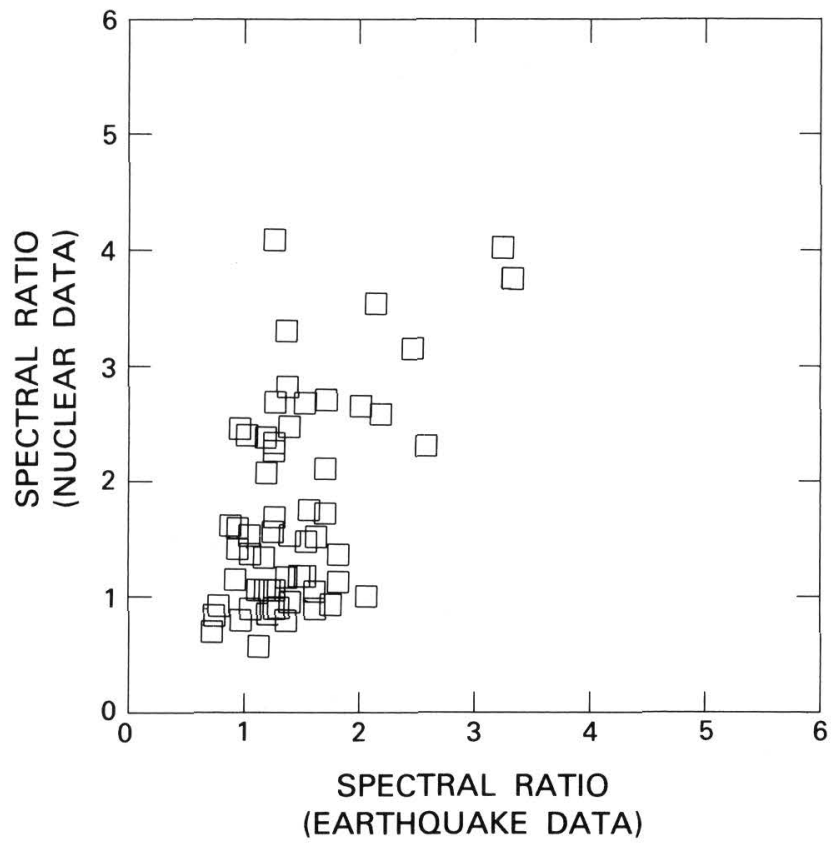

FIGURE 103.-Comparisons of the geometric mean spectral ratios in four period bands determined from ground-motion recordings of distant underground nuclear explosions and from the 1971 San Fernando earthquake (from Rogers and others, 1984). A, 0.2 to $10.0 \mathrm{~s}$. B, 0.2 to $0.5 \mathrm{~s}$. C, 0.5 to $1.0 \mathrm{~s}$. $D, 1.0$ to 3.3 . $\mathrm{s}$. These data indicate that small ground motions obtained from distant sources can be used to estimate differences in ground response from nearby damaging earthquakes.

fault (Hays and Algermissen, 1982). A magnitude 7 to 7.5 earthquake, for instance, develops velocities on soil sites exceeding $100 \mathrm{~cm} / \mathrm{s}$ at distances of less than 7 to 13 $\mathrm{km}$ from the fault (dependent on the magnitude) (Joyner and Boore, 1981). For soil sites having $200-\mathrm{m} / \mathrm{s}$ shearwave velocities, strains of $5 \times 10^{-3}$ will be developed 
TABLE 37.-Peak ground motions and estimated strains recorded at selected sites underlain by unconsolidated sediments $[--$, no data]

\begin{tabular}{|c|c|c|c|c|c|}
\hline Earthquake & Station & $\begin{array}{l}\text { Acceleration, } \\
\text { in } \mathrm{g}\end{array}$ & $\begin{array}{l}\text { Velocity, } \\
\text { in } \mathrm{cm} / \mathrm{s}\end{array}$ & $\begin{array}{l}\text { Estimated } \\
\text { strain }\end{array}$ & References \\
\hline 1966 Parkfield --1-- & 2 & 0.48 & 78.1 & $5 \times 10^{-3}$ & $\begin{array}{l}\text { Earthquake Engineering Research Laboratory } \\
\text { (1969-1975). } \\
\text { Nuclear Regulatory Commission (1980) }\end{array}$ \\
\hline 1979 Imperial Valley --_---_- & 6 & .72 & 108.8 & $\begin{array}{l}5 \times 10^{-3} \\
\text { to } 10^{-4}\end{array}$ & $\begin{array}{l}\text { Porcella and Matthiesen (1979) } \\
\text { Mueller and others (1982) }\end{array}$ \\
\hline 1972 Ancona, Italy, and 1976 Friuli, Italy --- & -- & $\begin{array}{l}\text { Up to } \\
0.5\end{array}$ & -- & -- & Chiaruttini and Siro (1981) \\
\hline
\end{tabular}

within this zone. Observations discussed in this section indicate that this strain level may still be below the level of significant nonlinear behavior. Because damaging motions on soils (Modified Mercalli intensities greater than or equal to VI) occur at distances of 60 to $100 \mathrm{~km}$ from the fault (Howell and Schultz, 1975), the region of damage within which nonlinear soil response is possible is about 2 to 9 percent of the total area of damage, if a $30-\mathrm{km}$ rupture is assumed. Where the fault passes through developed regions, the zone of nonlinear behavior may be the area of greatest life loss, but a high percentage (as much as 90 percent) of the economic loss occurs outside this zone (Algermissen and others, 1972). Where the fault passes outside the developed zone or the earthquake is too small to induce nonlinear soil response, this behavior will not be a factor at all (for example, the 1967 Caracas, Venezuela, earthquake and the 1977 Romanian earthquake).

\section{COMPARATIVE GROUND RESPONSE IN THE LOS ANGELES REGION}

Comparative ground response to distant nuclear explosions was measured at 98 sites throughout the Los Angeles region. When these measurements are coupled with available geologic and geotechnical data, they provide an extensive data base to delineate potential geographic variations in strong ground shaking. Threecomponent recordings of Nevada Test Site nuclear explosions were made at each site. A total of 19 nuclear explosions were used; because some sites were reoccupied for several events, 159 three-component records were obtained. Sites for the study (fig. 104) were chosen to obtain as complete a sample of underlying geologic conditions and as broad a geographic coverage as possi-

\section{Earthquake Hazards in the Los Angeles Region}

ble. Because the seismic source lies between 400 and $450 \mathrm{~km}$ from the recording sites, the effects of azimuthal variations in the energy radiated by the source and the major portions of the crustal propagation paths are similar for all sites.

The response characteristics of each site over the period band 0.2 to $10 \mathrm{~s}$ were computed by using Fourier spectral ratios (Borcherdt and Gibbs, 1976). The Fourier spectral ratios $(F)$ were computed from

$$
F_{i j}(k / T)=\left[s_{i j}(k / T)\right] /\left[s_{0_{j}}(k / T)\right] \quad \begin{aligned}
k & =0, \ldots, n \\
i & =1, \ldots, m \\
j & =v, t, r
\end{aligned}
$$

where $s_{i j}(k / T)$ corresponds to the smoothed Fourier amplitude spectra for a signal of length $T$ at frequency $k / T$ for the jth component at the ith station and $s_{0_{j}}(k / T)$ designates the corresponding smoothed amplitude spectra computed from a simultaneous recording at the reference station. The ratios were computed only at those frequencies for which a signal-to-noise ratio greater than a factor of two existed for both spectra. The noise level was determined by examining the spectra of a time segment before the arrival of the signal on each component of motion. These data, including processing techniques, copies of recorded time-histories, and spectral ratios, have been compiled and discussed by Rogers and others (1980).

A site located on crystalline rock (CIT) (fig. 104) was reoccupied for every recorded nuclear explosion. By using CIT spectra $\left(s_{0_{j}}(k / T)\right)$ as the base rock site, it was possible to minimize the effects of source, transmission path, and instrument response in the spectral ratios (Rogers and others, 1979). Thus, the spectral ratios are assumed to reflect only frequency-dependent site amplification effects. The spectral ratio technique has been used by a number of investigators to obtain a first- 
A
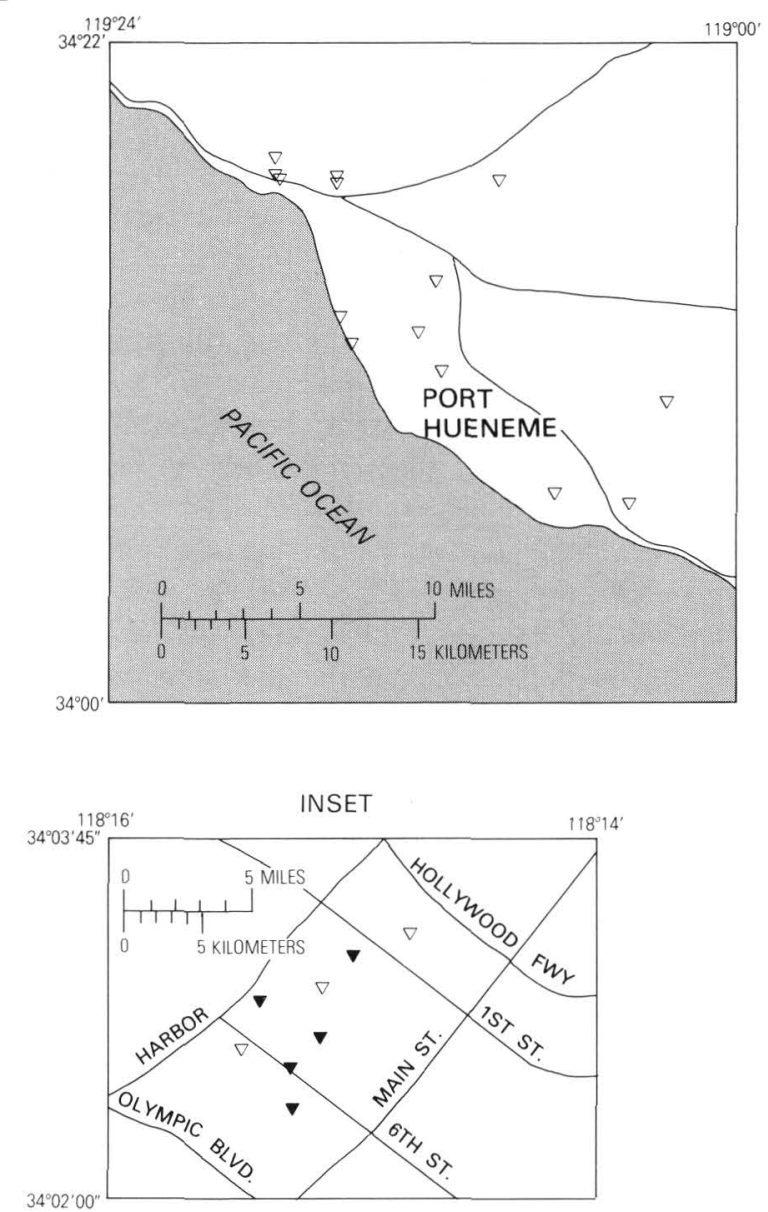

C

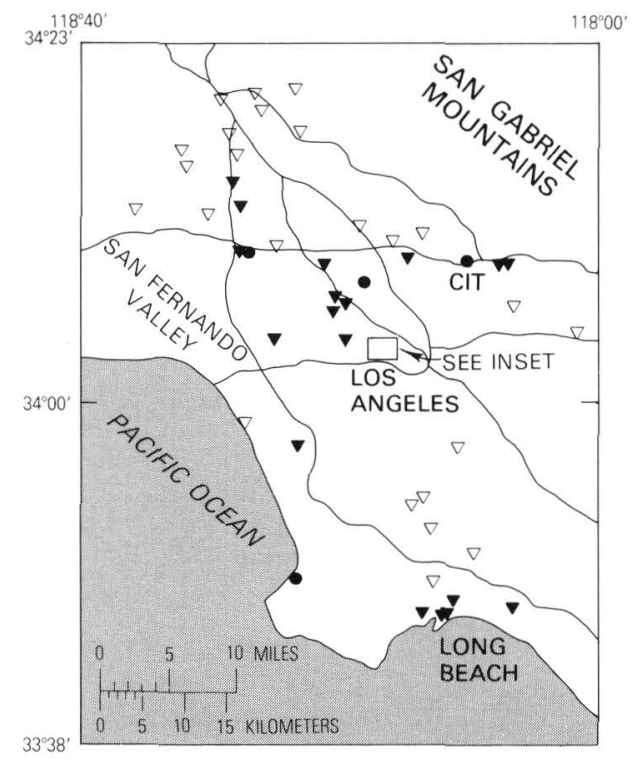

$B$
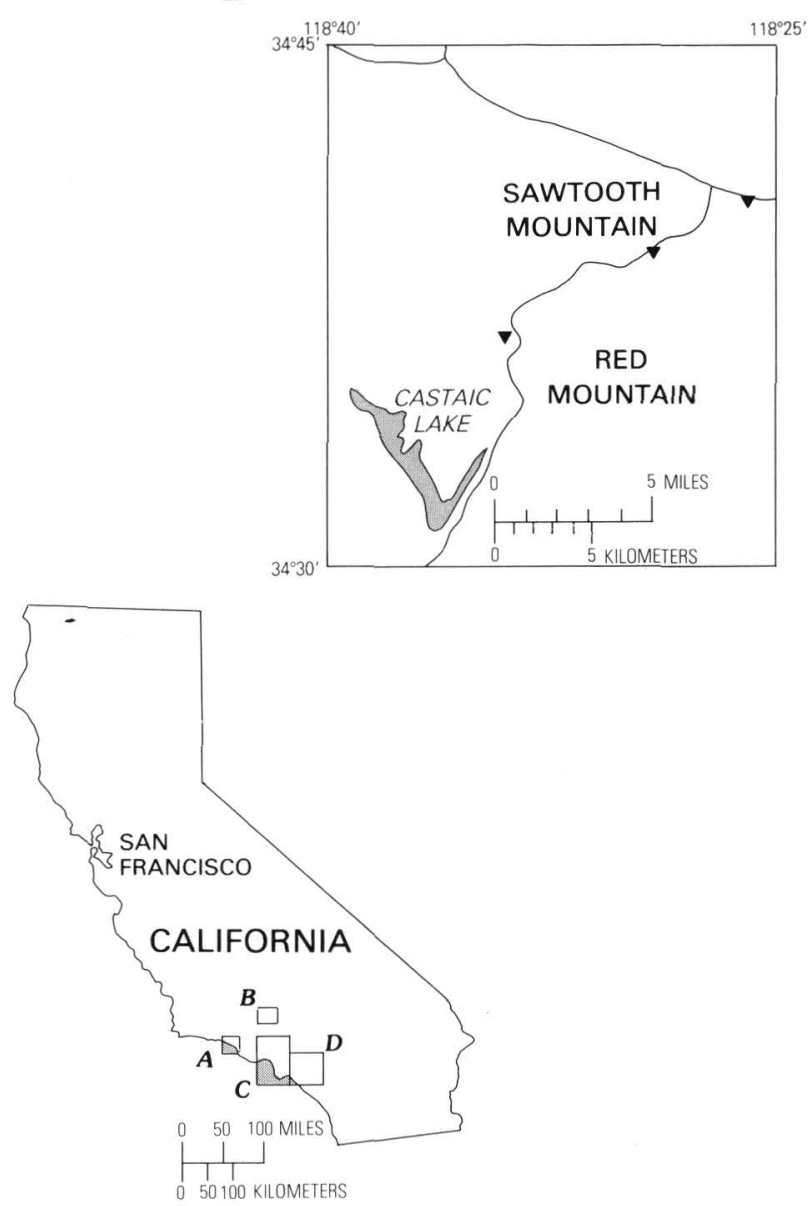

$D$

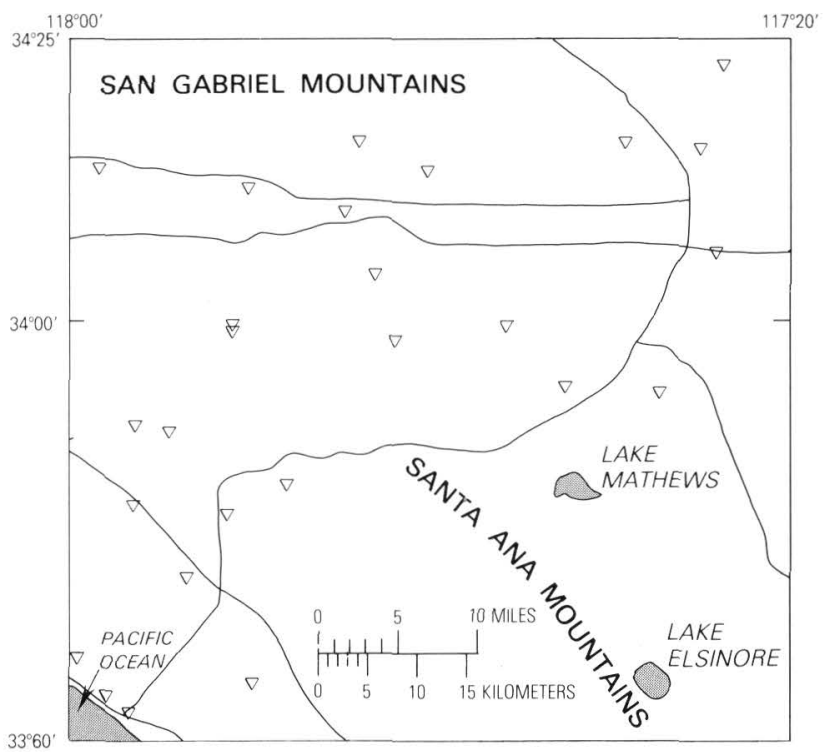

FIGURE 104.-Locations of sites (triangles) in the Los Angeles region at which ground-motion recordings of underground nuclear explosions at the Nevada Test Site were obtained. Strong-motion recordings of the 1971 San Fernando earthquake were also available at some of these locations, indicated by the solid triangles. Open triangles indicate that only nuclear test recordings are available at a site. Station names and locations are taken from Rogers and others (1980). 
order approximation of the site amplification of local geologic deposits (Kanai and others, 1956; Gutenberg, 1957; Borcherdt, 1970; Rogers and others, 1979). The ease with which the extraneous effects are removed from nuclearevent recordings is one of the prime motivations for using such events; nearby earthquakes produce recordings in which site amplification, source, and propagation-path phenomena are intertwined and difficult to study individually (Hanks, 1975).

In the case of ground motions from distant nuclear explosions, the effects of site conditions dominate on the recorded time-histories. Figure 105, for example, shows time-histories from a single Nevada Test Site nuclear explosion recorded simultaneously at eight sites. The example illustrates several effects of local site conditions commonly observed on recorded time-histories from distant sources of shaking. Maximum amplitudes of motion recorded on the alluvial sites, for instance, are several times larger than those recorded on the sedimentary- or crystalline-rock sites. The duration of ground motion at the alluvial sites is generally longer than that at the rock sites. The degree of amplification occurring in the longperiod peak amplitudes of these records is greatest at sites underlain by the thickest sediments. Comparison of all three components of ground motion recorded at each site (Rogers and others, 1980) shows that the amplification of horizontal ground motions is commonly larger than that of vertical motions. In the following discussion, only the horizontal components of ground motion are emphasized, because they are the most important in structural engineering.

The amplitude spectral ratios computed for the simultaneous recordings shown in figure 105 are presented in figure 106, where station CIT has been used as the reference station. The ratios show that the effects of site conditions relative to those at CIT are strongly frequency dependent and that amplification occurs for many of the sites over most of the frequency band for which a good signal-to-noise ratio exists. Horizontal amplification factors in the range 2 to 7 are apparent for the lower frequency ground motions $(<1 \mathrm{~Hz})$ for those sites on thick sections of alluvium; lower amplifications are apparent at these periods for sites underlain by thin sections of alluvium. Considerable amplification at the intermediate frequencies $(1-2 \mathrm{~Hz})$ and at the higher frequencies $(2-5 \mathrm{~Hz})$ is readily apparent at several of the sites, the horizontal amplification at site FS4 being indicative of a predominant ground-resonant frequency. Note that resonance is not a factor for the thick alluvial sites, which display relatively flat spectra across the entire observed frequency range. The spectral ratios for the GOC and CIT sites show that the spectral levels of the two crystalline-rock sites are very similar for the lower frequencies, but the intermediate-frequency and higher frequency motions recorded at GOC are larger than those recorded at CIT. Site 3838, located on sedimentary rock, indicates a uniformly higher response in comparison with the response at CIT over most of the frequency band.

Amplification does not produce large peaks in the time-history for FS4 because the frequency of maximum incoming energy is not coincident with the resonance peak frequency. This result points out the pitfall of examining peak ground-motion parameters for site effects. A site may have a strong amplification effect that is not necessarily reflected by the peak accelerations, for instance.

The spectral ratios are similar for most of the nuclear explosions analyzed. An example of the spectral geometric means and their geometric standard deviations is shown in figure 107, together with data from the individual events used to compute the statistics. Additional examples have been computed by Rogers and others (1980), who have shown that the geometric standard deviation averages 1.38 independent of frequency (this result is seen more clearly in their log-log plots). By comparison, this dispersion is lower than that associated with the empirical prediction of root-mean-square acceleration on rock (Hanks and McGuire, 1981).

The spectral ratios computed from shaking induced by distant nuclear explosions suggest that the observed ground motions varied significantly from site to site, depending on the type of underlying geologic deposits. At many sites, amplification is strongly frequency dependent. The level of spectral response at alluvial sites commonly is higher than that at rock sites, and the amplitude and duration of shaking depend on the thickness of the underlying sediments. Sites having thin alluvium tend to amplify shaking over a narrow frequency range, whereas sites having thick alluvium amplify shaking over a broad frequency range. These general conclusions are consistent with similar data and a similar interpretation reported by Borcherdt and Gibbs (1976) for the San Francisco Bay region.

\section{GEOLOGIC AND GEOTECHNICAL PARAMETERS AFFECTING GROUND RESPONSE}

The diverse geologic framework of southern California offers a unique opportunity to study variations in earthquake-generated ground shaking as a function of geologic setting. Crystalline rocks, for example, are exposed in rugged mountains more than $3 \mathrm{~km}$ above sea level and, in the deepest parts of the Los Angeles basin, are buried beneath at least $10 \mathrm{~km}$ of sedimentary rock

\section{Earthquake Hazards in the Los Angeles Region}




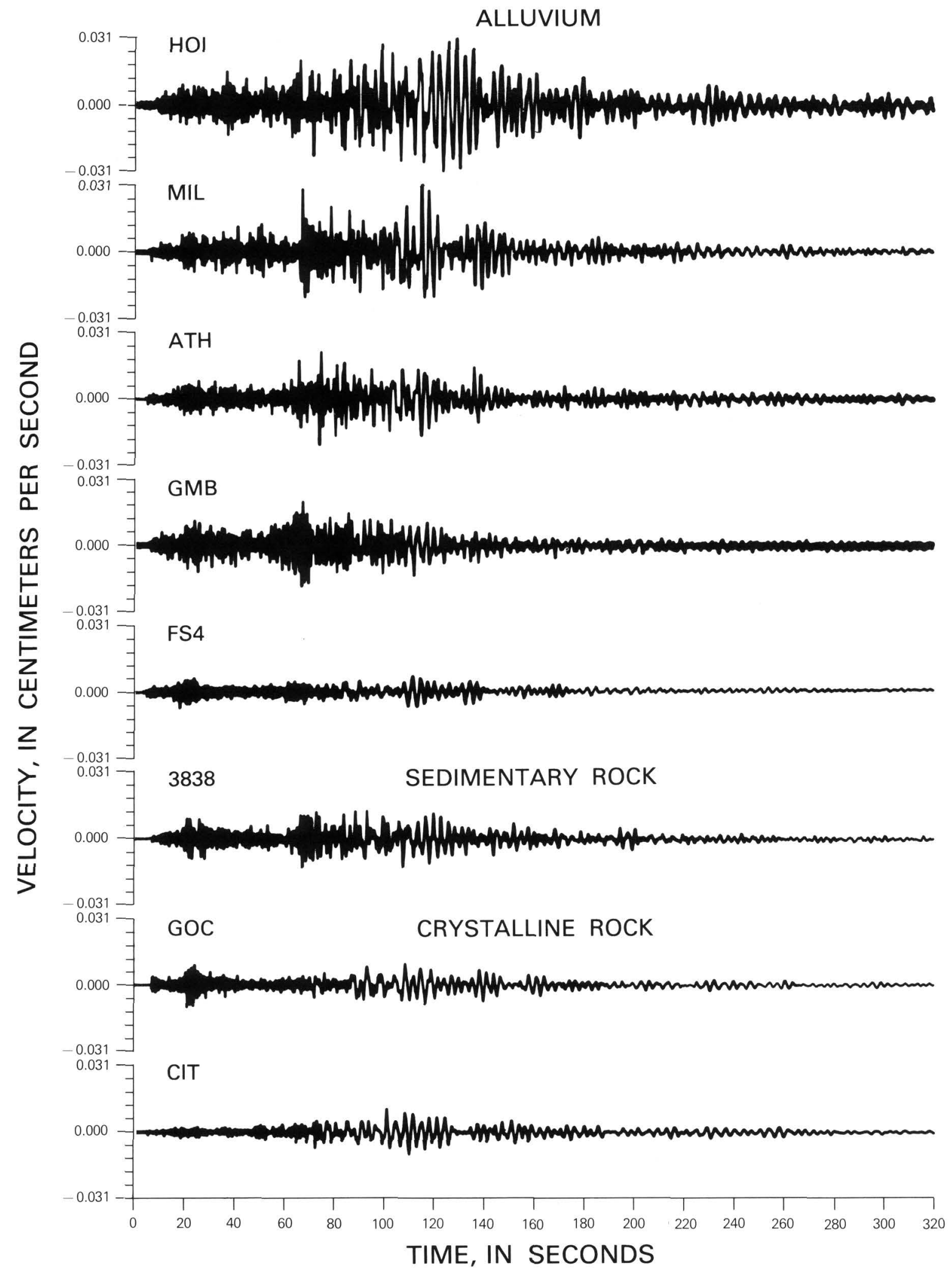

FIGURE 105.-Radial component time-histories of ground motion from a distant underground nuclear explosion in Nevada recorded simultaneously at eight sites in the Los Angeles region and grouped according to the type of geologic materials immediately beneath each recording station. The amplitude levels at locations underlain by alluvium clearly are greater than those at locations underlain by rock. The degree of amplification also appears to be related to the thickness of underlying alluvium: HOI, Holiday Inn, 300 m; MIL, Millikan Library, 372 m; ATH, Athenaeum, 372 m; GMB, Glendale Municipal Building, $120 \mathrm{~m}$; FS4, Fire Station 4, $15 \mathrm{~m}$. GOC, CIT, and 3838 are rock sites. 

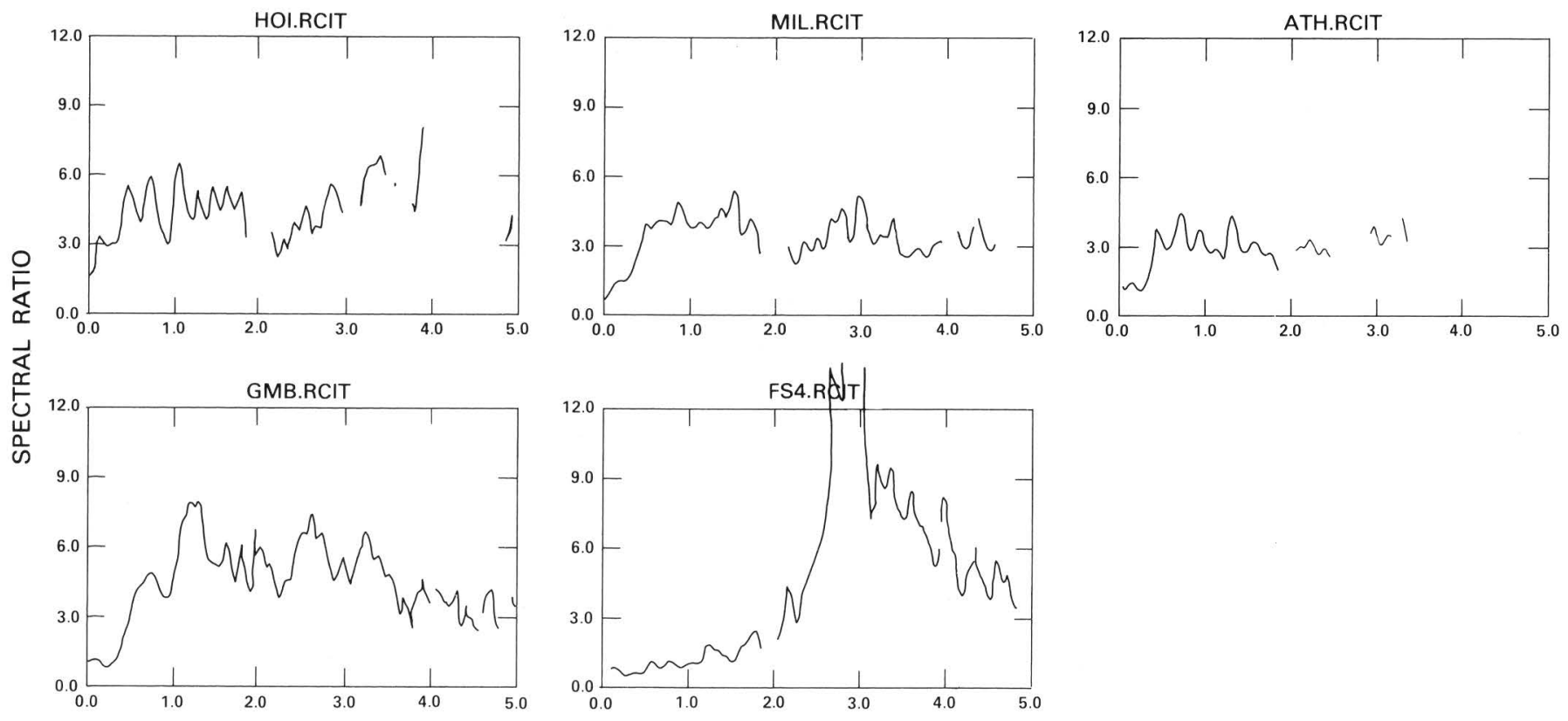

SEDIMENTARY ROCK/CRYSTALLINE ROCK

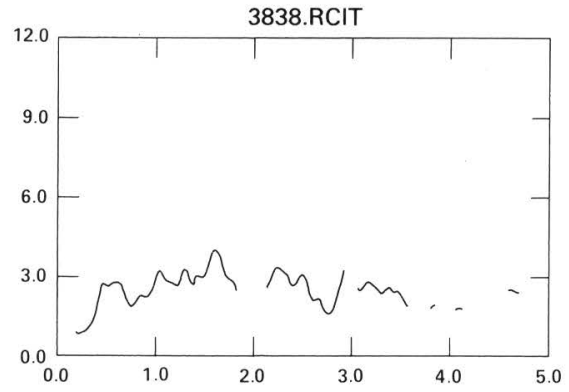

CRYSTALLINE ROCK/CRYSTALLINE ROCK

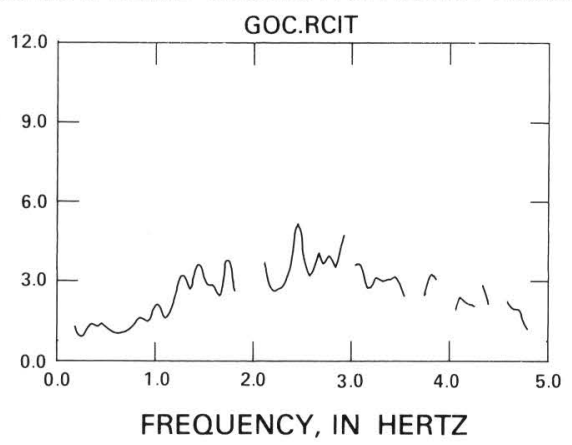

FIGURE 106.-Spectral ratios of the radial components of ground motion (see fig. 105) recorded on sites having geologic conditions different from the crystalline-rock site (CIT). These diagrams show that spectral site amplification ranges from about 1 to greater than 12; the highest ratios occur at sites underlain by alluvium. Site FS4 displays a resonant frequency between 2 and $3 \mathrm{~Hz}$, whereas other sites have more uniform amplification, averaging as much as 6 in some frequency bands.

and alluvium (Yerkes and others, 1965). The youngest deposits in the basins of the Los Angeles region consist chiefly of unconsolidated to partly consolidated alluvialfan and river flood-plain sediment. These deposits range in thickness from 0 to $10 \mathrm{~m}$ near basin margins to, perhaps, more than $50 \mathrm{~m}$ in coastal basins. Sand and mud occur in ancient and modern shore areas; windblown sands are present locally in inland basins. Basin 
fill, mostly of Quaternary age and some of Pliocene age, ranges widely in texture; gravel, cobbles, and boulders occur chiefly near mountain fronts and in channels on alluvial fans emanating from the mouths of major canyons, and silt and some clay commonly are deposited on flood plains tens of kilometers from the mountains.

The 98 recording sites used in this study encompass a broad range of the variations in depth to basement rock and in the texture and physical properties of basin fill. Geologic and geotechnical information about the uppermost few tens of meters of basin fill at each groundmotion recording site was compiled from logs of soilengineering boreholes, water wells, and limited field investigations (Gibbs and others, 1980; Fumal and others, 1981, 1982; J. C. Tinsley, written communication, 1982). The soil-engineering logs, chiefly of foundation studies, are from files maintained by city, county, State, and Federal agencies and from geotechnical consulting firms. These records describe the near-surface sediment in terms of its grain size, moisture content, and dry density. Many of these boreholes penetrate the uppermost 5 to $10 \mathrm{~m}$ of the alluvial deposits, although foundation studies for major structures may penetrate up to $30 \mathrm{~m}$ or more.

The general geologic character and the thickness of surficial sediments in the depth range from 15 to $300 \mathrm{~m}$ have been inferred from drillers' lithologic logs of water wells and from geophysical logs of oil and water wells filed with State and local agencies. Studies of the regional hydrology (Poland, 1959; Poland and others, 1956, 1959; Thomas and others, 1961; California Water Rights Board, 1961; Dutcher and Garrett, 1963; California Department of Water Resources, 1966) describing the geologic and hydrologic setting of the late Quaternary alluvial basins have been incorporated where pertinent.

For each recording site, several engineering and water-well logs were examined, and the most representative data-usually obtained from the borings closest to, if not beneath, the site-were used to characterize each site. We regard three thickness parameters as significant for characterizing the sites: (1) the total thickness of sedimentary deposits, expressed as the depth to the crystalline igneous and (or) metamorphic rocks underlying the basins; (2) the approximate thickness of semiconsolidated sediment, expressed as the approximate thickness of the Quaternary (less than 1.7 m.y. old) deposits; and (3) the approximate thickness of unconsolidated or poorly consolidated sediments, expressed as the approximate thickness of Holocene (less than 10,000 yr old) sediment. The lithologic and time-stratigraphic horizons bounding these rock units commonly correspond to physically significant interfaces in the subsurface across which the shear-wave velocities and relative den- sities of the sediment may change (Fumal, 1978; Gibbs and others, 1980; Fumal and others, 1981, 1982) and thus alter the response characteristics of the site.

A number of geotechnical factors (table 38) were chosen to characterize the recording sites either because they have some direct application in a theoretical model of site response and (or) because they have been reported to have some influence on ground shaking in past studies. Parameters such as mean percentage of silt and clay, void ratio, and depth to water table have been reported to influence site response (Barosh (1969) has summarized many of these studies), whereas shearwave velocity, Holocene deposit thickness, Quaternary deposit thickness, depth to cementation, and depth to basement rocks are all parameters that might be used directly in a theoretical model of site effects. The alluvium-to-rock spectral ratios were reduced to a small set of numbers by computing the geometric mean spectral ratio over 10 period bands. Because a high degree of correlation was observed between the mean spectral values in some of these period bands, only three nonoverlapping bands were used in further analysis. These bands are referred to as the short-period $(0.2-0.5 \mathrm{~s})$, intermediate-period (0.5-3.3 s), and long-period (3.3-10 s) bands. A discussion of the geotechnical parameters themselves follows.

Mean void ratio.-Void ratios (e) are computed from dry-density (GD) data obtained from the foundationengineering data by using the relation $e=(G S / G D)-1$, where GS is the density of the solids without voids. For most soils, GS varies from 2.65 to 2.70 . By assuming the lower value for sand and the higher value for clay, mean e values were computed for each alluvial site, generally for the upper $8 \mathrm{~m}$. At layered sites having several values of $e$, the depth-weighted mean was computed. Mean $e$ rather than mean shear-wave velocity was used in this study to characterize the sites for several reasons. First, laboratory studies by Hardin and Drnevich (1972) have indicated that $e$ and shear modulus are inversely related, and Rogers and others (1979) have determined that site response increases as e increases, a result that might be predicted from the relation between $e$ and shear-wave velocity. Figure 108 uses data from Los Angeles and San Francisco to show this relation. The curve fit to these data can be used to estimate shearwave velocity from $e$. Second, data on void ratios were readily available from engineering boreholes and were therefore a useful and inexpensive way to estimate near-surface shear-wave velocity. Data on void ratios were also available at nearly twice as many sites as data on shear-wave velocity; because of the effort and expense involved in collecting borehole measurements, the shear-wave velocities were not available for many sites until this study was almost complete. Third, void 
FS4. V BACKBEACH

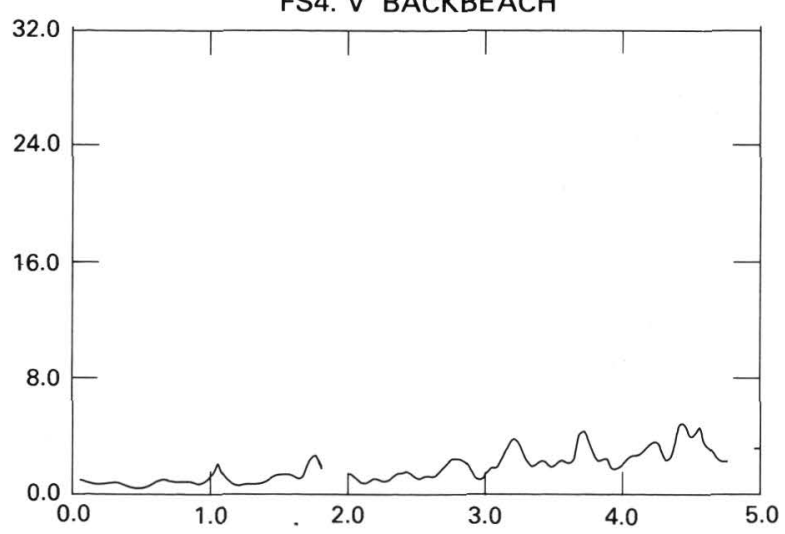

FS4. T BACKBEACH

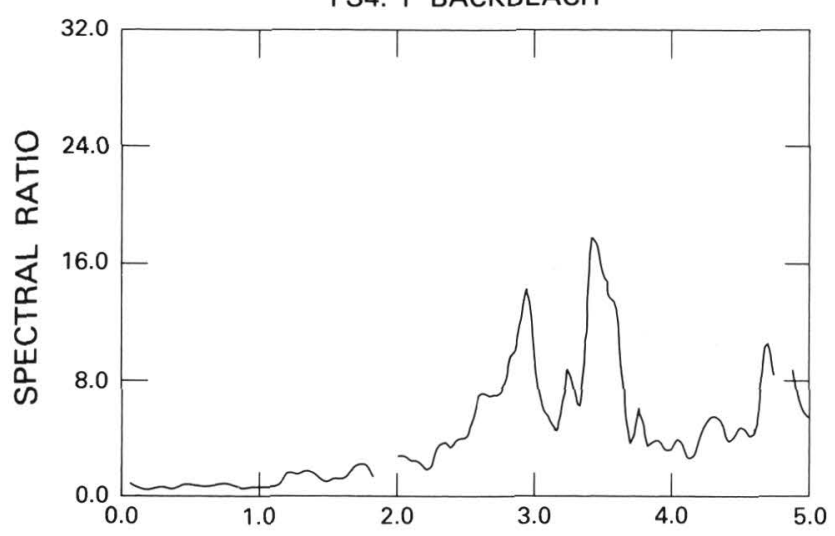

FS4. R BACKBEACH

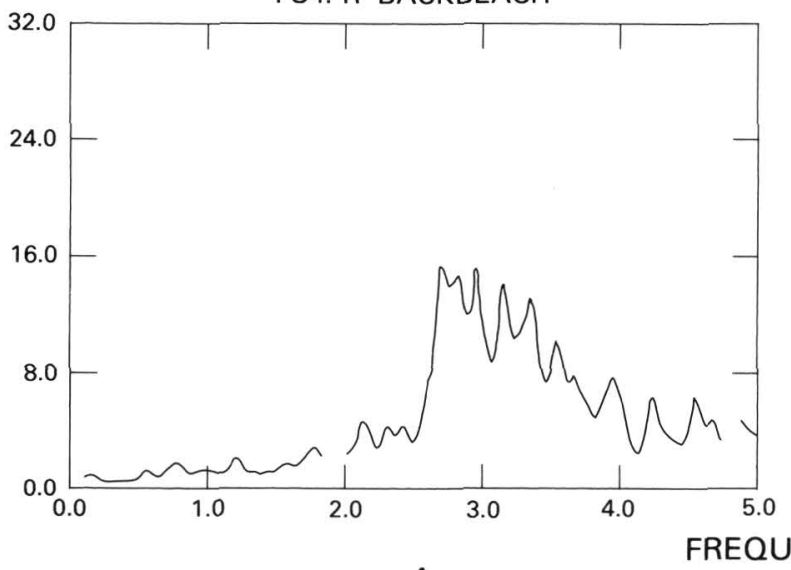

A

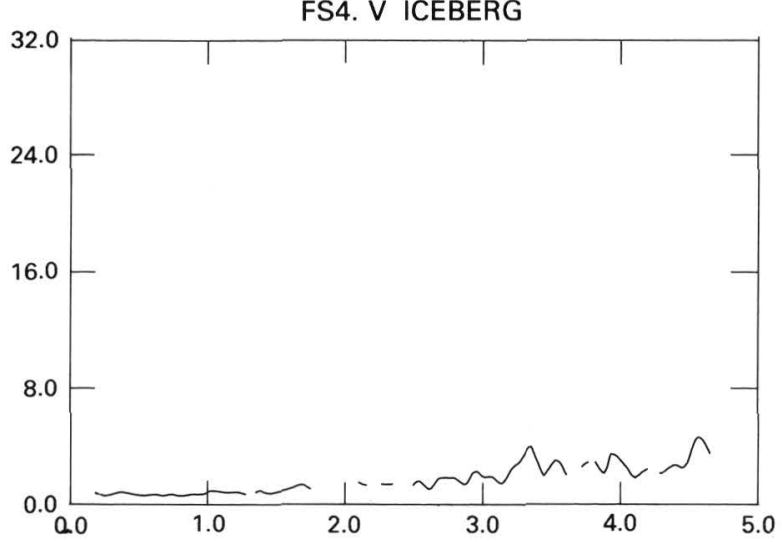

FS4. T ICEBERG

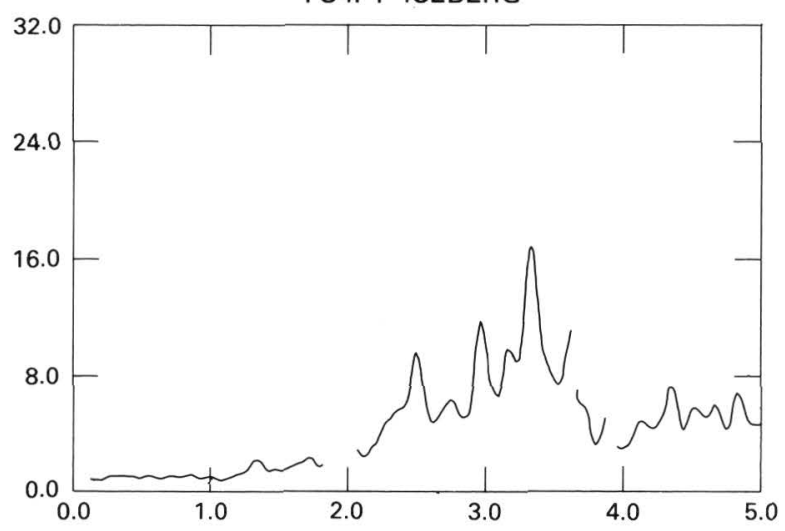

FS4. R ICEBERG

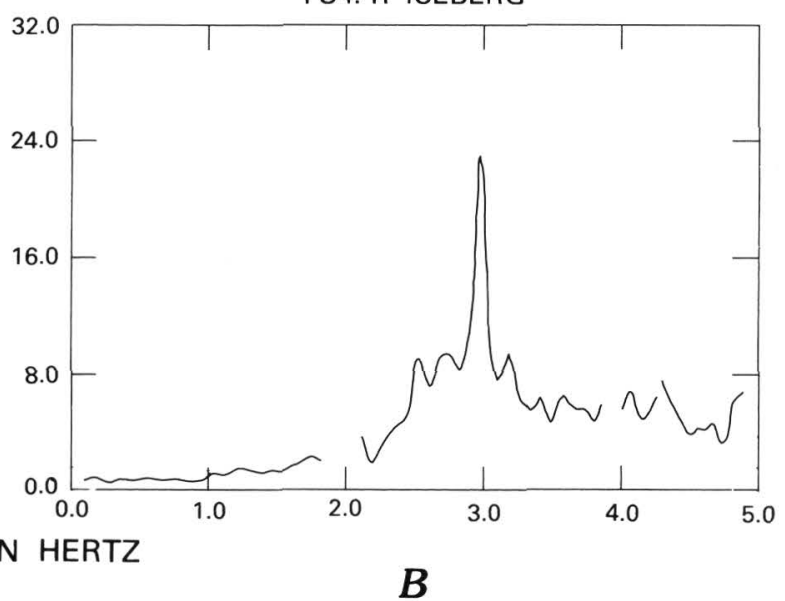

FIGURE 107.-Comparison of spectral ratios computed for stations FS4 (alluvium) and CIT (crystalline rock) for distant nuclear explosions. A, Backbeach. B, Iceberg. C, Fondutta. Components of shaking are vertical (V), transverse (T), and radial (R). The geometric mean spectral ratio (solid line) and one geometric standard deviation about the mean (dashed and dotted lines) are also shown (D). The geometric standard devia- 
FS4. V FONDUTTA

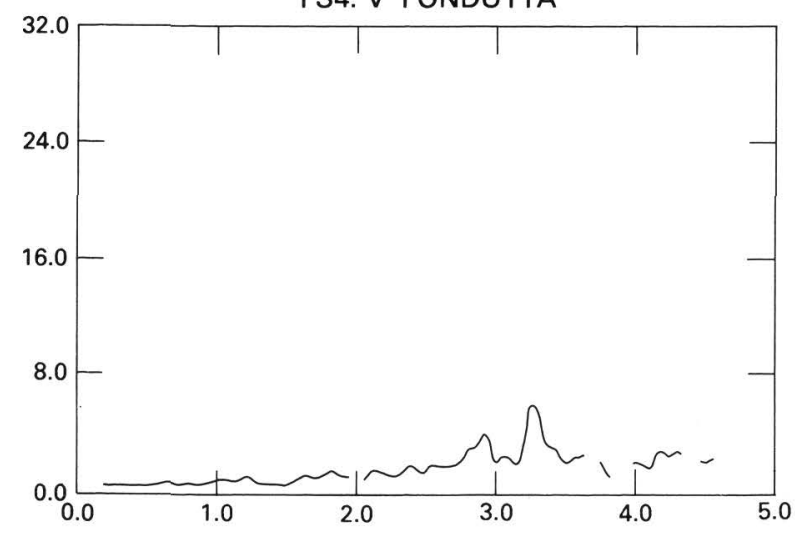

FS4. T FONDUTTA

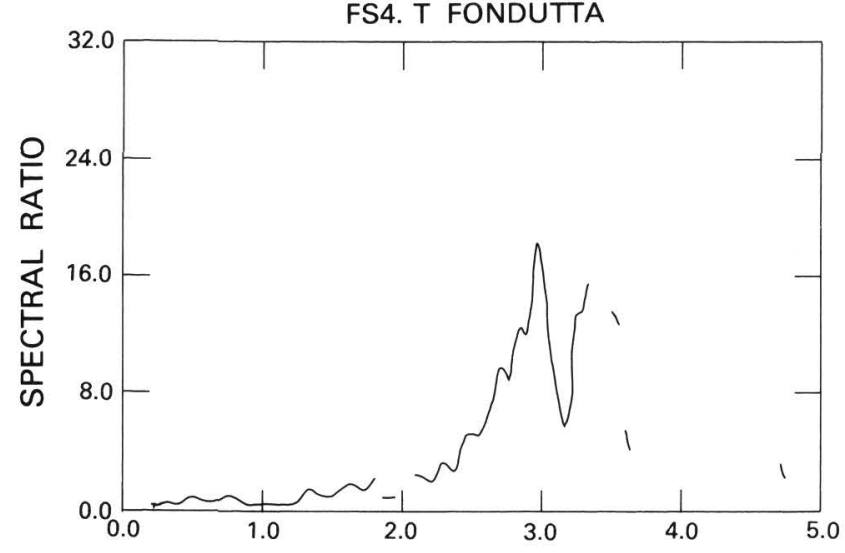

FS4. R FONDUTTA

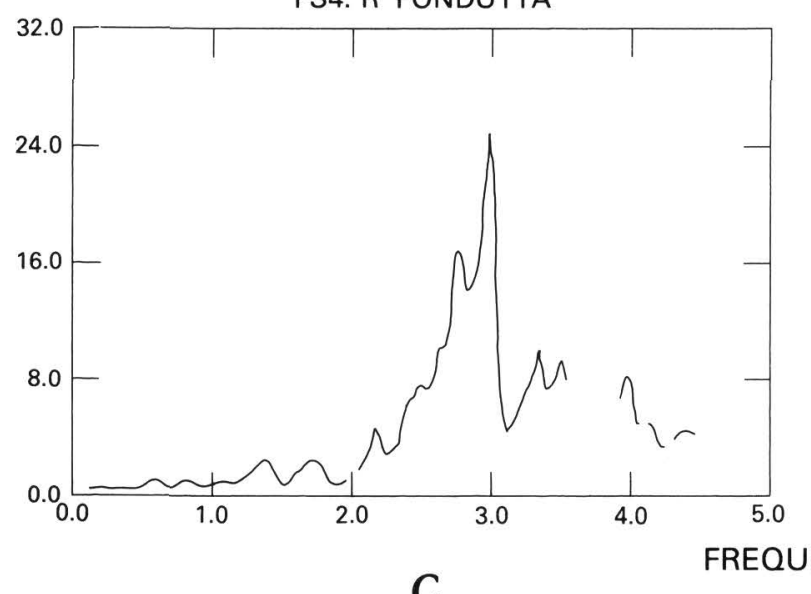

C
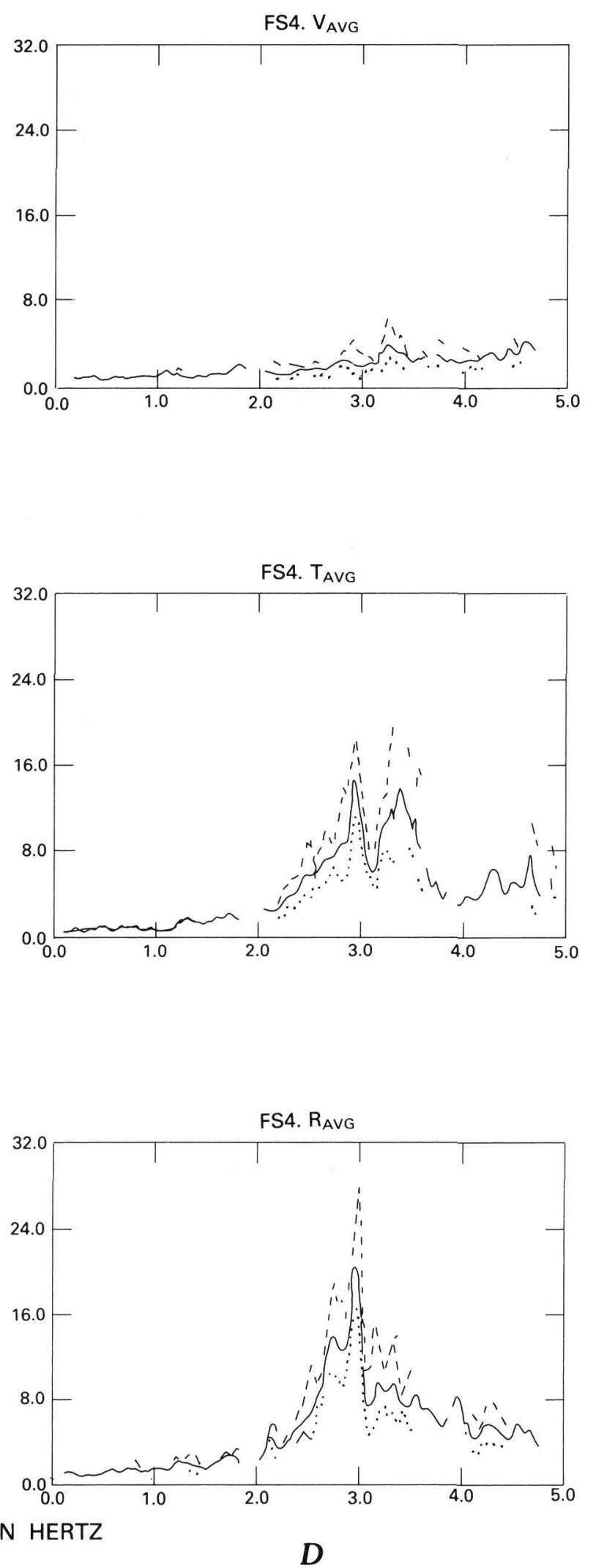

tion in this case averages to a factor of about 1.3 across the frequency band. Similar examples for other stations have been shown by Rogers and others (1984). These diagrams demonstrate the reproducibility of the spectral ratios between distant nuclear events. 
TABLE 38.-Geotechnical parameters and the percentage of stations for which each parameter was available

\begin{tabular}{|c|c|}
\hline $\begin{array}{r}\text { Statior } \\
\text { paramete } \\
\text { in }\end{array}$ & $\begin{array}{l}\text { ns for which } \\
\text { r was available, } \\
\text { percent }\end{array}$ \\
\hline Mean void ratio $(0-8 \mathrm{~m})$ & 82 \\
\hline $\begin{array}{l}\text { Mean percentage of silt and - } \\
\text { clay (four depth intervals). }\end{array}$ & 37-95 \\
\hline Thickness of Quaternary -- & 100 \\
\hline Age - - & 100 \\
\hline Thickness of Holocene -- & 99 \\
\hline Depth to water table - - & 97 \\
\hline 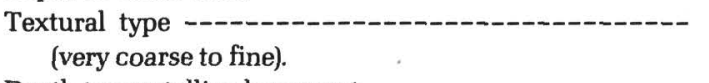 & 99 \\
\hline Depth to crystalline basement - & 100 \\
\hline Depth to cementation -- & 91 \\
\hline $\begin{array}{l}\text { Mean borehole shear-wave - } \\
\text { velocity (four depth intervals). }\end{array}$ & 42 \\
\hline
\end{tabular}

ratios were frequently measured at the building where the nuclear-event recordings were made, whereas shear-wave velocity measurements sometimes had to be taken tens to hundreds of meters away. Thus, in some cases, an e value computed for the recording site may be a more relevant measure of the shaking response at the recording site than a shear-wave velocity measurement made some distance away. Even though the void ratio is generally known only in the upper $8 \mathrm{~m}$, which represents only a fraction of the near-surface wavelength in the short-period band, the high correlation observed in this period band between void ratio and shaking response indicates that the near-surface void ratio reflects information about the mean shear-wave velocity over a deeper sediment section. This supposition is supported by the highly significant correlation coefficient $(-0.6)$ in our data between mean void ratio in the upper $8 \mathrm{~m}$ and mean shear-wave velocity in the upper $30 \mathrm{~m}$.

Mean percentage of silt and clay.-The mean percentage of silt and clay was determined from the lithologic descriptions of boreholes for selected thicknesses of 8 , 15,30 , and $122 \mathrm{~m}$ by summing the total incremental thicknesses of sediment logged as silt or clay within the interval, dividing that sum by the thickness of the interval, and then multiplying the quotient by 100 .

Thickness of Quaternary.-The base of the Quaternary sedimentary deposits was selected arbitrarily at the base of the marine San Pedro Formation in the coastal basin areas and at the base of the nonmarine(?) sand and gravel that comprise the freshwater-bearing alluvium in the interior basins. Some of these basinal nonmarine(?) deposits are almost certainly preQuaternary in age, but correlations among these deposits are not reliable.

Age.-Recording sites were classed according to the geologic age of the underlying surficial deposits-for

\section{Earthquake Hazards in the Los Angeles Region}

example, Holocene alluvium, Pleistocene alluvium, Tertiary sedimentary rock, Tertiary volcanic rock, or preTertiary crystalline igneous and metamorphic rock (crystalline basement). Sites were classed as rock sites where a thin alluvial veneer had been excavated and had been removed during construction of the building that housed the recording instrument.

Thickness of Holocene.-Holocene deposits are commonly associated with historical flooding and are capped by soils having minimally developed profiles. In practical terms, in the field, the base of the Holocene section is placed generally at the top of the uppermost red or reddish-brown buried soil. Early Holocene deposits may have nonclayey (cambic) B horizons or nonreddened clay-enriched B horizons, except within historically active flood basins (McFadden and Tinsley, 1982).

Depth to water table.-The distance from the ground surface to free ground water, expressed here as "depth to ground water" (including perched water), was determined from logs of boreholes located near each instrument site and from selected maps and records maintained by the California Department of Water Resources, the Los Angeles County Flood Control District, and the City of Los Angeles Department of Water and Power.

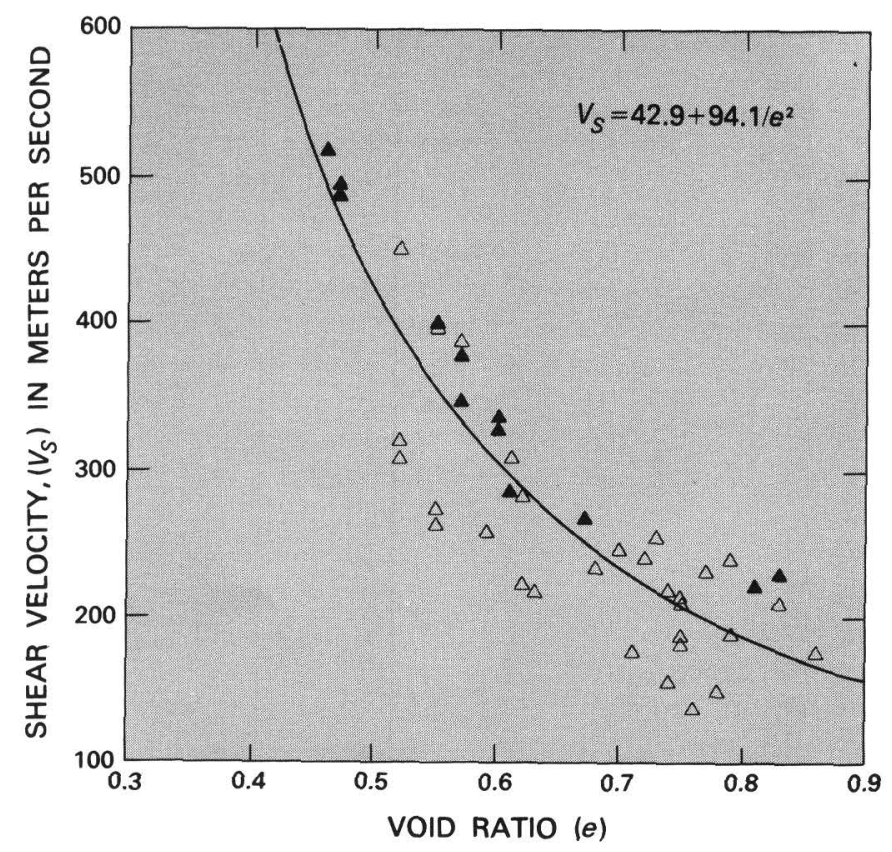

FIGURE 108.-Relation between mean shear-wave velocity in the upper $10 \mathrm{~m}$ and mean void ratio in the upper $8 \mathrm{~m}$. Solid triangles are data from the San Francisco region (Fumal, 1978), and open triangles are data from the Los Angeles region. The curve, which is a leastsquares fit to all of the data, can be used to estimate shear-wave velocity $\left(V_{S}\right)$ for sediments in cases where only void-ratio (e) data are available. 
Textural type.-The grain-size distribution of the surface sediment at the instrument site was classified as very coarse, coarse, medium, or fine, depending on the texture of the surface soil as mapped by the U.S. Department of Agriculture or the U.S. Bureau of Soils. Very coarse grained deposits contain boulders and cobbles, coarse-grained deposits contain gravel, medium-grained deposits contain chiefly sand, and fine-grained deposits contain chiefly silt and clay.

Depth to crystalline basement.-The depth to basement rock is the vertical distance from the land surface to crystalline igneous or metamorphic rock. Depths to basement, which may exceed $10 \mathrm{~km}$ in the Los Angeles basin (Yerkes and others, 1965, p. A4), have been estimated from electric logs, lithologic logs, and gravity models, such as McCulloh's $(1957,1960)$ model.

Depth to cementation.-Depth to cementation is defined as the distance from the land surface to sediments described in drilling logs as "cemented." The stratigraphic position at which this effect is noted apparently varied from driller to driller as well as from place to place.

Shear-wave velocity.-Borehole shear-wave velocity measurements were made to a depth of $30 \mathrm{~m}$ at 41 of the 98 nuclear recording sites (Gibbs and others, 1980; Fumal and others, 1981, 1982, 1984). Mean shear-wave velocity was computed for depth intervals of 0 to 2,0 to 5,0 to 15 , and 0 to $30 \mathrm{~m}$.

\section{COMPARING GROUND RESPONSE WITH GEOLOGIC FACTORS}

We will first explore the dependence between response data and geotechnical parameters to determine which factors have the strongest influence on site response in each period band. Having determined the most important factors, we will then present an empirical technique for predicting site response on the basis of these variables, whereby recording sites are grouped or clustered on the basis of similarity among the most important geologic site factors in a given period band. Grouping of the sites is accomplished by using the techniques of cluster analysis and discriminant analysis of cluster trials. To use these techniques, the mean siteresponse values and the geologic variables first must be assembled into a 98 -station by 27 -variable matrix, which permits us to easily extract relevant columns for analysis. After the clusters are formed, a geographic area is classified into one of the clusters on the basis of its geologically distinctive characteristics for a given period band, and the geometric mean cluster response is assigned as the response for that area. Although it is impractical to show all the details of the process leading to the final results of this study, we will examine the more important stages in the following discussions.

To examine the relation between site response and geologic parameters, the most straightforward approach is to group the sites according to variations in one of the geologic factors and to compute the mean response for each group, as table 39 does. These results indicate that, for the Los Angeles region, (1) levels of shaking at sites underlain by Holocene and Pleistocene sedimentary deposits are three to four times greater than those at sites underlain by crystalline rock for all period bands; (2) the void ratio has a strong influence on short-period response (void ratios in the 0.8 to 0.9 range indicate a mean response on soil that is six times greater than that on crystalline rock and three times greater than that on soils having low void ratios); and (3) amplitudes in the long-period band generally increase as the thickness of Quaternary deposits and (or) the depth to basement increases. The apparently anomalous finding (table 39) that the response of sites on Miocene rock is higher than that of sites on Pliocene rock may be attributed to causes other than age. Three of the Miocene rock sites are on ridges or areas of high topography and may be affected by topographic amplification (Boore, 1972; Rogers and others, 1974). The results given in brackets in table 39 are computed exclusive of these topographically high sites and show a closer correspondence between the two age groups at short and intermediate periods. In addition, the Pliocene rock sites that we have used are all located in downtown Los Angeles within an area of about $1 \mathrm{~km}^{2}$ and thus do not represent an even geographic distribution of sites. The Pliocene rock sites in our sample may be characterized by anomalously low response, which reflects factors that we have not considered in our analysis. We have no means by which to analyze this possibility, however. The dependence of the response variables on each of the geologic factors was examined for each period band by grouping on one factor; table 39 shows some of the stronger interrelations between these variables, but a more elaborate analysis enabled us to study these interactions and others in more detail.

The smoothing techniques of exploratory data analysis (Mosteller and Tukey, 1977; Velleman and Hoaglin, 1981) can be applied to determine the influence of one factor on the response variable, given a body of data in which several factors are changing simultaneously. The chief problem is that, for a limited data set, it may not be possible to hold several factors constant while studying the influence of another; these smoothing techniques can be a helpful analysis tool for data satisfying certain assumptions. Figure 109, for instance, shows the smoothed short-period spectral ratio versus Holocene deposit thickness and void ratio. The broad 
TABLE 39.-Comparision of mean ground response (relative to crystalline rock) from distant underground nuclear explosions recorded at sites within the Los Angeles region

[Geometric standard deviation in the response variable for these groups ranges from about 1.6 to 1.9 . Short period, 0.2 to $0.5 \mathrm{~s}$; intermediate period, 0.5 to $3.3 \mathrm{~s}$; long period, 3.3 to $10.0 \mathrm{~s}$

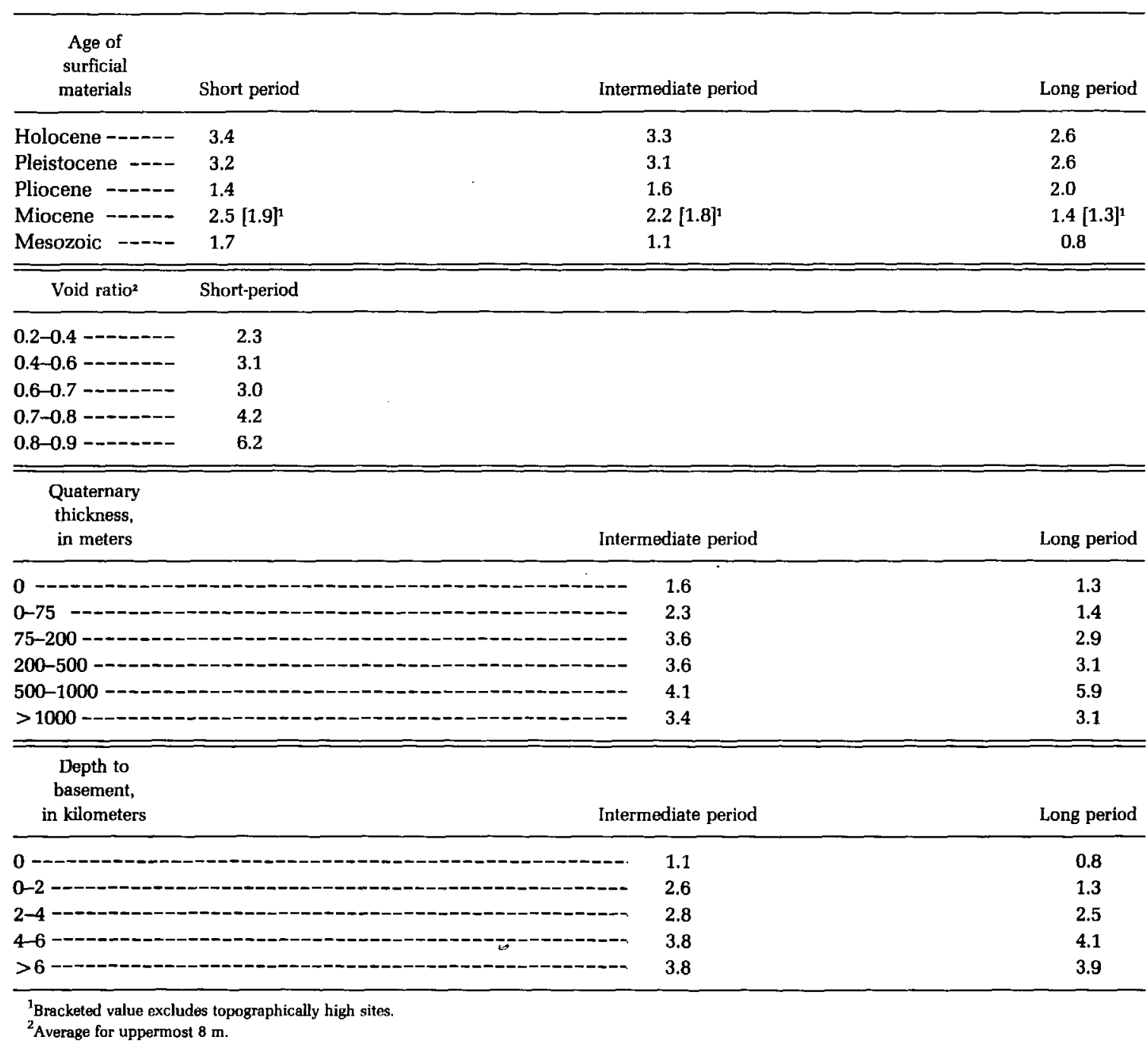

peak in the Holocene thickness plot near $15 \mathrm{~m}$ is due to the shift through this period band of the fundamental resonance period of the Holocene layer. The general increase in the short-period response as void ratio increases is caused principally by the increase in shearwave velocity between Holocene and Pleistocene deposits. For comparative purposes, theoretical spectral ratios were computed by using a horizontally layered SH-body-wave model and assuming viscous damping. The physical properties of the geologic column used in this modeling were generated by computer from the geologic data matrix; variable surface-layer velocities, fixed lower layer velocities, and depths to velocity contrasts were determined by Holocene and Quaternary deposit thicknesses and depth to basement, as figure 110 outlines. Surface-layer velocities were either measured borehole shear-wave velocities or computed from void ratios (fig. 108). The theoretical spectral ratios and the mean spectral values were processed in exactly the same fashion as the observed quantities. The concordance between observed data and theory supports our interpretation of the observed behavior and shows the utility of theoretical models for predicting mean site response. Although similar analysis of other factors indicates that variables such as depth to basement and Quaternary thickness have an effect on the short-period response, these variables and others are of secondary importance in comparison with Holocene deposit thickness and near-surface void ratio.

Identifying the chief geologic factors that control intermediate and long-period response is more difficult than identifying those that control short-period response

\section{Earthquake Hazards in the Los Angeles Region}



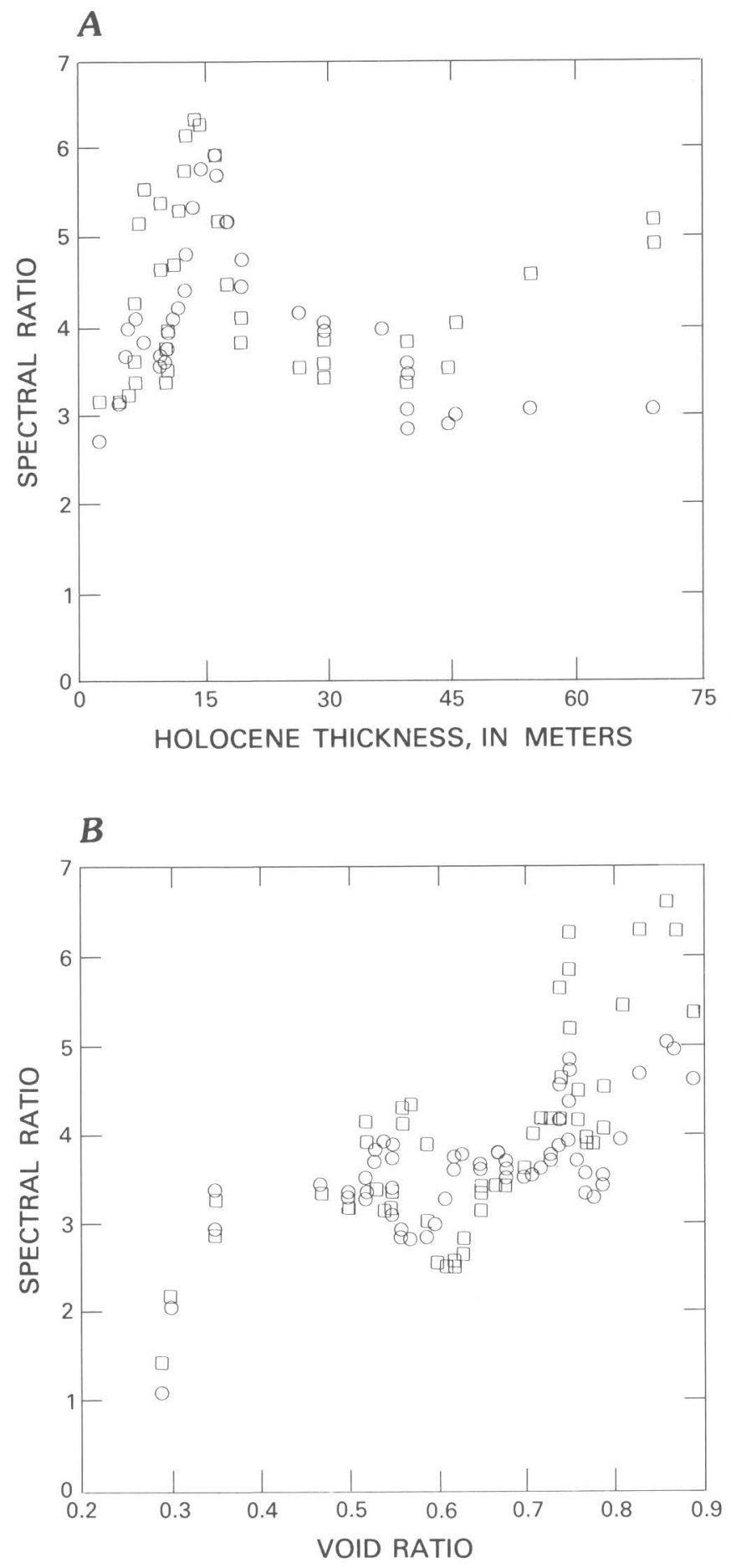

FIGURE 109.-Smoothed short-period spectral ratios at sites on Holocene deposits in comparison with Holocene thickness $(A)$ and void ratio (B). To minimize the influence of void ratio in $A$, only sites having void ratios greater than 0.65 were included. A circle indicates theoretical values; a square indicates observed values.

because a larger number of variables may be involved. Some factors, such as Quaternary thickness and depth to basement rocks, are highly interdependent, because the deep parts of the Los Angeles basin have continued to subside during the Quaternary. Moreover, the deeper structural features and shear-wave velocities may not be as well determined as the geotechnical factors controlling the short-period response, and the amount of data (for the number of variables involved) may be too limited to fully explore the problem. Some consistent behavior in these two period bands is observed, nevertheless. For thin Quaternary soils and sedimentary-rock deposits, for instance, the response in these two bands is low, whereas, for thick deposits, high response is observed, as table 39 and figures 111 and 112 show. Although the SH-body-wave model partially predicts this behavior, the correspondence between observed and predicted values is poorer at longer periods, probably because the theory applied does not model the behavior of surface waves as they propagate through laterally inhomogeneous layers. Attempts to model surface waves in such media, however, have shown that surface-wave amplitudes increase as the waves propagate from thin layers to thicker ones (Drake and Mal, 1972; Murphy and Hewlett, 1975) and thus qualitatively support the results discussed above. Examination of factors other than Quaternary thickness and depth to basement indicates that the other factors have only secondary influence on the site response in these period bands.

After studying earthquake intensities in the Soviet Union, Medvedev (1962) reported that the presence of shallow ground water in alluvial sediments apparently increased the intensity of seismic shaking. On the basis of this conclusion, Evernden and Thomson (this volume) have increased predicted intensities by one unit where saturated alluvium occurs near the surface. We reevaluated Medvedev's (1962, figs. 2.1-2.7) data in light of the results of our study in the Los Angeles region. For the types of sites that Medvedev examined, as the depth to the water table decreased to less than $10 \mathrm{~m}$, the thickness of the soil deposits increased to between 10 and $20 \mathrm{~m}$. Thus, Medvedev's observation that the highest intensities occur at sites having shallow water tables $(<10 \mathrm{~m})$ can be attributed to resonant effects associated with soils between 10 and $20 \mathrm{~m}$ thick rather than to the effect of differences in depth to the water table. Our interpretation is supported by the lack of correlation between shear-wave velocities or site response and depth to water table in San Francisco (Borcherdt and Gibbs, 1976; Fumal, 1978). In Los Angeles, sites having a water table at less than $10 \mathrm{~m}$ have a distribution of void ratios whose mean is slightly higher than that of sites where the water table is deeper; furthermore, the number of Pleistocene sites in this group is proportionately larger than that in the group where the water table is shallow. Both of these occurrences may be due to some depositional or geomorphologic causes; in the data of this 


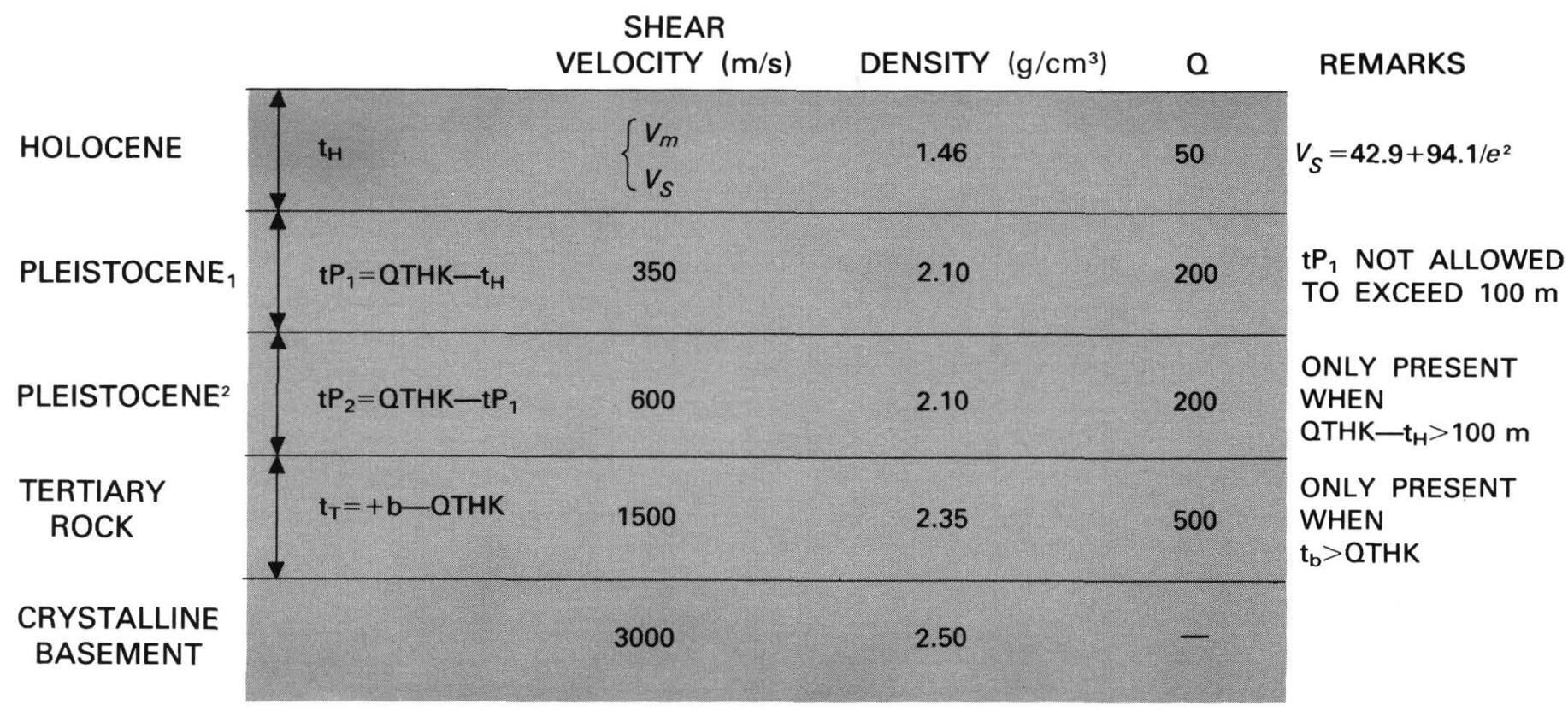

FIGURE 110.-Shear-wave-velocity model used to compute theoretical damped SH-wave response. The values for the symbols used in this figure either are calculated as shown or come from the geologic data matrix described in the text and table 38. $t_{\mathrm{h}}$ is the thickness of Holocene deposits; e, void ratio; $V_{S}$, shear-wave velocity calculated from the equation shown; $V_{m}$, borehole shear-wave velocity; $t_{p}$ and $t_{p 2}$, Pleistocene deposit thicknesses; $t_{Q}$, Quaternary deposit thickness; $t_{T}$, thickness of the Tertiary section; $t_{b}$, depth to crystalline rock. The quality factor, $Q$, is assumed in the model to include the effects of material attenuation.

study, however, these correlations are not strong enough to demonstrate a clear dependence between water table and site response. Thus, in the Los Angeles region, the lack of correlation between depth to the water table and mean short-period response or other factors controlling site response suggests that depth to water table apparently is not a reliable predictor of variation in shaking level, a view that conflicts with Evernden and Thomson's (this volume).

\section{CLUSTERING SITES TO REFLECT GROUND-RESPONSE VARIABILITY}

Sites having similar response characteristics can be clustered by computing some analytical measure of similarity between a list of items on the basis of their attributes. In our analysis, the items are recording sites, and the attributes are the geotechnical properties of each site (note that we do not use the response factor as an attribute, because we are attempting to predict response as a function of the geologic properties of a site). The clustering algorithm (Anderberg, 1973; Hartigan, 1975; IMSL, 1982) uses a computing rule to determine those items most nearly alike and the similarity level at which clusters of similar items are alike. The results can be plotted simply as an inverted hierarchical tree of similarity nodes (fig. 113). In this example, sites 5 and 6 are more nearly alike than any other pair, and 4 and 5 are more dissimilar than 1,2, 3, and 4 or $5,6,7$, and 8 . The definition of clusters is determined by specifying the level of similarity below which clusters form. At similarity level one, 5 and 6 form a cluster; at level two, 1 and 2 and 5, 6, and 7 form two clusters; at level three, 1, 2, 3, and 4 and 5, 6, 7, and 8 form two clusters. The choice of a similarity level below which clusters form is subjective and, in practice, may change across the cluster diagram.

Once a set of clusters is formed by this procedure on a chosen set of factors, it is possible to analyze the degree to which these factors define unique groups by means of discriminant analysis (Morrison, 1969, 1974; Cooley and Lohnes, 1971; Nie and others, 1975), which determines the significance of each factor's discriminating power by using the statistics of factors within and between clusters. A set of discriminant functions is computed that permits calculation of the probability that a single member of a cluster belongs to that cluster or any other cluster; given a table of these probabilities, it is possible to calculate the percentage of sites that have been correctly classified.

Our application of this procedure was a trial-anderror process, during which some of the data analysis described above was done concurrent with the cluster and discriminant analysis. At the start, the site-response data were divided into rock and alluvial groups, and then clusters were examined in which many or all of the measured factors were part of the clustering model. 
A

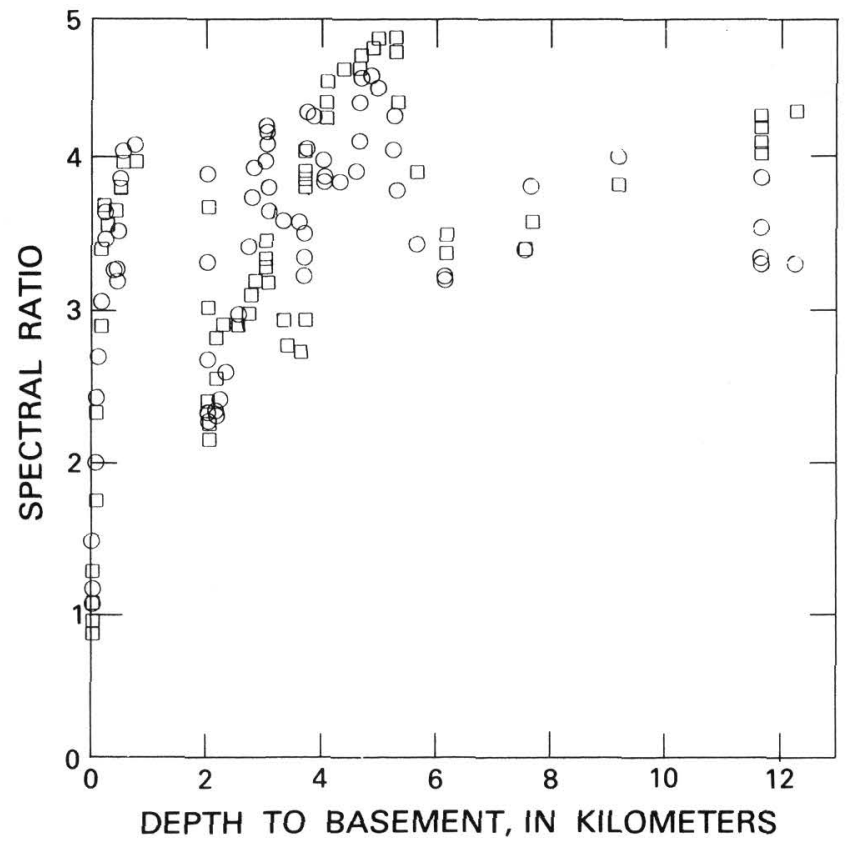

B

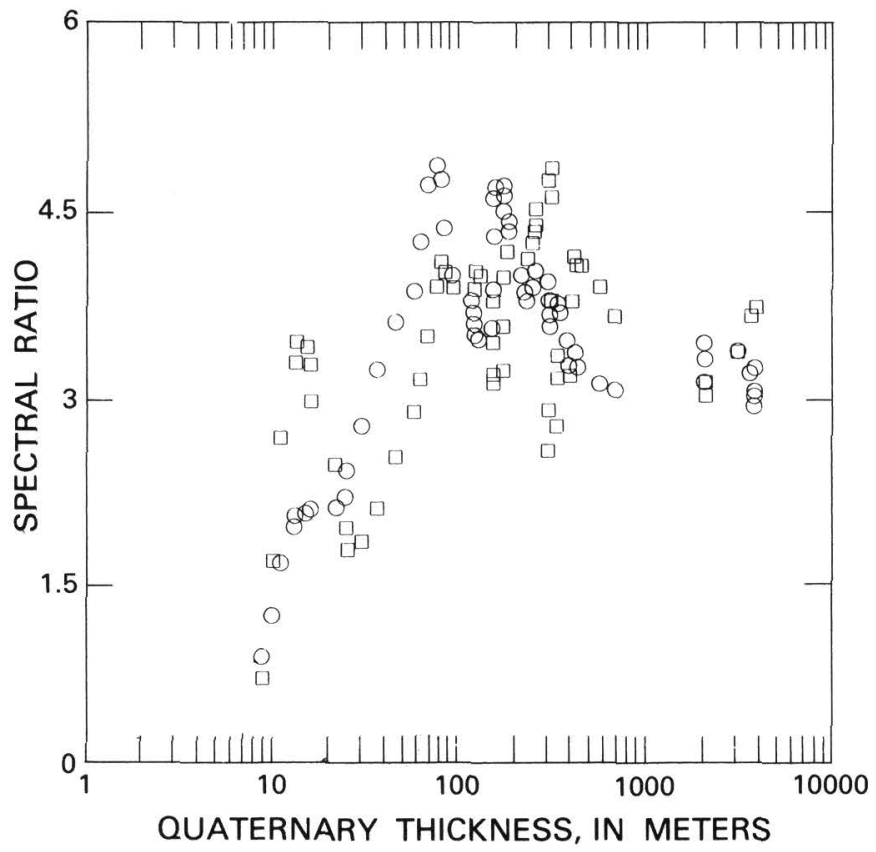

FIGURE 111.-Smoothed intermediate-period spectral ratio compared with depth to basement rock (A) and Quaternary thickness (B). A circle indicates theoretical values; a square indicates observed values.

This approach, however, produced too many clusters, each of which had too few station members. The number of factors in the clustering process was reduced in a series of trials by gradually discarding factors that
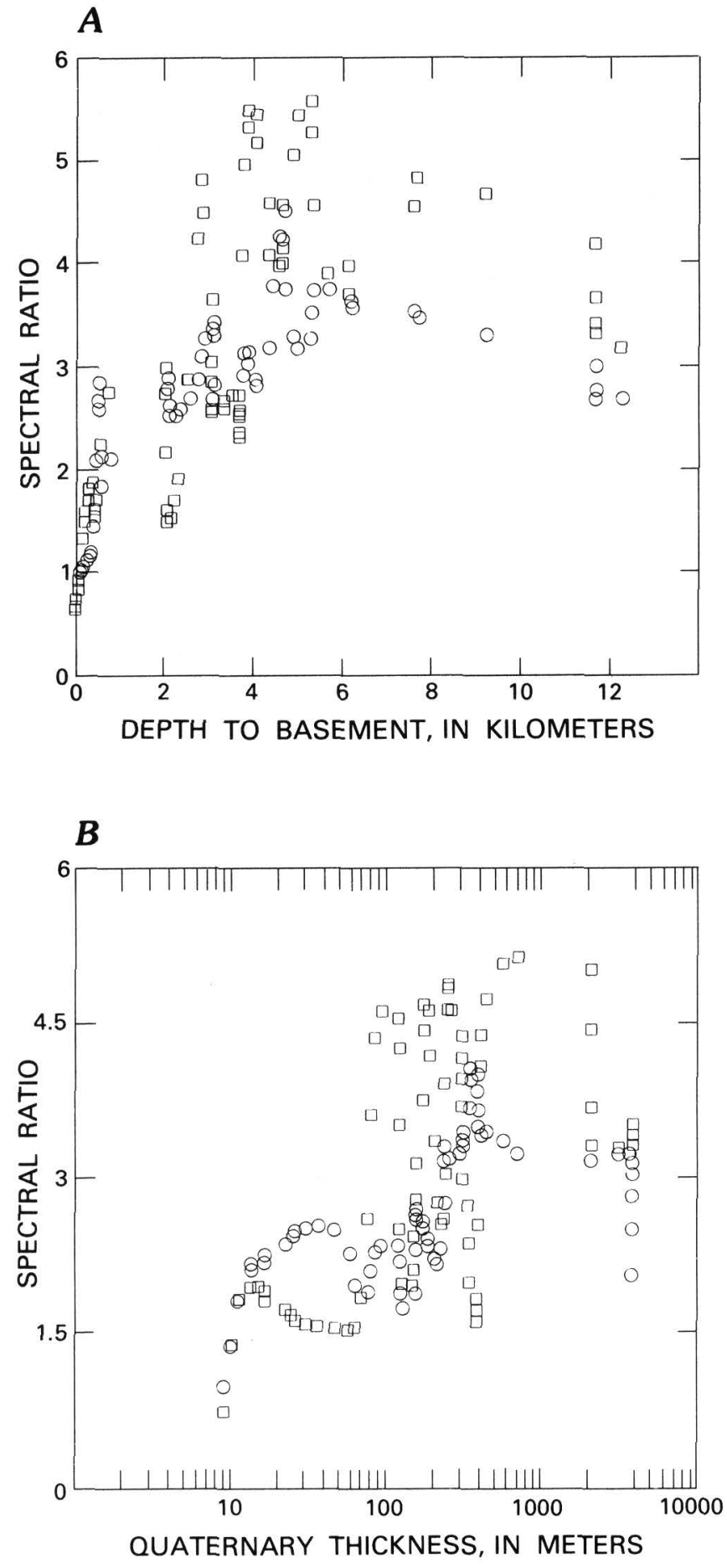

FIGURE 112.-Smoothed long-period spectral ratios compared with depth to basement rock (A) and Quaternary thickness (B). A circle indicates theoretical values; a square indicates observed values.

discriminated poorly between clusters on the basis of statistics produced by the discriminant analysis. Some continuous variables were categorized into discrete ranges to satisfy certain requirements of the analysis 


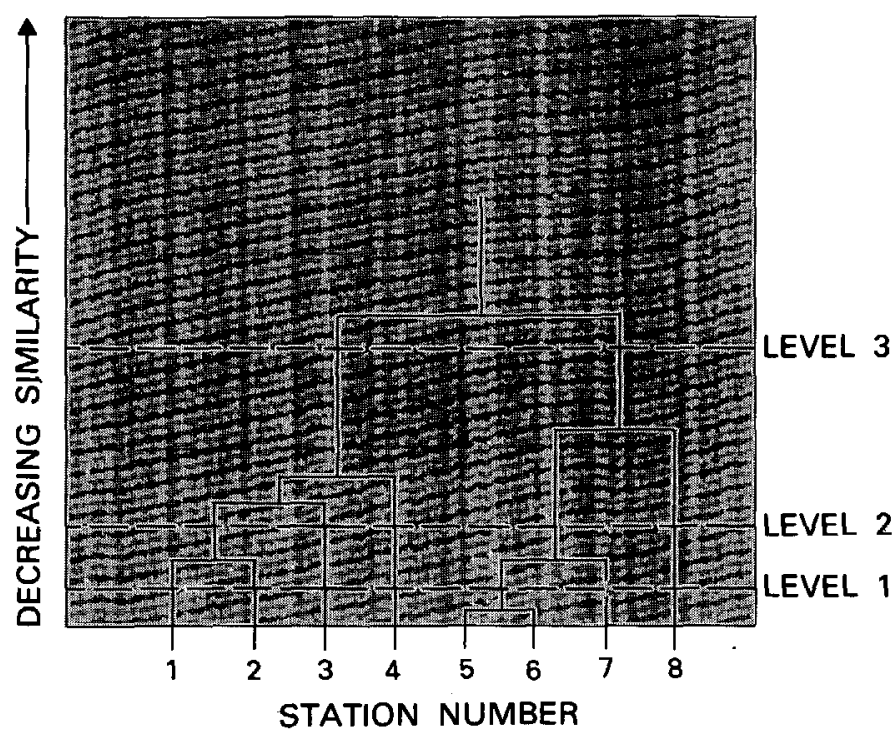

FIGURE 113.-A simple example of the clustering technique showing the cluster tree and the clusters that form at various levels of similarity.

techniques. In some cases, relevant ranges in this classifying scheme were apparent from the preliminary data analysis. For unconsolidated sediment thickness, for example, sites were classified into three ranges of thickness:

$$
\begin{gathered}
>0 \mathrm{~m} \text { and }<11 \mathrm{~m} \\
>11 \mathrm{~m} \text { and }<20 \mathrm{~m} \\
>20 \mathrm{~m}
\end{gathered}
$$

These values are based on the behavior of the shortperiod response as a function of this variable. Comparison of the mean response values in the three period bands for each cluster set examined revealed that some cluster parameters reduced the response variance in each cluster better than others, in accord with the results of the preliminary data analysis (figs. 109, 111; table 39), which showed that the most important factors in each period band should be different. Ultimately, those cluster sets selected were chosen (1) because they had the lowest dispersion in the defining variables and because they used those factors having the strongest effect in a given period band, (2) because the probability of misclassification was low, and (3) because there was enough data in each cluster in the set to estimate the mean cluster properties. The final sets of clusters are a compromise between the many clusters that would be required to preserve all the complexity in the site response as a function of site geology and the requirement that each cluster contain enough cases to estimate its average response with acceptable variance.

Figure 114 shows the set of two rock clusters and eight alluvial clusters that was derived for the short- period band. This figure can be understood by using cluster $4 \mathrm{~A}$ as an example. That cluster includes sites having a depth to basement rock of more than $0.5 \mathrm{~km}$, an unconsolidated sediment thickness greater than $20 \mathrm{~m}$, void ratios in the 0.6 to 0.7 range, and a geometric mean spectral ratio (hereafter shortened to spectral ratio) of about 3.6. The response predicted by using these clusters preserves the important features of site behavior noted above. For a given unconsolidated sediment thickness, for instance, the spectral ratio in creases as the void ratio increases (for example, compare clusters $1 \mathrm{~A}, 3 \mathrm{~A}$, and $6 \mathrm{~A}$ ). The spectral ratio

2 also increases, for a constant void ratio, as the unconsolidated sediment (mostly Holocene sites) thickness increases to the critical range (for example, compare clusters $6 \mathrm{~A}, 7 \mathrm{~A}$, and $8 \mathrm{~A}$ ). Note that the thin unconsolidated sediment clusters contain most of the Pleistocene sites; those unconsolidated Pleistocene sites in the thickness range 11 to $20 \mathrm{~m}$, however, are grouped with the Holocene sites in this range. The spectral ratio of rock sites $1 R$ and $2 R$ is typically lower than that of the alluvial clusters, as one might predict on the basis of their shear-wave velocities. A comparison of clusters $1 \mathrm{~A}$ and $2 \mathrm{~A}$ shows that sites underlain by shallow alluvium over crystalline rock (2A) have a spectral ratio two times higher than that of the same type of site overlying a deep sedimentary basin; this difference further emphasizes the importance of high-impedance contrasts at shallow depths. Even though we were able to divide the sites into only 10 clusters, which result in a moderate range in the geologic and spectral ratio factors in each cluster, a useful result can be demonstrated by comparing average spectral level with shaking intensity. Borcherdt and others (1975) have shown that a factor of two in mean spectral level corresponds to a change in intensity units of $1 \mathrm{MM}$ (Modified Mercalli); we infer, then, from the data in figure 114, that these clusters predict the true spectral ratio of a site more closely than one intensity-unit increment for 90 percent of the cases, because the geometric 90-percent confidence interval is less than a factor of two (1.45).

Figure 115 shows the clusters derived for the intermediate- and long-period bands. In principle, clustering for the intermediate-period band should be determined separately; it is known, for instance, that Holocene sites more than $\mathbf{3 0} \mathrm{m}$ thick produce high spectral ratios in this period band. Because no clustering scheme was discovered for this band that was significantly better than that derived for the long-period band, however, these two bands are treated similarly. These cluster sets show that the spectral ratio increases as depth to basement rock increases up to $6 \mathrm{~km}$; spectral ratios decrease slightly for greater sediment thicknesses. At the shorter periods in the intermediate-period

\section{Earthquake Hazards in the Los Angeles Region}




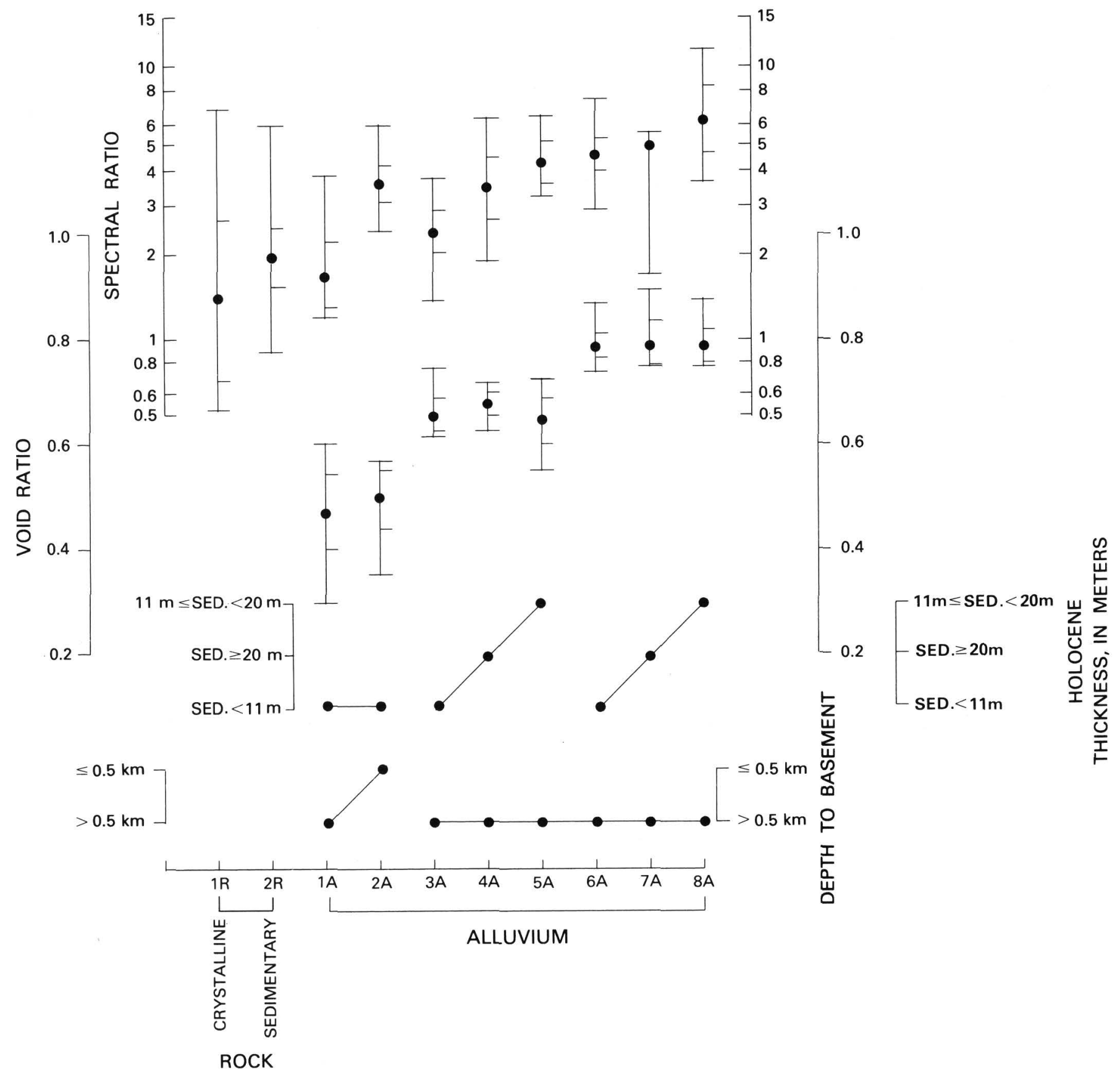

SITE RESPONSE CLUSTER NUMBERS

FIGURE 114.-Site clusters for short-period ground motions in the Los Angeles region. Solid circles indicate the geometric mean of the short-period spectral ratios, the mean void ratio, the unconsolidated sediment thickness, and the depth to basement rock for a given cluster. Vertical bars indicate the range in a variable, and side ticks indicate the 90-percent confidence intervals.

band, this decrease may be caused partially by wave attenuation in both the soil and the rock column. Although the cause of this behavior in the long-period band is not clear, it is also predicted by the SH-wave results shown in figures 111 and 112 and may be produced by the first minimum in the theoretical spectral ratio that occurs near $6 \mathrm{~s}$ owing to destructive wave interference. The geometric mean spectral ratios at rock sites range up to two, whereas those at soil sites can reach up to about five for clusters having a depth to basement rock in the 


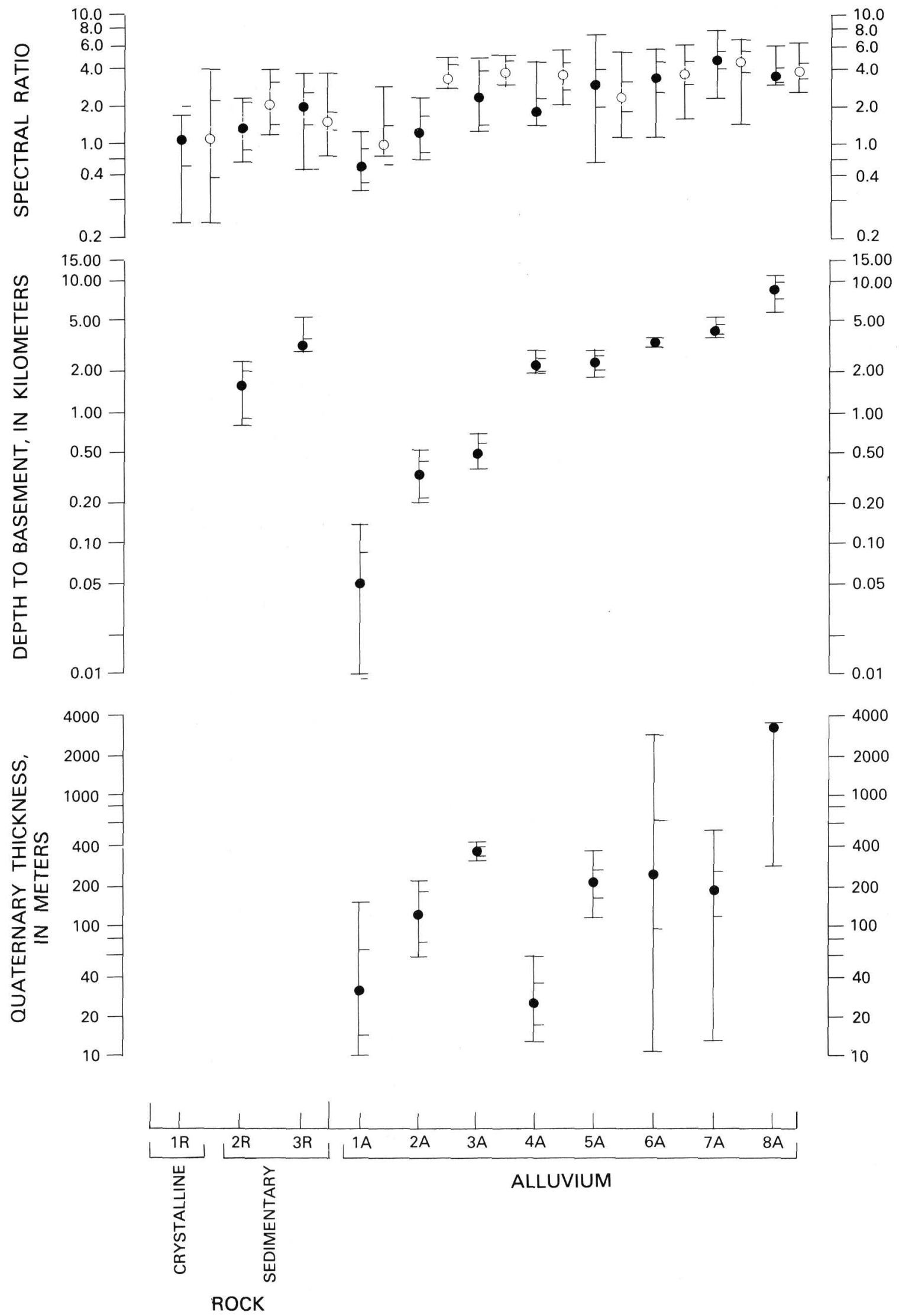

\section{SITE RESPONSE CLUSTER NUMBERS}

FIGURE 115.-Site clusters for intermediate- and long-period ground motions in the Los Angeles region. Top scale: Open circles and solid circles indicate the geometric mean of the intermediate- and long-period spectral ratio values, respectively. Bottom scales: Solid circles indicate the geometric mean depth to basement rock or Quaternary thickness. The range and the 90-percent confidence intervals for each factor are indicated by vertical bars and side ticks, respectively. 
4- to 6-km range. The low spectral ratio $(0.7)$ for sites underlain by very thin soils is not completely understood. Several of the sites that have the lowest amplification factors in this cluster lie within mountain ranges, however. Long-period surface waves may have unusually low amplitudes relative to CIT in such locations because surface-wave energy can be reflected by the boundaries of the ranges (Aki, 1969; Murphy and Hewlett, 1975; Johnson, 1979).

\section{PREDICTING GEOGRAPHIC VARIATION IN GROUND RESPONSE}

Cluster sets such as those described above can be used to map the relative ground response (in comparison with that at sites on crystalline bedrock) expected for a particular region from future earthquakes. As a demonstration of the methods and techniques, we have prepared a set of predictive ground-response maps for a small area approximately centered on the Los Angeles Civic Center (figs. 116A, 116B, 116C). In brief, our proposed procedure associates geographic areas having particular geologic attributes with a given site-response cluster. The spectral ratio for that cluster is then assigned to the geographic area.

We will discuss the procedures used to produce the relative ground-response map for the short-period band (fig. 116C) as an example of the general technique. Figure 117 schematically illustrates the method. The first two steps are (1) to prepare a cluster diagram for the study area that relates observed spectral ratios to geologic factors influencing levels of shaking and (2) to assemble a suite of maps that show rock and sediment types, depths to basement rocks, thicknesses of unconsolidated (Holocene and Pleistocene) sediments, and the distribution of void ratios characteristic of unconsolidated sediments. The third step combines the geologic maps assembled in step 2 into groups that reflect the geographic distribution of the important cluster factors for a given period band. The easiest method is to visually compare the geologic data maps (by using transparent overlays), noting where two or more sets of geologic attributes are coincident, and then draw zone boundaries. An area of high void ratio, for instance, may coincide with one or more of the three categories of unconsolidated sediment thickness. Where it coincides with an area in the thick category, cluster $7 \mathrm{~A}$ is assigned to the area; where it coincides with an area in the thin catagory, cluster $6 \mathrm{~A}$ is assigned, and so on. In the final step, each zone associated with a particular cluster is assigned a response value on the basis of spectral ratios from figure 114. This procedure was judged more reasonable than attempting to contour the response values, because it is known from damage studies that site response can vary rapidly over very short distances, particularly for low structures. Step changes in response can thus occur as a function of near-surface variations in geology, and this method of mapping predicted response reflects this behavior, at least for the short-period map. The long- and intermediate-period maps are prepared in the same manner, but, because ground response at these periods changes more gradually as a function of variable geologic factors, these maps are more nearly like contour maps on which transitions from low to high response occur over broad zones.

The map showing predicted relative ground response for long periods (fig. 116A) is of significance to structures more than 30 stories high. It predicts that low response will characterize areas underlain by rock and thin alluvial deposits; the highest levels of response will occur in areas where the depth to basement rock ranges from 4 to $6 \mathrm{~km}$, and slightly lower levels are predicted in the deepest parts of the basin. The lowest response will be where crystalline basement is located at or near the surface in the Santa Monica Mountains and Verdugo Mountains areas. South of Burbank and west of Pasadena, the relatively thin alluvium in the intermontane basin areas and along the Los Angeles River valley near the eastern end of the Santa Monica Mountains and north of the Los Angeles Civic Center also will exhibit a low response. Response is expected to increase to the northwest (San Fernando Valley), to the east (San Gabriel Valley), and to the south (Los Angeles basin). The southwestern part of the map shows a relatively low response where crystalline basement rock is about $3 \mathrm{~km}$ deep along the Newport-Inglewood zone.

The map showing predicted relative ground response for intermediate periods (fig. 116B) is of significance to 5- to 30-story structures. This map is similar to the longperiod map. The chief difference is that the response in this period band of areas covered locally by a thin veneer of alluvial deposits and overlying crystalline basement rock or Tertiary sedimentary rock $(1 \mathrm{~A}, 2 \mathrm{~A}$, and $4 \mathrm{~A}$ of fig. 115) is expected to be higher than that in the long-period band.

The map showing predicted relative ground response for short periods (fig. 116C), which is most relevant to buildings in the two- to five-story class, has been prepared for only the central third of the area shown in the intermediate- and long-period maps. The lowest response is predicted for areas underlain by crystalline and sedimentary rock, and the highest response occurs in regions where thicknesses of near-surface alluvium $(11-20 \mathrm{~m}$ ) and high void ratios $(\geq 0.7)$ produce significant resonant response in this period band. In some respects, 


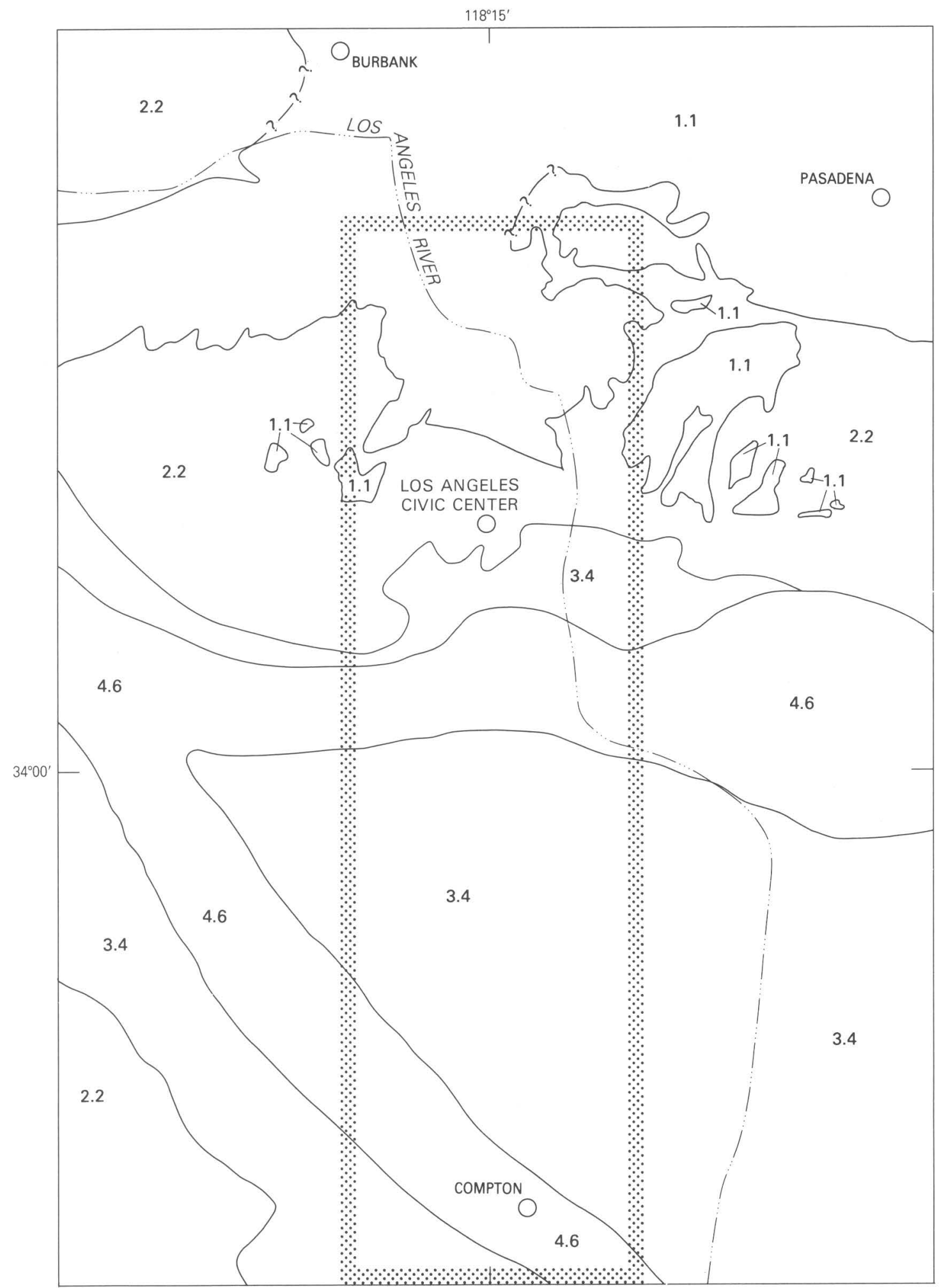

A

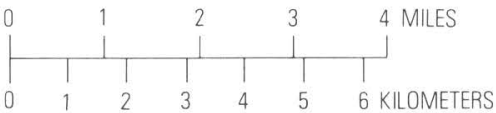

FIGURE 116.-Predicted relative ground response for part of the Los Angeles basin. Numbers are mean amplification factors compared with levels of shaking at sites on crystalline basement rock. A, Map for the long-period band (3.3-10 s) of significance to buildings 30 stories high or more. Stippling outlines area shown in C. B, Map for the

\section{Earthquake Hazards in the Los Angeles Region}




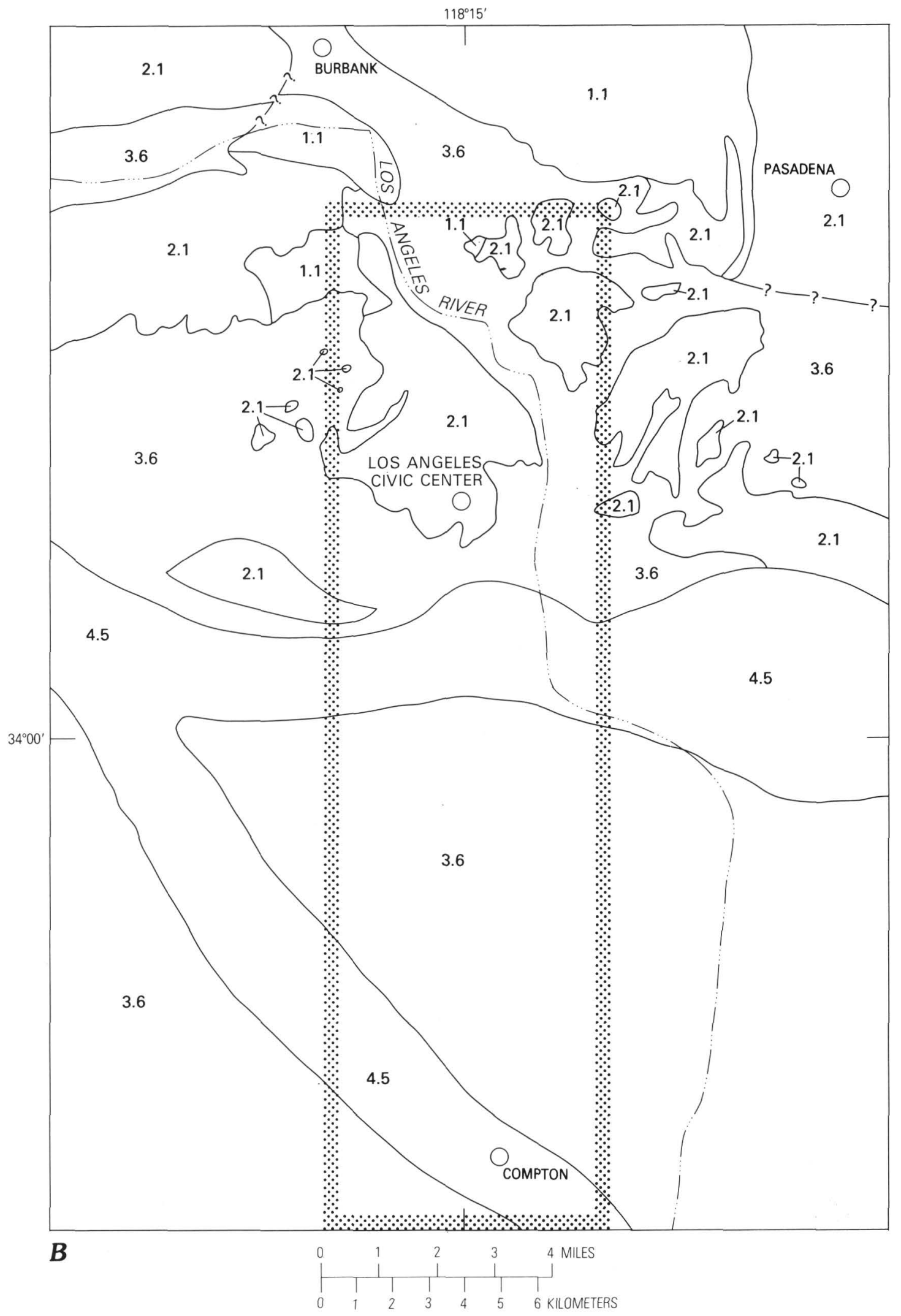

intermediate-period band (0.5-3.3 s) of significance to buildings 5 to 30 stories high. Stippling outlines area shown in C. C, Map for the short-period band ( $0.2-0.5 \mathrm{~s})$ of significance to buildings two to five stories high. 


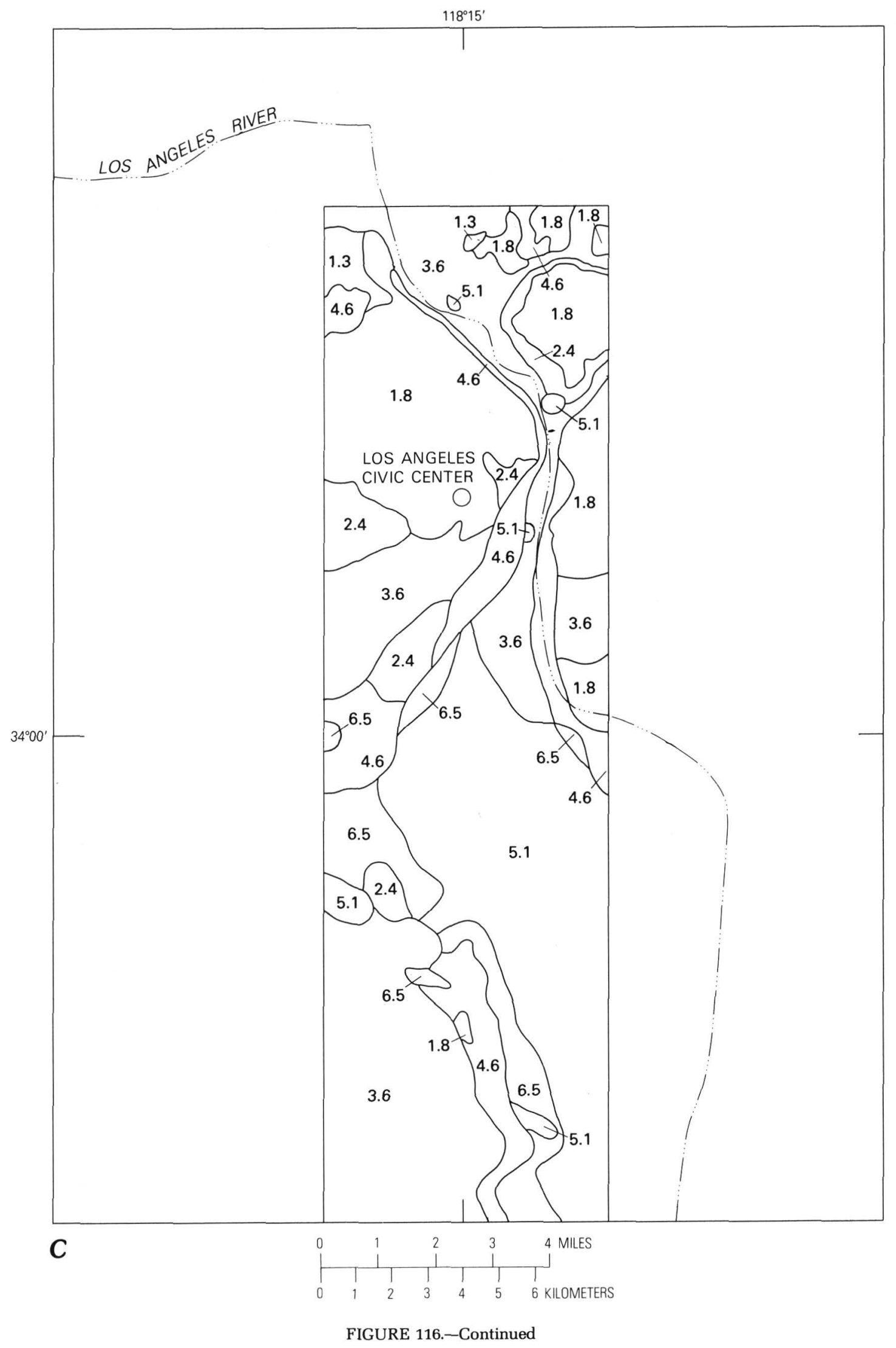

244 Earthquake Hazards in the Los Angeles Region 
DETERMINE SITE RESPONSE CLUSTERS AND THEIR MEAN SPECTRAL RATIOS

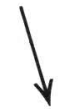

COMPILE MAPS RELATING GEOLOGIC FACTORS THAT INFLUENCE SHAKING IN THE STUDY REGION TO OBSERVE SPECTRAL RATIOS

COMPARE GEOLOGIC DATA MAPS TO IDENTIFY AREAS OF COINCIDENT ATTRIBUTES PERTINENT TO SITE-RESPONSE CLUSTERS

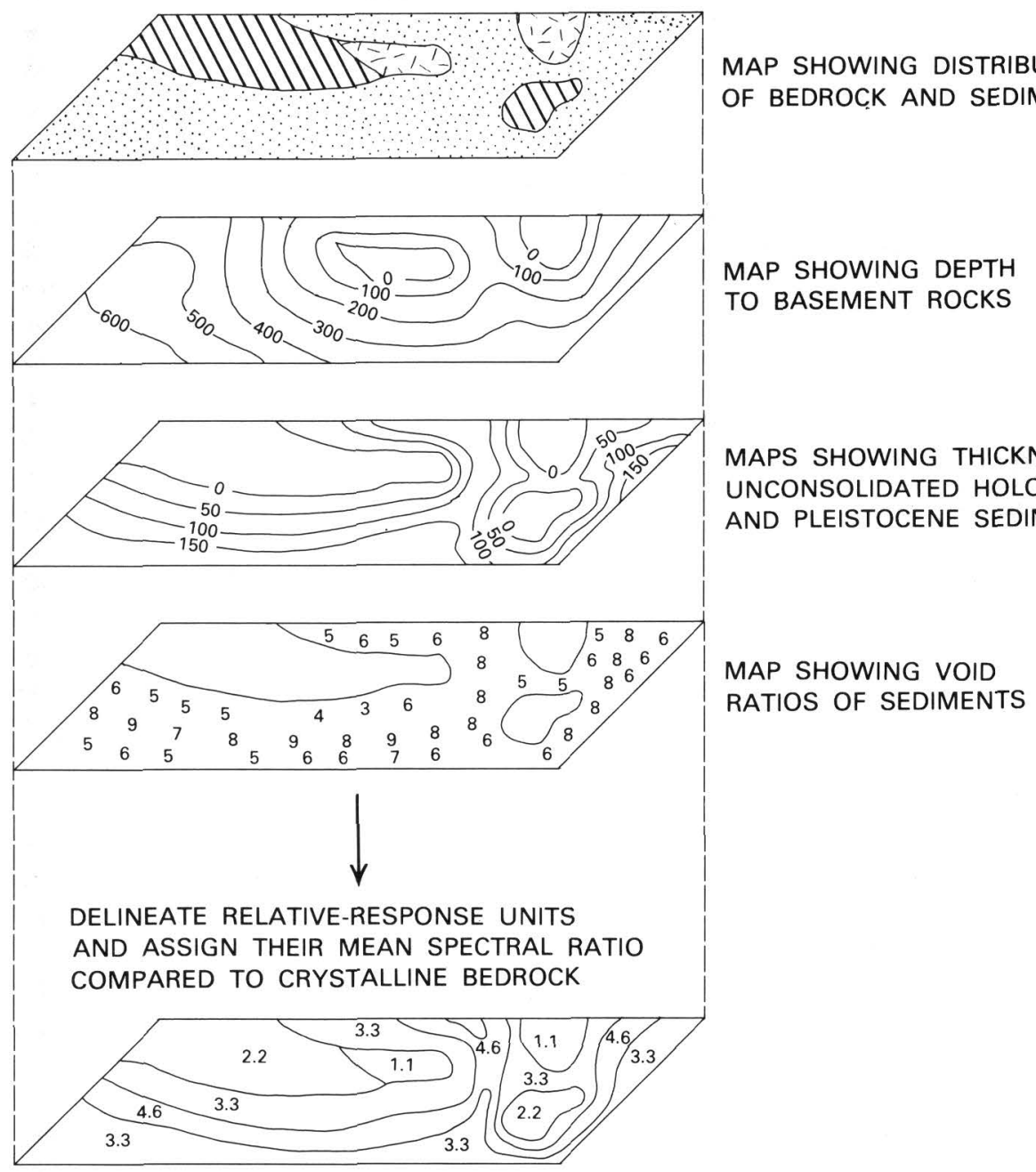

FIGURE 117.-Procedure used to construct the predicted relative ground-response maps shown in figure 116.

this map closely resembles a surficial geologic map; thus, sedimentologic details of the alluviated valleys, including those of the Los Angeles River valley, are expressed clearly by the mapped response units. The southwestern part of the map depicts an area where silt (characterized by high void ratios) deposited by the Los Angeles River thins to the west and wedges out along the eastern flank of the Newport-Inglewood zone, where deformed Pleistocene deposits characterized by low void ratios are exposed. It should be noted that high response at short periods may occur at sites underlain by rock if these sites are near the crest of a ridge or other pronounced topography, as the range of high response for clusters $1 R$ and $2 R$ (fig. 114) shows. 


\section{VALIDITY AND LIMITATIONS OF TECHNIQUE}

In a qualitative way, data from several other studies support this study's conclusions about the importance of unconsolidated sediment thickness. As noted above, Chiaruttini and Siro (1981) have observed accelerations at sites underlain by thin soils $(<20 \mathrm{~m})$ that were greater than those observed on rock or thicker soil sites by factors of four or five. The difference in the behaviors of thin and thick soil is not so great in the data of this study, but this discrepancy may be due to the fact that we have no data for periods shorter than $0.2 \mathrm{~s}$, where peak acceleration energy commonly occurs and attenuation effects become strong. We infer from Chiaruttini and Siro's data that material attenuation may have an important effect at sites underlain by thick soils and for ground motions in the period range where peak acceleration energy occurs. This conclusion is also supported by the work of McEvilly and Johnson (1980), who have found that $Q$ factors, which measure attenuation of seismic energy, must be between 6 and 40 for shear waves in order to explain the amplitude levels on their accelerograms.

The effect of near-surface sediment thickness can also be seen in the data of Minakami and Sakuma (1948) for the 1946 Nankai, Japan, earthquake. The highest levels of ground motion were observed in regions where the thickness of fine sand was in the 10 - to $20-\mathrm{m}$ range (figs. 103-109). Ooba (1957, fig. 10) has shown that, for the 1944 Tonankai, Japan, earthquake (M 8.0), the highest percentage of collapsed houses ( $>50$ percent) occurs where the thickness of clayey overburden is in the $15-$ to $35-\mathrm{m}$ range, and the lowest ( $<10$ percent) occurs in regions underlain by thinner sediment or rock.

The clustering scheme proposed here to predict site response can be partially tested by applying it in other areas where strong ground motion has been recorded and sufficient data about site conditions are available. We classify the Richmond recording station (McEvilly and Johnson, 1980), for instance, into clusters 7A (short period) and 4A (intermediate period) and Coyote Lake earthquake recording station 2 (Joyner and others, 1981) into clusters $6 \mathrm{~A}$ (short period) and $2 \mathrm{~A}$ (intermediate period). At both sites, the predicted mean response for both period bands ranges between 3 and 5 , and the observed response ranges between 3 and 4 .

This clustering scheme, however, cannot be applied to all site conditions. If, for example, near-surface mean shear-wave velocity is considerably less (say, $100 \mathrm{~m} / \mathrm{s}$ ) or greater (say, $400 \mathrm{~m} / \mathrm{s}$ ) than the mean value for sites displaying resonant conditions in Los Angeles (about $200 \mathrm{~m} / \mathrm{s}$ ), then resonant conditions in the short-period band would occur at one-half or twice the thickness range, respectively, of this study, and the mean spectral values would also be modified by as much as twice or one-half the levels of this study. Thus, in regions where shear-wave velocities are exceptionally low, at least three additional high void-ratio clusters having different ranges of near-surface sediment thickness would be required. Applying these clusters to other regions requires critical evaluation of the important geotechnical factors to determine if sites in the region, in fact, fit the clusters of this study, which do not represent all geologic conditions.

\section{SUMMARY}

Local geologic conditions can significantly influence the relative levels of ground shaking caused by earthquakes. Based on the generally valid assumption that the relative responses of different sites are approximately equivalent for both low and high levels of motion, comparative studies of ground motion recorded within a region provide a reliable method for estimating the shaking effects likely to be caused by future earthquakes.

We have analyzed the geographic variation in relative ground response at 98 locations within the Los Angeles region by using a collection of ground-motion recordings from a series of underground nuclear test explosions at the Nevada Test Site. The mean spectral levels of the site responses from these distant events were evaluated in three period bands of engineering importance as a function of the underlying geotechnical conditions at each site. These properties were collected from a wide range of sources, including engineering borehole and water-well logs in city files, geologic and gravity maps, and a limited number of measured shearwave velocities in near-surface sediments. In preliminary evaluations of the data, we determined, for instance, that the levels of shaking experienced by sites underlain by Holocene and Pleistocene sediments are three to four times greater than those experienced by sites underlain by crystalline rock for periods less than $0.5 \mathrm{~s}$ and that ground motions at periods greater than $0.5 \mathrm{~s}$ increase as Quaternary thickness and (or) depth to basement rock increases.

The geotechnical factors having the strongest influence on site response in each period band were identified by means of statistical clustering techniques. The results indicate that, at periods less than $0.5 \mathrm{~s}$, the most significant factors controlling ground response are mean void ratio in the near-surface layers, unconsolidated sediment thickness (principally Holocene deposit thickness), and depth to basement rock, those sites having near-surface sediment thickness in the 10 - to $20-\mathrm{m}$

\section{Earthquake Hazards in the Los Angeles Region}


range demonstrating site resonance effects. At periods greater than $0.5 \mathrm{~s}$, depth to basement rock and the thickness of Quaternary sediments were found to be controlling factors.

These clusters were used in a procedure developed to produce maps of relative ground response for part of the Los Angeles basin. The clusters can also be used to make estimates of shaking effects at specific locations, if the necessary geotechnical information is available for the site. This technique has important implications for earthquake hazard reduction in Los Angeles and elsewhere, because it can be used to predict future relative ground response from geotechnical data that are ordinarily obtained in the course of urban development. The utility of the technique is further enhanced by provisions permitting ground-response estimates to be made for period bands pertinent to structures of different sizes. This mapping procedure may be useful for seismic zonation in other earthquake-prone urban areas, if clusters applicable to the specific geologic framework of the region being studied can be determined. 


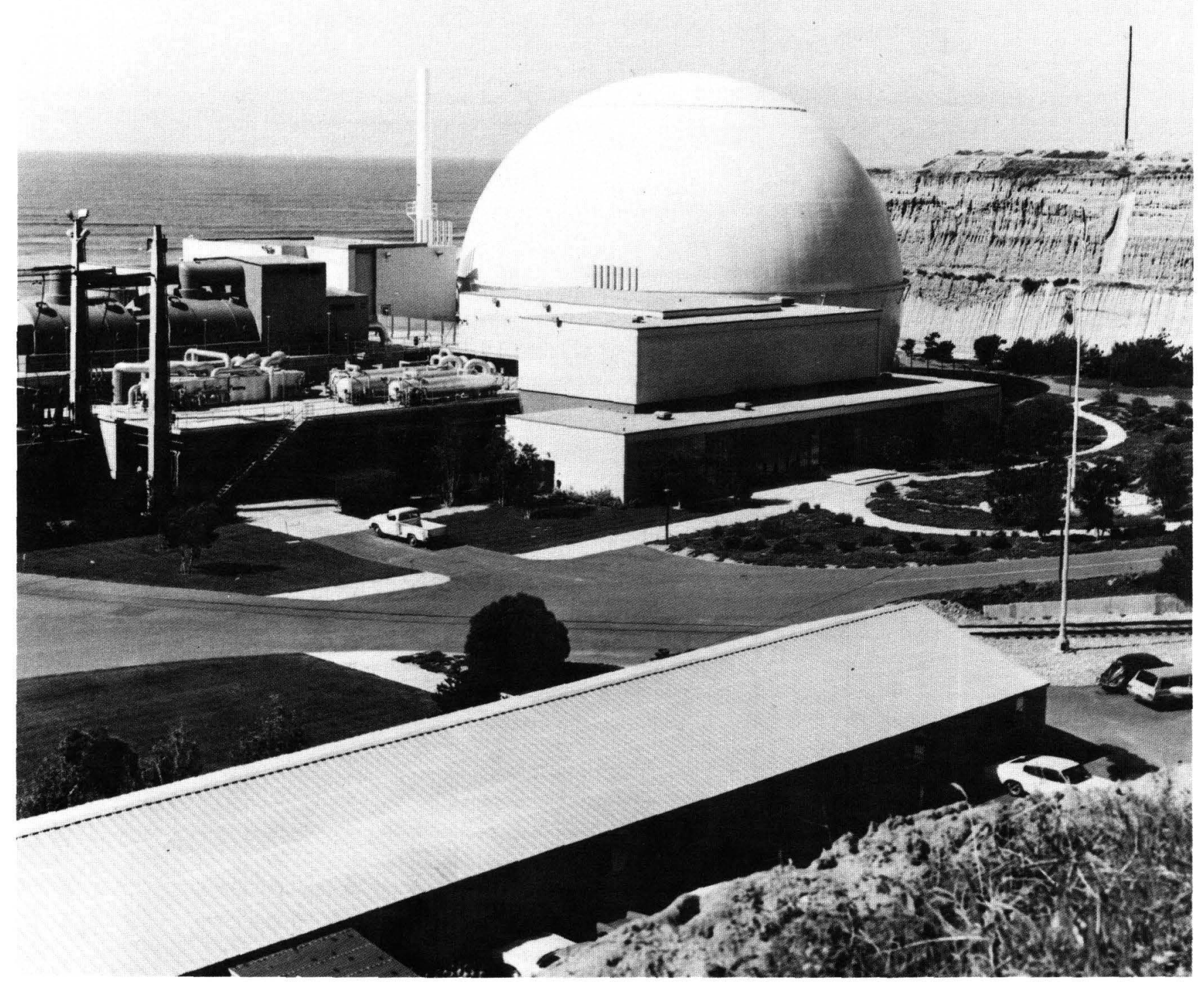

248 Earthquake Hazards in the Los Angeles Region 


\title{
PREDICTING EARTHQUAKE GROUND-MOTION TIME-HISTORIES
}

\author{
By P. A. Spudich and S. H. Hartzell
}

\section{INTRODUCTION}

Engineers are often called upon to design facilities that are to be built at specific sites near known active faults. To do so, the engineer may require an estimate of the ground motions that would occur at the site owing to an earthquake on a nearby fault. If the facility to be built is simple, an estimate of anticipated peak values of ground motion (for example, acceleration, velocity, or duration) may be all that is required. In many cases, however, the engineer may need to know anticipated ground-motion time-histories at the site. If soil tests reveal a buried sand layer at the site that is prone to.liquefaction, for example, the engineer may need to know how many cycles of seismic loading the sand layer will be subjected to and how large this loading will be. The engineer may require ground-motion time-histories in order to calculate response spectra for the structure, and, if damaging levels of ground motion are anticipated, the engineer may need to know whether the damaging motion will occur as a single pulse or as a series of oscillations that cause progressive inelastic deformation with each cycle.

If the engineer is lucky, a strong-motion accelerogram may already exist that is a suitable example of the worst shaking anticipated; that is, a record will exist that has been recorded at the proper distance from an earthquake of the desired size and mechanism in a similar geologic structure. Often a suitable strong-motion recording cannot be found, however; perhaps a record the correct distance from the right size event exists, for example, but the recording site is hard rock, unlike the thick layer of alluvium that characterizes the proposed facility's site. Similarly, the observed record may have rather low levels of motion owing to the effects of rupture propagation away from the recording site, whereas a worst-case scenario for the proposed facility would include rupture propagation toward the site. Lack of strong ground-motion data for many such situations of interest has necessitated development of theoretical techniques for predicting ground-motion time-histories of hypothetical earthquakes.

This chapter discusses some of the techniques used to calculate these theoretical ground-motion time-histories, the information necessary to make a relevant calculation, and the approximations commonly used to make the calculations tractable. These methods are applicable to ground-motion evaluation in any earthquake-prone region. In a later chapter (Ziony and others, this volume), we demonstrate, for the Los Angeles region, how ground-motion time-histories are calculated for a postulated magnitude 6.5 earthquake on the NewportInglewood zone.

This paper is structured to be readable by both a general audience and a more specialized audience of people who may have to use the results obtained by studies like the one conducted by Apsel and others (1981) and discussed in this paper. Sections of this paper having the word "detail" or "detailed" in their headings contain caveats, explanations, and interpretations that the general audience may safely skip.

\section{THE EARTHQUAKE RUPTURE PROCESS}

Although the details of the earthquake rupture process are largely unknown, the gross features are understood theoretically and observationally, and a reasonable model of an earthquake source can be specified by a handful of parameters. This section examines these parameters and comments on how well they might be predicted in a simulation of earthquake rupture.

Let us start by examining a very simple model of an earthquake source-a crack that grows on a plane surface in an infinite homogeneous medium. We assume that a uniform tectonic shear stress is applied parallel to the plane to drive the crack, as figure 118 shows, and we also assume that slip initiates at some point on the plane (the earthquake hypocenter). Subsequently, the 


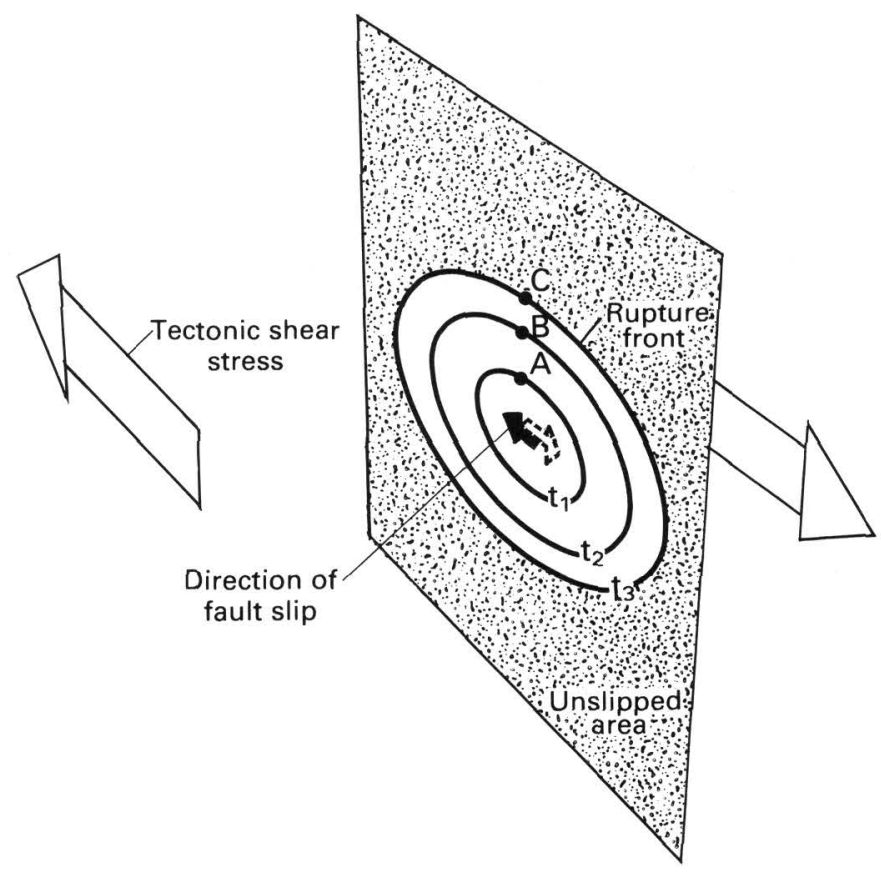

FIGURE 118.-Idealized rupturing fault at time $t_{3}$. The yet unbroken part of the fault is stippled, and the actively slipping part is unstippled. Contours show positions of the rupture front at times $t_{1}, t_{2}$, and $t_{3}$. The fault slips in the direction of applied stress. Slip timehistories for A, B, and C are shown in figure 119. The dashed arrow shows the motion of material on the opposite side of the fault.

slipping area will grow and spread away from the hypocenter. If we define the rupture front as the boundary between the slipping and the unslipped regions of the fault plane, the position of the rupture front at three successive times $t_{1}, t_{2}$, and $t_{3}$ will be as figure 118 shows. The shape of the rupture front will be either circular or elliptical, and the front itself will advance at a velocity dependent on direction. In the direction perpendicular to the applied stress, the rupture will travel at the speed of a Rayleigh wave in the medium $\left(\sim 0.92 V_{S}\right.$, where $V_{S}$ is the shear-wave velocity); in the direction parallel to the applied stress, the rupture will travel at the Rayleighwave speed if the cohesion between the two sides of the fault is great, or it will travel as fast as the P-wave velocity if the fault cohesion is low (Mikumo and Miyatake, 1978). Everywhere within the ruptured area (the unstippled region of fig. 118), the offset of the two sides of the fault will be parallel to the applied stress.

In general, observational studies of earthquakes, such as those summarized by Geller (1976), show rupture velocities to be about 60 to 90 percent of the shear-wave velocity in the surrounding rock, in rough agreement with theory. Recently, Olson and Apsel (1982), Archuleta (1984), and Spudich and Cranswick (1984) have found evidence for rupture velocities near the P-wave velocity in the 1979 Imperial Valley, Calif., earthquake.

To return to the idealized earthquake source in figure 118 , if the tectonic stress and the cohesion between the two sides of the fault are uniform everywhere, there is nothing to stop the rupture from expanding indefinitely; consequently, the relative offset or slip between the two sides of the fault will grow endlessly. The rupture front can be stopped, however, if the rupture encounters a region of the fault where the tectonic stress is not large enough to overcome the fault's resistance to rupture. Thus, nonuniformities in either the tectonic stress or the strength of the fault-zone materials or both will cause the rupture process to stop. We can examine, for example, the time-histories of slip at points A, B, and C (fig. 118) for the cases of a rupture that stops, shown by the dotted lines in figure 119 (Archuleta and Frazier, 1978), and a rupture that continues indefinitely, shown by the solid lines in figure 119 (Kostrov, 1964). In either case, slip at A, B, and C is initiated by the passage of the rupture front at times $t_{1}, t_{2}$, and $t_{3}$. Slip ceases, however, only if the rupture front stops at a boundary. If we follow Boatwright (1981) and say that healing initiates when the slip function deviates from that expected for a fault without boundaries, we can see in figure 119 that the healing starts earliest at point $C$, nearest the fault boundary, and that it propagates away from the boundaries. An apt analogy would be an automobile accident in which the lead car (rupture front) in a long string of vehicles smashes into an obstacle and causes a chainreaction collision among the following vehicles. As each vehicle smashes into the one ahead (healing), the collision propagates backward through the line of cars, even though all the cars are moving forward. The last car to come to a stop is the one farthest from the initial obstacle.

Although we have apparently been talking about circular or elliptical faults, the same principles apply to long strike-slip faults. Figure 120 shows a theoretical calculation by Archuleta and Day (1980) of rupture propagation along a strike-slip fault resembling the San Andreas fault near Parkfield in central California. The actively slipping region of the fault is shown at 2-s intervals after rupture initiation. In this case, the first barriers encountered by the rupture front are the left side, the bottom, and the top of the fault, and healing propagates inward from these boundaries.

From theoretical studies like those of Kostrov (1964), Archuleta and Frazier (1978), and others, we can make a reasonable guess that, during an earthquake, the slip time-history at any point will look like the slip timehistory for an unbounded fault until information from the boundaries reaches that point and initiates healing,

\section{Earthquake Hazards in the Los Angeles Region}




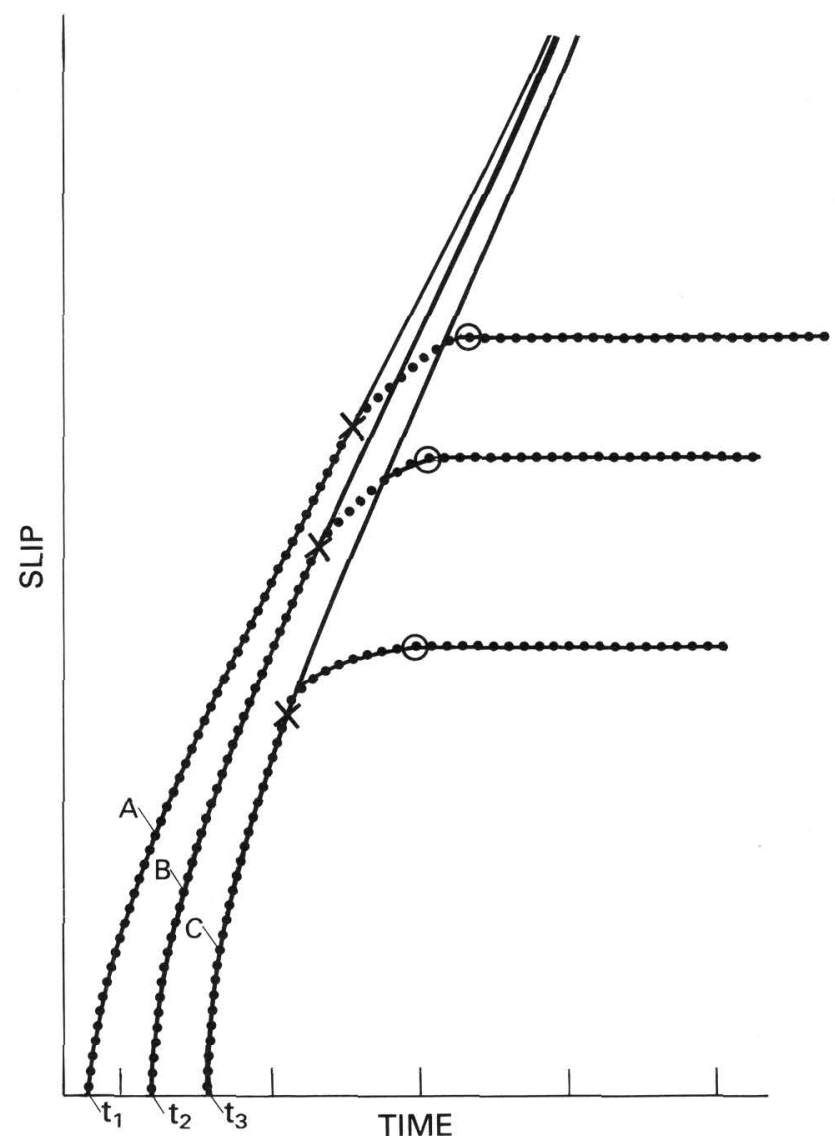

FIGURE 119.-Slip time-histories of points A, B, and C (fig. 118) under two assumptions: (1) there are no boundaries to stop the rupture front, so slip continues indefinitely (solid line), and (2) the rupture front stops at a boundary, and slip ceases at internal points (dotted line). Crosses indicate the points at which healing is initiated; open circles, points at which healing is completed.

as figure 119 shows. Boatwright (1981) has elaborated on this presumption and has used it to study aftershocks of the 1975 Oroville, Calif., earthquake.

Before proceeding to more complicated models of rupture, let us examine the major features of the ground motions caused by these simple models. The most well known effect of a propagating rupture is to amplify energy radiated in the direction of rupture and to diminish energy radiated opposite the direction of rupture (Ben-Menahem, 1961). This effect, termed directivity, has been observed in many theoretical and observational studies (for example, Boatwright and Boore, 1982; Hartzell and Helmberger, 1982) and is apparent in the ground-motion calculations that we present for the hypothetical Newport-Inglewood event later in this volume (Ziony and others, this volume). The magnitude of this effect is related to the average rupture velocity. A second effect, which is of great engineering signifi-
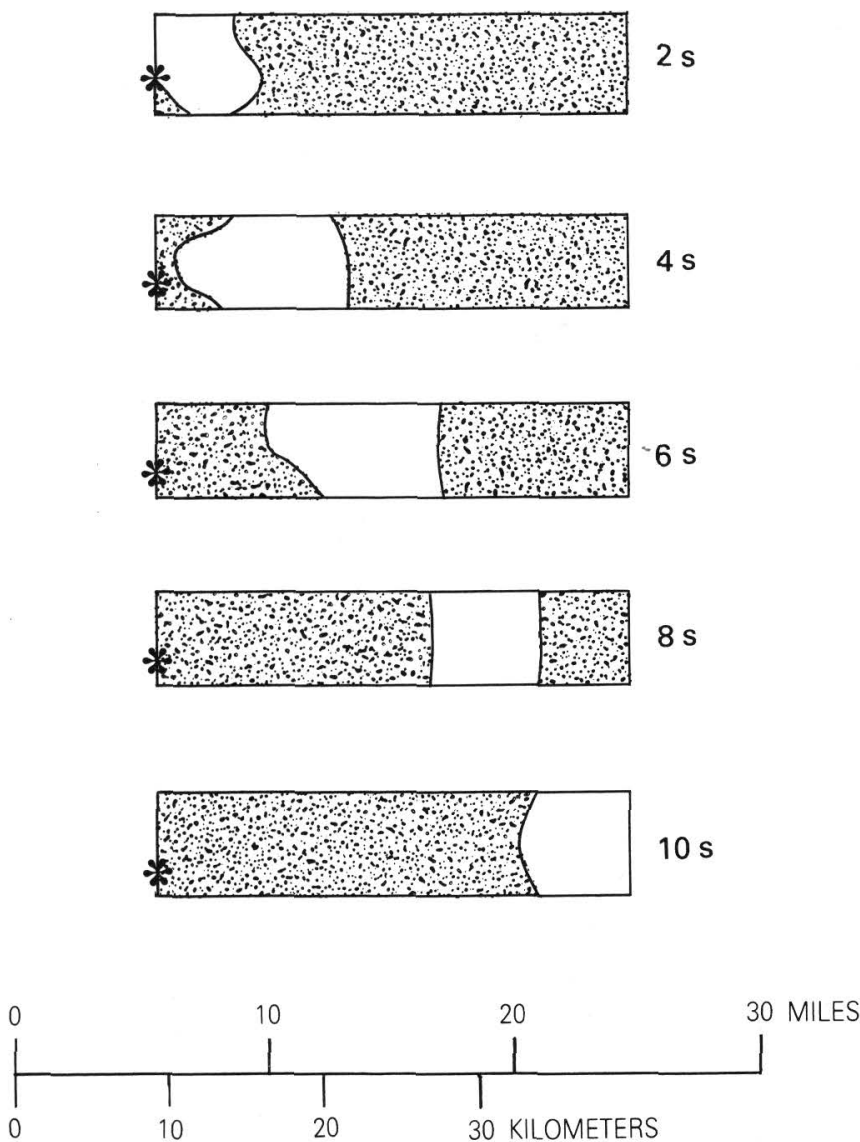

FIGURE 120.--Rupture-propagation model for long strike-slip fault, adapted from Archuleta and Day (1980). Diagrams of fault plane at 2-s intervals after rupture initiation. Unstippled area is actively slipping. Stippled area to the right has not yet broken; stippled area to the left has been healed and now exhibits a net static offset. Hypocenter shown by asterisk.

cance, is that most of the high-frequency energy is radiated from the rupture front itself and that this energy is radiated most profusely under two circumstances: (1) when the rupture front accelerates or decelerates and (2) when the rupture front crosses a region of the fault where the amount of slip varies from place to place (Madariaga, 1977; Spudich and Frazer, 1984). In the simple rupture models that we have discussed thusfar, where the rupture front propagates uniformly until it hits the boundary of the fault, almost all the high-frequency radiation occurs when the rupture front stops at the fault boundary. This characteristic is a well-known feature of the simple Haskell (1964) fault model.

The theoretical observation that most $\cdot h i g h$-frequency energy is radiated by changes in the velocity of the rupture front and by spatial variations in the amount of slip has important implications for the high-frequency ground motions caused by earthquake source models 


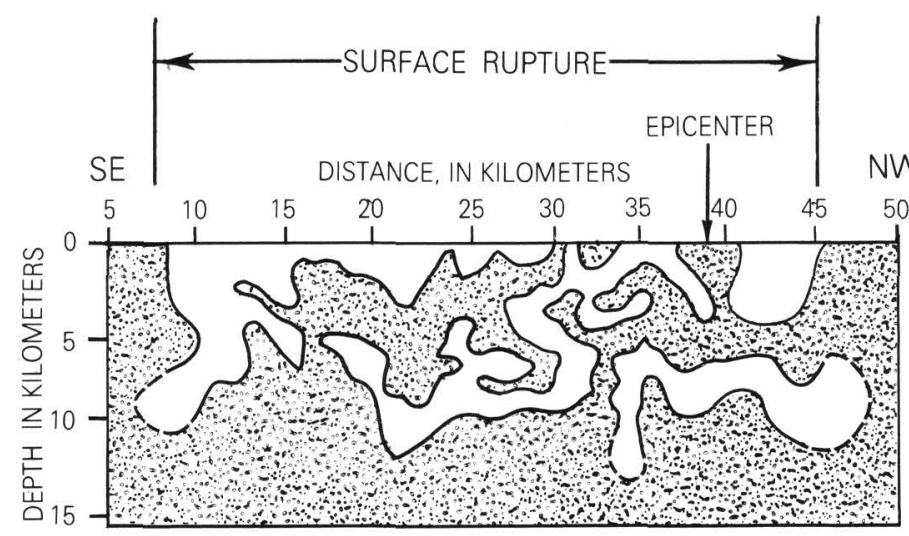

FIGURE 121.-Possible heterogeneity of rupture during the 1966 Parkfield, Calif., earthquake, modified from Aki (1979). Unstippled area was postulated to have slipped during the earthquake; the stippled area remains locked. Dashed lines have been added to close contours.

that are more realistic than those discussed above. Since both the state of stress on a fault and the strength of the fault material may be quite heterogeneous over a real fault surface, we might expect that, during an earthquake, the rupture front will advance very irregularly and that some regions of the fault will be so strong that the rupture front will jump past them and leave them unbroken. The result might be a pattern of broken and unbroken regions on the fault similar to that shown in figure 121, which is the pattern suggested by Aki (1979) for the 1966 Parkfield earthquake. Several theoretical studies, including those of Das and Aki (1977a, b), Mikumo and Miyatake (1978), and Day (1982), have shown that, in the presence of stress and strength heterogeneities, rupture fronts can advance unevenly and even jump around unyielding regions of the fault (termed barriers). Because high-frequency radiation is generated by nonuniform rupture-front motion and an irregular slip distribution, the pattern of preexisting stress and strength on the fault will control the highfrequency ground motions that the earthquake generates.

Unfortunately, the distribution of stress and strength on real faults is unknown, so that it is impossible at this point to predict deterministically the details of how any particular active fault would rupture. Hence, beginning with Haskell (1966) and Aki (1967), investigators have tried to discover the statistical distribution of material properties or rupture parameters on the fault surface in an effort to simulate higher frequency ground motions.

Considerable work on the statistical nature of earthquake slip functions has been done more recently by Aki and others (1977), Andrews (1981), Papageorgiou and Aki (1983), and many others that they cite, and incoherent source behavior has been used in various forms by Bouchon (1978), Boore and Joyner (1978), and Apsel and others (1981). In their study, Boore and Joyner allowed the rupture velocity or the amplitude of the slip function to vary randomly, with certain statistical properties, over the fault surface while maintaining the constant shape of the slip time-function over the fault. W Bouchon allowed both the amplitude and the shape of his slip functions to vary over the fault plane in accordance with Das and Aki's (1977a) theoretical study of fault rupture, and he included a small number of highstrength barriers to rupture on the fault. Apsel and his coworkers allowed an even greater degree of randomness by adding a random component to the local rupture velocity, the rupture direction, the slip direction, and the slip time-function at each point. Their work will be discussed below.

\section{HOW GROUND MOTIONS ARE SIMULATED}

Conceptually, the problem of calculating earthquake ground-motion time-histories (henceforth called simply ground motions) can be divided into two parts, the first being the determination of what happens at the earthquake source to generate seismic waves and the second being the determination of how those waves are altered by the geologic structures that they pass through as they propagate away from the source. This section will describe Green's function summation methods, which are mathematical methods for calculating earthquakegenerated ground motions. We concentrate on these particular methods for several reasons; they are the easiest to understand, they explicitly separate the action of the earthquake source from the subsequent propagation of seismic waves, they have been the most commonly used methods in practice, and any other method can be expressed equivalently as a Green's function summation method without approximation.

The basic idea underlying Green's function summation methods is that, at a particular observation point, the overall ground motion caused by a large earthquake can be obtained by summing contributions to the ground motion from slip along many small segments of the causative fault. To do so, one must first specify how each segment of the fault slips during the earthquake and determine, for each small segment of the fault, how the ground at the observation point moves when only that part of the fault slips. Once we know the groundmotion time-histories caused at the observation point by slip on each individual segment of the fault, we can determine the ground motion caused by the large event simply by adding all the ground-motion time-histories caused by individual segments of the fault.

The ground motion caused by instantaneous slip on an individual segment of a fault is usually represented by a mathematical entity called a Green's function. For 


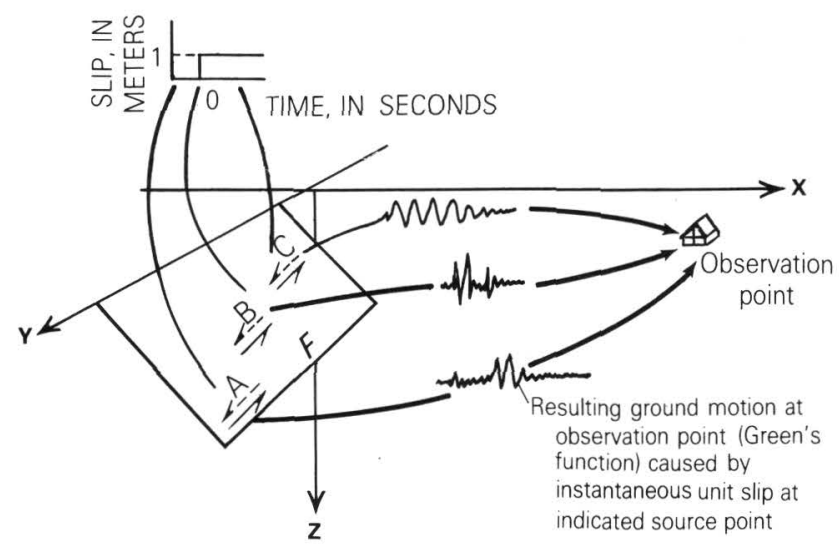

FIGURE 122.-Depictions of Green's functions in an $\mathbf{x}-\mathbf{y}-\mathbf{z}$ coordinate system. Individual points on the fault surface $F$ undergo instantaneous unit-amplitude slip, as the graphs indicate. The ground motion caused at the observation point by a single point source is a Green's function. Green's functions at points A, B, and C differ from one another because of varied epicentral distances from the observation point, varied source depths, and differences in geologic structure along the travel paths. The Green's functions must be further modified before they can be added together to simulate the rupture of the fault surface.

simplicity, let us assume that these small segments of a fault are points on that fault. To define a Green's function, imagine that we allow a single point on the fault to slip instantaneously from zero offset to unit offset and then stop (point $\mathrm{A}$ in fig. 122). The ground-motion timehistory caused at the observation point by this individual source point is called by seismologists the Green's function for the source point. The reason for introducing Green's functions is that, once the Green's function for a point on a fault is known, the ground motions caused by any arbitrarily complicated slip of that individual point can be easily obtained from the Green's function by the mathematical operation of convolving the slip time-history of the point with the Green's function (Bracewell (1965, p. 24-35) provides a simple description of convolution). Hence, to determine the ground-motion con'-ibution of each point on the fault, we first determine the Green's functions for each point on the fault (points A, B, and C in fig. 122). Green's functions from different points on the fault will in general differ from one another because the distances between the source and the observation point will vary, and the geologic structures through which the waves pass will also vary. We then convolve each Green's function with the slip time-history of the source point to get the point's total contribution.

The next step is the specification of the hypothetical earthquake source. The earthquake source may be specified completely by knowing the slip function (that is, the slip time-history) at every point on the fault. To

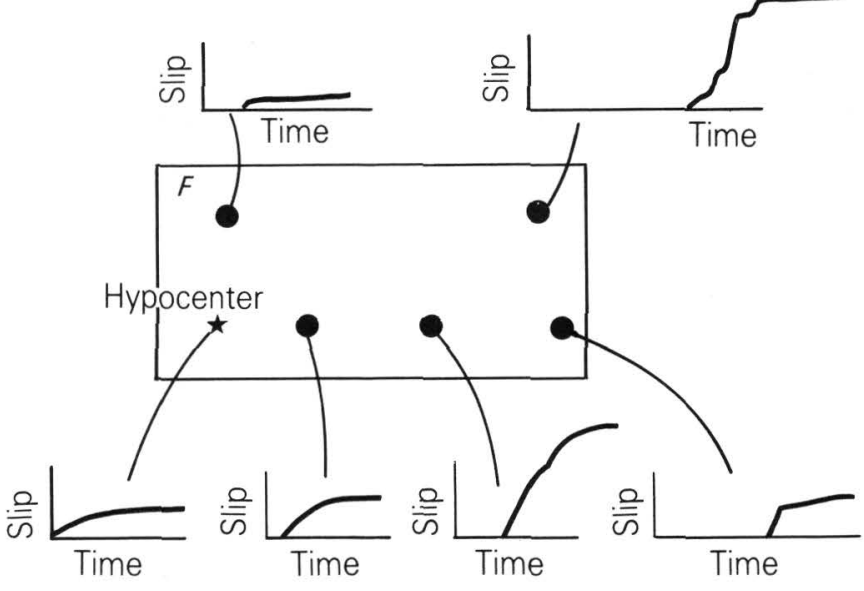

FIGURE 123.--Slip functions at various points on a hypothetical fault surface $F$. Note that slip initiates later at points farther from the hypocenter owing to the delay of the rupture in propagating from the hypocenter to each point. Both the shape and the amplitude of the slip functions may vary irregularly over the fault. Only one component of slip is shown.

manufacture a sensible source model, we rely on the basic properties of earthquake rupture described previously. Figure 123, for example, shows slip functions at six points on a fault surface $F$ that might result from a hypothetical earthquake that ruptures the fault surface. Note that each slip function starts at zero offset and ends with a constant offset, consistent with the premise that earthquakes result in a permanent offset between the two sides of the fault. Note also in figure 123 that, at each point on the fault surface, the shape and the amplitude of the slip functions are different, and slip initiates at different times. If we were to make plots like these for both components of slip at every point on the fault, the earthquake source would be completely characterized. Such a source description is called a kinematic description, because it specifies the motion of every point on the fault surface rather than the forces acting on every point.

Once we have a complete description of the action of each point on the fault $F$ and a description of what motions are caused at the observation point per unit slip at each point on $F$ (the Green's functions), we can find the total motion at the observation point simply by summing the contributions from each point on the fault. Consider, for example, a hypothetical earthquake in which the slip function at each point on the fault is simply instantaneous unit-amplitude slip whose onset time varies over the fault surface. In this case, the total motion at the observation point would be a simple sum of the Green's functions, each function being delayed in time to take into account the delayed action of its source point. Now imagine that the amplitudes of the source slip also vary from point to point on the fault. In this case, the Green's 


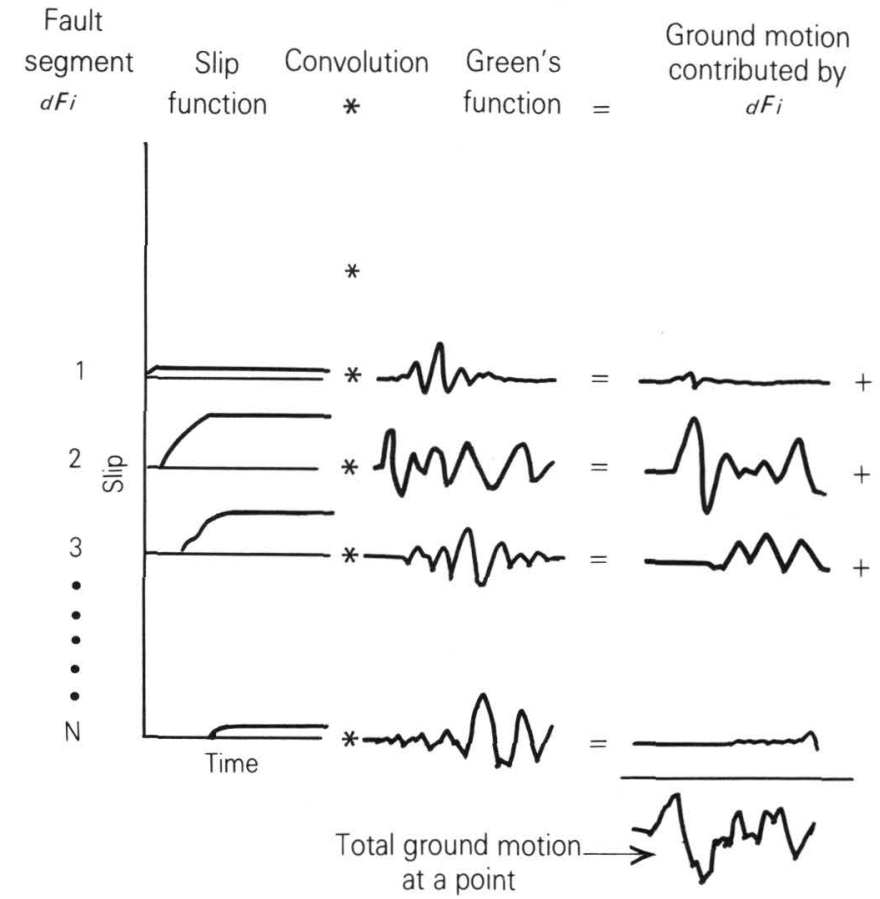

FIGURE 124.-Schematic illustration of ground-motion simulation. The left-hand column shows slip functions for several small areas of the fault, shown in figure 123. The center column shows the Green's functions caused by instantaneous unit slip on each part of the fault. The right-hand column shows the ground motion caused at the observation point by the slip function in the left-hand column (a convolution of the slip function and the Green's function). The results of these convolutions are automatically scaled to account for slip-function amplitude and delay. The total ground motion at the observation point (lower right-hand corner) is a sum of the contributions from each part of the fault (right-hand column).

functions would not only be delayed, as they were before, but would also be multiplied by the amplitudes of their respective source points before being summed. In the most general case, where the shape of the slip function varies from point to point on the fault, as figure 123 shows, each Green's function would be convolved by its respective slip function before being summed. This procedure is shown schematically in figure 124 .

A convenient aspect of Green's function summation methods is that the Green's functions are largely independent of the earthquake being simulated; they depend only on the geologic structure and the locations of the fault surface and the observation points, not on the details of how the earthquake ruptures. Hence, the Green's functions can be calculated once and stored for repeated use in simulating many different earthquakes as long as the fault surface and the observation sites remain the same. Often, calculating the Green's functions is the bulk of the computational labor. In this case, a wide variety of hypothetical earthquakes in the same study area can be simulated with relatively little effort if the Green's functions have been calculated previously and stored for reuse, as we have done (Ziony and others, this volume).

To calculate the ground motions from a postulated earthquake, all that one needs, in theory, is a complete specification of the slip function on every point of the fault and a complete knowledge of the Green's functions connecting each point on the fault with each observation point. Since neither of these goals has been attained in practice, we discuss how approximations of each are commonly obtained.

\section{MATHEMATICAL DETAILS}

Before proceeding, we pause to clarify a few terms used in the preceding discussions and in ensuing ones. We have used the term Green's function to refer to the ground motions caused by instantaneous slip at a point on a fault. Other authors assume different sources of waves for their Green's functions; some, for example, use point-force sources applied at the fault surface, whereas others use point-force sources applied at the observation point and evaluate their Green's functions on the fault surface. In addition, instead of using a step function for the source time-function (fig. 122), some use delta functions. Other details involve the directions of motion. Slip on the fault surface can occur in any direction parallel to the surface and can be broken into strike-slip and dip-slip components. Hence, a more complete specification of the Green's functions requires that we determine ground motions at the observation point caused by a strike-slip point dislocation and a dip-slip point dislocation. In addition, each source will generally cause motions in all three orthogonal directions ( $\mathbf{x}, \mathbf{y}$, and $\mathbf{z})$ at the observation point. Hence, if the Green's function is to be specified completely, it must be expressed in the form:

$$
\begin{aligned}
& \mathbf{G}^{\mathrm{ss}}\left(\mathbf{x}_{0}, t ; \mathbf{y}, 0\right) \\
& \mathbf{G}^{\mathrm{ds}}\left(\mathbf{x}_{\mathbf{0}}, t ; \mathbf{y}, \mathbf{0}\right)
\end{aligned}
$$

where $\mathbf{G}$ is the three-component vector consisting of the motions in the $\mathbf{x}, \mathbf{y}$, and $\mathbf{z}$ directions and the ss and $d s$ superscripts denote strike-slip and dip-slip sources, respectively; $\mathbf{y}$ is the slipped point on the fault, $\mathbf{x}_{0}$ is the observation point, and the argument $\left(\mathbf{x}_{0}, t ; \mathbf{y}, 0\right)$ specifies that the motions are caused by a source acting at position $\mathbf{y}$ and time 0 and are observed at $\mathbf{x}_{0}$ and time $t$.

In general, the slip that occurs as a function of time can be different at every point on the fault surface, so that we would characterize the strike-slip and dip-slip components of slip by $s^{s s}(\mathbf{y}, t)$ and $s^{d s}(y, t)$, where $y$ is a point on the fault. When we use the phrases slip function of the earthquake or slip model of the earthquake, we are referring to $s^{s s}(y, t)$ and $s^{d s}(y, t)$ for every point on the fault. When we say slip function at a point, we mean $s^{\mathrm{ss}}\left(\mathbf{y}_{0}, t\right)$ and $s^{d s}\left(\mathbf{y}_{0}, t\right)$, where $\mathbf{y}_{0}$ is the particular point in question. A 
less general description of slip on the fault would be $\mathrm{s}(\mathbf{y}, t)=\mathrm{a}(\mathbf{y}) \mathrm{T}(t)$, where $a(y)$ is the amplitude of the slip functions, which may vary with position on the fault, and $T(t)$ is the shape of the slip functions, which in this case is the same for all points on the fault surface. Clearly, if $s\left(y_{1}, t\right)=5 T(t)$ and $s\left(y_{2}, t\right)=T(t)$, the slip functions have the same shapes and different amplitudes.

Thus, the ground displacement at observation point $\mathrm{x}_{0}$ may be written

$$
\begin{aligned}
\mathbf{u}\left(\mathbf{x}_{0}, t\right) & =\frac{d}{d t} \iint_{F}\left[s^{s s}(\mathbf{y}, t){ }^{*} \mathbf{G}^{s s}\left(\mathbf{x}_{0}, t ; \mathbf{y}, 0\right)\right. \\
& \left.+s^{d \mathrm{~d}}[\mathbf{y}, t){ }^{*} \mathbf{G}^{\mathrm{ds}}\left(\mathbf{x}_{0}, t ; \mathbf{y}, 0\right)\right] d F
\end{aligned}
$$

where $\mathbf{y}$ is a point on the fault surface $F$, the asterisk denotes temporal convolution (Bracewell, 1965), and where the $\mathrm{d} / \mathrm{dt}$ compensates for our use of a step function rather than a delta function as the Green's function's source time-function. Imagine that we break $F$ up into $N$ subfaults $\mathrm{d} F_{i}$ having center point $\mathbf{y}_{i}$ and that, within $\mathrm{d} F_{i}$, $s(\mathbf{y}, t)$ and $\mathbf{G}\left(\mathbf{x}_{\mathbf{0}}, t ; \mathbf{y}, 0\right)$ are approximately constant with respect to $y$. Then we can rewrite the integral as a sum of contributions from each subfault

$$
\begin{aligned}
\mathbf{u}\left(\mathbf{x}_{0}, t\right) & =\frac{d}{d t} \sum_{i=1}^{N}\left[s^{s s}\left(\mathbf{y}_{i}, t\right) * \mathbf{G}^{\mathrm{ss}}\left(\mathbf{x}_{0}, t ; \mathbf{y}_{\mathrm{i}}, 0\right)\right. \\
& \left.+\mathbf{s}^{d s}\left(\mathbf{y}_{\mathrm{i}}, t\right) * \mathbf{G}^{\mathrm{ds}}\left(\mathbf{x}_{\mathbf{0}}, t ; \mathbf{y}_{i}, 0\right)\right] d F_{\mathrm{i}}
\end{aligned}
$$

This technique is almost identical to the procedure used by Heaton and Helmberger (1979) to simulate the 1971 San Fernando earthquake, by Hartzell and Helmberger (1982) to simulate the 1979 Imperial Valley earthquake, and by us (Ziony and others, this volume) and has been well summarized by Heaton (1982).

\section{GREEN'S FUNCTIONS AND THEIR APPROXIMATION}

Although great progress has been made recently in understanding seismic wave propagation in the Earth, two obstacles force seismologists to use approximate Green's functions in ground-motion simulations. This section discusses those obstacles, the approximations used, and their effect on the relevance of the resulting predicted time-histories of shaking. We stress that the effect of each approximation is to diminish the accuracy of the calculations for some types of waves in certain frequency bands and certain geologic structures. Conse- quently, in choosing an approximation, the user must know which types of waves will be the most important contributors to strong ground motions in the situation being simulated and must choose the method that most accurately represents those types of waves.

The first obstacle to accurate calculation of Green's functions is the fact that the Earth's velocity structure is rarely known well enough to allow an exact calculation of Green's functions, even in principle. In particular, we cannot detect most of the heterogeneities that are responsible for scattered waves in the Earth. Aki and Chouet (1975) have pointed out that most of the energy in the S-wave codas of local earthquakes is due to latearriving $S$ waves scattered from random heterogeneities. If such heterogeneities are not included in velocity models, the Green's functions obtained from the model will lack the scattered waves that exist in reality. Although this problem may not be very severe for calculations at frequencies of $1 \mathrm{~Hz}$, for which the associated seismic wavelengths are long, the problem is quite severe at frequencies of $20 \mathrm{~Hz}$.

\section{Details of Uncertainties Due to Poorly Known Velocity Structure}

To calculate seismic waves accurately up to frequencies of $10 \mathrm{~Hz}$ in a region where the minimum shear-wave velocity is $1.5 \mathrm{~km} / \mathrm{s}$, we need to know details about the seismic velocity, the density, and the attenuation structures having a spatial resolution of $75 \mathrm{~m}$. In most regions of interest, this goal is unattainable. So, can we say, in general, how well these structures are known and how our imperfect knowledge of structure affects the reliability of Green's function calculations?

The degree of detail in which a velocity structure is known is dependent on the type of data from which the structure was derived and the method used to analyze those data. Generally, P-wave velocity is the only physical property of the crust that is easily observed in any detail, because it is easy to generate $P$ waves artificially (for example, by explosions or vibrator trucks) and difficult to generate $\mathrm{S}$ waves. When an S-wave velocity structure cannot be observed directly, it is derived from a P-wave velocity structure by assuming a fixed ratio of $P$ - and $S$-wave velocities in various materials (Hamilton, 1979). Density can be measured directly by means of gravity surveys, or it can be inferred from the P-wave velocity by using empirical relations, such as those given by Hamilton (1978). Fortunately, seismic waves are not affected much by density variations (Wiggins and Helmberger, 1974), so accurate density estimation is not crucial. P- and S-wave attenuations are very difficult to measure directly, and, usually, 
educated guesses are made on the basis of what few observations do exist. Of all the physical properties listed above, the lack of a directly measured S-wave velocity structure and the poor knowledge of S-wave attenuation introduce the largest. uncertainties into Green's function calculation. Although poor knowledge of $V_{s}$ affects all frequencies of ground motion, uncertainties in S-wave attenuation become progressively more important for computations at higher frequencies. Hence, a good knowledge of S-wave attenuation is quite important in calculating peak accelerations.

Since P-wave velocity is the most easily observed physical property of the crust, how well is it typically known? A very dense multichannel seismic-reflection survey can resolve details of the P-wave velocity structure 100 to $200 \mathrm{~m}$ in extent within the top few kilometers of the crust. Such information rarely exists, however, and is often proprietary. Good-quality modern seismic refraction analysis, such as that done by McMechan and Mooney (1980), is capable of resolving details about $1 \mathrm{~km}$ in vertical extent and 2 to $3 \mathrm{~km}$ in horizontal extent. Work of this type usually interprets the refraction data in terms of seismic velocity models that vary both vertically and horizontally and can therefore deal adequately with major lateral changes of velocity structure. Most available velocity structure information, however, comes from an earlier style of refraction data analysis, which interpreted the data in terms of a stack of layers of constant-velocity material separated by flat or dipping planes (Biehler and others, 1964). Although this type of analysis is quite appropriate for some places, it is not especially reliable for others, such as those characterized by horizontal variation in structure. In particular, it is completely incapable of resolving crustal heterogeneities having limited horizontal extent (say, a few kilometers).

\section{Computational Limitations}

The second obstacle to accurate Green's function calculation is the computational effort required. The most powerful and general methods for calculating Green's functions are the finiteelement and the finitedifference methods (Boore, 1972). These methods can, in principle, calculate the complete seismic wavefield in Earth models having an arbitrary three-dimensional velocity structure, but the computational effort is great. Of course, it should be noted that the computational effort required by a finiteelement analysis yields a truly complete solution. Rather than generating ground motions at only 10 sites, for example, as the ground-motion simulation for the postulated earthquake along the Newport-Inglewood zone does (Ziony and others, this volume), a comparable finite-element analysis, like the one described below, would generate ground motions at a grid of 63,000 sites in the Los Angeles basin. Moreover, because the finite lement analysis accounts for the effects of horizontal variations in basement depth and in near-surface shear-wave velocity, it is an extremely powerful, albeit expensive, tool for seismic zonation.

Consider, for example, the computational effort that would be required by a finite-element method for calculating ground motions in the Los Angeles basin from a magnitude 6.5 earthquake on the NewportInglewood fault. If the method of Archuleta and Frazier (1978) is used to calculate 30-s ground-motion timehistories at 63,000 sites for frequencies ranging from 0 to $2 \mathrm{~Hz}$, approximately 19 million words of computer storage would be required, and the calculation would take about $40 \mathrm{hr}$ on a fast, currently available computer such as the CRAY-1.

Since, in practice, the large amounts of computer time required to use the finite-element or finite-difference method in routine calculations of Green's functions in the frequency band of engineering interest are not made available, other more approximate, less computationally expensive methods are generally used. Two principle alternatives exist at present. The distinction between them is that, in one, the geologic structure is approximated by a simpler structure in which Green's functions can be obtained exactly, and, in the other, the exact geologic structure is used but the Green's functions are obtained only approximately.

In the first alternative, the true Earth's structure is approximated by a laterally homogeneous structure (that is, a structure in which seismic velocities, densities, and attenuations vary only with depth and are independent of horizontal position). Once this approximation is made, it is possible to calculate complete Green's functions (that is, Green's functions that contain the complete seismic response of the approximate structure, including all possible body and surface waves). We will refer to such Green's function calculation methods as lateral homogeneity methods. It is important to note that, when one assumes lateral homogeneity of the geologic structure, absolute horizontal position becomes irrelevant, and the only meaningful horizontal variable is the location of the observation point relative to the seismic source. The lateral homogeneity approximation is usually a reasonable first approximation of the true Earth structure, because the material properties of the Earth generally vary more with depth than they do with horizontal position. In many regions of greatest interest for earthquake hazards evaluation, such as the Los Angeles region, where crystalline uplands are adjacent to deep alluvial basins, the approximation of lateral homogeneity is not always good, however.

\section{Earthquake Hazards in the Los Angeles Region}


To date, the lateral homogeneity approximation has been used in almost all practical ground-motion simulations. Ground motions from the 1971 San Fernando earthquake were simulated by Bouchon (1978), Heaton and Helmberger (1979), and Heaton (1982), all of whom used a laterally homogeneous Earth model consisting of a uniform halfspace. The 1966 Parkfield earthquake was simulated by Bouchon (1979), who used a uniform layer overlying a halfspace, and by Archuleta and Day (1980), who used an Earth model consisting of two uniform layers overlying a halfspace. More complicated laterally homogeneous models, shown in figure 125, have been used in simulations of the 1979 Imperial Valley earthquake (Hartzell and Helmberger, 1982; Olson and Apsel, 1982; Hartzell and Heaton, 1983; Archuleta, 1984) and in studies of the Los Angeles region (Apsel and others, 1981; Ziony and others, this volume).

If it is important to retain lateral variations in the geologic structure, then one must currently choose Green's function methods that give only approximate Green's functions. The most widely used of these approximate methods are the body-wave methods (also called ray methods), which construct the seismic response of the medium from a finite sum of discrete body waves (such as direct $P$ and $S$ waves). The resulting Green's functions are necessarily incomplete because neither surface waves nor most of the infinite possible number of body waves is included. An additional strength of body-wave methods is that they are 10 to 100 times faster computationally at high frequencies $(10 \mathrm{~Hz})$ than lateral homogeneity methods are. As more strong ground-motion data are gathered fróm earthquakes, it is becoming clear that horizontal variations in geologic structure can affect the strength of the ground motions. Liu and Heaton (1984) have presented an excellent example of how the structures of the San Fernando Valley, the Santa Monica Mountains, and the Los Angeles basin altered the character of the ground motions from the 1971 San Fernando earthquake. Consequently, research on body-wave methods, which are appropriate for laterally varying structure, is currently quite active. Both Hong and Helmberger (1978) and Nowack and Aki (1984) have used body-wave methods to study amplification of ground motion in sedimentary basins, and Rial (1984) has examined how the damage patterns observed in the 1967 Caracas, Venezuela, earthquake could be predicted by body-wave theory. Cormier and Spudich (1984) have used body-wave methods to show that ground motions can be amplified in fault zones owing to their geologic structure. Both Bernard and Madariaga (1984) and Spudich and Frazer (1984) have devised extremely simple and efficient methods for combining body-wave Green's functions with earthquake rupture models.

\section{Details of Choosing a Green's Function Method}

Clearly, to choose between these methods in a sitespecific simulation, one must decide how important surface waves are in the study situation, how strong the horizontal variations in geology are at the site, and how well a finite sum of body waves would approximate the actual Green's functions. Although these questions are difficult to answer a priori, certain considerations can be addressed. Surface waves, for example, start to become an important component of ground motion only at epicentral ranges that are about two to three times the seismic source depth; thus, if one is simulating ground motions from an earthquake whose rupture surface is confined to depths greater than $3 \mathrm{~km}$, surface waves will be unimportant at horizontal distances less than about $10 \mathrm{~km}$ but may be very important at distances greater than $20 \mathrm{~km}$. Additional discussion of the characteristics of surface and body waves has been presented by Spudich and Orcutt (1982).

When the importance of horizontal variation in geologic structure is assessed, the scale of variation must be considered. For example, accelerograms from both the 1979 Coyote Lake and Imperial Valley earthquakes were recorded in alluvial basins, but the scales of the basins vary dramatically. Figure 126 shows cross sections of the Santa Clara Valley (Mooney and Luetgert, 1982), site of the Coyote Lake earthquake, and the Imperial Valley (from line $1 \mathrm{E}-2 \mathrm{~W}$ of Fuis and others (1982)). Although one could find a laterally homogeneous velocity model that would be a reasonable approximation of the Imperial Valley structure between the fault and accelerometer sites 1 through 11 , one would be hard pressed to find a laterally homogeneous model that would approximate the velocity structure between the Calaveras fault and any of the Santa Clara Valley accelerometer sites. In fact, Cormier and Spudich (1984) have shown that the Santa Clara Valley velocity structure amplified ground motions in the Calaveras fault zone. For this reason, lateral homogeneity methods for calculating Green's functions have been used quite successfully in simulating ground motions caused by the Imperial Valley earthquake but have been of lesser utility in simulating Coyote Lake ground motions (Bouchon, 1982; Liu and Helmberger, 1983).

Lateral homogeneity methods have been studied intensively. In such techniques, the Earth models used consist of stacks of layers whose material properties and thicknesses vary. In some methods, the layers are required to be perfectly uniform, whereas, in others, the material properties may vary smoothly with depth within each layer. Although this second type of Earth structure is more realistic, the uniform-layer models can 

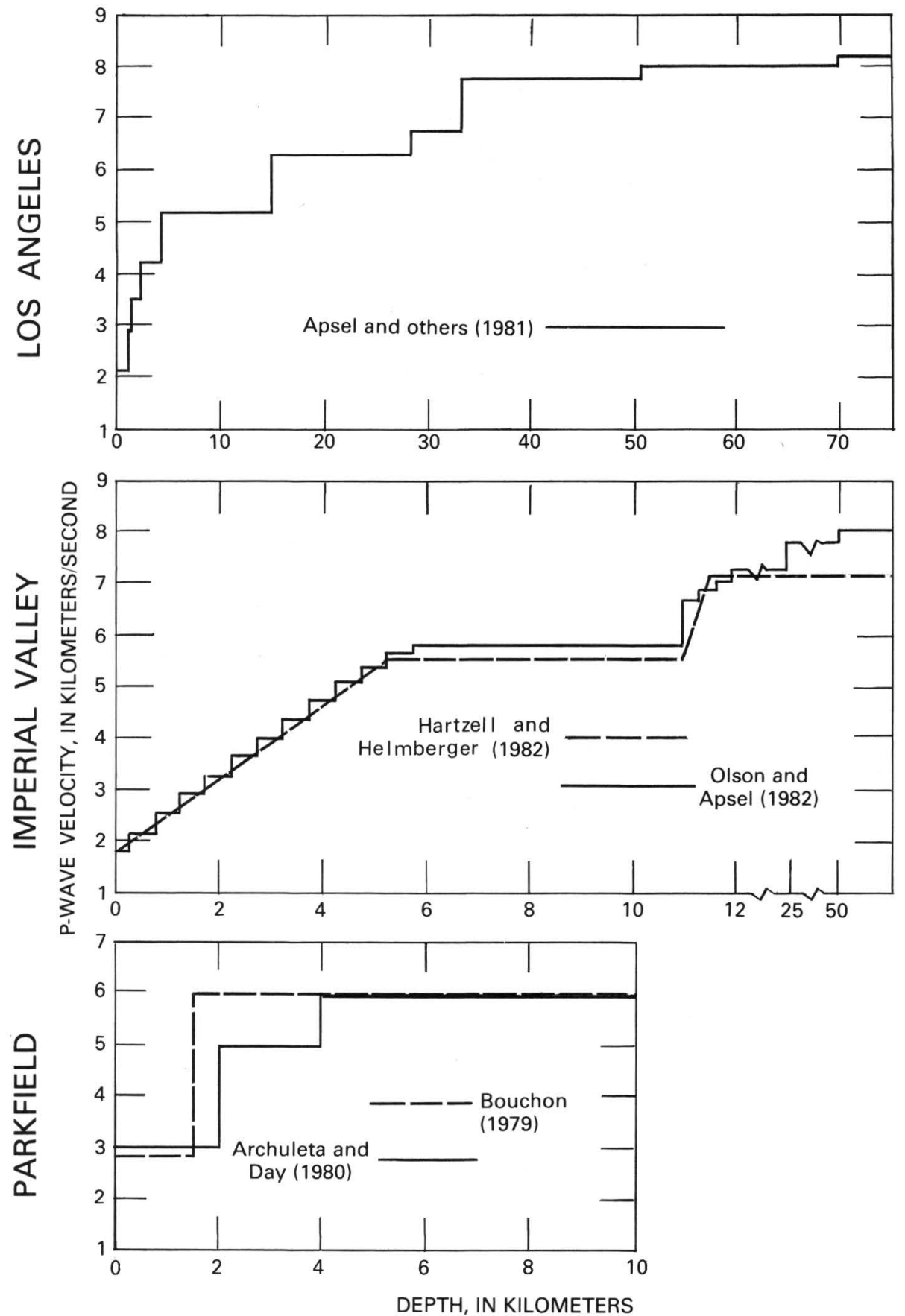

FIGURE 125.-Graphs of laterally homogeneous P-wave velocity structures used in groundmotion simulations in the Parkfield, Imperial Valley, and Los Angeles regions of California. Note the varying depth scales.

be made arbitrarily close to a smooth Earth model by taking many very thin, uniform layers whose material properties change gradually between layers (like the two Imperial Valley models in fig. 125). Of course, the cost of calculating Green's functions rises as the number of layers in the Earth model increases; because the cost of computing Green's functions by these methods is gen- erally the major expense in ground-motion simulation, the motivation for calculating them once and storing them for later reuse is strong.

Of the uniform-layer methods, one of the first and most widely used is the generalized ray theory (GRT) of Helmberger (1968) and Helmberger and Harkrider (1978). Although the GRT is extremely powerful in some 
SANTA CLARA VALLEY
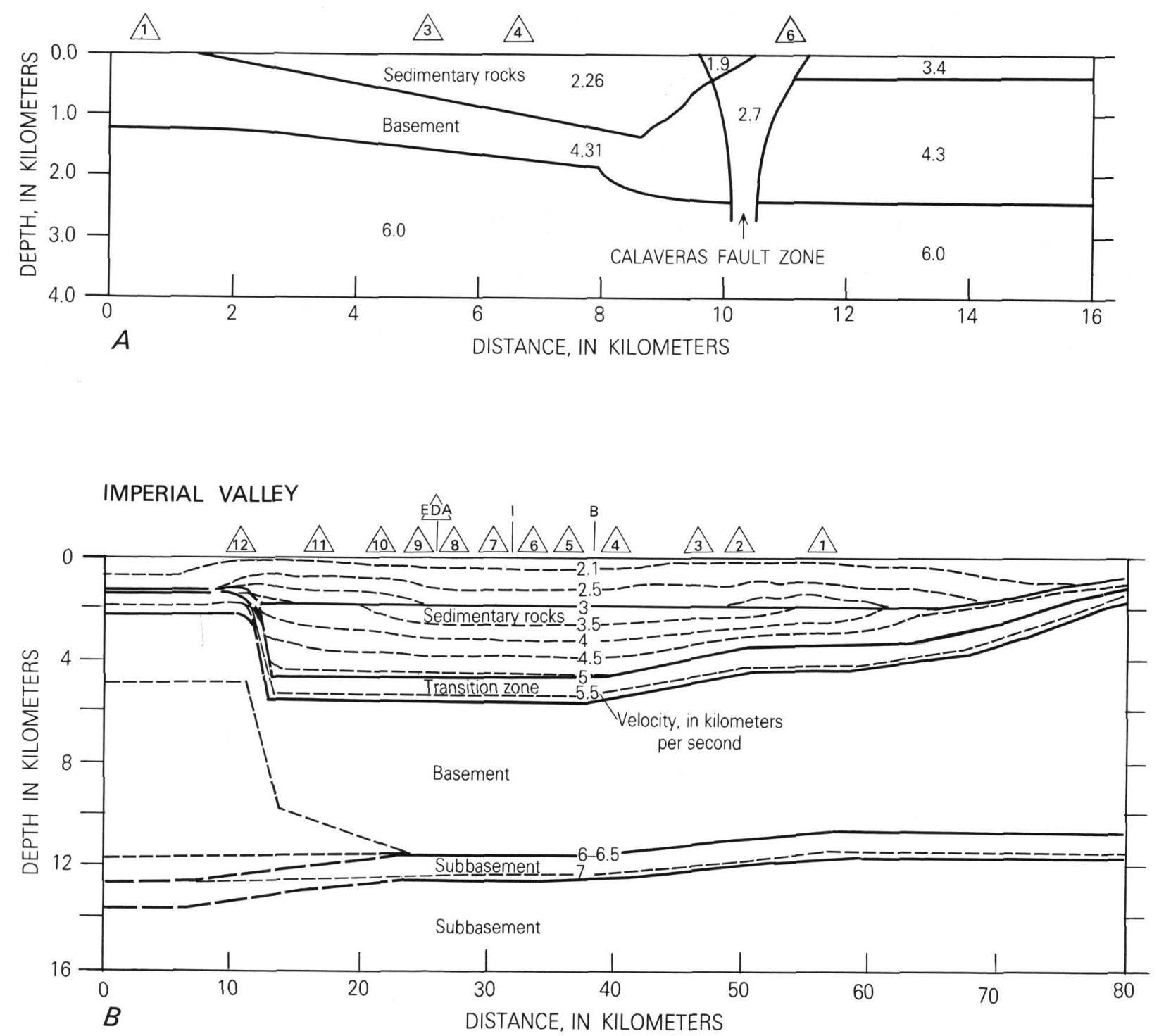

FIGURE 126.-Cross sections of P-wave velocity structures in the Santa Clara Valley (A) and the Imperial Valley (B) of California. Accelerometer sites are indicated by numbered triangles. A, Numbers inside the cross section are the P-wave velocities (in kilometers per second) of the labeled units. B, Dashed lines are isovelocity contours. I and B indicate surface traces of the Imperial and Brawley faults, respectively. The Imperial Valley cross section is taken from line 1E-2W of Fuis and others (1982). Note the difference in the vertical and horizontal scales in both cross sections.

applications (Burdick and Orcutt, 1979), one drawback is that it does not automatically generate complete Green's functions for the layered medium. As Hartzell and Helmberger (1982) have shown, this shortcoming can be very inconvenient for ground-motion synthesis. Consequently, other methods for generating the complete response of uniform-layer models have been developed (Kind, 1978; Herrmann, 1979; Bouchon, 1980; Kennett, 1980; Harvey, 1981; Apsel and Luco, 1983) and have been used in ground-motion simulations by Bouchon (1978, 1979, 1982), Apsel and others (1981), and Olson and Apsel (1982).
To overcome the expense of using finely layered Earth models to approximate continuous velocity-depth profiles, several investigators have determined methods to generate complete Green's functions for arbitrary smooth or discontinuous velocity profiles (Alekseev and Mikhailenko, 1980; Cormier, 1980; Kennett and Illingworth, 1981; Olson and others, 1984; Spudich and Ascher, 1983). Such techniques have been used in ground-motion simulations by Hartzell and Helmberger (1982), Hartzell and Heaton (1983), Archuleta (1984), Liu and Helmberger (1983), and Ziony and others (this volume). 
Two drawbacks common to all these methods of generating complete Green's functions in laterally homogeneous Earth models are that they are expensive to use in the frequency band of engineering interest $(1-20 \mathrm{~Hz})$ and that they require the use of an often unrealistic Earth model. For these reasons, considerable interest is being shifted toward body-wave methods for calculating Green's functions. Several methods exist for calculating body-wave Green's functions (Hong and Helmberger, 1978; McMechan and Mooney, 1980; Červený, 1983), and several more are under development. The chief pitfall of using such methods, mentioned earlier, is the possibility that an impractically large number of body waves must be included in the Green's functions in some Earth models. Hong and Helmberger (1978) have shown a good example in which one or two body waves alone are insufficient. In certain situations, however, the complete seismic response of a geologic structure may be well represented by a few body waves. If, for example, a particular geologic structure contains very few reflectors (abrupt velocity discontinuities), body waves traveling directly from source to receiver without reflection will probably be the most important waves. If, in addition, surface waves are not important, for the reasons noted above, then the ground motions resulting from an earthquake in this structure may well consist primarily of direct body waves. Spudich and Cranswick (1984) have shown that these conditions prevailed at a site $5.6 \mathrm{~km}$ from the $M_{S} 6.9$ Imperial Valley earthquake of 1979. The ground motions at that site consisted primarily of the direct $P$ and $S$ waves only. A body-wave method like that of Spudich and Frazer (1984) would be well suited for synthesizing the ground motions observed by Spudich and Cranswick.

\section{Empirical Green's Functions}

Of course, all the Green's function calculation methods mentioned above are theoretical calculations based on an inferred approximate Earth model. Empirically obtained Green's functions may also be used. Hartzell (1978), for example, used recordings of small earthquakes as Green's functions for a larger earthquake simulation. If the small earthquake occurs on the same fault surface as the hypothetical large event and if recordings of the small earthquake are available at the sites where simulated ground motions for the hypothetical large event are desired, the recordings are in some respects ideal Green's functions, because their source is virtually a point in space and the effects of wave propagation in the local structure are included exactly. This use of small-earthquake recordings as Green's functions may prove to be very important, but its utility depends on the existence of a very good set of recordings. Other studies using this approach have been done by Kanamori (1979), Hartzell (1982), and Irikura (1983).

\section{DETAILED EXAMPLE OF GROUND-MOTION SIMULATION}

Apsel and others (1981) have simulated ground motions in the Los Angeles basin caused by a magnitude 7.5 event on the "big bend" segment of the San Andreas fault and by a magnitude 6.8 event on the NewportInglewood fault near Long Beach. Because of the size of the events, the large horizontal distances between points on the faults and sites in the basin, the geologic complexity of the region, and the frequency bandwidth covered, this study was particularly difficult to execute. Although we will comment on some of the techniques used, a cursory review such as this one is not sufficient to judge the validity of the results of such a large study. The following discussion concentrates on the San Andreas event simulation.

Green's functions.-Apsel and Luco's (1983) method, which requires a laterally homogeneous, uniform-layer Earth model, was used to generate Green's functions in the $0-$ to $5-\mathrm{Hz}$ frequency band. Because of the lateral variations between the geologic structures of the San Andreas fault and points in the Los Angeles basin, a 10-layer velocity model representing a composite of velocities observed at different depths in southern California was used (fig. 125). In the top $15 \mathrm{~km}$, the velocity structure used by Apsel and others (1981) was appropriate to the Los Angeles basin specifically and included the low-velocity materials that velocity logs in oil wells have shown to exist at shallow depths. For deeper structure, they used velocities derived from regional traveltime studies. Certainly, the assumption of lateral homogeneity in this study is an important one, and, although we cannot comment on its validity without further study, one might be able to check its validity by determining what part of the Earth model transmitted most of the seismic energy and by checking the lateral homogeneity assumed for that depth range. If, for example, it were determined that 95 percent of the seismic energy stayed trapped in the top $5 \mathrm{~km}$ of the model of Apsel and others (1981), then the lateral homogeneity assumption might break down if the top $5 \mathrm{~km}$ of the San Gabriel Mountains differed considerably from their model. On the other hand, the lateral homogeneity assumption may be much better for the deeper structure. In this light, it is interesting to consider the observations of Liu and Heaton (1984).

Because of the relatively high frequencies and the long epicentral ranges that Apsel and his coworkers 
dealt with, they were forced to include attenuation $(Q)$ in their Earth model. They pointed out that their calculated peak accelerations are strongly influenced by the $Q$ of the Earth model and that uncertainties in $Q$ could lead to uncertainties in the computed peak accelerations of more than a factor of two.

Slip model.-The slip model used in this study was a kinematic model in which many parameters were derived from dynamic models of earthquake rupture and in which a degree of randomness was added to the source behavior. Our description of this slip model is intended to convey only the general principles.

The shape of the slip time-function at each point on the fault was selected to be a simple function approximating the shapes of slip functions observed in dynamic rupture models such as those of Archuleta and Frazier (1978) (fig. 119). This shape was held constant over the entire fault surface. At each point on the fault, the theoretical arrival time of a rupture front propagating at 0.9 of the local shear-wave velocity was determined. Rather than allowing slip to initiate at each point at the theoretical arrival time of the rupture front, Apsel and his coworkers allowed slip to initiate at a random time delay (generally less than $1 \mathrm{~s}$ ) after the theoretical time. In this way, they introduced the irregular propagation of rupture discussed in the section describing the earthquake rupture process. Additional randomness was added by allowing the direction of rupture advance to vary irregularly from the overall along-strike direction, by allowing the slip mechanism at each point on the fault to vary randomly about a predominantly strike-slip mechanism, and by allowing the amplitude of the slip function to vary randomly about a mean amplitude at each point on the fault. The amount of random variation was chosen on the basis of simulations of several earthquakes for which local strong-motion data existed. Thus, the slip model of Apsel and others (1981) was intermediate between the essentially dynamic model of Archuleta and Day (1980) and the entirely kinematic model of Bouchon (1979).

Green's function summation.-The Green's function summation technique that Apsel and others (1981) used was also essentially a point-source summation like that of Hartzell and Helmberger (1982), although Apsel and his coworkers used a different method of interpolating Green's functions and used additional measures to ensure that the distribution of point sources on the fault surface was dense enough.

\section{SUMMARY}

Time-histories of ground motion from a hypothetical earthquake can be predicted by determining how each point on a fault is displaced during the event, calcu- lating the ground motions caused by each individual point on the fault, and then summing the contributions to get the total ground motion of the hypothetical event at distant sites. Some methods for simulating ground motions use essentially this procedure (for example, Ziony and others, this volume), whereas, in other methods (for example, Archuleta and Frazier, 1978), the action of the earthquake source is calculated along with the propagation of seismic waves away from the source. Even in these cases, however, the validity of the calculated ground motions may be tested by determining whether the fault slipped in a realistic way, whether a realistic Earth structure was used, and whether the method used to calculate seismic-wave propagation was accurate.

The ground motion caused by sudden slip at any point along a fault can be represented by a mathematical entity called a Green's function. If ground- motion calculations explicitly use Green's function summations, calculation of those functions is often the bulk of the computational labor, but, if they are stored, they may be summed repeatedly, relatively effortlessly, to simulate a wide variety of hypothetical earthquakes in the same study area.

At present, the theory for calculating complete Green's functions (that is, Green's functions containing the complete response of the Earth model) is most fully developed for Earth models in which material properties vary with depth only; such models assume no horizontal change in geologic structure. In more realistic models, where horizontal variation in geologic structure occurs, incomplete Green's functions can be calculated for individual body waves, such as direct $P$ or $S$ waves, or for waves that have undergone a specified number of reflections and mode conversions. The complete response of laterally varying media cannot be determined easily except in very simple circumstances, although it can always be obtained with great computational effort by using three-dimensional finite-element or finitedifference calculations. In many instances, however, the bulk of the ground motion observed at a specific site may consist primarily of direct $P$ and $S$ waves, and, in these cases, it may be possible to simulate ground motions in the laterally varying structure with little computational effort.

Incomplete knowledge of the geologic structure of a region and uncertainties about seismic source behavior are important obstacles to the prediction of ground motions. One way around the obstacle of Green's function determination might be to use seismograms from small earthquakes as Green's functions. Purely theoretical attempts to circumvent these voids in our knowledge, however, will probably rely on a more statistical description of seismic source action and seismic-wave propagation. 


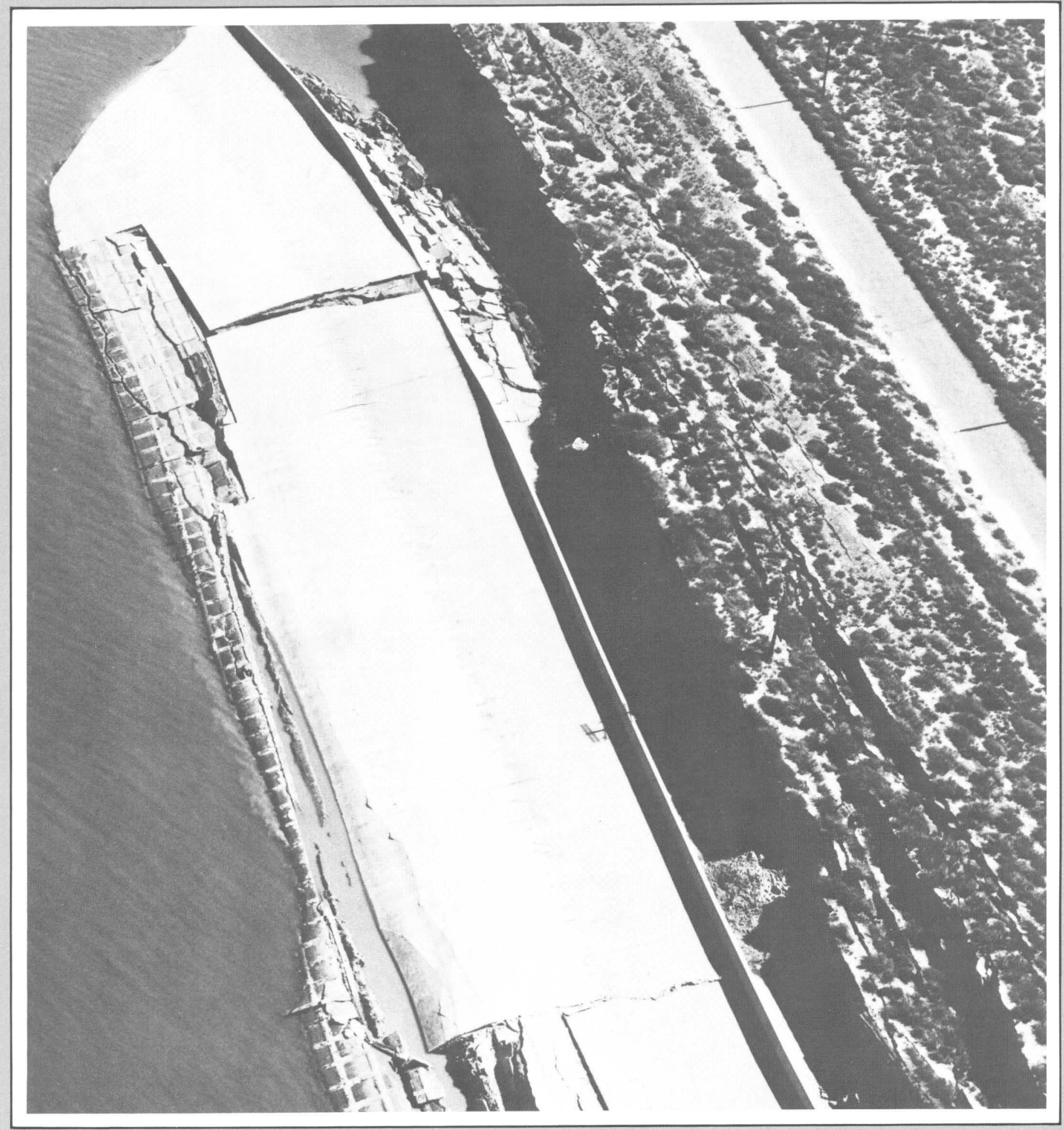

\section{Earthquake-Triggered Ground Failure}




\title{
EVALUATING LIQUEFACTION POTENTIAL
}

\author{
By J. C. Tinsley, T. L. Youd, ${ }^{4}$ D. M. Perkins, and A. T. F. Chen
}

\section{INTRODUCTION}

Liquefaction, a process by which water-saturated sediment loses strength and may fail during strong shaking, commonly accompanies moderate to great earthquakes throughout the world. Research into the process and consequences of liquefaction was stimulated by catastrophic ground failures triggered by the 1964 Alaska earthquake (Hansen, 1965; McCulloch and Bonilla, 1970); the 1964 Niigata, Japan, earthquake (Seed and Idriss, 1967); the 1967 Caracas, Venezuela, earthquake (Seed and Alonso, 1973); and the 1971 San Fernando, Calif., earthquake (Youd, 1971; Seed and others, 1975). These and subsequent studies of other earthquakes have firmly linked liquefaction to certain hydrologic and geologic conditions. Liquefaction as a process is now relatively well understood. The environments that favor the occurrence of liquefaction can be delineated with reasonable precision, and the geographic variation in liquefaction potential can be used in planning the reduction of earthquake hazards.

Liquefaction-related ground failures have occurred during past earthquakes in southern California. The great 1857 Fort Tejon earthquake caused fissuring of the ground in the beds of the Los Angeles, San Gabriel, Santa Clara, and Santa Ana Rivers. Sand boils occurred at Santa Barbara and in the flood plain of the Santa Clara River (Agnew and Sieh, 1978). During the 1933 Long Beach earthquake, liquefaction-generated ground failures damaged parts of Compton, Huntington Beach, and Long Beach (Barrows, 1974). Figure 127 shows liquefaction-related ground failure manifested as slumping and cracking along the Bolsa Bay causeway near Huntington Beach in Orange County, Calif. During the 1973 Point Mugu earthquake, ground failures due to liquefaction were noted in the estuarine areas near Port Hueneme and along the lower reaches of Calleguas Creek (Weber and Kiessling, 1976). During the 1979 and 1981 earthquakes in the Imperial Valley, locally extensive ground failures damaged roads, utilities, irrigation

\footnotetext{
${ }^{4}$ Now at Department of Civil Engineering, 370 Clyde Building, Brigham Young University. Provo, UT 84602.
}

canals, and other agricultural facilities (Youd and Wieczorek, 1982, 1984). In all these instances, a range of liquefaction-related effects was reported-from minimal ground cracking causing negligible damage, to sand boils, lateral spreads, and slumping causing greater damage. During the 1971 San Fernando earthquake, for example, liquefaction-related ground failures severely damaged facilites at the San Fernando Juvenile Hall (fig. $128 \mathrm{~A}$ ), inflicted major damage to the newly constructed Jensen Water Filtration Plant, and triggered nearcatastrophic failure of the Lower Van Norman Reservoir Dam (fig. 128B) (Seed and others, 1975). Future major earthquakes undoubtedly will cause comparable liquefaction-related ground failure in parts of the alluvial basins of the Los Angeles region.

This chapter reviews how liquefaction potential is evaluated and then defines the relative liquefaction potential for six areas in five alluvial basins in the Los Angeles region (fig. 129). Our regional assessments consider the geologic age and type of sedimentary deposits, the ground-water depth, and the likelihood that earthquakes strong enough to cause liquefaction will occur.

The occurrence of liquefaction is limited chiefly to certain mappable geologic and hydrologic settings and to regions of high seismicity. Water-saturated, cohesionless, granular sediment situated at depths less than $30 \mathrm{ft}$ subsurface constitutes the principal environs of the liquefaction process. These geologic conditions are widespread in parts of each of the six areas considered in this chapter: the San Fernando Valley, the San Gabriel Valley, the coastal basin in Los Angeles County, the flatland area of Orange County, the upper Santa Ana River basin, and the Oxnard Plain.

\section{Acknowledgments}

This report is based in large measure on the logs of several thousand exploratory boreholes and wells filed by numerous public and private agencies and organizations. We are indebted to the following for their important contributions, including access to records, in discussions or in reviews: California Division of Mines

Evaluating Liquefaction Potential 


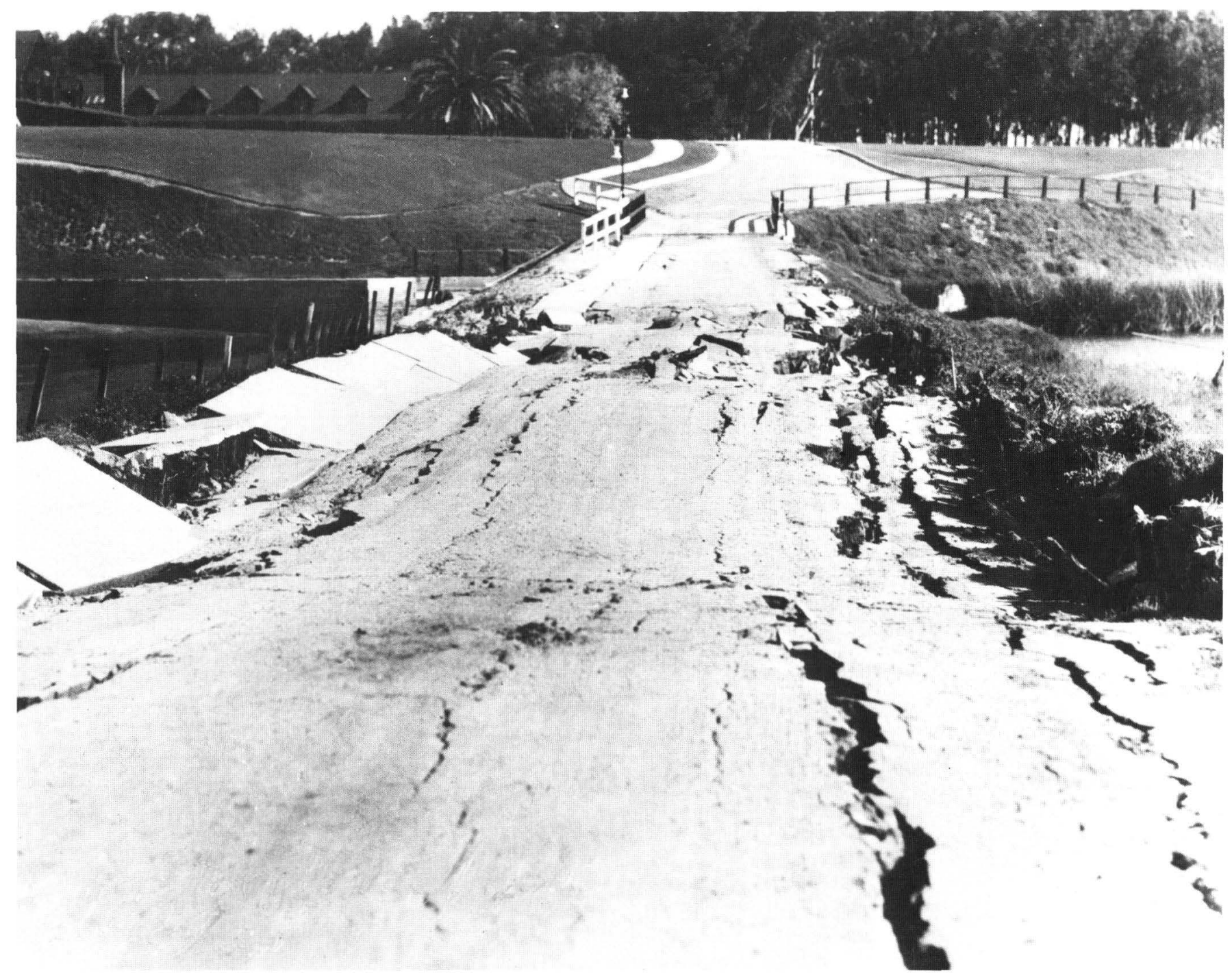

FIGURE 127.-Damage to causeway across Bolsa Bay northwest of Huntington Beach as a result of the 1933 Long Beach earthquake. Slumping and cracking of the road were probably due to liquefaction of the underlying fill or the Holocene sediment of Bolsa Bay. (Photograph from the City of Long Beach Public Library Historical Collection.)

and Geology, Los Angeles; California Department of Water Resources, Southern District, Los Angeles; California Department of Transportation, Division of Structures, Sacramento; California Division of Oil and Gas, Long Beach; City of Los Angeles Department of Building and Safety and Department of Water and Power; County of Los Angeles Department of the County Engineer (Geologic Section), Department of Facilities (Architectural Division), Department of Public Works (Soils Section), Flood Control District (Materials Engineering Division and Water Conservation Division, Groundwater Studies and Operations Section), and Department of Roads; Southern California Rapid Transit
District, Rapid Transit Department; Metropolitan Water District of Southern California; U.S. Army, Corps of Engineers, Los Angeles District; and LeRoy Crandall and

FIGURE 128.-A, Damage to San Fernando Juvenile Hall facility caused by lateral spreading ground failure during the February 9, 1971, San Fernando earthquake. (Photograph by T. L. Youd, from U.S. Geological Survey Professional Paper 733.) B, Lower Van Norman Dam Reservoir. Slumping of the concrete lining on the northern side of the dam was caused by the 1971 San Fernando earthquake. Considerable water had been emptied by the time the photograph was taken. Subsequent investigation of the failure indicated that part of the hydraulic fill comprising the earthen dam had failed owing to liquefaction (Seed and others, 1975). (Photograph by R. E. Wallace, from U.S. Geological Survey Professional Paper 733.) 

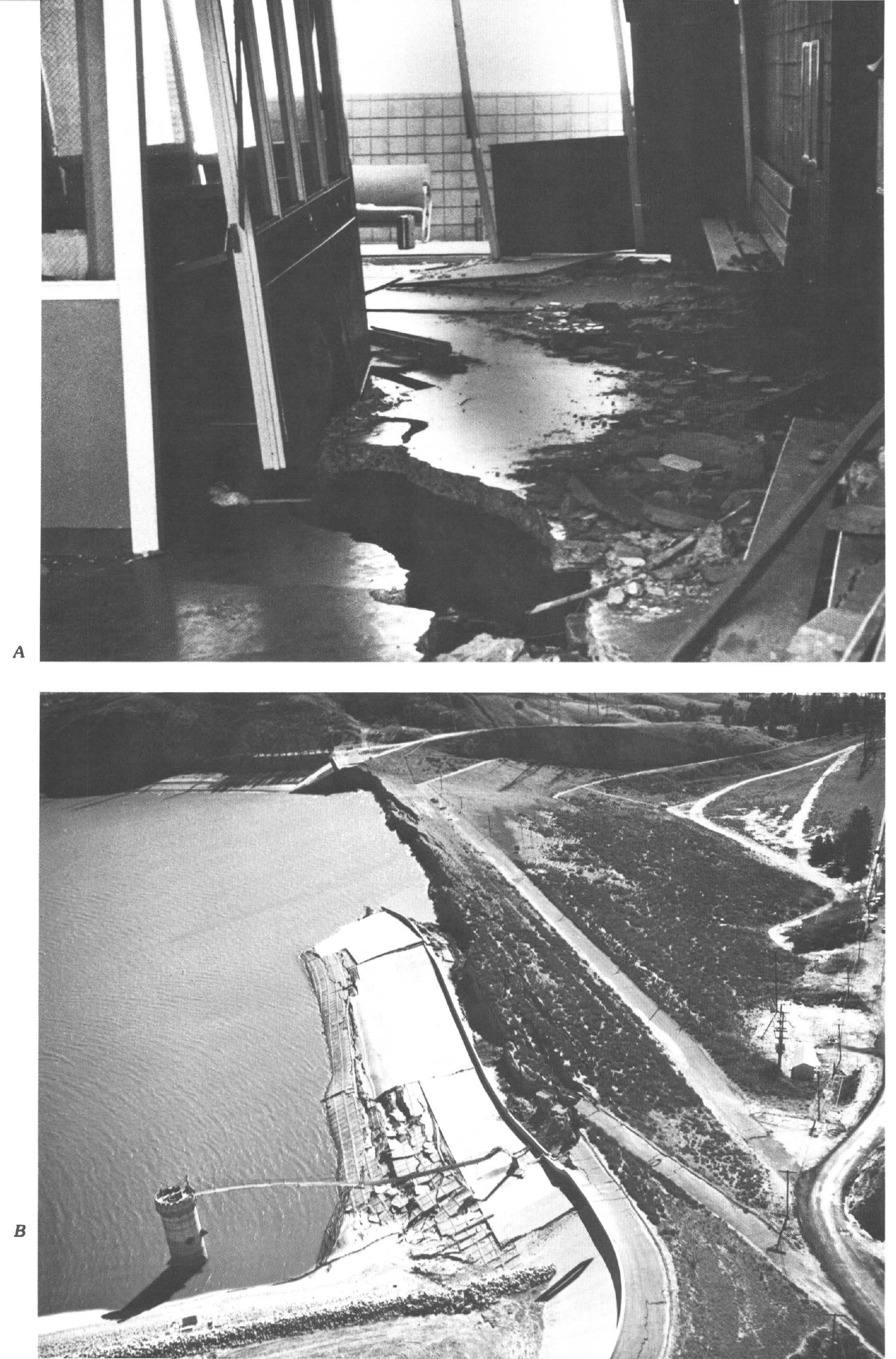


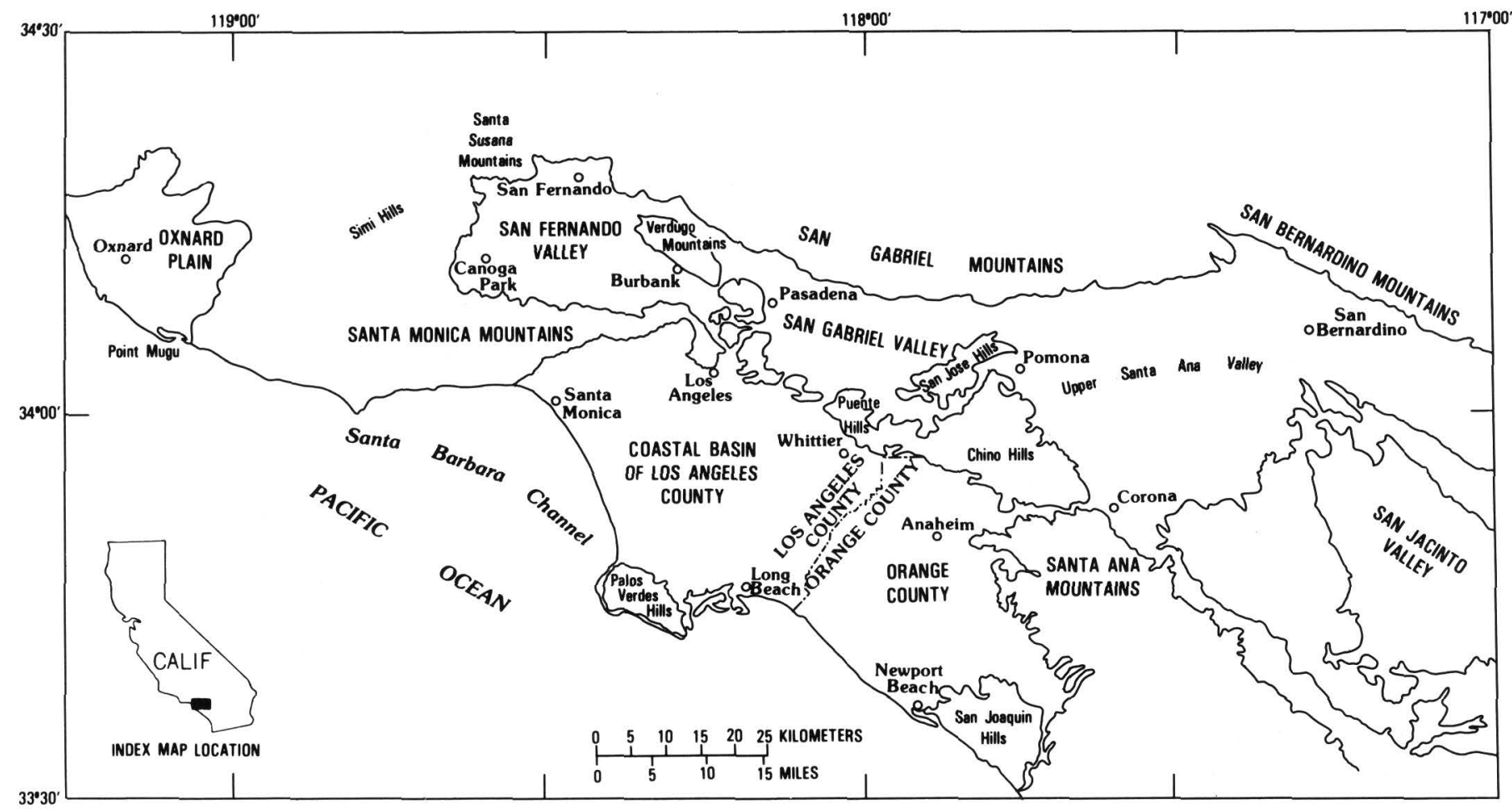

FIGURE 129.-Six areas for which liquefaction potential has been analyzed in the Los Angeles region--the San Fernando Valley, the San Gabriel Valley, the coastal basin in Los Angeles County, the flatland area of Orange County, the upper Santa Ana River basin, and the Oxnard Plain.

Associates, Consulting Geotechnical Engineers, Los Angeles. C. A. Hastorf, E. J. King, E. Layman, J. P. McCalpin, J. M. McManus, D. M. Merritts, M. Nicholson, R. J. Preston, D. J. Ponti, D. Sato, K. Seals, S. L. Wert, and K. M. Williams assisted in procuring and processing the data used in this report.

\section{LIQUEFACTION AND RESULTING GROUND FAILURE}

Liquefaction is defined as "the transformation of a granular material from a solid state into a liquefied state as a consequence of increased pore-water pressures" (Youd, 1973, p. 1). The process of liquefaction must be distinguished from the effects of ensuing ground failure, which actually result in damage. Youd (1980) suggested that displacement accompanying ground failure must exceed about $10 \mathrm{~cm}$ for significant damage to affect most structures. Four types of ground failure commonly result from liquefaction (Youd, 1978a, b): lateral spread, flow failure, ground oscillation, and loss of bearing strength. These modes of ground failure and the nature of the damage that they are likely to cause are discussed below.

Lateral spreads include the lateral displacement of surficial blocks of sediment as a result of liquefaction in a subsurface layer. Once the process of liquefaction transforms a subsurface layer into a fluidized mass, gravitational forces plus inertial forces resulting from the earthquake may cause the mass to move downslope or toward a cut slope or free face (for example, an incised river channel, an irrigation canal, or an openconduit storm drain). The historical record indicates that lateral spreads most commonly occur on gentle slopes that range between $0.3^{\circ}$ and $3^{\circ}$; lateral displacements commonly amount to several meters, perhaps tens of meters if soil conditions are especially favorable for liquefaction and if earthquake shaking is of sufficient duration. This mode of ground failure is especially destructive to pipelines, utilities, bridge piers, and other structures having shallow foundations, particularly those located in flood-plain areas adjacent to river channels. Lateral spreads resulting in ground displacements of only a few feet caused damage at every major pipeline that broke in San Francisco during the 1906 earthquake (Youd, 1978a, p. 47); hence, liquefaction was responsible for the severely compromised ability to fight the fires that caused about 85 percent of the damage to that city.

Ground oscillation takes place if liquefaction occurs at depth and if the slopes are too gentle to permit lateral displacement. Following liquefaction at depth, overlying soil blocks that are not liquified may decouple from one

\section{Earthquake Hazards in the Los Angeles Region}


another and oscillate on the liquified substrate. The resulting ground oscillation is often observed as a traveling ground wave. Ground settlement, the opening and closing of fissures, and sand boils may accompany the oscillations. Overlying structures and subgrade facilities commonly sustain damage through this mode of ground failure.

Flow failure constitutes the most catastrophic mode of ground failure caused by liquefaction. Usually developing on slopes greater than $3^{\circ}$, the flows are comprised chiefly of liquefied soil or blocks of intact material riding on a liquefied substrate. Flow failures commonly displace soil masses by tens of meters; in favorable circumstances, flow failure has displaced materials by tens of kilometers at velocities of tens of kilometers an hour. Flow failures can occur on land or under water; the extensive damage to Seward and Valdez, Alaska, during the 1964 Alaska earthquake was caused by submarine flow failures.

Loss of bearing strength can occur under a structure when the soil loses strength and liquefies. Large deformations can then occur within the soil mass and allow buildings to settle and tip; if the structures are buoyant, they may float upward. Among the more spectacular examples of this failure mode was the tilting of structures in the Kwangishicho apartment complex, where four buildings tipped as much as $60^{\circ}$ during the 1964 Niigata, Japan, earthquake, and buried septic tanks rose as much as $3 \mathrm{ft}$.

\section{METHOD FOR EVALUATING LIQUEFACTION POTENTIAL}

Although a number of methods for evaluating the liquefaction hazard have been proposed (for example, Seed and Idriss, 1971; Seed and others, 1983; Roth and Kavazanjian, 1984), the techniques applied in this chapter combine those of Youd and Perkins (1978) and Youd and others (1975) updated to incorporate new information, including liquefaction failure in clay-bearing sediments (Seed and others, 1983), and rely on geologic and hydrologic mapping and basinal stratigraphic analyses by J. C. Tinsley and on his compilations of field mapping by others. Preliminary results of some of our findings were reported by Youd and others (1978), Tinsley and Youd (1979), and King and others (1981) This chapter incorporates much hydrologic and geotechnical data from public and private sources not compiled in earlier regional studies of liquefaction. As a result, we have identified several areas that contain or are likely to contain shallow or perched ground water and that have not been recognized previously.
The procedure used to determine areal variations in liquefaction potential requires the development of a liquefaction susceptibility map and a liquefaction opportunity map. A liquefaction susceptibility map delineates areas where liquefiable materials are most likely to be present and is based chiefly on generalizations pertaining to the geology and hydrology of late Quaternary deposits in a sedimentary basin. The liquefaction opportunity map shows return periods for earthquake shaking strong enough to generate liquefaction in susceptible materials and is based on an appraisal of regional earthquake potential. These two maps are then considered together to determine liquefaction potential, the relative likelihood that an earthquake will cause liquefaction in water-saturated cohesionless silts and sands that may be present.

The concept of a liquefaction potential map merits a brief discussion, because the liquefaction susceptibility maps presented in this chapter can be regarded as liquefaction potential maps as well. As originally proposed by Youd and Perkins (1978), a liquefaction potential map is derived by superimposing a liquefaction susceptibility map and a liquefaction opportunity map. A liquefaction potential map thus would express the concept that the probability of liquefaction-induced ground failure in certain areas may be greater than that in other areas, either owing to differences in the physical properties of near-surface earth materials (liquefaction susceptibility) or to differences in the return periods of earthquakes strong enough to induce liquefaction in susceptible materials (liquefaction opportunity). Our ability to estimate the size and frequency of future earthquakes expected from the numerous potentially active faults and fault zones in the Los Angeles region is improving (Ziony and Yerkes, this volume), but we are as yet unable to determine that statistically significant changes in liquefaction opportunity occur across the region. In the study area, liquefaction potential is controlled chiefly by regionally mappable differences in the liquefaction susceptibility of late Quaternary basin sediments rather than by areal differences in earthquake potential. The liquefaction susceptibility maps in this chapter, therefore, also serve as liquefaction potential maps because the current seismic model of earthquake potential suggests that the liquefaction opportunity is generally constant across the Los Angeles region.

Liquefaction potential maps delineate areas where a relative potential for liquefaction and associated ground failure may exist. Maps drawn at regional scales, however, are not sufficient for evaluating the actual liquefaction potential at a specified site. Site-specific geotechnical studies, using procedures and techniques such as those summarized by Seed and others (1983), are re- 
TABLE 40A.-Sediment-source factors determining the nature of late Quaternary basin sediment in the Los Angeles region

\begin{tabular}{|c|c|}
\hline Factors & Effects \\
\hline \multicolumn{2}{|c|}{$\begin{array}{c}\text { High topographic relief --1-- } \\
\text { ment readily to streams. }\end{array}$} \\
\hline Semiarid, Mediterr & $\begin{array}{l}\text { ntense episodic rainfall promotes removal of loose } \\
\text { soil and rock on steep slopes. }\end{array}$ \\
\hline Vegetation ----- & $\begin{array}{l}\text { equent fires remove vegetation and spall rock } \\
\text { and expose steep slopes. }\end{array}$ \\
\hline Bedrock character & $\begin{array}{l}\text { ractured and deformed sedimentary, igneous, } \\
\text { and metamorphic terranes yield sediment to } \\
\text { high-gradient streams. Largest clasts are } \\
\text { determined by fracture spacing in bedrock } \\
\text { areas; soft siltstone and shale yield chiefly } \\
\text { silt and clay. }\end{array}$ \\
\hline
\end{tabular}

quired to evaluate the liquefaction potential beneath an individual parcel of land.

Users of these regional maps must consider that a potential for liquefaction does not necessarily indicate a similar potential for any other specified type of ground failure. Ground failures, however, commonly occur as a consequence of liquefaction and hence should be anticipated in areas where susceptible, water-saturated, cohesionless granular sediment may exist.

\section{MAPPING LIQUEFACTION SUSCEPTIBILITY}

The geologic and hydrologic factors that affect liquefaction susceptibility are (1) the age and type of sedimentary deposit, (2) the looseness of cohesionless sediment, and (3) the depth to perched or other ground water. Liquefaction susceptibility maps compiled for the Oxnard Plain, the flatland area of Orange County, and the upper Santa Ana River basin reflect susceptibility categories based on the age and type of sedimentary deposits as reported in the literature and on the depth to free water or other ground water as compiled from published or unpublished sources. For the Los Angeles basin, the San Fernando Valley, and the San Gabriel Valley areas, the liquefaction analyses incorporate new and unpublished geologic and hydrologic mapping by the senior author as well as limited geologic data compiled from published studies.

\section{Age and Type of Sedimentary Deposit}

In general, analyses of historical occurrences of liquefaction indicate that the more recently a sediment has been deposited, the more likely it is to be susceptible to liquefaction and that certain types of deposits, such as river-channel and flood-plain deposits, are more susceptible to liquefaction than other deposits, such as alluvialfan deposits (Youd and Perkins, 1978). Sediment source factors partly determining the nature of late Quaternary sediment in the Los Angeles area are shown in table $40 \mathrm{~A}$. The effect of selected transport processes on grain size, sorting, and bedding characteristics in different sedimentary deposits is shown in table $40 B$. These factors and processes chiefly determine the physical characteristics of sediment deposited at various places within a region. The distribution of particle sizes (sorting) and the packing (the grain-to-grain arrangement) of the sand particles influence liquefaction susceptibility. Sand and silty sand are the textural classes that have the greatest likelihood of liquefaction. Gravelly sand or deposits containing less than 15 percent clay are less likely to liquefy. Bouldery and cobbly gravels or deposits containing more than 15 percent clay are not known to liquefy. The standard penetration test (SPT) is used by engineers as an index to show how densely packed the sediment is. For a given particle-size distribution, the more loosely packed the sediment, the lower the penetrometer resistance and the more likely the sediment is to liquefy during earthquake shaking.

To assess liquefaction susceptibility, we have subdivided the late Quaternary deposits of the Los Angeles region into three informal stratigraphic units according to relative age: the latest Holocene deposits, formed chiefly during the past $1,000 \mathrm{yr}$; the earlier Holocene deposits, formed chiefly during the remainder of the Holocene from 1,000 to about $10,000 \mathrm{yr}$ ago; and the undifferentiated late and middle Pleistocene marine and nonmarine deposits, formed chiefly during the past $0.5 \mathrm{~m} . \mathrm{y}$. The criteria and characteristics used to identify

\section{Earthquake Hazards in the Los Angeles Region}


TABLE 40B.-Erosional and transport processes controlling grain-size, sorting, and bedding characteristics of sedimentary deposits

[A comprehensive summary of the identification and classification of principal sedimentary paleoenvironments has been given by Rigby and Hamblin [1972)]

\begin{tabular}{ll}
\hline Process & Deposit \\
\hline
\end{tabular}

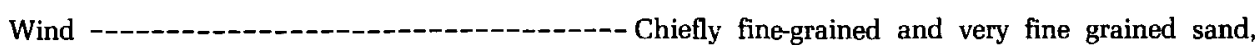
silt; very well sorted; preserved as dunes in coastal and inland basin areas; also as patchy, thin deposits on alluvial fans and flood plains; forms overthickened soil horizons in fine-grained sediment and silt coats on clasts in bouldery gravels.

Beach and coastal terrace ------_---------- Fine- to coarse-grained sand; some gravel and boulders present in highenergy settings; chiefly well-sorted, laminated deposits mantle wave-roded benches along modern and tectonically uplifted shorelines.

Coastal lagoon or marsh ------------------- Fine- and medium-grained sand; the proportion of silt and clay depends on the degree of winnowing in the depositional environment.

River channel, levee, and flood basin -------_---- Grain size generally decreases as distance from sediment-source area increases.

Channel facies: Boulders, cobbles, gravel, and sand; moderately to poorly sorted; scour and fill and cross stratification are common sedimentary structures; deposits are well to poorly stratified; scale of sedimentary structures depends on size of stream.

Levee facies: Chiefly coarse- and medium-grained sand, often containing some gravel; often well bedded and cross stratified; moderately well sorted.

Flood-basin facies: Chiefly fine-grained and very fine grained sand, silt, and some clay; often thinly laminated, moderately well sorted; commonly burrowed; interfingers with channel and levee facies.

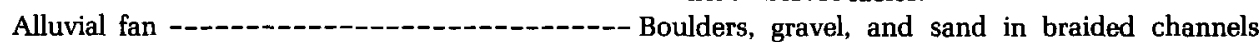
and bars emanating from canyons draining mountainous areas; sediment size decreases downslope; deposits commonly are well stratified but may be crudely stratified and poorly sorted; deposited by braided stream channel, sheet-flood, and debris flow processes in piedmont areas.

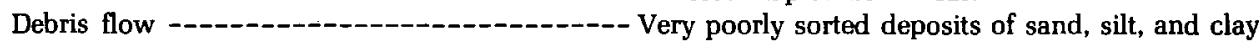
(matrix) that form a high-density aqueous slurry capable of entrainment and transport of boulders weighing tons.

and map these deposits are discussed below. The maps showing surficial deposits differ from those done to map relative shaking response (Tinsley and Fumal, this volume) in that the surficial geologic maps presented in this chapter depict two Holocene stratigraphic units, whereas the surficial geologic maps presented by Tinsley and Fumal (this volume) do not distinguish between younger and older Holocene deposits. Identifying the youngest Holocene deposits is critical for evaluating liquefaction susceptibility. These deposits typically are less than $4 \mathrm{~m}$ thick, however-too thin to be a significant factor in evaluating site-dependent variations in seismic shaking in period bands of interest for most structural engineering considerations Uoyner and Fumal, this volume; Rogers and others, this volume). 
TABLE 41.-Diagnostic soil-profile characteristics of Holocene and late Pleistocene deposits in the Los Angeles basin

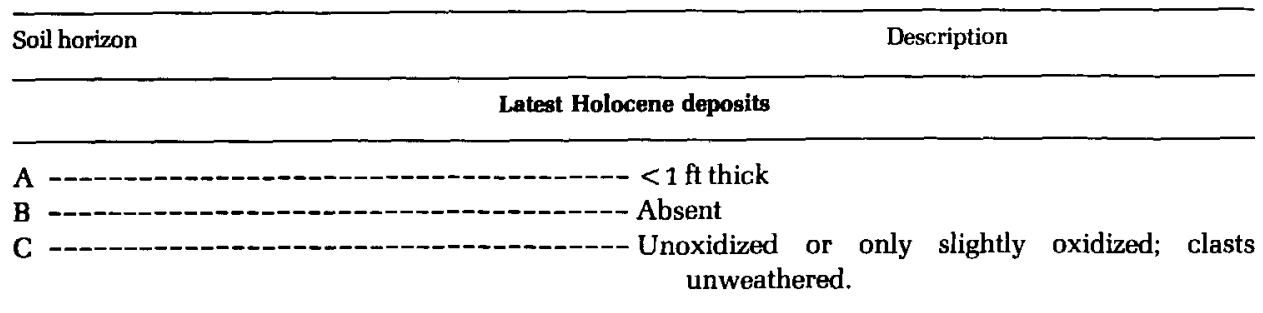

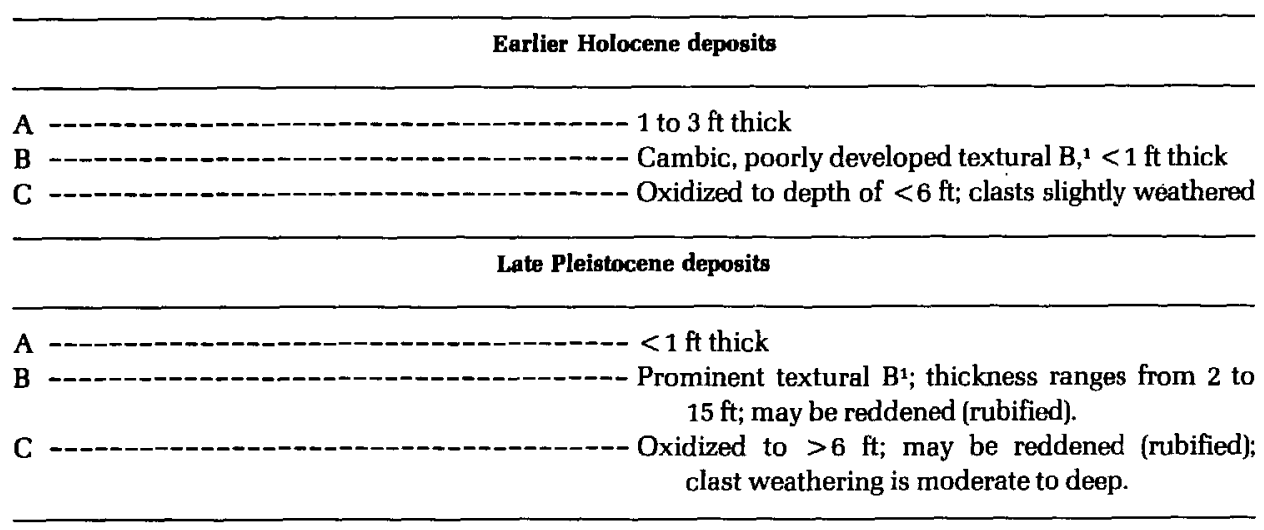

\footnotetext{
${ }^{1}$ Textural B refers to the horizon in which weathering products (including both translocated and authigenic clay and metallic oxides]
} accumulate as soil formation proceds from negligible to advanced states at the Earth's surface.

\section{Youngest Holocene Deposits $\left(\right.$ Map Unit Qya ${ }_{2}$ )}

Youngest Holocene deposits are composed chiefly of boulders, gravel, sand, silt, and clay known or inferred to have been deposited in very recent alluvial-fan, stream, river, swamp, lake, windblown dune, or beach depositional environments. This unit delineates those alluvial areas believed to contain the youngest sediment $(0-1,000 \mathrm{yr}$ old) that is least well consolidated (Youd and Perkins, 1978) and is most likely to liquefy as a result of moderate or large earthquakes. These deposits are identified chiefly from historical records and from anecdotal accounts of major floods occurring before extensive urbanization of the alluvial basins. Where urbanization has not obliterated the uppermost parts of these deposits, the relative degree of soil-profile development is also useful; the diagnostic soil-profile characteristics are summarized in table 41.

The limits of historical flooding have been established chiefly on the basis of two sources: (1) unpublished field notes and maps (1:24,000 scale), on file with the Los Angeles County Flood Control District, that describe and delineate areas flooded during major storms in 1934, 1938, 1941, 1943, 1944, 1952, 1954, and 1956 and (2) flood records for major drainage basins in southern California, including reports by Troxell and Peterson
(1937) and Troxell (1942). Other data used include photointerpretive studies of 1928 and 1938 black-andwhite aerial photography at scales of 1:24,000 or greater. The 1928 photography is the C-300 series obtained from the Fairchild Collection at Whittier College, Whittier, Calif.; the 1938 photography is from the U.S. Archives, Washington, D.C., and was flown 3 to 5 months following the devastating floods of March 1938. Photographic and topographic features used to infer areas recently inundated include changes observed in the configuration of active drainage channels from 1928 to 1938; areas where row crops, orchards, or other cultural features were disrupted or washed out; areas adjacent to stream courses where channels are incised $5 \mathrm{ft}$ or less below the natural levees; and areas characterized by prominent or fresh bar-and-swale channel morphology typical of distributary channels on alluvial fans and on flood plains of braided rivers. In our analysis, we have excluded localized areas inundated when water backed up owing to plugged culverts and also areas identified by the Los Angeles County Flood Control District as having been inundated by sheet flooding-a form of inundation that occurs commonly when intense precipitation accumulates on a tract of land and runs off as a thin sheet of water rather than as overflow from a channel system or breached levee. In all cases, our interpretations identify and delineate the youngest parts of a very youthful depositional system,

\section{Earthquake Hazards in the Los Angeles Region}


because these areas are most likely to contain sediments susceptible to liquefaction.

\section{Earlier Holocene Deposits (Map Unit Qya ${ }_{1}$ )}

Deposits mapped as earlier Holocene are differentiated chiefly where (1) there is no recorded history of flooding, (2) the topographic position of the area is slightly higher in the landscape than that of areas mapped as youngest Holocene deposits, (3) channels commonly show a somewhat subdued bar-and-swale microtopography in comparison with latest Holocene deposits, and (4) pedogenic soils are characterized by weakly developed, nonreddened but perceptibly oxidized C horizons (B horizons, if they are present, may exhibit small amounts of translocated clay typical of soil stage S5 in the San Gabriel Mountains soil stratigraphy of McFadden (1982) and McFadden and Tinsley (1982)). These characteristics are summarized in table 41 .

\section{Late Pleistocene Deposits (Map Unit Qoa)}

Areas mapped as Pleistocene deposits were differentiated chiefly according to the relative degree of soilprofile development. These deposits generally are exposed along the margins of youthful anticlines, along topographic benches and terraces near the margins of valleys, and along the rising blocks adjacent to reverse faults having a history of deformation of Quaternary age or younger. These deposits are characterized by surface soils having moderately developed to well-developed textural B (argillic) horizons. Distinguished readily from Holocene soils by physical and chemical soil-profile characteristics, including degree of clast weathering, all but the latest Pleistocene soils contain appreciable ferric iron and are reddened (rubified) from initial hues of 2.5 Y or 10 YR to hues of 5 YR, 2.5 YR, or $10 \mathrm{R}$, according to the Munsell system of color notation and description (Munsell Soil Color Charts, 1975). These soil profile characteristics are summarized in table 41; soil chronosequences and stages of soil-profile development for the San Gabriel Mountains area have been described fully by McFadden (1982) and briefly by McFadden and Tinsley (1982). These soil profiles commonly display characteristics developed under climatic conditions that allowed soil moisture to penetrate somewhat more deeply in the profile than conditions today would permit, an indication that these soil profiles developed during one or more of the cooler or wetter climatic episodes that characterize the Pleistocene epoch in western North America.
In areas underlain by late Pleistocene deposits, the original constructional landforms typically have been deformed tectonically and (or) dissected by erosion; in relatively undissected areas, primary depositional topography has been strongly modified or obliterated by later erosional and depositional processes. Five Pleistocene stratigraphic units have been grouped and mapped as undifferentiated late Pleistocene deposits for the purpose of evaluating liquefaction susceptibility.

Youd and Hoose (1977) have estimated from the historical record that, on the basis of geologic age alone, relatively well sorted, saturated river-channel deposits no more than several hundred years old (corresponding in age to our latest Holocene unit) would have a very high susceptibility to liquefaction-induced ground failure. Earlier Holocene river-channel deposits are presumed to have a high susceptibility, and deposits of Pleistocene age and older are presumed to have low and very low susceptibilities, respectively. Similar relations are noted for flood-plain and alluvial-fan deposits, although the estimated relative susceptibility is less for alluvial-fan and flood-plain deposits, which tend to be less well sorted than river-channel deposits. In general, saturated, cohesionless sediment would have very high or high susceptibility if it is of latest Holocene age, high or moderate susceptibility if it is of earlier Holocene age, and low to very low susceptibility if it is of Pleistocene age or older, depending on the depositional environment.

\section{Penetration Resistance and Liquefaction Susceptibility}

We verified our qualitative estimates of liquefaction susceptibility based on the age of the generalized geologic deposits mapped in the Los Angeles County area by comparing these estimates with calculated liquefaction susceptibilities determined from a sample of Standard Penetration Test (SPT) data taken from these deposits. To make these calculations, we applied a technique developed by Seed and others (1983) and used a computer code of that technique prepared by Chen (1984). The technique described by Seed and others (1983) incorporates several empirical constants and relations that have been revised from time to time as data have been accumulated. This technique is presently the most widely used procedure for evaluating liquefaction susceptibility in engineering practice. The general criteria that we derived from Seed and others' (1983) procedure are plotted in figure 130. Our analysis is discussed below.

Evaluating Liquefaction Potential 
We extracted standard penetration data from bore hole logs supplied to us by several public agencies and private consultants. Most of the data came from subsurface investigations conducted by or for the California Department of Transportation in conjunction with construction of freeways in the Los Angeles area. Only SPT data from sediment listed as sand, sandy silt, silty sand, and silt were used in the analysis. Test data from sediment logged as clayey, gravelly, or cobbly were not used.

In our analysis, borehole sites were plotted on surficial geologic maps, and the thicknesses of stratigraphic units sampled by the SPT were determined as follows. The thicknesses of the two Holocene units were inferred from lithologic information on logs of the SPT and nearby holes and from our regional geologic mapping studies. Criteria used to assign thicknesses to the informal generalized stratigraphic units include identifying subsurface features logged by the drillers such as (1) an oxidized (reddened) clay-rich layer, which may indicate a late Pleistocene soil formed on a landscape now covered by Holocene deposits; (2) a dark-gray or organic-rich sand, silt, or clay layer greater than $1 \mathrm{ft}$ in apparent thickness and overlying nonreddened but slightly oxidized layers, which may be a now-buried soil that formed on early or middle Holocene deposits; (3) at sites where ancient soils were not logged and apparently may not be preserved, an estimated maximum thickness of the latest Holocene unit of about $12 \mathrm{ft}$ (this value is based on a maximum average cumulative thickness of sediment deposited during and (or) following major historical floods in 1938, 1944, and 1956, as observed by the Los Angeles County Flood Control District); and (4) also at sites without apparent buried soil profiles, a base for the Holocene series arbitrarily inferred where the penetration data indicate an abrupt increase of resistance sustained through several layers but not ascribable to a gravel layer. The thickness of the stratigraphic horizons inferred from the borehole logs broadly corresponds to and is seemingly confirmed by thicknesses noted at those few places in the field where sections of the late Pleistocene and Holocene deposits are exposed, such as in foundation excavations, quarries, railroad cuts, and stream incisions.

The liquefaction susceptibility indicated by each SPT datum was evaluated by using the technique of Seed and others (1983) for the two earthquake conditions and three ground-water conditions depicted in figure 130. Soil properties assumed in the calculation are a dry unit weight of $100 \mathrm{lb} / \mathrm{ft}^{3}$ (dry density of $1.6 \mathrm{~g} / \mathrm{cm}^{3}$ ), a relative density generally greater than 60 percent, and a mean grain size less than $0.15 \mathrm{~mm}$ (silty sediment). The two earthquake conditions are a nearby $M \quad 6.5$ event generating approximately 8 cycles of strong ground motion and a 0.2-g maximum surface acceleration at the borehole sites in question and a nearby $M 8.0$ event generating approximately 20 cycles of strong ground motion and a 0.5-g maximum surface acceleration (Seed and others, 1983, p. 471). The three ground-water conditions considered are ground-water level at the ground surface, ground-water level at a depth of $10 \mathrm{ft}$, and ground-water level at a depth of $30 \mathrm{ft}$. These water levels are those postulated to exist at the time of the earthquake, not necessarily those obtained when the SPT was conducted. The water level observed during the penetration test is recorded on the borehole log; the water level at the time of the penetration test typically was below the level of the penetration test in most instances for the data that we obtained and have shown in figure 130.

The liquefaction susceptibility calculated for each datum and for each ground-water condition was then placed into one of four categories:

1. Results indicating that liquefaction would occur during a $M$ 6.5 event are listed in the high susceptibility category.

2. Results indicating that liquefaction would not occur during a $M$ 6.5 event but would occur during an $M 8$ event are listed in the moderate susceptibility category.

3. Results indicating that liquefaction would not occur even if an area were shaken by a $M 8$ event are listed in the low susceptibility category.

4. SPT data points that lie above ground-water level for the postulated water condition being analyzed (not the water level observed at the time of the test) were tabulated as "above ground water" and are considered nonliquefiable.

The results from our analysis are listed in table 42 .

In summary, the tabulation shows that liquefaction susceptibility is strongly a function of the age and depth of the sediment and the depth to ground water. For a ground-water level at the surface, the data indicate that most of the latest Holocene sand and silt is highly liquefiable, that the earlier Holocene sediment is moderately liquefiable, and that the Pleistocene sediment generally has moderate to low susceptibility. When the ground water is at a depth of $10 \mathrm{ft}$, only a fraction of the data from any unit indicates a high susceptibility, but those parts of the latest and earlier Holocene units that are below the water table generally have moderate susceptibility. For a ground-water level at $30 \mathrm{ft}$, nearly all the sediment in all three stratigraphic units either is above the postulated water level or has low susceptibility.

\section{Earthquake Hazards in the Los Angeles Region}




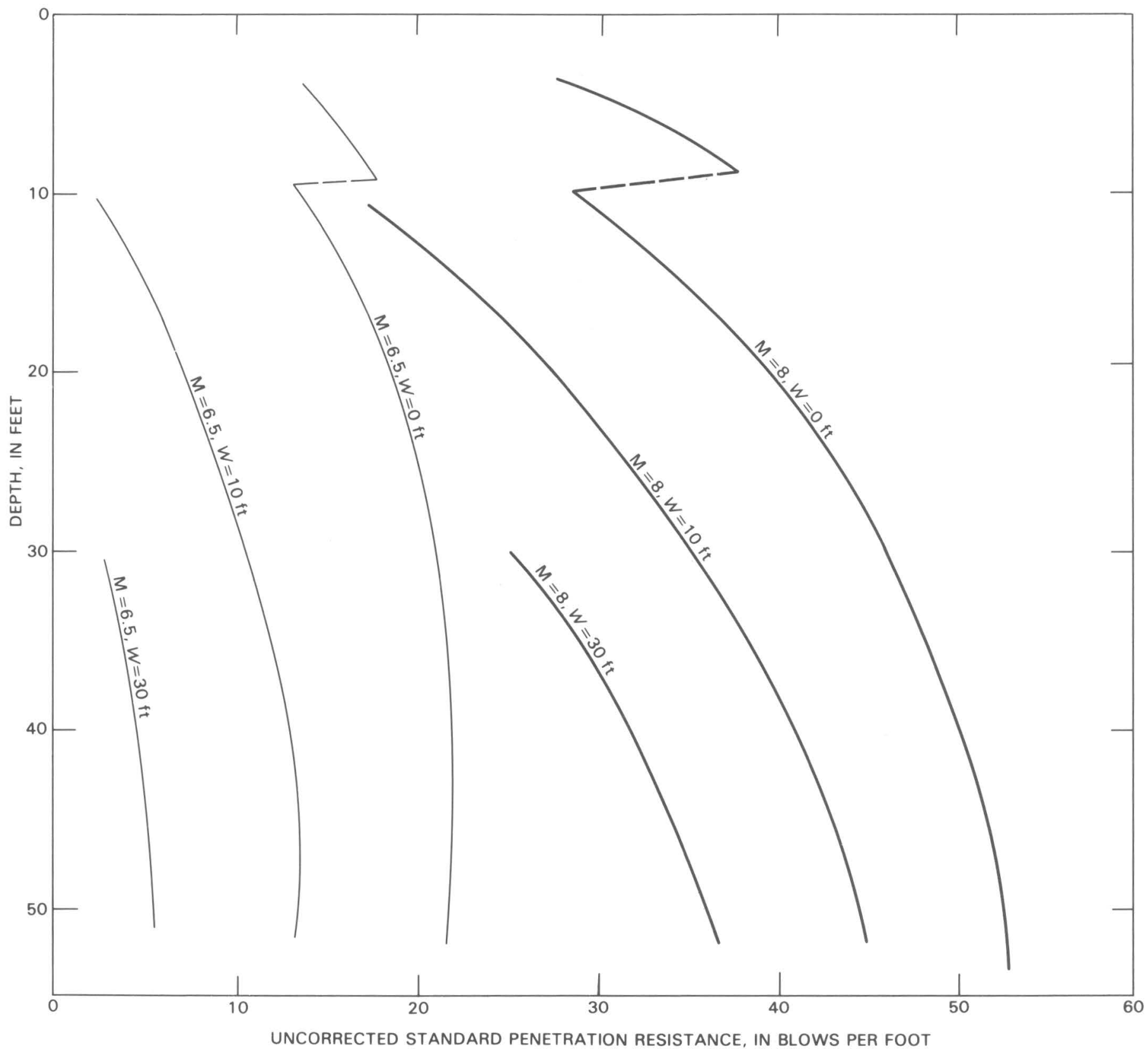

FIGURE 130.-Criteria used for estimating liquefaction susceptibility in the Los Angeles region, calculated by using the procedure developed by Seed and others (1983). Assumptions used in making the calculation include peak horizontal accelerations of 0.2 and $0.5 \mathrm{~g}$ for the $\mathbf{M} 6.5$ and M 8.0 earthquakes, respectively; a uniform dry unit weight of the sediment of $100 \mathrm{lb} / \mathrm{ft}^{3}$; silty sediment (mean grain size less than $0.15 \mathrm{~mm}$ ); a relative density generally greater than 60 percent; and values of $w$ (depth to free ground water) as indicated.

\section{Depth to Ground Water}

The final factor considered in regional mapping of liquefaction susceptibility is the depth to ground water, including water that is perched. Perched ground water refers to unconfined ground water separated from an underlying main body of ground water by an unsaturated zone (Bates and Jackson, 1980). Liquefaction susceptibility generally decreases as the depth to water increases, for two reasons. First, the greater the depth to ground water, the greater the normal effective stress acting on saturated sediment at any specified depth. Increasing the normal effective stress decreases susceptibility to liquefaction. Second, age, cementation, infilling of intergranular voids, alteration, and compactness of sediment generally increase with depth. Each of these 
TABLE 42.-Evaluation of liquefaction susceptibility (in percent) in cohesionless nongravelly sediment from standard penetration data taken in the upper $16 \mathrm{~m}$ of late Quaternary sediment in the Los Angeles area for three hypothetical positions of the water table using criteria developed by Seed (1983)

[The total number of test results for each stratigraphic unit is found in the far right column. In the San Fernando Valley, for example, 76 percent of 153 penetıation tests obtained in latest Holocene sediment indicate high susceptibility if the water level were at the ground's surface]

\begin{tabular}{|c|c|c|c|c|c|c|c|c|c|c|c|c|c|}
\hline \multirow[b]{2}{*}{ Age } & \multicolumn{4}{|c|}{ Water level at surface } & \multicolumn{4}{|c|}{ Water level at $10 \mathrm{ft}$} & \multicolumn{4}{|c|}{ Water level at $30 \mathrm{ft}$} & \multirow{2}{*}{$\begin{array}{c}\text { Total, } \\
\text { Standard } \\
\text { Penetra- } \\
\text { tion Tests }\end{array}$} \\
\hline & High & Moderate & Low & $\begin{array}{l}\text { Above } \\
\text { water }\end{array}$ & High & Moderate & Low & $\begin{array}{l}\text { Above } \\
\text { water }\end{array}$ & High & Moderate & Low & $\begin{array}{l}\text { Above } \\
\text { water }\end{array}$ & \\
\hline \multicolumn{14}{|c|}{ San Fernando Valley } \\
\hline Latest Holocene --- & 76 & 23 & 1 & 0 & 7 & 39 & 4 & 50 & 0 & 0 & $\mathbf{0}$ & 100 & 153 \\
\hline Earlier Holocene --- & 54 & 43 & 3 & 0 & 5 & 57 & 14 & 24 & $\mathbf{0}$ & 8 & 2 & 90 & 588 \\
\hline Late Pleistocene --- & 17 & 46 & 37 & 0 & 2 & 40 & 55 & 3 & 0 & 15 & 35 & 50 & 413 \\
\hline \multicolumn{14}{|c|}{ San Gabriel Valley } \\
\hline Latest Holocene --- & 81 & 19 & 0 & 0 & 1 & 25 & 3 & 71 & 0 & 0 & 0 & 100 & 75 \\
\hline Earlier Holocene --- & 38 & 56 & 6 & 0 & 3 & 57 & 19 & 21 & 0 & 12 & 12 & 76 & 473 \\
\hline Late Pleistocene --- & 7 & 42 & 51 & 0 & $\mathbf{0}$ & 22 & 57 & 21 & 0 & 5 & 22 & 73 & 26 \\
\hline \multicolumn{14}{|c|}{ Coastal basin, Los Angeles County } \\
\hline Latest Holocene --- & 81 & 19 & $\mathbf{0}$ & 0 & 0 & 21 & 1 & 78 & 0 & 0 & 0 & 100 & 250 \\
\hline Earlier Holocene --- & 34 & 48 & 19 & 0 & 3 & 49 & 30 & 18 & 0 & 16 & 16 & 68 & 1,131 \\
\hline Late Pleistocene --- & 6 & 39 & 55 & 0 & 0 & 20 & 71 & 9 & 0 & 4 & 20 & 76 & 950 \\
\hline
\end{tabular}

factors increases resistance to liquefaction. Thus, as the depth to ground water increases, the saturated sediments tend to be older and more compact and to have increased density and normal stress; consequently, the liquefaction susceptibility decreases (Youd and others, 1978).

The following criteria are applicable to liquefaction susceptibility with respect to depth to ground water. For ground-water depths less than $10 \mathrm{ft}$, maximum possible susceptibility is very high. For water depths between 10 and $30 \mathrm{ft}$, maximum possible susceptibility is high. For water depths between 30 and $50 \mathrm{ft}$, maximum possible susceptibility is low. For water depths greater than $50 \mathrm{ft}$, maximum possible susceptibility is very low. These criteria, summarized in table 43 , are based on those suggested by Youd and Perkins (1978) and used by Youd and others (1978); they are confirmed by the data compiled in table 42.

Maps showing depth to ground water, including perched ground water, were compiled for each alluvial basin considered in this report. Unless otherwise specified, the lines shown on these depth-to-groundwater maps are not necessarily equipotential lines in the conventional usage of hydrologists. For example, hydrologists commonly describe a ground-water basin in two dimensions by using equipotential lines (lines connecting points having equal potential within the flowage system). Thus, the direction of flow is normal to the equipotential lines and is from areas of relatively higher

\section{Earthquake Hazards in the Los Angeles Region}

potential toward areas of relatively lower potential, such as a basin outlet or a pumping well. The data in our study are not sufficient to show patterns of movement, recharge, or depletion, especially where the depth to water is identified from a single observation in a given boring. Our lines may be equipotential in some areas, but we commonly cannot determine if they are from our data; hence, our lines simply enclose or indicate areas within a stratigraphic unit where our data show that either perched or unconfined ground water has been found within the specified depth intervals. Where depths to water are not tightly constrained, lines are dashed; where depths are speculative or constrained by factors other than borehole data or water levels measured in wells, lines are dashed and queried.

The ground-water data are from Federal, State, county, and city governmental agencies, private consultants, water purveyors, and private individuals; unless anonymity was requested, the sources are acknowledged. The data are not uniformly distributed, and, in areas where control is sparse, constructing the maps re quired considerable generalization, extrapolation, and interpretation.

The reliability of these types of maps varies considerably across the Los Angeles region. Sources of uncertainty are described briefly, so that users may better comprehend the limitations of liquefaction susceptibility maps. 
The principal difficulty encountered in mapping shallow occurrences of ground water is that the network of observation wells used to chart the recharge storage and extraction of water is not designed to monitor shallow ground water in most areas. Monitoring of the deeper aquifers is emphasized to safeguard potable water supplies (California Department of Water Resources, 1961). Because shallow and (or) perched water-bearing layers tend to be irregularly distributed and often contain water of dubious or unreliable quality, these layers are not usually monitored and have recharge characteristics and transmissivities that are poorly known. In contrast, the water-monitoring network is excellent where it was developed for a specific purpose. For example, the Coastal Barrier and Replenishment Projects (systems of water-injection and observation wells administered by Los Angeles County) achieved their objective of safeguarding and even improving water quality in parts of the county otherwise threatened by saltwater intrusion. The system of key and observation wells used within interior basins to monitor recharge of ground water from spreading grounds and injection wells is designed in part to monitor water levels, including those in shallow aquifers, but coverage is localized near spreading grounds and was never intended to be geographically comprehensive in its scope or to include perched-water occurrences. Thus, the hydrology of the shallowest undeveloped aquifers is poorly known, and the degree to which those ground-water occurrences contribute to the liquefaction susceptibility is poorly understood.

Borings that penetrate to ground water are sparse in many areas. We have some coverage over many areas from borings for storm-drain construction, but these borings often are shallow (seldom more than $30 \mathrm{ft}$ deep). Thus, such data tend to imply the absence of ground water at very shallow depths, on the date and at the time specified for these studies, rather than to define the depth at which water is found.

Ground water is commonly encountered during civil engineering studies, but water levels usually are not monitored for more than several hours. In the absence of routine ground-water observations, only by examining records of holes drilled in proximity to one another over a period of years can one obtain any assurance that water may persist from year to year, although the hydrology remains speculative.

Water levels in some deep wells may have been higher than the phreatic surface in the surrounding surficial strata, owing to artesian pressures at depth. To reduce this source of uncertainty, we have obtained well-casing perforation information for wells monitored by the California Department of Water Resources and the Los Angeles County Flood Control District and relied on wells perforated at appropriate intervals to aid in our interpretations. Knowing the depths at which well casings are perforated enables the analyst to exclude wells that tap more than one water-bearing layer or that do not tap only the shallow ground water. Perforation data indicate that relatively few wells unambiguously monitor shallow zones of ground water.

Some water-depth measurements, especially along freeways or for certain large buildings or storm drains, were made two or three decades ago, and water levels may have changed in the interim. We retain high confidence in these data if additional, more recent geotechnical studies also show ground water to have been present or if there are monitored wells nearby showing reliable depth-to-water measurements. If subsequent confirmation of depth to water is lacking, map lines enclosing the occurrences of water are dashed and queried.

Seasonal fluctuations in water levels affect our interpretations. If there is no adequate monitoring network, the only effective recourse is the historical record. Ground-water data from the middle 1940's may be the best approximation of what high ground-water conditions would probably be. The 1944-45 water year followed several relatively wet winters, before pumpage from ground-water basins reached the volumes occasioned by urbanization following World War II. To address this uncertainty, two sets of ground-water maps are presented for each of three basins in Los Angeles County. The first set shows shallow ground-water conditions based on records from 1945 or earlier; the second set shows conditions based on water depths reported chiefly from 1960 to 1978. The first set may be appropriate for evaluating liquefaction susceptibility seasonally or during wet years. During years when available moisture and ground-water recharge are average, the liquefaction susceptibility will be less widely distributed than it will during wet years.

Since 1945, development of the ground-water basins has intensified; today, depending on pumping practices, water levels are generally lower than 1944-45 levels, although basins are carefully monitored and managed to reduce the likelihood of contamination and depletion. Development of the ground-water resource in southern California has been the single most effective step in reducing or eliminating the liquefaction hazard in many areas, because extractive pumping of ground water has lowered the water table in many areas to depths that make liquefaction unlikely. An exception may be an area in and near San Bernardino, east of the San Jacinto fault, where development of the ground-water resource has included recharge of the ground-water reservoir by using water brought from northern California through the California Aqueduct. 
TABLE 43.-Probable susceptibility of cohesionless, granular, nongravelly layers as criteria used to compile liquefaction susceptibility map

\begin{tabular}{|c|c|c|c|c|}
\hline \multirow[b]{2}{*}{ Sedimentary unit } & \multicolumn{4}{|c|}{ Depth to ground water, in feet } \\
\hline & 0 to 10 & 10 to 30 & 30 to 50 & $50+$ \\
\hline \multicolumn{5}{|l|}{ Holocene: } \\
\hline Latest --------- & high to high $^{1}$ & Moderate ${ }^{2}$ & Low & Very low \\
\hline 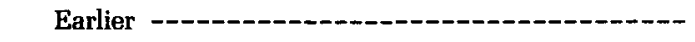 & & Moderate & Low & Very low \\
\hline \multicolumn{5}{|l|}{ Pleistocene: } \\
\hline 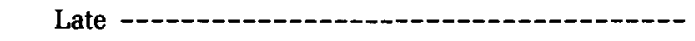 & & Low & Very low & Very low \\
\hline Middle and early -- & low & Very low & Very low & Very low \\
\hline Tertiary and pre-Tertiary ----------------------- & low & Very low & Very low & Very low \\
\hline
\end{tabular}

As future water-management policies and practices evolve, the effect of a series of years in which precipitation is greater than normal may become marked. The city of Beverly Hills, for example, went out of the waterpumping business during the late 1970's and is now supplied by the Metropolitan Water District of Southern California. The city abandoned and destroyed its wells. The wetter-than-normal winters from 1978 to 1983 have caused ground-water recharge to parts of basins that are no longer so intensively pumped. As these basins recharge, ground-water levels may approach predevelopment levels, and areas that used to be mapped as swamps are likely to return to their formerly saturated state. Dewatering practices may be increasingly re quired over wider areas to protect property, especially in areas formerly identified as artesian and as swamps (cienegas) by Mendenhall (1905a, b). In general, as the depth to ground water decreases, the susceptibility to liquefaction increases.

Errors may have been made in measuring or reporting the depth to ground water in some boreholes. To partially redress this source of uncertainty, we have arbitrarily eliminated from consideration those values that seemed to us to be truly aberrent or that could not be confirmed by nearby wells.

\section{Compilation of Liquefaction Susceptibility Maps}

The criteria delineated above and summarized in table 43 were used to compile the susceptibility maps presented in subsequent sections of this report. The surficial geologic map and the ground-water maps were superimposed to derive the susceptibility map. As climatic conditions or basin-management practices change, ground-water levels are likely to change, and liquefaction susceptibility is likely to increase during wet cycles and decrease during dry cycles. These changes reflect a probable greater areal extent of shallow ground water or ground water persisting at shallower depth during a relatively wet cycle as opposed to a relatively dry cycle.

\section{LIQUEFACTION SUSCEPTIBILITY IN THE LOS ANGELES REGION}

For each of six areas, we now discuss the surficial geologic map, one or two ground-water maps, and the corresponding liquefaction susceptibility maps derived according to the methods presented in the preceding sections. The sources of the geologic, hydrologic, and geochronologic data are given, unless anonymity was re quested by those persons or firms supplying the data.

The six study areas are best grouped into two subsets corresponding to the relative amounts of effort expended in our analysis of the liquefaction problem. The data bases are not at all comparable in scope; major efforts in this study are focused on Los Angeles County and its principal basins (the San Fernando Valley, the San Gabriel Valley, and the Los Angeles basin proper). Reconnaissance maps of liquefaction susceptibility have also been compiled for the Oxnard Plain, the upper Santa Ana River basin, and the flatland area of Orange County by using the relative age and depth-to-groundwater criteria shown in table 42 to interpret existing maps showing surficial deposits and average groundwater conditions. Of the data bases assembled for these last three areas, the one for Orange County is the most comprehensive, having been put together by the California Division of Mines and Geology specifically for evaluating earthquake hazards, including liquefaction. The liquefaction potential of the upper Santa Ana River basin area currently is being mapped by S. A. Carson 
and J. C. Matti (U.S. Geological Survey). Their analysis will be based on improved mapping of surficial deposits, drilling and standard penetration studies of selected localities, and improved knowledge of the near-surface occurrences of ground water, in comparison with the reconnaissance-style mapping incorporated in this analysis. The liquefaction maps presented in this report showing the Oxnard Plain rely heavily on hydrologic mapping as published by the California Division of Mines and Geology. The criteria in table 42 were used to derive the liquefaction susceptibility maps; a few modifications were made on the basis of more recent but unpublished mapping in parts of the area near Ventura by A. M. Sarna-Wojcicki (U.S. Geological Survey).

We now describe the surficial geologic maps, the ground-water maps, and the derivative liquefaction susceptibility maps of the San Fernando Valley, the San Gabriel Valley, the Los Angeles basin area of Los Angeles County, the flatland area of Orange County, the upper Santa Ana River basin area of Riverside and San Bernardino Counties, and the Oxnard Plain area of Ventura County.

\section{San Fernando Valley}

\section{Surficial Geology}

The San Fernando Valley is located within the Transverse Ranges province and is bounded on the north and east by the San Gabriel and Verdugo Mountains, on the south by the Santa Monica Mountains, and on the west and northwest by the Simi Hills and the Santa Susana Mountains (fig. 129). The entire basin is drained by the Los Angeles River and its tributary drainages. The alluvium deposited by these streams chiefly reflects the types of rock exposed along the basin's perimeter, and these broad lithologic characteristics strongly influence the nature and distribution of deposits susceptible to liquefaction (table 42). The generalized surficial geology of the San Fernando Valley is shown in figure 131. The alluvial deposits and the ground-water-bearing characteristics of the alluvium in the San Fernando Valley have been analyzed comprehensively by the California Water Rights Board Referee (1962), and we use those data where they are applicable.

Alluvial deposits in the eastern half of the San Fernando Valley are composed chiefly of cobbles, gravel, and sand; silt and clay often are relatively minor components. This alluvium was deposited chiefly by Pacoima Wash and Tujunga Wash, which drain mostly granitic and metamorphic rocks of the western San Gabriel Mountains. The sandy, highly permeable char- acter of the deposits enables large volumes of ground water to percolate to depths exceeding $50 \mathrm{ft}$ subsurface.

Alluvium in the western half of the San Fernando Valley was deposited by small streams draining areas underlain by chiefly fine-grained Tertiary and preTertiary sedimentary rocks (the Simi Hills, the Santa Monica Mountains, and the Santa Susana Mountains). In contrast to the coarse-textured alluvial deposits of the eastern half, these flood-plain deposits contain a large proportion of fine-grained clayey alluvium. Vertical permeability is correspondingly reduced, perched water occurs commonly in sandy channel deposits, and the regional water table locally is relatively close to the ground surface. Exposures in foundation excavations indicate that sand, gravel, and silty sand occur chiefly as buried stream channels that traverse the subsurface from the surrounding uplands toward the Los Angeles River. It is these cohesionless, granular channel deposits that may be susceptible to liquefaction. Their distribution within the area is not known in detail, however. It may be possible to locate and map these channels by means of special-wavelength radar or seismic reflection techniques; the present data do not permit these deposits to be delineated.

\section{Ground Water}

The regional distribution of ground water for the year 1944 is shown in figure 132 by contour lines (equipotential lines) drawn on the surface of the water table. Ground water flows normal to equipotential lines; thus, figure 132 indicates that the ground water generally flows along a gradient that is parallel or subparallel to the topography of the ground surface and is toward and along the Los Angeles River. The 1944 water year was characterized by high annual precipitation, as were the years 1943 and 1941. Consequently, the ground-water levels were high, and areas of near-surface ground water were especially extensive in the 1944 water year. The 1944 water levels are the best documented, highest water levels for the San Fernando Valley on record (California Water Rights Board, 1962).

A depth-to-ground-water map based on the data in figure 132 was superimposed on the surficial geologic map (fig. 131), and these two maps were then used to construct the "high-water-level" liquefaction susceptibility map shown in figure 133. Areas having depths to water of less than $10 \mathrm{ft}$ were extensive in 1944 and include a corridor along the Los Angeles River, areas along tributary drainages, and areas near flood-control basins.

Many of these areas were flooded historically (King and others, 1981), and the resultant deposits pre- 


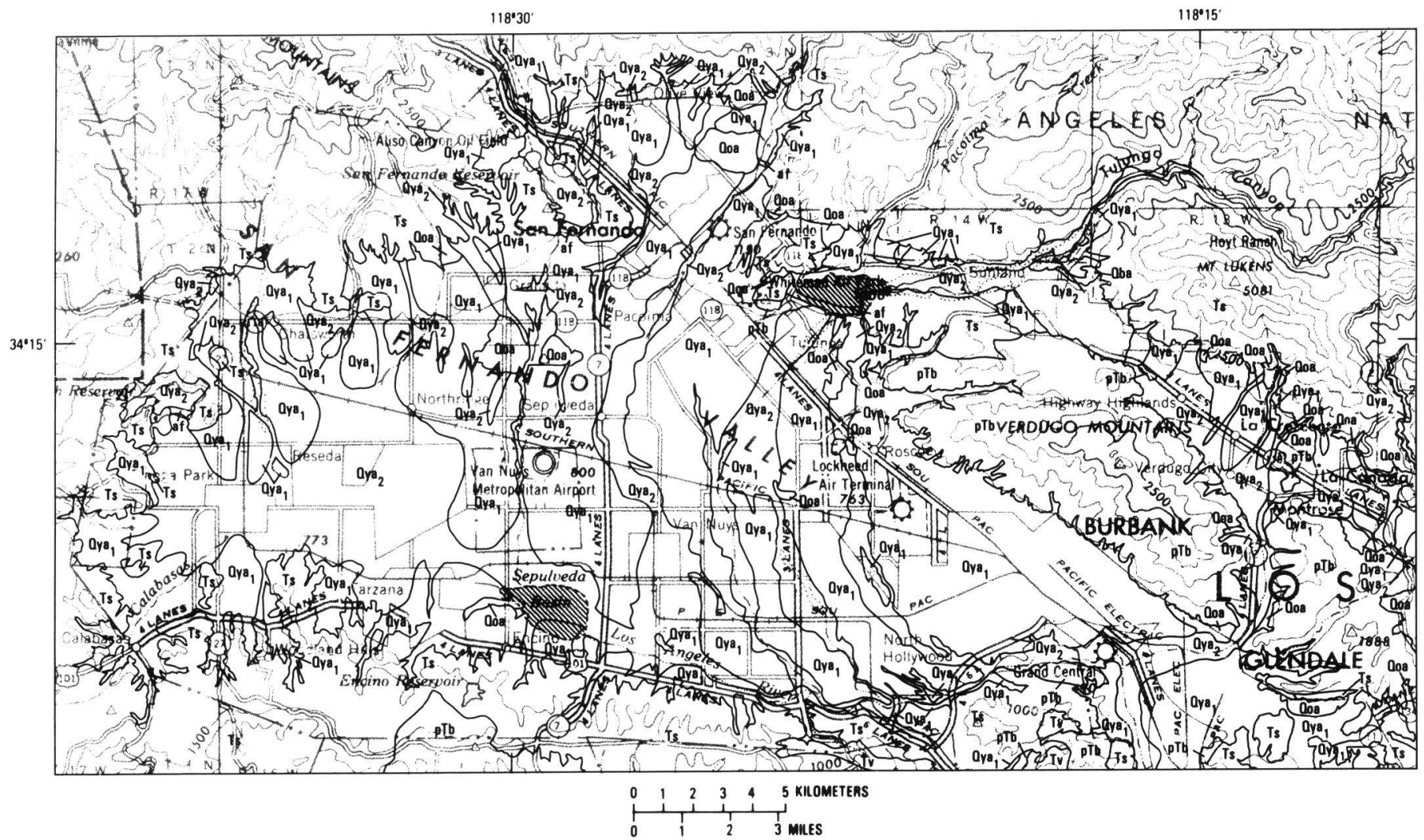

EXPLANATION
$\mathrm{Ova}_{2}$ Late Holocene alluvium; gravel, sand, silt, and clay; unconsolidated, uncemented; herein restricted to areas that flooded historically, including tidal mar- shes. Thickness 0 to $3 \mathrm{~m}$. Age less than 1,000 yr.
Qya, Undifferentiated Holocene alluvium; gravel, sand, silt, and clay: uncemented, unconsolidated. Thickness 0 to $30 \mathrm{~m}$. Age 1,000 to $10,000 \mathrm{yr}$. Locally may include thin deposits of late Holocene alluvium
Dos Undifferentiated late Pleistocene alluvium; gravel, sand, silt, and clay; moderately to well consolidated; often slightly cemented: locally well cemented

Ts Undifferentiated pre-Quaternary lithified sedimentary rocks

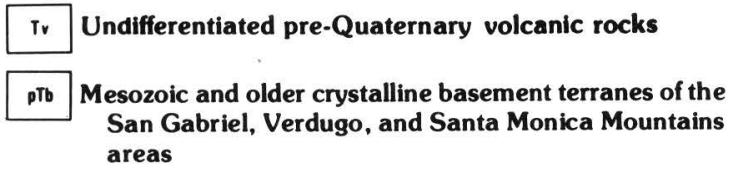

af Artificial fill

FIGURE 131.-Generalized surficial geology of the San Fernando Valley.

sumably include some of the youngest sediment in the basin. Where cohesionless granular materials are present as stream-channel and levee deposits, the sediments are interpreted to have a very high to high susceptibility to liquefaction. Areas having moderate susceptibility commonly occur adjacent to areas of very high to high susceptibility, chiefly along the Los Angeles River and its tributaries and in the Van Norman Reservoirs area west of San Fernando (fig. 129).

Figure 134 illustrates depth to ground water, including perched ground water, in the San Fernando Valley compiled from several thousand exploratory boreholes that were drilled for engineering purposes from 1950 to 1981. Few of these localities are used to monitor ground water, and the measured depths to ground water are subject to many of the uncertainties discussed in a preceding section of this chapter. Nevertheless, these data are distributed over about three decades and tend to confirm the occurrence of shallow ground water in areas along the Los Angeles River, near reservoirs, recharge facilities, and flood-control basins. In comparison with 1944 data, the major areas of shallow ground water are reduced in geographic extent, a reflection of the increased volume of water extracted from wells in the southeastern portion of the valley along the Los Angeles River. 

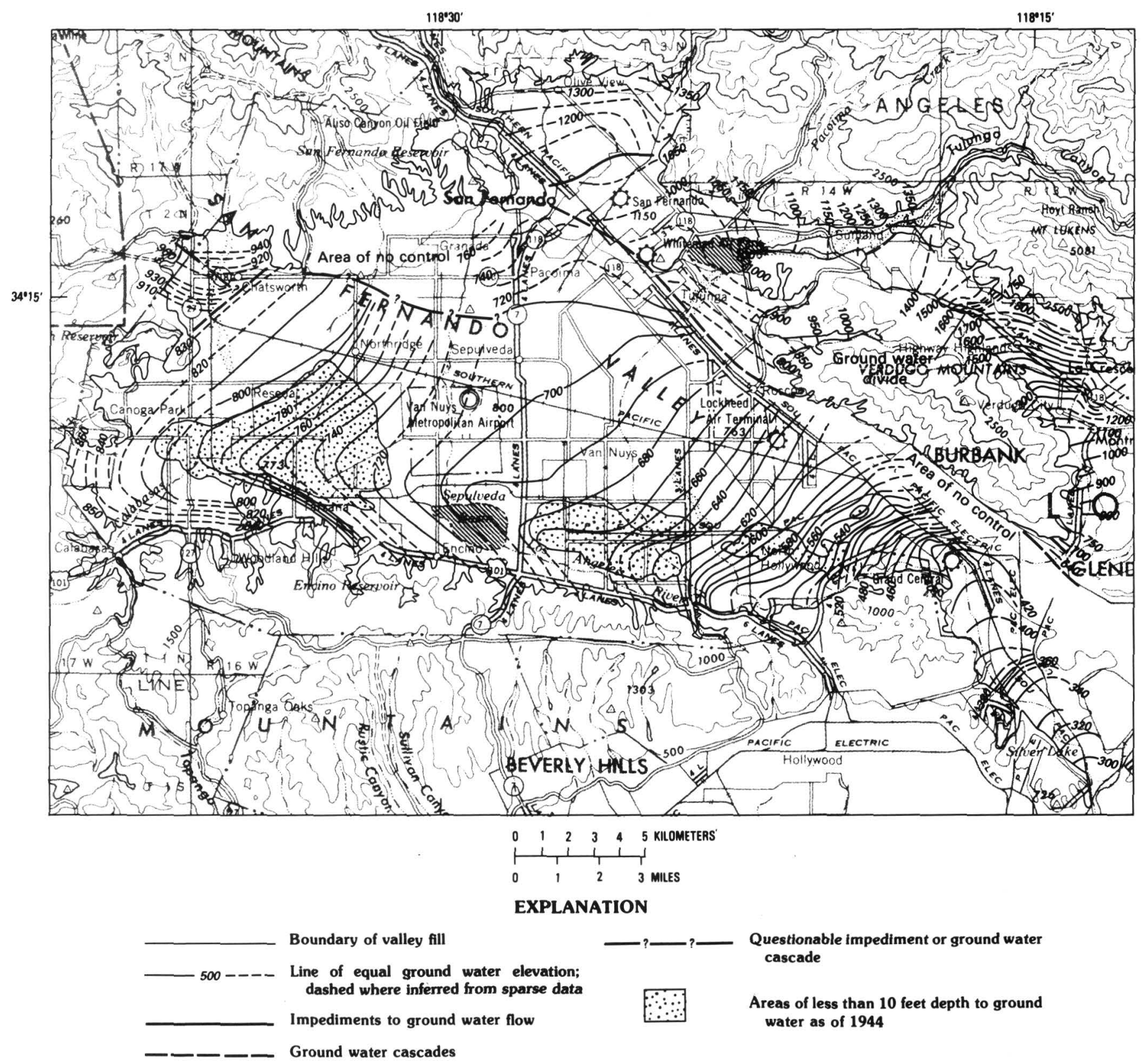

FIGURE 132.-1944 high ground-water conditions in the San Fernando Valley (modified from California Water Rights Board, 1962).

\section{Liquefaction Susceptibility}

A "low-water-level" liquefaction susceptibility map of the San Fernando Valley area derived from figures 131 and 134 is shown in figure 135. Comparing figures 133 and 135 shows that, since 1944, the increased depth to ground water has resulted in an apparent decrease of susceptibility, chiefly along the Los Angeles River. Areas of very high liquefaction susceptibility may exist where cohesionless, water-saturated, granular sediment occurs chiefly as present and former streamchannel deposits in the Reseda-Canoga Park area, as figure 135 notes. Field observations, borehole logs, and the relatively fine grained nature of the source rocks suggest that linearly distributed stream-channel deposits, although of limited areal extent, are likely to be the most susceptible deposits in the Reseda-Canoga Park area. 


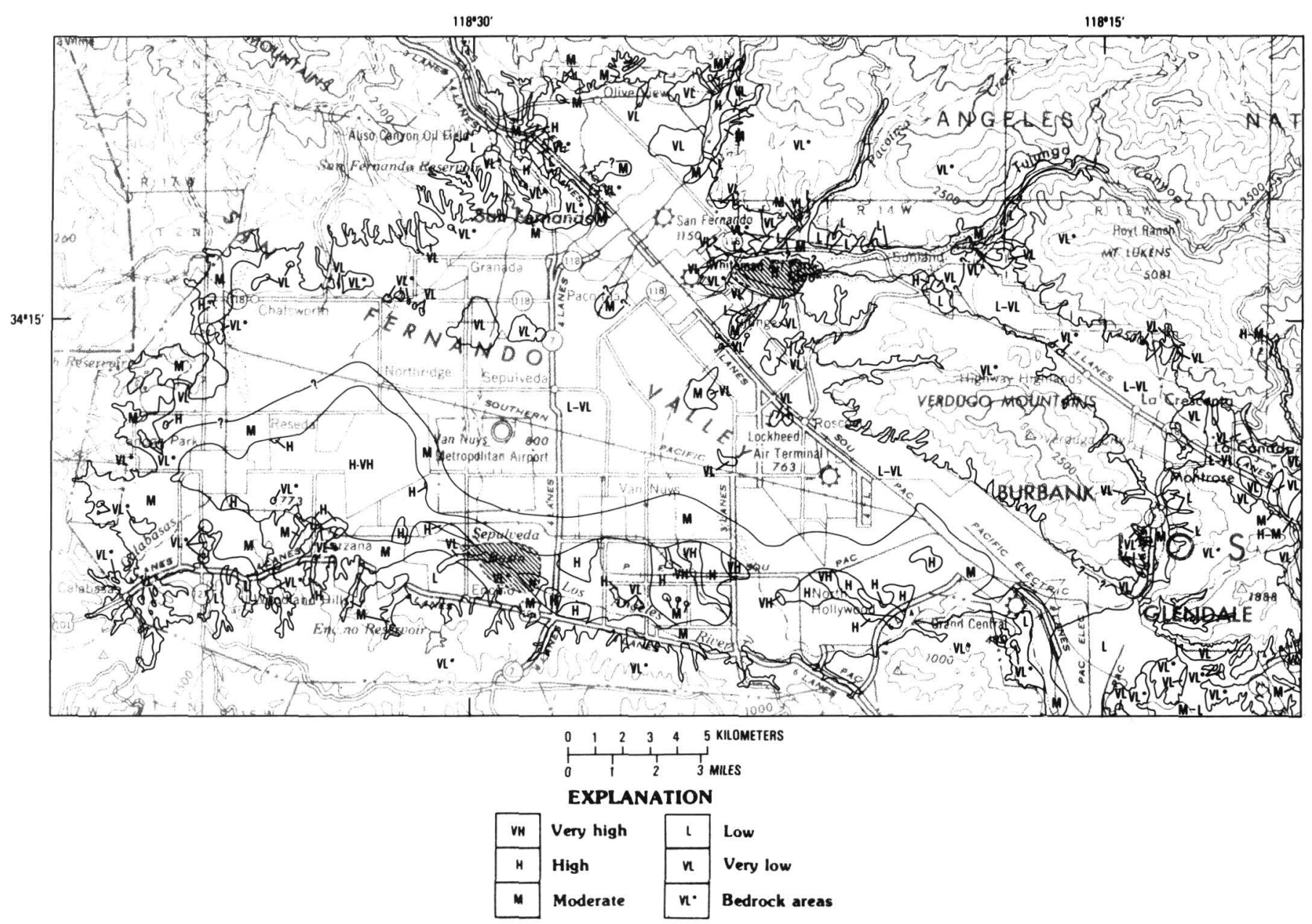

FIGURE 133.-Relative liquefaction susceptibility in the San Fernando Valley based on 1944 ground-water data (compare with fig. 135). Relative susceptibility to liquefaction-related ground failure is interpreted as a function of the age of the saturated materials and the depth to ground water. VH designates areas likely to contain very young, relatively well sorted stream-channel and levee deposits where the depth to ground water is less than $10 \mathrm{ft}$.

\section{San Gabriel Valley}

\section{Surficial Geology}

The generalized surficial geology of the San Gabriel Valley is shown in figure 136. The San Gabriel Valley is located north and east of the Los Angeles Civic Center and is bounded on the north by the San Gabriel Mountains, on the east by the San Jose Hills, on the south by the Puente Hills, and on the west and southwest by the Verdugo Mountains and the Repetto Hills (fig. 129). Principal surface streams draining the basin include the Arroyo Seco along the western margin; the Rio Hondo and the San Gabriel River drain through the Whittier Narrows to the Los Angeles River. All other drainages are tributary to these principal drainages.
The alluvial deposits of the San Gabriel Valley consist chiefly of boulders, gravel, and sand derived from the San Gabriel Mountains. Fine-grained alluvium, often containing appreciable clay, is derived from the San Jose Hills, the Puente Hills, and the Repetto Hills and volumetrically dominates the sediment deposited along the southern margin of the basin. The channel and levee deposits of present and former streams draining valleys underlain by Tertiary sedimentary rock, however, are likely to contain cohesionless, granular sediment susceptible to liquefaction.

\section{Ground water}

Two principal ground-water basins characterize the San Gabriel Valley: the Raymond basin and the San 


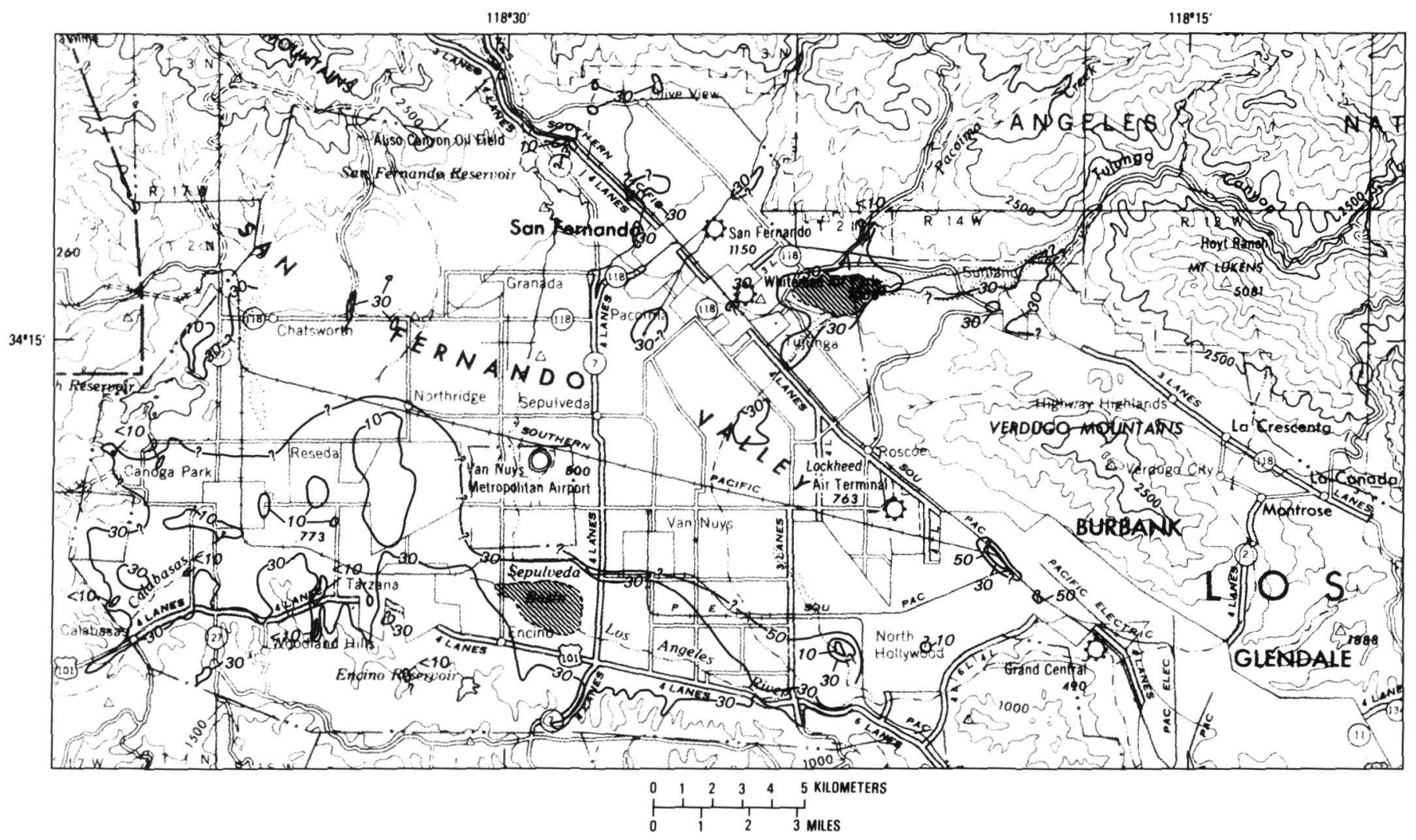

FIGURE 134.--Depths to near-surface ground water in the San Fernando Valley compiled from post-1944 water level data and data from engineering boreholes, chiefly from 1960 through 1975. Isobaths are in feet.

Gabriel basin. These basins were recognized initially by Mendenhall (1908), who noted that they were separated by a prominent ground-water barrier subsequently recognized and named the Raymond fault by Eckis (1934). Buwalda (1940) reported on the geology of the Raymond basin for the Pasadena Water Department.

In the Raymond basin, ground water flows from north to south (Buwalda, 1940). Before the extensive pumping that has lowered the water table in most areas along either side of the Raymond fault, ground water was forced to the surface along the fault zone, and numerous swamps, springs, and small perennial lakes indicated that shallow ground water was present (Mendenhall, 1908). Today, high ground water occurs seasonally and only in restricted areas along the Raymond fault zone (Crook and others, 1979). Elsewhere in the Raymond basin, seasonal occurrences of shallow ground water are associated with flood-control basins and groundwater recharge operations.

In the San Gabriel basin, ground water generally flows southwesterly, parallel to the topographic gradient from principal drainages of the San Gabriel Mountains and other hillslope areas toward and through the
Whittier Narrows, as the contours drawn on the groundwater table for the year 1944 show (fig. 137) (California Department of Water Resources, 1966, fig. 19).

The surficial geologic map (fig. 136) and a depth-toground-water map based on 1944 ground-water data (fig. 137) were superimposed to derive a liquefaction susceptibility map (fig. 138). Areas of shallow ground water (less than $10 \mathrm{ft}$ to water) occur chiefly within and around the area now designated as the Whittier Narrows Flood Control Basin, where the liquefaction susceptibility is designated high to very high. This area is surrounded by an area of moderate susceptibility, where the water table is somewhat deeper $(10-30 \mathrm{ft}$ subsurface) and older Holocene deposits are saturated. This area of moderate susceptibility extends up Walnut Creek between the San Jose Hills and the Puente Hills.

Figure 139 illustrates the depth to shallow ground water, including perched ground water, compiled from several hundred exploratory borings and from several dozen water wells monitored by the State of California. Geologic structures known or presumed to influence the movement of ground water at shallow depths (less than $50 \mathrm{ft}$ ) include the Raymond fault and elements of the 


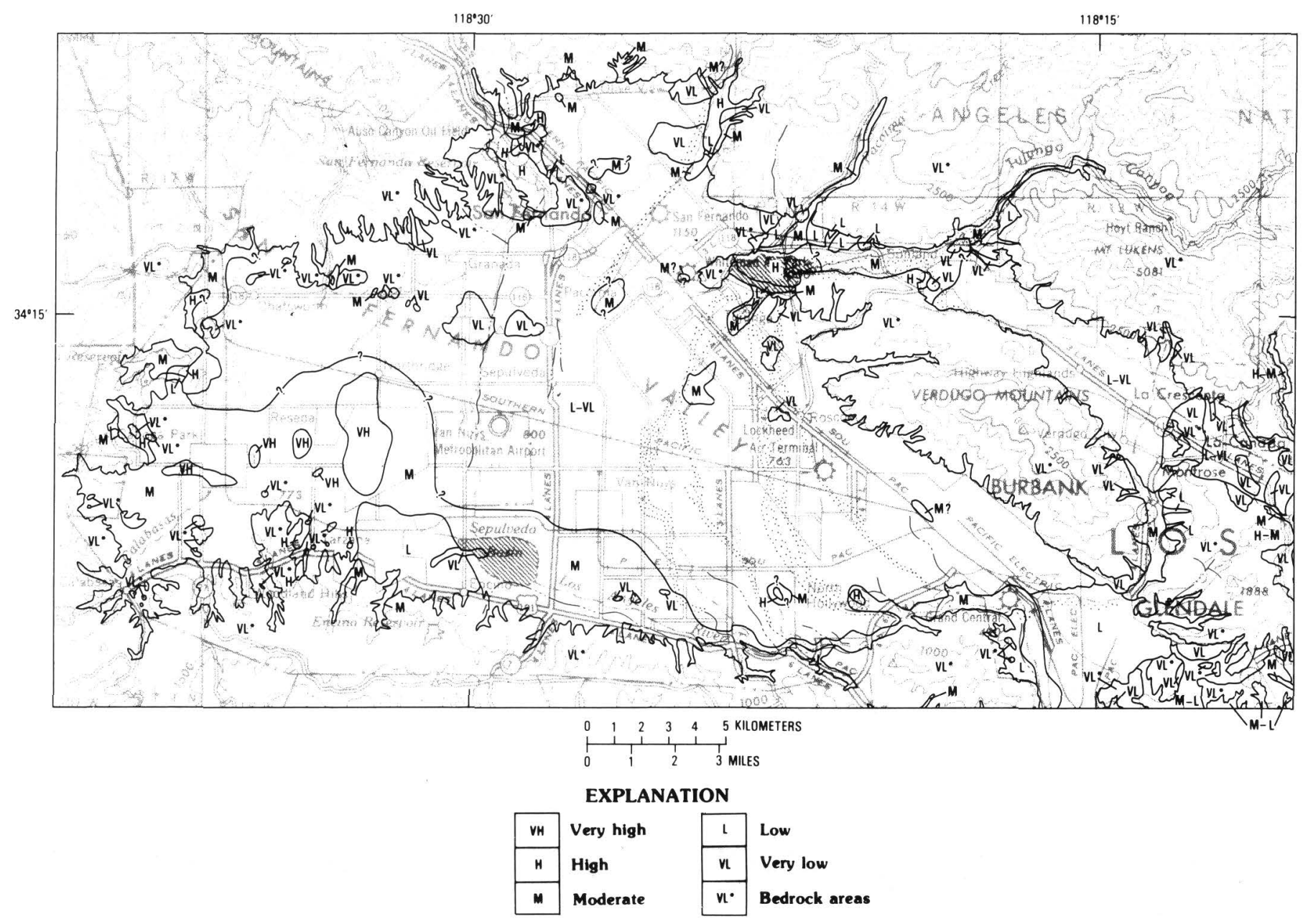

FIGURE 135.-Relative liquefaction susceptibility in the San Fernando Valley based on the ground-water data shown in figure 134. Comparison with figure 133 shows that areas designated as having high and moderate susceptibility are much smaller.

Sierra Madre fault along the southern margin of the San Gabriel Mountains; areas of shallow ground water from this study are shown where they are associated with those structures.

\section{Liquefaction Susceptibility}

Comparision of ground-water data from 1944 and from the post-1944 (chiefly 1965-75) period indicates that the areal extent of shallow ground water has been sharply reduced. This reduction is presumed to stem chiefly from the development of ground-water resources. A "low-water-level" liquefaction susceptibility map prepared from the data in figure 139 is shown in figure 140. The Whittier Narrows Flood Control Basin is classified as chiefly within the moderate susceptibility designation, reflecting a depth to ground water in the range of 10 to $30 \mathrm{ft}$ subsurface.

\section{Earthquake Hazards in the Los Angeles Region}

The extent of areas having high and moderate susceptibility to liquefaction is very sensitive to changes in the depth to ground water. Most of the San Gabriel Valley is at low or very low levels of risk from liquefaction, because the ground water is more than $30 \mathrm{ft}$ subsurface; in many noncoastal basin areas, deposits at depths of $30 \mathrm{ft}$ or more are often Pleistocene in age, especially in the Raymond basin area.

\section{Los Angeles County Area of the Los Angeles Basin}

The Los Angeles basin is bounded on the north by the Santa Monica Mountains, on the west by the Pacific Ocean, on the south and southeast by the San Joaquin Hills and Santa Ana Mountains, and on the east by the Puente Hills and Chino Hills (fig. 129). The part of the 


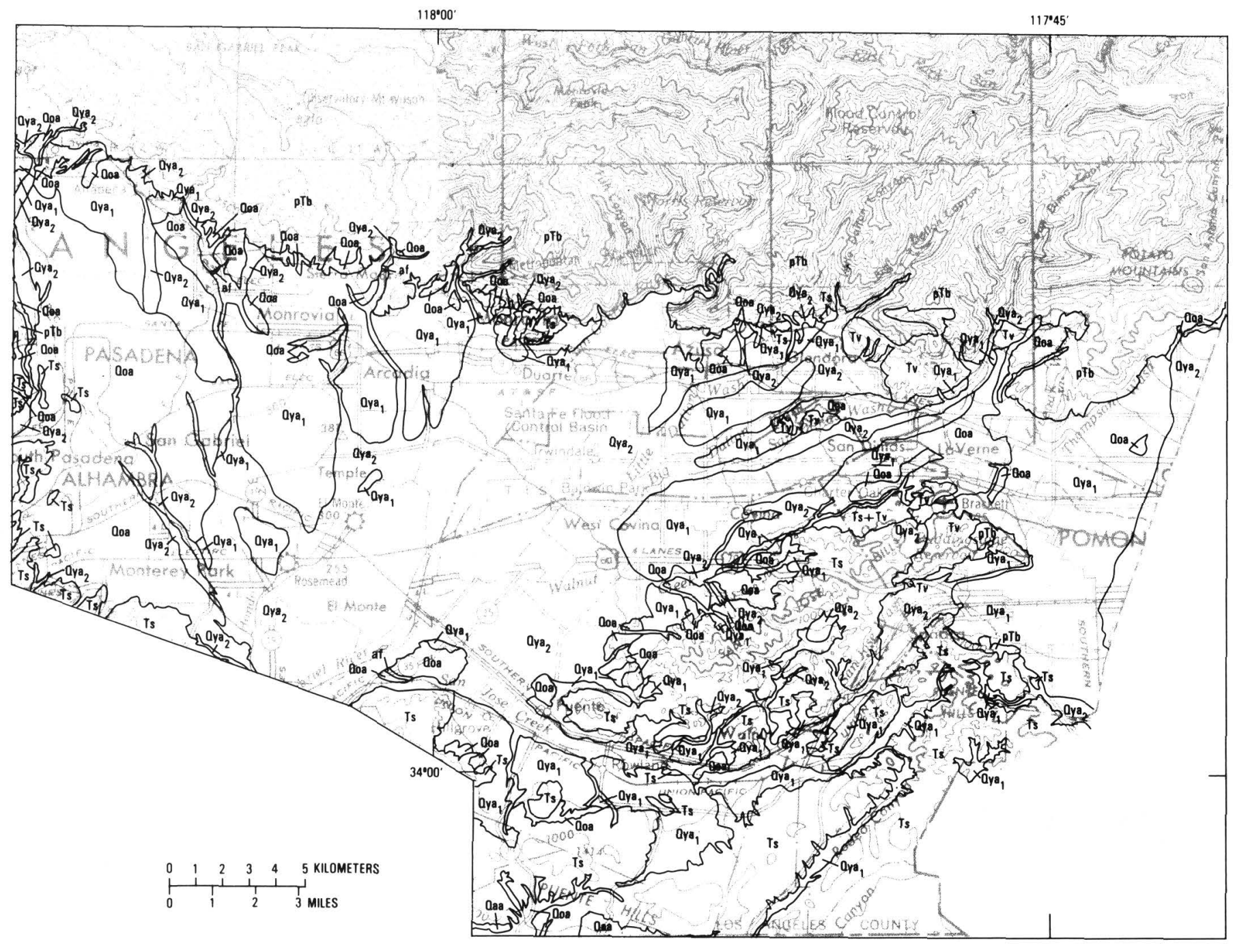

EXPLANATION

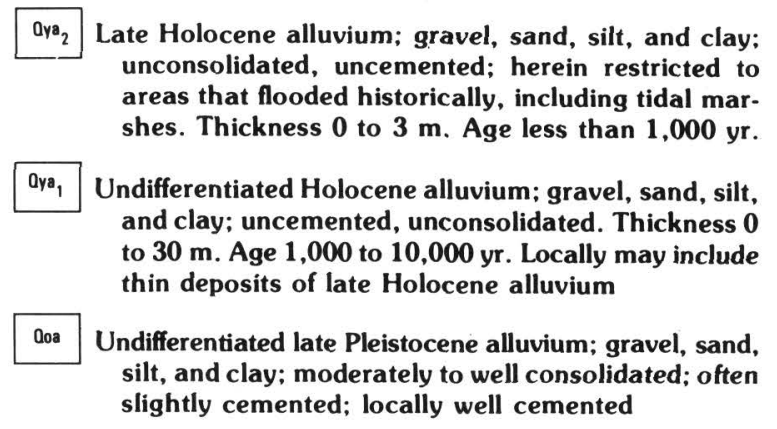

0as Undifferentiated early and middle Pleistocene deposits

Ts Undifferentiated pre-Quaternary lithified sedimentary rocks; Ts + Tr where co-mingled

Tv Undifferentiated pre-Quaternary volcanic rocks

PTb Mesozoic and older rocks of the San Gabriel, Verdugo, and Santa Monica Mountains areas silt, and clay; moderately to well consolidated; often slightly cemented; locally well cemented

af Artificial fill

FIGURE 136.-Generalized surficial geology in the San Gabriel Valley.

Los Angeles basin situated in Orange County is discussed separately in a later section.

Yerkes and others (1965) have described the structural and stratigraphic framework of the Los Angeles basin. The subsurface configuration of the Quaternary deposits is known chiefly from studies of the basinal hydrology. Mendenhall (1905a, b) first described the general occurrence of ground water and delineated the principal ground-water barriers, including the NewportInglewood fault zone. Subsequent regional hydrologic studies to determine safe yields from the various waterbearing zones and to safeguard the coastal aquifers 


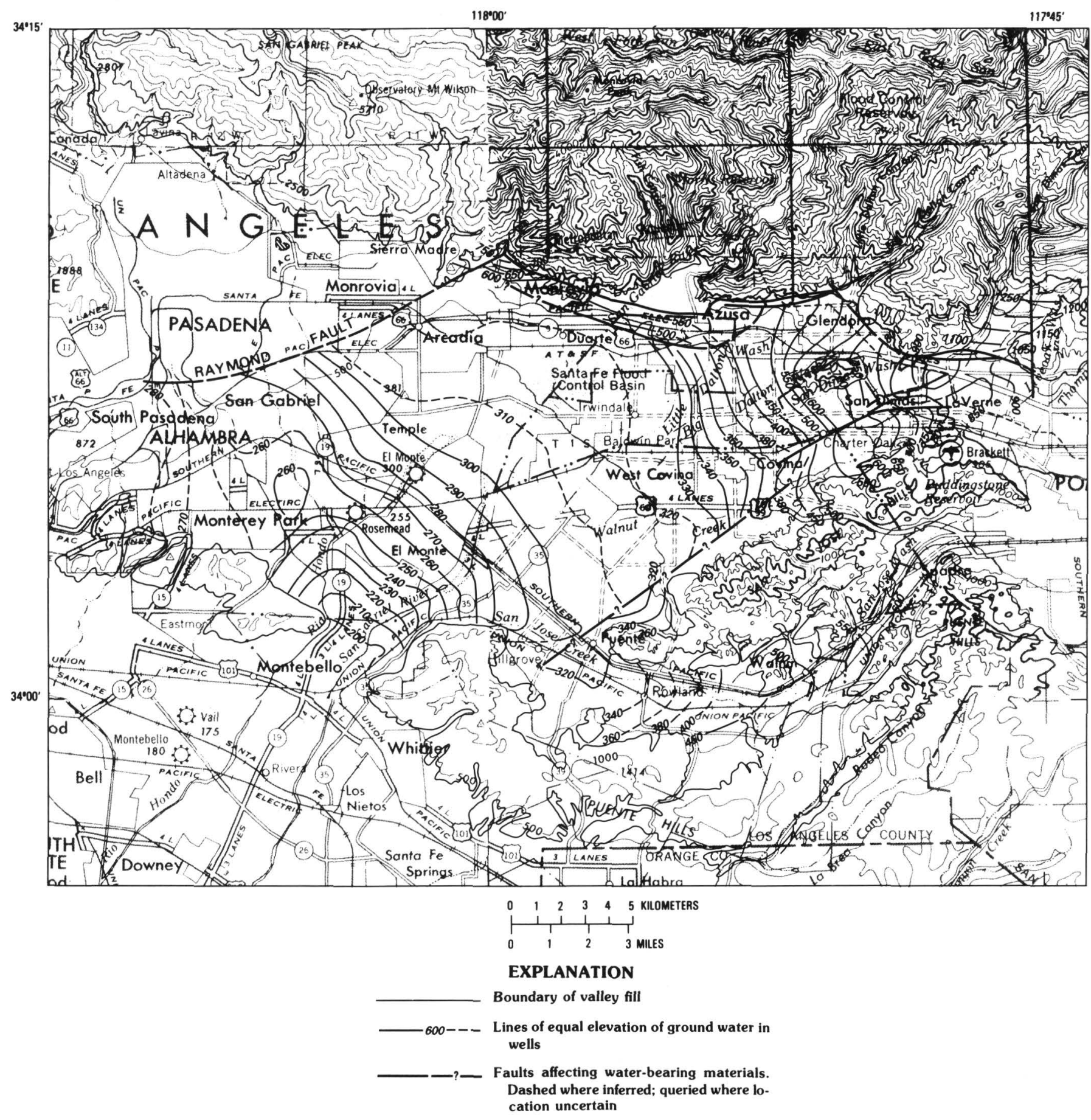

FIGURE 137.-1944 high ground-water conditions in the San Gabriel Valley (modified from California Department of Water Resources, 1966, fig. 19).

from saltwater intrusion include the works of Eckis (1934), Poland and others (1956, 1959), Poland (1959), Zielbauer and others $(1961,1962)$, and the California Department of Water Resources $(1961,1962)$.

\section{Surficial Deposits}

The generalized surficial deposits of the Los Angeles area are shown in figure 141. The distribution of the

284 Earthquake Hazards in the Los Angeles Region 


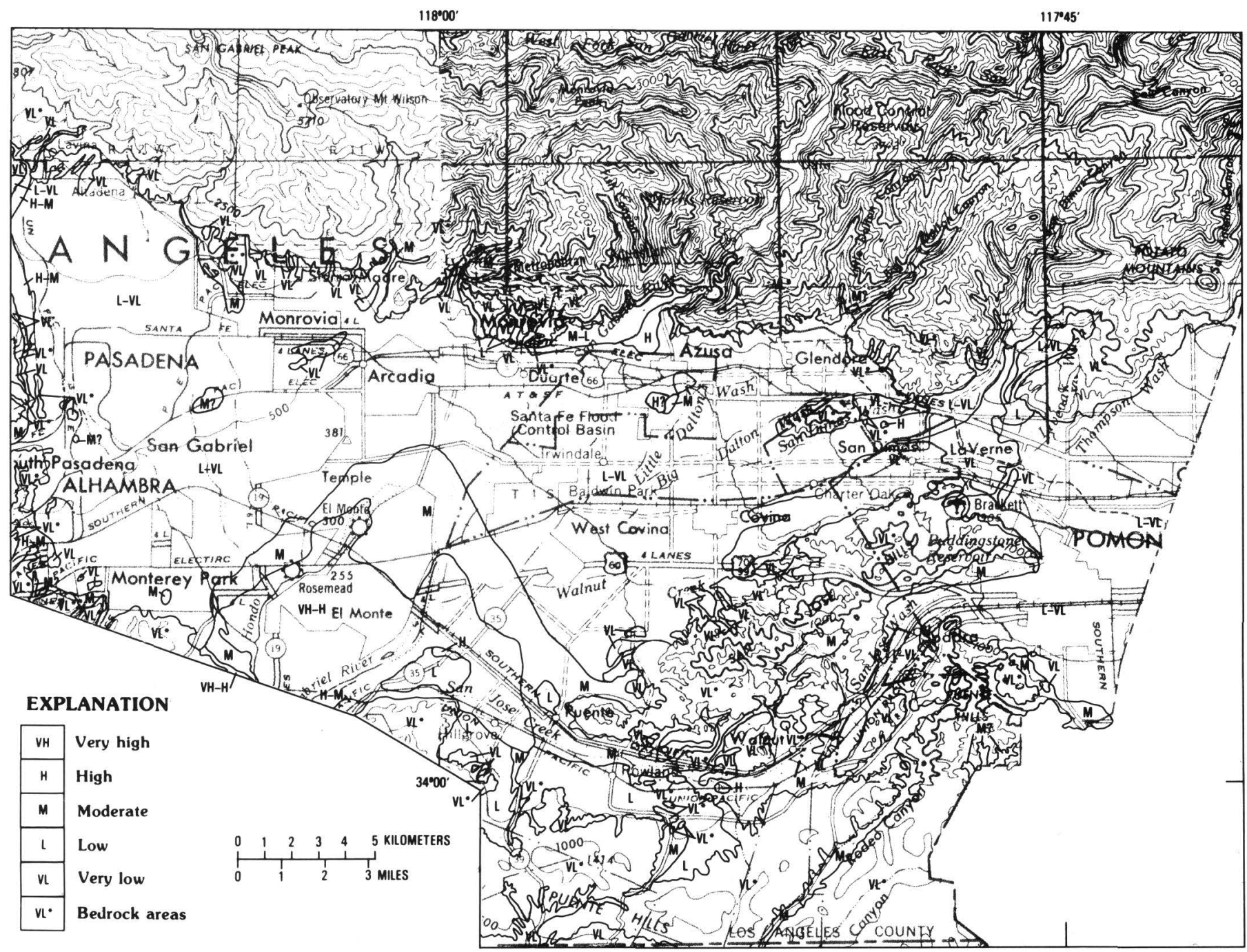

FIGURE 138.-Relative liquefaction susceptibility in the San Gabriel Valley based on 1944 high ground-water conditions (compare with fig. 140). Relative susceptibility to liquefaction-related ground failure is interpreted as a function of the age of the saturated materials and the depth to ground water. VH designates areas likely to contain very young, relatively well sorted stream-channel and levee deposits where the depth to ground water is less than $10 \mathrm{ft}$.

stratigraphic units as mapped reflects the continuing tectonic deformation of the area (Yerkes and others, 1965; Yerkes, 1972), the distribution of the first- and second-order sources of sediment, and areas of historical flooding (Los Angeles County Flood Control District, unpublished maps and field notes, 1938-1956; Troxell, 1942). The youngest sediment occurs in the modern flood-plain areas of the Los Angeles, San Gabriel, Rio Hondo, and Santa Ana Rivers, which have caused multiple known episodes of inundation during at least the past $150 \mathrm{yr}$.

These principal drainages flow west to the Pacific Ocean, across the uplifting area of Pleistocene deposits that crop out along the Newport-Inglewood zone of deformation. Early Holocene deposits crop out chiefly along the flood-plain margins, on the flanks of uplifting folds along the basin margins of the structural basin. Late Pleistocene deposits, locally including the early Pleistocene San Pedro Formation, are exposed in the broad northwest-trending outcrop shown along the western third of figure 141. The eastern half of the area of Pleistocene deposits lies along the Newport-Inglewood zone of folds and faults. The western half is comprised chiefly of Pleistocene and Holocene eolian sand, which overlies older Pleistocene marine and nonmarine strata. A small area of Holocene deposits containing sediment reworked from adjacent uplands along the NewportInglewood zone drains south and then west through Dominguez Gap. Tertiary and pre-Tertiary sedimentary rocks and Mesozoic and older plutonic and metamorphic 


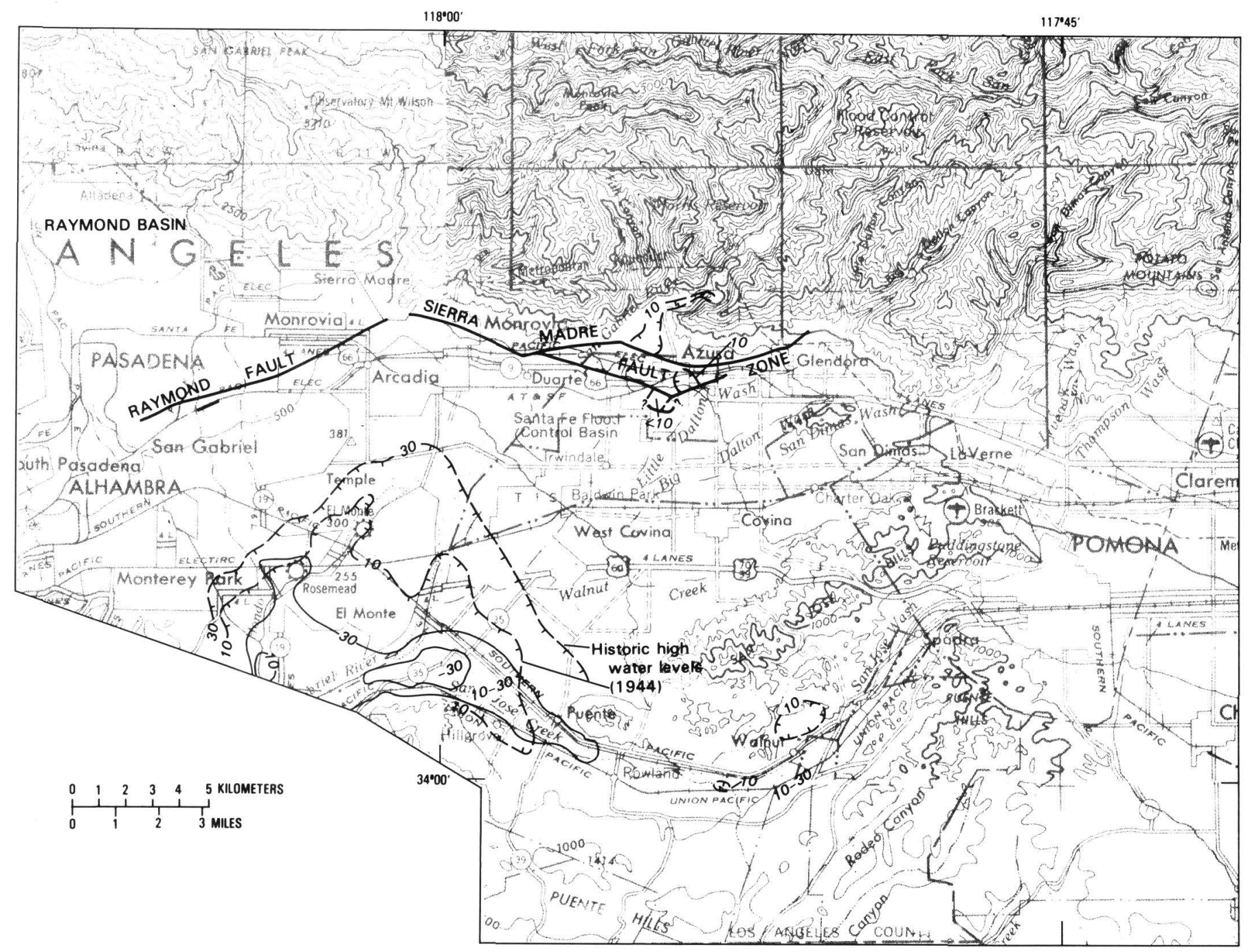

FIGURE 139.-Depths to near-surface ground water in the San Gabriel Valley compiled from post-1944 water data, including data from engineering boreholes, chiefly for 1960 through 1975. Isobaths are in feet.

rocks frame the alluviated parts of the Los Angeles basin.

\section{Ground Water}

The distribution of near-surface ground water apparently has changed markedly because of the development and management of ground-water resources since 1905. The geologic framework is important to understanding evolving hydrologic conditions in the Los Angeles basin area, as figure 142 illustrates. The latest Tertiary and Quaternary deposits that fill the Los Angeles basin comprise an alternating sequence of relatively permeable and relatively less permable strata or zones. The relatively permeable zones are composed chiefly of gravel and sand; these aquifers yield copious volumes of water to wells. The aquifers are separated by zones or layers of sediment (called aquicludes) that are relatively less permeable because they contain a relatively high proportion of silt and clay. The more clay rich the sediment, the less readily it yields water to wells. In some parts of the Los Angeles basin, the aquicludes are quite impermeable, and little, if any, water passes through them. In nearby areas, however, the aquicludes are quite "leaky," and ground water can pass upward or downward from one aquifer to another through confining aquicludes, if pressure gradients are favorable. A comprehensive description of the deeper, principal aquifers and aquicludes has been given by the California Department of Water Resources (1961); the hydrologic sections in that report characterize the hydrology of the area also shown in figure 141. Figure 142, compiled chiefly from Mendenhall (1905a, b) and

\section{Earthquake Hazards in the Los Angeles Region}




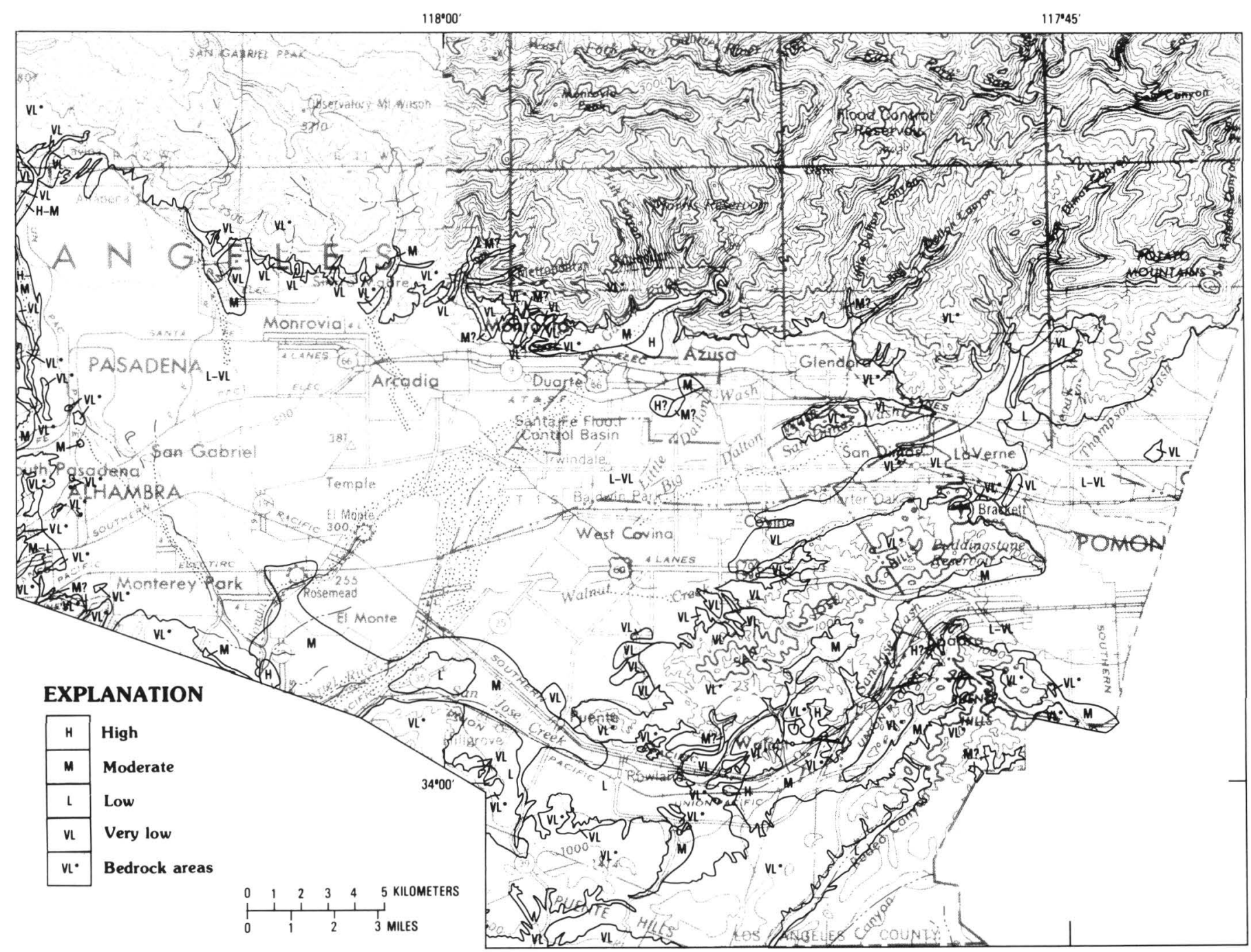

FIGURE 140.-Relative liquefaction susceptibility in the San Gabriel Valley based on the ground-water isobaths presented in figure 139. Areas designated as high and moderate susceptibility are smaller relative to those based on the 1944 ground-water levels and are confined chiefly to the flood-control basins and ground-water recharge facilities near the Whittier Narrows.

Conkling (1927), shows the decreasing extent of confined or "artesian" ground water in the deposits along the Los Angeles and San Gabriel Rivers before 1905, in 1905, and in 1928. The stippled areas contained water within $8 \mathrm{ft}$ of the surface as recently as 1935 (Los Angeles County Flood Control District, unpublished map, scale 1:62,500). The depths to water measured in numerous shallow wells and tabulated by Mendenhall (1905a, b) indicate that shallow ground water was common within the artesian area shown by the solid line in figure 141 . Because the near-surface aquicludes in this formerly artesian area are known to be somewhat "leaky" (California Department of Water Resources, 1961), we infer that, before the ground-water reservoir was pumped, many of these areas of shallow water could have been recharged from below by upward seepage through permeable zones in the aquicludes.

Figure 143 is a "high-water-level" liquefaction susceptibility map derived by assuming that the depth to ground water was approximately as described by Mendenhall's (1905a, b) hydrographic contours. Floodplain areas containing latest Holocene deposits of cohesionless, granular sediments are assigned a very high susceptibility; the susceptibility is reduced as the sediment becomes older or as the depth to ground water increases (table 43).

In figure 144, dashed lines are isobaths (lines that enclose areas found to contain ground water within the indicated limits of depth). These occurrences of ground water are based on relatively recent (1950-80) records 


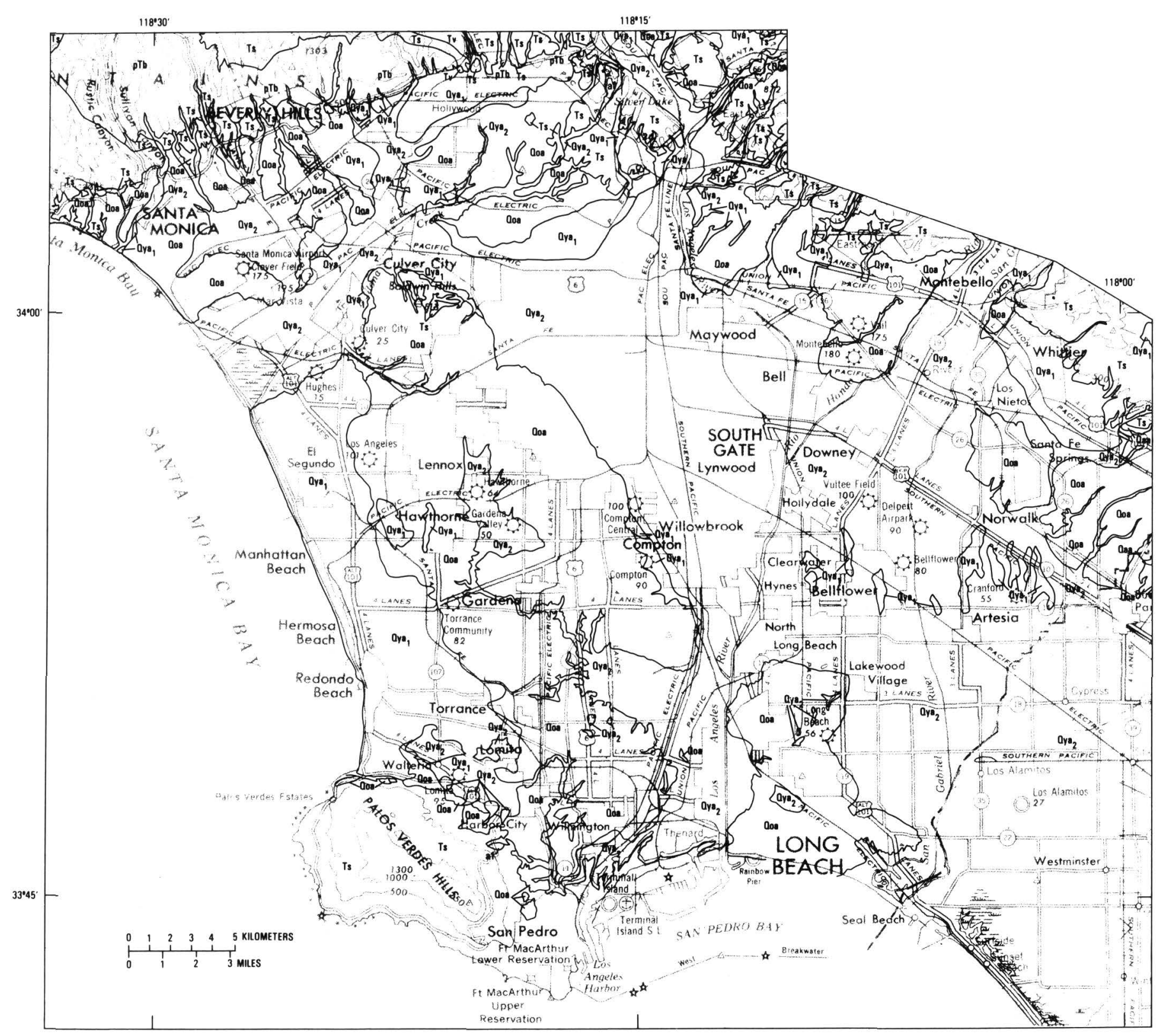

EXPLANATION

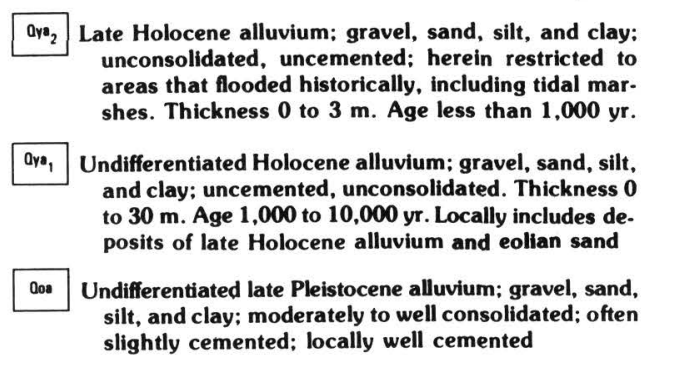

Qase Undifferentiated early and middle Pleistocene deposits of gravel, sand, silt, and clay; locally well cemented

is Undifferentiated pre-Quaternary lithified sedimentary
rocks

pib Mesozoic and older rocks of the San Gabriel, Verdugo, and Santa Monica Mountains areas

af Artificial fill

FIGURE 141.-Generalized surficial geology of the Los Angeles County portion of the Los Angeles basin.

of water wells and of exploratory boreholes drilled for engineering studies. Comparing figure 143 with figure 145 indicates that the extensive area of shallow ground water noted in the Los Angeles River area in 1905 had been reduced markedly following development of the ground-water resource.

\section{Earthquake Hazards in the Los Angeles Region}




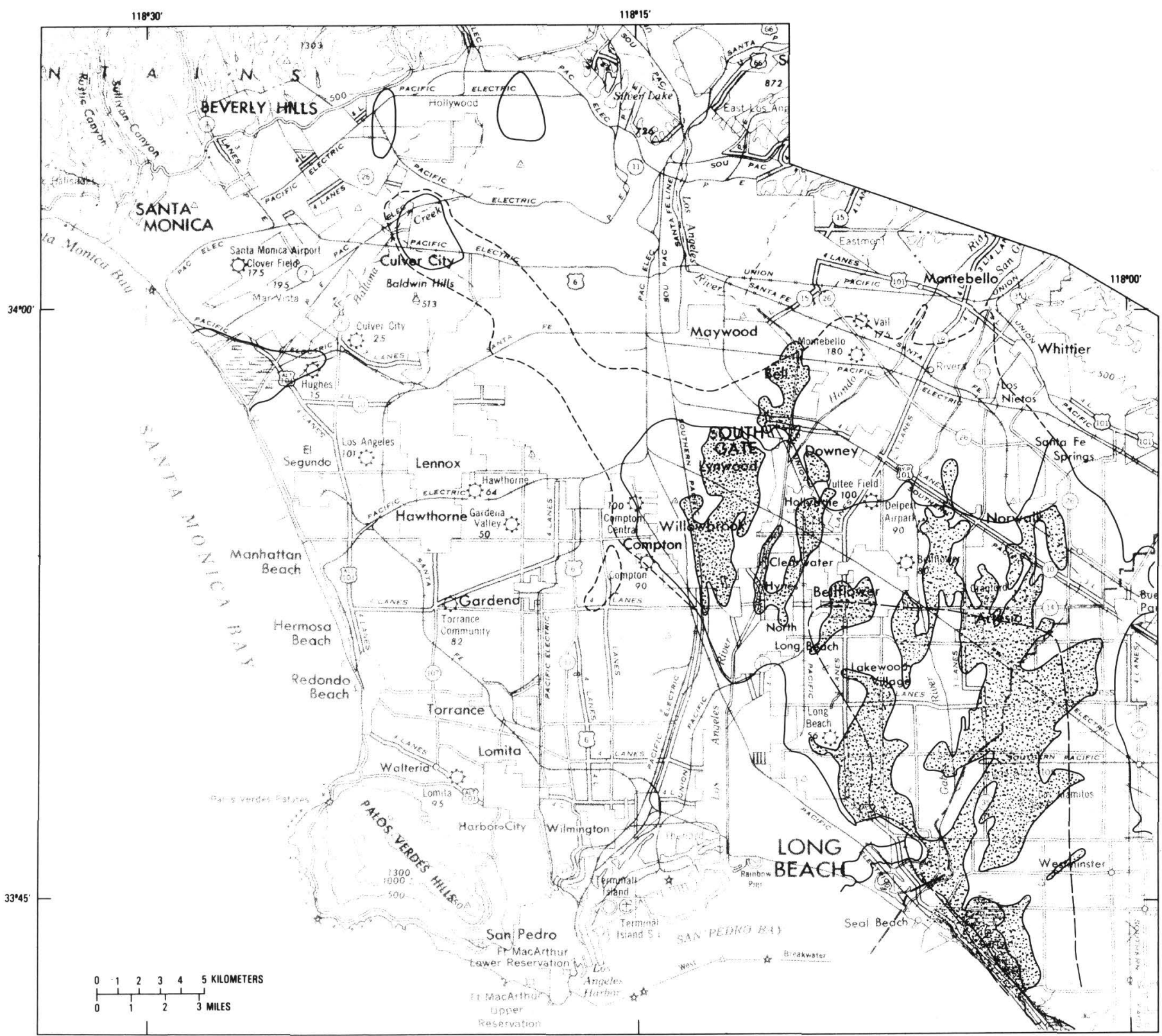

FIGURE 142.-Areas of artesian ground-water conditions have decreased as ground-water resources have been developed. The maximum pre-1905 extent of the artesian area is shown by a short dashed line; the limit of the artesian area in 1904 is shown by a solid line (Mendenhall, 1905a, b); the limit of the artesian area in 1926 is shown by a heavy dashed line; areas containing shallow ground water $8 \mathrm{ft}$ or less below the ground surface as of October 1926 are shown by stippling (Conkling, 1927, pl. 13).

In the "low-water-level" map (fig. 145), areas having high, very high, or moderate susceptibility to liquefaction (if cohesionless, granular materials are present) occur in only a few localities and are restricted to areas near the mouth of a drainage such as Ballona Creek and in harbor areas of Los Angeles, near Long Beach and Los Alamitos (Randell, 1983). Apparently, the development of the ground-water resource has had an important beneficial effect on reducing the number and extent of areas where liquefaction can occur in the Los Angeles area.

As ground-water management practices change, due care must be exercised to ensure that several consecutive seasons of relatively high precipitation do not recharge hydrologic basins to a point where shallow ground water once more becomes extensive and the liquefaction susceptibility correspondingly widespread. 


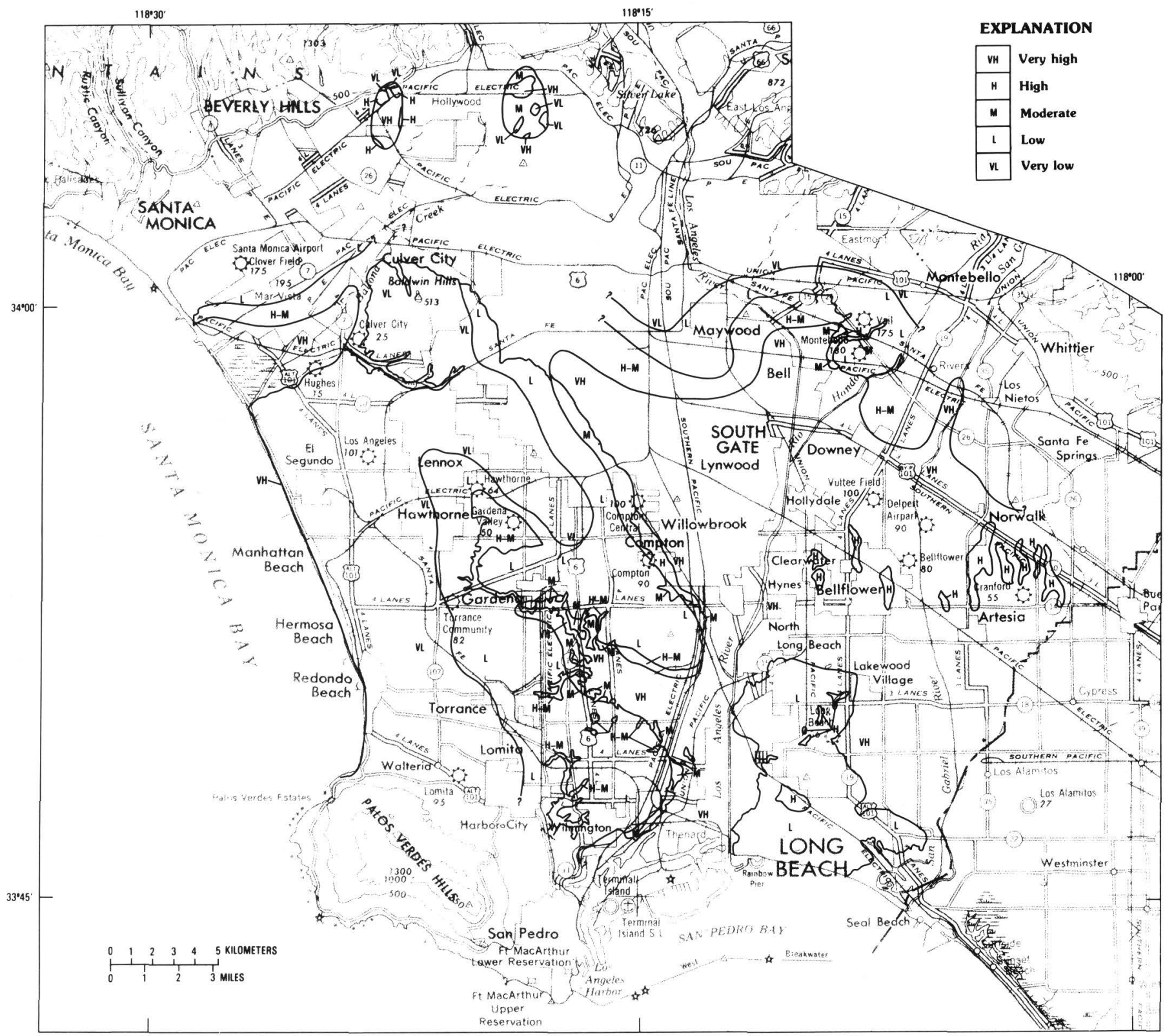

FIGURE 143.-Extensive areas of probable high and moderate susceptibility to liquefaction in the Los Angeles basin, based on ground-water data from Mendenhall (1905a, b) and Conkling (1927). Much of the area shown in the central part of the map could have been recharged from pressurized water-bearing layers partially confined below the near-surface water-bearing layers. These layers may contain only perched water today. A comparison with figure 145 shows how the withdrawal of ground water has reduced the size of susceptible areas.

\section{Orange County Area of the Los Angeles Basin}

\section{Surficial Geology}

The Orange County area comprises the southern half of the Los Angeles basin. Broadly upwarped and tilted Pleistocene marine terraces occur intermittently along the Pacific shoreline and the part of the NewportInglewood fault zone extending from Newport Bay north to Alamitos Bay. The extensive alluvial plain that extends inland to the San Joaquin Hills in the south and to the Santa Ana Mountains in the east contains in its uppermost part chiefly alluvial deposits of the Santa Ana River, plus contributions of sediment from smaller basins that drain the adjoining, mainly sedimentary terranes of the adjacent uplands.

The distributions, thicknesses, and characters of the surficial deposits in the Orange County area have been mapped at a scale of 1:48,000 for purposes of seismic 


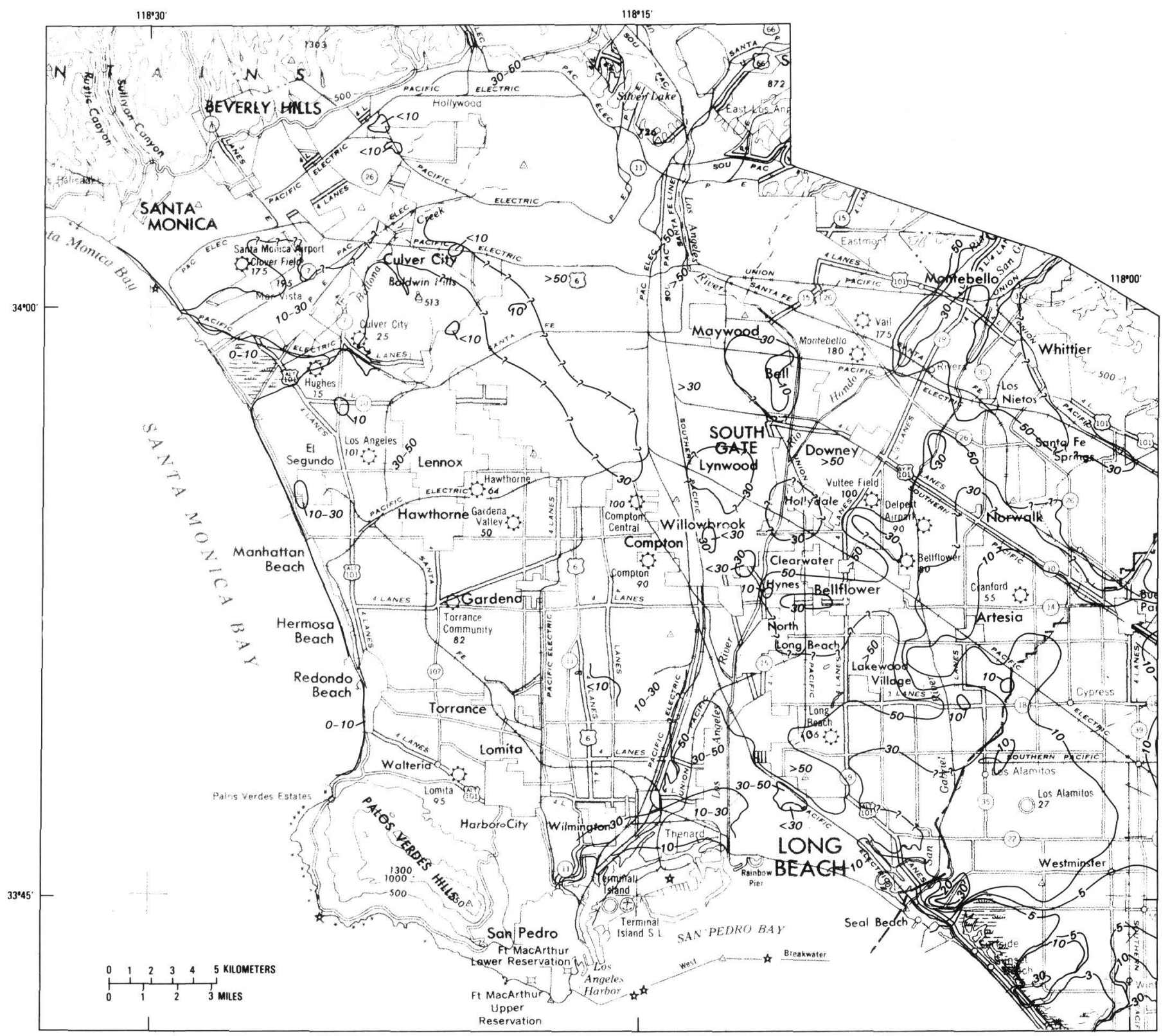

FIGURE 144.-Ground-water levels compiled from post-1928 data in the Los Angeles basin area of Los Angeles County. Data include measurements made at selected wells monitored by the State of California and made in exploratory borings from 1960 through 1975 . Isobaths are in feet.

zonation by Sprotte and others (1980) and Sherburne and others (1981). The reader is referred to those publications for additional details. A highly generalized surficial geologic map compiled from Sprotte and others (1980), Rogers (1965), and Yerkes (1972) is shown in figure 146 .

\section{Ground Water}

The extent of shallow ground water has been mapped in the flatland area of Orange County by Sprotte and others (1980). Figure 147 is an isobath map compiled from Sprotte and other (1980, pl. 1). The dashed lines enclose areas of equal depth to ground water, based on logs of exploratory borings undertaken for construction projects before 1955 and on drillers' logs of water wells excavated since 1920. The lines thus are not equipotential lines in the hydrologic sense but are isobath lines. The map is a compilation of the shallowest reported occurrences of ground water and is thus a conservative interpretation that represents a regional evaluation of 


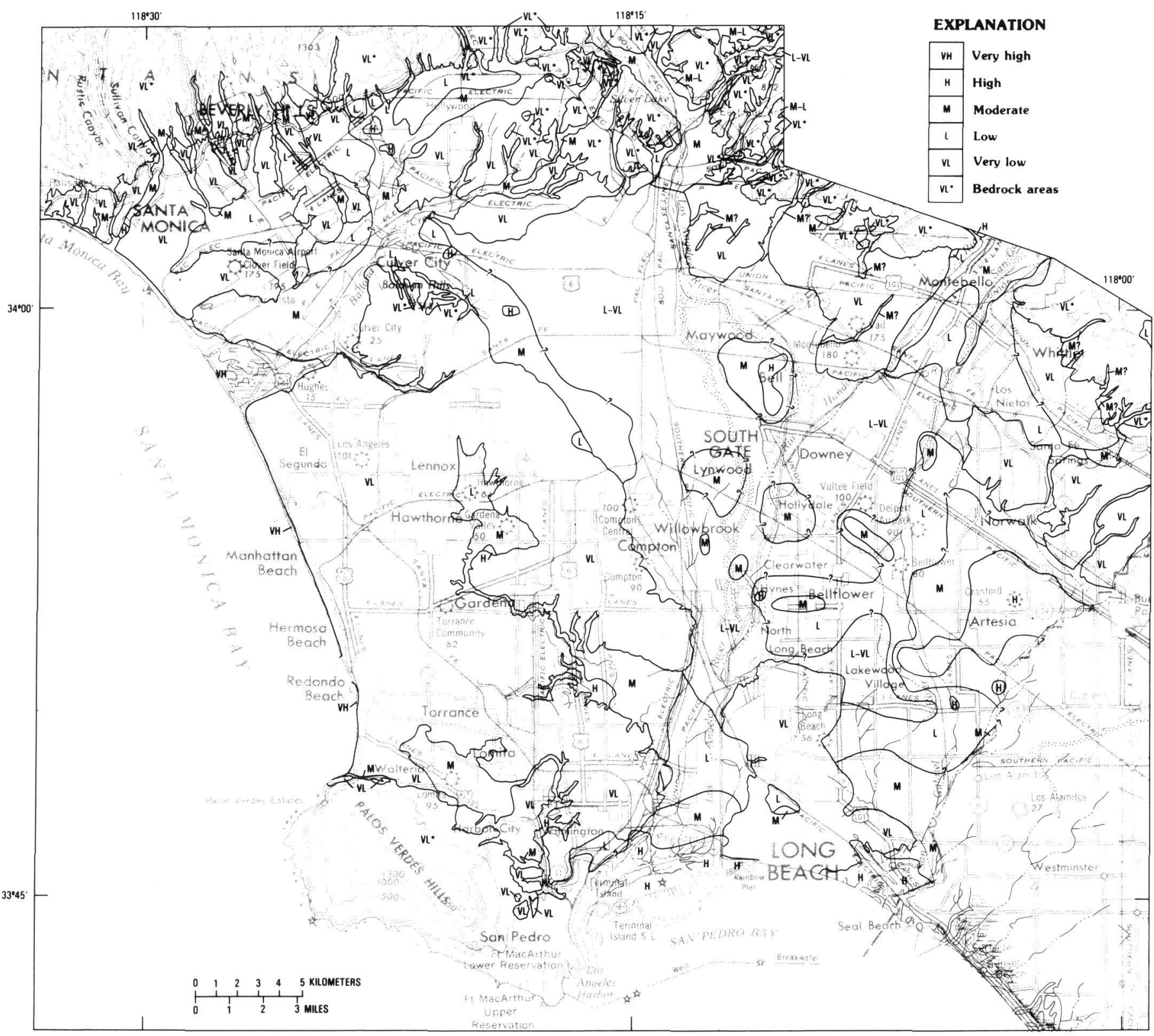

FIGURE 145.-Relative liquefaction susceptibility in the Los Angeles basin, based on depths to ground water measured from 1960 through 1975 (compare with fig. 143). Relative susceptibility to liquefaction-related ground failure is interpreted as a function of the age of the saturated materials and the depth to ground water. VH designates areas likely to contain very young, relatively well sorted stream-channel and levee deposits where the depth to ground water is less than $10 \mathrm{ft}$.

the "worst possible" ground-water conditions for considerations of seismic response (Sprotte and others, 1980, p. 7).

\section{Liquefaction Susceptibility}

The depth-to-ground-water thresholds in table 43 and the depth-to-ground-water data in figure 147 have been used to derive a preliminary liquefaction susceptibility map (fig. 148). The highest susceptibility would be associated with the occurrences of cohesionless, granular materials and the shallowest $(0-10 \mathrm{ft})$ depths to ground water. Stippled areas show positions of former drainage channels as given on 1890 U.S. Geological Survey topographic maps. These channels predate construction of storm drains and channelization of natural drainages and are likely to contain sediment susceptible to liquefaction. They are not, however, the

\section{Earthquake Hazards in the Los Angeles Region}




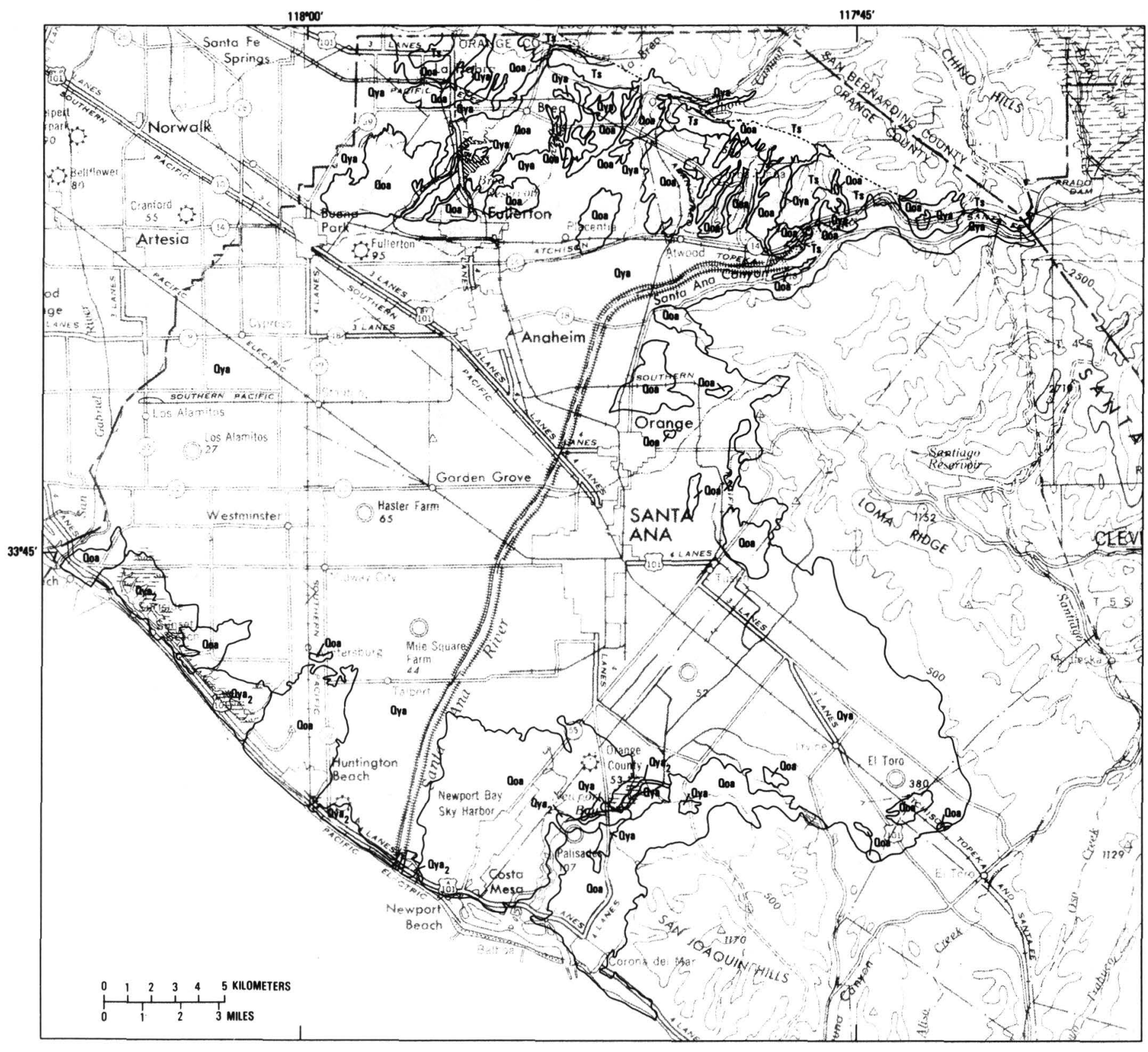

EXPLANATION

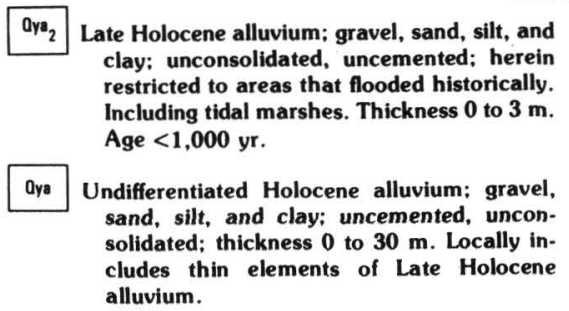

\begin{tabular}{|l} 
Undifferentiated Pleistocene alluvium; gravel, \\
sand, silt, and clay: moderately to well con- \\
solidated often slightly to well cemented.
\end{tabular} solidated often slightly to
Thickness 0 to $>1,200 \mathrm{~m}$.

Ts Pre-Quaternary lithified rock units, undifferentiated. Chiefly includes Tertiary and pre Tertiary sedimentary rock, locally includes Tertiary intrusive and extrusive rock of the Santa Ana Mountains.

FIGURE 146.-Generalized surficial geology of the flatland areas of the Orange County portion of the Los Angeles basin (from Sprotte and others, 1980; Rogers, 1965; Yerkes, 1972).

only channels to have traversed the coastal plain (Troxell, 1942), so channel deposits may occur in the near subsurface in other places as well as in those localities shown in figure 148. 


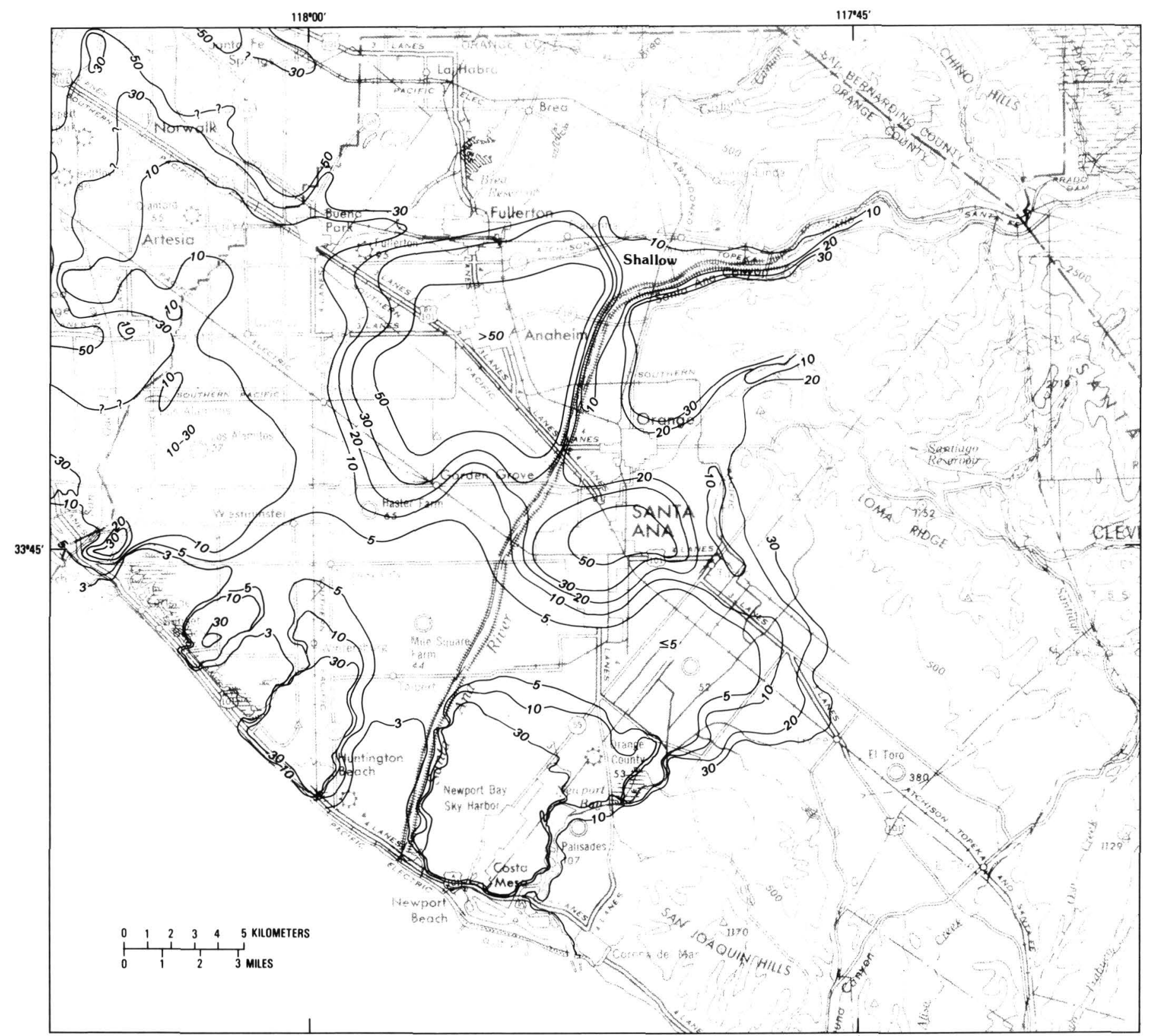

FIGURE 147.-Generalized depth to ground water in the flatland areas of Orange County (modified from Sprotte and others, 1980). Isobaths (in feet) are dashed where approximately located and queried where ground-water data are sparse.

\section{Upper Santa Ana River Basin Area}

\section{Surficial Geology}

The upper Santa Ana River basin area is shown relative to the other alluvial basins in the study in figure 129. The alluvial basin is bounded on the north by the San Gabriel Mountains, on the east by the San Bernardino Mountains and the San Andreas fault, on the south by Tertiary-Cretaceous sediments in the northern Santa Ana Mountains and the granitic rocks of the eastern basement complex of Yerkes and others, (1965), and on the west by the Tertiary sedimentary rocks of the Puente Hills, the Chino Hills, and the San Jose Hills (Durham and Yerkes, 1964).

The generalized surficial deposit map compiled by Cox and Morton (1978) is the surficial geologic base map for our reconnaissance appraisal of liquefaction suscep- 


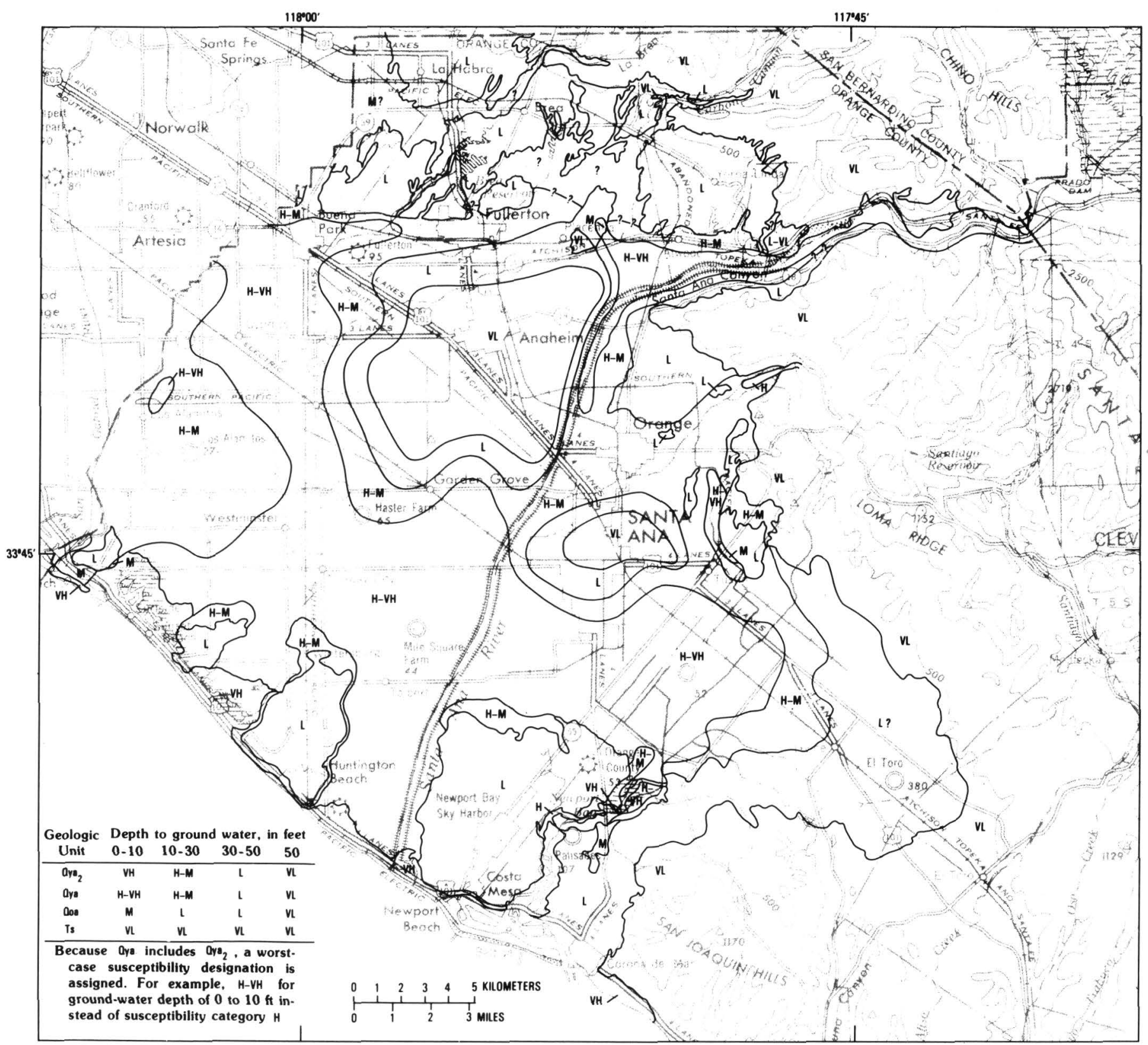

FIGURE 148.-Relative liquefaction susceptibility in the flatland area of Orange County. Stippled areas indicate positions of former drainage channels as shown on 1890 U.S. Geological Survey topographic maps. Relative susceptibility to liquefaction-related ground failure is interpreted as a function of the age of the saturated materials and the depth to ground water. VH designates areas likely to contain very young, relatively well sorted stream-channel and levee deposits where the depth to ground water is less than $10 \mathrm{ft}$. 
tibility and is shown in figure 149. This map shows the two principal systems of sediment dispersal that dominate the region. One suite of alluvial deposits, derived from the rugged canyons draining the San Gabriel Mountains, forms coalesced alluvial fans that slope south from the piedmont of the San Gabriel Mountains to the Jurupa Hills and the Santa Ana River. The second suite, derived from the chiefly granitic rocks exposed northeast, east, and south of the Riverside-San Bernardino area, consists of the alluvial fans and fluvial terraces of drainages that are directly tributary to the Santa Ana River near the eastern part of the area shown in figure 149.

\section{Ground Water}

The ground-water map that we used to compile a liquefaction susceptibility map of this area (fig. 150) is a small-scale map generalized from a 1:48,000-scale ground-water map by Carson and Matti (1982) and shows the minimum depth to ground water in the upper Santa Ana River basin area. Carson and Matti (1982) analyzed the water-level data for the period from 1973 through 1979, using wells monitored by the California Department of Water Resources. Their study shows that cycles of natural recharge and management of groundwater basins profoundly affect the temporal and spatial distribution of ground water. In parts of San Bernardino, rising water has invaded cellars, undermined road fills, and affected foundations. In several places where water levels have continued to rise since 1979, the areas underlain by shallow ground water have expanded beyond what is depicted in this report. Principal areas where shallow ground water was detected are located north of Pomona, within the Prado Dam Flood Control Basin, along the Santa Ana River basin, locally in Cajon Creek Valley, and along parts of the San Jacinto fault zone in the Riverside-San Bernardino area (Dutcher and Garrett, 1963).

\section{Liquefaction Susceptibility}

A "high-water-level" liquefaction susceptibility map was compiled from figures 149 and 150 by using the model developed in this chapter. Areas where shallow ground water resulted in a designation of high or moderate liquefaction susceptibility (if cohesionless granular materials are present) are shown in figure 151. Carson and Matti (1982) have identified 20 areas in which shallow ground water was detected by various water-monitoring agencies. Some of these areas contain shallow ground water only part of the year; other areas

296 Earthquake Hazards in the Los Angeles Region have hydrologic settings in which shallow ground water occurs during much of the year in connection with natural and artificial recharge operations, groundwater barriers, flood-control operations, and other hydrologic basin management practices. Carson and Matti (1982) have given a more comprehensive discussion of the ground-water data used for this reconnaissance.

Figure 151 indicates that the principal areas where liquefaction is likely to occur (if cohesionless granular sediment is present) include:

1. The Santa Ana River channel and parts of the adjacent flood plains, from the San Jacinto fault to Prado Dam.

2. The San Bernardino area, chiefly northeast of the San Jacinto fault and ground-water barrier.

3. Several localities around the margin of the basin adjacent to fault systems that apparently are barriers to the subsurface movement of ground water or localities where impermeable layers may perch water seasonally. These localities include small areas near La Verne, south of Pomona, the Claremont area, the Upland area, the San Antonio wash area, and the San Antonio Canyon alluvial fan shown in the western and northwestern parts of figure 151.

4. In the eastern part of figure 151, where shallow ground water has been reported in the Mentone area, in Lytle Creek Canyon Wash, in an area east of Yucaipa, and in San Timoteo Canyon and the Mill Creek area.

\section{Oxnard Plain Area}

A reconnaissance study of liquefaction susceptibility in the Oxnard Plain area of Ventura County was compiled by using the techniques presented in this chapter, a surficial materials map that identifies areas according to the age and grain size of sediments (McCoy and Sarna-Wojcicki, 1978), and a ground-water map based on historical high ground-water levels (Sprotte and Johnson, 1976).

The Oxnard Plain, which represents the southwestern part of the onshore portion of the Ventura basin, is situated within the Transverse Ranges structural province. The Oxnard Plain is a relatively flat, alluviated area that extends inland from the Santa Barbara Channel shoreline and terminates along the base of South Mountain and the Camarillo Hills on the northeast and the Santa Monica Mountains on the east. The inland margin of the alluviated surface is about $100 \mathrm{ft}$ above sea level. 
The Holocene deposits of the Santa Clara River, Calleguas Creek, and Camarillo Creek are extensive and contain locally abundant, cohesionless granular materials; the uppermost $50 \mathrm{ft}$ of sediment within much of the Oxnard Plain corresponds to the Perched Water Zone of Sprotte and Johnson (1976, p. 227).

\section{Surficial Deposits}

The present and former flood plains of the principal drainage contributing sediment to the Oxnard Plain have been subdivided by McCoy and Sarna-Wojcicki (1978) according to sediment age and grain size; their map is reproduced in figure 152. The surficial deposits consist partly of unconsolidated or loosely consolidated gravelly sand and sand associated with present and former river channels; these cohesionless sediments are interbedded with lenses of silt, clay, and carbonaceous sediments (including peat), which represent deposits formed in flood-basin areas. Near the shoreline, deposits also include lagoonal or estuarine sediment and beach and eolian deposits. The distribution of cohesionless granular deposits in the near subsurface is not known with any degree of certainty except along principal drainages, but stream channels presumably have shifted position many times during the accumulation of late Pleistocene and Holocene deposits in the Oxnard Plain.

Sprotte and Johnson (1976) have compiled maps showing depth to ground water in the Oxnard Plain; the maps are based on the shallowest depth at which ground water has been encountered historically. Thus, the ground-water map presented in figure 153 may represent excessively severe conditions in some areas. However, a comparison of Sprotte and Johnson's (1976) ground-water map with the shallowest depths to ground water measured in wells monitored by the California Department of Water Resources from 1970 to 1975 indicated that ground water commonly was found at depths broadly corresponding to the historical high level indicated by Sprotte and Johnson. In the absence of reliable hydrologic information concerning the uppermost aquifer zone in the Oxnard Plain and the intervals perforated in the monitoring wells, we conservatively use Sprotte and Johnson's (1978) data.

\section{Liquefaction Susceptibility}

A map showing "high-water-level" liquefaction susceptibility in the Oxnard Plain has been compiled according to the criteria in table 43 and is shown in figure 154. Zones having the highest susceptibility coincide with the channels of the Santa Clara River and Calleguas Creek. Liquefaction effects were noted in both drainages following the Point Mugu earthquake of February 21, 1973 (Sprotte and others, 1975, pl. 8). An extensive area of historically high ground water occurs across much of the central Oxnard Plain, especially inland from Port Hueneme and Mugu Lagoon. Where the water table is 15 to $40 \mathrm{ft}$ subsurface, areas are mapped as having moderate susceptibility at the most. Areas of chiefly Pleistocene deposits have low susceptibility to liquefaction.

\section{DETERMINING LIQUEFACTION OPPORTUNITY}

When soils are shaken in the laboratory, the likelihood of liquefaction increases with both the amplitude of applied motion and the duration of that motion. For earthquake ground motion, both amplitude and duration increase as magnitude increases. Hence, soil liquefaction due to strong ground shaking will be strongly influenced by earthquake magnitude.

When a sufficiently large earthquake occurs, liquefaction effects are experienced at sites various distances from the earthquake rupture. The more susceptible sites liquefy at greater distances. The larger the magnitude of the earthquake, the greater the distance at which liquefaction is observed. Figure 155 shows a curve from Youd and Perkins (1978) that estimates, for a given magnitude, the distance beyond which liquefaction is not expected to occur at a highly susceptible site. This curve is based on observations of the farthest distance from a fault rupture at which significant liquefaction has occurred in historical earthquakes. (Liquefaction that produces horizontal movement of $10 \mathrm{~cm}$ or more is considered significant in terms of hazard to ordinary structures.) The role of ground motion and duration is implicit in the curve rather than being mathematically or physically modeled. The curve represents the locus of a threshold such that, if a site is at a distance that lies above the curve, the combination of earthquake ground-motion amplitude and duration is sufficient to cause significant liquefaction, provided that the geologic materials at the site are susceptible to liquefaction. (The liquefaction susceptibilities of some uncompacted artificial fill composed of sand can be higher than those of natural, fluvially deposited sediment; these artificial fills may have blow counts of less than three. Susceptible materials, as used in this chapter, are sand and silt layers of late Holocene origin whose standard penetration resistance is between about 3 and 20). Thus, if a specific site lies within the 


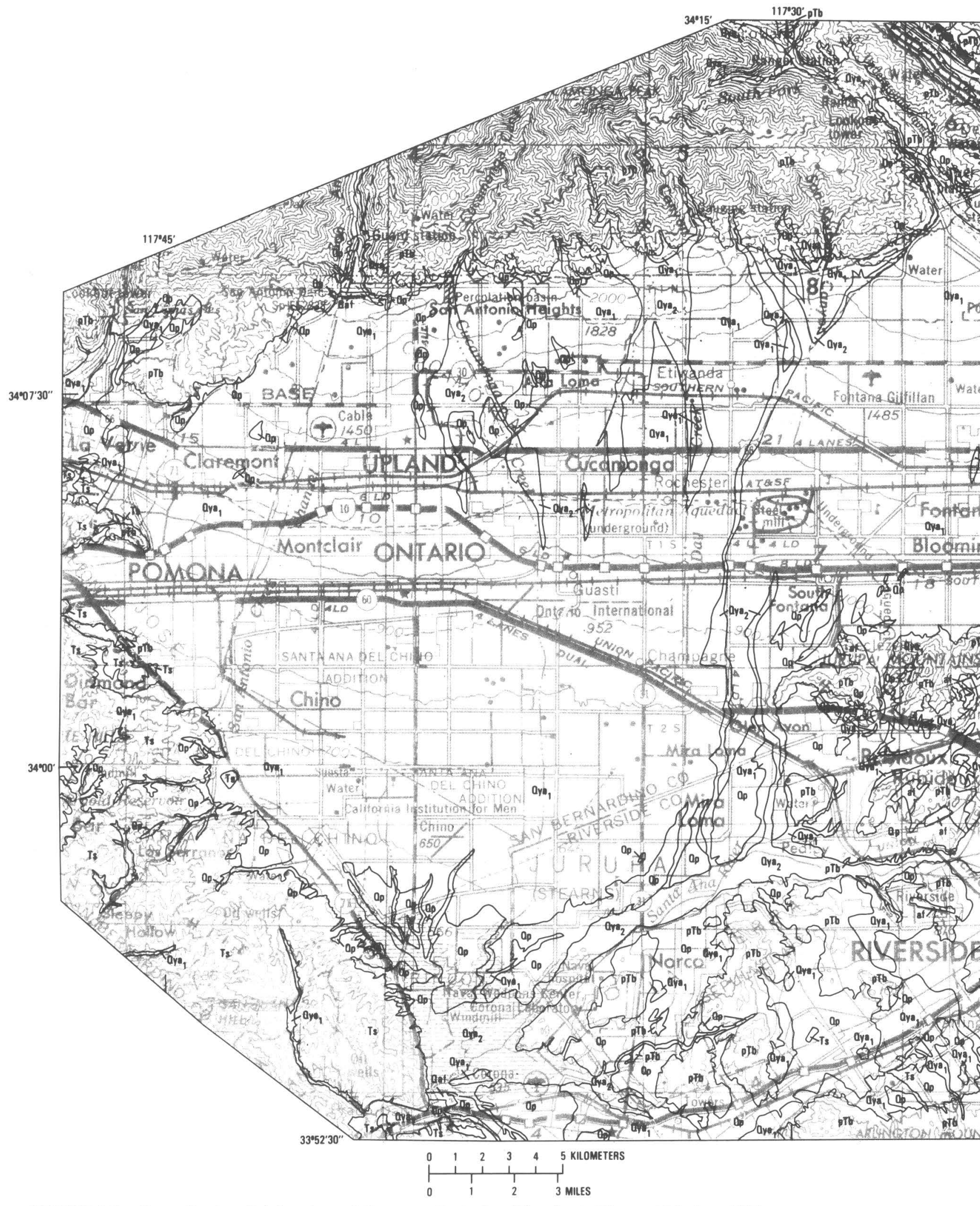

FIGURE 149.-Generalized surficial geology of the upper Santa Ana River basin (Cox and Morton, 1978).

298 Earthquake Hazards in the Los Angeles Region 


\section{EXPLANATION}

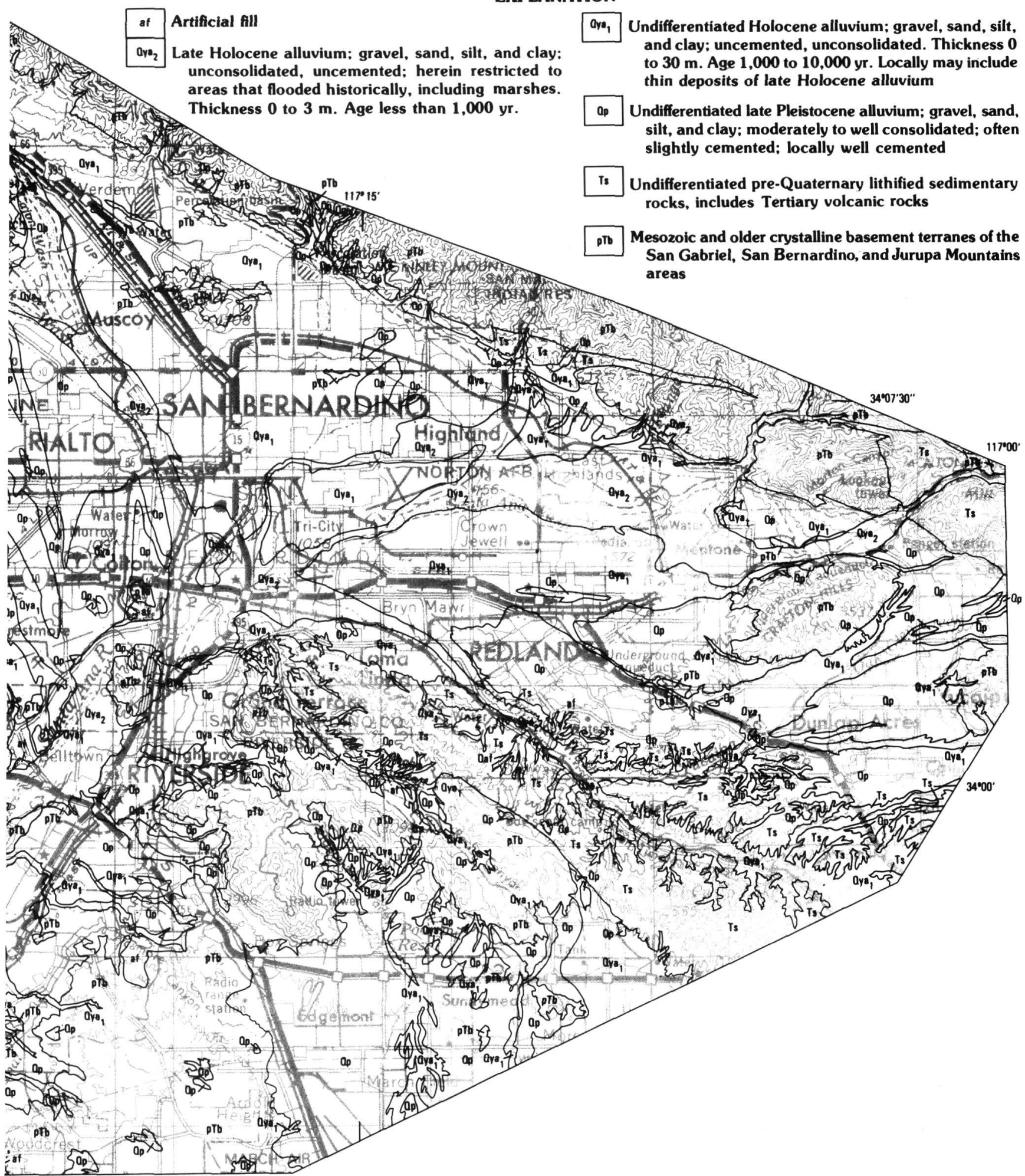

Evaluating Liquefaction Potential 


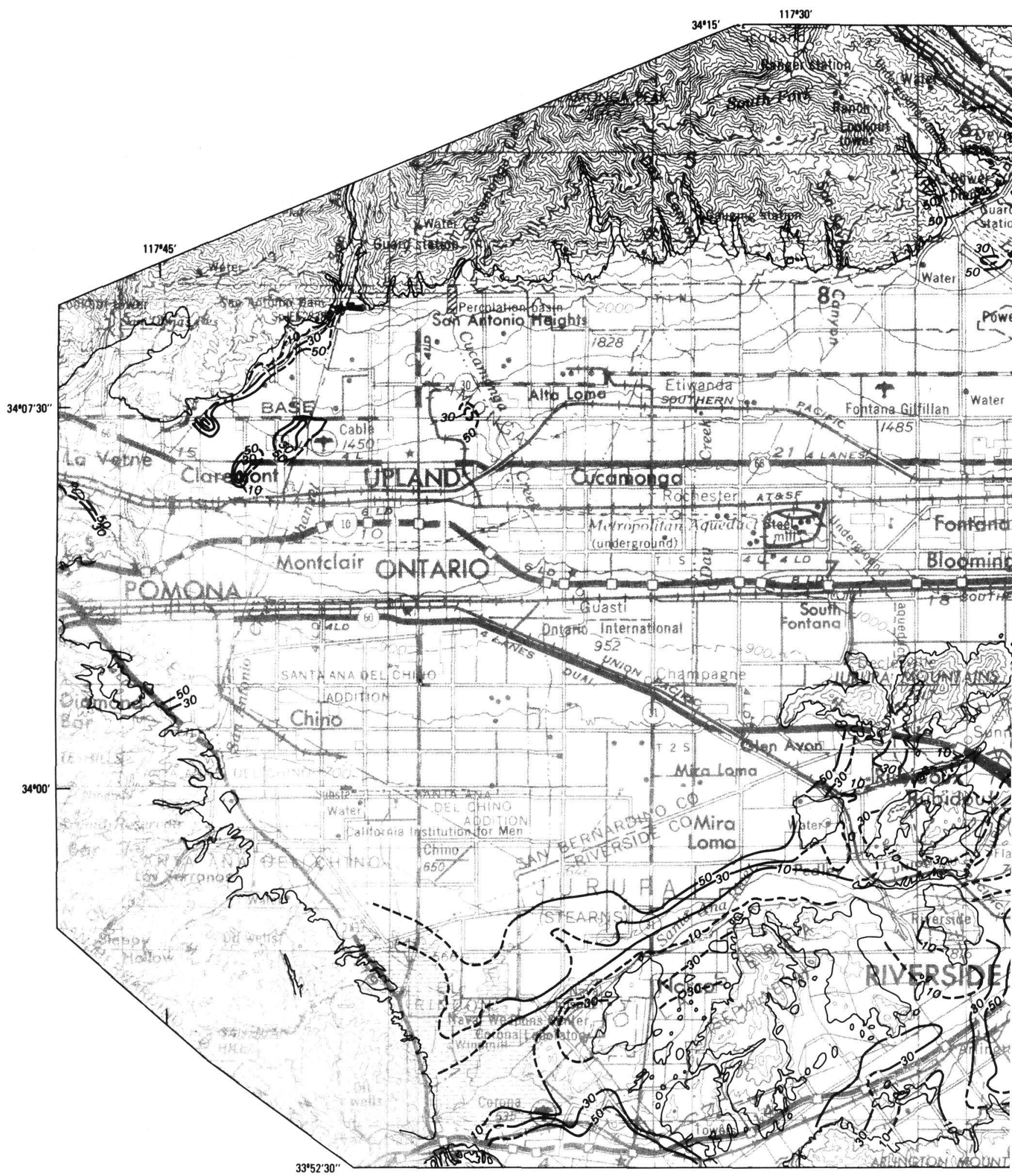

FIGURE 150.-Generalized depth to shallow ground water in the upper Santa Ana River basin (Carson and Matti, 1982). Contours (in feet) are dashed where data are sparse and solid where data are relatively abundant.

300 Earthquake Hazards in the Los Angeles Region 


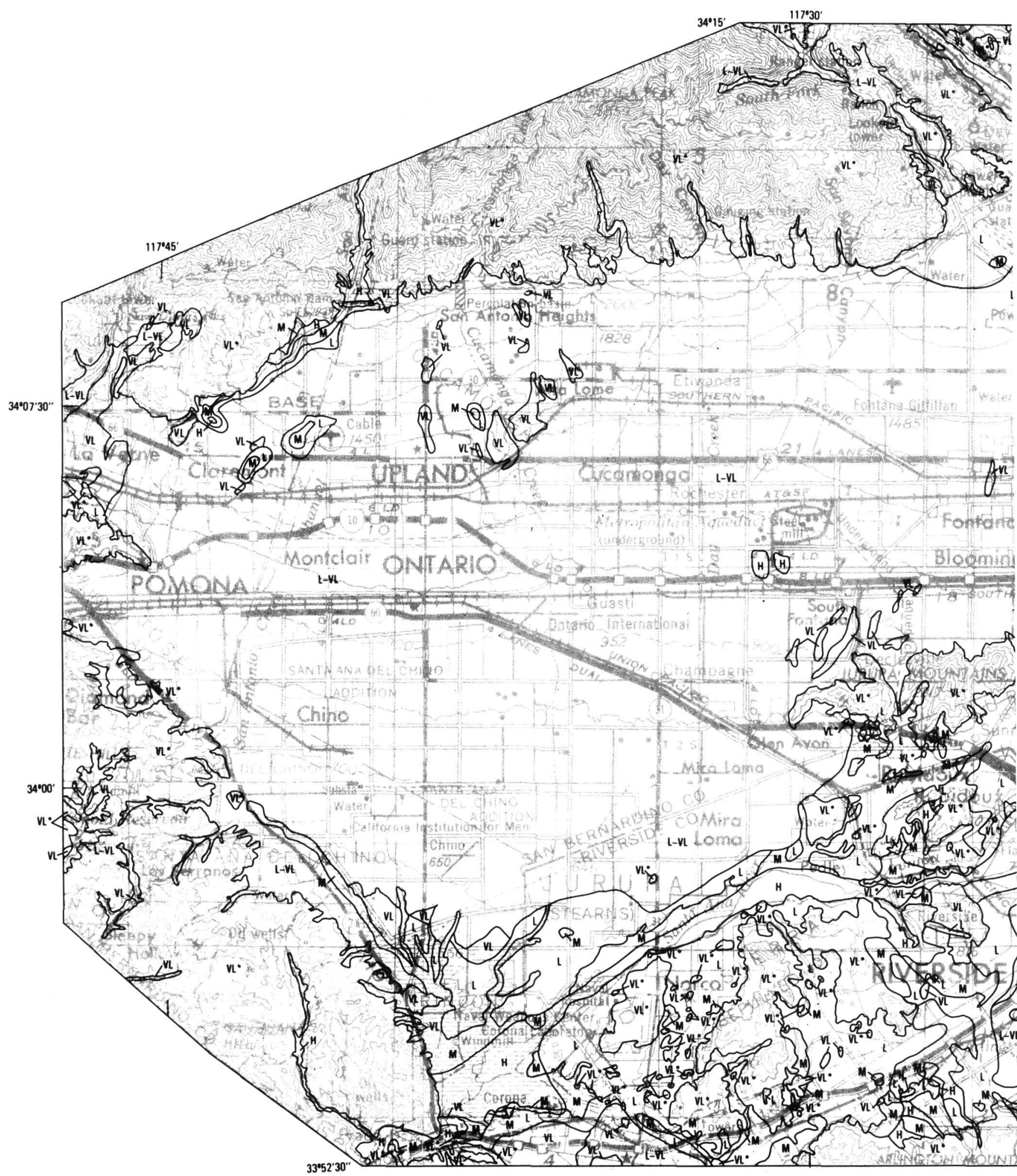

FIGURE 151.-Relative liquefaction susceptibility in the upper Santa Ana River basin. Relative susceptibility to liquefaction-related ground failure is interpreted as a function of the age of the saturated materials and the depth to ground water.

302 Earthquake Hazards in the Los Angeles Region 


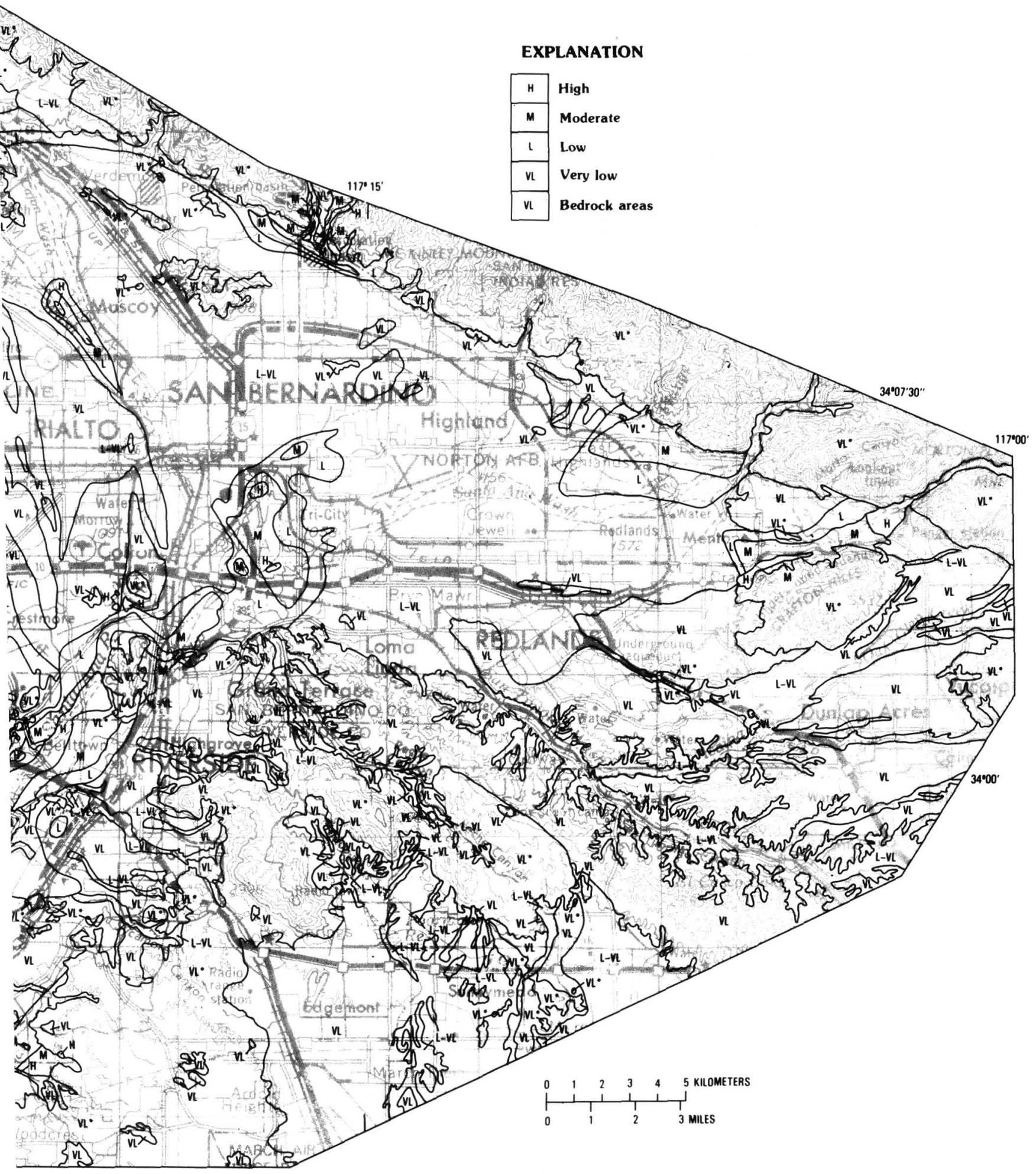

Evaluating Liquefaction Potential 303 


\section{EXPLANATION}

\section{af Artificial fill}

$a_{\text {ya }}$ Late Holocene alluvium; gravel, sand, silt, and clay; unconsolidated, uncemented; herein restricted to areas that flooded historically, including tidal marshes. Thickness 0 to $3 \mathrm{~m}$. Age less than 1,000 yr.

Qya ${ }_{1}$ Undifferentiated Holocene alluvium; gravel, sand, silt, and clay; uncemented, unconsolidated. Thickness 0 to $30 \mathrm{~m}$. Age 1,000 to $10,000 \mathrm{yr}$. Locally may include thin deposits of late Holocene alluvium

Qoa Undifierentiated late Pleistocene alluvium; gravel, sand, silt, and clay: moderately to well consolidated; often slightly cemented; locally well cemented
OTs Undifferentiated middle and early Pleistocene sedimentary rock

Ts Undifferentiated pre-Quaternary lithified sedimentary rocks

Iv Undifferentiated pre-Quaternary volcanic rocks
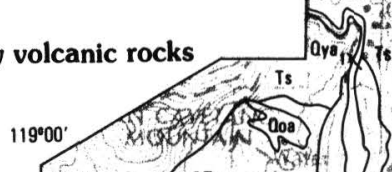

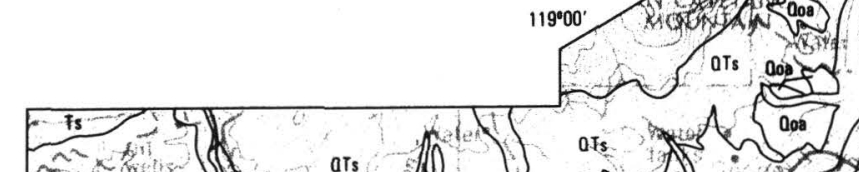




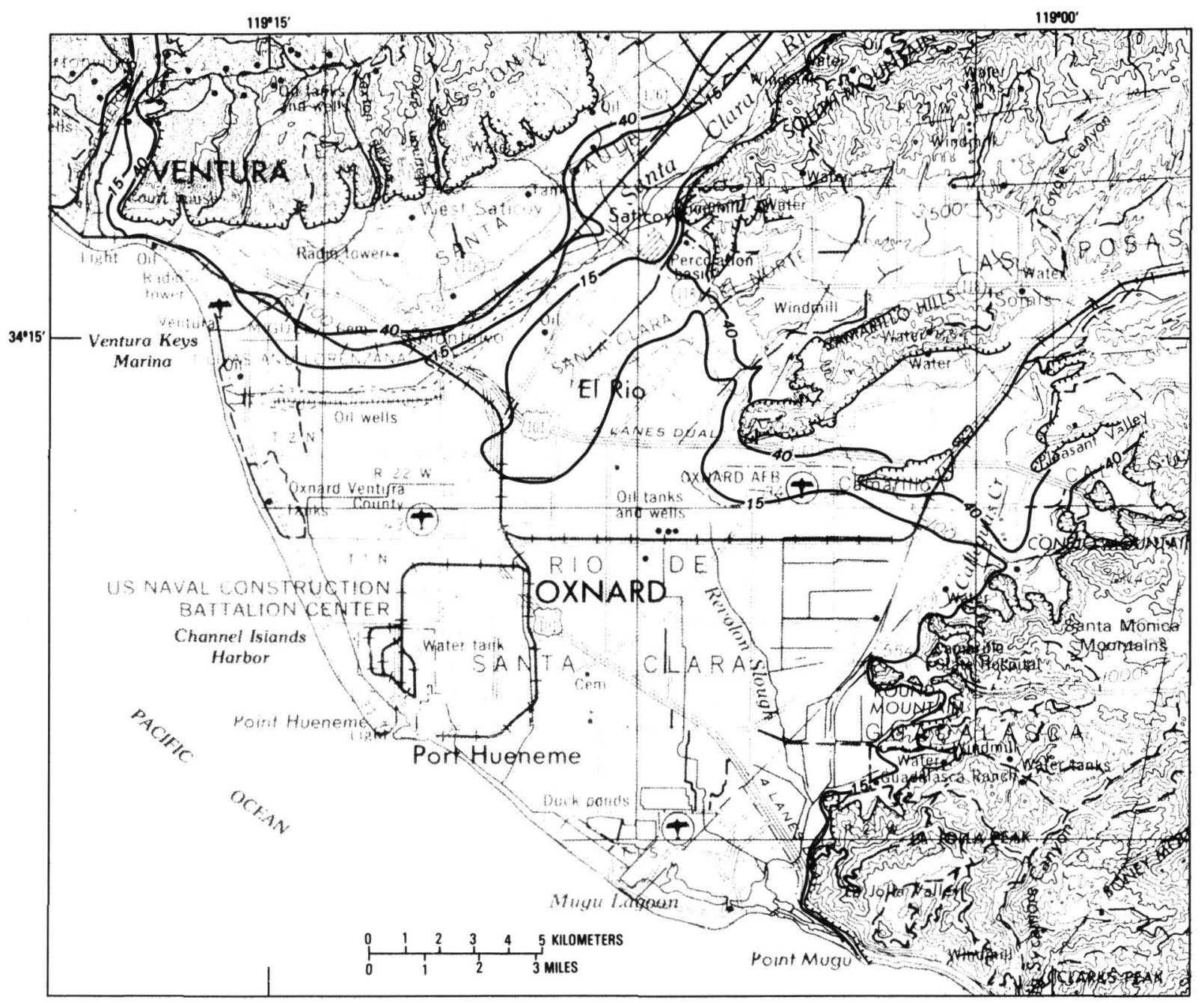

FIGURE 153.-Generalized depth to ground water in the Oxnard Plain of Ventura County. From hydrologic maps compiled by Sprotte and Johnson (1976) and water levels compiled by the California Department of Water Resources between 1970 and 1975. Contours in feet.

threshold distance of an earthquake rupture, that site has an opportunity to liquefy.

For an earthquake-prone region, we can model possible future earthquake locations by using what we call sources. A source may be either a source zone or a source fault. The source zone is a map area over which earthquakes are modeled as point ruptures that are equally likely anywhere in the zone. The source fault is a segmented line on a map over which ruptures of a length appropriate to the earthquake magnitude are equally likely anywhere; source faults may be contained within source zones. In general, the smaller magnitude earthquakes are assumed to occur as points in the source zones, and the larger magnitude earthquakes are assumed to occur as line ruptures on the source faults. The long-term relative rate of occurrence of the various magnitudes possible on those sources can be characterized from the regional seismicity by using a magnitudefrequency relation described by Gutenberg and Richter (1941, p. 102-107) and Richter (1958, p. 359):

$$
\log N=a+b M
$$

where $N$ is the number of shocks of magnitude $M$ or greater per unit time and $a$ and $b$ are constants. Figure 156 shows the source zones used for southern Califor- 


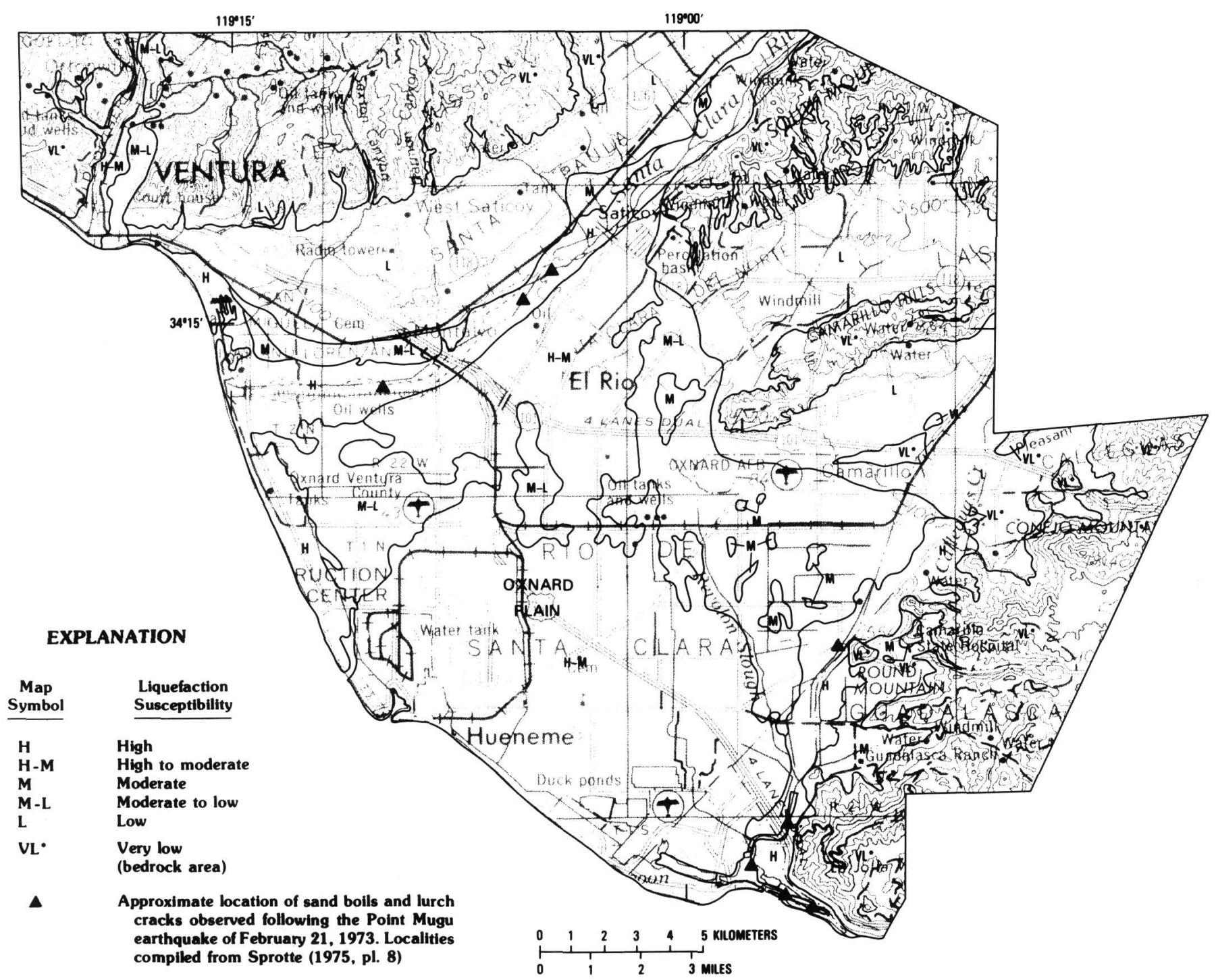

FIGURE 154.-Relative liquefaction susceptibility within the Oxnard Plain of Ventura County. Relative susceptibility to liquefaction-related ground failure is interpreted as a function of the age of the saturated materials and the depth to ground water.

nia, along with stippling to indicate those source zones in which either individual faults or parallel systems of faults were placed.

\section{Examples of Determining Liquefaction Opportunity}

Suppose a site lies within a modeled region. Then it is possible to calculate, by using the threshold locus curve (fig. 155), the fraction of the possible earthquake occurrences on a source for which the site will lie within the threshold distance of an earthquake of a given magnitude in one of the sources. For each source, there is an expected annual rate of occurrence of that magnitude from that source. The product of that annual rate and the fraction of possible occurrences is the annual rate of liquefaction opportunity caused by an earthquake of that magnitude on that source. The calculation can be repeated for all possible magnitudes from that source, and the annual rates of opportunity can be accumulated. If all the sources are independent of one another, we can add together the annual opportunity rates for that site due to each source in the region. The result of this accumulation is the total liquefaction opportunity rate at the site (fig. 157B). Because this rate is usually very much less than 1.0 , it is convenient to talk about it in terms of its inverse, which is called return

\section{Earthquake Hazards in the Los Angeles Region}




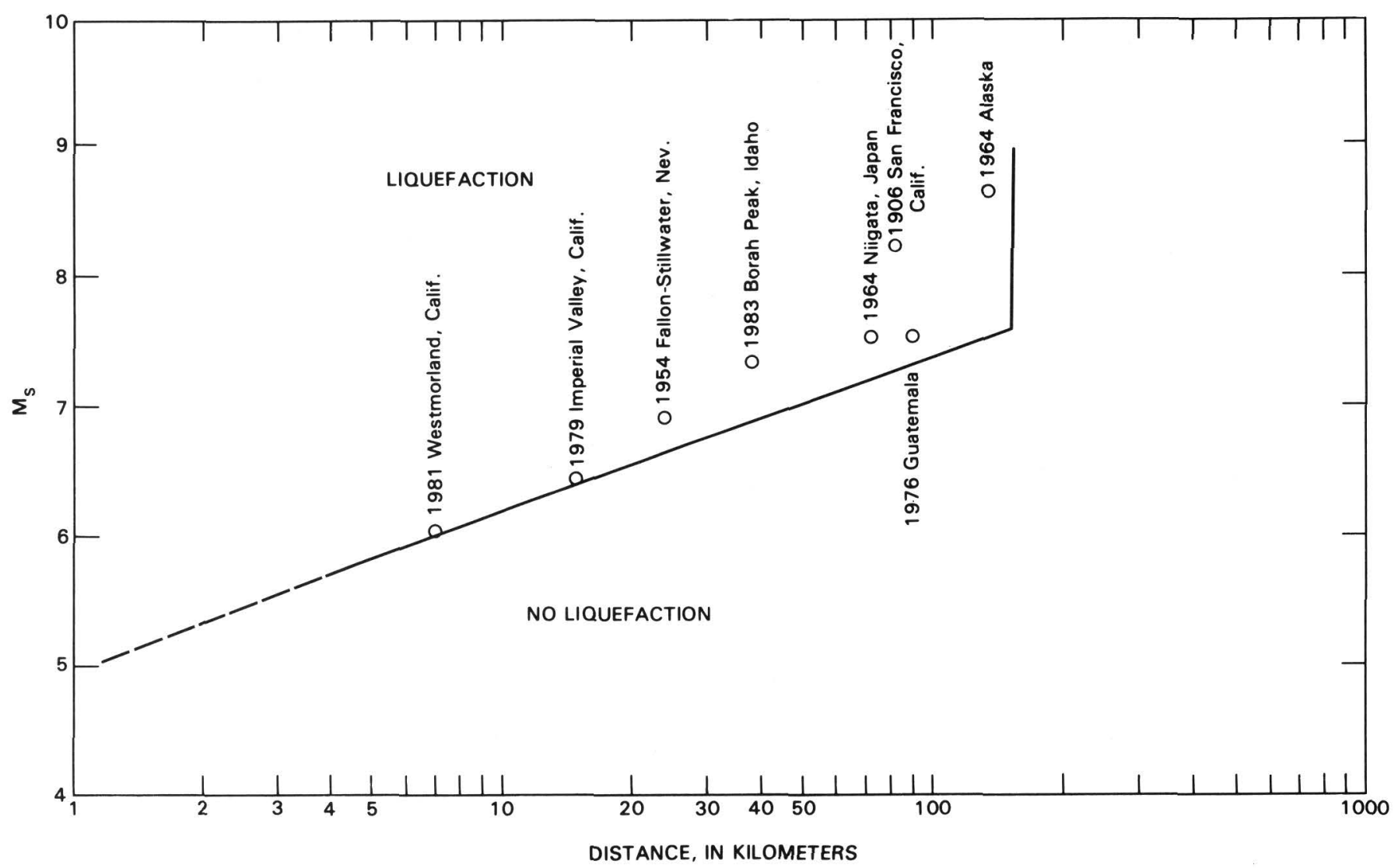

FIGURE 155.-Relation of earthquake magnitude to the maximum threshold distance at which liquefaction has been observed. Based on historical data (Youd and Perkins, 1978; Youd and Wieczorek, 1982).

period (the long-term average number of years between liquefaction opportunities at a site). We provide an example of this calculation in the following paragraphs.

If the threshold model given in figure 155 is assumed to be correct, liquefaction in susceptible materials is possible whenever an earthquake of sufficient size occurs closer than a threshold distance from a site. In calculating liquefaction opportunity, it is important to understand the role played by an earthquake's rupture length in assessing the rate at which a given earthquake occurs within a given threshold distance. Figure 157A shows (1) the interaction between fault length, rupture length, and site location in determining how many earthquakes of a given magnitude might occur at distances less than or equal to a given distance from a fault source and (2) how the analysis differs when a point rupture is assumed instead of a rupture along a line source of earthquakes.

As an example, consider a fault source $150 \mathrm{~km}$ long (fig. 157A). The potential earthquakes are assumed to occur on the fault. Let us now choose two sites, each situated so that a circle having a threshold radius of $50 \mathrm{~km}$ includes one-third of the fault's length. For site A, the circle includes the middle third of the fault; for site $B$, the circle includes the end third of the fault. If potential earthquakes on the fault are represented as point ruptures equally likely anywhere on the fault, the circles around site A and around site B each include one-third of all such potential earthquake occurrences. If the potential earthquakes on the fault are not represented as point ruptures but as linear ruptures having appreciable lengths, however, the results differ depending on the lengths of the ruptures. If the ruptures are small enough, the results do not differ much from the results obtained by using point ruptures. Suppose, however, that an earthquake of sufficient magnitude ruptured the entire 150-km length of the fault. All such ruptures would have part of the rupture segment lying within the circles surrounding each site; hence, all occurrences of earthquakes of this magnitude would contribute to ground motions at distances of $50 \mathrm{~km}$ or less from the sites, even though only one-third of the fault rupture lies within the $50-\mathrm{km}$ radius. Now consider an earthquake such that the expected rupture length is $60 \mathrm{~km}$. These ruptures can occur randomly on the fault, subject to the restriction that the rupture is contained 


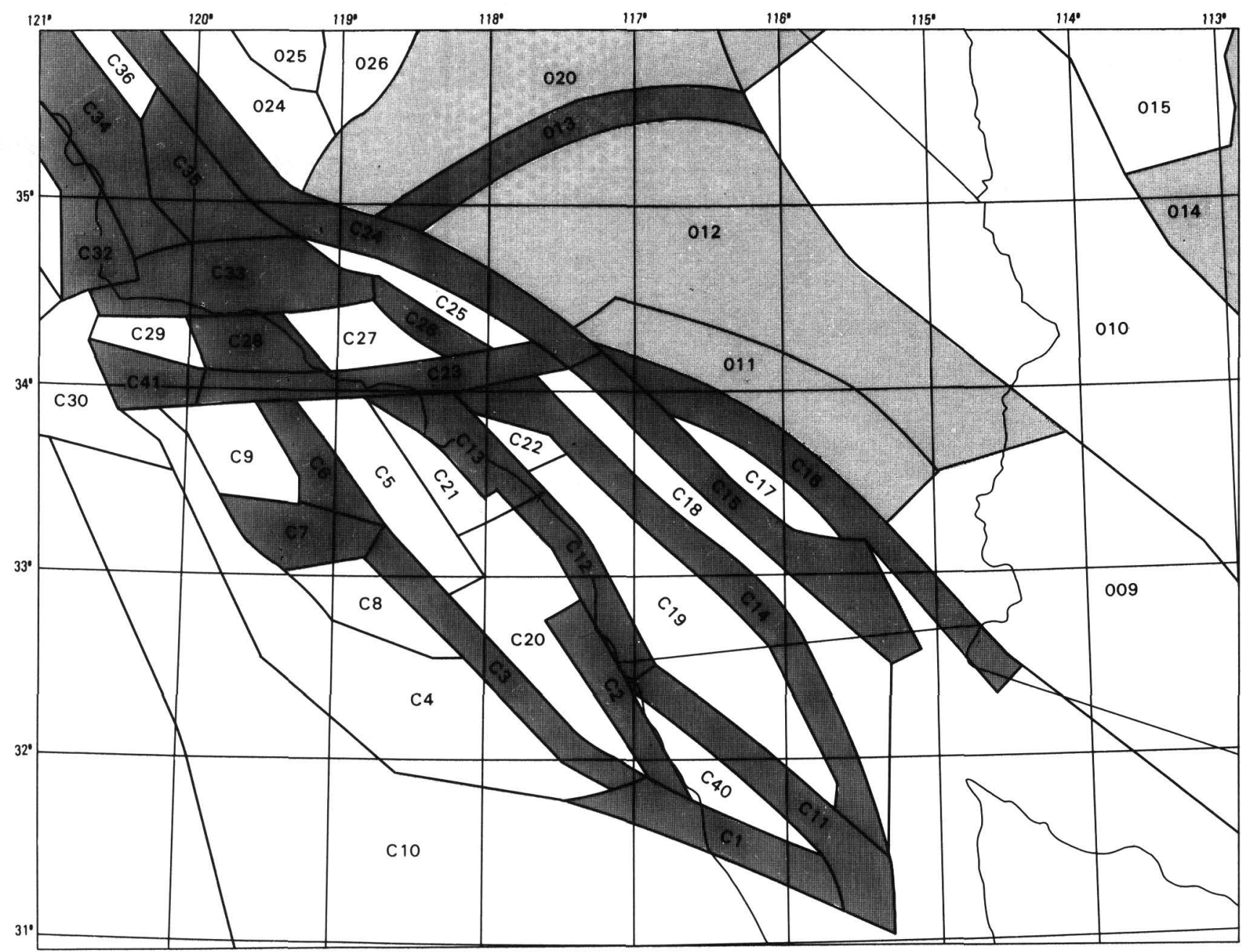

FIGURE 156.-Source zones used in computing liquefaction opportunity for southern California. Zones in which all earthquakes are modeled as point sources are indicated by unstippled areas. Zones in which large-magnitude earthquakes $(\mathbf{M} \geq 5.8)$ are placed on known fault traces and modeled as ruptures whose lengths are dependent on magnitude are indicated by heavy stippling. Zones in which large-magnitude earthquakes are modeled as ruptures on systems of parallel, equally spaced faults are indicated by light stippling. Labels on seismic sources correspond to those used by Thenhaus and others (1980) and Algermissen and others (1982).

entirely within the fault. All such occurrences will produce some part of the rupture within the $50-\mathrm{km}$ circle from site $\mathrm{A}$, because a $60-\mathrm{km}$ rupture on this fault must produce at least $10 \mathrm{~km}$ of rupture within the middle third of the fault. Only 55 percent $(50 / 90)$ of such occurrences will lie within the $50-\mathrm{km}$ circle from site $\mathrm{B}$, because the near end of a $60-\mathrm{km}$ rupture must lie within that $150-60=90 \mathrm{~km}$ of fault nearest site $\mathrm{B}$. Thus, the percentage of the larger magnitude earthquakes that produce ruptures lying within some radius of a site depends on the magnitude of the earthquake, the length of the fault rupture, and the portion of the fault that lies closest to the site.
An idealized example of the calculation of liquefaction opportunity is shown in figure 157B. Three different sites are located with respect to two faults. We assume that only $\boldsymbol{M} 7$ earthquakes occur on fault $\mathrm{AD}$ and that only $\boldsymbol{M} 6$ earthquakes occur on fault EJ; there are no other earthquake sources in this idealized example. On the basis of this model (fig. 155), liquefaction is possible at susceptible sites within $45 \mathrm{~km}$ of a $\boldsymbol{M} 7$ earthquake rupture and at points within $7 \mathrm{~km}$ of a $\boldsymbol{M} 6$ earthquake rupture. Thus, liquefaction is possible at site 1 (fig. $157 B$ ) from fault $A D$ only. Liquefaction is possible at site 2 from both fault $\mathrm{AD}$ and fault EJ. Liquefaction is not possible at site 3 because site 3 is located more than 


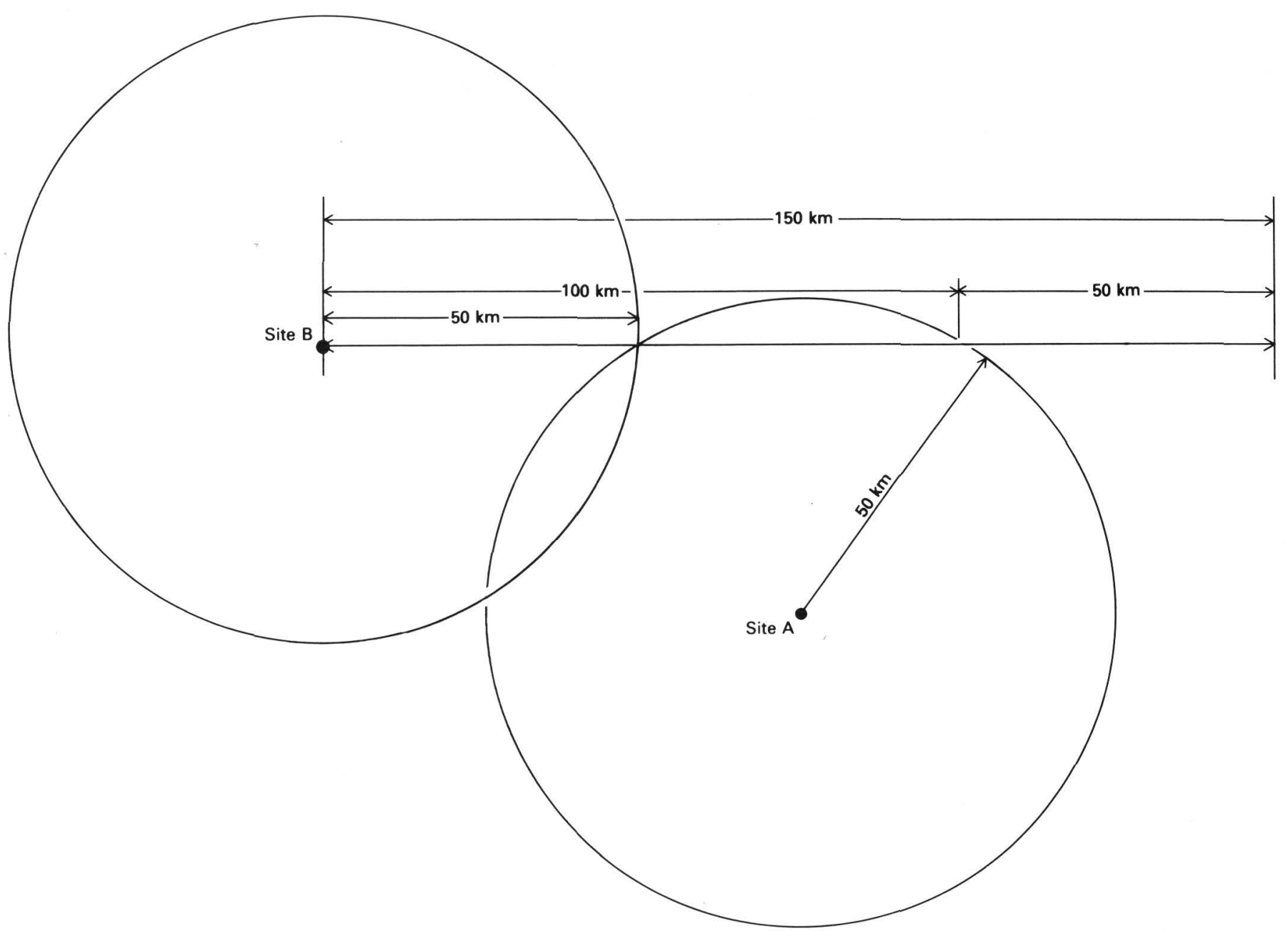

FIGURE 157A.-Effect of assumed rupture length on the number of potential earthquakes occurring within a given distance of a site susceptible to liquefaction. A and B are two sites near a 150-km-long fault; one-third of the fault is contained within $50 \mathrm{~km}$ of each site. For earthquakes treated as point ruptures, one-third of the earthquakes on the fault occur within $50 \mathrm{~km}$ of both site A and site B. For a given magnitude, however, if earthquakes are modeled by ruptures having lengths of $50 \mathrm{~km}$ and the ruptures occur randomly on the fault, part of the rupture of each potential earthquake will be within $50 \mathrm{~km}$ of site A. However, because all 50-km-long ruptures will have a left-hand endpoint within $100 \mathrm{~km}$ of site B, only 50/100 (or half) of the earthquakes will have some part of a rupture within $50 \mathrm{~km}$ of site B.

$45 \mathrm{~km}$ from any potential point of rupture on fault AD and more than $7 \mathrm{~km}$ from any potential point of rupture on fault EJ.

To calculate liquefaction opportunity at sites 1 and 2 (fig. 157B), we must know what percentage of the earthquakes that might occur on the faults will have some part of a rupture close enough to the sites that an earthquake could cause liquefaction in susceptible materials. The discussion of figures $157 C, 157 D$, and $157 E$ illustrates the calculation of these percentages. We assume that $\mathbf{M} 7$ earthquakes occur along fault $\mathrm{AD}$ at an annual rate of 0.02 events per year and that $\boldsymbol{M} 6$ earthquakes occur along fault EJ at an annual rate of 0.01 events per year.
We need a measure of all possible ruptures of a given length that can be placed on a fault trace. To obtain such a measure, we will show that portion of the fault where the right-hand ends of these ruptures may lie. We assume that $M 7$ events have ruptures $32 \mathrm{~km}$ long, a value derived from Bonilla and others (1984, fig. $1 \mathrm{E}$, p. 2392). In figure $157 \mathrm{C}$, the location of the right-hand ends of all $32-\mathrm{km}$ ruptures must lie at or to the right of point $\mathrm{B}$, which is $32 \mathrm{~km}$ from the left-hand end of the fault. All points between C and D on the fault are within $45 \mathrm{~km}$ of site 1 . Hence, any rupture that has a right-hand endpoint between $C$ and $D$ will contain a point located less than $45 \mathrm{~km}$ from site 1 . Therefore, the length of segment $\mathrm{CD}$ divided by the length of segment $\mathrm{BD}$ and 


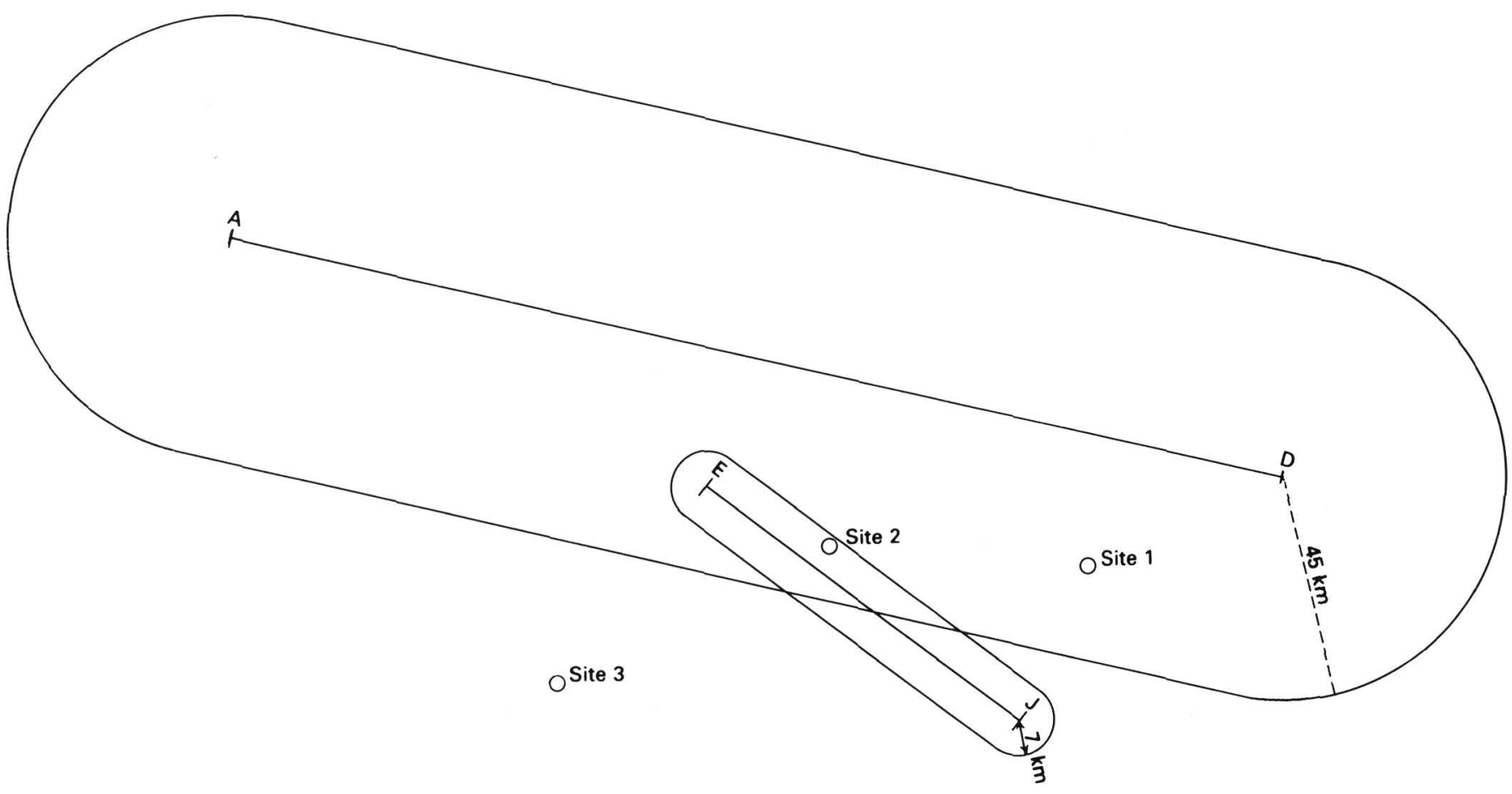

\section{\begin{tabular}{llllll}
0 & 10 & 20 & 30 & 40 & 50 \\
\hline
\end{tabular}}

FIGURE 157B.-Three sites located with respect to two potentially seismogenic faults. Fault AD is assumed to generate only $\mathbf{M} 7$ earthquakes, and fault EJ is assumed to generate only $\mathbf{M} 6$ earthquakes. Liquefaction is assumed to be possible within the threshold distances indicated for the two faults, if highly susceptible sediment is present.

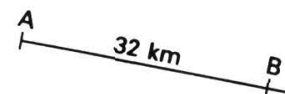

S Site 2

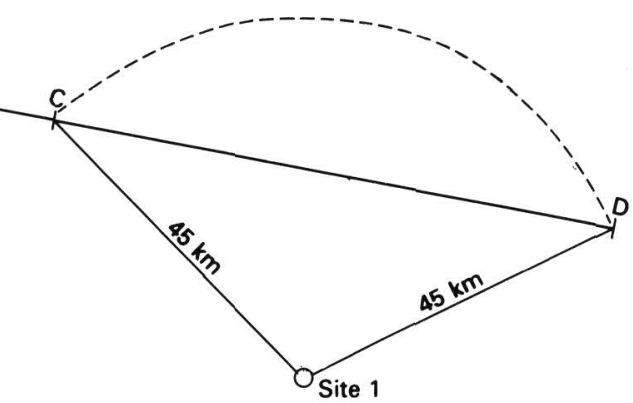

$$
\text { Site } 3
$$

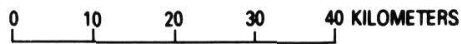

FIGURE 157C.-Determining the percentage of 32-km-long ruptures (M 7) on fault AD that lies within $45 \mathrm{~km}$ of site 1. All $\mathbf{M} 732-\mathrm{km}-\mathrm{long}$ ruptures have right-hand endpoints lying on segment BD. Each rupture having a right-hand endpoint on segment $\mathrm{CD}$ also has a point on that rupture within $45 \mathrm{~km}$ of site 1 .

\section{Earthquake Hazards in the Los Angeles Region}



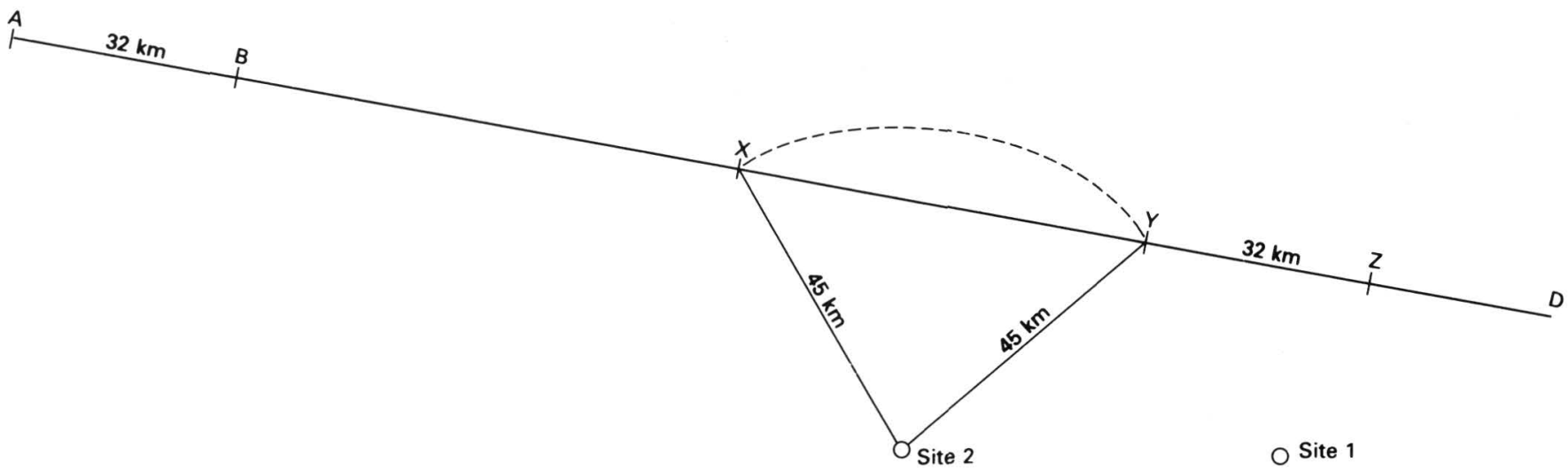

O Site 3

FIGURE 157D.-Determining the percentage of 32-km-long ruptures on fault AD that lies within $45 \mathrm{~km}$ of site 2 . All points on segment XY lie within $45 \mathrm{~km}$ of site 2 . Point $\mathrm{Z}$ is $32 \mathrm{~km}$ to the right of point $\mathrm{Y}$. Each 32-km-long rupture having a right-hand endpoint on segment XZ also has a point on that rupture within $45 \mathrm{~km}$ of site 2 .

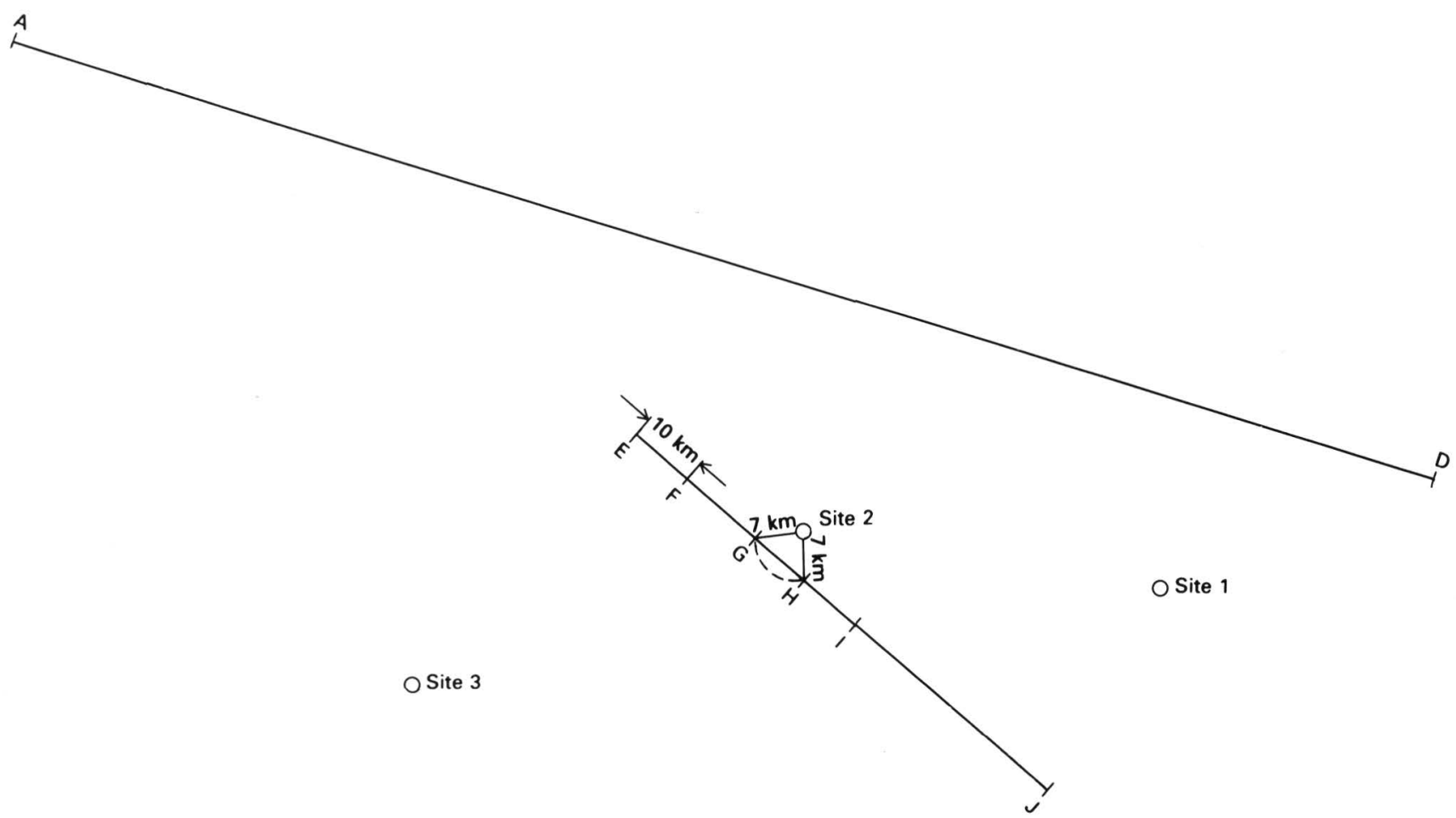

FIGURE 157E.-Determining the percentage of 10-km-long ruptures (M 6) on fault EJ that lies within $7 \mathrm{~km}$ of site 2. All 10-km-long ruptures have right-hand endpoints on segment FJ. All points on segment GH lie within $7 \mathrm{~km}$ of site 2. Point I lies $10 \mathrm{~km}$ to the right of point $\mathrm{H}$. Each rupture having a right-hand endpoint on segment GI also has a point on that rupture within $7 \mathrm{~km}$ of site 2 .

Evaluating Liquefaction Potential 311 
multiplied by 100 is the percentage of all possible $\boldsymbol{M} 7$ earthquakes having a $32-\mathrm{km}$ length of rupture that can cause liquefaction at site 1.

The evaluation for site 2 is somewhat more complicated, both because we must consider contributions from both fault AD (fig. 157D) and fault EJ (fig. 157E) and because it is more difficult to specify the relevant line segment of fault $\mathrm{AD}$. We now consider these hypothetical examples.

All points at or between $\mathrm{X}$ and $\mathrm{Y}$ on fault $\mathrm{AD}$ lie within $45 \mathrm{~km}$ of site 2 (fig. 157D). Any $M 7$ earthquake rupture having a right-hand endpoint at or to the right of $\mathrm{X}$ and a left-hand endpoint at or to the left of $Y$ will contain at least one point that is located within $45 \mathrm{~km}$ of site 2 . Because the $\boldsymbol{M} 7$ ruptures are $32 \mathrm{~km}$ long and because location $\mathrm{Z}$ is $32 \mathrm{~km}$ to the right of $\mathrm{Y}$, all $32-\mathrm{km}$-long earthquake ruptures having right-hand endpoints at or between $\mathrm{X}$ and $\mathrm{Z}$ will contain at least one point on the rupture within $45 \mathrm{~km}$ of site 2 . Thus, the ratio of the length of segment $\mathrm{XZ}$ to the length of segment $\mathrm{BD}$, multiplied by 100 , is the percentage of all possible $M 7$ ruptures that can cause liquefaction at site 2 .

There is also a contribution to liquefaction opportunity from fault EJ at site 2. Figure 157E shows how we determine the percentage of $M 6$ occurrences whose ruptures have some part of a rupture within $7 \mathrm{~km}$ of site 2. The ruptures from $M 6$ earthquakes are assumed to be $10 \mathrm{~km}$ long, on the basis of Bonilla and others' (1984, p. 2392) data. The right-hand edges of all possible $10-\mathrm{km}$ ruptures lie alongside segment FJ. All points along segment GH lie within $7 \mathrm{~km}$ of site 2 . Point I is $10 \mathrm{~km}$ to the right of point $\mathrm{H}$. Therefore, all $\boldsymbol{M} 6$ ruptures having a right-hand endpoint along segment GI will have a part of the rupture within $7 \mathrm{~km}$ of site 2 . The percentage of $\boldsymbol{M} 6$ occurrences that can cause liquefaction at site 2 is given by the ratio of the length of segment GI to the length of segment FJ.

The percentage of $\boldsymbol{M} 7$ events on fault $\mathrm{AD}$ that can cause liquefaction at site 1 (fig. $157 \mathrm{C}$ ) is determined as follows. Fault segment $C D$ is $72 \mathrm{~km}$ long and represents that portion of fault $\mathrm{AD}$ situated less than the threshold distance $(45 \mathrm{~km})$ from site 1 . The length of segment BD represents the percentage of the total fault length that can generate $\boldsymbol{M} \mathbf{7}$ ruptures and is given by the difference between the overall fault length and the rupture length; fault $A D$ is $220 \mathrm{~km}$ long, and $M 7$ events produce ruptures $32 \mathrm{~km}$ long, so $220 \mathrm{~km}-132 \mathrm{~km}=188 \mathrm{~km}$. Thus, the percentage of $M 7$ events on fault $A D$ that can cause liquefaction at site 1 is given by $C D / B D=72 \mathrm{~km} /$ $188 \mathrm{~km}=0.38$ (or 38 percent).

The percentage of $M 7$ events on fault $A D$ that can cause liquefaction at site 2 (fig. 157D) is determined as follows. Fault segment $\mathrm{XZ}$ is $90 \mathrm{~km}$ long and represents the portion of fault AD situated at less than the threshold distance $(45 \mathrm{~km})$ from site 2 . Segment $\mathrm{BD}$ as calculated in the preceding paragraph is $188 \mathrm{~km}$ long. Thus, the percentage of $M 7$ events on fault AD that can cause liquefaction at site 2 is given by $X Z / B D=90 \mathrm{~km} /$ $188 \mathrm{~km}=0.48$ (or 48 percent).

The percentage of $\boldsymbol{M} 6$ events on fault EJ that can cause liquefaction in susceptible materials at site 2 (fig. $157 E$ ) is determined as follows. Fault segment GI is $19 \mathrm{~km}$ long and represents the portion of fault EJ situated at less than threshold distance $(7 \mathrm{~km})$ from site 2 . The length of fault EJ. that can generate 10-km-long ruptures in $\mathbf{M} 6$ earthquakes is given by $\mathrm{FJ}=\mathrm{EJ}-10 \mathrm{~km}=90$ $\mathrm{km}-10 \mathrm{~km}=80 \mathrm{~km}$. Thus, the percentage of $M 6$ events on fault EJ that can cause liquefaction at site 2 is given by $\mathrm{GI} / \mathrm{FJ}=19 \mathrm{~km} / 80 \mathrm{~km}=0.24$ (ог 24 percent).

The annual rate of liquefaction opportunity at site 1 is given by the product of the percentage of $\boldsymbol{M} 7$ events on fault $A D$ causing liquefaction at site 1 and the annual rate of occurrence of $\boldsymbol{M} 7$ events for fault $A D$, assumed to be 0.02 per year. Thus, $(0.38)(0.02)=0.0076$ liquefaction events per year or a return period of $1 / 0.0076=131 \mathrm{yr}$.

The annual rate of liquefaction opportunity at site 2 is given by the sum of the contributions owing to fault $A D$ and fault EJ. The fraction of $\boldsymbol{M} 7$ events from fault $\mathrm{AD}$ causing liquefaction at site 2 multiplied by the annual rate of occurrence of $\boldsymbol{M} 7$ events amounts to $(0.48)(0.02)=0.0096$ liquefaction events per year. The fraction of $M 6$ events from fault EJ causing liquefaction at site 2 multiplied by the annual rate of occurrence of $\boldsymbol{M}$ 6 events on fault EJ, assumed to be 0.01 events per year, amounts to $(0.24)(0.01)=0.0024$ liquefaction events per year. The sum of the annual liquefaction rates at site 2 owing to $M 7$ events and $M 6$ events is equal to $0.0096+0.0024=0.012$ or a return period of $1 / 0.012$ or $83 \mathrm{yr}$.

We have shown the calculation of annual rates and return periods for three sites and a simple model of earthquake recurrence. Calculations for actual sites would involve more complex models. These more sophisticated models would need to characterize activity on a fault by a suite of possible magnitudes assumed for each of a large number of source faults (and source zones) instead of a single earthquake magnitude. Thus, at a site, we would have to accumulate liquefaction opportunity rates due to each magnitude for each source close enough to the site to cause liquefaction. For each magnitude, we would also have to take into account a probabilistic distribution of future rupture lengths rather than just one rupture length. Figure 158 shows such a map for the Los Angeles region; this map uses a complex model discussed earlier in the text, a model for which we have considered, for each fault, not simply a single-magnitude earthquake or rupture length origi-

\section{Earthquake Hazards in the Los Angeles Region}




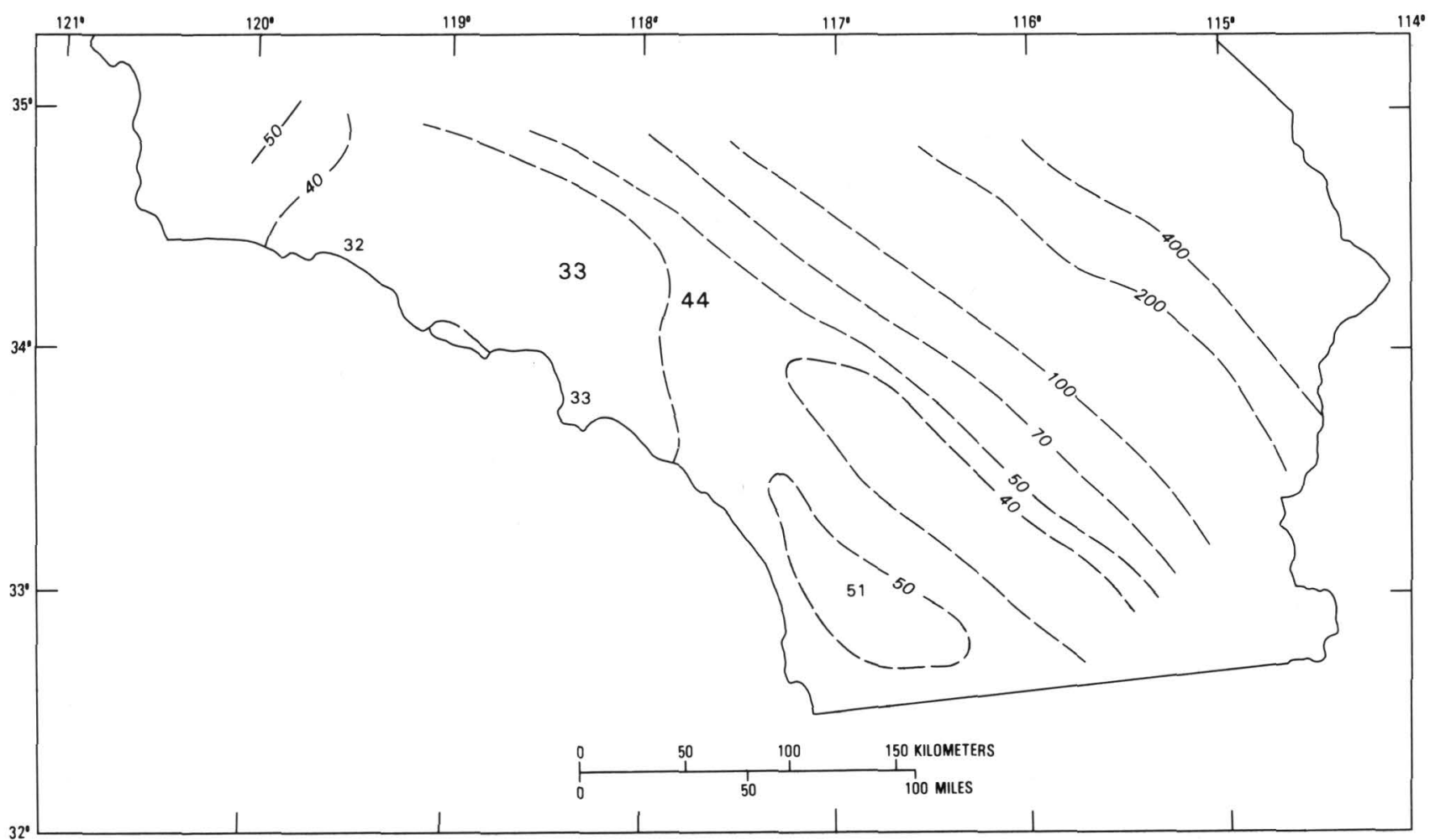

FIGURE 158.-Return period of liquefaction opportunity in southern California. Contours represent the average number of years before an earthquake of $\mathbf{M} 5$ or larger occurs closer to the site than the threshold radius of liquefaction given by the magnitude-distance locus shown in figure 155.

nating from a fault but a suite of possible magnitudes and a suite of possible rupture lengths for each magnitude.

\section{Mapping Liquefaction Opportunity}

If the opportunity calculation is made for a large number of sites in a region and if the resulting return periods are plotted on a map, it is possible to contour the return period of opportunity. We have performed these calculations for the Los Angeles region by using the seismic source zones, faults, and earthquake occurrence rates of Thenhaus and others (1980) and Algermissen and others (1982). The result is shown in figure 158.

Because the radius of the opportunity threshold increases so rapidly as magnitude increases, the liquefaction opportunity map is dominated by those faults that can generate the larger magnitude earthquakes. One might therefore expect that the San Andreas fault would dominate the results in this region, and, certainly, it makes an important contribution. Other active faults in the Los Angeles region that lie closer to most urban sites than the San Andreas does, however, do make significant contributions. Much of the Los Angeles region is within the threshold distance of the lower magnitude events expected on one or more relatively short faults. These lower magnitude events are estimated to occur about as frequently as the higher magnitude events on the San Andreas fault. As a result, the map shows a broad area in which the return period for liquefaction opportunity is about 30 to $50 \mathrm{yr}$.

It must be pointed out that these values refer to the long-term average rate of opportunity at individual sites. If we consider the average rate of damaging earthquakes for the entire Los Angeles region, we would expect shaking strong enough to induce liquefaction to occur several times but at different sites in a 30 - to 50-yr time span, perhaps once every 6 to $8 \mathrm{yr}$ somewhere within the region. Therefore, the values suggest that only one in four or five of these damaging earthquake events will be close enough to produce a liquefaction opportunity at any single site.

The results presented on our map (fig. 158) depend largely on the models used for the source and rate of earthquake occurrences. Because magnitude is so important in estimating liquefaction opportunity, the max- 
imum magnitude assumed for a source fault and the $b$ value of the relation $\log N=a+b M$ (Gutenberg and Richter, 1941), which is assumed here to govern the relative rate of the larger events, significantly influence the calculations. The map also assumes a Poisson distribution of earthquake occurrences through time. Obviously, different models would yield different results.

A Poisson distribution model implies that there is insufficient information to determine changes in earthquake probability for a given source as a function of time. Because of the detailed geologic information on earthquake recurrence being developed for the San Andreas fault (see Ziony and Yerkes, this volume), it may be possible in the future to validate a non-Poissonian model of earthquake occurrence for the larger magnitude events on that fault. For such a model, the largemagnitude earthquakes are less likely to occur in the early years after one such occurrence and are more likely after some longer time has passed. Thus, larger magnitude events may be more likely in the next two or three decades than the Poisson distribution would predict. Therefore, liquefaction opportunity rate would increase considerably (and return period would decrease) for some distance around the San Andreas fault.

Instead of using the Gutenberg-Richter relation for the relative occurrence rates of the various magnitudes, a different model, such as the so-called characteristic earthquake model, might be applied. For this model, above a certain magnitude, only earthquakes of a particular magnitude occur on a fault. In this case, intermediate-magnitude earthquakes may not occur at all along the San Andreas fault; therefore, the liquefaction opportunity rate very near the fault may decrease significantly because of these earthquakes. There would also be a compensating smaller increase in opportunity rate for a greater distance around the fault because of some increase in the likelihood that the larger magnitude characteristic event would occur.

It is also possible that applying slip-rate models to calculate future seismic rates (such as Joyner and Fumal (this volume) propose) on faults may change estimates of the rates of earthquake occurrence for the faults in the Los Angeles metropolitan area. Because the results in this area depend so strongly on the earthquake rates assumed for these faults, the return period for liquefaction in this area would be significantly affected.

Finally, we emphasize that opportunity is a threshold measure. Opportunity tells us only how frequently that threshold is exceeded, not by how much.

\section{Earthquake Hazards in the Los Angeles Region}

\section{LIQUEFACTION POTENTIAL MAPS AND THEIR LIMITATIONS}

Concomitant consideration of the liquefaction susceptibility maps (figs. 133, 135, 138, 140, 143, 145, 148, 151), which show those areas where susceptible materials are likely to occur, and the liquefaction opportunity map (fig. 158), which shows how often threshold severities of ground shaking are likely to impact the region, provides an assessment of the liquefaction potential across the Los Angeles region. The implication is that, every three to four decades, liquefaction-related phenomena are expected to occur at susceptible sites in southern California. Because liquefaction opportunity as presently evaluated does not vary significantly across the Los Angeles region, liquefaction potential is controlled chiefly by differences in liquefaction susceptibility of basin sediment; thus, liquefaction susceptibility maps also serve as liquefaction potential maps.

These studies of liquefaction potential that we have reported are not a substitute for a site-specific evaluation of liquefaction potential. The maps presented in this chapter are small scale and indicate general areas where susceptible materials are likely to be present. Areas shown as having very high, high, or moderate susceptibility are expected to be the loci of liquefaction in future earthquakes, if cohesionless, granular, watersaturated materials are present. Areas designated as having very low or low susceptibility are not expected to incur liquefaction-related ground failures during future earthquakes. Because we cannot guarantee that we have correctly mapped all shallow ground-water occurrences or denoted all occurrences of susceptible sediment, these maps are approximations; they do, however, provide a regional guide to those areas where liquefaction should be considered a potential hazard and where special investigations may be needed to assure the safety of some constructed works.

\section{SUMMARY}

Maps showing liquefaction susceptibility have been compiled for six areas in five basins in the Los Angeles area; for most basins, "low-water-level" and "highwater-level" cases have been mapped. These liquefaction susceptibility maps delineate areas in which any cohesionless granular layers are estimated to have very high, high, moderate, or low susceptibility to liquefaction. The liquefaction susceptibility of cohesionless granular layers is estimated from analyses of lithology, geologic age, depth to ground water, and SPT data. 
Analysis of areal seismicity provides a probabilistic estimate of the average return period (in years) of ground shaking severe enough to cause liquefaction in susceptible materials. Liquefaction potential is greatest where high water level, highly susceptible deposits, and frequent moderate to large (greater than $M$ 5) earthquakes coexist. Within the Los Angeles region, a return period of about 30 to $50 \mathrm{yr}$ is anticipated for ground motions sufficient to exceed the liquefaction threshold at a given susceptible site.

Where the water table is less than $10 \mathrm{ft}$ subsurface, fluvial silt and sand less than 1,000 yr old have very high susceptibility; older Holocene cohesionless deposits have high susceptibility, and Pleistocene cohesionless deposits have low susceptibility. Where the water table is 10 to $30 \mathrm{ft}$ subsurface, Holocene cohesionless deposits are considered to have moderate susceptibility to liquefaction; Pleistocene cohesionless deposits generally have low susceptibility to liquefaction. Liquefaction is not likely to occur in any material when depth to ground water exceeds $30 \mathrm{ft}$. The susceptibility depends critically on depth to ground water, a parameter that may change abruptly in response to land use, ground-water recharge operations, patterns of ground-water extraction, or abnormal yearly precipitation.

The maps do not delineate the type of ground failure that may occur. Lateral spreading has occurred on very gently sloping alluvial plains in southern California in past earthquakes; that mode of failure is likely to occur during future moderate to great earthquakes.

These maps are small-scale, highly generalized models derived from widely scattered data; data in some wellexplored areas are generalized and applied to entire map units in some instances. Thus, the maps are not a substitute for detailed studies of liquefaction potential at any particular site. Rather, the maps should serve their intended purpose of broadly delineating areas where the likelihood of earthquake-generated ground failure is greatest and where special consideration may be desirable. 


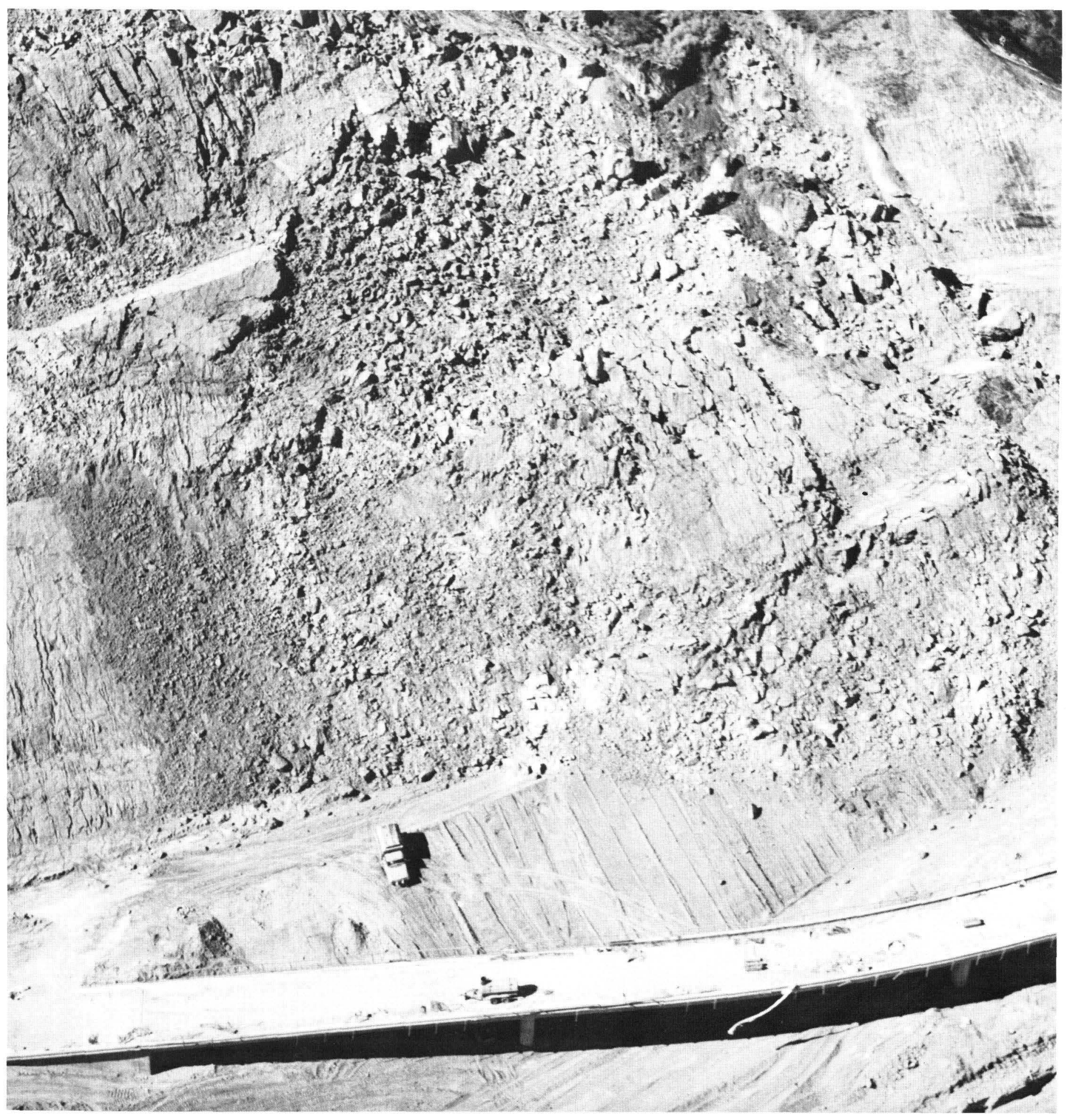

316 Earthquake Hazards in the Los Angeles Region 


\title{
PREDICTING AREAL LIMITS OF EARTHQUAKE-INDUCED LANDSLIDING
}

\author{
By R. C. Wilson and D. K. Keefer
}

\section{INTRODUCTION}

Just as manmade structures can be damaged or destroyed by severe shaking from an earthquake, so, too, can natural slopes weaken and fail (figs. 159-163). The resulting landslides can undermine buildings and thereby cause severe foundation damage or collapse. Landslides can overrun people and structures, block roads, and sever lifelines such as water pipes, power lines, or gas mains. Roads blocked by landslides can isolate communities and disrupt rescue and relief operations. Because a large earthquake in a mountainous region can generate thousands of landslides in a few minutes, the overall impact on the population is thus increased far beyond that of any single landslide.

Earthquake-induced landslides have caused tens of thousands of deaths and billions of dollars in losses worldwide in this century; in many earthquakes, the resulting landslides have caused as much or more damage than the other effects of seismic shaking. The great 1964 Alaska earthquake, for example, caused an estimated 1.2 billion 1984 dollars in damage; 0.67 billion 1984 dollars (56 percent of the total) was due to landslides (W. R. Hansen, oral communication, 1977; Reuben Kachadoorian, oral communication, 1977; T. L. Youd, oral communication, 1977). Landslides also caused at least 48 of the 130 deaths reported in this earthquake (Keefer, 1984b). In a study of large $(M>6.9)$ Japanese earthquakes since 1964, Kobayashi (1981) determined that more than half of all earthquake-related deaths were caused by landslides. In several other foreign earthquakes, where particularly hazardous conditions were present, landslides have caused thousands of deaths. The most catastrophic of these landslides was a rock avalanche in the Peruvian Andes, which was triggered by an earthquake in 1970 . This rock avalanche buried two cities and several villages and killed at least 18,000 people (Plafker and others, 1971).

The Los Angeles region, because of its mountainous terrain and seismic activity, faces a potential hazard from earthquake-induced landslides. The topographic, geologic, and seismologic conditions of some areas are nearly optimum for producing earthquake-induced landslides, and a large population lives on steep hillsides and along deep, narrow canyons. This combination of steep slopes and relatively dense population is most significant in the eastern Santa Monica Mountains, but other upland areas at risk include the Baldwin, Puente, Palos Verdes, and San Rafael Hills, the canyons in the Verdugo Mountains, and the foothills of the San Gabriel, Santa Ana, and San Bernardino Mountains. In addition, earthquake-induced lateral-spread landslides can originate on or move down gentle slopes $\left(<1^{\circ}\right.$ in some cases), so that areas of gently sloping to near-level ground underlain by saturated sandy materials may also be at risk. During the 1971 San Fernando earthquake (M 6.6), landslides caused 135 million 1984 dollars in damage to buildings, utilities, highways, and dams (Kachadoorian, 1971; Youd, 1971; California Division of Highways, 1975); one landslide on the Lower Van Norman Dam resulted in the temporary evacuation, of 80,000 people. The San Fernando earthquake was centered in the relatively sparsely populated foothills of the San Gabriel Mountains, but a future large earthquake located closer to population centers could cause hundreds of millions of dollars in damage and numerous casualties from landslides alone.

This chapter describes a new method for predicting the areal limits of various types of landslides triggered by earthquakes such as those that could occur in the Los Angeles region. The method is based both on studies of landslides in historical earthquakes and on a numerical analysis of dynamic slope stability. The first section of this chapter describes the characteristics of earthquake-induced landslides and the observed relations between earthquake magnitude and areal extent of landslides. The second section briefly describes known landslides that have occurred in representative California earthquakes. Then, the dynamic slope stabil- 


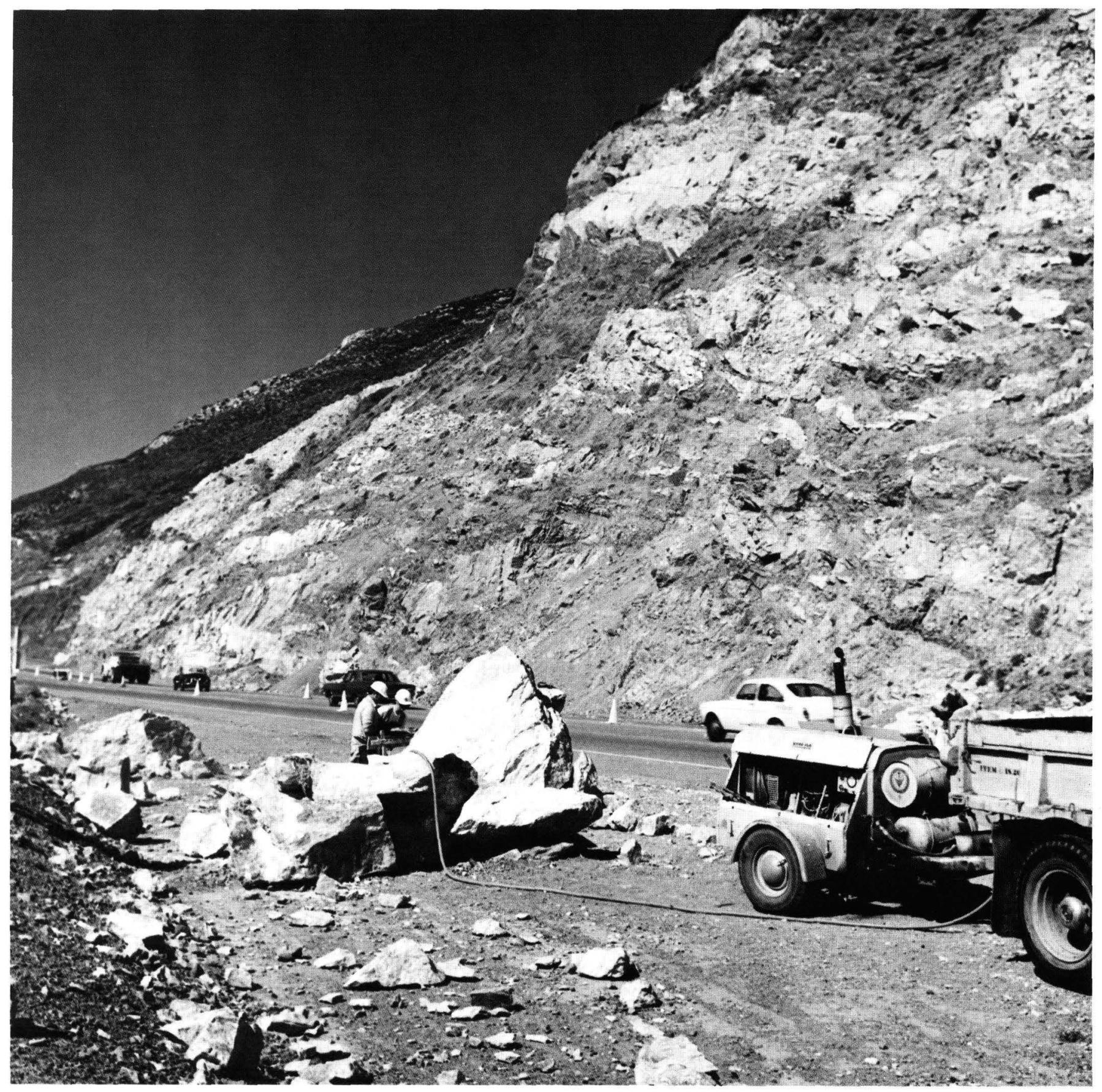

FIGURE 159.-Rock falls along the Pacific Coast highway caused by the 1973 Point Mugu earthquake. Rock falls-individual boulders or disrupted masses of rock that descend slopes by bounding, rolling, or free falling-are the most abundant landslides (table 45) and the third leading cause of landslide-related deaths in historical earthquakes.

ity analysis that links slope failure with levels of ground motion is discussed; a discussion of the severity of ground motion as a function of earthquake magnitude and distance follows. Relations are next developed for predicting the areal limits of ground motion sufficient to trigger landslides of various types, and maps are pre- sented showing the distribution of landslides predicted from a postulated $\boldsymbol{M} 6.5$ earthquake on the NewportInglewood fault system. Finally, the relations between slope stability and shaking severity are illustrated by a hypothetical site evaluation for the postulated $M 6.5$ event.

\section{Earthquake Hazards in the Los Angeles Region}




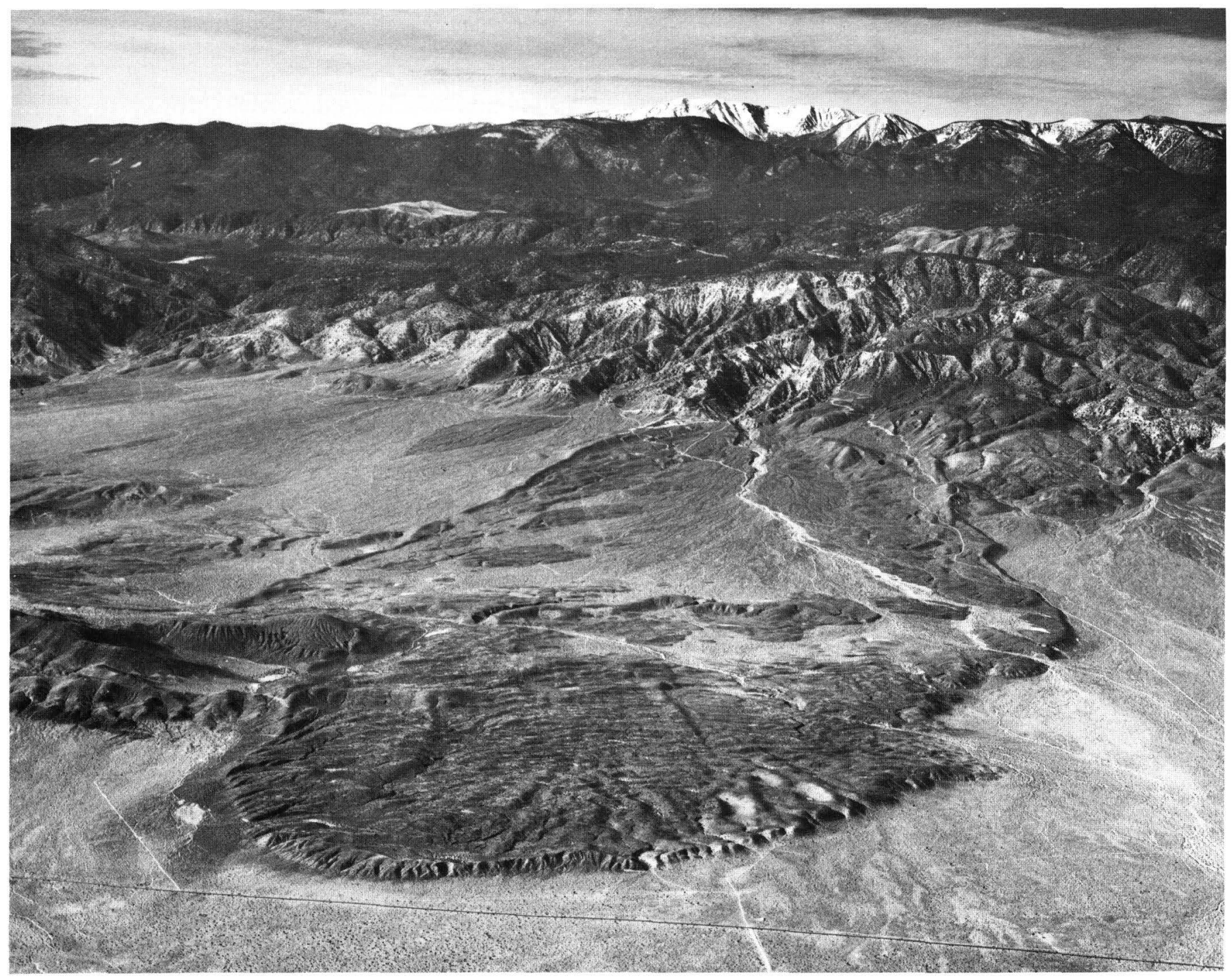

FIGURE 160.-Oblique aerial view of the prehistoric Blackhawk rock avalanche in the Lucerne Valley north of the San Bernardino Mountains. This rock-avalanche deposit contains about 300 million cubic meters of material; the maximum width of the lobe is $3 \mathrm{~km}$, and the height of the raised distal rim is about $15 \mathrm{~m}$. The triggering mechanism of this prehistoric landslide is uncertain, but it may have been an earthquake. (Photograph by J. S. Shelton; published with permission.)

\section{LANDSLIDES IN HISTORICAL EARTHQUAKES WORLDWIDE}

A recent study of worldwide data from historical earthquakes (Keefer and others, 1978; Keefer and Tannaci, 1981; Keefer, 1984a, b) shows that there are constraints on the types and distribution of landslides in seismic events. Following the principles of Varnes (1978), we classified earthquake-induced landslides primarily by material type and character of movement and secondarily by other attributes such as degree of internal disruption and degree of saturation. Material was classified as "rock" or "soil" on the basis of its state before landslide initiation. "Rock" signifies firm, intact bedrock. "Soil" signifies a loose, unconsolidated, or poorly cemented aggregate of particles that may or may not contain organic material. Many earthquakeinduced landslides are complex and involve two or more modes of movement and both rock and soil material; these landslides were classified according to the predominant mode of movement and material.

Fourteen types of landslides were identified from historical earthquakes (Keefer, 1984b); most or all of them could occur in certain geologic environments in the 


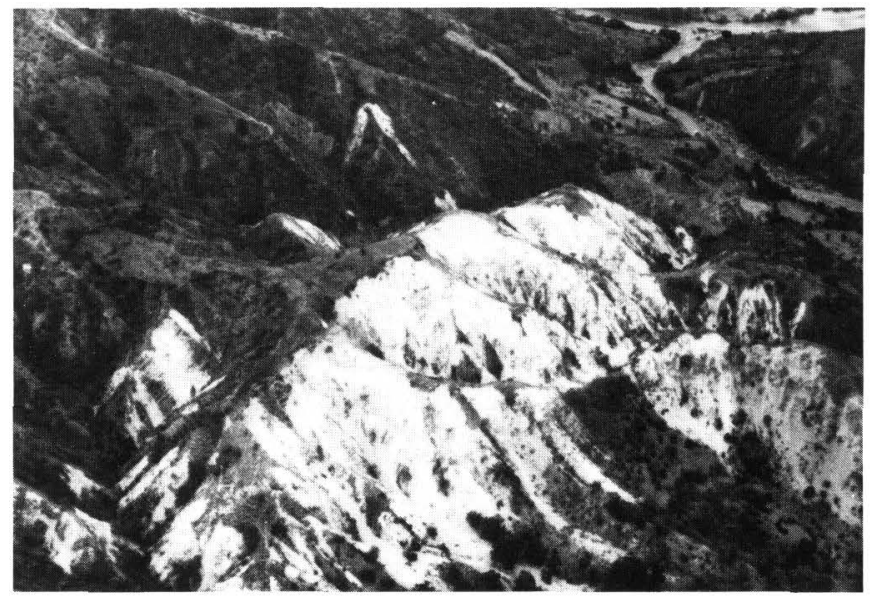

FIGURE 161.-Aerial view of coalescing disrupted soil slides caused by the 1976 Guatemala earthquake. Slides stripped away vegetation and sheets of sandy residual soil, generally less than $0.6 \mathrm{~m}$ thick, exposing white pumice bedrock. Slopes in the foreground are approximately $30 \mathrm{~m}$ high. Disrupted soil slides are chaotic jumbles of small blocks and soil grains that slide on planar or gently curved basal shear surfaces formed at soil-bedrock contacts or at boundaries between different soil layers. Hundreds of similar landslides in loose silty and sandy soils were triggered by the 1971 San Fernando earthquake. (Photograph taken from Harp and others (1981).)

Los Angeles region. The fourteen types of landslides were grouped into three major categories-disrupted slides and falls, coherent slides, and lateral spreads and flows-on the basis of distinctions in movement, internal disruption, and geologic environments (table 44). Disrupted slides and falls (rock falls, rock slides, rock avalanches, soil falls, disrupted soil slides, and soil avalanches) are broken during movement into chaotic masses of small blocks, rock fragments, or individual soil grains. With the exception of rock avalanches, these landslides are generally shallow. They are detached from steep slopes and move at moderate to extremely rapid velocities (table 44). Coherent slides (rock slumps, rock block slides, soil slumps, soil block slides, and slow earth flows) are generally deeper seated and consist of a few relatively coherent blocks that slide at slow to very rapid velocities on moderate to steep slopes (table 44). Lateral spreads and flows (soil lateral spreads, rapid soil flows, and subaqueous landslides ${ }^{5}$ ) involve some component of fluidlike flow. They move at rapid to extremely rapid velocities, commonly on gentle slopes. Several of these types of landslides are illustrated in figures 159 to 163 .

${ }^{5}$ Earthquake-induced subaqueous landslides are commonly complex, involving components of slumping, block sliding, lateral spreading, and (or) flow. They are grouped with lateral spreads and rapid flows, because most exhibit some component of fluidlike movement.
The most abundant landslides in the historical earthquakes studied by Keefer (1984b) were rock falls, disrupted soil slides, and rock slides (see list, this page), all of which are shallow, internally disrupted, and detached from steep slopes (table 44). All these types of landslides are likely to be abundant in moderate or large earthquakes in the Los Angeles region. Reports of subaqueous landslides, slow earth flows, rock block slides, and rock avalanches were rare in the historical earthquakes (see list, this page). The apparent rarity of subaqueous landslides is due partly to difficulties in observation. The reported numbers of the other three types, however, are probably good approximations of their actual numbers. In contrast to the worldwide record, rock slumps and block slides were relatively common in the 1971 San Fernando earthquake and probably would be abundant in future earthquakes in the Los Angeles region as well.

The hazards presented by earthquake-induced landslides depend on their potential abundance, their movement characteristics, and the distribution of population and constructed works relative to likely sources of landslides. Although all types of earthquake-induced landslides pose some hazard to life, at least 90 percent of the landslide-caused deaths in the historical earthquakes studied resulted from rock avalanches, rapid soil flows, and rock falls (Keefer, 1984b).

Rock avalanches and rapid soil flows, the two leading causes of death, are similar in that they can travel several kilometers at high velocities on slopes as gentle as a few degrees. Most deaths caused by these landslides resulted from burial of cities or towns on gently

\footnotetext{
Relative abundances of earthquake-induced landslides in $\mathbf{4 0}$ historical earthquakes worldwide

[Landslide type listed in order of decreasing total numbers. From Keefer (1984b)]

Very abundant $(>100,000)$ :

Rock falls

Disrupted soil slides

Rock slides

Abundant $(10,000$ to 100,000$)$ :

Soil lateral spreads

Soil slumps

Soil block slides

Soil avalanches

Moderately common $(1,000$ to 10,000$)$ :

Soil falls

Rapid soil flows

Rock slumps

Uncommon (100 to 1,000$)$ :

Subaqueous landslides

Slow earth flows

Rock block slides

Rock avalanches
} 


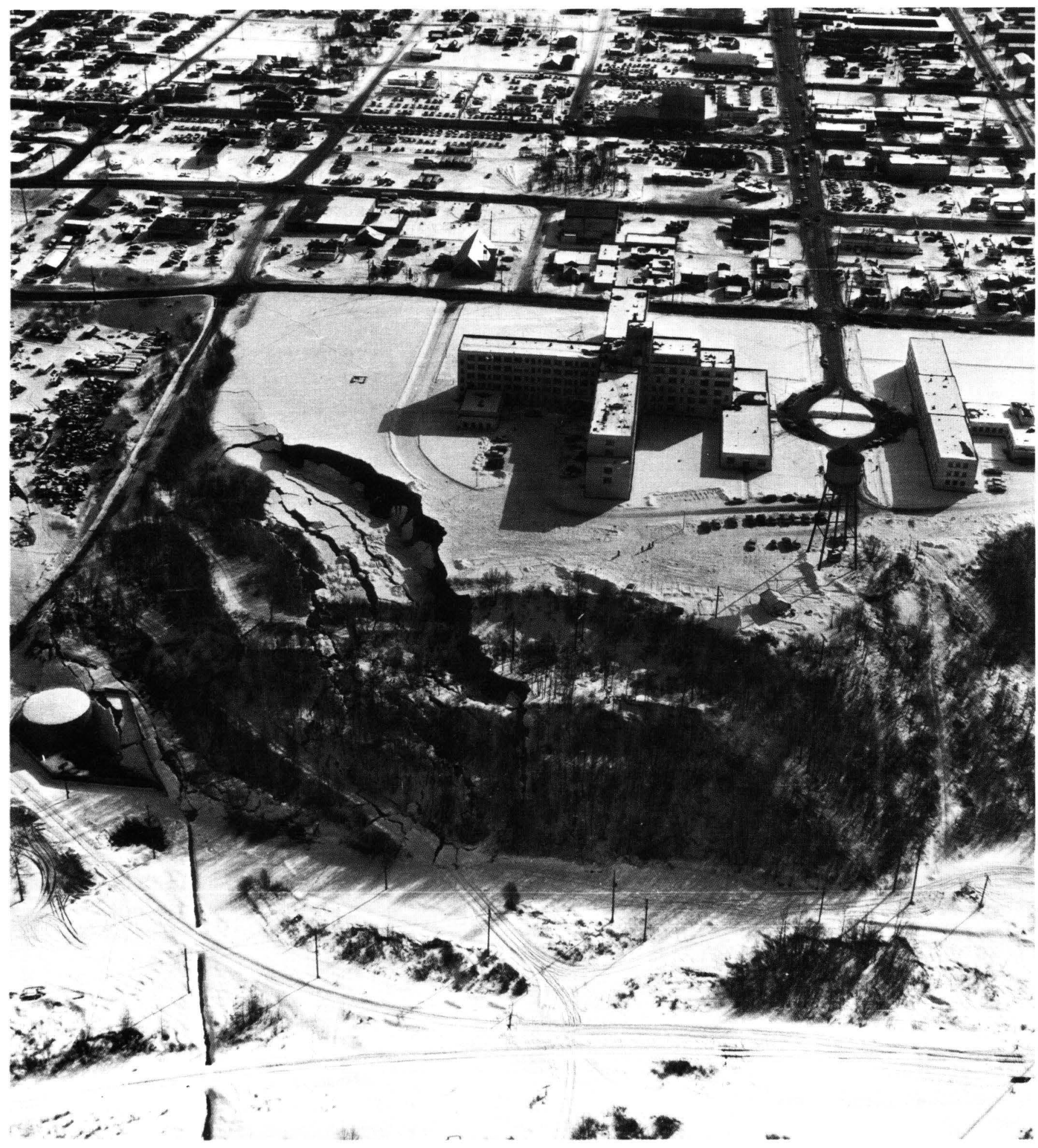

FIGURE 162.-Aerial view of the Native Hospital slide, a large soil block slide in Anchorage, Alaska, caused by the 1964 earthquake. Soil block slides consist of one or a few coherent blocks that slide in a translational manner, exhibiting little or no rotation. Most have grabens at their heads and pressure ridges at their toes. Similar landslides, in somewhat different geologic environments, have been triggered by several southern California earthquakes, including the 1940 Imperial Valley, the 1952 Kern County, the 1966 Parkfield, and the 1971 San Fernando. (Photograph courtesy of U.S. Army.) 


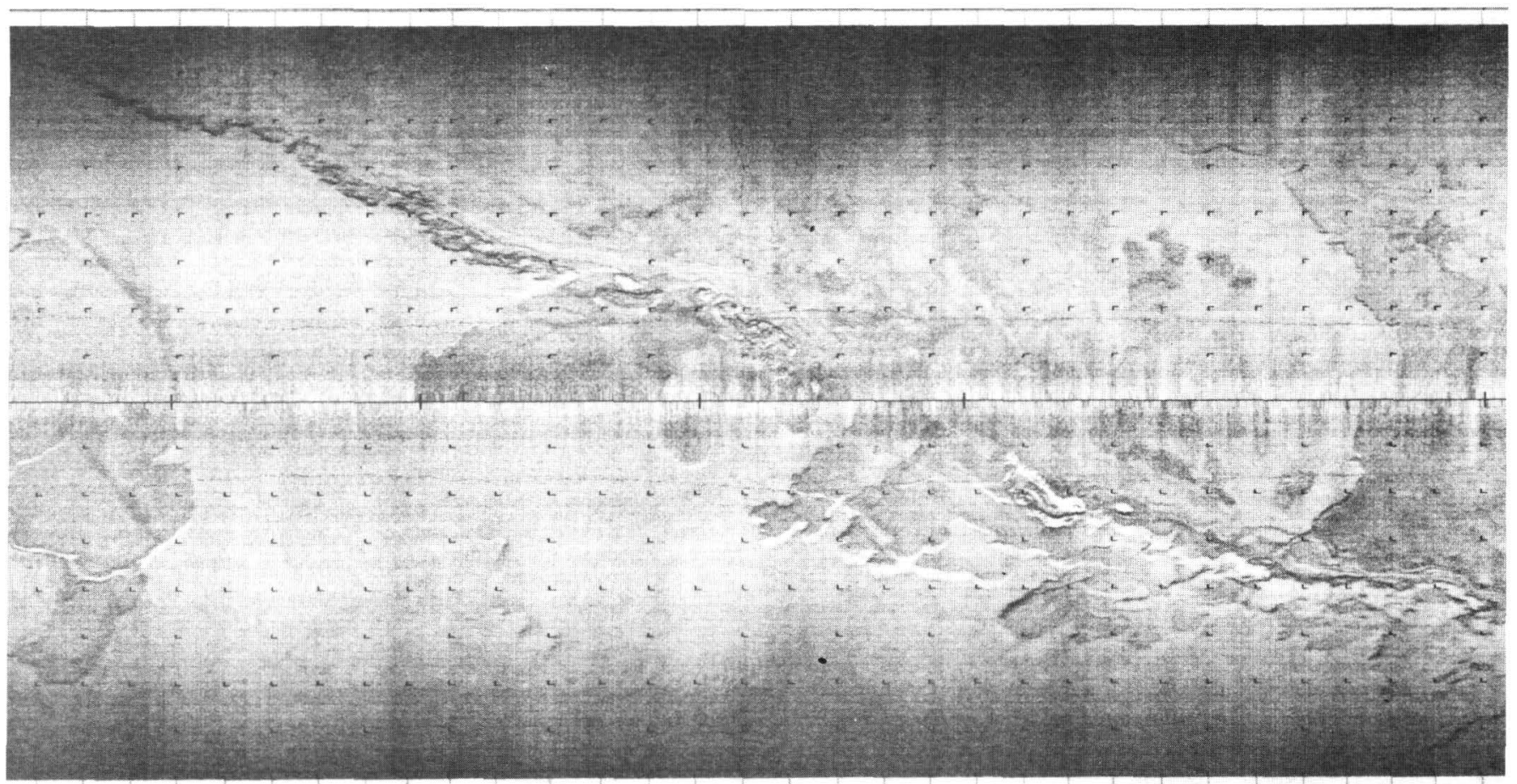

FIGURE 163.-Side-scan sonograph record of part of a subaqueous landslide offshore of the Klamath River, triggered by the Humboldt County, Calif., earthquake of November 8,1980 . The sinuous ridge running from the upper left to the lower right is the primary landslide toe. The lobes near center to the left of the toe are subsidiary flows. The direction of landslide movement is toward the lower left. Sonograph from Field and Hall (1982).

sloping ground several kilometers from the sites of landslide initiation. These landslides are relatively uncommon in the worldwide historical record (see list, p. 320); no rock avalanches and only a few earthquake-induced rapid soil flows are known from the historical record in the Los Angeles region. Rapid soil flows are common in the region during periods of high rainfall, however (Campbell, 1975). Furthermore, a single large rock avalanche or rapid soil flow could cause catastrophic damage.

Rock falls, the third leading cause of death, are also the most abundant landslides in earthquakes and occur in virtually all types of rocks on slopes steeper than $40^{\circ}$. Areas at risk from rock falls are limited by the distances (as much as several hundred meters) that boulders can bounce or roll when they reach the bases of steep slopes.

In addition to rock avalanches, rapid soil falls, and rock falls, leading causes of property damage among earthquake-induced landslides are soil slumps and soil lateral spreads. The propensity of such slumps and lateral spreads to cause property damage is due to their abundance (see list, p. 320) and to their occurrence on gentle slopes, where human development is common, and in manmade fill (Youd and Perkins, 1978; Keefer, 1984b). Soil slumps and lateral spreads caused more than half of the landslide-related damage in the 1971 San Fernando earthquake. Conditions favoring formation of lateral spreads in the Los Angeles region are discussed by Tinsley and others (this volume).

Whether a particular slope produces a landslide during an earthquake depends on the strength of the hillside materials, the slope geometry, the ground-water conditions, and the level of shaking. Analytical techniques treating these factors are developed and presented later in this chapter. General types of geologic environments most likely to produce landslides during earthquakes in the Los Angeles region are shown in table 45.

Maximum distances of landslides from the faultrupture zones of historical earthquakes are plotted in relation to magnitude in figure 164 for the three major categories of landslides. Approximate upper bounds were fitted to the data to show the greatest distance from the fault rupture at which an earthquake of given magnitude is likely to cause landslides in each category. Extension of the upper bounds to $\boldsymbol{M}<5.3$ is based on intensity data from U.S. earthquakes, which suggest that

\section{Earthquake Hazards in the Los Angeles Region}


the smallest events likely to cause disrupted slides and falls, coherent slides, and lateral spreads and flows are $M$ 4.0, $M$ 4.5, and $M$ 5.0, respectively. The estimate of a M 5.0 event as the smallest likely to cause lateral spreads and flows agrees with Kuribayashi and Tatsuoka's (1975, 1977), Youd's (1977), and Youd and Perkins' (1978) estimations that soil liquefaction is unlikely to occur in $\boldsymbol{M}<5$ events.

Scatter in the data in figure 164 indicates that factors other than magnitude influence the maximum distance from the fault rupture at which landslides occur. Factors probably causing significant scatter include earthquake focal depth, variations in the ground-motion characteristics of individual earthquakes, uncertainties in distances and magnitude determinations, and local geologic conditions. Geologic conditions particularly influence distances by controlling the distribution of susceptible sites, an effect most evident for small events where the area shaken is small and thus may contain only a few scattered susceptible slopes.

\section{EXAMPLES OF LANDSLIDES IN CALIFORNIA EARTHQUAKES}

Landslides caused by five earthquakes in California are discussed in this section to illustrate the range in potential for earthquake-induced landslides in the Los Angeles region. The earthquakes chosen are discussed in order of increasing magnitude. Because the effects of the 1857 Fort Tejon earthquake, the only great event to have occurred in southern California in historical time, are not well documented, we use the 1906 San Francisco earthquake to illustrate the potential for landslides in such a large California event.

\section{Santa Barbara Earthquake}

The 1978 Santa Barbara earthquake (M 5.6), centered $4 \mathrm{~km}$ offshore of Goleta Point (Lee and others, 1978), caused a few dozen small rock falls, rock slides, and soil falls scattered throughout an area of approximately $200 \mathrm{~km}^{2}$ (Harp and others, 1980). These landslides were confined to steep roadcuts in the Santa Ynez Mountains and sea cliffs near Goleta Point. The landslides were primarily in weakly cemented and closely jointed sedimentary rocks and in residual and colluvial soils developed on them. Most of these landslides had volumes of only a few cubic meters. The largest rock fall-and the only one to cause reported damage-had a volume of about $100 \mathrm{~m}^{3}$ and blocked California State Highway 154 near San Marcos pass for 30 hours.
One soil slump, near Elwood, was reported in the earthquake. This slump, in an uncompacted railroad embankment composed of excavated rock, soil, and waste lumber, was at least partially responsible for derailing a freight train that moved onto the embankment a few minutes after the earthquake (Harp and others, 1980). On the University of California's Santa Barbara campus, a lateral spread occurred in soft alluvial fill on the banks of Goleta slough (Miller and Felszeghy, 1978).

\section{Long Beach Earthquake}

Documentation of landslides and other ground failures in the 1933 Long Beach earthquake (M 6.2) is incomplete. On and near the coast between Long Beach and Newport Beach, manmade fills in areas underlain by wet sand and mud settled and spread (Wood, 1933). In the Belmont Shore residential district of Long Beach, pavement was buckled, and cracks up to $100 \mathrm{~mm}$ wide opened along the banks of a filled canal (Maher, 1933), probably because of lateral spreading. Slumps were observed in manmade fills and unconsolidated sediments between Long Beach and Compton (Neumann, 1935). The slumps and lateral spreads caused some localized damage (fig. 165). Sand boils were reported north of Newport Beach, at Huntington Beach, in the Alamitos-Seal Beach area, near the mouth of the Santa Ana River, at Bolsa Chica, at Cabrillo Beach, and in the Compton area (Wood, 1933; Barrows, 1973; Oakeshott, 1973). Rock falls and other landslides of undetermined type in mountainous terrain were reported from canyons in central Los Angeles County, from as far south as San Clemente, and from as far north and west as Anacapa Island (Maher, 1933; Neumann, 1935).

\section{San Fernando Earthquake}

Landslides in the 1971 San Fernando earthquake (M 6.6) were concentrated in about $250 \mathrm{~km}^{2}$ of mountainous terrain north of the surface fault rupture (fig. 166A) and also occurred throughout an additional $3,000 \mathrm{~km}^{2}$ stretching southward from the epicentral region to the Palos Verdes Peninsula (Coffman and von Hake, 1973) and eastward through most of the San Gabriel Mountains (Morton, 1971). These landslides caused at least 135 million 1984 dollars in damage.

The earthquake triggered several hundred rock falls, rock slumps, soil falls, disrupted soil slides, soil avalanches, and soil slumps (fig. 166B) (Morton, 1971, 1975; California Division of Highways, 1975; Yen and Trotter, 


\begin{tabular}{|c|c|c|c|c|c|c|c|c|}
\hline \multirow[b]{2}{*}{ Name } & \multirow[b]{2}{*}{$\begin{array}{l}\text { Type of } \\
\text { movement }\end{array}$} & \multirow[b]{2}{*}{ Internal disruption ${ }^{1}$} & \multicolumn{4}{|c|}{ Water content } & \multirow[b]{2}{*}{ Velocity ${ }^{2}$} & \multirow[b]{2}{*}{ Depth $^{3}$} \\
\hline & & & Dry & Moist & $\begin{array}{c}\text { Partly } \\
\text { saturated }\end{array}$ & Saturated & & \\
\hline \multicolumn{9}{|c|}{ Landslides in rock } \\
\hline \multicolumn{9}{|l|}{ Disrupted slides and falls: } \\
\hline Rock falls -- - & $\begin{array}{l}\text { Bounding, rolling, free } \\
\text { falling. }\end{array}$ & High or very high & $\mathrm{X}$ & $\mathrm{X}$ & $\mathrm{x}$ & $\mathrm{X}$ & Extremely rapid & Shallow \\
\hline Rock slides ------- & $\begin{array}{l}\text { Translational sliding } \\
\text { on basal shear } \\
\text { surface. }\end{array}$ & High & $\mathrm{x}$ & $\mathrm{X}$ & $\mathrm{x}$ & $\mathrm{x}$ & $\begin{array}{l}\text { Rapid to } \\
\text { extremely } \\
\text { rapid. }\end{array}$ & Shallow \\
\hline Rock avalanches -- & $\begin{array}{l}\text { Complex, involving } \\
\text { sliding and (or) } \\
\text { flow } \\
\text { as stream } \\
\text { of rock } \\
\text { fragments. }\end{array}$ & Very high & $\mathrm{X}$ & $\mathrm{X}$ & $\mathrm{x}$ & $\mathrm{X}$ & Extremely rapid & Deep \\
\hline \multicolumn{9}{|l|}{ Coherent slides: } \\
\hline Rock slumps ----- & $\begin{array}{l}\text { Sliding on basal shear } \\
\text { surface; } \\
\text { component } \\
\text { of headward } \\
\text { rotation. }\end{array}$ & Slight or moderate & $?$ & $\mathrm{X}$ & $\mathrm{x}$ & $\mathrm{X}$ & Slow to rapid & Deep \\
\hline Rock block slides -- & $\begin{array}{l}\text { Translational sliding } \\
\text { on basal } \\
\text { shear surface. }\end{array}$ & Slight or moderate & $?$ & $\mathrm{X}$ & $\mathrm{x}$ & $\mathrm{X}$ & Slow to rapid & Deep \\
\hline
\end{tabular}

\section{Landslides in soil}

Disrupted slides and falls:

Soil falls ---------
Disrupted soil
slides. --------

slides. -

Soil avalanches ---

subsidiary flow.

Very high

ounding, rolling, free

High or very high

falling.

Translational sliding

High

basal shear

surface or

zone of

weakened,

sensitive

clay.

Coherent slides:

Soil slumps -------

Sliding on basal shear surface;

component

of headward rotation.

Soil block slides --- Translational sliding on basal shear surface.

Slow earth flows -- Translational sliding Slight on basal shear surface; minor internal flow.

\section{Earthquake Hazards in the Los Angeles Region}

Slight or moderate

$\begin{array}{cccccc}\mathrm{X} & \mathrm{X} & \mathrm{X} & \mathrm{X} & \begin{array}{c}\text { Extremely rapid } \\ \text { Shallow }\end{array} \\ \mathrm{X} & \mathrm{X} & \mathrm{X} & \mathrm{X} & \begin{array}{c}\text { Moderate to } \\ \text { rapid. }\end{array} & \text { Shallow }\end{array}$

$\mathrm{X} \quad \mathrm{X}$

$\mathrm{X} \quad$ Very rapid to extremely

Shallow rapid.

Slight or moderate

? $\quad \dot{X}$

$\mathrm{X}$

$\mathrm{X} \quad$ Slow to rapid

Deep

X Slow to very

Deep rapid.

$\mathrm{X}$

$\mathrm{X}$ Very slow to

moderate

with very

rapid

surges.
Generally shallow; occasionally deep. 
TABLE 44.-Characteristics of earthquake-induced landslides-Continued

\begin{tabular}{|c|c|c|c|c|c|c|c|c|}
\hline \multirow[b]{2}{*}{ Name } & \multirow[b]{2}{*}{$\begin{array}{c}\text { Type of } \\
\text { movement }\end{array}$} & \multirow[b]{2}{*}{ Internal disruption' } & \multicolumn{4}{|c|}{ Water content } & \multirow[b]{2}{*}{ Velocity ${ }^{2}$} & \multirow[b]{2}{*}{ Depth ${ }^{3}$} \\
\hline & & & Dry & Moist & $\begin{array}{c}\text { Partly } \\
\text { seturated }\end{array}$ & Saturated & & \\
\hline \multicolumn{9}{|c|}{ Landslides in soil-Continued } \\
\hline \multicolumn{9}{|l|}{ Lateral spreads and flows: } \\
\hline $\begin{array}{l}\text { Soil lateral ------- } \\
\text { spreads. }\end{array}$ & $\begin{array}{l}\text { Translation on basal } \\
\text { zone of liquefied } \\
\text { gravel, sand, or } \\
\text { silt or weakened, } \\
\text { sensitive clay. }\end{array}$ & $\begin{array}{l}\text { Generally moderate; } \\
\text { occasionally } \\
\text { slight; occasion- } \\
\text { ally high. }\end{array}$ & & & $\mathrm{x}$ & $\mathrm{x}$ & Very rapid & Variable \\
\hline Rapid soil flows --- & Flow & Very high & $\mathrm{X}$ & $?$ & $?$ & $\mathrm{X}$ & $\begin{array}{l}\text { Very rapid to } \\
\text { extremely } \\
\text { rapid. }\end{array}$ & Shallow \\
\hline $\begin{array}{l}\text { Subaqueous ------ } \\
\text { landslides. }\end{array}$ & $\begin{array}{l}\text { Complex, involving } \\
\text { slumping, lateral } \\
\text { spreading, and } \\
\text { (or) flow. }\end{array}$ & $\begin{array}{l}\text { Generally high or } \\
\text { very high; } \\
\text { occasionally } \\
\text { moderate. }\end{array}$ & & & $\mathrm{x}$ & $\mathrm{X}$ & $\begin{array}{l}\text { Rapid to } \\
\text { extremely } \\
\text { rapid. }\end{array}$ & Deep \\
\hline
\end{tabular}

\footnotetext{
${ }^{1}$ Slight: landslide consisting of one or a few coherent blocks. Moderate: landslide consisting of several coherent blocks. High: landslide consisting of numerous small blocks and individual soil grains and rock fragments. Very high: landslide almost completely disaggregated into individual soil grains or small rock fragments.

${ }^{2}$ Extremely slow, less than $0.6 \mathrm{~m} / \mathrm{yr}$; very slow, between 0.6 and $1.5 \mathrm{~m} / \mathrm{yr}$; slow, between $1.5 \mathrm{~m} / \mathrm{yr}$ and $1.5 \mathrm{~m} / \mathrm{mo}$; moderate, between $1.5 \mathrm{~m} / \mathrm{mo}$ and $1.5 \mathrm{~m} / \mathrm{d} ;$ rapid, between $1.5 \mathrm{~m} / \mathrm{d}$ and $0.3 \mathrm{~m} / \mathrm{min}$; very rapid, between $0.3 \mathrm{~m} / \mathrm{min}$ and $3 \mathrm{~m} / \mathrm{s}$; extremely rapid, more than $3 \mathrm{~m} / \mathrm{s}$. Terminology from Varnes (1978).

${ }^{3}$ Shallow, generally less than $3 \mathrm{~m}$; deep, generally more than $3 \mathrm{~m}$.
}

1978; Clark and others, 1979). Rock falls were common in roadcuts and on steep cliffs in intensely jointed conglomerates, gneisses, and granites. Soil falls occurred in uncemented and weakly cemented sands and gravels along streambanks. Disrupted soil slides and soil avalanches involved loose, unsaturated layers of silty and clayey sand less than $1 \mathrm{~m}$ thick. Most rock slumps reactivated preexisting slumps. Soil slumps took place in weak, fine-grained highway and bridge-approach fills; slumps and roadcut failures caused an estimated 12 million 1984 dollars in damage to highways (California Division of Highways, 1975). Landslides also damaged the Camp Karl Holton Juvenile Facilities and several buildings near the Olive View Hospital (Yerkes, 1973).

Several soil lateral spreads occurred in the Van Norman Lakes area. The largest lateral spread, the Juvenile Hall slide, caused more than 58 million 1984 dollars in damage to the San Fernando Valley Juvenile Hall, the Sylmar electrical converter station, and adjacent highway structures, railroad facilities, pipelines, and canals (Youd, 1971; Youd and Olsen, 1971). This lateral spread involved alluvial-fan materials containing a subsurface zone of saturated, loose sandy silt and fine sand (Fallgren and Smith, 1973) which was inferred to have liquefied (Youd, 1971). The average surface slope of the landslide was only $1.5^{\circ}$ (Youd, 1971).

A potentially catastrophic liquefaction-induced landslide occurred on the upstream face of the Lower Van Norman Dam (Youd and Olsen, 1971; Seed and others, 1975) (see Tinsley and others, this volume, fig. 128B). This landslide seriously weakened the dam and resulted in the temporary evacuation of 80,000 people living downstream. The cost of rebuilding the dam was estimated at 66 million 1984 dollars (Kachadoorian, 1971). The dam, constructed in several stages from 1912 through 1940, consisted of a hydraulically placed sandfill embankment capped by several types of rolled fills; the main failure zone was in the hydraulic fill (Seed and others, 1975).

\section{Kern County Earthquake}

The 1952 Kern County earthquake (M 7.5) and its aftershocks caused hundreds of landslides in the southwestern Sierra Nevada, the Tehachapi Mountains, and the San Gabriel Mountains (Buwalda and St. Amand, 1955). Types of landslides included rock falls, rock slides, rapid soil flows, disrupted soil slides, and reactivations of existing coherent, deep-seated slides. Landslides blocked numerous highways, some for several weeks, and dammed several canyons, creating small lakes. The highest concentrations of landslides, including most reactivations, were on steep slopes near the surface expression of the fault-rupture zone, where shaking was presumably most severe. Rock falls were reported as far from the fault rupture as the Angeles Forest Highway between Vincent and Pasadena (Oakeshott, 1955).

On the floor of the San Joaquin Valley, ground cracks were reported from an area of several hundred square kilometers between Arvin and Maricopa (Steinbrugge 
TABLE 45.-Geologic environments likely to produce earthquake-induced landslides in the Los Angeles region

\begin{tabular}{|c|c|c|}
\hline $\begin{array}{l}\text { Landslide } \\
\text { type }\end{array}$ & $\begin{array}{l}\text { Minimum } \\
\text { slope } \\
\text { inclination, } \\
\text { in deg }\end{array}$ & Remarks \\
\hline $\begin{array}{l}\text { Rock falls --1-- Rocks weakly cemented, intensely fractured, or } \\
\text { weathered; contain conspicuous planes of } \\
\text { weakness dipping out of slope or contain } \\
\text { boulders in a weak matrix. }\end{array}$ & 40 & $\begin{array}{l}\text { Particularly common near ridge crests and on spurs, } \\
\text { ledges, artificially cut slopes, and slopes under- } \\
\text { cut by active erosion. }\end{array}$ \\
\hline Rock slides --------- Do. & 35 & $\begin{array}{l}\text { Occasionally reactivate preexisting rock slide } \\
\text { deposits. Particularly common in hillside flutes } \\
\text { and channels, on artificially cut slopes, and on } \\
\text { slopes undercut by active erosion. }\end{array}$ \\
\hline $\begin{array}{l}\text { Rock avalanches ---- Rocks intensely fractured and exhibiting one of the } \\
\text { following properties: significant weathering, } \\
\text { planes of weakness dipping out of slope, weak } \\
\text { cementation, or evidence of previous } \\
\text { landsliding. }\end{array}$ & 25 & $\begin{array}{l}\text { Restricted to slopes of }>150-\mathrm{m} \text { relief that are under- } \\
\text { cut by active erosion. }\end{array}$ \\
\hline $\begin{array}{l}\text { Rock slumps ------- Intensely fractured rocks, preexisting rock slump } \\
\begin{array}{l}\text { deposits, shale, and other rocks containing } \\
\text { layers of weakly cemented or intensely } \\
\text { weathered material. }\end{array}\end{array}$ & 15 & \\
\hline $\begin{array}{l}\text { Rock block -------- Rocks having conspicuous bedding planes or similar } \\
\text { slides. } \\
\text { planes of weakness dipping out of slopes. }\end{array}$ & 15 & \\
\hline $\begin{array}{l}\text { Soil falls -------- Granular soils that are slightly cemented or } \\
\text { contain clay binder. }\end{array}$ & 40 & $\begin{array}{l}\text { Particularly common on streambanks, terrace } \\
\text { faces, coastal bluffs, and artificially cut slopes. }\end{array}$ \\
\hline $\begin{array}{l}\text { Disrupted soil ------- Loose, unsaturated sands } \\
\text { slides. }\end{array}$ & 15 & \\
\hline Soil avalanches ------ Do. & 25 & $\begin{array}{l}\text { Occasionally reactivate preexisting soil avalanche } \\
\text { deposits. }\end{array}$ \\
\hline $\begin{array}{l}\text { Soil slumps---1--- Loose, partly to completely saturated sand or silt; } \\
\text { uncompacted or poorly compacted manmade } \\
\text { fill composed of sand, silt, or clay; preexisting } \\
\text { soil slump deposits. }\end{array}$ & 10 & $\begin{array}{l}\text { Particularly common on embankments built on soft, } \\
\text { saturated foundation materials, in hillside cut- } \\
\text { and-fill areas, and on river and coastal flood } \\
\text { plains. }\end{array}$ \\
\hline $\begin{array}{l}\text { Soil block ------ Loose, partly or completely saturated sand or silt; } \\
\text { slides. } \\
\begin{array}{ll}\text { uncompacted or slightly compacted manmade } \\
\text { fill composed of sand or silt; bluffs containing } \\
\text { horizontal or subhorizontal layers of loose, } \\
\text { saturated sand or silt. }\end{array}\end{array}$ & 5 & $\begin{array}{l}\text { Particularly common in areas of preexisting land- } \\
\text { slides along river and coastal flood plains, and } \\
\text { on embankments built on soft, saturated } \\
\text { foundation materials. }\end{array}$ \\
\hline $\begin{array}{l}\text { Slow earth ------- Stiff, partly to completely saturated clay and pre- } \\
\text { flows. } \\
\text { existing earth-flow deposits. }\end{array}$ & 10 & \\
\hline $\begin{array}{c}\text { Soil lateral ------ Loose, partly or completely saturated silt or sand; } \\
\text { spreads. } \\
\text { uncompacted or slightly compacted manmade } \\
\text { fill composed of sand. }\end{array}$ & .3 & $\begin{array}{l}\text { Particularly common on river and coastal flood } \\
\text { plains, embankments built on soft, saturated } \\
\text { foundation materials, delta margins, sand } \\
\text { dunes, sand spits, alluvial fans, lake shores, } \\
\text { and beaches. }\end{array}$ \\
\hline $\begin{array}{l}\text { Rapid soil flows ----- Saturated, uncompacted or slightly compacted } \\
\text { manmade fill composed of sand or sandy silt } \\
\text { (including hydraulic-fill earth dams and } \\
\text { tailings dams); loose, saturated granular soils. }\end{array}$ & 2.3 & \\
\hline $\begin{array}{l}\text { Subaqueous -------- Loose, saturated granular soils } \\
\text { landslides. }\end{array}$ & .5 & Particularly common on delta margins \\
\hline
\end{tabular}

and Moran, 1954; Warne, 1955). The cracks, some of which were associated with soil slumps, block slides, and (or) lateral spreads, caused significant damage to agricultural land and building foundations (Steinbrugge and Moran, 1954). Slumps also caused minor damage to highway and bridge-approach fills in the epicentral region (Perry, 1955). The total area affected by land-

\section{Earthquake Hazards in the Los Angeles Region}

slides in this earthquake sequence was approximately $7,000 \mathrm{~km}^{2}$.

\section{San Francisco Earthquake}

The 1906 San Francisco earthquake (M 7.7) caused thousands of landslides in an area of $32,000 \mathrm{~km}^{2}$ stretch- 
ing from Arcata on the north to near King City on the south. Landslides killed at least 11 and probably several dozen people and caused significant damage to buildings, roads, bridges, railroads, and other manmade structures. The summary of landslides and related effects caused by this earthquake is based on information compiled and interpreted by Youd and Hoose (1978).

In mountainous terrain of the northern California Coast Ranges, the most numerous landslides were rock and soil falls, rock slides, disrupted soil slides, and soil slumps. Rock falls, soil falls, and rock slides affected $300 \mathrm{~km}$ of coastal bluffs as well as many roadcuts and steep canyon walls. One person was killed by a rock fall. Many preexisting soil slumps were reactivated, probably because the earthquake occurred during a rainy season when preexisting landslides were marginally stable because of high ground-water levels. Rock slumps, block slides, and avalanches, rapid soil flows, and slow earth flows were reported in smaller numbers in the Coast Ranges. Two rock avalanches, each involving several hundred thousand or million cubic meters of material, killed at least 10 people in the Santa Cruz Mountains south of San Francisco.

In areas of loose sandfill in downtown San Francisco, soil lateral spreads, ground settlement, and other soilliquefaction effects caused significant damage in three major zones totaling about $3 \mathrm{~km}^{2}$ in area. Among the many buildings damaged was the Valencia Street Hotel, which collapsed and burned, killing several dozen people. The collapse may have been partially caused by a lateral spread in the ground beneath the structure. Ground movements also broke two water mains, cutting off the water supply to a major part of San Francisco that subsequently was destroyed by fire. Outside San Francisco, soil lateral spreads and related phenomena occurred in alluvial, coastal, and filled areas (fig. 167). Many stretches of river flood plains several kilometers long were disrupted by cracks, settlements, and lateral spreads.

\section{NUMERICAL MODELS FOR EARTHQUAKE-INDUCED LANDSLIDES}

Whether a particular slope will fail during an earthquake depends on the answers to two questions: (1) how stable was the slope before the earthquake and (2) how severely did the earthquake shake the slope? Thus, we seek some way to numerically express both the preearthquake stability of the slope and the severity of the shaking in the same dimensional units, so that they can be directly compared with each other.
In the next section, we develop mathematical models of the mechanics of landslides to measure and express the slope stability under both static (aseismic) and dynamic (seismic) conditions. In the following sections, we use statistical analyses of strong-motion data to measure the shaking severity. Finally, we discuss the relation of the shaking severity to the magnitude and distance from the seismic source.

\section{Mechanics of Slope Stability}

We begin the analysis by examining slope stability under static (aseismic) conditions. Figure 168 depicts a hypothetical landslide of the block-slide type. Two forces act on the center of mass of this potential landslide-the gravitational load (L), which is the downslope component of the weight of the landslide mass, and an opposing force (R), which is the resistance of the slope to deformation from downslope movements. The maximum resistance $\left(R_{\max }\right)$ is a function of the strength of the slope material and can be expressed as the integration of the shear strength over the area of the sliding surface. Following standard slopeengineering nomenclature, we express the static slope stability as the ratio of the maximum resistance to the load and call this ratio the factor of safety (FS):

$$
F S \equiv \frac{R_{\text {max }}}{L}
$$

For a dynamic (seismic) situation, this analysis must be taken a step further. During an earthquake, seismic waves passing through the slope create an acceleration field $(a(t))$, which exerts an additional body force on the mass (m) of the potential landslide. During the time of strong shaking, this seismically induced force will fluctuate and sporadically add to the downslope load. If this downslope seismic force is large enough, the total downslope load $(L+m$ a(t)) may exceed the maximum resistance, and the slope will undergo irreversible displacement. As Wilson and Keefer (1983) have done, we express this level of ground motion in terms of a critical acceleration $(A)$, which is the seismic acceleration that, when multiplied by the mass, is equal to the difference between the maximum resistance and the gravitational load,

$$
m A_{c}=R_{\max }-L
$$

or

$$
m A_{c}=\left(\frac{R_{\max }}{L} \frac{-L}{L}\right) L=(F S-1) L
$$

Earthquake-Induced Landsliding $\mathbf{3 2 7}$ 

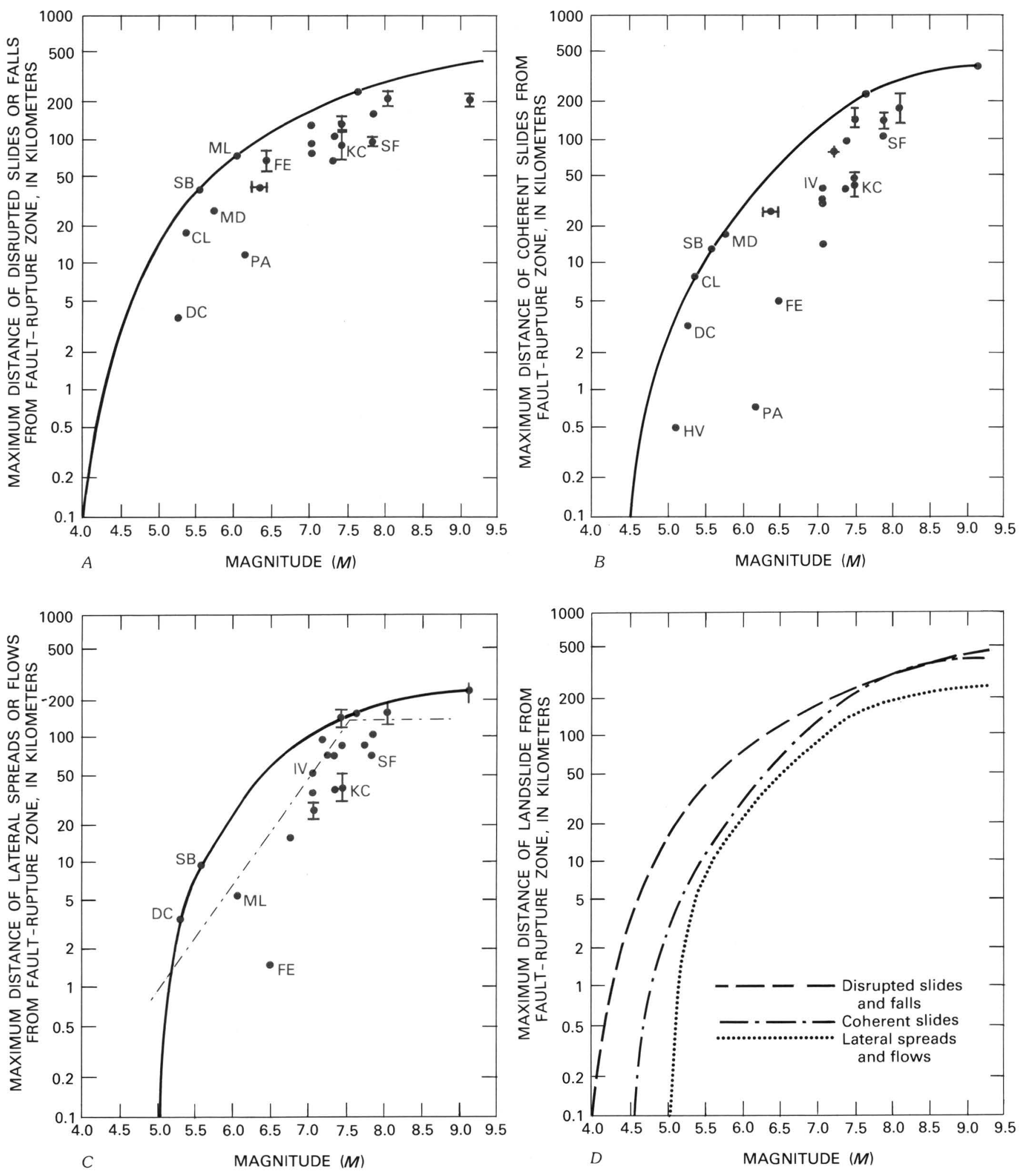

328 Earthquake Hazards in the Los Angeles Region 
so that

$$
A_{c}=(F S-1) L / m
$$

Therefore,

$$
A_{c}=(F S-1) g \sin \theta
$$

where $\mathrm{g}$ is the acceleration due to gravity and $\theta$ is the slope angle. Thus, the critical acceleration is the minimum ground acceleration required to overcome the maximum resistance of the slope to sliding. To cause a landslide on a particular slope, the ground acceleration must exceed $A_{c}$ for a finite length of time (the time requirement is examined in a following section). Henceforth, we will use the critical acceleration as the numerical measure of the stability of a slope and its susceptibility to an earthquake-induced landslide.

If the slope steepness and the strength of the slope materials are known, we can estimate the critical acceleration of a shallow landslide on an infinitely long slope (fig. 168) from the equation

$$
\frac{A_{c}}{g}=\frac{c^{\prime}}{\gamma h}+(1-\lambda) \tan \phi^{\prime} \cos \theta-\sin \theta
$$

where $\theta$ is the slope steepness angle, $\gamma$ is the specific weight of slope material, $h$ is the thickness of the potential landslide, $c^{\prime}$ is the effective cohesion, $\phi^{\prime}$ is the effective friction angle of the slope material, and $\lambda$ is the ratio of pore pressure to overburden stress. Values of $c^{\prime}$ and $\phi^{\prime}$ appropriate for dynamic conditions, which Newmark (1965, p. 150) noted should be used, "may involve considerably reduced shearing strengths owing to the dynamic effects on the pore pressures." Values of $c^{\prime}$ and $\phi^{\prime}$ measured in standard undrained tests should yield reasonably conservative results.

This infinite-slope analysis can be further generalized by grouping various types of slope materials into three broad lithologic categories, each having assumed average values of $c^{\prime}$ and $\phi^{\prime}$ (for dynamic conditions) (fig. 169). Figure 169 is a plot of $A_{c}$ versus slope steepness for each category of slope material. If this plot is used, the qualitative slope-lithology combinations described in table 45 as being susceptible to seismically induced landsliding can be seen to have relatively low values of $A_{c}(<0.3 \mathrm{~g})$.

\section{Newmark Analysis}

The critical acceleration $\left(A_{c}\right)$ represents the ground motion necessary to begin the process of slope failure. Because small, irreversible displacements do not necessarily result in a slope failure of practical or engineering significance, however, how far the landslide would move must now be determined. This distance can be estimated by using a technique developed by Newmark (1965), which hereafter will be called the Newmark analysis. The Newmark analysis, which models the landslide as a rigid friction block resting on a slope, uses a record of ground acceleration versus time (a strongmotion record) to calculate the expected displacement of the block. This model is most directly applicable to translational, coherent slides (block slides and slow earth flows) (table 44) and, after slight modification, to rotational slumps. If yet another modification is introduced to account for the importance of tensile failure and more brittle behavior, the model can also be applied to the initial stages of disrupted landslides. The model, however, has only limited applicability to liquefactioninduced lateral spreads and flows.

The significance of critical accelerạtion is illustrated in figure $170 \mathrm{~A}$, a plot of acceleration versus time for an actual strong-motion record. Superimposed on this strong-motion record is a horizontal line corresponding to the critical acceleration of a hypothetical slope. If the strong-motion record contained a peak acceleration less than the critical acceleration for our hypothetical slope, then the displacement of the block would be zero, and the slope would remain stable. When the ground motion does exceed the critical acceleration, however, the next

FIGURE 164.-Maximum distance from the fault-rupture zone (surface or subsurface) to landslides in earthquakes of different magnitudes (from Keefer, 1984b). California earthquakes in the data set as follows: CL, August 6, 1979, Coyote Lake; DC, March 22, 1957, Daly City; FE, February 9, 1971, San Fernando; HV, March 15, 1979, Homestead Valley; IV, May 19, 1940, Imperial Valley; KC, July 21, 1952, Kern County (not included by Keefer (1984b)); MD, January 24, 1980, Greenville-Mount Diablo; ML, May 25, 1980, Mammoth Lakes; PA, June 28, 1966, Parkfield-Cholame; SB, August 13, 1978, Santa Barbara; SF, April 18, 1906, San Francisco. Unlabeled points represent earthquakes outside California (identified by Keefer (1984b)). Vertical bars indicate uncertainties, where they are known, in boundaries of fault-rupture zones, in locations of most distant landslides, or both. Horizontal bars indicate the range in reported magnitudes. Magnitudes greater than or equal to 7.5 are generally moment magnitudes as defined by Kanamori (1977); magnitudes less than 7.5 are generally Richter surface-wave magnitudes. A, Maximum distance from the fault-rupture zone to a disrupted slide or fall. The solid line is an approximate upper bound enclosing all data. B, Maximum distance from the fault-rupture zone to a coherent slide. The solid line is an approximate upper bound enclosing all data. C, Maximum distance from the fault-rupture zone to a lateral spread or flow. The solid line is an approximate upper bound enclosing all reported occurrences. The dot-dash line is an upper bound determined by Youd and Perkins (1978) for soil liquefaction phenomena having displacements of at least $10 \mathrm{~cm}$ in gently sloping Holocene flood-plain, deltaic, or eolian materials. $D$, Comparison of the upper bounds from $A$, $B$, and $C$. The dashed line is the bound for disrupted slides and falls; the dash-doubledot line is the bound for coherent slides; the dotted line is the bound for lateral spreads and flows. 
step is to integrate those portions of the strong-motion record that lie above the critical acceleration (fig. $170 A$ ).

The integration begins at point $A$ (figs. $170 \mathrm{~A}, 170 \mathrm{~B}$, $170 C$ ), where the ground acceleration first exceeds the critical acceleration. We integrate over time that portion $\mathrm{AB}$ of the ground motion above $A_{\mathrm{c}}$ to calculate the velocity of the block (fig. 170B). At point $B$, the block reaches the maximum velocity for this acceleration pulse. After point $B$, when the ground acceleration drops below the critical acceleration, the block is still in motion because of its inertia but is now being decelerated by the friction that still exists beneath the block. Also, the ground acceleration may well swing around in the opposite direction and directly oppose the motion of the block (as it does at the end of the second pulse). Eventually, the motion of the block will cease, and the block will come to rest at point $C$. (The point at which the block again comes to rest occurs at some finite time after point $B$, the point where ground acceleration first falls below $A_{c}$ ) Finally, the displacement of the block is calculated by integrating the velocity of the block over time (fig. 170C). Note where points $A, B$, and $C$ fall on the displacement-time curve. In this example, there is also a second pulse of ground acceleration exceeding $A_{c}$ and producing a second displacement increment, which ends with a small displacement in the upslope direction.

In his original report, Newmark (1965) was concerned with artificial embankments, and computed displacement was used as a design factor; one can either design the embankment to tolerate the seismically induced displacement without significant loss of strength or design a stronger embankment to reduce the seismic displacement. In either case, the resistance of the slope to sliding, expressed as $A_{c}$, can be treated as a constant during the dynamic analysis. In actual cases, however, as the displacement becomes significant, the slope material may lose some shear strength, and $A_{c}$ thus may decrease (Goodman and Seed, 1966). If the displacement continues, the slope may lose so much strength that $A_{c}$ will go to zero, and the slope will become statically unstable $(F S<1)$. In this case, the slope may continue to move even after the seismic shaking ceases.

For a specified slope and known slope materials, we could, by careful laboratory measurements of strength versus strain, estimate the loss of strength of the slope (and thus the decrease in $A_{d}$ ) as a function of displacement. Goodman and Seed (1966), for example, performed such an analysis for a laboratory-scale model of a slope in uncemented sand. Such an analysis, however, is restricted to slopes where the mechanical properties are well known. For a regional application, such as mapping susceptibility, it is simply not practical to consider decreases in $A_{c}$ as a function of displacement as an integral part of the numerical analysis.

Instead, the numerical analysis of the strong-motion record is performed under the arbitrary assumption of a constant value of critical acceleration. The displacement thus calculated is then compared with a "benchmark" value of displacement, herein termed the critical displacement, beyond which it is likely that the slope would lose a significant amount of strength. If the computed value of displacement (assuming a constant $A_{d}$ ) is a small fraction of the value of the critical displacement, then the slope probably lost little strength and regained most of its stability when the seismic shaking ceased. In such a case, little damage would be expected, either to the slope itself or to overlying structures. If, however, the computed (constant $A_{c}$ ) displacement exceeds the critical displacement, then significant damage becomes a potential result of the seismic shaking; if the computed displacement greatly exceeds the critical displacement, then catastrophic failure of the slope could result.

The actual value of the critical displacement may vary widely, depending on the mechanism of slope failure (rock fall, slump, block slide, and so on), the lithology, the slope geometry, and the previous history of slope movement. To quantify this parameter for regional application, we assign a value of $10 \mathrm{~cm}$ for the critical displacement of coherent slides (table 44). This value is consistent with two ideas:

1. In moving $10 \mathrm{~cm}$, a landslide will probably have broken most of the cohesive bonds along the slip surface and across the scarp at the top of the landslide and will also have begun to override the toe at the bottom.

2. Ten centimeters is our estimate of the displacement that a typical house foundation could withstand before experiencing significant damage. This second reason would also apply to slope failures from lateral spreads and flows; thus, a value of $10 \mathrm{~cm}$ is also assigned for the critical displacement for landslides of these types. Youd (1980), in a study of damage to building foundations as a consequence of ground-failure displacement, found that most flexible buildings on wellreinforced foundations can withstand $10 \mathrm{~cm}$ of extensional ground displacement before incurring significant damage.

Rock falls and most other disrupted landslides (table 44) involve a significant component of tensile failure, a mechanism more brittle than shear and for which the critical displacement is lower. So, we shall assume a value of $2 \mathrm{~cm}$ for the critical displacement for disrupted landslides.

\section{Earthquake Hazards in the Los Angeles Region}




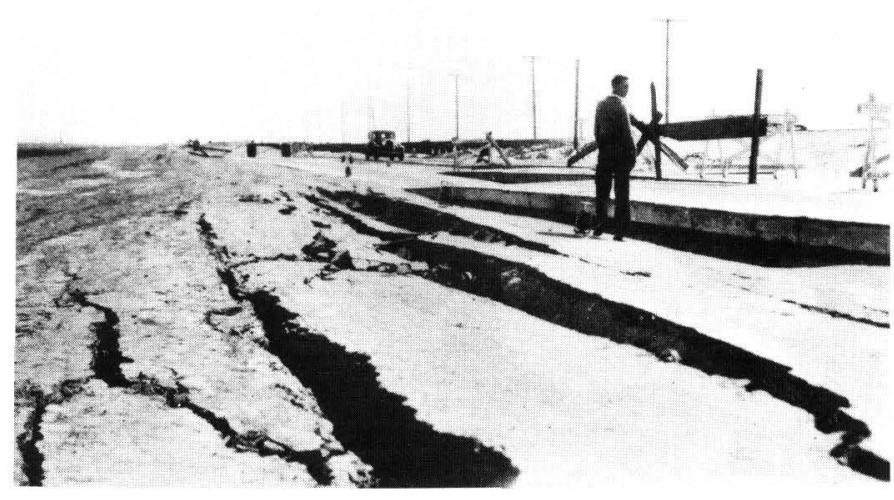

FIGURE 165.-Damage to the Pacific Coast Highway from slumping or lateral spreading southeast of Huntington Beach during the 1933 Long Beach earthquake. (Photograph from the City of Long Beach Public Library History Collection.)

The Newmark analysis, commonly used in designing artificial embankments for more than $15 \mathrm{yr}$, has recently been checked against an actual case of earthquakeinduced failure on a natural slope (Wilson and Keefer, 1983) and was demonstrated to be a valid predictor of the displacement of a landslide during seismic shaking. The Newmark analysis was also used with the plot in figure 169 to derive susceptibility units for an experimental seismic slope stability map of San Mateo County in California (Wieczorek and others, 1985).

\section{Relating Shaking Severity to Slope Stability}

In the preceding sections, we have discussed how the preearthquake stability of a slope can be expressed in terms of the critical acceleration $\left(A_{c}\right)$, a function of slope steepness and material properties. The Newmark analysis also allows calculation of how far a landslide with a given $A_{c}$ would move under the time-history of shaking represented by a particular strong-motion record. The displacement can be compared directly with the critical displacement $\left(U_{c}=2\right.$ or $10 \mathrm{~cm}$, depending on landslide type) to determine whether the slope would produce a landslide of practical significance. Now we need to describe the severity of seismic shaking in terms of a single number, independent of the stability of any individual slope but expressed in the same physical units (acceleration), so that the severity can be compared directly with the stability.
By taking the same given strong-motion record and repeatedly running the Newmark analysis (as depicted in fig. 170) for a family of values of $A_{c}$, from zero to the peak acceleration $(A)$ of the record, a predicted displacement for each value of $A_{c}$ can be calculated. In this way, we can calculate the response of any possible slope to the seismic ground motion represented by the given strong-motion record. (This procedure is analogous to the "response spectrum" analysis used in the engineering design of earthquake-resistant manmade structures.)

Figure 171 is a plot of critical accelerations versus the corresponding displacements predicted from a number of strong-motion records. By taking the value of $A_{c}$ that corresponds to a predicted displacement equal to the critical displacement $(10 \mathrm{~cm}$ for coherent landslides) for a given strong-motion record, a measure of the seismic shaking intensity that is directly related to slope stability can be derived. We abbreviate this value of $A_{c}$ as $\left(A_{c}\right)_{10}$. Thus, the Taft record, for example, has an $\left(A_{\mathrm{c}}\right)_{10}=0.03 \mathrm{~g}$, whereas the Pacoima record has an $\left(A_{c}\right)_{10}=0.33 \mathrm{~g}$ (fig. 171).

The advantage of using the value of $\left(A_{c}\right)_{10}$ to express the seismic shaking severity, as marked by the position of the $A_{c}$-displacement curve, is that it is expressed in the same physical units (acceleration) as our measure of seismic slope stability $\left(A_{c}\right)$ and is directly referenced to the critical displacement. The $\left(A_{c}\right)_{10}$ value gives the critical acceleration of the most resistant slope that would be expected to undergo significant displacement as a coherent slide for this level of seismic shaking. All slopes for which $A_{c}>\left(A_{c}\right)_{10}$ should survive this shaking without significant failure. In the same way, we can reference the severity of seismic shaking to the critical displacement for disrupted landslides $\left(U_{c}=2 \mathrm{~cm}\right)$ by deriving a value for $\left(A_{c}\right)_{2}$. Therefore, $\left(A_{c}\right)_{10}$ and $\left(A_{c}\right)_{2}$ become useful parameters for expressing seismic shaking severity for predicting earthquake-induced landslides.

A somewhat less complicated way of expressing the severity of seismic shaking as recorded by a strongmotion record was developed by Arias (1970). Arias intensity $\left(I_{a}\right)$ is defined as an integration over time of the acceleration squared (Arias, 1970):

$$
I_{a} \equiv \frac{\pi}{2 g} \int_{0}^{\infty}\left[[a(t)]^{2} d t\right.
$$

The Arias intensity is expressed in units of velocity, usually in meters per second. We can use the Arias intensity to replace the hundreds of points in a digitized 


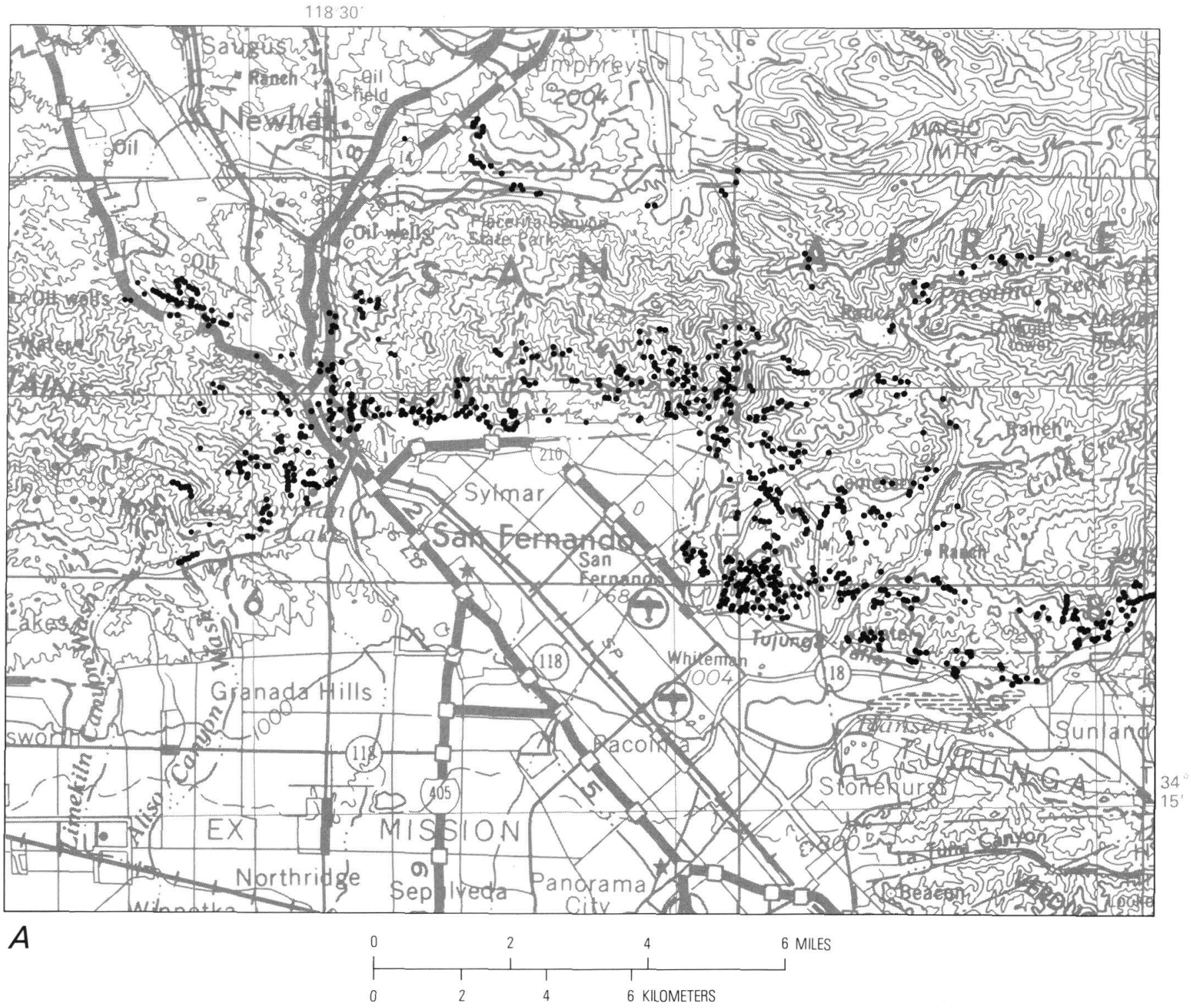

FIGURE 166.-A, Locations of landslides (solid circles) in the area where slope failures triggered by the February 9, 1971, San Fernando earthquake were most abundant (Morton, 1971). B, Aerial view of landslides triggered in the Lopez Canyon area by the February 9, 1971, San Fernando earthquake. (Photograph by D. M. Morton.)

strong-motion record with a single value and simplify the seismic input to the Newmark analysis by taking advantage of newly developed empirical relations between $\left(A_{\mathrm{c}}\right)_{10},\left(A_{\mathrm{c}}\right)_{2}$, and the Arias intensity (fig. 172).

Figure 172 plots $\left(A_{c}\right)_{10}$ and $\left(A_{c}\right)_{2}$ versus the Arias intensity. Each data point represents a single strong-motion record in table 46 for which both the Arias intensity and the value of $\left(A_{c}\right)_{10}$ and $\left(A_{c}\right)_{2}$ were calculated. Figure 172 shows a linear logarithmic relation plotted between the Arias intensity and both $\left(A_{c}\right)_{10}$ and $\left(A_{c}\right)_{2}$. For many cases, where only approximate estimates of $\left(A_{c}\right)_{10}$ or $\left(A_{c}\right)_{2}$ are required, we can avoid performing a number of Newmark analyses by simply calculating the Arias intensity and using the plot in figure 172.

\section{Earthquake Hazards in the Los Angeles Region}

\section{SEVERITY OF SHAKING AS A FUNCTION OF MAGNITUDE AND DISTANCE}

Because strong-motion records are available for only a limited number of sites in a relatively small number of earthquakes, an independent technique is needed to estimate the distance over which a particular earthquake could trigger landslides on slopes having a given value of critical acceleration. To fill this need, we have developed an empirical relation for the severity of seismic shaking (as expressed by the Arias intensity) as 


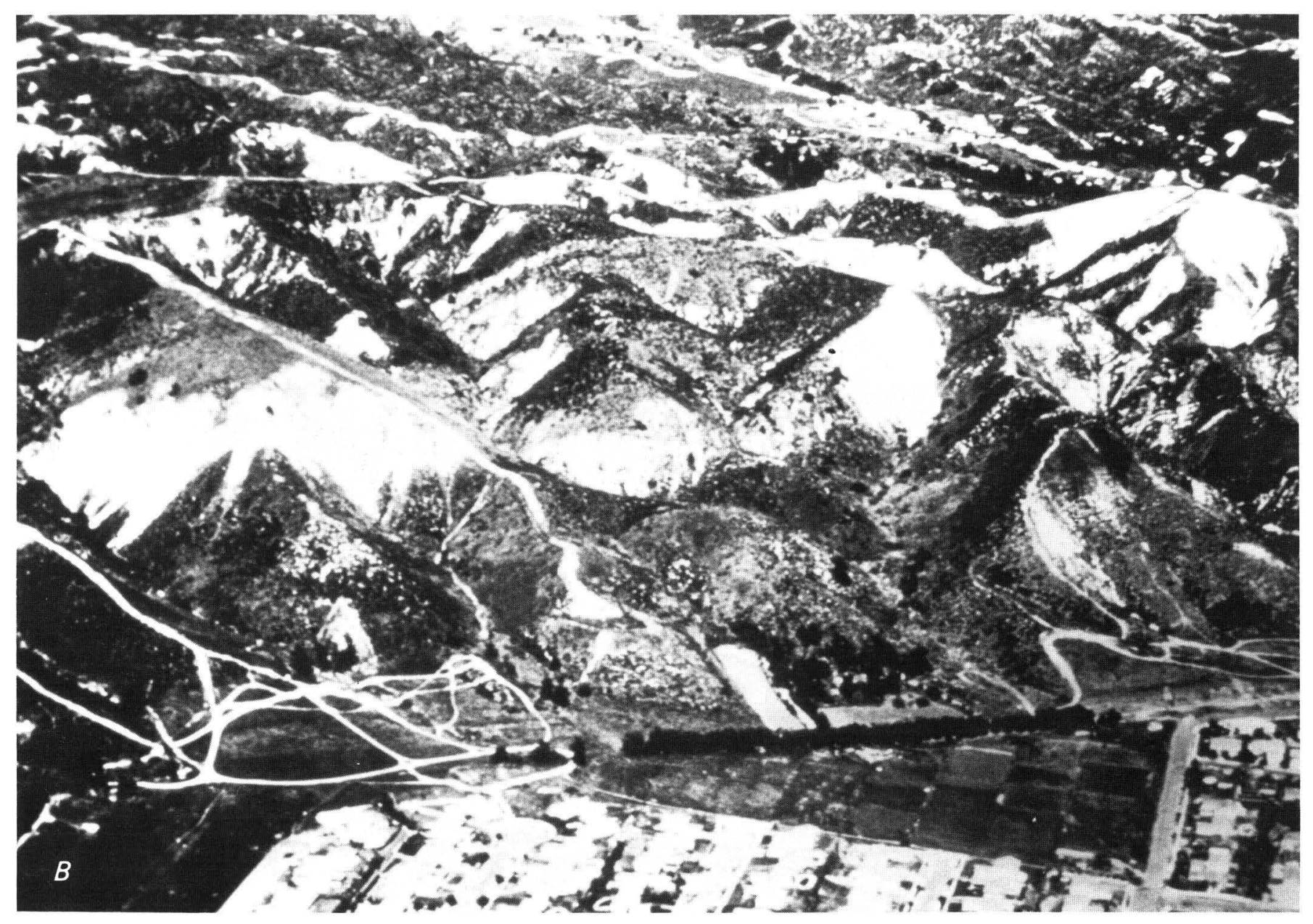

FIGURE 166.-Continued

a function of earthquake magnitude and distance from the seismic source.

Because the data set of reported Arias intensity values is rather limited (table 47), two assumptions were used to constrain the statistical analysis:

1. For a given distance from the seismic source, the logarithm of the Arias intensity is assumed to be a linear function of the magnitude of the earthquake as measured by the moment magnitude scale of Hanks and Kanamori (1979).

2. For a given earthquake magnitude, an inverse square relation was assumed between the Arias intensity and the source distance.

These two assumptions result in the following empirical magnitude-distance-Arias intensity relation:

$$
\log I_{a}=K_{0}+K_{m} M-2 \log r+K_{\sigma} P
$$

where $\boldsymbol{M}$ is the moment magnitude, $\mathrm{r}$ is the source distance (measured from the slip surface), $K_{0}$ and $K_{m}$ are proportionality constants, $K_{\sigma}$ is the standard deviation of the distribution of values of Arias intensity for a given magnitude and distance, and $P$ is exceedance probability $(P=0$ for the mean (50-percent exceedance probability) and $P= \pm 1$ for one standard deviation above or below the mean (16- or 84-percent exceedance probability), respectively).

The first assumption (that $\log I_{a} \propto \mathbf{M}$ ) is supported by several relations from source-mechanism theory (Hanks and McGuire, 1981), which also allow the proportionality constant $\left(K_{m}\right)$ to be evaluated (W. Joyner, personal communication, 1983). The chain of reasoning laid out by Joyner is as follows:

1. For a constant stress drop, the root mean square of the acceleration $\left(A_{\mathrm{rms}}\right)$ is inversely proportional to the square root of the corner frequency, $f_{0}$ (Hanks and McGuire, 1981).

Earthquake-Induced Landsliding

333 


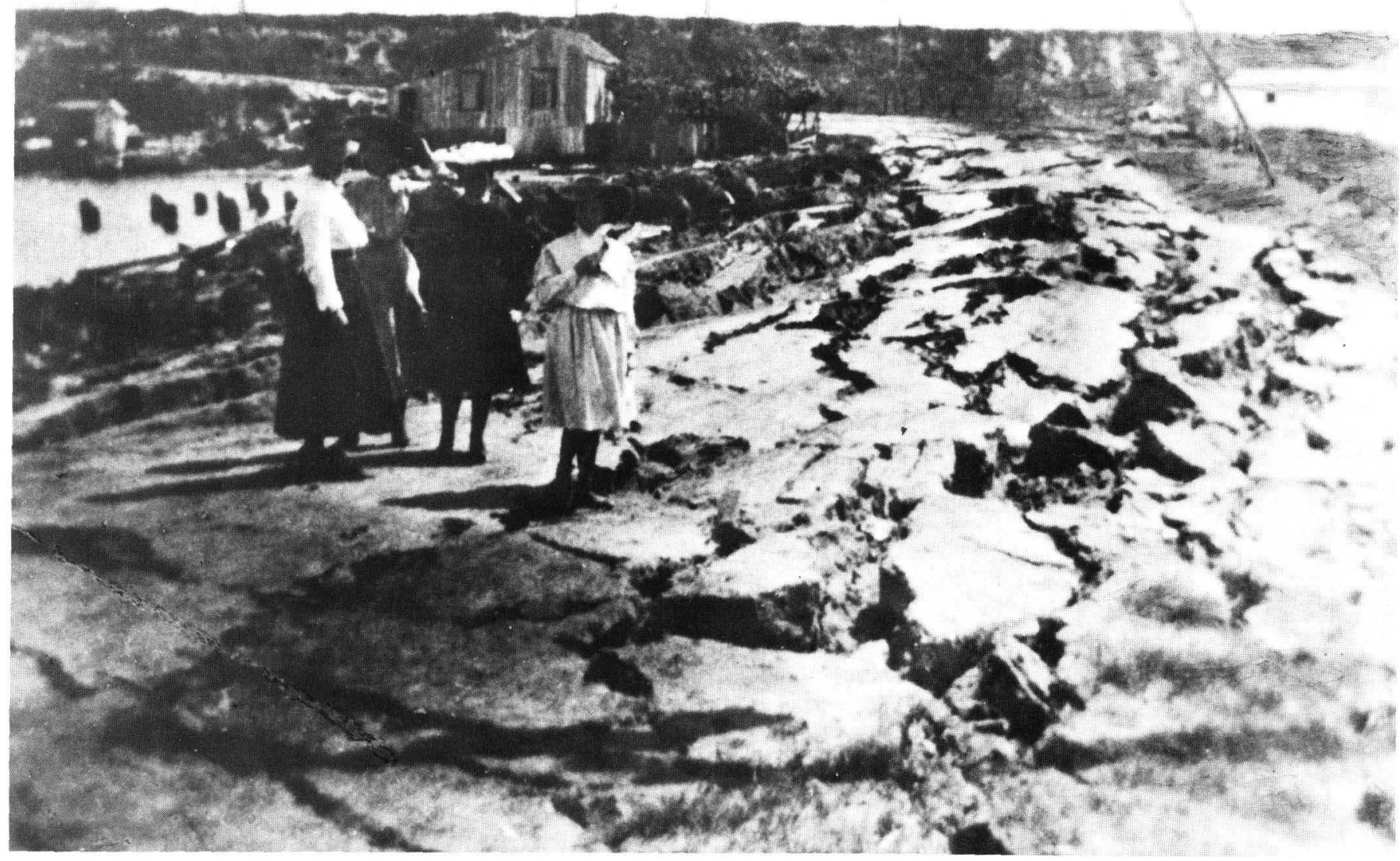

FIGURE 167.-Lateral spreading in Moss Landing caused by the April 18, 1906, San Francisco earthquake. Large areas in the Los Angeles region are susceptible to liquefaction-induced lateral spreading (Tinsley and others, this volume). (Photograph courtesy of Monterey County Historical Society, Inc., Salinas, Calif.)

2. The corner frequency is inversely proportional to the cube root of the seismic moment $M_{0}$.

3. The duration of seismic shaking $\left(T_{d}\right)$ is inversely proportional to the corner frequency (Hanks and McGuire, 1981); thus, $T_{d} \propto M_{0}^{1 / 3}$.

4. By definition, the Arias intensity is proportional to the integral of the acceleration squared over the time (Arias, 1970), which is equal to $A_{\mathrm{rms}}^{2} \mathrm{~T}_{d}$; so,

$$
I_{a} \propto A_{r m s}^{2} T_{d} \propto\left(M_{0}^{1 / 6}\right)^{2} M_{0}^{1 / 3}=M_{0}^{2 / 3}
$$

and so,

$$
\log I_{a} \propto 2 / 3 M_{0}
$$

5. By definition, the moment magnitude is equal to

$$
M=2 / 3 \log M_{0}-10.7
$$

(Hanks and Kanamori, 1979).

6. Therefore, $\log \mathrm{I}_{a}$ is proportional to $\mathbf{M}$, and the proportionality constant $K_{m}=1.0$ (W. Joyner, personal communication, 1983).

\section{Earthquake Hazards in the Los Angeles Region}

To have a common reference for magnitude, we corrected the reported Arias intensity values for a variety of magnitudes equivalent to a $\mathbf{M} 6.5$ event for the same source distance $\left(I_{\alpha}{ }^{*}\right)$ by using the linear assumption; that is, $\log I_{a}^{*}=\log I_{a}+(6.5-M)$. We then compared these "corrected" values of Arias intensity with the log of the source distance (fig. 173) and derived the value of $K_{0}$ that best fits the data, $K_{0}=-4.1$. The source distance was corrected for focal depth. The standard deviation was found to be $K_{\sigma}=0.44$. Thus, our magnitude-distance relation for Arias intensity becomes

$$
\log I_{a}=-4.1+M-2 \log r+0.44 P
$$

Using this relation between magnitude, distance, and Arias intensity, we can estimate the seismic shaking severity at any site, given the magnitude of the event, the distance from the site to the seismic source, and the probability $(P)$ of the actual Arias intensity's exceeding the predicted Arias intensity. For example, a site $20 \mathrm{~km}$ from a M 6.5 event would have a 50-percent chance 


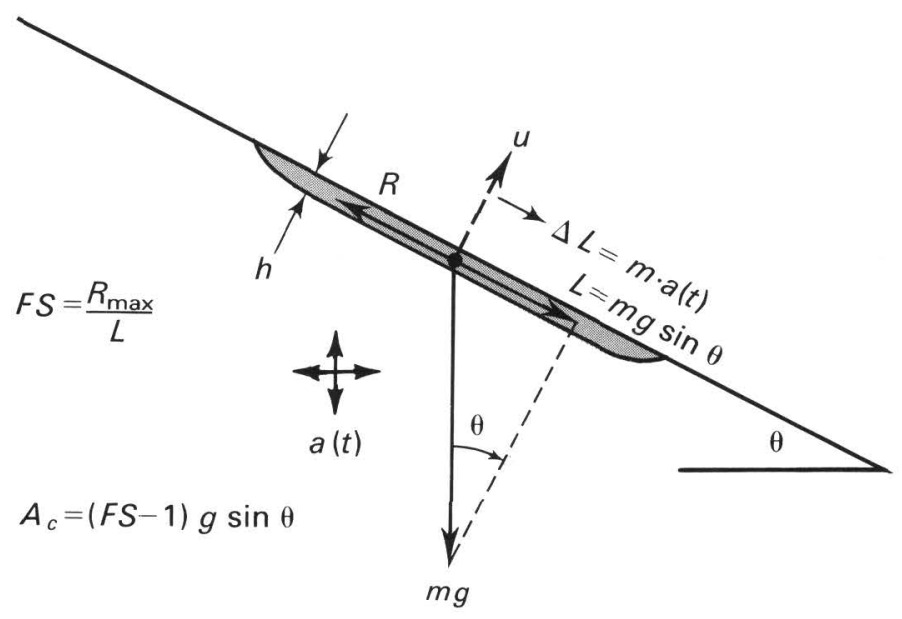

FIGURE 168.--Model of a potential landslide (shaded area) on a constant slope showing the interaction of the gravitational load $(L)$, the resistance force $(R)$, and the seismic acceleration field $\left(a\left(t_{1}\right)\right)$. The slope has a steepness angle equal to $\Theta$; the potential slide block has a thickness equal to $h$. The potential slide has a mass equal to $m$. The term $g$ is acceleration due to gravity.

$(P=0)$ of experiencing an Arias intensity of $0.63 \mathrm{~m} / \mathrm{s}$ or greater, corresponding to an $\left(A_{c}\right)_{10}$ of $0.05 \mathrm{~g}$ (fig. 172). A site $50 \mathrm{~km}$ away would have a 50-percent chance of exceeding $I_{a}=0.1 \mathrm{~m} / \mathrm{s}\left(\left(A_{c}\right)_{10}=0.012 \mathrm{~g}\right)$ (fig. 172) but would also have a finite probability (3.5 percent, corresponding to $P=1.8$ ) of experiencing an $I_{a}$ of $0.63 \mathrm{~m} / \mathrm{s}$ or greater-the same value calculated for $20 \mathrm{~km}$ (for $\mathrm{P}=0$ ).

\section{PREDICTING THE LIMITS OF LANDSLIDING FROM AN EARTHQUAKE}

The relation between magnitude, source distance, and seismic shaking severity derived above provides a partial means of answering the question, "How far away can an earthquake of a given size trigger landslides?" We now need, however, an additional piece of information: "What is the minimum seismic shaking severity (as measured by $I_{a}$ ) at which landsliding is likely on susceptible slopes?" One approach to this question is to make a direct comparison of our magnitude-source distance-Arias intensity relation and the relations between magnitude and most distant landslides developed from our studies of historical earthquakes (fig. 164). We can make such a comparison simply by plotting the magnitude versus the source distance ( $r$ ) for given values of Arias intensity and exceedance probabilities (fig. 174). After the statistical variations have been taken into account, the "best fits" to the historical earthquake data are (1) a value of $I_{a}=0.5 \mathrm{~m} / \mathrm{s}$ for coherent landslides (fig. $174 \mathrm{~A}$ ), (2) $I_{a}=0.15 \mathrm{~m} / \mathrm{s}$ for disrupted landslides (fig.

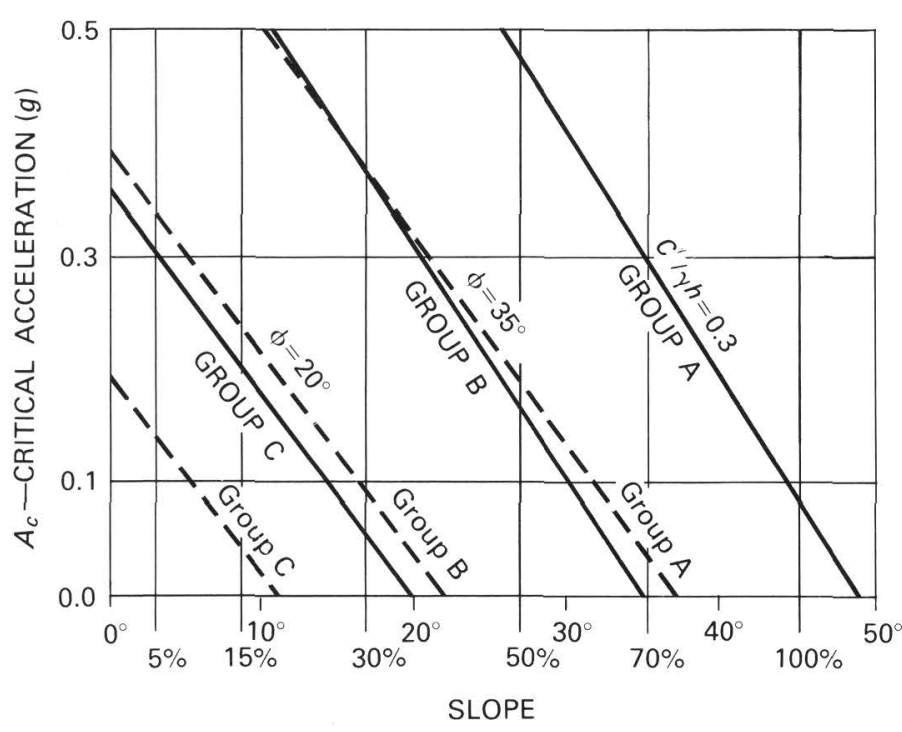

FIGURE 169.-Plots of critical acceleration $\left(A_{c}\right)$ versus slope steepness for three sets of lithologies: group A, strongly cemented rocks (crystalline rock and well-cemented sandstone); group B, weakly cemented rocks (sandy soil and poorly cemented sandstone); group $\mathrm{C}$, argillaceous rocks (clayey soil and shale). The cohesion factor, $c^{\prime} / \gamma \mathrm{h}$, for group A assumes values of $\mathrm{c}^{\prime}=300 \mathrm{psf}, \gamma=100 \mathrm{pcf}$, and $h=10 \mathrm{ft}$. The angle of internal friction $(\phi)$ (peak strength, undrained conditions) is $35^{\circ}$ for sands, sandstone, and crystalline rocks and $20^{\circ}$ for clayey soils and shales. The solid lines depict dry slope materials, and the dashed lines depict saturation from the slide plane to the surface.

174B), and (3) $I_{a}=0.5 \mathrm{~m} / \mathrm{s}$ for lateral spreads and flows (fig. 174C). For these values of $I_{a}$, the historical data are completely contained within two standard deviations of the mean $(P= \pm 2)$, corresponding to exceedance probabilities of 2 and 98 percent, respectively.

Using the relations in figure 172, we can convert the "threshold" values of Arias intensity to $\left(A_{c}\right)_{10}=0.05 \mathrm{~g}$ for $I_{a}=0.5 \mathrm{~m} / \mathrm{s}$ (coherent slides and lateral spreads and flows) and $\left(A_{c}\right)_{2}=0.05 \mathrm{~g}$ for $I_{a}=0.15 \mathrm{~m} / \mathrm{s}$ (disrupted slides). Thus, a value of critical acceleration of $0.05 \mathrm{~g}$ appears to be the approximate value of the susceptibility of the slopes that failed at the greatest distance from the source areas of these historical earthquakes. Of course, the actual slopes that failed almost certainly had a wide range of values of critical acceleration, just as we would expect a range of $A_{c}$ values in any given region. To construct numerical models of the areal distribution of earthquake-induced landslides, however, a value of $A_{c}=0.05 \mathrm{~g}$ appears to be a useful approximation of a "lower bound" for the seismic stability of susceptible slopes, whatever the mechanism of failure.

At first glance, this estimate $\left(A_{c}=0.05 \mathrm{~g}\right)$ for the critical acceleration of the "most susceptible slopes" appears to be rather high. Is it not possible for a slope to have a value of $A_{c}=0.01 \mathrm{~g}$ or even less? Why, in fact, should there be any lower limit to $A_{c}$ ? Is the value of 


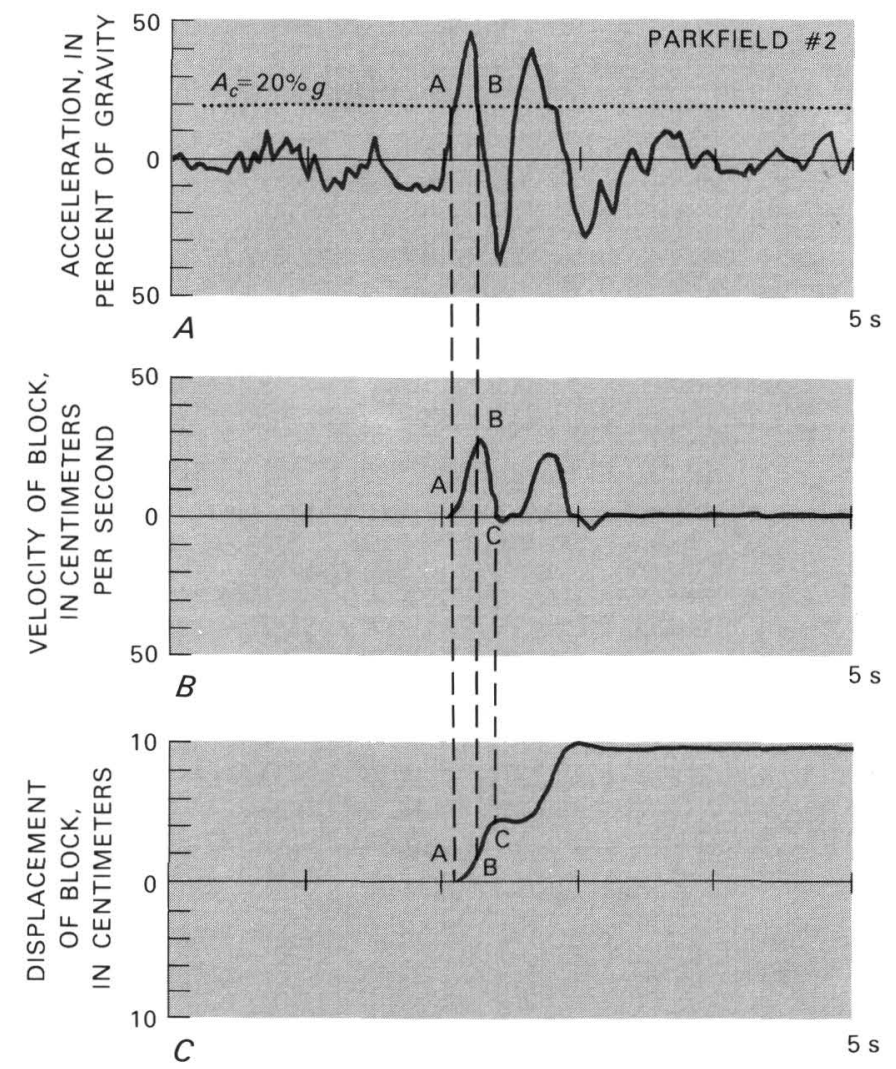

FIGURE 170.-Algorithm for the Newmark analysis. A, Strong-motion record (1966 Parkfield earthquake, station 2) on which critical acceleration $\left(A_{c}=0.2 \mathrm{~g}\right)$ for a hypothetical slope has been superimposed. B, Velocity of block versus time. C, Displacement of block versus time. Point $\mathrm{A}$, ground acceleration of block first exceeds critical acceleration; point $\mathrm{B}$, block reaches maximum velocity; point $\mathrm{C}$, motion ceases, and block comes to rest.

$A_{c}=0.05 \mathrm{~g}$ for the lower bound merely an artifact of our numerical analysis?

An argument can be made that there is, in fact, a practical minimum for the critical acceleration, below which slopes would have a high probability of failure from nonseismic causes over a time period much shorter than the return period for strong seismic shaking at any particular site. For example, heavy rainfall causes many landslides in the Santa Monica Mountains on a return period of 10 to $25 \mathrm{yr}$ (Campbell, 1975), whereas the return period of strong seismic shaking in the same region is probably at least several decades.

As an illustration, consider a hypothetical slope in cohesionless material (loose sandy soil) having an angle of friction of $\phi=30^{\circ}$ and a porosity of 25 percent. The slope steepness is $24^{\circ}$. The optimum slide plane is located at a depth of $5 \mathrm{~m}$, which is below a water table at $2.9 \mathrm{~m}$ depth. The critical acceleration of this slope is approximately $A_{c}=0.01 \mathrm{~g}$, so the slope is highly susceptible to seismically induced failure. A rise in the water table of only $19 \mathrm{~cm}$, however, would also cause this slope to fail under static conditions $(F S=1)$. If there are no losses from runoff or bedrock infiltration, this rise in water level would require only 1.8 in of rainfall in a period of a few hours-a fairly common occurrence in this area (return period less than $1 \mathrm{yr}$ ). On the other hand, a similar slope in similar materials having a slightly lower water table or a slightly gentler slope angle, such that $A_{c}=0.05 \mathrm{~g}$, would require 9.2 in of rainfall within the same period of time-a much less common occurrence whose return period begins to approach that of strong seismic shaking. Therefore, a slope where $A_{c}=0.01 \mathrm{~g}$ would be much more likely to fail because of heavy rainfall than from seismic shaking. A slope where $A_{c}=0.05 \mathrm{~g}$, on the other hand, would survive all but the heaviest rainfall yet still be highly vulnerable to failure under strong seismic shaking.

We can now use our magnitude-source distanceArias intensity relation (fig. 173) to estimate the source distance from a given earthquake at which the probability that the seismic shaking severity will exceed any given value is 50 percent $(P=0)$. Taking $I_{a}=0.5 \mathrm{~m} / \mathrm{s}$ as the threshold shaking severity for coherent slides, we estimate this distance to be approximately $24 \mathrm{~km}$ for a M 6.5 event (fig. 174A). Figure 175 is a map of the Los Angeles area showing a hypothetical seismic source zone for a $M 6.5$ event on the northern NewportInglewood fault. A line is drawn $24 \mathrm{~km}$ from the source to indicate the area within which the chance that the ground motion will exceed the threshold severity is greater than 50 percent. Figure 175 also includes a line $65 \mathrm{~km}$ from the source zone, corresponding to the predicted outer limit for coherent slides as determined from worldwide historical data (fig. 164). Beyond this $65-\mathrm{km}$ limit, coherent slides are unlikely during this event, even for susceptible slopes. In a middle zone, between 24 and $65 \mathrm{~km}$ from the fault rupture, the probability that shaking would be severe enough to cause coherent slides on susceptible slopes is finite but less than 50 percent.

The same reasoning can be followed with regard to rock falls and other disrupted landslides. If the historical magnitude-distance relation for disrupted landslides (fig. $164 \mathrm{~A}$ ) is compared with the magnitudedistance-Arias intensity relation, the best fit to the historical data is obtained with an Arias intensity value of approximately $0.15 \mathrm{~m} / \mathrm{s}$ (fig.174B). As we did above for coherent slides, we take this value of $I_{a}$ as the threshold shaking severity for disrupted landslides and calculate a source distance corresponding to a 50-percent exceedance probability for this value. This distance is approximately $41 \mathrm{~km}$. 


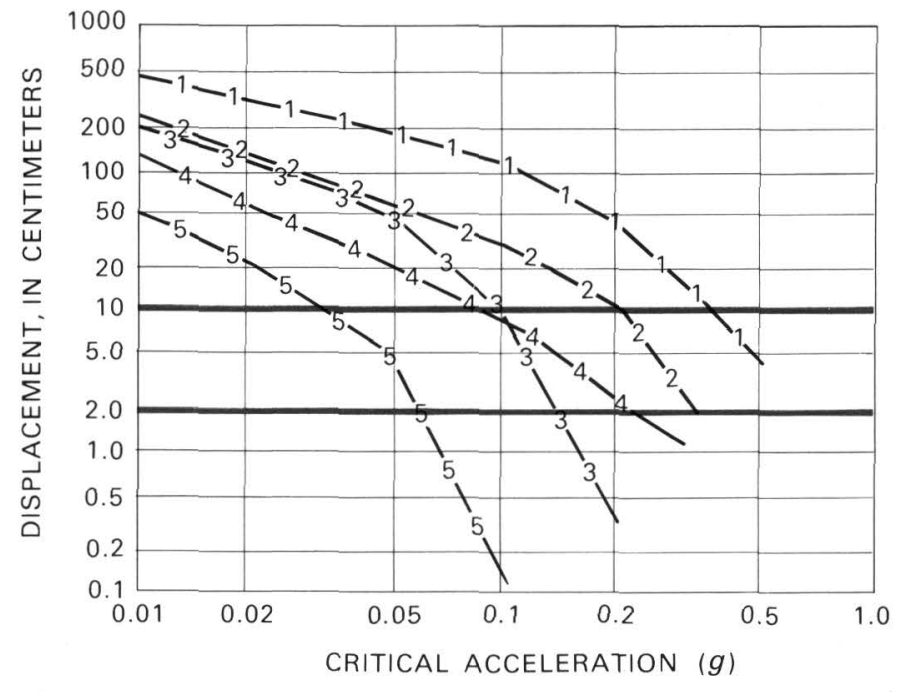

FIGURE 171.-Displacements predicted by the Newmark analysis as a function of assumed critical acceleration for several strong-motion records from California earthquakes. The stronger of the two horizontal components of the records was used in each case. Also indicated for reference are the values of critical displacement for coherent landslides (slumps, block slides, and earth flows) $(10 \mathrm{~cm})$ and for disrupted landslides (falls, slides, and avalanches) $(2 \mathrm{~cm})$. 1, S. $16^{\circ}$ E. component of horizontal ground motion recorded at Pacoima damsite from the 1971 San Fernando earthquake; 2, 1966 Parkfield earthquake, station 2; 3, 1940 El Centro earthquake; 4, 1966 Parkfield earthquake, station 5; 5, 1952 Taft earthquake.

Figure 176 is a second map, similar to figure 175 , whose lines show distances of $41 \mathrm{~km}$ (50-percent exceedance probability) and $112 \mathrm{~km}$ (historical limit from fig. 164A) from the source area of the postulated $M 6.5$ event on the Newport-Inglewood fault. Again, the inner area denotes a zone having a high probability that shaking will exceed the threshold level required to cause

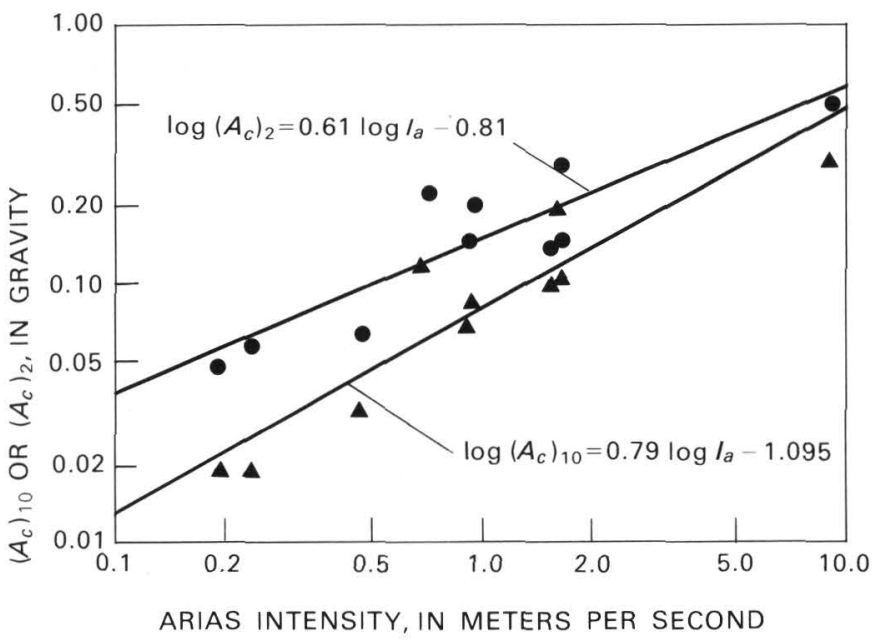

FIGURE 172.- $\left(A_{c}\right)_{10}$ (triangles) and $\left(A_{c}\right)_{2}$ (circles) versus Arias intensity $\left(I_{a}\right)$ for 10 strong-motion records. Regression lines are also plotted for $\log \left(A_{c}\right)_{10}$ versus $\log I_{a}$ and $\log \left(A_{c}\right)_{2}$ versus $\log I_{a}$. The standard deviations for these regressions are 0.144 and 0.151 , respectively.

disrupted landslides from susceptible slopes $\left(A_{c}<0.05 \mathrm{~g}\right)$ (geologic characteristics as shown in table 45), a middle area (between 41 and $112 \mathrm{~km}$ ) having less than a 50-percent (but still significant) probability that shaking will be severe enough to trigger such landslides, and a zone beyond $112 \mathrm{~km}$ where landslides are unlikely.

Figure 177 is a third map, similar to figures 175 and 176, depicting the probabilities of failure of slopes susceptible to lateral spreads, flows, or subaqueous landslides. Taking a value of $I_{a}=0.5 \mathrm{~m} / \mathrm{s}$ as the threshold shaking severity for landslides of these types (fig. 175C), we plot an equidistance line $24 \mathrm{~km}$ from the source area of the postulated $\mathbf{M} 6.5$ event on the Newport-Inglewood fault; this line corresponds to a 50-percent probability

TABLE 46.-Measures of shaking severity for several strong-motion records

[All earthquakes occurred in California, unless otherwise noted. $A$, acceleration; $I$, Arias intensity; $\left(A_{c}\right]_{10}$, critical acceleration for coherent landslides; $\left(A_{C}\right)_{2}$, critical acceleration for disrupted landslides]

\begin{tabular}{|c|c|c|c|c|}
\hline Record/component & $\begin{array}{l}(A),{ }^{1} \\
\text { in } g\end{array}$ & $\begin{array}{c}(I){ }^{1},{ }^{1} \\
\text { in } \mathrm{m} / \mathrm{s}\end{array}$ & $\begin{array}{c}(A)_{10} \\
\text { in } g\end{array}$ & $\begin{array}{l}\left(A_{c}\right)_{2}, \\
\text { in } g\end{array}$ \\
\hline 1966 Parkfield ----------------------- Station 2/065 & 0.485 & 1.64 & 0.20 & 0.31 \\
\hline 1966 Parkfield -- & .447 & .96 & .09 & .21 \\
\hline 1979 Coyote Lake ------------------- Station 6/050 & .36 & .71 & .12 & .24 \\
\hline 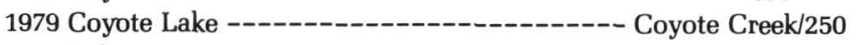 & .206 & .25 & .02 & .06 \\
\hline 1975 Kalapana, Hawaii ------------------- Hilo/344 & .205 & .20 & .02 & .05 \\
\hline 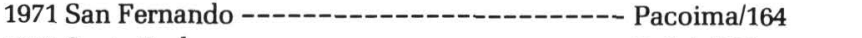 & 1.22 & 9.16 & .33 & .52 \\
\hline 1978 Santa Barbara ---------------------- Goleta/180 & .338 & .93 & .07 & .15 \\
\hline 1952 Kern County ----------- & .144 & .48 & .033 & .065 \\
\hline 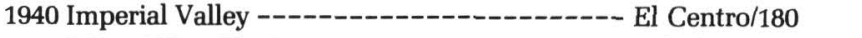 & .293 & 1.61 & .10 & .15 \\
\hline 1978 Miyagi-Ken Oki, Japan -------------- Tohoku Univ./000 & .238 & 1.69 & .11 & .16 \\
\hline
\end{tabular}

${ }^{1}$ The values of $A$ and $I$ reported in this table may vary slightly from those reported in tables 47 and in the standard catalogs, because of differences in digitization, time base, and correction factors. These differences should not affect the correlations developed in figure 172 . 


\begin{tabular}{|c|c|c|c|c|c|}
\hline Earthquake/station & $\begin{array}{c}\text { Moment } \\
\text { magnitude } \\
(M)\end{array}$ & $\begin{array}{c}\text { Source } \\
\text { distance } \\
\text { (r), } \\
\text { in } \mathbf{k m}\end{array}$ & $\begin{array}{c}\text { Acceleration } \\
\text { (A) }\end{array}$ & $\begin{array}{c}\text { Arias } \\
\text { intensity } \\
\left(I_{0}\right) \\
\text { in } \mathrm{m} / \mathrm{s}\end{array}$ & $\begin{array}{c}\text { Corrected } \\
\text { Arias intensity, } \\
\left(I_{\alpha}\right) \\
\text { in } \mathrm{m} / \mathrm{s}\end{array}$ \\
\hline Kern County/Taft ---------- & 7.4 & 43 & 0.179 & 0.59 & 0.074 \\
\hline Parkfield/Station 2 - & 6.1 & $6.6^{1}$ & .498 & 1.71 & 4.30 \\
\hline Parkfield/Station 5 - & 6.1 & $9.3^{1}$ & .434 & .85 & 2.135 \\
\hline Lower California/El Centro ----- & 6.5 & 53 & .182 & .62 & .62 \\
\hline Imperial/El Centro -------- & 7.0 & 12 & .348 & 1.93 & .61 \\
\hline San Fernando/Castaic --------- & 6.6 & 21 & .271 & .99 & .79 \\
\hline Eureka/Federal Building ------- & 6.5 & 25 & .257 & .710 & .71 \\
\hline San Fernando/Orion -------- & 6.6 & 20 & .255 & 1.28 & 1.02 \\
\hline Lytle Creek/Wrightwood ------- & 5.3 & 14 & .198 & .14 & 2.22 \\
\hline Parkfield/Temblor --------- & 6.1 & $16^{1}$ & .347 & .45 & 1.13 \\
\hline Ferndale/City Hall ---------- & 5.6 & 25 & .237 & .105 & .83 \\
\hline San Fernando/Palmdale ------ & 6.6 & 34 & .113 & .334 & .265 \\
\hline Kern County/Pasadena -------- & 7.4 & 130 & .053 & .114 & .014 \\
\hline Hollister/City Hall -- ------- & 5.6 & 40 & .065 & .135 & 1.072 \\
\hline San Francisco/Golden Gate ---- & 5.3 & 11 & .105 & .05 & .79 \\
\hline San Francisco/State Bldg. ------ & 5.3 & 17 & .085 & .052 & .82 \\
\hline San Francisco/Alex. Bldg. ----- & 5.3 & 16 & .043 & .016 & .25 \\
\hline San Francisco/Oakland ------- & 5.3 & 26 & .04 & .010 & .16 \\
\hline Borrego/San Onofre ------- & 6.6 & 122 & .046 & .035 & .028 \\
\hline Kern County/(A005) - & 7.4 & 85 & .131 & .29 & .037 \\
\hline Kern County/(A006) ------- & 7.4 & 109 & .053 & .11 & .014 \\
\hline Borrego/(A020) - & 6.6 & 96 & .029 & .03 & .024 \\
\hline Long Beach/Vernon -------- & 6.3 & 53 & .133 & .23 & .365 \\
\hline San Jose/(A010) - & 5.8 & 10 & .102 & .075 & .376 \\
\hline Southern California/(B023) ----- & 5.4 & 38 & .033 & .010 & .126 \\
\hline Wheeler Ridge/(B031) --_----- & 5.9 & 43 & .068 & .042 & .167 \\
\hline Central California/(U307) ------ & 5.0 & 6 & .057 & .05 & 1.58 \\
\hline Northern California/(U308) ----- & 5.7 & 59 & .075 & .04 & .25 \\
\hline Torrance-Gardena/(V316) ----- & 5.4 & 6 & .055 & .04 & .50 \\
\hline Southern California/(V329) ----- & 5.0 & 6 & .167 & .100 & 3.16 \\
\hline
\end{tabular}

${ }^{1}$ Source distances for the 1966 Parkfield earthquake adjusted for the surfacerupture zone proposed by Lindh and Boore (1981).

that the ground motion will exceed the threshold severity. We plot another equidistance line at $59 \mathrm{~km}$ from the fault to denote the predicted outer limit of lateral spreads, flows, and subaqueous landslides from a $\boldsymbol{M} 6.5$ event as determined from worldwide historical data (fig. 164C) (Keefer, 1984b). Thus, areas having a high susceptibility to lateral spreads, flows, and subaqueous landslides (see table 45; Tinsley and others, this volume; Clarke and others, this volume) would have a high probability of failure in the postulated event if they were located within $24 \mathrm{~km}$ of the fault and a low probability of failure if they were located farther than $59 \mathrm{~km}$ from the fault.

\section{A HYPOTHETICAL SITE EVALUATION}

To illustrate how the methods developed in this chapter might be applied, we will consider a residence on the northern slope of the eastern Santa Monica Mountains, near the city of Sherman Oaks. The lot has a grade of 25 percent (equal to a slope angle $\theta$ of $14^{\circ}$ ), facing to the north. Would this site run a significant risk of damage from slope failure in an earthquake?

The first step in answering this question would be to locate the property on a geologic map (Yerkes and

\section{Earthquake Hazards in the Los Angeles Region}




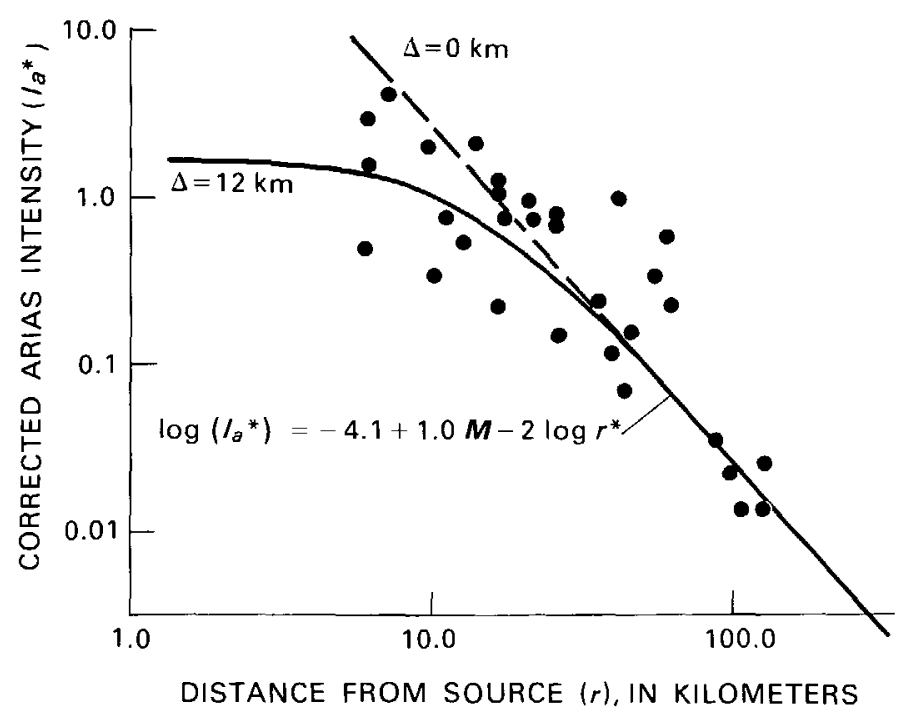

FIGURE 173.-Corrected Arias intensity versus distance from the seismic source area. The values of Arias intensity were calculated from strong-motion records (table 46) and adjusted to be equivalent to a $M$ 6.5 event at the same source distance, on the basis of an assumed log-linear relationship between magnitude and Arias intensity for a given distance. $\Delta$, focal depth; $r^{*}, \sqrt{r^{2}+\Delta^{2}} ; K_{\sigma}, 0.44$.

Campbell, 1980). On doing so, we find that the lot is located within the Modelo Formation, a "siltstone, soft mudstone, and siliceous shale, [with] minor interbedded sandstone." Consulting table 45, we find that the slope of the lot is not steep enough to have a significant risk of rock falls, rock slides, or rock avalanches. The slope steepness $\left(14^{\circ}\right)$, however, closely approaches the minimum slope for rock slumps $\left(\theta \geq 15^{\circ}\right)$. Also, the shale units within the Modelo generally fit the "type of material" in which rock slumps occur (table 45), and some of the shale horizons may be weak enough to fit the criteria for soil slumps $\left(\theta>10^{\circ}\right)$ or soil block slides $\left(\theta>5^{\circ}\right)$. If the colluvium is thick ( $>3 \mathrm{~m}$ ) or, as is very likely, the house is built on a pad of artificial fill, the criteria for soil slumps or block slides may be met. If the bedding of the Modelo Formation dips out of the slope at this location, the likelihood of a block slide increases (see table 45).

Although local codes required the cut-and-fill foundation pad for the house to meet a minimum specification of $F S=1.5$, that value would correspond to a critical acceleration of only $A_{c}=(F S-1) \sin \theta=0.12 \mathrm{~g}$. Figure 169 shows that the Modelo Formation (a group $C$ lithology) on a slope of $14^{\circ}$ would also have an $A_{c}$ of roughly $0.12 \mathrm{~g}$ under moist (but not necessarily saturated) conditions. Should the earthquake occur after a period of heavy rainfall, the critical acceleration could be significantly lower, depending on the drainage of the lot, the local hydrologic conditions, and other site-specific factors.
We shall take $A_{c}=0.12 \mathrm{~g}$ as our reference value for subsequent calculations.

Given this value of $A_{c}$, the property in question could sustain significant damage if it were subjected to seismic shaking more severe than $(A)_{10}=0.12 \mathrm{~g}$. (We take $10 \mathrm{~cm}$ as the value of the critical displacement because we are concerned about a slope failure of the slump or block slide type.) How likely is it that the postulated M 6.5 event on the Newport-Inglewood fault zone would cause such severe shaking on this site?

From figure 172 , we see that $\left(A_{c}\right)_{10}=0.12 \mathrm{~g}$ correlates with an Arias intensity value of $1.65 \mathrm{~m} / \mathrm{s}$. Although this residence is well within the 50-percent probability line for exceeding the threshold shaking severity for coherent slides (fig. 175), the threshold severity is only $I_{a}=0.5 \mathrm{~m} / \mathrm{s}$, significantly less than the severity required to cause coherent sliding at this less susceptible site $\left(I_{a}=1.65 \mathrm{~m} / \mathrm{s}\right)$. Using the magnitude-source distance-Arias intensity relation, we calculate that the source distance from a $M$ 6.5 event, which corresponds to a 50-percent exceedance proability for $I_{\alpha}=1.65 \mathrm{~m} / \mathrm{s}$, is approximately $12.5 \mathrm{~km}$. The residence under study is located approximately $16 \mathrm{~km}$ from the nearest point on the Newport-Inglewood fault trace involved in this scenario event. Thus, there is a less than even but significant (roughly one in three) chance that the shaking from this event would exceed $I_{a}=1.65 \mathrm{~m} / \mathrm{s}$ and thus cause displacements of $10 \mathrm{~cm}$ or greater, possible damage being a consequence. Even if this residence experienced little structural or foundation damage, however, utilities and road access could be severely impacted if there were nearby slope failures.

Although this example deals with a specific site, the analytical methods presented in this chapter and the assumptions on which they are based are more appropriate for evaluating the potential for seismically induced landsliding on a regional scale. The results of these methods should be the beginning, not the end, of any evaluation of a specific site. For a more detailed assessment, a homeowner should engage a geologist or an engineer to perform a property inspection.

\section{SUMMARY}

Landslides have caused significant damage in historical southern California earthquakes and will probably pose substantial hazards in future moderate and large events in the Los Angeles region. The number, geographic extent, and hazard potential of landslides increases as earthquake magnitude increases; an event of about $M 4$ is the smallest likely to cause any landslides, 

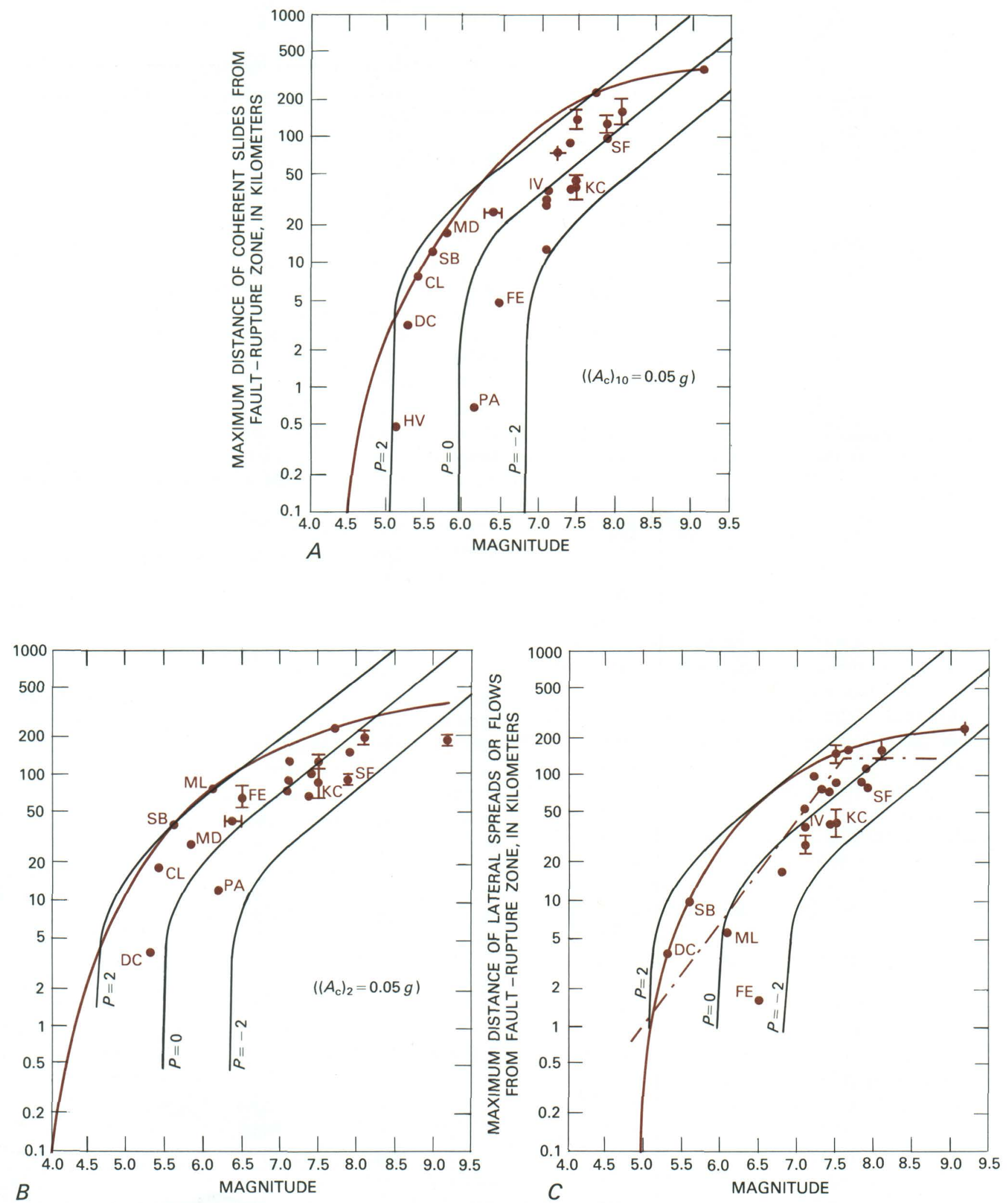

FIGURE 174.-Comparison of data on landsliding from historic earthquakes to the magnitude-source distance relation for Arias intensity. California earthquakes in the data set are as follows: CL, August 6, 1979, Coyote Lake; DC, March 22, 1957, Daly City; FE, February 9, 1971, San Fernando; HV, March 15, 1979, Homestead Valley; IV, May 19, 1940, Imperial Valley; KC, July 21, 1952, Kern County (not included by Keefer (1984b)); MD, January 24, 1980, Greenville-Mount Diablo; ML, May 25, 1980, Mammoth Lakes; PA, June 28, 1966, Parkfield-Cholame; SB, August 13, 1978, Santa Barbara; SF, April 18, 1906, San Francisco. Unlabeled points represent earthquakes outside California (identified by Keefer (1984b)). The heavy lines are the upper bound from historical data. The magnitude-source distance relation for Arias intensity is plotted as a locus of points corresponding to the Arias intensity that appears to provide the "best fit" to the historical data and to exceedance probabilities of $P=0$ (50 percent), $P=2$ standard deviations (2 percent), and $P=-2$ standard deviations ( 98 percent). An average focal depth of $12 \mathrm{~km}$ is assumed for these plots. A, Coherent landslides (slumps and block slides). $I_{a}=0.5 \mathrm{~m} / \mathrm{s}$. B, Disrupted landslides (falls, disrupted slides, and avalanches). $I_{a}=0.15 \mathrm{~m} / \mathrm{s}$. C, Lateral spreads or flows. $I_{a}=0.5 \mathrm{~m} / \mathrm{s}$. The dot-dash curve is the upper bound postulated by Youd and Perkins (1978). 


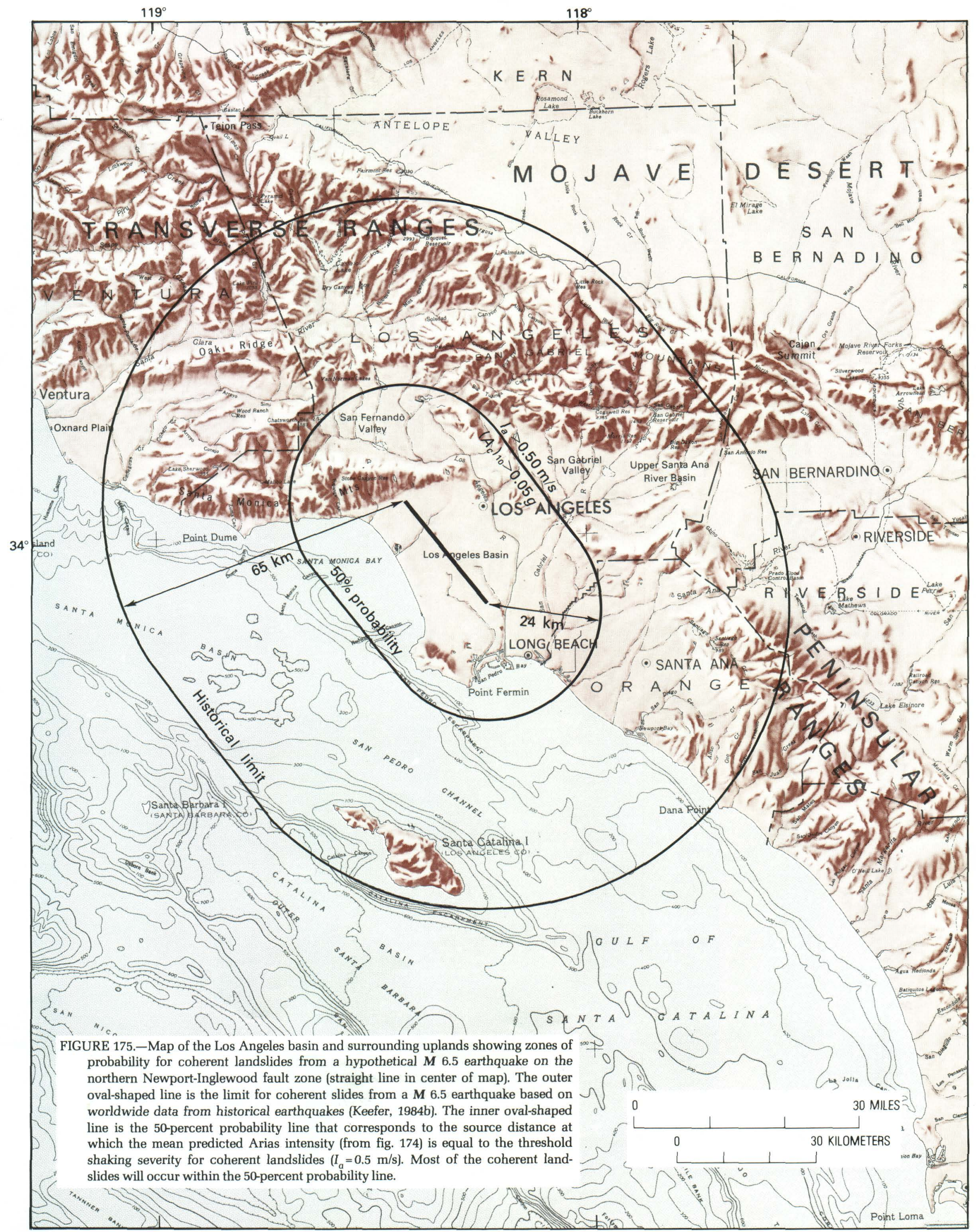




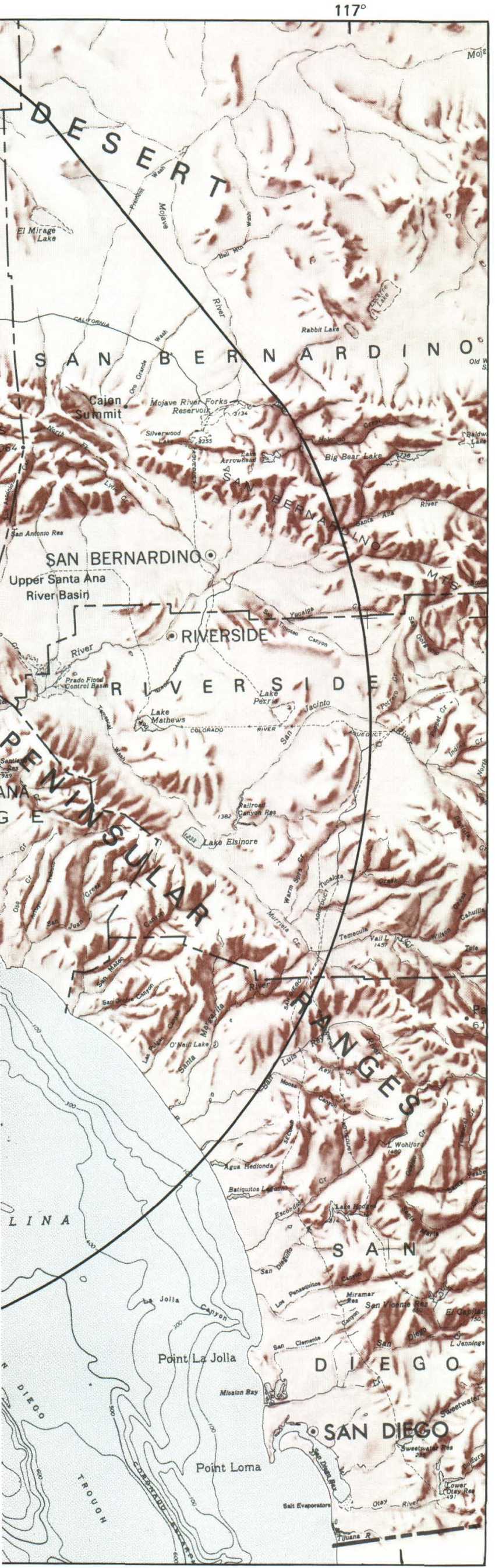

whereas an earthquake of about $\mathbf{M} 8$ or larger is capable of triggering tens of thousands of landslides throughout a region that extends to more than $400 \mathrm{~km}$ from the fault.

Studies of historical events have shown that earthquakes trigger 14 types of landslides. In order of decreasing abundance, these are rock falls, disrupted soil slides, rock slides, soil lateral spreads, soil slumps, soil block slides, soil avalanches, soil falls, rapid soil flows, rock slumps, subaqueous landslides, slow earth flows, rock block slides, and rock avalanches.

Although most or all types of earthquake-induced landslides pose some hazard to human life and property, historical evidence shows that the predominant hazards to life come from rock avalanches, rapid soil flows, and rock falls. Zones at risk from rock falls extend only a few hundred meters from the bases of steep slopes, but zones at risk from rock avalanches or rapid soil flows extend for several kilometers from the localities of landslide initiation. Leading causes of property damage, in addition to these three types of landslides, are soil slumps and soil lateral spreads.

Materials that are most susceptible to earthquakeinduced landslides and the predominant types of landslides in each are (1) weakly cemented, weathered, or intensely fractured rocks (rock falls, slides, avalanches, slumps, and block slides); (2) more indurated rocks where prominent discontinuities dip out of slopes (rock falls and slides, block slides, avalanches, and, possibly, slumps); (3) loose, unsaturated sand (disrupted soil slides and soil avalanches); (4) loose, partly to completely saturated sand or silt (soil slumps, block slides, lateral spreads, subaqueous landslides, and rapid soil flows); (5) saturated soils containing sand and gravel layers alternating with sensitive clay (disrupted soil slides, soil avalanches, and rapid soil flows); (6) loess (rapid soil flows); (7) granular soils that are slightly cemented or contain a clay binder (soil falls); and (8) uncompacted or poorly compacted manmade fill containing little or no clay (soil slumps, block slides, lateral spreads, and rapid soil flows).

The probability that a landslide will occur on a particular slope during a particular earthquake is a func-

FIGURE 176.-Map of the Los Angeles basin and surrounding uplands showing zones of probability for disrupted landslides from a hypothetical M 6.5 earthquake on the Newport-Inglewood fault zone (straight line in center of map). The outer oval-shaped line probability line is the limit for disrupted landslides from a $\mathbf{M} 6.5$ earthquake based on worldwide data from historical earthquakes (Keefer, 1984b). The inner oval-shaped line is the 50-percent probability line that corresponds to the source distance at which the mean predicted Arias intensity is equal to the threshold shaking severity for disrupted slides $\left(I_{a}=0.15 \mathrm{~m} / \mathrm{s}\right)$. Most of the disrupted landslides will occur within the 50-percent probability line. 
]'d

\section{.}

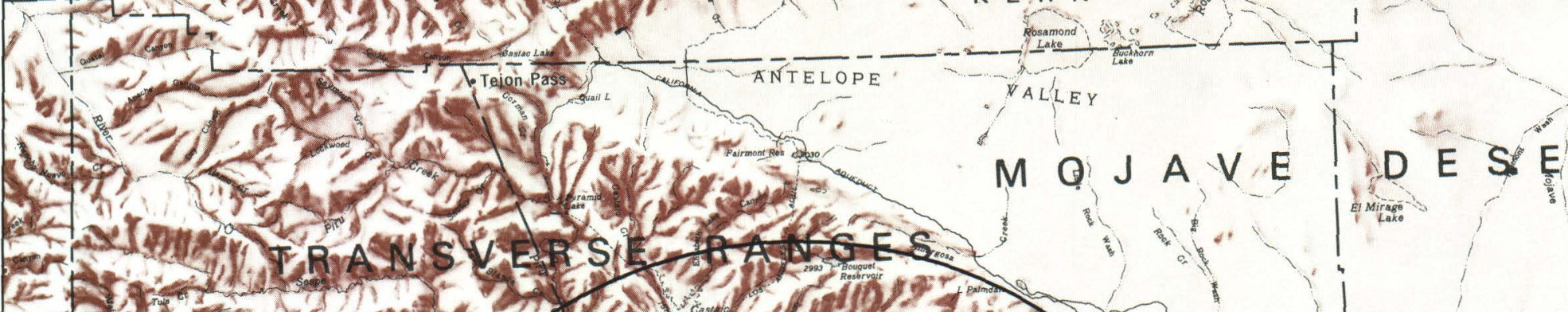

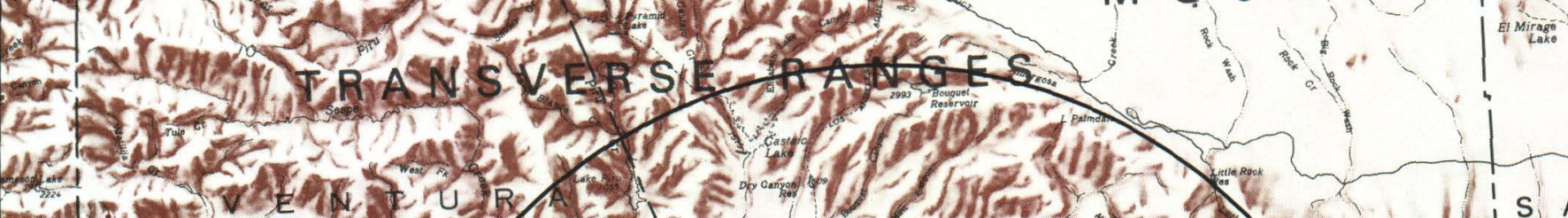
We

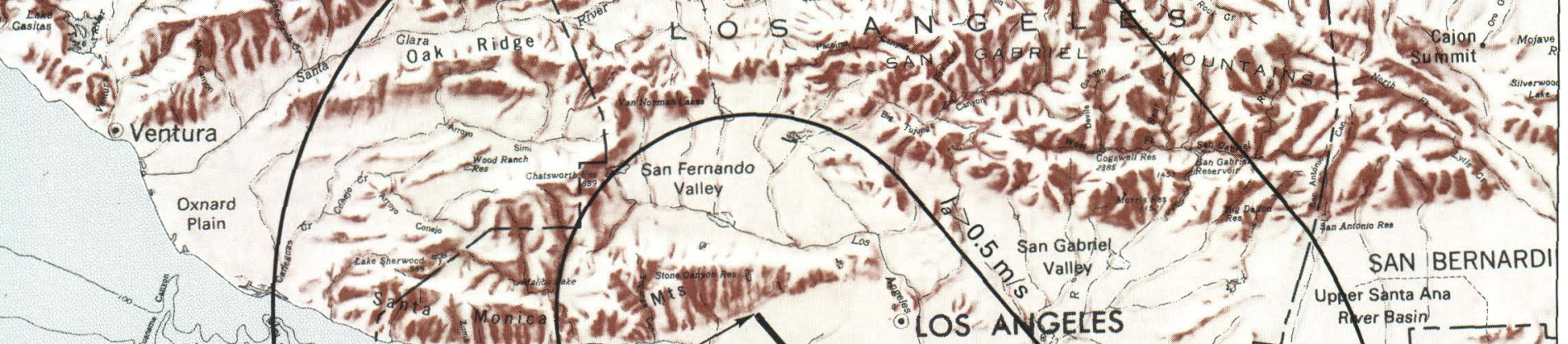

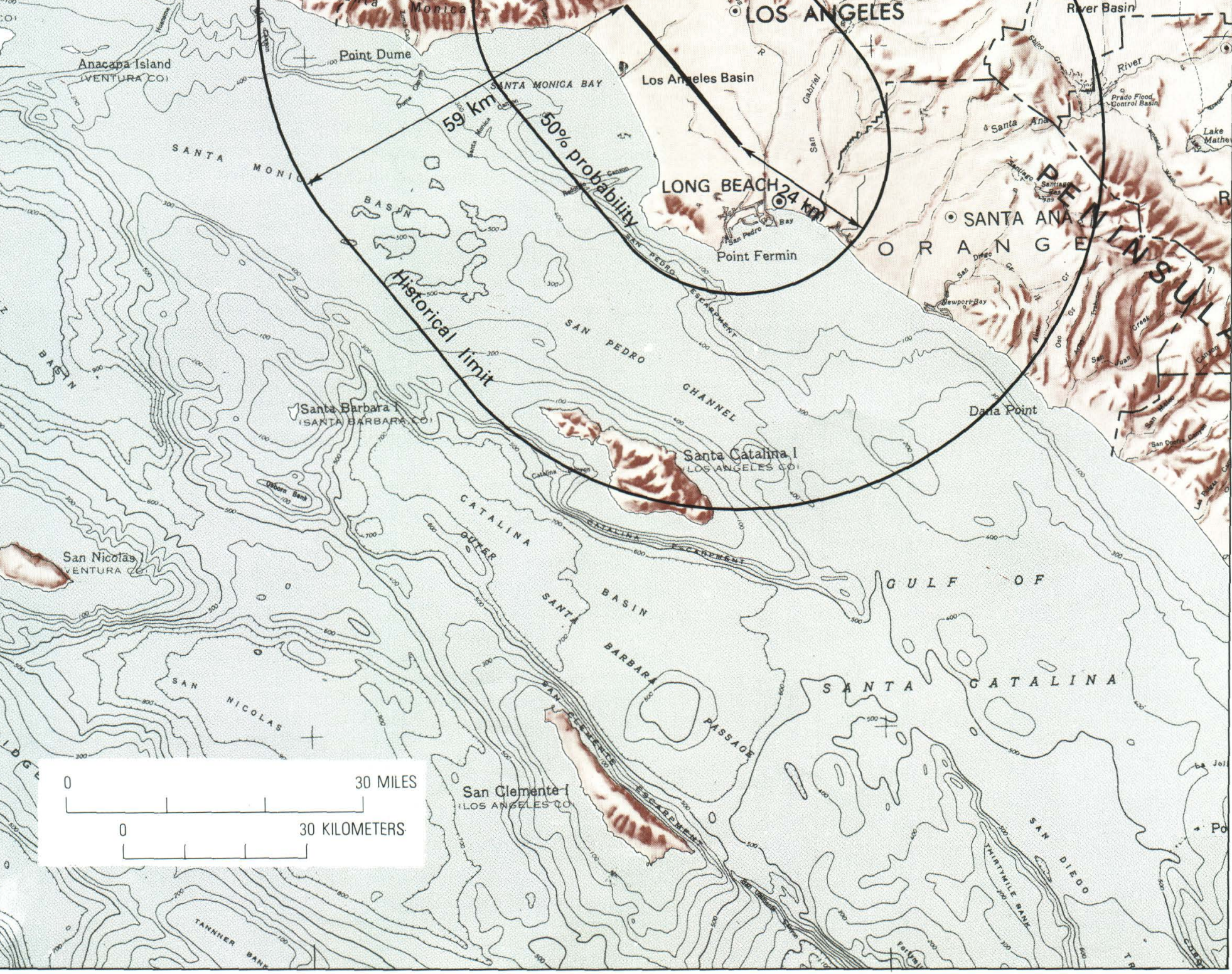


tion of both the preearthquake stability of the slope and the severity of the seismic ground motion. The preearthquake stability of the slope is controlled by both the strength of the slope material and the steepness of the slope. The combinations of slope and lithology that are particularly vulnerable to earthquake-induced landsliding have been determined by a study of historical landslides and experience in postearthquake investigations and are listed in table 45. Another way to express the susceptibility of a slope to seismically induced landsliding is the critical acceleration $\left(A_{c}\right)$, which can be calculated from the static factor of safety as determined by a standard slope stability analysis.

The second factor (severity of the ground shaking re quired for earthquake-induced landsliding) has been investigated by using both empirical data from historical earthquakes and a numerical technique developed by Newmark (1965). The Newmark analysis allows for inputs of both the static slope stability and a seismic strong-motion record; thus, slope stability and seismic ground motion are linked. The Newmark analysis computes the displacement of a rigid friction block, which is used to represent a potential landslide on the slope under study. We have defined the "critical displacement" as that beyond which the slope can be considered to have produced a landslide. We have assigned values of 10 and $2 \mathrm{~cm}$ as the critical displacements for coherent and disrupted landslides (table 44), respectively. The severity of seismic shaking required to cause coherent slides is thus defined as that which, according to the Newmark analysis, would produce a displacement of more than $10 \mathrm{~cm}$ on a slope having a given $A_{c}$ (that is, $\left.\left(A_{c}\right)_{10}\right)$.

Using both the theoretical and the historicalempirical studies, we can delineate three zones surrounding a seismic event: (1) a zone (within the 50-percent probability line) within which there is a high probability that susceptible slopes $\left(A_{c}<0.05 \mathrm{~g}\right)$ will fail; (2) a zone having a less than even but still finite probability that susceptible slopes will fail; and (3) a zone beyond the outer limit defined by data from worldwide historical events that is so far from the seismic source that the probability of landslides is very small, even on susceptible slopes. Three maps were prepared to show these zones for a postulated $M 6.5$ event-the first for coherent slides, the second for disrupted slides or falls, and the third for lateral spreads or flows. These maps; in combination with the geologic criteria for seismic landslide susceptibility (table 45) and existing geologic maps of the Los Angeles region, provide the basic tools for assessing the potential hazard from earthquake-induced landslides on a local level. A general analysis of which upland areas could experience the most significant damage from landslides in a postulated $M 6.5$ earthquake on the northern part of the Newport-Inglewood fault zone is presented by Ziony and others (this volume).
FIGURE 177.-Map of the Los Angeles basin and surrounding areas showing zones of probability for lateral spreads and flows from a hypothetical M 6.5 earthquake on the Newport-Inglewood fault zone (straight line in center of map). The outer oval-shaped line is the limit for lateral spreads and flows from a $\mathbf{M} 6.5$ earthquake based on worldwide data from historical earthquakes (Keefer, 1984b). The inner oval-shaped line is the 50-percent probability line that corresponds to the source distance at which the mean predicted Arias intensity is equal to the threshold shaking severity for lateral spreads and flows $\left(I_{a}=0.50 \mathrm{~m} / \mathrm{s}\right)$. Most of the lateral spreads and flows will occur within the 50-percent probability line. 


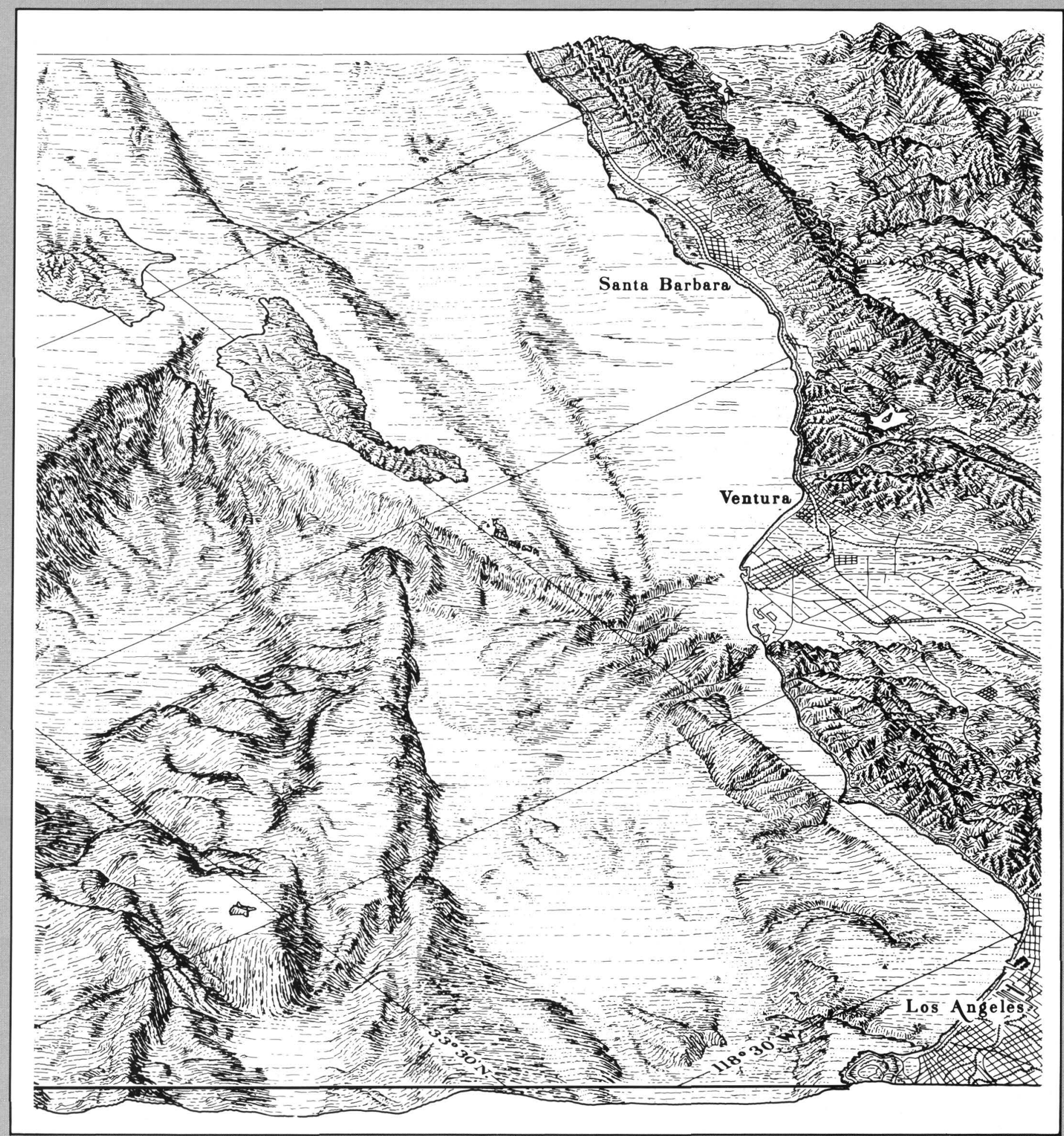

\section{Earthquake-Related Phenomena Offshore}




\title{
IDENTIFYING POTENTIALLY ACTIVE FAULTS AND UNSTABLE SLOPES OFFSHORE
}

\author{
By S. H. Clarke, H. G. Greene, and M. P. Kennedy ${ }^{6}$
}

\section{INTRODUCTION}

Evaluating the earthquake hazards associated with the offshore areas of the Los Angeles region poses distinctive challenges. Although many of the hazards are the same as those onshore (for example, ground shaking, fault rupture of the sea floor, and earthquakeinduced ground failure), specialized remote-sensing techniques are required to evaluate and map them in the marine environment. This chapter describes the principal method-acoustic reflection profiling-available for analyzing geologic hazards offshore and summarizes present knowledge of the distribution of potentially active faults and unstable slopes in the offshore Los Angeles region (fig. 178). An additional earthquake hazard unique to the marine environment-tsunamis or seismic sea waves-is discussed by McCulloch (this volume).

\section{Previous Investigations}

Numerous studies of the geology of the southern California continental borderland and its significance to offshore development have been completed during the past $15 \mathrm{yr}$. The first regional study of structure and depositional history using acoustic reflection records was conducted by Moore (1969). Known and postulated faults, both offshore and onshore, were compiled for this area by Ziony and others (1974) and Jennings (1973, 1977). Vedder and others (1974) summarized knowledge of the regional stratigraphy, structure, and geologic history of emergent and submergent parts of the southern California borderland. The geology and geologic hazards of the offshore Santa Monica and San Pedro Basins and the Gulf of Santa Catalina were

${ }^{6}$ California Division of Mines and Geology, Scripps Institution of Oceanography, La Jolla, CA 92093. studied by Greene and others (1975, 1979), Clarke and others (1983), and Edwards (1982) and those of the eastern Santa Barbara Basin by Greene and others (1978). The structure and stratigraphy of the Santa Monica and San Pedro Basins were mapped and described by Junger and Wagner (1977). Yerkes and Lee (1979a, b), Yerkes and others (1981), and Lee and others $(1978,1979)$ evaluated seismicity in relation to faults in the Santa Barbara Basin and the Transverse Ranges region, and Field and Edwards (1980) discussed processes of sea-floor mass movement and mapped zones of failure on slopes and basin margins throughout much of the southern California borderland.

Nardin (1981) and Nardin and Henyey (1978) mapped the stratigraphy and structure and discussed the tectonic and depositional history of the Santa Monica and San Pedro Basin areas, and Malouta and others (1981) described Holocene depositional processes and the nature and rates of basin filling in the Santa Monica Basin. Quaternary stratigraphy, structure, and depositional processes in the Santa Barbara Basin were described and discussed by Fischer (1972) and Thornton (1981). Maps by Clarke and others (1985) and Vedder and others (1985) have summarized recent knowledge of the geology and geologic hazards of the inner and midsouthern California continental borderland from the U.S.-Mexican border to the vicinity of Goleta (fig. 178).

\section{Physiographic Character}

The offshore region addressed in this chapter extends from west of Santa Barbara southeastward to the vicinity of Oceanside, a distance of about $280 \mathrm{~km}$, and from the shoreline seaward an average distance of about $35 \mathrm{~km}$ (fig. 178). The mainland shelf is the major physiographic feature along the eastern margin of this region. South of the Palos Verdes peninsula, between the Palos Verdes Hills and Newport Beach, the shelf is relatively broad (10-20 km wide) and is referred to here as the San 


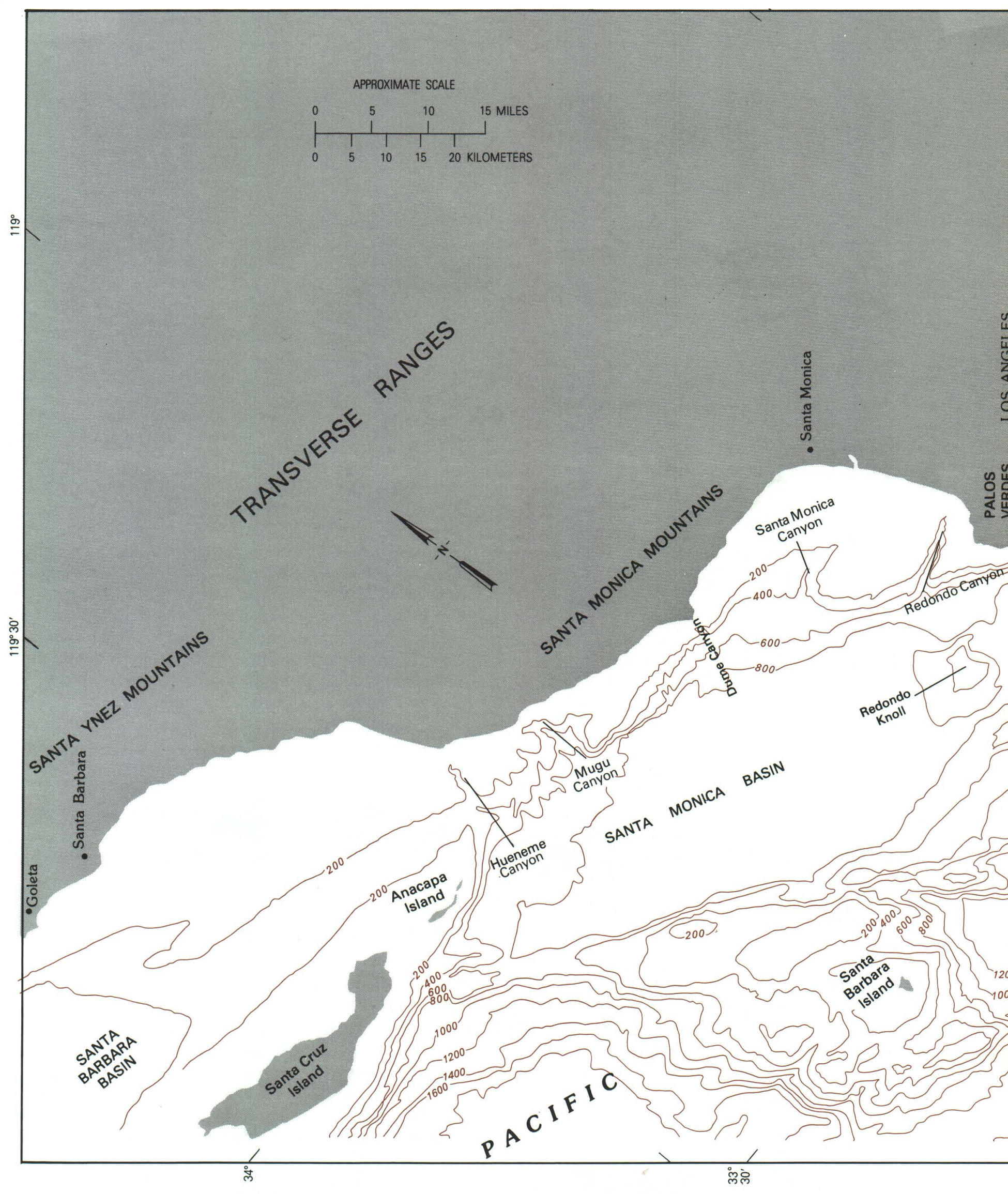

FIGURE 178.-Principal physiographic features of the offshore Los Angeles region. Contour interval is $200 \mathrm{~m}$.

348 Earthquake Hazards in the Los Angeles Region 


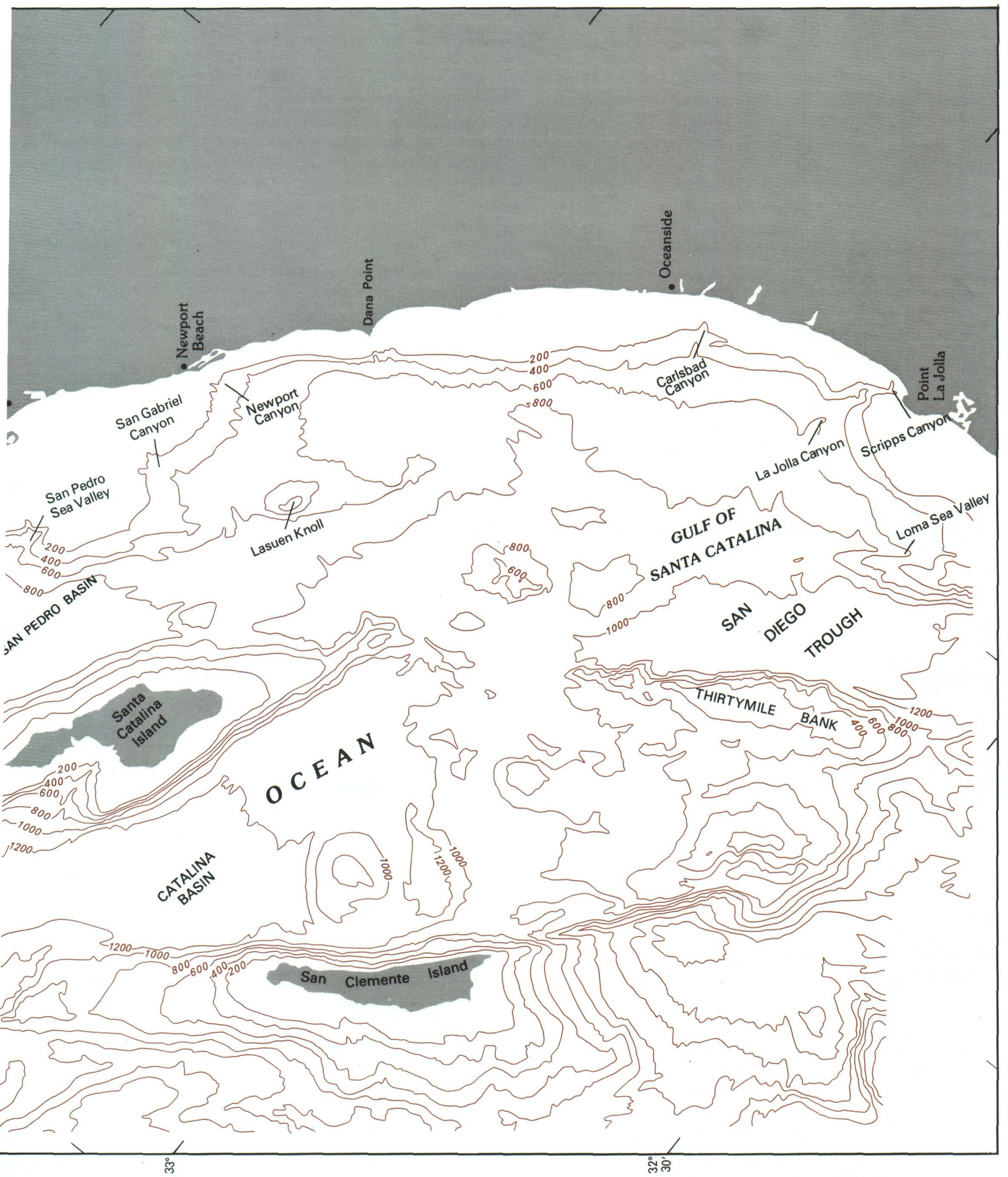

Faults and Unstable Slopes Offshore 349 
Pedro shelf. Farther south, between Newport Beach and Oceanside, the shelf is much narrower (3-9 km wide). The break in slope marking the western margin of the shelf is as shallow as $75 \mathrm{~m}$ in the northern part of the area off San Pedro Bay, but, farther south, it averages 90 to $125 \mathrm{~m}$ in depth. Several prominent submarine canyons cutting the mainland shelf in the San Pedro Bay area include the San Pedro Sea Valley, which empties westward into the San Pedro Basin, and the San Gabriel and Newport Canyons, which cut the southern margin of the shelf and drain southward into the Gulf of Santa Catalina. Newport Canyon forms the physiographic boundary between the San Pedro shelf and the narrow shelf segment south of Newport Beach. Water depth in the area south of the Palos Verdes peninsula ranges from approximately 20 to $30 \mathrm{~m}$ along the inner shelves to a maximum of about $900 \mathrm{~m}$ in the San Pedro Basin and the Gulf of Santa Catalina. Bedrock knolls (for example, Lasuen Knoll) rise as much as $420 \mathrm{~m}$ above the sea floor in these offshore basins. The Gulf of Santa Catalina is bounded on the west by bedrock ridges comprising Thirtymile Bank and the emergent Santa Catalina Island platform.

North of the Palos Verdes peninsula, the shelf break occurs at water depths as shallow as 75 to $80 \mathrm{~m}$ in the vicinity of Santa Monica Bay; farther west, the depth of the break gradually increases to depths of 90 to $105 \mathrm{~m}$. Here, the mainland shelf is cut by five submarine canyons-Redondo, Dume, Mugu, and Hueneme Canyons, which head near shore, and Santa Monica Canyon, which heads about $9 \mathrm{~km}$ offshore. These canyons empty southward and westward into the Santa Monica Basin. In addition, the slope between Dume and Hueneme Canyons is cut by several large submarine gullies. Water depths over the area range upward to a maximum of about $950 \mathrm{~m}$ in the southeastern end of the Santa Monica Basin and about $600 \mathrm{~m}$ in the Santa Barbara Basin southwest of Goleta. A bedrock knoll-Redondo Knoll-rises about $420 \mathrm{~m}$ above the sea floor and forms a portion of the sill between the Santa Monica and San Pedro Basins. The area is bounded along its seaward margin by the Santa Cruz-Catalina Ridge, a bedrock ridge of exposed Tertiary sedimentary and volcanic rocks, and by the Channel Islands platform. The eastern terminus of the Channel Islands platform-the Anacapa Ridge-forms the physiographic boundary between the east-trending Santa Barbara Basin and the northwesttrending Santa Monica Basin.

\section{ACQUIRING AND INTERPRETING MARINE GEOPHYSICAL DATA}

Geologic features on and beneath the sea floor commonly must be evaluated by remote-sensing methods

350 Earthquake Hazards in the Los Angeles Region rather than by direct observation. Although a variety of techniques is available for marine geologic studies, acoustic reflection profiling is presently the principal method used to map sea-floor and subbottom features. The basic principal of acoustic reflection profiling is echo sounding, in which a pulse of sound is generated and transmitted downward through the water from a ship-mounted or towed acoustic source. Some of this acoustic energy is reflected from the sea floor, and some is reflected from interfaces between subbottom units that can be differentiated by their acoustic characteristics. These acoustic units have physical properties such as bulk density and acoustic velocity that differ significantly from the properties of adjacent units. The reflected energy is received by sensors (hydrophones) in or towed by the survey vessel, and the signals are processed and recorded by analog or digital methods. The recorded signals are graphically presented as continuous acoustic reflection profiles (fig. 179); these profiles depict cross sections of acoustic units plotted as a function of acoustic traveltime beneath the sea surface (vertical direction) and distance along the survey track (horizontal direction). To determine the depth to a reflecting interface, the velocity of sound in acoustic units (including the water column) above the interface must be assumed or determined. By interpreting a series of acoustic reflection profiles obtained for an area, geologists can infer and map geologic features on and beneath the sea floor. Dobrin (1976) has published a comprehensive description of the acoustic reflection technique.

Much of the information presented in this chapter is based on the interpretation of subbottom acoustic reflection records collected aboard the R/V Sea Sounder during 1978 and 1979 (cruises S2-78-SC and S2-79-SC) and the R/V S. $P$. Lee during 1981 (cruise L2-81-SC). These records consist of high-resolution profiles gathered with $12-\mathrm{kHz}, 3.5-\mathrm{kHz}$, minisparker, and Uniboom systems and intermediate- to deep-penetration profiles gathered with a $160-\mathrm{kJ}$ sparker and dual $40-\mathrm{in}^{3}$ air-gun systems. Subsurface features ranging upward in vertical dimension from approximately 1.0 to $1.5 \mathrm{~m}$ can be resolved on high-resolution data that vary in subbottom penetration from 150 to over $400 \mathrm{~m}$. The intermediate to deep-penetration data used to determine structures at greater depths beneath the sea floor can resolve features larger than about $15 \mathrm{~m}$ in vertical dimension and commonly record useful information at subbottom depths of well over $1 \mathrm{~km}$. Ship positioning was accomplished by range-range triangulation and Loran C, augmented in remote locations by satellite navigation and ship's radar. Location accuracy of the acoustic data ranges from about $15 \mathrm{~m}$ where precision equipment was used to about $250 \mathrm{~m}$ where ship's radar alone was used. 


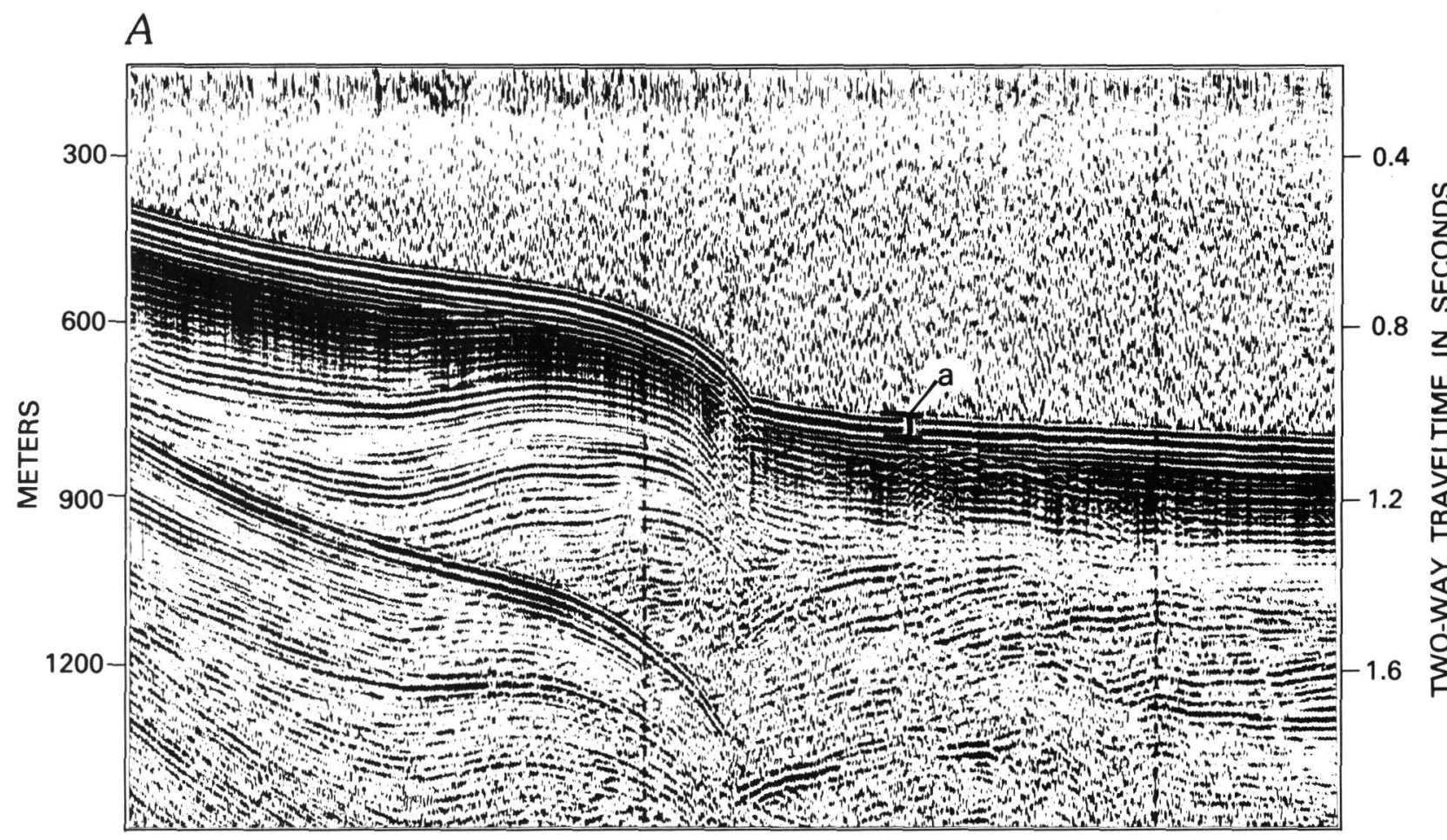

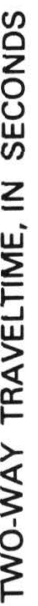

$B$
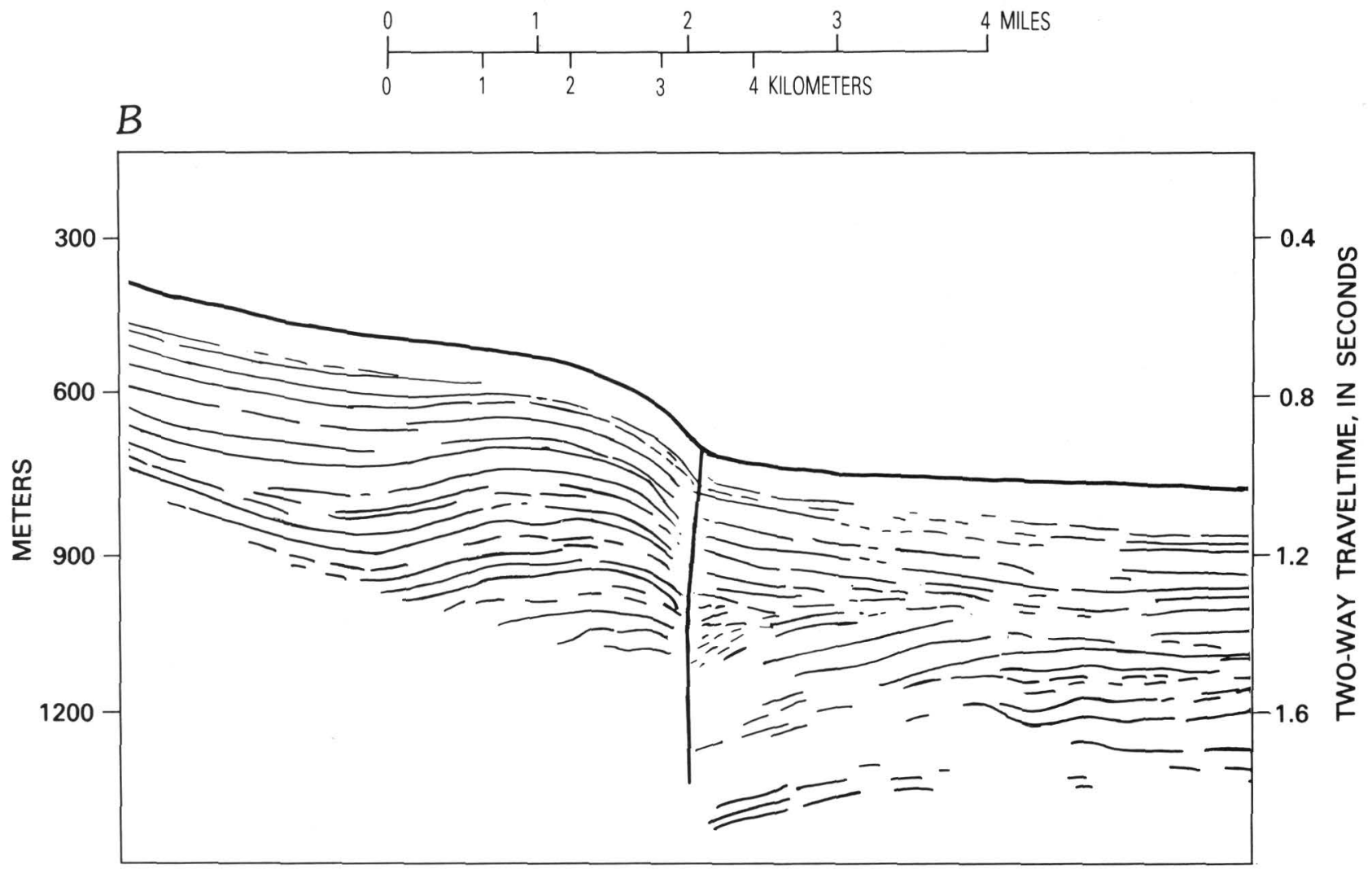

FIGURE 179.-Intermediate-penetration acoustic reflection profile across the mainland shelf near Oceanside showing well-defined fault (Kennedy and others, in press). Vertical exaggeration 7:1. A, Acoustic reflection record. Note interruption and displacement of prominent reflectors, sea-floor offset, and bubble pulse (a). B, Line drawing of prominent reflectors. 

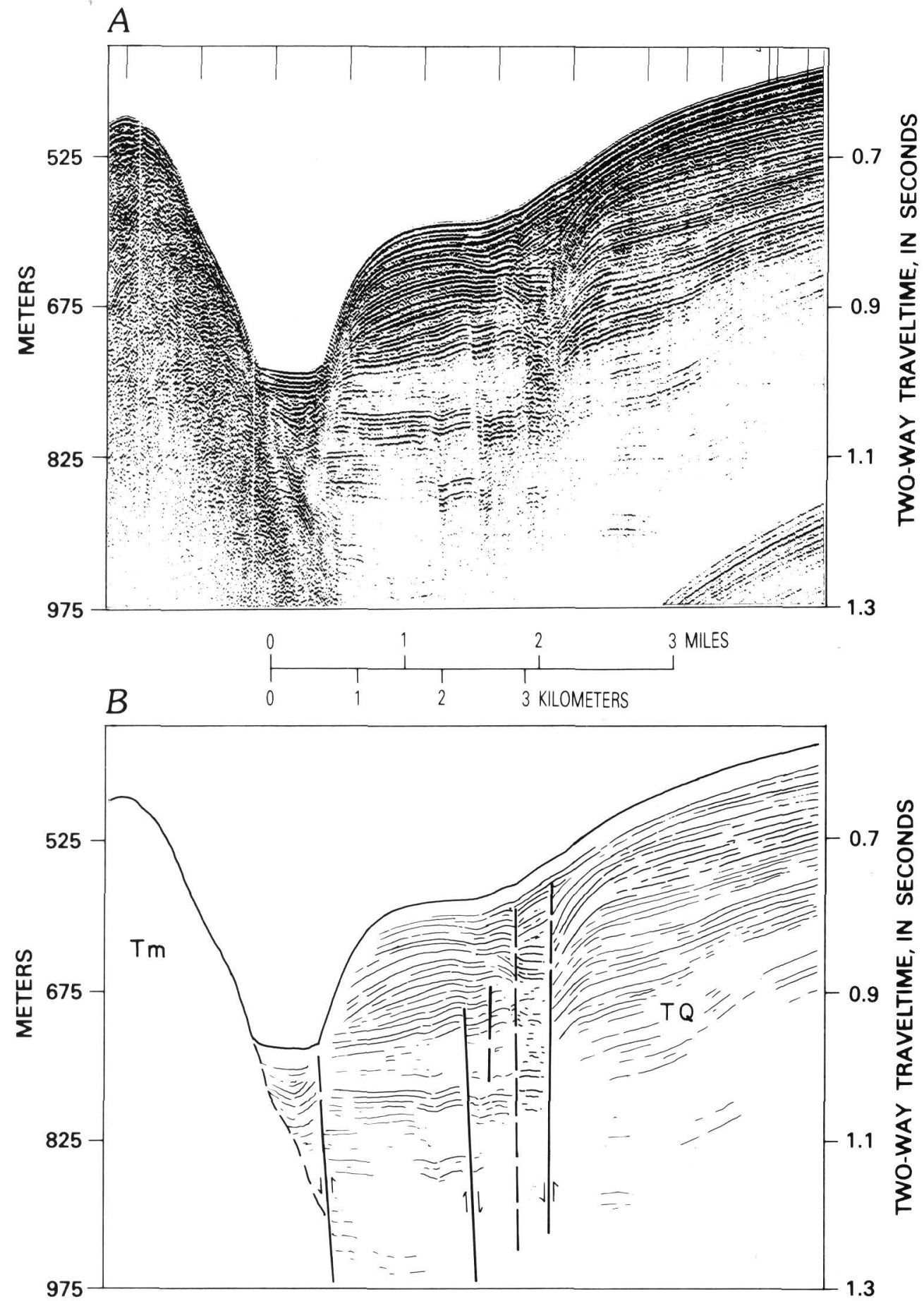

FIGURE 180.-Intermediate-penetration acoustic reflection profile across the eastern flank of the Coronado Bank, the Loma Sea Valley, and the shelf off San Diego showing well-defined faults (solid lines), indicated by discontinuation and displacement of prominent reflectors, and inferred faults (dashed lines), indicated by bending, changes in dip, and relatively small displacements of prominent reflectors (Kennedy and others, in press). Vertical exaggeration 12:1. A, Acoustic reflection record. B, Line drawing of prominent reflectors. The fault at left juxtaposes Tertiary-Quaternary strata (TQ) and exposed bedrock block of Miocene ( $\mathrm{Tm}$ ) age.

\section{Earthquake Hazards in the Los Angeles Region}


Standard interpretive methods were used in analyzing the acoustic reflection data. Criteria for interpreting faults follow Greene and others (1973) and Kennedy and others (in press) and are, for well-defined faults (figs. 179, 180), (1) distinct displacement of prominent reflectors, (2) an abrupt termination of prominent reflectors or the juxtaposition of intervals of prominent reflectors that have contrasting acoustic characteristics, or (3) an abrupt change in the dip of reflectors across a distinct boundary. For inferred faults (fig. 180), the criteria are (1) small displacement of prominent reflectors, in which the upper or shallow reflectors may be bent rather than broken, (2) prominent reflectors that are discontinuous and contrasting acoustic characteristics that are present on either side of an acoustically obscure disturbed zone, or (3) apparent changes in dip on either side of the disturbed zone. For questionable faults (mapped where obscure interruptions of acoustic reflectors are present in the subsurface), the criteria are (1) a shift in phase of reflectors that is not due to instrumental malfunction, (2) bent or broken reflectors that can be correlated with known faults on other lines, (3) termination of weak reflectors, or (4) any other zone of acoustic contrast, especially where the zone appears similar to and aligned with faults identified on adjacent lines. Faults (fig. 179) shown as cutting the sea floor are interpreted from disturbances in the uppermost sediment layers and (or) slight changes in the slope of the sea floor directly above the fault. Some questionable and inferred faults have been mapped where topographic lineaments appear to support the continuation of known faults.

The strike of a fault is determined principally by correlation from one acoustic profile to another. Features that can be used to correlate faults from profile to profile typically include reflectors that are similar and displaced in the same direction and that have similar drag or other subsidiary folding associated with them. Contrasts in acoustic characteristics that appear similar across a fault on adjacent profiles can also be used to make correlations.

Where fault planes dip more than about $35^{\circ}$, the vertical exaggeration common to acoustic profiles precludes determining the dip, even though the records clearly indicate that a fault is present. Consequently, faults dipping $35^{\circ}$ or more are shown as vertical. Determining the amount and direction of movement on a fault is difficult. Only the apparent vertical component (dip separation) of offset can be measured on acoustic reflection profiles; the horizontal component (strike separation) can be determined only where piercing points of lines representing equivalent geologic features can be identified on opposite sides of a fault.

The depth to the upper limit of a fault trace can be calculated from acoustic profiles by multiplying the acoustic velocity assumed or determined for the particular rock unit by half of the two-way acoustic traveltime obtained at the shallowest (stratigraphically highest) subsurface reflector cut by the fault. Generally, the stratigraphically highest point at which a fault can be identified in an acoustic reflection profile is at the base of the "bubble pulse", " about $6 \mathrm{~m}$ beneath the ocean floor on high-resolution records and about 50 to $60 \mathrm{~m}$ below the sea floor on intermediate-penetration records. An exception is sea-floor offset apparent on acoustic reflection records.

An approach commonly used onshore to evaluate the recency of fault activity is to determine the age of the youngest deposit cut by a particular fault or the youngest landform offset by the fault; the time span (for example, Quaternary or Holocene) chosen to designate a fault as active then is selected on the basis of the likely consequences of renewed faulting on engineered structures (Ziony and others, 1974; Ziony and Yerkes, this volume). This type of evaluation is also the basis for identifying offshore faults as active. However, several factors complicate an evaluation of the offshore region:

1. Faults (especially strike-slip faults) that displace rocks having similar acoustic characteristics on opposing fault blocks commonly are difficult to detect in acoustic reflection profiles.

2. The ages of rock and sediment in the offshore region cannot always be closely determined. Correla- . tions of stratigraphic units commonly are based on similarities in acoustic character rather than on direct physical evidence such as bottom samples or cores from wells.

3. Young deposits may not be present along some active offshore faults, and thus the ages of latest faulting cannot be closely constrained. Faults where only Tertiary or pre-Tertiary rocks are exposed at the sea floor might not be identified as geologically youthful in the absence of associated seismicity.

4. Active faults in some tectonic settings in California do not penetrate rocks near the Earth's surface (Ziony and Yerkes, this volume, p. 73). The $M_{L}$ 6.7 Coalinga earthquake, for example, apparently was associated with sudden fault slippage at depths of 4 to $12 \mathrm{~km}$, whereas shallower deformation was expressed by folding (Stein and King, 1984). Faults that are limited to deeper and older strata might be interpreted from acoustic reflection data to be geologically

\footnotetext{
7The "bubble pulse" results from attenuating reverberations in the water column after the primary pulse has been produced. These reverberations are reflected back from the ocean bottom and appear as pseudo-sea-floor traces on the acoustic record (see fig. 179A), effectively masking any signals reflected from shallow structures inmediately beneath the sea floor.
} 
old faults unless seismicity indicates contemporary activity.

Because of these factors, the age of latest faulting as inferred from acoustic reflection profiles may not always be a reliable indicator of fault activity.

Criteria used to infer conditions of sea-floor instability from acoustic reflection data have been described by Clarke and others (1983) and Kennedy and others (in press). Sea-floor instability here denotes conditions that result from mass movement and liquefaction of sea-floor sediment, phenomena that can be earthquake induced. Potentially unstable sea-floor conditions in the offshore Los Angeles region are associated with subaqueous sediment slides, subaqueous mass flows (including sediment creep), and, to a limited extent, accumulations of shallow gas.

Subaqueous slides are mass movements of rigid or semiconsolidated sediment masses along discrete shear surfaces, accompanied by relatively little internal deformation (Dott, 1963). A side-scan sonograph record showing the sea-floor characteristics of a subaqueous slide offshore of northern California is presented by Wilson and Keefer (this volume, fig. 163). Slides are commonly identified on acoustic reflection records (figs. 181, 182) by the presence (in longitudinal sections) of some or all of the following features: (1) a headscarp where the slip surface extends upward to and is expressed in the sea floor, (2) compressional ridges and folded and contorted subbottom reflectors resulting from small-scale thrusting and folding at the toe of the slide, (3) transverse (tensional) cracks in the body of the slide, (4) evidence of rotation or limited internal deformation of reflectors, and (5) the presence of a slip surface, which may be upwardly concave or planar, represented by a discrete failure plane or by an intensely deformed (and in some cases acoustically transparent) zone beneath the slide mass. The term slump is commonly applied to a slide that shows evidence of rotational movement along a curved slip surface; the term block glide is used for those slides having a relatively planar, usually gently dipping slide surface. Subaqueous slides may occur on slopes of less than $1^{\circ}$ and may range in size from simple failures covering tens of square meters to composite failure zones thousands of square kilometers in area and from a few meters to hundreds of meters thick (Moore, 1961; Heezen and Drake, 1964; Lewis, 1971; Hampton and Bouma, 1977). Subaqueous mass flows involve the downslope movement under gravity of watersaturated, unconsolidated sediment; the moving mass may behave plastically or as a very viscous fluid, and movement may be slow or rapid (Dott, 1963). Shear oc- curs extensively throughout the displaced mass rather than along a few discrete planes, as it does in slides. The velocity and displacement of flow characteristically decrease with depth below the sea floor, so that the deposit lacks a distinct slip surface. Subaqueous sediment flow deposits (fig. 183) are identified on acoustic reflection profiles by (1) the presence of anomalously thick sediment masses apparently detached from underlying strata, (2) the absence of an identifiable slip plane, and (3) acoustic transparency or chaotic internal structure. Sediment creep in the marine environment is a form of flow; it is a poorly understood, poorly documented phenomenon. As used here, this term refers to the slow, more-or-less continuous, downslope movement of the upper layers of unconsolidated sediment. The occurrence of creep is inferred on acoustic reflection records from the presence of hummocky sea-floor topography, deformed but identifiable acoustic bedding in the upper sediment layers, a downward decrease in the degree of deformation, and the apparent absence of a slip surface. Zones of sediment creep in the southern California borderland appear to extend to depths of 15 to $20 \mathrm{~m}$ below the sea floor; they may be areally extensive and are commonly associated with other types of failure.

Gas present as bubbles in the pore space of sediment can lower the shear strength of the enclosing sediment and thereby increase the likelihood of failure (Sangrey, 1977); under some circumstances, gas-charged sediment can liquefy spontaneously when it is subjected to cyclic loading, as it is in earthquake shaking (Hall and Ensiminger, 1979). Gas accumulation in sediment (fig. 184) is suggested on medium- and high-resolution acoustic reflection profiles by (1) the presence of amplitude anomalies (apparent as enhanced or "bright" subbottom reflectors), (2) the sharp termination or displacement of reflectors commonly associated with acoustically turbid zones, (3) the absence of surface multiples indicating absorption of the seismic signal (Nelson and others, 1978), and (4) the presence in reflectors of "pull downs," apparent depressions resulting from the decreased velocity of sound in gaseous sediment and the consequent delayed arrivals of acoustic returns. Watercolumn anomalies on high-resolution acoustic profiles in some cases suggest gas bubbles in the water column, although other phenomena such as kelp and fish produce features that appear similar. Side-scan sonographs and underwater video or photographic coverage can show seep mounds or craters on the sea floor, as well as gas bubbles. Sampling and geochemical analyses, however, are needed to verify the presence of gas and identify its origin.

\section{Earthquake Hazards in the Los Angeles Region}



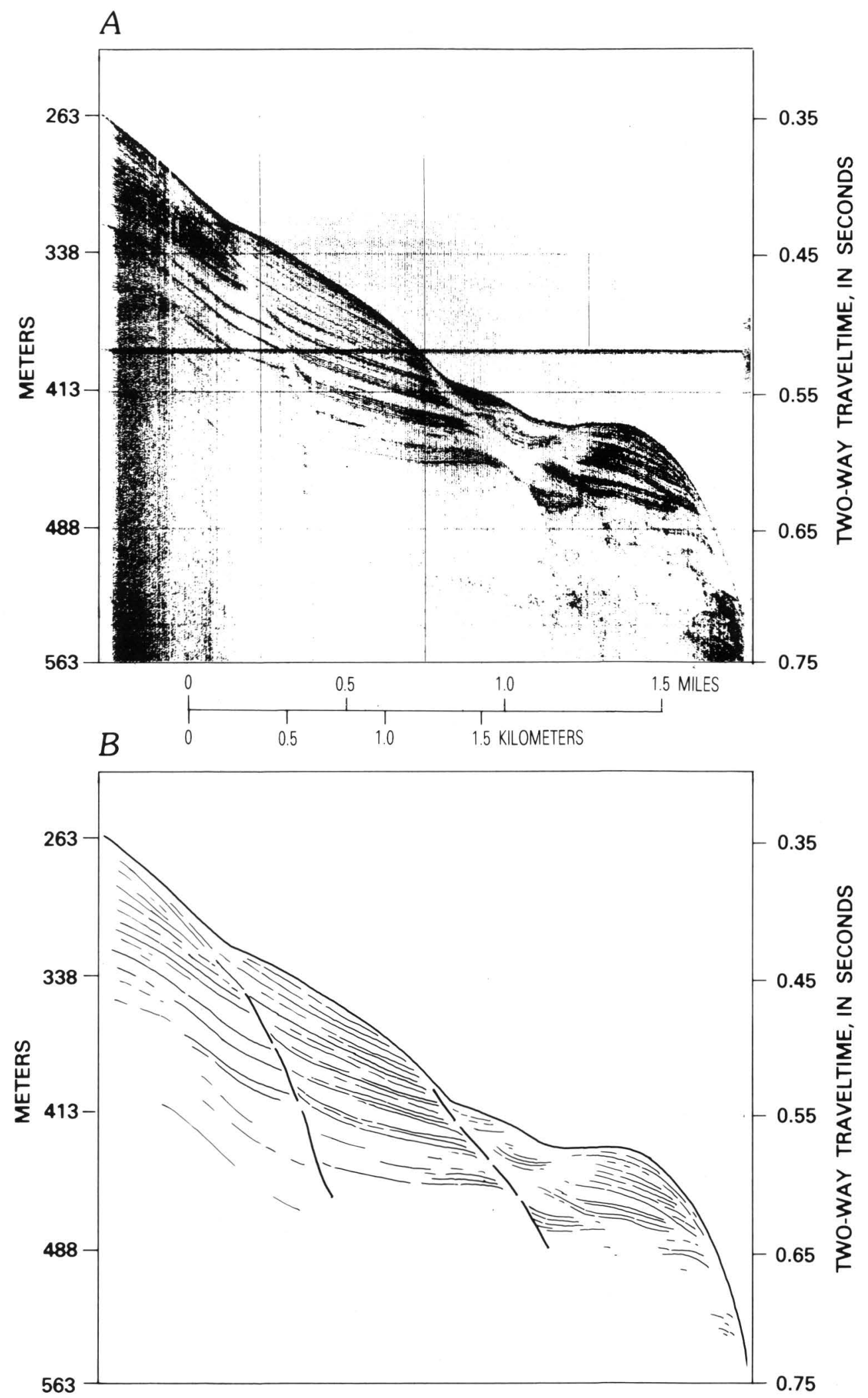

FIGURE 181.-High-resolution acoustic reflection profile near Dume Canyon showing a subaqueous slide (slump) (from Kennedy and others, in press). Vertical exaggeration 9:1. A, Acoustic reflection record. $B$, Line drawing of prominent reflectors. Note the slip surfaces, the apparent drag folding of strata adjacent to slip surfaces, and the relative absence of internal deformation of reflectors. The zone of movement extends to a subbottom depth in excess of $100 \mathrm{~m}$. 


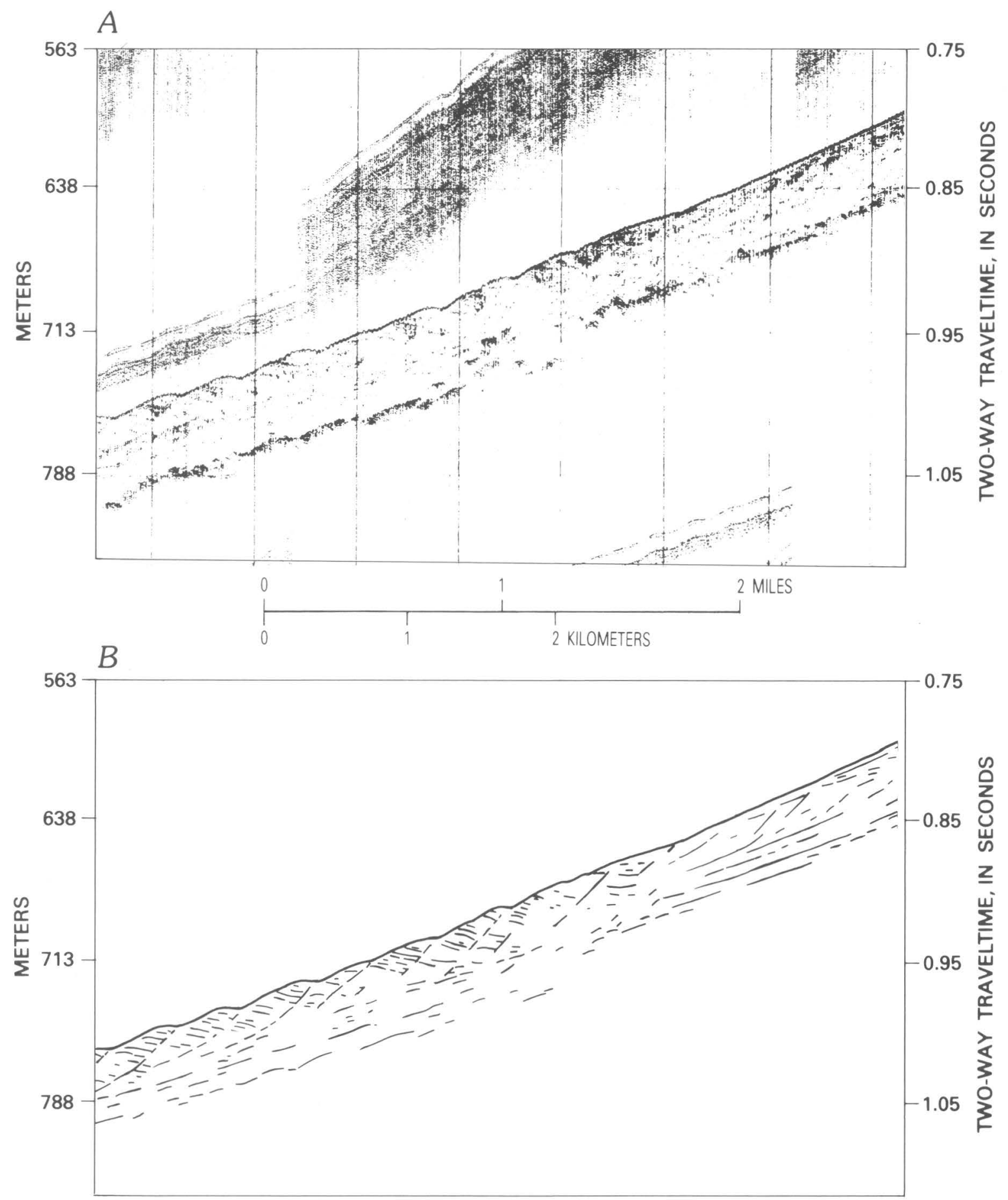

FIGURE 182.- High-resolution acoustic reflection profile across the continental slope off Crescent City on the northern California continental margin showing subaqueous slides (retrogressive slumps) (from Kennedy and others, in press). Vertical exaggeration 13:1. A, Acoustic reflection profile. B, Line drawing of prominent reflectors. Note hummocky sea-floor surface produced by headscarps, back rotation and limited internal deformation of reflectors, and multiple slip surfaces. The zone of movement extends to a depth of approximately $20 \mathrm{~m}$ beneath the sea floor.

\section{Earthquake Hazards in the Los Angeles Region}



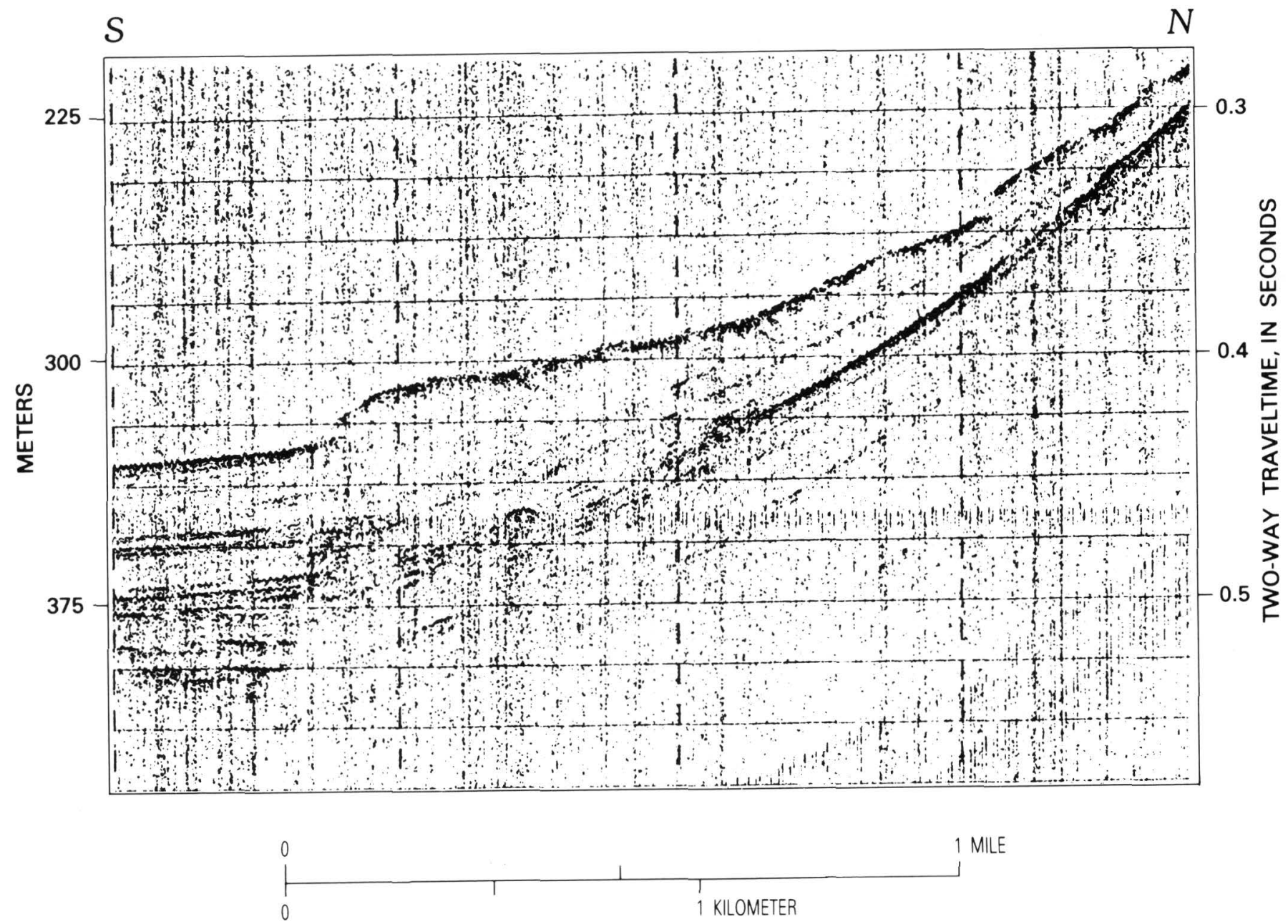

FIGURE 183.-High-resolution acoustic reflection profile across the slope of the Santa Barbara Basin showing a subaqueous flow deposit (from Edwards, 1982). Vertical exaggeration 8:1. Note the apparent absence of a slip surface and the acoustic transparency of the sediment mass.

\section{POTENTIAL GEOLOGIC HAZARDS IN THE OFFSHORE LOS ANGELES REGION}

The discussion of earthquake hazards in the offshore Los Angeles region is divided into three parts: principal Quaternary faults, sea-floor instability, and shallow gas accumulations. This arbitrary subdivision is only to facilitate discussion, and it should be borne in mind that these hazards are closely interrelated; that is, sudden fault movement may result in ground rupture and shaking and consequent sea-floor failure, which in turn is dependent in part on factors such as sediment thickness and composition, degree of induration, state of water and gas saturation, and sea-floor declivity. The discussion of principal Quaternary faults describes briefly the character and evidence for recency of rupture along the most prominent and geologically youthful faults in this region, faults that we consider to have the potential for generating earthquakes and producing fault offset of the sea floor. The discussion of inferred sea-floor instability summarizes the types and distribution of sea-floor failures in this region, as well as evidence leading to the conclusion that sea-floor failures may be earthquake induced. Finally, the discussion of hydrocarbon seepage and shallow gas accumulation briefly describes the nature and distribution throughout the region of gascharged sediment, deposits probably prone to failure by liquefaction and mass movement when they are subjected to earthquake shaking.

\section{Principal Quaternary Faults}

This section summarizes the geologic and seismologic character of the principal fault zones offshore (fig. 185) that have been active during Quaternary time (the past 

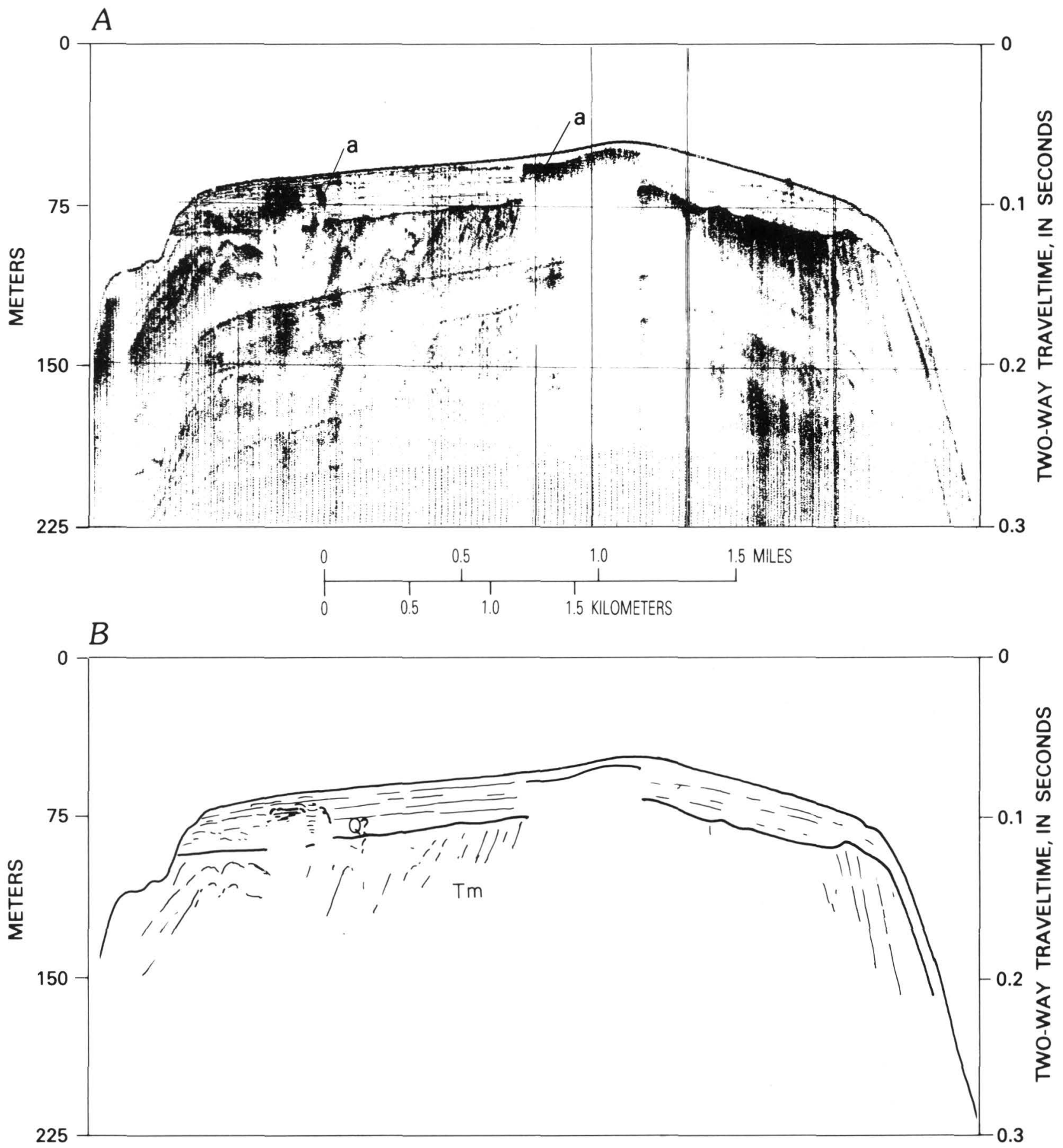

FIGURE 184.-High-resolution acoustic reflection profile across the San Pedro shelf and escarpment showing acoustic anomalies possibly indicating the presence of gas-saturated sediment (Kennedy and others, in press). Vertical exaggeration 13:1. A, Acoustic reflection profile. B, Line drawing of prominent reflectors. Note amplitude anomalies (a) apparent as enhanced subbottom reflectors, the sharp termination of other reflectors at the margin of these anomalies, and the zone of acoustic transparency beneath the anomalies. These acoustic anomalies are in nearly flat lying Quaternary (Q?) sediment overlying an eroded flat-topped Miocene (Tm) bedrock ridge.

1.7 m.y.). Our emphasis is on the ages of latest faulting along these zones as interpreted from acoustic reflection profiles. Yerkes (this volume) presents details of historical and instrumentally recorded seismicity for the entire Los Angeles region. Ziony and Yerkes (this volume) discuss the character of the offshore faults and their onshore counterparts, summarize geologic evidence for the rates of fault slip and earthquake recurrence, and evaluate the potential for future earthquakes. Our analysis here considers evidence for fault

\section{Earthquake Hazards in the Los Angeles Region}


displacement at or near the sea floor during Quaternary time instead of late Quaternary time, as Ziony and Yerkes (this volume) have done. The longer time span has been used because, for much of offshore southern California, the Pleistocene sedimentary rock sequence cannot be subdivided on acoustic reflection profiles with confidence.

South of the Palos Verdes Hills, the predominant structural grain within the Gulf of Santa Catalina area trends northwest. Two major fault zones-the NewportInglewood and the Palos Verdes Hills-form the northeastern and southwestern boundaries, respectively, of a relatively undeformed structural block, named the Catalina block by Greene and others (1979). Faults of both zones are geologically youthful, locally displacing the sea floor and cutting Quaternary sediment within the offshore Los Angeles area. No single fault within either zone appears to continue uninterrupted for more than about $40 \mathrm{~km}$. This pattern resembles other fault zones of California, onshore and offshore, that are composed of short, en echelon faults and folds in relatively narrow (1-10 km) zones.

The Newport-Inglewood fault zone, which projects offshore at Newport Beach, appears to have influenced the development of the eastern slope of the Gulf of Santa Catalina physiographic basin. The zone is defined at the surface by discontinuous, generally northwest-trending faults and folds within Tertiary and Quaternary strata; these structural features and similarly aligned faults offshore form a discrete belt that extends for at least $240 \mathrm{~km}$ from near the Santa Monica Mountains into Baja California. To the south, near Oceanside, faults aligned with the Newport-Inglewood zone step to the west and have been mapped southward offshore to the vicinity of La Jolla, where they appear to link with the Rose Canyon fault zone, which Legg and Kennedy (1979) have suggested may connect with the Vallecitos-San Miguel fault zone in Mexico. Onshore and northwest of Newport Beach, the fault zone extends northward across the western Los Angeles basin and appears to terminate abruptly at the Santa Monica fault (Barrows, 1974; Ziony and others, 1974; Jennings, 1977). Moody and Hill (1956) and Harding (1973) have postulated a right-slip wrench tectonic model for the NewportInglewood fault zone in the Los Angeles basin. We have noted apparent offsets and en echelon folds suggesting this same sense of motion offshore along the southern extension of the zone (for example, Scripps Submarine Canyon appears to be a right laterally offset head of La Jolla Submarine Canyon (Greene and others, 1979)).

The Newport-Inglewood fault zone has a measured right-lateral strike-slip displacement of 1,000 to $2,000 \mathrm{~m}$ in lower Pliocene strata (Yerkes and others, 1965) and probably 3,000 $\mathrm{m}$ in middle Miocene strata (Hill, 1971); apparent vertical separation across the fault zone is locally more than $1,000 \mathrm{~m}$ at the buried basement surface (Yerkes and others, 1965). Additionally, this zone of faulting apparently overlies the aftershock zone of the 1933 Long Beach earthquake (M 6.2) (Barrows, 1974; Ziony and Yerkes, this volume, table 5). Offshore, faults aligned with the Newport-Inglewood fault zone are observed near or seaward of the shelf edge on several acoustic reflection lines between Laguna Beach and Oceanside. Where this zone can be mapped on the mainland shelf, it is characterized by a gentle 3- to 5-m-high upwardly convex "bulge" of the erosional surface on Tertiary bedrock landward of the fault trace (fig. 186). This bulge is, in some locations, mirrored in the overlying Quaternary sediment and the sea floor, and Quaternary sediment commonly thins over these low-relief bedrock highs. The fault extends to the sea floor in areas devoid of Quaternary sediment. Locally, the erosional surface on Tertiary bedrock shows an apparent vertical separation of 5 to $7 \mathrm{~m}$, seaward (western) side down. Where Quaternary sediment is present, it is buttressed against this scarp, and, on one profile, Holocene sediment appears to be offset by a fault aligned with the Newport-Inglewood zone. In a recent comprehensive review of acoustic reflection data from the shelf off Oceanside, Greene and Kennedy (1981) noted that faults of this zone extend to the sea floor, where they "questionably offset Holocene sediment"; an acoustic reflection survey for the Southern California Edison Company similarly indicated that, in this area, faults aligned with the Newport-Inglewood zone appear locally to displace marine terrace deposits of probable Holocene age (U.S. Nuclear Regulatory Commission, 1981, para. 2.5.1.12(4)(d)). Although this evidence is not definitive, it strongly supports a history of deformation on offshore faults aligned with the Newport-Inglewood fault zone that extends to the present time.

The Palos Verdes Hills fault zone extends from northern Santa Monica Bay southeastward across the Palos Verdes peninsula and the San Pedro shelf to the vicinity of Lasuen Knoll, a distance of more than $110 \mathrm{~km}$. The segment of the fault zone near San Pedro is well defined and continuous. The fault zone steps southwestward in the vicinity of Lasuen Knoll; the splay passing southwest of Lasuen Knoll extends for $80 \mathrm{~km}$ or more southeastward to its intersection with elements of the Coronado Bank fault zone that pass along the eastern edge of Coronado Bank offshore of San Diego (Greene and others, 1979). The Coronado Bank fault zone has, in turn, been postulated by Legg and Kennedy (1979) to continue southward and to join the Agua Blanca fault zone in Baja California. If it does so, these faults comprise a complex multipart Quaternary zone of deformation more

Faults and Unstable Slopes Offshore 359 


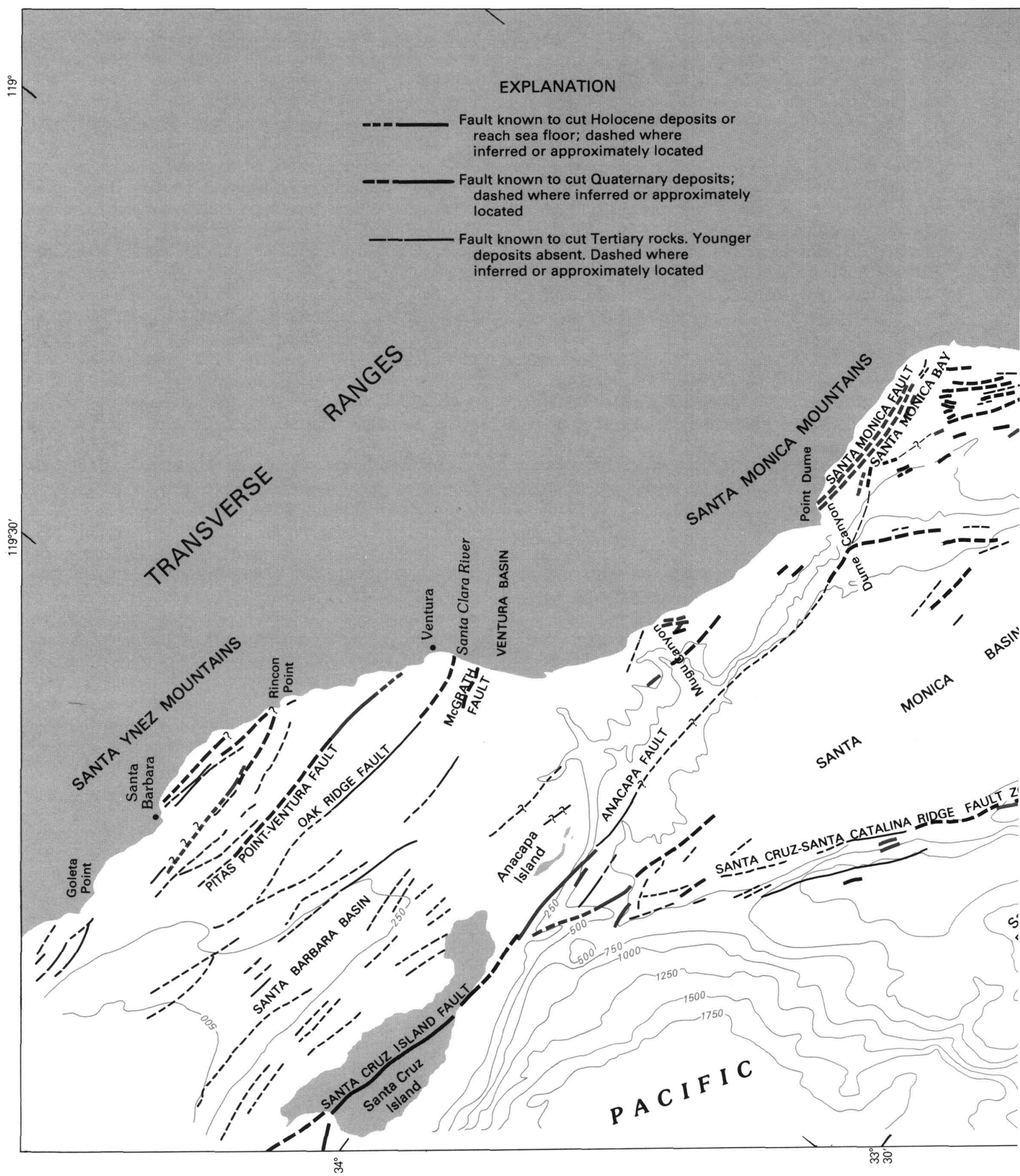

FIGURE 185.-Principal Quaternary faults in the offshore Los Angeles region. Data sources are indicated in text. Contour interval is $250 \mathrm{~m}$. Bathymetry from U.S. Coast and Geodetic Survey (1967a, b).

360 Earthquake Hazards in the Los Angeles Region 


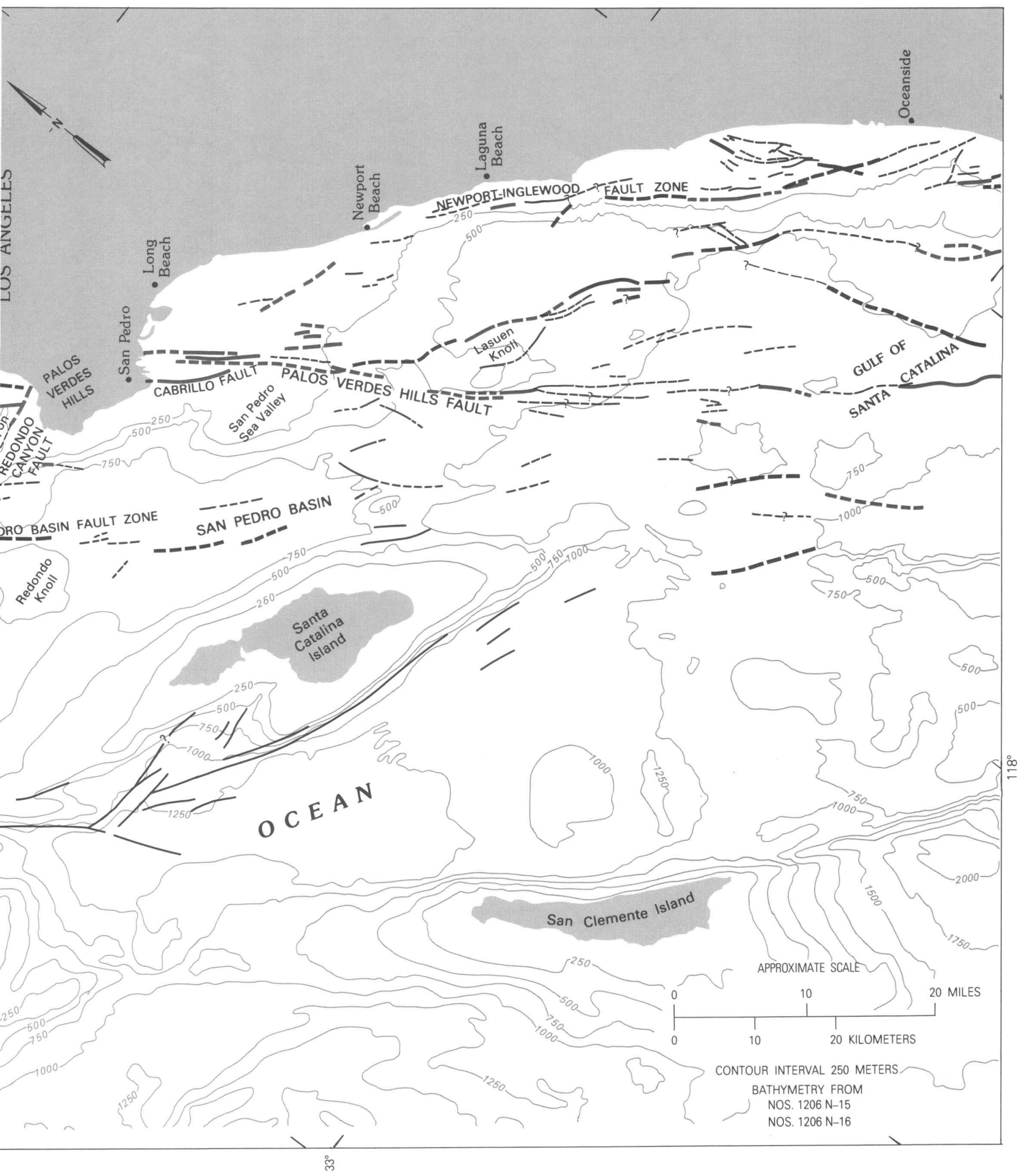

Faults and Unstable Slopes Offshore 361 


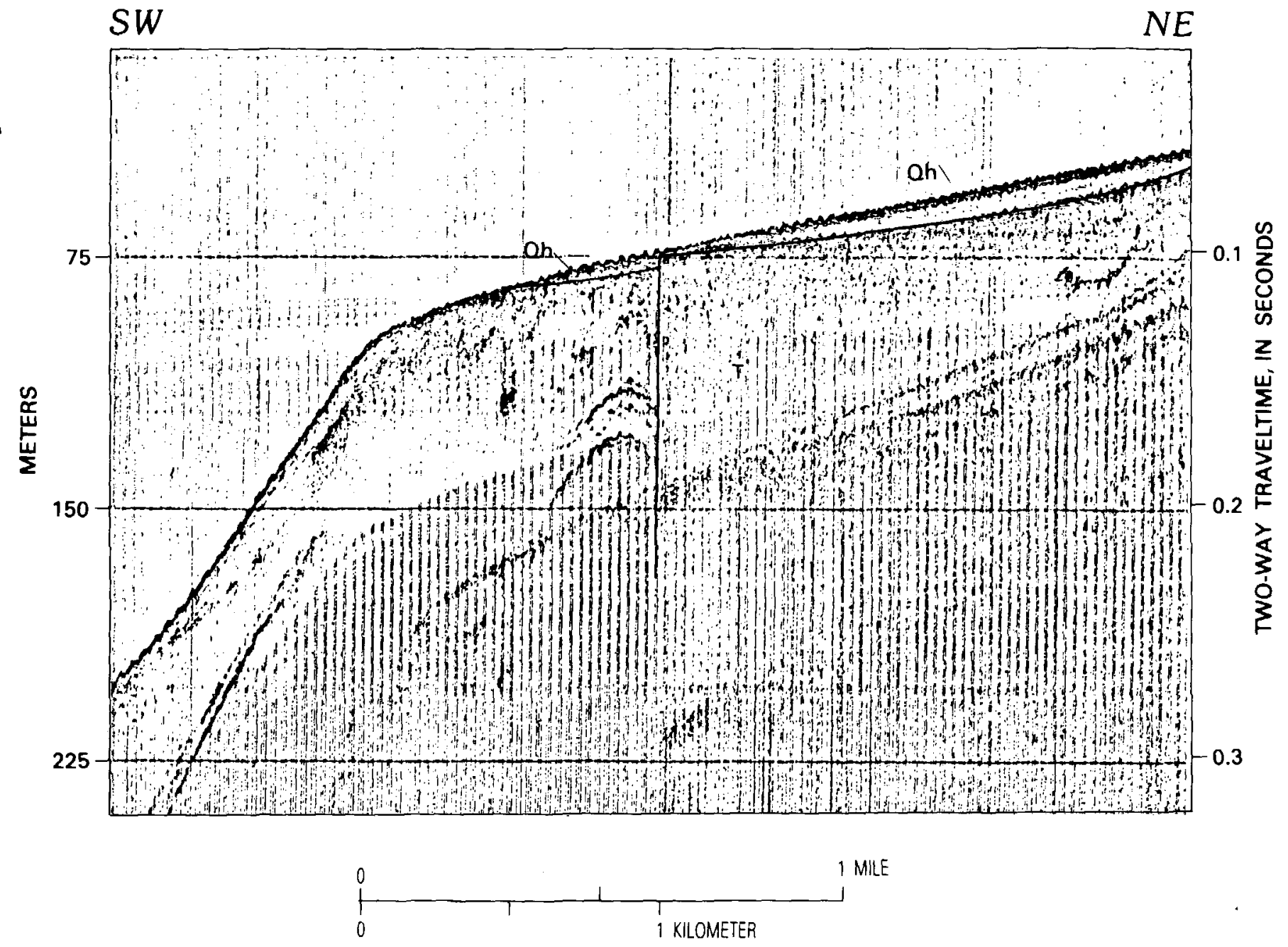

FIGURE 186.-High-resolution acoustic reflection profile showing a strand of the Newport-Inglewood fault zone on the mainland shelf about $28 \mathrm{~km}$ south-southeast of Laguna Beach. Vertical exaggeration 11:1. Note the upwardly convex "bulge" of the erosional surface on Tertiary (T) bedrock, the buttressing of acoustically transparent Holocene (Qh) sediment against the seaward margin of this bulge, and the slight deformation of the sea floor above the fault.

than $440 \mathrm{~km}$ long that we consider to be the result of wrench faulting. The Palos Verdes Hills fault zone in the vicinity of the Palos Verdes Hills shows an 1,800-m vertical separation, southwestern side up, of Catalina Schist basement (Yerkes and others, 1965); a series of elevated marine terraces in the Palos Verdes Hills shows that this movement continued into late Pleistocene time. Abrupt changes in the configuration of the basement surface and differences in the thickness and lithology of Tertiary rocks juxtaposed by the fault suggest important components of strike-slip offset as well (Yerkes and others, 1965). The generally accepted sense of offset on the Palos Verdes Hills fault is dominantly right lateral, suggested by its northwestern trend and by fold axes that diverge westward from the fault in the vicinity of the Palos Verdes uplift. Its inter- section with the north-dipping Anacapa fault in Santa Monica Bay is not well understood but coincides with a dense cluster of earthquake epicenters recorded since 1976 (R. F. Yerkes, oral communication, 1983).

The Palos Verdes Hills fault zone in the Los Angeles Harbor area and on the San Pedro shelf is a complex en echelon to anastomosing group of fault splays comprising a zone $1.5 \mathrm{~km}$ wide in which no single fault trace can be mapped for more that about $10 \mathrm{~km}$ (Dames and Moore and $\mathrm{MESA}^{2}$, 1983). Here, faults of this zone offset Holocene sediment and (or) the sea floor (Greene and others, 1975; Junger and Wagner, 1977; Clarke and others, 1983; Dames and Moore and MESA2, 1983), although, throughout much of the Gulf of Santa Catalina, these faults appear to cut only units of Pleistocene age or older. Figure 187 shows a fault (probably correspond- 


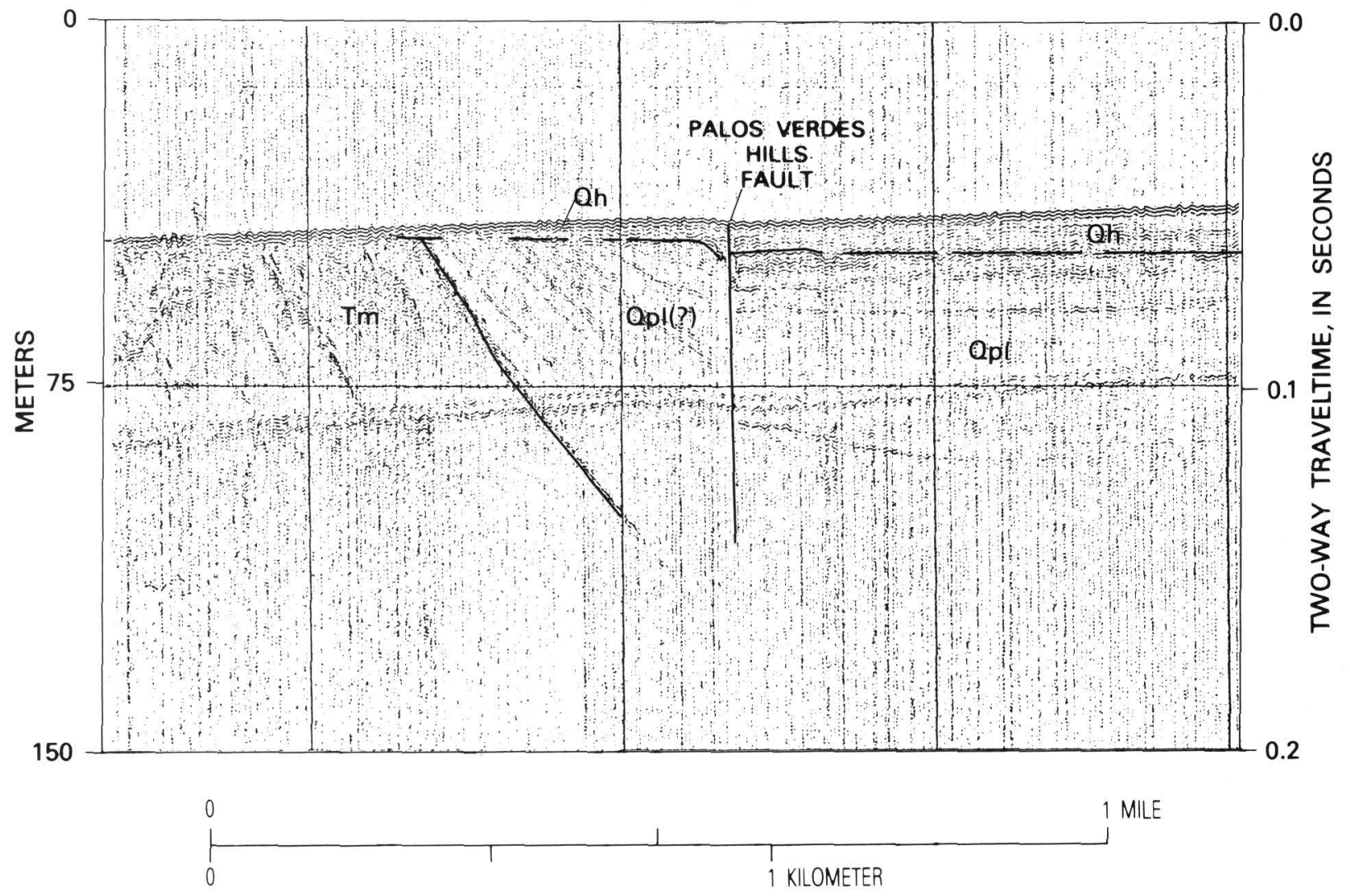

FIGURE 187.-High-resolution acoustic reflection profile showing a principal strand of the Palos Verdes Hills fault zone on the San Pedro shelf about $15 \mathrm{~km}$ south of Long Beach. Vertical exaggeration 9:1. The basal Holocene reflector shows a vertical separation of $3 \mathrm{~m}$, and the sea floor is offset about $1 \mathrm{~m}$, southwestern side up. Qh, Holocene; Qpl, Pleistocene; Tm, Miocene.

ing to fault S-4 of Dames and Moore and MESA ${ }^{2}$ (1983)) of the Palos Verdes Hills fault zone that lies along the northeastern flank of the Palos Verdes uplift; this fault offsets the basal Holocene reflector approximately $3 \mathrm{~m}$, southwestern side up, and produces a scarp $1 \mathrm{~m}$ high at the sea floor. The presence of a "topographic anomaly," considered to reflect tectonic upbowing of the sea floor above the Neogene bedrock units southwest of this fault, further suggests Holocene activity along this fault strand (Dames and Moore and MESA ${ }^{2}$, 1983). Holocene activity on the Palos Verdes Hills fault zone is also suggested by seismologic data from the San Pedro shelf and the northern Gulf of Santa Catalina (Hileman and others, 1973; Teng and Henyey, 1975).

A potentially active segment of the Palos Verdes Hills fault zone-the Cabrillo fault-was mapped principally as an inferred fault by Woodring and others (1946) for about $3.5 \mathrm{~km}$ from the central Palos Verdes Hills to Cabrillo Beach, where, in seacliffs, it is seen to dip northeasterly (southwestern side upthrown) and cut Miocene strata. Greene and others (1975) extended the trace southward offshore to near the head of the San Pedro Sea Valley, where it is shown as offsetting the base of Holocene sediment; however, the fault as Greene and his coworkers drew it is not aligned with other structural elements on the San Pedro shelf, and the connection of onshore and offshore strands of the fault seems questionable. Nardin and Henyey (1978) mapped the Cabrillo fault for $9 \mathrm{~km}$ southeastward across the San Pedro shelf along a different trace but did not discuss its age or structural significance. In a recent study for the U.S. Geological Survey (Dames and Moore and MESA², 1983), investigators mapped the Cabrillo fault as a zone of disruption $11 \mathrm{~km}$ long and $500 \mathrm{~m}$ wide and occupying a position similar to that mapped by Nardin and Henyey (1978) but, at its southeastern end, joining the Palos Verdes Hills fault. The presence of two 1.2-m-high southfacing "scarps" in late Quaternary sediment and lowrelief "topographic anomalies" thought to have been produced by tectonic deformation of the sea floor is considered by the Dames and Moore and MESA ${ }^{2}$ study as evidence of latest Holocene activity. We have mapped a fault on high- and intermediate-resolution acoustic reflection profiles in the position shown for the Cabrillo fault (fig. 185) by the Dames and Moore and MESA ${ }^{2}$ investigators. This fault closely approaches or reaches the 

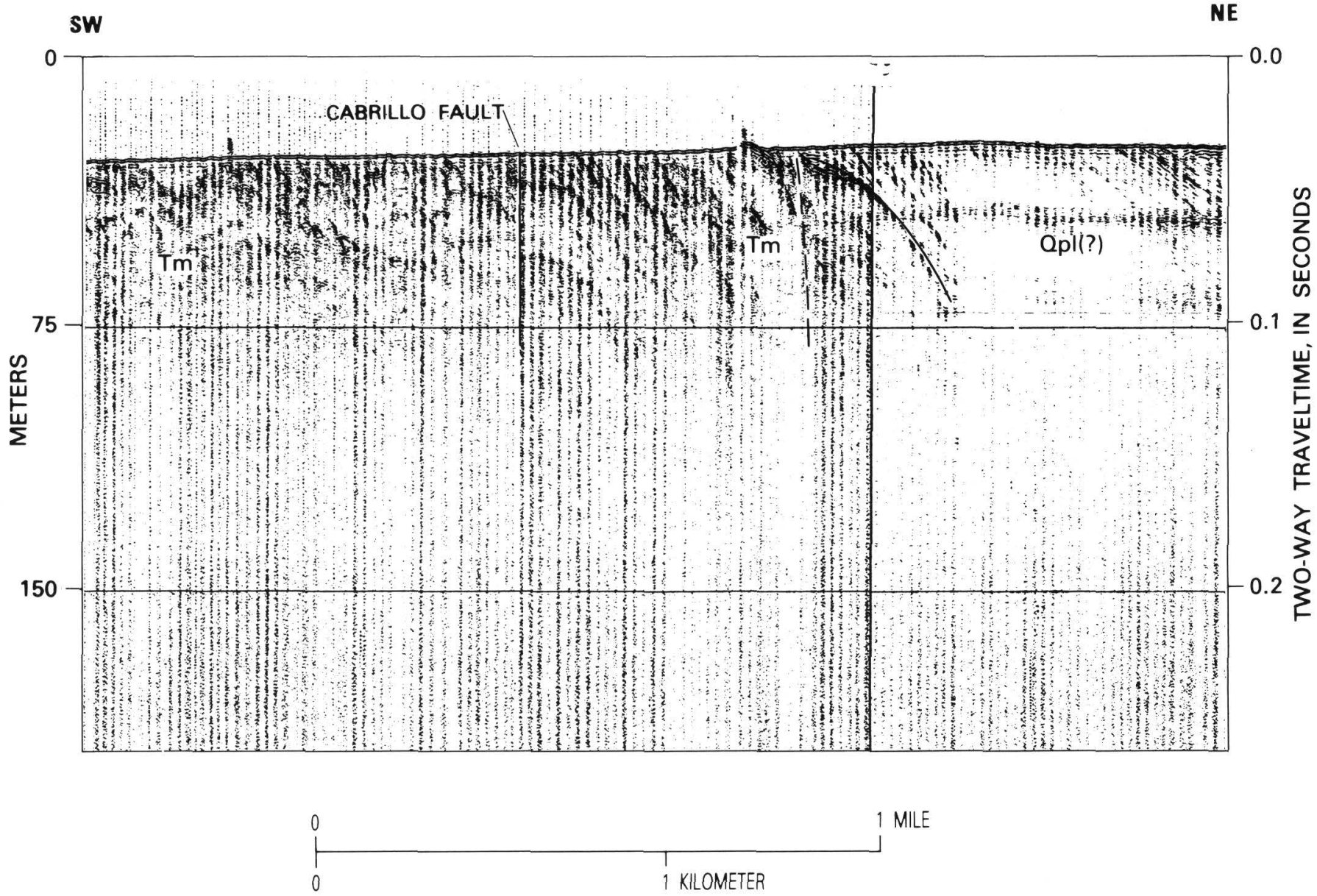

FIGURE 188.-High-resolution acoustic reflection profile showing the Cabrillo fault on the San Pedro shelf about 9 km southeast of San Pedro. Vertical exaggeration 10:1. Note that this fault cuts Miocene strata to the sea floor, but there is no apparent sea-floor offset. QPl, Pleistocene; Tm, Miocene.

sea floor in Miocene strata, but there is no apparent surface displacement (fig. 188). On balance, it seems possible that the Cabrillo fault is an active 15-km-long strand of the Palos Verdes Hills fault zone, but additional documentation of the age and nature of offset is desirable.

The length, trend, and character of the offshore Newport-Inglewood-Rose Canyon and Palos Verdes Hills-Coronado Bank fault zones are comparable to those of the Whittier-Elsinore and San Jacinto fault zones onshore. Short, en echelon, second-order faults are associated with each major fault zone and commonly splay from the primary faults at angles ranging from $20^{\circ}$ to $40^{\circ}$. Second-order fold axes are similarly related to these fault zones. These structural relations follow the stress pattern for wrench faulting described by Moody and Hill (1956) and Wilcox and others (1973) and suggest that each of these major fault zones may represent a throughgoing, right-slip fault within the underlying basement rock. Major structural and physiographic features within and bounding the Catalina block are also compatible with the wrench tectonic model. The La Jolla Submarine Canyon near San Diego, for example, appears to be a graben formed as a result of tension associated with dilation within the Catalina block. Similarly, the Coronado Bank and Point Loma in the San Diego area appear to be horsts produced by compression.

The presence of the Palos Verdes Hills fault on the Palos Verdes peninsula is indicated by vertical separation of the Catalina Schist basement, the elevation of the Palos Verdes Hills largely during late Tertiary and Quaternary time, and the presence of deformed strata of early to late Pleistocene age along the northeastern flank of the Palos Verdes Hills (Woodring and others, 1946; Schoellhamer and Woodford, 1951; Yerkes and others, 1965). The Palos Verdes Hills fault appears to extend northwestward across Santa Monica Bay, cuts the head of Redondo Canyon, and terminates against or merges with the Anacapa fault southeast of Point Dume

\section{Earthquake Hazards in the Los Angeles Region}


(fig. 185); whether Holocene motion is taken up principally along this strand of the fault is problematic, however. In Santa Monica Bay, the Palos Verdes Hills fault cuts strata ranging in age from Pliocene to Quaternary, although major fault motion appears to be preQuaternary (Junger and Wagner, 1977). An alternative view of activity along the Palos Verdes Hills fault in Santa Monica Bay was taken by Nardin and Henyey (1978), who considered that right-lateral offset along this fault southeast of Redondo Canyon is accommodated in Santa Monica Bay by south-over-north reverse faulting along the Redondo Canyon fault, a highangle fault first mapped by Emery (1960, p. 79) (see also Yerkes and others, 1967; Junger and Wagner, 1977) along the southern wall of Redondo Canyon and the narrow shelf adjacent to the Palos Verdes Hills (fig. 185). Nardin and Henyey cited as evidence the apparent absence of large vertical offsets along the Palos Verdes Hills fault in Santa Monica Bay northwest of Redondo Canyon and the presence of large vertical separation and Holocene displacements on the Redondo Canyon fault and on the Palos Verdes Hill fault on land and farther to the southeast in San Pedro Bay. The Redondo Canyon fault joins the main strand of the Palos Verdes Hills fault at or near the coast line and cuts the sea floor and Holocene deposits on the shelf south of the head of Redondo Canyon (Junger and Wagner, 1977; Nardin and Henyey, 1978; Nardin, 1981). Seismicity data for Santa Monica Bay are inconclusive as to whether recent motion on the Palos Verdes Hills fault is accommodated on the strand mapped across Santa Monica Bay by Junger and Wagner (1977) or along the Redondo Canyon fault. The length of the Palos Verdes Hills fault from its juncture with the Redondo Canyon fault to the vicinity of Lasuen Knoll, a segment characterized by continuous to intermittent offsets of Holocene strata, is approximately $70 \mathrm{~km}$, however.

Other northwest-trending zones of faulting in the offshore San Pedro-Santa Monica Basin area include (1) the San Pedro Basin fault zone and (2) a zone of en echelon faults that lies along the crest and slope of the Santa Cruz-Santa Catalina Ridge (fig. 185). The San Pedro Basin fault zone consists of steeply dipping, en echelon, generally left-stepping faults extending from the southeastern sill of the San Pedro Basin northwestward along the northern flank of Redondo Knoll to the vicinity of Dume Canyon, a total distance of about $85 \mathrm{~km}$ (Junger and Wagner, 1977). This fault zone appears, at its northwestern terminus, to join or terminate against the Anacapa fault. Faults of the San Pedro Basin fault zone vertically displace Pliocene strata $200 \mathrm{~m}$ or more near the mouth of Dume Canyon, whereas, farther southeast, near Redondo Knoll, Miocene rocks show a minimum displacement of $500 \mathrm{~m}$. Nardin (1981) indi- cated that sediment of late Pleistocene age or younger-and locally the sea floor-may be displaced by faults of the San Pedro Basin fault zone in both the San Pedro and the Santa Monica Basins. Faults showing vertical separation are predominantly northeastern side down, although apparent reversals of relative vertical offset suggest a component of strike slip (Nardin, 1981). Seismicity data show clusters of epicenters associated with youthful faults in the vicinity of Dume Canyon, near the juncture of the Anacapa fault and the San Pedro Basin fault zone, and in the San Pedro Basin northeast of the San Pedro Basin fault zone; relatively few epicenters are evident in the San Pedro and Santa Monica Basins southwest of the San Pedro Basin fault zone. This distribution of faults and epicenters suggests that the San Pedro Basin fault zone forms the southwestern margin of a major structural block. Nardin (1981) indicated that this block may be a tipped graben resulting from a combination of compression and right shear in a broad transform margin. The extent of the San Pedro Basin fault zone may be greater than figure 185 shows, if, as Junger and Wagner (1977) and Nardin (1981) suggested, it adjoins faults that extend farther southeast through the Gulf of Santa Catalina and the San Diego Trough to or beyond the Mexican border. However, a southeastward continuation of the fault zone is not indicated by recent mapping in the Gulf of Santa Catalina (Greene and others, 1979; Clarke and others, 1983).

A northwest-trending zone of faulting as wide as $4 \mathrm{~km}$ has been mapped along the base and flank of the bathymetric ridge extending from Santa Catalina Island to the Santa Cruz Island platform, where it appears to merge with the east-trending Santa Cruz Island fault (Edwards, 1982). These faults dip steeply and are predominantly downthrown to the northeast, toward the Santa Monica Basin; they cut rocks of Miocene and Pliocene age, and Quaternary strata are cut locally (Edwards, 1982). This fault zone has been identified as the source of the 1981 Santa Barbara Island earthquake $\left(\mathrm{M}_{\mathrm{L}} 5.2\right)$ (Corbett and Piper, 1981). Individual faults of this zone appear to be discontinuous, generally a few kilometers to as much as about $30 \mathrm{~km}$ long, although the zone itself may extend for more than $100 \mathrm{~km}$. A sinuous, west-northwesttrending, 27-km-long fault that cuts Quaternary sediment in the Santa Monica Basin and Miocene rocks on the crest and flank of the ridge is mapped in the area of complex folding and faulting where the ridge abuts the Channel Islands platform south of Santa Cruz Island (Edwards, 1982). A fault of similar length is present low on the slope of the ridge northwest of Santa Catalina Island, where it reaches the sea floor and juxtaposes volcanic and sedimentary rocks of Miocene age (Junger and Wagner, 1977).

Faults and Unstable Slopes Offshore 
West-trending structures along the southern margin of the Transverse Ranges abut the northwest-trending structural grain to the south along a 200-km-long zone of late Quaternary dislocation comprising the Santa Monica-Malibu Coast, Anacapa, Santa Cruz Island, and Santa Rosa Island faults (fig. 185). These are northdipping reverse faults, and at least two-the Santa Monica and Santa Cruz Island faults-show components of left-lateral offset. The Santa Monica fault extends for $\mathbf{4 0} \mathrm{km}$ along the southern margin of the Santa Monica Mountains and forms the southern structural boundary of the Transverse Ranges province in this area. Vertical separation of basement rocks is estimated to be as much as 2,400 to $3,660 \mathrm{~m}$, and a large amount of left-lateral strike slip is inferred to account for the juxtaposition of dissimilar pre-upper Miocene rocks across this fault (McCulloh, 1960; Campbell and Yerkes, 1976). Elements of the Santa Monica fault appear to cut upper Pleistocene terrace deposits at several localities onshore (Yerkes and Lee, 1979b), and two west-trending faults that are probable offshore extensions of the Santa Monica fault may cut Holocene sediment in northern Santa Monica Bay (Greene and others, 1975, pl. 10).

The Santa Monica fault apparently bifurcates westward in northern Santa Monica Bay (fig. 185). The northern branch-the Malibu Coast fault-cuts the coast north of Point Dume; the southern branch extends westward offshore as the Anacapa fault. The Malibu Coast fault is a narrow, north-dipping zone of reverse faults 25 to $30 \mathrm{~km}$ long that juxtaposes dissimilar basement and younger rocks along its entire length and for which 60 to $90 \mathrm{~km}$ of left-lateral strike slip has been inferred (Campbell and Yerkes, 1976). This fault, which separates the Santa Monica Mountains from the lowlying coastal plain to the south, has thrust upper Miocene strata more than $15 \mathrm{~m}$ over upper Pleistocene terrace deposițs near Malibu Canyon and has cut Pleistocene strata at other localities onshore (Yerkes and Lee, 1979b). Offshore, the Malibu Coast fault appears to terminate in Pleistocene deposits on the slope near Mugu Canyon, where a vertical displacement of $200 \mathrm{~m}$ in Miocene rocks has been noted Junger and Wagner, 1977). The Anacapa fault forms the southern structural boundary of the Transverse Ranges province in the offshore. This fault extends as one or two northdipping strands along the northern slope of Santa Monica Bay to the Santa Cruz Island platform, a distance of about $45 \mathrm{~km}$. Major offset on the Anacapa fault appears to have taken place during Pliocene time. Junger and Wagner (1977, fig. 7) indicated north-side-up vertical separations of several hundred meters in lower Pliocene strata south of Point Dume and substantially greater offsets in Miocene rocks. They also show (Junger and Wagner, 1977, fig. 4) Quaternary sediment to be cut locally in the general vicinity of Dume Canyon, but, elsewhere, the Anacapa fault appears to terminate in Pliocene strata. However, the Anacapa fault is associated with the Santa Monica and Santa Cruz Island faults, both of which show well-documented late Quaternary offset, and the identification of this fault as the probable source of the 1973 Point Mugu earthquake (M 5.3) and its aftershocks (Lee and others, 1979; Yerkes and Lee, 1979b; Yerkes, this volume) suggests that it is active.

The Anacapa fault appears to merge westward with the Santa Cruz Island fault near the base of the Channel Islands platform southeast of Anacapa Island (Junger and Wagner, 1977; Edwards, 1982). The Santa Cruz Island fault continues as a narrow zone westnorthwestward for nearly $70 \mathrm{~km}$ to its juncture with the Santa Rosa Island fault near the western coast of Santa Cruz Island (fig. 185). Throughout most of its length, the Santa Cruz Island fault is steeply north dipping and lies in the prominent central valley of Santa Cruz Island, where it juxtaposes dissimilar pre-Tertiary and Tertiary basement, volcanic, and sedimentary rocks Junger, 1976). This fault cuts Quaternary strata on the Channel Islands platform east of Santa Cruz Island, and the westward offshore continuation of the fault cuts Quaternary deposits with a minimum of $15 \mathrm{~m}$ of vertical separation Uunger and Wagner, 1977; Junger, 1979; Edwards, 1982). On Santa Cruz Island, stream deflections of up to $300 \mathrm{~m}$ in a left-lateral sense suggest at least that much late Quaternary lateral displacement (Junger, 1979; Patterson, 1979). The Santa Cruz Island fault is a possible source for the 1973 Anacapa Island earthquake $\left(M_{L} 5.0\right)$ (Ziony and Yerkes, this volume, table 5).

Faults within the eastern Santa Barbara Basin and the northeastern Transverse Ranges are characterized by thrust and high-angle reverse displacements, generally subordinate left slip, great structural relief, and moderate to large amounts of late Quaternary vertical offset. These displacements reflect the profound northsouth compression that has (and is presently) shaping this region. Several faults-most notable among them the Oak Ridge (Montalvo) and McGrath faults and the Pitas Point-Ventura fault-extend offshore into the eastern Santa Barbara Basin (fig. 185). The Oak Ridge fault-the dominant structural feature of the eastern Santa Barbara Basin-is a west-trending zone of deformation comprising folds and faults that can be traced for nearly $100 \mathrm{~km}$, from the eastern Ventura Basin westward and offshore into the Santa Barbara Basin. The Oak Ridge fault dips shallowly to steeply southward and is characterized by thrusting, reverse faulting, and isoclinal folding. On land, it occupies a narrow zone that generally follows the Santa Clara River westward to the coast south of Ventura. East of Ventura, strata of

366 Earthquake Hazards in the Los Angeles Region 
Miocene age and older show an apparent stratigraphic separation of $2,000 \mathrm{~m}$ or more and, in places, have been thrust over upper Pleistocene strata (Baddley (1954) as cited by Yerkes and Lee (1979b)). Although sea-floor displacement is not observed along the fault trace, upper Pleistocene strata offshore locally show an apparent vertical displacement of more than $135 \mathrm{~m}$ (Greene and others, 1978). The McGrath thrust-a branch to the south of the Oak Ridge fault-extends only about $3 \mathrm{~km}$ offshore. The McGrath fault dips gently south in the offshore, similar to the Oak Ridge fault, and cuts strata as young as late Pleistocene in age (Greene and others, 1978). The western part of the Oak Ridge fault has been suggested by Ziony and Yerkes (this volume, table 5) as a possible source for the 1925 Santa Barbara earthquake (M 6.8).

The Pitas Point-Ventura fault is a $50-\mathrm{km}$-long northdipping reverse or left-oblique fault that has been traced along the northern side of the Santa Clara River valley and the foothills of the Santa Ynez Mountains before it extends offshore at Ventura. Offshore, $3 \mathrm{~km}$ southeast of Pitas Point, this fault displaces an upper Pleistocene erosion surface $25 \mathrm{~m}$, northern side up, and cuts the base of the overlying Holocene sediment (Greene and others, 1978). About $15 \mathrm{~km}$ southeast of Santa Barbara, the Pitas Point fault dips steeply northward and displaces late Pleistocene strata (Yerkes and Lee, 1979a); still farther west, it joins the Pitas Point thrust of Weaver and others (1969). The Ventura fault, inferred to be an onshore extension of the Pitas Point fault, dips steeply north and cuts Holocene sediment near Ventura (Sarna-Wojcicki and others, 1976). Vertical separation at the base of upper Pleistocene strata has been estimated as $275 \mathrm{~m}$ (Ogle and Hacker, 1969), and a component of left slip is indicated by related folds and by the fault-plane solution of a 1970 earthquake $\left(M_{L}\right.$ 3.6) associated with this fault (Lee and others, 1979; Yerkes and Lee, 1979b). Luyendyk and others (1983), using high-resolution acoustic reflection data, have mapped a curvilinear step in the sea floor on the shelf between Goleta and Rincon Point, about 5 to $7 \mathrm{~km}$ north of and roughly parallel to the trace of the Pitas Point-Ventura fault. They interpreted this step as the expression of a 33-km-long, south-dipping reverse fault that shows as much as $\mathbf{1 0} \mathbf{m}$ of sea-floor offset and probable offsets of "Holocene materials." They named this feature the Goleta-Rincon fault and correlated it in part with "fault Y" as mapped by Yerkes and Lee (1979a). The Pitas Point-Ventura fault has been suggested by Ziony and Yerkes (this volume, table 5) as the source for the 1941 Santa Barbara earthquake (M 6.0) and the 1978 Santa Barbara earthquake $\left(M_{L}\right.$ 5.1). Evernden and Thomson (this volume) concluded, from patterns of observed and predicted seismic intensities, that the
Pitas Point-Ventura fault and possible eastward extensions could have generated the large earthquake of December 21, 1812, which severely damaged missions throughout the western Transverse Ranges.

\section{Sea-Floor Instability}

Much of the southern California continental borderland is characterized by slopes having thick accumulations of poorly consolidated or unconsolidated fine-grained sediment of Quaternary age. Because this sediment is typically water saturated, its shear strength is commonly lower than that of corresponding sediment exposed onshore. As a consequence, many failures in the marine environment are larger and occur on lower slopes than typical failures on land. In fact, failures on submarine slopes of less than $4^{\circ}$ are commonplace (see, for example, Lewis, 1971; Prior and Coleman, 1977), and failures on slopes as low as $0.25^{\circ}$ have been documented (Field and others, 1982). Zones of sea-floor failure commonly measure in the range of kilometers on a side and may be much larger, covering areas in the range of tens of thousands of square kilometers (Selnes, 1982). Forces acting to trigger movement in accumulations of unconsolidated sediment are those that tend to increase the load on the sediment mass or to reduce the shear strength. These forces may be static (for example, imposed by loading associated with high rates of sedimentation) or cyclic (for example, imposed by storm waves or earthquake shaking). Thus, proximity to sources of sediment supply, proximity to seismogenic faults, and wave climate, as well as sea-floor declivity, are critical factors to consider in evaluating susceptibility to failure. The interrelation of these and other potential influences promoting failure is complex and has been discussed in greater detail as it relates to slope stability in the offshore Los Angeles region by Field and Edwards (1980). Most submarine failures that we have noted appear to be composite rather than single events, and it is usually impossible to determine, through a remote-sensing study using standard equipment, the nature, scale, timing, and rate of motion of the individual slides and flows that contribute to failure. Zones of past failure should be viewed as having an unknown potential for renewed movement. As a consequence of having failed already, some may be more stable than unfailed accumulations of sediment on the adjacent slopes; others, however, may have unchanged or even reduced stability. Consequently, the geologic and engineering properties of past failures and of the adjacent slopes must be studied on a case-by-case basis. Earthquake-induced sea-floor slides are rarely reported for historical earthquakes worldwide, probably because of difficulties in documenting such failures 
in the marine environment (Wilson and Keefer, this volume). Wilson and Keefer's (this volume) figure $164 C$ shows the estimated limiting distances, for earthquakes of different magnitudes, of liquefaction-related failures such as subaqueous slides.

Geotechnical and sedimentologic evaluations of two widely separated zones of sea-floor failure (off San Mateo Point $70 \mathrm{~km}$ southeast of Los Angeles and in the Santa Barbara Basin $15 \mathrm{~km}$ southeast of Gaviota) provide evidence that sea-floor failures off southern California may be earthquake induced (Edwards and others, 1980; Edwards, 1982). Each zone of failure off San Mateo Point is about $1.5 \mathrm{~km}$ wide, $3.5 \mathrm{~km}$ long (downslope), and $50 \mathrm{~m}$ thick and comprises multiple discrete slumps on slopes of $4^{\circ}$ or less. The heads of these failures are at water depths of about $600 \mathrm{~m}$, and their toes lie at depths of about $750 \mathrm{~m}$, in the southern part of Newport Submarine Canyon. The failure off Gaviota is about $2 \mathrm{~km}$ wide and $2 \mathrm{~km}$ long and is a mass flow deposit that heads in $395 \mathrm{~m}$ of water and toes at a depth of $510 \mathrm{~m}$. Geotechnical studies of cores from these deposits and from undisturbed sediment on the adjacent slopes suggest that horizontal ground accelerations of 0.13 to $0.17 \mathrm{~g}$ would be sufficient to initiate failure on the $3^{\circ}$ to $4^{\circ}$ slopes characteristic of much of this region.

Strong shaking from earthquakes is thought to be the triggering mechanism, because these failures occur well below the water depths at which cyclic loads imposed by surface waves are significant. According to Seed and others (1976), the mean ground acceleration produced in deep cohesionless soil by an earthquake of magnitude 6.5 at an epicentral distance of $45 \mathrm{~km}$ is $0.1 \mathrm{~g}$; the mean acceleration plus one standard deviation under these conditions is slightly less than $0.2 \mathrm{~g}$ (reported by Edwards and others, 1980). Numerous historical earthquakes of about $\boldsymbol{M} 6$ or greater-large enough to have generated ground motions at this level or greater-are reported for the offshore and coastal Los Angeles region (Yerkes, this volume, table 3). Clearly, ground motions theoretically capable of triggering the massive failures observed on submarine slopes throughout this region occur repeatedly. Although not taken from the southern California offshore, additional documentation that seafloor failures can be earthquake induced has been provided by a recent study of the Klamath River delta on the northern California shelf (Field and others, 1982). Geophysical surveys conducted before and after a $M_{L} 6.5$ earthquake (November 9, 1980) centered $75 \mathrm{~km}$ northwest of Eureka indicated that failure by liquefaction and sediment flowage on very low slopes over a $120-\mathrm{km}^{2}$ area was triggered by that earthquake.

Sea-floor failures in the offshore San Pedro Bay-Gulf of Santa Catalina area have been mapped and described by Greene and others (1975), Richmond and others (1981), Edwards and others (1980), and Clarke and others (1983). Numerous sediment slides are present in the Gulf of Santa Catalina area, the majority in the northern part between San Mateo Point and the San Pedro shelf (Clarke and others, 1983) (fig. 189). These areas of failure, in general, are characterized on highresolution acoustic reflection records by a hummocky sea-floor surface and, in the subsurface, by steeply dipping, more-or-less distinct reflectors extending upward to or near the sea floor. These reflectors are interpreted as geologically young slip surfaces, and the areas comprise a continuous series of rotated and displaced sediment masses. Zones of failure typically occur on slopes of $4^{\circ}$ or less, at water depths ranging from 250 to $900 \mathrm{~m}$, and extend to a depth of as much as $50 \mathrm{~m}$ below the sea floor. Where the dimensions of these zones of failure could be determined, they range in area from about 1 to about $12 \mathrm{~km}^{2}$.

A rotational slump covering an area of 8 to $9 \mathrm{~km}^{2}$ is located near the base of the San Pedro escarpment 15 to $20 \mathrm{~km}$ south of Point Fermin at water depths of 700 to $850 \mathrm{~m}$ (fig. 189). Two other failures flanking the San Pedro shelf have been mapped by Greene and others (1975). The larger of these failures covers an area of about $10 \mathrm{~km}^{2}$ and apparently involves strata of early Pliocene age and younger at water depths of 200 to $700 \mathrm{~m}$ about $5 \mathrm{~km}$ south of Point Fermin. A second failure, located just below the shelf edge $15 \mathrm{~km}$ southeast of Point Fermin, covers $3 \mathrm{~km}^{2}$ and involves probable Pleistocene and Holocene deposits. Two areas of rotational slumping are also present on the eastern slope of the Gulf of Santa Catalina within about $10 \mathrm{~km}$ of Oceanside. These failures, both of which involve late Quaternary deposits, cover areas of about 15 and $10 \mathrm{~km}^{2}$ and head at water depths of about 200 and $500 \mathrm{~m}$.

Sediment masses interpreted as subaqueous flow deposits are located in two areas at or near the base of the slope between Newport Beach and Dana Point, at water depths ranging from about 400 to $700 \mathrm{~m}$. These areas are characterized, on high-resolution acoustic reflection records, by upwardly convex, hummockyappearing bulges of the sea floor and the disruption or absence of shallow subbottom reflectors. The larger of the areas was determined to cover nearly $60 \mathrm{~km}^{2}$ and to extend to a depth of $40 \mathrm{~m}$ or more below the sea floor. These deposits probably represent repeated episodes of relatively recent, small-scale mass movement.

Evidence of sediment creep was noted on the eastern slope of the Gulf of Santa Catalina off Newport Beach and off Oceanside. The zones of creep are about 3 to $5 \mathrm{~km}$ in their downslope dimension and extend from water depths of 200 to 250 to about $500 \mathrm{~m}$. Creep in this region appears from acoustic reflection records to affect sediments to a maximum depth of about $20 \mathrm{~m}$ below 
the sea floor; in the areas off Newport Beach, creep zones appear to merge downslope with sediment slides.

Sea-floor failures in Santa Monica Bay between the Palos Verdes peninsula and Point Dume have been described by Greene and others (1975), Haner and Gorsline (1978), and Edwards (1982). Rotational slumps up to $3 \mathrm{~km}$ in breadth are present in Santa Monica Canyon, especially along its oversteepened southern and eastern walls; typically, however, these failures are smaller, averaging about $1 \mathrm{~km}^{2}$ in area (fig. 189). These failures commonly lack a modern sediment drape, an indication that they are geologically youthful (Edwards, 1982). Additional zones of failure are present on the slope between Santa Monica Canyon and Point Dume. A zone of individual slides 4.5 to $7.5 \mathrm{~km}$ long and about 9 to $40 \mathrm{~m}$ thick has been mapped by Haner and Gorsline (1978) as extending diagonally across the slope between Dume Canyon, at a depth of $580 \mathrm{~m}$, to the slope off Malibu, at a depth of about $220 \mathrm{~m}$; the upper part of this slide zone coincides approximately with the trace of the Anacapa fault east of its juncture with the San Pedro Basin fault zone. Parts of the lower Santa Monica Canyon are filled at depths of about 600 to $800 \mathrm{~m}$ by a major slide that covers an area of $15 \mathrm{~km}^{2}$. In addition, an extensive zone of sediment creep is mapped below the shelf break as covering an area of at least $35 \mathrm{~km}^{2}$ on the $0.8^{\circ}$ to $2.7^{\circ}$ slope north of the upper reaches of Santa Monica Canyon (Haner and Gorsline, 1978; Edwards, 1982).

Submarine slides in the northern Santa Monica Basin are associated principally with the Hueneme and Mugu Submarine Canyons. Hueneme Canyon is cut through a thick section of poorly consolidated Pleistocene sediment and, perhaps partly as a consequence, is the site of several rotational slumps, the largest being 4 to $5 \mathrm{~km}^{2}$ in area and extending from water depths of 100 to about $450 \mathrm{~m}$ (Greene and others, 1978). Other smaller failures are present along the western side of the upper part of Hueneme Canyon (near its head), in upper Mugu Canyon, and on the slope between these two canyon systems (Greene and others, 1975, 1978). These slides are mapped at water depths of 50 to $600 \mathrm{~m}$ and are typically $1 \mathrm{~km}^{2}$ or less in area, although Edwards (1982) reported an area of sediment slides (possibly block glides) measuring $30 \mathrm{~km}^{2}$ in area on the extensively gullied slope west of Dume Canyon at depths between 100 and $500 \mathrm{~m}$.

Evidence for downslope sediment creep is extensive and commonly occurs in association with failures within and between the Hueneme and Mugu Canyon systems and on the Hueneme fan (Greene and others, 1978; "unstable sediment masses" of Edwards, 1982). A large single area of creep deformation extends for nearly $15 \mathrm{~km}$ just below the shelf break west of Hueneme Canyon and appears to affect slope deposits down to a water depth of about $250 \mathrm{~m}$.
Extensive zones of failure are also present in the Santa Barbara Basin. According to Richmond and others (1981, p. 11), "over 20 percent of the central Santa Barbara Basin is covered by areas of unstable sediment moving downslope toward the center of the basin." Two principal areas of mass movement are delineated, each covering more than $150 \mathrm{~km}^{2}$; these areas comprise multiple failures and show evidence of sediment disturbance that extends, in many places, to depths of more than $90 \mathrm{~m}$ below the sea floor.

\section{Hydrocarbon Seepage and Shallow Gas Accumulation}

Natural gas of biogenic and thermogenic origin may be present in marine sediment. Biogenic gas-principally methane-is derived from bacterial alteration of organic material in sediment (Claypool and Kaplan, 1974). Thermogenic gas, characterized by relatively high levels of hydrocarbons heavier than methane, is a byproduct of petroleum formation (Bernard and others, 1976). The presence of thermogenic gas in sediment can reflect an overpressured zone that is discharging gas into the overlying strata either directly or through a conduit such as a fault or a bedding plane. Gas of either type present as bubbles in the pore space of sediment can increase pore pressure and reduce the shear strength of the enclosing sediment and thus enhance the likelihood of failure (Sangrey, 1977). Additionally, sediment containing dissolved gas can liquefy spontaneously when it is subjected to cyclic loading, like that caused by earthquake ground motion (Hall and Ensiminger, 1979). Consequently, identifying areas of possible shallow gas accumulation is an important adjunct of studies of sediment instability in the offshore. Indications of shallow gas accumulation from acoustic reflection records (see criteria on p. 354) are in themselves inconclusive if there is no direct measurement of gas content in cores or underwater sonographic or photographic evidence of gas seepage at the sea floor. Nonetheless, acoustic reflection data commonly provide useful indications of the presence of gas in sediment offshore. Oil and gas seeps and areas of possible shallow gas accumulation identified from acoustic reflection studies in the offshore Los Angeles region are shown in figure 189.

Wilkinson's (1971) study of California oil and gas seeps shows that oil seepages were reported from the San Pedro shelf near Point Fermin and from the northeastern slope of the San Pedro Basin and that gas (probably methane) seepage was reported from near shore in the vicinity of Huntington Beach (fig. 189). Additional seeps were mapped by Greene and others (1975) on the inner shelf seaward of the Palos Verdes Hills and off 


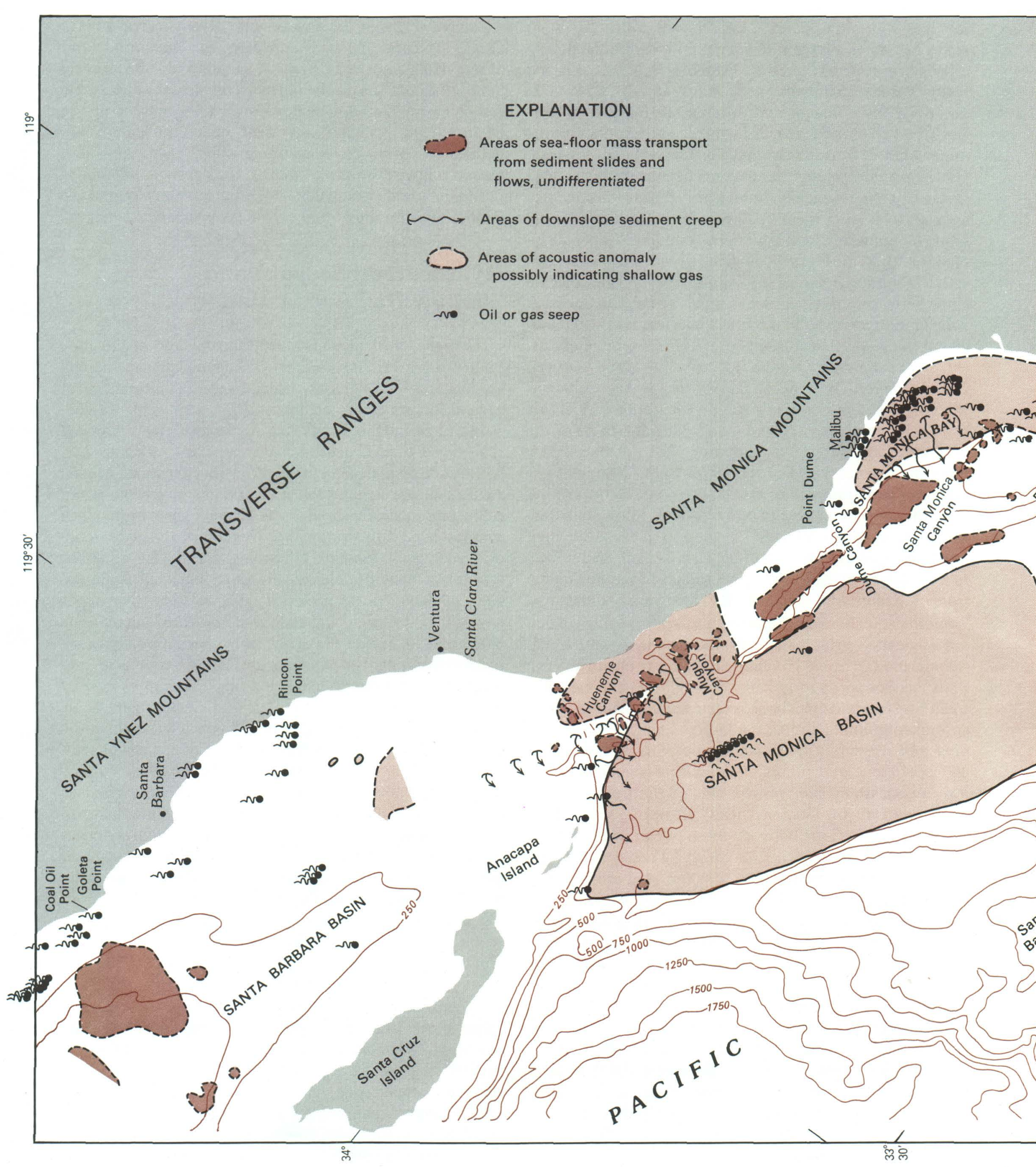

FIGURE 189.-Sea-floor failures, hydrocarbon seeps, and areas of shallow gas accumulation in the offshore Los Angeles region. Areas of sea-floor mass transport and sediment creep have been compiled from the following sources: Santa Barbara Basin from Richmond and others (1981); Santa Monica Bay and the Santa Monica Basin from Edwards (1982), Greene and others (1975, 1978), and Haner and Gorsline (1978); San Pedro Bay, the San Pedro Basin, and the Gulf of Santa Catalina from Clarke and others (1983), Edwards (1982), and Greene and others (1975). 


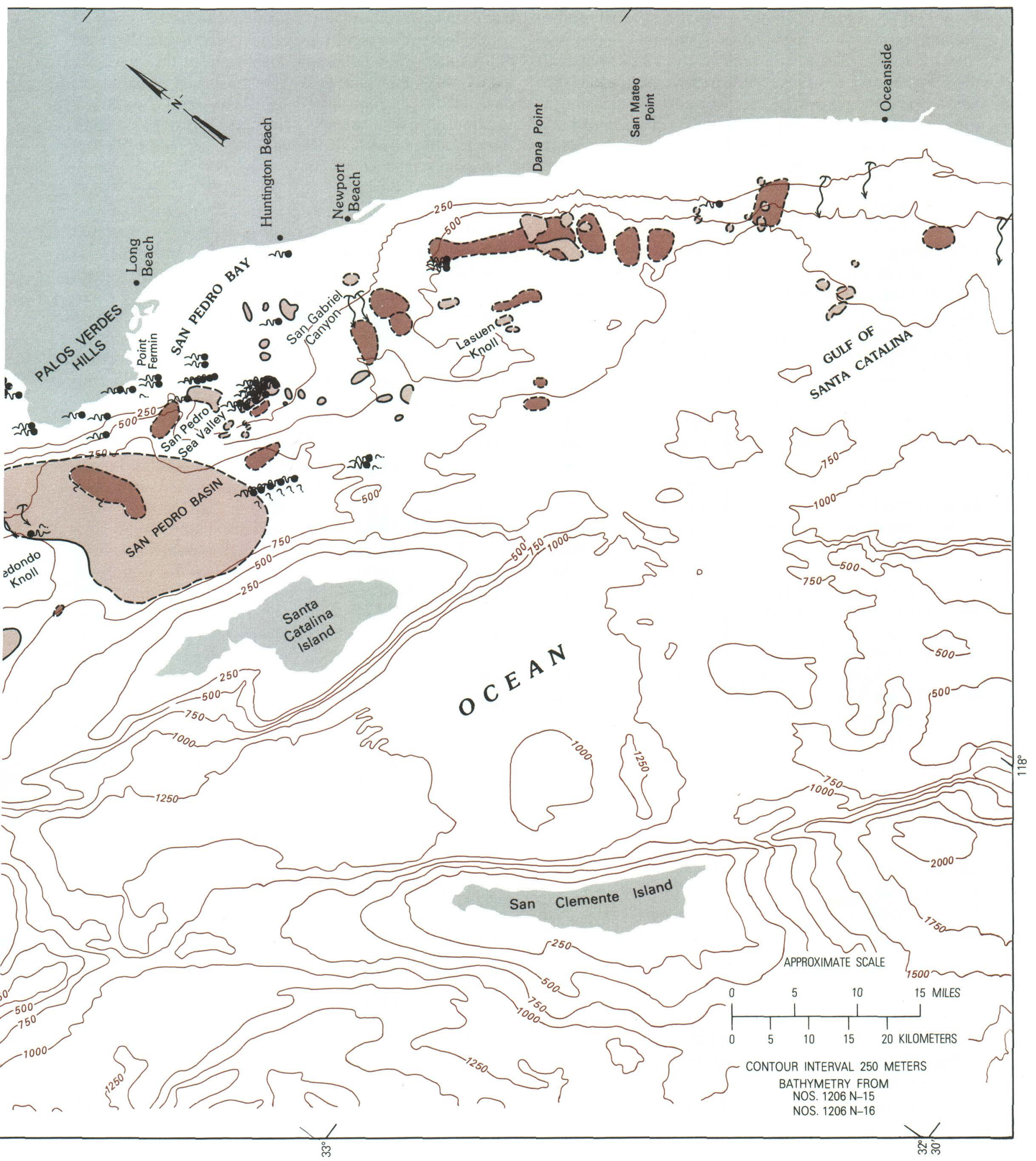

Areas of acoustic anomaly and oil and gas seeps have beer compiled from the following sources: Santa Barbara Basin from Richmond and others (1981) and Wilkinson (1971); Santa Monica Bay and the Sarta Monica Basin from Edwards (1982), Greene and others (1975), and Wilkinson (1971); San Pedro Bay, the San Pedro Basin, and the Gulf of Santa Catalina from Clarke and others (1983), Greene and others (1975), Richmond and others (1981), and Wilkinson (1971). Contour interval is $250 \mathrm{~m}$. Bathymetry from U.S. Coast and Geodetic Survey (1967a, b). 
Point Fermin. Acoustic anomalies in the water columnpossibly seeps-were reported by Richmond and others (1981) from the San Pedro shelf in the vicinity of both the Cabrillo and the Palos Verdes Hills fault zones. We identified a single water-column anomaly-possibly a seep-on the San Pedro shelf about $16 \mathrm{~km}$ south of Long Beach; this anomaly lies above folded and faulted strata of probable late Miocene age and in close proximity to deformation associated with the offshore extension of the Palos Verdes Hills fault zone.

Four small areas of acoustic anomaly thought to reflect the presence of gas in sediment were mapped by Clarke and others (1983) at shallow subbottom depths on the San Pedro shelf (figs. 184, 189). Three areas are in relatively shallow water 15 to $20 \mathrm{~km}$ south of Long Beach; two are in dipping strata of probable late Tertiary and Quaternary age, and one of them appears to be associated with an offshore strand of the Palos Verdes Hills fault zone. The third area, south of Long Beach, is in horizontally bedded strata of Quaternary age at a subbottom traveltime depth of 30 to 35 milliseconds. The fourth area is mapped about $7 \mathrm{~km}$ southwest of Newport Beach 10 to 20 milliseconds beneath the sea floor in flat-lying Quaternary sediment. Several additional areas of acoustic anomaly thought to reflect the presence of gas were reported by Richmond and others (1981) from the San Pedro shelf and the adjacent northern slope of the Gulf of Santa Catalina; these anomalies range in size from about 1 to $12 \mathrm{~km}^{2}$. Elsewhere, acoustic anomalies are reported in isolated localities from the slope southwest of Dana Point and Oceanside, at water depths in excess of $500 \mathrm{~m}$ and at traveltime depths below the sea floor of 50 to more than 350 milliseconds (Richmond and others, 1981).

Hydrocarbon seeps are widespread in Santa Monica Bay; many oil and gas seeps apparently are associated with the northwest-trending Palos Verdes Hills fault zone, especially near the head of Redondo Canyon (fig. 189) (Wilkinson, 1971; Greene and others, 1975; Edwards, 1982). Flow rates per seep of 12 to $15 \mathrm{bbl} / \mathrm{d}$ of oil and an undetermined amount of gas have been estimated for these seeps (Wilkinson, 1971). A second eastwest-trending cluster of seeps-principally oil seeps-occurs in northern Santa Monica Bay, where it may be associated with the offshore Santa Monica fault (Greene and others, 1975, pl. 10). Methane seepage from the sea floor off Malibu Point in northern Santa Monica Bay was reported following the 1971 San Fernando earthquake (Clifton and others, 1971); subsequent radioisotope analysis of the evolved gases indicate that they are Holocene in age and probably biogenic in origin (H. E. Clifton, oral communication, 1983). These seeps had a linear trend initially considered to have been fault controlled but now seen as probably following the trend of an ancient filled channel. Elsewhere in this area, Edwards (1982) has indicated (1) a cluster of possible gas seeps in the northern San Pedro Basin aligned with and apparently associated with the San Pedro Basin fault zone south and west of the Palos Verdes peninsula and (2) a group of predominantly gas seeps in the northern Santa Monica Basin.

Areas of oil and gas seepage in the northern Santa Barbara Basin east of $120^{\circ} \mathrm{W}$. are mostly associated with the offshore Rincon anticlinal trend and with eastwest trending faults between Rincon Point and Goleta Point (Wilkinson, 1971). The most voluminous of these areas of seepage is off Coal Oil Point near Goleta, where about 250 active oil or gas-oil seeps (not shown on fig. 189) are located primarily along or near the crests of highly faulted anticlines covered by a relatively thin veneer of unconsolidated sediment (Fischer and Stevenson, 1973).

Areas of acoustic anomaly interpreted by Edwards (1982) to reflect the presence of gas-charged sediment are distributed throughout the Santa Monica Basin. These areas underlie much of the shelf of the northeastern Santa Monica Bay between Point Dume and Redondo Canyon, where they extend seaward as much as about $13 \mathrm{~km}$, and the Ventura shelf in the vicinity of Hueneme and Mugu Canyons, where they extend 6 to $10 \mathrm{~km}$ offshore. Both areas extend from the shallow waters of the inner shelf seaward to water depths of about $250 \mathrm{~m}$. Large areas characterized by blotchy, intermittent subbottom reflections thought to result from gas accumulation in basin sediment occupy most of the Santa Monica Basin, including the Hueneme and Mugu submarine fan complexes, and the northwestern part of the San Pedro Basin between the Palos Verdes peninsula and Santa Catalina Island. These reflections appear to lie 30 to $50 \mathrm{~ms}$ below the sea floor (Edwards, 1982, fig. A-9).

\section{SUMMARY}

Acoustic reflection profiling-a marine geophysical method for remotely mapping geologic features on and beneath the sea floor-has been used to identify potentially active faults and areas susceptible to slope failures offshore from the Los Angeles region. A complex offshore network of Quaternary fault zones poses hazards to coastal and offshore development from fault offset, ground shaking, earthquake-induced ground failure, and possible tsunamis. South of the Los Angeles

372 Earthquake Hazards in the Los Angeles Region 
basin, faults of the $240+-\mathrm{km}$-long Newport-InglewoodRose Canyon fault zone apparently cut Holocene strata off Laguna Beach and Oceanside; this seismically active fault zone is associated with at least one major damaging earthquake, the 1933 Long Beach event (M 6.2). The Palos Verdes Hills-Coronado Bank fault zone cuts Holocene deposits along much of the $70-\mathrm{km}$ distance between Redondo Canyon and Lasuen Knoll. Holocene deformation also may be associated with the Cabrillo fault, an apparent splay from the Palos Verdes Hills fault zone on the San Pedro shelf.

Farther north, activity on several faults in the San Pedro Basin, the Santa Monica Basin, and the eastern Santa Barbara Basin is reflected by the regional seismicity, even though these faults have not been conclusively shown to cut Holocene strata. These faults include the San Pedro Basin fault zone, faults of the Santa Catalina-Santa Cruz Island escarpment (source of the $M_{L} 5.21981$ Santa Barbara Island earthquake), and faults of the 200-km-long zone of late Quaternary deformation comprising the Santa Monica-Malibu Coast, Anacapa (source of the $\boldsymbol{M} 5.31973$ Point Mugu earthquake), and Santa Cruz Island (possible source of the $M_{L}$ 5.0 1973 Anacapa Island earthquake) faults. In addition to continuing seismic activity along this zone, the Santa Monica fault apparently cuts Holocene sediment in the northern Santa Monica Bay. West-trending, high-angle reverse and thrust faults of the eastern Santa Barbara Basin are characterized by great structural relief and evidence of recent deformation. Most notable among these faults are the Oak Ridge fault, which cuts late Quaternary strata and is a possible source of the 1925 Santa Barbara earthquake ( $M$ 6.8), and the Pitas PointVentura fault, which cuts Holocene sediment onshore and offshore and may have generated several moderate to large historical earthquakes that affected the Santa Barbara region.

Much of the offshore Los Angeles region is characterized by slopes having thick deposits of watersaturated, fine-grained sediment that is prone to failure by sliding, flowing, and liquefaction, even on low slopes. Geotechnical analyses of recently deposited sediment in the eastern Santa Barbara Basin and off San Mateo Point southeast of Los Angeles indicate that, on the $3^{\circ}$ to $4^{\circ}$ slopes common in this region, sea-floor failures can be expected to result from ground shaking associated with earthquakes having magnitudes within the range of those recorded from the offshore Los Angeles region.

Evidence of geologically youthful sea-floor mass movement is common on acoustic reflection profiles throughout the offshore Los Angeles region. Large sediment gravity slides extending to $50 \mathrm{~m}$ below the sea floor cover areas of up to $12 \mathrm{~km}^{2}$ along the eastern slope of the Gulf of Santa Catalina but are most common between San Mateo Point and the San Pedro shelf. Rotational slumps cover more than $20 \mathrm{~km}^{2}$ on the slopes flanking San Pedro Bay and are also mapped off Oceanside in two zones having a combined area of about $25 \mathrm{~km}^{2}$. Subaqueous flow deposits are extensive in deeper water below the eastern slope of the Gulf of Santa Catalina between Newport Beach and Dana Point, covering an area of more than $60 \mathrm{~km}^{2}$ to a depth of up to $40 \mathrm{~m}$ below the sea floor. Deformation inferred to result from sediment creep extends as much as $20 \mathrm{~m}$ below the sea floor on this slope off Newport Beach and off Oceanside. Gas seeps and areas of acoustic anomaly thought to represent shallow gas accumulations in Quaternary sediment are present on the San Pedro shelf and on the eastern slope of the Gulf of Santa Catalina.

Farther northwest, geologically youthful slumps and slides are abundant in Santa Monica Canyon, on the slope between Santa Monica Canyon and Point Dume, on the slope between Dume Canyon and Malibu, in the vicinity of Hueneme and Mugu Canyons, and in the central Santa Barbara Basin, where zones of failure cover areas of hundreds of square kilometers and extend to depths of $90 \mathrm{~m}$ or more beneath the sea floor. Deformation from downslope sediment creep is extensive below the shelf break north of Santa Monica Canyon, in the vicinity of Hueneme and Mugu Canyons, and on the Hueneme submarine fan.

Hydrocarbon seeps are common in Santa Monica Bay, where they appear to be associated with offshore segments of the Palos Verdes Hills fault zone and the Santa Monica fault, and in the central Santa Barbara Channel off Coal Oil Point. Extensive areas of gascharged sediment underlie much of northeastern Santa Monica Bay, the Ventura shelf, the northwestern part of the San Pedro Basin, and most of the Santa Monica Basin. 


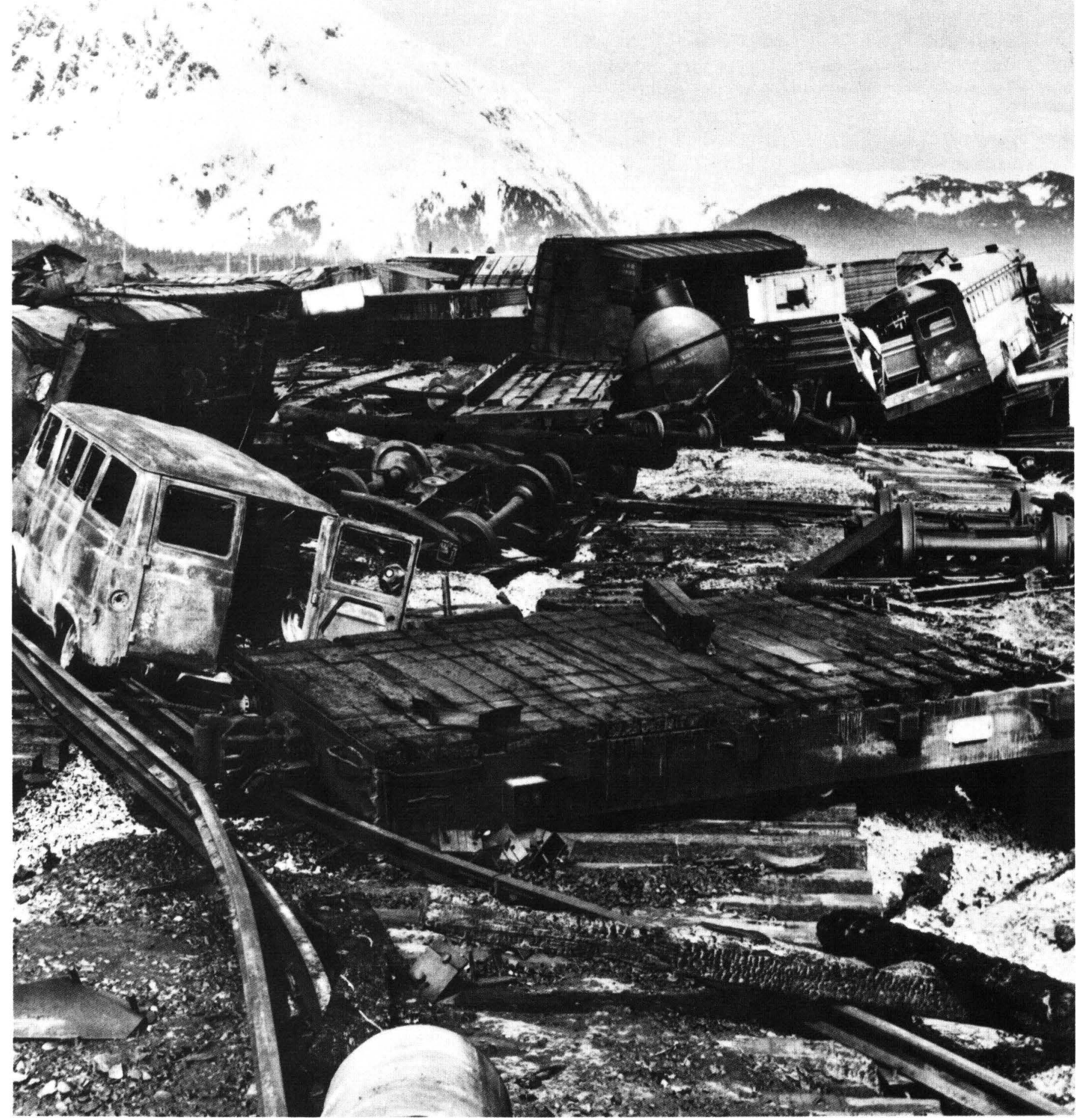

374 Earthquake Hazards in the Los Angeles Region 


\title{
EVALUATING TSUNAMI POTENTIAL
}

\author{
By D. S. McCulloch
}

\section{INTRODUCTION}

Tsunamis-impulsively generated wave trains-are among the most destructive and life-claiming natural phenomena to ravage coastal areas (see list, opposite). Although most coasts of the Pacific basin have a long history of tsunami-caused death and destruction, tsunami damage to coastal California has been relatively slight in historical time. The only tsunami to cause appreciable damage and loss of life along the California coast occurred on March 27, 1964, as a result of the great Alaska earthquake (fig. 190). Even though earlier tsunamis produced little damage in California, extensive development of some of the affected coast line over the last $100 \mathrm{yr}$ has increased the risk of loss of life and property damage.

This chapter reviews the major physical phenomena related to the generation, propagation, and runup of tsunami waves and summarizes the historical tsunami record of California to provide a basis for understanding the tsunami potential in coastal southern California. The chief methods for reducing losses from future tsunamis-warning systems, hazard maps, and public awareness-are also discussed.

During the last quarter-century, increasing concern for coastal hazards has prompted considerable study of tsunamis. Some impetus for these studies has been provided by recent large tsunamis (1960 Chile, 1964 Alaska), by concern for the safety of coastal nuclear reactors, and by the need to assess coastal flood hazards as a basis for assigning insurance risk.

Recent advances in seismology have made possible a better understanding of the relation between tsunamis and tsunamigenic earthquakes, in terms of both the energy released and the configuration of the associated sea-floor displacement. Increased understanding of earthquake generation at the subducting margins of colliding lithospheric plates permits time and space modeling of large tsunamigenic earthquakes around the margin of the Pacific Ocean. Finally, development of high-speed computer-aided multidimensional numerical models permits simulation of tsunamis and analysis of their coastal impact. Readers interested in pursuing this subject might see Wiegel's (1970) and Murty's (1977) excellent expositions on tsunamis, Hwang and Lee's
Some major tsunamis during the last 275 yr

- 1707 Japan Great Hoei Tokaido-Nankaido tsunami; 30,000 dead, 7,763 houses destroyed.

- 1737 Kamchatka Runup of 30 to $60 \mathrm{~m}$; great loss of life and property.

- 1755 Portugal Runup of $15 \mathrm{~m}$ in Lisbon; waves hit coasts of North Africa and England and reached as far north as Holland. Waves crossed Atlantic; 3-m wave runup heights in San Martin in the West Indies. More than 60,000 killed in Lisbon.

- 1868 Chile Runup of $14 \mathrm{~m} ; 25,000$ dead; wrecked most ships in the harbor and overwhelmed and devastated the city. U.S. Gunboat Wateree carried $3.2 \mathrm{~km}$ inland and left stranded. Waves affected Hawaii, New Zealand, and Japan.

- 1877 Chile Waves 3 to $4 \mathrm{~m}$ in Samoa, 2.5 to $6 \mathrm{~m}$ in Japan, 1 to $6 \mathrm{~m}$ in Australia and New Zealand.

- 1883 Indonesia Explosion of Krakatoa, a volcanic island. Wave runup of $35 \mathrm{~m}$; at least 36,417 people killed along the shores of Java, Sumatra, and Borneo.

- 1896 Japan Great Meiji Sanriku tsunami, Honshu. 27,000 deaths; runup greater than $30 \mathrm{~m}$ at Umnak, Alaska, and $17 \mathrm{~m}$ in Hawaiian Islands, where 159 were killed and 488 houses were destroyed.

- 1933 Japan Sanriku tsunami, Honshu. Runup $28 \mathrm{~m} ; 3,022$ dead, 8,900 homes and 8,200 boats destroyed.

- 1946 East Aleutians Runup greater than $30 \mathrm{~m}$. There were 241 deaths and 36 million dollars of damage to the Hawaiian Islands. There was one death in California and damage to coastal Chile.

- 1960 Chile Runup $23 \mathrm{~m}$ in Chile, $5.5 \mathrm{~m}$ in Japan. Coastal towns and ships destroyed in Chile; more than 1,000 deaths. Considerable damage in Japan, where 4,885 structures were destroyed and 199 killed. There was major damage and 61 deaths at Hilo, Hawaii.

- 1976 Philippines Moro Gulf, $5.9 \mathrm{~m}$ runup. Possibly 5,000 deaths. 


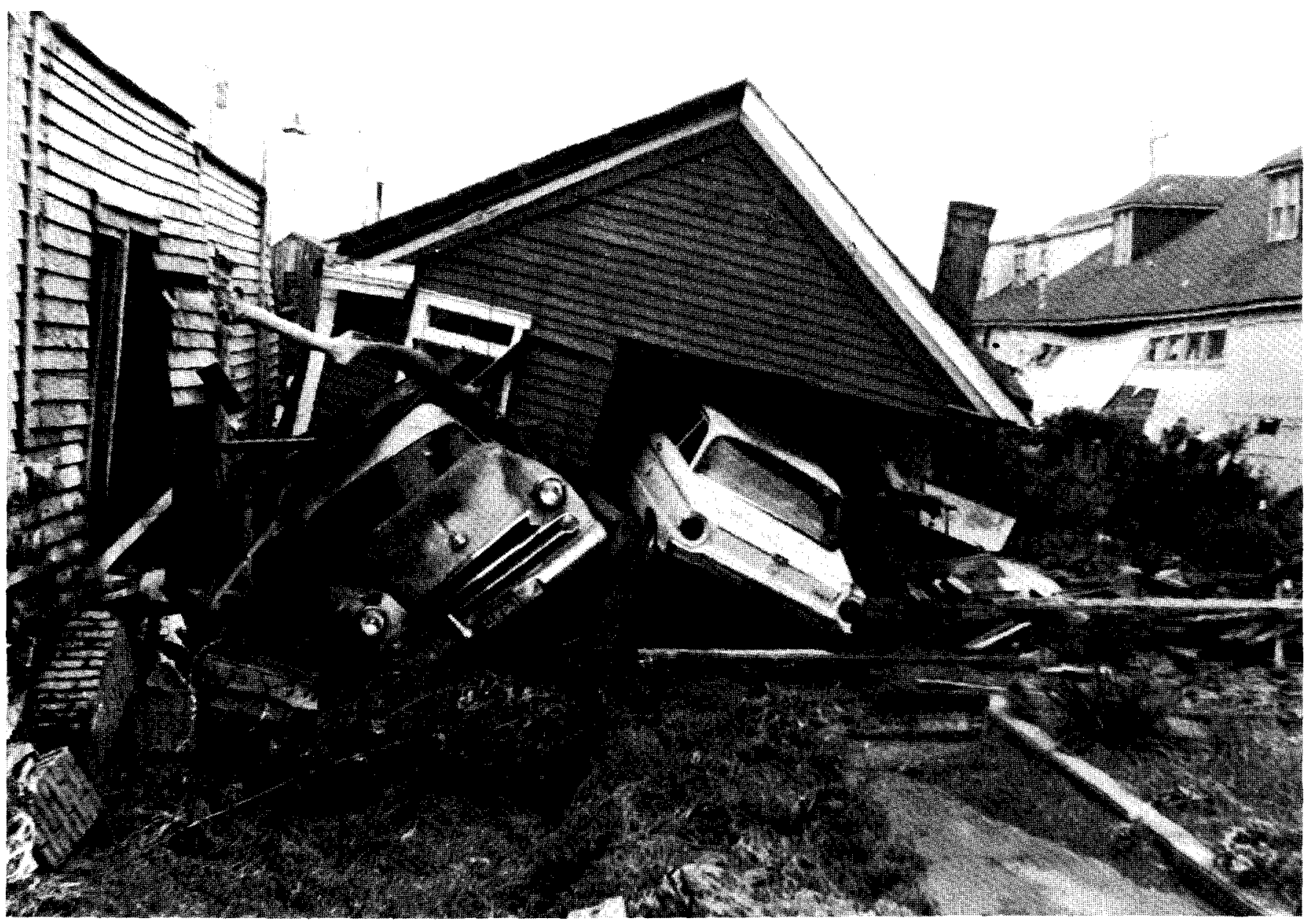

FIGURE 190.-A house torn from its foundations and penetrated by an automobile during the 1964 tsunami at Crescent City, Calif. (Photograph used by permission, W. Griffin, Crescent City Printing Co., Crescent City, Calif.)

(1979) volume on the proceedings of a National Science Foundation tsunami workshop, Houston's (1979) and Bernards and Goulet's (1981) state-of-the-art reviews of tsunami research, Pararas-Carayannis and others' (1982) annotated bibliography of tsunami-related phenomena, and Lockridge and Smith's (1984) annotated map of tsunamis in the Pacific basin.

\section{Acknowledgments}

The author thanks the following, who read all or part of this chapter and offered helpful suggestions: E. N. Bernard, Pacific Marine Environmental Laboratory, National Oceanic and Atmospheric Administration (NOAA); J. R. Houston, Coastal Engineering Center, U.S. Army Corps of Engineers; R. T. Lenaburg, Federal Emergency Management Agency; R. L. Slingerland, Pennsylvania State University; T. J. Sokolowski, Alaska Tsunami Warning Center, NOAA; R. L. Wiegel, Universi- ty of California, Berkeley; and H. C. Wagner, R. F. Yerkes, and J. I. Ziony, U.S. Geological Survey (USGS). The author also thanks the following, who kindly supplied information and discussion: B. Edwards and P. McClellan, USGS; J. Harrison, U.S. Army Corps of Engineers; L. S. Hwang and F. Wu, Tetra Tech; J. W. Joy, Marine Advisors; J. Kellerher, Redwood Research, Inc.; Y. Kobayashi, Kyoto University; and, finally, Reuben Kachadoorian, USGS, with whom the author examined 1964 tsunami damage in Whittier, Alaska, and whose careerlong association with the USGS was an inspiration to his colleagues.

\section{TSUNAMI GENERATION AND PROPAGATION}

Commonly cited causes of tsunamis are tectonic displacement of the sea floor associated with large, 


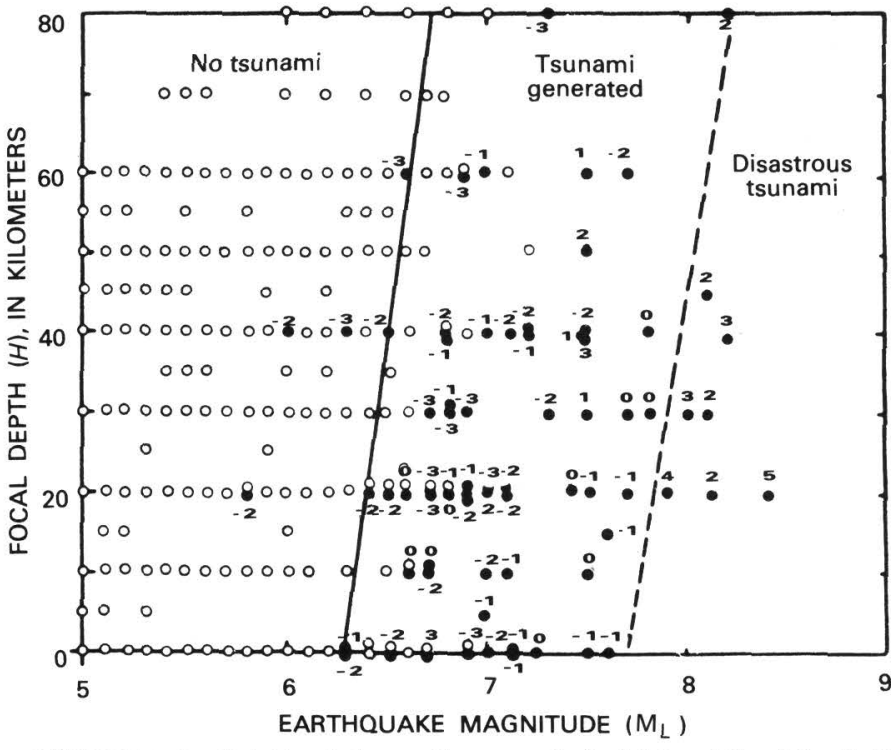

FIGURE 191.-Relation between the magnitude $\left(M_{L}\right)$ and focal depth $(H)$ of submarine earthquakes and the occurrence and size of associated tsunamis (Iida, 1970). Open circles indicate no tsunami; solid circles indicate tsunamis, the accompanying number being the nearest whole tsunami magnitude (see table 48). Iida divided the data into three fields: no tsunami, tsunami generated, and disastrous tsunami. The limiting magnitude for tsunamigenic earthquakes, excluding three "tsunami earthquakes" in which the released seismic energy is abnormally small (solid line), is $\mathrm{M}_{\mathrm{L}}=6.3+0.005 \mathrm{H}$, and the limit for disastrous tsunamis having a magnitude of more than two (dashed line) is $\mathrm{M}_{\mathrm{I}}=7.7+0.007 \mathrm{H}$.

shallow earthquakes; sea-floor landslides; rock falls into bays and oceans; exploding volcanic islands (for example, Krakatoa and Santorini); and underwater nuclear explosions (for example, Bikini Atoll) (Wiegel, 1970; Furneaux, 1964; Galanopoulos and Bacon, 1969).

Other suggested causes include earthquake-related horizontal tectonic displacement of a basin (on the upper plate of a megathrust) containing a confined or semiconfined water body (Tudor, 1964; Plafker, 1972). Studies of the tsunami hazard to coastal nuclear reactors (Marine Advisors, 1965) have considered the remote possibility of waves generated by meteor impact.

The name tsunami does not have universal meaning. Many who use the term are concerned with long-period waves that travel great distances and are generated by large-scale tectonic sea-floor displacement associated with large earthquakes. Others call these large panoceanic waves "seismic sea waves" and reserve the name tsunami for waves generated by smaller events such as explosions and subaerial and submarine landslides that affect a much smaller area. In this chapter, we follow Wiegel (1970), who takes the broader view of wave mechanics and applies the name to all impulsively generated waves, whether of local or transoceanic scale.
The terms used to describe tsunami wave height are also ambiguous. Rigorously defined, height is the vertical distance from the crest to the trough (double amplitude) of the tsunami wave before it runs up on the land. Runup elevation or runup height is the highest altitude above tide level that the water reaches as it runs up on the land. However, height is often used synonymously with runup height or to indicate the height of the wave crest at some specific location during runup; predicted runup heights may be referred to mean sea level. Context is often the best guide to meaning.

\section{Earthquake-Generated Tsunamis}

It is generally accepted that large tsunamis are the result of seismotectonic deformation in which there is appreciable and relatively rapid vertical displacement (uplift and (or) subsidence) of many hundred to more than a thousand square kilometers of the sea floor. Iida (1963a) showed that, for tsunamis generated by seismic events associated with thrusting along the Japan-Kurile Trench, the larger the earthquake and the shallower its focus, the larger the associated tsunami (fig. 191). He presented a revision of the tsunami magnitude scale proposed earlier by Imamura (1949) and related the runup height of the tsunami to the associated amount of energy (table 48). He also related tsunami size or magnitude to Richter magnitude, (that is, local magnitude $\mathrm{M}_{\mathrm{L}}$ ) (fig. 192A) and demonstrated that tsunami period increases as earthquake magnitude increases (fig. 192B). Several workers (Iida, 1963a, b; Van Dorn, 1964) recognized that the size of the tsunami is related to the area of the displaced sea floor.

TABLE 48.-Magnitude, energy, and runup heights of tsunamis in Japan

[From lida (1963a)]

\begin{tabular}{rcc}
\hline $\begin{array}{c}\text { Tsunami } \\
\text { magnitude } \\
\text { classification }\end{array}$ & $\begin{array}{c}\text { Tsunami energy, } \\
\text { in ergs (foot-pounds) }\end{array}$ & $\begin{array}{c}\text { Maximum runup height, } \\
\text { in meters (feet) }\end{array}$ \\
\hline $5-----25.6 \times 10^{23}\left(18.9 \times 10^{14}\right)$ & $>32(>105)$ \\
$4.5-----$ & $12.8 \times 10^{23}\left(9.4 \times 10^{14}\right)$ & $24-32(79-105)$ \\
$4------$ & $6.4 \times 10^{23}\left(4.7 \times 10^{14}\right)$ & $16-24(52.5-79)$ \\
$3.5-----$ & $3.2 \times 10^{23}\left(2.4 \times 10^{14}\right)$ & $12-16(39.2-52.5)$ \\
$3------$ & $1.6 \times 10^{23}\left(1.2 \times 10^{14}\right)$ & $8-12(26.2-39.2)$ \\
$2.5-----$ & $.8 \times 10^{23}\left(.59 \times 10^{14}\right)$ & $6-8(19.7-26.2)$ \\
$2------$ & $.4 \times 10^{23}\left(.29 \times 10^{14}\right)$ & $4-6(13.1-19.7)$ \\
$1.5-----$ & $.2 \times 10^{23}\left(.15 \times 10^{14}\right)$ & $3-4(9.9-13.1)$ \\
$1------$ & $.1 \times 10^{23}\left(.074 \times 10^{14}\right)$ & $2-3(6.6-9.9)$ \\
$.5-----$ & $.05 \times 10^{23}\left(.037 \times 10^{14}\right)$ & $1.5-2(4.9-6.6)$ \\
$0------$ & $.025 \times 10^{23}\left(.018 \times 10^{14}\right)$ & $1-1.5(3.2-4.9)$ \\
$-.5------$ & $.0125 \times 10^{23}\left(.0092 \times 10^{14}\right)$ & $.75-1(2.5-3.2)$ \\
$-1------$ & $.006 \times 10^{23}\left(.0044 \times 10^{14}\right)$ & $.50-.75(1.6-2.5)$ \\
$-1.5-----$ & $.003 \times 10^{23}\left(.0022 \times 10^{14}\right)$ & $.30-.50(1.0-1.6)$ \\
$-2-----$ & $.0015 \times 10^{23}\left(.0011 \times 10^{14}\right)$ & $<.30(<1.0)$ \\
\hline
\end{tabular}

\footnotetext{
${ }^{1}$ From Imamura (1949).
} 


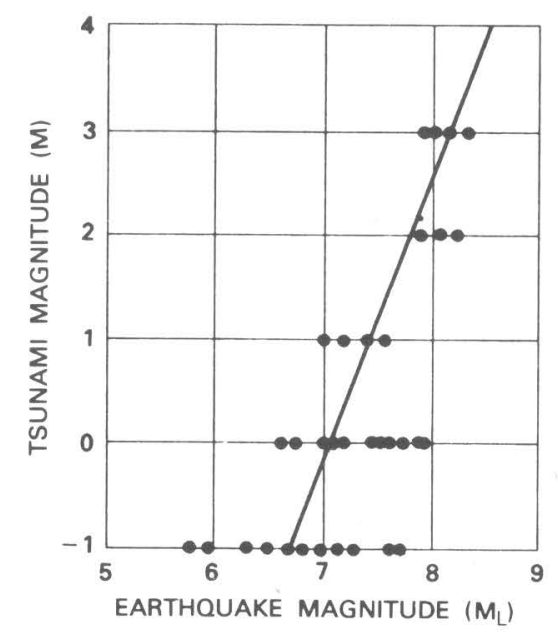

$A$

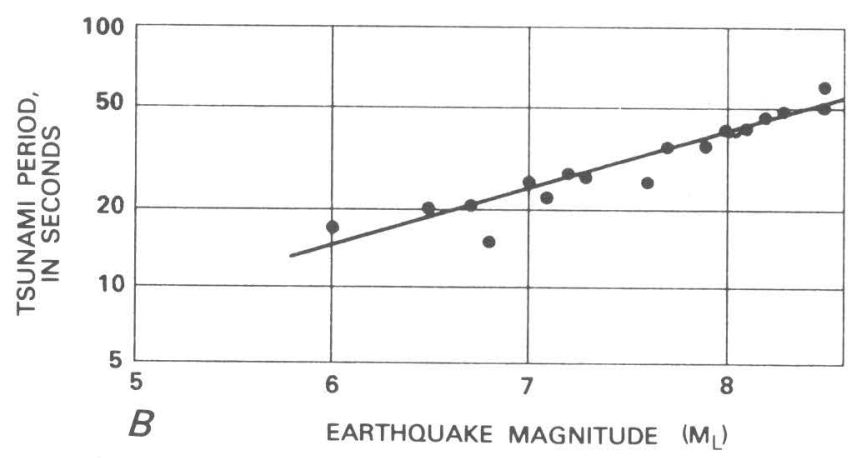

FIGURE 192.-A, Relation between tsunami magnitude and earthquake magnitude $\left(M_{L}\right)$ (Iida, 1963a). $B$, Relation between the maximum period of a tsunami and the associated earthquake magnitude $\left(M_{L}\right)$ (Iida, 1963b).

To refine the relations between tsunami size and seafloor deformation, Abe $(1973,1975)$ examined several coastal Japanese earthquakes. Using seismic-wave first motions and the polarity of the initial waves in the tsunami wave train, he established the attitude of the fault slip plane and the sense of real displacement (uplift and (or) subsidence) of the sea floor. He approximated the area of displaced sea floor by examining the aftershock distribution and by projecting the tsunami wave fronts back to the source area from a dense onshore tide-gauge network. Finally, by comparing tsunami wave heights at the edge of the source area with the amplitude of the sea-floor displacement (calculated from seismic movement and fault area), Abe demonstrated that tsunami wave heights at the source area were approximately the same as the amplitude of the displaced sea floor. He interpreted his findings as strongly indicating that large tsunamis are generated by tectonic deformation rather than by large submarine landslides and slumps, whose time constants would be larger than those observed. Abe (1975) noted that the relation between the area of the fault-rupture surface (S) defined by the one-day aftershock distribution and the tsunami source area $\left(S_{t}\right)$ is $S=0.8 S_{t}$ (fig. 193), and Kanamori (1977) indicated that the aftershock distribution measured several months after the main event $\left(S_{m}\right)$ averages about 75 percent larger than the 24-hr distribution $\left(S_{m} \approx 1.4 S_{t}\right)$.

In 1977, Kanamori pointed out that recorded earthquake ground motions used for assigning magnitudes in conventional scales saturate (cease to increase) in great earthquakes when the rupture dimension $(\geq 100 \mathrm{~km})$ exceeds the wavelength of the waves used to calculate $\mathrm{M}_{\mathrm{S}}$ and therefore fail to account for all the energy released (Kanamori, 1977) (see Evernden and Thomson (this volume) for an explanation of why ground-motion parameters saturate). Kanamori related the overall physical deformation at the earthquake source (rigidity of faulted rocks, average fault displacement, and area of the fault-rupture surface) and the change in elastic strain and proposed a new moment magnitude scale $\left(\mathrm{M}_{\mathrm{w}}\right.$, now indicated by the $\boldsymbol{M}$ of Hanks and Kanamori (1979)) for earthquakes in which the stress drop is complete.

Moment magnitudes gave Abe (1979) the opportunity to compare the tsunami size with a more accurate estimate of the strain energy or seismic energy released during large earthquakes. He proposed a new tsunami magnitude scale, $M_{t}$, calculated from the logarithm of the maximum amplitude of the far-field tsunami waves measured by tide gauges; that is, $\mathrm{M}_{\mathrm{t}}=\log \mathrm{H}+\mathrm{B}$, where

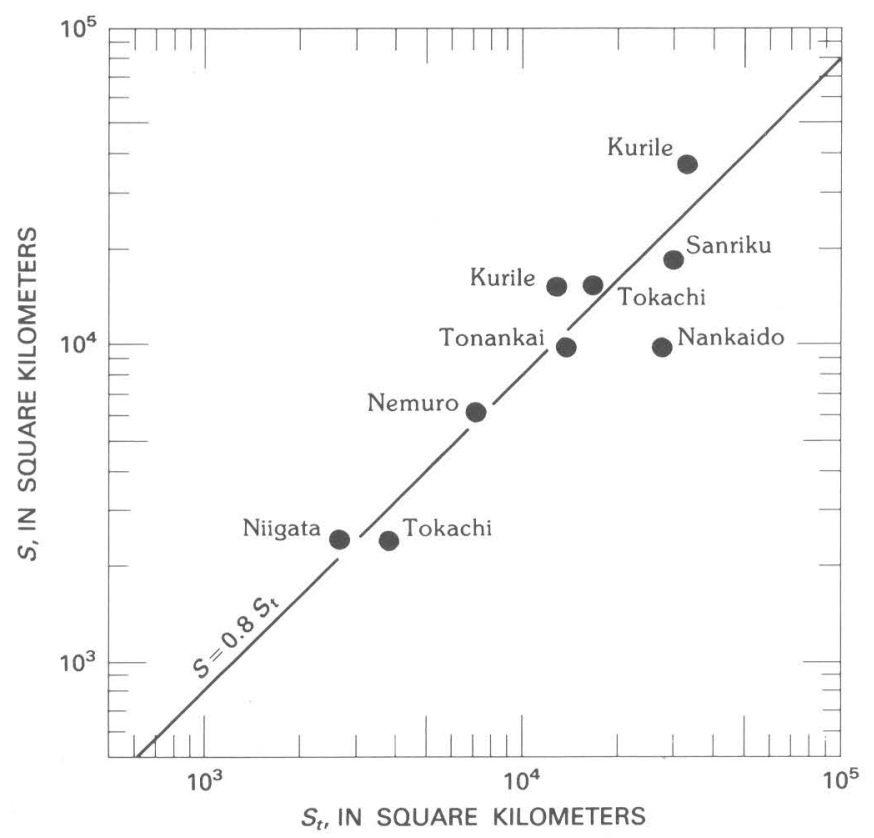

FIGURE 193.--Relation between the calculated area of the faultrupture surface $(S)$ and the size of the related tsunami source area $\left(S_{t}\right)$ as given by Abe (1975). The linear relation of the exponential function is $S=0.8 S_{t}$.

\section{Earthquake Hazards in the Los Angeles Region}




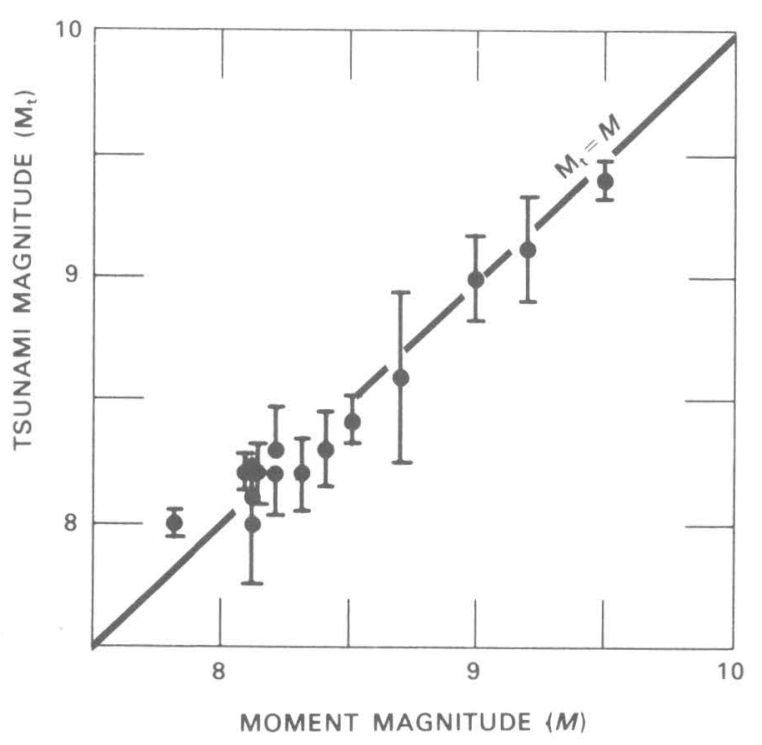

FIGURE 194.- Relation between tsunami magnitude $\left(\mathrm{M}_{t}\right)$ and earthquake moment magnitude $(\mathbf{M})$ for earthquakes derived by Abe (1979) from $H$ (observed maximum amplitude of tsunami waves, in miles) and $B$ (a constant depth that depends on the source region and the recording station) to calibrate his $\mathrm{M}_{t}$ tsunami magnitude scale. Standard deviation is indicated by bars.

$H$ is the maximum observed tsunami amplitude (in meters) and $B$ is a constant that depends on both the source region and the behavior of the tsunami at the tide-gauge station. Abe evaluated $H$ and $B$ by using 14 large dip-slip earthquakes (M 7.8-9.5) that occurred around the Pacific and for which there were good runup tide-gauge measurements. A comparison of tsunami magnitude and moment magnitude for the calibration earthquakes shows good agreement (fig. 194).

Several large earthquakes have produced tsunamis apparently too large for the associated stress drops. Kanamori (1972) called such events tsunami earthquakes. Fukao (1979) examined two tsunami earthquakes and suggested that seismogenic thrust faulting occurred between oceanic and overlying continental plates in a subduction zone but that the fault did not reach the sea floor. The displacement on the deep thrust placed a sudden load on the overlying, normally ductile sediment wedge at the edge of the continent. This wedge then failed by brittle fracture along one or more steeply dipping secondary faults that broke to the surface and displaced the sea floor. The steep dip of the secondary faults contributed to the vertical component of sea-floor offset, and, presumably, the low rigidity of the sediment wedge accounted for the low stress drop.

Tsunami size is related not only to the size and rate of displacement of the source area but also to the shape and sense of motion of the source area (up and (or) down). As Wiegel (1970) noted, the large tsunamis of $M_{t}$ 9.4 and $\mathrm{M}_{t}$ 9.1 of the $\mathbf{M} 9.41960$ Chile and the $\mathbf{M} 9.21964$

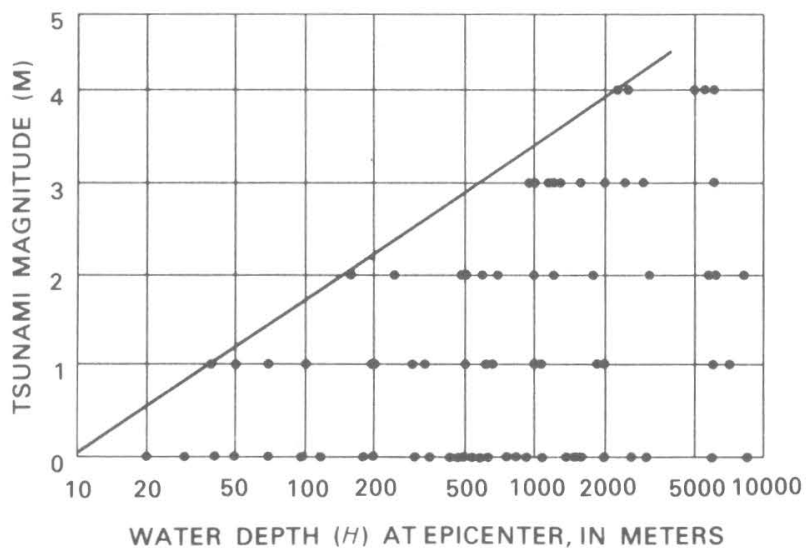

FIGURE 195.-Relation between Imamura-Iida tsunami magnitude (table 48) and water depth at the epicenter of the associated earthquake (Iida, 1963a).

Alaska earthquakes, respectively, were produced by uplift of elongate areas of sea floor (Plafker, 1972), which accounts for the large associated tsunamis. Model experiments (Takahasi (1963), cited by Wiegel (1970)) indicate that, when an elongate source is raised or lowered, the wave having maximum amplitude travels perpendicular to the long axis of the source. In addition, when an elongate source is raised, the amplitude of the larger wave decreases more slowly $\left(1 / r^{1 / 2}\right.$ or $1 / r^{1 / 3}$, where $r$ is radial distance from the source area) than that of the smaller wave that travels perpendicular to the short axis of the source (which decreases by $1 / r^{3 / 2}$ ). By contrast, when the source area is more equidimensional, the resulting wave has a more circular wave front. A circular wave loses amplitude quickly because of radial spreading and dispersion, and its amplitude decreases in proportion to $1 / \mathrm{r}$.

Tsunami size is also related to water depth at the epicentral area. Iida (1963a) showed that, for earthquake-generated tsunamis observed in Japan, there is an upper bound relation between water depth and tsunami magnitude (fig. 195). The physical reason for this relation is not fully understood. As Iida noted, the increase in tsunami magnitude with water depth is too large to be explained by amplification due to reflection as the wave approaches the shore.

It is generally accepted that offshore strike-slip faulting, in which displacement of the sea floor is primarily lateral, has not caused tsunamis, but proof remains elusive. Historically, there was no observed coastal tsunami thought to have resulted from the 1906 horizontal displacement on the San Andreas fault (see discussion of event 26, app. 4) and none within San Francisco Bay associated with the 1868 displacement on the Hayward fault. However, mathematical and laboratory modeling indicate that a significant tsunami could be generated by lateral displacement of a major submarine 
ridge such as the Gorda Escarpment off Cape Mendocino (Garcia, 1972).

Large-scale tsunamis are not single waves but a long train of waves. If deformation occurs on a shelf, the shelf may act as a partially resonant chamber; energy is reflected back onto the shelf both from the shore and from the deep water at the continental slope (Tuck, 1979). The cross-shelf width largely determines the length of the chamber and hence the length of the tsunami. When the cross-shelf length of the deformation is large and close to the natural mode of chamber oscillation, the excitation may be greatest. Tuck estimated that, as the gravity water waves oscillate back and forth between the shore and the slope, perhaps 25 percent of the waves escape into the deep ocean. The returning waves lose energy through dispersion along the shoreline. Thus, there is a general decrease in the energy of successive waves that are propagated shoreward and seaward off the shelf.

In general, long-period tsunamis are associated with sea-floor deformation of the continental shelf, and shorter period tsunamis are associated with deformation in deeper water. Large tsunamis generated on continental shelves (1952 Kamchatka, 1960 Chile, 1964 Alaska) had periods greater than $40 \mathrm{~min}$. Main waves from deep-water Aleutian tsunamis $(1946,1957)$ had very short period waves of 7 to 10 and 10 to $15 \mathrm{~min}$ (Kajiura, 1979).

\section{Tsunami Wave Propagation}

As long-period tsunami waves cross the deep ocean, they behave as linear nondispersive gravity waves. Their periods may exceed $1 \mathrm{hr}$, amplitudes are probably less than $1 \mathrm{~m}$, and wavelengths are on the order of 40 to $200 \mathrm{~km}(\mathrm{Wu}, 1979)$. Because of their great wavelengths, tsunamis act as shallow-water waves that feel the bottom when the water depth is less than one-twentieth to one-twenty-fifth the wavelength. Thus, wave velocity is dependent in part on water depth such that velocity equals the square root of the acceleration of gravity times the water depth. The initial wave in the wave train appears, from model studies (Prins, 1958; Weigel, 1970), to travel slightly faster. In the open ocean, where wavelengths are large and water depths equal or exceed the average ocean depth $(38,000 \mathrm{~m}$, as given by McLellan (1965)), tsunamis may travel at great speeds of 550 to $800 \mathrm{~km} / \mathrm{hr}$ (Wiegel, 1970).

The direction of wave travel from the source to the affected shore is largely determined by refraction. Because wave velocity is depth dependent; waves are slowed as the water shoals, the wave crest is bent or refracted, and the travel path is altered so that it becomes more perpendicular to the bottom contours.

Refraction can be expressed by

$$
\frac{\sin \propto 2}{\sin \propto 1} \frac{V_{2}}{V_{1}}
$$

where $\propto 1$ and $\propto 2$ are angles between adjacent wavefront positions and their respective bottom contours and $V_{1}$ and $V_{2}$ are the corresponding wave velocities. For wave-path prediction, refraction diagrams of the timehistory of the successive wave-front positions can be drawn, given the original wave position, the wave velocity, and the sea-floor configuration (fig. 196). On refraction diagrams, orthogonals (rays normal to the moving wave front) can be drawn to indicate the direction of wave travel and also to evaluate changes in tsunami wave amplitude. Where orthogonals converge, energy is concentrated, and wave amplitude increases. Where orthogonals diverge, the tsunami wave is stretched, and amplitude decreases.

As a tsunami wave passes above a sea-floor irregularity, it may lose energy by reflection. If the slope of the irregularity is gradual and the length of the slope is a moderate multiple of the wavelength, there is practically no reflection. The larger the irregularity and the more steplike it becomes (for example, at the edge of the continental shelf), the greater the reflection and, therefore, the less the energy that continues landward. Steplike irregularities may do more than reduce energy in the transmitted wave. Wu (1979) noted that strong reflection over a steplike irregularity may produce considerable change in the tsunami waveform near the step. For predictive purposes, it is important to know the waveform that may strike a coast. Thus, with regard to both amplitude and waveform, reflection is an important parameter in evaluating tsunami hazard.

Because of their small height, tsunamis go undetected by ships at sea; however, compressional waves generated at the sea floor in the epicentral area are transmitted through the water, and ships struck by such seaquakes report an experience akin to running aground or striking another vessel. Energy in the compressional wave may be considerable. The 32,500-ton tanker Ida Knudsen, sailing in $4,900 \mathrm{~m}$ of water approximately $35 \mathrm{~km}$ from the epicenter of a $1969 \mathrm{M}_{\mathrm{S}} 8.0$ earthquake west of Gibralter, suffered such extensive damage to its hull girders and beams, equipment, and machinery that, although later extensively rebuilt, it was at first listed as a total loss (Hove and others, 1982). Seaquakes are more than just an interesting phenomenon. Hove and others (1982) analyzed the damage to the Ida Knudsen and 11 other ships hit by seaquakes (table 49) and concluded that offshore structures in seismically active areas 


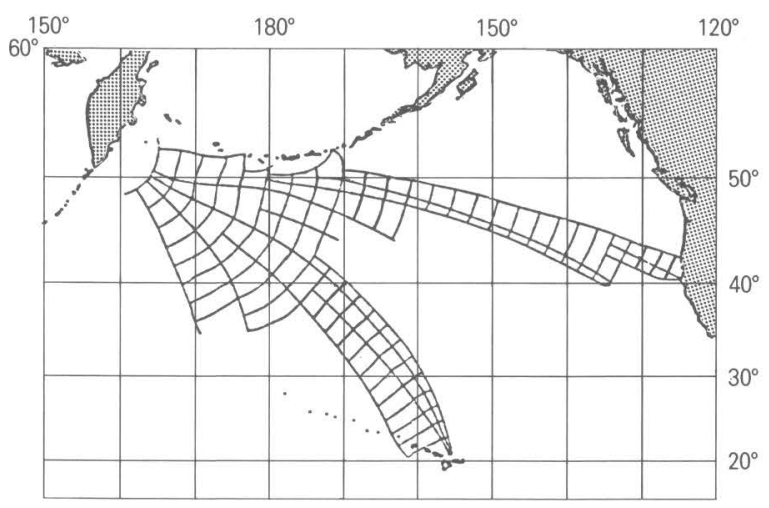

A
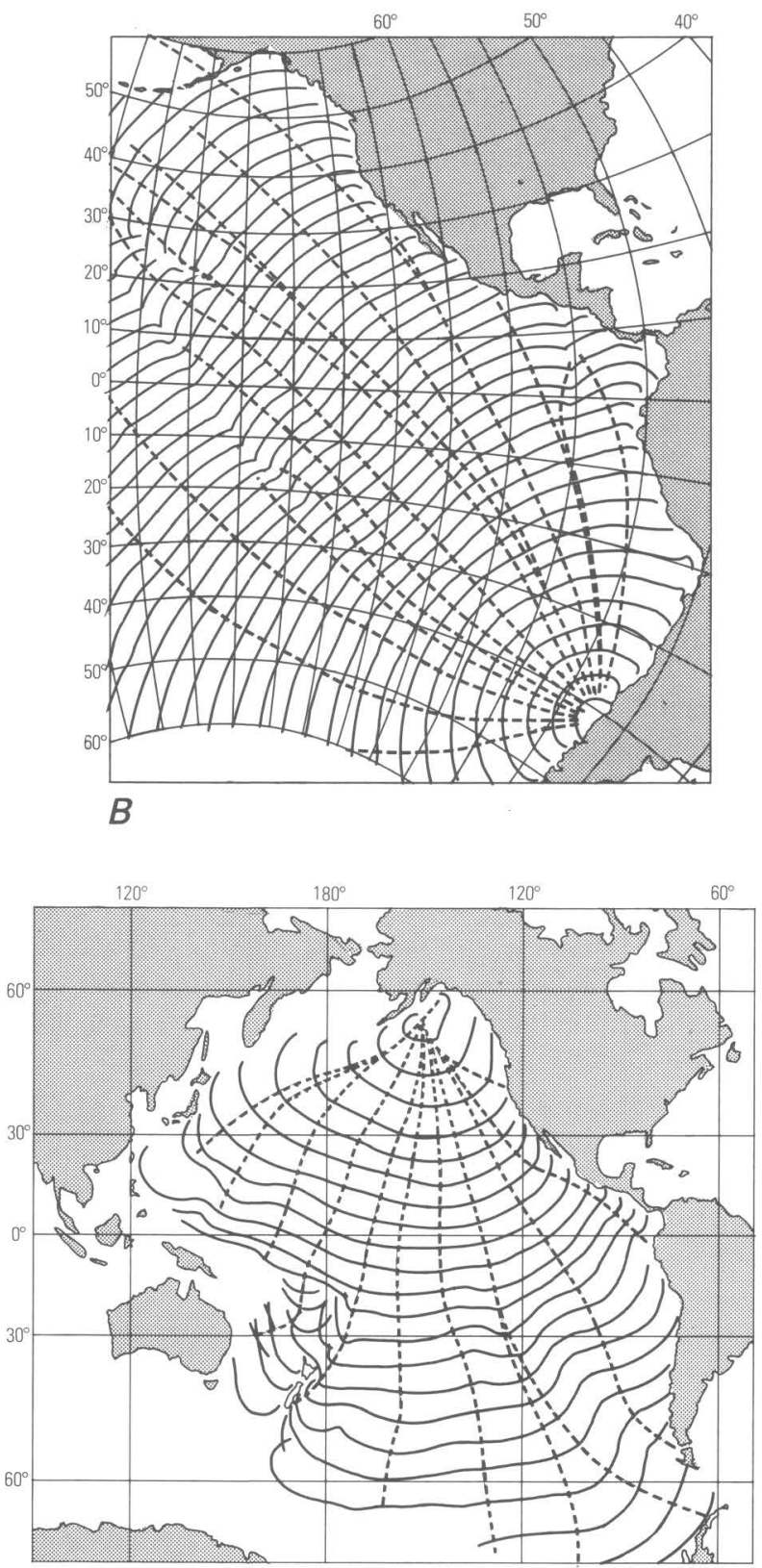

C should be designed to withstand earthquake loads similar to those predicted for shore-sited structures. They note that the seismically induced forces may be large and of long duration and that the force delivered to the structure is largely independent of the water depth. These forces have generally been ignored in the design of floating structures.

\section{Tsunami Runup}

When long-period tsunami waves encounter shoaling water as they approach a shoreline, fundamental properties of the waves change in a progressively nonuniform way, and predicting wave behavior becomes more difficult. As each wave runs up a sloping sea floor, the increased frictional drag decreases the speed of the wave and shortens its wavelength. The energy within each wave is crowded into progressively less water. Because the volume of water in a tsunami wave is large, it cannot dissipate significant energy by breaking along its leading edge, as do waves having shorter wavelengths, and the crowding takes place so rapidly that the energy cannot be lost by dispersion. Tsunami waves adjust by increasing their height. Waves that were $1 \mathrm{~m}$ or so high in the ocean may reach heights in excess of $20 \mathrm{~m}$ during runup. If successive waves in the tsunami wave train are similar, they are affected in a similar way as they cross shoaling water; they undergo a similar decrease in velocity, and their periods remain nearly constant. In an area where tsunami waves are coming ashore, it is of great importance for people to know that intervals between successive major waves may be similar.

In the real world of nonuniform sea-floor slope and irregular coastal configuration, the local sea-floor bathymetry and the shape of the shoreline can have a large effect on refraction, reflection, and the formation of secondary waves by reflection, diffraction, and the setting up of high-amplitude resonant waves in semienclosed bays and harbors. To estimate how high a tsunami wave will be as it crosses the coastline, these local effects must be considered and add to the complexity of runup predictions.

Tsunamis come ashore in several ways. Shepard (1948, p. 49) described the arrival of the April 1946

FIGURE 196.-Wave refraction and orthogonal diagrams for three major tsunamis that have affected the California coast. A, 1952 Kamchatka (Keulegan and others, 1969). B, 1960 Chile (Hisamoto and Murayama, 1962). C, 1964 Alaska (Wilson and Tфrum, 1968). Successive wave-front positions are shown in hour and half-hour increments (Chile and Alaska) or 16.5-min intervals (Kamchatka). 
TABLE 49.-Parameters of earthquakes, vessels damaged by associated seaquakes, and seismic forces experienced by the vessels [Modified from Hove and others (1982). --, no data]

\begin{tabular}{|c|c|c|c|c|c|c|c|c|}
\hline \multirow{2}{*}{$\begin{array}{l}\text { Region of } \\
\text { earthquake }\end{array}$} & \multicolumn{2}{|c|}{ Magnitude } & \multirow{2}{*}{$\begin{array}{l}\text { Depth to } \\
\text { hypocenter, } \\
\text { in km }\end{array}$} & \multirow[b]{2}{*}{ Vessel } & \multirow{2}{*}{$\begin{array}{l}\text { Water depth, } \\
\text { in } \mathrm{m}\end{array}$} & \multirow{2}{*}{$\begin{array}{c}\text { Distance from } \\
\text { ship to epicenter, } \\
\text { in } \mathbf{k m}\end{array}$} & \multirow{2}{*}{$\begin{array}{l}\text { Duration } \\
\text { of quake, } \\
\text { in s }\end{array}$} & \multirow{2}{*}{$\begin{array}{l}\text { Acceleration, } \\
\text { in percent } g\end{array}$} \\
\hline & $\overline{\mathrm{M}_{\mathrm{b}}}$ & $\overline{\mathrm{M}_{\mathrm{S}}}$ & & & & & & \\
\hline \multirow[t]{3}{*}{ Nicaragua --------- } & ---- & 7.0 & 160 & Magician & 3,400 & 330 & 100 & $<1$ \\
\hline & & & & Eagle & 3,400 & 340 & 120 & $<1$ \\
\hline & & & & Solana & 1,500 & 80 & 7 & 16 \\
\hline \multirow[t]{3}{*}{ Mexico -------- } & ---- & 8.1 & $=-$ & Sevenur & 3,000 & 100 & 60 & 10 \\
\hline & & & & Northern Sun & 2,500 & 230 & 180 & 3 \\
\hline & & & & Arizona & 2,500 & 260 & 75 & 2 \\
\hline Mexico ----------- & ---- & 7.7 & 100 & Unknown & 500 & 90 & -- & 9 \\
\hline Solomon Islands --- & 6.1 & 7.3 & -- & Ninghai & 4,000 & 50 & -- & 20 \\
\hline Peru -- - - - & 6.3 & -- & -- & Belmont & 110 & 170 & 15 & 3 \\
\hline Gibraltar ------ & 6.5 & 8.0 & 14 & Ida Knudsen & 4,900 & 20 & $(60)$ & 75 \\
\hline Peru-Ecuador ------ & 6.3 & 7.6 & 15 & Bergensfjord & 3,000 & 100 & 40 & 7 \\
\hline Thessaloniki ------- & 6.1 & 6.4 & 3 & Troyka & 20 & 35 & 10 & 15 \\
\hline
\end{tabular}

tsunami at Oahu generated by the $M 8.4$ Aleutian earthquake:

The waves were probably low as they came in to the coast. At our residence we estimated that the second wave which broke over the outer reef was about 16 feet high, not any higher than the storm waves that were breaking at the time. At the coast it was possible to see over the advancing wave from a height of eye level of about 18 feet above the tide. However, unlike normal waves the tsunami kept on coming rather than dissipating its energy where it encountered the reef.

Some tsunami waves look like a rapid rise in tide. In the 1964 Alaskan earthquake, the low-lying shore of Kodiak Island was inundated by at least five successive tsunami waves (Kachadoorian and Plafker, 1967, p. F22). One resident described the first wave as "a nonturbulent rapid rise of tide." The wave reached a height of 2.6 to $3.8 \mathrm{~m}$. The second wave arrived about $20 \mathrm{~min}$ later and was reported by several eyewitnesses as a surge of about $1.8 \mathrm{~m}$ followed by a rise to about $4.3 \mathrm{~m}$. The third wave reached about the same height. Although the description of the waves as a nonturbulent rapid rise of tide may sound benign, these waves were anything but. They reached a maximum runup height of about $10 \mathrm{~m}$. As they surged in and out across the city, they tore buildings apart, demolished waterfront industrial buildings, wreaked havoc on the fishing fleet, and severely scoured the land surface (Kachadoorian and Plafker, 1967, p. F24):

\section{Earthquake Hazards in the Los Angeles Region}

The violent incoming and outgoing waves destroyed more than 212 structures. About 200 of them were on land and approximately 15 were private and commercial docking facilities. The inland structures included 158 homes, 25 commercial structures and about 20 miscellaneous buildings.

To the south at Crescent City, Calif., tsunami waves from this same earthquake had the same general aspect (Tudor, 1964, p. 65-66):

One observer related that as the first wave moved into the city bringing logs and debris with it, the water rose rapidly with the small waves riding the crest. Front Street was covered in places with considerable water and logs which partially blocked traffic. As the first wave subsided, officers of the City Police and Sheriff's Department moved into the area to survey the damage and to deal with the sightseers and possible looters. They began moving the public out almost immediately as the second wave started building up. The second and third waves seemed of lesser magnitude than the first and to hit with less force. But the fourth wave was fast in rising; it hit the city hardest, such that it left in its wake a large area of total destruction. One reporter said the wave came into the city in fingers of water. Another observer reports the first wave in the city at 0009 PST, 28 March. Two more waves came and both threw driftwood onto the street 
at 0030 and 0045 . Then, at 0140, the water began pouring onto the streets, slowly, then more swiftly. When this wave receded cars, refrigerators, gas tanks, and debris of all sorts floated toward the sea. It was this highest wave that was responsible for the 12 dead.

In areas near the tsunami source but also less commonly in areas remote from the source where the wave height is large or the slope is very low (for example, in a river channel) or when a wave encounters runoff of a preceding wave, the wave may come ashore as a bore having an abrupt front accompanied by a roaring, breaking frontal zone. Eaton and others (1961, p. 139) described the arrival of a bore at Hilo, Hawaii, generated by the 1960 Chilean earthquake:

At first there was only the sound, a dull rumble like a distant train, that came from the darkness far out toward the mouth of the bay. By 1:02 a.m. all could hear the loudening roar as it came closer through the night. As our eyes searched for the source of the ominous noise, a pale wall of tumbling water, the broken crest of the third wave, was caught in the dim light thrown across the water by the lights of Hilo. It advanced southward nearly parallel to the coast north of Hilo and seemed to grow in height as it moved steadily toward the bayshore heart of this city. At 1:04 a.m. the 20-foot-high nearly vertical front of the inrushing bore churned past our lookout, and we ran a few hundred feet toward safer ground. Turning around, we saw a flood of water pouring up the estuary. The top of the incoming current caught in the steel-girder roadway of the south half of the bridge and sent a spray of water high into the air. Seconds later, brilliant blue-white electrical flashes from the north end of Kamehameha Avenue a few hundred yards south of where we waited signalled that the wave had crossed the sea wall and buffer zone and was washing into the town with crushing force. Flashes from electrical short circuits marked the impact of this wave as it moved swiftly southeastward along Kamehameha Avenue. Dull grating sounds from buildings ground together by the waves and sharp reports from snapped-off power poles emerged from the flooded city now left in darkness behind the destroying wave front. At 1:05 a.m. the wave reached the power plant at the south end of the bay, and after a brief greenish electrical arc that lit up the sky above the plant, Hilo and most of the Island of Hawaii was plunged into darkness.

Many of the forms taken by tsunami waves were well documented during the tsunami that accompanied the 1983 Nihonkai-Chubu earthquake beneath the Japan Sea. The tsunami, which struck the northwestern coast of Honshu, Japan, Korea, and coastal Siberia, is probably the most photographed major tsunami ever to occur (Osamu, 1984; Bertero and others, 1985). In areas adjacent to shallow parts of the shelf, where the waves were strongly influenced by the bottom, the waves were multicrested, dispersively deformed bores and acted as short-period waves. Where the shelf was deeper nearshore, the waves had long periods more typical of tsunamis. Locally, the waves were refracted and reflected by coastal irregularities and, in some areas, reflected obliquely back into the oncoming wave train, adding amplitude to the combined wave (Mach-stem wave).

Tsunamis may be preceded by drawdown along the shore when the initial part of the wave train is a trough. Drawdown can be dramatic. The constant sound of surf may disappear in an eerie quiet. If coastal residents recognize the withdrawal of the sea as a precursor to a tsunami, a withdrawal can provide adequate warning. Saint-Amand (1961, p. 12) described such an incident associated with the tsunami generated by the M 9.51960 Chilean earthquake:

Then, suddenly, they noted that the sea was beginning to retreat from the shores, exposing the ocean floor to distances well beyond the lowest tides. When this happened, the fire alarms were sounded, and firemen and carabineros systematically went through the streets warning everyone of the impending danger. The people fled afoot and on horseback to the hills and waited. Those on horseback made repeated trips to save the old and infirm. After 15 to 30 minutes, the sea returned, advancing upon the shore in a wave that was, in places, over 20 feet high. The wave rushed over the land, covering and carrying away the houses, killing the animals that could not be evacuated, and carrying off some of the people who, for one reason or another, had not left their homes....In Quele...according to press reports, nearly 500 people were lost because they returned to their houses too soon or because they had failed to heed the warning of 
the receding water. In several villages along the southern coast, such as Carelmapu. . the mariscadores, or shellfish collectors, took advantage of the recession of the sea to wander over the exposed sea floor collecting shellfish in their baskets. When they had collected more than the usual quantity of mussels and locos, they returned to the shore, climbed upon the hills, and waited for the water to return. The waves continued all afternoon. The third or fourth wave was reported as the highest. A group of mapuchis or Araucanian Indians sacrificed a 7-year-old boy to the gods of the sea to calm the remorseless surf.

Where drawdown is not recognized as a precursor, the loss of life has been high. Immediately following the 1964 Alaska earthquake at the small fishing village of Chenega on Chenega Island in Prince William Sound, the water withdrew to an estimated depth of $40 \mathrm{~m}$ and a distance of about $600 \mathrm{~m}$ offshore (Plafker and others, 1969). Drawdown exposed the rocky floor of the shallow cove that lay directly in front of the village. The following tsunami was about $12 \mathrm{~m}$ high. It overwhelmed and destroyed most of the houses. Many of the children and some of the adults recognized the danger and sought protection at the school house, which was built on high ground, but 23 people (about one-third of the village population and nearly one-fifth of all those killed in Alaska by the earthquake) were lost to the wave.

Unfortunately, a warning drawdown does not always precede the first wave. Tide-gauge records from the western coasts of North and South America and from islands in the Pacific (Spaeth and Berkman, 1967) all show that the 1964 Alaskan earthquake produced a wave train in which the first wave was a crest. Tudor (1964, p. 4) noted that the U.S. Coast Guard observed a 7-ft drop in water level at Fort Point (the tide-gauge station beneath the southern end of Golden Gate Bridge at San Francisco) just seconds before the arrival of the first positive wave. It seems unlikely that people on the beach would have taken what must have been a relatively short wavelength trough as an indication of an approaching tsunami or that, even having recognized it as such, they would have had time to reach higher ground.

\section{Landslide-Generated Tsunamis}

Earthquake-triggered subaerial and submarine landslides have caused many highly destructive local tsunamis. It has also been suggested that earthquakeinduced submarine landslides may cause tsunamis of transoceanic scale. There is no question that earth- quakes do cause very large submarine slides. For example, in the $M 7.91923$ Kanto earthquake in Japan, approximately $70 \mathrm{~km}^{3}$ of unconsolidated sediment slumped from the floor and sediment-filled submarine canyon tributaries beneath Sagami Bay into the Japan Trench (Shepard, 1933), and Edgers and Karlsrud (1982) listed 11 slides that ranged in volume from 1 to $800 \mathrm{~km}^{3}$ that are known or conjectured to have been generated by earthquakes. There is, however, little evidence that submarine landslides are responsible for significant tsunami waves that affect regions remote from the slide. Furthermore, as Abe (1973) noted, the deformation of the sea floor predicted from seismic events quantitatively satisfies tsunami parameters (size and rate of displacement of sea floor), whereas submarine slides have too slow a time constant.

There are, nevertheless, many instances of highly destructive local tsunamis generated by slides. Subaerial landslides and rock falls that slid or fell into water have generated local tsunamis having runup heights of as much as $\mathbf{5 2 5} \mathrm{m}$ (Lituya Bay, Alaska), nearly one and one-half times the height of the Empire State Building, and have resulted in catastrophic loss of life (Miller, 1960; Slingerland and Voight, 1979). In 1792, an earthquake triggered a slide of about $0.5 \mathrm{~km}^{3}$ of volcanic debris from the slopes of Mount Shimabara on the Japanese island of Kyushu. The slide impacted Shimabara Bay and generated three tsunami waves that crossed the bay, reached a height of $10 \mathrm{~m}$, and killed more than 15,000 people in the vicinity of Kumamoto.

One of the primary causes of death in the 1964 Alaskan earthquake was waves generated by slides from the fronts of fan deltas. Unlike the previously noted slides, which were largely or entirely subaerial, most of the material that slid from these fan deltas was below water level before sliding. In many cases, as the sliding mass became fully submerged, water rushed in to fill the void left by the slide. In some places, the velocity of the water was high enough that inertia carried it well inshore, to runup heights of at least $10 \mathrm{~m}$. Some of these waves decimated the shores of Alaskan coastal communities (Coulter and Migliaccio, 1966; Lemke, 1967; Kachadoorian, 1965; McCulloch, 1966). At Kenai Lake, they broke off spruce trees near the ground and uprooted others, some as much as $0.5 \mathrm{~m}$ in diameter. These trees were driven like battering rams as far as $100 \mathrm{~m}$ ashore. Some trees were stripped of nearly all their bark and limbs. Those that remained standing had bark and limbs torn from the sides exposed to the wave. Large blocks of frozen sediment, some weighing an estimated 50 tons, were pulled from the sinking slide mass and carried ashore with the trees (McCulloch, 1966). Slide-generated waves of this kind are not confined to Alaska. A similar wave resulting from an

384 Earthquake Hazards in the Los Angeles Region 


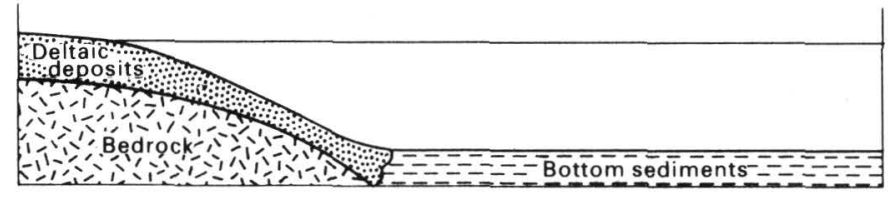

A
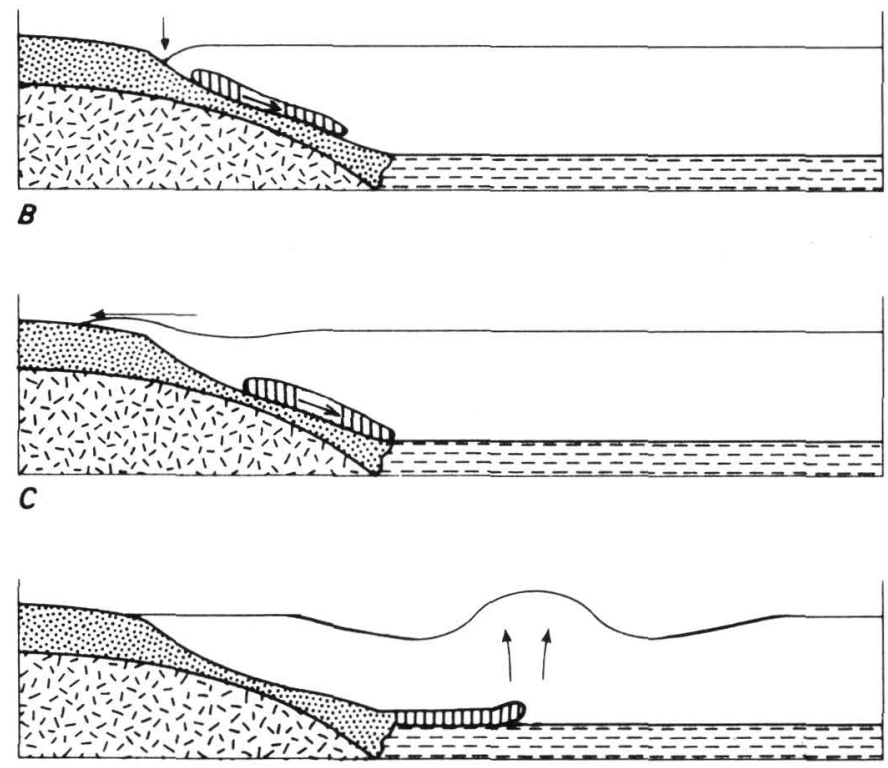

D

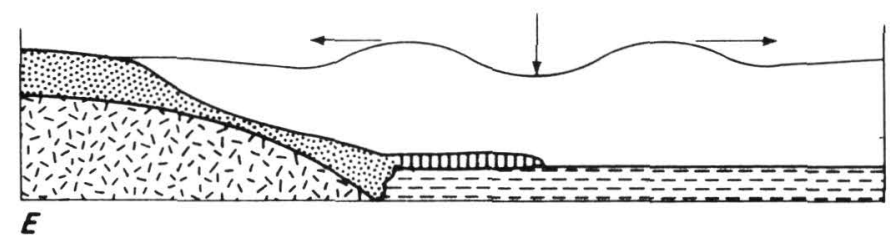

FIGURE 197.-Schematic sequential cross sections showing waves generated by a subaqueous slide. A, Preslide conditions. B, Start of sliding; local drawdown at the head of the slide. $C$, Wave overtopping the delta margin. $D$, Generation of a mound of water by upward displacement of the slide toe. E, Unstable mound sinking and generating waves (probably a series) that radiate away from the oscillatory mound. Modified from Kachadoorian (1965).

earthquake-triggered slide may have been responsible for the destruction of Port Royal on the island of Jamaica in 1692 (Heath, 1748; Link, 1960).

The 1964 Alaska submarine slides also generated waves that appear to have been caused by water forced upward or laterally by the moving slide debris. Upward water displacement was common. Seward, Valdez, and Whittier, for example, were first flooded by waves resulting from water rushing landward to replace the sinking slides. All three towns were then struck by a wave or wave train that radiated from what was often described as a "mound of water" that formed some distance from shore (fig. 197) (Grantz and others, 1964; Kachadoorian, 1965; Coulter and Migliaccio, 1966;
Lemke, 1967; Wilson and Torum, 1968). At Whittier (Kachadoorian, 1965, p. B6), eyewitnesses described the formation of the mound ". . .as if something seemed to be exploding underneath the water." Postearthquake soundings and bottom sampling showed that the water mound formed approximately above the deposited slide mass. At Valdez, Wilson and Torum (1968) suggested that the water mound resulted from upward rotation of the toe of a large slide that started as a rotational failure and then disintegrated into a thin blanket downslope.

Waves generated by horizontal displacement of water below the water surface occurred at Kenai Lake. Such horizontal currents (turbidity currents) generated by submarine slides have been examined theoretically and experimentally (for example, Hampton, 1972) and are inferred to have been formed where submarine cables have been cut beyond the limits of earthquake-triggered slides (Heezen and Ewing, 1952). In a few cases, such as at Kenai Lake and at Lake Zurich in Switzerland (Kuenen, 1950) where the slide mass was partially subaerial, the current-generating slides have been observed directly, but, where slides are entirely submarine and were found by later sounding, the contemporaneity of the slides and the currents is inferrential. At Kenai Lake, slides from partially subaerial fan deltas traveled across a nearly flat lake floor and forced water ahead of them. The water burst to the surface along the shoreline, where it broke off spruce trees and stripped the vegetation and soil from the steep, rocky lake shore. Runup heights of 6 to $8 \mathrm{~m}$ were common, the maximum being $33 \mathrm{~m}$.

Not all submarine slides that generate tsunamis are triggered by earthquakes. On October 16, 1979, approximately $30 \mathrm{~km}$ of the French Riviera coast, from near the Italian border to Antibes, including the shore at Monaco and the port city of Nice, were struck by two waves approximately $3 \mathrm{~m}$ high that smashed beach-front homes, hurled automobiles into buildings, and claimed 10 lives (San Francisco Examiner, 1979). The Monaco Observatory recorded no earthquake at this time. As Gennesseaux and others (1980) and Auffret and others (1982) described, a lowering of the sea level was seen at about the time that a fill $300 \mathrm{~m}$ wide by $300 \mathrm{~m}$ long slid beneath the sea. The fill had been placed on the delta of the Var River to extend an airport runway, and postslide soundings indicated a water depth of $50 \mathrm{~m}$ where the fill had been. Gennesseaux and others (1980) suggested that the volume of the slide (minimum of $300 \mathrm{~m}^{2} \times 50$ $\mathrm{m}=4.5 \times 10^{6} \mathrm{~m}^{3}$ ) was too small to have generated the tsunami and that the waves were probably caused by two much larger slides (total volume $400 \times 10^{6} \mathrm{~m}^{3}$ ), identified by post-tsunami soundings, that were dislodged from the walls of two submarine valleys downslope from 


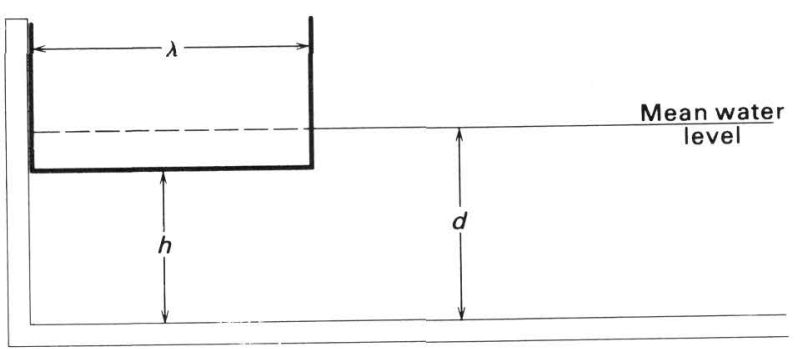

A
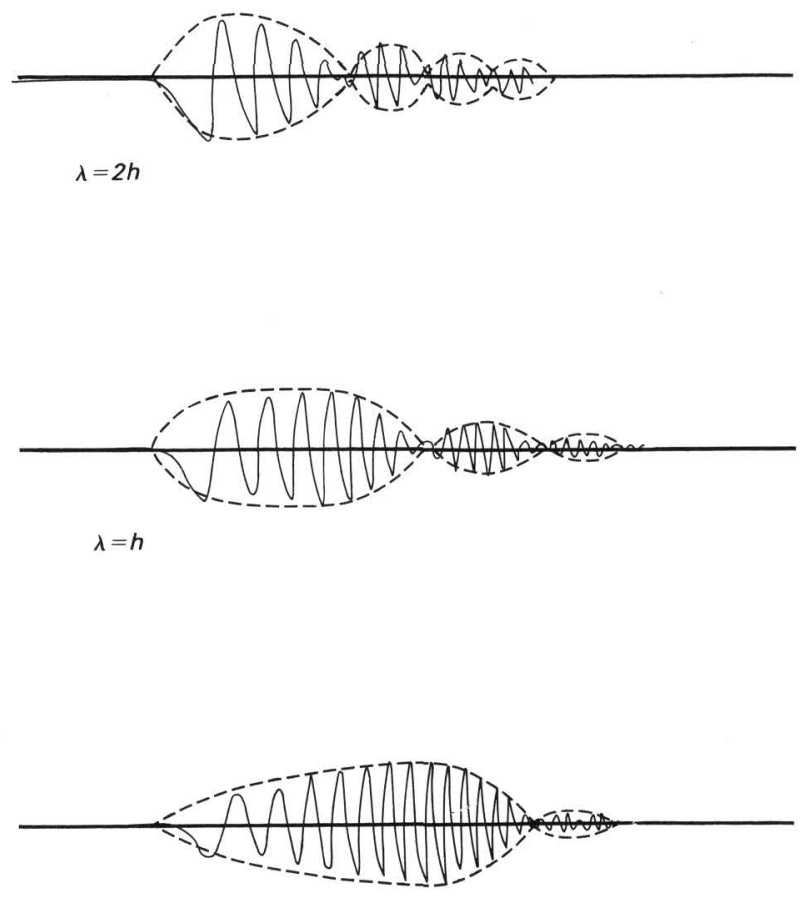

$\lambda=1 / 3 h$

$B$

FIGURE 198.-A, Laboratory model for generating impulsive waves (Wiegel, 1970). The length $(\lambda)$ and displacement (h) of the box and the water depth (d) can be varied. B, Recorded waves generated by the model. A single displacement of the block produces a train of oscillatory waves, and changes in the model configuration shift the position of the high-amplitude waves in the wave train.

the failed fill. The slides traveled downslope to the base of the continental slope and generated turbidity currents that traveled beyond the slides and cut submarine cables 80 and $110 \mathrm{~km}$ offshore of Nice.

Slide-generated waves pose a clearly recognized hazard to reservoirs, harbors, and lakes, where they may endanger lives, overtop or breach dams, or destroy waterside property. Thus, there has been some effort to develop predictive models of such waves. Some models are largely theoretical and are based on principles of fluid dynamics. Others are largely empirical, and results may depend on specific physical aspects of the models. Some are general case studies designed to examine how variations in the input energy (for example, differences in size, density, failure angle, velocity, degree of submersion of slide mass before sliding, or water depth) affect wave generation; still others are concerned with a specific site, such as a reservoir (for example, Davidson and Whalin, 1974), and are designed to examine the kinds of waves that will be generated by a specific slide falling or sliding into a water-filled basin of a specific bathymetry. An excellent summary of model studies has been given by Wiegel (1970).

Some aspects of slide-generated waves have been deduced from field study and eyewitness accounts of actual waves. Applying such observations to other areas is difficult or inappropriate because of significant differences in parameters such as the character and mechanism of failure of the slide mass and the bathymetry of the basin. Furthermore, it is difficult to form a generalized quantitative model from such observations because of large uncertainties in the time-history of water response to slide impact.

As a result, much that is known or conjectured about slide-generated tsunamis is deduced from laboratory scale models. In one very instructive type of model (Prins, 1958; Wiegel and others 1970), a block representing a slide is either dropped or rapidly raised at the end of an elongate water-filled tank, and recorders at several locations along the tank record the passing wave train (fig. 198). The depth, height, and length of the displaced water can be changed independently to examine their effect on the wave train (fig. 198). As Wiegel and others (1970) noted, changes in depth, height, and length of the displaced water can change the position of the highest amplitude wave in the wave train (fig. 198) and the characteristics of the leading waves (fig. 199). For a given set of conditions, the wave train stays the same if the block is raised or lowered, except that the first wave is a crest if the block is raised and a trough if the block is dropped.

In a laboratory model more appropriately applied to movement of a submerged landslide, Wiegel (1955) found that, for a given slide (block) moving into water of a given depth, the steeper the failure slope, the longer the period and the greater the amplitude of the major wave produced by the slide.

Some studies of slide-generated waves integrate several approaches; for example, Slingerland and Voight (1979) compared field data, empirical models, and theoretical studies of waves generated by slides and rock falls that were largely or entirely subaerial. They concluded that maximum wave height at a large distance from the slide can be computed and that, for detailed wave analysis, either scale models or a numerical approach can be used. One such numerical

\section{Earthquake Hazards in the Los Angeles Region}


model (Raney and Butler, 1975) deals adequately with wave nonlinearity and considers complex basin geometry and thus takes into account amplification or reduction in wave height due to refraction. As Slingerland and Voight (1979) noted, application of this numerical model is difficult because it is highly sensitive to parameters that are difficult to predict-the size of the slide mass, the time-history of emplacement of the slide mass in the water, and the deceleration of the mass as it is immersed. Nevertheless, they concluded that this approach provides a technique for establishing conservatively safe estimates of the risk of tsunamis generated by subaerial slides or rock falls.

\section{CALIFORNIA TSUNAMI HISTORY}

Most of the world's major tsunamis have been generated at subduction-convergent plate boundaries along the margin of the Pacific Ocean (fig. 200). Over the past $200 \mathrm{yr}$, nearly a third of all major tsunamis have occurred along deep-sea trenches bordering Japan, the Aleutians, and South America. Dip-slip fault displacements associated with large $(\mathbf{M} \geq 7)$ shallow earthquakes that accompany thrusting at these subduction zones occur at appropriate rates and are accompanied by changes in elevation of an area of sea floor large enough to produce large tsunamis. Fortunately for California, the major tsunamis generated at the Pacific-Eurasian plate boundary in the western Pacific that have repeatedly decimated the Japanese coast are reduced to small, generally undamaging but detectable waves after crossing the Pacific. However, this statement is not true for all distantly generated tsunamis. The five major distantly generated tsunamis that have affected the entire California coast during the post-1812 period of record are shown in table 50.

Appendix 4 lists the heights of distantly and locally generated tsunamis reported along the California coast since the earliest reported tsunami of 1812. The pre-1940's data base is poor because most west coast tide gauges were only recently installed. Most pre-1940's reports are from San Diego and San Francisco, where tide gauges were installed in 1854 . Because a uniform data base for the entire coast is lack-

FIGURE 199.-A, Characteristic wave types formed by landslides and in the laboratory model shown in figure 198. Water particles in oscillatory waves move in closed orbits, showing no net forward motion, whereas water particles in solitary waves (which travel wholly above mean water level) and bores have a forward translation (modified from Slingerland and Voight, 1979). B, Relation between source length $(\lambda)$ water depth (d), vertical displacement (h), and characteristics of the leading wave in the laboratory model shown in figure 198 (Prins, 1958).
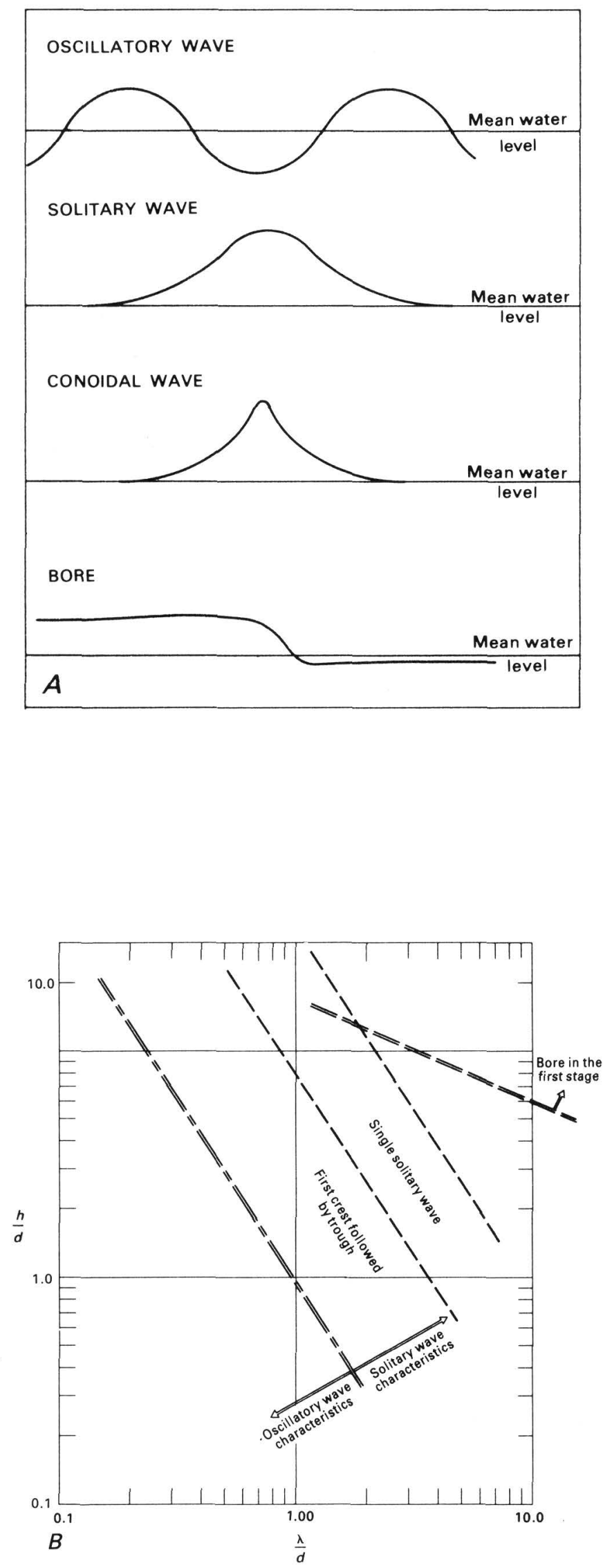

Tsunami Potential 387 


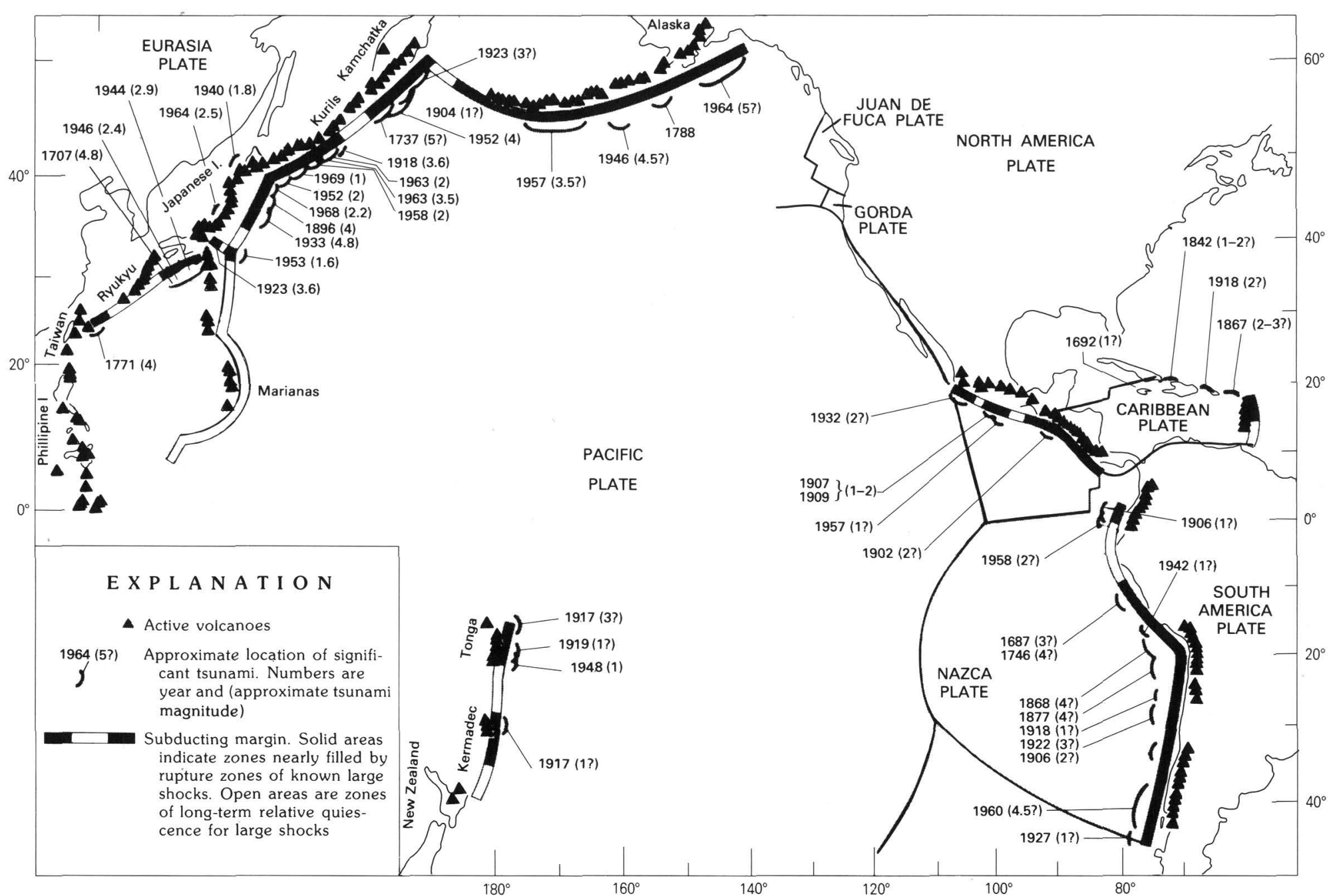

FIGURE 200.-Tsunamigenic lithospheric plate boundaries in the Caribbean Sea and the Pacific Ocean (Kelleher, 1979). Tsunami magnitude is $\log _{2} \mathrm{H}$, where $\mathrm{H}$ is the tsunami height in meters. 
TABLE 50.-Major distantly generated tsunamis that have affected the entire California coast since 1812

\begin{tabular}{|c|c|c|c|c|c|}
\hline Source location & $\begin{array}{l}\text { Earthquake } \\
\text { magnitude }\end{array}$ & $\begin{array}{c}\text { Tsunarni } \\
\text { magnitude }\left(\mathrm{M}_{\mathrm{t}}\right)^{1}\end{array}$ & $\begin{array}{c}\text { Places of } \\
\text { major impact } \\
\text { in United States }\end{array}$ & Fatalities $^{2}$ & $\begin{array}{l}\text { Cost of U.S. } \\
\text { damage, in millions } \\
\text { of } 1981 \text { dollars }\end{array}$ \\
\hline 1946 -- - East Aleutian Trench & $8.4\left(\mathrm{M}_{\mathrm{S}}\right)$ & 9.3 & Hawaiian Islands & 173 & 119.2 \\
\hline 1951 - - Kamchatka Trench & $9.0(\mathrm{M})$ & 9.0 & Hawaiian Islands & $\mathbf{0}$ & 2.1 \\
\hline 1957 ---- Central Aleutian Trench & $9.1(M)$ & 9.0 & Hawaiian Islands & 0 & 10.5 \\
\hline $1960----$ Chile Trench & $9.4(M)$ & 9.4 & Hawaiian Islands & 61 & 66.9 \\
\hline $1964----$ Gulf of Alaska & $9.2(M)$ & 9.1 & $\begin{array}{l}\text { Alaska, California, } \\
\text { Hawaiian Islands. }\end{array}$ & 119 & 282.3 \\
\hline
\end{tabular}

${ }^{1}$ Abe (1979).

${ }^{2}$ Bernard and Goulet (1981).

ing, tsunami heights are listed several ways in the appendix.

Refraction diagrams showing sequential wave-front positions and orthogonals for three of the major distantly generated tsunamis that have affected California are shown in figure 196. Despite the fact that these major tsunamis were generated to the north, west, and south of California, refraction on the California continental margin locally gave the waves an easterly travel direction toward the coast.

The largest recorded waves generated by the five major distantly generated tsunamis listed in table 50 are shown in figure 201. Wava heights are given as the largest crest-to-trough tide-gauge measurement (Spaeth and Berkman, 1967). As noted earlier, runup heights can be significantly higher than tide-gauge measurements. For comparison, some 1964 Alaska tsunami runup heights along the northern and central California coast (Magoon, 1965) are also given in figure 201. The highest 1964 wave at Crescent City was not measured by a tide gauge. As Wiegel noted, the tide gauge broke, and the wave washed over the top of the building housing the gauge. There were, however, some probably reliable eyewitnesses who established a $20-\mathrm{ft}$ height for this wave, for there were "...three gentlemen sitting on top of. . [another] building at the time of the tsunami keeping very close track of where the wave was" (Wiegel, 1969, p. 62).

Wave-height variation (fig. 201) demonstrates the influence of the local sea-floor configuration in determining tsunami wave height along coastal California. Despite great differences in the source locations of these distantly generated tsunamis, some sites consistently experience high or low waves. Van Dorn (1979b) attributed the generally low tsunami heights experienced by southern California to a combination of the generally low glancing angles of the main open-ocean tsunami waves and the reflection and (or) wave transformation as the waves cross the complex basin-ridge bathymetry of the wide southern California borderland terrane (see fig. 204). This complex submerged physiography does more than just reduce the amplitude. Tide-gauge records of tsunami waves along this coast exhibit a long "ringing" that may last several tens of hours after the arrival of the first tsunami wave. Wilson (1971) suggested that the ringing may be produced by oscillation of the water mass on the shelf rather than being a long wave train in the tsunami that is propagated across the borderland. It is well known that tsunamis can excite waves within harbors to oscillate at some frequency determined by harbor configuration. The ringing is most pronounced at Santa Monica Bay; however, the ringing is probably not determined by oscillation within Santa Monica Bay, which is wide open to the Pacific, for Raichlen (1979) has shown that wave energy is concentrated at approximately the same ringing frequencies at Santa Monica, Los Angeles Harbor, and the La Jolla promontory. He suggested that all three bathymetrically different sites are therefore probably responding to shelfwide oscillation rather than to locally generated waves.

The frequency distribution of the waves may be affected by the oscillation of water on the shelf, but the duration of oscillation may be related in part to continued input of energy from the Pacific. Analysis of a long-period-wave recorder in operation at La Jolla during and after the 1960 Chile tsunami (Miller and others, 1962) indicates, as might be expected, that highfrequency oscillation decreased rapidly but that lower frequency tsunami-related waves were still detectable above background waves for a week after the arrival of the tsunami. Similar waves decaying at about the same rate were recorded on a long-period-wave recorder at Wake Island by W. G. Van Dorn (unpublished data, cited by Miller and others (1962, p. 39)) following the 1957 Aleutian tsunami. It is generally thought that Wake Island is so small in relation to the size of passing tsunami waves that tide-gauge records there show no significant interaction between the island and the passing tsunami (Van Dorn, 1970). Thus, in the open Pacific, 


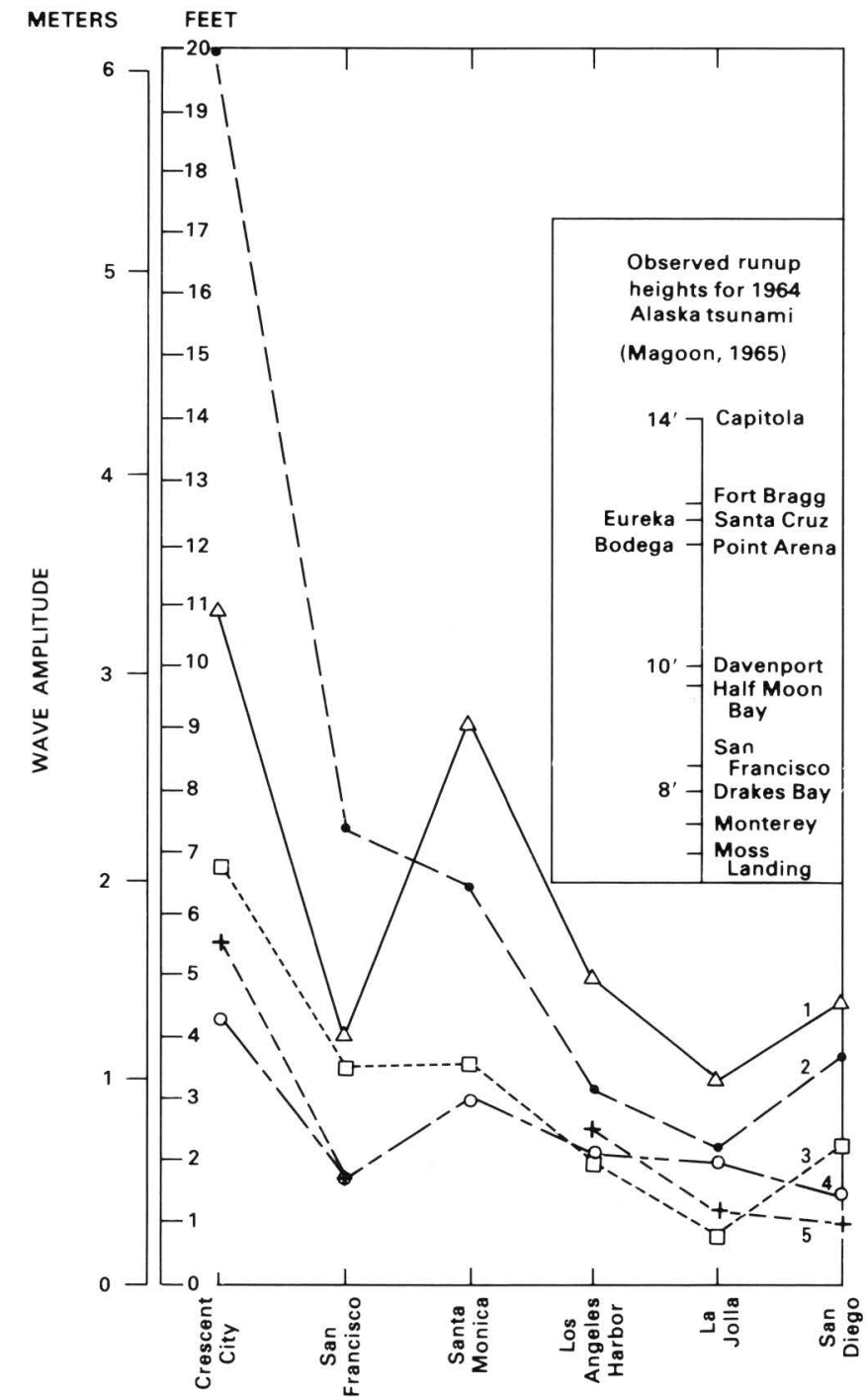

FIGURE 201.-Crest-to-trough heights of the highest waves from five major tsunamis recorded by tide gauges along the California coast (drawn from data of Abe, 1979; Spaeth and Berkman, 1967; Wiegel, '1969). Some sites generally experience large waves (Crescent City and Santa Monica Bay), but, in general, waves tend to be lower in southern California. Tide-gauge heights are usually exceeded by the highest runup heights, as shown on the inset graph of runup heights of the 1964 tsunami. 1, 1964 Alaska, $M$ 9.2, $M_{t} 9.1 ; 2$, 1960 Chile, $M$ 9.5, $M_{t}$ 9.4; 3, 1952 Kamchatka, M 9.0, $M_{t}$ 9.0; 4, 1976 east Aleutian Trench, $M_{S}$ 8.4, $M_{t}$ 9.3; 5, 1957 central Aleutian Trench, M 9.1, $M_{t}$ 9.0. Modified from Magoon (1965).

tsunami energy appears to persist over periods of several days. The occurrence of long-duration oscillations presents no hazard if wave amplitude is low, but, in areas like Santa Monica Bay, the currents that these oscillations produce may put considerable loads on moored structures and contribute to scouring. At Santa Monica Bay, waves with crest-to-trough measurements of about $1 \mathrm{~m}$ (approximately half the height of the largest wave) were still occuring 17 to $19 \mathrm{hr}$ after the arrival of the first wave of the 1964 Alaskan tsunami. Total tidal amplitude at the time of the tsunami was about $1.5 \mathrm{~m}$; thus, in every 20-min crest-to-trough tsunami wave period, the bay experienced about 70 percent of the full tidal reversal that normally occurs every $6 \mathrm{hr}$.

Another important peculiarity of tsunami wave behavior observed along the California coast is the occurrence of high runup in bays and behind hooks that appear to have the best protection from approaching tsunamis (Wiegel, 1970; Willard Bascom, unpublished report, 1946, cited by Wiegel (1970)). The 1946 Aleutian tsunami probably produced no wave at the city of Monterey, on the southern side of Monterey Bay, but water rose to $3.5 \mathrm{~m}$ at Santa Cruz on the northern side of the bay. Waves from the 1964 Alaskan tsunami were $2.3 \mathrm{~m}$ at Monterey but almost twice as high $(4.3 \mathrm{~m})$ at Santa Cruz. Wilson and Tфrum (1968) suggested that the deep submarine Monterey Canyon bisecting the bay may favor northward refraction of wave energy entering the bay. Half Moon Bay also experienced high waves during these tsunamis (4.6 m in 1946 and $2.9 \mathrm{~m}$ in 1964) and a possible height of $4.6 \mathrm{~m}$ in 1859 .

Locally generated tsunamis, usually attributed to coastal earthquakes, have produced 13 possible recorded events from 1812 to 1975 (table 51). Reports of these locally generated tsunamis are so sketchy that there is often doubt not only as to what was seen but also as to where observations were made. It has been suggested that event 1 is a misdated and mislocated description of event 2, the tsunami that resulted from an estimated $\mathbf{M} 7$ to 7.5 earthquake beneath Santa Barbara Channel. The 1812 Santa Barbara Channel tsunami was once reported to have had a height of $5 \mathrm{~m}$ at Gaviota and 9 to $10.5 \mathrm{~m}$ at Santa Barbara, but a more recent assessment suggests a runup of only 3 to $4 \mathrm{~m}$ at Gaviota and a still smaller runup at Santa Barbara (see discussion, app. 4). Event 23 was originally described as "[a] tidal wave, the largest in the history of Santa Barbara..." (Holden, 1898 , p. 152). Although originally accurately attributed to a high tide, it has since erroneously been ascribed to a tsunami (see app. 4). Half Moon Bay (event 12, 1859) is reported to have had a 4.6-m runup, but Iida and others (1967) suggested that this height may be exaggerated. As noted above, however, well-documented high runup has occurred at Half Moon Bay. These high waves resulted from distantly generated tsunamis, and Iida and others (1967a) suggested that the source for the 1859 runup may have been Chile rather than San Francisco. The only other locally generated tsunami that produced significant waves resulted from the M 7.31927 earthquake off Point Arguello, which produced local runup of $1.8 \mathrm{~m}$ at Surf and $1.4 \mathrm{~m}$ at Port San Luis, 13 and

\section{Earthquake Hazards in the Los Angeles Region}


TABLE 51.-High waves along California coast (1812-1975) correctly or erroneously attributed to locally generated tsunamis

\begin{tabular}{|c|c|c|c|}
\hline Event $^{1}$ & Year & Area affected & Waves reported \\
\hline $1----$ & 1812 & San Francisco(?), Santa Barbara(?) & $\begin{array}{l}\text { In Santa Barbara, "covered ground } \\
\text { where plaza now is" (app. 4). }\end{array}$ \\
\hline $2-----$ & 1812 & $\begin{array}{l}\text { North shore of Santa Barbara } \\
\text { Channel. }\end{array}$ & 3- to 4-m runup at Gaviota (see app. 4) \\
\hline 6 ----- & 1854 & San Francisco(?), Benicia(?) & Sea wave following shocks or shock \\
\hline $10----$ & 1855 & Capistrano & Two unusually heavy sea waves \\
\hline $12----$ & 1859 & Half Moon Bay & $\begin{array}{l}\text { 6-m withdrawal in San Francisco Bay, } \\
\text { 4.6-m runup in Half Moon Bay. }\end{array}$ \\
\hline $13-\cdots$ & 1862 & San Diego Bay & $<1 \mathrm{~m}$ \\
\hline $19----$ & 1879 & Santa Monica Bay & Affected Santa Monica \\
\hline $21----$ & 1885 & San Francisco & A series of waves \\
\hline $23----$ & 1896 & Santa Barbara & $\begin{array}{l}\text { High tide erroneously reported as } \\
\text { tsunami. }\end{array}$ \\
\hline $26----$ & 1906 & San Francisco & $\begin{array}{l}\text { 0.1-m drawdown followed by series of } \\
\text { waves having } 5-\mathrm{cm} \text { amplitudes. } \\
\text { Flooding at mouth of Navaro } \\
\text { River. }\end{array}$ \\
\hline $33-----$ & 1923 & Cape Mendocino & $0.3-$ to $0.6-\mathrm{m}$ runup \\
\hline $37-----$ & 1927 & Point Arguello & $\begin{array}{l}\text { 1.8-m runup at Surf, } 1.5-\mathrm{m} \text { runup at } \\
\text { Port San Luis. }\end{array}$ \\
\hline $39-\ldots$ & 1930 & Santa Monica Bay & Local oscillations to about $0.6 \mathrm{~m}$ \\
\hline $42----$ & 1933 & Long Beach & Uncertain records \\
\hline
\end{tabular}

${ }^{1}$ Numbers taken from appendix 4.

$66 \mathrm{~km}$ north along the coast from Point Arguello, respectively (Byerly, 1930).

Four local tsunamis were observed along the southern California coast during the period of record from 1812 to 1975. For three of these events (events 10, 19, and 42), wave heights were not indicated. Although it is difficult to say with assurance for the older events, it is probable that, if the waves had been high or had caused much damage, they would have been reported; thus, they were probably small. The 1862 tsunami in San Diego Bay (event 13) also produced a small runup ( $<1 \mathrm{~m}$ ?), and Agnew (1979) has suggested that the event may have been caused by shoreline slumping. Thus, with the exception of the 1812 Santa Barbara and the 1927 Point Arguello tsunamis, locally generated tsunamis have posed little hazard to the coast of southern California.

The 1964 Alaskan earthquake generated the only tsunami that caused extensive damage to California during the period from 1812 to 1975 . The cost of damage was approximately $\$ 13,375,000$ adjusted to 1971 dollars and $\$ 32,260,000$ in 1983 dollars (table 52). For comparison, the cost of California earthquake damage resulting from 26 earthquakes during the same period (1812-1971) was $\$ 7,200,000,000$ adjusted to 1971 dollars (Alfors and others, 1973) and $\$ 17,366,400,000$ in 1983 dollars. Although the cost of tsunami damage was only $\mathbf{0 . 2}$ percent of earthquake damage, the bulk of the cost was incurred in Crescent City, where 11 of the 13 tsunami deaths in California also occurred. Damage to the 34-block downtown section of Crescent City was described by Tudor (1964): 54 houses were destroyed, and 37 were damaged; 42 business establishments were totally destroyed, 108 sustained major damage, and 29 experienced minor damage. Houses floated free of foundations and grounded in streets, as did large logs. Wiegel (1969) pointed out that cars and single-story frame structures float in relatively shallow water; in the current velocities of perhaps $30 \mathrm{mi} / \mathrm{hr}$ that probably occurred in Crescent City, both can become destructive agents. There was also heavy damage in the harbor; 15 boats capsized, and Citizens Dock was heavily damaged by buoyant forces and by a heavily loaded lumber barge that was forced against it by the current surge. Damage

TABLE 52.-Cost of 1964 tsunami damage to California coast [From Alfors and others (1973)]

\begin{tabular}{|c|c|}
\hline Location & Damage, in 1971 dollars \\
\hline Crescent City - & $11,000,000$ \\
\hline Long Beach --- & 100,000 \\
\hline Los Angeles --1- & 275,000 \\
\hline 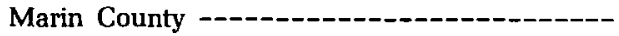 & $1,000,000$ \\
\hline Noyo Harbor -- & $1,000,000$ \\
\hline 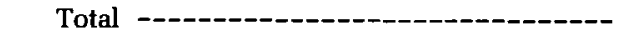 & $13,375,000^{1}$ \\
\hline
\end{tabular}

${ }^{1} \$ 32,260,000$ (1983 dollars). 
in the rest of California from the 1964 tsunami was caused largely by high-velocity current surges in ports, marinas, and narrow entrances to bays. Thus, most damage was to boats, related harbor facilities, and moored navigation aids. Magoon (1965) reported damage to boats and marine facilities at Noyo River, the fishing port at Fort Bragg, Bodega Bay, Tomales Bay, Bolinas, San Francisco Bay, Santa Cruz and Santa Cruz Harbor, Moss Landing, Monterey Harbor, and Los Angeles. Some of the damage was detailed by Spaeth and Berkman (1967, p. 24):

...Mendocino County reported that approximately 100 fishing boats in Noyo Harbor suffered damage with 10 being sunk. A dredge in the harbor was carried upstream about onefourth mile and grounded on a sandbar. Estimates of the damage ranged from $\$ 250,000$ to $\$ 1$ million. In Marin County, approximately $\$ 1$ million worth of damage was done to small boats and berthing facilities, mostly in Loch Lomond Harbor in San Rafael. Los Angeles County Civil Defense reported $\$ 100,000$ to $\$ 200,000$ damage to six small-boat slips, pilings, and the Union Oil Company fuel dock; $\$ 75,000$ damage due to scouring action on the harbor sides in Los Angeles County Harbor; and 8 docks with a value of $\$ 100,000$ destroyed in Long Beach Harbor.

San Diego escaped damage from the 1964 tsunami, but high currents resulting from the 1960 Chilean tsunami tore out several hundred feet of rotted wharfage (Van Dorn, 1979b).

\section{TSUNAMI POTENTIAL IN COASTAL SOUTHERN CALIFORNIA}

\section{Potential for Local Fault-Generated Tsunamis.}

In southern California, displacement between the North American and the Pacific plates is accommodated in part by movements along strike-slip faults, some of which are in the offshore borderland. Geologic structures in the Transverse Ranges, including the Santa Barbara Channel and the offshore Point Arguello area to the west, lie athwart the strike-slip motion and are experiencing compressive tectonic deformation (Yerkes, this volume). It is not surprising that the only welldocumented local tsunamis thusfar recorded in southern California (the 1812 Santa Barbara and the 1927 Point Arguello tsunamis) were generated in this compressive tectonic geologic setting. There is, however, some suggestive evidence that episodes of vertical displacement capable of tsunami generation may be associated with the offshore extension of the Palos Verdes Hills reverse fault to the southwest in an area otherwise dominated by strike-slip displacement.

Before much was known of offshore California geology, it was proposed that the tsunami accompanying the $1927\left(M_{S}\right.$ 7.3) earthquake off Point Arguello was generated by submarine landsliding or by displacement along an east-west fault (Marine Advisors, 1965). Sliding can probably be eliminated as a cause. Recent mapping of the offshore Point Arguello area has delineated submarine slides 20 and $60 \mathrm{~km}$ northwest of Point Arguello, but these slides are nested retrogressive slumps that resulted from progressive upslope failures in which no slump had appreciable downslope displacement (McCulloch and others, 1980). In addition, the tsunami was recorded at Honolulu and Hilo (fig. 202) (Iida and others, 1967a), and, as noted above, it is doubtful that submarine slides can generate transoceanic tsunamis.

There is some evidence that the Point Arguello earthquake may have had significant dip-slip displacement. Gawthrop (1978a) located the 1927 epicenter on the southeastern end of the long, seismically active northwest-trending Hosgri fault (Hoskins and Griffiths, 1971; Wagner, 1974; McCulloch and others, 1980; Lindh and others, 1981) (fig. 203). The epicenter has been placed farther offshore by others (Byerly, 1930; Smith, 1975; Hanks, 1979). Displacement accompanying the earthquake deduced from fault-plane solutions has been described as primarily oblique right-lateral strike slip accompanied by some northeastern-side-up dip slip (Gawthrop, 1978a) or as primarily vertical dip slip, northeastern side up, accompanied by only minor strikeslip displacement (Yeh, 1975). Geodetic measurements (Savage and Prescott, 1978) indicate that the fault displacement associated with the 1927 earthquake had a large component of thrust and no appreciable right slip. A fault-plane solution of a more recent $M_{L} 5.1$ earthquake (May 20, 1980), located nearly coincident with Gawthrop's 1927 epicenter location, indicated very nearly pure dip-slip northeastern-side-up displacement on a northwest-striking high-angle reverse fault (Eaton, 1984).

Other potentially tsunamigenic faults occur offshore of Point Arguello. Northwest-trending seismically active faults as long as $70 \mathrm{~km}$, some having sea-floor expression as long as $40 \mathrm{~km}$, lie within and bound the Santa Lucia Bank, a structural high at the upper edge of the continental slope (McCulloch, and others, 1980). Faultplane solutions (Gawthrop, 1975, 1978b) for the two

\section{Earthquake Hazards in the Los Angeles Region}




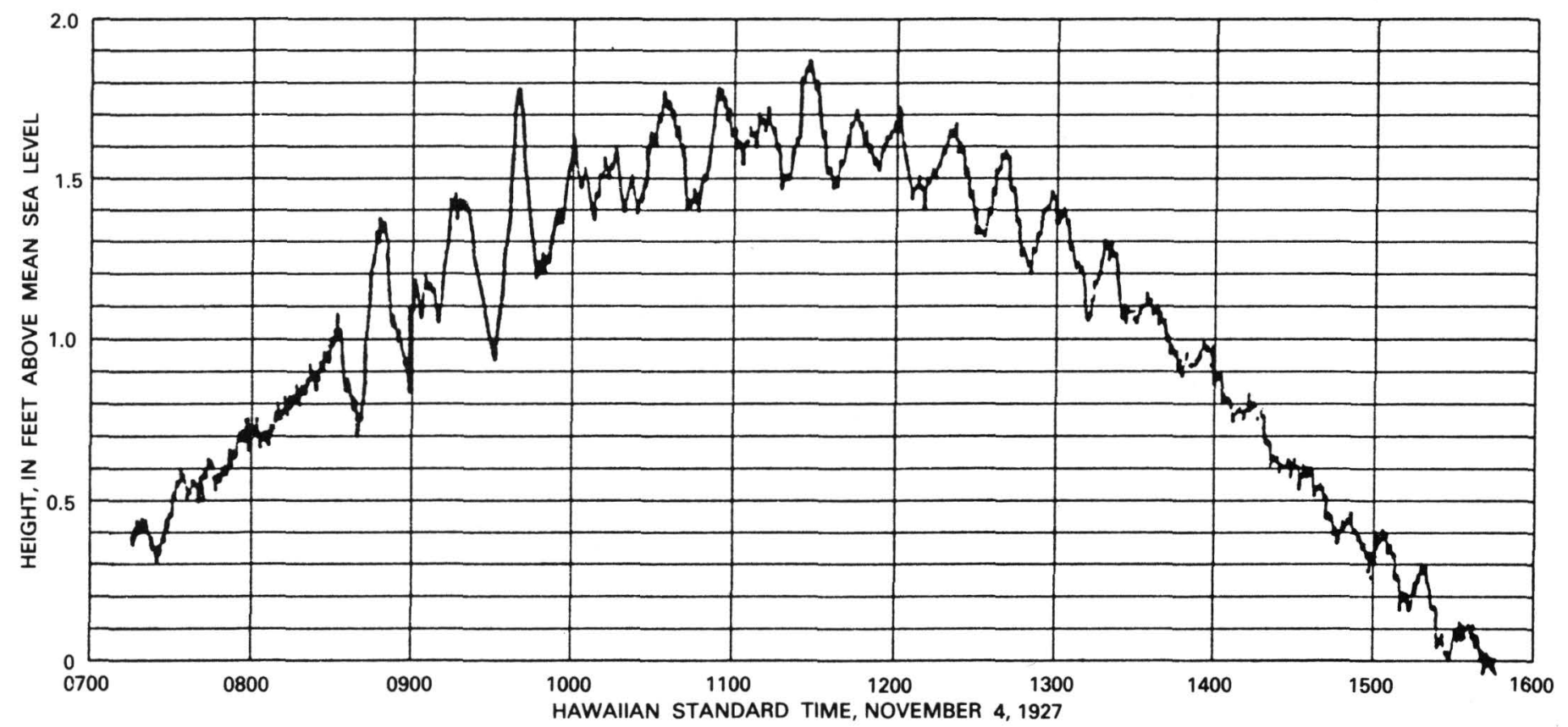

FIGURE 202.-Tide-gauge record at Hilo, Hawaii, showing the beginning of the tsunami wave train generated by the November 4, 1927, Point Arguello earthquake in California. The wave train began at about 8:30 a.m. with a drawdown and had a maximum range of about $1 \mathrm{ft}$. The earthquake epicenter was approximately $3,950 \mathrm{~km}$ from Hilo, and the wave traveled approximately $750 \mathrm{~km} / \mathrm{hr}$ (The Volcano Letter, 1931).

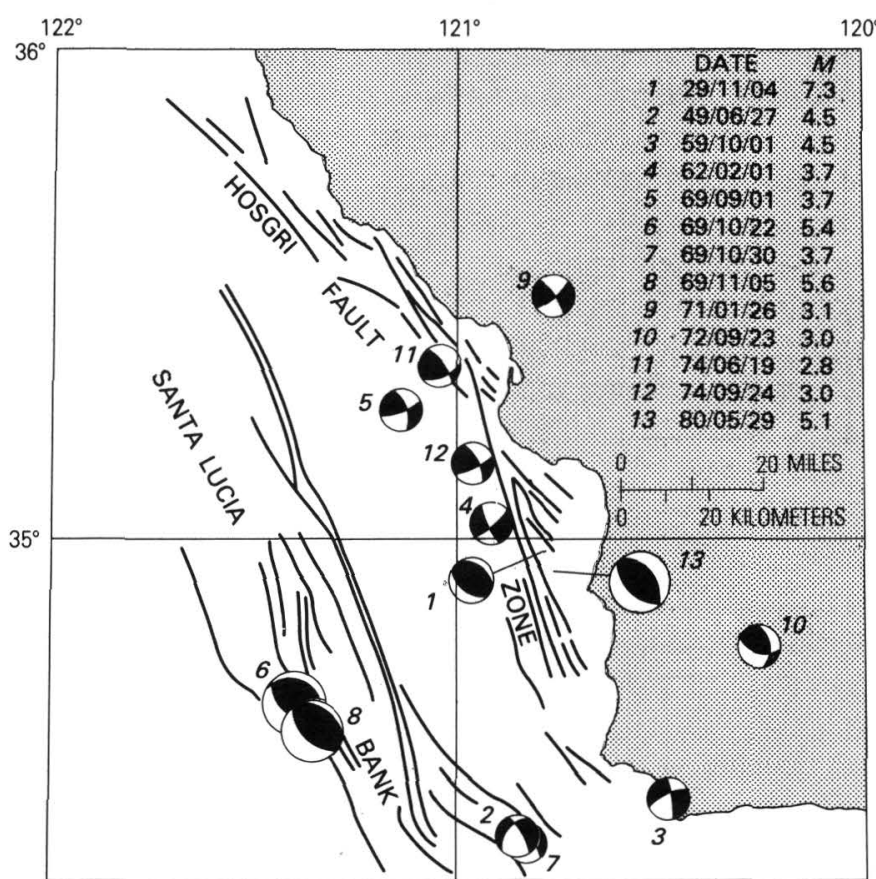

FIGURE 203.-Offshore faults and the locations of associated epicenters for which first-motion determinations have been made in the vicinity of Point Arguello, Calif. (after McCulloch and others, 1980). First-motion diagrams are lower hemisphere plots; white indicates dilation, and black indicates compression. Larger diagrams are generally well constrained first-motion determinations. The 1927 Point Arguello earthquake (1) is shown as located by Gawthrop (1975); first motion is as given by Yeh (1975). First motions for events 3 through 6 and 8 through 12 from Gawthrop (1978b); for 2 and 7 from Gawthrop (1975); for 13 from Eaton (1984). main shocks $\left(\mathrm{M}_{\mathrm{L}}\right.$ 5.4-5.6) of a 1969 earthquake swarm centered on the southwestern end of Santa Lucia Bank indicate pure dip slip, southwestern side up, on steep southwest-dipping high-angle reverse faults (fig. 203). Within the constraints of epicenter location, these events may have occurred on the faults having sea-floor expression. If the long sea-floor expression of these faults represent single-event displacements, the faults are capable of producing large earthquakes. Thenhaus and others (1980) estimate a recurrence interval of 230 years for $6.4 \leq M_{S}<7.0$ earthquakes in this area. Thus, these faults may have the potential to generate tsunamis.

Another potential source area for local faultgenerated tsunamis lies to the east along the major geologic boundary between the Santa Barbara Channel and the adjoining Transverse Ranges, where seismically active northeast-dipping reverse faults separate the rocks beneath the Santa Barbara Channel to the south from the elevated and folded rocks of the Transverse Ranges to the north (Yerkes and Lee, 1979). Active tectonic deformation along this boundary is also indicated by the fact that the highest short- and long-term uplift rates in California are found along this coast (Yerkes and others, 1981). Surface fault rupture accompanied by sea-floor displacement is a distinct possibility beneath the Santa Barbara Channel. This area has experienced large, damaging earthquakes (Yerkes, this volume). On December 21, 1812, two large earthquakes 
of estimated $M 7$ to 7.5 probably occurred beneath the channel, and Spanish mission structures were severely damaged for a horizontal distance of about $185 \mathrm{~km}$ along this geologic boundary (Toppozada and others, 1981; Yerkes and others, 1981); comparing the reported damage pattern with predicted intensities from several possible fault sources suggests that fault rupture probably occurred beneath the northern Santa Barbara Channel (Evernden and Thomson, this volume) along the Pitas Point-Ventura fault and its possible western extension. In 1971, a $M$ 6.6 earthquake inflicted severe damage to San Fernando at the eastern end of the zone of faulting and produced surface rupture for at least $15 \mathrm{~km}$ and a total measured vertical offset of $2.20 \mathrm{~m}$ (Burford and others, 1971). Lee and Ellsworth (1975) suggested a maximum credible earthquake of $M_{L} 7.3$ in the Santa Barbara Channel, although Ziony and Yerkes (this volume) suggest that it might be as large as $M$ 7.5. If the relations between tsunami size, earthquake magnitude, and hypocentral depth established for Japanese earthquakes can be applied in this very different geologic environment, the occurrence of a sea-floorrupturing earthquake having a magnitude of 7.5 and a hypocentral depth of 4 to $14 \mathrm{~km}$ could produce a tsunami having a magnitude of 2 accompanied by a runup height of 4 to $6 \mathrm{~m}$ (figs. 191, 192).

Still farther to the south, offshore of Huntington and Newport Beaches, Holocene deposits less than approximately 10,000 yr old are offset along an appreciable length of the offshore Palos Verdes Hills fault (Greene and others, 1975; Junger and Wagner, 1977; Darrow and Fischer, 1983; Clarke and others, this volume). Maximum observed displacement of the base of the Holocene deposits on this fault is approximately $3 \mathrm{~m}$, and the maximum observed offset of the surface of the Holocene deposits at the sea floor is $1 \mathrm{~m}$. From a tsunamigenic point of view, a worst case might presume a single 3-m vertical offset of the sea floor. If one makes the common assumption that half $(35 \mathrm{~km})$ the mapped trace of the fault $(70 \mathrm{~km})$ can break as a single rupture (Bonilla and others, 1984) and that the maximum probable magnitude of an earthquake associated with this fault is $M_{S} 7.3$ (Thenhaus and others, 1980), a 3-m surface offset is not unreasonable in terms of what is known about relations between fault length, earthquake magnitude, and surface displacement from a study of worldwide faulting (Bonilla and others, 1984). If good reason is found to discount a 3-m single-event offset, there is still possible concern for a repeat of the observed 1-m offset. If seismicity rates determined by Thenhaus and others (1980) are used, a recurrence interval of about $135 \mathrm{yr}$ for a $6.4 \leq \mathrm{M}_{\mathrm{S}}<7$ earthquake that would be capable of producing a 1-m single-event displacement (Bonilla and others, 1984) can be estimated. Thus, the recurrence interval is

394 Earthquake Hazards in the Los Angeles Region short enough to be of concern. A very rough approximation of the potential tsunami can be made. If one assumes a $\boldsymbol{M} 7$ event at a hypocentral depth of about $10 \mathrm{~km}$ (using estimates by Wood (1933) and Woodward-Clyde, Inc. (1979) for the hypocentral depth of the $M 6.21933$ Long Beach earthquake that occurred just toward shore of this fault) and the relation between magnitude and hypocentral depth (fig. 191), this earthquake could be tsunamigenic. And, if the relation between earthquake and tsunami magnitude for Japanese tsunamigenic earthquakes is valid in this case (fig. 192A), this earthquake could generate a magnitude 1 tsunami having a maximum runup of 2 to $3 \mathrm{~m}$. The upper bound relation between tsunami magnitude and water depth at the epicenter (fig. 195) (the shallower the water, the less efficient the energy coupling between the water and the deforming sea floor) suggests, however, that, if the offshore Palos Verdes Hills fault were to offset the shallow shelf, water depth would be an important factor in reducing wave height.

\section{Potential for Local Slide-Generated Tsunamis}

Interpretations of a relatively dense network of subbottom acoustic reflection profiles on which it is possible to see both the surface topography and the internal structure of submarine landslides have revealed many slides within zones of mass soil failure that lie about 3.5 to $14 \mathrm{~km}$ offshore of the Los Angeles region in water depths of 250 to $750 \mathrm{~m}$ (fig. 204) (Field and Edwards, 1980; Clarke and others, this volume). Dimensions of single slides are usually considerably smaller than those of the zones in which they occur. Seismic shaking, which reduces the shear strength of ocean-floor sediment by cyclic loading, may be a cause of the observed sliding. Geotechnical studies (Edwards and others, 1980) suggest that ground motion whose horizontal acceleration is in excess of $0.13 \mathrm{~g}$ at the sea floor, which can be expected in this area (Thenhaus and others, 1980; Spudich and Orcutt, 1982), should be sufficient to produce failure. In fact, the geotechnical measurements suggest that much of the unfailed sediment is metastable and subject to sliding, and it is difficult to understand why sliding is not more widespread. Geotechnical studies of slides off Alaska (Schwab and Lee, 1983) have shown that slope failures occur given the proper combination of water content in the sediment (35 to 45 percent, a reflection of porosity and grain-size distribution) and seismic shaking during which the effective acceleration (not just the peak acceleration) exceeds the critical acceleration (the threshold acceleration at which a given slope starts to fail). Although the presumption has been 


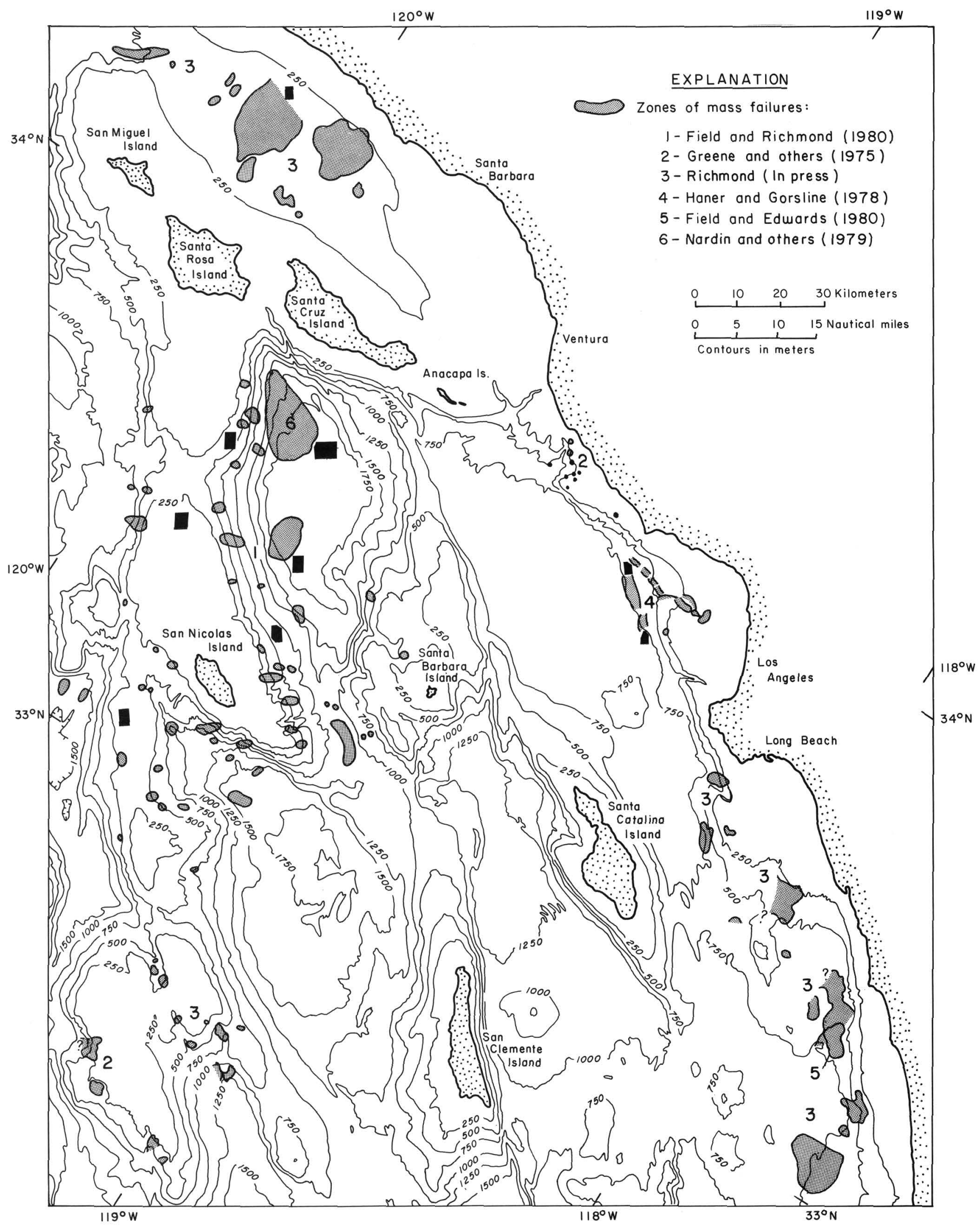

FIGURE 204.-Known sediment failures in the southern California borderland (Field and Edwards, 1980). Contours in meters.

Tsunami Potential 395 


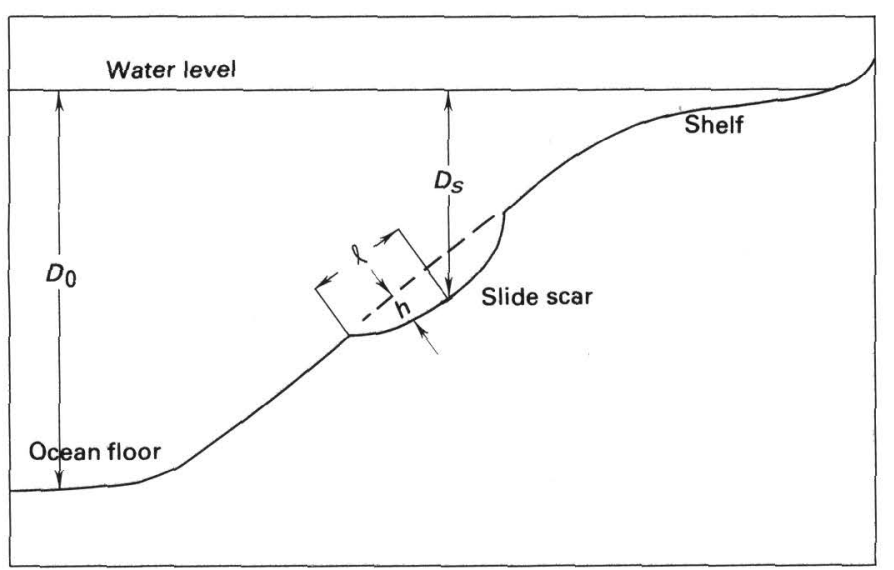

FIGURE 205.-Schematic cross section of a submarine landslide scarp showing the parameters used to estimate the amplitude of a slidegenerated wave (after Striem and Miloh, 1975). $D_{0}$ is the water depth at the base of the slope, $D_{s}$ is the water depth to the center of gravity of the slide, $\ell$ is the distance from the center of gravity to the edge of the slide, and $h$ is the slide thickness.

that earthquakes may trigger slides off southern California, opportunities for observing such slides are rare, and there have been no direct observations of slides that were initiated or moved during southern California earthquakes. The only offshore California submarine slide known to have been initiated by an earthquake is a large liquefaction-induced failure off northern California that occurred in conjunction with a $\boldsymbol{M} 7.2$ earthquake (Field and others, 1982).

To estimate the tsunami that might be generated by an earthquake-triggered slide, we must assume the dimensions of a representative slide. B. D. Edwards (oral communication, 1983), who has examined most of the nearshore zones of mass failure offshore of Los Angeles, estimated the following parameters for a representative slide block:

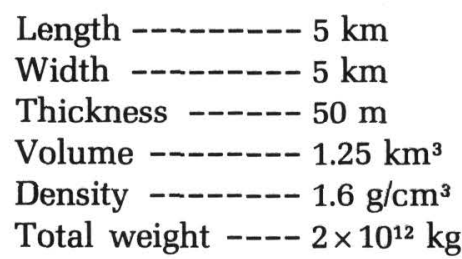

In falling $100 \mathrm{~m}$, the block represents an energy output of $0.147 \times 10^{23} \mathrm{erg}$, which, if it is fully converted to wave generation, is comparable to an energy input associated with tsunamis of 2- to 3-m runup heights (table 48). However, Wiegel (1970) has shown, in a dropping-block model, that only 1 to 2 percent of the potential energy is converted to wave generation. The energy output would thus be reduced to $0.00147 \times 10^{23} \mathrm{erg}$, and the runup height would be reduced to about $1 \mathrm{~m}$. Waves of this height are insignificant and would probably lose amplitude exponentially as they traversed the long distance to the shoreline. If this approximation is valid, it suggests that tsunamis generated by slides of the dimensions known along the southern California coast pose no tsunami hazard.

The wave generated by the postulated representative slide block can also be estimated by using an equation developed by Striem and Miloh (1975) that Murty (1979) applied to a wave generated by a submarine slide investigated by Prior and others (1982) at Kitimat Arm, British Columbia. The model assumes that the wave energy is uniformly distributed over the width of the slide and, consistent with Wiegel's observations, that only a very small fraction of the potential energy released by the slide is converted to wave energy. The equation takes the form

$$
\left.H=\frac{1}{D}\left[8(3)^{1 / 2}\right) \mu \ell h(\delta-1)\left(D_{0}-D_{S}\right)\right]^{2 / 3}
$$

As figure 205 shows, $D_{s}$ is the water depth at the center of gravity of the slide, $D_{0}$ is the water depth at the base of the slope, $\ell$ is the distance from the edge to the center of gravity of the slide, $h$ is the slide thickness, $\mu$ is the assumed percentage of energy transferred from the slide to the wave, and $\delta$ is the density of the slide divided by the density of water. Substituting the values from the postulated slide block $\left(D_{\mathrm{s}}=600 \mathrm{~m}, D=D_{0}\right.$ $=700 \mathrm{~m}, \ell=2,500 \mathrm{~m}, h=50 \mathrm{~m}, \mu=0.01$, and $\delta=1.6)$ yields a calculated wave height $H$ of $0.14 \mathrm{~m}$.

The fact that this small wave should have approximately the same order of magnitude runup as the wave estimated by the preceding model suggests that there is little hazard of tsunamis generated by slides of the dimensions observed off the southern California coast. It is stressed that this calculation is sensitive to the assumed slide-to-wave energy transfer ( 1 percent), which is derived from laboratory models, and that this parameter is not well evaluated in actual cases.

\section{Potential for Distantly Generated Tsunamis}

Several approaches have been used to predict the frequency of occurrence and the height of distantly generated tsunamis that might affect coastal California. One relates tsunami height to tsunami frequency from historical California data. Another combines longer term historical data from the shores of the entire Pacific with numerically simulated tsunamis in the source areas thought to be most threatening to California and examines the height and frequency of occurrence of the predicted waves. A third identifies existing seismic gaps

\section{Earthquake Hazards in the Los Angeles Region}


in distant tsunamigenic areas, evaluates which might produce the most damaging tsunami in California, and considers the probability of a large tsunamigenic earthquake in that seismic gap.

\section{California Tsunami Record}

Using recorded tsunami heights, Wiegel (1970) described a tsunami height distribution function for Japan, for Hilo, Hawaii, and for several California sites (fig. 206). The distribution functions demonstrate the relation between expected wave height and frequency and can be used for estimating recurrence intervals. The San Diego curve is added by using data from appendix 4. For moderate and large tsunamis (heights above approximately $1.5 \mathrm{~m}$ ), these curves suggest that wave height is related to the log of the frequency.

As figure 206 indicates, the recurrence interval for large tsunamis is approximately $100 \mathrm{yr}$ in California and $10 \mathrm{yr}$ in Japan. The difference in recurrence interval reflects the generation of local tsunamis along the Japan-Kurile Trench and the sensitivity of Japan to distant tsunamis as opposed to (1) the absence of significant locally generated tsunamis along the California coast, (2) the transoceanic dieoff of tsunamis generated off Japan, and (3) the relative insensitivity of California to distantly generated waves. Figure 206 also shows that waves from distantly generated tsunamis tend to be smaller in southern California.

\section{Long-Term Historical Data and Mathematical Models}

Tsunamis can be simulated by using mathematical models that specify the location, geometry, and amount of elevation change in a source area, the paths of the resulting waves, and the effects of shoaling on wave amplitude as waves approach a coast line (for example, Brandsma and others, 1978; Houston, 1980; Hwang and others, 1972). By combining historical data and numerical modeling, the U.S. Army Corps of Engineers has predicted 100- and 500-yr runup elevations for the U.S. west coast for the Federal Insurance Administration to use as a basis for calculating flood-insurance rates (Garcia and Houston, 1975; Houston and Garcia, 1974, 1978; Houston and others, 1975; Houston, 1980). Because no historical record was long enough or complete enough to make statistically valid predictions for most of the California coast, these predictions are based on numerical models of distantly generated tsunamis and the historical record of tsunamis elsewhere in the Pacific. These models indicate that the California coast is most sensitive to tsunamis generated along the Alaska-Aleutian and Peru-Chile margins. For modeling purposes, these two source areas were divided into 12 segments, and 5 tsunamis ranging from 2.5 to 4.5 in intensity (in increments of 0.5 ) were modeled in each segment by using a numerical finite difference model (Garcia, 1976). The modeled tsunami is initiated by an uplift of the sea surface assumed to be identical to the uplift of the sea floor. The tsunamis are presumed to be large, made up of linear nondispersive waves having wavelengths greater than $160 \mathrm{~km}$. The wave trains are propagated across a wide-spaced computational grid representing the Pacific Ocean (using actual water depths along wave paths) to the base of the California continental slope.

On reaching a water depth of $500 \mathrm{~m}$ at the base of the slope, wave trains predicted for the 5 tsunamis in each of the 12 segments were propagated up the continental

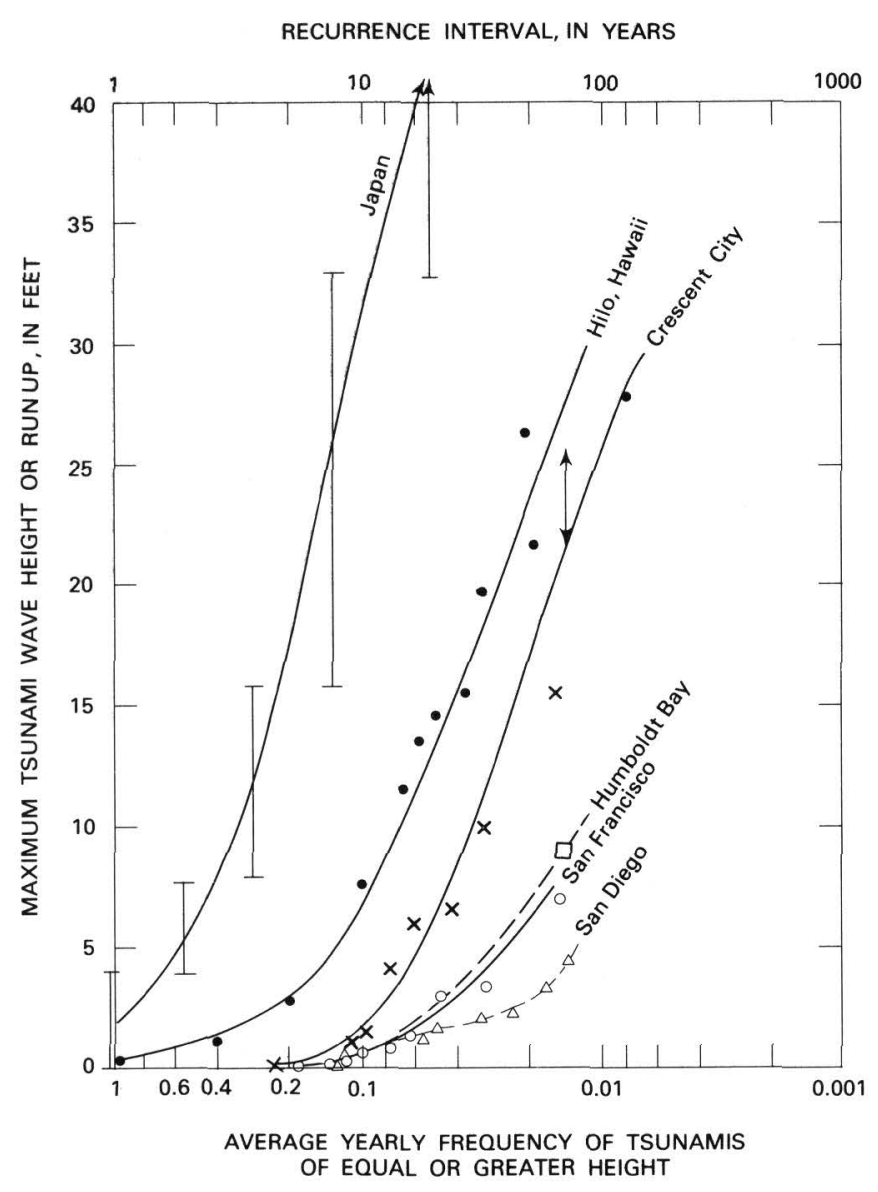

FIGURE 206.-Comparison of maximum height or runup with frequency and recurrence interval for tsunami waves in Japan, California, and Hawaii. Modified from Wiegel (1970). 

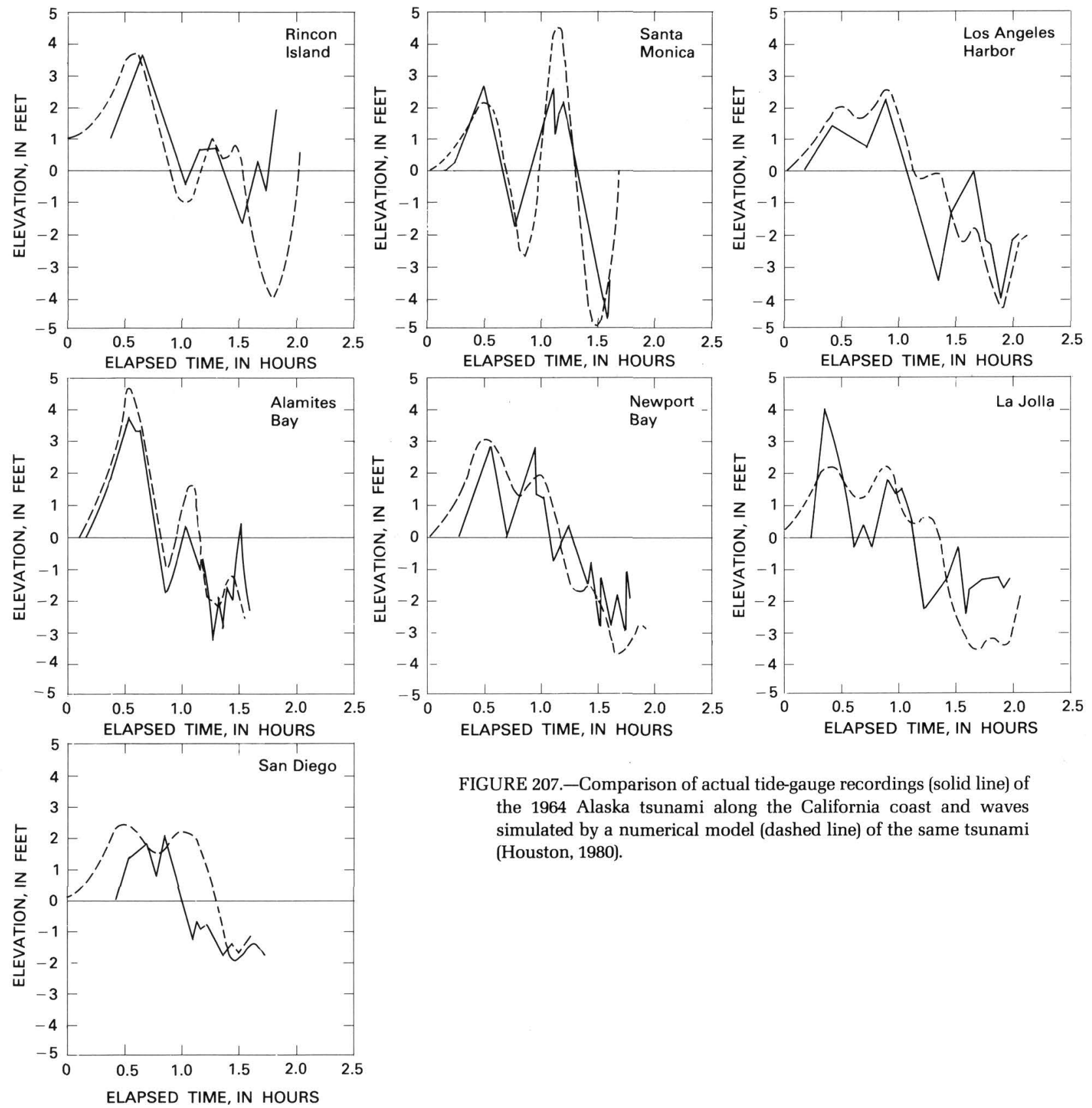

FIGURE 207.-Comparison of actual tide-gauge recordings (solid line) of the 1964 Alaska tsunami along the California coast and waves simulated by a numerical model (dashed line) of the same tsunami (Houston, 1980).

slope and across the continental shelf by means of a shallow-water numerical model. The resulting waves were described for 199 shoreline locations from Point Conception to the Mexican border. The shallow-water model is a finite difference model, developed by Leendertse (1967) and modified by Butler (1978), that treats the shoaling waves as nonlinear through a finemesh computational grid in which grid size is decreased to accommodate the increasing effect of local bathymetry as the shoreline is approached. Verification of the model was made by comparing a simulation of the 1964 tsunami with tide-gauge records from the available seven southern California tide-gauge records of the actual tsunami (fig. 207). As Houston (1980, p. 9-10) concluded,

[The] numerical model calculation agrees reasonably well with the tide gage records [however] the tide gages do not record tsunamis without distortions of amplitude, period and phase. The greatest amplitude difference [approximately $0.6 \mathrm{~m}$ ] is for the second wave crest at Santa Monica...However, the tide gage may have had response problems while recording the wave crest since the recording appears to be truncated and there 
are unusual high frequency oscillations in the truncated region of the wave form.

To make predictions, temporal distributions of intensity must be known. Houston (1980) used the Imamura-Iida intensity scale (table 48) as modified by Soloviev (1970), where

$$
\text { intensity }=\log _{2}\left(\sqrt{2 \text { height (meters })_{\text {avg }}}\right)
$$

so as to use a generally representative average runup rather than risk skewing the data to an unrepresentative runup at a single point along the coast. By combining this measure of intensity with the recorded tsunami histories for the two major source areas and by assuming a linear distribution between frequency and intensity, Houston established predictions for tsunamis of a given intensity (i) that would be generated in any given year along the Peru-Chile Trench:

$$
n(i)=0.074 e^{-0.63 i}
$$

and along the Alaskan-Aleutian margin:

$$
n(i)=0.113 e^{-0.71 i}
$$

This approach presumes that tsunamis have a Poisson distribution - that is, a frequency distribution of single noncontagious events in which the probability of a single event is small and the number of events is large (McCulloch and Pitts, 1948). Elevations of the waves expected to be equaled or exceeded once every 100 to 500 yr were then calculated from the numerically simulated tsunamis (fig. 208). The predicted wave heights, shown above the shoreline, incorporate the effect of astronomical tides by means of an analytical solution used to determine the combined tsunami and astronomical-tide cumulative probability distribution (Houston, 1980). These predicted heights above the shoreline are considered by Houston to equal runup elevations for most of southern California, except that runup elevations may be lower where waves flood lowlying or estuarine areas or higher where waves encounter steep topography at or near the shoreline. Although the limits of coastal flooding or inundation resulting from the predicted waves were not determined in this study, Houston and Butler (1979) have developed and applied a two-dimensional numerical model for inundation that they have tested against the observed 1964 tsunami inundation at Crescent City.

In assessing the foregoing predicted recurrence intervals and heights of the 100 - and $500-\mathrm{yr}$ tsunamis, the reader should be aware that (1) workers in the field disagree on whether the tsunami record is long enough to allow extrapolation to future events, especially large events (Hwang and Lee, 1979, p. 272-277); (2) the predicted heights are not maximum credible heights and do not presume coincidence of the highest tsunami wave with peak high tide or with storm-induced high-water setup and superimposed storm waves; and (3) the designations $100-$ and 500-yr tsunamis do not mean that, for any specific time period, it will be 100 or $500 \mathrm{yr}$ between such events, because these calculated recurrence intervals are a statement of probability over a time period many times greater than the predicted intervals.

\section{Seismic Gaps}

The third method of tsunami prediction is based on recognition of seismic gaps and provides a model for predicting which portions of tsunamigenic subducting margins are likely to produce large tsunamis in the near future (McCann and others, 1979). Analysis of the seismic histories of areas adjacent to seismic gaps has provided accurate forecasts (location and magnitude) of large earthquakes (Ohtake and others, 1977). In 1970, J. A. Kelleher recognized a seismic gap at the Shumagin Islands along the Aleutian Trench. This spatial gap in seismic activity along an otherwise seismically active convergent plate boundary that has not had a large $(M>7.0)$ earthquake for several decades is one of several later described by Kelleher (1972), Kelleher and others (1974), and Sykes (1971) along island arcs of the Pacific margin. In 1981, L. S. House and others identified the Unalaska gap, adjacent to the Shumagin gap.

The California coast is sensitive to tsunamis that might be generated in the Shumagin or Unalaska gaps. This sensitivity has been demonstrated by numerical simulation of hypothetical tsunamis generated at subduction zones around the Pacific to provide an estimation of the maximum credible tsunami waves that might occur along the west coast of the United States (Brandsma and others, 1978). In this study, tsunamis were simulated at 34 sites along island arcs and trenches around the Pacific margin (fig. 209); it was presumed that each site was capable of producing sea-floor displacements somewhat larger than those of the 1964 Alaska and 1960 Chile earthquakes. The simulated tsunamis were propagated across the Pacific to specified offshore locations through a finite difference grid having a minimum water depth of $180 \mathrm{~m}$. Maximum wave heights (departure from still water) for each location produced by any of the 34 simulated maximum credible tsunamis are shown in figure 209. With the exception of one station off southern California (station 16), which is controlled by a tsunami at Samoa (area 3, fig. 209), the maximum wave heights along the west 


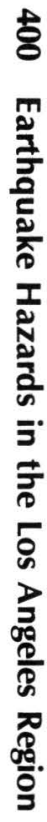


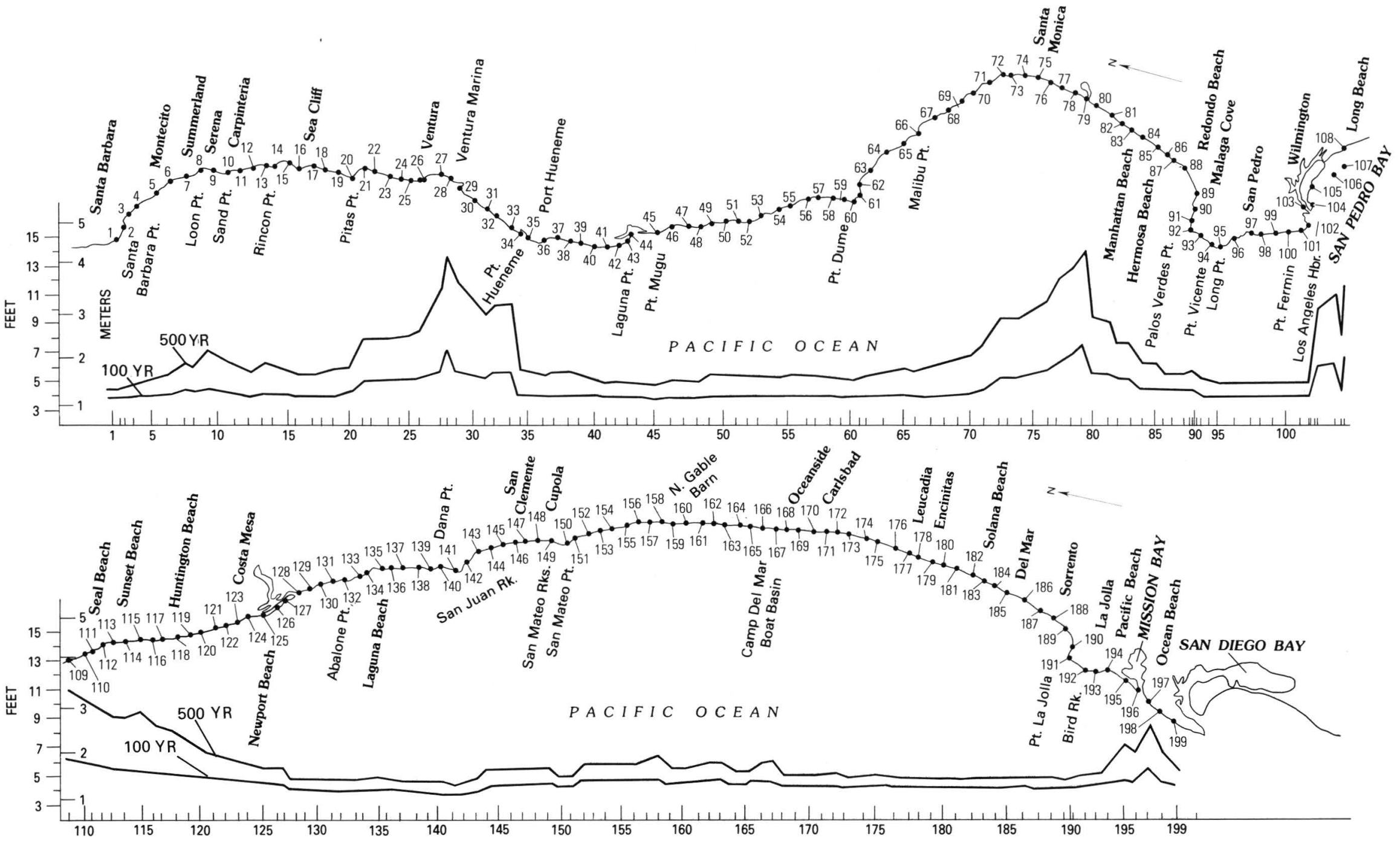

FIGURE 208.- Heights of the 100- and 500-yr tsunamis along the southern California coast (Santa Barbara to San Diego) as predicted by numerically modeled tsunamis. Modified from Houston (1980). Wave heights given for each numbered coastal location are the values predicted as the wave crosses the shoreline and include the effects of astronomical tides. Runup elevations may be higher where waves encounter steep topography at or near the shoreline or lower where waves flood low-lying or estuarine areas. 

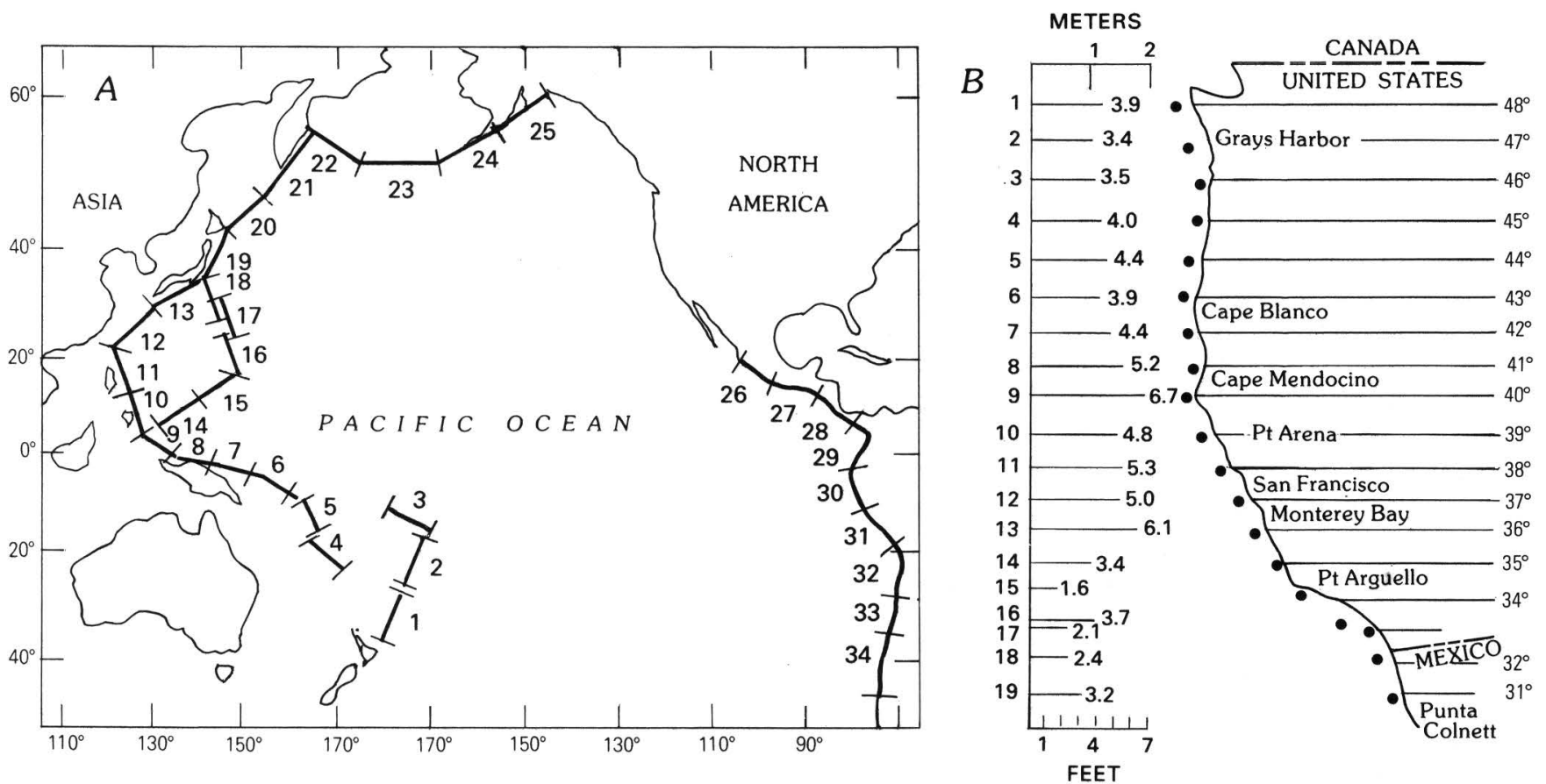

FIGURE 209.-A, Locations of mathematically simulated tsunamis at subduction margins around the Pacific Ocean. B, Maximum absolute wave displacement from still water at stations located at a water depth of $180 \mathrm{~m}$ along the California coast as calculated by simulated maximum credible tsunamis located at numbered sources shown in A (Brandsma and others, 1978).

coast of the United States were produced by tsunamis along the Aleutian Trench and the Alaskan coast (areas 24 and 25), which contain the Shumagin and Unalaska gaps. Of these two sources, Brandsma and others (1978, p. 145) said:

The waves generated at source 24 exceed those generated at source 25 at some locations in spite of the latter's closer proximity and better directional orientation to the west coast. This effect probably arises from the fact that more of the displacement of source 24 occurs in water than is the case for source 25; consequently, source 24 imparts a greater potential energy to the water.

Independent lines of evidence have convinced several workers that a great earthquake is imminent in the Shumagin gap, where stress appears to be accumulating. House and Boatwright (1980) interpreted two recent moderate-sized earthquakes $\left(M_{b} 5.8\right.$ and 6.0) accompanied by relatively high stress drop as indicating the release of locally high stress concentration associated with heavy stress loading in the gap. They see these events as precursors to a great earthquake. Hauksson (1983) has described recent moderate earthquakes in the gap as having a doughnut-shaped distribution, which Mogi (1969) demonstrated is a typical distribution preceding a large event within the doughnut. An unusual deep aseismic-slip event detected by a tiltmeter array occurred beneath the Shumagin Islands between 1978 and 1980 and is thought by Beavan and others (1983a, b) to have contributed to increased stress in the shallower locked main-thrust zone.

The historical record is also interpreted by some as indicating the imminence of a great earthquake in the Shumagin gap. Davies and others (1981) and Sykes and others (1981) concluded, from a review of about $200 \mathrm{yr}$ of historical documents, that at least half the Shumagin gap ruptured in major earthquakes in 1788 and 1847 and may have ruptured again between 1899 and 1903 . Average recurrence times for large events in the gap are therefore 50 to $75 \mathrm{yr}$, or, if it is assumed that no rupture occurred between 1899 and 1903, recurrence time is $91 \mathrm{yr}$. These investigators conclude that a great earthquake is likely within the next 10 to $20 \mathrm{yr}$ in the Shumagin gap. Recent calculations of the probability for large earthquakes $(M \geq 7.8)$ along the Aleutians Jacob, 1983) indicate that the Shumagin gap shows the highest probability (17-90 percent) of a great earthquake before 1993.

A comparison of seismic events in the Shumagin gap and tsunami history is informative. Iida and others (1967a) reported a 1788 Alaska-generated tsunami observed on the Alaska peninsula and in the Shumagin Islands. Their catalogue records no Alaska-generated 
tsunami in 1847 or between 1899 and 1903, when Davies and others (1981) and Sykes and others (1981) have suggested major ruptures in the Shumagin gap. Large earthquakes in the Shumagin gap should produce tsunami runup at San Francisco. Using the relations of earthquake magnitude to fault rupture area $\left(M_{w}=\log S+4\right)$ derived from Kanamori (1977) and that of far-field tsunami amplitude to earthquake magnitude (log $H=M_{w}-B$ ) from Abe (1979), Blackford (1981) estimated that a $M$ 8.8 earthquake could occur in the gap and that it should produce a wave with a crest-to-trough measure in excess of $0.64 \mathrm{~m}$ at San Francisco. The excess will depend on wave directivity. No tsunami between 1899 and 1903 has been identified on records of tide gauges installed in San Francisco and San Diego in 1854.

Opinions differ about possible recurrence intervals of great earthquakes at subduction margins. Plafker (1972, 1978) noted that the apparent contradictions between recurrence intervals on the order of $100 \mathrm{yr}$ indicated by seismologic data and intervals of 300 to $500 \mathrm{yr}$ as suggested both by dated uplifted marine terraces (each uplift representing movement along a megathrust associated with a major earthquake) and by the amount of time required for the small rates at which the lithospheric plates are converging across the eastern Aleutian and the southern Peru-Chile Trenches account for the large amounts of net slip that accompanied the large 1964 Alaskan and 1960 Chilean thrust-fault earthquakes. Sykes and others (1981) suggested that the apparent long repeat times may reflect movement of a secondary imbricate fault within the upper plate that does not move with every major slip event on the main plate boundary.

\section{TSUNAMI HAZARD REDUCTION}

\section{Tsunami Warning Systems}

Most hazards related to geologic events (for example, earthquake shaking, flooding, landslides, and tsunamis) can be greatly reduced in the long term by appropriate structural design and land use and in the short term by warning systems that allow sufficient time to avoid the hazard. The cost of inadequate tsunami warning systems has been high (Spaeth and Berkman, 1967, p. 5):

After the devastating Aleutian tsunami of April 1, 1946, military and civilian sources criticized the U.S. Coast and Geodetic Survey for the lack of warning in the Hawaiian Islands. The critics correctly pointed out that seismic waves from this earthquake were recorded at Honolulu and other observatories within minutes after the occurrence of the earthquake; and consequently, the tsunami could have been predicted. The error in this criticism lay in the fact that seismograph records were changed only once each day, and until the film records were developed, no knowledge of an earthquake occurrence was normally available. In addition, the great majority of underwater earthquakes does not cause tsunamis, and no arrangements were in effect to verify the existence of a tsunami through actual observations.

As Shepard and others (1950, p. 392) reported:

On the morning of April 1, 1946, the Hawaiian Islands experienced the most disastrous tsunami in their history. More than 150 persons were killed, principally by drowning, and 163 others were badly injured. Hundreds of houses and other small buildings were destroyed or badly damaged. Property damage probably amounted to $\$ 25,000,000$.

And again (Hellmuth and others, 1963, p. 1126-1127):

...9 hours after the [1960 Chilean] earthquake,...the following message was sent from Hawaii: This is a tidal wave alert bulletin. A violent earthquake in Chile has caused a tidal wave that is radiating in all directions over the Pacific Ocean. It is estimated that the first wave will reach the Island of Hawaii at midnight Hawaiian time and $\mathbf{3 0}$ minutes later at the Island of Oahu. Its destructive effects will last several hours. The intensity of the wave cannot be predicted. The southern part of Hawaii will be the first to be affected and will be the first indication of the damage that might be produced in other parts and other islands of the Hawaiian group. The times have been calculated for the arrival at other Pacific islands based on the best data obtainable; they are not very exact: Tahiti 0230 hours, Christmas Island 0400 hours, Samoa 0500 hours, Fiji and Canton 0600 hours, Johnston 0700 hours, and Midway 0830 hours.... At 0654 the first wave arrived at the Hawaiian Islands, producing great damage in Hilo; but the activity of the Magnetic Observatory at Honolulu did not cease. At 1211 on 23 May, the state of alarm on the Hawaiian Islands terminated, but the waves of the tsunami con- 
tinued their destructive voyage until they were stopped and then reflected by the coasts of Japan, Russia, New Zealand, Australia, etc.

Unfortunately, it was Saturday afternoon in Tokyo, and the Japanese Meteorological Agency, which is responsible for issuing tsunami warnings, had closed at noon; thus, no warning was issued in Japan (Yoshimasa Kobayashi, oral communication, 1983). Iida and others (1967a) reported the widespread destruction-199 people killed or missing, 4,875 structures wrecked or washed away, and 7,534 boats wrecked or lost.

Tsunami warnings for tsunamigenic earthquakes occurring along coastal British Columbia, Washington, Oregon, and California are issued from the Alaska Tsunami Warning Center (ATWC), operated by the National Weather Service, in Palmer, Alaska. The following procedure is used (T. Sokolowski, written communication, 1983):

The warning services are based on seismic data. Real-time seismic data, from more than 75 remote sites, are continually telemetered to the ATWC and used to locate earthquakes. An alarm system is attached to several site signals that are telemetered from California and Alaska. Since the Center must react to earthquakes 24 hours a day, personnel are required to live within a specified travel time from the Center. [The office is manned 5 days a week, 8 hours per day and, during nonoffice hours, personnel are made aware of large earthquakes by a radio-alarm system that is connected to the Center's seismic alarm system.]

The seismic data are processed interactively and automatically to determine earthquake locations $( \pm 50 \mathrm{~km})$, Richter magnitude $( \pm 0.3)$, and tsunami arrival time $( \pm 20 \mathrm{mins})$. Tide data are telemetered in real-time from 8 remote Alaskan sites to the Center, but from the continental U.S. west coast states, data are requested via teletypewriter and telephones.

The issuance of a tsunami WARNING is based upon the magnitude of the earthquake. A warned area includes those places that are within 3 hours of water wave travel time from the epicenter. The appropriate remaining areas, outside the warned area, are placed in a WATCH status.

If an earthquake occurs in the west coast areas, with a magnitude greater than 6.75 and less than 7.5, an earthquake information message would be disseminated to the ATWC's recipients. The tide site's data about the epicenter would be requested to ensure that a tsunami was not generated. If the magnitude is 7.5 or greater, a WARNING would be issued and the tide site's data obtained.

Upon confirmation from tide gage data that a tsunami has been generated, the previously designated WATCH status areas are upgraded to a WARNING status. If an area has received a WARNING and subsequent tide data shows no tsunami activity, the WARNING and WATCH are cancelled.

Once the decision has been made to issue a warning or a watch, the messages are transmitted on the National Warning System (NAWAS) telephone line. In California, the message goes to the Federal Emergency Management Agency (FEMA) and to the State of California Office of Emergency Planning, which is manned $24 \mathrm{hr}$ a day.

The watch or warning is immediately relayed by telephone to local coastal county offices, such as sheriffs' departments, that are also open $24 \mathrm{hr}$ a day. The message must be acknowledged by the recipient, who is immediately sent the same message by teletype. These telephone links are also checked three times a day.

Both Hawaii and Alaska have rapid-response regional-warning networks that issue tsunami warnings in those areas on the basis of earthquake magnitude alone. Washington, Oregon, and California have no similar regional warning system that can respond rapidly to a locally generated tsunami. A period of approximately $21 \mathrm{~min}(6 \mathrm{~min}$ for the arrival of the first seismic wave and $15 \mathrm{~min}$ for the arrival of the five to six large surface waves necessary for analysis) would be required before the decision could be made to issue a warning for a tsunami generated off southern California. Additional time would be required to relay the warning to local agencies and to translate the warning into action.

Although there is no historical record of a recent locally generated tsunami along the Washington, Oregon, and northern California coasts, there is both seismologic and geologic evidence that the subduction zone at which the Gorda and Juan de Fuca plates are converging at rates of about 3 to $4 \mathrm{~cm} / \mathrm{yr}$ with the North American plate (fig. 200) may be the site of a future great tsunamigenic earthquake. Heaton and Kanamori (1984, p. 939) describe the Juan de Fuca plate boundary as a ". . .500 km long seismic gap...[that]. . .represents one of the most remarkable to be found in the circumPacific seismic belt," and their comparison of the age, convergence rate, and seismicity of the Juan de Fuca plate with those of other actively subducting plates 
leads them to suggest the possibility of a future great earthquake at this subduction zone. Geologic evidence that this subduction zone should be considered tsunamigenic is presented by P. D. Snavely, Jr. (written communication, 1985):

Landward tilting in the Oregon and Washington Coast Range and the Olympic Peninsula has been documented using tide gauges and geodetic leveling of uplifted marine terraces. Landward tilt and crustal shortening shown by thrust faults and folds on the outer Oregon shelf and slope are characteristic of many other subduction zones that have experienced major thrust earthquakes. Interpretations of multichannel seismic-reflection profiles across the continental slope of California, Oregon, and Washington support episodic underthrusting of the Gorda and Juan de Fuca plates beneath the North American plate on a long time scale. This convergence has produced a series of elongate en echelon anticlinal ridges bounded by thrust faults. These ridges have bathymetric expression and uplift abyssal sediments as much as $1,100 \mathrm{~m}$. If one accepts the consensus of geologic data that faulting and folding along the lower slopes are the result of episodic events that uplifted abyssal sediments $400-1,000 \mathrm{~m}$ above their original depositional positions, these dramatic uplifts of elongated anticlinal ridges, tens of kilometers long, are capable of generating destructive tsunamis.

There is also the possibility that the northern offshore San Andreas fault might be capable of producing a tsunami. This fault is marked for much of its length by a scarp that offsets the modern sea floor (Curray and Nason, 1961; McCulloch and others, 1980; event 26, app. 4), and a conservative worst-case model should probably assume several meters of vertical displacement on the fault.

In tsunamigenic areas, where time is critical, the absence of a regional warning system automatically triggered by a large local earthquake can be costly. The May 26, 1983, Nihonkai-Chubu earthquake (M 7.7) occurred beneath the Sea of Japan about $140 \mathrm{~km}$ west of Honshu, $1 \mathrm{~min}$ or so after 12 noon Japan Times, 1983; Osamu, 1984; Bertera and others, 1985). At 12:12, the first wave of $29 \mathrm{~cm}$ was observed at Aomori. A tsunami warning for the Sea of Japan side of Honshu and central Tohoku was issued to the disaster prevention section of the Japanese Meteorological Agency at 12:18 (Hokubei Mainchi, 1983):

\section{Earthquake Hazards in the Los Angeles Region}

...After receiving the warning at 12:18 p.m., an official in charge ran up from his office on the second floor to the radio room on the seventh floor.

The official, according to the investigation, started to activate the warning system at 12:20 p.m....

The wireless tidal wave warning system is designed to simultaneously convey a warning to all the 69 villages and towns. The system, however, did not work due to the official's mistake....

In the procedure the official was supposed to depress three buttons to connect the system with the fire station headquarters, offices of cities, towns and villages, as well as welfare offices. The official pushed only the button for the fire station headquarters, failing to touch the remaining two....

According to McKean and Mohs (1983, p. 18, 21):

Akimasa Otomo, a Japanese man, saw it happen. Shortly after noon on May 26, while tying up at a dock 36 miles from Akita, a prefectural capital on the northwest coast of Honshu, he saw a group of schoolchildren swarm out of an excursion bus and run toward the beach for a seashore lunch. Suddenly the water beneath Otomo receded-and then began to rise. He recognized the ominous signs. "I knew this was a tsunami... and rushed to higher ground," he later recalled. When he looked back, "I saw all the children floating and their bodies being carried out to sea." As soon as the huge wave receded, he rushed back to his boat, cast off and was able to pick up ten of the children. Others saved themselves by grabbing onto rocks or clinging to pieces of shed that had been swept away with them. But 13 of the 43 young picnickers drowned.

Elsewhere, along the westeru coast of Honshu and the southwestern tip of Hokkaido, in an arc of destruction extending some 500 miles, 86 others perished in a series of great waves. The earthquake (measuring 7.7 on the Richter scale) that caused the waves claimed three more victims inland. Between the quake and the tsunami waves, which rose to 20 feet in places, 52 houses were washed away, 139 destroyed, and 491 others damaged. Farms were flooded, roads split open, railway tracks torn up, and 14 bridges swept away. Fishing vessels and other craft caught close to shore or 
in harbors were hard hit; at least 225 of them sank outright and 414 others were carried out to sea or dumped on docks or village streets.

Across the Sea of Japan, waves almost 30 feet high hit the Siberian coast and battered Korean fishing villages....

Even if it had been issued properly, the warning that should have been given at 12:20 would have come too late for the many people killed by this tsunami, for, by then, the tsunami was sweeping over the Oga Peninsula. Experience should have alerted the warning agency, for the 1983 tsunami was not a unique event for the west coast of Japan. The recent $M 7.51964$ Niigata earthquake, also beneath the Sea of Japan, generated a tsunami that had runup heights of as much as $5.8 \mathrm{~m}$ (Iida and othérs, 1967a) and killed five(?) people (Kobayashi, 1981). A regional warning system automatically triggered by the occurrence of these earthquakes might have reduced the death toll greatly.

The shortcomings of warning systems are well recognized and are of considerable concern to those involved in the study and prediction of tsunamis. The principal needs are:

- Techniques for rapid determination of earthquake source mechanisms (distinguishing nontsunamigenic strike slip from possibly tsunamigenic dip slip) for remote and local earthquakes.

- Techniques for more rapid collection and analysis of seismological and tidal data and distribution of warnings.

- Reasonable estimates of probable runup heights and areas of inundation in the path of the tsunami.

Although several techniques (Brune and others, 1960; Ben-Menahem, 1961) have been devised for determining the source mechanisms of remote earthquakes by examining low-amplitude long-period Rayleigh surface waves, analysis time for such techniques is long, or else records of Rayleigh waves are not routinely available because seismographs dedicated to determining the magnitudes of large seismic events are insensitive to such waves. Fumumoto (1969) noted that Rayleigh waves traversing the Earth's surface generate acoustic waves in the overlying air that propagate upward into the high atmosphere and produce detectable waves in the ionosphere. $\mathrm{He}$ suggested that observations of ionospheric waves might be used to indicate the source mechanisms of distant earthquakes. More recently, Ward (1979) has demonstrated that the ratio of "ringing waves" (long-period compressional $P$ waves that bounce between the top and the base of a water layer) to body waves can be related to focal depth, thrust or steep-dip focal mechanisms, and shallow structures-all parameters common to tsunamigenic earthquakes. He concluded that real-time observation of the ringing $P$ waves that accompany large earthquakes in tsunamigenic areas provides a diagnostic tool for helping to establish tsunami potential. Kanamori and Given (1982) devised a rapid method of using Rayleigh-wave spectra at a long distance from the earthquake to determine both seismic moment and source mechanism within $\mathbf{1 0} \mathrm{min}$ of receiving the seismograph data. Kanamori is presently investigating a method for near-field determination of seismic moment and source mechanisms using bodywave information. Thus, techniques for rapid determination of source mechanisms are available, and techniques for more rapid determination are being developed.

Designs and hardware for improved regional tsunami warning systems to deal with the remaining problems of rapid data acquisition, analysis, runup prediction, and warning issuance are presently available (Van Dorn, 1979a; Bernard and others, 1982). These systems receive seismograph and tide-gauge data automatically by satellite and transmit them to a computer for analysis. Given the proper store of historical data and modeling parameters, a computer could determine the existence of a tsunami and its likely travel path, wavearrival times, and estimated runup heights. The systems could automatically issue warnings to locations in jeopardy. Bernard and others (1982) estimate that the rapid-response and analytical network proposed for developing nations of the Pacific could reduce the time between the occurrence of an earthquake and the issuance of a tsunami warning from about $1 \mathrm{hr}$ to several minutes for areas now without regional warning systems. Thus, the analytical tools and hardware for rapid-response tsunami warning systems appear to have been developed. Now they await deployment.

\section{Inundation Maps and Land Use Planning}

In light of the tragic loss of life, the cost of property damage, and thè disruption of commerce and personal lives suffered as a result of the 1964 Alaskan tsunami along the west coast of the United States, one might expect communities that were seriously affected to have incorporated some level of protection for their citizens against the recurrence of such a tsunami. In fact, not all have done so. Although the city of Kodiak, on Kodiak Island, was heavily damaged in the 1964 tsunami, it has not incorporated consideration of the tsunami hazard into its land use planning process (Preuss, 1982). 
Considerable incentive to recognize the tsunami hazard is now provided by the National Flood Insurance Program, which makes available low-cost federally subsidized insurance that cannot be cancelled by the Federal Government. To qualify for program participation, a community must adopt special construction re quirements for buildings in areas that can be expected to be flooded in the 100-yr event (owing to storm or tsunami coastal flooding or river overflow). These building requirements must meet or exceed standards set by FEMA. The water elevations and the inundation limits for the 100-yr event are established by FEMA. For critical structures (such as nuclear reactors, hospitals, hazardous-waste storage areas, and record centers), FEMA specifies the higher water elevations and larger inundation areas of a 500-yr tsunami.

The inundation area for the 100-yr event is divided into two major zones of structural requirements-a $\mathrm{V}$ zone, in which the anticipated water depth is greater than $3 \mathrm{ft}$ and breaking waves are probable, and an $\mathrm{A}$ zone, in which the anticipated water depth is less than $3 \mathrm{ft}$ and there are no breaking waves. Each zone is further divided into 30 subdivisions for fixing appropriate insurance rates (Federal Emergency Management Agency, 1982). Construction requirements within the $\mathrm{V}$ zone include fixing the minimum height of building floors above sea level (sea level is referred to the $1929 \mathrm{Na}$ tional Geodetic Vertical Datum), using pile foundations to anchor structures that otherwise might float free and be damaged by or damage other structures, prohibiting use of erodable fill for structural support, and prohibiting structures seaward of the mean-lower-lowwater shoreline.

Inundation maps have been made for coastal California counties (Flood Insurance Rate Maps, available through FEMA, Flood Map Distribution Center, 6930 San Tomas Rd., Baltimore, MD 21227-6227). These maps are updated as experience dictates or as new data become available. Participating communities are given a grace period to adjust their building ordinances to the revised inundation maps. If they do not, they lose their option to obtain flood insurance through participation in the National Flood Insurance Program, access to Federal Housing Administration and Veterans Administration loans, and possibly the right to qualify for Federal Disaster Relief in identified flood-hazard areas. If an applicant for or holder of a Small Business Administration loan were to lose Federal insurance, he would have to seek more costly, nonsubsidized cancelable insurance from the private sector. The National Flood Insurance Program exerts influence on the developer who does not wish to conform to FEMA standards, because an entire community can be denied Federal insurance if it grants a single variance adjudged by FEMA not to meet its standards. In southern California, the cities of San Diego and Morro Bay and the counties of Orange, Los Angeles, Ventura, and Santa Barbara either have or will soon adopt building requirements that qualify them for Federal flood insurance (R. T. Lenaburg, oral communication, 1983).

The most recent FEMA study of flood hazard to selected areas of southern California, from Morro Bay to the Mexican border (Lee and others, 1982), evaluated the following flood-generating mechanisms:

- Runup of swell generated by intense offshore winter storms in the north Pacific.

- Runup of wind waves generated by landfalling storm systems.

- Runup of swell generated by tropical cyclones of Baja California.

- Runup and surge from landfalling tropical cyclones.

- Runup from tsunamis generated along the AleutianAlaskan and Peru-Chile Trenches. The 100- and 500-yr tsunami heights developed by Houston (1980) were used (see fig. 208).

As Lee and others $(1982$, p. 1) noted:

\begin{abstract}
Each of the above mechanisms is considered to act alone. That is, the joint occurrence of any combination of the above mechanisms to produce a flooding event is considered to be irrelevant to the determination of flood elevations with return periods of less than 500 years. The influence of the astronomical tides on coastal flooding is also an important factor in each of the above mechanisms. Each flood producing event from any of the above mechanisms can occur with a random phase of the astronomical tide.
\end{abstract}

With the exception of damage in Crescent City, where the business district was severely affected by the 1964 tsunami, most tsunami damage to California has been sustained by marine-oriented structures. Rail, ship, and highway freight often meet at dockside, where materials either are stored in bulk for local redistribution or await transport elsewhere. Tsunami inundation should be an important consideration when designating facilities for both long- and short-term storage of hazardous materials. Experience at Niigata and in Alaska (Whittier, Seward, and Valdez) has shown that petroleum storage facilities near dockside may rupture, and burning oil may be carried ashore on the tsunami waves. Direct wave damage to a storage facility is not always the problem, however. At Crescent City, a wave slammed a gasoline truck through a garage door. The impact

\section{Earthquake Hazards in the Los Angeles Region}


dislodged an electrical junction box and ignited an oil tank farm, which burned for three days (Spaeth and Berkman, 1967). Accordingly, caution suggests that events external to the design of facilities for storing hazardous materials in or adjacent to a probable inundation area should be considered in assessing the integrity of such facilities.

\section{Public Awareness}

Reduction in tsunami hazard can also be attained through public awareness, both in long-term and immediate response. $\mathrm{A}^{\prime}$ well-informed populace can respond on short notice and without panic to warnings of imminent danger if it knows what to do, as the people of London did during the nightly bombing raids on their city in World War II. When danger occurs only rarely and false alarms are raised, fewer people will respond. Tsunami predictions involving the fewest possible false alarms are highly desirable; however, when a population is transient, both education and an understanding of the hazard become a problem. Furthermore, if the recurrence interval of large tsunamis like the 1964 Alaska tsunami is $\mathbf{1 0 0} \mathrm{yr}$ or longer, it will be difficult to sustain concern for the hazard. Prominent markers could be erected throughout areas inundated by historical tsunamis to show the highest recorded water height-a passive daily reminder of what did happen and could happen again. Such markers might encourage recognition of tsunami hazards for both long- and shortterm land use.

Experience suggests that, in regions where tsunamis are frequent, routine public education and practice drills are helpful. At Sanriku, on the eastern shore of Japan's Honshu Island, where the Great 1896 Meiji Sanriku tsunami killed 27,000 people and the 1933 tsunami killed 3,022 people, the public has been trained to literally run for the hills if they feel an earthquake, and escape routes have been widened to accommodate the rush (Yoshimasa-Kobayashi, oral communication, 1983). In contrast, no such routine training is given on the western shore of Honshu Island. Had the west coast residents sought inland refuge, the 1964 Niigata and 1983 Nihonkai-Chubu tsunamis would have caused many fewer deaths.

Even where tsunamis are rare, as they are in the Los Angeles region, certain individual actions could save lives:

- If you are on low ground near the coast and a large earthquake occurs in your area, move to high ground. There may be no time to either issue or receive an official warning.
- If you recognize a premonitory drawdown of the sea, move to high ground.

- The first tsunami wave may not be the highest. In major tsunamis, later waves commonly have the highest runup heights.

- Periods between successive major waves may be similar. Thus, you may have time between waves to move to higher ground or to assist in rescue efforts.

- Do not assume that, because the incoming tsunami wave is not breaking or because it is just coming in like a rapidly rising tide, it will not be destructive. The forces contained in this high-velocity, often debris-laden torrent are extremely destructive during runup and runoff.

- Do not assume that areas behind beaches generally shielded from storm waves will be immune from high runup. Tsunami runup heights have historically been higher in some such areas along the California coast.

- Do not go to the beach to watch a tsunami coming in. Not only might you hamper rescue efforts, but you may also have made your last sightseeing trip.

\section{SUMMARY}

Tsunamis are impulsively generated water waves that, throughout recorded history, have claimed hundreds of thousands of lives and wreaked havoc on coastal towns and cities. Most are caused when hundreds to more than a thousand square kilometers of the submerged continental shelf or slope are rapidly displaced several meters vertically during a large earthquake. Damage may be confined to the nearby coast, but waves may cross oceans and devastate distant shorelines. Local highly destructive tsunami waves are also generated when earthquake-triggered rock falls and avalanches or landslides fall or slide into water bodies or, in rare cases, when volcanic islands explode.

The size of tsunamis caused by seismotectonic seafloor displacement can be related to the energy released by the earthquake, to the hypocentral depth and the water depth at the epicenter, and to the area and vertical displacement of the affected sea floor. The size of tsunamis generated by rock falls or slides can be estimated by theoretical, laboratory, and empirical models.

Tsunamis are long wave trains. While they cross deep oceans, wave heights are about $1 \mathrm{~m}$, but wavelengths may exceed $100 \mathrm{~km}$, and waves may travel hundreds of kilometers per hour. Even at oceanic depths, tsunami waves interact with the sea floor. This interaction partially determines the travel direction of the wave. As tsunamis encounter shoaling coastal water, increasing interaction with the sea floor shortens the wavelengths, and the waves become steeper, sometimes reaching 
heights of several tens of meters. Many tsunamis come ashore as rapid successive rises of sea level. Less commonly, they come roaring ashore with a steep, breaking frontal wave. Both forms can cause extreme damage. Buildings torn from foundations, uprooted trees, cars, and even whole lines of railway cars may arm successive waves with tremendous destructive force.

Historically, California has suffered little tsunami damage. The only tsunami to cause extensive damage during the period from 1812 to 1964 was generated by the 1964 Gulf of Alaska earthquake. The cost of damage from this tsunami, adjusted to 1983 dollars, was about $\$ 32.2$ million, or about 0.2 percent of the dollar loss from California earthquakes during the same time period. Damage from the 1964 tsunami was most severe at Crescent City, where waves as high as $7 \mathrm{~m}$ overwhelmed 30 blocks of the city. Damage was less severe to the south but extended to Los Angeles. The wide, physiographically complex offshore borderland may decrease tsunami effects in southern California.

Both distant and locally generated tsunamis present a long-term hazard to southern California, but the risk is much lower than that from the more common, geologically controlled earthquake hazards. Distantly generated tsunamis of concern are those that may be produced along Pacific subduction margins. Large earthquakes in the Chile, Kamchatka, and Aleutian Trenches and the Gulf of Alaska have produced tsunamis recorded along the entire west coast of the United States. Mathematical simulation of tsunamis generated along the Pacific subduction margins suggests that California is most sensitive to tsunamis originating in the eastern Aleutian Trench and the Gulf of Alaska. Locally generated tsunamis also occur along California. The best documented affected the northern shoreline of the Santa Barbara Channel (1812) and the shoreline near Point Arguello (1927). Both were related to large earthquakes, and the tsunami from the Port Arguello event was recorded from San Francisco in central California to La Jolla near the Mexican border and was observed in the Hawaiian Islands. Seismically active faults that reach the sea floor may be capable of producing future tsunamis in these areas, and similar faults may produce tsunamis off the Los Angeles area. Movement of earthquake-triggered submarine slides of the dimensions of existing slides found off the Los Angeles area does not appear to present a serious tsunami hazard.

Despite the fact that there have been locally generated tsunamis along the California coast, predictions of tsunami size and frequency consider only those tsunamis that are distantly generated. The three predictive methods used are based on (1) an analysis of the California tsunami record, (2) a combination of mathe- matically simulated tsunamis and analysis of the longer term Pacific tsunami record, and (3) an identification of seismic gaps around the Pacific margin, where large tsunamigenic earthquakes can be expected, and an assessment of when such an earthquake might occur. The first method suggests that large tsunamis along the California coast have a recurrence interval of about 100 yr. The second predicts the heights of the 100- and 500-yr tsunamis along the coast. The third has identified a seismic gap along the Aleutian Trench (Shumagin gap), where geologic evidence suggests that a large tsunamigenic earthquake may soon occur.

The tsunami hazard in the Los Angeles region is much less than that in many other places along the circumPacific border. Predictive models for distantly generated tsunamis indicate that wave heights of $2 \mathrm{~m}$ are exceeded on the average of once every $500 \mathrm{yr}$, except locally along Santa Monica Bay and San Pedro Bay and near Ventura, where wave heights of $3 \mathrm{~m}$ are exceeded on the average of once every 500 yr. A preliminary appraisal of the potential for locally generated tsunamis suggests that wave runup heights as great as 4 to $6 \mathrm{~m}$ could be caused by sea-floor faulting in the Santa Barbara Channel; wave runup heights no greater than 2 to $3 \mathrm{~m}$ are estimated for the dominantly strike-slip faults farther south. Earthquake-triggered sea-floor slides having the dimensions observed in the offshore region are unlikely to cause tsunamis.

Warnings for distantly generated tsunamis are issued to California, Oregon, and Washington by the Alaska Tsunami Warning Center. No provision exists, however, for timely warning of tsunamis generated locally along the northern California, Oregon, or Washington coasts, where a large local tsunami generated by subductionrelated faulting is a possibility. Although tsunami warnings have been limited to the estimated time of firstwave arrival, studies indicate that it is now feasible to include expectable wave heights and inundation areas. Such inclusions will greatly reduce the tsunami hazard.

Reduction of the tsunami hazard is one of the aims of the Federal Flood Insurance Program, which makes lowcost insurance available to coastal communities that follow restrictive building standards set by the Federal Government for areas subject to tsunamis or stormwave flooding. The predicted 100-yr tsunami is used as a basis for noncritical structures such as dwellings and businesses, and the 500-yr tsunami is used as a basis for critical structures such as nuclear reactors, schools, and hospitals. Most southern California coastal communities have adopted building codes that meet or exceed requirements for participation in this program. Finally, public awareness of tsunami behavior can help the individual greatly reduce his personal risk. 


\section{APPENDIX 4.-CALIFORNIA TSUNAMIS FROM 1812 TO 1975}

The information presented in this appendix has been compiled from a number of sources. Most entries are direct quotations taken from those sources. Many of the reference works cited in this quoted material have not been consulted directly by the author and thus do not appear in the list of references for this chapter. The sources used are designated by the following letter symbols: I, catalog of Pacific tsunamis (Iida and others, 1967); A, tsunamis recorded at San Diego (Agnew, 1979); W, tsunamis recorded at San Francisco (Wiegel, 1970); M, wave heights (Magoon, 1965); MA, Marine Advisors (1965). Because reported tsunami wave measurements are not uniform, the following terms are used to indicate the size of tsunami waves. Range or maximum rise or fall is the maximum peakto-trough value recorded on a tide gauge and can be significantly smaller than runup height. Height is the maximum departure from mean sea level as determined from the tide-gauge record or runup height. Amplitude is used where the definition of wave height is unclear. Wave arrival dates are given in local time. Earthquake magnitudes are as given by Iida and others (1967) or as recalculated by Abe (1979).

\section{Event Year $\quad$ Remarks}

1812

Month unknown. Earthquakes possibly near San Francisco. Report based on second-hand communication that " $\ldots$ in 1812 the earthquakes were so severe as to cause tidal waves which covered the ground where the plaza now is." Iida and others (1967a) suggested possibly mislocated report of December 21 waves at Santa Barbara, but Wood (1916) cited these waves as evidence for displacement on a fault across San Francisco Bay rather than a more seaward fault.

December 21. This tsunami has received considerable attention because it was locally generated by an earthquake of estimated $M 7$ to 7.5 within or near the Santa Barbara Channel and because the reported waves were so large. There is, however, reason to suspect that the waves were not as large as reported. According to Houston (1980, p. 5-6), "...Wood and others (1966) reported that run-up heights of a tsunami generated by the 1812 Santa Barbara earthquake reached $50 \mathrm{ft}$ at Gaviota, $30-35 \mathrm{ft}$ at Santa Barbara, and $15 \mathrm{ft}$ or more at Ventura in southern California. Berkeley (cited by Wood and others (1966) as a basis for their reported run-up heights) has shown that the run-up for this possible tsunami was not nearly as large as reported. Professor G. D. Louderback (unpublished data) used an old report that said that the sea flowed $1 / 2$-mile inland and plotted the information on a present day topographic map in the vicinity of Gaviota Canyon. This yielded a 50-ft run-up level for the sea water. However, the study by Marine Advisors, Inc. (1965), discovered that the old report may have referred to an estuary (El Estero) near Santa Barbara that is approximately at sea level. In addition, they learned that there were no reported drownings even though Indian villages were on the beach at the time and many people were there. (The mission padres kept meticulous records of Indian births, deaths, and other statistics). Other evidence indicates that there may have been a run-up as great as 10 to $12 \mathrm{ft}$ at Gaviota and a smaller run-up at Santa Barbara (Marine Advisors, Inc., 1965)."

January 16-18. Earthquake and tsunami near Santa Cruz (I). Marine Advisors (1965) indicated report of tsunami is erroneous.

November 13. Earthquake at San Francisco Bay. Motion of the waters of the bay. Perhaps a seiche, not a tsunami (I).

July 24. No source is known, but the tidal observer at San Diego (Cassidy, 1862) noted that, on this date, "Water rose and fell nearly a foot in 10 minutes-currents set up also; harbor calm." (A)

1854 October 26. Earthquake at San Francisco and Benicia. Sea wave following shock or shocks. Observed at San Francisco(?) and Benicia(?) (I). "from calm sea with no wind; water rose several feet with high waves, lasting half hour." Perhaps a distant tsunami (1).

\section{December 23. Japan, $34^{\circ}$ N., $138^{\circ}$ E.; $\mathrm{M}_{\mathrm{S}}$ 8.4. Range $0.1 \mathrm{~m}$ at San Diego (A) and $0.2 \mathrm{~m}$ at San} Francisco (I). 
December 24. Japan, 33.2 ${ }^{\circ}$ N., 135.6 ${ }^{\circ}$ E.; $M_{S}$ 8.4. Great Ansei Nankaido tsunami. Considerable damage and many deaths in Japanese islands. Height $0.3 \mathrm{~m}$ at San Francisco and 0.3 at San Diego (I). unusually heavy sea waves after last of four shocks (I). Yerkes (this volume) located this earthquake onshore, along the Raymond fault. August 23. Japan, $42^{\circ}$ N., $141^{\circ}$ E.; $M$ 6.9. R
and loss of life in Hokkaido and Sanriku (I).

September 24. Earthquake location not firmly known. Tsunami location has been reported as San Francisco, but observation may be of the October 5 Chilean tsunami; water "receded 15 feet and returned suddenly" or "left the bay for several seconds." Reports seem greatly exaggerated if at San Francisco. Maximum runup heights of $4.6 \mathrm{~m}$ at Half Moon Bay (I).

May 27. Earthquake at San Diego caused a small tsunami in San Diego Bay. This event is the only locally generated tsunami that has affected San Diego. It was associated with an earthquake that caused the most intense shaking known in San Diego. The tide gauge was being repaired at the time, so there is no quantitative record of the event, but an eyewitness account by tidal observer Andrew Cassidy has been preserved. At the time of the earthquake, Cassidy was on the beach. He wrote that, "The water in the Bay did not appear to be much agitated notwithstanding the sea run-up on the beach between 3 and 4 feet, and immediately returned to its usual level." The value of 3 to $4 \mathrm{ft}$ probably refers to the horizontal distance along the beach; the wave height would have been much less. It is possible that one of the earthfalls noted by Cassidy along the bank might have generated the wave (A).

April 2. Hawaii, $19.3^{\circ}$ N., $155.3^{\circ}$ W. (Wood, 1914). Height $0.1 \mathrm{~m}$ at San Diego (A). Range $0.15 \mathrm{~m}$ at San Francisco (W).

August 13. Chile, $18.5^{\circ} \mathrm{S} ., 71^{\circ} \mathrm{W}$. Amplitude $0.8 \mathrm{~m}$ at San Diego (A).

August 14. Near Arica, northern Chile. $\mathrm{M}_{\mathrm{S}}$ 8.5. Height $0.3 \mathrm{~m}$ at San Diego. Montessus de Ballore (1907) referred to a report by Schmick (1879) of a 21-m runup at San Pedro. Gutenberg and Richter (1954) gave the reported height as $18 \mathrm{~m}$ but indicated that it was most probably a mistake. Known as the Great Peru earthquake and tsunami, reported to have caused 25,000 deaths (I). Range $0.43 \mathrm{~m}$ at San Francisco (W).

August 23. On this date, a tsunami was recorded at San Diego, San Francisco, and Astoria. Relative arrival times infer a source in the northwestern Pacific (A).

May 9. Chile, $21.5^{\circ} \mathrm{S}$., $71^{\circ}$ W.; $\mathrm{M}_{\mathrm{S}} 8$ to 8.5 . Height $0.3 \mathrm{~m}$ at San Francisco. Great Chilean tsunami caused considerable damage to Chile, Peru, and Japan (I). Range $0.37 \mathrm{~m}$ at San Fran$\operatorname{cisco}(W)$.

August 10. San Fernando earthquake. Tsunami reported to have affected Santa Monica, but no details available (I).

August 27. Explosion of Krakatoa Island in the Sunda Strait. Waves caused widespread damage and loss of life in Indonesia. Waves felt in Japan, Australia, New Zealand, Hawaiian Islands, Alaska, and California (I). Range $0.1 \mathrm{~m}$ at San Francisco (W).

November 19. Epicenter unknown. In San Francisco, a series of waves occurred (I).

June 15. Sanriku, Japan, 39.6 ${ }^{\circ}$ N., $144.2^{\circ}$ E.; $M_{S}$ 7.6. Great Meiji Sanriku tsunami. Disastrous; caused 27,122 deaths and 9,247 injuries. 10,617 houses swept away, 2,456 damaged (I). Range $0.15 \mathrm{~m}$ at San Francisco (W).

December 17. In a catalogue of earthquakes on the Pacific coast, Holden (1898, p. L52-L53) cited the following description of high water at Santa Barbara: "A tidal wave, the largest in the history of Santa Barbara, washed over the boulevard at 8 o'clock this morning, carrying back with it a large section of that beautiful and expansive driveway. The boulevard was built some five years ago and bulkheaded so securely that it was thought to be impervious to the action of the waves but the bounding billows carried off a portion of asphaltum and solid masonry, heavy framework and iron in its receeding grasp nearly fifty feet square and eight feet deep. A large sand hill between the boulevard and ordinary high tide was carried com- 
pletely out to sea." Although Holden presented this description with no comment, its inclusion in his catalogue indicates that he attributed it to an earthquake-generated tsunami or to a tsunami of unknown cause. Neither Holden's (1898) or Townley and Allen's (1939) catalogue of California earthquakes notes the occurrence of a local earthquake on this date. More recently, this same high-water event was noted by lida and others (1967a), who reported it as an isolated tsunami not related to a distantly generated tsunami. An account of this same event in the December 17, 1896, edition of the Daily Independent (now the Santa Barbara News Press) indicated that the erosion was caused by an abnormally high tide: "The flood tide this morning was one of the highest ever known in this city, and the boulevard suffered considerable damage. Between seven and eight o'clock the water was at the highest point and the waves washed over the one hundred foot driveway, carrying seaweed to the farthest side and filling the car track with sand. At the Chapala Street crossing on the boulevard, the tide had unrestricted entry to the driveway. A hole about eight feet deep and extending across the base of the sulfur water fountain necessitated immediate repairs to prevent further damage, and a force of men filled the break with bags of sand as a temporary measure. The tide has not been so high for years; even the big washout last spring not being so extensive, the water then coming in under a heavy southeast wind. This time there was no wind for a week. The grassy sand hill between Chapala and State Street on the beach has been washed out, exposing the boulevard front nearly the entire distance. The tide will be unusually high for the rest of the week."

February 2 or 26. El Salvador. Much damage to coast of El Salvador and Guatemala; 185 deaths. Observed in San Diego, but no details available (I).

April 18. San Francisco on San Andreas fault. $M_{S}$ 8.25. Sea dropped $0.1 \mathrm{~m}$ at Fort Point (southern end of Golden Gate Bridge) and returned to normal. Started a series of waves having an amplitude of $5 \mathrm{~cm}$ (I). The Fort Point tide-gauge record was shown by Lawson and others (1908, p. 370), who ascribed the initial lowering (without an immediate rise) to a possible minor downward displacement of the sea floor west of the San Andreas fault on the floor of the Gulf of the Farallones and the delayed succeeding two or three waves (40- to 45-min periods and 1-to 2-in amplitude) to east-west oscillations of San Francisco Bay. It is conceivable that the initial negative wave was caused by the lowering of a geologically young fault-bounded graben ( 2 to $3 \mathrm{~km}$ wide and $22 \mathrm{~km}$ long) that Cooper (1971) mapped along the western side of the San Andreas fault in the Gulf of the Farallones. Undoubtedly, there was movement on the San Andreas fault along the eastern boundary of the graben in 1906, but it is not known if it was acompanied by downward displacement of the graben.

Lawson and others (1908, p. 371) cited evidence for high water that may have been caused by a local tsunami: "The only other report indicating that the level of the ocean was affected along the coast is by W. W. Fairbanks, of Point Arena, who says: 'I have endeavored to learn of any unusual action of water along the sea-coast, and can relate but one instance of anything approaching the character of a tidal wave. On the day of the shock I traveled by wheel and on foot from Albion to Point Arena, 25 miles. At the mouth of Navarro River, at 8 o'clock on the morning of the 18th, I learned from reliable sources that a section of about 10 acres of low, flat land about the mouth of this river was entirely submerged for some minutes immediately after the shock."' The San Andreas fault passes out to sea at Point Arena and parallels the coast for about $115 \mathrm{~km}$ until it comes ashore near Shelter Cove. For most of its offshore length, it is marked by a geologically young sea-floor offset (Curray and Nason, 1961; McCulloch and others, 1980). The sea-floor scarp faces west (maximum vertical offset $27 \mathrm{~m}$ ) to near Noyo Submarine Canyon (latitude $39^{\circ} 33^{\prime} \mathrm{N}$.) and then faces east (maximum vertical offset $9 \mathrm{~m}$ ) until it passes into the shallow Tolo Bank area off Shelter Cove. Although there was no welldocumented tsunami along the coast from the 1906 earthquake and no account of a distantly recorded tsunami, a cautiously conservative worst-case model should probably assume the

Tsunami Potential 411 
possibility of several meters of sea-floor displacement along the northern California offshore San Andreas fault.

August 17. Coastal Chile, $33^{\circ} \mathrm{S}$., $72^{\circ} \mathrm{W}$.; $\boldsymbol{M}$ 8.2. The Great Valparaiso earthquake. 0.7 to $0.8 \mathrm{~m}$ of uplift intermittent along $350 \mathrm{~km}$ of coast. Height $0.1 \mathrm{~m}$ at San Diego; observed at San Francisco (I). A second great earthquake $\left(\mathrm{M}_{\mathrm{S}}\right.$ 8.2) occurred on this date, $30 \mathrm{~min}$ earlier, in the Aleutians.

May 2. Kermadec Islands, $29^{\circ}$ S., $177^{\circ} \mathrm{W}$.; $\mathrm{M}_{\mathrm{S}}$ 8. Recorded on the west coast of the United States (A).

1923 April 14. East coast of Kamchatka, 56.5 ${ }^{\circ}$ N., $162.5^{\circ}$ E.; M 7.2 (Gutenberg and Richter, 1954). Height $0.1 \mathrm{~m}$ at San Diego (A) and $0.2 \mathrm{~m}$ at San Francisco (I).

1925 October 4. Epicenter and magnitude unknown. $0.34 \mathrm{~m}$ at Long Beach. Source unknown. Possibly of meteorological origin. Only tide-gauge records for this event exist (I).

1927 November 4. Off Point Arguello, Calif.; $\mathrm{M}_{\mathrm{S}} 7.3$ (Gawthrop, 1978a). Townley and Allen (1939, p. 251) reported "a small sea wave recorded on tide gages at San Diego and San Francisco, and observed at Surf and Port San Luis. At Surf the rise in water was $6 \mathrm{ft}(1.8 \mathrm{~m})$; at Port San Luis it was $5 \mathrm{ft}(1.5 \mathrm{~m})$." Range $0.006 \mathrm{~m}$ at La Jolla (Byerly, 1930). Wave recorded in Hawaiian Islands (I). Well-documented, locally generated tsunami; probably generated by dip-slip fault displacement of sea floor. See discussion in text.

1928 June 16. Offshore southern Mexico, $16.25^{\circ} \mathrm{N}$., $98^{\circ} \mathrm{W}$.; $\mathrm{M}$ 8. Height $0.1 \mathrm{~m}$ at La Jolla and $<0.1 \mathrm{~m}$ at San Francisco (I).

1930 August 31. Santa Monica Bay, 33.9 N., 118.6 W.; M 5.25. Amplitude 0.6 m at Santa Monica. Possibly landslide-triggered seiche (MA). October 4. Solomon Islands, $10.5^{\circ} \mathrm{S} ., 161.75^{\circ} \mathrm{E}$.; $\mathrm{M}_{\mathrm{S}}$ 7.9. Recorded at Santa Barbara (I).

1933 March 2. East of Honshu, 39.2 ${ }^{\circ}$ N., 144.5 ${ }^{\circ}$ E.; M 8.4. Great Sanriku tsunami. Height $0.2 \mathrm{~m}$ at San Francisco, $0.1 \mathrm{~m}$ at Santa Monica, $0.2 \mathrm{~m}$ at Los Angeles, and $<0.1 \mathrm{~m}$ at La Jolla (A, I).

1933 March 10. Long Beach, 33.6 ${ }^{\circ}$ N., 118.0 ${ }^{\circ}$ W.; $M$ 6.25. Height $0.1 \mathrm{~m}$ at Long Beach. Uncertain records (I).

1938 May 19. Strait of Macassar, $1^{\circ}$ S., $120^{\circ}$ E.; M 7.6. Height $<0.1 \mathrm{~m}$ at Santa Monica (I).

1938 November 10. Shumagin Island, Alaskan Peninsula, 55.5 N., $158^{\circ}$ W.; M 8.2. Observed in Santa Monica (I).

1944 December 7. Near Honshu, 33.7 N., $136^{\circ}$ E.; $M$ 8.1. Height $0.1 \mathrm{~m}$ at San Diego (A) and $0.1 \mathrm{~m}$ at Terminal Island (I).

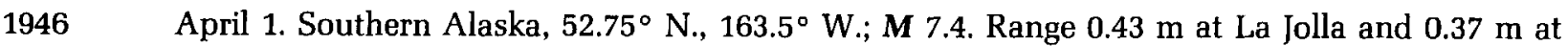
San Diego (A). Heights of $0.9 \mathrm{~m}$ at Crescent City, $0.3 \mathrm{~m}$ at San Francisco, $3.5 \mathrm{~m}$ at Half Moon Bay, $0.3 \mathrm{~m}$ at Alameda, $0.1 \mathrm{~m}$ at San Mateo, $3.5 \mathrm{~m}$ at Santa Cruz, $1.2 \mathrm{~m}$ at Avila, $0.7 \mathrm{~m}$ at San Luis Obispo, $0.8 \mathrm{~m}$ at Port Hueneme, $0.4 \mathrm{~m}$ at Los Angeles, $0.3 \mathrm{~m}$ at La Jolla, and $0.2 \mathrm{~m}$ at San Diego (I). In light of the small heights reported for most stations, the 3.5-m values at Santa Cruz and Half Moon Bay are surprising; however, the Santa Cruz Sentinel reported that a 15-ft wave occurred at Half Moon Bay and that a man was killed when he was washed out to sea from Cowles Beach at Santa Cruz.

December 21. Nankaido, Japan, $33^{\circ}$ N., $135.6^{\circ}$ E.; $M$ 8.1. Height $0.3 \mathrm{~m}$ at Crescent City and 0.1 $\mathrm{m}$ at San Francisco (I).

March 4. Hokkaido, Japan, $42.5^{\circ}$ N., $143^{\circ}$ E.; $M$ 8.1. Range $0.02 \mathrm{~m}$ at La Jolla (A). Height $0.2 \mathrm{~m}$ at Crescent City, $0.6 \mathrm{~m}$ at San Francisco, and $0.8 \mathrm{~m}$ at Los Angeles (I).

\section{Earthquake Hazards in the Los Angeles Region}


November 5. Off east coast of Kamchatka, $52.7^{\circ}$ N., $159.5^{\circ}$ E.; M 9.0. Range $0.24 \mathrm{~m}$ at La Jolla and $0.7 \mathrm{~m}$ at San Diego (A). Height $1.1 \mathrm{~m}$ at Crescent City, $0.6 \mathrm{~m}$ at San Francisco, $1.0 \mathrm{~m}$ at Avila, $0.7 \mathrm{~m}$ at Port Hueneme, $0.7 \mathrm{~m}$ at Los Angeles, and $0.4 \mathrm{~m}$ at San Diego (I). March 30. Kamchatka, $55^{\circ}$ N., $160.9^{\circ}$ E. Height $0.1 \mathrm{~m}$ at Avila (I). Diego (A). Height $0.7 \mathrm{~m}$ at Crescent City, $1.7 \mathrm{~m}$ at Bodega Harbor, $0.2 \mathrm{~m}$ at San Francisco, $0.6 \mathrm{~m}$ at Avila, $0.3 \mathrm{~m}$ at Los Angeles, $0.5 \mathrm{~m}$ at Anaheim Bay, $0.3 \mathrm{~m}$ at La Jolla, and $0.2 \mathrm{~m}$ at San Diego (I).

November 7. South Kurile Islands,
Range $0.9 \mathrm{~m}$ at San Francisco (W).

May 22. Coast of central Chile, $39.5^{\circ}$ S., $74.5^{\circ}$ W.; M 9.5. Range $2.7+m$ at Santa Monica and $1.52 \mathrm{~m}$ at Los Angeles (S); $1 \mathrm{~m}$ at La Jolla and $1.5 \mathrm{~m}$ at San Diego (A). Height $3.7 \mathrm{~m}$ at Crescent City, $0.5 \mathrm{~m}$ at San Francisco, $1.5 \mathrm{~m}$ at Port Hueneme, and $0.7 \mathrm{~m}$ at San Diego (I).

October 12. South Kurile Islands, $44.8^{\circ} \mathrm{N}$., $149.5^{\circ} \mathrm{E}$.; $M$ 8.5. Height $0.5 \mathrm{~m}$ at Crescent City (I).

March 27. Southern Alaska, $61^{\circ}$ N., $147.8^{\circ}$ W.; $M$ 9.2. Range $0.7 \mathrm{~m}$ at La Jolla and $1.1 \mathrm{~m}$ at San Diego (A). Height $6.3 \mathrm{~m}$ at Crescent City, $1.3 \mathrm{~m}$ at San Francisco, $0.6 \mathrm{~m}$ at Los Angeles, and 0.6 $\mathrm{m}$ at La Jolla (I). Crest to trough of largest recorded wave $2.3 \mathrm{~m}$ at San Francisco, $1.65 \mathrm{~m}$ at Alameda, $3.17+\mathrm{m}$ at Avila, $1.80+\mathrm{m}$ at Rincon Island, $2.0 \mathrm{~m}$ at Santa Monica, $1.0 \mathrm{~m}$ at Los Angeles, $0.85 \mathrm{~m}$ at Alamitos Bay, $0.55 \mathrm{~m}$ at Newport Bay, $0.67 \mathrm{~m}$ at La Jolla, and $1.13 \mathrm{~m}$ at San Diego (S). Maximum runup height above mean-lower-low water $3.8 \mathrm{~m}$ at Humboldt Bay, $3.8 \mathrm{~m}$ at Fort Bragg, $3.7 \mathrm{~m}$ at Point Arena, $2.5 \mathrm{~m}$ at Drakes Bay, $2.9 \mathrm{~m}$ at Half Moon Bay, $3.8 \mathrm{~m}$ at Santa Cruz, $4.3 \mathrm{~m}$ at Capitola, $2.1 \mathrm{~m}$ at Moss Landing, and $2.3 \mathrm{~m}$ at Monterey (M).

October 17. Peru, $10.7^{\circ}$ S., $78.7^{\circ}$ W.; $M$ 8.1. Height $0.1 \mathrm{~m}$ at Crescent City and $<0.1 \mathrm{~m}$ at San Diego (I).

May 15. East of Honshu, $29.9^{\circ}$ N., $129.4^{\circ}$ E.; M 8.2. Amplitude $0.1 \mathrm{~m}$ at La Jolla (A).

November 29. Hawaii, $19.3^{\circ} \mathrm{N}$., $155^{\circ} \mathrm{W} . ; \mathrm{M}_{\mathrm{S}}$ 7.1. Amplitude $0.3 \mathrm{~m}$ at La Jolla, $0.12 \mathrm{~m}$ at San Diego, and $0.37 \mathrm{~m}$ at Imperial Beach (A). 


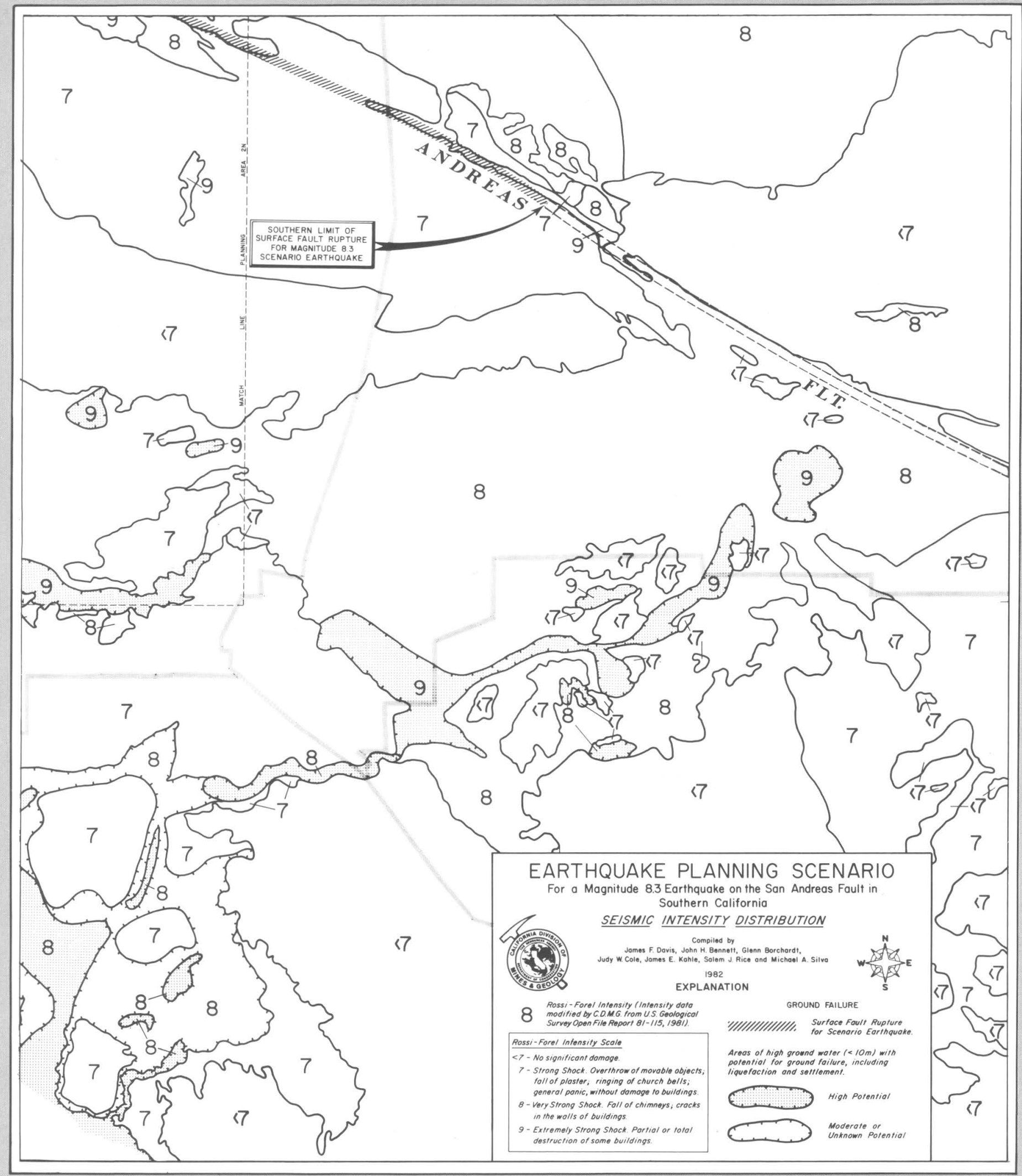

\section{Applications}




\title{
PREDICTED GEOLOGIC AND SEISMOLOGIC EFFECTS OF A POSTULATED MAGNITUDE 6.5 EARTHQUAKE ALONG THE NORTHERN PART OF THE NEWPORT-INGLEWOOD ZONE
}

\author{
By J. I. Ziony, J. F. Evernden, T. E. Fumal, E. L. Harp, S. H. Hartzell, \\ W. B. Joyner, D. K. Keefer, P. A. Spudich, J. C. Tinsley, R. F. Yerkes, \\ and T. L. Youd
}

\section{INTRODUCTION}

The geologic and seismologic effects of a specified future earthquake in the Los Angeles region can be anticipated by applying the techniques of hazard evaluation described in the preceding chapters. Predictions of the distribution and severity of expected effects could be the basis for land use, engineering design, and emergency preparedness actions to reduce potential losses. The reliability of the forecasts, however, varies with the geologic information that is available, with the validity of methods used, and with the type of hazard that is addressed.

This chapter is intended primarily to demonstrate some of the methods described in this volume rather than to predict the effects of a particular future earthquake. The Los Angeles basin and environs have been chosen for this demonstration because the area is the most densely populated part of the region and because it contains a wide range of geologic conditions that are reasonably well known in three dimensions. In this example, we consider the likely effects of surface faulting and related deformation, ground shaking, liquefaction, and landsliding that might be expected from a moderatesized earthquake on the northern part of the NewportInglewood zone. Although the term "prediction" commonly is used with respect to forecasting the time, location, and magnitude of an impending earthquake, the term as used in this chapter refers to estimating effects that would result if an earthquake of postulated size and location were to occur. We have no information

${ }^{8}$ Now at Department of Civil Engineering, 370 Clyde Building, Brigham Young University, Provo, UT 84602. that the occurrence of an earthquake such as that postulated is imminent.

The effects predicted in this chapter should be considered only as approximations of what might occur. Many of the techniques applied here are still in their developmental stages, and their scientific validity has not been conclusively established. In particular, there are significant differences in scientific opinion concerning the relative influence of different geologic factors on levels of ground shaking. Furthermore, the results of some techniques are highly sensitive to the simplifying assumptions about the geologic conditions, and small changes in the assumed conditions commonly yield results that are markedly disparate. Readers also are cautioned that the maps and evaluations presented here should not be used for site-specific purposes because the geologic information varies in completeness across the demonstration area and because testing of subsurface materials usually is required to reach conclusions about a site. Finally, possible effects in the adjacent offshore area generally are neglected because there are no detailed data about the character of sea-floor sediments.

\section{GEOLOGY OF THE DEMONSTRATION AREA}

The demonstration area includes parts of the Los Angeles basin, the Santa Monica Mountains, the San Fernando Valley, the Verdugo Mountains, the San Gabriel Valley, and the Palos Verdes Hills (fig. 210). Crystalline basement rocks and Tertiary sedimentary rocks characterized by relatively high shear and compressive strengths are exposed in the upland areas,

Effects of the Postulated Earthquake 415 


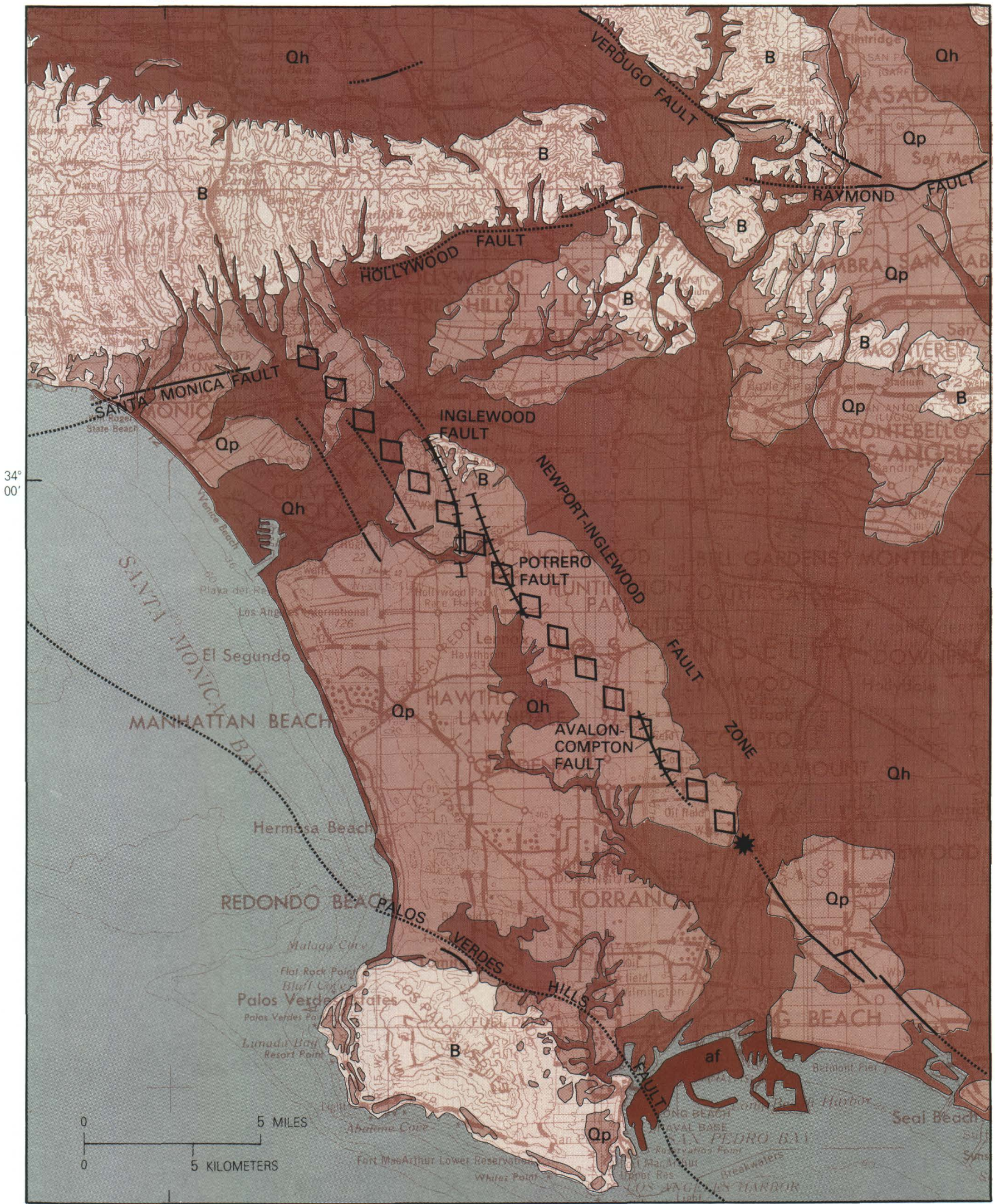

EXPLANATION

\begin{tabular}{|l|}
\hline af \\
\hline Op \\
\hline
\end{tabular}

Artificial fill

Holocene alluvium

Pleistocene alluvium

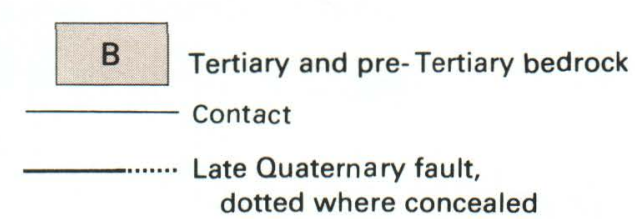

dotted where concealed

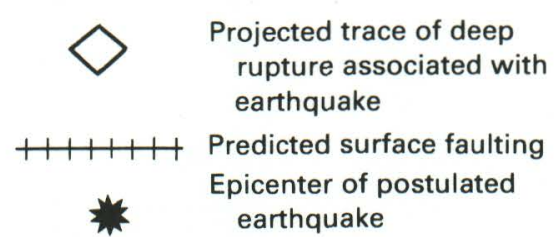


whereas weaker Quaternary sedimentary deposits underlie the lowland areas. The area straddles the northwest-trending Newport-Inglewood zone of deformation and such predominantly east-trending reverse faults as the Santa Monica, Hollywood, and Raymond faults, which form the southern boundary of the Transverse Ranges. The Newport-Inglewood zone, which extends southeastward from Beverly Hills, is expressed topographically by an aligned series of low hills that rise as much as $120 \mathrm{~m}$ above the adjacent plains; structurally, the zone at the surface is a series of discontinuous north- to northwest-striking faults, northwest- to west-trending folds, and numerous short subsidiary normal and reverse faults. The structural style of the Newport-Inglewood zone suggests right-lateral strikeslip faulting at depth (Harding, 1973; Barrows, 1974). The fault-plane solution for the main shock of the 1933 Long Beach earthquake (Woodward-Clyde Consultants, 1979) that probably occurred on an offshore element of the Newport-Inglewood zone is compatible with such motion.

The configuration of the crystalline basement rock surface buried beneath the Los Angeles basin has been reasonably outlined by numerous wells drilled for petroleum and by analyses of gravity measurements (McCulloh, 1960; Yerkes and others, 1965, fig. 2). Southwest of the Newport-Inglewood zone, the basement rock surface generally is at depths of 1.5 to $4 \mathrm{~km}$ (except in the Palos Verdes Hills, where it locally is more than $300 \mathrm{~m}$ above sea level) and slopes gently northeastward. Northeast of the Newport-Inglewood zone, the same surface is dominated by a large synclinal trough that extends southeastward beyond Santa Ana and is as deep as $10 \mathrm{~km}$. The rocks between the crystalline basement and the ground surface chiefly are Tertiary and early and middle Pleistocene sedimentary rocks.

The lowland areas are blanketed by late Quaternary deposits, whose distribution and character will strongly influence the ground-motion and ground-failure effects of any earthquake. Along and west of the NewportInglewood zone, these deposits include as much as $75 \mathrm{~m}$ of late Pleistocene marine and nonmarine terrace sediments; farther east, these deposits grade laterally into flood-plain deposits (gravel, sand, and silt) as much as $105 \mathrm{~m}$ thick. Holocene alluvial fan and flood-plain deposits form much of the surface of the southern San Fernando Valley and the western San Gabriel Valley and extend along the Los Angeles and San Gabriel

FIGURE 210.-Generalized geologic map of demonstration area showing the epicenter of the postulated $\mathbf{M} 6.5$ earthquake, the presumed trace of the associated fault rupture at depth along the NewportInglewood zone, and predicted locations of associated surface faulting.
Rivers. Clayey and organic-rich Holocene marsh deposits adjoin and locally extend several kilometers inland from the mouths of the major streams that enter the ocean at Marina Del Rey, Wilmington, and Seal Beach; similar deposits also occur locally at the northern end of the Baldwin Hills.

Ground water occurs at depths of $15 \mathrm{~m}$ or more in much of the demonstration area (Tinsley and others, this volume, figs. 134, 144). Extensive zones of shallow (less than $10 \mathrm{~m}$ deep) ground water underlie the flood plains and flood-control basins of the Los Angeles and San Gabriel Rivers, occur within the Ballona and Dominguez Gaps, and adjoin the marina and harbor areas along the coast, however. Scattered but areally significant occurrences of ground water at depths of less than $10 \mathrm{~m}$, presumed to be perched; also are present near Beverly Hills, Hollywood, Southgate, and Downey and in a narrow belt just east of the Newport-Inglewood zone. The ground-water levels fluctuate seasonally and in response to changes in management practices in the ground-water basins (for example, increased pumping or recharging of aquifers).

\section{THE POSTULATED EARTHQUAKE}

For the purpose of demonstration, we postulate an earthquake associated with right-lateral seismic slip at depth along the northernmost $30 \mathrm{~km}$ of the NewportInglewood zone. In California, breaks of this length commonly generate earthquakes of moment magnitude $(M)$ 6.5. Such slip is considered credible because the geometry of the exposed echelon faults and folds of the Newport-Inglewood zone is compatible with repeated strike-slip motion along a throughgoing fault or faults within the underlying basement rocks (Harding, 1973; Yeats, 1973; Barrows, 1974).

The earthquake hypocenter is placed beneath the southeastern corner of the Dominguez Hills about $5 \mathrm{~km}$ south of Compton. The location and slip character of this event are shown in figures 210 and 211. Primary tectonic rupture having a pure right-lateral strike-slip motion is assumed to propagate northwestward for $30 \mathrm{~km}$ along a vertical fault at depths of between 3 and $13 \mathrm{~km}$. The unidirectional rupture propagation of this hypothetical event is similar to that which may have occurred during the 1933 Long Beach earthquake (on the basis of its aftershock pattern) and would resemble the rupturing that occurred north of the epicenter of the 1979 Imperial Valley earthquake, which, like the Long Beach earthquake, was a dominantly strike-slip event. Fault slip is postulated to average $70 \mathrm{~cm}$, reaching a maximum of $140 \mathrm{~cm}$ about $10 \mathrm{~km}$ northwest of the hypocenter. The model permits ground warping and second- 


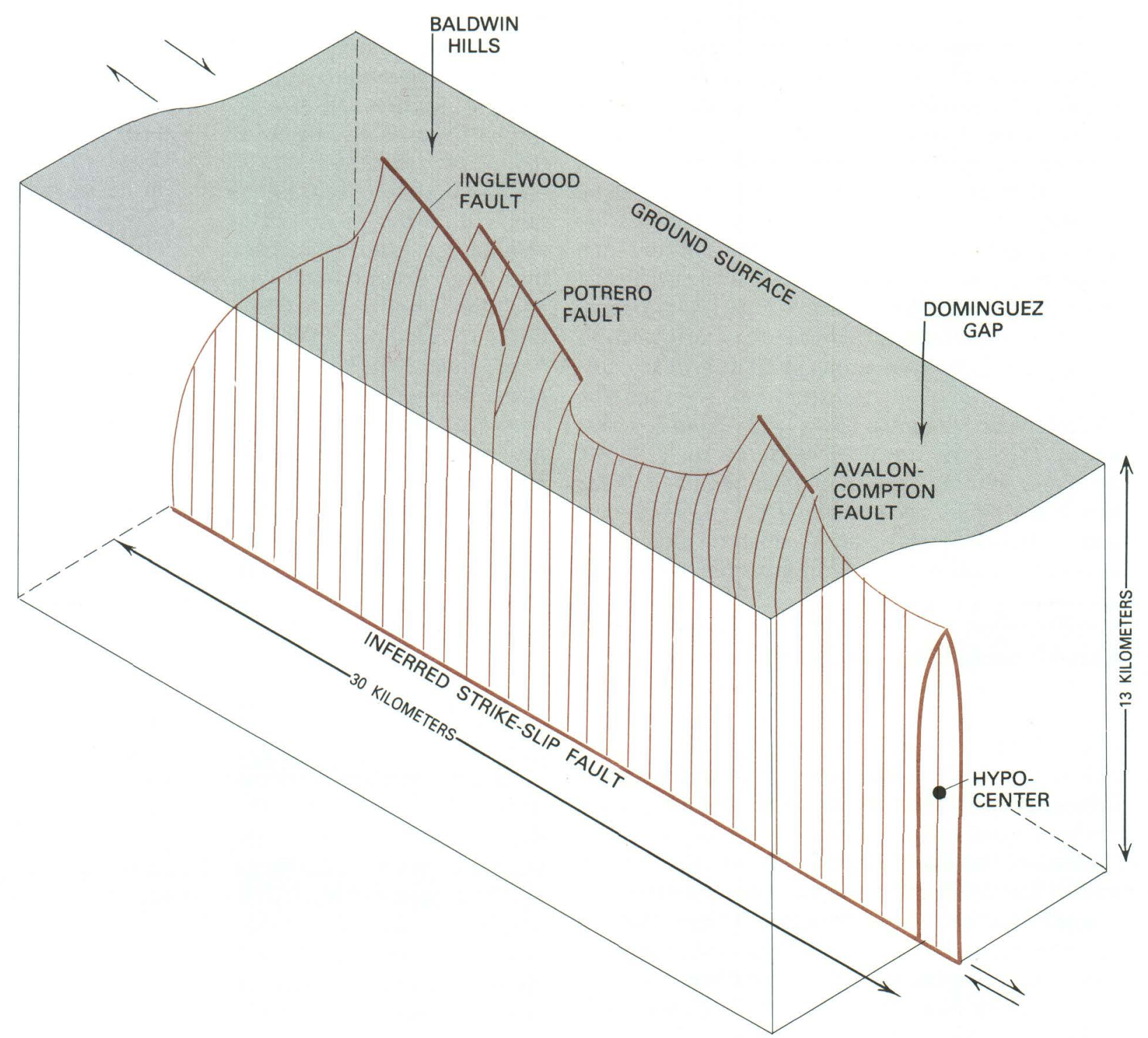

FIGURE 211.-Schematic model of faulting associated with the postulated earthquake. Fault rupture is assumed to start $10 \mathrm{~km}$ below the southeastern margin of the Dominguez Hills and to spread northwestward for a distance of $30 \mathrm{~km}$ along a throughgoing vertical fault presumed to underlie the Newport-Inglewood zone. Primary tectonic rupture having a right-lateral strike-slip sense of displacement occurs at depths between 13 and $3 \mathrm{~km}$; the average slip is $70 \mathrm{~cm}$. Ground warping and secondary faulting having significant components of vertical offset are predicted to occur at and near the Earth's surface.

ary faulting having significant components of vertical offset at and near the Earth's surface.

A comparison (table 53) of the characteristics of the postulated event with those of the 1933 Long Beach earthquake, which occurred offshore near the southern part of the Newport-Inglewood zone, is useful. The postulated event is slightly larger than the 1933 Long Beach earthquake and is similar in size to the 1971 San Fernando earthquake. The example earthquake thus is a moderate-sized event that could occur along any late Quaternary fault of adequate length in the region; it does not necessarily represent the largest earthquake that might occur along the Newport-Inglewood zone. 
TABLE 53.-Comparison of postulated earthquake with the 1933 Long Beach earthquake

\begin{tabular}{|c|c|c|c|}
\hline \multirow[b]{2}{*}{ Parameter } & \multicolumn{2}{|c|}{ Earthquake } & \multirow[b]{2}{*}{ References } \\
\hline & Postulated & $\begin{array}{l}1933 \text { Long } \\
\text { Beach }\end{array}$ & \\
\hline Moment magnitude ---_- & 6.5 & 6.2 & $\begin{array}{l}\text { Hanks and Kanamori (1979) } \\
\text { Toppozada and Parke (1982) }\end{array}$ \\
\hline Moment, in $10^{25}$ dyne-cm - & 6 & $2-6$ & $\begin{array}{l}\text { Hanks and Kanamori (1979) } \\
\text { Woodward-Clyde Consultants (1979) }\end{array}$ \\
\hline \multicolumn{4}{|l|}{ Location of epicenter: } \\
\hline Latitude, ${ }^{\circ}$ N. - - & 33.85 & 33.62 & Toppozada and Parke (1982) \\
\hline Longitude, ${ }^{\circ} \mathrm{W}$. & 118.22 & $117.97^{1}$ & Toppozada and Parke (1982) \\
\hline $\begin{array}{l}\text { Depth of hypocenter, in km ------- } \\
\text { Seismic rupture: }\end{array}$ & 10 & Seismic rupture: & Woodward-Clyde Consultants (1979) \\
\hline Length, in km - & 30 & $22-30$ & $\begin{array}{l}\text { Woodward-Clyde Consultants (1979) } \\
\text { Evernden and others (1981) }\end{array}$ \\
\hline Width (vertical extent), in km ----------- & 10 & $15(?)$ & Woodward-Clyde Consultants (1979) \\
\hline Average slip, in $\mathrm{m}-\cdots$ & .7 & $0.31-0.46$ & Woodward-Clyde Consultants (1979) \\
\hline Sense of slip - & Right lateral & Right lateral & Woodward-Clyde Consultants (1979) \\
\hline
\end{tabular}

\section{SURFACE FAULTING AND DEFORMATION}

\section{By J. I. Ziony and R. F. Yerkes}

Right-lateral slip at depth associated with the postulated earthquake is expected to be manifest at and near the ground surface in secondary faulting and in warping and localized uplift.

The historical record of earthquake-related deformation along the Newport-Inglewood zone is used, together with methods of evaluating surface-faulting potential described by Ziony and Yerkes (this volume), to estimate what deformation of the ground surface might occur. Although surface-fault rupture was not recognized at the time of the 1933 Long Beach earthquake, recent trenching investigations near Newport Beach (about $20 \mathrm{~km}$ southeast of the demonstration area) have documented historical surface rupture that could have occurred during that event (Guptill and Heath, 1981). At a site on Newport Mesa, as much as $30 \mathrm{~cm}$ of vertical separation of a post-1920 manmade fill has been observed across the northern branch of the NewportInglewood fault; stratigraphic differences in late Pleistocene river terrace deposits offset by the fault, together with the geometry of the shear zone, indicate a major component of strike-slip faulting. Because nearly the entire main-shock and aftershock zone of the 1933 earthquake was offshore of this site, we believe that the surface rupture at Newport Mesa may represent slip along a secondary fault rather than displacement along the primary seismogenic rupture.

Historical faulting also has occurred in the shallow subsurface near Gardena in association with two modest-sized earthquakes $\left(\mathrm{M}_{\mathrm{L}} 4.9\right.$ in 1941 and $\mathrm{M}_{\mathrm{L}} 4.5$ in 1944) centered in the Dominguez Hills area (Bravinder, 1942; Martner, 1948). As offsets in the metal casings of producing oil wells have documented, several centimeters of slip occurred at depths as shallow as $1 \mathrm{~km}$ along minor south-dipping reverse faults along the western side of the Newport-Inglewood zone during each event. These offsets probably represent secondary faulting along faults that are suitably oriented to slip in response to north-south compression associated with primary strike slip at greater depths within the Newport-Inglewood zone.

We predict surface faulting totaling as much as $16 \mathrm{~km}$ along the Avalon-Compton fault, the Potrero fault, and the west-dipping main strand of the Inglewood fault (fig. 210). Each of these faults has experienced significant offset during late Quaternary time and, on the basis of physiographic expression, appears to have repeatedly offset the present land surface. The style of geologically recent displacements along these faults and their orientation (striking about north-south and dipping steeply westward) with respect to the trend of the NewportInglewood zone suggest that surface rupture along them will be normal-right oblique slip. On the basis of the slip parameters of the postulated earthquake (average slip $70 \mathrm{~cm}$, maximum about $140 \mathrm{~cm}$ approximately $10 \mathrm{~km}$ northwest of the hypocenter), we estimate that surface 
fault displacement could range from a few to a few tens of centimeters, depending on how the slip at depth is accommodated by deformation within the overlying sedimentary rocks. The geomorphic expression of these faults suggests that vertical components of offset may be as large as the horizontal component. The main zones of surface rupture along the faults will range in width from several centimeters to a few meters, but small shears and permanent ground distortion are likely to extend to distances as great as several tens of meters.

Within the Baldwin Hills, minor faulting at the ground surface also may occur along the east-dipping western strand of the Inglewood fault and along some of the northeast-striking faults that intersect the main trace of the Inglewood fault. Ground cracking and normal-slip movements of a few millimeters or centimeters also may be triggered along the system of short north-northeaststriking faults in the northern Baldwin Hills that has periodically experienced subsidence-induced creep (Castle and Yerkes, 1976).

One or more of the numerous east-trending reverse faults in the subsurface between the Rosecrans and Dominguez Hills probably will experience as much as a few centimeters of reverse slip in association with the postulated earthquake. Although such rupture is not likely to extend to the ground surface and pose a surface-faulting hazard, it could disrupt production from the oil and gas wells that penetrate these faults.

Warping and uplift of the land surface probably will accompany the postulated earthquake. This distortion will be most pronounced adjacent to the zone of surface faulting and in the Rosecrans and Dominguez Hills, which coincide with large exposed anticlines. By analogy with the 1933 Long Beach earthquake, with which was associated a northwest-trending uplift of the land surface centered about $3 \mathrm{~km}$ east of the NewportInglewood zone opposite Seal Beach (Gilluly and Grant, 1949), uplift and subsidence resulting in elevation changes locally of as much as a few tens of centimeters can be expected. It is difficult to predict the distribution of such elevation changes, but they are likely to be largest around the southern third of the postulated earthquake rupture zone.

\section{SEISMIC INTENSITIES}

\section{By J. F. Evernden}

Seismic intensities are predicted for the postulated earthquake by using the method discussed by Evernden and Thomson (this volume). The computer-based technique incorporates a numerical model of the earthquake source, a mathematical expression for the rate of attenuation in the crust of the region, an empirical correlation of geologic ground conditions with differences in expected intensity, and a digitized map of geologic ground conditions for the area studied.

To carry out the calculations, the following assumptions are made:

1. The regional attenuation factor $(k)$ is $13 / 4$ (Evernden and others, 1981).

2. Although the event is postulated as a unidirectional rupture propagating northwestward from an epicenter at $33^{\circ} 51^{\prime}$ N., $118^{\circ} 13^{\prime}$ W., the predicted seismic intensities are insensitive to propagation direction. Thus, the earthquake is modeled as a rupture spreading from the center $\left(33^{\circ} 58^{\prime}\right.$ N., $118^{\circ} 18^{\prime}$ W.) toward both ends at shear-wave velocity.

3. The parameter related to depth of focus $(C)$ is set at 25, the value appropriate for all strike-slip faults in California.

We categorized the rock and sediment units of the Los Angeles region according to the geologic groundcondition units of Evernden and Thomson (this volume, table 22). Geologic ground-condition maps were prepared by digitizing the 1:250,000-scale Los Angeles, Long Beach, San Bernardino, and Santa Ana sheets of the Geologic Atlas of California (California Division of Mines and Geology [1958-1969]) on a $1 / 2-\min \times 1 / 2-\min$ grid. The relative intensity values that we assign to the different geologic ground-condition units are from Evernden and Thomson (this volume, table 23); these values are based on empirically determined relations for groups of geologic units of comparable age and lithology in the San Francisco Bay region and have not yet been verified directly through detailed comparisons of ground-motion recordings on geologic units of the Los Angeles region. As presently applied in southern California, our method for assessing shaking potential assumes that the physical characteristics of all Quaternary alluvium are similar, unlike procedures used in the San Francisco Bay region and unlike another technique discussed in this chapter that considers variations in the shear-wave velocities of the alluvial deposits (Fumal and Joyner, p. 423). Alluvium, however, is differentiated as saturated or unsaturated depending on whether the water table is known to be shallower or deeper than $10 \mathrm{~m}$ (on the basis of modern data from Tinsley and others (this volume)). Figure 212 is a map of the demon-

FIGURE 212.-Geologic ground conditions and relative intensity increments used in computing predicted intensities in the demonstration area. Units correspond to those presented by Evernden and Thomson (this volume, tables 22, 23).

\section{Earthquake Hazards in the Los Angeles Region}




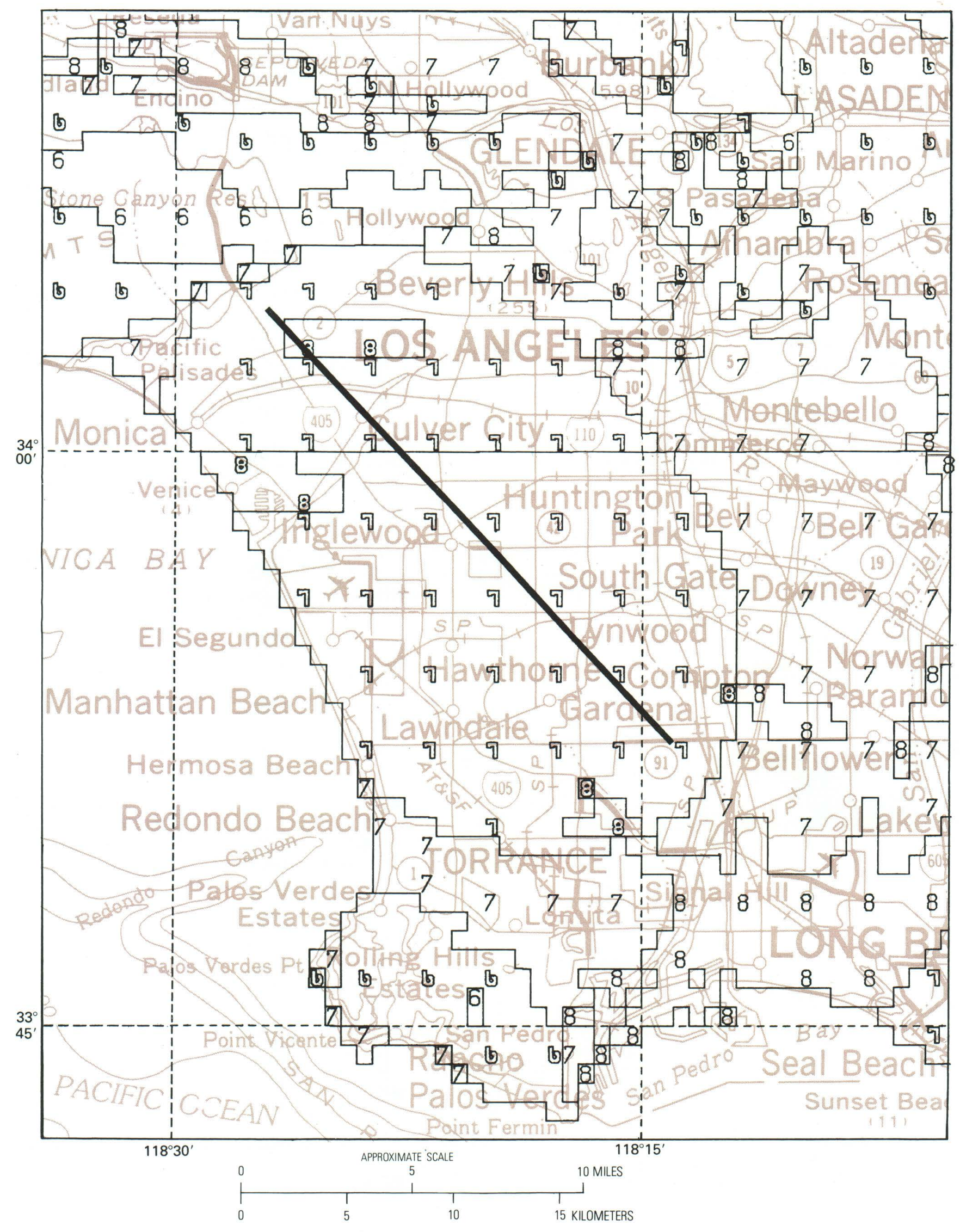




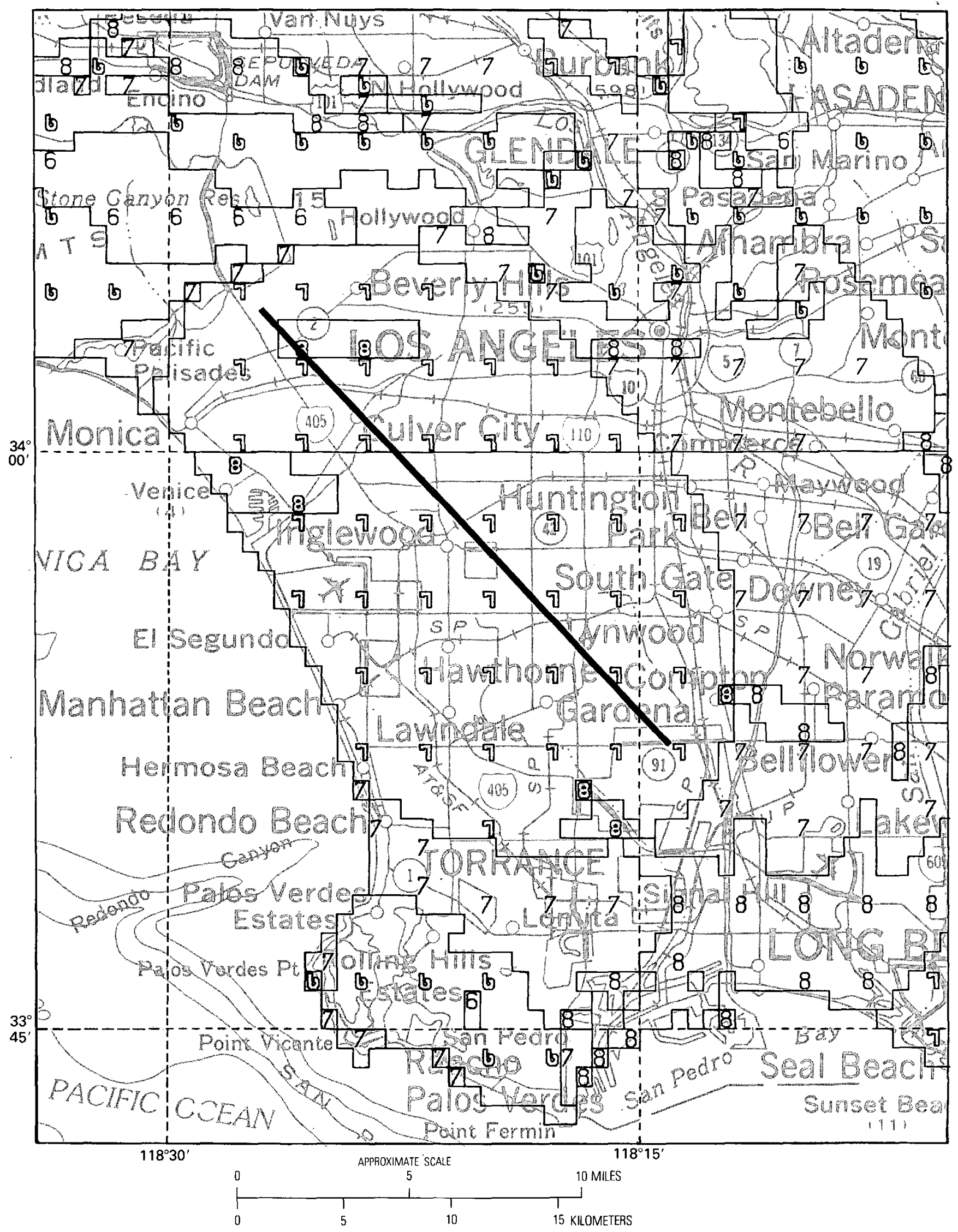


stration area showing geologic ground conditions and corresponding relative intensity increments used in calculating the seismic intensities.

Calculations of expected intensity are sensitive to the depth to the water table. Shaking intensities on alluvium where the water table is deeper than $10 \mathrm{~m}$ will be one intensity unit lower than those on alluvium where the water table is near the ground surface. The predicted values for alluviated areas thus are subject to modifications if better estimates of the present ground-water distribution become available or if ground-water levels change by several meters. Levels may vary because of seasonal fluctuations in rainfall or because of changes in management of the ground-water basins (either increased pumping or recharging of aquifers).

The predicted intensities for the postulated $\boldsymbol{M} 6.5$ earthquake are presented in figures 213 and 214. These maps show that ground shaking of Modified Mercalli intensity VI or greater will affect approximately $6,400 \mathrm{~km}^{2}$ of the onshore region and that most of the alluviated parts of the Los Angeles basin and the San Fernando Valley will experience shaking of intensity VII (see inside back cover for an abridged description of this scale). Small areas of intensity VIII are predicted for the southern San Fernando Valley, near Marina Del Rey, in the Long Beach area, and for other scattered localities in the Los Angeles basin assumed to have saturated alluvium. Intensities of VII can be expected at distances of as much as $40 \mathrm{~km}$ from the modeled rupture where shallow ground water may be present (for example, near Pomona).

Intensities of VI will occur in the Santa Monica Mountains, the Palos Verdes Hills, and other upland areas of Tertiary or older bedrock that ring the Los Angeles basin. Shaking of this severity is predicted as far as $80 \mathrm{~km}$ from the modeled rupture (for example, near Oxnard and near San Bernardino) in areas underlain by saturated alluvium.

FIGURE 213.-Predicted Modified Mercalli intensities for the postulated $M$ 6.5 earthquake in the demonstration area onshore. The heavy line is the trace of the postulated seismic source. Singlestroke characters indicate intensities in the lower half of an intensity band; hollow characters indicate intensities in the upper half. For example, intensities 5.50 to 5.99 are indicated by the singlestroke character 6; intensities 6.00 to 6.50 are indicated by a hollow 6. Onshore areas of intensity $V$ or less are shown without symbol.

\section{HORIZONTAL ACCELERATION, VELOCITY, AND RESPONSE SPECTRAL VALUES}

\author{
By T. E. Fumal and W. B. Joyner
}

We calculated predicted values of peak horizontal acceleration, velocity, and response spectra for the postulated earthquake by using the method described by Joyner and Fumal (this volume). This method relies on equations linking ground-motion parameters to earthquake magnitude, source distance, and site conditions. The magnitude and location of the postulated earthquake are specified; thus, it was necessary only to compile data on site conditions to apply the predictive equations. Because the three-dimensional geology of the Los Angeles basin is relatively well known, we used shear-wave velocity rather than a rock-versus-soil classification to predict the effects of site conditions on ground motion.

Figure 215 shows, for the demonstration area, the geographic variation in the mean shear-wave velocity calculated over a depth equal to one-quarter wavelength of a 1-s wave. The method used to make this map is, in general, the same as that described by Fumal and Tinsley (this volume) for the upper Santa Ana River basin but varies in detail because the subsurface distribution of Quaternary deposits is better known in the Los Angeles basin. Published reports describing the ground-water geology of the Los Angeles basin, the San Gabriel Valley, and the San Fernando Valley (California Department of Water Resources, 1961, 1966; California Water Rights Board, 1962) were the main sources of geologic data used to prepare the map of mean shearwave velocity.

The report on the Los Angeles basin (California Department of Water Resources, 1961), which covers most of the demonstration area, includes a map showing the distribution of exposed geologic units, 14 cross sections showing the distribution of subsurface Quaternary sedimentary units to depths of 100 to $400 \mathrm{~m}$, maps showing the thickness and the elevation of the bases of $10 \mathrm{ma}-$ jor aquifers, and descriptions of geologic units present in the demonstration area. We used these descriptions, along with table 18 of Fumal and Tinsley (this volume), to assign mean shear-wave velocities to each Quaternary unit on the basis of age and texture (table 54). 


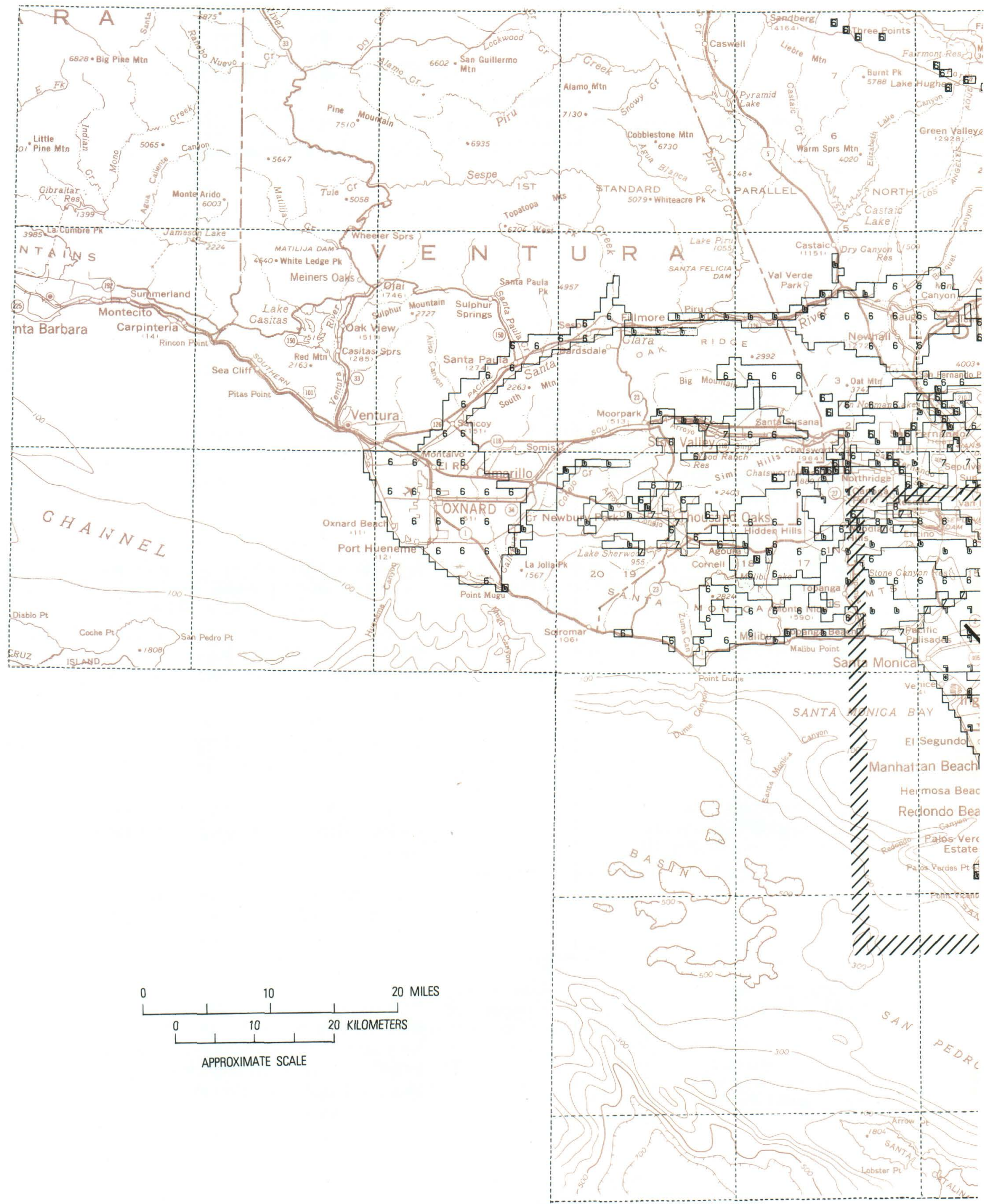

FIGURE 214.-Predicted Modified Mercalli intensities for the postulated M 6.5 earthquake for the entire onshore Los Angeles region. The hachured line delineates the demonstration area. The heavy line is the trace of the postulated seismic source. Single-stroke characters indicate intensities in the lower half of an intensity band; hollow characters indicate intensities in the upper half. For example, intensities 5.50 to 5.99 are in- 


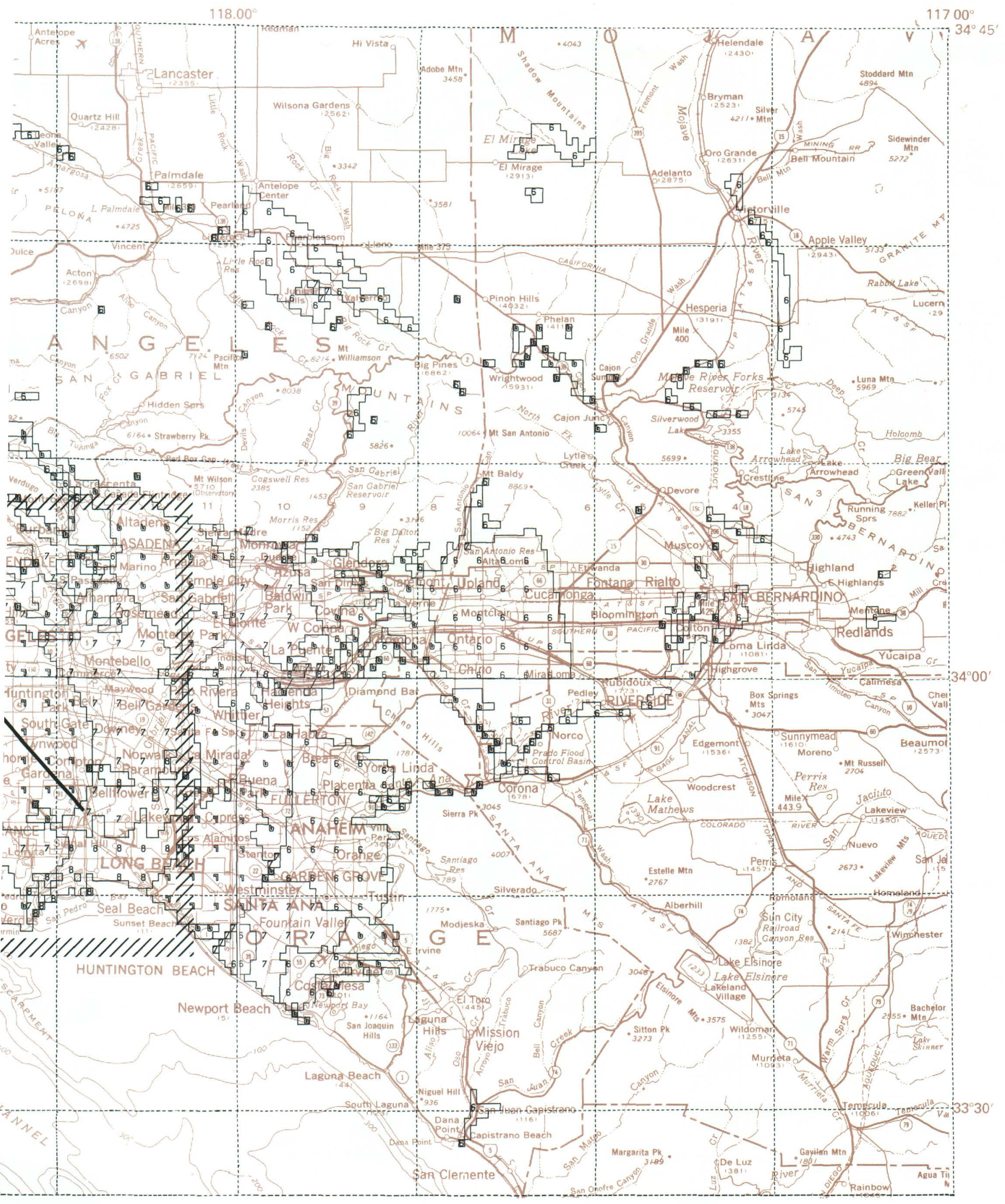

dicated by the single-stroke character 6; intensities 6.00 to 6.50 are indicated by a hollow 6 . Onshore areas of intensity V or less are shown without symbol. 


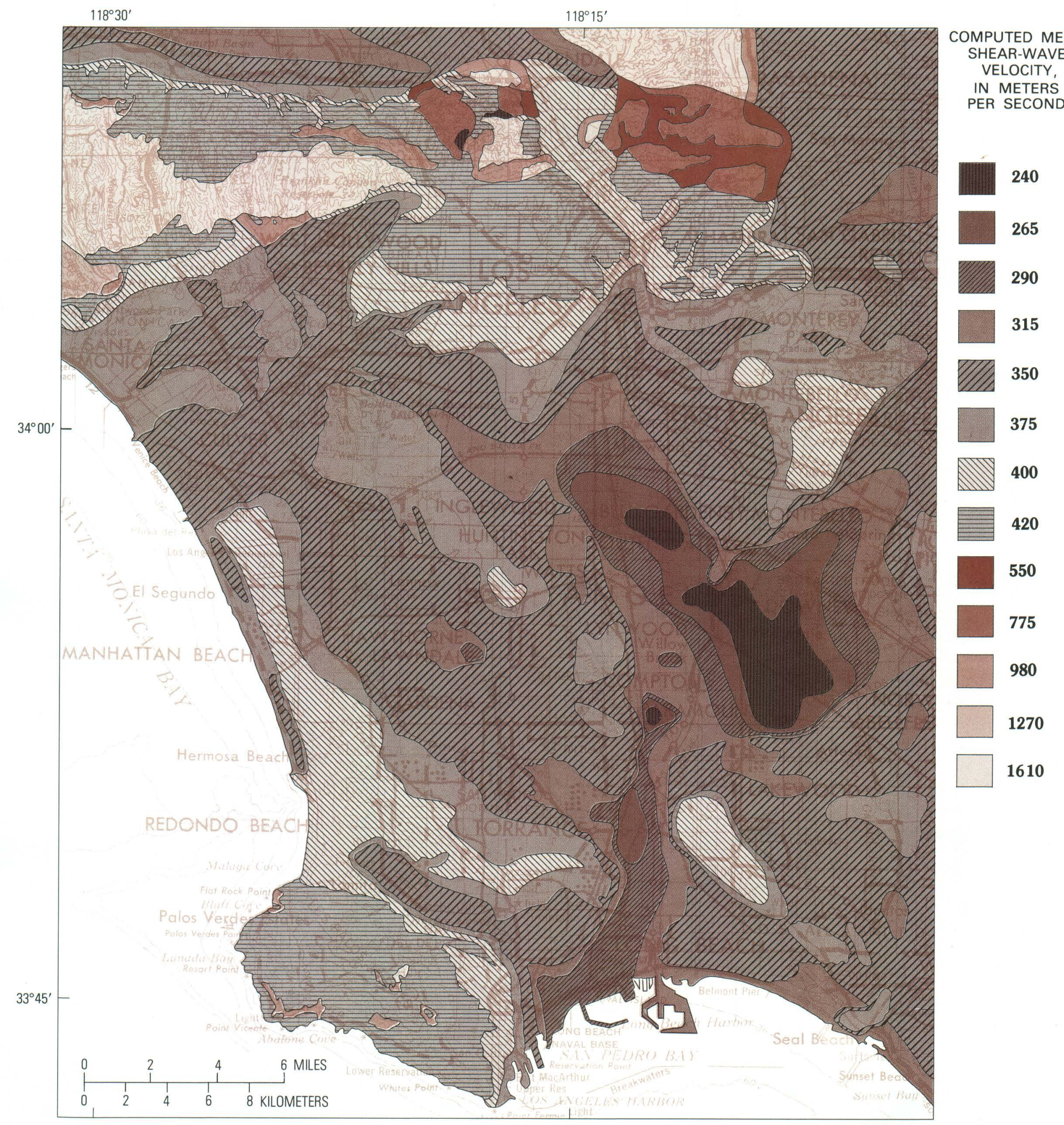

FIGURE 215.-Mean shear-wave velocity in the demonstration area calculated over a depth corresponding to one-quarter wavelength of a 1-s shear wave. Boundaries shown between velocity zones are gradational.

\section{Earthquake Hazards in the Los Angeles Region}


TABLE 54.-Mean shear-wave velocities assigned to exposed and subsurface Quaternary geologic units in the Los Angeles basin on the basis of age and sediment texture

\begin{tabular}{|c|c|}
\hline $\begin{array}{l}\text { Dominant } \\
\text { sediment texture }\end{array}$ & $\begin{array}{l}\text { Assigned shear-wave } \\
\text { velocity, } \\
\text { in } \mathrm{m} / \mathrm{s}\end{array}$ \\
\hline \multicolumn{2}{|l|}{ Holocene } \\
\hline $\begin{array}{l}\text { Dune sand and semiperched --- } \\
\quad \text { aquifer. }\end{array}$ & 230 \\
\hline Bellflower aquiclude ---------------- Fine & 210 \\
\hline Gaspur-Ballona aquifer --_-_-_-_--- Medium and coarse & 250 \\
\hline \multicolumn{2}{|l|}{ Upper and middle(?) Pleistocene } \\
\hline $\begin{array}{l}\text { Older dune sand and semiperched ---------- Medium } \\
\quad \text { aquifer. } \\
\text { Lakewood Formation: }\end{array}$ & 430 \\
\hline Bellflower aquiclude ---------------- Fine & 310 \\
\hline Exposition-Artesia aquifers ------ Fine, medium, and coarse & 420 \\
\hline Aquiclude -- - & 310 \\
\hline Gage aquifer ----_- Medium & 430 \\
\hline 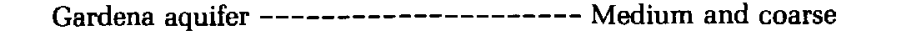 & 445 \\
\hline \multicolumn{2}{|l|}{ Middle Pleistocene } \\
\hline $\begin{array}{l}\text { San Pedro Formation: } \\
\text { Aquifers (Silverado, - } \\
\text { Hollydale, Jefferson, Lynwood, } \\
\text { and Sunnyside). }\end{array}$ & 445 \\
\hline Aquicludes ----- & 310 \\
\hline
\end{tabular}

${ }^{1}$ California Department of Water Resources (1961).

These velocities, assigned to the different geologic units, were then used to calculate mean shear-wave velocity over a depth equal to one-quarter wavelength of a 1-s wave at more than 400 points along cross sections in the Los Angeles basin and the San Gabriel and San Fernando Valleys. We calculated mean velocities at an additional 350 points between the cross-section lines by using the maps of the thickness and the elevation of the bases of major aquifers. At each point chosen, the thickness of each subsurface geologic unit was divided by the mean shear-wave velocity assigned to that unit to give a traveltime through that layer. These layer traveltimes were summed downward through the profile until a total traveltime of $0.25 \mathrm{~s}$ was reached. The total thickness of sediment involved was divided by $0.25 \mathrm{~s}$ to obtain a mean shear-wave velocity for each site. As many as 11 superposed layers had to be considered in these velocity calculations at a given site.

The geologic units vary continuously in thickness from site to site, resulting in a very complex threedimensional distribution of sedimentary deposits. Mean shear-wave velocity at a site, however, is most strongly dependent on the thickness of Holocene deposits and the proportion of fine- to medium- and coarsegrained sedi- ment within the Pleistocene deposits; consequently, shear-wave velocity is relatively constant over large areas. For the parts of the demonstration area underlain by thick Quaternary deposits, we have delineated seven shear-wave velocity zones (first seven zones in fig. 215). Although the velocities assigned to these zones differ significantly (more than about 7 percent) from one another, mean shear-wave velocities calculated for sites within each zone differ by no more than $10 \mathrm{~m} / \mathrm{s}$ from the assigned velocity. Because thicknesses of the geologic units vary continuously, the boundaries between each of these seven zones are gradational.

We assigned mean shear-wave velocities to the bedrock units exposed in the demonstration area (table 55) by using both the classification of engineering-geologic units for the Los Angeles basin (Wentworth and others, 1970) and velocities measured in bedrock materials in the Los Angeles and San Francisco Bay regions. Each bedrock unit was assumed to be at least as thick as the one-quarter wavelength depth $(100-400 \mathrm{~m})$, so that the mean shear-wave velocity over this depth interval was taken to be equal to the mean shear-wave velocity assigned to that geologic unit in table 55. We differentiated the bedrock units exposed in the demonstration 
TABLE 55.-Mean shear-wave velocities assigned to bedrock units exposed in the Santa Monica and Verdugo Mountains and the Palos Verdes Hills

\begin{tabular}{lc}
\hline \multicolumn{1}{c}{ Geologic unit } & $\begin{array}{c}\text { Assigned mean shear- } \\
\text { wave velocity, } \\
\text { in } \mathrm{m} / \mathrm{s}\end{array}$ \\
\hline $\begin{array}{l}\text { Pico, Fernando, Modelo, Upper - } \\
\text { Topanga of Durrell (1954), Monterey, } \\
\text { and Puente Formations. }\end{array}$ & 420 \\
$\begin{array}{l}\text { Topanga Formation in area -- } \\
\text { southwest of Pasadena. }\end{array}$ & 775 \\
$\begin{array}{l}\text { Middle Miocene volcanic rocks - } \\
\text { and Lower Topanga Formation of } \\
\text { Durrell (1954). }\end{array}$ & 980 \\
$\begin{array}{l}\text { Undivided Martinez and Chico -- } \\
\text { Formations and Chico Formation. }\end{array}$ & 1,270 \\
Granitic rocks, Catalina Schist, and - \\
Santa Monica Slate.
\end{tabular}

area into five groups having distinct mean shear-wave velocities. We delineated an additional shear-wave velocity unit in the relatively small sections of the demonstration area where thin Quaternary sediments overlie bedrock having a strongly contrasting mean shear-wave velocity.

Several features of the mean shear-wave velocity map shown in figure 215 should be noted:

1. The lowest velocities occur in the $Y$-shaped area in the southeastern quarter of the demonstration area underlain by Holocene deposits. These deposits are up to $50 \mathrm{~m}$ thick, much thicker than equivalent units in the upper Santa Ana River basin demonstration area (Fumal and Tinsley, this volume).

2. Mean velocities at sites underlain by predominantly medium- and coarse-grained Pleistocene sediments are about 1.7 times greater than velocities at sites underlain by the thickest Holocene deposits.

3. The greatest contrast in mean shear-wave velocity occurs in the northern part of the demonstration area, where unconsolidated sediments and soft sedimentary rocks abut hard crystalline rocks, whose mean shear-wave velocities are about four times greater.

Using figure 215 and applying the methods given by Joyner and Fumal (this volume) to the postulated earthquake, we made predictive maps showing peak horizontal acceleration, velocity, and response spectra at 0.2 and $1.0 \mathrm{~s}$ for 5-percent damping (figs. 216A, 216B, 216C, 216D).

For peak acceleration, the site-condition term in the predictive equation is not significant. Thus, the contours shown in figure $216 A$ are not affected by local geology and are smooth curves. We predict that the highest value of peak horizontal acceleration attained at the fault trace will be about $0.42 \mathrm{~g}$. This value decreases by onehalf about $13 \mathrm{~km}$ from the fault trace. Predicted values of pseudoacceleration response at $0.2 \mathrm{~s}$ (fig. 216C) are slightly affected by the site-condition term, so that a twofold rock-versus-soil classification is used in the predictive equation. We predict that the highest value of pseudoacceleration response at $0.2 \mathrm{~s}$ attained at the fault trace will be near $1.16 \mathrm{~g}$. This value will decrease by one-half about $14 \mathrm{~km}$ from the fault trace.

In contrast, the site-condition terms in the predictive equations for both peak velocity and pseudovelocity response at $1.0 \mathrm{~s}$ are statistically significant. Thus, the contours of predicted values are markedly irregular. As we noted previously, the range of mean shear-wave velocity is not large $(240-400 \mathrm{~m} / \mathrm{s})$ within most of the demonstration area underlain by Quaternary deposits. In figures $216 B$ and $216 D$, the variations in distance from the fault trace at which a given level of ground motion is expected to occur are generally less than $2 \mathrm{~km}$ over this range of mean shear-wave velocity. We predict that the highest values of peak velocity at the fault trace will reach 90 to $100 \mathrm{~cm} / \mathrm{s}$, depending on site mean shearwave velocity. These values will decrease by one-half about $7 \mathrm{~km}$ from the fault trace. For pseudovelocity response at $1.0 \mathrm{~s}$, we predict that the highest values attained at the fault trace will be 160 to $180 \mathrm{~cm} / \mathrm{s}$, depending on site mean shear-wave velocity. These values will decrease by one-half about $8 \mathrm{~km}$ from the fault trace.

The most noticeable effects of local geology on the predicted ground-motion values occur in the northern part of the demonstration area, where the shear-wave velocity contrasts are greatest between the soft sedimentary deposits and the hard crystalline rocks of the Santa Monica and Verdugo Mountains. Values of pseudovelocity response at $1.0 \mathrm{~s}$, for example, are predicted to be greater than $50 \mathrm{~cm} / \mathrm{s}$ in the southernmost San Fernando Valley but less than $25 \mathrm{~cm} / \mathrm{s}$ in the Santa Monica Mountains at an equal distance from the fault trace.

FIGURE 216.-Geographic variation in predicted ground-motion values (for the random horizontal component) in the demonstration area for the postulated earthquake. The heavy line is the trace of the postulated seismic source. A, Peak acceleration (in percent of gravity). The maximum value reached at the fault trace is about 0.42 g. B, Peak velocity (in centimeters per second). Maximum values reached at the fault trace range from about 90 to $100 \mathrm{~cm} / \mathrm{s}$ depending on site condition. $C$, Pseudoacceleration response (percent of gravity) at $0.2 \mathrm{~s}$ and 5-percent damping. The maximum value reached at the fault trace is about $1.16 \mathrm{~g}$. $D$. Pseudovelocity response (in centimeters per second) at $1.0 \mathrm{~s}$ and 5-percent damping. Maximum values reached at the fault trace range from about 160 to $180 \mathrm{~cm} / \mathrm{s}$, depending on site condition.

\section{Earthquake Hazards in the Los Angeles Region}



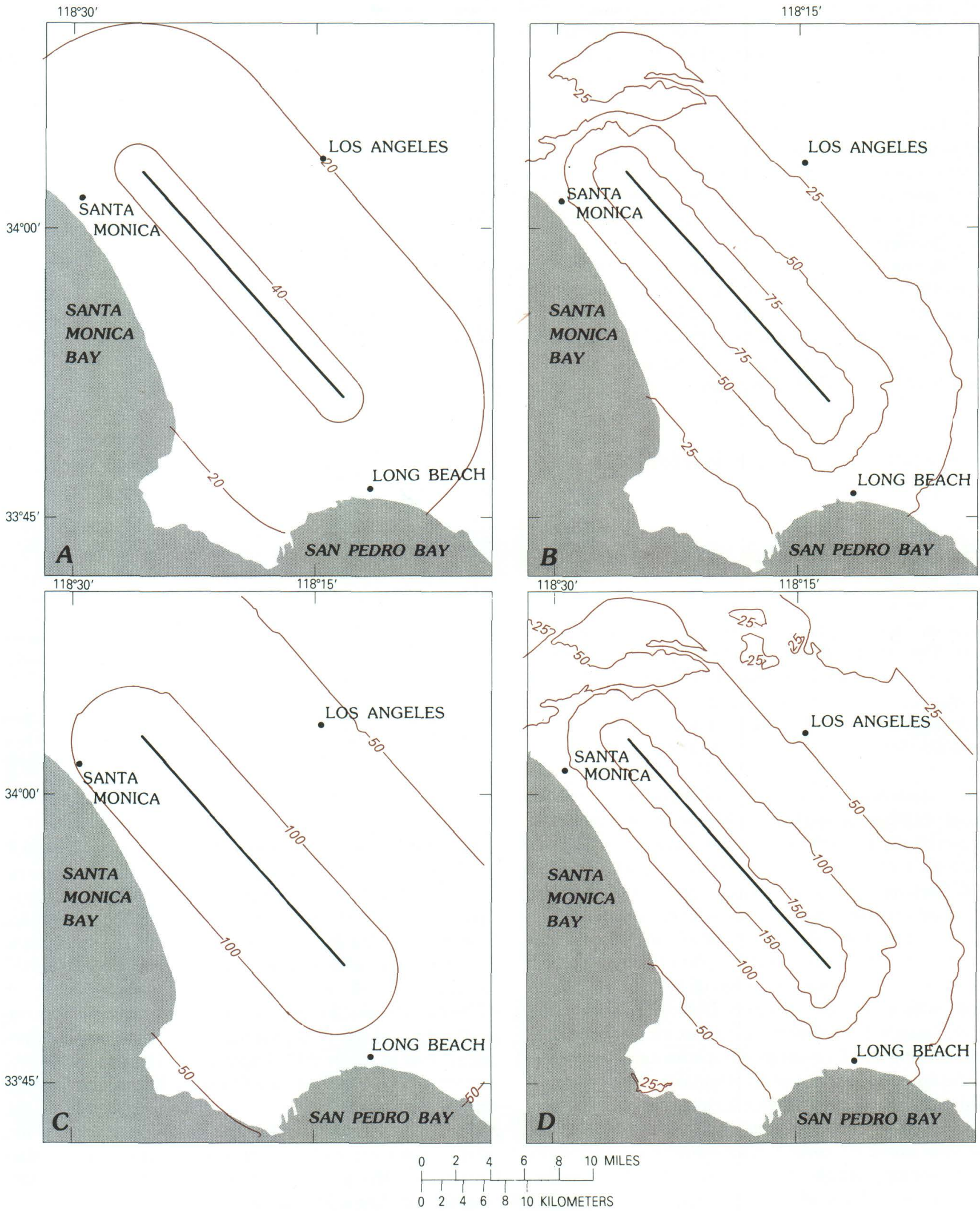
Comparison of figures 216A, 216B, 216C, and 216D shows that predicted values of peak velocity and pseudovelocity response at $1.0 \mathrm{~s}$ attenuate more rapidly in the region near the fault than values of peak acceleration and pseudoacceleration response at $0.2 \mathrm{~s}$ do. This characteristic of the predictive equations is required by the existing strong-motion data.

Although the postulated earthquake would be generated by a unilateral rupture propagating from southeast to northwest, our methods do not take into account the direction of rupture propagation. Figures 216A through $216 D$, therefore, do not show directivity effects on ground-motion values. The map patterns thus are the same as they would be if the propagation had been in the other direction or if the rupture had been bilateral. The following section on predicted ground-motion timehistories considers unidirectional rupturing and thus shows results that reflect directivity.

\section{TIME-HISTORIES OF GROUND MOTION}

\section{By S. H. Hartzell and P. A. Spudich}

Time-histories of ground motion from the postulated earthquake can be predicted by assuming how each point on the slipping fault might be displaced, determining the ground motions caused by each point, and then summing the ground-motion contributions from each point to obtain the total motion at a given distant site. The results depend greatly on assumptions concerning (1) the velocity structure of the Earth's crust in the demonstration area and (2) the detailed character of the expected rupture propagation. Methods of simulating ground-motion time-histories commonly use Green's functions, mathematical expressions that estimate ground shaking caused by a single point source for an appropriate crustal model. These techniques, described by Spudich and Hartzell (this volume), are used in this section to simulate ground velocity from the hypothetical earthquake in the frequency range of 0.05 to $2.0 \mathrm{~Hz}$ for 10 sites within the Los Angeles basin. The particular sites are selected to illustrate variations in predicted ground motion at different positions around the postulated rupture zone of the earthquake. The suite of ground motions that we predict is only one of many possible suites that could be caused by a moderate-sized earthquake on the Newport-Inglewood zone and probably represents neither the largest nor the smallest possible motions for a $\mathbf{M} 6.5$ earthquake.

To simplify calculation of the required point shear dislocation responses (or Green's functions), several

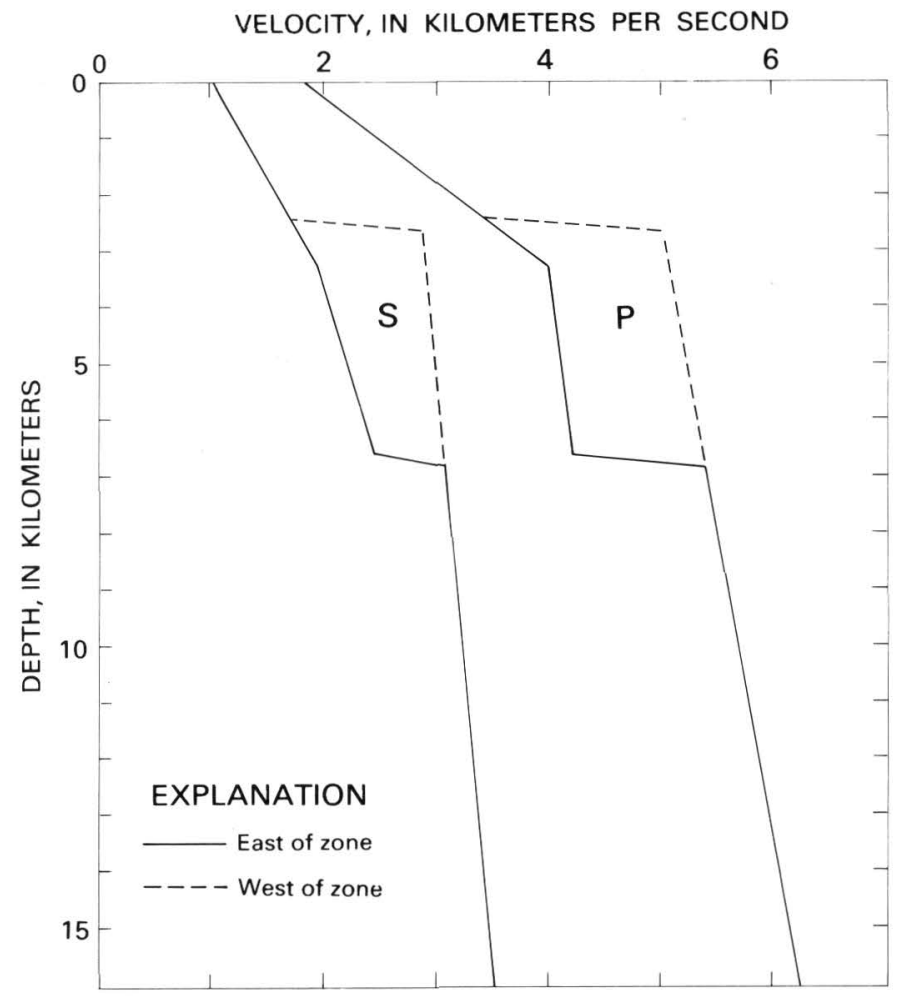

FIGURE 217.-Velocity structure assumed for the Los Angeles basin for compressional (P) and shear (S) waves. A different structure is used on the eastern and western sides of the Newport-Inglewood zone to account for differences in depths to basement rocks. Calculations use data on rock density and depth to basement from McCulloh (1960) and Yerkes and others (1965). P-wave velocity structure is based on Teng and others (1973) and Hill and others (1977). S-wave velocity structure is calculated from P-wave velocity structure by assuming a $V_{p} / V_{s}$ ratio of $V_{p}=V_{s} \sqrt{3}$ below $6.5 \mathrm{~km}$ and varying the ratio smoothly to $V_{p}=1.9 V_{s}$ at the surface.

assumptions are made about the Earth's seismic velocity, density, and attenuation structure in the demonstration area. The Earth structure is laterally homogeneous; that is, the physical properties vary only with depth. This assumption is reasonable, because the fault zone and the points at which ground motions are calculated in this study all lie within the Los Angeles basin. A different laterally homogeneous structure, used on opposite sides of the Newport-Inglewood zone in the manner shown in figure 217, however, reflects considerably greater thickness of sedimentary rocks on the eastern side of that zone. For sites on the eastern side of the zone, Green's functions for the east-side structure are used to calculate ground motions. When ground motion for sites on the western side of the zone is computed, Green's functions for the west-side structure are used. A further assumption is that the shear-wave velocity at the surface of the Los Angeles basin is about $500 \mathrm{~m} / \mathrm{s}$,

\section{Earthquake Hazards in the Los Angeles Region}




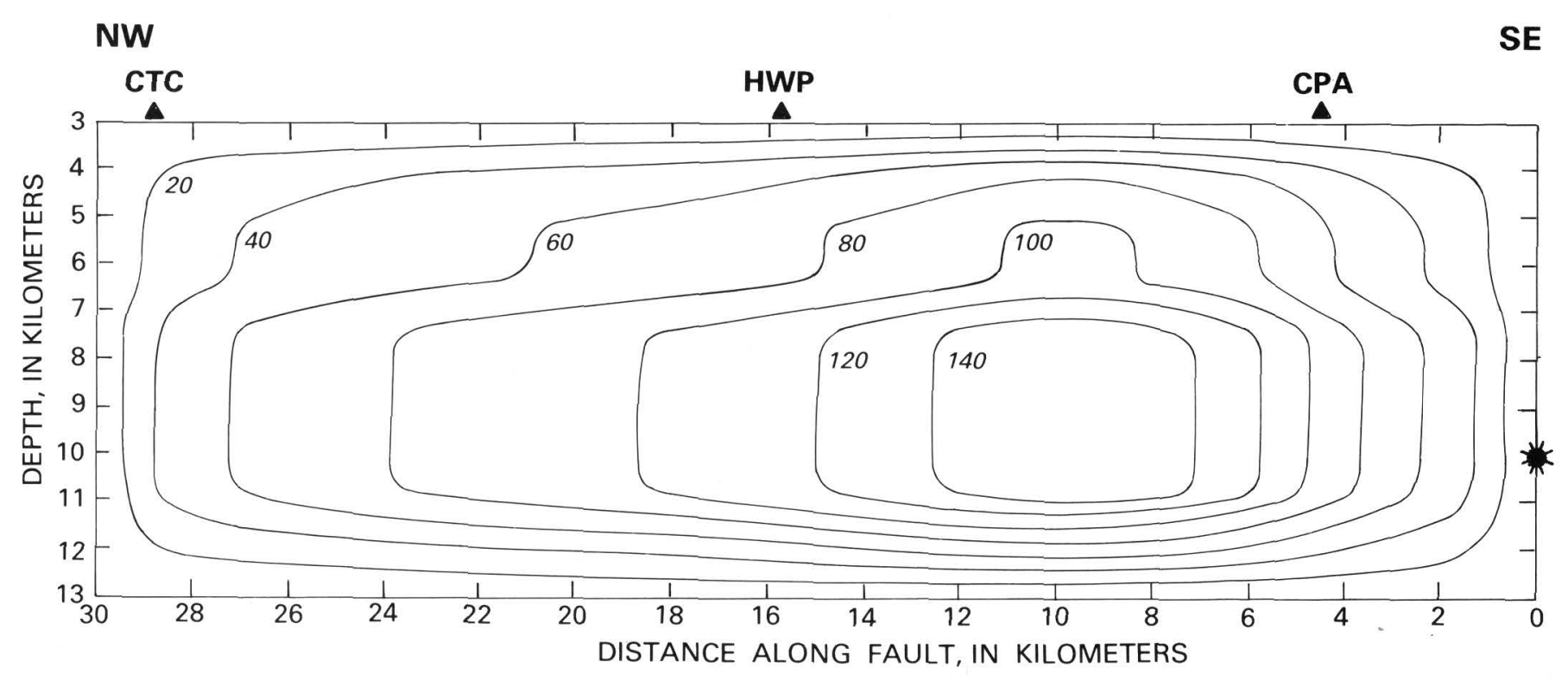

FIGURE 218.-Assumed distribution of slip on a hypothetical rupture surface between depths of 3 and $13 \mathrm{~km}$. Contours (in centimeters) represent amounts of final slip. The hypocenter is indicated by an asterisk. Nearby sites at which ground velocity is calculated are indicated by CTC (Century City), HWP (Hollywood Park), and CPA (Compton Airport).

which is higher than the velocities estimated for late Quaternary sediments by Fumal and Joyner (table 54). This assumption enabled us to reduce the computation time of the calculations. Had a lower near-surface velocity been chosen (for example, $375 \mathrm{~m} / \mathrm{s}$ ), the ground motions that we calculated might have been 10 to 20 percent larger. Finally, the Earth structure is assumed to have a perfectly elastic response and no attenuation of seismic energy. This approximation is probably acceptable at the low frequencies being calculated.

Green's functions were calculated for the velocity structures given in figure 217 by using the discrete wavenumber-finite-element method (Olson and others, 1984). The depth range over which Green's functions are needed is controlled by the top and bottom depths of the postulated rupture surface. The required epicentral distances at which Green's functions are needed are controlled by the distances from the postulated rupture surface to the sites where ground motion is to be computed. In this study, additional Green's functions are obtained by the interpolation method of Hartzell and Helmberger (1982). This interpolation is an approximation and assumes that the Green's functions are known at a spatial interval small enough that the variation in the waveforms between adjacent Green's functions is not great.

The assumed model of slip across the rupture surface is shown in figure 218. The furthest extent of the postulated rupture fills a rectangular region from a depth of $3 \mathrm{~km}$ down to a depth of $13 \mathrm{~km}$. The amplitudes of the offsets in figure 218 are chosen to be compatible with a total moment of $6 \times 10^{25}$ dyne-cm, corresponding to a moment magnitude of about 6.5. The distribution of slip has been arbitrarily selected, but some of its features are similar to those inferred for the 1979 Imperial Valley earthquake (Olson and Apsel, 1982; Hartzell and Heaton, 1983; Archuleta, 1984). Although the slip distribution used here is reasonable for the postulated earthquake, we stress that it is only one of an infinite number of possible configurations.

For computational purposes, the modeled rupture surface is divided into a regular gridwork of point shear dislocation sources spaced $0.37 \mathrm{~km}$ apart both horizontally and vertically. Enough point sources are used so that, when their individual responses are added together, the earthquake appears as a uniform rupture rather than as a series of discrete sources. In a propagating rupture, seismic waves tend to pile up on one another in the direction of rupture propagation. This effect is called directivity (Boore and Joyner, 1978; Archuleta and Frazier, 1978). Similarly, at an azimuth opposite to the direction of rupture propagation, seismic waves tend to be stretched out in time. This stretching out reveals the individual sources on the rupture surface. Thus, the accuracy of the point-source-summation approximation to a uniform rupture can depend on the frequency of the calculation and on the azimuth of the site in relation to the strike of the rupture surface. Furthermore, the analysis is sensitive to assumptions about the rupture velocity. Figure 219A shows the model of the rupture front that is used in this simulation. The rupture velocity is assumed to be 0.8 times the shear-wave 

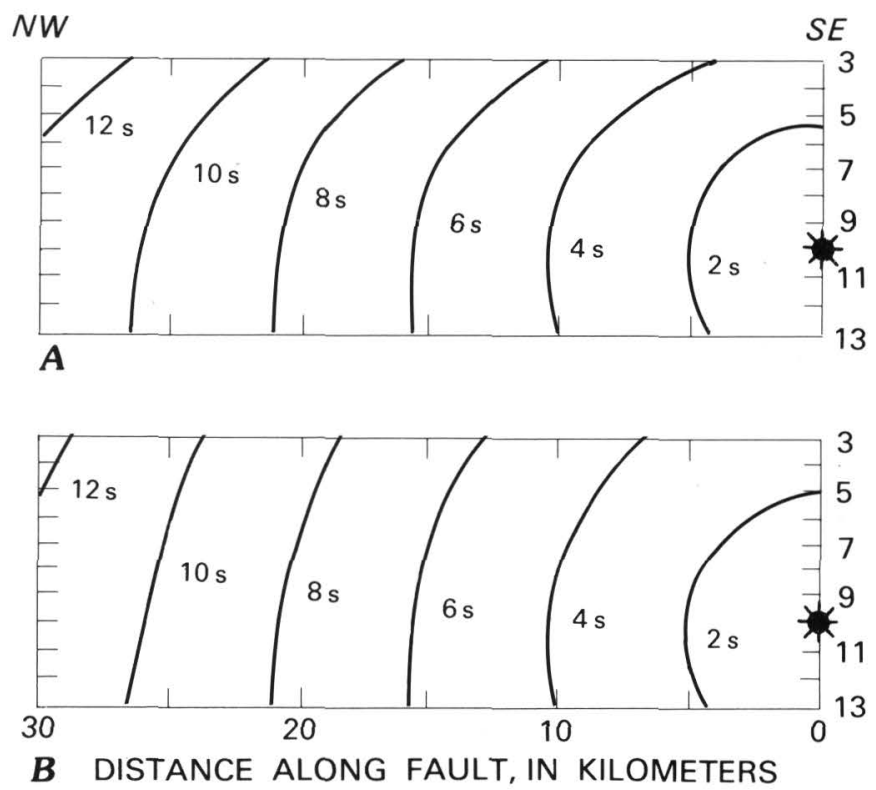

FIGURE 219.-Contours of the position of the rupture front at 2-s intervals after initiation of the earthquake. A, Rupture history used in calculations. $B$, An alternate rupture history. Hypocenter is indicated by asterisk.

velocity on the eastern side of the Newport-Inglewood zone. A rupture velocity 0.8 times the shear-wave velocity is consistent with inferred rupture for moderate to large earthquakes (Geller, 1976) and with rupture velocities obtained from numerical studies of shear cracks (Andrews, 1976). Use of a different rupture history (for example, the one in figure 219B) can yield markedly different amplitudes of ground velocity, although the waveforms are similar. The alternate rupture history is for a rupture velocity 0.8 times the shearwave velocity west of the Newport-Inglewood zone.

The predicted ground-motion time-histories are shown in figures $220 \mathrm{~A}, 220 \mathrm{~B}$, and $220 \mathrm{C}$ for the components of velocity normal to the rupture surface, parallel to the rupture, and vertical, respectively. Ground-motion velocities are shown for 10 sites within the Los Angeles basin; the station names and their predicted peak velocities are given in table 56 . The main conclusions that can be drawn from the amplitude distributions are that (1) strong shaking from the postulated earthquake lasts for about 10 to $15 \mathrm{~s}$; (2) the component normal to the rupture surface has the largest amplitudes; and (3) both the directivity of the moving rupture and the radiation patterns of different seismic phases are important in evaluating the amplitude of the ground motion at specific sites.

The component of ground motion normal to the rupture surface in figure $220 \mathrm{~A}$ is mainly SH waves (horizontally polarized shear waves). This component is largely symmetric across the fault zone (compare, for example, the predicted motions at LAX and USC). The normal component of velocity is relatively unaffected by the different depths to basement on the northeastern and southwestern sides of the fault zone. Velocities of this component toward the northwestern end of the fault are generally larger than those toward the southeastern end. The larger amplitudes to the northwest are due to directivity from the northward-propagating rupture (compare, for example, CTC and LBA). The normal components at CTC and HWP are particularly large for two $\leqslant$ reasons: (1) they lie close to the trace of the rupture surI face near the SH-wave radiation pattern maximum, and (2) a significant portion of the postulated fault slip lies to the south of each site, between each site and the hypocenter. We note that the peak ground velocities normal to the seismic slip surface (table 56), which are the largest motions, agree reasonabaly well in magnitude with those predicted by Fumal and Joyner (fig. 216B). The main discrepancy is that the peak velocity distribution predicted by our model is skewed to the northwest because of our explicit inclusion of the effect of directivity, which is absent from figure $216 B$.

The component of ground motion parallel to the rupture surface in figure $220 \mathrm{~B}$ and the vertical component in figure $220 \mathrm{C}$ are mainly $\mathrm{P}$ (compressional waves), SV (vertically polarized shear waves), and surface waves. These two components do not show the symmetry across the fault that the normal component does (compare, for example, LAX and USC). Larger surface waves are generated on the eastern side of the fault zone because of the greater thickness of sedimentary rocks on that side (see, for example, the vertical component at USC). The peak values at USC, HWC, and LAX are relatively large because these sites lie near a P-SV radiation pattern maximum $\left(45^{\circ}\right.$ off the strike of the postulated subsurface fault) for the large dislocations south of HWP (fig. 218). In contrast, COM at an azimuth of about $90^{\circ}$ from the strike of the rupture surface is near a radiation pattern minimum (fig. 220C). The parallel and vertical components of velocity for LBA are small because of the northwestward directivity. These components are largest for CPA because of vertical directivity from the hypocenter, which lies at about a $60^{\circ}$ angle under the station. That is, the parallel and vertical components at CPA are large for the same reasons that the normal components of CTC and HWP are large.

Figure 221 illustrates the effect at site HWP of using the alternate rupture history depicted in figure 219 . Although the waveforms are similar, the amplitudes are significantly increased in the new rupture history. At the other sites, the increase in amplitude is much less. These observations can be understood by considering figures 218 and 219 . We see from figure 219 that, in the

\section{Earthquake Hazards in the Los Angeles Region}



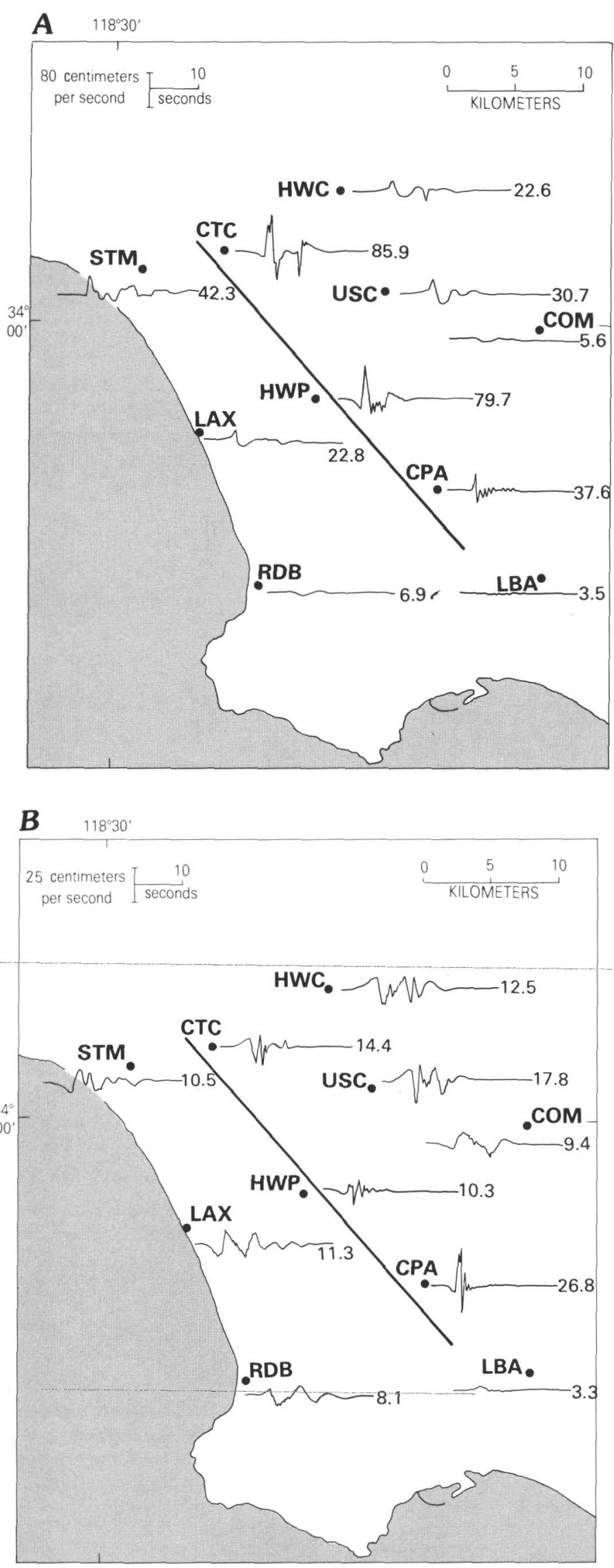

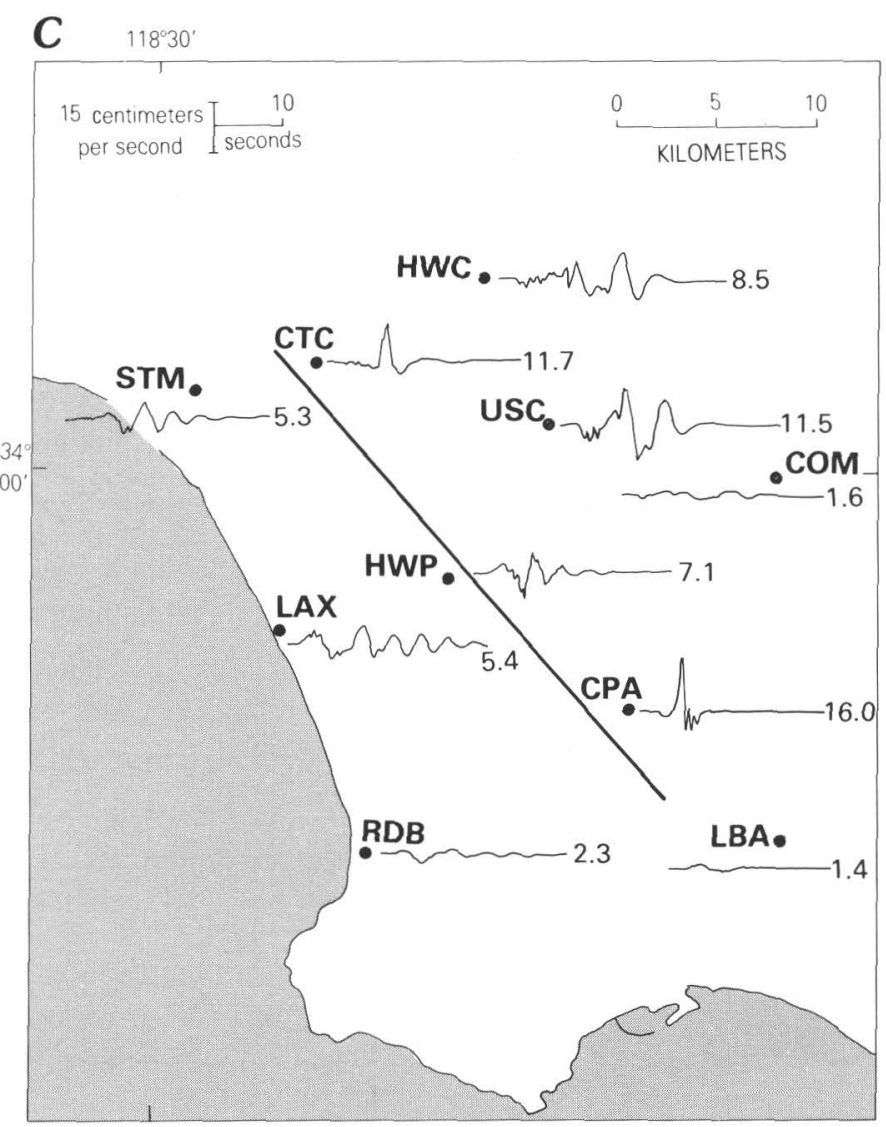

FIGURE 220.-Predicted ground-motion time-histories of velocity components for 10 sites in the Los Angeles basin (see table 56 for station designations). All time-histories are plotted at the same horizontal and vertical scales for ease of comparison. Numbers to the right of each time-history indicate the peak amplitude of the trace (in centimeters per second). Heavy line is the trace of the postulated seismic rupture. $A$, Gomponent of velocity normal to rupture surface. $B$, Component of velocity parallel to rupture surface. C, Vertical component of velocity.

TABLE 56.-Peak velocities (in $\mathrm{cm} / \mathrm{s}$ ) from postulated earthquake computed for 10 sites within the Los Angeles basin

\begin{tabular}{|c|c|c|c|}
\hline \multirow[b]{2}{*}{ Location } & \multicolumn{3}{|c|}{ Component } \\
\hline & $\begin{array}{l}\text { Normal to } \\
\text { rupture }\end{array}$ & $\begin{array}{l}\text { Parallel to } \\
\text { rupture }\end{array}$ & Vertical \\
\hline CTC ---- Century City & 85.9 & 14.4 & 11.7 \\
\hline HWP ---- Hollywood Park & 79.7 & 10.3 & 7.1 \\
\hline STM ---- Santa Monica & 42.3 & 10.5 & 5.3 \\
\hline CPA ---- Compton Airport & 37.6 & 26.8 & 16.0 \\
\hline $\begin{array}{c}\text { USC ---- University of Southern } \\
\text { California. }\end{array}$ & 30.7 & 17.8 & 11.5 \\
\hline LAX ---- Los Angeles Airport & 22.8 & 11.3 & 5.4 \\
\hline HWC --- Hollywood Cemetery & 22.6 & 12.5 & 8.5 \\
\hline RDB ---- Redondo Beach & 6.9 & 8.1 & 2.3 \\
\hline COM --- City of Commerce & 5.6 & 9.4 & 1.6 \\
\hline LBA ---- Long Beach Airport & 3.5 & 3.3 & 1.4 \\
\hline
\end{tabular}


VELOCITIES FOR ASSUMED RUPTURE HISTORY
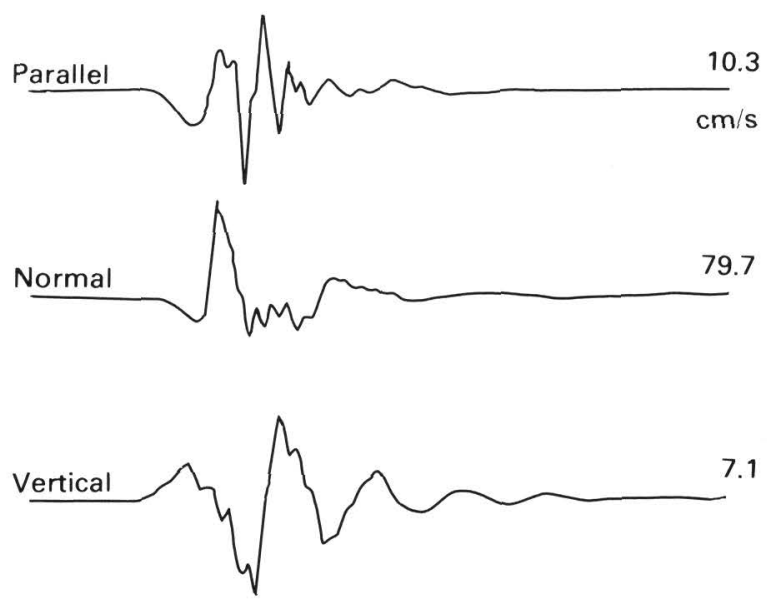

VELOCITIES FOR ALTERNATE RUPTURE HISTORY
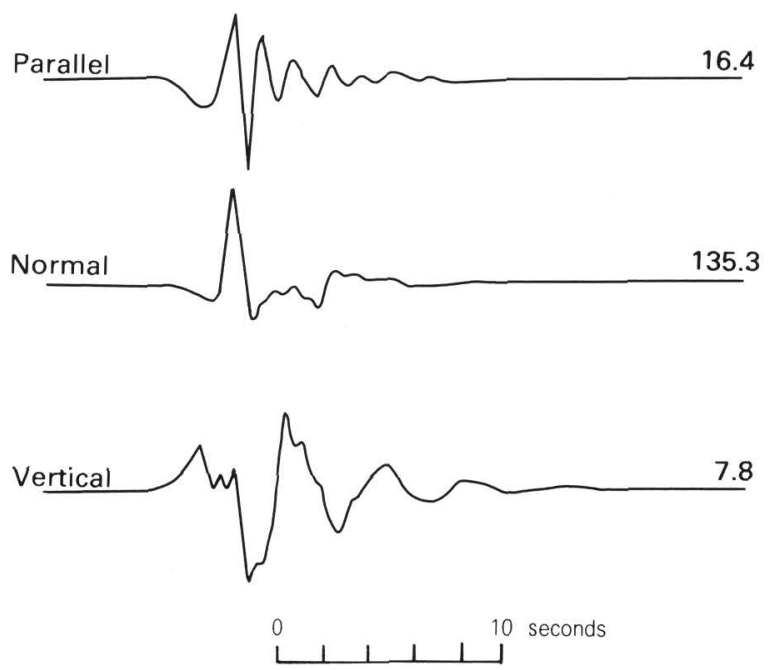

FIGURE 221.-Comparison of time-histories of ground velocity for the same site-HWP (Hollywood Park-using the two different rupture histories shown in figure 219. Numbers to the right of each time-history indicate peak values. Different vertical scales are used for the two rupture histories to demonstrate that the waveforms are similar even though peak values are different.

alternate rupture history, the upper part of the fault plane ruptures a little faster. Site HWP is particularly sensitive to this change in rupture velocity because of the larger values of slip at shallow depths just south of HWP (fig. 218). These shallower dislocations lie between HWP and the hypocenter and are involved in a directivity effect, which is in turn strongly dependent on the rupture velocity. Thus, we see that a fairly complicated interplay can exist between the rupture history, the distribution of slip, the location of the site, and the resulting ground motion.

\section{LIQUEFACTION-RELATED GROUND FAILURE}

\section{By J. C. Tinsley and T. L. Youd}

Liquefaction-related ground failure is expected to occur in association with the postulated earthquake at scattered localities within relatively flat alluvial areas. Figures 135 and 145 (Tinsley and others, this volume) delineate relative liquefaction susceptibility for the onshore part of the demonstration area by using methods described by Tinsley and others (this volume). These figures are based on our assessment of the age and type of sedimentary deposits and the depth to ground water as compiled from modern data. We analyzed the physical properties of the late Quaternary alluvial deposits, grouped them according to their densities and their probable contents of loose cohesionless sand or silt, and determined whether they are saturated with ground water at depths of less than about $15 \mathrm{~m}$. Holocene sediments, especially those deposited during the past few hundred years, are the most susceptible to liquefaction-related ground failure. Sea-floor sediments susceptible to liquefaction may also be present on or along the margins of the Santa Monica and San Pedro shelves (Clarke and others, this volume, fig. 189), but we lack sufficient information on their distribution and character to consider them in this analysis.

For the postulated earthquake (M 6.5), we predict that significant liquefaction effects will occur at distances not more than $18 \mathrm{~km}$ from the surface projection of the fault rupture. This inference is based on the empirical relation between earthquake magnitude and the greatest distance at which liquefaction effects in gently sloping Holocene sediments are observed with respect to the seismic source (Youd and Perkins, 1978; Tinsley and others, this volume, fig. 155). Observations of liquefaction generated by the 1979 Imperial Valley earthquake of comparable magnitude indicate that the greatest likelihood of liquefaction-related ground failures probably will be within 5 or $6 \mathrm{~km}$ of the surface projection of the fault rupture (Youd and Wieczorek, 1982).

We predict that, within $18 \mathrm{~km}$ of the seismic rupture, ground failure due to liquefaction may occur at scattered localities within areas designated as having very high and high susceptibility (that is, where deposits are very young and where ground water is less than $10 \mathrm{ft}$ subsurface). Figure 222 shows the geographic distribu-

FIGURE 222.-Predicted relative potential for liquefaction-related ground failure from the postulated earthquake in the demonstration area. The oval-shaped dashed line, $18 \mathrm{~km}$ from the trace of the seismic source (heavy line), is the predicted areal limit for liquefaction effects causing ground displacements exceeding $0.1 \mathrm{~m}$. 


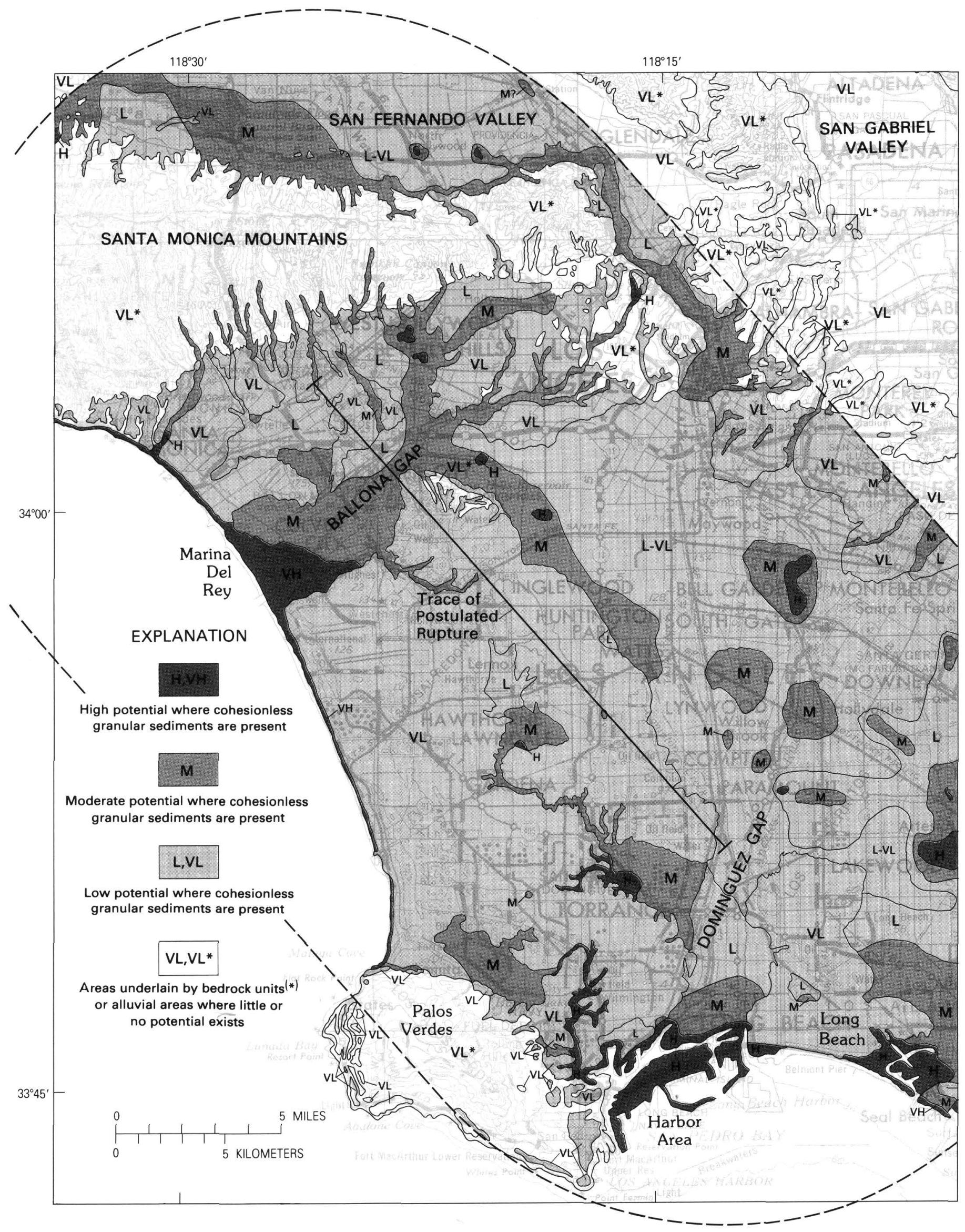

Effects of the Postulated Earthquake 435 
tion of ground within which liquefaction is likely during the postulated earthquake. These areas include all beach areas, the present and former tidal marshes and sloughs near Marina del Rey, the Los Angeles and Long Beach harbor areas, and parts of the flood-plain and tidewater areas of the Los Angeles and San Gabriel River basins. Liquefaction is less likely (but not unlikely) to occur in those areas designated as having moderate susceptibility. Areas having moderate susceptibility contain deposits that are water saturated at greater depths, are older, or are more deeply buried in comparison with areas containing highly susceptible materials. Areas designated as having low or very low susceptibility are unlikely to sustain ground failures by liquefaction, either because the deposits are unsaturated or because they are well consolidated and (or) cemented.

\section{Nature of Liquefaction Failures}

"Ground failure" is herein regarded as a permanent ground disruption exhibiting either (or both) horizontal and vertical components of displacement. Modes of liquefaction-induced ground failure include lateral spreading and ground settlement caused by lateral displacement of liquefied materials or by compaction of cohesionless, granular, water-saturated sediment, respectively. Ground failure is considered to be significant if the differential displacement exceeds $0.1 \mathrm{~m}$, the threshold required to damage common structures and engineering works (Youd and Perkins, 1978; Youd, 1980).

Lateral spreading is most likely to occur where loose, water-saturated, sandy sedimentary deposits and poorly compacted fills are situated near a free face (for example, storm-drain channels, sloughs, and waterfront areas). Once the granular water-saturated deposit has been transformed to a fluidized state, the liquefied mass is free to move toward the free face and to carry with it any engineered works constructed on or within its volume. Differential settlement is likely to occur along buried channels of former streams, in beach areas, along former sloughs in tidewater areas, and in sandy channel-fill deposits and natural levees of principal streams such as the Los Angeles and San Gabriel Rivers, Ballona Creek, and Compton Creek.

The differential settlements and displacements that result from liquefaction-related ground failure likely will include disturbances and disruptions of public and private utilities services, including surface and subgrade water, gas and sewerage facilities, storm drains, irrigation works, channelized surface drainages, and shallow-seated foundations of structures.

\section{Earthquake Hazards in the Los Angeles Region}

\section{Limitations of Prediction}

The ground-water data presently available for the demonstration area constitute a principal source of uncertainty in these predictions of liquefaction potential. There are very few well or control points used by State and local agencies to monitor shallow or perched ground water. Consequently, many occurrences of shallow ground water have been compiled from foundation investigations conducted before construction of storm drains, freeway overpasses, and public and private structures. The depth below grade at which any free or perched water was reported became the water depth used to evaluate liquefaction susceptibility. Because little is known concerning the hydrologic setting of these shallow occurrences of ground water, a seasonal recharge factor reflecting irrigation practice or rainfall doubtless controls the amount of, depth to, or, locally, the presence or absence of free ground water in near-surface sediment. We are unable to address this uncertainty in this study. The zones of potential liquefaction delineated in figure 222 are assumed to represent average or typical ground-water conditions that reflect average levels of precipitation and volumes of ground-water extraction. Water levels following winter rains are certain to be higher than water levels measured during the summer and autumn months. Consequently, seasonally and during sequences of years of above-average precipitation, the areas susceptible to liquefaction may be slightly larger than those shown in figure 222. Conversely, seasonally and during drought years, the areas susceptible to liquefaction may be smaller than those shown. Any change in the pattern of management (extraction or recharge) of the groundwater resource may also grossly modify the occurrence of shallow ground water and thus modify the limits of areas susceptible to liquefaction.

Figure 222 does not provide a site-specific prediction of liquefaction-related ground failure. Detailed geotechnical studies, including direct testing of subsurface materials, are required to identify specific sites where water-saturated, loose, cohesionless sediment occurs and where significant lateral or vertical components of ground displacement are possible.

\section{LANDSLIDING}

\section{By E. L. Harp and D. K. Keefer}

Strong shaking from the postulated earthquake is expected to trigger the local failure of many slopes within upland areas in and adjacent to the demonstration area. Figure 223 shows the predicted 50-percent probability 

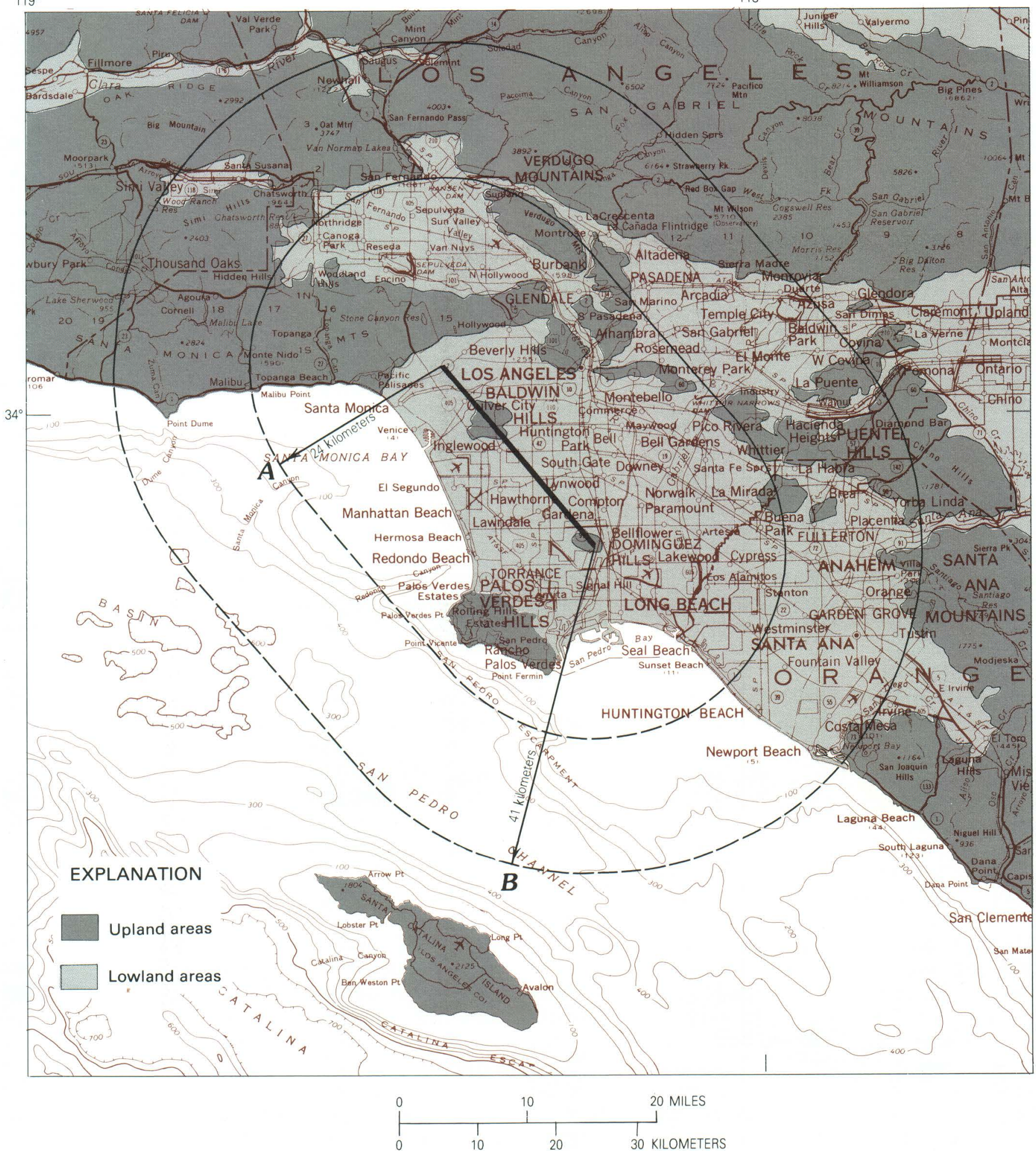

FIGURE 223.-Fifty-percent probability limits of ground motion from the postulated earthquake that exceeds threshold levels necessary to trigger landslides of different types on susceptible slopes onshore in the Los Angeles region. Darker shaded areas are uplands, which are most likely to contain susceptible slopes. Oval-shaped line A is the 50-percent probability limit for coherent failures (slumps and block slides). Oval-shaped line B is the 50-percent probability limit for disrupted failures (rock and soil falls and slides). The likelihood of ground motion sufficient to trigger landslides increases toward the postulated zone of seismic rupture (heavy line). A few landslides may occur outside the 50-perrcent probability limits at distances as great as 65 and $112 \mathrm{~km}$ from the seismic source for coherent and disrupted failures, respectively. (See Wilson and Keefer (this volume, figs. 175, 176) for the geographic outer bounds of perceptible slope failure relevant to the postulated earthquake.) 
limits of ground motion that would exceed threshold levels necessary to trigger landslides of different types on susceptible slopes. The limits were determined by using the newly established correlations (Wilson and Keefer, this volume) between earthquake magnitude, critical displacement of a slope, and intensity of shaking for an earthquake source distance appropriate to a M 6.5 earthquake. Susceptible slopes are those areas where lithologic, hydrologic, and slope characteristics are optimum for failure under seismic shaking. Because accurate slope and material-properties data are not available for the demonstration area, we can address the distribution of susceptible slopes in a general way only. Most landslides triggered by the postulated earthquake probably will occur within the ellipses shown in figure 223, but a few could occur at greater distances. The reader is referred to figures 175 and 176 (Wilson and Keefer, this volume) for the outer limits of perceptible slope failures for a $\boldsymbol{M}$ 6.5 earthquake as determined from worldwide data on historical earthquake-induced landsliding.

Areas of potential sea-floor instability also have been identified along the margins of the Santa Monica and San Pedro shelves (Clarke and others, this volume, figure 189) that are within the estimated 59-km limiting distance for subaqueous slides triggered by $M 6.5$ earthquakes (Wilson and Keefer, this volume, figs. 164C, 177). The geotechnical character of these potentially unstable slopes is not known well enough, however, to judge which, if any, might fail during the postulated earthquake.

Although many types of landslides are triggered by earthquakes (Keefer, 1984; Wilson and Keefer, this volume, table 44), for the postulated earthquake we consider only the most common types likely to occur on land and the categories of slopes that generally will fail. Furthermore, we restrict our predictions of landslide occurrence to upland areas. Liquefaction-related ground failure within alluvial deposits of adjacent valleys has been discussed in the preceding section. Our analysis of landslide occurrence from the postulated earthquake is heavily influenced by what is known about slope failures during the 1971 San Fernando earthquake. Much of the upland areas likely to sustain landslides have similar vegetative cover and topography and, in the case of the Santa Monica Mountains and the Verdugo Hills, share many of the same lithologic units as the area affected by landslides in the San Fernando earthquake.

The predominant landslide types generated will be shallow disrupted failures (soil slides, rock falls, and rock slides). As many as a few hundred landslides of each of these types are likely to occur. Most soil slides probably will occur in thin (generally less than $2 \mathrm{~m}$ ) colluvial and residual soils on slopes; most probably will originate on slopes between $35^{\circ}$ and $45^{\circ}$, but a few may occur on slopes as gentle as $15^{\circ}$. Except for a few areas where cliffs steeper than $50^{\circ}$ are abundant, most of the rock falls and rock slides will be restricted to roadcuts and other artificially cut slopes, because upland areas adjacent to the Los Angeles basin have few natural slopes in excess of $45^{\circ}$, the lower limit for most rock slide occurrences. The local climate and vegetation influence the slope limits for rock falls and rock slides. Although historical earthquake data worldwide establish general minimum slope values for rock falls and rock slides as $40^{\circ}$ and $35^{\circ}$, respectively (Wilson and Keefer, this volume, table 45), upland areas likely to be affected by the postulated earthquake generally do not have bedrock slopes of less than $50^{\circ}$ or talus slopes of less than $45^{\circ}$. Most of the upland areas having slopes less than $45^{\circ}$ to $50^{\circ}$ are grassy or covered with brush rather than being bedrock or covered with talus. Few rock falls or rock slides are likely on these colluvial or residual soil-covered slopes.

Only a few deep-seated rotational slumps and block slides in rock are expected. We cannot predict exactly where these may occur, because the data from historical earthquakes define relations between susceptible materials and slopes for rock slumps and block slides only in a general way. Worldwide experience from historical earthquakes has indicated that large preexisting slumps and block slides generally do not reactivate from seismic shaking (Wilson and Keefer, this volume; Harp and others, 1981; Keefer, 1984).

The postulated earthquake also will probably trigger several tens (possibly up to a few hundred) of slumps from those older artificial fills that have not received enough compaction to meet modern grading standards. Typical of such deposits that have shown high susceptibility in past earthquakes are fills for housing developments, railroad embankments, outer edges of road and highway embankments, dikes, and bridge abutments. Soil falls and slumps are expected along the banks of stream channels that have not been lined with concrete but will pose little hazard because of small slope heights and lack of adjacent development.

Although the postulated earthquake is expected to trigger a few scattered landslides as far distant as the outer bounds shown in figures 175 and 176 (Wilson and Keefer, this volume), landslides will be concentrated within the 50-percent probability exceedance lines for both disrupted and coherent failures, which are at 41 and $24 \mathrm{~km}$, respectively, from the postulated fault rupture (fig. 223). Slope failures (except for those related to liquefaction) will occur chiefly within several upland areas, where slopes exceed $10^{\circ}$. These areas are the Baldwin and Dominguez Hills, the eastern Santa Monica Mountains, the Palos Verdes Hills, the central Santa

438 Earthquake Hazards in the Los Angeles Region 
Monica Mountains and Pacific Palisades, the Verdugo Mountains and the adjacent San Gabriel Mountains, and the Puente Hills. Environments where the earthquake is most likely to produce slope failures from the earthquake within these areas are discussed individually below and are summarized in table 57.

\section{Baldwin and Dominguez Hills}

The most common landslide type generated in the Baldwin and Dominguez Hills by the earthquake will be shallow soil slides. We expect the incidence of soil slides to be highest within slopes underlain by the Culver sand, the Baldwin Hills sandy gravel, and the Inglewood Formation of Weber (1982), judging from the susceptibility of these units to these types of failures during the 1978-79 rainfall season and because of their generally noncohesive nature (Weber, 1982).

A few deep-seated slumps could occur in the Inglewood Formation and in artificial fill. Many of the slopes in the Baldwin Hills have been modified by cut and fill, and, where older fill slopes have not been compacted sufficiently to meet modern grading standards, they may

TABLE 57.-Areas, geologic materials, and slopes most likely to fail in the postulated earthquake, with types of landslides

$\begin{array}{ccc}\text { Area } & \text { Most susceptible } & \text { Most susceptible } \\ \text { slopes } & \text { Leologic materials }\end{array}$

Baldwin and Dominguez Hills ---- Soil slides

Eastern Santa Monica Mountains -- Rock falls and rock slides (east of Sepulveda Canyon).

Soil slides

Deep-seated slumps and block slides.

Palos Verdes Hills - slides.

Central Santa Monica - - - - - Rock falls and rock slides Mountains-Pacific Palisades.
Massive conglomerate of Topanga

Soil slides

Deep-seated slumps and block In Santa Monica Mountains: Fernslides. Verdugo Mountains and -
adjacent San Gabriel

Mountains.

Rock falls and rock slides

Puente Hills Soil slides

Rock falls and rock slides

All areas -- - Sespe Formations.
Soil developed on weakly cemented sandstone of the Culver sand, Baldwin Hills sandy gravel, and Inglewood Formation of Weber (1982). Canyon Formation.

All units susceptible; most intensely fractured, fragment size small.

All units susceptible

Shale units of Modelo and Topanga Canyon Formations.

Altamira Shale Member of Monterey Formation.

Conglomerate of Coal Canyon Formation; conglomerate and sandstone of Tuna Canyon Formation; alluvial fan deposits of Pacific Palisades.

Modelo Formation and parts of Topanga Canyon Formation.

Natural slopes, $15^{\circ}-50^{\circ}$

Falls: natural and artificial slopes steeper than $50^{\circ}$.

Slides: slopes steeper than $45^{\circ}$

Natural slopes with colluvial or re sidual soil, $20^{\circ}-50^{\circ}$.

Slopes steeper than $15^{\circ}$, generally in areas where failures already exist.

Slopes steeper than $15^{\circ}$

Slopes steeper than $50^{\circ}$ (rock falls) and $45^{\circ}$ (rock slides) in Topanga Canyon area and along Palisades.

Soil-covered slopes between $20^{\circ}$ and $50^{\circ}$.

Slopes steeper than $15^{\circ}$ wood Member of Topanga Canyon Formation; in Pacific Palisades: Topanga Canyon, Tuna Canyon, Modelo, and

Granitic, metamorphic, and igneous rock (occupies most of area).

Same as above

La Vida Member of Puente Formation.

Conglomerate in Sycamore Canyon Member of Puente Formation and lower member of Fernando Formation.

Poorly consolidated artificial fill
Slopes between $15^{\circ}$ and $50^{\circ}$ having soil cover.

Slopes steeper than $50^{\circ}$ (rock falls) and $45^{\circ}$ (rock slides)

Slopes between $15^{\circ}$ and $50^{\circ}$

Slopes steeper than $35^{\circ}$

Embankments steeper than $10^{\circ}$ 
fail. The susceptibility of artificial-fill embankments has been well documented in many earthquakes (Harp and others, 1980; California Division of Highways, 1975; Asada and others, 1980; Keefer, 1984).

\section{Eastern Santa Monica Mountains}

Nearly all lithologic units in the eastern Santa Monica Mountains are susceptible to shallow soil slides involving mantles of colluvium, residual soil, or weathered bedrock. Soil slides will occur mainly on slopes between $20^{\circ}$ and $50^{\circ}$, a maximum incidence occurring on slopes of $35^{\circ}$ to $45^{\circ}$ (on the basis of the occurrence of soil slides in the Santa Monica Mountains under conditions of heavy rainfall (Campbell, 1975) and the geometric and slope characteristics of shallow soil slides from the 1971 San Fernando earthquake (Yen and Trotter, 1978)). The steepest portions of canyons on the southern flank of the Santa Monica Mountains are the most likely sites for soil slides. Canyons on the northern flank of the range may also experience soil slides in areas underlain by the Modelo Formation, a unit that has shown high susceptibility to soil slides under high-intensity rainfall (Weber, 1979).

Rock falls and rock slides are likely in some roadcuts and other artificial slopes. Intensely fractured units such as the Santa Monica Slate and fine-grained parts of the Modelo Formation, which, upon failure, produce angle-of-repose piles of small rock fragments, are likely to produce the most rock falls; such rock falls, however, may be individually less hazardous than those produced by massive, less fractured rocks such as conglomerate and breccia of the Topanga Canyon Formation, from which boulder-sized fragments could dislodge. Long, steep slopes in the Cahuenga Peak and Mount Hollywood areas that have massive outcrops of Topanga Canyon conglomerate may produce rock falls that could gain sufficient momentum on the $40^{\circ}$ to $50^{\circ}$ slopes to travel several hundred meters.

\section{Palos Verdes Hills}

The Palos Verdes Hills contain many active, deepseated slump-earth flow-type landslides that are climate controlled and undergo accelerated movement in response to winter storms (Ehlig, 1982). The best known is the Portuguese Bend-Abalone Cove landslide complex, chiefly within the Altamira Shale Member of the Monterey Formation, which could accelerate locally because of earthquake ground motion. Scattered areas outside the boundaries of existing landslides within the Altamira Shale Member may also slump or slide as blocks. Scattered rock falls can be expected along the near-vertical cliffs bordering the ocean but will likely be thin $(1-3 \mathrm{~m})$ failures.

\section{Central Santa Monica Mountains and Pacific Palisades}

Rock falls and rock slides are likely to be numerous in the south-central Santa Monica Mountains and in the Pacific Palisades. Particularly susceptible are the late Pleistocene alluvial-fan deposits forming the Pacific Palisades that border the ocean near Santa Monica. These deposits contain near-vertical joints and support near-vertical slopes but have low cohesion (McGill, 1982). Rock falls, including large boulders, are likely north of the mouth of Topanga Canyon, where massive conglomerate of the Coal Canyon Formation forms nearvertical slopes several hundred meters high; it is here that a large (greater than $100,000 \mathrm{~m}^{3}$ ) rock fall avalanche may be triggered. Rock falls also may occur from other lithologic units where slopes are $50^{\circ}$ or steeper. Rock slides will form under slope conditions similar to those under which rock falls form, except that they will occur on slopes of $45^{\circ}$ or greater.

Soil slides will be common on slopes between $20^{\circ}$ and $50^{\circ}$ in colluvial or residual soils. The Modelo Formation, a slide-prone unit in the 1971 San Fernando earthquake (Morton, 1971), and similar beds of the Topanga Canyon Formation are the most susceptible units.

Slumps and block slides exist within clayey and silty members of the Topanga Canyon Formation, the Tuna Canyon Formation, the Modelo Formation, and the Sespe Formation in the Pacific Palisades (McGill, 1982), and extensive landslide deposits are present in the Fernwood Member of the Topanga Canyon Formation (Yerkes and Campbell, 1980). A few of these landslides may be reactivated during the postulated earthquake.

\section{Verdugo and San Gabriel Mountains}

The Verdugo Mountains and parts of the San Gabriel Mountains east of the San Fernando Valley could experience scattered soil slides, rock falls, and rock slides. Most of the Verdugo Mountains and adjacent areas of the San Gabriel Mountains consist of moderately steep slopes (up to $50^{\circ}$ ) underlain by closely fractured crystalline basement rocks. The soils developed on these rocks are characteristically granular, noncohesive, and thin (generally less than $2 \mathrm{~m}$ ). These soils occupy most slopes except those greater than $45^{\circ}$ where crystalline basement rocks are exposed. These soils are highly 
susceptible to soil slides when they are strongly shaken, but, because they are farther away from the postulated seismic source, they probably will have fewer failures than similar susceptible slopes in the eastern Santa Monica Mountains. Tertiary and Quaternary rocks and soils developed on slopes in the mountains immediately north of San Fernando will have few landslides in comparison with the 1971 San Fernando earthquake, because they are farther from the seismic source.

\section{Puente Hills}

Scattered rock falls and rock slides could occur from steep slopes formed by outcrops of resistant conglomerate of the Sycamore Canyon Member of the Puente Formation and the lower member of the Fernando Formation. Most of these slopes are located in the area north of Turnbull Canyon, the area just east of Whittier, and north of La Habra. A few scattered soil slides are also expected.

\section{Seasonal Influences on Earthquake-Induced Landslide Susceptibility}

The potential for earthquake-induced slope failures changes seasonally. Although seasonal effects on the potential for rock falls and rock slides would be slight, the susceptibility of some slopes to slumps and block slides would be increased by seasonally high groundwater levels. Moreover, intense rainfall at the time of the postulated earthquake could affect the behavior of earthquake-triggered soil slides, especially in terms of runout distance. If slopes were nearly saturated at the time of the earthquake, the shaking could liquefy the more cohesionless granular soils and mobilize the soil slide material into debris flows. Because of the fluid nature of debris flows, they can attain speeds as great as several tens of kilometers an hour if suitable runout paths exist. The characteristics of debris flows in the Santa Monica Mountains and their hazards have been well documented from past intense storms (Campbell, 1975; Weber 1979, 1980), but there are few data to estimate how much greater the occurrence of debris flows would be if an earthquake occurred when the soil was nearly saturated.

\section{OTHER EFFECTS}

The postulated earthquake is not likely to generate a tsunami because the source zone of the earthquake is entirely on land and is associated with dominantly strike-slip displacement. Furthermore, the known areas of sea-floor instability offshore from the Los Angeles region are not large enough to generate tsunamis if these areas suddenly fail owing to earthquake shaking (McCulloch, this volume). Other water-related earthquake phenomena can be expected, however. Seismically induced fluctuations of water levels in lakes, reservoirs, tanks, and wells commonly accompany earthquakes of $\mathbf{M}$ 5 or greater and have been associated with moderatesized earthquakes in southern California (Waananen and Moyle, 1971, 1972). Shaking from the 1971 San Fernando earthquake, for instance, generated a $0.6-\mathrm{m}$ surge in the Van Norman Reservoir and induced seiches (oscillations of the surface of an enclosed body of water) in countless swimming pools as far as $70 \mathrm{~km}$ from the epicenter. Water levels in wells as distant as $500 \mathrm{~km}$ from the epicenter exhibited measurable changes. Comparable effects could accompany the postulated earthquake.

\section{SUMMARY}

A moderate-sized (M 6.5) earthquake along the northern part of the Newport-Inglewood zone would generate a variety of geologic and seismologic effects that could be hazardous to people and property. The expected distribution and severity of these effects can be estimated by using many of the hazardevaluation techniques described in the previous chapters.

Fault rupture of the land surface, generated by secondary faulting along as much as $16 \mathrm{~km}$ of late Quaternary faults exposed in the Baldwin, Rosecrans, and Dominguez Hills, is expected. Oblique normal slip as great as a few tens of centimeters may occur locally. Minor movement along reverse faults in the subsurface near the Rosecrans Hills could cut nearby oil and gas wells. Tectonic elevation changes of as much as a few tens of centimeters also are expected near the earthquake source zone.

Ground shaking of Modified Mercalli intensity VI or greater will affect about $6,400 \mathrm{~km}^{2}$. Most of the alluviated parts of the Los Angeles basin and the San Fernando Valley will experience shaking of intensity VII, but intensities of VIII are predicted for some areas in the southern San Fernando Valley, near Marina Del Rey, in the Long Beach area, and locally elsewhere within about $18 \mathrm{~km}$ of the trace of the northern NewportInglewood zone. Peak ground-motion values of about $0.4 \mathrm{~g}$ acceleration, $90-$ to $100-\mathrm{cm} / \mathrm{s}$ velocity, $1.2-\mathrm{g}$ pseudoacceleration response, and 160 to $180-\mathrm{cm} / \mathrm{s}$ pseudovelocity response are predicted near the surface trace of the earthquake source zone. Numerical modeling of an idealized tectonic rupture assumed to be

Effects of the Postulated Earthquake 441 
associated with the earthquake suggests that strong shaking will last about 10 to $15 \mathrm{~s}$; if the tectonic rupture propagates northwestward from the postulated epicenter at Dominguez Gap, the components of shaking velocity normal to the trend of the rupture will be markedly higher toward the northwestern end of the Newport-Inglewood zone.

Although liquefaction-related ground failure may occur at distances as great as about $18 \mathrm{~km}$ from the earthquake source, the areas where liquefaction is most likely are the beaches, the area near Marina del Rey, the Los Angeles and Long Beach harbor areas, and parts of the Los Angeles and San Gabriel River flood plains. Strong shaking also is expected to trigger land- slides locally, rock and soil falls and slides being the predominant types of failure. These disrupted failures are most likely in the upland areas within about $40 \mathrm{~km}$ of the northern Newport-Inglewood zone. A few slumps and block glides may be reactivated, or new ones may be formed, along susceptible slopes generally within about $24 \mathrm{~km}$ of the earthquake source.

Strong shaking also will cause oscillation of the surfaces of enclosed small bodies of surface water (lakes, reservoirs, tanks, and swimming pools) at distances of up to several tens of kilometers. Levels of water in wells locally will fluctuate temporarily to distances of a few hundred kilometers. 


\title{
USING EARTH-SCIENCE INFORMATION FOR EARTHQUAKE HAZARD REDUCTION
}

\author{
By W. J. Kockelman
}

\section{INTRODUCTION}

The preceding chapters have summarized what is currently known about the major earthquake hazards in the Los Angeles region and have described methods that might be used to further evaluate the severity and distribution of such hazards. This information is valuable to society only if it is used by planners, engineers, decisionmakers, and the public to take action that will reduce the potentially destructive effects of future earthquakes.

Recently, earthquake hazard reduction in California has generated much interest; the creation of the Southern California Earthquake Preparedness Project (1981), which is making use of scientific information to develop prototypical emergency plans, is an example of that interest. This chapter illustrates, through five examples, the range of applications of geologic and seismologic information used by planners, engineers, and decisionmakers to reduce earthquake hazards in the Los Angeles region. Among the users are State legislators, State agencies, county planning commissioners, county board supervisors, mayors, council members, city and county planners, State engineers, local building inspectors, and real-estate sellers. The examples include the entire State, a metropolitan region, a $2,740-\mathrm{mi}^{2}\left(7,097 \mathrm{~km}^{2}\right)$ county, a city of almost three million people, and individual lots and acreages offered for sale. The selection of these five examples does not imply endorsement by the U.S. Geological Survey.

Each example presents a summary of the problems or needs faced by the users, the earth-science information used or available, the specific action taken, the methods and procedures used to carry out each action, and brief comments on the impact of each plan or decision and its adaptation for earthquake hazard reduction by other users. The users applied the earth-science information available at the time; they can revise, update, or amend their plans and decisions as newer or better information becomes available. Examples of similar uses of geologic and seismologic information have been reported else- where (Kockelman, 1975, 1976, 1979, 1980; Kockelman and Brabb, 1978; Robinson and Spieker, 1978; Blair and Spangle, 1979; Brown and Kockelman, 1983).

I gratefully acknowledge the many helpful comments of those who reviewed this chapter in draft form: James Kahle, Theodore Smith, and Earl Hart, geologists, California Division of Mines and Geology; Albert McCurdy, Deputy Director, Santa Barbara County Current Planning Division; David Doerner, geologist, Santa Barbara County Resource Management Department; James Gates and Guy Mancarti, bridge engineers, California Department of Transportation; Earl Schwartz, Chief, Conservation Bureau, Los Angeles Department of Building and Safety; Glenn Johnson and Victor Hernandez, Citywide Planning Division, Los Angeles City Planning Department; Rachel Gulliver Dunne, senior geologist, Dames and Moore, and former President, Los Angeles Board of Building and Safety Commissioners; William Spangle and George Mader, William Spangle and Associates; J. Laurence Mintier, planning consultant, formerly of the California Office of Planning and Research; and Richard Andrews, Assistant Director, California Office of Emergency Services, and former Executive Director, California Seismic Safety Commission.

\section{ANTICIPATING DAMAGE TO CRITICAL FACILITIES}

Scenarios can be used to assess the impact of a major future earthquake. A scenario is usually thought of as a synopsis or outline of a play or a movie; thus, a scenario for an earthquake can be considered a synopsis or outline of a large seismic event and its severe impacts on an urban region. Our first example shows how a scenario can be used to assess the effects of a future earthquake on principal lifelines for emergency planning purposes. An analysis of readiness can then be used to provide planning insights, recommend further work, and serve as a basis for making or improving emergency preparedness, response, recovery, and reconstruction plans. 
Property losses to buildings and their contents, deaths, injuries requiring hospitalization, and failure of critical facilities ${ }^{9}$ and other facilities were estimated for seven postulated earthquakes in California, including a $M_{L} 8.3$ event on the southern San Andreas fault system in the Los Angeles-San Bernardino region, by the Federal Emergency Management Agency (FEMA) (1980, p. 15-26). FEMA and the California Office of Emergency Services then conducted an analysis of readiness and discussed Federal, State, and local responses and response planning (Federal Emergency Management Agency, 1980, p. 27-32, 43-51). In addition, the National Oceanic and Atmospheric Administration (Algermissen and others, 1973) made a study of earthquake losses in the Los Angeles area; Blume and others (1978) predicted damage to structures in southern California; and the U.S. Geological Survey (USGS) (1981) presented detailed scenarios for the seven postulated earthquakes affecting major California population centers, including the Los Angeles and San Diego metropolitan regions.

Many critical facilities, particularly lifelines, are vulnerable to the effects of earthquakes. Landslides and rock falls, for example, can block highways and railways; surface fault ruptures can damage highways, runways, and railbeds or break sewer, water, or fuel pipelines and thereby cause pollution and fire hazards. Strong shaking can cause transmission lines and overpass structures to fail, and power transmission and highway and railway use will be interrupted; liquefaction and the resulting ground failures can cause failure of bulkheads, piers, and quays and thereby disrupt shipping.

A radio network may use a complex combination of telephone lines, microwave circuits, satellite interfaces, and underground cables. According to Davis and others (1982, p. 68), the failure of one link in this "electronic chain" can effectively disable a large portion of the system. Most of southern California's water supply arrives by way of three major aqueduct systems-the Los Angeles Aqueduct from the eastern Sierra Nevada Mountains, the California Aqueduct from northern California, and the Colorado River Aqueduct. Both the Los Angeles and the Colorado River Aqueducts cross the San Andreas fault; the California Aqueduct closely parallels the San Andreas fault for over $160 \mathrm{mi}(100 \mathrm{~km})$ and crosses the fault at four locations (see fig. 226).

\footnotetext{
9The term "critical facilities" is used here to include (1) lifelines such as major communication, utility, and transportation facilities and their connections to emergency facilities; (2) unique or large structures whose failure might be catastrophic, such as dams or buildings where explosive, toxic, or radioactive materials are stored or handled; (3) high-occupancy buildings such as schools, churches, hotels, offices, auditoriums, and stadiums; and (4) emergency facilities such as police and fire stations, hospitals, communications centers, and disaster-response centers.
}

\section{Earthquake Hazards in the Los Angeles Region}

\section{Earth-Science Information}

Evernden and others (1981) have developed procedures for predicting the intensities of any hypothetical earthquake at any location in the conterminous United States. Their computer model calculates the groundshaking parameter of Rossi-Forel or Modified Mercalli intensity on a grid of reference points throughout a region by using equations that include the influence of the distance from the fault source, the attenuation, and the geology of the area. They published a series of intensity maps for specific earthquakes, including a magnitude 8.3 event on the southern part of the San Andreas fault. Their work includes a map of southern California (Evernden and others, 1981, pl. 1) showing 10 ground-condition units correlated to geologic units digitized on a $1 / 2-\min \times{ }^{1 / 2}$-min grid and 8 categories of predicted Rossi-Forel intensities for an event similar to the 1857 Fort Tejon earthquake.

Geologic information at a scale of $1: 250,000$ is available from the California Division of Mines and Geology (CDMG) Geologic Atlas of California. Information on ground water and liquefaction is available from the USGS, the CDMG, and other sources, including Youd and others (1979), Fife and others (1976), and local and metropolitan water departments.

\section{Decision}

Using an intensity map provided by the USGS, the CDMG prepared a planning scenario for the Governor's Emergency Task Force on Earthquake Preparedness based on a repeat occurrence of the great Fort Tejon earthquake of January 9, 1857 (Davis and others, 1982). The map was based on the method described by Evernden and others (1981) and was modified according to additional geologic information. The scenario assumed that a magnitude 8.3 earthquake on the southern San Andreas fault would produce:

- Two hundred miles $(320 \mathrm{~km})$ of surface rupture from Cholame Valley in northern San Luis Obispo County to near San Bernardino.

- Intense shaking continuing for at least $60 \mathrm{~s}$ throughout the planning area.

- Slip (predominantly horizontal) on the fault reaching a maximum of $33 \mathrm{ft}(10 \mathrm{~m})$ within a zone generally less than $330 \mathrm{ft}(100 \mathrm{~m})$ wide.

- No concurrent secondary movement on other faults.

- Aftershocks, with some events as large as magnitude 7 continuing for several weeks. 
Zones roughly paralleling the postulated surface rupture along the San Andreas fault are shown on a map (fig. 224) as isoseismal areas (that is, areas within which the anticipated seismic intensities are comparable). Each zone is assigned an intensity rating based on the Rossi-Forel (RF) scale. According to Davis and others (1982, p. 34):

Regionally, the isoseismal values diminish to intensity 7 or less (R-F) southward and westward across the Los Angeles Basin toward the coast at successively greater distances from the fault. In the Long Beach and Huntington Beach areas, the Santa Clara Valley, and Ventura-Oxnard areas farther west, the groundwatersaturated substrates are considered to be intensity 8 (R-F) with ground failure potential. These regional patterns associated with the scenario event are of sufficient plausibility to form a credible basis for valuation of general effects upon lifelines that service the greater Los Angeles area and adjacent communities.

Davis and others' (1982) map showing the distribution of seismic intensity (fig. 224) is intended for emergency planning purposes only and is based on the following hypothetical chain of events: the specified earthquake occurs, various localities in the planning area experience a specific type of shaking or ground failure, and certain critical facilities undergo damage and others do not. Because the scenario is based on the occurrence of a specific earthquake on the San Andreas fault, it is not valid for the assessment of possible damage produced by an earthquake on any other fault or by a different earthquake on the San Andreas fault (Davis and others, 1982, p. 23).

\section{Application}

Davis and others (1982, p. 35-116) developed individual scenarios showing damage to critical facilities, specifically lifelines such as highways, airports, railroads, marine facilities, communication lines, watersupply and waste-disposal facilities, and electrical power, natural gas, and petroleum lines. The scenarios for lifelines are based on evaluation of earthquakeengineering literature, comments by numerous engineers and officials of public agencies, and judgments by the authors. This assessment of the effects of the earthquake on lifelines was made to establish a regional pattern of ground shaking and ground failure (fig. 224) and to evaluate the resulting performance of lifeline segments throughout the Los Angeles region. The communications map, for example, assesses telephonesystem performance following the postulated earthquake (fig. 225). Other maps (those for water-supply and waste-disposal facilities, for example) (fig. 226) show the location of and estimates of damage to facilities. Most of the planning maps for the scenario contain notations that are explained in the text; for example, the notation W12 on a Metropolitan Water District transmission pipeline shown in figure 226 reads, "Water deliveries through the MWD Upper Feeder will be temporarily interrupted by pipe rupture where this major transmission line crosses the Santa Ana River."

According to Davis and others $(1982$, p. 9), most of the lifelines will sustain significant damage that could require a major emergency-response effort. Each scenario map is accompanied by a discussion of the general patterns of effects of the earthquake:

Interstate 5 from the San Joaquin Valley and Interstate 15 through Cajon Pass will be closed, leaving U.S. 101 along the coast as the only major viable route open from the north. Highway connections with San Diego will remain open. (p. 37)

Not all of the (telephone) systems in the greater Los Angeles region are set up to process emergency calls automatically on previously established priority bases. Thus overloading of equipment still in service could be very significant. (p. 67)

Two of the three major aqueduct systems that import water to southern California will be ruptured by displacement of the San Andreas fault, and supply will not be restored for a three- to six-month period. (p. 85)

Each planning map is accompanied by specific examples of anticipated damage:

In San Bernardino County, Interstate 15 will be closed by settlement of major fills and rockfalls in Cajon Canyon. Other freeway damage along Interstate $15 \mathrm{E}$ to the south, including major damage to the Interstate $15 \mathrm{E} / 10$ interchange will result in closure of this route south to Riverside and Interstate 10 to the east. (p. 39)

Norton Air Force Base near San Bernardino could experience some shaking of an intensity high enough to damage runways through the secondary effects of ground

Using Earth-Science Information 


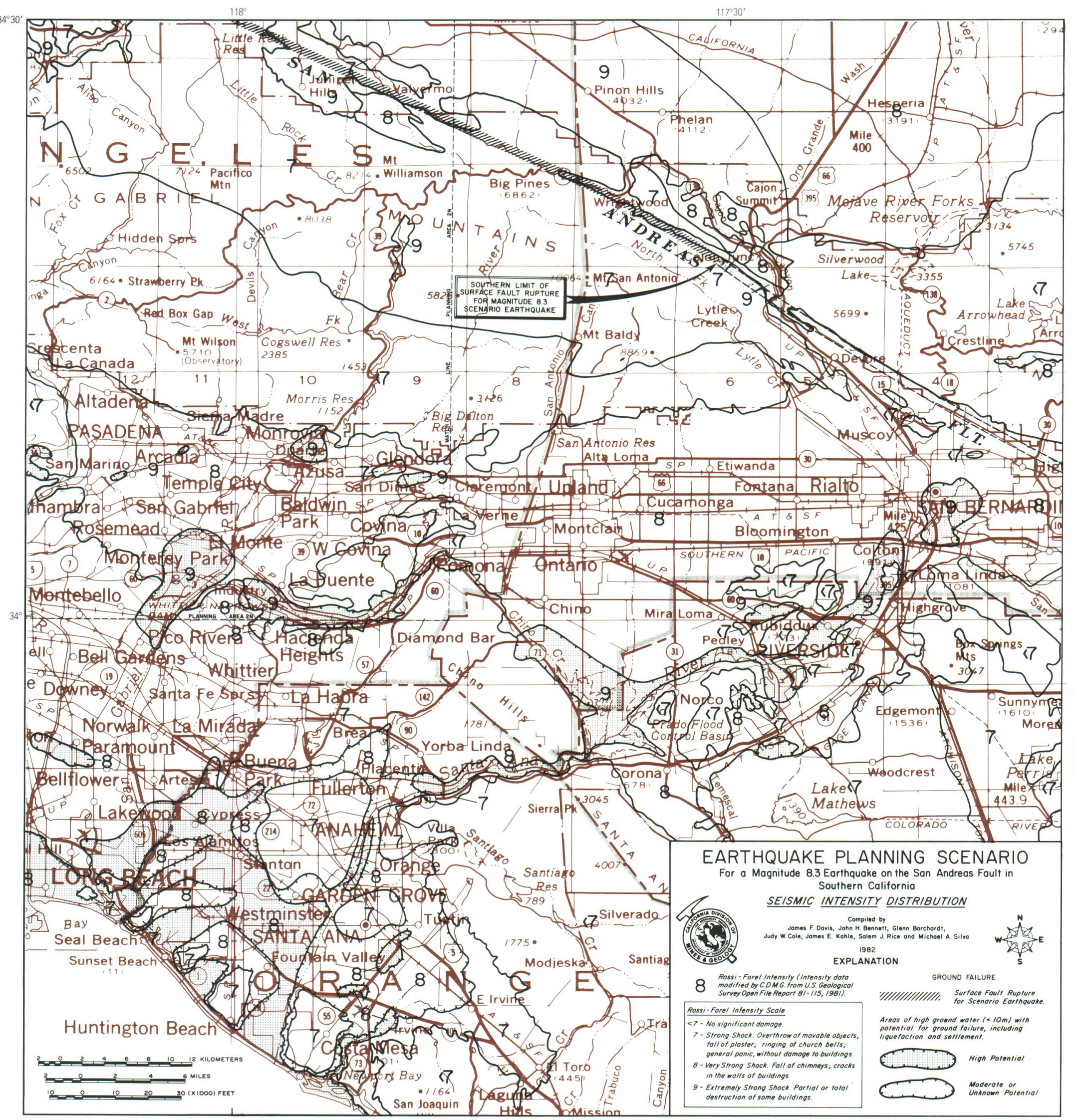

FIGURE 224.-Predicted seismic intensity distribution from an 1857-sized earthquake along the south-central San Andreas fault for part of the Los Angeles region. Compilation by Davis and others (1982) shows areas subject to surface fault rupture, liquefaction or other ground failure, and predicted intensity corresponding to the Rossi-Forel scale. Richter (1958, p. 651) aligned the Rossi-Forel (arabic numerals) and Modified Mercalli (roman numerals) intensity scales as follows: 1 (I), 1 to 2 (II), 3 (III), 4 to 5 (IV), 5 to 6 (V), 6 to 7 (VI), 8 - (VII), 8 + to 9- (VIII), $9+$ (IX), and $10(\mathrm{X}-\mathrm{XII})$.

446 Earthquake Hazards in the Los Angeles Region 


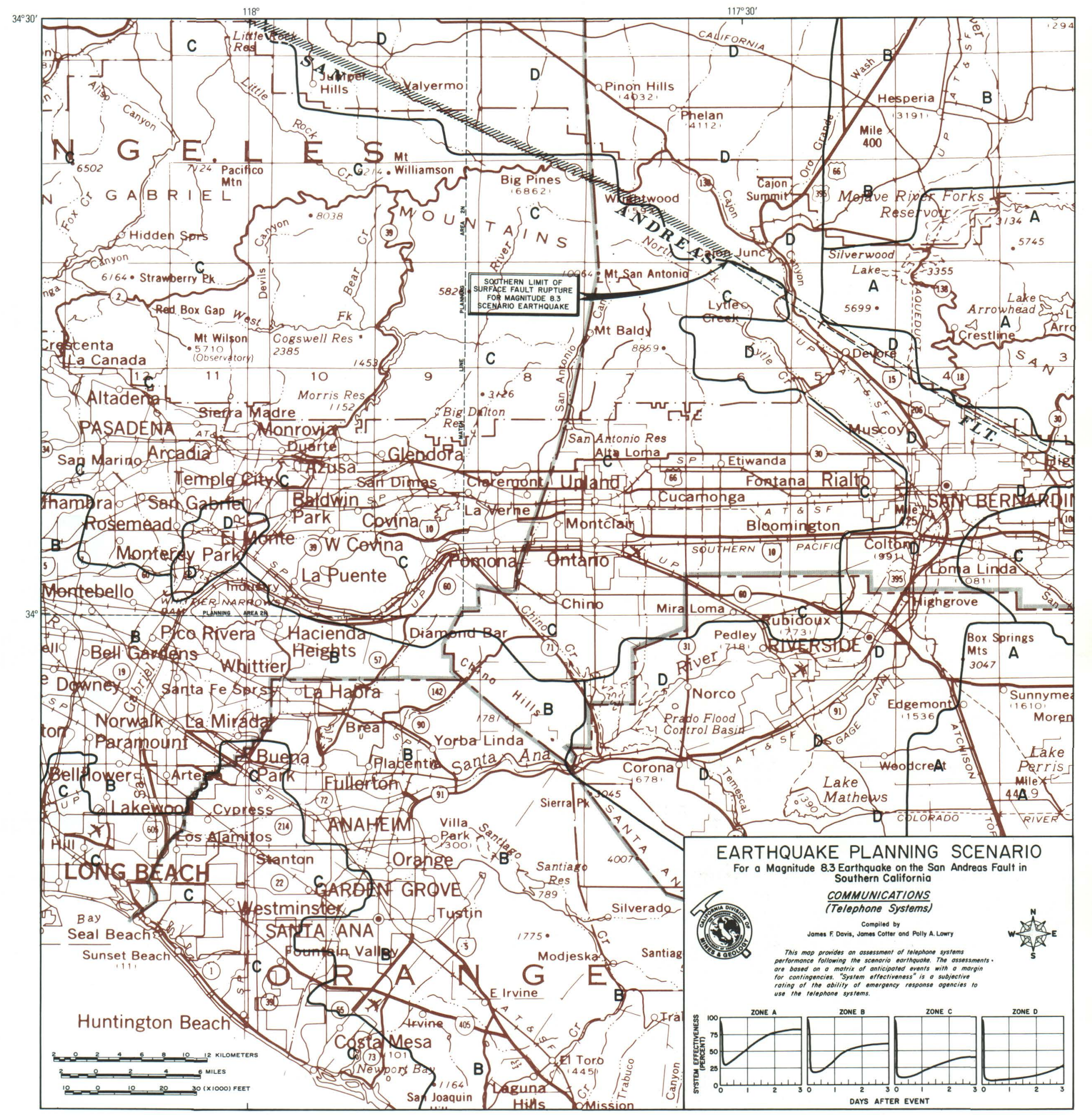

FIGURE 225.-Impact of scenario San Andreas earthquake on communications (telephone systems) for part of the Los Angeles region. Compilation by Davis and others (1982) shows the percentage of telephone-system effectiveness in four zones designated A, B, C, and D up to 3 days after the postulated earthquake. 


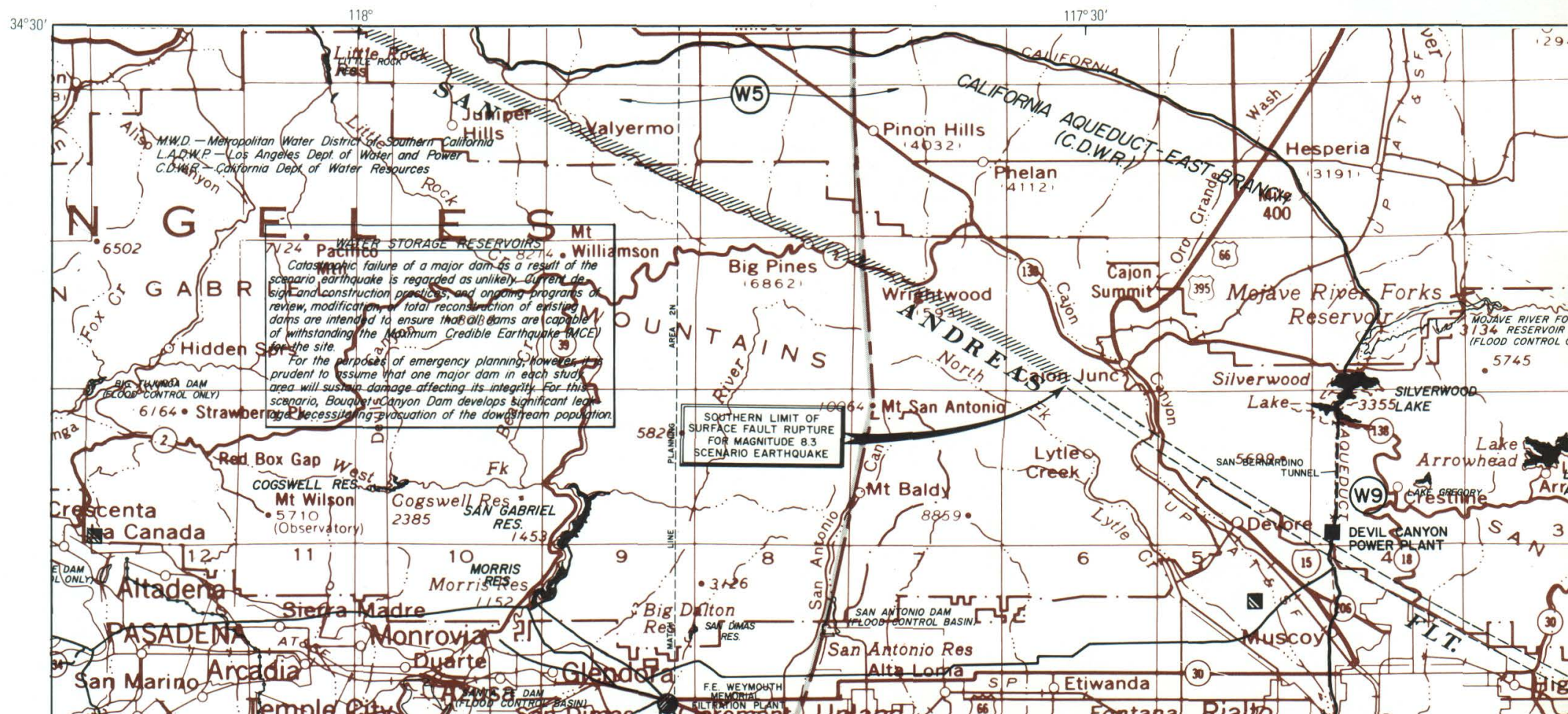

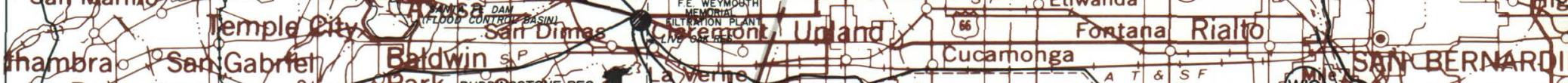

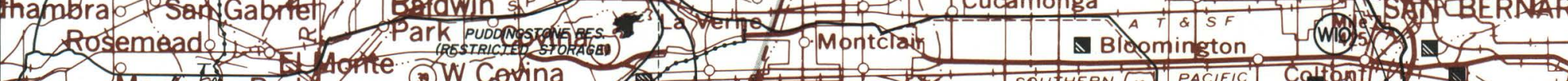
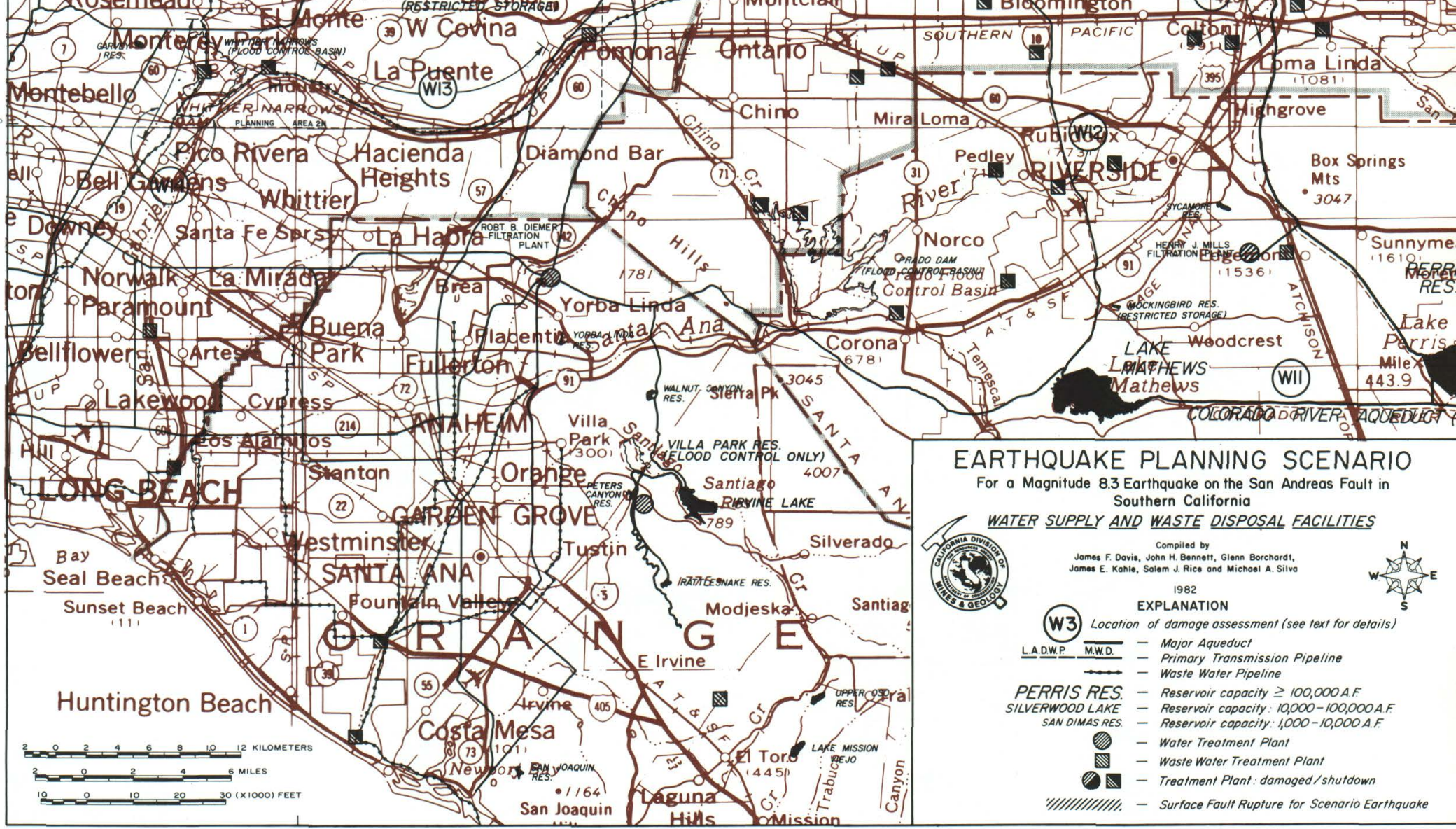

FIGURE 226.-Impact of scenario San Andreas earthquake on water-supply and waste-disposal facilities for part of the Los Angeles region. Compilation by Davis and others (1982) shows the location of and estimates of damage to specific facilities (aqueducts, pipelines, reservoirs, and treatment plants) from the postulated earthquake. The damage to specific facilities labeled $\mathrm{W}$ and numbered on the map are explained in the text accompanying the map. 
failure. Some damage could also occur to runways at Los Alamitos Armed Forces Reserve Center, but this may not be great enough to disrupt emergency operations. (p. 51)

The several hydroelectric-power plants located on the California and Los Angeles aqueducts in northwestern Los Angeles County and the Devil Canyon Power Plant near San Bernardino will be out of service for an extended period of time due to major damage to both of the aqueduct systems. (p. 100)

Each planning map for the scenario is also accompanied by planning needs:

Emergency planners need to identify major emergency routes that can be most readily opened immediately following the earthquake....alternative emergency routes should be selected which are at grade, wide, not flanked by buildings which are likely to be damaged, and not likely to be obstructed by fallen powerlines or other obstructions. (p. 40-41)

Selection of air cargo delivery sites will influence the manner in which off-loaded personnel and supplies will be distributed by helicopters, highway, rail, or marine transport. Preferred airports need to be identified. (p. 52)

Plans should be developed to ensure gas availability for those users who have priority emergency responsibilities. (p. 110)

Each planning map is also accompanied by some recommendations for further work:

An inventory of commercial and amateur broadcasting capabilities should be undertaken and the resulting information employed in developing the regional emergency communications plan. (p. 83) Further analysis should be undertaken to confirm the tentative conclusion that up to 50 percent of the total power supply could be lost by this or a similar scenario earthquake and evaluate utility capabilities necessary to accomplish timely repairs to various damaged facilities. (p. 104)

Plans for fire control should be developed for areas where these pipelines cross the San Andreas fault. Plans should also exist to ensure distribution of fuel supplies to airports selected for emergency activity and to other locations where fuel supplies for emergency response activities will be needed. (p. 115)

\section{Comments}

Each planning map contains a caveat to users concerning the assessment of damage:

The conclusions regarding the performance of facilities are hypothetical and not to be construed as site-specific engineering evaluations. For the most part, damage assessments are strongly influenced by the seismic intensity distribution map for this planning area. There is disagreement among investigators as to the most realistic model for predicting seismic intensity distribution. None have been fully tested and each would yield a different earthquake planning scenario. Facilities that are particularly sensitive to emergency response will require a detailed geotechnical study.

The damage assessments are based upon this specific scenario. An earthquake of significantly different magnitude or epicentral location on this or any one of many other faults in the planning area will result in a markedly different pattern of damage.

It should be stressed that the lifeline damages anticipated in the scenario are for planning purposes only, and some may consider them overly pessimistic. In emergency planning, however, it is important to consider the worst possible disruptions of lifelines after a major earthquake so as to be better able to prepare, re spond, and recover.

\section{ADOPTING SEISMIC SAFETY PLANS}

The California Legislature (1971, sec. 65300 and following) requires that each city and county prepare and adopt a comprehensive, long-term general plan for 
the physical development of the county. In addition to other elements, this general plan must include:

A seismic safety element consisting of an identification and appraisal of seismic hazards such as susceptibility to surface ruptures from faulting, to ground shaking, to ground failures, or to the effects of seismically induced waves such as tsunamis and seiches.

The seismic safety element shall also include an appraisal of mudslides, landslides, and slope stability as necessary geologic hazards that shall be considered simultaneously with other hazards such as possible surface ruptures from faulting, ground shaking, ground failure, and seismically induced waves.

All counties in the Los Angeles region have prepared and adopted seismic safety plans (Orange County Environmental Management Agency, 1975; Los Angeles County Department of Regional Planning, 1974; Riverside County Planning Department, 1978; Santa Barbara County Planning Department, 1979; San Bernardino County Planning Department, 1979; San Diego County Environmental Development Agency, 1975; Ventura County Environmental Resources Agency, 1974). Santa Barbara County's plan is presented here to illustrate how a seismic safety plan is prepared and adopted.

Santa Barbara County lies in the Transverse Range and southern Coast Range provinces. The county includes $2,740 \mathrm{mi}^{2}\left(7,097 \mathrm{~km}^{2}\right)$ and four channel islands. Because of its excellent climate, Santa Barbara County has been experiencing a rapid growth in population. According to the Santa Barbara County Planning Department (1979, p. 14), the county is not yet so urbanized that planning is in the "too little and too late" category. The department's report stated that

... in the past, rapid population growth in California has pushed new urbanized development into geologically unfriendly terrain, where even minimal precautions were not observed because of ignorance of facts that were often readily available. Planning can avoid the areas least feasible for development from a geologic point of view.

For more than two centuries, significant earthquakes have been felt or have caused damage in Santa Barbara County. Strong shaking and major damage from earthquakes occur an average of every 15 to $20 \mathrm{yr}$.

\section{Earthquake Hazards in the Los Angeles Region}

\section{Earth-Science Information}

Much geologic and seismologic information is available and is referred to in the report by the Santa Barbara County Planning Department (1979, p. 181-190). Basic geologic maps, for example, have been prepared by Dibblee (1950, 1966, 1973) and Woodring and Bramlette (1950). Various USGS papers on ground-water supply (Evenson and Miller, 1963; Muir, 1968; Upson, 1951; Worts, 1951) have been used to identify areas of possible liquefaction. A report on recency of faulting by Ziony and others (1973) is frequently cited, as is a report on seismicity by Hamilton and others (1969). The discussions of seismic risk refer to methods for calculating recurrence intervals on the basis of long-term slip rates on the fault as developed by Wallace (1970), Clark and others (1972), and Lamar and others (1973).

\section{Decision}

The county planning department used a consultative team headed by a firm of city and regional planners (Livingston and Associates) and a firm of consulting engineers and geologists (Moore and Taber). The county board of supervisors unanimously adopted the county seismic safety plan on January 22, 1979. The planning department and the investigative team were assisted by area advisory committees and others, including the California Earth Science Corporation, Lindvall-Richter and Associates, and R. M. Norris and R. W. Webb of the University of California, Santa Barbara. The Santa Barbara County Planning Department (1979, p. 7) stated that:

The study consisted primarily of a thorough review of the general geology of Santa Barbara County and its compilation onto base maps, and an investigation of the main geologic and soil problems, with emphasis on those associated with faults and earthquakes. Specific geologic and soil problems that were considered, together with their effect on land use planning, were ground rupture, ground shaking, tsunamis and seiches, soil liquefaction, landslides and slope stability, expansive soils, soil creep, compressible and collapsible soils, high groundwater, erosion and shoreline regression, and subsidence.

The county was divided into four study areas mainly on the basis of population patterns and potential 
development. According to the Santa Barbara County Planning Department $(1979$, p. 33), geologic, soil, and seismic factors "affect the suitability of land for various uses and... should be considered, along with other factors, in land-use planning in order to eliminate or minimize their adverse effects..." The department also developed the following tabulation, which provides a rough classification of factors to be considered in land-use planning:

\section{Critical:}

Ground rupture from fault movement

Tsunamis and seiches

Liquefaction

Sometimes critical:

Ground shaking

High ground water

Subsidence (normally correctable with engineering)

Slope stability and landslides

Soil creep

Less critical:

Expansive soils

Compressible and (or) collapsible soils

The county planning department (p. 33) concluded that:

Ground rupture from fault offset and tsunamis and seiches are the only geologic problems for which there are no really feasible engineering solutions, and which could be considered as dominant factors in planning (assuming fairly frequent occurrence). Items lower on the list should also be taken into account during development, and probably should be given some consideration in planning land use or density.

\footnotetext{
"Seismic Safety and Safety Element," a report prepared by the Santa Barbara County Planning Department (1979), includes a description of each geologic and seismologic hazard. The fundamentals of engineering seismology (including earthquake intensity, magnitude, frequency, recurrence intervals, and duration of shaking) are discussed; general seismicity and a condensed earthquake history are presented; a three-zone seismotectonic map for each study area is shown; earthquake recurrence intervals for the San Andreas and Big Pine faults are estimated; 47 faults classified as either active, potentially active, or inactive are described; five major areas subject to inundation by future tsunamis are identified; areas subject to liquefaction are mapped (fig. 227); and areas subject to landsliding are identified and mapped.
}

\section{Application}

Geologic and seismologic information was compiled and transferred to USGS $7^{1 / 2}-$ min quadrangle maps (topographic series) at a scale of 1:24,000 (1 in =2,000 ft) for the four study areas. A reproducible mylar geologic map of the county at a scale of $1: 96,000$ ( 1 in $=8,000 \mathrm{ft})$ is on file at the county's public works department. The geologic maps show major bedrock units, surficial geologic units, faults, and folds.

The hazards were evaluated and rated according to their severity by applying geologic and engineering judgments. The areal extent and severity of the hazards were shown on the topographic base maps for the study areas. The data were then transferred to 5 -acre $(2 \mathrm{ha})$ grid base maps, and the ratings for individual hazards were encoded to produce computerized maps. Each geologic hazard evaluated was given one of three ratings-high, moderate, or none to low (fig. 227).

The Santa Barbara County Planning Department (1979) then assigned a composite number, on the basis of known geologic hazards, as an overall indication of the difficulty of developing any particular area. The department devised a system for rating geologic hazards for a given area on both an individual and a collective basis-a system that could be implemented by computer. The resulting cumulative value was designated the geologic problem index (GPI). The GPI values for the four study areas were obtained by multiplying each geologic hazard by a weighting factor that took into account the seriousness of the hazard, the difficulty of alleviating it, and the frequency of its occurrence. The GPI values were then divided into five categories ranging from low through moderate to severe.

The GPI was calculated for each 5 -acre ( 2 ha) cell in the computer-analysis areas for each study area and then assigned to the appropriate severity category and displayed on a computer-produced map (fig. 228). These computer GPI maps thus reflect a summation of the ratings delineated on the geologic hazard maps (fig. 227).

Recommendations then were made by the Santa Barbara County Planning Department (1979) concerning land use planning, subdivision procedures, grading codes, building codes, and land-stability insurance. The land use planning section, for example, contains the following recommendation concerning areas designated as severe on the GPI index:

These areas should be given primary consideration for minimum development and use. They could be planned as natural areas, or for recreational or agricultural use. If development is permitted, it should generally be of low density. (p. 139)

Using Earth-Science Information 


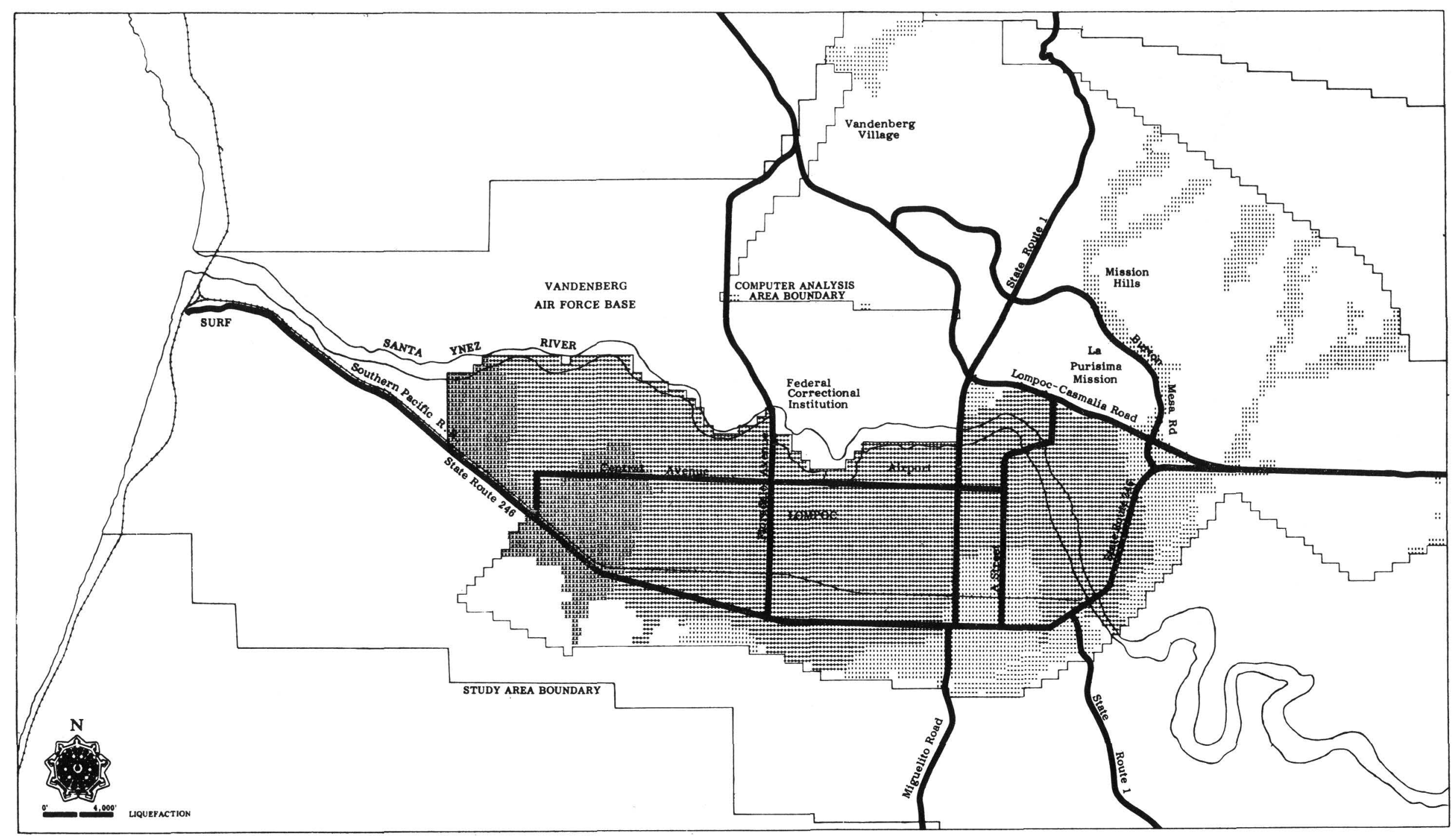

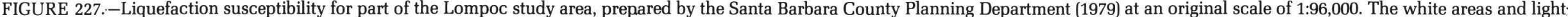

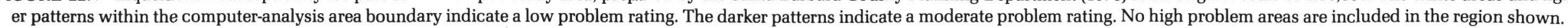




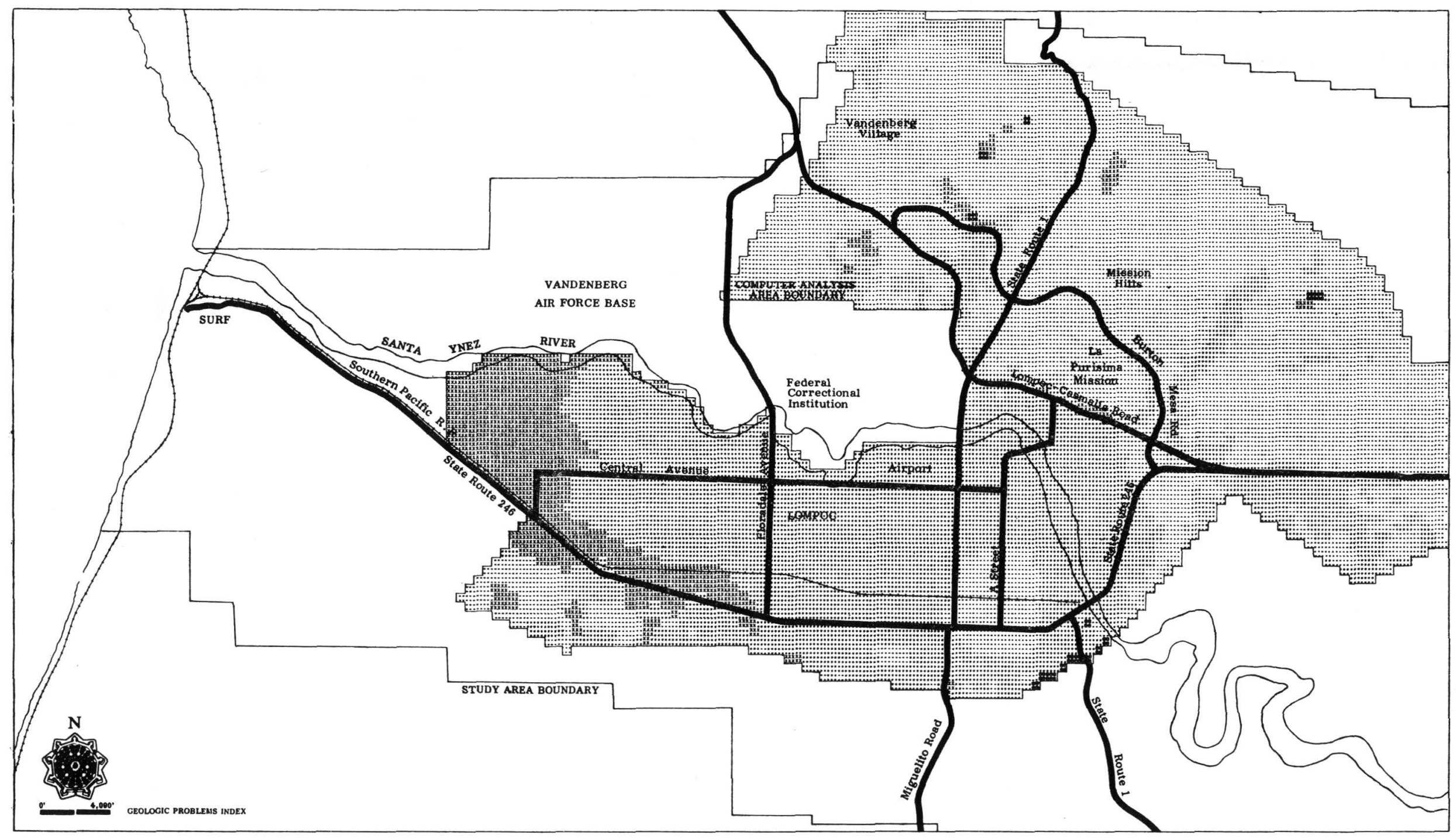

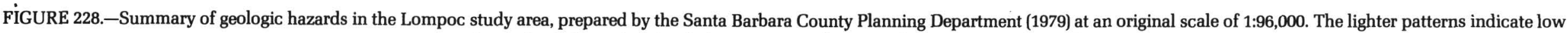
to moderate hazards. The darker patterns indicate moderate to severe hazards. 
One of the recommendations concerning subdivision procedures is that geologic reports should generally be required when the property contains or is near an active or potentially active fault or has a moderate to severe GPI.

In addition, the county planning department made recommendations for future studies such as updating basic geologic maps, investigating potentially active faults, installing additional seismic instrumentation, and inventorying existing structures to determine their physical conditions and locations relative to potential geologic problems.

\section{Comments}

This example illustrates how a county planning department, assisted by planning, engineering, and geotechnical consultants, compiled, evaluated, digitized, and rated a wide range of geologic and seismologic information. The Santa Barbara County Planning Department (1979, p. 138) concluded that the time and effort expended on developing the GPI system for the county were well spent and that,

[as] a planning aid, it shows the range in occurrence and severity of geologic problems within the County, providing valuable input necessary to the development of an intelligent plan for land use. The individual problem rating maps can be used by developers and by the various governmental agencies responsible for their supervision and guidance as an index to the specific geologic problems that can be expected in a particular area.

\section{RETROFITTING HIGHWAY BRIDGES}

The 1971 San Fernando earthquake represented a major turning point in the development of seismic design criteria for bridges. Gates (1976, p. 2301), a senior bridge engineer in the California Department of Transportation (CALTRANS), reported that, before the earthquake, very little bridge damage was caused directly by vibrational effects; however,

[after] the 1971 San Fernando event. ..we observed a significant amount of vibrational effects on bridge structures....

454 Earthquake Hazards in the Los Angeles Region
These effects were the result of very large vertical and horizontal ground accelerations, possibly exceeding $0.5 \mathrm{~g}$....The total damage to highway bridges in San Fernando was about $\$ 6,500,000$. The major damage, especially the vibrational damage, was concentrated within the narrow region close to and possibly within the causative fault zone of the magnitude 6.6 event.

One of the problems was a design feature deliberately built into bridges and overpasses throughout the United States during the 1950's and 1960's. Bridge and overpass superstructures traditionally were not attached to the supporting piers and abutments to accommodate expansion and contraction caused by temperature changes; the weight of the roadbed was expected to hold them in place. The flaw in this design feature was not realized until the 1971 earthquake, when the ends of many bridges in the San Fernando Valley fell off the abutments or hinge seats upon which they sat. CALTRANS has found that 1,133 of the approximately 13,000 bridges throughout the State need attention and is now focusing on retrofitting the unrestrained joints of these bridges $(\mathrm{J}$. H. Gates, written communication, 1981).

\section{Earth-Science Information}

After the 1971 San Fernando earthquake, a map showing maximum credible ground acceleration on bedrock from future California earthquakes was prepared by the CDMG (Greensfelder, 1972). The method used assumed that faults active in Quaternary time would indicate the distribution of future earthquake epicenters (Greensfelder, 1973). According to Gates (1976), each of the selected faults was then assigned a maximum probable earthquake magnitude based on Bonilla's (1970) data on fault rupture length. A set of curves relating peak ground acceleration, distance from fault rupture, and magnitude based on Seed and Schnabel's (1972) work was used to plot peak ground-acceleration values for bedrock sites on each fault. These values were then contoured to produce a map covering all of California, a portion of which is shown in figure 229. Gates (1976) discussed how this map information is combined with soil data and used as a basis for the seismic design criteria for California's bridges.

More recently, probabilistic estimates of the levels of ground shaking have been made. Thenhaus and others (1980), for example, showed earthquake shaking anticipated in California coastal and Outer Continental Shelf areas on a series of six maps at a scale of 


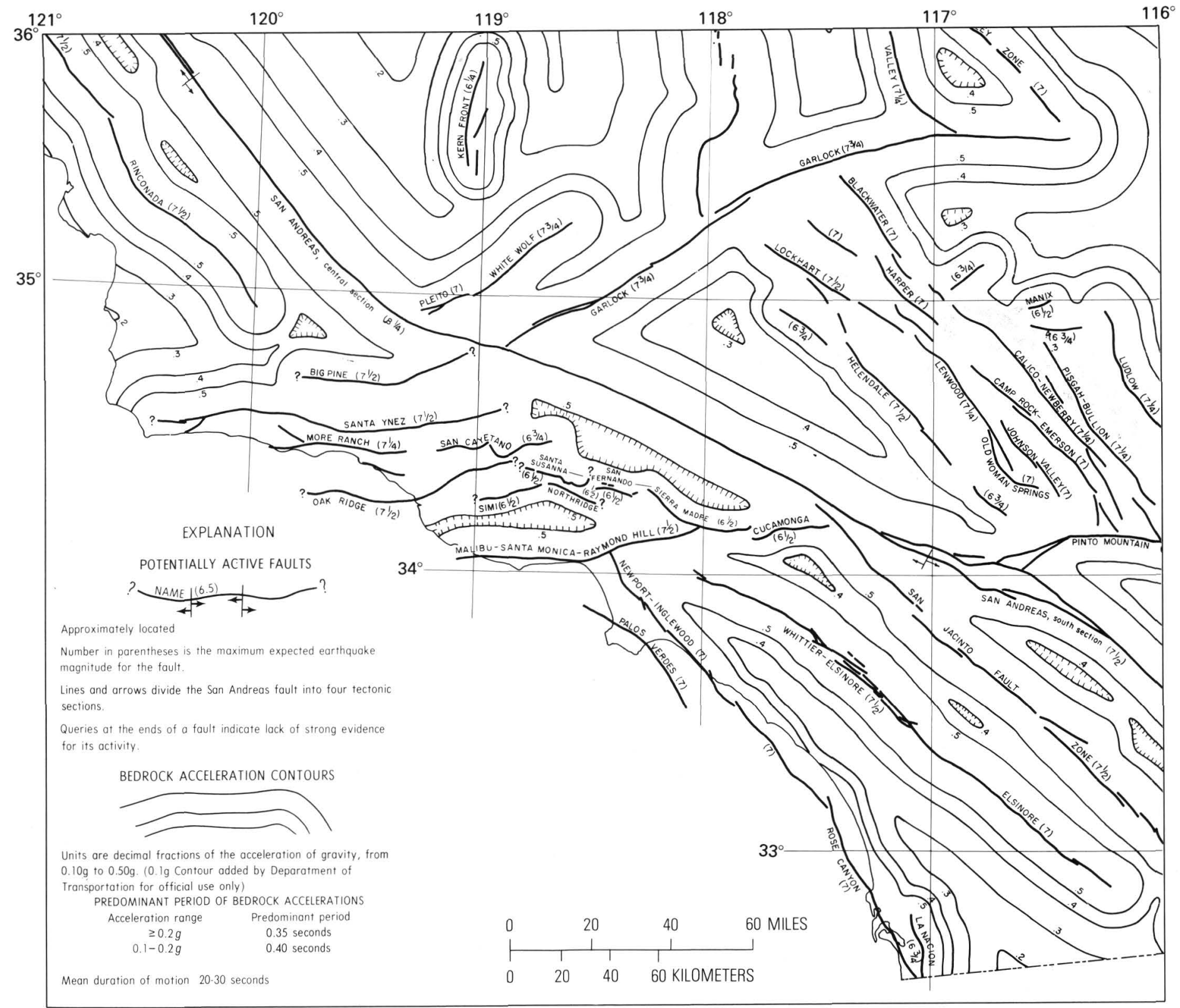

FIGURE 229.-Maximum credible ground acceleration on bedrock from future earthquakes, prepared by Greensfelder (1972) at an original scale of 1:2,000,000 to show potentially active faults and acceleration contours for part of southern California. Numbers next to a fault name indicate the maximum assumed magnitude for an earthquake on that fault.

1:5,000,000. The maps show values of peak horizontal acceleration and peak horizontal velocity on rock that have a 90-percent probability of not being exceeded in 10 , 50, and $250 \mathrm{yr}$, the return periods being approximately 100, 500, and 2,500 yr, respectively. Algermissen and others (1982) showed earthquake shaking anticipated for the contiguous United States on a series of six maps. The maps show maximum values of horizontal acceleration and horizontal velocity in rock that have a 90-percent probability of not being exceeded in 10, 50, and 250 yr. Hays (1980) reviewed the current proce- dures for specifying the characteristics of ground motion needed for earthquake-resistant design.

\section{Decision}

One of the major conclusions drawn after the 1971 San Fernando earthquake was that deficiencies in details, especially at connections of major structural components, played a major role in all of the collapse failures of bridges. According to Gates (1976, p. 2302), 


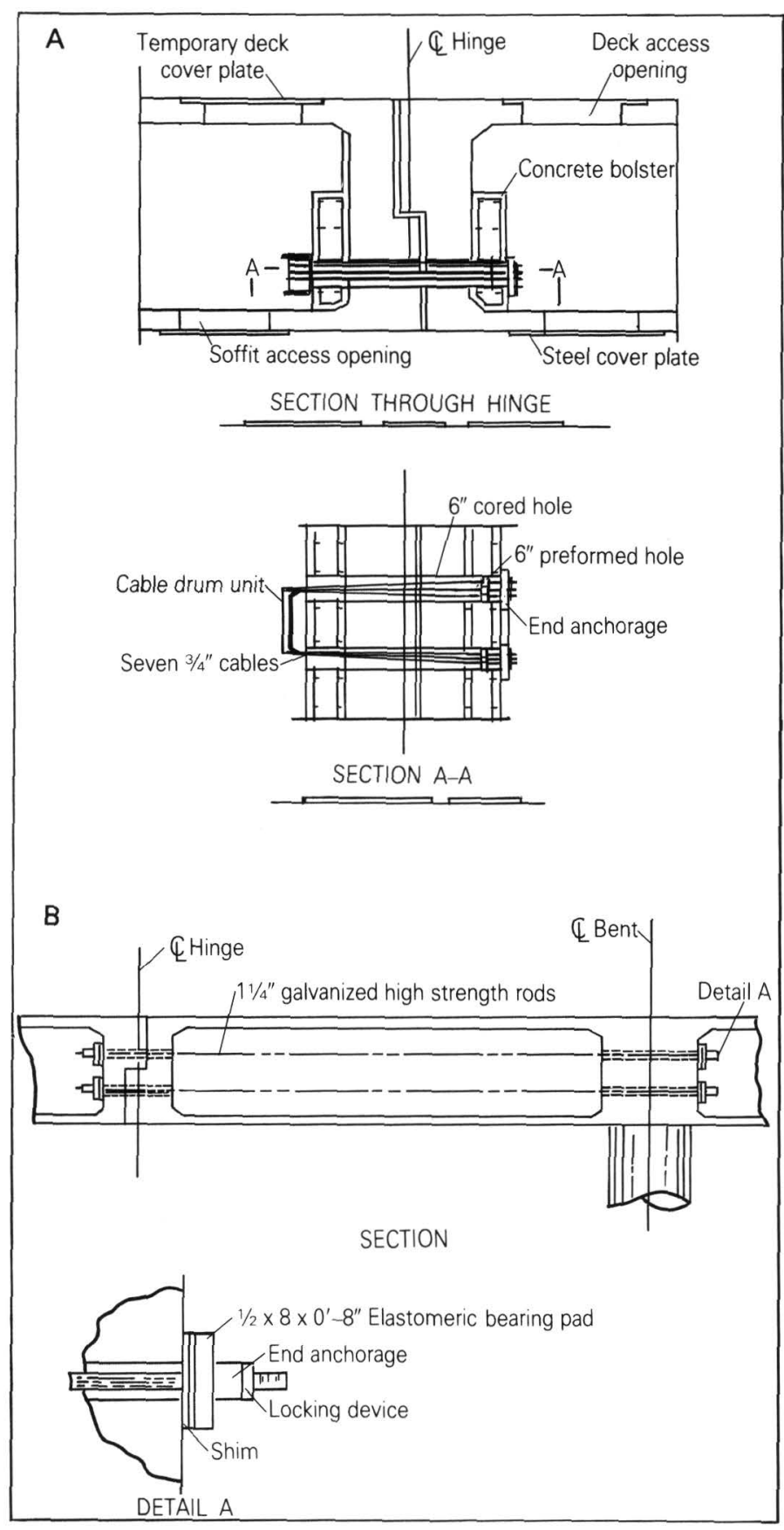

FIGURE 230.-Hinge connections designed to make concrete highway bridges earthquake resistant (Mancarti, 1981). Cross sections and details for cable restrainer $(A)$ and high-strength rod restrainer $(B)$ are shown.

the decision was then made (1) to develop rational design criteria that take site-dependent characteristics into consideration, (2) to incorporate improved details into all bridges being designed and constructed, and (3) to evaluate and determine priorities for upgrading the earthquake resistance of existing bridges. Two factors selected for inclusion in the design criteria were the location of the site relative to active faults and the effect of maximum credible earthquakes originating on individual active faults.

A CALTRANS bridge engineer (Mancarti, 1981, p. 1, 2), in discussing highway bridge retrofit, described the types of restrainers (steel cables, rods, hinges, and bearing-support hardware) used to tie bridge superstructures together as well as to tie superstructures to substructures and stated that the main purpose is

...to prevent spans from separating at hinges or falling off their bearing supports and to make structures seismically resistant to the extent that while they may sustain localized damage, they will not collapse catastrophically. It is also desirable that highway structures be rendered capable of carrying emergency traffic, with quickly performed temporary repairs so as to provide transportation lifelines for a stricken community immediately after a disaster.

The new designs for hinges have substantial cable restrainers (for example, multiple units of seven $3 / 4$-in (19 $\mathrm{mm}$ ) cables that form a tendon inside a pipe (fig. $230 \mathrm{~A}$ )J. These restrainers allow bridges to move in small increments; their joints can open or close as much as 1 to 3 in $(25-76 \mathrm{~mm})$, depending on the maximum amount needed to accommodate temperature changes. Wendell Pond, in a bulletin of the California State Division of Highways $(1972$, p. 3), observed that, once this movement has occurred, the restrainers are designed to limit further movement and to prevent collapses such as those that occurred during the 1971 San Fernando earthquake.

\section{Application}

Since 1971, CALTRANS has been involved in retrofitting existing bridges. Its program began almost immediately after the 1971 San Fernando earthquake. The initial goal of the retrofitting program was to tie bridge superstructures together at hinges and bearings and to tie superstructures to substructures at bearing supports. CALTRANS concentrated first on the hinges in the continuous structures and developed a fairly simple hinge restrainer unit for use in concrete box girder bridges (fig. 230A); Mancarti (1981, p. 3) stated that, "Components were easily fabricated from standard, available hardware and our retrofit contractors quickly developed the knack of installing them in structures at a reasonable price." Because the unit did not have a high 
enough load capacity for certain superstructure configurations in highly seismic areas, CALTRANS developed a high-strength rod restrainer (fig. 230B). A unit composed of four symmetrically placed 11/4-in (31.75 $\mathrm{mm}$ ) high-strength rods is rated at 600,000 lb design load. Units using one, two, or four rods have been successfully installed. They possess the additional advantage of requiring smaller holes to be cored through existing concrete elements (Mancarti, 1981, p. 4).

Selection of structures for retrofit is currently based on a priority system. Mancarti $(1981$, p. 1) reported that this system

...takes into account the bedrock acceleration at the structure site, the estimated cost to retrofit the structure, the cost of replacement in the event of loss, the ratio of the replacement cost to the retrofit cost, the length and availability of detours, and the average daily traffic on the main line as well as other factors which reflect the importance of the structure in the system.

This rating technique has been put on the CALTRANS computer in conjunction with an ongoing program for structure replacement and improvement; structures are then ranked for inclusion in the annual State transportation improvement program. To date, over half of these structures have been retrofitted at a cost of $\$ 24$ million. According to J. H. Gates (written communication, 1981), current budget allocations will permit completion of all bridges identified as deficient by 1990 .

\section{Comments}

The average CALTRANS retrofit project consists of adding steel restrainer cables at hinge and expansion joints to prevent spans from collapsing. The potential for collapse can be minimized even if extensive damage occurs. The design criteria and priority system selected can be easily modified as estimates of likely shaking are refined and as new developments are made in earthquake engineering.

J. H. Gates (written communication, 1981) reported that the CALTRANS-designed details for restrainep units have evolved to the point where the systems are performing satisfactorily in the field, although none have been tested by a natural earthquake. CALTRANS engineers warn that retrofitting will not keep an overpass bridge from collapsing if the fault rupture of a major earthquake is under or adjacent to the structure.

\section{REGULATING DEVELOPMENT IN POTENTIAL SURFACE FAULT RUPTURE AREAS}

As Ziony and Yerkes (this volume) discussed, many potentially active fault zones underlie the Los Angeles region. The surface traces of these faults are likely to be the sites of significant displacement during future major earthquakes. It is difficult and costly to design and build structures to withstand fault displacement. Even an inch or two (25-50 mm) of sudden fault movement can severely damage some structures. The probability that an earthquake will destroy buildings and kill or injure people becomes significant where high-density urban development or critical facilities straddle active faults. Thus, the dominant strategy for reducing the hazard from surface rupture is to avoid potential surface fault rupture areas.

If new fault traces are discovered or new areas are designated as hazardous, existing structures may be deemed unsafe. Many schools, hospitals, and other public and private developments have been built on or near the surface traces of previously unrecognized active faults. The 1971 San Fernando earthquake in southern California, for example, damaged structures erected over an active fault whose trace was not generally recognized at the time of development. Much of the damage associated with fault rupture can be limited if construction on active faults is avoided. Utility lines and transportation facilities can be located, designed, and operated to reduce outages and other disruptions. Some of the methods for using earth-science information and hazard mapping in land use planning and regulations have been discussed by Blair and Spangle (1979).

Reconstruction, however, commonly takes place in the same hazardous areas after an earthquake. Youd and others (1978, p. 111), for example, observed that, after the San Fernando earthquake, “...buildings had been repaired, new buildings have been built, and a freeway interchange has been constructed across the trace of the 1971 fault rupture."

\section{Earth-Science Information}

In California, many potentially active and recently active faults have been identified and mapped at various scales. A preliminary map showing recency of faulting (Ziony and others, 1974) shows the location of presently known or inferred faults in the coastal region of southern California and what is currently known about the recency of displacement along each fault. Maps by 


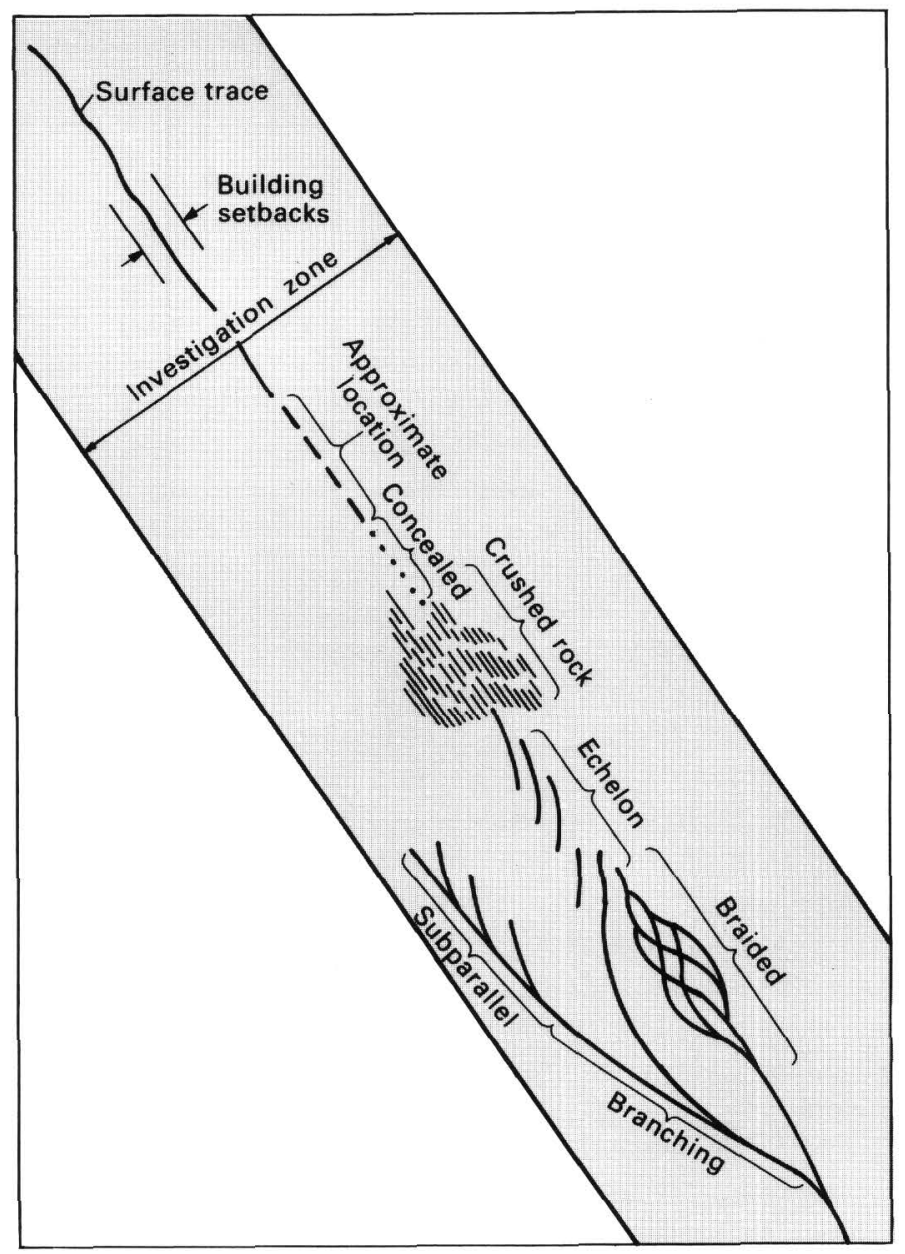

FIGURE 231.-Hypothetical fault traces showing possible complexities of faulting and demonstrating the necessity for detailed geologic investigations within a broad zone astride a known fault rupture trace.

the USGS and the CDMG are available chiefly at scales of 1:24,000 or smaller for many individual faults or fault rupture zones. Examples include Sharp's (1972) map of the San Jacinto fault zone, Sarna-Wojcicki and others' (1976) map of the Ventura fault, Barrows and others' (1976) map of the Palmdale segment of the San Andreas fault zone, and Weber's (1977) map of the Elsinore and Chino faults.

The trace of an active fault cannot always be seen at the surface. It may be concealed, and the geologist may have to approximate its location. Displacements do not always occur along a single fault trace; branching, braided, and en echelon fault segments may result in wide zones of disturbance (fig. 231). Therefore, regulatory measures for avoiding or reducing the hazards of fault rupture commonly require detailed geologic investigations to accurately identify and evaluate all the strands of the faults. Once a trace has been completely located, specific regulations (such as prohibiting certain uses or requiring specific buildings to be set back from the active strands) can be applied.

\section{Decision}

In response to public concern and because of the availability of scientific information, the California Legislature (1972) enacted the Alquist-Priolo Special Studies Zones Act. The act provides for public safety by restricting development near or over the surface traces of active faults. In addition, the act provides for geologic reports, approval of projects by cities and counties, exemptions for altering and adding to existing structures, disclosure of hazards by property sellers and their agents, and the charging of reasonable project approval application fees.

To assist the cities and counties, the act requires the State Geologist to delineate Special Studies Zones that include all "potentially and recently active" traces of the San Andreas, Calaveras, Hayward, and San Jacinto faults and other faults that he deems "sufficiently active and well defined" to constitute a potential hazard from surface fault rupture. For the purpose of the act, a fault is considered "sufficiently active" if there is evidence of surface displacement along one or more of its segments or branches during the last $11,000 \mathrm{yr}$; a fault is considered "well defined" if its trace is clearly detectable by a trained geologist as a physical feature at or just below the ground surface (Hart, 1980, p. 5-6).

The State Geologist initially delineated zones about one-quarter of a mile $(400 \mathrm{~m})$ wide. Currently, the zones delineated are about 400 to $600 \mathrm{ft}(130-200 \mathrm{~m})$ wide. The best information available has been used to delineate surface traces of well-known faults on about 300 quadrangle maps (fig. 232). Special Studies Zones are established by selecting turning points located at obvious features on either side of a mapped fault trace. The zone boundaries are drafted as straight lines connecting these points. Because fault traces vary (some have branching segments, curved or discontinuous traces, or wide areas of crushed rock), the zones are irregular and may exceed one-quarter of a mile $(400 \mathrm{~m})$ in width. Maps similar to figure 233 show faults, historical offsets and the years of their occurrence, displacement caused by creep, and lineaments seen on aerial photographs. Currently, the CDMG is evaluating those faults identified as "sufficiently active and well defined." Results, methods of evaluation, recommended zoning and zone revisions, and some of the problems encountered during evaluation have been summarized by Hart and others (1977, 1978, 1979). 


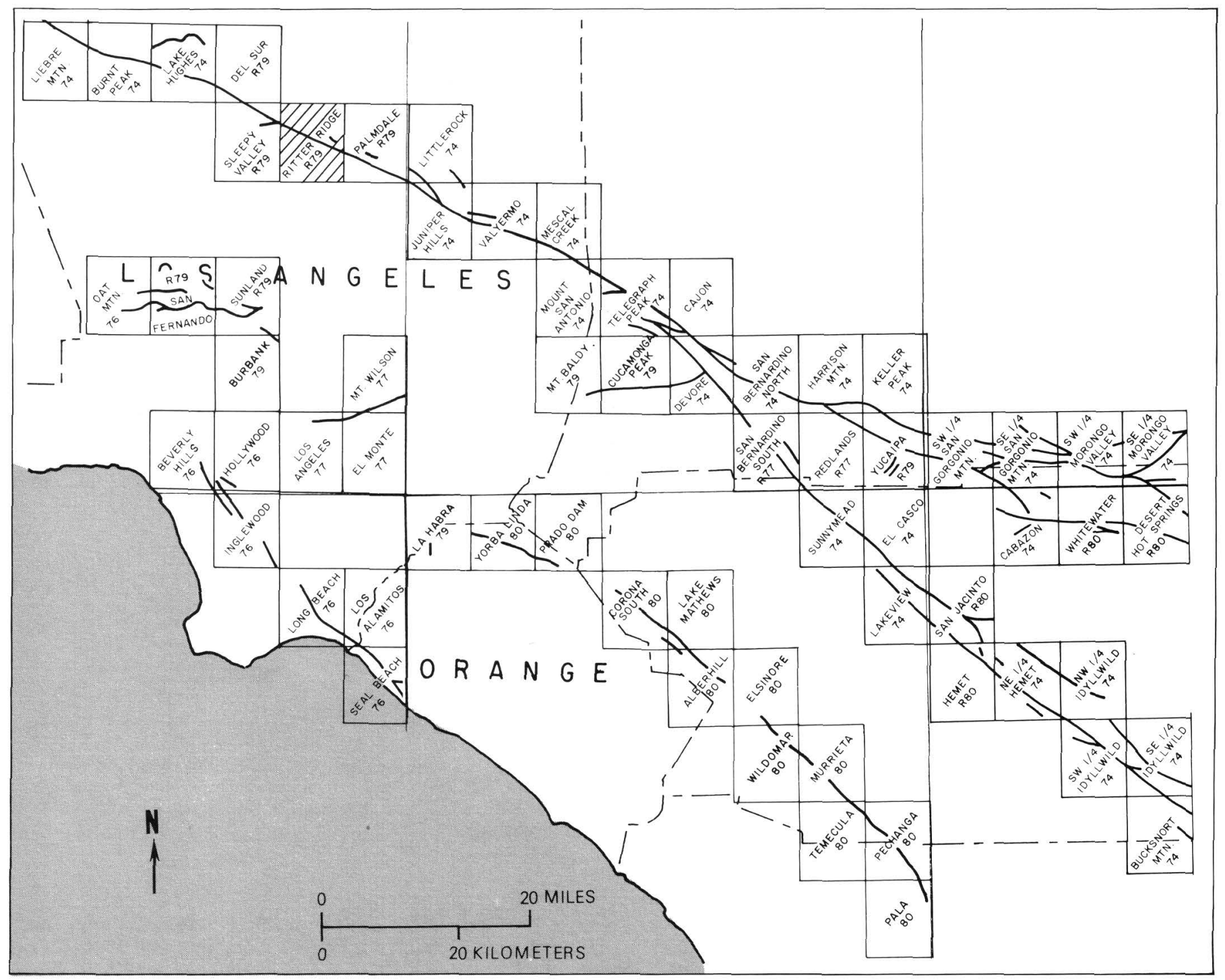

FIGURE 232.-Part of the index to the Special Studies Zones maps showing faults zoned for special geologic studies (Hart, 1980). The official name of each quadrangle map and the year issued or revised are indicated. Part of the cross-hatched quadrangle is shown as figure 233. Information about the availability of the maps and their updating can be obtained from the Fault Evaluation Program Supervisor, California Division of Mines and Geology, Suite 100, 380 Civic Dr., Pleasant Hill, CA 94523.

\section{Application}

The State Geologist uses USGS $7 \frac{112-m i n}{\text { quadrangle }}$ maps (topographic series) as the base for delineating Special Studies Zones. Information is transferred from published and unpublished fault and geologic maps to the quadrangle maps, each of which lists specific references to the sources of that information. The geologic reports of Sarna-Wojcicki and others (1976) and Weber and others (1975), for example, are cited as the references used to compile the Ventura fault data for the Saticoy and Ventura quadrangle maps. As of January 1, 1982, Special Studies Zones encompassed 25 counties and more than 70 cities in California; reproducible master copies of pertinent quadrangles have been provided to each affected city and county.

The California Legislature (1972, sec. 2623) provides that cities and counties shall require, before approval of a project in a Special Studies Zones, "a geologic report defining and delineating any hazard of surface fault rupture" and that approval shall be in accord with the policies and criteria established by the California Mining and Geology Board.

The California Mining and Geology Board (Hart, 1980, app. B) has prepared and adopted specific and detailed criteria prohibiting specific development in Special 


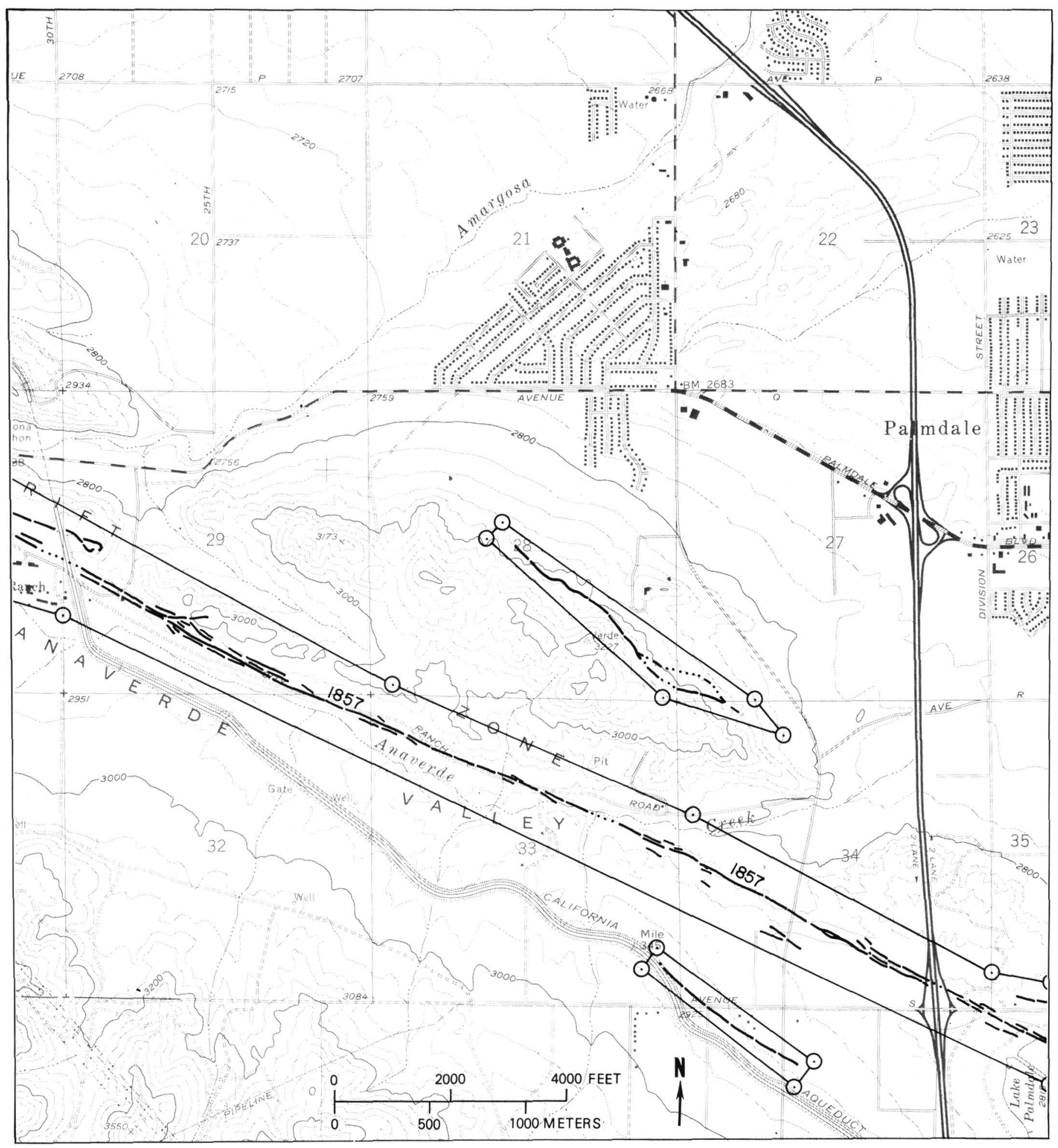

FIGURE 233.-Part of the Ritter Ridge quadrangle map used by the California Division of Mines and Geology (1979) to show the boundaries of the Special Studies Zones (lighter lines) and their turning points (circles) along part of the San Andreas fault southwest of Palmdale. Traces of potentially active faults (heavier lines) are indicated by solid lines where accurately located, by a long dash where approximately located, by a short dash where inferred, and by dots where concealed. Geologic reports defining the hazard of surface fault rupture are required before development within a Special Studies Zone. 
Studies Zones until a geologist, registered in California and retained by each city or county, has evaluated the geologic report that must accompany an application for development. The fault information shown on a quadrangle map (fig. 233) does not fulfill the requirement for a "geologic report"; cities and counties must require that a developer retain a registered geologist to evaluate sites within the Special Studies Zones to determine if a potential hazard from any fault exists. If a city or county finds that no undue hazard exists, the geologic report may be waived, if the State Geologist approves. The CDMG can provide information on the availability of waiver forms, maps showing Special Studies Zones, guidelines for evaluating surface fault ruptures, indexes to zone maps, and indexes to geologic reports within the zones.

The act and the criteria allow cities and counties to establish more restrictive policies and criteria. One criterion initially adopted by the board provided that "[no] structure for human occupancy... shall be... placed across the trace of an active fault...." The area within $50 \mathrm{ft}(15 \mathrm{~m})$ of an active fault is assumed to be underlain by active branches of that fault until an investigation by a registered geologist proves otherwise. In 1976, the California Legislature (1972, sec. 2621.6(a)) amended the original act to exclude ". . . a single-family wood frame dwelling not exceeding two stories when such dwelling is not part of a development of four or more dwellings" and therefore removed such buildings from the board's criteria. Some cities and counties, however, retain the $50-\mathrm{ft}(15 \mathrm{~m})$ setback for all structures for human occupancy; others, like the Portolà Valley Town Council (1973), require greater setbacks in certain instances. The California Mining and Geology Board now recommends that a geologic report be required if the single-family dwelling lies on or within 100 $\mathrm{ft}(32 \mathrm{~m})$ of the trace of an historically active fault or other known active fault.

The California Association of Realtors (1977) has published an instruction booklet on the legal obligations of Realtors ${ }^{10}$ to disclose geologic hazards that relate to the use of real estate. The California Association of Realtors (1981) includes, in its real-estate purchase contract form, a place for attaching information about Special Studies Zones. The California Association of Realtors (1978) has also prepared a disclosure form for Special Studies Zones that can be attached to the contract. The last paragraph of this form provides a space for the number of days that a prospective buyer has, from the time that a seller accepts his purchase offer, to make further inquiries concerning the use of the prop-

\footnotetext{
${ }^{10}$ The word Realtor denotes a member of the National Association of Real Estate Boands.
}

erty under the Special Studies Zones Act and provides that, where inquiry discloses conditions unsatisfactory to the buyer, the buyer may cancel the contract.

\section{Comments}

This example illustrates how earth-science information can be used by State legislators, State geologists, city and county officials, consulting geologists, and realestate buyers to avoid the hazards of surface fault rupture. The act's provisions, the board's criteria, and local ordinances discourage the construction of certain public and private buildings over faults that may creep or move suddenly during a major earthquake. This method of providing for public safety can be adapted to other types of potential ground failure, such as landslides or liquefaction, and to States other than California where similar hazards exist and where adequate scientific information is available. The fault rupture information on Special Studies Zones maps is used directly by cities and counties for other earthquake hazard reduction opportunities such as seismic safety elements, environmental assessments, and project reviews.

\section{STRENGTHENING OR REMOVING UNSAFE MASONRY BUILDINGS}

Officials of the city of Los Angeles know that the city will be subjected to intense ground shaking during a moderate or major earthquake. In the seismic safety plan adopted by the Los Angeles City Council as required by the California Legislature (1971), the Los Angeles Department of City Planning (1974, p. 1) stated that shaking
...causes the greatest amount of damage from earthquakes occurring in rather populous areas. It is estimated the major- ity of structural failure that has been caused by earthquakes results from: (1) shaking which damages the structure directly, (2) shaking which causes soil failure beneath the foundation of a struc- ture, and (3) shaking which causes the soil beneath the foundation to densify and set- tle, thus causing the structure to fail.

The department noted that ground shaking can result in loss of life, personal injuries, property damage, and economic and social dislocations but that most of this 
loss is preventable. Consequently, to keep loss to a minimum, the Los Angeles Department of City Planning (1974), in an environmental impact repcrt, specified policies and programs regarding geologic evaluation, existing development, new development, critical facilities, emergency preparednesss, and postdisaster recovery.

The major earthquake-related problem faced by the city is the strengthening or removal of existing hazardous buildings. The policies adopted concerning existing development include recommendations that:

- Buildings that do not meet requirements for seismic safety should be strengthened or removed in an orderly manner.

- Priorities for seismic upgrading of existing buildings should be based on the hazard to life, the type of occupancy, the location of the structure, and the capability of the structure to withstand earthquake forces.

Some specific ways listed to implement these policies are:

- Giving priority to pre-1934 unreinforced masonry structures, starting with structures that are most hazardous to life.

- Considering an amended building code that would evaluate existing pre-1934 unreinforced masonry structures on their ability to meet an acceptable level of seismic safety.

- Considering an ordinance that would require building owners to conduct structural surveys and (or) seek State or Federal funding to identify structures that do not meet lateral force requirements.

In 1976, the mayor of Los Angeles established a task force to explore and evaluate the range of possible city responses to an earthquake prediction. The Los Angeles City Task Force on Earthquake Prediction (Dunne, 1978, p. 21) identified unreinforced masonry structures built before 1934 as the greatest life hazard in an earthquake and recommended that "priorities for reinforcement, decreasing occupancy levels, or demolition should be established before we are confronted with a credible earthquake prediction."

A complete inventory of pre-1934 masonry buildings was conducted by specially trained city building inspectors to document the nature and extent of the problem and then was made available to building owners and other interested persons. There are at present approximately 8,000 pre-1934 unreinforced masonry buildings in the city of Los Angeles (fig. 234). These buildings have been classified by the Los Angeles City Building Department $(1979, p .3)$ as follows:

$\begin{array}{cr}\text { Use } & \text { Number } \\ \text { Commercial ------- } & 4,108 \\ \text { Industrial --------- } & 2,393 \\ \text { Apartment -------- } & 811 \\ \text { Hotel ----------- } & 268 \\ \text { Public ----------- } & 134 \\ \text { Other ----------- } & 162 \\ \quad \text { Total ---------- } & 7,876\end{array}$

More than 80 percent of these structures are commercial and industrial buildings providing places of employment for an estimated 70,000 workers. About 14 percent are residential apartments and hotels containing nearly 46,000 units housing perhaps 137,000 persons (Los Angeles City Planning Department, 1980, p. F-iii). Because these structures are vulnerable to total collapse or to the shedding of outside walls under moderate to strong ground shaking, they present a substantial risk to their occupants and to passersby. The department concluded that, "It is the consensus of seismic safety experts that these pre-1934 unreinforced masonry buildings represent the greatest single threat to life and limb in Los Angeles in the event of a major quake." According to the Los Angeles City Planning Department (1979, p. 4), the unreinforced masonry buildings constructed before 1934 were found to be more vulnerable to earthquake forces than anyone had realized when they were designed and built:

This fact was dramatically demonstrated during the Long Beach quake occurring in March of 1933 and the San Fernando Valley quake and aftershock of February and March of 1971. Earthquake resistance in buildings has deteriorated over the years due to factors such as: decreases in the strength of construction materials, fire damage, foundation settlement, alterations that have weakened structural elements, and damage sustained in past earthquakes.

\section{Earth-Science Information}

Many estimates of potential ground shaking and its effects are available for the Los Angeles region-for ex-

\section{Earthquake Hazards in the Los Angeles Region}




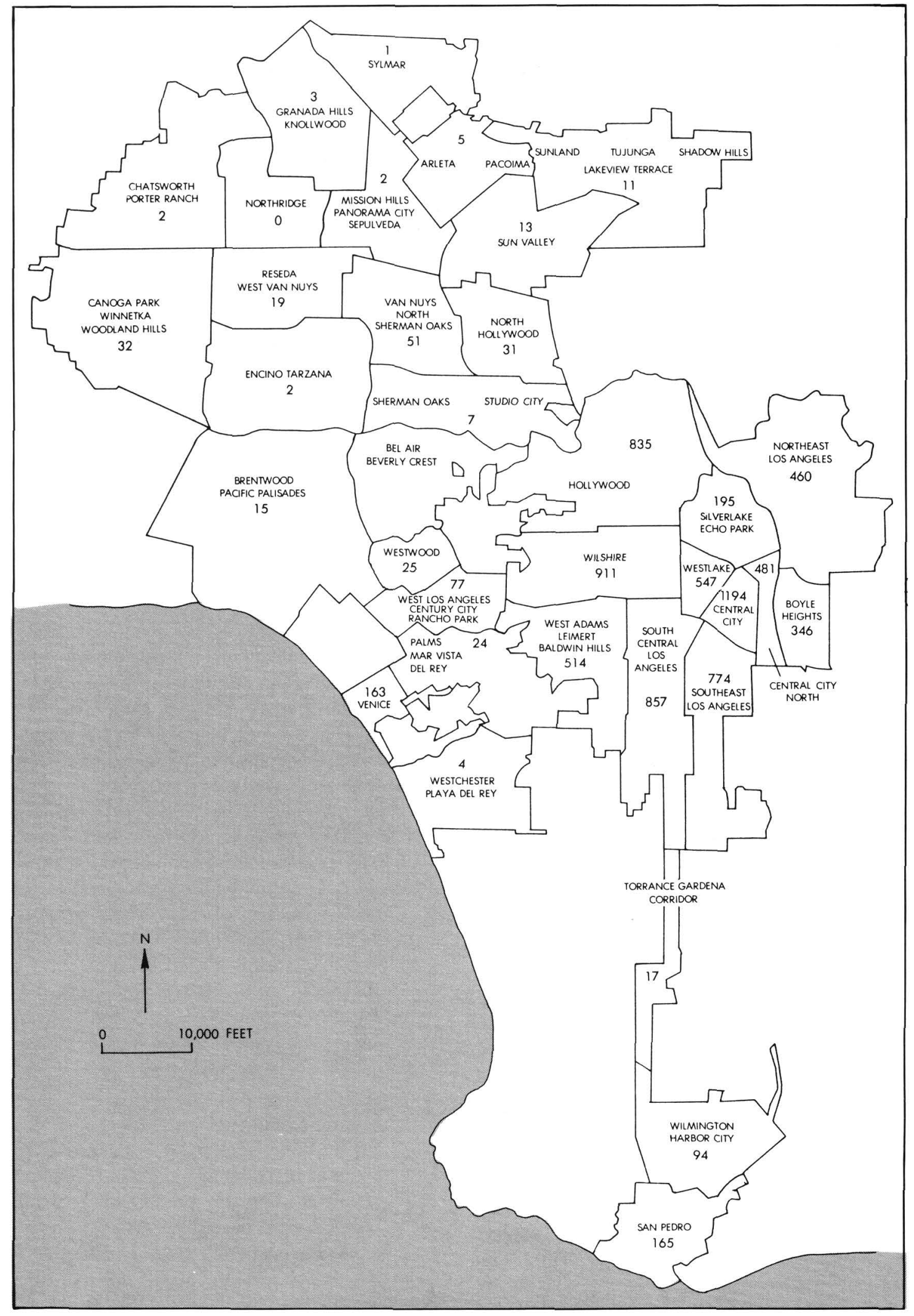

FIGURE 234.-The number of unreinforced masonry buildings originally verified in the field for each census tract by the Los Angeles Department of Building and Safety (Los Angeles City Planning Department, 1979) are shown here by community area. Similar diagrams are available showing the number of dwelling units in apartment buildings or the number of guest rooms in hotels and motels. Unnumbered areas are outside the city's corporate limits. 
ample, maximum credible ground acceleration (fig. 229) (Greensfelder, 1972), earthquake losses (Algermissen and others, 1973), seismic risk zones (International Conference of Building Officials, 1979, fig. 1, p. 145), probabilistic estimates of maximum horizontal ground motion (Thenhaus and others, 1980), predicted intensities (Evernden and others, 1981), and maximum horizontal acceleration and horizontal velocity (Algermissen and others, 1982). Using Algermissen and others' (1973) estimates for losses from a major earthquake in the Los Angeles area and assuming that 70 percent of those losses would be within the Los Angeles city limits, the Los Angeles City Planning Department (1979, p. 4) estimated that, if a structural improvement program was not implemented, up to 8,500 deaths and 34,000 injuries could be caused by damage to unreinforced masonry buildings.

\section{Decision}

After 2 yr of deliberation, an ordinance amending the building code of the city of Los Angeles was formulated by the Los Angeles Earthquake Safety Study Committee (1978) and submitted to the city council in 1979. The ordinance was designed to reduce earthquake hazards by requiring the strengthening or removal of pre-1934 buildings that have bearing walls of unreinforced masonry. The strengthening standards were not identical to those required for new construction but were especially adapted to the type of construction used in these older buildings and to their typical weaknesses.

Because the cost of compliance was expected to be high, the Earthquake Safety Study Committee requested that a detailed cost study be prepared. The city council authorized and funded a structural engineering cost study, which was carried out by Wheeler and Gray, Consulting Engineers, under contract to the Los Angeles Department of Building and Safety (Los Angeles City Planning Department, 1979, app. G). The consultants evaluated a four-story apartment building, two-story apartments over a one-story industrial building, a onestory warehouse, a one-story warehouse with a mezzanine, and a two-story commercial and office building. According to the study, total compliance costs calculated for these five actual buildings ranged from $\$ 6.22$ to $\$ 12.08$ per square foot. The estimated cost of anchoring the walls to the floors and roof ranged from $\$ 1.00$ to $\$ 1.60$ per square foot.

Some of the advantages of the proposed ordinance, as noted by the Los Angeles City Planning Department (1980), were that (1) the city's greatest single hazard to life would be substantially reduced and casualties reduced perhaps fivefold; (2) buildings not worth repairing would eventually be demolished and land possibly made available for more productive use; and (3) repair or demolition would provide work for the construction industry.

Some of the disadvantages of the proposed ordinance were that (1) some of the city's lowest priced housing would be demolished; (2) tenants would probably have to be temporarily relocated while remedial work was carried out; (3) rents in affected buildings would have to be increased to amortize the expense of repairs; and (4) interruption of normal business during remedial construction would impose severe hardships on many small businesses and perhaps force layoffs and closures.

The Los Angeles City Planning Department (1980, p. F-iv) made a number of recommendations for mitigating some of the ordinance's adverse impacts. In the case of historical buildings, for example, adverse impacts and measures to alleviate them were assessed as follows:

Adverse impacts.-Some buildings demolished under the proposed ordinance could have historical significance. Loss of irreplaceable cultural resources could result.

Recommended or code-required mitigation measures.-Proposed regulations have been prepared to incorporate the provisions of the State Historical Building Code into the ordinance. These regulations provide alternative requirements for designated historical structures to facilitate their preservation.

Net mitigated adverse impacts.-Historical buildings will not be exempted from remedial measures, but the special provisions should make it unlikely that any would have to be demolished.

The alternative of upgrading existing buildings to meet current standards for new buildings was considered in 1976 but not adopted by the city council. The alternative of no ordinance was considered but, according to the Los Angeles City Planning Department (1980, p. F-vii), would have tended
...to preserve the status quo, leaving any remedial measures to the discretion of building owners. It is considered unlikely that many would choose to make the nec- essary investment. The likely result would be heavy casualties and property damage in the event of a major earthquake.

The proposed ordinance was approved and adopted by an 11 to 3 vote of the Los Angeles City Council on January 7, 1981 (fig. 235).

\section{Earthquake Hazards in the Los Angeles Region}




\section{Application}

The ordinance provides systematic procedures and standards for identifying and classifying buildings having unreinforced masonry bearing walls; these procedures and standards are based on a building's present use and occupancy. Priorities, time periods, and standards are also established under which buildings are required to be structurally analyzed and anchored. Where analysis determines deficiencies, the ordinance requires that a building be strengthened or demolished. The ordinance applies to all buildings having bearing walls of unreinforced masonry that were constructed or under construction before October 6, 1933, or for which a building permit was issued prior to October 6, 1933, the effective date of the city's first seismic building code. The ordinance does not apply to detached one- or two-story single-family dwellings and detached apartment houses containing less than five dwelling units and used solely for residential purposes.

Affected buildings are classified according to type of function and occupancy as essential, high-risk, mediumrisk, and low-risk buildings (fig. 235, sec. 91.6803). The strengthening standards and time schedules for notification and compliance vary with the risk category. A structural analysis of each individual building is also required in order to determine the remedial measures necessary to meet the appropriate standards. A specific time schedule is provided (fig. 235, sec. 91.6805).

An alternative compliance schedule, intended to lessen the financial and social impacts of the ordinance, gives a building owner the option of performing a portion of the remedial work within $1 \mathrm{yr}$ of notification in exchange for a longer time in which to reach full compliance. The work to be performed within a year involves the anchoring of unreinforced masonry walls to the roof and to each floor of the building with bolts and washers. This procedure yields an immediate and substantial improvement in safety for perhaps one-fifth the cost of full compliance (Los Angeles City Planning Department, 1979 , p. 5). The compliance schedule, including the anchoring alternative, has the following features:

- All affected buildings are scheduled to be strengthened within $14 \mathrm{yr}$.

- It will take at least $4 \mathrm{yr}$ to notify all affected owners.

- Building owners have the option, after notification, of either anchoring all the building walls within $1 \mathrm{yr}$ or strengthening the entire building within $3 \mathrm{yr}$.
- If the walls are anchored within 1 yr of notification, 1 to $7 \mathrm{yr}$ more (depending on the building risk classification) are allowed for full compliance.

In addition, the ordinance provides for service of orders, appeals, and enforcement. Various analyses and design factors, such as allowable stresses of construction materials, alternate materials, and minimum acceptable quality of existing unreinforced masonry walls, are specified. As of January 8, 1983, the Los Angeles Department of Building and Safety has issued 895 orders to owners to meet minimum seismic standards. Over 200 of those so notified have chosen to use the wall-anchor alternative and are now in the automatic extension period (Earl Schwartz, oral communication, 1983). A Los Angeles city councilman (Hal Bernson, written communication, undated) emphasizes that

...this is a life safety rather than a property ordinance. That is, the level of seismic resistance that we provided in the ordinance does not necessarily guarantee than the structure will come through a major earthquake intact, or even usable. It is intended to assure that the structure will not collapse outright. This resulted from a compromise between optimum engineering goals and rehabilitation costs. Other cities may, and have, set their compromise at a different point.

\section{Comments}

According to the Los Angeles Earthquake Safety Study Committee, compliance with the provisions of this ordinance could reduce the number of deaths within the Los Angeles city limits from 8,500 to 1,500 and the number of injuries from 34,000 to 8,000 for a single future earthquake. It was estimated by the Los Angeles City Planning Department $(1979$, p. 4) that a major earthquake in the Los Angeles area would result in structural damage to about two-thirds of all old unreinforced masonry buildings. Implementation of the ordinance would reduce this structural damage by approximately three-fourths and save an estimated $\$ 900$ million in building costs.

\section{OTHER EXAMPLES}

Many other examples of how geologic and seismologic information is or might be used to reduce earthquake

Using Earth-Science Information

465 
Ordinance No. 154,807

An ordinance adding Division 68 of Article 1 of Chapter IX of the in existing bulldings. Code is hereby amended to add a Division 68 to read: ISTING BUILOINGS

The purpose of this Division is to promote pubilc safety and welfare by reducing the risk of death or iniury that may result from buildings constructed before 1934 . Such buildings have been widely partal or complete collaps The provisions of this Division are minimum standards for strue life loss or injury and will not necessarilyprevent loss of life or Iniury or prevent earthquake damage to on existing building which complles
with these standards. This Division shall not requite existing elec trlcai, plumbing mechanical or fire safety systems to be altere This they constitute a hazard to life or property. buildings based on their present use. Priorities, time per lods and stan dards are also established under which these buildings are required to mines deficiencies, this' strengthened or demolished. cluded in this' Division.

The provisions of this Division shall apply to all builings con tive date of this ordinance have unreinforced masonry bearing wall as defined herein. two story-family dwellings and detached apartment houses contain poses EC. 91.6803. DE FINITIONS:

For purposes of this Division, the applicable definitions in $\mathrm{Sec}$ Essential Building: Any building housing a hospital or other medical facility having surgery or emiergenny treatment areas: fire
or police stations; municipal government disaster operation and com munication centers
High $R$ Risk Building: Any building, not classified an essential
building, having an occupant load as defermined by Section 91.3301 (d) of this Code of loo occupants or more. ing: 1 . Any building having exterior walls braced with masonry crosh story.
e. Any building used for its intended purpose, as determined by
the Department for less than 20 hours per week. building by an agpropriate Federal state or City jur isdiction. building, having an occupant load as defermined by Section 91.3301 (d) of less than 20 occupants.
Medium Risk Building: Any building, not classified as a high risk
building or an essential building, having an occupant load as deterbuilding or an essential bui Any ing, having an occuppant load as deter
mined by Section 97330 (d) of 20 occupants or more. of the following ced Masonry Bearing Wall: A masonry

1. Provides the vertical support for a floor or roof.
T.

3. The total superimposed load is over 100 pounds per linear foot. quired by Section 91.2418(e) OT this Code.

hereby established and each building within the scope of this Divisio shall be placed in one such rating classification by the Department. tion $91.3301(d)$ shall be used to determine the rating classification. EXCEPTION: For the purpose of this Division, portions of
buildings constructed to act independently when resisting seismic
forces may be placed in separate rating classifications.

TABLE NO. 68-A

RATING CLASSIFICATIONS

\begin{tabular}{|l|c|}
\hline Type of Building & Classification \\
\hline Essential Building & I \\
High Risk Building & II \\
Medium Risk Building & III \\
Low Risk Building & IV \\
\hline
\end{tabular}

SEC. 91.6805. GENERAL REQUIREMENTS cause a structural and alysils to we made of the building by a civil or and, if the bullding does not meet the minimum earthquake standards specified in this Division, the owner shall cause it to be structurally The owner of a building within the scope of this Division shalf comply with the requirements set forth above by submitting to the a. Within 270 days after the service of the order, a structural
analysis. Such analysis which is subiect to approval by the Depart
ment, shall demonstrate that the building meets the minimum re quirements of this Division; or analysis and plans for the proposed structurat alterations of the
building necessary to comply to the minimum requirements of this Divisionior 120 days after service of the order, plans for the installa-
c. Within 120
tion of wall anchors in accordance with the requirements specified in tion of wall anchors in accordance with the requirements specified in demolition of the building after the service of the order. plans for the
After plans are submitted and approved by the Department, the quired construction or demolition within the time limits set forth in

\section{Earthquake Hazards in the Los Angeles Region}

TABLE NO. $68-$ B
TIMITS FOR COMPLIANCE

\begin{tabular}{|c|c|c|c|}
\hline $\begin{array}{c}\text { Required Action } \\
\text { By Owner }\end{array}$ & $\begin{array}{c}\text { Obtain Building } \\
\text { Permit Within }\end{array}$ & $\begin{array}{c}\text { Commence } \\
\text { construction } \\
\text { Withln }\end{array}$ & $\begin{array}{c}\text { Complete } \\
\text { contruction } \\
\text { Within }\end{array}$ \\
\hline $\begin{array}{c}\text { Complete Struc- } \\
\text { tural Alters } \\
\text { tions or } \\
\text { Builaing } \\
\text { Demolition }\end{array}$ & 1 year & 180 days* & 3 years \\
\hline $\begin{array}{c}\text { Wall Anchor } \\
\text { Installation }\end{array}$ & 180 days & 270 days & l year \\
\hline
\end{tabular}

"Measured from date of building permit issuance.

Owners electing to comply with ltem $c$ of this Section are also re
quired to comply with Items $b$ or d of this Section provided, however. limits for obtaining a building permit, commencing construction and completing construction for complete structural alterations or the time limit for commencling construction shall begin to run from
the date the order is served in accordance with secfor 9.6806 (b)
The time limit for commencing construction shall commence to run The time limit for commencing construct

\begin{tabular}{|c|c|c|c|}
\hline $\begin{array}{c}\text { Rating } \\
\text { Classification }\end{array}$ & $\begin{array}{c}\text { Occupant } \\
\text { Load }\end{array}$ & $\begin{array}{l}\text { Extension of Time } \\
\text { if Wa11 Anchors } \\
\text { are Ingtalled }\end{array}$ & $\begin{array}{l}\text { Minimum Time } \\
\text { Periods for } \\
\text { Service of order }\end{array}$ \\
\hline$\stackrel{\text { IHighest Priority) }}{\text { I }}$ & Any & 1 year & 0 \\
\hline II & 100 or more & 3 years & 90 days \\
\hline III & $\begin{array}{l}100 \text { or more } \\
\text { More than } \\
50, \text { but } \\
\text { less than } \\
100 \\
\text { More than } \\
19 \text {, but } \\
10 \text { s than } \\
51\end{array}$ & $\begin{array}{l}5 \text { years } \\
6 \text { years } \\
6 \text { years }\end{array}$ & $\begin{array}{l}1 \text { year } \\
2 \text { years } \\
3 \text { years }\end{array}$ \\
\hline $\begin{array}{l}\text { IV } \\
\text { (Lowest Priority) }\end{array}$ & Less than 20 & 7 years & 4 years \\
\hline
\end{tabular}

SEC. 91.6806. ADMINISTRATION:

vided in Section 91.6806 (b). to the owner of each building within the scope of this Division in accordance with the minimum fime periods
for service of such orders set forth in Table No. 68 -C The minimum time period for the service of such orders shall be measured from the written request from the owner, order a building to comply with this
Division prior to the normal service date for such building set forth in this Section.
(b) Contents of Order. The order shall be written and shall be
served either personally or by certified or registered mail upon the served either personally or by certifled or registered mail upon the
owner as shown on the Yast equallzed assessment, and upon the per.
son if any in apparent charge or control of the building. The order son, if any, in apparent charge or control of the bined by the Depart
shall specify that the building has been determined ment to be within the scope of this Division and, theretore, is required
to meet the minimum sejsmic standards of this Division The order companied by a copy of section 91.6805 which sets forth the owner's alternatives and time limits for compllance.
(c) Appeal From Order. The owner or person in charge or control
of the bulding may appeal the Department's inltial determination that the build ing is within the scope of this Division to the Board o

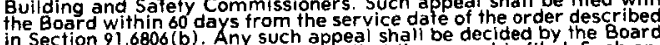
in Section $91.6806(b)$. Any such appeal shall be decided by the Board
no later than 60 days after the date that the appeal is filed. Such ap. peal shall be made in writing upon appropriate
therefor, by the Department and the grounds thereor shall be stated
clearly and concisely. Each appeal shall be accompanied by a filing
fee as set forth in table 4-A of Section 98.0403 of the Los Angeles Municipal Code.
Appeals or requests for sllght modifications from any other deter.
minafions, orders or actions by the Department pursuant to this Divi. Section 98.0403 .
(d) Recoration. At the time that the Department serves the aforementioned order, the Superintendent of Building shall file with the Office of the County Recorder a certiflcate stating that he subject
building is within the scope of Division 68 - Earthquake Hazard
Reduction in Existing Buidings - of the Los Angeles Municipal Code. The certificate shan also sate that the owner thereof has been
ordered to structurally analyze the building and to structurally alter or demolish it where compliance with Division 68 is not exhibited. scope of this Division, or is structurally capable of resisting minimum selsmic forces required by this Division as a result of structura
alterations or an analysis. the Superintendent of Bulding shall file
with the Office of the County Recorder a certificate terminating the with the Office of the County Recorder a certificate terminating the
status of the subiect building as being classified within the scoge of
Ditusion of the Los Angeles Municipal Code. of the subject bullding falls to comply with any order issued by the

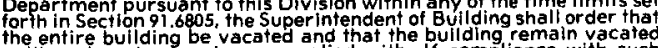
the entire bullding be vacated and that the building remaln vacated
unt il such order has been complied with if complance with such order has not been accomplished within 90 days after the date the have been granted bythe Board and the Superintendent may order its this Code. 91.6807 . HISTORICAL BUILDINGS:

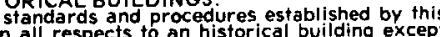
ming to preserve original architectural elements and wacilitate restoration, an historical building may, in addition. comply with the speclal provisions set forth in this Section
(ib) nburned Clay Masonry or Abode. Existing or re-erected
walls of abode construction shall conform to the following:
L Unreinforced abode masonry wall shall not exceed a helght or length to thickness ratio of 5 , for exterior bearing walls and must be 
hazards in the Los Angeles region can be cited under several general headings.

\section{Preparing Development Studies and Plans}

Earthquake hazard reduction techniques under this heading include land use planning and reconstruction after earthquakes (Spangle and Associates, Inc., and others, 1980); preearthquake planning for postearthquake rebuilding (Spangle and Associates, Inc., and others, 1981); environmental impact analyses of growth forecast (Southern California Association of Governments, 1982); Long Beach city seismic safety element (Woodward-McNeill and Associates, 1975); derived seismic zones for the city of Simi Valley (Envirocom Corporation, 1974); seismic safety study for the city of San Diego (Woodward-Gizienski and Associates and F. Beach Leighton and Associates, 1974); risk determination and land use suitability (Riverside County Planning Department, 1978, p. II-1-II-9); criteria for preparing environmental impact reports (Los Angeles County Department of Regional Planning, undated); guidelines for preparing and implementing city and county general plans and plan elements (California Office of Planning and Research, 1980); and a policy map for special management areas (Los Angeles County Department of Regional Planning, 1980, p. II-41).

\section{Designing and Building Structures}

Earthquake hazard reduction techniques under this heading include guidelines for preparing geologic and seismologic reports (Association of Engineering Geologists, 1973); guidelines for preparing engineeringgeologic reports (Ventura County Department of Public Works, 1974); guidelines for preparing geologic reports on offshore operations and facilities (California Division of Mines and Geology, 1975); review of the adequacy of the seismic design basis of nuclear generating stations (U.S. Nuclear Regulatory Commission, 1981, p. 97-108); dynamic stability analysis of hydraulic fill dams by the California Department of Water Resources Jansen and others, 1976); evaluation of geologic hazards along an existing water main (Los Angeles County Department of

FIGURE 235.-Part of the Los Angeles City Council (1981) earthquake hazard reduction ordinance requiring owners of buildings having unreinforced masonry bearing walls constructed before October 6, 1933 , to obtain a structural analysis. If the building does not meet the minimum standards, the owner is required to strengthen or remove it according to a specific time schedule.
County Engineering, 1977); study of a roadcut failure and recommendations for corrective measures (Los Angeles County Department of County EngineeringFacilities, 1979); homebuilders guide for earthquake design (U.S. Department of Housing and Urban Development, 1980); design and construction of police communication and emergency operating center (Los Angeles County Sheriff's Department, undated); study of the minimum earthquake forces to be used in the design and construction of structures (International Conference of Building Officials, 1979, sec. 2312); and recommendations concerning the seismic safety and engineering design of a proposed liquefied natural gas terminal (LNG Seismic Review Panel, 1981).

\section{Discouraging New or Removing Hazardous Development}

Earthquake hazard reduction techniques under this heading include an instructor's guide for a "hands-on earthquake learning package" (Southern California Earthquake Preparedness Project and Environmental Volunteers, Inc., 1983); recommendations for reducing hazardous buildings (California Seismic Safety Commission Hazardous Building Committee, 1979); developing awareness among members of the architectural profession (American Institute of Architects Research Corporation, 1975); earthquake advisor's handbook for wood-frame houses (University of California Center for Planning and Development Research, 1982); getting ready for a large earthquake (Sunset Magazine, 1982); estimating potential insured earthquake loss (California Department of Insurance, 1982); and guidelines for earthquake disaster prevention (United Nations, 1976, p. 39-55).

\section{Regulating Development}

Earthquake hazard reduction techniques under this heading include guidelines for determining credible and probable earthquakes (California Building Safety Board Geotechnical Subcommittee, 1975); State regulations for designing and constructing elementary and secondary school buildings (California Education Code, section 39140 and following) and community colleges (section 81130 and following), for repairing, reconstructing, or replacing unsafe school buildings (section 39210 and following, section 81160 and following), and for making geologic- and soil-engineering studies of public school sites (sections 39002, 81003 and following); recommendations for reducing landslide damages [California 
Assembly Select Committee on Landslide Prevention, 1980); fault investigation and evaluation of potential for surface rupture before land subdivision (EberhartAxten and Associates, Inc., 1980); model ordinance for an earthquake building code (Wiggins and Moran, 1971, app. F); ordinance for earthquake hazard reduction in existing buildings as part of a redevelopment plan (Santa Ana City Council, 1981); seismic design guidelines for Southern California Edison Company electrical substation facilities (Ostrom, 1976; Conway and others, 1978); siting criteria for liquefied natural gas facilities (California Public Utilities Commission, 1979); cost-benefit analyses based on isointensity maps and computed for different building codes (Paté and Shah, 1980); and fault rupture zone information and its disclosure (San Fernando Valley Board of Realtors, Inc., 1976).

\section{Preparing for and Responding to Disasters}

Earthquake hazard reduction techniques under this heading include risk analysis, facility design, and emergency response planning (Southern California Gas Company, written communication, 1979); emergency response planning (Metropolitan Water District of Southern California Earthquake Committee, 1978); automated database for disaster preparedness planning and response (Hoffman and others, 1983); educational program and school emergency preparedness and response (Los Angeles Unified School District, 1975); inspection of State water project facilities following an earthquake (California Department of Water Resources, 1981); and planning for earthquake prediction response (Los Angeles City Office of the Mayor, 1980).

\section{SUMMARY}

The examples presented or listed in this chapter include anticipating damage to critical facilities; preparing, adopting, or implementing seismic safety studies, plans, and programs; retrofitting highway bridges; regulating development in areas subject to fault rupture; strengthening or removing unreinforced masonry buildings; and many others. The collective effect of these activities is to provide greater public safety, health, and welfare for individuals and their communities.

The examples are typical of the problems faced by planners, engineers, and decisionmakers and the actions that they could take to reduce the effects of future earthquakes. Their innovative responses are based on the use of geologic and seismologic information to reduce earthquake hazards and property damage. Each plan or decision was influenced by many factors-the nature of the geologic hazard, public concern, strong community interest, State enabling legislation, the availability of scientific information, and the ability of geologists, engineers, planners, and lawyers to incorporate the information into a study, plan, program, or regulation.

The criteria and methods used in each example can be valuable to other urban regions where similar earthquake hazards exist and where adequate scientific information is available. The adaptation to and adoption by other jurisdictions and users depend on similarities in public awareness, enabling legislation, targeted issues, order of priorities, community interests, and abilities of planners, engineers, and decisionmakers.

Some of the geologic and seismologic information needed for prudent land use and general planning in the Los Angeles region is available but generally not at the level of detail and scale needed for engineering and decisionmaking. Even greater detail at larger scales ranging from $1: 1,200$ to $1: 12,000$ ( 1 in $=100$ to $1,000 \mathrm{ft}$ ) is needed for other purposes, including development planning, site investigation, ordinance administration, project review, and permit issuance. Public staffs and consulting firms either have or can develop this information in greater detail and at larger scales.

Earthquake hazard research is continuing, the information base is improving, the methods for evaluating hazards are being perfected, and new reduction techniques are being tested. Planners, engineers, and decisionmakers (both public and private) need to recognize these facts and use the latest information, methods, and techniques, but they cannot be expected to have the training or experience necessary to understand and use untranslated scientific information. Therefore, if nonscientists are to benefit from this information, it must be interpreted and transferred to usable maps. Such information includes recurrence intervals for major earthquakes, relative intensities of ground shaking, susceptibility to landsliding, locations of active faults, potential for liquefaction, and predicted geologic effects of postulated earthquakes.

Within the Los Angeles region, planners, engineers, and decisionmakers (public and private) live and work in a complex environment. Moreover, the geologic environment is just one aspect of their life and work. Other aspects include social, economic, political, and esthetic considerations, some of which are more apparent or more important to individual planners, engineers, or decisionmakers and their constituents. 
Even with adequate research, accurate information, usable products, effective communication, and proper use of the appropriate earthquake hazard reduction techniques, the lasting effectiveness of such techniques depends on many other factors, including:

- Continued awareness and interest by the public and their decisionmakers.

- Meticulous updating of hazard information and maps by geologists, seismologists, and geotechnical engineers.

- Careful revision of enabling legislation (if needed) by legislative bodies.

- Accurate site investigations by registered geologists or geotechnical engineers.
- Conscientious administration of regulations by inspectors.

- Consistent enforcement by government officials.

- Sustained support of inspection and enforcement officials by political leaders.

- Judicious adjustment of regulations by administrative-appeal bodies.

- Skillful advocacy by public officials and informed interpretation by the courts, if the regulations are challenged.

- Concern for individual, family, and community health, safety, and welfare by home buyers and real-estate developers. 


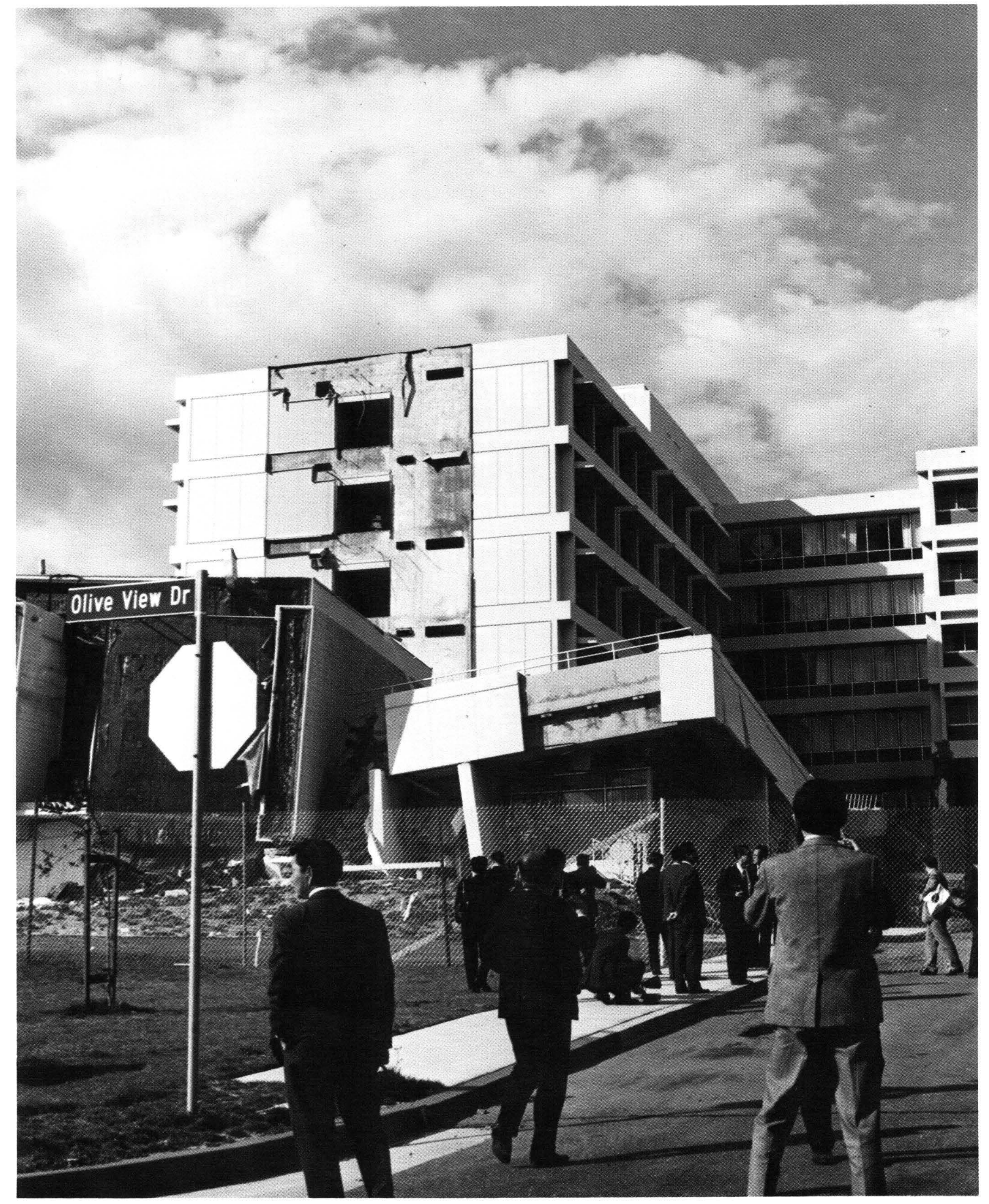

470 Earthquake Hazards in the Los Angeles Region 


\section{REFERENCES CITED}

\section{Introduction}

Bancroft, H. H., 1884, History of California, 1542-1800, v. 1, in The works of Hubert Howe Bancroft, v. 18: San Francisco, A. L. Bancroft, $744 \mathrm{p}$.

Blair, M. L., and Spangle, W. E., 1979, Seísmic safety and land-use planning-Selected examples from California: U.S. Geological Survey Professional Paper 941-B, $82 \mathrm{p}$.

Borcherdt, R. D., ed., 1975, Studies for seismic zonation of the San Francisco Bay region: U.S. Geological Survey Professional Paper 941-A, $102 \mathrm{p}$.

California Legislature, 1971, Planning and zoning law, as amended: Sec. 65302(f), West's annotated California Government Code.

California Legislature Joint Committee on Seismic Safety, 1974, Meeting the earthquake challenge-Final report to the Legislature, January 1974: California Division of Mines and Geology Special Publication $45,223 \mathrm{p}$.

Executive Office of the President, 1978, The National Earthquake Hazards Reduction Program: Washington, D.C., 30 p.

Federal Emergency Management Agency, 1980, An assessment of the consequences and preparations for a catastrophic California earthquake-Findings and actions taken: Washington, D.C., 59 p.

Hopkins, D. M., 1975, Time stratigraphic nomenclature for the Holocene epoch: Geology, v. 3, no. 1, p. 10.

Izett, G. A., 1982, The Bishop ash bed and some older, compositionally similar ash beds in California, Nevada, and Utah: U.S. Geological Survey Open-File Report 82-582, 44 p.

Kockelman, W. J., 1975, Use of U.S. Geological Survey earth-science products by city planning agencies in the San Francisco Bay region, California: U.S. Geological Survey Open-File Report 75-276, $110 \mathrm{p}$

1976, Use of U.S. Geological Survey earth-science products by county planning agencies in the San Francisco Bay region, California: U.S. Geological Survey Open-File Report 76-547, 186 p.

\section{Geologic and Seismologic Setting}

Agnew, D. C., and Sieh, K. E., 1978, A documentary study of the felt effects of the great California earthquakes of 1857: Bulletin of the Seismological Society of America, v. 68, no. 6, p. 1717-1729.

Allen, C. R., 1975, Geological criteria for evaluating seismicity: Geological Society of America Bulletin, v. 86, no. 8, p. 1041-1057. 1981, The modern San Andreas fault, in Ernst, W. G., ed., The geotectonic development of California (Rubey volume I): Englewood Cliffs, N.J., Prentice-Hall, p. 511-534.

Allen, C. R., St. Amand, P., Richter, C. F., and Nordquist, J. M., 1965, Relationship between seismicity and geologic structure in the southern California region: Bulletin of the Seismological Society of America, v. 55, no. 4, p. 753-797.

Anderson, D. L., 1971, The San Andreas fault: Scientific American, v. 225 , no. 5 , p. $52-68$.

Atwater, Tanya, 1970, Implications of plate tectonics for the Cenozoic tectonic evolution of western North America: Geological Society of America Bulletin, v. 81, no. 12, p. 3513-3536

Atwater, Tanya, and Molnar, P., 1973, Relative motion of the Pacific and North American plates deduced from sea-floor spreading in the Atlantic, Indian, and south Pacific oceans, in Kovach, R. L., and
1979, Use of U.S. Geological Survey earth-science products by selected regional agencies in the San Francisco Bay region, California: U.S. Geological Survey Open-File Report 79-221, $173 \mathrm{p}$.

1984, Reducing losses from earthquakes through personal preparedness: U.S. Geological Survey Open-File Report 84-765, 13 p.

Lindh, A. G., 1983, Preliminary assessment of long-term probabilities for large earthquakes along selected fault segments of the San Andreas fault system in California: U.S. Geological Survey Open-File Report 83-63, 15 p.

Ruddiman, W. F., and McIntyre, A., 1984, Ice-age thermal response and climatic role of the surface Atlantic Ocean, $40^{\circ} \mathrm{N}$. to $63^{\circ} \mathrm{N}$.: Geological Society of America Bulletin, v. 95, p. 381-396.

Schnell, M. L., and Herd, D. G., eds., 1984, National Earthquake Hazards Reduction Program-Report to the United States Congress, fiscal year 1983 activities: U.S. Geological Survey Circular $919,148 \mathrm{p}$.

Steinbrugge, K. V., Algermissen, S. T., Lagorio, H. J., Cluff, L. S., and Degenkolb, H. J., 1981, Metropolitan San Francisco and Los Angeles earthquake loss studies-1980 assessment: U.S. Geological Survey Open-File Report 81-113, 46 p.

U.S. Geological Survey, 1981, Scenarios of possible earthquakes affecting major California population centers with estimates of intensity and ground shaking: U.S. Geological Survey Open-File Report $81-115,35 \mathrm{p}$.

1984, Geologic time chart, in Stratigraphic notes, 1983: U.S Geological Survey Bulletin 1537-A, p. A1-A4.

U.S. Office of Science and Technology Policy, 1978, Earthquake hazards reduction-Issues for an implementation plan: Washington, D.C., Executive Office of the President, $231 \mathrm{p}$.

Wesson, R. L., and Wallace, R. E., 1985, Predicting the next great earthquake in California: Scientific American, v. 252, no. 2, p. $35-43$.

Nur, A., eds., Proceedings of the Conference on Tectonic Problems of the San Andreas Fault System: Stanford University Publications, Geological Sciences, v. 13, p. 136-148.

Beal, C. H., 1915, The earthquake at Los Alamos, Santa Barbara County, California, January 11, 1915: Bulletin of the Seismological Society of America, v. 5, no. 1, p. 14-25.

Beeby, D. J., and Hill, R. L., 1975, Galway Lake fault; a previously unmapped active fault in the Mojave Desert, San Bernardino County California: California Geology, v. 28, no. 10, p. 219-221.

Branner, J. C., 1917, The Tejon Pass earthquake of October 22, 1916: Bulletin of the Seismological Society of America, v. 17, no. 1 , p. 51-59.

Bravinder, K. M., 1942, Los Angeles basin earthquake of October 21, 1941, and its effect on certain producing wells in Dominguez field, Los Angeles County, California: American Association of Petroleum Geologists Bulletin, v. 26, no. 1, p. 388-399.

Buika, J. A., and Teng, T. L., 1979, A seismicity study for portions of the Los Angeles basin, Santa Monica basin, and Santa Monica Mountains, California: University of Southern California Geophysical Laboratory Technical Report 79-9, 191 p. 
Byerly, Perry, 1930, The California earthquake of November 4, 1927: Bulletin of the Seismological Society of America, v. 20, no. 2 , p. 53-66.

Castle, R. O., 1978, Levelling surveys and the southern California uplift U.S. Geological Survey Earthquake Information Bulletin, v. 10, no. 3, p. 88-92.

Cloud, W. K, and Scott, N. H., 1972, Intensity distribution and field effects, in The Borrego Mountain earthquake of April 9, 1968: U.S Geological Survey Professional Paper 787, p. 142-153.

Cockerham, R. S., and Eaton, J. P., 1982, The Point Sal, California earthquake of May 29, 1980: Earthquake Notes, v. 53, no. 1, p. 51.

Coffman, J. L., and von Hake, C. A., 1972, eds., United States earthquakes 1970: Washington, D.C., National Oceanic and Atmospheric Administration, 81 p.

1973a, Earthquake history of the United States (revised through 1970): National Oceanic and Atmospheric Administration Publication 41-1, $208 \mathrm{p}$.

1973b, United States earthquakes 1971: Washington, D.C., National Oceanic and Atmospheric Administration, $176 \mathrm{p}$.

1975, United States earthquakes, 1973: Washington, D.C., National Oceanic and Atmospheric Administration, $112 \mathrm{p}$.

Corbett, E. J., and Johnson, C. E., 1982, The Santa Barbara earthquake of 13 August 1978: Bulletin of the Seismological Society of America, v. 72, no. 6, pt. A, p. 2201-2226.

Corbett, E. J., and Piper, K. A. 1981, Santa Barbara Island, California earthquake, September 4, 1981 [abs.]: EOS, Transactions of the American Geophysical Union, v. 62, no. 45, p. 958.

Dickinson, W. R., 1981, Plate tectonics and the continental margin of California, in Ernst, W. G., ed., The geotectonic development of California (Rubey volume 1): Englewood Cliffs, N.J., Prentice-Hall, p. 1-28.

Dickinson, W. R., and Snyder, W. S., 1979, Geometry of triple junctions related to San Andreas transform: Journal of Geophysical Research, v. 84, no. 2, p. 561-572.

Gawthrop, William, 1975, Seismicity of the central California coastal region: U.S. Geological Survey Open-File Report 75-134, 87 p.

Gutenberg, B., Richter, C. F., and Wood, H. O., 1932, The earthquake in Santa Monica Bay, California, on August 30, 1930: Bulletin of the Seismological Society of America, v. 22, no. 2, p. 138-154.

Hanks, T. C., 1979, The Lompoc, California, earthquake (November 4 , 1927; $M-7.3)$ and its aftershocks: Bulletin of the Seismological Society of America, v. 69, no. 2, p. 451-462.

Hanks, T. C., and Kanamori, H., 1979, A moment magnitude scale: Journal of Geophysical Research, v. 84, no. 5, p. 2348-2350.

Kanamori, H., and McNally , K., 1981, Seismicity studies for earthquake prediction in southern California using a mobile seismicity array: U.S. Geological Survey Open-File Report 81-282, p. 17-33.

Lachenbruch, A. H., Sass, J. H., and Galanis, S. P., 1978, New heat-flow results from southern California [abs.]: EOS, Transactions of the American Geophysical Union, v. 59, no. 12, p. 1051.

Lajoie, K. R., Kem, J. P., Wehmiller, J. F., Kennedy, G. L., Mathieson, S. A., Sarna-Wojcicki, A. M., Yerkes, R. F., and McCrory, P. A., 1979, Quaternary marine shorelines and crustal deformation, San Diego to Santa Barbara, California, in Abbott, P. L., ed., Geological excursions in the southern California area, original papers and field trip roadlog prepared for the Geological Society of America Annual Meeting, November, 1979: San Diego, Calif., San Diego State University, Department of Geological Sciences, p. 3-15.

Lee, W. H. K., Johnson, C. E., Henyey, T. L., and Yerkes, R. F., 1978, A preliminary study of the Santa Barbara, California, earthquake of August 13, 1978, and its major aftershocks: U.S. Geological Survey Circular 797, 11 p.

Lee, W. H. K., Yerkes, R. F., and Simirenko, M., 1979, Recent earthquake activity and focal mechanisms in the western Transverse Ranges, California: U.S. Geological Survey Circular 799-A, 26 p.

472 Earthquake Hazards in the Los Angeles Region
Lindh, A., Fuis, G., and Mantis, C., 1978, Seismic amplitude measurements suggest foreshocks have different focal mechanisms than aftershocks: Science, v. 201, no. 4350, p. 56-59.

Matti, J. C., Tinsley, J. C., Morton, D. M., and McFadden, L. D., 1982, Holocene faulting history as recorded by stratigraphy within the Cucamonga fault zone: A preliminary view, 1982, in Tinsley, J. C., Matti, J. C., and McFadden, L. D., eds., Late Quaternary pedogenesis and alluvial chronologies of the Los Angeles and San Gabriel Mountains areas, southern California: Geological Society of America Annual Meeting, Cordilleran Section, 78th, Anaheim, Calif., 1982, Guidebook 12, p. 29-44.

McNally, K. C., and Pechmann, J., 1981, Recent seismicity changes along the San Andreas fault near Palmdale, California, in Kanamori, H., and McNally, K., Seismicity studies for earthquake prediction in southern California using a mobile seismographic array: U.S. Geological Survey Open-File Report 81-282, p. 176-195.

Moоre, G. W., 1981, Plate perimeters and motion vectors, in Drummond, K. J., chairman, Plate-tectonic map of the circum-Pacific region: American Association of Petroleum Geologists, scale 1:10,000,000, northeastern sheet.

Murphy, L. M., and Cloud, W. K., 1956, United States earthquakes 1954: U.S. Coast and Geodetic Survey Publication 793, $110 \mathrm{p}$

Neumann, Frank, and Cloud, W. K., 1955, Strong-motion records of the Kern County earthquakes, in Oakeshott, G. B., ed., Earthquakes in Kern County during 1952: California Division of Mines and Geology Bulletin 171, p. 205-210.

Pechmann, J. C., Hutton, L. K., Johnson, C. E., Ebel, J. E., Given, J. W., Cole, D. M., and German, P. T., 1980, Epicentral locations for the Homestead Valley earthquake sequence, March 15, 1979: California Geology, v. 33, no. 5, p. 110-114.

Real, C. R., Toppozada, T. R., and Parke, D. L., 1978, Earthquake epicenter map of California, 1900 through 1974: California Division of Mines and Geology Map Sheet 39, scale 1:1,000,000.

Richter, C. F., 1935, An instrumental earthquake magnitude scale: Bulletin of the Seismological Society of America, v. 25, no. 1 , p. 1-32.

1958, Elementary seismology: San Francisco, Calif., W. H. Freeman, $768 \mathrm{p}$

1970, Magnitude of the Inglewood, California, earthquake of June 21, 1920: Bulletin of the Seismological Society of America, v. 60 , no. 2, p. $647-649$

Richter, C. F., Allen, C. R., and Nordquist, J. M., 1958, The Desert Hot Springs earthquakes and their tectonic environment: Bulletin of the Seismological Society of America, v. 48, no. 4, p. 315-337.

Rodgers, D. A., 1973, Isoseismal map for the 10 March 1933 Long Beach earthquake: California Geology, v. 26, no. 3, cover.

Sanders, C., McNally, K., and Kanamori, H., 1981, The state of stress near the Anza seismic gap, San Jacinto fault zone, southern California, in Brown, A. R., and Ruff, R. W., eds., Geology of the San Jacinto Mountains: South Coast Geological Society Annual Field Trip Guidebook 9, p. 61-67.

Scott, N. H., 1973, Felt area and intensity of San Fernando earthquake, in Murphy, L. M., ed., San Fernando, California, earthquake of February 9, 1971, v. 3, Geological and geophysical studies: Washington, D.C., National Oceanic and Atmospheric Administration, p. $23-48$.

Stover, C. W., and von Hake, C. A., eds., 1980, United States earth quakes, 1978: Washington, D.C., U.S. Geological Survey and $\mathrm{Na}$ tional Oceanic and Atmospheric Administration, $112 \mathrm{p}$.

Strand, C. L., 1980, Pre-1900 earthquakes of Baja California and San Diego County: San Diego, Calif., San Diego State University, unpublished M.Sc. thesis, $316 \mathrm{p}$

Taber, Stephen, 1920, The Inglewood earthquake in southern California, June 21, 1920: Bulletin of the Seismological Society of America, v. 10, no. 3, p. 129-145. 
Teng, T. L., 1979, Earthquake hazard research in the Los Angeles basin and its offshore area: Menlo Park, Calif., technical report to U.S. Geological Survey under contract 14-08-0001-16704, 191 p.

Thatcher, Wayne, 1979, Systematic inversion of geodetic data in central California: Journal of Geophysical Research, v. 84, no. 5, p. 2283-2295.

Thatcher, Wayne, Hileman, J. A., and Hanks, T. C., 1975, Seismic slip distribution along the San Jacinto fault zone, southern California, and its implications: Geological Society of America Bulletin, v. 86, no. 8, p. 1140-1146

Toppozada, T. R., and Parke, D. L., 1975, Isoseismal map for the 29 June, 1925, Santa Barbara earthquake: California Geology, v. 28, no. 6, p. 132 (scale approximately 1:4,300,000).

1982, Areas damaged by California earthquakes, 1900-1949: California Division of Mines and Geology Open-File Report 82-17 $\mathrm{SAC}, 65 \mathrm{p}$.

Toppozada, T. R., Parke, D. L., and Higgins, C. T., 1978, Seismicity of California 1900-1931: California Division of Mines and Geology Special Report 135, $39 \mathrm{p}$.

Toppozada, T. R., Real, C. R., and Parke, D. L., 1981, Preparation of isoseismal maps and summaries of reported effects for pre-1900 California earthquakes: California Division of Mines and Geology Open-File Report 81-11 SAC, $182 \mathrm{p}$.

Townley, S. D., 1918, The San Jacinto earthquake of April 21, 1918: Bulletin of the Seismological Society of America, v. 8, nos. 2 and 3, p. 45-62. von Hake, C. A., and Cloud, W. K., eds., 1971, United States earthquakes 1969: Washington, D.C., National Oceanic and Atmospheric Administration, $80 \mathrm{p}$.

Whitcomb, J. H., Allen, C. R., Garmany, J. D., and Hileman, J. A., 1973 San Fernando earthquake series, 1971-Focal mechanisms and tectonics: Reviews of Geophysics and Space Physics, v. 11, no. 3, p. 693-730.

Wood, H. O., 1937, The Terwilliger Valley earthquake of March 25, 1937: Bulletin of the Seismological Society of America, v. 27, no. 4, p. 305-312.

Wood, H. O., and Richter, C. F., 1931, Recent earthquakes near Whittier, California: Bulletin of the Seismological Society of America, v. 21, no. 3, p. 183-203.

Woodward-Clyde Consultants, 1979, Report of the evaluation of maximum earthquake and site ground motion parameters associated with the Offshore Zone of Deformation San Onofre Nuclear Generating Station: Los Angeles, Calif., report prepared for Southern California Edison Company, 56 p., 11 figs., 10 apps.

Yeats, R. S., 1981, Quaternary flake tectonics of the California Transverse Ranges: Geology, v. 9, no. 1, p. 16-20.

Yerkes, R. F., Greene, H. G., Tinsley, J. C., and Lajoie, K. R., 1981 Seismotectonic setting of the Santa Barbara Channel area, southern California: U.S. Geological Survey Map Miscellaneous Field Studies Map MF-1169, scale 1:250,000, 25-p, text.

\section{Evaluating Earthquake and Surface-Faulting Potential}

Allen, C. R., 1957, San Andreas fault in San Gorgonio Pass, southern California: Geological Society of America Bulletin, v. 68, p. $315-350$.

1975, Geological criteria for evaluating seismicity: Geological Society of America Bulletin, v. 86, p. 1041-1057.

Allen, C. R., Wyss, M., Brune, J. N., Grantz, A., and Wallace, R. E., 1972, Displacements on the Imperial, Superstition Hills, and San Andreas faults triggered by the Borrego Mountain earthquake, in The Borrego Mountain earthquake of April 9, 1968: U.S. Geological Survey Professional Paper 787, p. 87-104.

Allen, C. R., Hanks, T. C., and Whitcomb, J. H., 1975, Seismological studies of the San Fernando earthquake and their tectonic implications, in Oakeshott, G. B., ed., San Fernando, California, earthquake of 9 February 1971: California Division of Mines and Geology Bulletin 196, p. 257-262.

Anderson, J. G., 1979, Estimating the seismicity from geological structure for seismic-risk studies: Bulletin of the Seismological Society of America, v. 69, no. 1, p. 135-158.

Barnett, D. M., and Freund, L. B., 1975, An estimate of strike-slip fault friction stress and fault depth from surface displacement data: Bulletin of the Seismological Society of America, v. 65, no. 5, p. 1259-1266.

Barnhart, I. T., and Slosson, I. E., 1973, The Northridge Hills and associated faults-A zone of high seismic probability, in Moran, D. E., Slosson, J. E., Stone, R. O., and Yelverton, G. A., eds., Geology, seismicity, and environmental impact: Los Angeles, Calif,, Association of Engineering Geologists, p. 253-256.

Barrows, A. G., 1974, A review of the geology and earthquake history of the Newport-Inglewood structural zone, southern California: California Division of Mines and Geology Special Report 114, $115 \mathrm{p}$.

1975, Surface effects and related geology of the San Fernando earthquake in the foothill region between Little Tujunga and Wilson Canyons, in Oakeshott, G. B., ed., San Fernando, California, , earthquake of 9 February 1971: California Division of Mines and Geology Bulletin 196, p. 97-117.

1979, Geology and fault activity of the Valyermo segment of the San Andreas fault zone, Los Angeles County, California: California Division of Mines and Geology Open-File Report 79-1 LA, 49 p.

1980, Geologic map of the San Andreas fault zone and adjoining terrane, Juniper Hills and vicinity, Los Angeles County, California: California Division of Mines and Geology Open-File Report 80-2 LA, scale 1:9,600.

Barrows, A. G., Kahle, J. E., and Beeby, D. J., 1976, Geology and fault activity of the Palmdale segment of the San Andreas fault zone, Los Angeles County, California: California Division of Mines and Geology Open-File Report 76-6 LA, 30 p.

1985, Earthquake hazards and tectonic history of the San Andreas fault zone, Los Angeles County, California: California Division of Mines and Geology Open-File Report 85-10 LA, 250 p.

Beeby, D. J., 1979, Geology and fault activity of the Lake Hughes segment of the San Andreas fault zone, Los Angeles County, California: California Division of Mines and Geology Open-File Report 79-2 LA, 35 p.

Blair, M. L., and Spangle, W. E., 1979, Seismic safety and land-use planning-Selected example from California: U.S. Geological Survey Professional Paper 941-B, 81 p.

Bonilla, M. G., 1970, Surface faulting and related effects, in Wiegel, R. L., ed., Earthquake engineering: Englewood Cliffs, N.J., PrenticeHall, p. 47-74.

1973, Trench exposures across surface fault ruptures associated with the San Fernando earthquake, in Murphy, L. M., ed., San Fernando, California, earthquake of February 9, 1971, v. 3, Geological and geophysical studies: Washington, D.C., National Oceanic and Atmospheric Administration, p. 173-182. 
1982, Evaluation of potential surface faulting and other tectonic deformation: U.S. Geological Survey Open-File Report 82-732, $88 \mathrm{p}$.

Bonilla, M. G., and Buchanan, J. M., 1970, Interim report on worldwide historic surface faulting: U.S. Geological Survey Open-File Report, $32 \mathrm{p}$.

Bonilla, M. G., Mark, R. K., and Lienkaemper, J. J., 1984, Statistical relations among earthquake magnitude, surface rupture length, and surface fault displacement: Bulletin of the Seismological Society of America, v. 74, no. 6, p. 2379-2411.

Boore, D. M., 1977, The motion of the ground in earthquakes: Scientific American, v. 237, no. 6, p. 68-78.

Bravinder, K. M., 1942, Los Angeles basin earthquake of October 21, 1941, and its effect on certain producing wells in Dominguez field, Los Angeles County, California: American Association of Petroleum Geologists Bulletin. v. 26, p. 388-399.

Bryant, M. E., and Fife, D. L., 1982 [1984], The Peralta Hills fault, a Transverse Ranges structure in the northern Peninsular Ranges, southern California, in Fife, D. L., and Minch, J. A., eds., Geology and mineral wealth of the California Transverse Ranges: Santa Ana, Calif., South Coast Geological Society, p. 403-409.

Bryant, W. A., 1978, The Raymond Hill fault-An urban geological in vestigation: California Geology, v. 31, no. 6, p. 127-142.

Buchanan-Banks, J. M., Pampeyan, E. H., Wagner, H. C., and McCulloch, D. S., 1978, Preliminary map showing recency of faulting in coastal south-central California: U.S. Geological Survey Miscellaneous Field Studies Map MF-910, scale 1:250,000.

Buika, J. A., and Teng, T., 1979, A seismicity study for portions of the Los Angeles basin, Santa Monica basin, and Santa Monica Mountains, California: Menlo Park, Calif., technical report to U.S. Geological Survey under contract 14-08-0001-16704, $134 \mathrm{p}$.

Bull, W. B., Menges, C. M., and McFadden, L. D., 1979, Stream terraces of the San Gabriel Mountains, California: Menlo Park, Calif., technical report to U.S. Geological Survey under contract $14-08-001-\mathrm{G}-394,140 \mathrm{p}$.

Burford, R. O., 1972, Continued slip on the Coyote Creek fault after the Borrego Mountain earthquake, in The Borrego Mountain earthquake of April 9, 1968: U.S. Geological Survey Professional Paper 787, p. 105-111.

Burford, R. O., and Harsh, P. W., 1980, Slip on the San Andreas fault in central California from alinement array surveys: Bulletin of the Seismological Society of America, v. 70, no. 4, p. 1233-1261.

California Department of Water Resources, 1966, Santa Ana Gap salinity barrier, Orange County: California Department of Water Resources Bulletin 147-1, 178 p.

1968, Sea-water intrusion, Bolsa-Sunset area, Orange County California Department of Water Resources Bulletin 63-2, 167 p.

1970, Meeting water demands in the Chino-Riverside area, Appendix A-Water supply: California Department of Water Resources Bulletin 104-3, 108 p.

Castle, R. O., 1966, Preliminary study of the geology of two proposed sites for a nuclear-powered desalting plant near Sunset Beach and Pelican Point, Orange County, California: U.S. Geological Survey open-file report to the U.S. Atomic Energy Commission, 73 p.

Castle, R. O., and Yerkes, R. F., 1976, Recent surface movements in the Baldwin Hills, Los Angeles County, California: U.S. Geological Survey Professional Paper 882, 125 p.

Cemen, I., 1977, Geology of the Sespe-Piru Creek area, Ventura County, California: Athens, Ohio, Ohio University, unpublished M.Sci. thesis, $68 \mathrm{p}$.

Chinnery, M. A., 1965, The vertical displacements associated with transcurrent faulting: Journal of Geophysical Research, v. 70, no. 18 , p. $4627-4632$.

\section{Earthquake Hazards in the Los Angeles Region}

Chung, D. H., and Bernreuter, D. L., 1981, Regional relationships among earthquake magnitude scales: Reviews of Geophysics and Space Physics, v. 19, no. 4, p. 644-663.

Church, J. P., Castle, R. O., Clark, M. M., and Morton, D. M., 1974, Continuing crustal deformation in the western Mojave Desert [abs.]: Geological Society of America Abstracts with Programs, v. 6, no. 7, p. 687 .

Clark, M. M., 1972, Surface rupture along the Coyote Creek fault, in The Borrego Mountain earthquake of April 9, 1968: U.S. Geological Survey Professional Paper 787, p. 55-86.

Clark, M. M., Grantz, A., and Rubin, M., 1972, Holocene activity of the Coyote Creek fault as recorded in sediments of Lake Cahuilla, in The Borrego Mountain earthquake of April 9, 1968: U.S. Geological Survey Professional Paper 787, p. 112-130.

Clark, M. M., Lienkaemper, J. J., Harwood, D. S., Lajoie, K. R., Matti, J. C., Perkins, J. A., Rymer, M. J., Sarna-Wojcicki, A. M., Sharp, R. V., Sims, J. D., Tinsley, J. C., III, and Ziony, J. I., 1984, Preliminary slip-rate table and map of late-Quaternary faults of California: U.S. Geological Survey Open-File Report 84-106, 5 sheets, scale 1:1,000,000.

Cluff, L. S., 1978, Geologic considerations for seismic microzonation, in International Conference on Microzonation for Safer Construction Research and Application, 2d, San Francisco, Calif., 1978, Proceedings: v. 1, p. 135-152.

Corbett, E. J., and Johnson, C. E., 1982, The Santa Barbara, California, earthquake of 13 August 1978: Bulletin of the Seismological Society of America, v. 72, no. 6, p. 2201-2226.

Corbett, E. J., and Piper, K. A., 1981, Santa Barbara Island, California, earthquake, September 4, 1981 [abs.]: EOS, Transactions of the American Geophysical Union, v. 62, no. 45, p. 958.

Cotton, W. R., Ehlig, P., and Seward, A. E., 1983, Holocene activity of the San Gabriel fault, Valencia, California [abs.]: Association of Engineering Geologists Annual Meeting, 26th, San Diego, Calif., 1983, Abstracts and Programs, p. 60.

Cramer, C. H., and Harrington, I. M., 1984, Seismicity and tectonics of the eastern San Gabriel Mountains area, San Bernardino and Los Angeles counties, California, in Cramer, C. H., Harrington, I. M., Chase, G. W., and Bennett, I. H., Microearthquake, geophysical, and geodetic surveys for earthquake hazards evaluation, eastern San Gabriel Mountains and upper Pomona Valley areas, San Bernardino County, California: California Division of Mines and Geology Open-File Report 84-23 SAC, p. 5-22.

in press, Seismicity and tectonics of the Cucamonga fault and the eastern San Gabriel Mountains, San Bernardino County, California, in Recent reverse faulting in the Transverse Ranges, California: U.S. Geological Survey Professional Paper 1339.

Crippen, R. E., Luyendyk, B. P., and Hajic, E. J., 1982, High resolution structural mapping in the Santa Barbara Channel [abs.]: Geological Society of America Abstracts with Programs, v. 14, no. 4, p. 157.

Crook, R., Jr., Proctor, R. J., and Lindvall, C. E., 1983, Seismicity of the Santa Monica and Hollywood faults determined by trenching: Menlo Park, Calif., technical report to U.S. Geological Survey under contract 14-08-0001-20523, 26 p.

Crook, R., Jr., Allen, C. R., Kamb, B., Payne, C. M., and Proctor, R. J., in press, Quaternary geology and seismic hazard of the Sierra Madre and associated faults, western San Gabriel Mountains, California, in Recent reverse faulting in the Transverse Ranges, California: U.S. Geological Survey Professional Paper 1339.

Darrow, A. C., and Fischer, P. J., 1983, Activity and earthquake potential of the Palos Verdes fault: Menlo Park, Calif., technical report to U.S. Geological Survey under contract 14-08-0001-19786, $90 \mathrm{p}$. 
Darrow, A. C., and Sylvester, A. G., 1983, Activity of the central reach of the Santa Ynez fault: Menlo Park, Calif., technical report to U.S. Geological Survey under contract 14-08-0001-19787, 28 p.

Davis, T., and Duebendorfer, E., 1982, Surficial structure and geomorphology of the western "Big Bend" San Andreas fault, in Cooper, J. D., compiler, Neotectonics in southern California: Geological Society of America Annual Meeting, Cordilleran Section, 78th, Anaheim, Calif., 1982, Guidebook, p. 79-106.

Dibblee, T. W., Jr., 1966, Geology of the central Santa Ynez Mountains, Santa Barbara County, California: California Division of Mines and Geology Bulletin 186, 99 p.

Durham, D. L., and Yerkes, R. F., 1964, Geology and oil resources of the eastern Puente Hills area, southern California: U.S. Geological Survey Professional Paper 420-B, 62 p.

Fett, J. D., Hamilton, D. H., and Fleming, F. A., 1967, Continuing surface displacements along the Casa Loma and San Jacinto faults in San Jacinto Valley, Riverside County, California: Engineering Geology, v. 4, no. 1, p. 22-32.

Fife, D. L., Hoffman, R. A., Bryant, M. E., Rushing, R. J., Ruff, R. W., Santareangelo, A. A., and Unruh, M. E., 1980, The Peralta Hills thrust fault, southern California [abs.]: Geological Society of America Abstracts with Programs, v. 12, no. 3, p. 106.

Freund, L. B., and Barnett, D. M., 1976, Two-dimensional analysis of surface deformation due to dip-slip faulting: Bulletin of the Seismological Society of America, v. 66, no. 3, p. 667-675.

Gardner, D. A., 1982, Seismic/ground rupture hazards associated with the Camarillo fault, in Cooper, J. D., compiler, Neotectonics in southern California: Geological Society of America Annual Meeting, Cordilleran Section, 78th, Anaheim, Calif., 1982, Guidebook, p. $59-60$.

Gilluly, J., and Grant, U. S., 1949, Subsidence in the Long Beach Harbor area, California: Geological Society of America Bulletin, v. 60, p. 461-530.

Given, D. D., 1981, Seismicity of the San Jacinto fault zone, in Brown, A. R., and Ruff, R. W., eds., Geology of the San Jacinto Mountains: South Coast Geological Society Annual Field Trip Guidebook 9, p. 55-60.

Green, S. M., 1983, Seismotectonic study of the San Andreas, Mission Creek, and Banning fault system: Los Angeles, Calif., University of California, unpublished M.Sci. thesis, $52 \mathrm{p}$. .

Greene, H. G., Wolf, S. C., and Blom, K. G., 1978, The marine geology of the eastern Santa Barbara Channel with particular emphasis on the ground water basins offshore from the Oxnard Plain, California: U.S. Geological Survey Open-File Report 78-305, 104 p.

Guptill, P. D., and Heath, E. G., 1981, Surface faulting along the Newport-Inglewood zone of deformation: California Geology, v. 34, no. 7, p. 142-148.

Guptill, P., Collins, D., Sugiura, R., and Birkhahn, P., 1979, Quaternary deformation along the Llano fault, southern Antelope Valley, California [abs.]: Geological Society of American Abstracts with Programs, v. 11, no. 3, p. 81.

Hadley, D., and Combs, J., 1974, Microearthquake distribution and mechanisms of faulting in the Fontana-San Bernardino area of southern California: Bulletin of the Seismological Society of America, v. 64, no. B5, p. 1477-1499.

Hanks, T. C., and Kanamori, H., 1979, A moment magnitude scale: Jour-nal of Geophysical Research, v. 84, no. B5, p. 2348-2350.

Hanks, T. C., Thatcher, W., and Hileman, J. A., 1975, Seismic moments of the larger earthquakes of the southern California region, 1890-1973: Geological Society of America Bulletin, v. 86, p. 1131-1139.

Hannan, D. L., Lung, R., and Leighton, F. B., 1979, Geologic investigation of recency of fault activity by surface trenching on the Whittier fault, California: Menlo Park, Calif., technical report to U.S. Geological Survey under contract 14-08-0001-16821, CEL-2024, $43 \mathrm{p}$.

Hanson, D. W., 1981, Surface and subsurface geology of the Simi Valley area, Ventura County, California: Corvallis, Oreg., Oregon State University, unpublished M.Sci. thesis, $95 \mathrm{p}$.

Hart, E. W., 1980, Fault-rupture hazard zones in California: California Division of Mines and Geology Special Publication 42, 25 p.

Hart, E. W., Bortugno, E. J., and Smith, T. C., 1977, Summary report-Fault evaluation program, 1976 area (western Transverse Ranges): California Division of Mines and Geology Open-File Report 77-8 SF, 8 p.

Hart, E. W., Smith, D. P., and Smith, T. C., 1978, Summary report-Fault evaluation program, 1977 area (Los Angeles basin region): California Division of Mines and Geology Open-File Report 78-10 SF, $8 \mathrm{p}$.

Hart, E. W., Smith, D. P., and Saul, R. B., 1979, Summary report-Fault evaluation program, 1978 area (Peninsula Ranges-Salton Trough region): California Division of Mines and Geology Open-File Report 79-10 SF, $10 \mathrm{p}$.

Hays, W. W., 1980, Procedures for estimating earthquake ground motions: U.S. Geological Survey Professional Paper 1114, 77 p.

Heath, E. G., Jensen, D. E., and Lukesh, D. W., 1982, Style and age of deformation on the Chino fault, in Cooper, J. D., compiler, Neotectonics in southern California: Geological Society of America Annual Meeting, Cordilleran Section, 78th, Anaheim, Calif., 1982, Guidebook, p. 123-134.

Herd, D. G., 1979, Neotectonic framework of central coastal California and its implications to microzonation of the San Francisco Bay region, in Brabb, E. E., ed., Progress on seismic zonation in the San Francisco Bay region: U.S. Geological Survey Circular 807, p. 3-12.

Hileman, J. A., and Hanks, T. C., 1975, Seismicity along the San Andreas fault, southern California, in Crowell, J. C., ed., San Andreas fault in southern California: California Division of Mines and Geology Special Report 118, p. 28-39.

Hileman, J. A., Allen, C. R., and Nordquist, J. M., 1973, Seismicity of the southern California region, 1 January 1932 to 31 December 1972: Pasadena, Calif., California Institute of Technology Seismological Laboratory, $487 \mathrm{p}$.

Hill, R. L., 1979, Potrero Canyon fault and University High School escarpment, in Field guide to selected engineering geologic features, Santa Monica Mountains, Association of Engineering Geologists, Southern California Section, Guidebook to May 19, 1979, field trip: Los Angeles, Calif., p. 83-103.

Hill, R. L., Sprotte, E. C., Bennett, J. H., Real, C. R., and Slade, R. C., 1979, Location and activity of the Santa Monica fault, Beverly Hills-Hollywood area, California, in Earthquake hazards associated with faults in the greater Los Angeles metropolitan area, Los Angeles County, California, including faults in the Santa Monica-Raymond, Verdugo-Eagle Rock, and Benedict Canyon fault zones: California Division of Mines and Geology Open-File Report 79-16 LA, p. B1-B43.

Jackson, P. A., and Yeats, R. S., 1982, Structural evolution of Carpinteria basin, western Transverse Ranges, California: American Association of Petroleum Geologists Bulletin, v. 66, no. 7, p. 805-829.

Jakes, M. C. K., 1979, Surface and subsurface geology of the Camarillo and Los Posas Hills area, Ventura County, California: Corvallis, Oreg., Oregon State University, unpublished M.Sci. thesis, 116 p.

Jungels, P. H., and Frazier, G. A., 1973, Finite element analysis of the residual displacements for an earthquake rupture-Source parameters for the San Fernando earthquake: Journal of Geophysical Research, v. 78, no. 23, p. 5062-5083. 
Junger, A., 1976, Offshore structure between Santa Cruz and Santa Rosa Islands, in Howell, D. G., ed., Aspects of the geologic history of the California Continental Borderland: American Association of Petroleum Geologists, Pacific Section, Miscellaneous Publication 24, p. 418-426.

1979, Maps and seismic profiles showing geologic structure of the northern Channel Islands platform, California Continental Borderland: U.S. Geological Survey Miscellaneous Field Studies Map MF-991, scale 1:250,000.

Junger, A., and Wagner, H. C., 1977, Geology of the Santa Monica and San Pedro basins, California Continental Borderland: U.S. Geological Survey Miscellaneous Field Studies Map MF-820, scale $1: 250,000$.

Kahle, J. E., 1975, Surface effects and related geology of the Lakeview fault segment of the San Fernando fault zone, in Oakeshott, G. B., ed., San Fernando, California, earthquake of 9 February 1971: California Division of Mines and Geology Bulletin 196, p. 119-136.

1979, Geology and fault activity of the San Andreas fault zone between Quail Lake and Three Points, Los Angeles County, California: California Division of Mines and Geology Open-File Report 79-3 LA, 42 p.

Kahle, J. E., and Barrows, A. G., 1980, Fault activity of the Three Points and Pine Canyon segments, San Andreas fault zone, Los Angeles County, California: California Division of Mines and Geology OpenFile Report 80-13 LA, 38 p.

Kahle, J. E., Smith, D. P., and Beeby, D. J., 1977, Geology of the Leona Valley segment of the San Andreas fault zone, Los Angeles County, California: California Division of Mines and Geology Open-File Report 77-2 LA, 167 p.

Kamb, B., Silver, L. T., Abrams, M. J., Carter, B. A., Jordan, T. H., and Minster, J. B., 1971, Pattern of faulting and nature of fault movement in the San Fernando earthquake, in The San Fernando, California, earthquake of February 9, 1971: U.S. Geological Survey Professional Paper 733, p. 41-54.

Kanamori, H., and Regan, J., 1982, Long-period surface waves, in The Imperial Valley, California, earthquake of October 15, 1979: U.S. Geological Survey Professional Paper 1254, p. 55-58.

Keaton, J. R., 1978, Geomorphic evidence for late Quaternary displacement along the Santa Ynez fault zone, Blue Canyon, eastern Santa Barbara County, California [abs.]: Geological Society of America Abstracts with Programs, v. 10, no. 3, p. 111.

Keller, E. A., Johnson, D. L., Clark, M. N., and Rockwell, T. K., 1980, Tectonic geomorphology and earthquake hazard, north flank, central Ventura basin, California: Menlo Park, Calif., technical report to U.S. Geological Survey under contract 14-08-0001-17678, $178 \mathrm{p}$.

Keller, E. A., Rockwell, T. K., Clark, M. N., Dembroff, G. R., and Johnson, D. L., 1982, Tectonic geomorphology of the Ventura, Ojai, and Santa Paula areas, western Transverse Ranges, California: in Cooper, J. D., compiler, Neotectonics in southern California: Geological Society of America Annual Meeting, Cordilleran Section, 78th, Anaheim, Calif., 1982, Guidebook, p. 25-42.

Kennedy, M. P., 1977, Recency and character of faulting along the Elsinore fault zone in southern Riverside County, California: California Division of Mines and Geology Special Report 131, $12 \mathrm{p}$.

Kern, J. P., 1977, Origin and history of upper Pleistocene marine terraces, San Diego, California: Geological Society of America Bulletin, v. 88, p. 1553-1566.

Kew, W. S. W., 1927, Geologic sketch of Santa Rosa Island, Santa Barbara County, California: Geological Society of America Bulletin, v. 38, p. 645-653.

Knuepfer, P. L., Coppersmith, K. J., and Cluff, L. S., 1981, A framework for classifying faults based on their relative degree of activity [abs.]: Earthquake Notes, v. 52, no. 1, p. 70-71.

\section{Earthquake Hazards in the Los Angeles Region}

Kowalewsky, D. B., 1978, Indications of Holocene activity along branches of the Mission Hills fault west of Balboa Boulevard, in Geologic guide and engineering geology case histories, Los Angeles metropolitan area: Association of Engineering Geologists, Annual California Section Conference, 1st, Los Angeles, Calif., 1978, Guidebook, p. 53-63.

Lajoie, K. R., Kern, J. P., Wehmiller, J. F., Kennedy, G. L., Mathieson, S. A., Sarna-Wojcicki, A. M., Yerkes, R. F., and McCrory, P. F., 1979, Quaternary marine terrace shorelines and crustal deformation, San Diego to Santa Barbara, California, in Abbott, P. L., ed., Geologic excursions in the southern California area: San Diego, Calif., San Diego State University, Department of Geological Sciences, p. 3-15.

Lamar, D. L., 1972, Microseismicity and recent tectonic activity in the Whittier fault area: Menlo Park, Calif., technical report to U.S. Geological Survey under contract 14-08-00001-12288, 40 p.

1973, Microseismicity of the Whittier fault, California, in Guidebook to the Tertiary geology of eastern Orange and Los Angeles Counties, California: South Coast Geological Society Field Trip Guidebook, p. 61-66.

Lamar, D. L., and Scrivner, P. J., 1983, Annotated bibliography of engineering geology reports prepared to satisfy the Alquist-Priolo Special Studies Zones Act in southern California, pt. III, in Lamar, D. L., Smith, J. L., LaViolette, J. W., Custis, K., and Scrivner, P., eds., 1983, Application of private site-specific data to regional evaluation of earthquake and faulting potential in southern California: U.S. Geological Survey Open-File Report 83-834, 105 p.

Lamar, D. L., and Swanson, S. C., 1981, Study of seismic activity by selective trenching along the Elsinore fault zone, southern California: Menlo Park, Calif., technical report to U.S. Geological Survey under contract 14-08-0001-19144, $35 \mathrm{p}$.

Lamar, D. L., Merifield, P. M., and Proctor, R. J., 1973, Earthquake recurrence intervals on major faults in southern California, in Moran, D. E., Slosson, J. E., Stone, R. O., and Yelverton, C. A., eds., Geology, seismicity, and environmental impact: Los Angeles, Calif., Association of Engineering Geologists, p. 265-276.

Langenkamp, D., and Combs, J., 1974, Microearthquake study of the Elsinore fault zone, southern California: Bulletin of the Seismological Society of America, v. 64, no. 1, p. 187-203.

Lee, W. H. K., and Stewart, S. W., 1981, Principles and applications of microearthquake networks: Advances in Geophysics, supp. 2, p. 153-163.

Lee, W. H. K., Johnson, C. E., Henyey, T. L., and Yerkes, R. F., 1978, A preliminary study of the Santa Barbara, California, earthquake of August 13, 1978, and its major aftershocks: U.S. Geological Survey Circular 797, $11 \mathrm{p}$.

Lee, W. H. K., Yerkes, R. F., and Simirenko, M., 1979, Recent earthquake activity and focal mechanisms in the western Transverse Ranges, California: U.S. Geological Survey Circular 799-A, 37 p.

Leighton, F. B., Lung, R., and Cann, L. R., 1977, Geologic investigation by surface trenching of active faulting on the Santa Susana fault, Los Angeles and Ventura Counties, California: Menlo Park, Calif., technical report to U.S. Geological Survey under contract 14-080001-15863, CEL-288, $63 \mathrm{p}$.

Lindh, A. G., 1983, A preliminary assessment of long-term probabilities for large earthquakes along selected fault segments of the San Andreas fault system: U.S. Geological Survey Open-File Report $83-63,15 \mathrm{p}$.

LNG Seismic Review Panel, 1981, Seismic safety review of the proposed liquefied natural gas facility, Little Cojo Bay, Santa Barbara County, California: San Francisco, Calif., California State Public Utilities Commission, $33 \mathrm{p}$.

Lofgren, B. E., 1976, Land subsidence and aquifer-system compaction in the San Jacinto Valley, Riverside County, California-A progress 
report: U.S. Geological Survey Journal of Research, v. 4, no. 1, p. 9-18.

Lung, R., and Weick, R. J., 1978, Exploratory trenching of the Santa Susana fault in Los Angeles and Ventura Counties, California, in Geologic guide and engineering geology case histories, Los Angeles metropolitan area: Association of Engineering Geologists, Annual California Section Conference, 1st, Los Angeles, Calif., 1978, Guidebook, p. 73-80.

McGill, J. T., 1981, Recent movement on the Potrero Canyon fault, Pacific Palisades area, Los Angeles, in Geological Survey research 1980: U.S. Geological Survey Professional Paper 1175, p. 258-259.

1982, Preliminary geologic map of the Pacific Palisades area, City of Los Angeles, California: U.S. Geological Survey Open-File Report 82-194, scale 1:4,800, 15-p. text.

Mark, R. K., and Bonilla, M. G., 1977, Regression analysis of earthquake magnitude and surface fault length using the 1970 data of Bonilla and Buchanan: U.S. Geological Survey Open-File Report 77-614, $8 \mathrm{p}$.

Martner, S. T., 1948, The Dominguez Hills, California, earthquake of June 18, 1944: Bulletin of the Seismological Society of America, v. 38, p. 105-119.

Matsuda, T,, 1975, Magnitude and recurrence interval of earthquakes from a fault: Zisin, ser. 2, v. 28, p. 269-283. (In Japanese with English abstract.)

1977, Estimation of future destructive earthquakes from active faults on land in Japan: Journal of Physics of the Earth, v. 25; suppl., p. S251-\$260.

Matti, J. C., and Morton, D. M., 1982, Geologic history of the Banning fault zone, southern California [abs.]: Geological Society of America Abstracts with Programs, v. 14, no. 4, p. 184.

Matti, J. C., Morton, D. M., Tinsley, J. C., and McFadden, L. D., in press, The Cucamonga fault zone, pt. 2, History of faulting on the Day Canyon and East Etiwanda Canyon alluvial fans, in Recent reverse faulting in the Transverse Ranges, California: U.S. Geological Survey Professional Paper 1339.

Matti, J. C., Tinsley, J. C., Morton, D. M., and McFadden, L. D., 1982 Holocene faulting history as recorded by alluvial stratigraphy within the Cucamonga fault zone-A preliminary view, in Tinsley, J. C., Matti, J. C., and McFadden, L. D., eds., Late Quaternary pedogenesis and alluvial chronologies of the Los Angeles and San Gabriel Mountains areas, southern California: Geological Society of America Annual Meeting, Cordilleran Section, 78th, Anaheim, Calif., 1982, Guidebook 12, p. 29-44.

Meisling, K. E., 1984, Neotectonics of the north frontal fault system of the San Bernardino Mountains, southern California: Pasadena, Calif., California Institute of Technology, unpublished Ph.D. thesis, $394 \mathrm{p}$.

Meisling, K. E., and Weldon, R. J., 1982a, Slip rate, offset, and history of the Cleghorn fault, western San Bernardino Mountains, southern California [abs.]: Geological Society of America Abstracts with Programs, v. 14, no. 4, p. 215.

1982b, The late-Cenozoic structure and stratigraphy of the western San Bernardino Mountains, in Geologic excursions in the Transverse Ranges: Geological Society of America Annual Meeting, Cordilleran Section, 78th, Anaheim, Calif., 1982, Guidebook, p. 75-81.

Mezger, L., and Weldon, R. J., 1983, Tectonic implications of the Quaternary history of lower Lytle Creek, southeast San Gabriel Mountains [abs.]: Geological Society of America Abstracts with Programs, v. 15, no. 5, p. 418.

Miller, F. K., 1979, Geologic map of the San Bernardino North quadrangle, California: U.S. Geological Survey Open-File Report 79-770, scale 1:24,000.

in press, Reverse fault system bounding the north side of the San Bernardino Mountains, in Recent reverse faulting in the Trans- verse Ranges, California: U.S. Geological Survey Professional Paper 1339.

Miller, F. K., and Morton, D. M., 1980, Potassium-argon geochronology of the eastern Transverse Ranges and southern Mojave Desert, southern California: U.S. Geological Survey Professional Paper $1152,30 \mathrm{p}$.

Millman, D. E., 1985, Neotectonics of part of the northern Elsinore fault zone in the Temescal Valley area, western Riverside County, California: San Diego, Calif., San Diego State University unpublished M.Sci. thesis.

Molnar, P., 1979, Earthquake recurrence intervals and plate tectonics: Bulletin of the Seismological Society of America, v. 69, no. 1, p. 115-133.

Morton, D. M., 1973, Geology of parts of the Azusa and Mount Wilson quadrangles, San Gabriel Mountains, Los Angeles County, California: California Division of Mines and Geology Special Report 105, $21 \mathrm{p}$.

1975, Synopsis of the geology of the eastern San Gabriel Mountains, southern California, in Crowell, J. C., ed., San Andreas fault in southern California: California Division of Mines and Geology Special Report 118, p. 170-176.

1976, Generalized fault map of southwestern San Bernardino County (west half), plates $2 A$ and $2 B$, in Fife, D. L., Rodgers, D. A., Chase, G. W., Chapman, R. H., and Sprotte, E. C., ads., Geologic hazards in southwestern San Bernardino County, California: California Division of Mines and Geology Special Report 113, 40 p.

1978, Ground fissuring in part of the San Jacinto Valley, southern California [abs.]: Geological Society of America Abstracts with Programs, v. 10, no. 3, p. 138.

Morton, D. M., and Matti, J. C., in press, The Cucamonga fault zone, pt. 1, Geologic setting and history of Quaternary faulting, in Recent reverse faulting in the Transverse Ranges, California: U.S. Geological Survey Professional Paper 1339.

Morton, D. M., and Miller, F. K., 1975, Geology of the San Andreas fault zone north of San Bernardino between Cajon Canyon and Santa Ana Wash, in Crowell, J. C., ed., San Andreas fault in southern California: California Division of Mines and Geology Special Report 118, p. 136-146.

Morton, D. M., Miller, F. K., and Smith, C. C., 1980, Photoreconnaissance maps showing young-looking fault features in the southern Mojave Desert, California: U.S. Geological Survey Miscellaneous Field Studies Map MF-1051, scales $1: 24,000$ to 1:62,500, 7 sheets.

Morton, D. M., Matti, J. C., and Tinsley, J. C., 1982, Quaternary history of the Cucamonga fault zone, southern California [abs.]: Geological Society of America Abstracts with Programs, v. 14, no. 4, p. 218.

Morton, P. K., Miller, R. V., and Fife, D. L., 1973, Preliminary geoenvironmental maps of Orange County, California: California Division of Mines and Geology Preliminary Report 15, 4 pls., scale $1: 48,000$.

Nardin, T. R., 1981, Seismic stratigraphy of Santa Monica and San Pedro basins, California Continental Borderland-Late Neogene history of sedimentation and tectonics: Los Angeles, Calif., University of Southern California, unpublished Ph.D. thesis, 270 p.

Nardin, T. R., and Henyey, T. L., 1978, Pliocene-Pleistocene diastrophism of Santa Monica and San Pedro shelves, California Continental Borderland: American Association of Petroleum Geologists Bulletin, v. 62, no. 2, p. 247-272.

Nelligan, F. M., 1978, Geology of the Newhall area of the eastern Ventura and western Soledad basins, Los Angeles County, California: Corvallis, Oreg., Oregon State University, unpublished M.Sci. thesis, $117 \mathrm{p}$.

Nuttli, O. W., and Hermann, R. B., 1982, Earthquake magnitude scales: Proceedings of the American Society of Civil Engineers, Journal of the Geotechnical Engineering Division, v. 108, no. GT5, p. 783-786. 
Olson, D. J., 1982, Surface and subsurface geology of the Santa Barbara-Goleta metropolitan area, Santa Barbara County, California: Menlo Park, Calif., technical report to U.S. Geological Survey under contract 14-08-0001-19173, $71 \mathrm{p}$.

Pampeyan, E. H., 1979, Preliminary map showing recency of faulting in coastal north-central California: U.S. Geological Survey Miscellaneous Field Studies Map MF-1070, scale 1:250,000.

Patterson, R. H., 1979, Tectonic geomorphology and neotectonics of the Santa Cruz Island fault, Santa Barbara County, California: Santa Barbara, Calif., University of California, unpublished M.Sci. thesis, $141 \mathrm{p}$.

Pechmann, J. C., in press, Tectonic implications of small earthquakes in the central Transverse Ranges, California, in Recent reverse faulting in the Transverse Ranges, California: U.S. Geological Survey Professional Paper 1339.

Pinault, C. T., and Rockwell, T. K., 1984, Rates and sense of Holocene faulting on the southern Elsinore fault: Further constraints on the distribution of dextral shear between the Pacific and North American plates [abs.]: Geological Society of America Abstracts with Programs, v. 16, no. 6, p. 624.

Poland, J. F., and Piper, A. M., 1956, Ground water geology of the coastal zone, Long Beach-Santa Ana area, California: U.S. Geological Survey Water-Supply Paper 1109, $126 \mathrm{p}$.

Poland, J. F., Garrett, A. A., and Sinnott, A., 1959, Geology, hydrology, and chemical character of ground waters in the Torrance-Sant Monica area, California: U.S. Geological Survey Water-Supply Paper 1461, $425 \mathrm{p}$.

Ponti, D. J., and Burke, D. B., 1980, Map showing Quaternary geology of the eastern Antelope Valley and vicinity, California: U.S. Geological Survey Open-File Report 80-1064, scale 1:62,500.

Proctor, R. J., 1962, Geologic features of a section across the Casa Loma fault, exposed in an aqueduct trench near San Jacinto, California: Geological Society of America Bulletin, v. 73, p. 1293-1296.

1974, New localities for fault creep in southern CaliforniaRaymond and Casa Loma faults [abs.]: Geological Society of America Abstracts with Programs, v. 6, no. 3, p. 238.

Raleigh, C. B., Sieh, K., Sykes, L. R., and Anderson, D. L., 1982 Forecasting southern California earthquakes: Science, v. 217, no. 4565, p. 1097-1104.

Rasmussen, G. S., 1981, Nature of surface rupture and recurrence interval, Casa Loma fault, in Brown, A. R., and Ruff, R. W., eds., Geology of the San Jacinto Mountains: South Coast Geological Society Annual Field Trip Guidebook 9, p. 48-54.

1982a, Geologic features and rate of movement along the south branch of the San Andreas fault, San Bernardino, California, in Cooper, J. D., compiler, Neotectonics in southern California: Geological Society of America Annual Meeting, Cordilleran Section, 78th, Anaheim, Calif., 1982, Guidebook, p. 109-114.

1982b, Historic earthquakes along the San Jacinto fault zone, San Jacinto, California: in Cooper, J. D., compiler, Neotectonics in southern California: Geological Society of America Annual Meeting, Cordilleran Section, 78th, Anaheim, Calif., 1982, Guidebook, p. 115-121.

Real, C. R., in press, Seismicity and tectonics of the Santa Monica-Hollywood-Raymond Hill fault and northern Los Angeles basin, Los Angeles County, California, in Recent reverse faulting in the Transverse Ranges, California: U.S. Geological Survey Professional Paper 1339.

Research Group for Active Faults of Japan, 1980, Active faults in Japan, sheet maps and inventories: Tokyo, University of Tokyo Press, 363 p. (In Japanese with English summary.)

Richter, C. F., 1935, An instrumental earthquake magnitude scale: Bulletin of the Seismological Society of America, v. 25, no. 1, n. 1-32.

\section{Earthquake Hazards in the Los Angeles Region}

1958, Elementary seismology: San Francisco, Calif., W. H. Freeman, 768 p.

Ricketts, E. W., and Whaley, K. R., 1975, Structure and stratigraphy of the Oak Ridge fault-Santa Susana fault intersection, Ventura Basin, California: Athens, Ohio, Ohio University, unpublished M.Sci. thesis, $81 \mathrm{p}$.

Rieser, R. B., 1976, Structural study of the Oak Ridge fault between South Mountains and Wiley Canyon, Ventura County, California: Athens, Ohio, Ohio University, unpublished M.Sci. thesis, 93 p.

Rockwell, T. K., 1982, Style, rates, and recency of deformation along the San Cayetano fault, western Transverse Ranges, California [abs.]: Geological Society of America Abstracts with Programs, v. 14, no. 4, p. 228.

1983, Soil chronology, geology, and neotectonics of the north central Ventura basin, California: Santa Barbara, Calif., University of California, unpublished Ph.D. thesis, 424 p.

Rockwell, T. K., Keller, E. A., Clark, M. N., and Johnson, D. L., 1984, Chronology and rates of faulting of Ventura River terraces, California: Geological Society of America Bulletin, v. 95, no. 12, p. 1466-1474.

Rockwell, T. K., Lamar, D. L., McElwain, R. S., and Millman, D. E., 1985, Late Holocene recurrent faulting on the Glen Ivy North strand of the Elsinore fault, southern California [abs.]: Geological Society of America Abstracts with Programs, Cordilleran Section, v. 17 , no. 6, p. 404

Ross, D. C., 1969, Map showing recently active breaks along the San Andreas fault between Tejon Pass and Cajon Pass, southern California: U.S. Geological Survey Miscellaneous Geologic Investigations Map I-553, scale 1:24,000.

Rust, D. J., 1982, Radiocarbon dates for the most recent large prehistoric earthquake and for late Holocene slip rates, San Andreas fault in part of the Transverse Ranges north of Los Angeles [abs.]: Geological Society of America Abstracts with Programs, v. 14 , no. 4, p. 229.

Sanders, C. O., and Kanamori, H., 1984, A seismotectonic analysis of the Anza seismic gap, San Jacinto fault zone, southern California: Journal of Geophysical Research, v. 89, no. B7, p. 5873-5890.

Sarna-Wojcicki, A. M., Williams, K. M., and Yerkes, R. F., 1976, Geology of the Ventura fault, Ventura County, California: U.S. Geological Survey Miscellaneous Field Studies Map MF-781, scale $1: 6,000$.

Sarna-Wojcicki, A. M., Bowman, H. R., Meyer, C. E., Russell, P. C., Woodward, M. J., McCoy, G., Rowe, J. J., Jr., Baedecker, P. A., Asaro, F., and Michael, H., 1984, Chemical analyses, correlations, and ages of upper Pliocene and Pleistocene ash layers of eastcentral and southern California: U.S. Geological Survey Professional Paper 1293, $40 \mathrm{p}$.

Sarna-Wojcicki, A. M., Lajoie, K. R., and Yerkes, R. F., in press, Recurrent Holocene displacement on the Javon Canyon fault-A comparison of fault movement history with calculated average recurrence intervals, in Recent reverse faulting in the Transverse Ranges, California: U.S. Geological Survey Professional Paper 1339.

Saul, R. B., 1975, Geology of the southeast slope of the Santa Susana Mountains and geologic effects of the San Fernando earthquake, in Oakeshott, G. B., ed., San Fernando, California, earthquake of 9 February 1971: California Division of Mines and Geology Bulletin 196, p. 53-70.

Savage, J. C., Burford, R. O., and Kinoshita, W. T., 1975, Earth movements from geodetic measurements, in Oakeshott, G. B., ed., San Fernando, California, earthquake of 9 February 1971: California Division of Mines and Geology Bulletin 196, p. 175-186.

Schlueter, J. C., 1976, Geology of the upper Ojai-Timber Canyon area, Ventura County, California: Athens, Ohio, Ohio University, unpublished M.Sci. thesis, $76 \mathrm{p}$ 
Schoellhamer, J. E., Vedder, J. G., Yerkes, R. F., and Kinney, D. M., 1981 Geology of the northern Santa Ana Mountains, California: U.S. Geological Survey Professional Paper 420-D, 119 p.

Scholz, C. H., 1982, Scaling laws for large earthquakes-Consequences for physical models: Bulletin of the Seismological Society of America, v. 72, no. 1, p. 1-14.

Schubert, C., and Crowell, J. C., 1980, Neotectonic map of the San Andreas fault between Valyermo and Wrightwood, California: Menlo Park, Calif., technical report to U.S. Geological Survey under contract 14-08-0001-17676, $20 \mathrm{p}$.

Schwartz, D. P., and Coppersmith, K. J., 1984, Fault behavior and characteristic earthquakes: Examples from the Wasatch and San Andreas fault zones: Journal of Geophysical Research, v. 89, no. B7, p. 5681-5698.

Sharp, R. V., 1967, San Jacinto fault zone in the Peninsula Ranges of southern California: Geological Society of America Bulletin, v. 78, p. 705-730.

1972, Map showing recently active breaks along the San Jacinto fault zone between the San Bernardino area and Borrego Valley, California: U.S. Geological Survey Miscellaneous Investigations Map I-675, scale 1:24,000.

1975, Displacement on tectonic ruptures, in Oakeshott, G. B., ed. San Fernando, California, earthquake of 9 February 1971: California Division of Mines and Geology Bulletin 196, p. 187-194.

1981a, Displacements on tectonic ruptures in the San Fernando earthquake of February 9, 1971-Discussion and some implications: U.S. Geological Survey Open-File Report 81-668, 14 p.

$1981 \mathrm{~b}$, Variable rates of late Quaternary strike slip on the San Jacinto fault zone, southern California: Journal of Geophysical Research, v. 86, no. B3, p. 1754-1762.

Sharp, R. V., and Clark, M. M., 1972, Geologic evidence of previous faulting near the 1968 rupture on the Coyote Creek fault, in The Eorrego Mountain earthquake of April 9, 1968: U.S. Geological Survey Professional Paper 787, p. 131-140.

Sharp, R. V., Lienkaemper, J. J., Bonilla, M. G., Burke, D. B., Cox, B. F., Herd, D. G., Miller, D. M., Morton, D. M., Ponti, D. J., Rymer, M. J., Tinsley, J. C., Yount, J. C., Kahle, J. E., Hart, E. W., and Sieh, K. E., 1982, Surface faulting in central Imperial Valley, in The Imperial Valley, California, earthquake of October 15, 1979: U.S. Geological Survey Professional Paper 1254, p. 119-143.

Shields, K. E., 1978, Faults along the northwestern margin of the San Fernando Valley, Los Angeles County, California, in Geologic guide and engineering geology casse histories, Los Angeles metropolitan area: Association of Engineering Geologists, Annual California Section Conference, 1st, Los Angeles, Calif., 1978, Guidebook, p. 44-52.

Sieh, K. E., 1978a, Slip along the San Andreas fault associated with the great 1857 earthquake: Bulletin of the Seismological Society of America, v. 68, p. 1421-1448.

1978b, Central California foreshocks of the great 1857 earthquake: Bulletin of the Seismological Society of America, v. 68, p. 1731-1749.

1978c, Prehistoric large earthquakes produced by slip on the San Andreas fault at Pallett Creek, California: Journal of Geophysical Research, v. 83, no. 8, p. 3907-3939.

1981, A review of geological evidence for recurrence times of large earthquakes, in Simpson, D. W., and Richards, P. G., eds., Earthquake prediction-An international review: American Geophysical Union Maurice Ewing Series, no. 4, p. 181-207.

1984, Lateral offsets and revised dates of large prehistoric earthquakes at Pallett Creek, southern California: Journal of Geophysical Research, v. 89, no. B9, p. 7641-7670.

Sieh, K. E., and Jahns, R. E., 1984, Holocene activity of the San Andreas fault at Wallace Creek, California: Geological Society of America Bulletin, v. 95, p. 883-896.
Simila, G. W., Eliades, P. G., Hagan, J. D., and Adams, H. G., 1982, Microearthquake activity in the Santa Susana Mountains and Simi Hills, San Fernando Valley [abs.]: Earthquake Notes, v. 53, no. 1, p. 84.

Slemmons, D. B., 1977, State-of-the-art for assessing earthquake hazards in the United States; faults and earthquake magnitude: U.S. Army Corps of Engineers Waterways Experiment Station Miscellaneous Paper S-3-73-1, Report 6, 166 p.

Stanley, K. O., 1966, The structural history of the Clearwater fault, northwest Los Angeles County, California: Los Angeles, Calif., University of California, unpublished M.A. thesis, 73 p.

Stein, R. S., and King, G. C. P., 1984, Seismic potential revealed by surface folding: 1983 Coalinga, California, earthquake: Science, v. 224 , p. 869-872.

Stein, R. S., and Thatcher, W., 1981, Seismic and aseismic deformation associated with the 1952 Kern County, California, earthquake and relationship to the Quaternary history of the White Wolf fault: Journal of Geophysical Research, v. 86, no. B6, p. 4913-4928.

Stitt, L. T., 1983, Geology, seismic hazard, and ground-rupture hazard of the San Gabriel and Holser faults, eastern Ventura and western Soledad basins, California: Menlo Park, Calif., technical report to U.S. Geological Survey under contract 14-08-0001-19138, 26 p.

Thatcher, W., Hileman, J. A., and Hanks, T. C., 1975, Seismic slip distribution along the San Jacinto fault zone, southern California, and its implications: Geological Society of America Bulletin, v. 86, p. 1140-1146.

U.S. Geological Survey Staff, 1971, Surface faulting, in The San Fernando, California, earthquake of February 9, 1971: U.S. Geological Survey Professional Paper 733, p. 55-76.

Upson, J. E., 1951, Geology and ground-water resources of the southcoast basins of Santa Barbara County, California, with a section on Surface-water resources, by H. G. Thomasson, Jr.: U.S. Geological Survey Water-Supply Paper 1108, 144 p.

Wallace, R. E., 1977, Profiles and ages of young fault scarps, northcentral Nevada: Geological Society of America Bulletin, v. 88, p. 1267-1281.

1981, Active faults, paleoseismology, and earthquake hazards in the western United States, in Simpson, D. W., and Richards, P. G., eds., Earthquake prediction-An international review: American Geophysical Union Maurice Ewing Series, no. 4, p. 209-216.

1982, Fault-scarp analysis in paleoseismicity [abs.]: EOS, Transactions of the American Geophysical Union, v. 63, no. 18, p. 435.

Weber, F. H., Jr., 1975, Surface effects and related geology of the San Fernando earthquake in the Sylmar area, in Oakeshott, G. B., ed., San Fernando, California, earthquake of 9 February 1981: California Division of Mines and Geology Bulletin 196, p. 71-96.

1977, Seismic hazards related to geologic factors, Elsinore and Chino fault zones, northwestern Riverside County, California: California Division of Mines and Geology Open-File Report 77-4 LA, 96 p.

1978, Geologic and geomorphic investigation of the San Gabriel fault zone, Los Angeles and Ventura Counties, California: Menlo Park, Calif., technical report to U.S. Geological Survey under contract 14-08-0001-16600, 78 p.

1980, Geological features related to character and recency of movement along faults, north-central Los Angeles County, California, in Weber, F. H., Jr., Bennett, J. H., Chapman, R. H., Chase, G. W., and Saul, R. B., eds., Earthquake hazards associated with the Verdugo-Eagle Rock and Benedict Canyon fault zones, Los Angeles County, California: California Division of Mines and Geology Open-File Report 80-10 LA, p. B1-B116.

1982, Geology and geomorphology along the San Gabriel fault zone, Los Angeles and Ventura Counties, California: California Division of Mines and Geology Open-File Report 82-2 LA, 157 p.

References Cited 479 
Weber, F. H., Jr., and Kiessling, E. W., 1975, General features of seismic hazards of Ventura County, California, in Seismic hazards of Ventura County, California: California Division of Mines and Geology Open-File Report 76-5 LA, p. 8-217.

Weldon, R. J., and Sieh, K. E., 1981, Offset rate and possible timing of recent earthquakes on the San Andreas fault in Cajon Pass, California [abs.]: EOS, Transactions of the American Geophysical Union, v. 62, no. 45, p. 1048.

Wentworth, C. M., Ziony, J. I., and Buchanan, J. M., 1970, Preliminary environmental map of the greater Los Angeles area, California: Springfield, Va., National Technical Information Service TID-25363, 41 p., 1:250,000 scale. (Available in microfiche only.)

Wesnousky, S. G., Scholz, C. H., and Shimazaki, K., 1982, Deformation of an island arc: Rates of moment release and crustal shortening in intraplate Japan determined from seismicity and Quaternary fault data: Journal of Geophysical Research, v. 87, no. 8, p. 6829-6852.

Wesnousky, S. G., Scholz, C. H., Shimazaki, K., and Matsuda, T., 1984, Integration of geological and seismological data for the analysis of seismic hazard: A case study of Japan: Bulletin of the Seismological Society of America, v. 74, no. 2, p. 687-708.

Wesson, R. L., Page, R. A., Boore, D. M., and Yerkes, R. F., 1974, Expectable earthquakes and their ground motions in the Van Norman reservoirs area, in The Van Norman reservoirs area, northern San Fernando Valley, California: U.S. Geological Survey Circular 691-B, p. B1-B9.

Wesson, R. L., Helley, E. J., Lajoie, K. R., and Wentworth, C. M., 1975 , Faults and future earthquakes, in Borcherdt, R. D., ed., Studies for seismic zonation of the San Francisco Bay region: U.S. Geological Survey Professional Paper 941-A, p. A5-A30.

Woodring, W. P., Bramlette, M. N., and Kew, W. S. W., 1946, Geology and paleontology of Palos Verdes Hills, California: U.S. Geological Survey Professional Paper 207, 145 p.

Woodward-Clyde Consultants, 1979, Report on the evaluation of maximum earthquake and site ground motion parameters associated with the Offshore Zone of Deformation, San Onofre Nuclear Generating Station: Los Angeles, Calif,, report prepared for Southern California Edison, 56 p., 11 figs., 10 apps.

Wyss, M., 1979, Estimating maximum expectable magnitude of earthquakes from fault dimensions: Geology, v. 7, p. 336-340.

Yeats, R. S., 1977, High rates of vertical crustal movement near Ventura, California: Science, v. 196, p. 295-298.

1982, Low-shake faults of the Ventura basin, California, in Cooper, J. D., compiler, Neotectonics in southern California: Geological Society of America Annual Meeting, Cordilleran Section, 78th, Anaheim, Calif., 1982, Guidebook, p. 3-23.

1983, Large-scale Quaternary detachments in Ventura basin, southern California: Journal of Geophysical Research, v. 88, no. 1, p. 569-583.

Yeats, R. S., and Olson, D. J., 1984, Alternate fault model for the Santa Barbara, California, earthquake of 13 August 1978: Bulletin of the Seismological Society of America, v. 74, no. 5, p. 1545-1553.

Yeats, R. S., Lant, K. J., and Shields, K. E., 1977, Subsurface geology of the Santa Susana fault in the aftershock area downstep of the 1971 San Fernando earthquake: Menlo Park, Calif., technical report to U.S. Geological Survey under contract 14-08-0001$15271,23 \mathrm{p}$.

Yeats, R. S., Clark, M. N., Keller, E. A., and Rockwell, T. K., 1981, Active fault hazard in southern California-Ground rupture versus seismic shaking: Geological Society of America Bulletin, v. 92, p. 189-196.
Yeats, R. S., Keller, E. A., Rockwell, T. K., Lajoie, K. R., Sarna-Wojcicki, A. M., and Yerkes, R. F., 1982, Field trip number 3-Neotectonics of the Ventura Basin-Road log, in Cooper, J. D., compiler, Neotectonics in southern California: Geological Society of America Annual Meeting, Cordilleran Section, 78th, Änaheim, Calif., 1982, Guidebook, p. 61-76.

Yeats, R. S., Lee, W. H. K., and Yerkes, R. F., in press, Geology and seismicity of the eastern Red Mountain fault, Ventura County, California, in Recent reverse faulting in the Transverse Ranges, California: U.S. Geological Survey Professional Paper 1339.

Yerkes, R. F., 1972, Geology and oil resources of the western Puente Hills area, southern California: U.S. Geological Survey Professional Paper 420-C, 60 p.

Yerkes, R. F., and Lee, W. H. K., 1979a, Faults, fault activity, epicenters, focal depths, and focal mechanisms, 1970-75 earthquakes, western Transverse Ranges, California: U.S. Geological Survey Miscellaneous Field Studies Map MF-1032, 2 sheets, scale 1:250,000.

1979b, Late Quaternary deformation in the western Transverse Ranges, California: U.S. Geological Survey Circular 799-B, 10 p.

Yerkes, R. F., and Wentworth, C. M., 1965, Structure, Quaternary history, and general geology of the Corral Canyon area, Los Angeles County, California: U.S. Geological Survey Open-File Report 864, $215 \mathrm{p}$.

Yerkes, R. F., McCulloh, T. H., Schoellhamer, J. E., and Vedder, J. G., 1965, Geology of the Los Angeles basin, California-An introduction: U.S. Geological Survey Professional Paper 420-A, $57 \mathrm{p}$.

Yerkes, R. F., Gorsline, D. S., and Rusnak, G. A., 1967, Origin of Redondo submarine canyon, southern California, in Geological Survey research 1967: U.S. Geological Survey Professional Paper 575-C, p. C97-C105.

Yerkes, R. F., Bonilla, M. G., Youd, T. L., and Sims, J. D., 1974, Geologic environment of the Van Norman reservoirs area, in The Van Norman reservoirs area, northern San Fernando Valley, California: U.S. Geological Survey Circular 691-A, p. A1-A35.

Yerkes, R. F., Greene, H. G., Tinsley, J. C., and Lajoie, K. R., 1981, Seismotectonic setting of the Santa Barbara Channel area, southern California: U.S. Geological Survey Miscellaneous Studies Map MF-1169, scale 1:250,000.

Yerkes, R. F., Ellsworth, W. L., and Tinsley, J. C., 1983, Triggered reverse fault and earthquake due to crustal unloading, northwest Traverse Ranges, California: Geology, v. 11, p. 287-291.

Yerkes, R. F., McGarr, A. F., Wentworth, C. M., and Walter, A. W., 1984, Abnormally high fluid pressures near the Coast RangesGreat Valley boundary, California, may aid northeast-directed thrusting responsible for the 1983 Coalinga earthquake [abs.]: EOS, Transactions of the American Geophysical Union, v. 65, no. 45, p. 995.

Youd, T. L., Yerkes, R. F., and Clark, M. M., 1978, San Fernando faulting damage and its effect on land use, in American Society of Civil Engineers Specialty Conference on Earthquake Engineering and Soil Dynamics, Pasadena, Calif., 1978, Proceedings: v. 2, p. 1111-1125.

Ziony, J. I., Wentworth, C. M., and Buchanan, J. M., 1973, Recency of faulting: A widely applicable criterion for assessing the activity of faults: World Conference on Earthquake Engineering, 5th, Rome 1973, Proceedings, v. 2, p. 1680-1683.

Ziony, J. I., Wentworth, C. M., Buchanan-Banks, J. M., and Wagner, H. C., 1974, Preliminary map showing recency of faulting in coastal southern California: U.S. Geological Survey Miscellaneous Field Studies Map MF-585, scale 1:250,000.

\section{Earthquake Hazards in the Los Angeles Region}




\section{Predicting Earthquake Ground Motion: An Introduction}

Apsel, R. I., Frazier, G. A., Jurkevics, A., and Fried, J. C., 1981, Ground motion prediction for the Los Angeles Basin from a major San Andreas earthquake: U.S. Geological Survey Open-File Report 81-276, $217 \mathrm{p}$.

Blume, J. A., Scholl, R. E., Somerville, M. R., and Honda, K. K., 1980, Damage prediction of an earthquake in southern California: U.S. Geological Survey Open-File Report 80-1145, 83 p.

Borcherdt, R. D., 1970, Effects of local geology on ground motion near San Francisco Bay: Bulletin of the Seismological Society of America, v. 60, p. 29-61.

ed., 1975, Studies for seismic zonation of the San Francisco Bay region: U.S. Geological Survey Professional Paper 941-A, 102 p.

Borcherdt, R. D., and Gibbs, J. F., 1976, Effects of local geological conditions in the San Francisco Bay region on ground motions and the intensities of the 1906 earthquake: Bulletin of the Seismological Society of America, v. 66, p. 467-500.

Borcherdt, R. D., Gibbs, J. F., and Lajoie, K. R., 1975a, Maps showing maximum earthquake intensity predicted in the southern San Francisco Bay region, California, for large earthquakes on the San Andreas and Hayward faults: U.S. Geological Survey Miscellane ous Field Studies Map MF-709, scale 1:125,000, 11-p. text.

Borcherdt, R. D., Brabb, E. E., Joyner, W. B., Helley, E. J., Lajoie, K. R., Page, R. A., Wesson, R. L., and Youd, T. L., 1975b, Predicted geologic effects of a postulated earthquake, in Borcherdt, R. D., ed., Studies for seismic zonation of the San Francisco Bay region: U.S. Geological Survey Professional Paper 941-A, p. A88-A96.

Borcherdt, R. D., Joyner, W. B., Warrick, R. E., and Gibbs, J. F., 1975c, Response of local geologic units to ground shaking, in Borcherdt, R. D., ed., Studies for seismic zonation of the San Francisco Bay region: U.S. Geological Survey Professional Paper 941-A, p. A52-A67.

Borcherdt, R. D., Gibbs, J. F., and Fumal, T. E., 1979, Progress on ground motion predictions for the San Francisco Bay region, in Brabb, E. E., ed., Progress on seismic zonation in the San Francisco Bay region: U.S. Geological Survey Circular 807, p. 13-25.

Davis, J. F., Bennett, J. H., Borchardt, G. A., Kahle, J. E., Rice, S. J., and Silva, M. A., 1982a, Earthquake planning scenario for a magnitude 8.3 earthquake on the San Andreas fault in southern California: California Division of Mines and Geology Special Publication 60, $128 \mathrm{p}$.

$1982 \mathrm{~b}$, Earthquake planning scenario for a magnitude 8.3 earthquake on the San Andreas fault in the San Francisco Bay area: California Division of Mines and Geology Special Publication 61, $160 \mathrm{p}$.

Evernden, J. F., 1975, Seismic intensities, "size" of earthquakes and related parameters: Bulletin of the Seismological Society of America, v. 65, p. 1287-1313.

Evernden, J. F., Hibbard, R. R., and Schneider, J. F., 1973, Interpretation of seismic intensity data: Bulletin of the Seismological Society of America, v. 63, p. 399-422.

Evernden, J. F., Kohler, W. M., and Clow, G. D., 1981, Seismic intensities of earthquakes of conterminous United States-Their prediction and interpretation: U.S. Geological Survey Professional Paper $1223,56 \mathrm{p}$.

Fumal, T. E., 1978, Correlations between seismic wave velocities and physical properties of near-surface geologic materials in the southern San Francisco Bay region, California: U.S. Geological Survey Open-File Report 78-1067, 52 p., 1 pl.
Fumal, T. E., Gibbs, J. F., and Roth, E. F., 1981, In-situ measurements of seismic velocity at 22 locations in the Los Angeles, California, region: U.S. Geological Survey Open-File Report 82-833, 140 p.

1982, In-situ measurements of seismic velocity at 10 strong motion accelerograph stations in central California: U.S. Geological Survey Open-File Report 82-407, 78 p.

1984, In-situ measurements of seismic velocity at 16 locations in the Los Angeles region: U.S. Geological Survey Open-File Report 84-681, 18 p., 65 figs., 32 tables.

Gibbs, J. F., Fumal, T. E., and Borcherdt, R. D., 1975, In-situ measurements of seismic velocities at 12 locations in the San Francisco Bay region: U.S. Geological Survey Open-File Report 75-564, 20 p., 44 figs., 24 tables.

1976, In-situ measurements of seismic velocities in the San Francisco Bay region, pt. II: U.S. Geological Survey Open-File Report 76-731, 145 p., 88 figs., 46 tables.

Gibbs, J. F., Fumal, T. E., Borcherdt, R. D., and Roth, E. F., 1977, In-situ measurements of seismic velocities in the San Francisco Bay region, pt. III: U.S. Geological Survey Open-File Report 77-850, 145 p., 46 pls., 87 figs.

Gibbs, J, F., Fumal, T. E., and Roth, E. F. 1980, In-situ measurements of seismic velocities at 27 locations in the Los Angeles, California, region: U.S. Geological Survey Open-File Report 80-378, 169 p.

Hays, W. W., 1980, Procedures for estimating earthquake ground motions: U.S. Geological Survey Professional Paper 1114, 77 p.

Kanai, K., 1952, Relation between the nature of the surface layer and the amplitudes of earthquake motions: Bulletin of the Earthquake Research Institute, University of Tokyo, v. 30, p. 31-37.

Kockelman, W. J., 1975, Use of U.S. Geological Survey earth-science products by city planning agencies in the San Francisco Bay region, California: U.S. Geological Survey Open-File Report 75-276, $110 \mathrm{p}$.

1979, Use of U.S. Geological Survey earth-science products by selected regional agencies in the San Francisco Bay region, California: U.S. Geological Survey Open-File Report 79-221, 173 p.

1980, Examples of the use of earth-science information by decisionmakers in the San Francisco Bay region, California: U.S. Geological Survey Open-File Report 80-124, 88 p.

Kockelman, W. J., and Brabb, E. E., 1979, Examples of seismic zonation in the San Francisco Bay region, in Brabb, E. E., ed., Progress on seismic zonation in the San Francisco Bay region: U.S. Geological Survey Circular 807, p. 73-84.

Lajoie, K. R., and Helley, E. J., 1975, Differentiation of sedimentary deposits for purposes of seismic zonation, in Borcherdt, R. D., ed., Studies for seismic zonation of the San Francisco Bay region: U.S. Geological Survey Professional Paper 941-A, p. A39-A51.

Page, R. A., Boore, D. M., and Dieterich, J. H., 1975, Estimation of bedrock motion at the ground surface, in Borcherdt, R. D., ed., Studies for seismic zonation of the San Francisco Bay region: U.S. Geological Survey Professional Paper 941-A, p. A31-A38.

Rogers, A. M., Covington, P. A., Borcherdt, R. D., and Tinsley, J. C., 1980, Comparative ground response studies in Los Angeles using NTS nuclear explosions and San Fernando earthquake data, in Proceedings of Conference XIII: Evaluation of regional seismic hazards and risk: U.S. Geological Survey Open-File Report 81-437, p. 143-161.

Rogers, A. M., Borcherdt, R. D., Covington, P. A., and Perkins, D. M., 1984, A comparative ground response study near Los Angeles using recordings of Nevada tests and the 1971 San Fernando 
earthquake: Bulletin of the Seismological Society of America, v. 74, no. 5, p. 1925-1949.

Richter, C. F., 1958, Elementary seismology: San Francisco, W. H. Freeman, $768 \mathrm{p}$.
Wood, H. O., 1908, Distribution of apparent intensity in San Francisco, in The California earthquake of April 18, 1906, report of the State Earthquake Investigation Commission: Carnegie Institute of Washington Publication 87, p. 220-245.

\section{Mapping Quaternary Sedimentary Deposits for Areal Variations in Shaking Response}

Birkeland, P. W., 1984, Soils and geomorphology: New York, Oxford University Press, 372 p.

Borcherdt, R. D., 1970, Effect of local geology on ground motion near San Francisco Bay: Bulletin of the Seismological Society of America, v. 60, p. $29-61$.

Borcherdt, R. D., and Gibbs, J. F., 1976, Effects of local geologic conditions in the San Francisco Bay region on ground motions and the intensities of the 1906 earthquake: Bulletin of the Seismological Society of America, v. 66, p. 467-500.

Borcherdt, R. D., Joyner, W. B., Warrick, R. E., and Gibbs, J. F., 1975, Response of local geologic units to ground shaking, in Borcherdt, R. D., ed., Studies for seismic zonation of the San Francisco Bay region: U.S. Geological Survey Professional Paper 941-A, p. A52-A67.

California Water Rights Board, 1962, Report of referee, City of San Fernando, California Superior Court, County of Los Angeles no. 650079: v. 1, 258 p.

Campbell, K. W., 1976, A note on the distribution of earthquake damage in Long Beach, 1933: Bulletin of the Seismological Society of America, v. 66, p. 1001-1006.

Cox, B. F., and Morton, D. M., 1978, Generalized map of surficial materials in northwestern Riverside and southwestern San Bernardino Counties, California: U.S. Geological Survey Open-File Report 78-978, scale 1:125,000.

Eckis, R., 1928, Alluvial fans of the Cucamonga district, southern California: Journal of Geology, v. 36, no. 3, p. 224-247.

1934, South Coastal basin investigation, geology and groundwater storage capacity of valley fill: California Department of Water Resources Bulletin 45, $279 \mathrm{p}$.

Eckmann, E. C., and Zinn, C. D., 1917, Soil survey of the Pasadena area, California: Washington, D.C., U.S. Department of Agriculture, Bureau of Soils, scâle 1:62,500.

Fumal, T. E., 1978, Correlations between seismic wave velocities and physical properties of near-surface geologic materials in the southern San Francisco Bay region: Santa Cruz, Calif., University of California, unpublished M.Sci. thesis, $113 \mathrm{p}$.

Gutenberg, B., 1957, Effects of ground on earthquake motion: Bulletin of the Seismological Society of America, v. 47, p. 221-250.

Hastorf, C. A., and Tinsley, J. C., 1981, Maps and index of radiocarbon dated samples from southern California: U. S. Geological Survey Miscellaneous Field Studies Map MF-1296, scales 1:125,000 and 1:500,000.

Holmes, L. C., Eckmann, E. C., Harrington, G. L., Guernsey, J. E., and Zinn, C. J., 1915, Soil map of California, San Fernando Valley sheet: Washington, D.C., U.S. Department of Agriculture, Bureau of Soils, scale 1:62,500.

Jennings, C. W., 1962, Geologic map of California, Long Beach sheet: Sacramento, Calif., California Division of Mines and Geology, scale 1:250,000.

Jennings, C. W., and Strand, R. G., 1969, Geologic map of California, Los Angeles sheet: Sacramento, Calif., California Division of Mines and Geology, scale 1:250,000.

Jenny, H., 1941, Factors of soil formation: New York, McGraw-Hill, $281 \mathrm{p}$.

482 Earthquake Hazards in the Los Angeles Region
1961, Derivation of state factor equations of soils and ecosystems: Soil Science Society of America Proceedings, v. 61, p. 385-388.

Kanai, K., 1952, Relation between the nature of the surficial layer and the amplitude of earthquake motion: Bulletin of the Earthquake Research Institute, University of Tokyo, v. 30, pt. 1, p. 31-37.

Knecht, A. A., 1971, Soil survey of the western Riverside area, California: U.S. Department of Agriculture Soil Conservation Service and U.S. Department of Interior Bureau of Indian Affairs, in cooperation with the University of California Agriculture Experiment Station, scale $1: 15,840$.

Lajoie, K. R., and Helley, E. J., 1975, Classification and mapping of Quaternary sediment for purposes of seismic zonation, in Borcherdt, R. D., ed., Studies for seismic zonation of the San Francisco Bay region: U.S. Geological Survey Professional Paper 941-A, p. A39-A51.

Lamar, D. L., 1970, Geology of the Elysian Park-Repetto Hills area, Los Angeles County, California: California Division of Mines and Geology Special Report 101, 45 p.

Lawson, A. C., and others, 1908, The California earthquake of April 18, 1906, in Atlas: Washington, D.C., Carnegie Institute of Washington, $643 \mathrm{p}$.

McFadden, L. D., 1982, The impacts of temporal and spatial climatic changes on alluvial soils genesis in southern California: Tucson, Ariz., University of Arizona, unpublished Ph.D. dissertion, $430 \mathrm{p}$.

McFadden, L. D., and Tinsley, J. C., 1982, Soil-profile development in xeric climates: A summary, in Tinsley, J. C., Matti, J. C., and McFadden, L. D., eds., Late Quaternary pedogenesis and alluvial chronologies of the Los Angeles and San Gabriel Mountains areas, southern California, and Holocene faulting and alluvial stratigraphy within the Cucamonga fault zone-A preliminary view: Geological Society of America Annual Meeting, Cordilleran Section, 78th, Anaheim, Calif., 1982, Guidebook 12, p. 15-19.

McFadden, L. D., Tinsley, J. C., and Hendricks, D., 1980, A preliminary soil chronosequence for the tectonically and climatically controlled terraces and alluvial fans of the San Gabriel Mountains and the Los Angeles basin, California [abs.]: Geological Society of America Abstracts with Programs, v. 12, no. 3, p. 119.

McCoy, G., and Sarna-Wojcicki, A. M., 1978, Preliminary map showing surficial materials of the Ventura-Oxnard Plain area, California: U.S. Geological Survey Open-File Report 78-1065, scale 1:125,000.

Medvedev, J. V., 1962, Engineering seismology: Moscow, Academia Nauk Press. (English translation by Israel Program for Scientific Translations. Available from National Technical Information Service, Springfield, Va.)

Milne, J., 1908, Seismology, 2d edition: London, K. Paul, Trench, Trubner, and Co., $320 \mathrm{p}$.

Munsell Soil Color Charts, 1975: Baltimore, Md., Kollmorgen Corporation, Macbeth Division.

Nelson, J. W., Pendleton, R. L., Dunn, J. E., Strahan, A. T., and Watson, E. B., 1915, Soil survey of the Riverside area, California: Washington, D.C., U.S: Department of Agriculture, Bureau of Soils, scale $1: 62,500$.

Nelson, J. W., Zinn, C. J., Strahorn, A. T., Watson, E. B., and Dunn, J. E., 1916, Soil survey of the Los Angeles area, California: Washington, 
D.C., U.S. Department of Agriculture, Bureau of Soils, scale 1:62,500.

Poland, J. F., 1959, Hydrology of the Long Beach-Santa Ana area, California: U.S. Geological Survey Water-Supply Paper 1471, $257 \mathrm{p}$.

Rabey, D. E., 1977, Soil survey of Los Angeles County, California, west San Fernando Valley area): West Los Angeles County Resource Conservation District, in cooperation with the U.S. Department of Agriculture Soil Conservation Service and the University of California Agriculture Experiment Station, unedited interim report, scale 1:24,000.

Rogers, A. M., Tinsley, J. C., Hays, W. W., and King, K. W., 1979, Evaluation of the relation between near-surface geologic units and ground response in the vicinity of Long Beach, California: Bulletin of the Seismological Society of America, v. 61, p. 1603-1622.

Rogers, T. H., 1965, Geologic map of California, Santa Ana sheet: Sacramento, Calif., California Division of Mines and Geology, scale $1: 250,000$.
1969, Geologic map of California, San Bernardino sheet: Sacramento, Calif., California Division of Mines and Geology, scale $1: 250,000$.

Schumm, S. A., 1977, The fluvial system: New York, John Wiley, 338 p.

Soil Conservation Survey Staff, 1969, Unpublished soil survey of the San Bernardino area, California: Redlands, Calif., U.S. Department of Agriculture, Soil Conservation Service, scale 1:24,000.

Soil Survey Staff, 1975, Soil taxonomy, a basic system of soil classification for making and interpreting soil surveys: U.S. Department of Agriculture Handbook 436, 754 p.

Thomas, R. G., Landry, J. J., and Turney, R. J., 1961, Planned utilization of the ground water basins of the coastal plain of Los Angeles County-Appendix A, Ground water geology: California Department of Water Resources Bulletin 104, $181 \mathrm{p}$.

Yerkes, R. F., 1965, Geology of the Los Angeles basin-An introduction: U.S. Geological Survey Professional Paper 420-A, $57 \mathrm{p}$.

Wood, H. O., 1933, Preliminary report on the Long Beach earthquake: Bulletin of the Seismological Society of America, v. 23, p. 42-56.

\section{Mapping Shear-Wave Velocities of Near-Surface Geologic Materials}

Bazarra, A. R. S., 1967, Use of the SPT for estimating settlements of shallow foundations on sand: Urbana, Ill., University of Illinois, unpublished Ph.D. thesis, $381 \mathrm{p}$.

Blackerby, B. A., 1965, The Conejo volcanics in the Malibu Lake area of the western Santa Monica Mountains, Los Angeles County, California: Los Angeles, Calif., University of California, unpublished Ph.D. thesis, $194 \mathrm{p}$.

Borcherdt, R. D., Gibbs, J. F., and Fumal, T. E., 1979, Progress on ground motion predictions for the San Francisco Bay region, California, in Brabb, E. E., ed., Progress on seismic zonation in the San Francisco Bay region: U.S. Geological Survey Circular 807, p. 13-25.

California Department of Water Resources, 1970, Meeting water demands in the Chino-Riverside area-Appendix A, Water supply: California Department of Water Resources Bulletin 104-3, $108 \mathrm{p}$.

California Division of Mines and Geology, 1976, Geologic hazards in southwestern San Bernardino County, California: California Division of Mines and Geology Special Report 113, 40 p.

Cox, B. F., and Morton, D. M., 1978, Generalized map of surficial materials in northwestern Riverside and southwestern San Bernardino Counties, California: U.S. Geological Survey Open-File Report 78-978, scale 1:125,000.

Dibblee, T. W., Jr., 1964, Geologic map of the San Gorgonio Mountain quadrangle, San Bernardino and Riverside Counties, California: U.S. Geological Survey Miscellaneous Geologic Investigations Map I-431, scale 1:62,500.

Durrell, Cordell, 1954, Geology of the Santa Monica Mountains, Los Angeles and Ventura Counties: California Division of Mines and Geology Bulletin 170, map sheet 8, scale 1:125,000.

Ellen, S. D., Wentworth, C. M., Brabb, E. E., and Pampeyan, E. H., 1972, Description of geologic units, San Mateo County, California, in Brabb, E. E., and Pampeyan, E. H., Preliminary geologic map of San Mateo County, California: U.S. Geological Survey Miscellaneous Field Studies Map MF-328, scale 1:62,500, 10-p. text.

Frick, C., 1921, Extinct vertebrate fauna of the badlands of Bautista Creek and San Timoteo Canyon, southern California: University of California Publications, Bulletin of the Department of Geology, v. 12 , no. 5 , p. $277-424$.

Fumal, T. E., 1978, Correlations between seismic wave velocities and physical properties of near-surface geologic materials in the southern San Francisco Bay region: Santa Cruz, Calif., University of California, unpublished M.Sci. thesis, $113 \mathrm{p}$.
Fumal, T. E., Gibbs, J. F., and Roth, E. F., 1981, In-situ measurements of seismic velocity at 19 locations in the Los Angeles, California, region: U.S. Geological Survey Open-File Report 81-399, 123 p.

1982 , In-situ measurements of seismic velocity at 22 locations in the Los Angeles, California, region: U.S. Geological Survey OpenFile Report 82-833, $140 \mathrm{p}$.

1984, In-situ measurements of seismic velocity at 16 locations in the Los Angeles, California, region: U.S. Geological Survey OpenFile Report 84-681, $109 \mathrm{p}$.

Gibbs, J. F., Fumal, T. E., and Borcherdt, R. D., 1975, In-situ measurements of seismic velocities at 12 locations in the San Francisco Bay region: U.S. Geological Survey Open-File Report 75-564, $20 \mathrm{p}$.

1976, In-situ measurements of seismic velocities in the San Francisco Bay region, pt. II: U.S. Geological Survey Open-File Report 76-731, $145 \mathrm{p}$.

Gibbs, J. F., Fumal, T. E., Borcherdt, R. D., and Roth, E. F., 1977, In-situ measurements of seismic velocities in the San Francisco Bay region, pt. III: U.S. Geological Survey Open-File Report 77-850, $145 \mathrm{p}$.

Gibbs, I. F., Fumal, T. E., and Roth, E. F., 1980, In-situ measurements of seismic velocity at 27 locations in the Los Angeles, California, region: U.S. Geological Survey Open-File Report 80-378, 169 p.

Hardin B. O., and Black, W. L., 1968, Vibration modulus of normally consolidated clay: Proceedings of the American Society of Civil Engineers, Journal of the Soil Mechanics and Foundations Division, v. 94, no. SM2, p. 353-369.

Hardin, B. O., and Drenevich, V. P., 1972, Shear modulus and damping in soils: Measurement and parameter effects: Proceedings of the American Society of Civil Engineers, Journal of the Soil Mechanics and Foundations Division, v. 98, no. SM6, p. 603-624.

Hardin, B. O., and Richart, F. E., 1963, Elastic wave velocities in granular soils: Proceedings of the American Society of Civil Engineers, Journal of the Soil Mechanics and Foundations Division, v. 89, no. SM1, p. 33-65.

Joyner, W. B., Warrick, R. E., and Fumal, T. E., 1981, The effect of Quaternary alluvium on strong ground motion in the Coyote Lake, California, earthquake of 1979: Bulletin of the Seismological Society of America, v. 71, p. 1333-1349.

Kobayashi, N., 1959, A method of determining the underground structure by means of SH waves: Zisin, ser. 2, v. 12, p. 19-24.

References Cited 
Lajoie, K. R., and Helley, E. J., 1975, Differentiation of sedimentary deposits for seismic-zonation purposes, in Borcherdt, R. D., Studies for seismic zonation of the San Francisco Bay region: U. S. Geological Survey Professional Paper 941-A, p. A39-A51.

Meade, R. H., 1968, Compaction of sediments underlying areas of land subsidence in central California: U.S. Geological Survey Professional Paper 497-D, $39 \mathrm{p}$.

Neuerburg, G. J., 1953, Geology of the Griffith Park area, Los Angeles County, California: California Division of Mines and Geology Spe cial Report 33, 29 p.

Ponti, D. J., and Burke, D. B., 1980, Map showing Quaternary geology of the eastern Antelope Valley and vicinity, California: U.S. Geological Survey Open-File Report 80-1064, scale 1:62,500.

Ponti, D. J., Burke, D. B., and Hedel, C. W., 1981, Map showing Quaternary geology of the central Antelope Valley and vicinity, California: U.S. Geological Survey Open-File Report 81-737, scale 1:62,500.

Schmertman, J. H., 1978, Use of the SPT to measure dynamic soil properties-Yes, but...!, in Dynamic geotechnical testing: American Society for Testing and Materials Special Technical Publication 654, p. 341-355.

Seed, H. B., Idriss, I. M., and Aarango, I., 1983, Evaluation of liquefaction potential using field performance data: Journal of Geotechnical Engineering, v. 109, no. 3, p. 458-482.

\section{Predicting Seismic Intensities}

Algermissen, S. T., and Steinbrugge, K. V., 1979, Earthquake losses to buildings in the San Francisco Bay area, in Brabb, E. E., ed., Progress on seismic zonation in the San Francisco Bay region: U.S. Geological Survey Circular 807, p. 61-72.

Archambeau, C. B., 1968, General theory of elastodynamic source fields: Reviews of Geophysics, v. 16, p. 241-288.

Archambeau, C. B., and Minster, J. B., 1978, Dynamics in prestressed media with moving phase boundaries: A continuous theory of failure in solids: Geophysical Journal of the Royal Astronomical Society, v. 52, p. 65-96.

Bancroft, H. H., 1885, History of California, 1801-1824, v. 2, in The works of Hubert Howe Bancroft, v. 19: San Francisco, A. L. Bancroft, $795 \mathrm{p}$

Blume, I. A., 1981, What is needed to significantly advance the state of the art in earthquake-resistant design, in Proceedings of Conference XIII, Evaluation of regional hazards and risk: U.S. Geological Survey Open-File Report 81-437, p. 11-12.

Blume, J. A., Scholl, R. E., Sommerville, M. R., and Honda, K. R., 1980 Damage prediction of an earthquake in southern California: U.S. Geological Survey Open-File Report 80-1145, 83 p.

Borcherdt, R. D., 1970, Effects of local geology on ground motion near San Francisco Bay: Bulletin of the Seismological Society of America, v. 60, p. 29-61.

California Division of Mines and Geology, [1958-1969], Geologic atlas of California, Olaf P. Jenkins edition: Sacramento, Calif., 27 map sheets, 1:250,000 scale.

Davis, J. F., Bennett, J. H., Borchardt, G. A., Kahle, J. E., Rice, S. J., and Silva, M. A., 1982a, Earthquake planning scenario for a magnitude 8.3 earthquake on the San Andreas fault in southern California: California Division of Mines and Geology Special Publication $60,160 \mathrm{p}$.

1982b, Earthquake planning scenario for a magnitude 8.3 earthquake on the San Andreas fault in the San Francisco Bay area: California Division of Mines and Geology Special Publication 61 $160 \mathrm{p}$.

484 Earthquake Hazards in the Los Angeles Region
Soil Survey Staff, 1951, Soil survey manual: U.S. Department of Agriculture Handbook 18, $503 \mathrm{p}$.

Stokoe, K. H., II, and Richart, F. E., 1973, In-situ and laboratory shear wave velocities: International Conference on Soil Mechanics and Foundation Engineering, 8th, Moscow 1973, Proceedings, v. 1, p. 2, 403-409.

Terzaghi, K., and Peck, R. B., 1967, Soil mechanics in engineering practice, 2d ed.: New York, John Wiley, 729 p.

Walsh, J. B., and Brace, W. F., 1966, Elasticity of rock: A review of some recent theoretical studies: Felsmechanik und Ingenieurgeologie, v. 4, p. 283-297.

Warrick, R. E., 1974, Seismic investigation of a San Francisco Bay mud site: Bulletin of the Seismological Society of America, v. 64, p. 375-385.

Wentworth, C. M., Ellen, Stephen, Frizzel, V. A., and Schlocker, J., 1985, Map of hillside materials and descriptions of their engineering characteristics, San Mateo County, California: U.S. Geological Survey Miscellaneous Investigations Map I-1257-D, scale $1: 62,500$.

Wentworth, C. M., Ziony, J. I., and Buchanan, J. M., 1970, Preliminary geologic environmental map of the greater Los Angeles area, California: Springfield, Va., National Technical Information Service TDI-25363, 41 p., 1:250,000 scale. (Available in microfiche only.)

Evernden, J. F., 1975a, Further studies on seismic discrimination: Bulletin of the Seismological Society of America, v. 65, p. 359-391. 1975b, Seismic intensities, 'size' of earthquakes, and related phenomena: Bulletin of the Seismological Society of America, v. 65, p. 1287-1315.

1982, Comments on seismological input to microzonation maps: International Earthquake Microzonation Conference, 3d, Seattle, Wash., 1982, Proceedings, v. III, p. 1170-1204.

1983, Intensities in eastern Asia: Chinese Geophysics, v. 2, no. 2, p. 405-438. [Published by the American Geophysical Union.]

Evernden, J. F., and Archambeau, C. B., in press, Seismological aspects of monitoring a Comprehensive Test Ban Treaty, in Technical means of verification of compliance with arms control treaties: New York, Pergamon/Brasserys.

Evernden, J. F., Hibbard, R. R., and Schneider, J. F., 1973, Interpretation of seismic intensity data: Bulletin of the Seismological Society of America, v. 63, p. 399-422.

Evernden, J. F., Kohler, W. M., and Clow, G. D., 1981, Seismic intensities of earthquakes of conterminous United States-Their prediction and interpretation: U.S. Geological Survey Professional Paper $1223,56 \mathrm{p}$

Federal Emergency Management Agency, 1980, An assessment of the consequences and preparations for a catastrophic California earthquake: Findings and actions taken: Washington, D.C., $59 \mathrm{p}$.

Freeman, J. R., 1932, Earthquake damage and earthquake insurance: New York, McGraw-Hill, 904 p.

Friedman, D. G., 1969, Computer simulation of earthquake hazards: California Office of Emergency Preparedness, Proceedings of Conference on Geologic Hazards and Public Problems, p. 153-181.

1975, Computer simulation in natural hazard assessment: Boulder, Colo., University of Colorado Monograph NSF-RAE-75-002, Institute of Behavioral Sciences, $192 \mathrm{p}$.

Gulliver, R. M., in press, Estimation of homeless caseload for disaster assistance due to an earthquake: San Francisco, Calif., Federal Emergency Management Agency, Region IX. 
Hanks, T. C., $1979, b$ values and $\omega^{-\gamma}$ seismic source models: Implications for tectonic stress variations along active crustal fault zones and the estimation of high-frequency strong ground motion: Journal of Geophysical Research, v. 84, p. 2235-2242.

Hanks, T. C., and Johnson, D. A., 1976, Geophysical assessments of peak accelerations: Bulletin of the Seismological Society of America, v. 66, p. 959-968.

Hanks, T. C., and McGuire, R. K., 1981, The character of highfrequency ground motion: Bulletin of the Seismological Society of America, v. 71, p. 2071-2095.

Helley, E. J., Lajoie, K. R., Spangle, W. E., and Blair, M. L., 1979, Flatland deposits of the San Francisco Bay region-Their geology and engineering properties, and their importance to comprehensive planning: U.S. Geological Survey Professional Paper 943, 88 p.

Joyner, W. B., and Boore, D. M., 1981, Peak horizontal acceleration and velocity from strong-motion records including records from the 1979 Imperial Valley, California, earthquake: Bulletin of the Seismological Society of America, v. 71, p. 2011-2038.

Kustu, O., 1981, A survey of low-rise damage from the August 6, 1979, Coyote Lake (Gilroy, California) earthquake: Menlo Park, Calif., technical report to U.S. Geological Survey under contract 14-08-0001-107310, $49 \mathrm{p}$.

Lomnitz, C., 1981, Environmental siting of nuclear power plants: International Association of Engineering Geology Bulletin 23, p. 26-36.

Maley, R. P., and Cloud, W. K., 1973, Strong-motion accelerograph records, in Murphy, L. M., ed., San Fernando, California, earthquake of February 9, 1971, v. 3, Geology and geophysics: Washington, D.C., U.S. Department of Commerce, p. 325-348.

Medvedev, S. V., 1962, Engineering seismology: Moscow, Akademia Nauk Press. (Translated into English by the Israel Program for Scientific Translations. Available from National Technical Information Service, Springfield, Va.]

1976, Seismic zoning of the U.S.S.R.: Moscow, Akademia Nauk Press. (Translated into English by the Israel Program for Scientific Translations. Available from the National Technical Information Service, Springfield, Va.)
Minster, J. B., 1973, Elastodynamics of failure in a continuum: Pasadena, Calif., California Institute of Technology, unpublished Ph.D. thesis.

Richter, C. F., 1958, Seismic regionalization: Bulletin of the Seismological Society of America, v. 49, p. 123-162. 1972, Seismic regionalization or zoning: Revision: International Conference on Microzonation, 1st, Seattle, Wash., 1972, Proceedings, v. I, p. 267-282.

Rojahn, C., and Mork, P. N., 1982, An analysis of strong-motion data from a severely damaged structure--The Imperial County Services Building, in The Imperial Valley earthquake of October 15, 1979: U.S. Geological Survey Professional Paper 1254, p. 357-375.

Scott, N. H., 1973, Felt area and intensity of San Fernando earthquake, in Murphy, L. M., ed., San Fernando earthquake of February 9, 1971 , v. 3, Geology and geophysics: Washington, D.C., U.S. Department of Commerce, p. 23-48.

Smolka, A., and Berz, G., 1981, Methods of hazard mapping-Require ments of the insurance industry: International Association of Engineering Geology Bulletin 23, p. 21-24.

Steinbrugge, K. V., and Schader, E. E., 1973, Earthquake damage and related statistics, in Murphy, L. M., ed., San Fernando earthquake of February 9, 1971, v. 1, pt. B: Washington, D.C., U.S. Department of Commerce, p. 691-724.

Trifunac, M. D., and Brady, A. G., 1975, A study on the correlation of seismic intensity scales with the peaks of recorded ground motion: Bulletin of the Seismological Society of America, v. 65, p. 139-162.

Tucker, B. E., and Brune, J. N., 1973, Seismograms, S-wave spectra and source parameters for aftershocks of San Fernando earthquake, in Murphy, L. M., ed., San Fernando earthquake of February 9, 1971, v. 3, Geology and geophysics: Washington, D.C., U.S. Department of Commerce, p. 69-122.

U.S. Geological Survey, 1981, Scenarios of possible earthquakes affecting major California population centers, with estimates of intensity and ground shaking: U.S. Geological Survey Open-File Report 81-115, 36 p.

U.S. Geological Survey Staff, 1982, Seismic zonation of the Los Angeles region-A progress report: International Earthquake Microzonation Conference, 3d, Seattle, Wash., 1982, Proceedings, v. 1, p. 157-172.

\section{Predictive Mapping of Earthquake Ground Motion}

Aki, K., and Richards, P. G., 1980, Quantitative seismology, v. 1: San Francisco, Calif., W. H. Freeman, 557 p.

Algermissen, S. T., and Perkins, D. M., 1976, A probabilistic estimate of maximum acceleration in rock in the contiguous United States: U.S. Geological Survey Open-File Report 76-416, 45 p.

Allen, C. R., 1975, Geological criteria for evaluating seismicity: Geological Society of America Bulletin, v. 86, p. 1041-1057.

Allen, C. R., Hanks, T. C., and Whitcomb, J. H., 1973, San Fernando earthquake-Seismological studies and their tectonic implications, in Murphy, L. M., ed., San Fernando, California, earthquake of February 9, 1971, v. 3, Geological and geophysical studies: Washington, D.C., National Oceanic and Atmospheric Administration, p. 13-21.

Anderson, J. G., and Luco, J. E., 1983, Consequences of slip rate constraints on earthquake occurrence relations: Bulletin of the Seismological Society of America, v. 73, p. 471-496.

Applied Technology Council, 1978, Tentative provisions for the development of seismic regulations for buildings: Applied Technology Council Publication 3-06, 505 p.
Bonilla, M. G., 1967, Historic surface faulting in continental United States and adjacent parts of Mexico: U.S. Geological Survey OpenFile Report 67-23, 36 p.

Bonilla, M. G., Mark, R. K., and Lienkaemper, J. J., 1984, Statistical relations among earthquake magnitude, surface rupture length, and surface fault displacement: Bulletin of the Seismological Society of America, v. 74, p. 2379-2411.

Boore, D. M., and Joyner, W. B., 1982, The empirical prediction of ground motion: Bulletin of the Seismological Society of America, v. 72, p. S269-S286.

Brady, A. G., Perez, V., and Mork, P. N., 1980, The Imperial Valley earthquake, October 15, 1979-Digitization and processing of accelerograph records: U.S. Geological Survey Open-File Report 80-703, $311 \mathrm{p}$.

Brune, J. N., 1968, Seismic moment, seismicity, and rate of slip along major fault zones: Journal of Geophysical Research, v. 73, p. 777-784.

Bullen, K. E., 1965, An introduction to the theory of seismology: Cambridge, Cambridge University Press, $381 \mathrm{p}$. 
Campbell, K. W., 1981, Near-source attenuation of peak horizontal acceleration: Bulletin of the Seismological Society of America, v. 71, p. 2039-2070.

Chavez, D., Gonzales, J., Reyes, A., Medina, M., Duarte, C., Brune, J. N., Vernon, F. L., III, Simons, R., Hutton, L. K., German, P. T., and Johnson, C. E., 1982, Main-shock location and magnitude determination using combined U.S. and Mexican data, in The Imperial Valley, California, earthquake of October 15, 1979: U.S. Geological Survey Professional Paper 1254, p. 51-54.

Cornell, C. A., 1968, Engineering seismic risk analysis: Bulletin of the Seismological Society of America, v. 58, p. 1583-1606.

Der Kiureghian, A., and Ang, A. H. S., 1977, A fault-rupture model for seismic risk analysis: Bulletin of the Seismological Society of America, v. 67, p. 1173-1194.

Dunbar, W. S., Boore, D. M., and Thatcher, W., 1980, Pre-, co-, and post-seismic strain changes associated with the $1952 \mathrm{M}_{\mathrm{L}}=7.2$ Kern County, California, earthquake: Bulletin of the Seismological Society of America, v. 70, p. 1893-1905.

Eaton, J. P., O'Neill, M. E., and Murdock, J. N., 1970, Aftershocks of the 1966 Parkfield-Cholame, California, earthquake-A detailed study: Bulletin of the Seismological Society of America, v. 60, p. 1151-1197.

Gutenberg B., and Richter C. F., 1954, Seismicity of the Earth and associated phenomena: Princeton, N.J., Princeton University Press, $310 \mathrm{p}$.

Hamilton, R. M., 1972, Aftershocks of the Borrego Mountain earthquake from April 12 to June 12, 1968, in The Borrego Mountain earthquake of April 9, 1968: U.S. Geological Survey Professional Paper 787, p. 31-54.

Hanks, T. C., and Kanamori, H., 1979, A moment magnitude scale: Journal of Geophysical Research, v. 84, p. 2348-2350.

Hanks, T. C., and Wyss, M., 1972, The use of body-wave spectra in the determination of seismic-source parameters: Bulletin of the Seismological Society of America, v. 62, p. 561-568.

Hanks, T. C., Hileman, J. A., and Thatcher, W., 1975, Seismic moments of the larger earthquakes of the southern California region: Geological Society of America Bulletin, v. 86, p. 1131-1139.

Ishimoto, M., and Iida, K., 1939, Observations sur les séismes enregistrés par le microsismographe construit dernierement: Bulletin of the Earthquake Research Institute, University of Tokyo, v. 17, p. 443-478. (In Japanese with summary in French.)

Joyner, W. B., and Boore, D. M., 1981, Peak horizontal acceleration and velocity from strong-motion records including records from the 1979 Imperial Valley, California, earthquake: Bulletin of the Seismological Society of America, v. 71, p. 2011-2038.

1982a, Estimation of response-spectral values as functions of magnitude, distance, and site conditions: U.S. Geological Survey Open-File Report 82-881, 14 p.

1982b, Prediction of earthquake response spectra: U.S. Geological Survey Open-File Report 82-977, 16 p.

Joyner, W. B., Warrick, R. E., and Fumal, T. E., 1981, The effect of Quaternary alluvium on strong ground motion in the Coyote Lake, California, earthquake of 1979: Bulletin of the Seismological Society of America, v. 71, p. 1333-1349.

Lahr, J. C., and Stephens, C. D., 1982, Alaska seismic zone: Possible example of non-linear magnitude distribution for faults [abs.]: Earth quake Notes, v. 53, p. 66.

Lindh, A. G., and Boore, D. M., 1981, Control of rupture by fault geometry during the 1966 Parkfield earthquake: Bulletin of the Seismological Society of America, v. 71, p. 95-116.

\section{Earthquake Hazards in the Los Angeles Region}

McGuire, R. K., 1974, Seismic structural response risk analysis, incorporating peak response regressions on earthquake magnitude and distance: Cambridge, Mass., Research Report R74-51, Massachusetts Institute of Technology, Department of Civil Engineering, 371 p.

1978, FRISK: Computer program for seismic risk analysis using faults as earthquake sources: U.S. Geological Survey Open-File Report 78-1007, $71 \mathrm{p}$.

McGuire, R. K., and Shedlock, K. M., 1981, Statistical uncertainties in hazard evaluations in the United States: Bulletin of the Seismological Society of America, v. 71, p. 1287-1308.

Molnar, P., 1979, Earthquake recurrence intervals and plate tectonics: Bulletin of the Seismological Society of America, v. 69, p. 115-133.

Newmark, N. M., and Hall, W. J., 1969, Seismic design criteria for nuclear reactor facilities: World Conference on Earthquake Engineering, 4th, Santiago, Chile, 1969, Proceedings, v. 2, p. B4-37-B4-50.

Scholz, C. H., 1982, Scaling laws for large earthquakes: Consequences for physical models: Bulletin of the Seismological Society of America, v. 72, p. 1-14.

Schwartz, D. P., Coppersmith, K. J., Swan, F. H., III, Somerville, P., and Savage, W. U., 1981, "Characteristic" earthquakes on intraplate normal faults [abs.]: Earthquake Notes, v. 52, p. 71.

Sharp, R. V., Lienkaemper, J. J., Bonilla, M. G., Burke, D. B., Fox, B. F., Herd, D. G., Miller, D. M., Morton, D. M., Ponti, D. J., Rymer, M. J., Tinsley, J. C., Yount, J. C., Kahle, J. E., Hart, E. W., and Sieh, K. E., 1982, Surface faulting in the central Imperial Valley, in The Imperial Valley, California, earthquake of October 15, 1979: U.S. Geological Survey Professional Paper 1254, p. 119-143.

Singh, S. K., Astiz, L., and Havskov, J., 1981, Seismic gaps and recurrence periods of large earthquakes along the Mexican subduction zone: A reexamination: Bulletin of the Seismological Society of America, v. 71, p. 827-843.

Slemmons, D. B., 1977, State-of-the-art for assessing earthquake hazards in the United States: Faults and earthquake magnitude: U.S. Army Corps of Engineers Waterways Experiment Station Miscellaneous Paper S-3-71-1, Report 6, 129 p.

Swanger, H. J., and Boore, D. M., 1978, Simulation of strong-motion displacements using surface-wave modal superposition: Bulletin of the Seismological Society of America, v. 68, p. 907-922.

Sykes, L. R., and Quittmeyer, R. C., 1981, Repeat times of great earthquake along simple plate boundaries, in Simpson, D. W., and Richards, P. G., eds., Earthquake prediction-An international review: American Geophysical Union Maurice Ewing Series, no. 4, p. 217-247.

Thatcher, W., 1975, Strain accumulation and release mechanism of the 1906 San Francisco earthquake: Journal of Geophysical Research, v. 80, p. $4862-4872$.

Trifunac, M. D., and Anderson, J. G., 1978, Preliminary empirical models for scaling pseudo-relative velocity spectra, appendix $A$, in Methods for prediction of strong earthquake ground motion: U.S. Nuclear Regulatory Commission Report NUREG/CR-0689, 565 p.

Tsai, Y. B., and Aki, K., 1969, Simultaneous determination of the seismic moment and attenuation of seismic surface waves: Bulletin of the Seismological Society of America, v. 59, p. 275-287.

U.S. Atomic Energy Commission, 1973, Design response spectra for seismic design of nuclear power plants: Washington, D.C., Regulatory guide $1.60,6 \mathrm{p}$.

Wesnousky, S. G., Scholz, C. H., Shimazaki, K., and Matsuda, T., 1983, Earthquake frequency distribution and the mechanics of faulting: Journal of Geophysical Research, v. 88, p. 9331-9340. 


\section{Predicting Relative Ground Response}

Aki, K., 1969, Analysis of the seismic coda of local earthquakes as scattered waves: Journal of Geophysical Research, v. 74, p. 615-631.

Algermissen, S. T., Rinehart, W. A., and Stepp, J. C., 1972, A technique for seismic zoning: Economic considerations, in International Conference on Microzonation for Safer Construction, 1st, Seattle, Wash., 1978, Proceedings: p. 943-956.

Anderberg, M. R., 1973, Cluster analysis for applications, in Probability and mathematical statistics, v. 19: New York, Academic, 359 p.

Barosh, P. J., 1969, Use of seismic intensity data to predict the effects of earthquakes and underground nuclear explosion in various geologic settings: U.S. Geological Survey Bulletin 1279, 93 p.

Boore, D. M., 1972, A note on the effect of simple topography on seismic SH waves: Bulletin of the Seismological Society of America, v. 62 , p. 275-284.

Borcherdt, R. D., 1970, Effects of local geology on ground motion near San Francisco Bay: Bulletin of the Seismological Society of America, v. 60, p. 29-61.

Borcherdt, R. D., and Gibbs, J. F., 1976, Effects of local geologic conditions in the San Francisco Bay region on ground motions and the intensities of the 1906 earthquake: Bulletin of the Seismological Society of America, v. 66, p. 467-500.

Borcherdt, R. D., Joyner, W. B., Warrick, R. E., and Gibbs, J. F., 1975, Response of local geologic units to ground shaking, in Studies for seismic zonation of the San Francisco Bay region: U.S. Geological Survey Professional Paper 941-A, p. A52-A67.

California Department of Water Resources, 1966, San Gabriel Valley, Appendix A-Geohydrology: California Department of Water Resources Bulletin 104-2, $229 \mathrm{p}$.

California Water Rights Board, 1961, Report of referee, City of Los Angeles vs. the City of San Fernando, Superior Court of the State of California case no. 650048: Sacramento, Calif., 258 p., apps.

Campbell, K. W., 1976, A note on the distribution of earthquake damage in Long Beach, 1933: Bulletin of the Seismological Society of America, v. 66, p. 1001-1006.

Chiaruttini, C., and Siro, L., 1981, The correlation of peak ground horizontal acceleration with magnitude, distance, and seismic intensity for Friuli and Ancona, Italy, and the Alpide Belt: Bulletin of the Seismological Society of America, v. 71, p. 1993-2009.

Cooley, W. W., and Lohnes, P. R., 1971, Multivariate data analysis: New York, John Wiley, $364 \mathrm{p}$.

Drake, L. H., and Mal, A. K., 1972, Love and Rayleigh waves in the San Fernando Valley: Bulletin of the Seismological Society of America, v. 62, p. 1673-1690.

Dutcher, L. C., and Garrett, A. A., 1963, Geologic and hydrologic features of the San Bernardino area, California: U.S. Geological Survey Water-Supply Paper 1419, $114 \mathrm{p}$.

Earthquake Engineering Research Laboratory, 1969-1975, Strongmotion earthquake accelerograms, VI, pts. A-Y: Pasadena, Calif., California Institute of Technology, v. 2.

Espinosa, A. F., and Algermissen, S. T., 1972, A study of soil amplification factors in earthquake damage areas, Caracas, Venezuela: National Oceanic and Atmospheric Administration Technical Report ERL 280-ESL 31, $201 \mathrm{p}$.

Esteva, L., 1977, Microzoning: Models and reality, in World Conference on Earthquake Engineering, 6th, New Delhi, 1977, Proceedings: p. $27-43$.

Fumal, T. E., 1978, Correlations between seismic wave velocities and physical properties of near-surface geologic materials in the southern San Francisco Bay region: Santa Cruz, Calif., University of California, unpublished M.Sci. thesis, $113 \mathrm{p}$.
Fumal, T. E., Gibbs, J. F., and Roth, E. F., 1981, In-situ measurements of seismic velocity at 19 locations in the Los Angeles, California, region: U.S. Geological Survey Open-File Report 81-399, 121 p.

1982, In-situ measurements of seismic velocity at 22 locations in the Los Angeles, California, region: U.S. Geological Survey OpenFile Report 82-833, 138 p.

1984, In-situ measurements of seismic velocity at 16 locations in the Los Angeles, California, region: U.S. Geological Survey OpenFile Report 84-681, 109 p.

Gibbs, J. F., Fumal, T. E., and Roth, E. F., 1980, In-situ measurements of seismic velocity at 27 locations in the Los Angeles, California, region: U.S. Geological Survey Open-File Report 80-378, 167 p.

Gutenberg, B., 1957, Effects of ground on earthquake motion: Bulletin of the Seismological Society of America, v. 47, p. 221-250.

Hanks, T. C., 1975, Strong ground motion of the San Fernando, Calif., earthquake: Ground displacement: Bulletin of the Seismological Society of America, v. 65, p. 193-225.

Hanks, T. C., and McGuire, R. K., 1981, The character of highfrequency strong ground motion: Bulletin of the Seismological Society of America, v. 21, p. 2071-2095.

Hardin, B. O., and Drnevich, V. P., 1972, Shear modulus and damping in soils: Measurement and parameter effects: Proceedings of the American Society of Civil Engineers, Journal of the Soil Mechanics and Foundations Division, v. 98, p. 603-624.

Hartigan, J. A., 1975, Clustering algorithms: New York, John Wiley, $351 \mathrm{p}$.

Hays, W. W., and Algermissen, S. T., 1982, Problems in the construction of a map to zone the earthquake ground shaking hazard, in International Earthquake Microzonation Conference, 3d, Seattle, Wash., 1982, Proceedings: p. 145-156.

Hays, W. W., and King, K. W., 1982, Zoning of the earthquake ground shaking hazard along the Wasatch Fault zone, Utah, in International Earthquake Microzonation Conference, 3d, Seattle, Wash., 1982, Proceedings: p. 1307-1318.

Howell, B. F., and Schultz, T. R., 1975, Attenuation of Modified Mercalli intensity with distance from the epicenter: Bulletin of the Seismological Society of America, v. 65, p. 651-666.

Hudson, J. A., and Douglas, A., 1975, Rayleigh wave spectra and group velocity minima, and the resonance of $P$ waves in layered structures: Geophysical Journal of the Royal Astronomical Society, v. 42, p. $175-188$.

IMSL, 1982, IMSL computer programs: Houston, Tex.

Johnson, C. E., 1979, I, Cedar-An approach to the computer automation of short-period local seismic networks; II, Seismotectonics of the Imperial Valley of southern California: Pasadena, Calif., California Institute of Technology, unpublished Ph.D. thesis, $332 \mathrm{p}$.

Joyner, W. B., and Boore, D. M., 1981, Peak horizontal accelerations and velocity from strong motion records including records from the 1979 Imperial Valley, California, earthquake: Bulletin of the Seismological Society of America, v. 71, p. 2011-2038.

Joyner, W. B., and Chen, A. T. F., 1975, Calculation of nonlinear ground response in earthquakes: Bulletin of the Seismological Society of America, v. 65, p. 1315-1336.

Joyner, W. B., Warrick, R. E., and Fumal, T. E., 1981, The effect of Quaternary alluvium on strong ground motion in the Coyote Lake, California, earthquake of 1979: Bulletin of the Seismological Society of America, v. 71, p. 1333-1349.

Kanai, K., 1952, Relation between the nature of surface layer and the amplitude of earthquake motion: Bulletin of the Earthquake Research Institute, University of Tokyo, v. 30, p. 31-37. 
, Kanai, K., and Yoshizawa, S., 1958, The amplitude and the period of earthquake motions: Bulletin of the Earthquake Research Institute, University of Tokyo, v. 36, p. 275-293.

Kanai, K., Takahasi, R., and Kawasumi, H., 1956, Seismic characteristics of ground, in World Conference on Earthquake Engineering, 1st, Berkeley, Calif., 1956, Proceedings: p. 31-131-16.

King, K. W., 1982, A study of surface and subsurface ground motions at Calico Hills, Nevada, Test Site: U.S. Geological Survey Open-File Report 82-1044, 19 p.

Lastrico, R., 1970, Effects of site and propagation path on recorded strong earthquake motions: Los Angeles, Calif., University of California, unpublished Ph.D thesis, 205 p.

Lawson, A. C., and others, 1908, The California earthquake of April 18, 1906, in Carnegie Institute of Washington Atlas: Washington, D.C., 2 v., 643 p.

McCulloh, T. H., 1957, Simple Bouguer gravity and generalized geologic map of the northwestern part of the Los Angeles basin, California: U.S. Geological Survey Geophysical Investigations Map GP-149, scale 1:48,000.

1960, Gravity variations and the geology of the Los Angeles basin of California, in Short papers in the geological sciences: U.S. Geological Survey Professional Paper 400-B, p. B320-B325.

McEvilly, T. V., and Johnson, L. R., 1980, The role of anelasticity in earthquake ground motion: U.S. Geological Survey Open-File Report 80-912, $36 \mathrm{p}$.

McFadden, L. D., and Tinsley, J. C., 1982, Soil profile development in xeric climates; a summary, in Tinsley, J. C., and others, eds. Guidebook; Late Quaternary pedogenesis and alluvial chronologies of the Los Angeles and San Gabriel Mountains, southern California, and Holocene faulting and alluvial stratigraphy within the Cucamonga fault zone: Boulder, Colo., Geological Society of America, p. 15-19.

Medvedev, J. V., 1962, Engineering seismology: Moscow, Academia Nauk. (Translated into English by Israel Program for Scientific Translations, Jerusalem, 1965, 260 p.)

Milne, J., 1898, Seismology, 1st ed.: London, Kegan Paul, Trench, Trüber, $320 \mathrm{p}$.

Minakami, T., and Sakuma, S., 1948, The earthquake-motions on various formations of the earth's surface, pt. I, Observations at Koti City: Bulletin of the Earthquake Research Institute, University of Tokyo, v. 26, p. 61-66.

Morrison, D. G., 1969, On the interpretation of discriminant analysis: Journal of Marketing Research, v, 6, p. 156-163.

1974, Discriminant analysis, in Ferber, R., ed., Handbook of marketing research: New York, McGraw-Hill, 1344 p.

Mosteller, F., and Tukey, J. W., 1977, Data analysis and regression Reading, Mass., Addison-Wesley, 588 p.

Mueller, C. S., D. M. Boore, and R. L. Porcella, 1982, Detailed study of site amplification at El Centro strong-motion array station no. 6, in International Earthquake Microzonation Conference, 3d, Seattle, Wash., 1982, Proceedings, v. 1: p. 413-424.

Murphy, J. R., and Hewlett, R. A., 1975, Analysis of seismic response in the city of Las Vegas, Nevada: A preliminary microzonation: Bulletin of the Seismological Society of America, v. 65, p. 1575-1597.

Murphy, J. R., Weaver, N. L., and Lamers, G. B., 1970, Effects of local geology on the amplitudes of seismic waves, in U.S. Atomic Energy Commission Report NVO-1163-205: Springfield, Va., National Technical Information Service, $3 \mathrm{v}$.

Murphy, J. R., Weaver, N. L., and Davis, A. H., 1971, Amplification of seismic body waves by low-velocity surface layers: Bulletin of the Seismological Society of America, v. 61, p. 109-145.

Nie, N. H., Hull, C. H., Jenkins, J. G., Steinbrenner, K., and Bent, D. H.,
1975, SPSS statistical package for the social sciences: New York, McGraw-Hill, 675 p.

Nuclear Regulatory Commission, 1980, Geotechnical data from accelerograph stations investigated during the period 1975-1979, in U.S. Nuclear Regulatory Commission Report NUREG/CR-1643 R6, RA: Springfield, Va., National Technical Information Service, $150 \mathrm{p}$.

Ooba, S., 1957, Study of the relation between subsoil conditions and the distribution of the damage percentage of wooden dwelling houses in the province of Totomi in the case of the Tonankai earthquake of December 7, 1944: Bulletin of the Earthquake Research Institute, University of Tokyo, v. 36, p. 201-295.

Poland, J. F., 1959, Hydrology of the Long Beach-Santa Ana area, California: U.S. Geological Survey Water-Supply Paper 1471, 257 p.

Poland, J. F., Garrett, A. A., and Sinnot, A., 1959, Geology, hydrology, and chemical character of ground water in the Torrance-Santa Monica area, California: U.S. Geological Survey Water-Supply Paper 1461, $425 \mathrm{p}$.

Poland, J. F., Piper, A. M., and others, 1956, Ground-water geology of the coastal zone, Long Beach-Santa Ana area, California: U.S. Geological Survey Water-Supply Paper 1109, 162 p.

Porcella, R. L., and Matthiesen, R. B., 1979, Preliminary summary of the U.S. Geological Survey strong-motion records from the Oct. 15, 1979, Imperial Valley earthquake: U.S. Geological Survey OpenFile Report 79-1654, 41 p.

Rogers, A. M., and Hays, W. W., 1978, Preliminary evaluation of site transfer functions developed from earthquake and nuclear explosions, in International Conference on Microzonation, 2d, San Francisco, Calif., 1978, Proceedings, v. 2: p. 753-764.

Rogers, A. M., Katz, L. J., and Bennett, T. J., 1974, Topographic effects on ground motion for incident $P$ waves: A model study: Bulletin of the Seismological Society of America, v. 64, p. 437-456.

Rogers, A. M., Tinsley, J. C., Hays, W. W., and King, K. W., 1979, Evaluation of the relation between near-surface geological units and ground response in the vicinity of Long Beach, California: Bulletin of the Seismological Society of America, v. 61, p. 1603-1622.

Rogers, A. M., Covington, P. A., Park, R. B., Borcherdt, R. D., and Perkins, D. M., 1980, Nuclear event time histories and computed site transfer functions for locations in the Los Angeles region: U.S. Geological Survey Open-File Report 80-1173, 207 p.

Rogers, A. M., Borcherdt, R. D., Covington, P. A., and Perkins, D. M., 1984, A comparative ground response study near Los Angeles using recordings from Nevada nuclear tests and the 1971 San Fernando earthquake: Bulletin of the Seismological Society of America, v. 74, p. 1925-1949.

Seed, H. B., and Idriss, I. M., 1970, Soil moduli and damping factors for dynamic response analysis: Berkeley, Calif., Report EERC 70-10, Earthquake Engineering Research Center, University of California, $15 \mathrm{p}$.

Thomas, R. G., Landry, J. J., and Turney, R. J., 1961, Planned utilization of the groundwater basins of the coastal plain of Los Angeles County, California, Appendix A-Groundwater geology: California Department of Water Resources Bulletin 104, $181 \mathrm{p}$.

Turner, E., and Stokoe, K. H., 1982, Static and dynamic properties of clayey soils subjected to 1979 Imperial Valley earthquake: Austin, Tex., Engineering Report GR 82-26, Geotechnical Engineering Center, University of Texas, $208 \mathrm{p}$.

Velleman, P., and Hoaglin, D., 1981, ABC's of EDA: Belmont, Calif., Duxbury Press, $354 \mathrm{p}$.

Wood, H. D., 1933, Preliminary report on the Long Beach earthquake: Bulletin of the Seismological Society of America, v. 23, p. 42-56.

Yerkes, R. F., McCulloh, T. H., Schoellhamer, J. E., and Vedder, J. G., 1965, Geology of the Los Angeles basin, California-An introduction: U.S. Geological Survey Professional Paper 420-A, 57 p.

\section{Earthquake Hazards in the Los Angeles Region}




\section{Predicting Earthquake Ground-Motion Time-Histories}

Aki, K., 1967, Scaling law of seismic spectrum: Journal of Geophysical Research, v. 72, p. 1217-1231.

1979, Characterization of barriers on an earthquake fault: Journal of Geophysical Research, v. 84, p. 6140-6148.

Aki, K., and Chouet, B., 1975, Origin of coda waves: Source, attenuation, and scattering effects: Journal of Geophysical Research, v. 80, p. 3322-3342.

Aki, K., Bouchon, M., Chouet, B., and Das, S., 1977, Quantitative prediction of strong motion for a potential earthquake fault: Annali Geofisica, v. 30, p. 341-368.

Alekseev, A. S., and Mikhailenko, B. G., 1980, The solution of dynamic problems of elastic wave propagation in inhomogeneous media by a combination of partial separation of variables and finite difference methods: Journal of Geophysics, v. 48, p. 161-172.

Andrews, D. J., 1981, A stochastic fault model, 2, Time-dependent case: Journal of Geophysical Research, v. 86, p. 10821-10834.

Apsel, R. J., and Luco, J. E., 1983, On the Green's functions for a layered half-space, pt. II: Bulletin of the Seismological Society of America, v. 73, p. 931-952.

Apsel, R. J., Frazier, G. A., Jurkevics, A., and Fried, J. C., 1981, Ground motion prediction for the Los Angeles basin from a major San Andreas earthquake: U.S. Geological Survey Open-File Report 81-276, $217 \mathrm{p}$.

Archuleta, R. J., 1984, A faulting model for the 1979 Imperial Valley earthquake: Journal of Geophysical Research, v. 89, p. 4559-4585.

Archuleta, R. J., and Day, S. M., 1980, Dynamic rupture in a layered medium: The 1966 Parkfield earthquake: Bulletin of the Seismological Society of America, v. 70, p. 671-689.

Archuleta, R. J., and Frazier, G. A., 1978, Three-dimensional numerical simulations and dynamic faulting in a half-space: Bulletin of the Seismological Society of America, v. 68, p. 573-598.

Ben-Menahem, A., 1961, Radiation of seismic surface waves from finite moving sources: Bulletin of the Seismological Society of America, v. 51, p. 401-435.

Bernard, P., and Madariaga, R., 1984, A new asymptotic method for the modeling of near-field accelerograms: Bulletin of the Seismological Society of America, v. 74, p. 539-558.

Biehler, S., Kovach, R. L., and Allen, C. R., 1964, Geophysical framework of the northern end of the Gulf of California structural province, in Van Andel, T. H., and Shor, G. G., Jr., eds., Marine geology of the Gulf of California: American Association of Petroleum Geologists Memoir 3, p. 126-143.

Boatwright, J., 1981, Quasi-dynamic models of simple earthquakes: Application to an aftershock of the 1975 Oroville, California, earthquake: Bulletin of the Seismological Society of America, v. 71, p. 69-94.

Boatwright, J., and Boore, D. M., 1982, Analysis of the ground accelerations radiated by the 1980 Livermore earthquakes for directivity and dynamic source characteristics: Bulletin of the Seismological Society of America, v. 72, p. 1843-1866.

Boore, D. M., 1972, Finite difference methods for seismic wave propagation in heterogeneous materials, in Bolt, B. A., ed., Methods of computational physics, 11: New York, Academic, p. 1-37.

Boore, D. M., and Joyner, W. B., 1978, The influence of rupture incoherence on seismic directivity: Bulletin of the Seismological Society of America, v. 68, p. 283-300.

Bouchon, M., 1978, A dynamic source model for the San Fernando earthquake: Bulletin of the Seismological Society of America, v. 68, p. 1555-1576.

1979, Predictability of ground displacement and velocity near an earthquake fault: An example: The Parkfield earthquake of 1966: Journal of Geophysical Research, v. 84, p. 6149-6156.
1980, Calculation of complete seismograms for an explosive source in a layered medium: Geophysics, v. 45, p. 197-203.

1982, The rupture mechanism of the Coyote Lake earthquake of August 1979 inferred from near-field data: Bulletin of the Seismological Society of America, v. 72, p. 745-758.

Bracewell, R., 1965, The Fourier transform and its application: New York, McGraw-Hill, p. 24-35.

Burdick, L. J., and Orcutt, J. A., 1979, A comparison of the generalized ray and reflectivity methods of waveform synthesis: Geophysical Journal of the Royal Astronomical Society, v. 46, p. 87-108.

Cervený, V., 1983, Synthetic body wave seismograms for laterally varying layered structures by the Gaussian beam method: Geophysical Journal of the Royal Astronomical Society, v. 73, p. 389-426.

Cormier, V. F., 1980, The synthesis of complete seismograms in an earth model specified by radially inhomogeneous layers: Bulletin of the Seismological Society of America, v. 70, p. 691-716.

Cormier, V. F., and Spudich, P., 1984, Amplification of ground motion and waveform complexity in fault zones: Examples from the San Andreas and Calaveras faults: Geophysical Journal of the Royal Astronomical Society, v. 79, p. 135-152.

Das, S., and Aki, K., 1977a, A numerical study of two-dimensional spontaneous rupture propagation: Geophysical Journal of the Royal Astronomical Society, v.50, p. 643-668.

1977b, Fault plane with barriers: A versatile earthquake model: Journal of Geophysical Research, v. 82, p. 5658-5670.

Day, S. M., 1982, Three-dimensional simulation of spontaneous rupture: The effect of nonuniform prestress: Bulletin of the Seismological Society of America, v. 72, p. 1881-1902.

Fuis, G. S., Mooney, W. D., Healy, J. H., McMechan, G. A., and Lutter, W. J., 1982, Crustal structure of the Imperial Valley region, in The Imperial Valley earthquake of October 15, 1979: U.S. Geological Survey Professional Paper 1254, p. 25-49.

Geller, R. J., 1976, Scaling relations for earthquake source parameters and magnitudes: Bulletin of the Seismological Society of America, v. 66, p. 1501-1523.

Hamilton, E. L., 1978, Sound velocity-density relations in sea-floor sediments and rocks: Acoustical Society of America Journal, v. 63 , p. 366-377.

1979, $V_{p} / V_{\mathrm{s}}$ and Poisson's ratios in marine sediments and rocks: Acoustical Society of America Journal, v. 66, p. 1093-1011.

Hartzell, S. H., 1978, Earthquake aftershocks as Green's functions: Geophysical Research Letters, v. 5, p. $1-4$.

1982, Simulation of ground accelerations for the May, 1980, Mammoth Lakes, California, earthquakes: Bulletin of the Seismological Society of America, v. 72, p. 2381-2388.

Hartzell, S. H., and Heaton, T. H., 1983, Inversion of strong ground motion and teleseismic waveform data for the fault rupture history of the 1979 Imperial Valley, California, earthquake: Bulletin of the Seismological Society of America, v. 73, p. 1553-1584.

Hartzell, S. H., and Helmberger, D. V., 1982, Strong motion modeling of the Imperial Valley earthquake of 1979: Bulletin of the Seismological Society of America, v. 72, p. 571-596.

Harvey, D. J., 1981, Seismogram synthesis using normal mode superposition: The locked mode approximation: Geophysical Journal of the Royal Astronomical Society, v. 66, p. 37-69.

Haskell, N. A., 1964, Total energy and energy spectral density of elastic wave radiation from propagating faults: Bulletin of the Seismological Society of America, v. 84, p. 6140-6148.

1966, Total energy and energy spectral density of elastic wave radiation from propagating faults, pt. II, A statistical source model: Bulletin of the Seismological Society of America, v. 56. p. 125-140. 
Heaton, T. H., 1982, The San Fernando earthquake: A double event?: Bulletin of the Seismological Society of America, v. 72, p. 2037-2062.

Heaton, T. H., and Helmberger, D. V., 1979, Generalized ray models of the San Fernando earthquake: Bulletin of the Seismological Society of America, v. 69, p. 1311-1341.

Helmberger, D. V., 1968, The crust mantle transition in the Bering Sea: Bulletin of the Seismological Society of America, v. 58, p. 179-214.

Helmberger, D. V., and Harkrider, D. G., 1978, Modeling earthquakes with generalized ray theory, in Miklowitz, J., and Achenbach, J. D., eds., Modern problems in elastic wave propagation: New York, John Wiley, p. 499-518.

Herrmann, R. B., 1979, SH-wave generation by dislocation sources-A numerical study: Bulletin of the Seismological Society of America, v. 69, p. 1-15.

Hong, T. L., and Helmberger, D. V., 1978, Glorified optics and wave propagation in non-planar structures: Bulletin of the Seismological Society of America, v. 68, p. 1313-1330.

Irikura, K., 1983, Semi-empirical estimation of strong ground motions during large earthquakes: Bulletin of the Disaster Prevention Research Institute, v. 33, p. 63-104.

Kanamori, H., 1979, A semiempirical approach to prediction of longperiod ground motions from great earthquakes: Bulletin of the Seismological Society of America, v. 69, p. 1654-1670.

Kennett, B. L. N., 1980, Seismic waves in a stratified half-space, II, Theoretical seismograms: Geophysical Journal of the Royal Astronomical Society, v. 61, p. 1-10.

Kennett, B. L. N., and Illingworth, M. R., 1981, Seismic waves in a stratified half-space, III, Piecewise smooth models: Geophysical Journal of the Royal Astronomical Society, v. 66, p. 633-675.

Kind, R., 1978, The reflectivity method for a buried source: Journal of Geophysics, v. 44, p. 603-612.

Kostrov, B. V., 1964, Self-similar problems of propagation of shear cracks: Journal of Applied Mathematics and Mechanics, v. 28, p. 1077-1087.

Liu, H.-L., and Heaton, T. H., 1984, Array analysis of the ground velocities in the 1971 San Fernando, California, earthquake: Bulletin of the Seismological Society of America, v. 74, p. 19511968.

Liu, H.-L., and Helmberger, D. V., 1983, The near-source ground motion of the August 6, 1979, Coyote Lake, California, earthquake: Bulletin of the Seismological Society of America, v. 73, p. 201-218.

Madariaga, R., 1983, High frequency radiation from dynamic earthquake fault models: Annales Geophysicae, v. 1, p. 17-23.

McMechan, G. A., and Mooney, W. D., 1980, Asymptotic ray theory and synthetic seismograms for laterally varying structures: Theory and application to the Imperial Valley, California, earthquake: Bulletin of the Seismological Society of America, v. 70, p. 2021-2035.

Mikumo, T., and Miyatake, T., 1978, Dynamical rupture process on a threedimensional fault with non-uniform frictions and near-field seismic waves: Geophysical Journal of the Royal Astronomical Society, v. 54, p. 417-438.

Mooney, W. D., and Luetgert, J. M., 1982, A seismic refraction survey of the Santa Clara Valley and southern Santa Cruz Mountains, westcentral California: Bulletin of the Seismological Society of America, v. 72, p. 901-910.

Nowack, R., and Aki, K., 1984, The 2-D Gaussian beam synthetic method: Testing and application: Journal of Geophysical Research, v. 89, p. 7797-7819.

Olson, A. H., and Apsel, R. J., 1982, Finite faults and inverse theory with applications to the 1979 Imperial Valley earthquake: Bulletin of the Seismological Society of America, v. 72, p. 1969-2002.

Olson, A. H., Orcutt, J. A., and Frazier, G. A., 1984, The discrete wavenumber/finite element method for synthetic seismograms: Geophysical Journal of the Royal Astronomical Society, v. 77, p. $421-460$.

Papageorgiou, A. S., and Aki, K., 1983, A specific barrier model for the quantitative description of inhomogeneous faulting and the prediction of strong ground motion, pt. II, Applications of the model: Bulletin of the Seismological Society of America, v. 73, p. 953-978.

Rial, J. A., 1984, Caustics and focusing produced by sedimentary basins: Applications of catastrophy theory to earthquake seismology: Geophysical Journal of the Royal Astronomical Society, v. 79, p. 923-938.

Spudich, P., and Ascher, U., 1983, Calculation of complete theoretical seismograms in vertically varying media using collocation methods: Geophysical Journal of the Royal Astronomical Society, v. 75, p. 101-124.

Spudich, P., and Cranswick, E., 1984, Direct observation of rupture propagation during the 1979 Imperial Valley, California, earthquake using a short-baseline accelerometer array: Bulletin of the Seismological Society of America, v. 74, p. 2083-2114.

Spudich, P., and Frazer, L. N., 1984, Use of ray theory to calculate highfrequency radiation from earthquake sources having spatially variable rupture velocity and stress drop: Bulletin of the Seismological Society of America, v. 74, p. 2061-2082.

Spudich, P., and Orcutt, J., 1982, Estimation of earthquake ground motion relevant to the triggering of marine mass movements, in Saxov, S., and Nieuwenhuis, J. K., eds., Marine slides and other mass movements: New York, Plenum, p. 219-232.

Wiggins, R. A., and Helmberger, D. V., 1974, Synthetic seismogram computation by expansion in generalized rays: Geophysical journal of the Royal Astronomical Society, v. 37, p. 73-90.

\section{Evaluating Liquefaction Potential}

Agnew, D. C., and Sieh, K. E., 1978, A documentary study of the felt effects of the great California earthquake of 1857: Bulletin of the Seismological Society of America, v. 68, p. 1717-1729.

Algermissen, S. T., Perkins, D. M., Thenhaus, P. C., Hanson, S. L., and Bender, B. L., 1982, Probabilistic estimates of maximum acceleration and velocity in rock in the contiguous United States: U.S. Geological Survey Open-File Report 82-1033, 107 p., 6 oversize sheets.

Barrows, A. G., 1974, A review of the geology and earthquake history of the Newport-Inglewood structural zone, southern California: California Division of Mines and Geology Special Report 114, $115 \mathrm{p}$.

490 Earthquake Hazards in the Los Angeles Region
Bates, R. L., and Jackson, J. A., eds., 1980, Glossary of geology, 2d ed.: Falls Church, Va., American Geological Institute, p. 465.

Bonilla, M. G., Mark, R. K., and Lienkaemper, J. J., 1984, Statistical relations among earthquake magnitude, surface rupture length, and surface fault displacement: Bulletin of the Seismological Society of America, v. 74, no. 6, p. 2379-2412.

Buwalda, J. P., 1940, Geology of the Raymond basin: Report to the Pasadena Water Department, $131 \mathrm{p}$.

California Department of Water Resources, 1961, Planned utilization of the ground water basins of the coastal plain of Los Angeles County-Appendix A, Ground water geology: California Department of Water Resources Bulletin 104, 181 p. 
1966, Planned utilizations of ground water basins, San Gabriel Valley-Appendix A, Geohydrology: California Department of Water Resources Bulletin 104-2, 229 p.

California Water Rights Board, 1962, Report of referee, City of San Fernando, California Superior Court, County of Los Angeles no. 650079: v. 1, $258 \mathrm{p}$.

Carson, S. E., and Matti, J. C., 1982, Contour map showing minimum depth to ground water, upper Santa Ana River valley, California, 1973-1979: U.S. Geological Survey Open-File Report 82-1128, $49 \mathrm{p}$.

Chen, A. T. F., 1984, Petal: Penetration testing and liquefaction, an interactive computer program: U.S. Geological Survey Open-File Report 84-290, 23 p.

Conkling, H., 1927, San Gabriel investigation: California Division of Water Resources Bulletin 5, 640 p.

Cox, B. F., and Morton, D. M., 1978, Generalized map of surficial materials in northwestern Riverside and southwestern San Bernardino Counties, California: U.S. Geological Survey Open-File Report 78-978, scale 1:125,000.

Crook, R. J., Jr., Allen, C. R., Kamb, B., Payne, C. M., and Proctor, R. J., 1979, Quaternary geology and seismic hazard of the Sierra Madre and associated faults: Menlo Park, Calif., annual technical report submitted to U.S. Geological Survey under contract 14-080001-15258, $117 \mathrm{p}$.

Durham, D. L., and Yerkes, R. F., 1964, Geology and oil resources of the eastern Puente Hills area, southern California: U.S. Geological Survey Professional Paper 420-B, $62 \mathrm{p}$.

Dutcher, L. C., and Garrett, A. A., 1963, Geologic and hydrologic features of the San Bernardino area, California-With special reference to the underflow across the San Jacinto fault: U.S. Geological Survey Water-Supply Paper 1419, $114 \mathrm{p}$

Eckis, R., 1934, Geology and ground water storage capacity of valley fill: California Division of Water Resources Bulletin 45, 279 p.

Gutenberg, B., and Richter, C. F., 1941, Seismicity of the earth: Geological Society of America Special Paper 34, p. 1-333.

Hansen, W. R., 1965, Effects of the earthquake of March 27, 1964, at Anchorage, Alaska: U.S. Geological Survey Professional Paper $542-A, 68 \mathrm{p}$.

King, E. J., Tinsley, J. C., and Preston, R. J., 1981, Maps showing historic flooding in the San Fernando Valley, California, 1934-1956: U.S. Geological Survey Open-File Report 81-153, 7 pls., 1:24,000 scale.

McCoy, G., and Sarna-Wojcicki, A. M., 1978, Preliminary map showing surficial materials of the Ventura-Oxnard Plain area, California: U.S. Geological Survey Open-File Report 78-1065, scale 1:125,000.

McCulloch, D. S., and Bonilla, M. G., 1970, Effects of the earthquake of March 27, 1964, on the Alaska Railroad: U.S. Geological Survey Professional Paper 543-A, $41 \mathrm{p}$

McFadden, L. D., 1982, The impacts of temporal and spatial climatic changes on alluvial soils genesis in southern California: Tucson, Ariz., University of Arizona, unpublished Ph.D. thesis, $430 \mathrm{p}$.

McFadden, L. D., and Tinsley, J. C., 1982, Soil profile development in xeric climates, in Tinsley, J. C., Matti, J. C., and McFadden, L. D., eds., Late Quaternary pedogenesis and alluvial chronologies of the Los Angeles and San Gabriel Mountains areas, southern California, and Holocene faulting and alluvial stratigraphy within the Cucamonga fault zone: A preliminary view: Geological Society of America Annual Meeting, Cordilleran Section, 78th, Anaheim, Calif., 1982, Guidebook 12, 45 p.

Mendenhall, W. C., 1905a, Development of underground waters in the central coastal plain region of southern California: U.S. Geological Survey Water-Supply Paper 138, $160 \mathrm{p}$.

$1905 b$, Development of underground waters in the western coastal plain region of southern California: U.S. Geological Survey Water-Supply Paper 139, 103 p.

1908, Ground waters and irrigation enterprises in the Foothill
Belt, southern California: U.S. Geological Survey Water-Supply Paper 219, $180 \mathrm{p}$.

Munsell Soil Color Charts, 1975, 1975 edition: Baltimore, Md., Kollmorgen Corporation, Macbeth Division.

Poland, J. F., 1959, Hydrology of the Long Beach-Santa Ana area California: U.S. Geological Survey Water-Supply Paper 1471, $257 \mathrm{p}$.

Poland, J. F., Piper, A. M., and others, 1956, Ground water geology of the coastal zone, Long Beach-Santa Ana area, California: U.S. Geological Survey Water-Supply Paper 1109, 162 p.

Poland, J. F., Garrett, A. A., and Sinnott, A., 1959, Geology, hydrology, and chemical character of ground waters in the Torrance-Santa Monica area, California: U.S. Geological Survey Water-Supply Paper 1461, $423 \mathrm{p}$.

Randell, D. $H_{*}, 1983$, Liquefaction potential in coastal areas in and around Long Beach, California: Long Beach, Calif., California State University, unpublished M.Sci. thesis, $250 \mathrm{p}$.

Richter, C. F., 1958, Elementary seismology: San Francisco, W. H. Freeman, p. 359

Rigby, J. K., and Hamblin, W. K., 1972, Recognition of ancient sedimentary environments: Society of Economic Paleontologists and Mineralogists Special Publication 16, $340 \mathrm{p}$

Rogers, T. H., 1965, Geologic map of California, Santa Ana sheet: San Francisco, Calif., California Division of Mines and Geology, scale $1: 250,000$.

Roth, R. A., and Kavazanjian, E., Jr., 1984, Liquefaction susceptibility mapping for San Francisco, California: Association of Engineering Geologists Bulletin, v. 21, no. 4, p. 459-478.

Seed, H. B., and Alonso, J.-L., 1973, Effects of soil-saturated interaction in the Caracas earthquake of 1967, in Earthquake engineering research at Berkeley: Berkeley, Calif., Report 72-23, University of California, College of Engineering Earthquake Engineering Research Center, p. 47-50.

Seed, H. B., and Idriss, I. M., 1967, Analysis of soil liquefaction: Niigata earthquake: Proceedings of the American Society of Civil Engineers, Journal of the Soil Mechanics and Foundations Division, v. 93, no SM3, p. 83-108.

1971, Simplified procedure for evaluating soil liquefaction potential: Proceedings of the American Society of Civil Engineers, Journal of the Soil Mechanics and Foundations Division, v. 97, no. SM9, p. 1249-1273.

Seed, H. B., Lee, K. L., Idriss, I. M., and Makdisi, F. I., 1975, The slides in the San Fernando Dams during the earthquake of February 9 1971: Proceedings of the American Society of Civil Engineers, Journal of the Geotechnical Division, v. 101, no, GT7, p. 651-688.

Seed, H. B., Idriss, I. M., and Arango, Ignacio, 1983, Evaluation of liquefaction potential using field performance data: American Society of Civil Engineers Journal of Geotechnical Engineering, v. 109 , no. 3 , p. $458-482$.

Sherburne, R. W., Fuller, D. R., Cole, J. W., Greenwood, R. B., Mumm, H. A., and Real, C. R., 1981, Classification and mapping of Quaternary sedimentary deposits for purposes of seismic zonation, south coastal Los Angeles basin, Orange County, California: California Division of Mines and Geology Open-File Report 81-10 LA, 245 p. 8 pls., scale 1:48,000.

Sprotte, E. C., and Johnson, J. A., 1976, Investigation of potential differential settlement and potential liquefaction of Holocene sediments due to seismically induced ground shaking, Oxnard Plain area, Ventura County, California, in Seismic hazards study of Ventura County, California: California Division of Mines and Geology Open-File Report 76-5 LA, p. 219-254.

Sprotte, E. C., Fuller, D. M., Greenwood, R. B., Mumm, H. A., Real, C. R., and Sherburne, R. W., 1980, Classification and mapping of Quaternary sedimentary deposits for purposes of seismic zonation, south coastal Los Angeles basin, Orange County, California: California

References Cited 491 
Division of Mines and Geology Open-File Report 80-19 LA, 267 p., 17 pls., scale 1:48,000.

Thenhaus, P. C., Perkins, D. M., Ziony, J. I., and Algermissen, S. T., 1980, Probabilistic estimates of maximum seismic horizontal ground motion on rock in coastal California and the adjacent outer continental shelf: U.S. Geological Survey Open-File Report 80-924, $36 \mathrm{p}$.

Tinsley, J. C., and Youd, T. L., 1979, Application of historic flood records to mapping of liquefaction susceptibility in urban areas-An example from the San Fernando Valley, California: Geological Society of America Abstracts with Programs, v. 11, p. 132.

Troxell, H. C., 1942, Floods of March 1938 in southern California: U.S. Geological Survey Water Supply Paper 844, 399 p.

Troxell, H. C., and Peterson, J. Q., 1937, Floods in La Canada Valley, California, January 1, 1934: U.S. Geological Survey Water-Supply Paper 796-C, $98 \mathrm{p}$.

Weber, F. H., Jr., and Kiessling, E. W., 1976, General features of seismic hazards of Ventura County, California, in Seismic hazards study of Ventura County, California: California Division of Mines and Geology Open-File Report 76-5 LA, p. 8-218.

Yerkes, R. F., 1972, Geology and oil resources of the western Puente Hills area, southern California: U.S. Geological Survey Professional Paper 420-C, $63 \mathrm{p}$.

Yerkes, R. F., McCulloh, T. H., Schoellhamer, J. E., and Vedder, J. G., 1965, Geology of the Los Angeles basin-An introduction: U.S. Geological Survey Professional Paper 420-A, 57 p.

Youd, T. L., 1971, Landsliding in the vicinity of the Van Norman Lakes, in The San Fernando, California, earthquake of February 9, 1971 U.S. Geological Survey Professional Paper 733, p. 105-109.

1973, Liquefaction, flow, and associated ground failure: U.S. Geological Survey Circular 688, $12 \mathrm{p}$.

1978a, Major cause of earthquake damage is ground failure Civil Engineering, v. 48, no. 4, p. 47-51.

1978b, Mapping liquefaction-induced ground failure potential: Proceedings of the American Society of Civil Engineers, Journal of the Geotechnical Engineering Division, v. 104, no GT4, p. 433-446.
1980, Ground failure displacement and earthquake damage to buildings: American Society of Civil Engineers Conference on Civil Engineering and Nuclear Power, 2d, Knoxville, Tenn., 1980, v. 2, p. 7-6-2-7-6-26.

Youd, T. L., and Hoose, S. N., 1977, Liquefaction susceptibility and geologic setting: World Conference on Earthquake Engineering, 6th, New Delhi 1977, Proceedings, v. 3, p. 2189-2194.

Youd, T. L., and Perkins, D. M., 1978, Mapping liquefaction-induced ground failure potential: Proceedings of the American Society of Civil Engineers, Journal of the Geotechnical Engineering Division, v. 104 , no. GT4, p. 433-446.

Youd, T. L., and Wieczorek, G. F., 1982, Liquefaction and secondary ground failure, in The Imperial Valley, California, earthquake of October 15, 1979: U.S. Geological Survey Professional Paper 1254, p. 223-246.

1984, Liquefaction during the 1981 and previous earthquakes near Westmorland, California: U.S. Geological Survey Open-File Report 84-680,36 p.

Youd, T. L., Nichols, D. R., Helley, E. J., and Lajoie, K. R., 1975, Liquefaction potential, in Studies for seismic zonation of the San Francisco Bay region: U.S. Geological Survey Professional Paper 941-A, p. A68-A74.

Youd, T. L., Tinsley, J. C., Perkins, D. M., King, E. J., and Preston, R. F., 1978, Liquefaction potential map of San Fernando Valley, California: International Conference on Microzonation for Safer Construction-Research and Applications, 2d, San Francisco 1978, Proceedings, v. 1, p. 267-278

Zielbauer, E. J., Burnham, W. L., and Keene, A. G., 1961, Coastal basins barrier and replenishment investigation, Alamitos Barrier Project geologic investigation: Los Angeles County Flood Control District, $28 \mathrm{p}$.

Zielbauer, E. J., Kues, H. A., Burnham, W. L., and Keene, A. G., 1962, Coastal basins barrier and replenishment investigation, Dominguez Gap Barrier Project geologic investigation: Los Angeles County Flood Control District, $29 \mathrm{p}$.

\section{Predicting Areal Limits of Earthquake-Induced Landsliding}

Arias, A., 1970, A measure of earthquake intensity, in Hansen, R. J., ed., Seismic design for nuclear power plants: Cambridge, Mass., MIT Press, p. 438-483.

Barrows, A. G., 1973, Earthquakes along the Newport-Inglewood structural zone: California Geology, v. 26, p. 60-68.

Buwalda, J. P., and St. Amand, Pierre, 1955, Geological effects of the Arvin-Tehachapi earthquake, in Oakeshott, G. B., ed., Earthquakes in Kern County, California, during 1952: California Division of Mines and Geology Bulletin 171, p. 41-56.

California Division of Highways, 1975, Highway damage in the San Fernando earthquake, in Oakeshott, G. B., ed., San Fernando, California, earthquake of February 9, 1971: California Division of Mines and Geology Bulletin 196, p. 369-379.

Campbell, R. H., 1975, Soil slips, debris flows, and rainstorms in the Santa Monica Mountains and vicinity, southern California: U.S. Geological Survey Professional Paper 851, $51 \mathrm{p}$

Clark, B. R., Leighton, F. B., Cann, L. R., and Gaffey, J. T., 1979, Surficial landslides triggered by seismic shaking, San Fernando earthquake of 1971: Menlo Park, Calif., final technical report to U.S. Geological Survey under contract 14-08-001-16810, $42 \mathrm{p}$.
Coffman, J. L., and von Hake, 1973, United States earthquakes 1971 Washington, D.C., National Oceanic and Atmospheric Administration, $176 \mathrm{p}$.

Dobry, R., Idriss, I. M., and Ng, E., 1978, Duration characteristics of horizontal components of strong-motion earthquake records: Bulletin of the Seismological Society of America, v. 68, p. $1487-1520$.

Fallgren, R. B., and Smith, J. L., 1973, Ground displacement at San Fernando Valley Juvenile Hall during San Fernando earthquake, in Murphy, L. M., ed., San Fernando, California, earthquake of February 9, 1971, v. 3, Geological and geophysical studies: Washington, D.C., National Oceanic and Atmospheric Administration, p. 189-196.

Field, M. E., and Hall, R. K., 1982, Sonographs of submarine sediment failure caused by the 1980 earthquake off northern California: Geo-Marine Letters, v. 2, p. 135-141.

Goodman, R. E., and Seed, H. B., 1966, Earthquake-induced displacements in sand embankments: Proceedings of the American Society of Civil Engineers, Journal of the Soil Mechanics and Foundations Division, v. 92, no. SM2, p. 125-146.

\section{Earthquake Hazards in the Los Angeles Region}


Hanks, T. C., and Kanamori, H., 1979, A moment magnitude scale: Journal of Geophysical Research, v. 84, no. B5, p. 2348-2350.

Hanks, T. C., and McGuire, R. K., 1981, The character of highfrequency strong ground motion: Bulletin of the Seismological Society of America, v. 71, p. 2071-2095.

Harp, E. L., Keefer, D. K., and Wilson, R. C., 1980, A comparison of artificial and natural slope failures, the Santa Barbara earthquake of August 13, 1978: California Geology, v. 33, p. 102-105.

Harp, E. L., Wilson, R. C., and Wieczorek, G. F., 1981, Landslides from the February 4, 1976, Guatemala earthquake: U.S. Geological Survey Professional Paper 1204-A, 35 p.

Joyner, W. B., and Boore, D. M., 1981, Peak horizontal acceleration and velocity from strong-motion records including records from the 1979 Imperial Valley, California, earthquake: Bulletin of the Seismological Society of America, v. 71, p. 2011-2038.

Kachadoorian, R., 1971, An estimate of the damage, in The San Fernando, California, earthquake of February 9, 1971: U.S. Geological Survey Professional Paper 733, p. 5 .

Kanamori, H., 1977, The energy release in great earthquakes: Journal of Geophysical Research, v. 82, no. 20, p. 2981-2987.

Keefer, D. K., 1984a, Rock avalanches caused by earthquakes-Source characteristics: Science, v. 223, no. 4642, p. 1288-1290. 1984b, Landslides caused by earthquakes: Geological Society of America Bulletin, v. 95, no. 4, p. 406-421.

Keefer, D. K., and Tannaci, N. E., 1981, Bibliography on landslides, soil liquefaction, and related ground failures in selected historic earthquakes: U. S. Geological Survey Open-File Report 81-572, 39 p.

Keefer, D. K., Wieczorek, G. F., Harp, E. L., and Tuel, D. H., 1978, Preliminary assessment of seismically induced landslide susceptibility, in International Conference on Microzonation, 2d, San Francisco, Calif., 1978, Proceedings, v. 1: p. 279-290.

Kobayashi, Y., 1981, Causes of fatalities in recent earthquakes in Japan: Journal of Disaster Science, v. 3, p. 15-22.

Kuribayashi, E., and Tatsuoka, F., 1975, Brief review of lique faction during earthquakes in Japan: Soils and Foundations, v. 15 , no. 4, p. 81-92.

1977, History of earthquake-induced soil liquefaction in Japan: Ministry of Construction of Japan, Public Works Research Institute Bulletin, v. 31, 26 p.

Lee, W. H. K., Johnson, C. E., Henyey, T. L., and Yerkes, R. F., 1978, A preliminary study of the Santa Barbara earthquake of August 13, 1978, and its major aftershocks: U.S. Geological Survey Circular $797,11 \mathrm{p}$.

Lindh, A. G., and Boore, D. M., 1981, Control of rupture by fault geometry during the 1966 Parkfield earthquake: Bulletin of the Seismological of America, v. 71, p. 95-116.

Maher, T. J., 1933, Abstract of reports received regarding the earthquake which occurred in southern California on March 10, 1933: San Francisco, Calif., U. S. Coast and Geodetic Survey, 64 p.

Miller, R. K., and Felszeghy, S. F., 1978, Engineering features of the Santa Barbara earthquake of August 13, 1978: Berkeley, Calif., Special Report UCSB-ME-78-2, Earthquake Engineering Research Institute, unpaginated.

Morton, D. M., 1971, Seismically triggered landslides in the area above the San Fernando Valley, in The San Fernando, California, earthquake of February 9, 1971: U.S. Geological Survey Professional Paper 733, p. 99-104.

1975, Seismically triggered landslides in the area above the San Fernando Valley, in Oakeshott, G. B., ed., San Fernando, California, earthquake of February 9, 1971: California Division of Mines and Geology Bulletin 196, p. 145-154.

Neumann, Frank, 1935, United States earthquakes, 1933: Washington, D.C., U.S. Coast and Geodetic Survey, p. 9-162.

Newmark, N. M., 1965, Effects of earthquakes on dams and embankments: Geotechnique, v. 15, no. 2, p. 139-160.
Oakeshott, G. B., 1955, The Kern County earthquakes in California's geologic history, in Oakeshott, G. B., ed., Earthquakes in Kern County, California, during 1952: California Division of Mines and Geology Bulletin 171, p. 15-22.

1973, 40 years ago...The Long Beach-Compton earthquake of March 10, 1933: California Geology, v. 26, p. 55-59.

Perry, O. W., 1955, Highway damage resulting from the Kern County earthquakes, with a section on Bridge earthquake report, ArvinTehachapi earthquake, by Stewart Mitchell, in Oakeshott, G. B., ed., Earthquakes in Kern County, California, during 1952: California Division of Mines and Geology Bulletin 171, p. 227-234.

Plafker, G., Erickson, G. E., and Fernández-Concha, J., Jr., 1971, Geological aspects of the May 31, 1970, Peru earthquake: Bulletin of the Seismological Society of America, v. 61, p. 543-578.

Seed, H. B., Lee, K. L., Idriss, I. M., and Makdisi, F. I., 1975, The slides in the San Fernando dams during the earthquake of February 9 , 1971: Proceedings of the American Society of Civil Engineers, Journal of the Geotechnical Engineering Division, v. 101, no. GT7, p. 651-688.

Steinbrugge, K. V., and Moran, D. F., 1954, An engineering study of the southern California earthquake of July 21, 1952, and its aftershocks: Bulletin of the Seismological Society of America, v. 44, p. 201-337.

Vanmarcke, E. H., and Lai, S. P., 1980, Strong-motion duration and RMS amplitude of earthquake records: Bulletin of the Seismological Society of America, v. 70, p. 1293-1307.

Varnes, D. J., 1978, Slope movement types and processes, in Schuster, R. L., and Krizek, R. I., eds., Landslides-Analysis and control: National Academy of Sciences Transportation Research Board Special Report 176, p. 12-33.

Warne, A. H., 1955, Ground fracture patterns in the southern San Joaquin Valley resulting from the Arvin-Tehachapi earthquake, in Oakeshott, G. B., ed., Earthquakes in Kern County, California, during 1952: California Department of Mines and Geology Bulletin 171 , p. $57-66$.

Wieczorek, G. F., Wilson, R. C., and Harp, E. L., 1985, Map of slope stability during earthquakes in San Mateo County, California: U.S. Geological Survey Miscellaneous Investigations Map I-1257-E, scale 1:62,500.

Wilson, R. C., and Keefer, D. K., 1983, Dynamic analysis of a slope failure from the 1979 Coyote Lake, California, earthquake: Bulletin of the Seismological Society of America, v. 73, p. 863-877.

Wood, H. O., 1933, Preliminary report on the Long Beach earthquake: Bulletin of the Seismological Society of America, v. 23, p. 42-56.

Yen, B. C., and Trotter, J. R., 1978, Shallow slides due to 1971 San Fernando earthquake: American Society of Civil Engineers, Proceedings of the Specialty Conference on Earthquake Engineering and Soil Dynamics, v. 2, p. 1076-1096.

Yerkes, R. F., 1973, Effects of San Fernando earthquake as related to geology, in Murphy, L. M., ed., San Fernando, California, earthquake of February 9, 1971, v. 3, Geological and geophysical studies: Washington, D.C., National Oceanic and Atmospheric Administration, p. 137-154.

Yerkes, R. F., and Campbell, R. H., 1980, Geologic map of east-central Santa Monica Mountains, Los Angeles County, California: U.S. Geological Survey Miscellaneous Investigations Map I-1146, scale 1:24,000.

Youd, T. L., 1971, Landsliding in the vicinity of the Van Norman Lakes, in The San Fernando, California, earthquake of February 9, 1971: U.S. Geological Survey Professional Paper 733, p. 105-109.

1977, Discussion of "Brief review of liquefaction during earthquakes in Japan," by E. Kuribayshi and F. Tatsuoka, 1975: Soils and Foundations, v. 17, no. 1, p. 82-85.

1980, Ground failure displacement and earthquake damage to buildings: American Society of Civil Engineers, Proceedings of the 
Specialty Conference on Civil Engineering and Nuclear Power, v. 2, p. $7-6-1-7-6-26$.

Youd, T. L., and Hoose, S. N., 1978, Historic ground failures in northern California triggered by earthquakes: U.S. Geological Survey Professional Paper 993, $177 \mathrm{p}$.

Youd, T. L., and Olsen, H. W., 1971, Damage to constructed works associated with soil movements and foundation failures, in The
San Fernando, California, earthquake of February 9, 1971: U.S. Geological Survey Professional Paper 733, p. 126-132.

Youd, T. L., and Perkins, D. M., 1978, Mapping liquefaction-induced ground failure potential: Proceedings of the American Society of Civil Engineers, Journal of the Geotechnical Engineering Division, v. 104, no. GT4, p. 433-446.

\section{Identifying Potentially Active Faults and Unstable Slopes Offshore}

Baddley, E. R., 1954, Geology of the South Mountain oil field, Ventura County, in Johns, R. H., ed., Geology of southern California: California Division of Mines Bulletin 170, map sheet 29.

Barrows, A. G., 1974, A review of the geology and earthquake history of the Newport-Inglewood structural zone, southern California: California Division of Mines and Geology Special Report 114, $155 \mathrm{p}$.

Bernard, B. B., Brooks, J. M., and Sackett, W. M., 1976, Natural gas seepage in the Gulf of Mexico: Earth and Planetary Science Letters, v. 31, p. 48-54.

Campbell, R. H., and Yerkes, R. F., 1976, Cenozoic evolution of the Los Angeles basin area-Relation to plate tectonics, in Howell, D. G., ed., Aspects of the geologic history of the California continental borderland: American Association of Petroleum Geologists (Pacific Section) Miscellaneous Publication 24, p. 541-558.

Clarke, S. H., Greene, H. G., Field, M. E., and Lee, W. H. K., 1983, Reconnaissance geology and geologic hazards of selected areas of the southern California continental borderland: U.S. Geological Survey Open-File Report 83-62, 78 p.

Clarke, S. H., Greene, H. G., Kennedy, M. P., and Vedder, J. G., 1985, Geologic map of the inner-southern California continental margin, in Greene, H. G., and Kennedy, M. P., eds., Geologic map series of the California continental margin: Sacramento, California Division of Mines and Geology, pl. 1A, scale 1:250,000.

Claypool, G. E., and Kaplan, I. R., 1974, The origin of methane in marine sediments, in Kaplan, I. R., ed., Natural gases in marine sediments: New York, Plenum, p. 94-129.

Clifton, H. E., Greene, H. G., Moore, G. W., and Phillips, R. L., 1971, Methane seep off Malibu Point following the San Fernando earthquake, in The San Fernando, California, earthquake of February 9, 1971: U.S. Geological Survey Professional Paper 733, p. 112-116.

Corbett, E. J., and Piper, K. A., 1981, Santa Barbara Island, California, earthquake, September 4, 1981 [abs.]: EOS, Transactions of the American Geophysical Union, v. 62, no. 45, p. 958.

Dames and Moore and MESA ${ }^{2}$ (Marine Environmental Science Associates), 1983, Activity and earthquake potential of the Palos Verdes fault: Menlo Park, Calif., final technical report to U.S. Geological Survey under contract 14-08-0001-19786, $90 \mathrm{p}$.

Dobrin, M. B., 1976, Introduction to geophysical prospecting: New York, McGraw-Hill, $630 \mathrm{p}$.

Dott, R. G., Jr., 1963, Dynamics of subaqueous gravity depositional processes: Bulletin of the American Association of Petroleum Geologists, v. 47, no. 1, p. 104-128.

Edwards, B. D., 1982, Geologic hazards in Santa Monica Basin: U.S. Geological Survey Administrative Report AA851-IA1-22, submitted to Bureau of Land Management (Los Angeles), $23 \mathrm{p}$.

Edwards, B. D., Field, M. E., and Clukey, E. C., 1980, Geological and geotechnical analyses of a submarine slump, California borderland: Annual Offshore Technology Conference, 12th, Houston, Tex., 1980, Proceedings, p. 399-410.

Emery, K. O., 1960, The sea off southern California: New York, John Wiley, $366 \mathrm{p}$.

494 Earthquake Hazards in the Los Angeles Region
Field, M. E., and Edwards, B. D., 1980, Slopes of the southern California continental borderland: A regime of mass transport, in Field, M. E., Bouma, A. H., Colburn, I. P., Douglas, R. G., and Ingle, J. C., eds., Quaternary depositional environments of the Pacific coast: Society of Economic Paleontologists and Mineralogists (Pacific Section), Pacific Coast Paleogeography Symposium 4, Los Angeles, Calif., 1980, p. 169-184.

Field, M. E., Gardner, J. V., Jennings, A. E., and Edwards, B. D., 1982, Earthquake-induced sediment failures on a $0.25^{\circ}$ slope, Klamath River delta, California: Geology, v. 10, p. 542-546.

Fischer, P. J., 1972, Geologic evolution and Quaternary geology of the Santa Barbara basin, California: Los Angeles, Calif., University of Southern California, unpublished Ph.D. thesis, 337 p.

Fischer, P. J., and Stevenson, A. J., 1973, Natural hydrocarbon seeps along the northern shelf of the Santa Barbara Basin, California: Annual Offshore Technology Conference, 5th, Houston, Tex., 1973, Procedings, p. 159-169.

Greene, H. G., and Kennedy, M. P., 1981, Review of offshore seismic reflection profiles in the vicinity of the Cristianitos fault, San Onofre, California, in Safety evaluation report (geology and seismology) related to the operation of San Onofre Nuclear Generating Station, units 2 and 3: Washington, D.C., Nuclear Regulatory Commission, Office of Nuclear Reactor Regulation, p. F-3-F-23.

Greene, H. G., Lee, W. H. K., McCulloch, D. S., and Brabb, E. E., 1973, Faults and earthquakes in the Monterey Bay region, California: U.S. Geological Survey Miscellaneous Field Investigation Map MF-518, 4 sheets, scale 1:200,000.

Greene, H. G., Clarke, S. H., Field, M. E., Linker, F. I., and Wagner, H. C., 1975, Preliminary report on the environmental geology of selected areas of the southern California borderland: U.S. Geological Survey Open-File Report 75-596, 70 p., 16 pls.

Greene, H. G., Wolf, S. C., and Blom, K. G., 1978, The marine geology of the eastern Santa Barbara channel with particular emphasis on the groundwater basins offshore from the Oxnard Plain, southern California: U.S. Geological Survey Open-File Report 78-305, 104 p., 13 pls.

Greene, H. G., Bailey, K. A., Clarke, S. H., Ziony, J. I., and Kennedy, M. P., 1979, Implications of fault patterns of the inner California continental borderland between San Pedro and San Diego, in Abbott, P. L., and Elliott, W. J., eds., Earthquakes and other perils, San Diego region: Geological Society of America Annual Meeting, 92d, San Diego, Calif., 1979, Field trip guidebook, p. 21-27.

Hall, R. W., and Ensiminger, H. R., eds., 1979, Potential geologic hazards and constraints for blocks in proposed mid-Atlantic OCS oil and gas léase sale 49: U.S. Geological Survey Open-File Report 79-264, 176 p., 12 figs., 1 pl.

Hampton, M. A., and Bouma, A. H., 1977, Slope instability near the shelf break, western Gulf of Alaska: Marine Geotechnology, v. 2, p. 309-322. 
Haner, B. E., and Gorsline, D. S., 1978, Processes and morphology of continental slope between Santa Monica and Dume submarine canyons, southern California: Marine Geology, v. 28, p. 77-87.

Harding, T. P., 1973, Newport-Inglewood trend, California-An example of wrenching style of deformation: Bulletin of the American Association of Petroleum Geologists, v. 57, no. 1, p. 97-116.

Heezen, B. C., and Drake, C. L., 1964, Grand Banks slump: Bulletin of the American Association of Petroleum Geologists, v. 48, no. 2, p. 221-225.

Hileman, J. A., Allan, C. R., and Nordquist, J. M., 1973, Seismicity of the southern California region, 1 January 1932 to 31 December 1972: California Institute of Technology Division of Geology and Planetary Sciences Contribution 2385, $404 \mathrm{p}$.

Hill, M. L., 1971, Newport-Inglewood zone and Mesozoic subduction, California: Geological Society of America Bulletin, v. 82, no. 10, p. 2957-2962.

Jennings, C. W., 1973, State of California preliminary fault and geologic map: California Division of Mines and Geology Preliminary Report 13, scale $1: 750,000$.

1977, Geologic map of California: California Division of Mines and Geology Geologic Data Map Series, scale 1:750,000.

Junger, Arne, 1976, Offshore structure between Santa Cruz and Santa Rosa Islands, in Howell, D. G., ed., Aspects of the geologic history of the California continental borderland: American Association of Petroleum Geologists (Pacific Section) Miscellaneous Publication 24, p. 418-426.

1979, Maps and seismic profiles showing geologic structure of the northern Channel Islands platform, California continental borderland: U.S. Geological Survey Miscellaneous Field Studies Map MF-991, 16-p. text, 5 sheets.

Junger, Arne, and Wagner, H. C., 1977, Geology of the Santa Monica and San Pedro basins, California continental borderland: U.S. Geological Survey Miscellaneous Field Studies Map MF-820, scale 1:250,000.

Kennedy, M. P., Greene, H. G., and Clarke, S. H., in press, Atlas of geologic features, stratigraphy, and bibliography from the California continental margin: California Division of Mines and Geology Bulletin.

Lee, W. H. K., Johnson, C. E., Henyey, T. L., and Yerkes, R. L., 1978, A preliminary study of the Santa Barbara, California, earthquake of August 13, 1978, and its major aftershocks: U.S. Geological Survey Circular 797, $11 \mathrm{p}$.

Lee, W. H. K., Yerkes, R. F., and Simirenko, M., 1979, Recent earthquake activity and focal mechanisms in the western Transverse Ranges, California: U.S. Geological Survey Circular 799-A, 37 p.

Legg, M., and Kennedy, M. P., 1979, Faulting offshore San Diego and northern Baja California, in Abbott, P. L., and Elliott, W. J., eds., Earthquakes and other perils, San Diego region: Geological Society of America Annual Meeting, 92d, San Diego, Calif., 1979, Fieldtrip guidebook, p. 29-46.

Lewis, K. B., 1971, Slumping on a continental slope inclined at $1^{\circ}-4^{\circ}$ : Sedimentology, v. 16, p. 97-110.

Luyendyk, B. P., Hajic, E. J., Crippen, R. E., and Simonett, D. S., 1983, Side-scan sonar and high-resolution reflection maps of the Santa Barbara Channel seafloor: Santa Barbara, Calif., California Sea Grant College Program Report T-CSGCP-006, Department of Geological Sciences, Department of Geography, and Marine Sciences Institute, University of California, 17 p., 7 sheets.

Malouta, D. N., Gorsline, D. S., and Thornton, S. E., 1981, Processes and rates of recent (Holocene) basin filling in an active transform margin: Santa Monica basin, California continental borderland: Journal of Sedimentary Petrology, v. 51, p. 1077-1095.

McCulloh, T. H., 1960, Gravity variations and the geology of the Los Angeles basin of California: U.S. Geological Survey Professional Paper 400-B, p. B320-B325.
Moody, J. D., and Hill, M. J., 1956, Wrench fault tectonics: Geological Society of America Bulletin, v. 67, p. 1207-1246.

Moore, D. G., 1961, Submarine slumps: Journal of Sedimentary Petrology, v. 31, p. 343-357.

1969, Reflection profiling studies of the California continental borderland: Structure and Quaternary turbidite basins: Geological Society of America Special Paper 107, 142 p.

Nardin, T. R., 1981, Seismic stratigraphy of Santa Monica and San Pedro basins, California continental borderland: Late Neogene history of sedimentation and tectonics: Los Angeles, Calif., University of Southern California, unpublished Ph.D. dissertation, 270 p.

Nardin, T. R., and Henyey, T. L., 1978, Plio-Pleistocene diastrophism of Santa Monica and San Pedro shelves, California continental borderland: Bulletin of the American Association of Petroleum Geologists, v. 62, no. 2, p. 247-272.

Nelson, C. H., Kvenvolden, K. A., and Clukey, E. C., 1978, Thermogenic gases in near surface sediments of Norton Sound, Alaska, in Annual Offshore Technology Conference, 10th, Houston, Tex., 1978, Proceedings: p. 2623-2633.

Ogle, B. A., and Hacker, R. N., 1969, Cross section, coastal area, Ventura County, in Geology and oil fields of coastal areas, Ventura and Los Angeles basins, California: American Association of Petroleum Geologists, Society of Exploration Geophysicists, and Society of Economic Paleontologists and Mineralogists (Pacific Sections) Annual Meeting, 44th, Los Angeles, Calif., 1969, Fieldtrip guidebook.

Patterson, R. H., 1979, Tectonic geomorphology and neotectonics of the Santa Cruz Island fault, Santa Barbara County, California: Santa Barbara, University of California, unpublished M.Sci. thesis, 141 p.

Prior, D. B., and Coleman, J. M., 1977, Disintegrating retrogressive landslides on very-low-angle subaqueous slopes, Mississippi delta: Marine Geotechnology, v. 3, p. 37-60.

Richmond, W. C., Cummings, L. J., Hamlin, S., and Nagaty, M. E., 1981, Geological hazards and constraints in the area of proposed OCS oil and gas lease sale 48, southern California: U.S. Geological Survey Open-File Report 81-307, $37 \mathrm{p}$.

Sangrey, D. A., 1977, Marine geotechnology-State of the art: Marine Geotechnology, v. 2, p. 45-80.

Sarna-Wojcicki, A. M., Williams, K. M., and Yerkes, R. F., 1976, Geology of the Ventura fault, Ventura County, California: U.S. Geological Survey Miscellaneous Field Studies Map MF-781, scale 1:6,000.

Schoellhamer, J. E., and Woodford, A. O., 1951, The floor of the Los Angeles basin, Los Angeles, Orange, and San Bernardino Counties, California: U.S. Geological Survey Oil and Gas Investigation Map OM-117, 2 sheets.

Seed, H. B., Murarka, R., Lysmer, J., and Idriss, I. M., 1975, Relationships between maximum acceleration, maximum velocity, distance from source, and local site conditions for moderately strong earthquakes: Bulletin of the Seismological Society of America, v. 66, no. 4, p. 1323-1342.

Selnes, P. B., 1982, Geotechnical problems in offshore earthquake engineering: Norwegian Geotechnical Institute Publication 140, p. 1-27.

Stein, R. S., and King, G. C. P., 1984, Seismic potential revealed by surface folding: 1983 Coalinga, California, earthquake: Science, v. 224, p. 869-872.

Teng, Ta-liang, and Henyey, T. L., 1975, Microearthquake monitoring in the city of Long Beach area for the year 1974: Los Angeles, Calif., Technical Report 75-2, University of Southern California Geophysical Laboratory, $50 \mathrm{p}$.

Thornton, S. E., 1981, Holocene stratigraphy and sedimentary processes in Santa Barbara basin: Influence of tectonics, ocean circulation, climate and mass movement: Los Angeles, Calif., University of Southern California, unpublished Ph.D. thesis, 351 p.

References Cited 
U.S. Coast and Geodetic Survey, 1967a, Santa Barbara-Huntington Beach: U.S. Coast and Geodetic Survey Bathymetric Map $1206 \mathrm{~N}-15$, scale 1:250,000.

1967b, Huntington Beach-Punta Sal Si Pudes: U.S. Coast and Geodetic Survey Bathymetric Map 1206N-16, scale 1:250,000.

U.S. Nuclear Regulatory Commission, 1981, Safety evaluation report related to the operation of San Onofre Nuclear Generating Station, units 2 and 3: Washington, D.C., Office of Nuclear Reactor Regulation, NUREG-0712, dockets 50-361, 50-362, $106 \mathrm{p}$.

Vedder, J. G., Beyer, L. A., Junger, Arne, Moore, C. W., Roberts, A. E., Taylor, J. C., and Wagner, H. C., 1974, Preliminary report on the geology of the continental borderland of southern California: U.S. Geological Survey Miscellaneous Field Studies Map MF-624, 34-p. text, 9 sheets.

Vedder, J. G., Greene, H. G., Clarke, S. H., and Kennedy, M. P., 1985, Geologic map of the mid-southern California continental margin, in Greene, H. G., and Kennedy, M. P., eds., Geologic map series of the California continental margin: California Division of Mines and Geology, pl. 2A, scale 1:250,000.

Weaver, D. W., Doerner, D. P., and Nolf, B., 1969, Geology of the northern Channel Islands, California: American Association of Petroleum Geologists and Society of Economic Paleontologists and Mineralogists (Pacific Sections) Special Publication, 200 p.

Wilcox, R. E., Harding, T. P., and Seely, D. R., 1973, Basic wrench tectonics: Bulletin of the American Association of Petroleum Geologists, v. 57, no. 1, p. 74-96.

\section{Evaluating Tsunami Potential}

Abe, K., 1973, Tsunami and mechanism of great earthquakes: Physics of the Earth and Planetary Interiors, v. 7, p. 143-153.

1975, Reliable estimation of the seismic moment of large earthquakes: Journal of Physics of the Earth, v. 23, p. 381-390.

1979, Size of great earthquakes of 1837-1974 inferred from tsunami data: Journal of Geophysical Research, v. 84, no. B4, p. 1561-1568.

Agnew, D. C., 1979, Tsunami history of San Diego, in Abbott, P. L., and Elliott, W. J., eds., Earthquakes and other perils, San Diego region: San Diego, Calif., San Diego Association of Geologists, p. 117-122.

Alfors, J. T., Burnett, J. L., and Gay, T. E., Jr., 1973, Urban geology master plan for California: California Division of Mines and Geology Bulletin 198, $112 \mathrm{p}$.

Auffret, G. A., Auzende, J. M., Gennesseaux, M., Monti, S., Pastouret, L., Pautot, G., and Vanney, J. R., 1982, Recent mass wasting processes on the Provincial Margin (western Mediterranean), in Saxov, S., and Nieuwahuis, J. K., eds., Marine slides and other mass movements: New York, Plenum, p. 53-58.

Beavan, J., Hauksson, E., McNutt, S. R., Bilham, R., and Jacob, K. H., 1983a, Tilt and seismicity changes in the Shuman seismic gap: Science, v. 222, p. 322-325.

Beavan, J., Bilham, R., and Hurst, K., 1983b, Coherent tilt signals observed in the Shumagin Islands seismic gap [abs.]: EOS, Transactions of the American Geophysical Union, v. 64, no. 18, p. 258.

Ben-Menahem, A., 1961, Radiation of seismic-surface waves from finite moving sources: Bulletin of the Seismological Society of America, v. 51, p. 401-435.

Bernard, E. N., and Goulet, R., 1981, Tsunami research opportunities: Washington, D.C., National Science Foundation, 50 p.

Bernard, E. N., Lander, J. F., and Hebenstreit, G. T., 1982, Feasibility study on mitigating tsunami hazards in the Pacific: National

\section{Earthquake Hazards in the Los Angeles Region}

Wilkinson, G. R., 1971, California offshore oil and gas seeps: California Oil Fields-Summary of Operations, v. 57, no. 1, p. 5-28.

Woodring, W. P., Bramlette, M. N., and Kew, W. S. W., 1946, Geology and paleontology of Palos Verdes Hills, California: U.S. Geological Survey Professional Paper 207, 145 p.

Yerkes, R. F., and Lee, W. H. K., 1979a, Faults, fault activity, epicenters, focal depths, focal mechanisms, 1970-75 earthquakes, western Transverse Ranges, California: U.S. Geological Survey Miscellaneous Field Studies Map MF-1032, 2 sheets, scale $1: 250,000$.

1979b, Late Quaternary deformation in the western Transverse Ranges, California: U.S. Geological Survey Circular 799-B, 10 p.

Yerkes, R. F., McCulloh, T. H., Schoellhamer, J. E., and Vedder, J. G., 1965, Geology of the Los Angeles basin, California-An introduction: U.S. Geological Survey Professional Paper 420-A, $57 \mathrm{p}$.

Yerkes, R. F., Gorsline, D. S., and Rusnak, G. A., 1967, Origin of Redondo submarine canyon, southern California, in Geological survey research 1967: U.S. Geological Survey Professional Paper 575-C, p. C97-C105.

Yerkes, R. F., Greene, H. G., Tinsley, J. C., and Lajoie, K. R., 1981, Seismotectonic setting of the Santa Barbara Channel area, southern California: U.S. Geological Survey Miscellaneous Field Studies Map MF-1169, 25-p. text, 1 sheet.

Ziony, J. I., Wentworth, C. M., Buchanan-Banks, J. M., and Wagner, H. C., 1974, Preliminary map showing recency of faulting in coastal southern California: U.S. Geological Survey Miscellaneous Field Studies Map MF-585, 3 sheets, scale 1:250,000.

Oceanic and Atmospheric Administration Technical Memorandum ERL PMEL-37, 43 p.

Bertero, V. V., Corley, W. G., and others, 1985, Damage survey of the Nihon-Kai-Chubu, Japan, earthquake of May 26, 1983: Earthquake Spectra, v. 1, no. 2, p. 319-352.

Blackford, M. E., 1981, Tsunami potential of seismic gaps in the Aleutian-Alaska arc [abs.]: EOS, Transactions of the American Geophysical Union, v. 62, no. 45, p. 945.

Bonilla, M. G., Mark, R. K., and Lienkaemper, J. J., 1984, Statistical relations among earthquake magnitude, surface rupture length, and surface fault displacement: Bulletin of the Seismological Society of America, v. 74, p. 2379-2411.

Brandsma, M., Divoky, D., and Hwang, L. S., 1978, Circumpacific variation of computed tsunami features, in Tsunami symposium: Ottawa, Canada, Marine Sciences Directorate, Department of Fisheries and Environment Manuscript Report Series 48, p. 132-151.

Brune, J. N., Nafe, J. E., and Oliver, J. E., 1960, A simplified method for the analysis and synthesis of dispersed wave trains: Journal of Geophysical Research, v. 65, no. 1, p. 287-304.

Burford, R. O., Castle, R. O., Church, J. P., Kinoshita, W. F., Kirby, S. H., Ruthven, R. T., and Savage, J. C., 1971, Preliminary measurements of tectonic movements of February 9, 1971: U.S. Geological Survey Professional Paper 773, p. 80-85.

Butler, H. L., 1978, Numerical simulation of Coos Bay-South Slough complex: U.S. Army Corps of Engineers Waterways Experimental Station Technical Report H-78-22, 31 p.

Byerly, P., 1930, The California earthquakes of November 4, 1927: Bulletin of the Seismological Society of America, v. 20, p. 53-66.

Cassidy, A., 1862, Miscellaneous notes on the tide gauge \& tidal observations at San Diego-California 1853-1854: San Diego, Calif., Serra Museum Library, unpublished papers. 
Cooper, A., 1971, Structure of the continental shelf west of San Francisco, California: U.S. Geological Survey Open-File Report, 65 p.

Coulter, H. W., and Migliaccio, R. R., 1966, Effects of the earthquake of March 27, 1964-Effects on communities-Valdez, Alaska: U.S. Geological Survey Professional Paper 542-C, p. C1-C36.

Curray, J. R., and Nason, R. D., 1967, San Andreas fault north of Point Arena, California: Geological Society of America Bulletin, v. 78, no. 3, p. 413-418.

Darrow, A. C., and Fischer, P. J., 1983, Activity and earthquake potential of the Palos Verdes fault zone: Menlo Park, Calif., technical report to U.S. Geological Survey under contract 14-08-0001-19786, $90 \mathrm{p}$.

Davidson, D. D., and Whalin, R. W., 1974, Potential landslide-generated water waves, Libby Dam and Lake Koocanusa, Montana: U.S. Army Corps of Engineers Waterways Experiment Station Technical Report H-74-15, $33 \mathrm{p}$.

Davies, J., Sykes, L., House, L., and Jacob, K., 1981, Shumagin seismic gap, Alaska Peninsula: History of great earthquakes, tectonic setting, and evidence for high seismic potential: Journal of Geophysical Research, v. 86, no. B5, p. 3821-3855.

Eaton, J. P., 1984, Focal mechanisms of near-shore earthquakes between Santa Barbara and Monterey, California: U.S. Geological Survey Open-File Report 84-477, 6 p.

Eaton, J. P., Richer, D. H., and Ault, W. J., 1961, The tsunami of May 23, 1960, on the island of Hawaii: Bulletin of the Seismological Society of America, v. 51, p. 135-157.

Edgers, L., and Karlsrud, K., 1982, Soil flows generated by submarine slides-Case studies and consequences: Norwegian Technical Institute Publication 143, p. 1-10.

Edwards, B. D., Field, M. E., and Clukey, E. C., 1980, Geological and geotechnical analysis of a submarine slump, California borderland: Offshore Technology Conference, 12th, Houston, Tex., 1980, Proceedings, p. 399-410.

Federal Emergency Management Agency, 1982, Flood insurance study, city of Huntington Beach, California, Orange County: San Francisco, Calif., FEMA Region IX, 28 p.

Field, M. E., and Edwards, B. D., 1980, Slopes of the southern California continental borderland: A regime of mass transport, in Field, M. E., Bouma, A. H., Colburn, I. P., Douglas, R. G., and Ingle J. C., eds., Proceedings of the Quaternary depositional environments of the Pacific Coast: Pacific Coast Paleogeography Symposium No. 4: Los Angeles, Calif., Society of Economic Paleontologists and Mineralogists, Pacific Section, p. 169-184.

Field, M. E., Gardner, J. V., Jennings, A. E., and Edwards, B. D., 1982, Earthquake-induced sediment failures on a 0.25 slope, Klamath River delta, California: Geology, v. 10, p. 542-546.

Fukao, Y., 1979, Tsunami earthquakes and subduction processes near deep-sea trenches: Journal of Geophysical Research, v. 84, no. B5, p. 2303-2314.

Fumumoto, A. S., 1969, Ionospheric recording of Rayleigh waves for estimating source mechanisms, in Adams, W. M., Tsunamis in the Pacific Ocean: Honolulu, Hawaii, East-West Center Press, p. 119-134.

Furneaux, R., 1964, Krakatoa: Englewood Cliffs, N.J., Prentice-Hall, $224 \mathrm{p}$.

Galanopoulos, A. G., and Bacon, E., 1969, Atlantis, the truth behind the legend: New York, Bobbs-Merrill, $216 \mathrm{p}$.

Garcia, A. W., 1976, Effect of source orientation and location in the Peru-Chile trench on tsunami amplitude along the Pacific coast of the continental United States: U.S. Army Corps of Engineers Waterways Experiment Station Research Report H-76-2, 20 p.

Garcia, A. W., and Houston, J. R., 1975, Type 16 flood insurance study-Tsunami predictions for Monterey and San Francisco Bays and Puget Sound: U.S. Army Corps of Engineers Waterways Experiment Station Technical Report H-75-17, 21 p.
Garcia, W. J., 1972, A study of water waves generated by tectonic displacements: Berkeley, Calif., Technical Report HEL 16-9, University of California, Berkeley, Hydraulic Engineering Laboratory, $114 \mathrm{p}$.

Gawthrop, H. W., 1975, Seismicity of the central California coastal region: U.S. Geological Survey Open-File Report 75-134, 87 p.

1978a, The 1927 Lompoc, California earthquake: Bulletin of the Seismological Society of America, v. 68, p. 1705-1716.

$1978 \mathrm{~b}$, Seismicity and tectonics of central California coastal region, in Silver, E. A., and Normark, W. R., eds., San GregoriaHosgri fault zone, California: California Division of Mines and Geology Special Report 137, p. 45-56.

Gennesseaux, A. M., Mauffret, A., and Pautot, G., 1980, Les glissements sous-marins de la pente continentale nicoise et la rupture de cables en mer Ligure (Mediterranee occidentale): Comptes Rendus Hebdomadaires des Seances de l'Academie des Sciences, v. 290, ser. D, p. 959-962.

Grantz, A., Plafker, G., and Kachadoorian, R., 1964, Alaska's Good Friday earthquake, March 27, 1964, a preliminary geologic evaluation: U.S. Geological Survey Circular 491, 35 p.

Greene, H. G., Clarke, S. H., Field, M. E., Linker, F. I., and Wagner, H. C., 1975, Preliminary report on the environmental geology of selected areas of the southern California borderland: U.S. Geological Survey Open-File Report 75-596, 70 p., 16 pls.

Hampton, M. A., 1972, The role of subaqueous debris flow in generating turbidity currents: Journal of Sedimentary Petrology, v. 42, p. 775-793.

Hanks, T. C., 1979, The Lompoc, California earthquake (November 4, 1927; $\boldsymbol{M}=7.3$ ) and its aftershocks: Bulletin of the Seismological Society of America, v. 69, p. 451-462.

Hanks, T. C., and Kanamori, H., 1979, A moment magnitude scale: Journal of Geophysical Research, v. 84, no. B5, p. 2348-2350.

Hauksson, E., 1983, Regular or precursory seismicity, 1973-1983, in the Shumagin seismic gap, Alaska [abs]: EOS, Transactions of the American Geophysical Union, v. 64, no. 18, p. 258.

Heath, E., 1748, A full account of the late dreadful earthquake at Port Royal in Jamaica, in A true and particular relation of the dreadful earthquake which happen'd at Lima ${ }^{* * *} 1746$ : London, printed for T. Osborne in Grays's Inn, p. 327-341.

Heaton, T. H., and Kanamori, H., 1984, Seismic potential associated with subduction in the northwestern United States: Bulletin of the Seismological Society of America, v. 74, no. 3, p. 933-941.

Heezen, B. C., and Ewing, M., 1952, Turbidity currents and submarine slumps and the Grand Banks earthquake: American Journal of Science, v. 250, p. 849-873.

Hellmuth, A., Sievers, C., Villegas, C. G., and Barros, G., 1963, The seismic sea wave of 22 May 1960 along the Chilean coast: Bulletin of the Seismological Society of America, v. 53, p. 1125-1190.

Hisamoto, S., and Murayama, C., 1962, Drawing the wave fronts of the Chilean tsunami of May 23, 1960: Quarterly Journal of Seismology, v. 26, p. 1-8.

Hokubei Mainichi (North American Daily), 1983, An account of the Akita earthquake: June 2, 1983.

Holden, E. S., 1898, A catalogue of earthquakes on the Pacific coast: Smithsonian Miscellaneous Collections, v. 37, no. E, 253 p.

Hoskins, E. G., and Griffiths, J. R., 1971, Hydrocarbon potential of northern and central California offshore, in Cram, I. H., ed., Future petroleum provinces of the United States-Their petroleum potential: American Association of Petroleum Geologists Memoir 15, p. 212-228.

House, L., and Boatwright, J., 1980, Investigation of two high stress drop earthquakes in the Shumagin seismic gap, Alaska: Journal of Geophysical Research, v. 85, no. B12, p. 7151-7165.

House, L. S., Sykes, L. R., Davies, J. N., and Jacob, K. H., 1981, Identification of a possible seismic gap near Unalaska Island, Eastern 
Aleutians, Alaska, in Simpson, D. W., and Richards, P. G., eds., Earthquake prediction: An international review: American Geophysical Union, Maurice Ewing Series, no. 4, p. 81-92.

Houston, J. R., 1979, Tsunamis, seiches, and landslide-induced water waves: State-of-the-art for assessing earthquake hazards in the United States: U.S. Army Corps of Engineers Waterways Experiment Station Miscellaneous Paper S-73-1, 88 p.

1980, Type 19 flood insurance study: Tsunami predictions for southern California: U.S. Army Corps of Engineers Waterways Experiment Station Technical Report HL-80-18, $172 \mathrm{p}$.

Houston, J. R., and Butler, H. L., 1979, A numerical model for tsunami inundation: U.S. Army Corps of Engineers Experimental Waterways Station Technical Report HL-79-2, 54 p.

Houston, J. R., and Garcia, A. W., 1974, Type 16 flood insurance study: Tsunami predictions for Pacific coastal communities: U.S. Army Corps of Engineers Waterways Experiment Station Technical Report H-74-3, $10 \mathrm{p}$.

1978, Type 16 flood insurance study: Tsunami predictions for the west coast of the United States: U.S. Army Corps of Engineers Waterways Experiment Station Technical Report H-78-26, 38 p.

Houston, J. R., Whalin, R. W., Garcia, A. W., and Butler, H. L., 1975, Effect of source orientation and location in the Aleutian Trench on tsunami amplitude along the Pacific coast of the continental United States: U.S. Army Corps of Engineers Waterways Experiment Station Research Report H-75-4, 22 p.

Hove, K., Selnes, P. B., and Bungum, H., 1982, Seaquakes: A potential threat to offshore structures: Norwegian Technical Institute Publication 143, p. 1-10.

Hwang, L. S., Butler, H. L., and Divoky, D., 1972, Tsunami model: Generation and open sea characteristics: Bulletin of the Seismological Society of America, v. 62, p. 1529-1596.

Hwang, L. S., and Lee, K. Y., 1979, Tsunamis, Proceedings of the National Science Foundation Workshop: Pasadena, Calif., Tetra Tech, Inc., $328 \mathrm{p}$.

Iida, K., 1963a, Magnitude, energy, and generation mechanisms of tsunamis and a catalog of earthquakes associated with tsunamis, in Proceedings of the 10th Pacific Science Congress Symposium: International Union of Geodesy and Geophysics Monograph 24, p. 7-18.

1963b, On the estimation of tsunami energy, in Proceedings of the 10th Pacific Science Congress Symposium: International Union of Geodesy and Geophysics Monograph 24, p. 167-173.

1970, The generation of tsunamis and the focal mechanisms of earthquakes, in Adams, W. M., ed., Tsunamis in the Pacific Ocean: Honolulu, Hawaii, East-West Center Press, p. 3-18.

Iida, K., Cox, D. C., and Pararas-Carayannis, G., 1967a, Preliminary catalog of tsunamis occurring in the Pacific Ocean: Hawaii Institute of Geophysics Data Report 5, 265 p.

1967b, Bibliography to the preliminary catalog of tsunamis occurring in the Pacific Ocean: Hawaii Institute of Geophysics Data Report 6,27 p.

Imamura, A., 1949, List of tsunamis in Japan [in Japanese]: Journal of the Seismological Society of Japan, v. 2, p. 23-28

Jacob, K. H., 1983, Aleutian seismic gaps: High probability for great Shumagin earthquake in next 10 years [abs.]: EOS, Transactions of the American Geophysical Union, v. 64, no. 18, p. 258.

Japan Times, 1983, Quake, tsunami kill 32 in Tohoku, Hokkaido: May 27 , no. 30,305 , p. 1 .

Junger, A., and Wagner, H. C., 1977, Geology of the Santa Monica and San Pedro basins, California Continental Borderland: U.S. Geological Survey Miscellaneous Field Studies Map MF-820, 10-p. text, scale 1:250,000.

Kachadoorian, R., 1965, Effects of the earthquake of March 27, 1964, at Whittier, Alaska: U.S. Geological Survey Professional Paper 542-B, p. B1-B21.

\section{Earthquake Hazards in the Los Angeles Region}

Kachadoorian, R., and Plafker, G., 1967, Effects of the earthquake of March 27, 1964, on the communities of Kodiak and the nearby islands: U.S. Geological Survey Professional Paper 542-F, 41 p.

Kajiura, K., 1979, Tsunami generation, in Hwang, L., and Lee, Y. K., eds., Tsunamis, Proceedings of the National Science Foundation Workshop: Pasadena, Calif., Tetra Tech, Inc., p. 15-36.

Kanamori, H., 1972, Mechanism of tsunami earthquakes: Physics of the Earth and Planetary Interiors, v. 5, p. 346-359.

1977. The energy release in great earthquakes: Journal of Geophysical Research, v. 82, no. 20, p. 2981-2987.

Kanamori, H., and Given, J. W., 1982, Use of long-period surface waves for rapid determination of earthquake source parameters: Physics of the Earth and Planetary Interiors, v. 30, p. 260-268.

Kelleher, J. A., 1970, Space-time seismicity of the Alaska-Aleutian seismic zone: Journal of Geophysical Reseach, v. 75, no. 29, p. $5745-5756$.

1972, Rupture zones of large South American earthquakes and some predictions: Journal of Geophysical Research, v. 77, no. 11, p. $2087-2103$.

1979, Summary map of tsunami source area, in Hwang, L., and Lee, Y. K., eds., Tsunami, Proceedings of the National Science Foundation Workshop: Pasadena, Calif., Tetra Tech, Inc., p. 12.

Kelleher, J., Savino, J., Rowlett, H., and McCann, W., 1974, Why and where great thrust earthquakes occur along island arcs: Journal of Geophysical Research, v. 79, no. 32, p. 4889-4899.

Keulegan, G. G., Harrison, J., and Mathews, M. J., 1969, Theoretics in design of the proposed Crescent City Harbor tsunami model: U.S. Army Corps of Engineers Technical Report H-69-9, 68 p.

Kuenen, Ph. H., 1950, Turbidity currents of high density: International Geologic Congress, 18th, London 1948, Report, pt. 8, p. 44-52.

Kobayashi, Y., 1981, Causes of fatalities in recent earthquakes in Japan: Journal of Disaster Science, v. 3, p. 15-22.

Lawson, A. C., and others, 1908, The California earthquake of April 18, 1906-Report of the State Earthquake Investigation Commission: Washington, D.C., Carnegie Institute of Washington, v. 1, 451 p.

Lee, W. H. K., and Ellsworth, W. L., 1975, Earthquake activity in the Santa Barbara Channel region, in Draft environmental statement, oil and gas development in the Santa Barbara Channel outer continental shelf off California: Menlo Park, Calif., U.S. Geological Survey, p. II-80-II-137.

Lee, W. H. K., Johnson, C. E., Henyey, T. L., and Yerkes, R. L., 1978, A preliminary study of the Santa Barbara, California, earthquake of August 13, 1978, and its major aftershocks: U.S. Geological Survey Circular 797, 11 p.

Lee, Y. K., Wu, F. H., Wier, W., Parnicky, P., and DeMers, D., 1982, Methodology for computing coastal flood statistics in southern California: Pasadena, Calif., Report TC-3205, Tetra Tech, Inc. $75 \mathrm{p}$.

Leendertse, J. J., 1967, Aspects of a computational model for long-period water-wave propagation: Santa Monica, Calif., Memorandum RM-5294-PR, Rand Corporation, $179 \mathrm{p}$.

Lemke, R. W., 1967, Effects of the earthquake of March 27, 1964, at Seward, Alaska: U.S. Geological Survey Professional Paper 542-E p. E1-E43.

Lindh, A., Motooka, C., Ball, S., and Dollar, R., 1981, Current seismicity of the central California coastal region from Point Buchon to Point Piedras Blancas-A preliminary report: U.S. Geological Survey Open-File Report 81-44, 14 p.

Link, M. C., 1960, Exploring the drowned city of Port Royal: National Geographic Magazine, no. 117, p. 151-183.

Lockridge, P. A., and Smith, R. H., 1984, Tsunamis in the Pacific basin: National Oceanic and Atmospheric Administration, National Geographic Data Center, scale 1:17,000,000. 
Magoon, O. T., 1965, Structural damage by tsunamis: American Society of Civil Engineers Specialty Conference on Coastal Engineering, Santa Barbara, Calif., 1965, Proceedings, p. 35-68.

Marine Advisors, 1965, Examination of tsunami potential at the San Onofre nuclear generating station: La Jolla, Calif., Report A-163, $59 \mathrm{p}$

McCann, W. R., Nishenko, S. P., Sykes, L. R., and Krause, J., 1979, Seismic gaps and plate tectonics: Seismic potential for major boundaries: Pure and Applied Geophysics, v. 117, no. 4, p. 1082-1147.

McCulloch, D. S., 1966, Slide-induced waves, seiching, and ground fracturing caused by the earthquake of March 27, 1964, at Kenai Lake, Alaska: U.S. Geological Survey Professional Paper 543-A, p. A1-A41.

McCulloch, D. S., Greene, H. G., Heston, K. S., and Rubin, D. M., 1980, A summary of the geology and geologic hazards in proposed Lease Sale 53, central California outer continental shelf: U.S. Geological Survey Open File-Report 80-1095, 76 p.

McCulloch, W. S., and Pitts, W., 1948, The statistical organization of nervous activity: Biometrics, v. 4, p. 91-99.

McKean, K., and Mohs, M., 1983, Tracking the killer waves: Discover, v. 4, no. 8, p. 18-24.

McLellan, H. S., 1965, Elements of physical oceanography: New York, Pergamon, 151 p.

Miller, D. J., 1960, Giant waves at Lituya Bay, Alaska: U.S. Geological Survey Professional Paper 354-C, p. C51-C83.

Miller, G. R., Munk, W. H., and Snodgrass, F. E., 1962, Long-period waves over California's continental borderland, pt. II, Tsunamis: Journal of Marine Research, v. 20, p. 31-41.

Montessus de Ballore, F. de, 1907, The science seismology-Earthquakes [in French]: Paris, Armand Colin, 579 p.

Murty, T. S., 1977, Seismic sea waves; tsunamis: Bulletin of the Fisheries Research Board of Canada 198, $337 \mathrm{p}$.

1979, Submarine slide-generated water waves in Kitimat Inlet, British Columbia: Journal of Geophysical Research, v. 84, no. C12, p. 7777-7779.

Mogi, K., 1969, Some features of recent seismic activity in and near Japan (2): Bulletin of the Earthquake Research Institute, University of Tokyo, v. 46, p. 1225-1236.

Ohtke, M., Matumoto, T., and Latham, G.V., 1977, Seismicity gap near Oaxaca, southern Mexico, as a possible precursor to a large earthquake: Pure and Applied Geophysics, v. 115, p. 375-385.

Osamu, T., 1984, A report on the 1983 Nihonkai-Chubu earthquake: Shizuoka, Japan, Tokai University, $64 \mathrm{p}$.

Pararas-Carayannis, G., Dong, B., and Farmer, R., 1982, Annotated tsunami bibliography 1962-1976: Prepared by National Oceanic and Atmospheric Administration International Tsunami Information Center for the Nuclear Regulatory Commission, Paper NUREG/CR-2840, $532 \mathrm{p}$.

Plafker, G., 1972, Alaskan earthquake of 1964 and Chilean earthquake of 1960: Implications for arc tectonics: Journal of Geophysical Research, v. 77, no. 5, p. 901-925.

1978, Closing comment, in Proceedings of Conference VI: Methodology for identifying seismic gaps and soon-to-break gaps: U.S. Geological Survey Open-File Report 78-943, p. 918.

Plafker, G., Kachadoorian, R., Eckel, E. B., and Mayo, L. P., 1969, Effects of the earthquake of March 27, 1964, at various communities: U.S. Geological Survey Professional Paper 542-G, p. G1-G50.

Preuss, J., 1982, Application of microzonation concept to land management in tsunami hazard zones: International Earthquake Microzonation Conference, 3d, Seattle, Wash., 1982, Proceedings, v. 11, p. $717-728$.

Prins, J. E., 1958, Characteristics of waves generated by a local disturbance: EOS, Transactions of the American Geophysical Union, v. 39 , no. 5 , p. $865-874$.
Prior, D. B., Bornhold, B. D., Coleman, J. M., and Bryant, W. R., 1982, Morphology of a submarine slide, Kitimat Arm, British Columbia: Geology, v. 10, p. 588-592.

Raichlen, F., 1979, Bay and harbor response to tsunamis, in Hwang, L., and Lee, Y. K., eds., Tsunamis, Proceedings of the National Science Foundation Workshop: Pasadena, Calif., Tetra Tech, Inc., p. 188-221.

Raney, D. C., and Butler, H. L., 1975, A numerical model for predicting the effects of landslide-generated water waves: U.S. Army Corps of Engineers Water Ways Experiment Station Research Report $\mathrm{H}-75-1,24 \mathrm{p}$.

Saint-Amand, P., 1961, Los Terremotos De Mayo-Chile 1960: China Lake, Calif., Technical Article 14, NOTS TP2701, U.S. Naval Ordnance Test Station, Michelson Laboratories, 39 p.

San Francisco Examiner, 1979, Tidal wave kills ten on Riviera: October 17,115 th year, no. 235 , p. 18.

Savage, J. C., and Prescott, W. H., 1978, Geodetic control and the 1927 Lompoc, California, earthquake: Bulletin of the Seismological Society of America, v. 68, p. 1699-1703.

Schwab, W. C., and Lee, H. J., 1983, Geotechnical analysis of submarine landslides in glacial marine sediment, northeast Gulf of Alaska, in Molnia, B. F., ed., Glacial-marine sedimentation: New York, Plenum, p. 145-184.

Shepard, F. P., 1933, Depth changes in Sagami Bay during the great Japanese earthquake: Journal of Geology, v. 41, p. 527-536. 1948, Submarine geology: New York, Harper, $348 \mathrm{p}$.

Shepard, F. P., McDonald, G. A., and Cox, D. C., 1950, The tsunami of April 1, 1946: University of California Scripps Institution of Oceanography Bulletin, v. 5, p. 391-528.

Slingerland, R. L., and Voight, B., 1979, Occurrences, properties, and predictive models of landslide-generated water waves, in Voight, B., ed., Rockslides and avalanches, v. 2: New York, Elsevier, p. 317-397.

Smith, S. W., 1975, Aftershocks of the 1927 Lompoc earthquake: Berkeley, Calif., TERA Technical Report, 18 p.

Soloviev, S. L., 1970, Recurrence of tsunamis in the Pacific, in Adams, W. M., ed., Tsunamis in the Pacific Ocean: Honolulu, Hawaii, EastWest Center Press, p. 149-163.

Spaeth, M. G., and Berkman, S. C., 1967, The tsunami of March 28, 1964 , as recorded at tide stations: U.S. Coast and Geodetic Survey Technical Bulletin 33, $86 \mathrm{p}$.

Spudich, P., and Orcutt, J., 1982, Estimation of earthquake ground motions relevent to the triggering of marine mass movements, in Saxov, S., and Nieuwauhuis, J. K., eds., Marine slides and other mass movements: New York, Plenum, p. 219-231.

Striem, H. L., and Miloh, T., 1975, Tsunamis induced by submarine slumpings off the coast of Israel: Tel Aviv, Israel, Israel Atomic Energy Commission, $23 \mathrm{p}$.

Sykes, L. R., 1971, Aftershock zones of great earthquakes, seismicity gaps, earthquake prediction for Alaska and the Aleutians: Journal of Geophysical Research, v. 76, no. 23, p. 8021-8041.

Sykes, L. R., Kisslinger, J. B., House, L., Davies, J. N., and Jacobs, K. H., 1981, Rupture zones and repeat times of great earthquakes along the Alaskan-Aleutian arc, 1784-1980, in Simpson, D. W., and Richards, P.G., eds., Earthquake prediction: An international review: American Geophysical Union Maurice Ewing Series, no. 4, p. 73-80.

Takahasi, R., 1963, On some model experiments on tsunami generation: Proceedings of the 10th Pacific Science Congress Symposium: International Union of Geodesy and Geophysics Monograph 24, p. 245-248.

The Volcano Letter, 1931, Hawaiian Volcano Observatory, National Park, Hawaii: February 13, no. 321, p. 1.

Thenhaus, P. C., Perkins., D. M., Ziony, J. I., and Algermissen, S. T., 1980, Probabilistic estimates of maximum seismic horizontal 
ground motion on rock in coastal California and the adjacent outer continental shelf: U.S. Geological Survey Open-File Report 80-924, $69 \mathrm{p}$.

Toppozada, T. R., Real, C. R., and Parke, D. L., 1981, Preparation of isoseismal maps and summary of reported effects for pre-1900 California earthquakes: California Division of Mines and Geology Open-File Report 81-11 SAC, 182 p.

Townley, S. D., and Allen, M. W., 1939, Descriptive catalog of earthquakes of the Pacific Coast of the United States, 1769 to 1928: Bulletin of the Seismological Society of America, v. 29, p. 1-297.

Tuck, E. O., 1979, Models for predicting tsunami propagation, in Hwang, L., and Lee, Y. K., eds., Tsunamis, Proceedings of the National Science Foundation Workshop: Pasadena, Calif., Tetra Tech, Inc., p. 43-104.

Tudor, W. J., 1964, Tsunami damage at Kodiak, Alaska and Crescent City, California, from Alaska earthquake of 27 March 1964: Port Hueneme, Calif., Technical-Note N-622, U.S. Naval Civil Engineering Laboratory, $128 \mathrm{p}$.

Van Dorn, W. G., 1964, Source mechanism of the tsunami of March 28, 1964, in Alaska, in Conference of Coastal Engineers, 9th, Lisbon 1964, Proceedings: New York, American Society of Civil Engineers, p. 166-190.

1970, Tsunami response at Wake Island: A model study: Journal of Marine Research, v. 28, p. 336-344.

1979a, Instrumentation and observations, in Hwang, L., and Lee, Y. K., eds., Tsunamis, Proceedings of the National Science Foundation Workshop: Pasadena, Calif., Tetra Tech, Inc., p. 281-295.

1979b, Theoretical aspects of tsunamis along the San Diego coastline, in Abbot, P. L., and Elliot, W. J., Earthquakes and other perils, San Diego region: San Diego, Calif., San Diego Association of Geologists, p. 115-116.

Wagner, H. C., 1974, Marine geology between Cape San Martin and Point Sal, south-central California offshore-A preliminary report: U.S. Geological Survey Open-File Report 74-252, 17 p.

Ward, S. N., 1979, Ringing $P$ waves and submarine faulting: Journal of Geophysical Research, v. 84, no. B6, p. 3057-3062.

Wiegel, R. L., 1955, Laboratory studies of gravity waves generated by the movement of a submerged body: EOS, Transactions of the American Geophysical Union, v. 36, p. 759-774.

1969, Seismic sea waves, in Olson, R. A., and Wallace, M. M., eds., Geologic hazards and public problems, State of California Office of Emergency Preparedness Conference, San Francisco, Calif., 1969, Proceedings: p. 53-75.
1970, Tsunamis, in Wiegel, R. L., ed., Earthquake engineering: Englewood Cliffs, N.J., Prentice-Hall, p. 253-306.

Wiegel, R. L., Noda, E. K., Kube, E. M., Gee, D. M., and Tornberg, G. F., 1970, Water waves generated by landslides in reservoirs: Proceedings of the American Society of Civil Engineers, Journal of the Waterways and Harbors Division, v. 96, no. WW2, p. 307-334.

Wilson, B. W., 1971, Tsunami-responses of San Pedro Bay and shelf, California: Proceedings of the American Society of Civil Engineers, Journal of the Waterways and Harbors Division, v. 97, no. WW2, p. 239-258.

Wilson, B. W., and Tørum, A., 1968, The tsunami of the Alaskan earthquake, 1964: Coastal Engineering Research Center Technical Memorandum 25, $50 \mathrm{p}$.

Wood, H. O., 1916, California earthquakes-A synthetic study of recorded shocks: Bulletin of the Seismological Society of America, v. 6, p. 55-180.

1933, Preliminary report on the Long Beach earthquake: Bulletin of the Seismological Society of America, v. 23, p. 43-56.

Wood, H. O., Heck, N. H., and Eppley, R. A., 1966, Earthquake history of the United States, pt. 2, Stronger earthquakes of California and western Nevada (revised through 1963): U.S. Coast and Geodetic Survey [Publication] 41-1, $48 \mathrm{p}$.

Woodward-Clyde, Inc., 1979, Report of the evaluation of maximum earthquake and site ground motion parameters associated with the offshore zone of deformation, San Onofre nuclear generating station: Rosemead, Calif., report prepared for Southern California Edison, $13 \mathrm{p}$.

Wu, T. Y., 1979, On tsunami propagation-Evaluation of existing models, in Hwang, L., and Lee, Y. K., eds., Tsunamis, Proceedings of the National Science Foundation Workshop: Pasadena, Calif., Tetra Tech, Inc., p. 110-143.

Yeh, H.C., 1975, Mechanism of the 1927 Lompoc earthquake from surface wave analysis: Seattle, Wash., University of Washington, unpublished M.Sci. thesis, 91 p.

Yerkes, R. F., and Lee, W. H. K., 1979, Faults, fault activity, epicenters, focal depths, focal mechanisms, 1970-75 earthquakes, western Transverse Ranges, California: U.S. Geological Survey Miscellaneous Field Studies Map MF-1032, 2 sheets, scale 1:250,000.

Yerkes, R. F., Greene, H. G., Tinsley, J. C., and Lajoie, K. R., 1981, Seismotectonic setting of Santa Barbara Channel area, southern California: U.S. Geological Survey Miscellaneous Field Studies Map MF-1169, 25-p. text, 1 sheet, scale 1:250,000.

\section{Predicted Geologic and Seismologic Effects of a Postulated Magnitude 6.5 Earthquake Along the Northern Part of the Newport-Inglewood Zone}

Andrews, D. J., 1976, Rupture velocity of plane shear cracks: Journal of Geophysical Research, v. 81, p. 5679-5687.

Archuleta, R. J., 1984, A faulting model for the 1979 Imperial Valley earthquake: Journal of Geophysical Research, v. 89, p. 4559-4585.

Archuleta, R. J., and Frazier, G. A., 1978, Threedimensional numerical simulations of dynamic faulting in a half-space: Bulletin of the Seismological Society of America, v. 68, p. 541-572.

Asada, A., Kawakami, R., and Yanagiasawa, E., 1980, Geological and soil mechanical studies on damage to housing sites by the Miyagiken-Oki earthquake, 1978: World Conference on Earthquake Engineering, 7th, Istanbul 1980, Proceedings, v. 3, Geotechnical aspects, p. 219-226.
Barrows, A. G., 1974, A review of the geology and earthquake history of the Newport-Inglewood structural zone, southern California: California Divison of Mines and Geology Special Report 114, $115 \mathrm{p}$.

Boore, D. M., and Joyner, W. B., 1978, The influence of rupture incoherence on seismic directivity: Bulletin of the Seismological Society of America, v. 68, p. 283-300.

Bravinder, K. M., 1942, Los Angeles basin earthquake of October 21, 1941, and its effect on certain producing wells in Dominguez field, Los Angeles County, California: Bulletin of the American Association of Petroleum Geologists, v. 26, p. 388-399.

California Department of Water Resources, 1961, Planned utilization of the ground water basins of the coastal plain of Los Angeles County,

\section{Earthquake Hazards in the Los Angeles Region}


Appendix A, Ground water geology: California Department of Water Resources Bulletin 104, $181 \mathrm{p}$.

1966, Planned utilization of ground water basins, San Gabriel Valley, Appendix A, Geohydrology: California Department of Water Resources Bulletin 104-2, 229 p.

California Division of Highways, 1975, Highway damage in the San Fernando earthquake, in Oakeshott, G. B., ed., San Fernando, California, earthquake of 9 February 1971: California Division of Mines and Geology Bulletin 196, p. 369-379.

California Division of Mines and Geology [1958-1969], Geologic atlas of California, Olaf P. Jenkins edition: Sacramento, Calif., 27 sheets, scale 1:250,000

California Water Rights Board, 1962, Report of referee, City of San Fernando: California Superior Court, County of Los Angeles no. $650079, v .1,258 \mathrm{p}$.

Campbell, R. H., 1975, Soil slips, debris flows, and rainstorms in the Santa Monica Mountains and vicinity, southern California: U.S. Geological Survey Professional Paper 851, 51 p.

Castle, R. O., and Yerkes, R. F., 1976, Recent surface movements in the Baldwin Hills, Los Angeles County, California: U.S. Geological Survey Professional Paper 882, 125 p.

Durrell, C., 1954, Geology of the Santa Monica Mountains, Los Angeles and Ventura Counties: California Division of Mines and Geology Bulletin 170, map sheet 8, scale 1:125,000.

Ehlig, P. L., 1982, Mechanics of the Abalone Cove landslide, including the role of ground water in landslide stability and a model for development of large landslides in the Palos Verdes Hills, in Cooper, J. D., compiler, Landslides and landslide abatement, Palos Verdes peninsula, southern California: Geological Society of America Annual Meeting (Cordilleran Section), 78th, Anaheim, Calif., 1982, Guidebook, p. 57-66.

Evernden, J. F., Kohler, W. M., and Clow, G. D., 1981, Seismic intensities of earthquake of conterminous United States-Their prediction and interpretation: U.S. Geological Survey Professional Paper $1223,56 \mathrm{p}$.

Geller, R. J., 1976, Scaling relations for earthquake source parameters and magnitudes: Bulletin of the Seismological Society of America, v. 66, p. 1501-1523.

Gilluly, J., and Grant, U. S., 1949, Subsidence in the Long Beach Harbor area, California: Geological Society of America Bulletin, v. 60 , p. 461-530.

Guptill, P. D., and Heath, E. G., 1981, Surface faulting along the Newport-Inglewood zone of deformation: California Geology, v. 34, p. 142-148.

Hanks, T. C., and Kanamori, H., 1979, A moment magnitude scale: Journal of Geophysical Research, v. 84, p. 2348-2350.

Harding, T. P., 1973, Newport-Inglewood trend, California-An example of wrenching style of deformation: Bulletin of the American Association of Petroleum Geologists, v. 57, p. 97-116.

Harp, E. L., Keefer, D. K., and Wilson, R. C., 1980, A comparison of artificial and natural slope failures-The Santa Barbara earthquake of August 13, 1978: California Geology, v. 33, p. 102-105.

Harp, E. L., Wilson, R. C., and Wieczorek, G. F., 1981, Landslides from the February 4, 1976, Guatemala earthquake: U.S. Geological Survey Professional Paper 1204-A, 35 p.

Hartzell, S. H., and Heaton, T. H., 1983, Inversion of strong ground motion and teleseismic waveform data for the fault rupture history of the 1979 Imperial Valley, California, earthquake: Bulletin of the Seismological Society of America, v. 73, p. 1553-1583.

Hartzell, S. H., and Helmberger, D. V., 1982, Strong motion modeling of the Imperial Valley earthquake of 1979: Bulletin of the Seismological Society of America, v. 72, p. 571-596.

Hill, R. L., Sprotte, E. C., Bennett, J. H., Chapman, R. H., Chase, G. W., Real, C. R., and Borchart, G., 1977, Santa Monica Raymond Hill fault zone study Los Angeles County, California: Menlo Park, Calif., final technical report to U.S. Geological Survey under contract 14-080001-15858.

Keefer, D. K., 1984, Landslides caused by earthquakes: Geological Society of America Bulletin, v. 95, no. 4, p. 406-421.

Martner, S. T., 1948, The Dominguez Hills, California, earthquake of June 18, 1944: Bulletin of the Seismological Society of America, $v$. 38, p. 105-119.

McCulloh, T. H., 1960, Gravity variations and the geology of the Los Angeles basin of California, in Geological Survey research 1960-Short papers in the geological sciences: U.S. Geological Survey Professional Paper 400-B, p. B320-B325.

McGill, J. T., 1982, Preliminary geologic map of the Pacific Palisades area, city of Los Angeles, California: U.S. Geological Survey OpenFile Report 82-194, 15 p., 2 pls.

Morton, D. M., 1971, Seismically triggered landslides in the area above the San Fernando Valley, in The San Fernando, California, earthquake of February 9, 1971: U.S. Geological Survey Professional Paper 733, p. 99-104.

Olson, A. H., and Apsel, R. J., 1982, Finite faults and inverse theory with applications to the 1979 Imperial Valley earthquake: Bulletin of the Seismological Society of America, v. 72, p. 1969-2002.

Olson, A. H., Orcutt, J. A., and Frazier, G. A., 1984, The discrete wavenumber/finite element method for synthetic seismograms: Geophysical Journal of the Royal Astronomical Society, v. 77, p. 421-460.

Teng, T. L., Real, C. R., and Henyey, T. L., 1973, Microearthquakes and water flooding in Los Angeles: Bulletin of the Seismological Society of America, v. 63, p. 859-875.

Toppozada, T. R., and Parke, D. L., 1982, Areas damaged by California earthquakes, 1900-1949: California Division of Mines and Geology Open-File Report 82-17 SAC, 65 p.

Waananen, A. O., and Moyle, W. R., Jr., 1971, Water-resource aspects, in The San Fernando, California, earthquake of February 9, 1971: U.S. Geological Survey Professional Paper 733, p. 119-125.

1972, Water-resource effects, in The Borrogo Mountain earthquake of April 9, 1968: U.S. Geological Survey Professional Paper 787 , p. 183-189.

Weber, F. H., Jr., 1979, General features of landsliding and debris flooding in southern California, in Landslides in the Los Angeles region, California-Effects of February-March 1978 rains: California Division of Mines and Geology Open-File Report 79-4 LA, p. 15-47.

1980, Landsliding and flooding in southern California during the winter of 1979-80: California Division of Mines and Geology OpenFile Report 80-3 LA, 69 p.

ed., 1982, Slope stability and geology of the Baldwin Hills, Los Angeles County, California: California Division of Mines and Geology Special Report 152, 93 p.

Wentworth, C. M., Ziony, J. I., and Buchanan, J. M., 1970, Preliminary geologic environmental map of the greater Los Angeles area, California: Springfield, Va., National Technical Information Service TID-25363, 41 p., 1:250,000 scale. (Available in microfiche only.)

Woodward-Clyde Consultants, 1979, Report on the evaluation of maximum earthquake and site ground motion parameters associated with the Offshore Zone of Deformation, San Onofre Nuclear Generating Station: Los Angeles, Calif., report prepared for Southern California Edison, 56 p.

Yeats, R. S., 1973, Newport-Inglewood fault zone, Los Angeles basin, California: Bulletin of the American Association of Petroleum Geologists, v. 57, p. 117-135.

Yen, B. C., and Trotter, J. R., 1978, Shallow slides due to 1971 San Fernando earthquake, in Earthquake engineering and soil dynamics: 
Proceedings of the American Society of Civil Engineers Geotechnical Engineering Division Specialty Conference, v. 2, p. 1076-1096.

Yerkes, R. F., and Campbell, R. H., 1980, Geologic map of east-central Santa Monica Mountains, Los Angeles County, California: U.S. Geological Survey Miscellaneous Investigations Map I-1146, scale 1:24,000.

Yerkes, R. F., McCulloh, T. H., Schoellhamer, J. E., and Vedder, J. G., 1965, Geology of the Los Angeles basin, California-An introduction: U.S. Geological Survey Professional Paper 420-A, 57 p.
Youd, T. L., 1980, Ground failure displacement and earthquake damage to buildings: American Society of Civil Engineers Conference on Civil Engineering and Nuclear Power, 2d, Knoxville, Tenn., 1980, v. 2, p. 7-6-2-7-6-26.

Youd, T. L., and Perkins, D. M., 1978, Mapping liquefaction-induced ground failure potential: Proceedings of the American Society of Civil Engineers, Journal of the Geotechnical Engineering Division, v. 104, no. GT 4, p. 433-446.

Youd, T. L., and Wieczorek, G. F., 1982, Liquefaction and secondary ground failure, in The Imperial Valley earthquake of October 15 , 1979: U.S. Geological Survey Professional Paper 1244, p. 223-246.

\section{Using Earth-Science Information for Earthquake Hazard Reduction}

Algermissen, S. T., Hopper, M. G., Campbell, Kenneth, Rinehart, W. A., Perkins, D. M., Steinbrugge, K. V., Lagorio, H. J., Moran, D. F., Cluff, L. S., Degenkolb, H. J., Duke, C. M., Gates, G. O., Jacobson, D. W., Olson, R. A., and Allen, C. R., 1973, A study of earthquake losses in the Los Angeles, California, area: Boulder, Colo., National Oceanic and Atmospheric Administration Environmental Research Laboratories, report prepared for the Federal Disaster Assistance Administration, $331 \mathrm{p}$.

Algermissen, S. T., Perkins, D. M., Thenhaus, P. C., Hanson, S. L., and Bender, B. L., 1982, Probabilistic estimates of maximum acceleration and velocity in rock in the contiguous United States: U.S. Geological Survey Open-File Report 82-1033, 107 p.

American Institute of Architects Research Corporation, 1975, Architects and engineers: Washington, D.C., 94 p.

Association of Engineering Geologists, 1973, Guidelines to geologic/seismic reports: California Division of Mines and Geology Note 37, 2 p.

Barrows, A. G., Kahle, J. E., and Beeby, D. J., 1976, Geology and fault activity of the Palmdale segment of the San Andreas fault zone, Los Angeles County, California: California Division of Mines and Geology Open-File Report 76-6 LA, 30 p.

Blair, M. L., and Spangle, W. E., 1979, Seismic safety and land-use planning-Selected examples from California: U.S. Geological Survey Professional Paper 941-B, 82 p.

Blume, J. A., Scholl, R. E., Somerville, M. R., and Honda, K. K., 1978, Damage prediction of an earthquake in southern California: Menlo Park, Calif., final technical report to U.S. Geological Survey under contract 14-08-0001-15889, $83 \mathrm{p}$

Bonilla, M. G., 1970, Surface faulting and related effects, in Weigel, R. L., ed., Earthquake engineering: Englewood Cliffs, N.J., PrenticeHall, p. 47-74.

Brown, R. D., Jr., and Kockelman, W. J., 1983, Geologic principles for prudent land-use-A decisionmaker's guide for the San Francisco Bay region: U.S. Geological Survey Professional Paper 946, 97 p.

California Assembly Select Committee on Landslide Prevention, 1980, A report based on committee hearing, Sacramento, California, April 18, 1980: Sacramento, Calif., California State Assembly Publications, $22 \mathrm{p}$.

California Association of Realtors, 1977, Disclosure of geologic hazards: Los Angeles, Calif., 43 p.

1978, Special studies zone and flood hazard disclosure-Standard form SSD-FHD-11: Los Angeles, Calif., 1 p.

1981, Real estate purchase contract and receipt for deposit-Standard form D-11-1, -2: Los Angeles, Calif., 2 p.

California Legislature, 1971, Local planning laws, as amended: Sec. 65300 and following, West's annotated California government code.

502 Earthquake Hazards in the Los Angeles Region
1972, Alquist-Priolo Special Studies Zones Act, as amended, in California public resources code: Sec. 2621 and following, West's annotated California government code.

California Building Safety Board Geotechnical Subcommittee, 1975, Recommended guidelines for determining the maximum credible and the maximum probable earthquakes: California Division of Mines and Geology Note 43, 1 p.

California Department of Insurance, 1982, California earthquake zoning and probable maximum loss program-An estimate of potential insured earthquake loss from analysis of data sumbitted by property and casualty companies in California: Sacramento, Calif., $41 \mathrm{p}$.

California Department of Water Resources, 1981, Earthquake inspection, in Earthquake safety and response plan: Castaic, Calif., sec. 8.0, p. $142-168$.

California Division of Highways, 1972, After quake disaster...the hard road back: Highway News Bulletin, District 7, Los Angeles, Spring $1972,7 \mathrm{p}$.

California Division of Mines and Geology, [1958-1969], Geologic atlas of California, Olaf P. Jenkins edition: Sacramento, Calif., 27 map sheets, 1:250,000 scale.

1975, Recommended guidelines for geologic reports on offshore operations and facilities: Note 47, $2 \mathrm{p}$.

1979, Ritter Ridge quadrangle: Sacramento, Calif., Special Studies Zones Map, scale 1:24,000.

California Education Code, 1933, as amended: Sec. 39140 and following, 81130 and following, 39210 and following, 81160 and following; 39002, 81003 and following, West's annotated California education code.

California Office of Planning and Research, 1980, General plan guidelines (revised Dec. 17, 1982): Sacramento, Calif., 348 p.

California Public Utilities Commission, 1979, Rules governing design, construction, testing, maintenance, and operation of utility gas gathering, transmission, and distribution piping systems, pt. III, Liquefied natural gas facilities safety standards of general order no. 112-D: San Francisco, Calif., p. III-B-7-III-B-30, app. B.

California Seismic Safety Commission Hazardous Buildings Committee, 1979, Hazardous buildings-Local programs to improve life safety (revised February 1980): Sacramento, Calif., 158 p.

Clark, M. M., Grantz, Arthur, and Rubin, Meyer, 1972, Holocene activity of Coyote Creek fault as recorded in sediments of Lake Cahuilla: U.S. Geological Survey Professional Paper 787, p. 112-130.

Conway, B. J., Fong, P. T., Hawkins, G. H., and Ostrom, D. K., 1978, Seismic design guidelines for substation facilities: Transactions on Power, Apparatus, and Systems, v. PAS-97, no. 3, p. 703-713.

Davis, J. F., Bennett, J. H., Borchardt, G. A., Kahle, J. E., Rice, S. J., and Silva, M. A., 1982, Earthquake planning scenario for a magnitude 
8.3 earthquake on the San Andreas fault in southern California: California Division of Mines and Geology Special Publication 60, $128 \mathrm{p}$.

Dibblee, T. W., Jr., 1950, Geology of southwestern Santa Barbara County, California: California Division of Mines and Geology Bulletin 150,95 p.

1966, Geology of the Central Santa Ynez Mountains, Santa Barbara County, California: California Division of Mines and Geology Bulletin 186, 99 p.

1973, Stratigraphy of the southern Coast Ranges near the San Andreas fault from Cholame to Maricopa, California: U.S. Geological Survey Professional Paper 764, 45 p.

Dunne, R. G., ed., 1978, Consensus report of the Task Force on Earthquake Prediction; City of Los Angeles: Los Angeles, Calif., 47 p.

Eberhart-Axten and Associates, Inc., 1980, Fault investigation and evaluation of surface rupture, 128-acre site, Leona Valley, California: Anaheim, Calif., 12 p.

Envirocom Corporation, 1974, Safety and seismic safety elements, comprehensive general plan, City of Simi Valley: Sherman Oaks, Calif. $69 \mathrm{p}$.

Evenson, R. E., and Miller, G. A., 1963, Geology and ground-water features of Point Arguello Naval Missile Facility, Santa Barbara County, California: U.S. Geological Survey Water-Supply Paper 1619-F, $35 \mathrm{p}$.

Evernden, J. F., Kohler, W. M., and Clow, G. D., 1981, Seismic intensities of earthquakes of conterminous United States-Their prediction and interpretation: U.S. Geological Survey Professional Paper $1223,56 \mathrm{p}$

Federal Emergency Management Agency, 1980, An assessment of the consequences and preparations for a catastrophic California earthquake; findings and actions taken: Prepared from analyses carried out by the National Security Council ad hoc committee on assessment of consequences and preparations for a major California earthquake, M\&R-2, January 1981: Washington, D.C., 59 p.

Fife, D. L., Rodgers, D. A., Chase, G. W., Chapman, R. H., Sprotte, E. C., and Morton, D. M., 1976, Geologic hazards in southwestern San Bernardino County, California: California Division of Mines and Geology Special Report 113, 40 p.

Gates, I. H., 1976, California's seismic design criteria for bridges: Proceedings of the American Society of Civil Engineers, Journal of the Structural Division, v. 102, no. ST-12, p. 2301-2313.

Greensfelder, R. W., 1972, Maximum credible bedrock acceleration from earthquakes in California: California Division of Mines and Geology Map Sheet 23, scale 1:2,000,000. (Revised August 1974; modified by California Department of Transportation Office of Structures, October 1974.)

1973, A map of maximum expected bedrock accleration from earthquakes in California: Sacramento, Calif., report accompanying California Division of Mines and Geology Map Sheet 23, $19 \mathrm{p}$

Hamilton, R. M., Yerkes, R. F., Brown, R. D., Jr., Burford, R. O., and DeNoyer, J. M., 1969, Seismicity and associated effects, Santa Barbara region, in Geology, petroleum development, and seismicity of the Santa Barbara channel region, California: U.S. Geological Survey Professional Paper 679-D, p. 47-68.

Hart, E. W., 1980, Fault-rupture hazard zones in California: California Division of Mines and Geology Special Publication 42, 25 p.

Hart, E. W., Bortugno, E. J., and Smith, T. C., 1977, Summary report; fault evaluation program, 1976 area (western Transverse Ranges): California Division of Mines and Geology Open-File Report 78-10 $\mathrm{SF}, 13 \mathrm{p}$.

Hart, E. W., Smith, D. P., and Smith, T. C., 1978, Summary report; fault evaluation program, 1977 area (Los Angeles basin region): California Division of Mines and Geology Open-File Report 78-10 SF, 16 p.

Hart, E. W., Smith, D. P., and Saul, R. B., 1979, Summary report; fault evaluation program, 1978 area (Peninsular Ranges-Salton Trough region): California Division of Mines and Geology Open-File Report 79-10 SF, $17 \mathrm{p}$.

Hays, W. W., 1980, Procedures for estimating earthquake ground motions: U.S. Geological Survey Professional Paper 1114, 77 p.

Hoffman, Richard, Meunier, Gary, and Kibbee, Joel, 1983, A database and pilot study design for the southern California region: Los Angeles, Calif., Southern California Association of Governments, $11 \mathrm{p}$.

International Conference of Building Officials, 1979, Uniform building code: Whittier, Calif., $734 \mathrm{p}$.

Jansen, R. B., Dukleth, G. W., and Barrett, K. G., 1976, Problems of hydraulic fill dams, in International Congress on Large Dams, Mexico City 1976, Proceedings: Q.14, R.16, p. 337-364.

Kockelman, W. J., 1975, Use of U.S. Geological Survey earth-science products by city planning agencies in the San Francisco Bay region, California: U.S. Geological Survey Open-File Report 75-276, $110 \mathrm{p}$

1976, Use of U.S. Geological Survey earth-science products by county planning agencies in the San Francisco Bay region, California: U.S. Geological Survey Open-File Report 76-547, 186 p.

1979, Use of U.S. Geological Survey earth-science products by selected regional agencies in the San Francisco Bay region, California: U.S. Geological Survey Open-File Report 79-221, 173 p.

1980, Examples of the use of earth-science information by decisionmakers in the San Francisco Bay region, California: U.S. Geological Survey Open-File Report 80-124, $88 \mathrm{p}$.

Kockelman, W. J., and Brabb, E. E., 1978, Examples of seismic zonation in the San Francisco Bay region, in Brabb, E. E., ed., 1979, Progress on seismic zonation in the San Francisco Bay region: U.S. Geological Survey Circular 807, p. 73-84.

Lamar, D. L., Merifield, P. M., and Proctor, R. J., 1973, Earthquake recurrence intervals on major faults in southern California, in Geology, seismicity, and environmental impact: Los Angeles, Calif., Association of Engineering Geologists, p. 265-276.

LNG Seismic Review Panel, 1981, Seismic safety review of the proposed liquefied natural gas facility, Little Cojo Bay, Santa Barbara County, California: Report prepared for the California State Public Utilities Commission, $33 \mathrm{p}$.

Los Angeles City Council, 1981, Ordinance no. 154,807 relative to earthquake hazard reduction in existing buildings: Los Angeles Municipal Code, ch. IX, art. 1, div. 68, sec. 91.6801 and following.

Los Angeles City Office of the Mayor, 1980, Emergency operations organization, earthquake prediction response plan (2d draft): City of Los Angeles Civil Defense and Disaster Board, $172 \mathrm{p}$.

Los Angeles City Planning Department, 1979, Draft environmental impact report on earthquake hazard reduction in existing buildings constructed before 1934 in the City of Los Angeles (amended September 1980): Environmental Review Section EIR 583-78-CW, $36 \mathrm{p}$., 3 exhibits, 2 apps.

1980, Final environmental impact report on earthquake hazard reduction in existing buildings constructed before 1934 in the City of Los Angeles: Environmental Review Section EIR 583-78-CW, $84 \mathrm{p}$.

Los Angeles County Department of County Engineer, 1977, Engineering geologic report, Skyline south easement (south segment), county water works district no. 29-Malibu: Los Angeles, Calif., Engineering Geology Section, $10 \mathrm{p}$.

Los Angeles County Department of County Engineer-Facilities, 1979, Preliminary geologic study, Kanan Dume Road cut failure, stations 132 to 136, March 1979: Los Angeles, Calif., Environmental Development Division, $5 \mathrm{p}$.

Los Angeles County Department of Regional Planning, undated, Content and format for environmental impact reports-Geotechnical hazards: Los Angeles, Calif., 3 p.

1974, Seismic safety element: Los Angeles, Calif., 170 p. 
1980, General plan: Los Angeles, Calif., 435 p.

Los Angeles County Sheriff's Department, undated, Computer-assisted communication system: Los Angeles, Calif., 8 p.

Los Angeles Department of City Planning, 1974, Seismic safety plan; a portion of the general plan of the City of Los Angeles; adopted by the Los Angeles City Council, September 10, 1975: Los Angeles, Calif., file no. 74-3401, 14 p.

Los Angeles Earthquake Safety Study Committee, 1978, Division 68-Earthquake hazard reduction in existing buildings: Preliminary draft as approved by the Earthquake Safety Study Committee, November 9, 1978: Los Angeles, Calif., 13 p.

Los Angeles Unified School District, 1975, Emergency procedures: Los Angeles, Calif., Student Auxiliary Services Branch, p. 30-35.

Mancarti, G. D., 1981, New concepts in earthquake retrofitting of highway bridges: Paper presented at Northwest Bridge Engineers Conference, Boise, Ida., 1981, 22 p.

Metropolitan Water District of Southern California Earthquake Committee, 1978, Emergency response plan-General procedures (revised August 1981): Los Angeles, Calif., 34 p, 8 apps.

Muir, K. S., 1968, Ground-water reconnaissance of the Santa BarbaraMontecito area, Santa Barbara County, California: U.S. Geological Survey Water-Supply Paper 1859-A, 28 p.

Orange County Environmental Management Agency, 1975, Safety ele ment, amended October 1977: Santa Ana, Calif., $67 \mathrm{p}$.

Ostrom, D. K., 1976, The need for a seismic design guide: Journal of Environmental Sciences, v. 19, no. 2, p. 28-33.

Paté, M.-E., and Shah, H. C., 1980; Public policy issues-Earthquake engineering: Bulletin of the Seismological Society of America, v. 70, no. 5, p. 1955-1968.

Portolà Valley Town Council, 1973, Zoning regulations: Ordinance no. 1967-80, sec. 6209.2.

Richter, C. F., 1958, Elementary seismology: San Francisco, W. H. Freeman, 768 p.

Riverside County Planning Department, 1978, Seismic safety/safety plan elements-Policy report: Riverside, Calif., 51 p.

Robinson, G. D., and Spieker, A. M., eds., 1978, "Nature to be commanded. ..": U.S. Geological Survey Professional Paper 950, 95 p.

San Bernardino County Planning Department, 1979, Consolidated general plan and implementation system: San Bernardino, Calif. $141 \mathrm{p}$.

San Diego County Environmental Development Agency, 1975, Seismic safety element; San Diego County general plan, pt. V: San Diego Calif., 14 p

San Fernando Valley Board of Realtors, Inc., 1976, Realtor report: Van Nuys, Calif., v. 56, no. 20, 9 p.

Santa Ana City Council, 1981, Seismic safety ordinance: Ordinance no. NS-1518 as amended by ordinance no. NS-1598, art. XI, sec 8-2000 and following.

Santa Barbara County Planning Department, 1979, Seismic safety and safety element: Santa Barbara, Calif., 207 p.

Sarna-Wojcicki, A. M., Williams, K. M., and Yerkes, R. F., 1976 , Geology of the Ventura fault, Ventura County, California: U.S. Geological Survey Miscellaneous Field Studies Map MF-781, scale 1:6,000.

Seed, H. B., and Schnabel, P. B., 1972, Accelerations in rock for earthquakes in the Western United States: Berkeley, Calif., Report 72-2, University of California Earthquake Engineering Research Center, $15 \mathrm{p}$.

Sharp, R. V., 1972, Map showing recently active breaks along the San Jacinto fault zone between the San Bernardino area and Borrego Valley, California: U.S. Geological Survey Miscellaneous Geologic Investigations Map I-675, scale 1:24,000.

Southern California Association of Governments, 1982, Executive summary of draft environmental impact report on Draft SCAG-82 growth forecast policy: Los Angeles, Calif., 36 p.

504 Earthquake Hazards in the Los Angeles Region
Southern California Earthquake Preparedness Project and California State Seismic Safety Commission, 1981, Work program: Van Nuys, Calif., 28 p.

Southern California Earthquake Preparedness Project and Environmental Volunteers, Inc., 1983, Hands on earthquake learning package-Instructor's guide: Van Nuys, Calif., $104 \mathrm{p}$.

Spangle and Associates, Inc., Degenkolb, and Associates, and Earth Sciences Associates, 1980, Land use planning after earthquakes: Portolà Valley, Calif., $158 \mathrm{p}$.

1981, Research program for pre-earthquake planning, 1981-1983: Portolà Valley, Calif., National Science Foundation, Project CEE 8024724, 19 p.

Sunset Magazine, 1982, Getting ready for a big quake: Menlo Park, Calif., Lane Publishing Company, March, p. 104-111.

Thenhaus, P. C., Perkins, D. M., Ziony, J. I., and Algermissen, S. T. 1980, Probabilistic estimates of maximum seismic horizontal ground motion on rock in coastal California and the adjacent outer continental shelf: U.S. Geological Survey Open-File Report 80-924, 69 p.

United Nations, 1976, Guidelines for disaster prevention, v, 2, Building measures for minimizing the impact of disasters: Geneva, Office of the United Nations Disaster Relief Coordinator, 59 p.

University of California Center for Planning and Development Research, 1982, An earthquake advisor's handbook for woodframe houses: Berkeley, Calif., College of Environmental Design, $90 \mathrm{p}$.

Upson, J. E., 1951, Geology and ground-water resources of the south coast basins of Santa Barbara County, California: U.S. Geological Survey Water-Supply Paper 1108, 144 p.

U.S. Department of Housing and Urban Development, 1980, The home builder's guide for earthquake design: Office of Policy Development and Research Guideline 6, 57 p.

U.S. Geological Survey, 1981, Scenarios of possible earthquakes affecting major California population centers, with estimates of intensity and ground shaking: U.S. Geological Survey Open-File Report 81-115, $36 \mathrm{p}$.

U.S. Nuclear Regulatory Commission, 1981, NRC staff's proposed findings of fact and conclusions of law in the form of a proposed initial decision before the Atomic Safety and Licensing Board in the matter of Southern California Edison Company, et al.: Washington, D.C., docket nos. 50-361 OL, 50-362 OL, 112 p.

Ventura County Department of Public Works, 1974, Recommended guidelines for preparing engineering geologic reports: California Division of Mines and Geology Note 44, 2 p.

Ventura County Environmental Resources Agency, 1974, Seismic safety and safety element of the general plan: Ventura, Calif., $303 \mathrm{p}$.

Wallace, R. E., 1970, Earthquake recurrence intervals on the San Andreas fault: Geological Society of America Bulletin, v. 81, p. 2875-2890.

Weber, F. H., Jr., 1977, Seismic hazards related to geologic factors, Elsinore and Chino fault zones, northwestern Riverside County, California: California Division of Mines and Geology Open-File Report 77-4 LA, $96 \mathrm{p}$.

Weber, F. H., Jr., Kiessling, E. W., Sprotte, E. C., Johnson, J. A., Sherburne, R. W., and Cleveland, G. B., 1975, Seismic hazards study of Ventura County: California Division of Mines and Geology OpenFile Report 76-5 LA, 396 p.

Wiggins, J. H., Jr., and Moran, D. F., 1971, Earthquake safety in the city of Long Beach based on the concept of "balanced risk": Redondo Beach, Calif., J. H. Wiggins, 128 p.

Woodring, W. P., and Bramlette, M. N., 1950, Geology and paleontology of the Santa Maria District, California: U.S. Geological Survey Professional Paper 222, 185 p. 
Woodward-Gizienski and Associates and F. Beach Leighton and Associates, 1974, Seismic safety study for the city of San Diego: San Diego, Calif., 41 p.

Woodward-McNeill and Associates, 1975, Draft seismic safety element: Orange, Calif., $167 \mathrm{p}$ :

Worts, G. F., Jr., 1951, Geology and ground-water resources of the Santa Maria Valley area, California: U.S. Geological Survey Water-Supply Paper 1000, $169 \mathrm{p}$.

Youd, T. L., Tinsley, J. C., Perkins, D. M., King, E. J., and Preston, R. F., 1979, Liquefaction potential map of San Fernando Valley, California, in Brabb, E. E., ed., 1979, Progress on seismic zonation in the San Francisco Bay region: U.S. Geological Survey Circular 807, p. 37-48.
Youd, T. L., Yerkes, R. F., and Clark, M. M., 1978, San Fernando faulting damage and its effect on land use, in Speciality Conference on Earthquake Enginering and Soil Dynamics, Proceedings: Pasadena, Calif., American Society of Civil Engineers, p. 1111-1125.

Ziony, J. I., Wentworth, C. M., and Buchanan, J. M., 1973, Recency of faulting; a widely applicable criterion for assessing the activity of faults: World Conference on Earthquake Engineering, 5th, Rome 1973, v. 2, p. $1680-1691$.

Ziony, J. I., Wentworth, C. M., Buchanan-Banks, J. M., and Wagner, H. C., 1974, Preliminary map showing recency of faulting in coastal southern California: U.S. Geological Survey Miscellaneous Field Studies Map MF-585, scale 1:250,000, 8-p. text. 

He-n
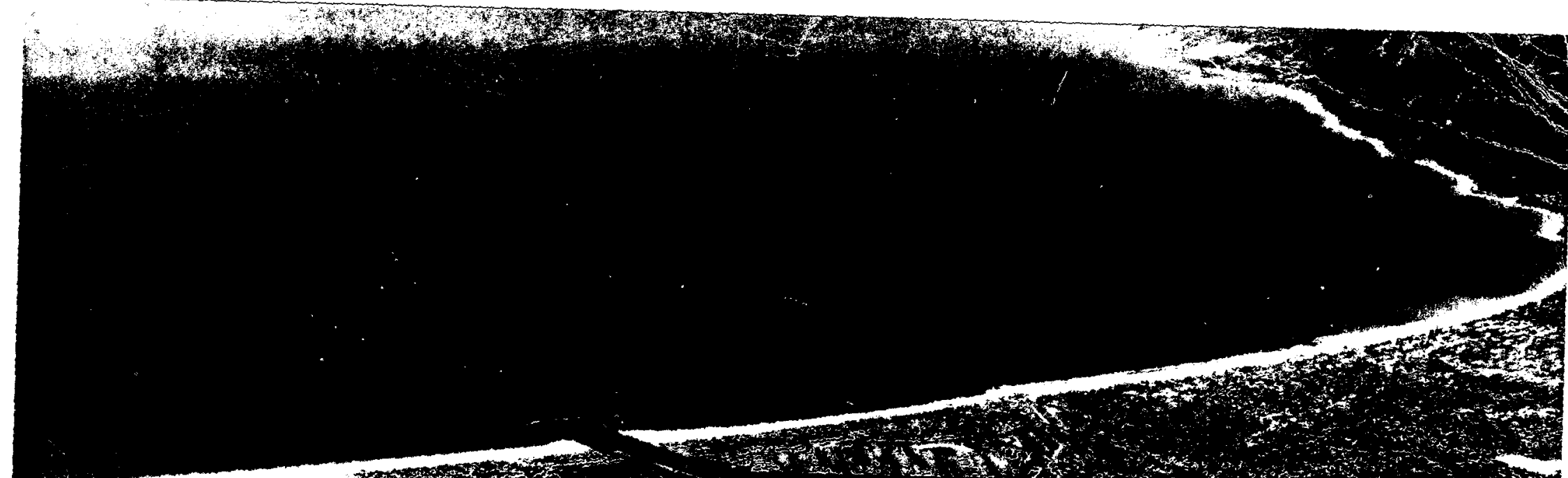

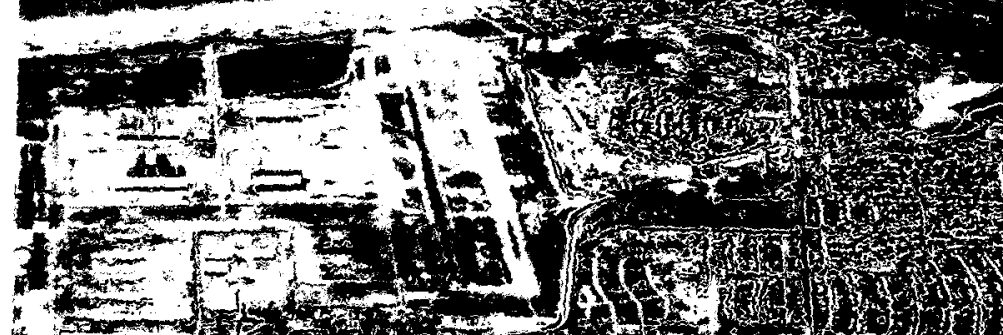

tertes

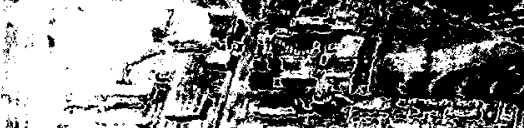

$400 \times$

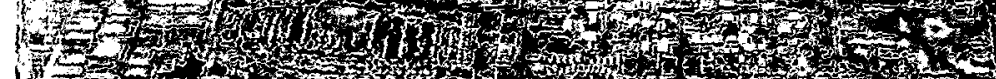

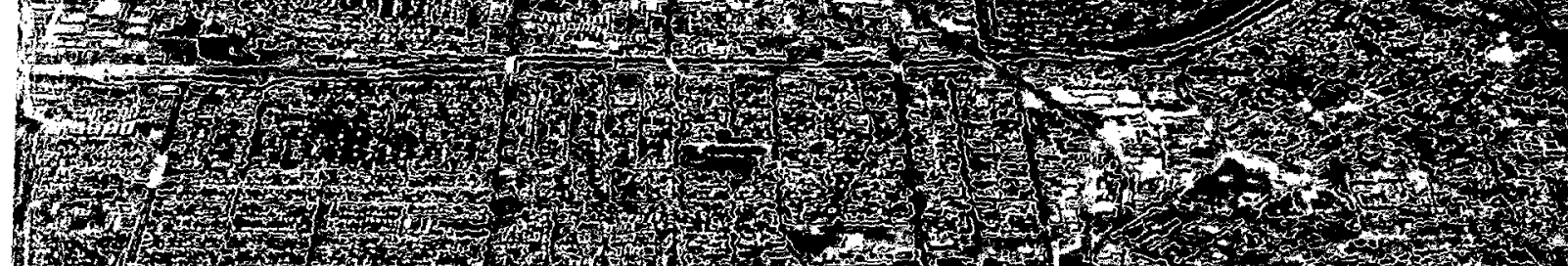

H.

137.

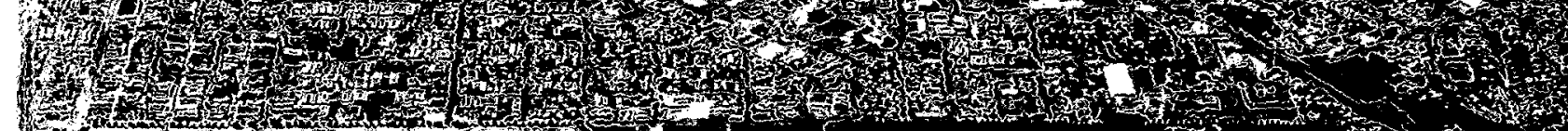

W(1)

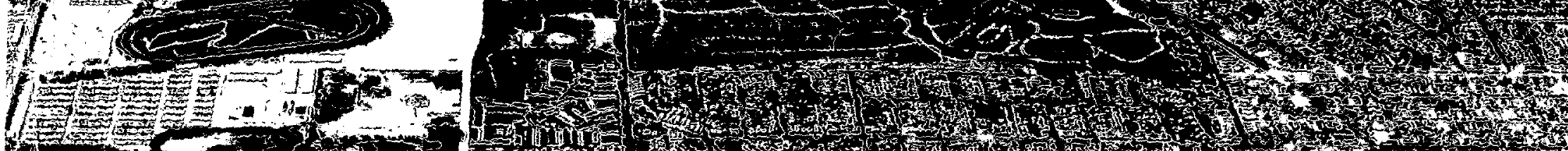
150, F,

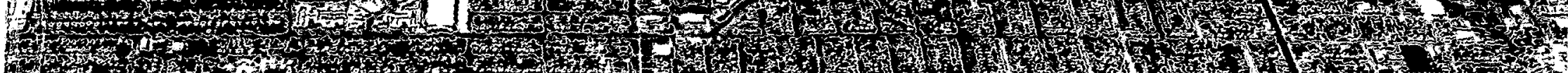
1.7.

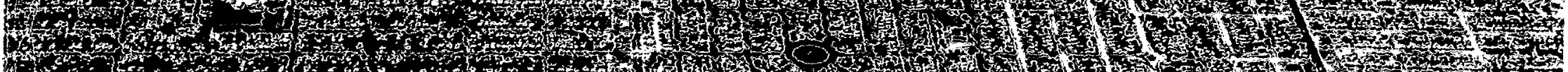
W.

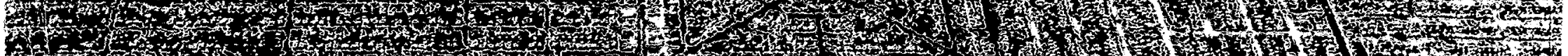
3.7.

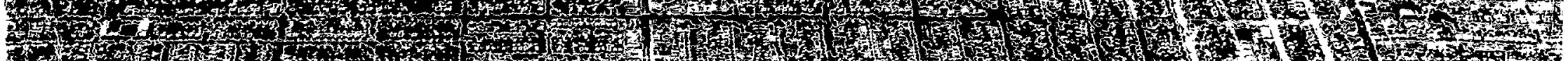
H.7.

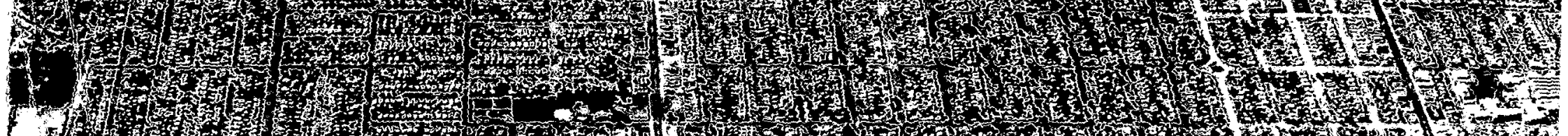

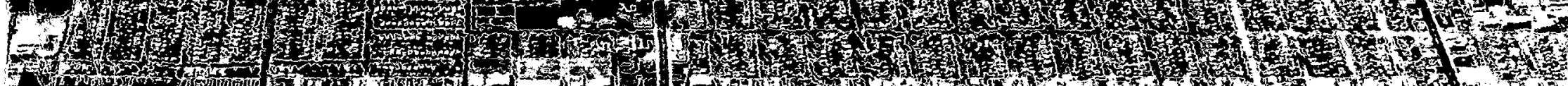
- 


\section{MODIFIED MERCALLI INTENSITY SCALE (ABRIDGED)}

I Not felt except by a very few under especially favorable circumstances (I, Rossi-Forel scale).

Il Felt by only a few persons at rest, especially on upper floors of buildings. Delicately suspended objects may swing (I to II, Rossi-Forel scale).

III Felt quite noticeably indoors, especially on upper floors of buildings, but many people do not recognize it as an earthquake. Standing motorcars may rock slightly. Vibration like passing of truck. Duration estimated (III, Rossi-Forel scale).

IV During the day, felt indoors by many, outdoors by few. At night, some awakened. Dishes, windows, and doors disturbed; walls make cracking sound. Sensation like heavy truck striking building. Standing motorcars rocked noticeably (IV to V, Rossi-Forel scale).

V : Felt by nearly everyone; many awakened. Some dishes, windows, and so on broken; a few instances of cracked plaster; unstable objects overturned. Disturbance of trees, poles, and other tall objects sometimes noticed. Pendulum clocks may stop (V to VI, Rossi-Forel scale).

VI Felt by all; many are frightened and run outdoors. Some heavy furniture moved; a few instances of fallen plaster or damaged chimneys. Damage slight (VI to VII, Rossi-Forel scale).

VII Eveybody runs outdoors. Damage negligible in buildings of good design and construction; slight to moderate in well-built ordinary structures; considerable in poorly built or badly designed structures; some chimneys broken. Noticed by persons driving motorcars (VIII, Rossi-Forel scale).

VIII Damage slight in specially designed structures; considerable in ordinary substantial buildings, with partial collapse; great in poorly built structures. Panel walls thrown out of frame structures. Chimneys, factory stacks, columns, monuments, and walls fall. Heavy furniture overturned. Disturbs persons driving motorcars (VIII + to IX, Rossi-Forel scale).

IX Damage considerable in specially designed structures; well-designed frame structures thrown out of plumb; damage great in substantial buildings, with partial collapse. Buildings shifted off foundations. Ground cracked conspicuously. Underground pipes broken (IX+, Rossi-Forel scale).

X Some well-built wooden structures destroyed; most masonry and frame structures destroyed, along with foundations; ground badly cracked. Rails bent. Landslides considerable from river banks and steep slopes. Shifted sand and mud. Water splashed (slopped) over banks (X, RossiForel scale).

XI Few, if any, (masonry) structures remain standing. Bridges destroyed. Broad fissures in ground. Underground pipelines completely out of service. Earth slumps and land slips in soft ground. Rails bent greatly.

XII Damage total. Waves seen on ground surfaces. Lines of sight and level distorted. Objects thrown upward into the air. 